Prepared for the U.S. Department of Energy under Contract DE-AC05-76RL01830

\title{
Characterization of Vadose Zone Sediments Below the T Tank Farm: Boreholes C4104, C4105, 299-W10-196, and RCRA Borehole 299-W11-39
}
RJ Serne
BN Bjornstad
DG Horton
DC Lanigan
HT Schaef
CW Lindenmeier

September 2008
MJ Lindberg

RE Clayton

VL LeGore

KN Geiszler

SR Baum
MM Valenta

IV Kutnyakov

TS Vickerman

RD Orr

CF Brown

September 2008

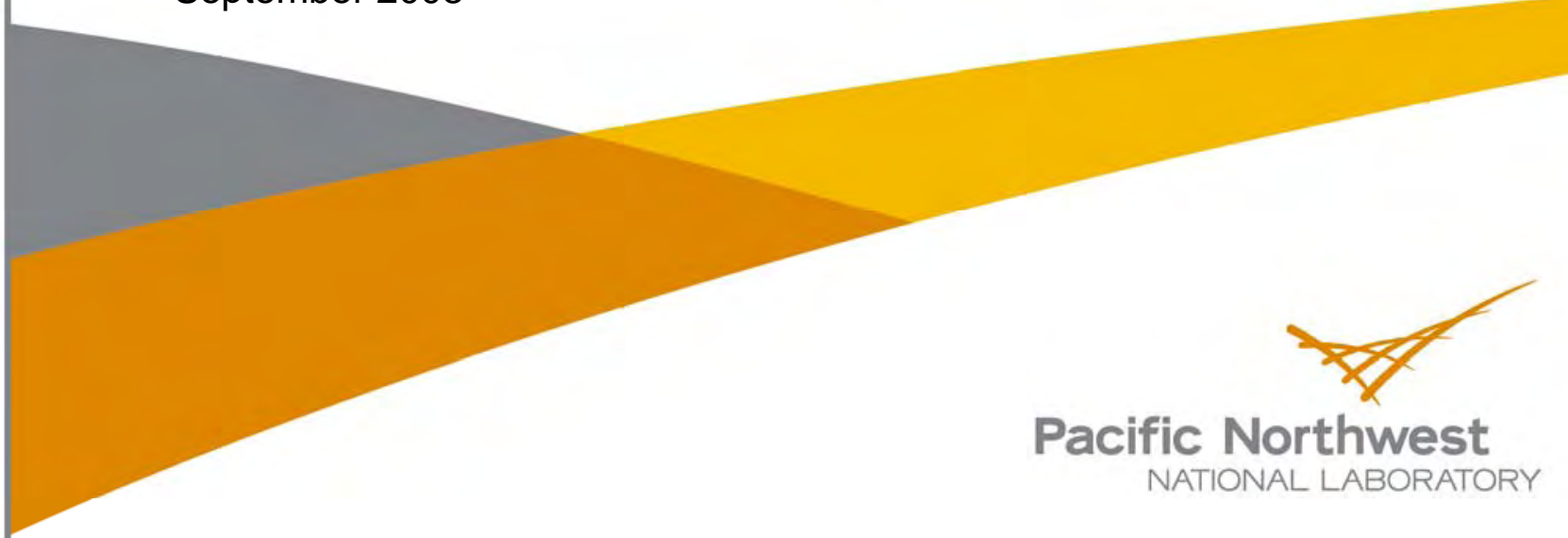




\section{Characterization of Vadose Zone Sediments Below the T Tank Farm: Boreholes C4104, C4105, 299-W10-196, and RCRA Borehole 299-W11-39}
R. J. Serne
M. J. Lindberg
M. M. Valenta
B. N. Bjornstad
R. E. Clayton
I. V. Kutnyakov
D. G. Horton
V. L. LeGore
T. S. Vickerman
D. C. Lanigan
K. N. Geiszler
R. D. Orr
H. T. Schaef
S. R. Baum
C. F. Brown
C. W. Lindenmeier

September 2008

Prepared for CH2M HILL Hanford Group, Inc. and the U.S. Department of Energy under Contract DE-AC05-76RL01830

Pacific Northwest National Laboratory

Richland, Washington 99352 


\section{Executive Summary}

This report was revised in September 2008 to remove acid-extractable sodium data from Tables 4.8, 4.28, and 4.52. The sodium data was removed due to potential contamination introduced during the acid extraction process. The rest of the text remains unchanged from the original report issued in September 2004.

The overall goal of the Tank Farm Vadose Zone Project, led by CH2M HILL Hanford Group, Inc., is to define risks from past and future single-shell tank farm activities at Hanford. To meet this goal, CH2M HILL Hanford Group, Inc. tasked scientists from Pacific Northwest National Laboratory to perform detailed analyses on vadose zone sediments from within Waste Management Area (WMA) T-TX-TY. This report is the second of two reports written to present the results of these analyses. Specifically, this report contains all the geologic, geochemical, and selected physical characterization data collected on vadose zone sediment recovered from boreholes C4104 and C4105 in the T Tank Farm, and from borehole 299-W-11-39 installed northeast of the T Tank Farm. Finally, the measurements on sediments from borehole C4104 are compared with a nearby borehole drilled in 1993, 299W10-196, through the tank T-106 leak plume.

Sediments from borehole 299-W-11-39 were considered to be background uncontaminated sediments against which to compare contaminated sediments for the T tank farm characterization effort. However, during characterization of the sediments from 299-W11-39, numerous indications were found that suggest some nearsurface contamination may have occurred in the past such that the water extract information for sediments from 299-W11-39 may not represent natural background conditions. Therefore, most of the comparisons of the contaminated $\mathrm{T}$ tank farm boreholes to natural background conditions used the sediment characterization information from background borehole 299-W10-27, just northeast of the TX Tank Farm.

This report also presents our interpretation of the data in the context of sediment types, the vertical extent of contamination, the migration potential of the contaminants, and the likely source of the contamination in the vadose zone and groundwater below the T Tank Farm. The information presented in this report supports the TTX-TY Waste Management Area field investigation report ${ }^{\text {(a) }}$ in preparation by CH2M HILL Hanford Group, Inc. Sediment samples from the boreholes were analyzed and characterized in the laboratory for the following parameters: moisture content, gamma-emitting radionuclides, one-to-one water extracts (which provide soil $\mathrm{pH}$, electrical conductivity, cation, trace metal, radionuclide and anion data), total carbon and inorganic carbon content, and $8 \mathrm{M}$ nitric acid extracts (which provide a measure of the total leachable sediment content of contaminants). Key radiocontaminants, technetium-99, actinides, fission products (including strontium-90, europium radioisotopes, ruthenium and molybdenum), cobalt-60, and uranium, along with other trace metals were determined in acid and water extracts using several techniques, including inductively coupled plasma mass spectrometry, gamma energy analysis, liquid scintillation, and alpha spectrometry.

Overall, our analyses showed that common ion exchange is a key mechanism that influences the distribution of contaminants within that portion of the vadose zone affected by tank liquor. Like the vadose zone sediments at the SX and BX Tank Farms, we did observe elevated pH values [from 8.6 to almost 10] in samples between the depths of 47 to $92.6 \mathrm{ft}$ bgs from borehole C4104 at WMA T. No signs of elevated $\mathrm{pH}$ were found in the sediments from borehole C4105.

(a) Field Investigation Report for Waste Management Areas T and TX-TY, by FJ Anderson (CH2M HILL Hanford Group, Inc., Richland, Washington), under preparation. 
The sediments from the three T tank farm boreholes, C4104, C4105, and 299-W10-196, do show that sodium-, nitrate-, and sulfate-dominated fluids are present below tank T-106 and have formed a salt plume. The fluids are more dilute than tank fluids observed below tanks at the SX and BX Tank Farms. Most of the chemical data for contaminants intercepted by boreholes C4104, 299-W10-196, and C4105 suggest that fluid leaked from Tank T-106 and percolated deeper into the sediments below C4104. More interesting is that the fluids traveled horizontally, within the lower Hanford formation $\mathrm{H} 2$ and the two Cold Creek Formation units, to the west at least as far as borehole C4105. Other spectral gamma logging data suggest that the tank T-106 leak also migrated east of tank T-106. To the east, the tank T-106 plume is overlain by a small leak from tank T-103. Thus, near tank T-106 there are signs of significant horizontal spreading of the original leak.

Our conceptual model of the borehole geology between core samples (recall that sampling was intermittent and collected $\sim 25 \%$ of the sediment profile) is based on our interpretation of the geophysical $\log$ and blow-count data. Three primary stratigraphic units were encountered in each of the three contaminated boreholes: 1) backfill material, 2) the Hanford formation, and 3) the Cold Creek unit. At C4104, we infer that there are at least two separate, relatively thin $(\leq 0.5 \mathrm{ft})$, moderately to well-sorted, silty fine sand beds in the Hanford formation $\mathrm{H} 2$ stratigraphic unit. These occur at depths starting at 58.6 and $63.5 \mathrm{ft}$ below ground surface (ft bgs). Up to four additional fine-grained beds may also be present between cored intervals in the profile at C4104. At C4105, we infer that there are at least two fine-grained layers within the Hanford formation $\mathrm{H} 2$ unit. These fine-grained layers were encountered at depths of $\sim 56.5$ and $~ 75 \mathrm{ft}$ bgs. These thin, fine-grained lenses within sands of the Hanford formation H2 unit may impact the flow of leaked fluids and affect irregular and horizontal flow.

Boreholes C4104 and C4105 could not penetrate below the gravel-rich strata of the Ringold Formation Wooded Island member $\left(\mathrm{R}_{\mathrm{wi}}\right)$ (refusal was met at about $130 \mathrm{ft}$ bgs at both holes); therefore, we did not identify the maximum vertical penetration of the tank-related plume. However, there is elevated electrical conductivity (EC) in the C4104 borehole sediments from $47 \mathrm{ft}$ bgs to the bottom of the borehole near $127 \mathrm{ft}$ bgs. At $46 \mathrm{ft}$ bgs, EC of the $\mathrm{C} 4104$ water extracts and actual porewaters are 6 times higher than background values and differences reach values of $\sim 40$ times larger than background at $116 \mathrm{ft}$ bgs. The dilution-corrected (calculated) porewaters are also quite elevated between 59 and $76 \mathrm{ft}$ bgs. The highest values of dilution-corrected porewater EC found at C4104 (33.4 mS/cm at $116 \mathrm{ft} \mathrm{bgs)} \mathrm{are}$ equivalent to a pore solution of $0.21 \mathrm{M} \mathrm{KCl}$, the salt solution used to calibrate the conductivity probe. There is also evidence of elevated EC starting at $86.7 \mathrm{ft}$ bgs to the bottom of the C4105 borehole. The EC values for 1:1 water extracts from the Cold Creek units' sediments at C4105 range from 1.2 to $3.1 \mathrm{mS} / \mathrm{cm}$, which is about 10 to 30 times higher than found in dilution-corrected porewaters from nearby background sediments. The highest values of dilution-corrected porewater EC in borehole C4105 occur in two zones, between 87 to $110 \mathrm{ft}$ bgs and at $123 \mathrm{ft}$ bgs. The dilution-corrected EC and actual porewater values for these two zones are equivalent to a pore solution of 0.10 to $0.175 \mathrm{M} \mathrm{KCl}$. The peak EC values for these two T boreholes are lower than the dilution-corrected EC maximum at borehole C3831 near Tank TX-107, which peaked between 60-61 ft bgs with a value equivalent to a pore solution of $0.4 \mathrm{M} \mathrm{KCl}$.

Despite the evidence that elevated EC values may be present in both T boreholes to their depth of refusal, the concentrations are not large. For example, the maximum dilution corrected EC at C4104 is $33.4 \mathrm{mS} / \mathrm{cm}$ and at C4105, the maximum is $\sim 19 \mathrm{mS} / \mathrm{cm}$. The leaks near the SX108-109 and BX-102 tanks had peak vadose zone porewater concentrations that were much more concentrated waste fluids: 524 to 1774 and $77 \mathrm{mS} / \mathrm{cm}$, respectively. 
The inventories of potential contaminants of concern—nitrate, technetium-99, uranium, and chromium, as a function of depth-are provided in Section 6.6. In addition, in situ desorption $\mathrm{K}_{\mathrm{d}}$ (distribution coefficient or sorption partition coefficient) values for these potential contaminants are provided based on the difference between acid [for cobalt-60 direct sediment gamma activities were used] and water extracts of the contaminated sediments. For bounding modeling purposes we recommend using $\mathrm{K}_{\mathrm{d}}$ values of $0 \mathrm{~mL} / \mathrm{g}$ for nitrate, cobalt- 60 , and technetium-99, a value of $0.1 \mathrm{~mL} / \mathrm{g}$ for uranium near borehole C4104 and $10 \mathrm{~mL} / \mathrm{g}$ for $\mathrm{U}$ near borehole C4105, and $1 \mathrm{~mL} / \mathrm{g}$ for chromium to represent the entire vadose zone profile from the bottoms of the tanks to the water table. These $\mathrm{K}_{\mathrm{d}}$ values, along with the provided inventories in the vadose zone sediments obtained from the three boreholes, can be used in long-term risk projections that rely on estimates of water recharge and vadose zone and aquifer transport calculations.

A technetium-99 groundwater plume exists northeast and east of T WMA. The highest technetium99 concentration in fiscal year 2003 was 9,200 pCi/L in well 299-W11-39. The most probable source for the technetium-99 is the T waste management area. Groundwater from wells in the west (up gradient) and north of WMA T appear to be highly influenced by wastes disposed to the cribs and trenches on the west side of the WMA. Groundwater from wells at the northeast corner and the east side of the WMA appears to be evolving toward tank waste that has leaked from T-101 or T-106. In the vadose zone sediments at boreholes C4104 and C4105, the actual and derived porewaters between the depths of 87 to $\sim 130 \mathrm{ft}$ bgs contain greater than $5 \times 10^{+5}$ to $2 \times 10^{+7} \mathrm{pCi} / \mathrm{L}$ technetium-99. These concentrations pose the largest risk of all the constituents present in the tank T-106 leak plume. 


\section{Acknowledgments}

This work was conducted as part of the Tank Farm Vadose Zone Project led by CH2M HILL Hanford Group, Inc. in support of the U.S. Department of Energy Office of River Protection. The authors wish to thank Frank J. Anderson, Anthony J. Knepp, Fredrick M. Mann, David A. Myers, Thomas E. Jones, and Harold A. Sydnor with CH2M HILL Hanford Group, Inc. for their support and technical review of this work, and Raziuddin Khaleel (Fluor Governmental Group), Marc I. Wood (Fluor Hanford, Inc.), and Dwayne Crumpler with Columbia Engineering \& Environmental Services for technical review. We would also like to express our gratitude to Robert Yasek with the Department of Energy Office of River Protection.

We would especially like to thank Kent D. Reynolds (Duratek Federal Services, Inc.) for his efforts in selecting depths to sample and executing the field work that obtained the samples, and Victoria Johnson and Kevin A. Lindsey (Kennedy/Jenks Consultants, Inc.) for their insights on the geologic nature of the materials penetrated by the boreholes.

Finally, we would like to thank Bill Deutsch for his technical review of this document, and Alexandra Amonette (Technical Writer's Ink Corp.), Karrol D. Lehman (Columbia Engineering \& Environmental Services) and David Payson and Rose Urbina (both with Pacific Northwest National Laboratory) for their editorial and document production support. 


\section{Acronyms and Abbreviations}

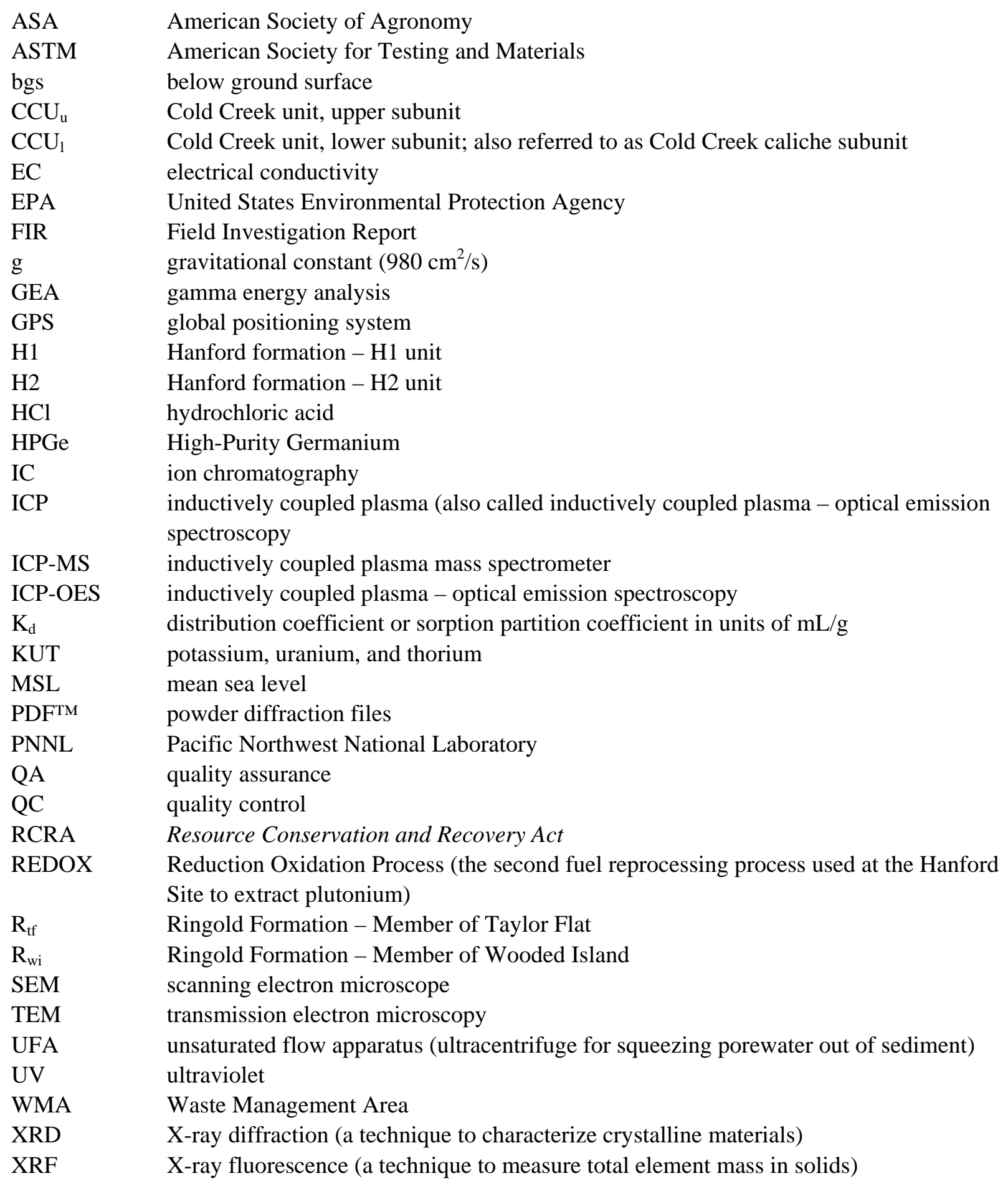




\section{Contents}

Executive Summary …..................................................................................................

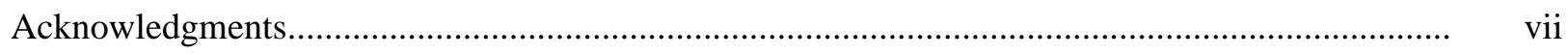

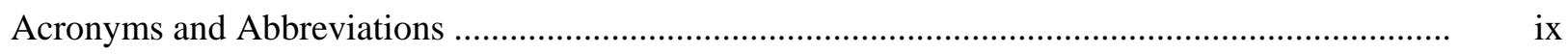

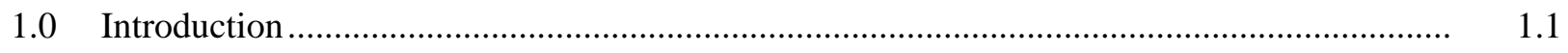

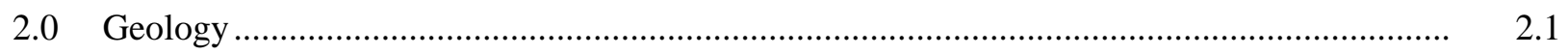

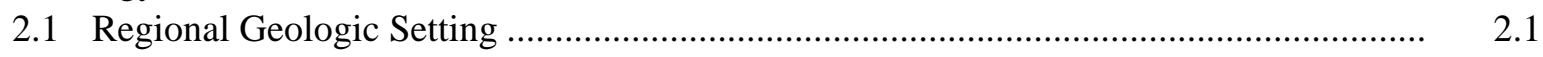

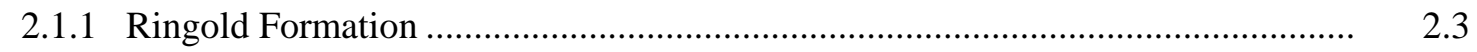

2.1.2 Cold Creek Unit ................................................................................................ 2.3

2.1.3 Hanford Formation ......................................................................................... 2.3

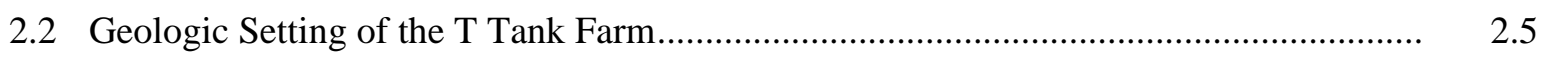

2.2.1 Stratigraphy and Lithology ....................................................................... 2.5

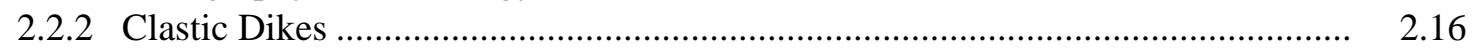

2.3 Summary of Recent Characterization Activities at T Tank Farm .................................. 2.17

2.3.1 Hydrogeologic Characterization.................................................................... 2.17

2.3.2 Hydrogeology of Borehole 299-W11-39 (Background Well)............................. 2.22

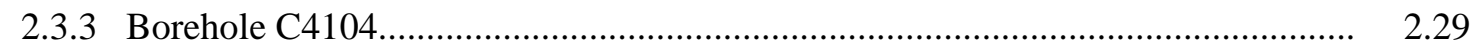

2.3.4 Borehole C4105................................................................................... 2.39

2.3.5 Previous Characterization Studies at Borehole 299-W10-196 ............................ 2.48

2.4 Discussion on Increased-Moisture Zones............................................................... 2.49

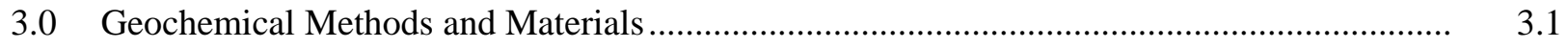

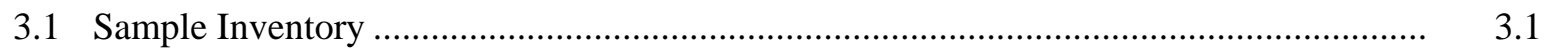

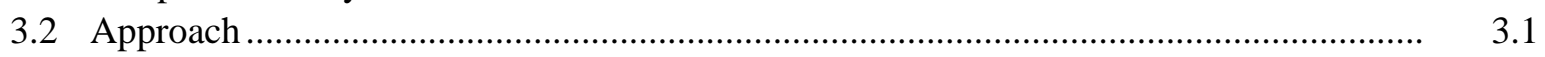

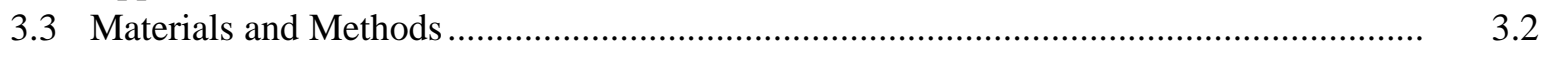

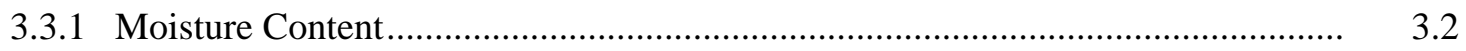

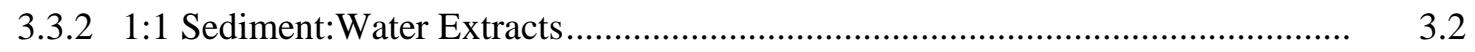

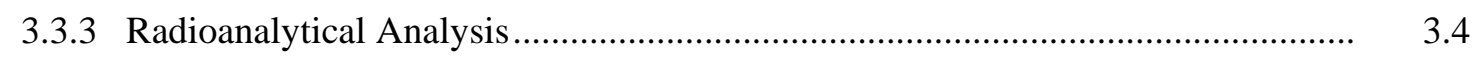

3.3.4 Porewater Composition ............................................................................... 3.6

3.3.5 Carbon Content of Sediment ........................................................................ 3.6

3.3.6 8 M Nitric Acid Extract................................................................................... 3.7

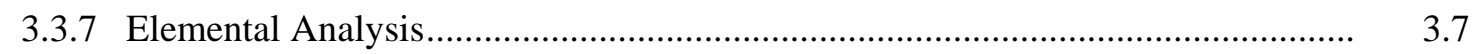

3.3.8 Particle Size Distribution .................................................................................. 3.7

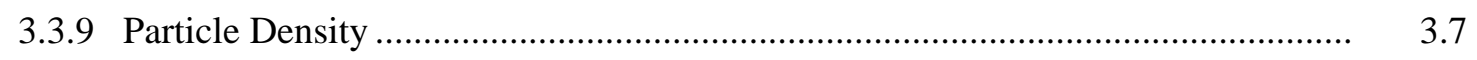

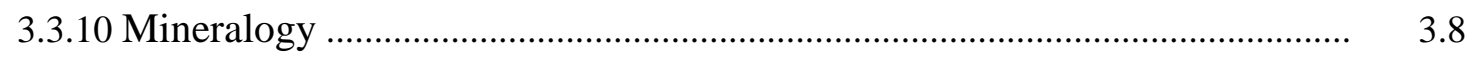

3.3.11 Water Potential (Suction) Measurements....................................................... 3.9 
4.0 Results and Discussion.

4.1 Vadose Zone Sediment from Borehole 299-W11-39...

4.1.1 Moisture Content...

4.1.2 1:1 Sediment:Water Extracts for Borehole 299-W11-39.....

4.1.3 8 M Nitric Acid-Extractable Amounts of Selected Elements

4.1.4 Bulk Chemical Composition of Sediment from 299-W11-39.

4.1.5 Radionuclide Content in Vadose Zone Sediment from 299-W11-39.

4.1.6 Total Carbon, Calcium Carbonate, and Organic Carbon Content of Vadose Zone Sediment from Borehole 299-W11-39.

4.1.7 Particle Size Measurements on Vadose Zone Sediment

4.1.8 Matric Suction Potential Measurements.

4.2 Vadose Zone Sediment from Borehole C4104...

4.2.1 Moisture Content....

4.2.2 1:1 Sediment:Water Extracts and Porewater Samples for Borehole C4104 ...

4.2.3 Vadose Zone Porewater Chemical Composition.

4.2.4 8 M Nitric Acid-Extractable Amounts of Selected Elements in C4104 Sediments ...

4.2.5 Radionuclide Content in Vadose Zone Sediment from C4104 ...

4.2.6 Total Carbon, Calcium Carbonate, and Organic Carbon Content of Vadose Zone Sediment from Borehole C4104.

4.2.7 Matric Potential of C4104 Vadose Zone Sediments

4.3 Comparison of Contaminant Distributions in C4104 and 299-W10-196 Vadose

Zone Sediments..

4.3.1 Technetium-99

4.3.2 Nitrate.

4.3.3 Cobalt-60

4.3.4 Uranium.

4.3.5 Cesium-137

4.3.6 Europium-154 and Europium-152.

4.3.7 Sodium ....

4.3.8 Calcium

4.3.9 Sulfate

4.3.10 Actinides

4.4 Vadose Zone Sediment from Borehole C4105...

4.4.1 Moisture Content.

4.4.2 1:1 Sediment:Water Extracts for Borehole C4105.

4.4.3 Derivation of Vadose Zone Porewater Chemical Composition

4.4.4 8 M Nitric Acid-Extractable Amounts of Selected Elements in C4105 Sediments

4.4.5 Radionuclide Content in Vadose Zone Sediment from C4105

4.4.6 Total Carbon, Calcium Carbonate, and Organic Carbon Content of Vadose Zone Sediment from Borehole C4105.

4.4.7 Particle Size Analyses

4.4.8 Mineralogy of C4105 Sediments. 
5.0 Groundwater Status Below the T Tank Farm...........................................................

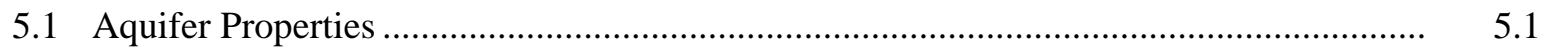

5.2 Existing Groundwater Contamination.................................................................... 5.12

5.2.1 Extent of Contamination - Depth Distribution ............................................. 5.13

5.2.2 Extent of Contamination - Geographic Distribution........................................ 5.20

5.3 Comparison of Groundwater, Vadose Zone Porewater, and Tank Leak Compositions.... 5.35

5.3.1 Technetium-99 - Chromium .......................................................................... 5.37

5.3.2 Technetium-99 - Nitrate ....................................................................... 5.43

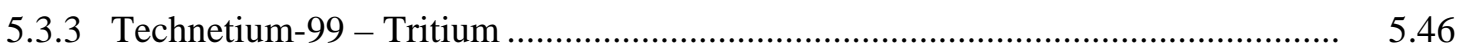

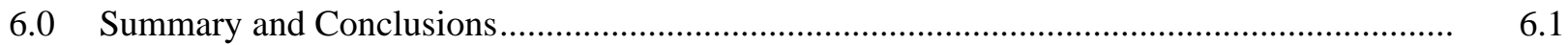

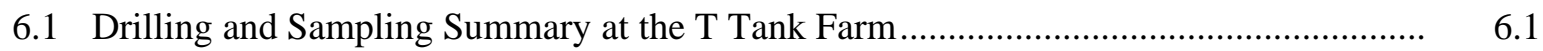

6.2 Conceptual Model for T Tank Farm Geology ................................................................ 6.2

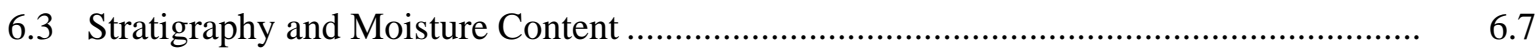

6.4 Vertical Extent of Contamination................................................................................ 6.7

6.5 Detailed Characterization to Elucidate Controlling Geochemical Processes .................... 6.11

6.6 Estimates of Contaminant Inventory and Sorption-Desorption Values ............................ 6.14

6.7 Other Geochemical Characterization Observations ........................................................ 6.21

6.8 Description of T Upper Unconfined Aquifer ............................................................. 6.24

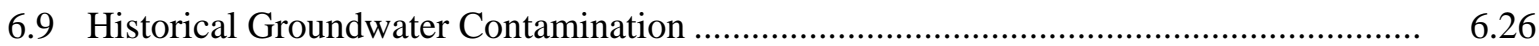

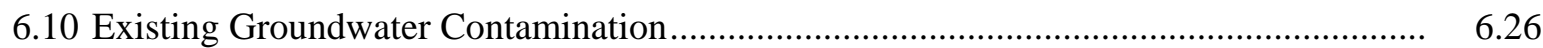

6.11 Complexities in Groundwater Data (Vertical and Temporal Variations)......................... 6.29

6.12 Vadose Zone Porewater and Groundwater Chemical Ratio Comparisons........................ 6.29

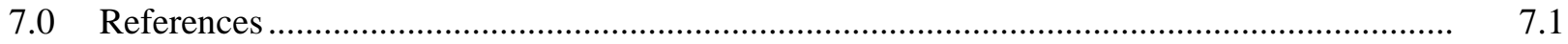

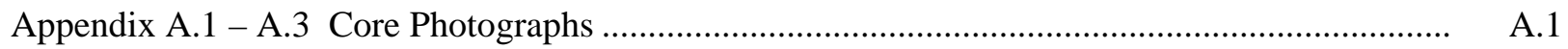

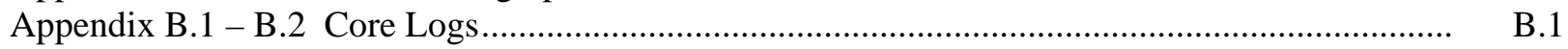

Appendix C - X-Ray Diffraction Patterns for C4105 (T-106) …........................................... C.1 


\section{Figures}

2.1 Stratigraphic Cross Section of the Vadose Zone Within the Central Pasco Basin.

2.2 Thickness and Distribution of Cataclysmic Flood Deposits (i.e., Hanford Formation)

Within the Central Pasco Basin.

2.3 Generalized, Composite Stratigraphy for the Late-Cenozoic Sediments Overlying the Columbia River Basalt Group at the T Tank Farm (Modified After Wood et al. 2001)..........

2.4 Selected Borehole Location Map for the T Tank Farm

2.5 East-West Hydrogeologic Cross Section A-A’ Across the T Tank Farm.

2.6 North-South Hydrogeologic Cross Section B-B' Across the T Tank Farm.

2.7 Sharp Contact at $89.9 \mathrm{ft}$ bgs between the Hanford formation $\mathrm{H} 2$ unit and the upper Cold Creek subunit $\left(\mathrm{CCU}_{\mathrm{u}}\right)$ in Borehole 299-W11-39

2.8 Sediment Textural Classification [Modified after Folk (1968) and Wentworth (1922)] ..........

2.9 Summary Geohydrologic Log for Background Borehole 299-W11-39.

2.10 Hanford Formation H1 Unit in Borehole 299-W11-39...

2.11 Hanford Formation H2 Unit in Borehole 299-W11-39.

2.12 Typical Backfill From Borehole C4104 ....................................................................... 2.32

2.13 Summary Hydrogeologic Log for Borehole C4104 …....................................................... 2.33

2.14 Hanford Formation H2 Unit in Borehole C4104. ............................................................ 2.35

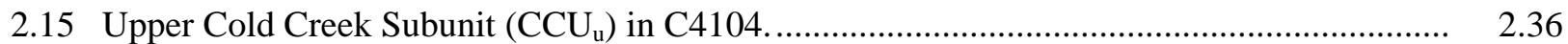

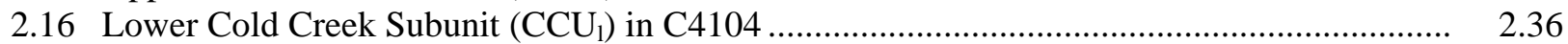

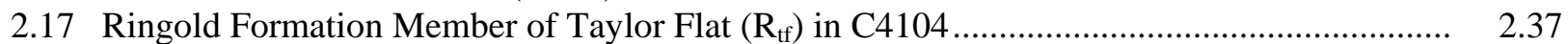

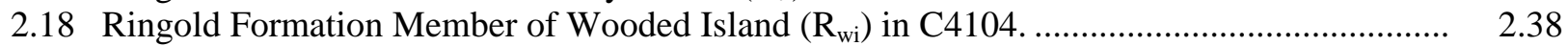

2.19 Summary Hydrogeologic Log for Borehole C4105 ........................................................... 2.42

2.20 Backfill material from borehole C4105 ........................................................................ 2.43

2.21 Hanford Formation H2 Unit in C4105 _.......................................................................... 2.44

2.22 Upper Cold Creek Subunit in C4105 ...................................................................... 2.45

2.23 Lower Cold Creek Subunit within C4105 _........................................................................ 2.46

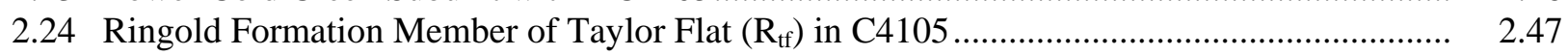

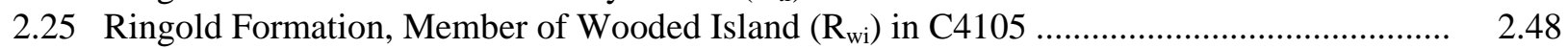

2.26 Summary Hydrogeologic Log for 299-W10-196............................................................ 2.49

2.27 Average Moisture Content (wt\% water) from Different Stratigraphic Units in the Vicinity of the T Tank Farm

4.1 $\mathrm{pH}$ and Electrical Conductivity Calculated From Sediment:Water Extracts for

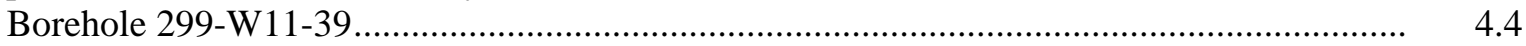

4.2 Major Anions in 1:1 Sediment:Water Extracts from Borehole 299-W11-39.......................

4.3 Cations in 1:1 Sediment:Water Extracts for Borehole 299-W11-39 ..................................... 4.11

4.4 Aluminum, Barium, Iron, Silicon, and Zinc in 1:1 Sediment:Water Extracts from Borehole 299-W11-39.

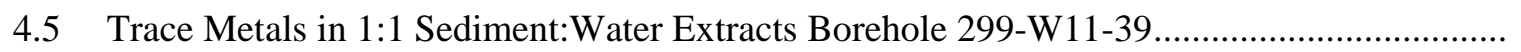

4.6 Acid-Extractable Concentrations of Major Cations in Borehole 299-W11-39 Sediment .........

4.7 Acid-Extractable Concentrations of Aluminum, Barium, Iron, Manganese, Silicon and Zinc from Borehole 299-W11-39 Sediments

4.8 Concentration of Uranium-238, Chromium, and Molybdenum in 299-W11-39

Borehole Sediment that is Acid-Extractable 
4.9 Comparison between Acid-and Water-Extractable Sulfate and Phosphate in Vadose

Zone Sediments from Borehole 299-W11-39.

4.10 Particle Size Distribution of Hanford formation H2 Unit Subsamples from Borehole 299-W11-39

4.11 Particle Size Distribution of Deepest H2 and the Cold Creek Unit Subsample from Borehole 299-W11-39....

4.12 Matric Water Potential Measured by Filter Paper Technique on Core Samples from Borehole 299-W11-39....

4.13 Borehole C4104 Sediment:Water Extract pH, Actual, and Calculated Porewater Electrical Conductivity.

4.14 Borehole C4104 Water-Extractable Anions....

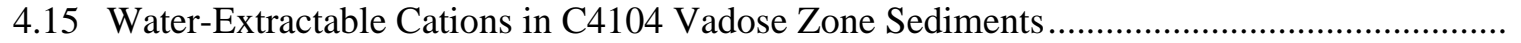

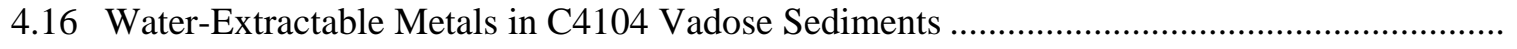

4.17 Distribution of Mobile Metals in Water Extracts of C4104 Vadose Zone Sediments ..............

4.18 Derived and Actual Porewater Composition of Major Cations in C4104 Vadose Zone Sediments .

4.19 Derived and Actual Porewater Anion Composition in C4104 Vadose Zone Sediments ..........

4.20 Derived and Actual Porewater Composition for Selected Metals in C4104 Vadose Zone Sediments.

4.21 Derived and Actual Porewater Composition of Mobile Metals in C4104 Vadose Zone Sediments

4.22 Acid-Extractable Cations in C4104 Vadose Zone Sediments..

4.23 Acid-Extractable Major Metals in C4104 Vadose Zone Sediments .......................................

4.24 Acid-Extractable Trace Metals in C4104 Vadose Zone Sediments .........

4.25 Acid-Extractable Mobile Metals in C4104 Vadose Zone Sediments...

4.26 Water- Versus Acid-Extractable Sulfate and Phosphate in C4104 Vadose Zone Sediments

4.27 Comparison of Lab Gamma Energy Analysis (GEA) and Field Log for Natural Gamma Emitters in Borehole C4104

4.28 Matric Potential for C4104 Core Samples (measured after cores were subsampled) ...............

4.29 Location of the Three Contaminated Boreholes Around Tank T-106 ...

4.30 Location of the Three Contaminated Boreholes in Relationship to Tanks T-106 and T-109.

4.31 Comparison of Tc-99 Content in Boreholes C4104 (in 2003) and 299-W10-196 (in 1993).

4.32 Comparison of Nitrate Content in Boreholes C4104 (in 2003) and 299-W10-196 (in 1993).

4.33 Comparison of Cobalt-60 in Boreholes C4104 (in 2003) and 299-W10-196 (in 1993)

But Decay-Corrected to 05/2003.

4.34 Comparison of Acid-Extractable Uranium in Boreholes C4104 (in 2003) and 299-W10-196 (in 1993).

4.35 Comparison of Cesium-137 in Boreholes C4104 (in 2003) and 299-W10-196 (in 1993) but Decay Corrected to 05/2003.

4.36 Comparison of Europium-154 in Boreholes C4104 (in 2003) and 299-W10-196 (in 1993) but Decay Corrected to 05/2003.

4.37 Comparison of Europium -152 in Boreholes C4104 (in 2003) and 299-W10-196 (in 1993) but Decay Corrected to 05/2003. 
4.38 Comparison of Acid-Extractable Sodium in Boreholes C4104 (in 2003) and 299-W10-196 (in 1993).

4.39 Comparison of Acid-Extractable Calcium in Boreholes C4104 (in 2003) and 299-W10-196 (in 1993).

4.40 Comparison of Water-Extractable Sulfate in Boreholes C4104 (in 2003) and 299-W10-196 (in 1993).

4.41 Borehole C4105 Sediment-to-Water Extract and Actual Porewater $\mathrm{pH}$ and Calculated and Actual Porewater EC and Total Alkalinity....

4.42 C4105 Borehole Water-Extractable Anions

4.43 Water-Extractable Cations in Borehole C4105 Vadose Zone Sediments .

4.44 Water-Extractable Metals in C4105 Borehole Vadose Sediments

4.45 Distribution of Mobile Metals in Water Extracts of C4105 Vadose Zone Sediments.....

4.46 Porewater Composition of Major Cations in C4105 Vadose Zone Sediments

4.47 Porewater Anion Composition in C4105 Vadose Zone Sediments 4.155

4.48 Porewater Composition for Selected Metals in C4105 Vadose Zone Sediments ...... 4.156

4.49 Porewater Composition of Mobile Metals in C4105 Vadose Zone Sediments... 4.157

4.50 Acid-Extractable Cations in C4105 Vadose Zone Sediments. 4.158

4.51 Acid-Extractable Metals in C3832 Vadose Zone Sediments ..... 4.165

4.52 Acid-Extractable Trace Metals in C4105 Vadose Zone Sediments . 4.166

4.53 Acid-Extractable MobileTrace Metals in C4105 Vadose Zone Sediments. 4.167

4.54 Water- versus Acid-Extractable Sulfates and Phosphate in C4105 Vadose Zone Sediments . 4.168

4.55 Comparison of Lab Gamma Energy Analysis (GEA) and Field Log for Natural Gamma Emitters

4.56 Particle Size Distribution for Selected Borehole C4105 Sediments

4.57 XRD Tracing for Sediment Sample 10A (88.2 ft bgs) Collected From Borehole C4105, With Matching PDF ${ }^{\mathrm{TM}}$ Files

4.58 XRD Tracing for Sediment Sample 11A (93.3 ft bgs) Collected From Borehole C4105, With Calcite PDFTM File.

4.59 XRD Tracing of Clay Fraction from Sediment Sample 19A (120.9 ft bgs) Collected From Borehole C4105, With Matching PDF ${ }^{\mathrm{TM}}$ Files.

5.1 Well Location Map for Waste Management Area T..... Discharge History for the 216-T Pond and the 216-U Pond.

Hydrographs of Selected Wells in the North 200 West Area

5.4 Groundwater Flow Directions in the North Part of 200 West Area.

March 2003 Water Table Map for the Area Around Waste Management Area T...................

5.6 Historic Water Table Elevations in Selected Wells at WMA T.

5.7 Specific Conductance versus Depth Below the Water Table in Well 299-W10-28 ................

5.8 Specific Conductance versus Depth Below the Water Table in Well 299-W11-42 ...

5.9 Technetium-99 Concentrations in Two Well Pairs at the Northeast Corner of T Tank Farm

5.10 Nitrate Concentration in Two Well Pairs Downgradient of WMA T.

5.11 Concentrations of Chromium in Filtered Samples from Two Downgradient Well Pairs ........ Near the T Tank Farm

5.12 Concentrations of Fluoride in Two Downgradient Well Pairs Near the T Tank Farm ............. 
5.14 Average Concentrations of Carbon Tetrachloride in the 200 West Area, Top of the Unconfined Aquifer (from Hartman et al. 2003) ....

5.15 Average Concentrations of Trichloroethene in the North Part of the 200 West Area, Top of the Unconfined Aquifer (from Hartman et al. 2003).

5.16 Average Concentrations of Tritium in the North Part of 200 West Area, Top of the Unconfined Aquifer (from Hartman et al. 2003)

5.17 Average Concentrations of Nitrate in the North Part of 200 West Area, Top of the Unconfined Aquifer (from Hartman et al. 2003)

5.18 Nitrate Concentration versus Time in Upgradient Wells at WMA T

5.19 Average Concentrations of Chromium in the Area of Waste Management Area T, Top of the Unconfined Aquifer (from Hartman et al. 2003)

5.20 Chromium Concentration versus Time for Selected Upgradient Wells at Waste Management Area T.

5.21 Chromium Concentration versus Time for Selected Wells North of Waste Management Area T

5.22 Average Concentrations of Fluoride in the Area of Waste Management Area T, Top of the Unconfined Aquifer (from Hartman et al. 2003)

5.23 Technetium-99 and Fluoride Concentrations in Downgradient Well 299-W-10-24

5.24 Average Concentrations of Technetium-99 in the Area of Waste Management Area T, Top of the Unconfined Aquifer (from Hartman et al. 2003).

5.25 Time Series Stiff Diagrams Showing Breakthrough of Calcium and Nitrate to Groundwater at Well 299-W11-27.

5.26 Gross Beta Contamination in Wells West and Southwest of WMA T ................................. 5.36

5.27 Technetium-99 and Chromium Concentrations in Selected Wells at WMA T...................... 5-40

5.28 Technetium-99/Chromium Concentration Ratios in Samples from Selected Wells at WMA T.

5.29 Technetium-99 and Nitrate Concentrations in Samples from Selected Wells at WMA T.......

5.30 Technetium-99/Nitrate Concentration Ratios in Samples from Selected Wells at WMA T....

5.31 Technetium-99/Tritium Concentration Ratios in Samples from Selected Wells at WMA T... 


\section{Tables}

2.1 Stratigraphic Terminology for the Vadose Zone Beneath T Tank Farm................................. 2.8

2.2 Four Borings Used for Recent Geochemical Characterization in the Vicinity of the T Tank Farm

2.3 Stratigraphic Contact Picks for Boreholes Used in This Report...

2.4 Core Samples Collected from 299-W11-39 for Paleomagnetic Analysis ...

2.5 Splitspoon Samples Selected for Physical and Chemical Characterization from the Vadose Zone in 299-W11-39.....

2.6 Gravimetric Moisture Content Measured in Core Samples ...

2.7 Splitspoon Core Samples from C4104...

2.30

2.8 Splitspoon Core Samples From C4105.

4.1 Gravimetric Moisture Content of Core Samples Obtained Between 20 and $92 \mathrm{ft}$ bgs in Borehole 299-W11-39.

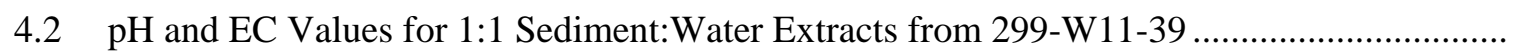

4.3 Anion Composition of Water Extracts of 299-W11-39 Sediment .....

4.4 Small Molecular Weight Organic Content of Water Extracts of 299-W11-39 Sediment.........

4.5 Water-Extractable Cations in Borehole 299-W10-27 Sediments.....

4.6 Other Water-Extractable Species in Borehole 299-W10-27 Sediments..................................

4.7 Water-Extractable Mobile Trace Contaminants in Borehole 299-W11-39 Sediments .............

4.8 Acid-Extractable Major Cations in Borehole 299-W11-39 Sediments ( $\mu \mathrm{g} / \mathrm{g}$ dry sediment) ...

4.9 Acid-Extractable Content for Major Constituents in Borehole 299-W11-39 Sediments .........

4.10 Acid-Extractable Mobile Trace Metals in Borehole 299-W11-39 Sediments .

4.11 Total Chemical Composition of Borehole 299-W11-39 Sediments (as Weight \% Oxides) ....

4.12 Trace Element Composition of Borehole 299-W11-39 Sediments......

4.13 Total, Inorganic, and Organic Carbon Content of Vadose Zone Sediments from Borehole 299-W11-39.

4.14 Wet Sieve Particle Size Results for Borehole 299-W11-39 Sediments

4.15 Particle Size Data for Borehole 299-W11-39 Sediments Using Two Techniques Reported as Cumulative Percent Finer Than.

4.16 Matric Potential as Measured by Filter Paper Method for Borehole 299-W11-39 Core Sediments

4.17 Moisture Content for Borehole C4104 Core Sediments

$4.18 \mathrm{pH}$ and EC Data for Sediment:Water Extracts and Actual Porewater from Borehole C4104

4.19 Water-Extractable Anions in Borehole C4104 Vadose Zone Sediments ................................

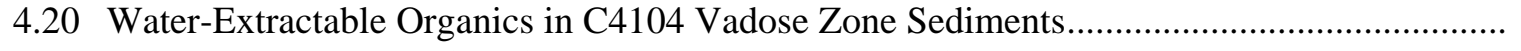

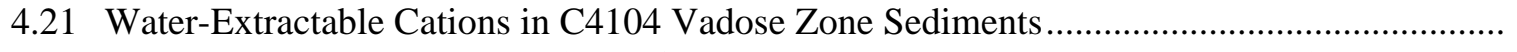

4.22 Water-Extractable Concentrations of Other Metals in C4104 Vadose Zone Sediments...........

4.23 Water-Extractable Concentrations of Mobile Metals in C4104 Vadose Sediments .................

4.24 Calculated and Actual Porewater Cation Concentrations in C4104 Vadose Zone Sediments .

4.25 Calculated and Actual Porewater Anion Concentrations in C4104 Vadose Zone Sediments.....

4.26 Calculated and Actual Porewater Concentrations of Selected Constituents in C4104 Vadose Zone Sediments. 
4.27 Calculated and Actual Porewater Concentrations of Potentially Mobile Constituents

in C4104 Vadose Sediments ................................................................................................ 4.64

4.28 Acid-Extractable Cations from C4104 Vadose Zone Sediments ........................................... 4.72

4.29 Acid-Extractable Constituents in C4104 Vadose Zone Sediments ....................................... 4.74

4.30 Acid-Extractable Trace Metals in C4104 Vadose Zone Sediments .......................................

4.31 Acid-Extractable Mobile Metals in C4104 Vadose Zone Sediments.................................... 4.78

4.32 Gamma Emitting Radionuclides in C4104 Vadose Zone Sediments ...................................... 4.87

4.33 Sr-90, Tc-99 and Actinides in C4104 Vadose Zone Sediments ........................................... 4.89

4.34 Carbon Contents of Vadose Zone Sediments in Borehole C4104 ....................................... 4.94

4.35 Matric Potential of Vadose Zone Sediments in Borehole C4104 ....................................... 4.95

4.36 Comparison of Tc-99 Contents in Sediments from C4104 and 299-W10-196 ..................... 4.100

4.37 Comparison of Nitrate and Nitrite Contents in Sediments from C4104 and 299-W10-196

4.38 Acid-Extractable Calcium and Sodium Concentrations in the Two Borehole Sediments ....... 4.116

4.39 Comparison of Water-Extractable Sulfate from Sediments from Both Boreholes ................. 4.120

4.40 Comparison of Strong Acid-Extractable Actinides from Sediments from Both Boreholes..... 4.122

4.41 Moisture Content of Borehole C4105 Cores ...................................................................... 4.128

$4.42 \mathrm{pH}$ and EC Data for Sediment-Water Extracts and Actual Porewater from Borehole C4105

4.43 Water-Extractable Anions in Borehole C4105 Vadose Zone Sediments .............................. 4.134

4.44 Water-Extractable Organics in C4105 Vadose Zone Sediments.......................................... 4.138

4.45 Water-Extractable Cations in C4105 Borehole Vadose Zone Sediments ............................. 4.139

4.46 Water-Extractable Concentrations of Other Metals in C4105 Vadose Zone Sediments.......... 4.140

4.47 Water-Extractable Concentrations of Mobile Metals in C4105 Vadose Sediments .............. 4.141

4.48 Derived and Actual Porewater Cation Concentrations in C4105 Vadose Zone Sediments ..... 4.147

4.49 Derived and Actual Porewater Anion Concentrations in C4105 Vadose Zone Sediments...... 4.149

4.50 Derived and Actual Porewater Concentrations of Selected Constituents in C4105 Vadose Zone Sediments ................................................................................................... 4.151

4.51 Derived and Actual Porewater Concentrations of Potentially Mobile Constituents in C4105 Vadose Sediments .......................................................................................... 4.153

4.52 Acid-Extractable Cations from C4105 Vadose Zone Sediments .......................................... 4.161

4.53 Acid-Extractable Constituents in C4105 Vadose Zone Sediments ........................................ 4.162

4.54 Acid-Extractable Trace Metals in C4105 Vadose Zone Sediments ...................................... 4.163

4.55 Acid-Extractable Mobile Trace Metals in C4105 Vadose Zone Sediments........................... 4.164

4.56 Gamma Emitter Concentrations in Vadose Zone Sediments in Borehole C4105................... 4.172

4.57 Total Beta Comparison to Technetium-99 Measurements in Water and Acid Extracts in Vadose Zone Sediments in Borehole C4105 .................................................................. 4.174

4.58 Carbon Contents of Vadose Zone Sediments in Borehole C4105 ….................................... 4.175

4.59 Particle Size Data for One Sample from Each Major Stratigraphic Unit in Borehole C4105 Sediments

4.60 Whole Rock Quantitative XRD Results Determined by JADE Whole Pattern Fitting on Sediment Samples Collected From Borehole C4105 ......................................................... 4.178

4.61 Semi Quantitative XRD Results of Clay Minerals in $<2$ um Fraction of Sediment Samples Collected From Borehole C4105. .....

5.1 Groundwater Flow Characterization Results Based on Trend Surface Analyses ................... 5.8

5.2 In-Well, Downward Vertical, Flow-Velocity Summary for Wells 299-W11-39 and 299-W11-40 at Waste Management Area T (Spane et al. 2002). 
5.3 Results from Tracer-Dilution and Tracer-Pumpback Tests in Wells at Waste

Management Area T (Spane et al. 2001a, b and 2002)

5.4 Hydraulic Properties from Slug and Constant Rate Pumping Tests and Calculated Horizontal Flow Velocities at New Wells at Waste Management Area T.

5.5 Nitrate and Specific Conductance in Samples Collected During Drilling at WMA T.

5.6 Average Concentration of Mobile Contaminants in Groundwater in the Vicinity of

Waste Management Areas T for Fiscal Year 2003

5.7 Partial Inventories for Past-Practice Facilities Upgradient of WMA T

5.8 Estimated Compositions for Tank Leaks and Waste Streams Associated with WMA T........

6.1 Stratigraphic Units and Contacts....

6.2 Maximum Pore Water Concentrations in Sediments from Contaminated Sediments in Various Tank Farms.

6.3 Inventory Estimates for Potential Contaminants of Concern in Borehole C4104 Sediments

6.4 Inventory Estimates for Potential Contaminants of Concern in Borehole C4105 Sediments .

6.5 Desorption $\mathrm{K}_{\mathrm{d}}$ Values for Potential Contaminants of Concern 


\subsection{Introduction}

The overall goals of the Tank Farm Vadose Zone Project, led by CH2M HILL Hanford Group, Inc., are 1) to define risks from past and future single-shell tank farm activities, 2) to identify and evaluate the efficacy of interim measures, and 3) to aid, via collection of geotechnical information and data, the future decisions that must be made by the Department of Energy (DOE) regarding the near-term operations, future waste retrieval, and final closure activities for the single-shell tank Waste Management Areas (WMA). For a more complete discussion of the goals of the Tank Farm Vadose Zone Project, see the overall work plan, Phase 1 RCRA Facility Investigation/Corrective Measures Study Work Plan for the Single-Shell Tank Waste Management Areas (DOE 1999). Specific details on the rationale for activities performed at WMA T-TX-TY are found in Crumpler (2002). To meet these goals, CH2M HILL Hanford Group, Inc. tasked scientists from Pacific Northwest National Laboratory (PNNL) to perform detailed analyses of vadose zone sediment, both uncontaminated and contaminated, in the vicinity of WMA T-TX-TY.

Specifically, this report contains all the geologic, geochemical, and selected physical characterization data collected on vadose zone sediment recovered from three sources: 1) new RCRA monitoring well, 299-W11-39, located just outside the WMA fenceline to the east and in the northern quadrant of tank T tank farm, 2) two boreholes that extended from ground surface down to refusal in the Ringold Formation Wooded Island member, and 3) the borehole 299-W10-196 that was emplaced in 1993 by Westinghouse Hanford Company (Freeman-Pollard et al. 1994). Drill locations for the boreholes were selected to evaluate the well-documented 1973 leak from tank T-106. Location maps are presented in Section 2. We have also provided our interpretation of the data in the context of determining the appropriate hydrogeologic model, the vertical extent of contamination, the migration potential of the contaminants that still reside in the vadose zone, and the correspondence of the contaminant distribution in the borehole sediment to groundwater plumes in the aquifer proximate and downgradient from the T tank farm.

This report is the second of two reports written to present recent data collected on vadose zone sediments, both uncontaminated and contaminated, from within WMA T-TX-TY. The first PNNL report (Serne et al. 2004) discussed the characterization of 1) uncontaminated sediment from a Resource Conservation and Recovery Act (RCRA) borehole (299-W10-27) that provides baseline data to compare against information from contaminated sediment; and 2) contaminated sediment obtained from three boreholes near tanks TX-104, TX-105, and TX-107. The two documents contain preliminary interpretations to identify the distribution of key contaminants within the vadose zone and to determine what their future migration potential could be. The two PNNL reports will be incorporated into Appendix B of the WMA T-TX-TY field investigation report (FIR) (scheduled for publication in 2005).

This document describes the characterization data collected and interpretations assembled by the Applied Geology and Geochemistry Group within the PNNL Environmental Technology Division. Based on a review of all available historical information on tank farm operations and vadose zone gross and spectral gamma monitoring of dry wells around the T tanks (see Crumpler 2002 and Wood et al. 2001), two areas of interests were identified. The historical data analysis found evidence that there were fluid losses at the T tank farm at both tanks T-103 and T-106. The latter is most well documented as to time, duration, and volume. 
Tank T-106 was placed in service in June 1947 and became a confirmed leaker in May 1973 at which time wastes were pumped out of it, rendering it inactive. Over its years of service numerous waste types were stored in the tank including first- and second-cycle decontamination wastes from T-plant bismuth phosphate processes, REDOX coating waste, and general decontamination wastes and waste from B-Plant fission product recovery activities. In March 1973, tank T-106 contained 78,000 gal of liquid and sludge, primarily from REDOX coating waste. In early April 1973, ion-exchange waste from fission product recovery operations was cascaded into tank T-106. In May and June 1973, two observations, a drop in tank T-106 liquid levels and elevated count rates in a nearby dry monitoring well [299-W10-51], led the operations staff to designate tank T-106 as a “confirmed” leaker on June 8, 1973. Based on dry well monitoring by gross gamma logging and some new borehole drilling (16 new dry wells emplaced between June and end of August 1973, some to a depth of $88 \mathrm{ft}$ bgs), Routson et al. (1979) estimated that the original leak contaminated a sediment volume of $\sim 25,000 \mathrm{~m}^{3}\left(883,000 \mathrm{ft}^{3}\right)$ and reached $108 \mathrm{ft}$ bgs. The leak volume was estimated at 115,000 gal and it contained 40,000 Ci of cesium-137, 14,000 Ci of strontium-90 and $4 \mathrm{Ci}$ of plutonium-239, 240 as well as 270,000 Ci of short-lived fission products, mostly ruthenium-106, as reported in Freeman-Pollard et al. (1993).

Between September 1973 and 1978, additional dry boreholes ( 25) were installed around tank T-106 and all existing and new boreholes were periodically monitored for gamma-emitting radionuclides. Routson et al. (1979) contains the results. Briefly, the conclusions are that the leak plume front moved horizontally between 1973 and 1974 but appeared to be relatively stationary from 1974 through 1978 . These conclusions are based on gross gamma counting, which was dominated by the short-lived ruthenium-106 isotope (half-life $\left[\mathrm{t}_{1 / 2}\right]=1 \mathrm{yr}$ ). The Freeman-Pollard et al. (1994) conclusions also suggest that there has not been significant vertical migration of mobile contaminants since the 1979 study of Routson et al.

The first new T WMA borehole in the CH2M HILL Hanford Group vadose zone characterization project, C4104, was drilled between April 4 and May 22, 2003 as close as possible ( 13 ft south) to the existing borehole, 299-W10-196 (drilled from November 13, 1992 through April 13, 1993), to allow comparisons to be made on the extent of vertical migration that occurred over the ten year time span. The second new borehole, C4105, was drilled between January 8 and March 12, 2003 downgradient of tank T-106 and about $87.7 \mathrm{ft}$ west of C4104 in hopes of quantifying the mobility and horizontal spreading of non-gamma emitting contaminants such as technetium-99, chromium, nitrate, fission products (strontium-90 and stable ruthenium and molybdenum) and actinides.

This report is divided into sections that describe the geology, geochemical characterization methods employed, geochemical results for the two new boreholes (C4104 and C4105), comparison between contaminant distributions for boreholes C4104 and 299-W10-196 (which are 13 feet apart and drilled $\sim 10$ years apart), and the correlation between the existing vadose zone porewater with current and past groundwater contamination characteristics. In addition, a summary and conclusions, references, and appendixes with additional geology details and sediment photographs are provided.

English units are used in this report for descriptions and discussions of drilling activities and samples because that is the system of units used by drillers to measure and report depths and well construction details. To convert feet to meters, multiply by 0.3048 ; to convert inches to centimeters, multiply by 2.54 . The metric system is used in this report for all other purposes. 


\subsection{Geology}

The discussion of the geology of T Tank Farm, presented in this report, focuses on the results of two new boreholes (C4104 and C4105) drilled to further investigate a 1973 tank leak from 241-T-106 single-shell tank (ARHCO 1973; Routson et al. 1979; Brown et al. 1979). The rationale for the location and methods used to drill and sample the new holes was presented in Crumpler (2002). For geochemical comparison, background samples were collected from a clean, uncontaminated RCRA borehole (299-W11-39), drilled just outside the northeastern boundary of T Tank Farm. In addition, extensive physical and chemical characterization from a fourth borehole (299-W10-196), previously drilled in 1993 (Freeman-Pollard et al. 1994) adjacent to new probe hole C4104, are integrated into our analysis.

The geology of the vadose zone underlying the 241-T Tank Farm (T Tank Farm) forms the framework through which contaminants that leaked from single-shell tanks or their ancillary piping and junction boxes move, and is fundamental to the understanding of migration and distribution of the contamination in the vadose zone. Of particular interest are the interrelationships between the coarser and finer-grained facies, and the degree of contrast in their physical, chemical, and radiological properties.

This section discusses 1) the regional geologic setting and the geology of the T Tank Farm, 2) the geohydrologic characterization methods and background information on an older borehole (299-W10-196), and 3) three recently completed boreholes sampled for physical, chemical, and radiological characterization.

\subsection{Regional Geologic Setting}

The Hanford Site is located within the Columbia Plateau of southeastern Washington State. This broad plain, situated between the Cascade Mountains to the west and the Rocky Mountains to the east, is underlain by a thick sequence of Miocene-age tholeiitic basalt flows (the Columbia River Basalt Group). The Columbia River Basalt Group is more than 3,000 m thick and forms the bedrock beneath southeastern Washington. Sedimentary interbeds are sandwiched between the basalt flows, particularly in the uppermost Saddle Mountains Basalt. These interbeds along with the porous basalt flow tops and flow bottoms form confined aquifers that extend across the Pasco Basin (DOE 1988).

The basalt flows have been folded and faulted, creating broad structural and topographic basins, separated by asymmetric anticlinal ridges. Sediments of late Miocene, Pliocene, and Pleistocene age have accumulated up to 1700 - $\mathrm{ft}$ (520 m) thick in some of these basins. The Hanford Site lies within the Pasco Basin, one of the larger basins. The Pasco Basin is partially bisected by the Umtanum-Gable Mountain anticline creating two subordinate synclinal basins. The largest of these is the Cold Creek syncline, which is further subdivided into two sub-basins, the Wye Barricade depression and the Cold Creek depression. The Cold Creek depression underlies the principal waste management areas (WMA) (200 East and 200 West Areas) of the Hanford Site, including the T Tank Farm.

The generalized stratigraphy beneath the Hanford Site consists of, in ascending order, the Columbia River Basalt Group, the Ringold Formation, the Cold Creek unit (formerly named the Plio-Pleistocene unit), and the Hanford formation. The Cold Creek unit and Hanford formation are both informal designations. A geologic cross section showing the stratigraphic relationships of these units in the western Pasco Basin is presented in Figure 2.1. Thin veneers of Holocene alluvium, colluvium, and/or 


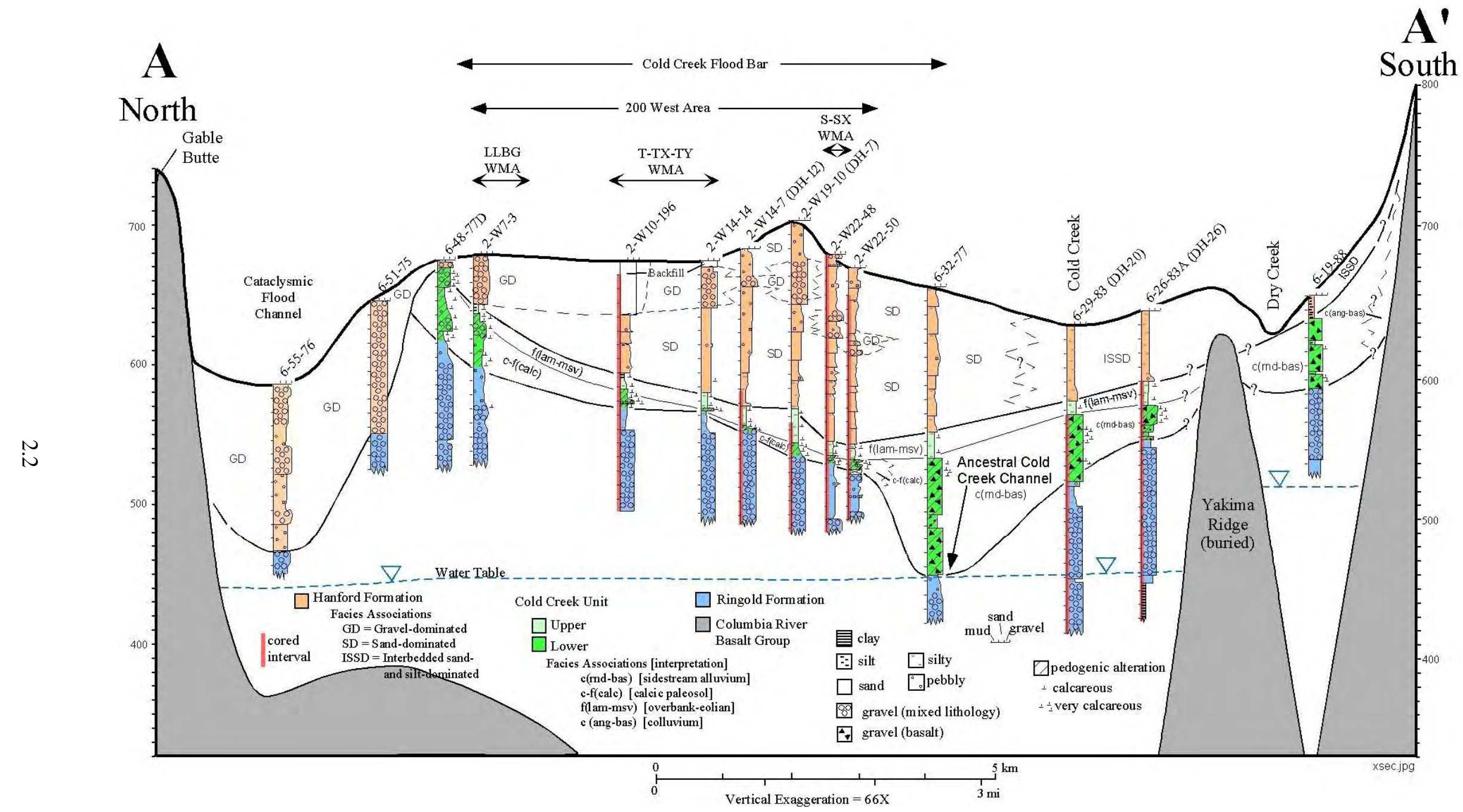

Figure 2.1. Stratigraphic Cross Section of the Vadose Zone Within the Central Pasco Basin. The study area (T Tank Farm) is located left of center along this cross section. Cross section is located in Figure 2.2. 
eolian sediments discontinuously overlie these principal geologic units. The regional suprabasalt stratigraphy is described in more detail elsewhere (Lindsey 1995; DOE 1988, 2002).

\subsubsection{Ringold Formation}

The Ringold Formation records fluvial-lacustrine deposition associated with the ancestral Columbia River drainage system, following the last eruption of basalt at the Hanford Site about 10.5 m.y. ago (Tallman et al. 1981; DOE 1988; Lindsey et al. 1994a; Lindsey 1995). Deformation of the Yakima folds, which began in the middle Miocene Epoch, concurrent with the Columbia River basalt volcanism, continued into Ringold time. As a result, the centers of down-warped basins received more sediments than the margins. The Ringold Formation is up to 600-ft (185 m) thick in the center of the basin and pinches out against the basin-bounding basalt ridges.

The Ringold Formation consists of semi-indurated clay, silt, fine- to coarse-grained sand, and variably cemented granule to cobble gravel. Ringold Formation sediments have been classified into five sediment facies associations: 1) fluvial gravel, 2) fluvial sand, 3) overbank deposits, 4) lacustrine deposits, and 5) alluvial fan deposits. See Lindsey $(1995,1996)$ and Lindsey et al. (2001) for more detailed descriptions of these facies. The unconfined aquifer within the 200 West Area and T Tank Farm lies entirely within the Ringold Formation (Figure 2.1)

\subsubsection{Cold Creek Unit}

After a period of post-Ringold incision, the eroded surface of the Ringold Formation was locally weathered and/or covered with accretionary deposits of the Cold Creek unit. These deposits consist of fluvial, eolian and/or colluvial sediment, often pedogenically altered (DOE 2002). The Cold Creek unit includes those deposits formerly referred to as the "Plio-Pleistocene unit" and "pre-Missoula Gravels," as well as the "early Palouse soil" and "caliche layer" within the 200 West Area. The new name, Cold Creek unit (CCU), was given to these deposits because recent studies suggest this unit is all of late Pliocene age. The Cold Creek unit is a more-appropriate name choice because it is independent of age and geographically better describes the unit, which is generally confined to the boundaries of the Cold Creek syncline within the west-central Pasco Basin (DOE 2002).

Five different facies of the CCU have been differentiated based on grain size, sedimentary structure, sorting, roundness, fabric, and mineralogic composition (DOE 2002). These facies include:

1) fluvial-overbank and/or eolian, 2) calcic paleosol, 3) mainstream alluvium, 4) colluvium, and 5) sidestream alluvium. Facies of the CCU within the T Tank Farm are generally limited to the fluvial-overbank and/or eolian facies (upper Cold Creek subunit), which overlies a calcic paleosol facies (lower Cold Creek subunit). These facies of the Cold creek unit are limited to the western portion of the Hanford Site. On the other hand, other facies, especially the mainstream alluvial facies, appear to have a much broader distribution (DOE 2002).

\subsubsection{Hanford Formation}

The Hanford formation is an informal name used within the Pasco Basin to describe Pleistocene cataclysmic flood deposits (Tallman et al. 1979, 1981; DOE 1988, 2002). Ice-Age floods originated from outbursts of glacial Lake Missoula, as well as other ice-dammed lakes (Baker and Bunker 1985), pluvial 
lake Bonneville (O’Connor 1993), or possible sub-glacial floods (Shaw et al. 1999) associated with the Cordilleran Ice Sheet. The Hanford formation may include some minor fluvial, colluvial, and/or eolian deposits interbedded with flood deposits.

Recently, the possibility of converting the Hanford formation into a formalized stratigraphic unit was investigated (Bjornstad et al. 2002; DOE 2002). However, the consensus is that the Hanford formation cannot be formalized as a stratigraphic unit at this time, even though it is a mappable unit, for several reasons as specified in the International Stratigraphic Guide (Salvador 1994). These include 1) the Hanford formation, as defined, is based on a common time period and depositional environment, which are invalid formalization criteria, 2) the Hanford formation is very diverse lithologically (i.e., facies range from bouldery gravels to silts); geologic formations, as defined in the stratigraphic code, should have similar lithologic properties, and 3) there is a lack of complete reference sections with which to define and characterize the Hanford formation. For example, the range of internal variability within the Hanford formation often exceeds that between adjacent stratigraphic units (e.g., CCU and Ringold Formation). Therefore, for the present, the Hanford formation should only be used informally to describe cataclysmic flood deposits within the Pasco Basin.

As mentioned above, the Hanford formation consists predominantly of unconsolidated sediments that cover a wide range in grain size, from boulder-size gravel to sand, silty sand, and silt. The sorting ranges from poorly sorted (for gravel facies) to well-sorted (for fine sand to silt facies). Traditionally the Hanford formation has been subdivided into three lithofacies (gravel-, sand-, and silt-dominated), which grade into one another, both vertically and laterally (DOE 1988, 2002; Baker et al. 1991; Lindsey et al. 1994a). These lithofacies may interfinger with or grade from gravel-dominated to sand-dominated facies, or sand-dominated to silt-dominated facies, but rarely from gravel-dominated to silt-dominated facies.

An interbedded sand- and silt-dominated facies (DOE 2002) is stratigraphically equivalent to Touchet Beds (Flint 1938). In the late 1980s, these deposits began to be called by a variety of other informal names, including "slackwater facies” (Moody 1987; Lindsey et al. 1992b; Connelly et al. 1992a; Last et al. 1989; Smith 1993), "silt-dominated facies" (Lindsey et al. 1992a, 1994b; Connelly et al. 1992b), “silty facies” (Lindsey et al. 1994a), and “rhythmite facies” (Baker et al. 1991). Interbedded sand- and silt-dominated facies occur as sequences of rhythmic, graded beds that range from 0.1 to $1 \mathrm{~m}$ ( 0.3 to $3.3 \mathrm{ft}$ ) in thickness and are characterized by loose, horizontal- to ripple-laminated, grayish, coarse to medium sand, grading up into brownish, cohesive, fine sand to silt.

Sand-dominated facies of the Hanford formation (Lindsey et al. 1992a, 1992b, 1994a, 1994b; Connelly et al. 1992a, 1992b) consist of relatively thick ( $\geq 1 \mathrm{~m}$ ), predominantly horizontally laminated, loose, basalt-rich, fine- to coarse-grained sand, sometimes grading upward into a thinner sequence of ripple-laminated fine sand to silt. The sand-dominated facies have also been referred to as the "transitional sand facies" (Reidel et al. 1992; Fecht and Weekes 1996) and the "plane-laminated sand facies” (Baker et al. 1991). Typically, sand-dominated facies contain approximately equal amounts of mafic (i.e., basalt) and quartz-feldspar grains (Tallman et al. 1979). This composition gives the Hanford formation its characteristic "salt and pepper" appearance that is frequently noted in drillers' and geologists’ logs.

The gravel-dominated facies (Lindsey et al. 1992a, 1992b, 1994b; Connelly et al. 1992a, 1992b) of the Hanford formation have been variously named "Pasco gravels” (Brown 1970; Myers and Price 1979; Tallman et al. 1979, 1981; DOE 1984), "Missoula flood gravels” (Webster and Crosby 1982), 
“coarse-grained main-channel facies" (DOE 1988, Last et al. 1989), and "coarse-grained flood gravels” (Moody 1987; Baker et al. 1991). Gravel-dominated facies consist of loose, massive to horizontal and large-scale, planar-tabular cross-bedded, poorly sorted mixtures of gravel, sand, and silt. Gravel clasts in flood gravels generally consist of 50\% to 75\% subangular to subrounded basalt (DOE 2002). Rounded rip-up clasts of caliche and/or semi-consolidated silt and clay are common in the gravel-dominated facies.

Below an elevation of approximately $300 \mathrm{~m}(1,000 \mathrm{ft})$ within the Pasco Basin, the Hanford formation unconformably overlies the Cold Creek unit (CCU) and, where the CCU is eroded, lies directly on the Ringold Formation or Columbia River basalt. Within the central Pasco Basin up to $100 \mathrm{~m}$ of flood deposits accumulated along Priest Rapids, Cold Creek, and Gable Mountain flood bars, which developed downstream of constrictions or obstructions to the flow of cataclysmic floods through the basin (Figure 2.2). The bulk of the vadose zone at Hanford lies within sediments of the Hanford formation.

\subsection{Geologic Setting of the T Tank Farm}

The geology in the vicinity of the T Tank Farm has been described in numerous reports (ARHCO 1973; Price and Fecht 1976; Brown et al. 1979; Tallman et al. 1979; Last et al. 1989; Bjornstad 1990; Connelly et al. 1992a; Freeman-Pollard et al. 1994; DOE/GJO 1999; Randall et al. 2000; Lindsey et al. 2001; Sobczyk 2001; Wood et al. 2001). A generalized stratigraphic column for the T Tank Farm is illustrated in Figure 2.3.

More detailed descriptions of the vadose zone units used in this report are presented in Table 2.1. This report follows the standardized stratigraphic nomenclature recommended by DOE (2002); therefore, the names for post-Ringold Formation stratigraphic units may be different than the terminology used in previous reports.

The subsurface geology of the T Tank Farm is interpreted from dozens of boreholes drilled in the area. A total of 67 dry wells were constructed in the early to mid 1970s to monitor for leaks from the twelve 530,000 gallon and four smaller, 55,000 gallon single-shell tanks within the T Tank Farm (DOE/GJO 1999a). Seven of the 12 larger tanks are designated assumed leakers; the remaining tanks within T Tank Farm are classified as sound. The shallow vadose-zone holes served as primary and secondary leak-detection devices. Most of the dry wells extend to depths of between 80 and $100 \mathrm{ft}$ bgs, while the groundwater is approximately $220 \mathrm{ft}$ bgs. While there are no wells that extend to the bottom of the uppermost aquifer within T Tank Farm, seventeen groundwater monitoring wells are located around the perimeter. Locations of the monitoring wells in the vicinity of the T Tank Farm, and other key boreholes used in this report, are shown in Figure 2.4.

\subsubsection{Stratigraphy and Lithology}

Stratigraphic terminology of the vadose zone used in this report is presented in Table 2.1. The tank farm was excavated into the Pleistocene-age Hanford formation and Holocene eolian deposits that mantle the central portion of the Cold Creek flood bar. The depth to groundwater in the vicinity of the T Tank Farm is about $220 \mathrm{ft}(67 \mathrm{~m})$. Stratigraphic units that make up the vadose-zone units beneath the tank farm include in descending order: 1) recent deposits, 2) Hanford formation, 3) Cold Creek unit, and 4) Ringold Formation. 


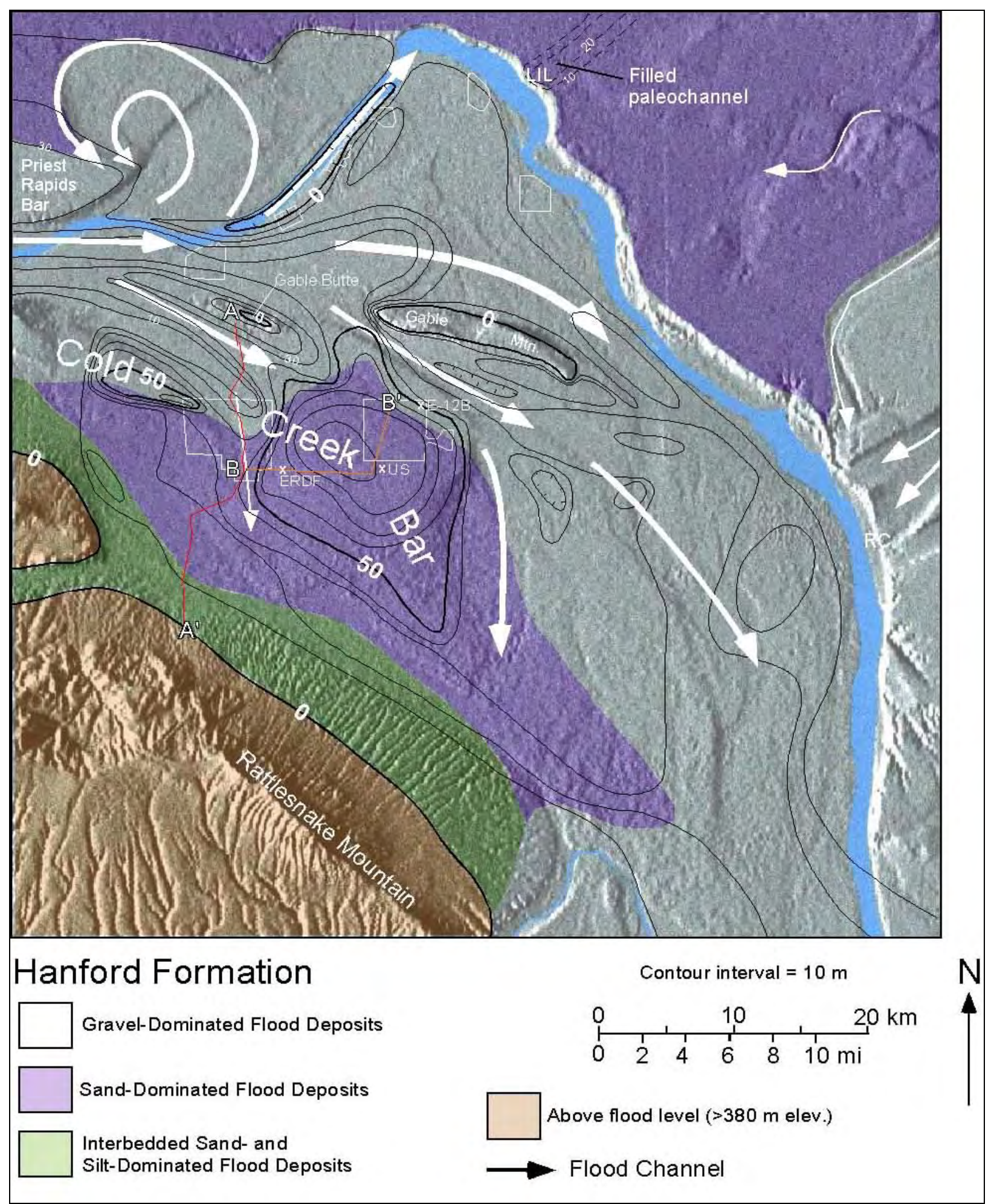

Figure 2.2. Thickness and Distribution of Cataclysmic Flood Deposits (i.e., Hanford Formation) Within the Central Pasco Basin. Cross section A-A' is shown in Figure 2.1. 
STRATIGRAPHIC COLUMN FOR 241-T TANK FARM

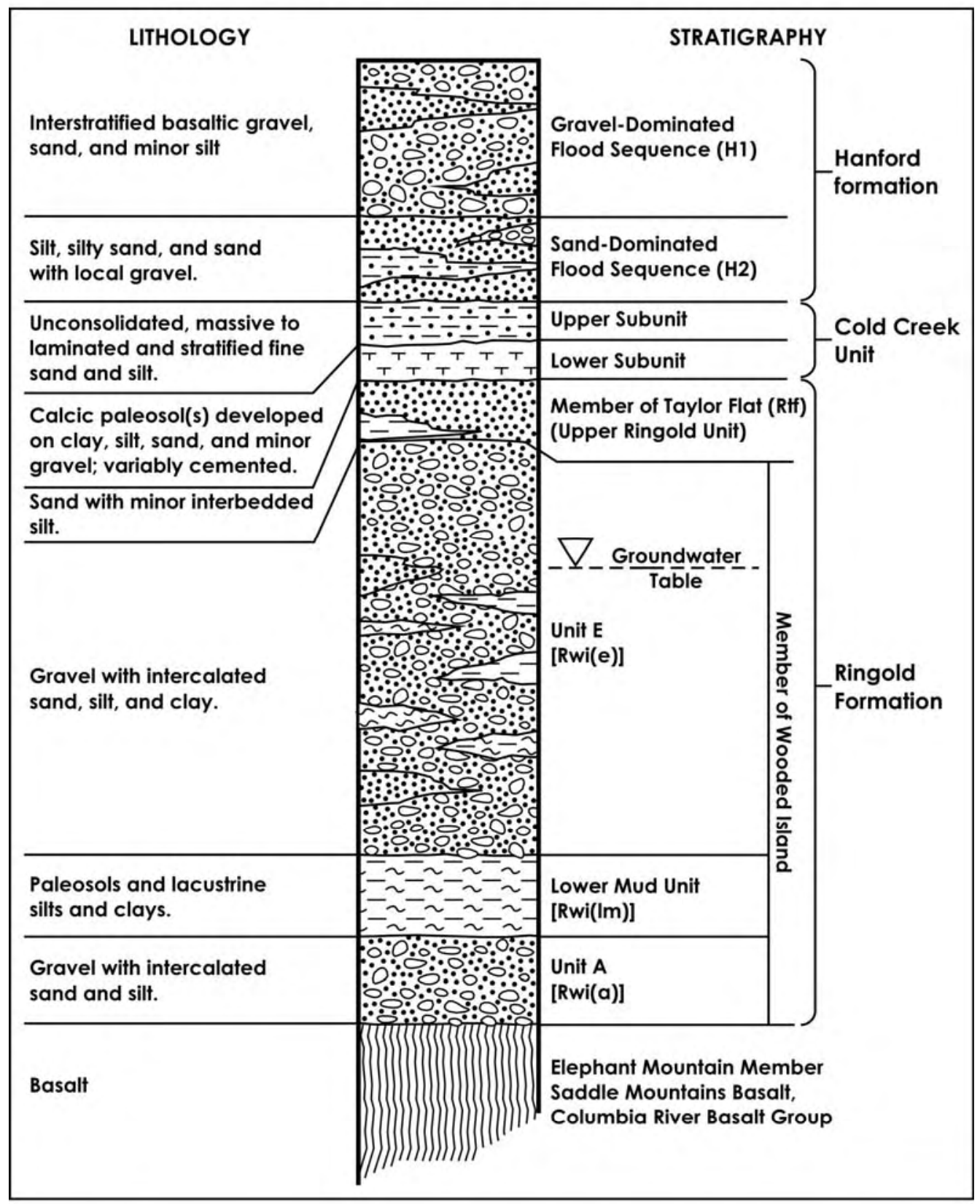

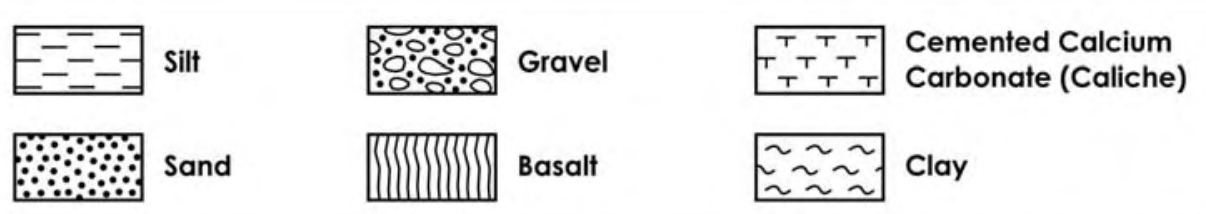

2002/DCL/T/003 (09/03)

Figure 2.3. Generalized, Composite Stratigraphy for the Late-Cenozoic Sediments Overlying the Columbia River Basalt Group at the T Tank Farm (Modified After Wood et al. 2001) 
Table 2.1. Stratigraphic Terminology for the Vadose Zone Beneath T Tank Farm

\begin{tabular}{|c|c|c|c|c|}
\hline Stratigraphic Symbol & Formation & Facies / Subunit & Description & Genesis \\
\hline Backfill & NA & Backfill & $\begin{array}{l}\text { Gravel-dominated sequence consisting of poorly to moderately } \\
\text { sorted cobbles, pebbles, and coarse to medium sand with some } \\
\text { silt derived from coarse-grained Hanford formation (H1 Unit) } \\
\text { excavated around tanks (Price and Fecht 1976; Wood et al. } \\
\text { 2001). }\end{array}$ & Anthropogenic \\
\hline H1 & & $\begin{array}{l}\text { Unit H1 (Gravel- } \\
\text { dominated facies } \\
\text { association) }\end{array}$ & $\begin{array}{l}\text { Gravel-dominated flood sequence composed of mostly poorly } \\
\text { sorted, basaltic, sandy gravel to silty sandy gravel. Equivalent } \\
\text { to the upper gravel sequence discussed by Last et al. (1989), the } \\
\text { Qfg documented by Reidel and Fecht (1994), Hanford Gravel } \\
\text { Unit A of Johnson et al. (1999), coarse-grained sequence (H1 } \\
\text { unit) of Wood et al. (2001) and gravel facies of unit H1 of } \\
\text { Lindsey et al. (2001), and gravel-dominated facies association } \\
\text { of DOE (2002). The majority of this unit was excavated out } \\
\text { and is missing from beneath T Tank Farm. }\end{array}$ & $\begin{array}{l}\text { Cataclysmic flood } \\
\text { deposits (high-energy) }\end{array}$ \\
\hline $\mathrm{H} 2$ & Hantord formation & $\begin{array}{l}\text { Unit H2 (Sand- } \\
\text { dominated facies } \\
\text { association) }\end{array}$ & $\begin{array}{l}\text { Sand-dominated flood sequence composed of mostly horizontal } \\
\text { to tabular cross-bedded sand to pebbly sand. Some sand beds } \\
\text { capped with thin layers of silty sand to sandy silt. Equivalent to } \\
\text { Hanford Sands of Johnson et al. (1999), Fine-Grained Sequence } \\
\text { (H2 unit) of Wood et al. (2001) and unit H2 of Lindsey et al. } \\
\text { (2001), the sandy sequence of Last et al. (1989) and Lindsey et } \\
\text { al. (1992a), and Qfs documented by Reidel and Fecht (1994), } \\
\text { and sand-dominated facies association of DOE (2002). The H2 } \\
\text { unit was subdivided into a lower and upper subunit by Sobczyk } \\
\text { (2001). }\end{array}$ & $\begin{array}{l}\text { Cataclysmic flood } \\
\text { deposits (moderate } \\
\text { energy) }\end{array}$ \\
\hline
\end{tabular}


Table 2.1. (contd)

\begin{tabular}{|c|c|c|c|c|}
\hline Stratigraphic Symbol & Formation & Facies / Subunit & Description & Genesis \\
\hline $\mathrm{CCU}_{\mathrm{u}}$ & \multirow{2}{*}{ Cold Creek Unit } & Upper subunit & $\begin{array}{l}\text { Silty sequence consisting of massive to interstratified, well- } \\
\text { sorted silt and fine sand. Uncemented but may be moderately } \\
\text { to strongly calcareous from detrital } \mathrm{CaCO}_{3} \text {. Equivalent to the } \\
\text { "early Palouse soil” (Brown 1970; Tallman et al. 1979; DOE } \\
\text { 1988; and DOE-GJO 1997) and the Hanford Formation(?)/Plio- } \\
\text { Pleistocene (?) deposits (H/PP) of Wood et al. (2001). Also } \\
\text { equivalent to the upper Plio-Pleistocene unit (Lindsey et al. } \\
\text { 2001; Sobczyk 2001) and the fine-grained, laminated to } \\
\text { massive [CCUf(lam-msv)] lithofacies of the Cold Creek unit } \\
\text { (DOE 2002). Same as PPu of Lindsey et al. (2001). }\end{array}$ & $\begin{array}{l}\text { Post-Ringold Fm. eolian } \\
\text { and/or overbank alluvial } \\
\text { deposits }\end{array}$ \\
\hline $\mathrm{CCU}_{\mathrm{l}}$ & & Lower subunit & $\begin{array}{l}\text { Calcic paleosol sequence, consisting of interbedded layers of } \\
\text { pedogenically altered to unaltered gravel, sand, silt, and/or clay, } \\
\text { cemented together with one or more layers of secondary } \\
\mathrm{CaCO}_{3} \text {, originally referred to as "caliche” (Brown 1959). Since } \\
\text { then the name has evolved from the Plio-Pleistocene unit } \\
\text { (Bjornstad 1984, DOE 1988, DOE/GJO 1997, Slate 2000), the } \\
\text { Plio-Pleistocene calcrete facies (DOE 1988, Wood et al. 2001), } \\
\text { the lower Plio-Pleistocene unit (Lindsey et al. (2001), and the } \\
\text { coarse- to fine-grained, CaCO }{ }_{3} \text {-cemented lithofacies [CCUc- } \\
\text { f(calc)] of the Cold Creek unit (DOE 2002). Same as PPc of } \\
\text { Lindsey et al. (2001). }\end{array}$ & $\begin{array}{l}\text { Calcic paleosols } \\
\text { developed on eroded } \\
\text { Ringold or post-Ringold } \\
\text { Fm. eolian and/or fluvial } \\
\text { deposits }\end{array}$ \\
\hline $\mathrm{R}_{\mathrm{tf}}$ & Ringold Formation & $\begin{array}{l}\text { Member of } \\
\text { Taylor Flat }\end{array}$ & $\begin{array}{l}\text { Fine-grained Ringold Formation sequence consisting of } \\
\text { interstratified, well bedded fine to coarse sand to silt. } \\
\text { Equivalent to the upper Ringold unit (DOE 1988). }\end{array}$ & $\begin{array}{l}\text { Ancestral Columbia } \\
\text { River System fluvial } \\
\text { channel, crevasse splay, } \\
\text { and/or overbank } \\
\text { deposits }\end{array}$ \\
\hline
\end{tabular}




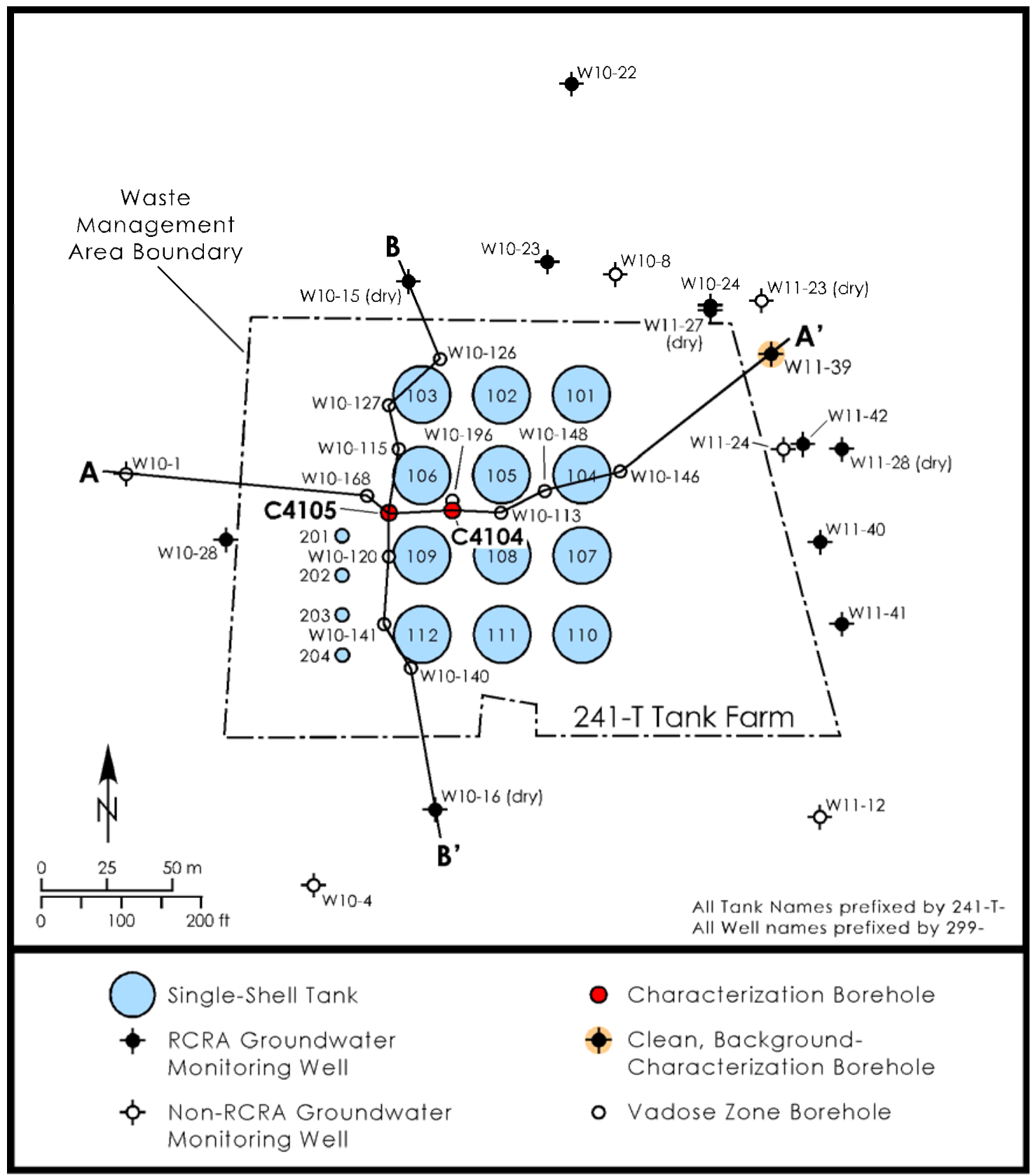

$2004 / \mathrm{DCL} / \mathrm{T} / 002(02 / 06)$

Figure 2.4. Selected Borehole Location Map for the T Tank Farm. Cross sections $A-A^{\prime}$ and $B-B^{\prime}$ are shown in Figures 2.5 and 2.6, respectively.

Two geologic cross sections (Figures 2.5 and 2.6) are presented for the T Tank Farm. The most recent investigations on the geology of T Tank Farm include those reported in Sobczyk (2001), Wood et al. (2001), and Lindsey et al. (2001). 


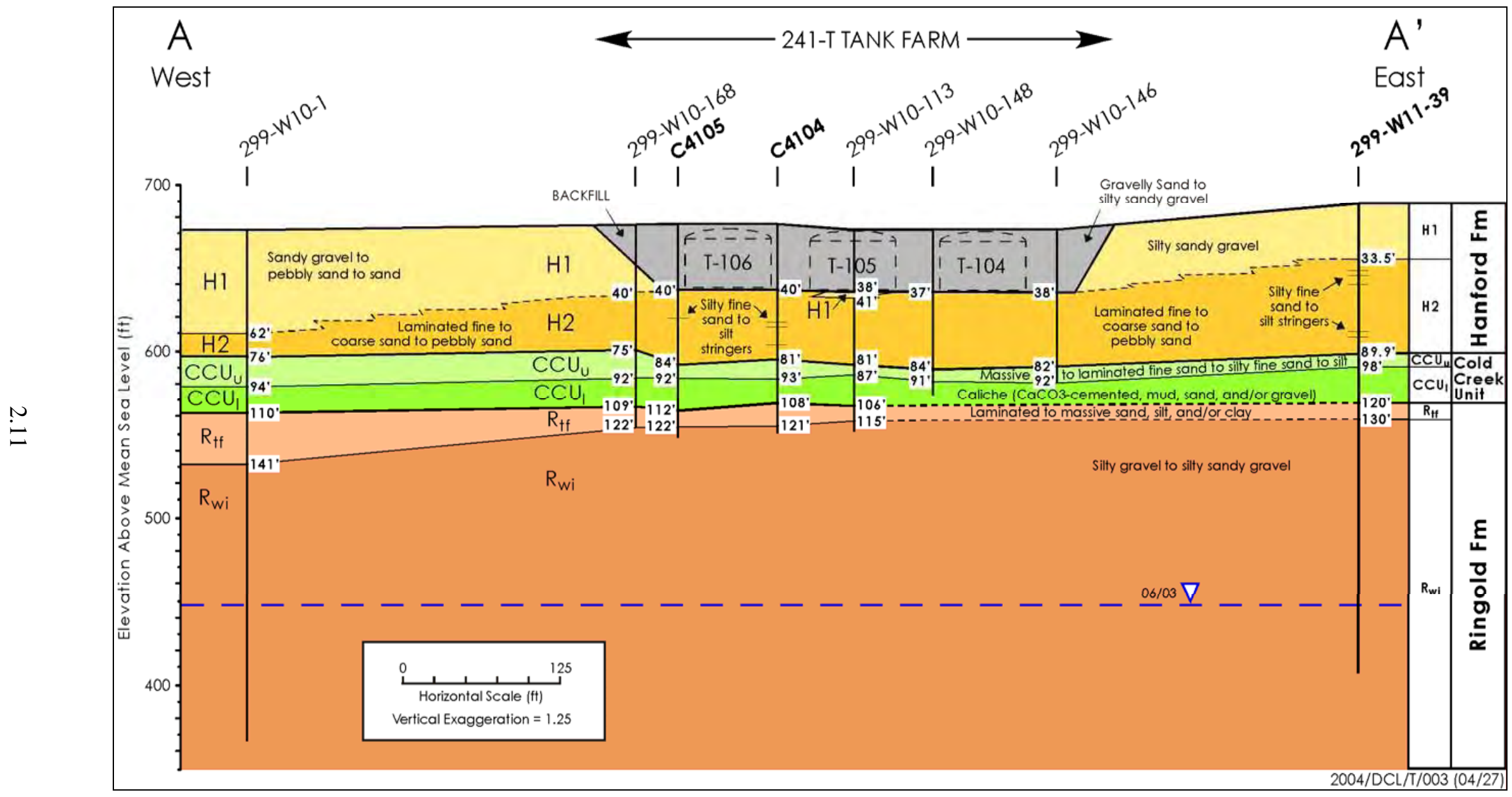

Figure 2.5. East-West Hydrogeologic Cross Section A-A’ Across the T Tank Farm. Located in Figure 2.4. 


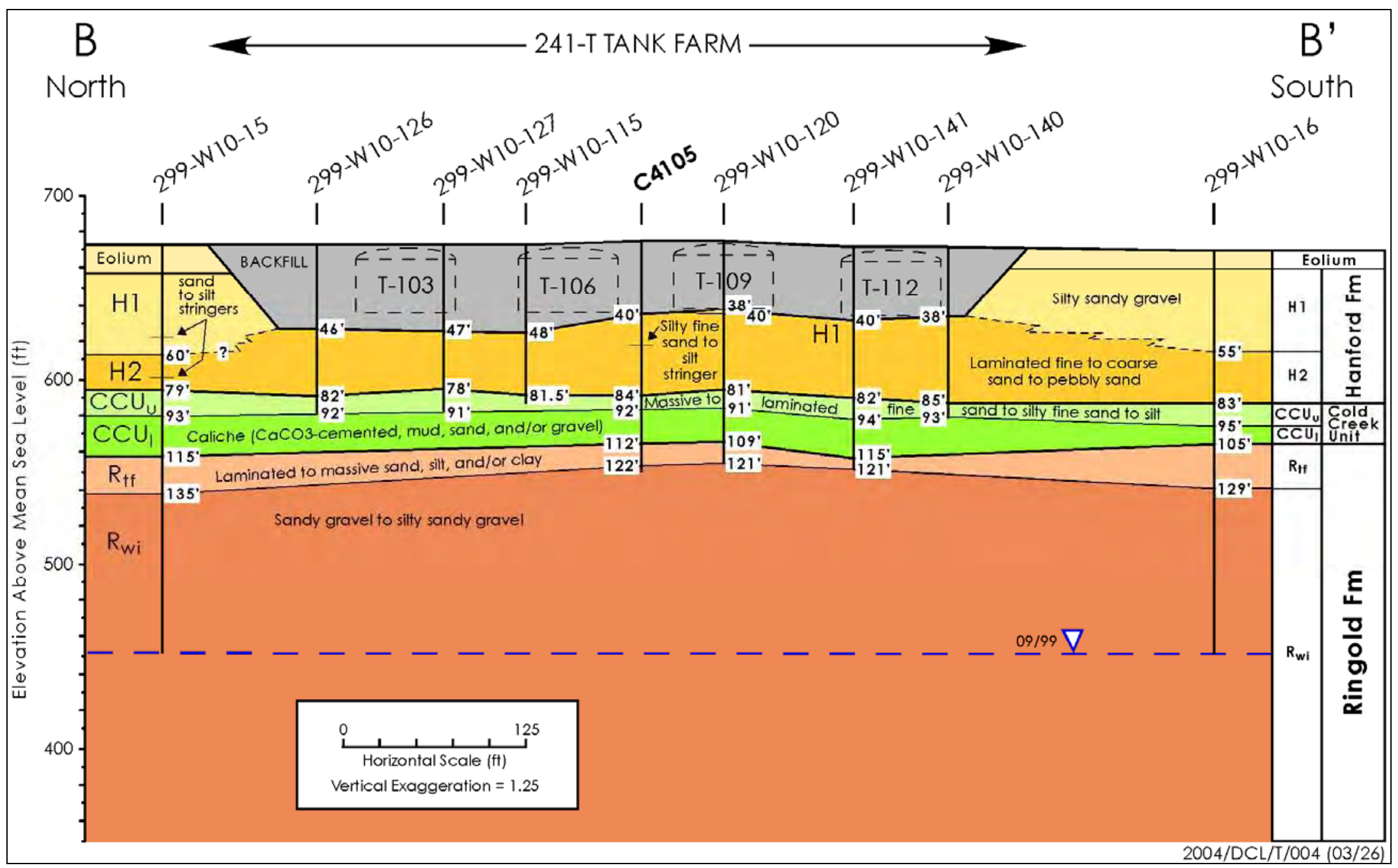

Figure 2.6. North-South Hydrogeologic Cross Section B-B’ Across the T Tank Farm. Located in Figure 2.4. 


\subsubsection{Holocene Deposits}

Holocene deposits within the T Tank Farm consist of backfill material emplaced around the tanks. This backfill material is composed of the mostly gravel-dominated $\mathrm{H} 1$ unit of the Hanford formation, perhaps mixed with eolian materials, which blanketed the area with up to $5 \mathrm{ft}(2 \mathrm{~m})$ of wind-blown sand and silt prior to construction of T Tank Farm. Bottoms of single-shell tanks within the T Tank Farm were placed at a depth of $37 \mathrm{ft}$ below ground surface (Crumpler 2002). During tank installation, up to $41 \mathrm{ft}$ of the Hanford formation (mostly $\mathrm{H} 1$ unit) were disturbed and/or removed and stockpiled for later placement around and over the underground storage tanks. The backfill consists of a mostly a loose, poorly sorted gravel mixed with variable amounts of sand and silt.

\subsubsection{Hanford Formation}

The Hanford formation, which comprises the upper half of the vadose zone in the T Tank Farm, consists of two informal subunits: the $\mathrm{H} 1$ and $\mathrm{H} 2$ units. The $\mathrm{H} 2$ unit, a sand-dominated sequence, underlies the gravel-dominated H1 unit. During excavation of the T Tank Farm, most of the Hanford formation $\mathrm{H} 1$ unit was removed, so that only the $\mathrm{H} 2$ unit occurs beneath backfill material emplaced around the tanks (Figures 2.5 and 2.6).

\subsection{Gravel-Dominated Sequence (H1 Unit)}

The Hanford formation $\mathrm{H} 1$ unit is present around the perimeter of the T Tank Farm and locally beneath the backfill in a few places within the tank farm (Figures 2.5 and 2.6). Most of the material used for backfill around the tanks is from the gravels and sands of the Hanford formation H1 unit removed during tank installation.

\subsection{Sand-Dominated Sequence (H2 Unit)}

The Hanford formation $\mathrm{H} 2$ unit consists of predominantly sand-dominated facies of the Hanford formation. Cementation is very minor or absent, and total calcium carbonate-content is generally only a few weight percent or less.

The Hanford formation H2 unit is continuous beneath the T Tank Farm; the base is well defined by a change from well-stratified fine-coarse-grained "salt and pepper"-like sands to silt-dominated deposits of the upper Cold Creek unit (Figure 2.7). Normally, a characteristic increase in total natural gamma and/or potassium- $40\left({ }^{40} \mathrm{~K}\right)$ activity, as well as moisture occurs at this contact.

\subsubsection{Cold Creek Unit}

The Cold Creek unit is a continuous layer beneath the T Tank Farm that lies midway between the ground surface and the water table (Figures 2.5 and 2.6). The Cold Creek unit lies unconformably on the tilted and truncated Ringold Formation that formed following incision and down cutting by the ancestral Columbia River toward the end of the Pliocene Epoch about 2.5 to 3.4 million years ago. Two distinct subunits of the Cold Creek unit are present beneath the T Tank Farm, as well as most of the 200 West Area (DOE 2002). The lower subunit consists of a variably cemented calcic paleosol sequence, equivalent to the CCUf-c(calc) lithofacies (DOE 2002). The upper subunit consists of unconsolidated, fine-grained, fluvial-overbank and/or eolian sediments, equivalent to the CCUf(lam-msv) lithofacies. 


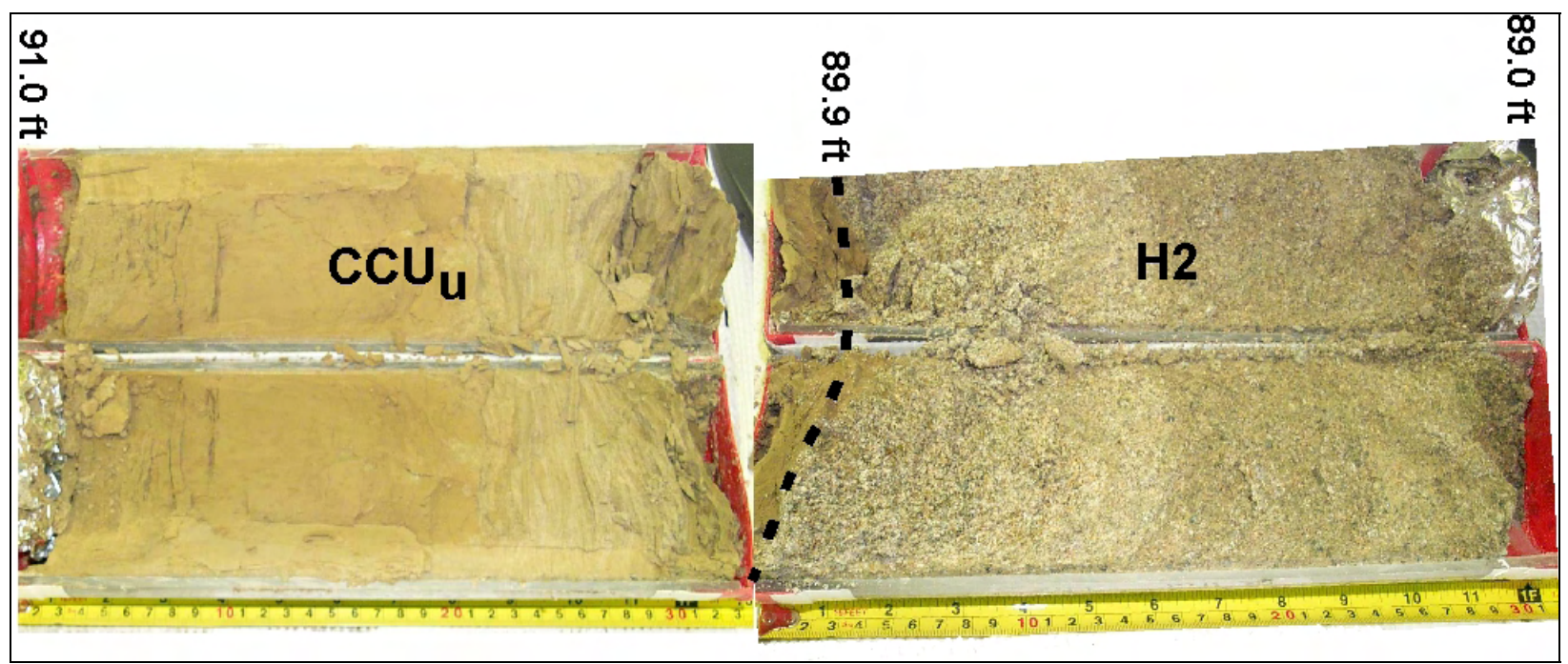

Figure 2.7. Sharp Contact at $89.9 \mathrm{ft}$ bgs between the Hanford formation $\mathrm{H} 2 \mathrm{unit}$ and the upper Cold Creek subunit $\left(\mathbf{C C U}_{\mathbf{u}}\right)$ in Borehole 299-W11-39. Loose, fine- to mediumgrained, "salt and pepper" sands of the H2 unit overlie compacted, yellowish-brown, laminated to massive, silty fine sand to fine sandy silt of the CCUu. The top of core is to the right.

\subsection{Upper Cold Creek Subunit $\left(\mathrm{CCU}_{\mathrm{u}}\right)$}

The unconsolidated, silt-rich sediments of the upper Cold Creek subunit consist of cohesive, compacted, massive to laminated and stratified, fine-grained sand and silt (Figure 2.7). This brown- to yellow-colored unit is also characterized as micaceous, very well sorted, and moderately to strongly calcareous, with relatively high natural background-gamma activity (DOE 2002). It is equivalent to the “early Palouse soil” (Brown 1960; Tallman et al. 1979, 1981; Bjornstad 1984, 1990; DOE 1988, Last et al. 1989; Lindsey et al. 1992b, Delaney et al. 1991, DOE/GJO 1999) and the "Hanford Formation (?)/Plio-Pleistocene (?) deposits" of Wood et al. (2001), and most recently identified as the CCUf (lam-msv) facies of the Cold Creek unit by DOE (2002). The upper CCU ranges from about 5-15 ft thick in the vicinity of the T Tank Farm, and dips slightly to the southwest beneath the T-TX-TY Waste Management Area (Wood et al. 2001; Lindsey et al. 2001).

While the upper CCU was originally interpreted as an eolian deposit, which was derived from the reworking of the underlying Ringold Formation and/or caliche (Brown 1960), more recent investigations indicate this facies may contain other fine-grained deposits besides eolian silt and fine sand (Lindsey et al. 1994b; Slate 1996). For example, recent studies in the S-SX Waste Management Area (Lindsey et al. 2000; Serne et al. 2002) indicate that the upper CCU is composed of mostly intercalated layers of fine sand and silt with some weakly developed paleosols, which is more characteristic of overbank-type alluvial deposits than eolian deposits. Regardless of its exact stratigraphic relationship and origin, the upper CCU is a distinctive lithostratigraphic unit, and it has a major influence on the moisture and contaminant distribution within the vadose zone. 


\subsection{Lower Cold Creek Subunit $\left(\mathrm{CCU}_{\mathrm{I}}\right)$}

Diagnostic features of the lower CCU include: (1) advanced induration with pedogenic calcium carbonate, (2) white color, (3) presence of pedogenic structures (e.g., root traces, animal burrows, or soil horizonation), as well as 4) erratic geophysical log response on natural-gamma, KUT $\left({ }^{40} \mathrm{~K},{ }^{238} \mathrm{U},{ }^{232} \mathrm{Th}\right)$, and neutron-moisture logs (DOE 1988; Bjornstad 1990; Sobczyk 2001; DOE 2002).

The upper boundary of the $\mathrm{CCU}_{1}$ subunit is normally sharp and distinct in contrast to the lower boundary, which is commonly gradational as is typical of paleosols. The upper CCU is easily distinguished from the lower CCU based on the sharp contrast in color, degree of cementation, as well as from geophysical logs. Furthermore, while the upper CCU is generally compacted and cohesive, it is uncemented, unlike the underlying pedogenically altered lower CCU. Even though the upper CCU may contain moderate to high concentrations of calcium carbonate, the carbonate is evenly disseminated as detrital grains. The bulk of the detrital calcium carbonate in the upper CCU is likely derived from the disintegration and mechanical reworking/redeposition of the underlying lower CCU, where discrete calcium carbonate-rich zones developed diagenetically as a result of pedogenesis. The top of the lower CCU is well defined as the top of the first pedogenically altered, carbonate-rich, cemented zone, accompanied by a sudden drop in natural-gamma and/or potassium-40 activity.

The lower CCU represents a highly weathered paleosurface that developed unconformably on top of the Ringold Formation (Brown 1959, 1960) following a period of erosion within the central Pasco Basin. Other names used to describe the lower CCU have included "caliche" (Brown 1959), and "calcrete" (DOE 1988). The lower CCU consist of basaltic to quartzitic gravels, sands, silt, and clay that are cemented with one or more layers of secondary, pedogenic calcium carbonate. Soil development associated with the lower CCU is frequently overprinted onto the underlying Ringold Formation. The concentration of calcium carbonate within the lower CCU is generally 20 to $30 \mathrm{wt} \%$ but ranges anywhere from 5 to $70 \mathrm{wt} \%$. The overall thickness of the lower CCU beneath the T Tank Farm is generally 10-20 ft and dips to the southwest about one degree (Wood et al. 2001).

Considerable variability may exist internally within the lower CCU because of natural heterogeneity inherent in soils and soil-forming processes which vary under different physical, chemical, and biological conditions (e.g., moisture, grain size, aspect, mineralogy, bioturbation, and microbial activity). An additional complicating factor is that the land surface during late Pliocene time was locally undergoing changes via fluvial and eolian activity, which resulted in variable rates of aggradation, degradation, and soil development (Bjornstad 1984, 1990; DOE 1988; Slate 1996, 2000; Wood et al. 2001). The calcium carbonate overprint is superimposed onto a variety of rock types, including silt, quartz-feldspar-rich sand and gravel, and locally derived basaltic sand and gravel (Slate 1996, 2000; Lindsey et al. 2000). In the vicinity of the T Tank Farm multiple, calcic-rich zones may be separated by relatively non-calcareous, un-cemented material indicating some rapid accumulations occurred periodically between periods of soil development.

At least two well-developed calcic layers are present beneath T Tank Farm; elsewhere in the 200 West Area as many as five have been identified (Slate 2000). Using spectral-gamma KUT logs, Sobczyk (2001) subdivided the lower CCU into an upper and lower caliche within T Tank Farm. Both caliche layers are characterized by extremely low levels of potassium-40. The two caliche layers are distinctly different, however, in their uranium-238 concentration; the upper caliche is depleted, while the 
lower caliche is enriched with uranium-238. The differences in concentration of potassium-40 and uranium-238 may be due to differing degrees of leaching and illuviation during soil development.

\subsubsection{Ringold Formation}

The Ringold Formation makes up the lower half of the vadose zone within the T Tank Farm (Figures 2.5 and 2.6). The upper part of the Ringold Formation consists of finer-grained fluvial sediments belonging to the Ringold Formation member of Taylor Flat. Below that are mostly fluvial gravels belonging to the Ringold Formation member of Wooded Island, Unit E.

\subsection{Member of Taylor Flat $\left(\mathbf{R}_{\mathrm{tf}}\right)$}

The Ringold Formation member of Taylor Flat (previously referred to as the upper Ringold unit) consists of interstratified, well-bedded fine to coarse sand to silt belonging to a mixture of fluvial-sand and overbank facies associations. Post-Ringold-Formation erosion locally stripped away most of this member from the central Pasco Basin, but in a few places such as the T Tank Farm, thin (2-6 m [6-20 ft]) erosional remnants of this unit remain (Wood et al. 2001).

Weathering and soil development associated with the overlying Cold Creek unit is often overprinted onto the Ringold Formation member of Taylor Flat. Because the degree of post-Ringold Formation pedogenesis decreases with depth, the contact with the overlying Cold Creek unit is gradational and generally defined by an upward decrease in natural-gamma and/or potassium- 40 activity on geophysical logs, increase in calcium-carbonate $\left(\mathrm{CaCO}_{3}\right)$ content, and/or decrease in mud content (indicative of more pedogenic cementation).

\subsection{Member of Wooded Island $\left(R_{\text {wi }}\right.$, Unit $\left.E\right)$}

Unit E consists predominantly of the fluvial-gravel facies association with occasional thin beds of the fluvial-sand and/or the overbank facies associations. No boreholes penetrate the full thickness of Unit E within the T Tank Farm, however Unit $\mathrm{E}$ in borings just to the south at the TX Tank Farm average about $85 \mathrm{~m}$ (275 ft) thick. The top of the unit dips very gently to the southwest (Wood et al. 2001), consistent with the top of basalt and underlying Ringold Formation units. The elevation at the top of the Ringold Formation Unit $\mathrm{E}$ varies by as much as $4.3 \mathrm{~m}(14 \mathrm{ft})$ beneath the $\mathrm{T}$ Tank Farm. The water table lies within the $\mathrm{R}_{\mathrm{wi}}$ member at about 220 - $\mathrm{ft}(67 \mathrm{~m}$ ) depth, about half-way between basalt bedrock and the ground surface.

\subsubsection{Clastic Dikes}

Clastic dikes are vertical to sub-vertical sedimentary structures that crosscut normal sedimentary layering that are common to ice-age flood deposits, especially in the sand- and silt-dominated facies of the Hanford formation (Black 1979; Fecht and Weekes 1996; Fecht et al. 1999). Some clastic dikes were noted during excavation (Price and Fecht 1976) but none have yet to be reported in boreholes from T Tank Farm. One exception is a narrow sand dikelet that might be part of a larger clastic dike observed within one of the new characterization boreholes documented in this report (see geologic description for C4104 in Section 2.3.3). 
Where clastic dikes intersect the ground surface, and are not covered with younger deposits, a feature known as "patterned ground" can be observed (Fecht et al. 1999). Well-developed "patterned ground" exists just south of the 200 West Area. Within the 200 West Area and the T-TX-TY WMA, however, visible "patterned ground" is rare due to the many man-made surface disturbances and/or because it is buried under a thin cover of recent eolian sand. Clastic dikes occur in swarms and form four types of networks: 1) regular-shaped polygonal-patterns, 2) irregular-shaped, polygonal-patterns, 3) pre-existing fissure fillings, and 4) random occurrences. Regular polygonal networks resemble 4- to 8-sided polygons and typically range from $3 \mathrm{~cm}$ to $1 \mathrm{~m}$ in width, from $2 \mathrm{~m}$ to greater than $20 \mathrm{~m}$ in depth and from 1.5 to $100 \mathrm{~m}$ along strike. Smaller dikelets, sills, and small-scale faults and shears are commonly associated with master dikes that form the polygons.

\subsection{Summary of Recent Characterization Activities at T Tank Farm}

Three boreholes were recently drilled and sampled within or near the T Tank Farm (Table 2.2). Two of these holes (C4104 and C4105) were drilled via the closed-end probe method between tanks 241-T-106 and -109 for the specific purpose of collecting core samples for physical, chemical, and radiological characterization as outlined in Crumpler (2002). Locations of the boreholes were selected to evaluate the migration of mobile contaminants from the 1973 leak at single-shell tank T-106. Intermittent core samples, 1.25 -ft long by 2.5-in. diameter, were collected at predetermined intervals within these two holes (Reynolds 2003a, 2003b).

In addition, almost continuous, 2.5-ft long by 4-in. diameter splitspoon core samples were collected in well 299-W11-39 (C3117) from 20 to 94 ft bgs (Lindsey et al. 2001). Well 299-W11-39 was installed as a RCRA groundwater monitoring well located along the northeast boundary of the T Tank Farm (Figure 2.4). Located outside of the tank farm, this well is considered generally free of contamination and chosen as a background control for the other two boreholes suspected of having chemical and radiological contamination. However, as noted in Section 4.1 there is evidence of higher than background dissolved salts, especially sodium and nitrate, in the porewaters in shallow depths at 299-W11-39. Therefore, background geochemistry data from sediments at 299-W10-27, near the TX tank farm are used in this report. For comparison, information from a fourth vadose-zone characterization borehole (299-W10-196), completed in 1993 (Freeman-Pollard et al. 1994), is included in this report. Key information on each of these four boreholes is presented in Table 2.2. Contact picks for the different stratigraphic units within these boreholes is presented in Table 2.3.

\subsubsection{Hydrogeologic Characterization}

Geophysical logs are available and used in characterization for all boreholes listed in Table 2.2. In addition, penetration resistance measured via hammer blow counts was recorded for all holes except 299-W11-39. Other hydrogeologic characterization information, performed in the laboratory, included geologic logging, photography, and gravimetric moisture content. Core photographs for all but the 299-W10-196 borehole, are presented in Appendix A and core geologic logs are shown in Appendix B. The geologist's log for 299-W10-196 is presented in Freeman-Pollard et al. (1994).

\subsubsection{Geophysical Logging}

Geophysical logs have been used extensively within T Tank Farm to evaluate the subsurface distribution and migration of gamma-emitting radionuclides over time (ARHCO 1973; Brown et al. 1979; 
Table 2.2. Four Borings Used for Recent Geochemical Characterization in the Vicinity of the T Tank Farm

\begin{tabular}{|c|c|c|c|c|c|c|c|c|c|c|c|c|c|}
\hline & \multirow{2}{*}{$\begin{array}{l}\text { Hanford } \\
\text { Well ID }\end{array}$} & \multirow{2}{*}{$\begin{array}{l}\text { Borehole } \\
\text { Number }\end{array}$} & \multicolumn{2}{|c|}{$\begin{array}{c}\text { Washington State Plane } \\
\text { Coordinates }\end{array}$} & \multirow{2}{*}{$\begin{array}{l}\text { Total } \\
\text { Depth } \\
\text { (ft bgs) }\end{array}$} & \multirow[b]{2}{*}{ Primary Purpose } & \multirow{2}{*}{$\begin{array}{c}\text { Drill } \\
\text { Method }\end{array}$} & \multirow{2}{*}{$\begin{array}{l}\text { Surface } \\
\text { Elevation } \\
\text { (ft) }\end{array}$} & \multirow{2}{*}{\begin{tabular}{|c|} 
Length/ \\
Inside \\
Diameter \\
of \\
Splitspoon
\end{tabular}} & \multirow{2}{*}{$\begin{array}{c}\text { Date } \\
\text { Cores } \\
\text { Collected }\end{array}$} & \multirow{2}{*}{$\begin{array}{c}\text { Date } \\
\text { Cores } \\
\text { Logged/ } \\
\text { Sampled }\end{array}$} & \multirow{2}{*}{$\begin{array}{l}\text { Percent } \\
\text { of Hole } \\
\text { Cored }\end{array}$} & \multirow{2}{*}{$\begin{array}{c}\text { Geologist } \\
\text { Performing } \\
\text { Logging }\end{array}$} \\
\hline & & & Northing & Easting & & & & & & & & & \\
\hline & 2-W10-196 & $\begin{array}{c}\text { 50-06-18, } \\
\text { A7274 }\end{array}$ & $136,724.78$ & $566,787.83$ & 179.6 & $\begin{array}{l}\text { Vadose-Zone } \\
\text { Core Sampling/ } \\
\text { Characterization }\end{array}$ & $\begin{array}{l}\text { Cable Tool/ } \\
\text { splitspoon }\end{array}$ & 675.36 & $\begin{array}{l}2.0 \mathrm{ft} / \\
4 \mathrm{in} . ?\end{array}$ & $\begin{array}{c}11 / 13 / 92 \\
\text { to } 3 / 29 / 93\end{array}$ & ? & 45.6 & $\begin{array}{l}\text { Dennis Anderson } \\
\text { (Westinghouse } \\
\text { Hanford Co.) }\end{array}$ \\
\hline \multirow[t]{3}{*}{$\stackrel{N}{\infty}$} & 2-W11-39 & С3117 & 136, 779.917 & $566,908.383$ & 282.31 & $\begin{array}{l}\text { RCRA } \\
\text { Groundwater } \\
\text { Monitoring }\end{array}$ & $\begin{array}{l}\text { Cable Tool/ } \\
\text { splitspoon }\end{array}$ & 688.6 & $\begin{array}{c}2.5 \mathrm{ft} / \\
4 \mathrm{in.}\end{array}$ & $\begin{array}{c}11 / 10 / 00 \\
\text { to } \\
11 / 14 / 00\end{array}$ & $\begin{array}{c}\text { Logged: } \\
\text { 5/15/01 } \\
\text { Sampled: } \\
\text { 5/15/01 } \\
\text { and } \\
\text { 11/21/02 }\end{array}$ & 27 & $\begin{array}{l}\text { Kevin Lindsey } \\
\text { (Kennedy / Jenks), } \\
\text { Bruce Bjornstad } \\
\text { (PNNL) }\end{array}$ \\
\hline & & C4104 & $136,720.823$ & $566,788.421$ & 127.46 & $\begin{array}{l}\text { Vadose-Zone } \\
\text { Core Sampling/ } \\
\text { Characterization }\end{array}$ & Push Probe & 675.32 & $\begin{array}{c}1.25 \mathrm{ft} / \\
1.9-2.6 \mathrm{in} .\end{array}$ & $\begin{array}{l}4 / 4 / 03 \text { to } \\
5 / 22 / 03\end{array}$ & $\begin{array}{l}\text { 5/15/03 } \\
\text { and } \\
5 / 26 / 03\end{array}$ & 24 & $\begin{array}{l}\text { Bruce Bjornstad } \\
\text { (PNNL), } \\
\text { Victoria Johnson } \\
\text { (Kennedy / Jenks) }\end{array}$ \\
\hline & & C4105 & $136,720.758$ & $566,761.692$ & 130.9 & $\begin{array}{l}\text { Vadose-Zone } \\
\text { Core Sampling/ } \\
\text { Characterization }\end{array}$ & Push Probe & 675.02 & $\begin{array}{c}1.25 \mathrm{ft} / \\
1.9-2.6 \mathrm{in} .\end{array}$ & $\begin{array}{l}1 / 8 / 03 \text { to } \\
3 / 12 / 03\end{array}$ & $\begin{array}{c}2 / 24 / 03 \text { to } \\
2 / 25 / 03 \\
\text { and } \\
3 / 21 / 03\end{array}$ & 23 & $\begin{array}{l}\text { Bruce Bjornstad } \\
\text { (PNNL), } \\
\text { Victoria Johnson } \\
\text { (Kennedy / Jenks) }\end{array}$ \\
\hline
\end{tabular}


Table 2.3. Stratigraphic Contact Picks for Boreholes Used in This Report

\begin{tabular}{|c|c|c|c|c|c|}
\hline & & \multicolumn{4}{|c|}{ Well ID } \\
\hline & & 299-W11-39 & C4104 & C4105 & 299-W10-196 \\
\hline & Surface Elev. ft (amsl) & 688.6 & 675.3 & 675.0 & 675.4 \\
\hline \multirow{7}{*}{ 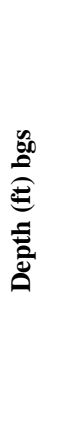 } & Backfill & 0 & 0 & 0 & 0 \\
\hline & H1 & 5 & NP & $\mathrm{NP}$ & NP \\
\hline & $\mathrm{H} 2$ & 33.5 & 40 & 40.6 & 38.9 \\
\hline & $\mathrm{CCU}_{\mathrm{u}}$ & 89.9 & 80.7 & 85.5 & 81 \\
\hline & $\mathrm{CCU}_{\mathrm{l}}$ & 98.0 & 92.5 & 92 & 91.8 \\
\hline & $\mathrm{R}_{\mathrm{tf}}$ & 120.0 & 108 & 111 & 105 \\
\hline & $\mathrm{R}_{\mathrm{wi}}$ & 130 & 120.9 & 122 & 121.3 \\
\hline \multirow{7}{*}{ 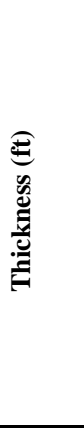 } & Backfill & 5 & 40 & 40.6 & 38.9 \\
\hline & H1 & 28.5 & NP & NP & NP \\
\hline & $\mathrm{H} 2$ & 55.4 & 40.7 & 44.9 & 42.1 \\
\hline & $\mathrm{CCU}_{\mathrm{u}}$ & 8.1 & 11.8 & 6.5 & 10.8 \\
\hline & $\mathrm{CCU}_{\mathrm{l}}$ & 22 & 15.5 & 19 & 13.2 \\
\hline & $\mathrm{R}_{\mathrm{tf}}$ & 10 & 12.9 & 11 & 16.3 \\
\hline & $\mathrm{R}_{\mathrm{wi}}$ & ND & ND & ND & ND \\
\hline \multirow{7}{*}{ 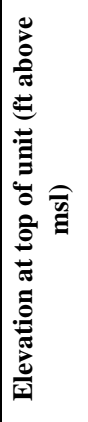 } & Backfill & 688.6 & 675.3 & 675.0 & 675.4 \\
\hline & H1 & 683.6 & NP & NP & NP \\
\hline & H2 & 655.1 & 635.3 & 634.4 & 636.5 \\
\hline & $\mathrm{CCU}_{\mathrm{u}}$ & 598.7 & 594.6 & 589.5 & 594.4 \\
\hline & $\mathrm{CCU}_{1}$ & 590.6 & 582.8 & 583.0 & 583.6 \\
\hline & $\mathrm{R}_{\mathrm{tf}}$ & 568.6 & 567.3 & 564.0 & 570.4 \\
\hline & $\mathrm{R}_{\mathrm{wi}}$ & 558.6 & 554.4 & 553.0 & 554.1 \\
\hline
\end{tabular}


DOE/GJO 1999; Sobczyk 2001). Sobczyk (2001) also used spectral-gamma logs for stratigraphic correlation within the T Tank Farm. Because radiological contamination masks the natural gamma response within the tank-farms, KUT logs are better for interpreting lithology and picking stratigraphic contacts. One limitation of the geophysical logs, which collect data every half foot, is that they generally can not detect strata smaller than $2 \mathrm{ft}$ in thickness (Sobczyk 2001). Therefore, thin, lower-permeability, fine-grained layers, such as those that commonly cap sand sequences within the Hanford formation $\mathrm{H} 2$ unit and may result in the lateral spreading of moisture and contaminants, are not readily revealed on geophysical logs.

Geophysical logging was performed on all four boreholes, reported herein, using a high-purity germanium (HPGe) spectral-gamma detector (Freeman-Pollard et al. 1994; Lindsey et al. 2001; Reynolds 2003a, 2003b). Processing of the spectral-gamma log data allows the identification of gamma-emitting man-made radionuclides (if present) and the background levels of radiogenic potassium, uranium, and thorium (KUT) that are naturally present in earth materials. As expected, man-made radiological contaminants were detected in both C4104 and C4105, as well as 299-W10-196, within the T Tank Farm while almost no man-made contaminants were detected in borehole 299-W11-39, outside the tank farm. An exception was a slight increase in cesium-137 within 2 feet of the ground surface at 299-W11-39, probably a result of wind-blown deposition from a nearby contamination source or another indication of a surface spill or nearby pipeline leak that is suggested by the higher than background 1:1 water extract data to be presented in section 4.1.2. Additional information on the geophysical logging results and contaminant distribution for the two recent $\mathrm{T}$ probe holes is presented below under the more-detailed discussions for these holes, as well as in Reynolds (2003a, 2003b).

Neutron-moisture logs were also obtained for the holes listed in Table 2-2. The neutron-moisture log is generally used to depict the relative moisture content within a $20-30 \mathrm{~cm}$ (8-12 in) radius around the borehole. However, the neutron-moisture logging tool was not calibrated for the casing conditions, therefore absolute moisture values can not be obtained directly from the neutron-moisture log. Generally, where there is no radiological contamination, the total gamma count rate increases in finer grained sediments with corresponding increase in moisture content due the moisture-retaining properties of these sediments.

\subsubsection{Sample Handling}

Because there was no man-made contamination in 299-W11-39, sample handling was slightly different for this clean background borehole compared to the two probe holes [C4104 and C4105] sampled within the T Tank Farm. In 299-W11-39 two, 4-in.-diameter, 1-ft-long lexan-lined core samples were recovered from each 2-ft splitspoon. Upon recovery, any open spaces in the ends of the liners were stuffed with aluminum foil in the field and plastic end caps secured with duct tape. The outside of the liner was labeled with borehole number, depth interval, and an "up" arrow. Alternatively, potentially contaminated core samples from the two probe holes were collected in two, 2.5-in diameter, $0.5 \mathrm{ft}$ long stainless-steel liners (Reynolds 2003a, 2003b). Liners were sealed with plastic end caps and the outsides labeled with chain-of-custody or borehole ID number, up arrow, and the letter "A" or "B”. The letter " $\mathrm{A}$ " was assigned to the deeper of the two cores in the one-foot core run. 
Once received at the PNNL 3720 Building, the C4104 and C4105 samples were stored in a refrigerator to maintain the sample temperatures between 2 and $4^{\circ} \mathrm{C}$. Core samples from the clean 299-W11-39 borehole were opened, sampled, and described within a non-radiologically controlled PNNL laboratory (Lindsey et al. 2001).

Because of the potential for radiological contamination, more precautions were taken while processing cores from within the tank farms. Within a month of collection, the core samples were sequentially taken to a fume hood in a radiologically controlled laboratory for sample processing. Initially, the liner end caps were removed and the contents of the liner were placed in a plastic tray - one plastic tray per $0.5 \mathrm{ft}$ liner. A geologic description was performed while the material in the tray was sampled and photographed. A complete set of core photographs for the two probe holes, as well as the background hole (299-W11-39), are presented in Appendix A. Sediment within the sample liners was extracted using either a hammer to tap on the stainless-steel liner or a specially constructed hydraulic "extruder". Efforts were made to keep the sample materials as intact as possible, at least until a photograph was taken. In the coarser-grained sediments however, the internal structures could generally not be preserved because of the unconsolidated, friable nature of those materials. Sample handling for the 299-W10-196 borehole is discussed in Freeman-Pollard et al. (1994).

\subsubsection{Subsampling and Geologic Description}

Cores from 299-W11-39 were opened in May 2001; geologic logs for this hole are presented in Lindsey et al. (2001). A PNNL geologist was also present to observe and collect samples for remnant paleomagnetic analysis. Cores from probe holes C4104 and C4105 were logged by PNNL and Kennedy / Jenks geologists in early 2003. The PNNL logs for the two probe holes are presented in Appendix B. Sampling, description, and analysis of the 299-W10-196 core were performed during a different characterization study performed in 1993 (Freeman-Pollard et al. 1994).

Moisture samples were collected immediately upon extracting material from a core liner from the two T Tank Farm probe holes. An attempt was made to sample the finer-grained and/or wetter materials as well as any distinct hydrogeologic units, while at the same time trying to avoid slough and/or other unrepresentative portions.

A visual geologic evaluation of cores from the T Tank Farm probe holes was conducted in accordance with the following procedures: ASTM D 2488 (ASTM 1993), PNL-MA-567-DO-1 (PNL 1990), and PNL-D9T81-99-GVL-1 (PNNL 1999). Throughout the subsampling and geologic evaluation activities, the PNNL geologist made visual observations regarding the mineralogy, structure, grain-size distribution (and sorting), maximum particle size, grain-shape (e.g. roundness), color, moisture, consolidation, and reaction to dilute hydrochloric acid $[\mathrm{HCl}]$ (used to test for the presence of calcium carbonate). Particular attention was given to estimate the percentage (by weight) of gravel, sand, and mud (silt+clay), and to classify the samples based on the modified Folk (1968)-Wentworth (1922) classification scheme historically used at the Hanford Site. This sediment classification scheme uses a ternary diagram to categorize the sediment into one of 19 textural classes based on the relative proportions of gravel, sand, and mud (Figure 2.8).

The tops of many of the cores contained several inches or more of sloughed material in the core liners. Slough is recognizable by its darker, more massive and poorly sorted nature and, if present, is always at the top of the core. The sloughed material represents sediment that fell back into the hole or 
was not completely removed between core runs. Re-coring of sloughed materials was more common in coarser and looser sediments found in backfill and the Hanford formation; it was generally not found in the finer-grained and/or higher moisture intervals, which are more cohesive and hold together better between core runs. Sampling of sloughed material was intentionally avoided during the collection of physical- and chemical-characterization samples within the laboratory.

\subsubsection{Hydrogeology of Borehole 299-W11-39 (Background Well)}

Borehole 299-W11-39 (C3117) was drilled using cable-tool methods between November 10 and December 6, 2000. The borehole is located in proximity to the northeast corner T Tank Farm Waste Management Area (Figure 2.4). Total depth of the borehole is $282.31 \mathrm{ft}(86 \mathrm{~m}$ ) bgs; the hole terminated within fluvial gravels of the Ringold Formation member of Wooded Island (Unit E), about $40 \mathrm{ft}(12.2 \mathrm{~m}$ ) below the groundwater table.

Near continuous core sampling was performed between 20 to $93.5 \mathrm{ft}$ bgs (Lindsey et al. 2001); 29 splitspoon cores were collected from this interval. Two, 1.0-ft long plastic (i.e., lexan) core liners were collected for each 2.5 -ft core run. The extra $0.5 \mathrm{ft}$ collected in the shoe of the splitspoon was used for geologic description in the field geologist's log. Generally, after performing a geologic description, the core material in the shoe was discarded. Accounting for the loss of the $0.5-\mathrm{ft}$ shoe samples and slough atop many of the cores, the total recovery for the 20 to $93.5 \mathrm{ft}$ interval is estimated at $66.6 \%$ (Lindsey et al. 2001). Below that, the hole was drilled to a total depth of $282 \mathrm{ft}$ using a hard tool, except for a few short splitspoon samples at 243-244, 253-254, and 273-274 ft bgs.

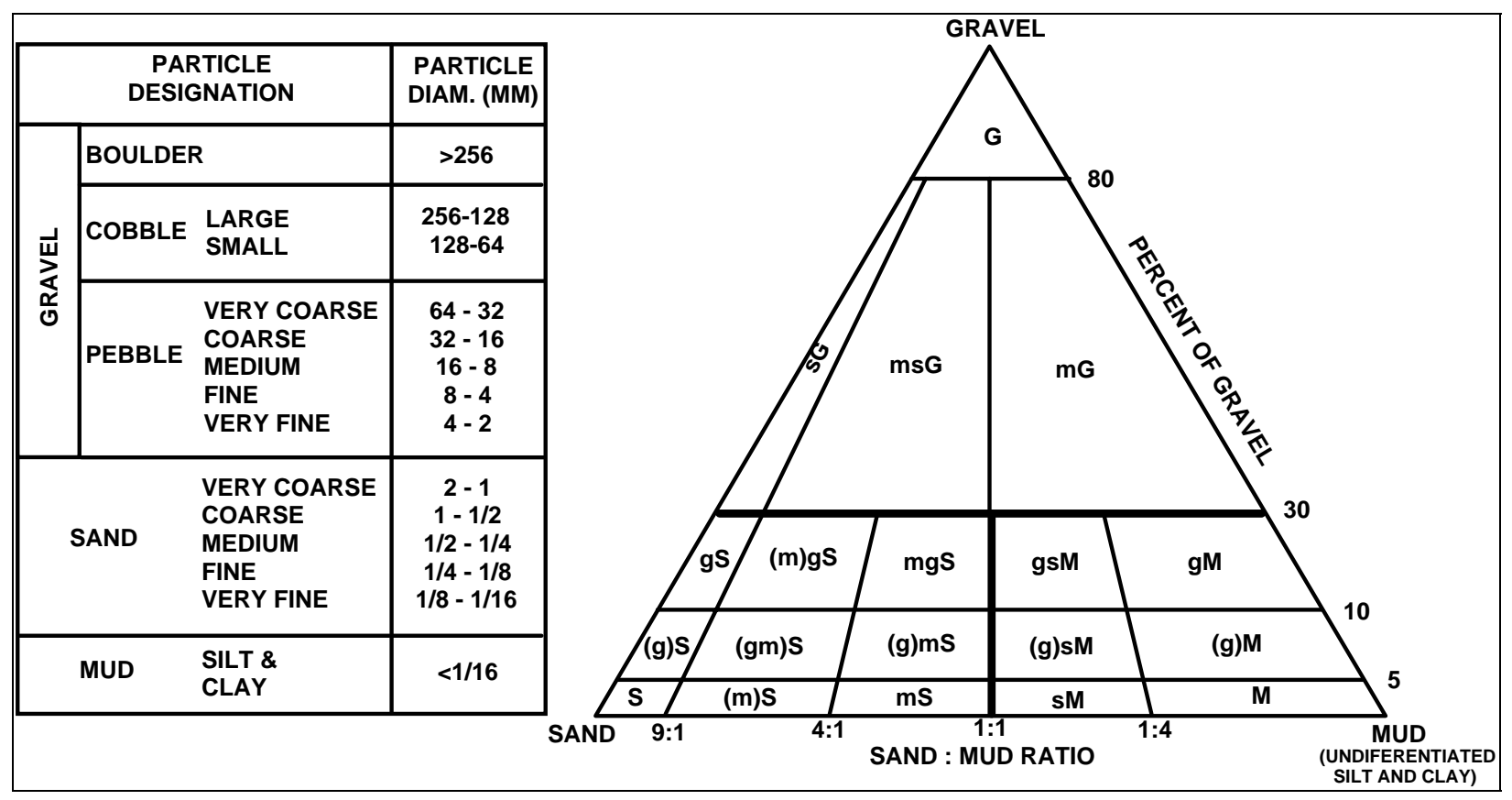

Figure 2.8. Sediment Textural Classification [Modified after Folk (1968) and Wentworth (1922)]. 
Core logging was performed by Kennedy Jenks Consultants, Inc. at PNNL's 3720 Building laboratory on May 15, 2001; core logs are presented in Lindsey et al. (2001 [Appendix A]). Geologic logging and sampling for gravimetric moisture occurred after each core segment was cut and split open, logged, and photographed. During logging, PNNL staff also collected 16 samples for paleomagnetic analysis (Table 2.4). Core photos taken during logging of this hole are presented in Appendix A-1 of this report. After geologic logging and photographing, the plastic-lined cores were resealed with duct tape and placed into cold storage for archival purposes.

Table 2.4. Core Samples Collected from 299-W11-39 for Paleomagnetic Analysis

\begin{tabular}{||l|l|l||}
\hline $\begin{array}{c}\text { Depth } \\
\text { (ft bgs) }\end{array}$ & $\begin{array}{c}\text { Stratigraphic } \\
\text { Unit }\end{array}$ & \multicolumn{1}{c||}{ Sample Description } \\
\hline 34.5 & H2 & Fine to medium sand; olive; moderately sorted; compact \\
\hline 37.0 & H2 & Fine to coarse sand; poorly sorted; compact; weakly laminated \\
\hline 39.4 & H2 & Fine to coarse sand; poorly sorted; compact to crumbly \\
\hline 43.4 & H2 & Silty fine sand; brown; interlaminated with clean medium sand \\
\hline 47.3 & H2 & Fine to medium sand; moderately sorted; compact; weakly laminated \\
\hline 49.6 & H2 & Silty very fine sand; well-sorted; 2” layer between medium-coarse sand \\
\hline 54.5 & H2 & Fine to coarse sand; poorly sorted; compact to crumbly; weakly laminated \\
\hline 60.5 & H2 & Fine to coarse sand; moderately sorted; well-laminated \\
\hline 64.8 & H2 & Medium to coarse sand; loose \\
\hline 76.7 & H2 & Silty fine sand; well-sorted; laminated \\
\hline 78.2 & H2 & Very fine sandy silt; laminated \\
\hline 83.1 & H2 & Fine to coarse sand; moderately sorted; loose \\
\hline 88.4 & H2 & Fine to medium sand; well-sorted; loose \\
\hline 89.8 & H2 & Fine to medium sand; loose \\
\hline 90.6 & $\mathrm{CCU}$ & Very fine sandy silt; brown; very well sorted; laminated \\
\hline 92.4 & $\mathrm{CCU}$ & Very fine sandy silt; brown; very well sorted; laminated \\
\hline
\end{tabular}

Selected cores from 299-W11-39 were reopened 18 months later and 4 subsamples were collected for geochemical characterization (Table 2.5).

Figure 2.9 presents a summary geologic log for borehole 299-W11-39 based on a compilation of field geologists' logs ("Hanford Well Information System” available online at URL http://172.17.20.14/eis/hwisapp), geological log notes on opened cores (Lindsey et al. 2001 [Appendix A]), geophysical logs ("Borehole Logs.pnl.gov” available online at URL http://boreholelogs.pnl.gov/200WEST/W10027), gravimetric moisture measurements, and core photographs (Appendix A-1 of this report). Four primary stratigraphic units were encountered in this borehole: 1) recent backfill or eolian materials, 2) the Hanford formation, 3) the Cold Creek unit, and 4) the Ringold Formation (Figure 2.9). A brief description of the sampled materials from each of these major stratigraphic units is presented below. 
Table 2.5. Splitspoon Samples Selected for Physical and Chemical Characterization from the Vadose Zone in 299-W11-39. One characterization sample was collected from each of the depths indicated.

\begin{tabular}{||l|c|c|c||}
\hline $\begin{array}{c}\text { Core Sample } \\
\text { ID }\end{array}$ & $\begin{array}{c}\text { Discrete } \\
\text { Sample } \\
\text { Depth (ft) }\end{array}$ & Lithology & Stratigraphic Unit \\
\hline C3117-49.5 & 49.5 & Silty sand & $\mathrm{H} 2$ \\
\hline C3117-60.5 & 60.5 & Silty sand & $\mathrm{H} 2$ \\
\hline C3117-78 & 78.0 & Sandy silt & $\mathrm{H} 2$ \\
\hline C3117-92 & 92.0 & Silty sand & $\mathrm{CCU}_{\mathrm{u}}$ \\
\hline
\end{tabular}

Based on the results of geophysical logging no radioactive contaminants were detected in borehole 299-W11-39 (Lindsey et al. 2001). Geophysical logging (Figure 2.9) shows a sharp increase in total gamma and neutron-moisture activity at a depth of $52 \mathrm{ft}$ where the casing telescopes down from a double to a single string of temporary steel casing. These casings were advanced during drilling of the hole and used to keep it open for geophysical logging and subsequent well installation. At depth, the total gamma count rate increases again between 90-98 ft bgs within the silts and fine sands of the upper CCU subunit, before dropping very sharply at the contact with the lower CCU subunit (i.e., top of the calcic paleosol sequence).

Zones of elevated moisture occur within the Hanford formation $\mathrm{H} 2$ unit between 75-79 ft bgs, as well as sporadically within the CCU and $\mathrm{R}_{\mathrm{tf}}$ units. Moisture ranged from as low as $2.8 \mathrm{wt} \%$ in pebbly sands of the Hanford formation H1 unit up to $22.8 \mathrm{wt} \%$ in the upper CCU subunit (Table 2.6).

\subsubsection{Recent Materials}

About 5 feet of recent construction material, composed of brown, pebbly, sand and silt, covers the surface at 299-W11-39.

\subsubsection{Hanford Formation}

Pleistocene cataclysmic flood deposits of the Hanford formation underlie recent sediments to a depth of $89.9 \mathrm{ft}$ in borehole 299-W11-39. Both units of the Hanford formation reported in the area (Wood et al. 2001) are represented, including a coarse-grained, gravel-dominated sequence (H1 unit) and an underlying sand-dominated sequence (H2 unit). The $\mathrm{H} 1$ unit, which extends from 5 to $34 \mathrm{ft} \mathrm{bgs,} \mathrm{consists}$ of mostly loose, poorly sorted, clast-supported sandy gravel to silty sandy gravel (Figure 2.10). The dark color is due to the relatively high concentration of basalt clasts in this material. 


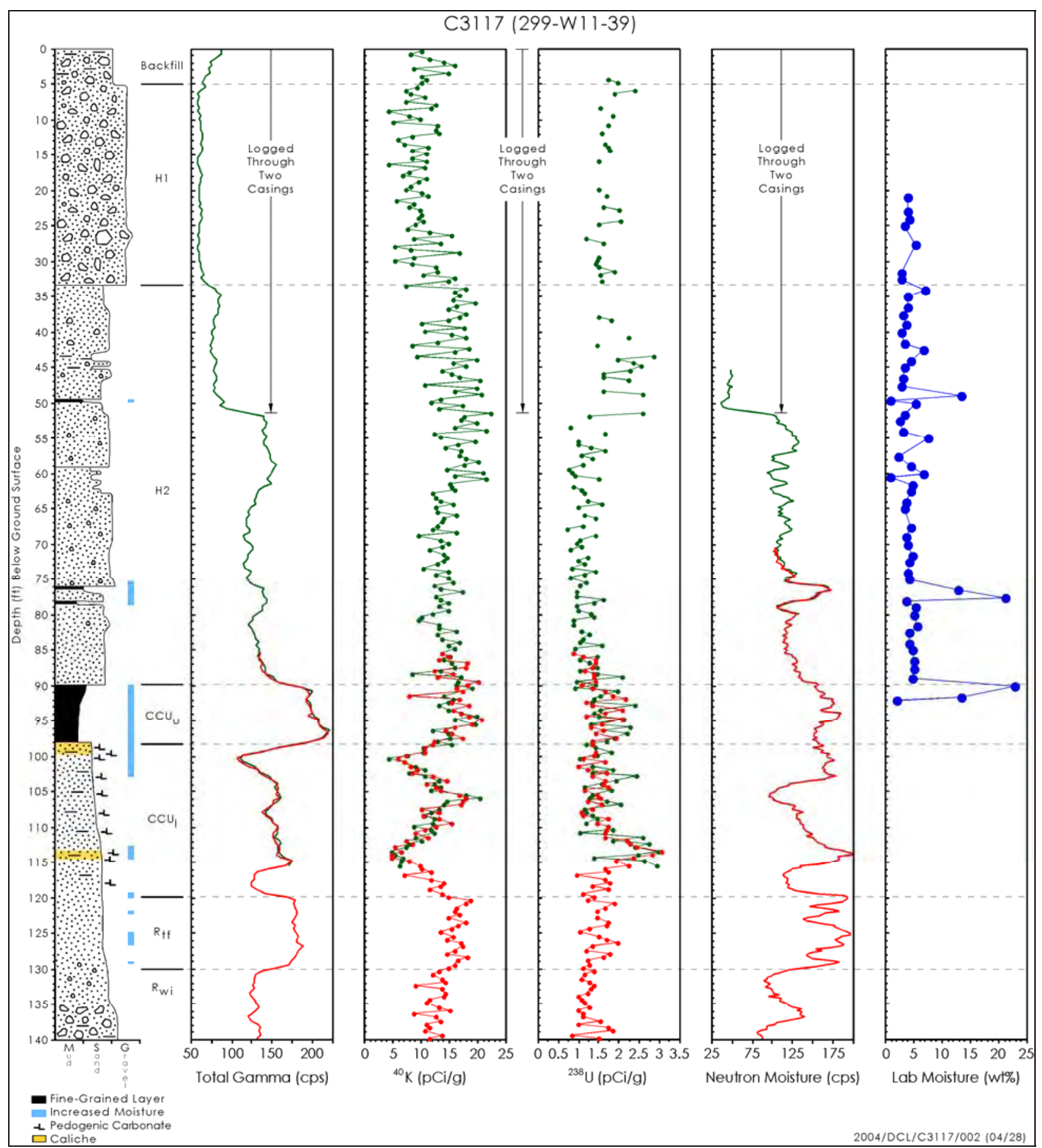

Figure 2.9. Summary Geohydrologic Log for Background Borehole 299-W11-39. Zones with relatively high moisture ( $>15 \mathrm{wt} \%$ ) are illustrated via a light blue vertical bar immediately to the right of the lithologic log. 
Table 2.6. Gravimetric Moisture Content Measured in Core Samples. Units are wt\% water.

\begin{tabular}{|c|c|c|c|c|c|c|c|c|c|c|c|c|c|c|c|c|c|c|c|c|}
\hline \multirow[b]{2}{*}{ Strat. Unit } & \multicolumn{5}{|c|}{ W11-39 } & \multicolumn{5}{|c|}{ C4104 } & \multicolumn{5}{|c|}{ C4105 } & \multicolumn{5}{|c|}{ 299-W10-196 } \\
\hline & $\#$ & Mean & Min. & Max. & S.D. & $\#$ & Mean & Min & Max & S.D. & $\#$ & Mean & Min. & Max. & S.D. & $\#$ & Mean & Min. & Max. & S.D. \\
\hline Backfill & N/A & N/A & N/A & N/A & N/A & 7 & 7.9 & 6.6 & 10.5 & 1.5 & 6 & 4.8 & 3.0 & 7.6 & 1.7 & 4 & 5.8 & 5.0 & 6.3 & 0.6 \\
\hline $\mathrm{H}_{1}$ & 7 & 3.8 & 2.8 & 5.2 & 0.8 & N/A & N/A & N/A & N/A & N/A & N/A & N/A & N/A & N/A & N/A & N/A & N/A & N/A & N/A & N/A \\
\hline $\mathrm{H}_{2}$ & 45 & 4.5 & 0.8 & 21.2 & 3.4 & 10 & 5.8 & 2.9 & 9.3 & 2 & 8 & 5.3 & 3.8 & 7.6 & 1.4 & 7 & 4.4 & 2.6 & 6.5 & 1.5 \\
\hline $\mathrm{CCU}_{\mathrm{u}}$ & 3 & 12.7 & 2 & 22.8 & 10.4 & 5 & 13.4 & 10.4 & 17.7 & 2.8 & 4 & 15.0 & 10.3 & 19.9 & 3.9 & 2 & 6.5 & 4.0 & 9.0 & 3.5 \\
\hline $\mathrm{CCU}_{\mathrm{l}}$ & N/A & N/A & N/A & N/A & N/A & 12 & 12.1 & 4.9 & 20.5 & 4.3 & 14 & 11.3 & 6.7 & 25.5 & 4.6 & 4 & 12.8 & 11.0 & 16.0 & 2.8 \\
\hline $\mathrm{R}_{\mathrm{tf}}$ & N/A & N/A & N/A & N/A & N/A & 6 & 18.3 & 15.9 & 24.2 & 3.2 & 4 & 14.7 & 3.9 & 25.6 & 10.7 & 3 & 14.0 & 9.0 & 17.0 & 4.4 \\
\hline $\mathrm{R}_{\mathrm{wi}}$ & N/A & N/A & N/A & N/A & N/A & 4 & 4.3 & 3.2 & 5.0 & 0.8 & 4 & 9.1 & 5.0 & 20.5 & 7.6 & 6 & 2.4 & 1.0 & 4.1 & 1.1 \\
\hline
\end{tabular}




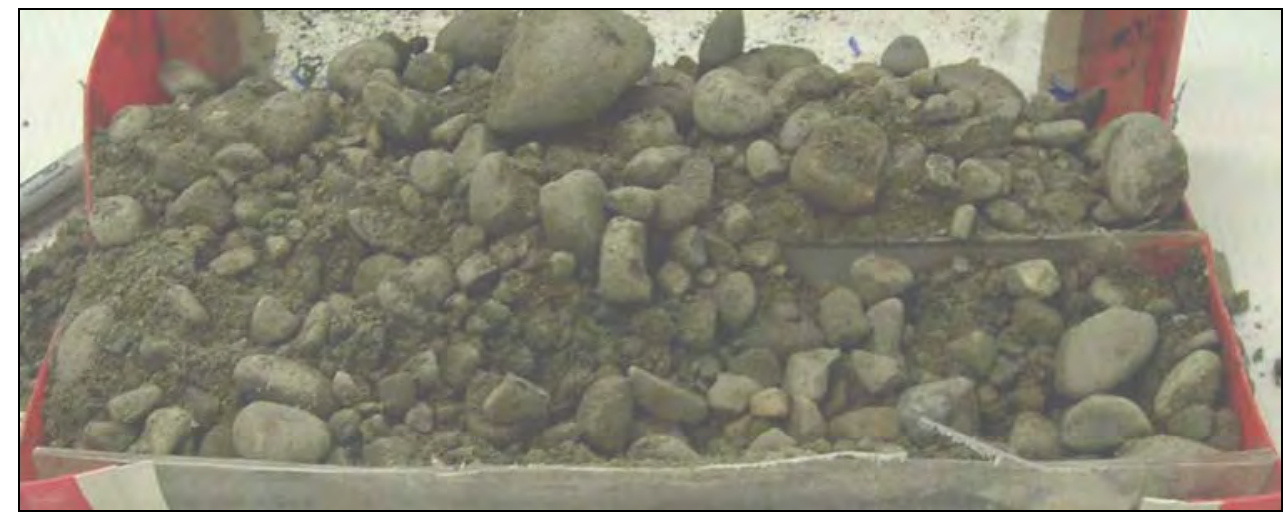

Figure 2.10. Hanford Formation H1 Unit in Borehole 299-W11-39. The top of the one-foot-long core is to the right. $23-24 \mathrm{ft}$ depth.

The $\mathrm{H} 2$ unit, on the other hand, is predominantly medium-to-coarse-grained sand to slightly pebbly sand, which extends to a depth of $89.9 \mathrm{ft}$ bgs. The term "salt and pepper" is often used to describe sands of the $\mathrm{H} 2$ unit on geologic logs due to the roughly equal amounts of dark- (basaltic) and light-colored (quartz and feldspar) grains. These beds show occasional weak horizontal laminations and are generally non-calcareous to weakly calcareous. A few, relatively thin, low permeability, well-sorted, fine-grained layers of laminated fine to silty fine sand are interspersed within the H2 unit (Figure 2.11).

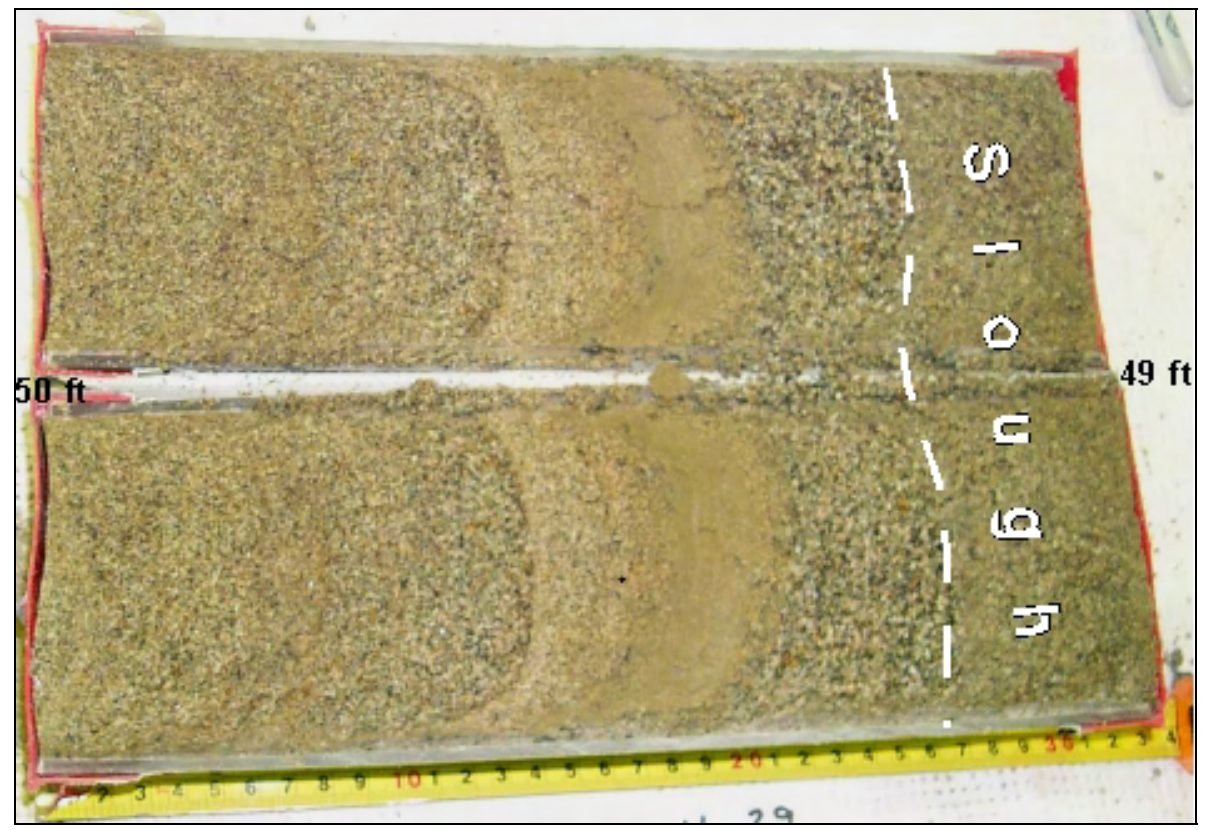

Figure 2.11. Hanford Formation H2 Unit in Borehole 299-W11-39. A thin (0.2 ft) layer of well-laminated silty very fine sand $(\mathrm{mS})$ lies between beds of medium- to coarse-grained "salt and pepper" sand (S). The top of the core is to the right. Notice drilling-induced drag folding along sides of core. 
No samples were analyzed for physical and chemical characterization from the Hanford formation $\mathrm{H} 1$ unit. Three characterization samples were obtained from the Hanford formation $\mathrm{H} 2 \mathrm{unit}$, however (Table 2.5). These were selected from finer-grained lenses within the H2 unit, including the one in Figure 2.11, because these typically contain more moisture and thus may have a higher probability for carrying contaminants.

\subsubsection{Cold Creek Unit}

The Cold Creek unit is subdivided into an upper and lower subunit within the T Tank Farm, as well as the greater 200 West Area (DOE 2002). The upper Cold Creek subunit consists of a brownish, wellsorted, unconsolidated fine-grained unit, which sharply overlies the lower subunit, characterized as a number of weakly to strongly-developed calcic paleosols. Splitspoon sampling ended at $93.5 \mathrm{ft}$ in 299 W11-39, within the upper Cold Creek subunit, so no intact physical samples were collected from which to evaluate the rest of the Cold Creek (and older) units. However, based on the geophysical logs there appears to be a sharp contact between the upper and lower CCU at $98 \mathrm{ft}$ bgs.

\subsection{Upper Cold Creek Subunit $\left(\mathrm{CCU}_{\mathrm{u}}\right)$}

The upper CCU, 8.1-ft (2.5 m) thick, underlies the basalt-rich, "salt and pepper" sands of the Hanford formation in borehole 299-W11-39 between $89.9 \mathrm{ft}(27.1 \mathrm{~m})$ and $98 \mathrm{ft}(29.9 \mathrm{~m})$ bgs (Figure 2.7). This unit consists of a brownish, laminated to massive, compacted and very well sorted, silty fine sand to fine sandy silt. This unit is also relatively unconsolidated and moderately to strongly calcareous. The un-cemented nature of this unit suggests the calcium carbonate is probably of detrital origin instead of that forming pedogenically in situ, as did carbonate in the underlying lower Cold Creek subunit. Another characteristic of this unit is its relatively high natural-gamma activity compared to adjacent units. The average moisture content $(12.7+/-10.4 \mathrm{wt} \%)$ for the upper CCU is significantly greater than that of the Hanford formation, which averaged $3.8+/-0.8 \%$ for the gravelly $\mathrm{H} 1$ unit and $4.5+/-3.4 \%$ for the sand-dominated $\mathrm{H} 2$ unit (Table 2.6).

A single sample was collected for physical and chemical characterization from the silty sand near the top of the upper CCU at $92 \mathrm{ft}$ bgs (Table 2.5).

\subsection{Lower Cold Creek Subunit $\left(\mathrm{CCU}_{\mathrm{l}}\right)$}

The lower Cold Creek unit extends from 98 to about $120 \mathrm{ft}$ bgs in 299-W11-39. The base of the CCU is pedogenically overprinted onto the underlying sands of the Ringold Formation member of Taylor Flat $\left(\mathrm{R}_{\mathrm{tf}}\right)$; therefore the contact is gradational and somewhat subjective. Characteristics of the lower CCU are the abundance of white, secondary calcium carbonate cement, and low to erratic natural-gamma and KUT activity on geophysical logs (DOE 1988, Bjornstad 1990, Wood et al. 2001, Sobczyk 2001). Sobczyk (2001) differentiated two separate caliche horizons within the lower CCU based on the geochemical signatures observed on the KUT logs. Both caliche horizons have markedly low potassium-40 activity. The uranium-238 activity, is also depleted in the upper caliche, yet enriched in the lower caliche.

Because coring stopped above the lower CCU subunit, there were no samples available for laboratory characterization in 299-W11-39. Based on the neutron-moisture log (Figure 2.9), moisture content is highly variable within the lower CCU subunit, a reflection of the high degree of internal heterogeneity within this unit. 


\subsubsection{Ringold Formation}

The Ringold Formation is present from about $120 \mathrm{ft}$ bgs to the bottom of 299-W11-39 (282.3 ft bgs). The uppermost portion of the Ringold Formation (member of Taylor Flat) consists of about $10 \mathrm{ft}$ of silty sand. Below that is predominantly clast-supported sandy gravel to silty sandy gravel to the bottom of the hole, belonging to the member of Wooded Island $\left(\mathrm{R}_{\mathrm{wi}}\right)$, unit E. Based on the neutron-moisture log, moisture is highly variable within the Ringold Formation, but generally greater within the $\mathrm{R}_{\mathrm{tf}}$ unit, compared to the $\mathrm{R}_{\mathrm{wi}}$ unit.

No characterization samples were collected from the Ringold Formation from borehole 299-W11-39.

\subsubsection{Borehole C4104}

Borehole C4104 was drilled and sampled using a driven-probe technique between April 4 and May 22, 2003 (Table 2.2). The borehole lies between single-shell tanks 241-T-105, -106, -108, and -109 within the 241-T Tank Farm (Figure 2.4). It is closest to tank 241-T-106, where it lies approximately $18.9 \mathrm{ft}(5.77 \mathrm{~m})$ to the southeast. Total depth of the borehole was $127.46 \mathrm{ft}(38.8 \mathrm{~m})$ bgs; the hole was terminated when refusal was encountered approximately $5 \mathrm{ft}$ into cemented gravels of the Wooded Island member of the Ringold Formation. Decommissioning of probe hole C4104 was completed on June 9, 2003 by back pulling the casing while filling the annulus with dry bentonite. Surface elevation of the boring was $675.3 \mathrm{ft}$ (205.8 m) and geographic coordinates were N136720.823 and E566788.421 (Reynolds 2003a).

During drilling, a total of 23, 1.25-ft long, splitspoon core samples were collected intermittently starting at a depth of $15 \mathrm{ft}$ bgs on April 4, 2003 (Table 2.7). Two 0.5-ft long stainless-steel core liners were collected within the splitspoon during each core run. All splitspoons, except for two, were unshielded, having an inside diameter of 2.51 in. The two shielded splitspoons (S03072-4 and -5) were of smaller diameter (1.93-in. inner diameter) Sediment recovery for most unshielded liners was 100\%; recovery on the shielded splitspoons, on the other hand, was only $50 \%$, with the upper liner coming up empty each time. A separate sample was collected in the laboratory from each of the $0.5 \mathrm{ft}$ liners for physical, chemical, and radiological characterization, making a total of 44 characterization samples collected from this hole. In all, about $30 \mathrm{ft}$ of core was obtained from C4104, or about $24 \%$ of the total length of the hole (Table 2.2). No samples or drill cuttings were collected between core runs because the hole was advanced in a closed configuration using a solid, removable tip (Reynolds 2003a).

The first 16 cores (S03072-1 through -16) were extracted, sampled, photographed, and geologically logged on May 15; a second set of cores (S03072-17 through -23) were logged on May 26, 2003. All cores were opened, observed, and sampled within a radiologically controlled PNNL laboratory. Geologic logs of the material within the core liners were generated by geologists Victoria Johnson (Kennedy / Jenks Consultants, Inc.) and Bruce Bjornstad (PNNL); the core logs for both geologists are presented in Reynolds (2003a). PNNL core logs are also presented in the back of this report (Appendix B-1). Geologic logging occurred after the contents of each 0.5-ft stainless-steel core liner was emptied into an open plastic container, followed by photographing and sub-sampling for physical, chemical, and radiological characterization. Upon completion of these activities the contents in the plastic containers were sealed shut and placed into cold storage for archival purposes. 
Table 2.7. Splitspoon Core Samples from C4104. Two characterization samples (labeled “A” and “B”) were collected from most of the cores for a total of $\mathbf{4 4}$ samples.

\begin{tabular}{|c|c|c|c|c|c|c|c|c|}
\hline $\begin{array}{l}\text { Core Sample } \\
\text { ID }\end{array}$ & COC\# & $\begin{array}{c}\text { Top } \\
\text { Depth (ft) }\end{array}$ & $\begin{array}{c}\text { Bottom } \\
\text { Depth } \\
\text { (ft) }\end{array}$ & $\begin{array}{c}\text { Mid } \\
\text { Depth (ft) }\end{array}$ & $\begin{array}{l}\text { Sampled } \\
\text { Interval } \\
\text { Thickness } \\
\text { (ft) }\end{array}$ & Lithology & $\begin{array}{l}\text { Stratigraphic } \\
\text { Unit }\end{array}$ & Comments \\
\hline C4104-14.98 & S03072-01 & 14.98 & 16.58 & 15.78 & 1.6 & Gravelly sand & backfill & \\
\hline C4104-21.68 & S03072-02 & 21.68 & 23.03 & 22.36 & 1.35 & $\begin{array}{l}\text { Silty sandy } \\
\text { gravel }\end{array}$ & backfill & \\
\hline C4104-29.73 & S03072-03 & 29.73 & 31.08 & 30.41 & 1.35 & $\begin{array}{l}\text { Silty gravelly } \\
\text { sand }\end{array}$ & backfill & \\
\hline C4104-35.90 & S03072-04 & 35.9 & 37.2 & 36.55 & 1.3 & $\begin{array}{l}\text { Silty gravelly } \\
\text { sand }\end{array}$ & backfill & $\begin{array}{l}\text { Small-diameter (1.93 in.) core - } \\
\text { upper liner empty }\end{array}$ \\
\hline C4104-39.00 & S03072-05 & 39 & 40.35 & 39.68 & 1.35 & Gravelly sand & backfill & $\begin{array}{l}\text { Small-diameter (1.93 in.) core - } \\
\text { upper liner empty; most or all of } \\
\text { sample recovered appears to be } \\
\text { slough }\end{array}$ \\
\hline C4104-46.00 & S03072-06 & 46 & 47.3 & 46.65 & 1.3 & Sand & $\mathrm{H} 2$ & $\begin{array}{l}\text { Spike (350,000 cpm) of }{ }^{60} \mathrm{Co} \text {, } \\
{ }^{152} \mathrm{Eu} \text {, and }{ }^{154} \mathrm{Eu}\end{array}$ \\
\hline C4104-58.04 & S03072-07 & 58.04 & 59.44 & 58.74 & 1.4 & $\begin{array}{l}\text { Silty sand to } \\
\text { sand }\end{array}$ & $\mathrm{H} 2$ & \\
\hline C4104-63.05 & S03072-08 & 63.05 & 64.35 & 63.7 & 1.3 & $\begin{array}{l}\text { Sand to silty } \\
\text { sand }\end{array}$ & $\mathrm{H} 2$ & \\
\hline C4104-75.05 & S03072-09 & 75.05 & 76.35 & 75.7 & 1.3 & Sand & $\mathrm{H} 2$ & \\
\hline \multirow{2}{*}{ C4104-80.05 } & \multirow{2}{*}{ S03072-10 } & \multirow{2}{*}{80.05} & \multirow{2}{*}{81.37} & \multirow{2}{*}{80.71} & \multirow{2}{*}{1.32} & \multirow{2}{*}{$\begin{array}{l}\text { Sand to silty } \\
\text { sand }\end{array}$} & $\mathrm{H} 2 /$ & \multirow{2}{*}{$\begin{array}{l}\text { Core straddles contact between } \mathrm{H} 2 \\
\text { and CCUu }\end{array}$} \\
\hline & & & & & & & $\mathrm{CCU}_{\mathrm{u}}$ & \\
\hline
\end{tabular}


Table 2.7. (contd)

\begin{tabular}{|c|c|c|c|c|c|c|c|c|}
\hline $\begin{array}{l}\text { Core Sample } \\
\text { ID } \\
\end{array}$ & COC\# & $\begin{array}{c}\text { Top } \\
\text { Depth (ft) }\end{array}$ & $\begin{array}{l}\text { Bottom } \\
\text { Depth } \\
\text { (ft) }\end{array}$ & $\begin{array}{c}\text { Mid } \\
\text { Depth } \\
\text { (ft) }\end{array}$ & $\begin{array}{c}\text { Sampled } \\
\text { Interval } \\
\text { Thickness (ft) }\end{array}$ & Lithology & $\begin{array}{c}\text { Stratigraphic } \\
\text { Unit }\end{array}$ & Comments \\
\hline C4104-86.3 & S03072-11 & 86.3 & 87.7 & 87 & 1.4 & Silt to silty sand & $\mathrm{CCU}_{\mathrm{u}}$ & \\
\hline \multirow{2}{*}{ C4104-91.63 } & \multirow{2}{*}{ S03072-12 } & \multirow[b]{2}{*}{91.63} & \multirow{2}{*}{92.93} & \multirow{2}{*}{92.28} & \multirow[b]{2}{*}{1.3} & \multirow{2}{*}{$\begin{array}{l}\text { Silty sand to } \\
\text { gravelly muddy } \\
\text { sand (caliche) }\end{array}$} & $\mathrm{CCU}_{\mathrm{u}} /$ & \multirow{2}{*}{$\begin{array}{l}\text { Core straddles contact between } \\
\text { upper and lower CCU }\end{array}$} \\
\hline & & & & & & & $\mathrm{CCU}_{\mathrm{l}}$ & \\
\hline C4104-92.58 & S03072-13 & 92.58 & 93.88 & 93.23 & 1.3 & $\begin{array}{l}\text { Slightly gravelly } \\
\text { muddy sand }\end{array}$ & $\mathrm{CCU}_{\mathrm{l}}$ & $0.35 \mathrm{ft}$ overlap with previous core \\
\hline C4104-93.75 & S03072-14 & 93.75 & 95.17 & 94.46 & 1.42 & $\begin{array}{l}\text { Gravelly muddy } \\
\text { sand to silty sand }\end{array}$ & $\mathrm{CCU}_{\mathrm{l}}$ & $0.13 \mathrm{ft}$ overlap with previous core \\
\hline C4104-99.37 & S03072-15 & 99.37 & 100.7 & 100.04 & 1.33 & $\begin{array}{l}\text { Slightly silty sand } \\
\text { to sand }\end{array}$ & $\mathrm{CCU}_{\mathrm{l}}$ & \\
\hline C4104-101.00 & S03072-16 & 101 & 102.3 & 101.65 & 1.3 & Sandy mud & $\mathrm{CCU}_{1}$ & \\
\hline C4104-105.04 & S03072-17 & 105.04 & 106.44 & 105.74 & 1.4 & $\begin{array}{l}\text { Slightly gravelly } \\
\text { sand }\end{array}$ & $\mathrm{CCU}_{\mathrm{l}}$ & \\
\hline C4104-106.44 & S03072-18 & 106.44 & 107.74 & 107.09 & 1.3 & Sandy silt to sand & $\mathrm{CCU}_{1}$ & \\
\hline C4104-110.00 & S03072-19 & 110 & 111.3 & 110.65 & 1.3 & Sandy silt & $\mathrm{R}_{\mathrm{tf}}$ & \\
\hline C4104-114.86 & S03072-20 & 114.86 & 116.41 & 115.64 & 1.55 & $\begin{array}{l}\text { Sandy silt to silty } \\
\text { sand }\end{array}$ & $\mathrm{R}_{\mathrm{tf}}$ & \\
\hline C4104-119.96 & S03072-21 & 119.96 & 121.3 & 120.63 & 1.34 & $\begin{array}{l}\text { Silty sand to sand } \\
\text { to sandy gravel }\end{array}$ & \begin{tabular}{l|l|}
$\mathrm{R}_{\mathrm{t}} /$ \\
$\mathrm{R}$
\end{tabular} & $\begin{array}{l}\text { Core straddles contact between } R_{\mathrm{tf}} \\
\text { and } \mathrm{R}_{\mathrm{wi}}\end{array}$ \\
\hline C4104-122.96 & S03072-22 & 122.96 & 124.41 & 123.69 & 1.45 & $\begin{array}{c}\text { to sandy gravel } \\
\text { Sandy gravel }\end{array}$ & $\frac{\mathrm{R}_{\mathrm{wi}}}{\mathrm{R}_{\mathrm{wi}}}$ & \\
\hline C4104-126.12 & S03072-23 & 126.12 & 127.46 & 126.79 & 1.34 & Sandy gravel & $\mathrm{R}_{\mathrm{wi}}$ & \\
\hline
\end{tabular}


The hole was advanced using a solid probe such that no grab samples were collected between core runs; thus no near-continuous geologic field log is available for this hole, unlike the background hole (299-W11-39). Figure 2.12 presents a summary log for C4104 based on available geologic descriptions, core photographs, geophysical logs, laboratory derived gravimetric moisture, and blow-count data. The hydrogeology between core runs is inferred and interpreted based on geophysical logging and blow-count data. Four primary stratigraphic units were encountered by this borehole: 1) recent backfill material, 2) the Hanford formation, 3) the Cold Creek unit, and 4) the Ringold Formation. A brief description of the sampled materials from each of these major stratigraphic units is presented below.

\subsubsection{Backfill}

The backfill in C4104 extends from the ground surface to a depth of $40 \mathrm{ft}(12.2 \mathrm{~m})$ where it lies in contact with the Hanford formation (Figure 2.12). A total of 8 physical, chemical, and radiological characterization samples were collected from five splitspoon intervals within backfill material (Table 2.7). Backfill material (Figure 2.13) consists of poorly to moderately sorted, massive, gravelly sand to slightly gravelly sand with variable amounts of silt (Figure 2.13). Colors range from grayish brown to olive and yellowish-brown. Backfill materials are unconsolidated and weakly to strongly calcareous (see Appendix B-1 for more detailed descriptions). The overall moisture content for backfill materials is relatively low, averaging about $7.9+/-1.5 \mathrm{wt} \%$ (Table 2.6).

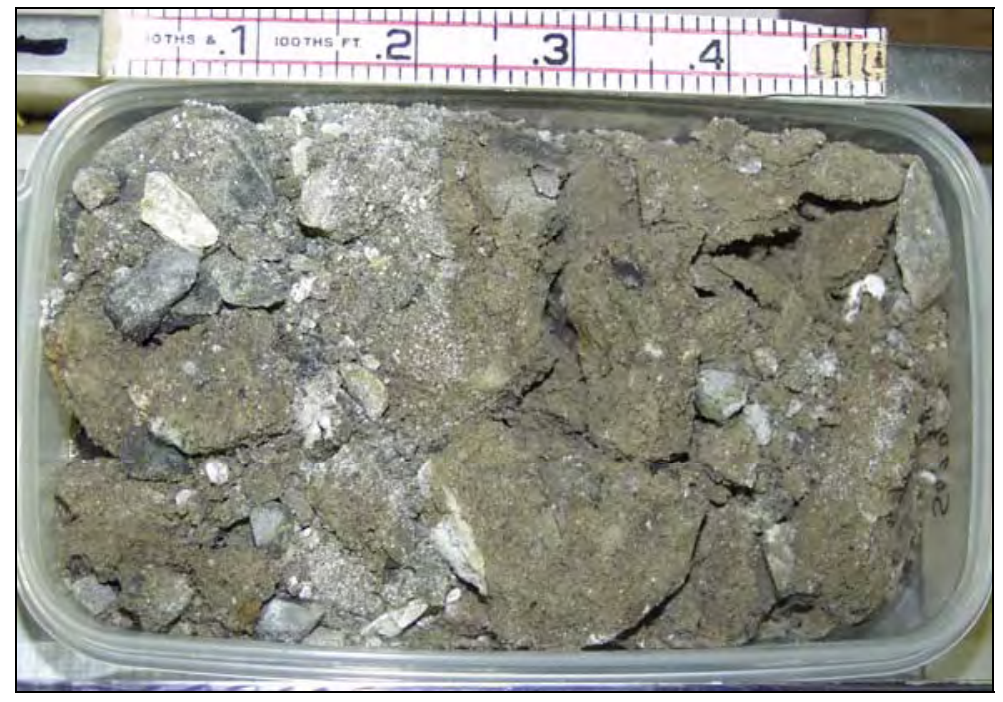

Figure 2.12. Typical Backfill From Borehole C4104. Core sample S03072-3A from a depth of 30.41 to $31.08 \mathrm{ft}$ bgs. Described as a slightly moist, olive-brown, poorly sorted, silty gravelly sand (mgS), weakly to moderately calcareous. The light-colored powdery material to the left is a granitic clast that was pulverized during the drilling process. 


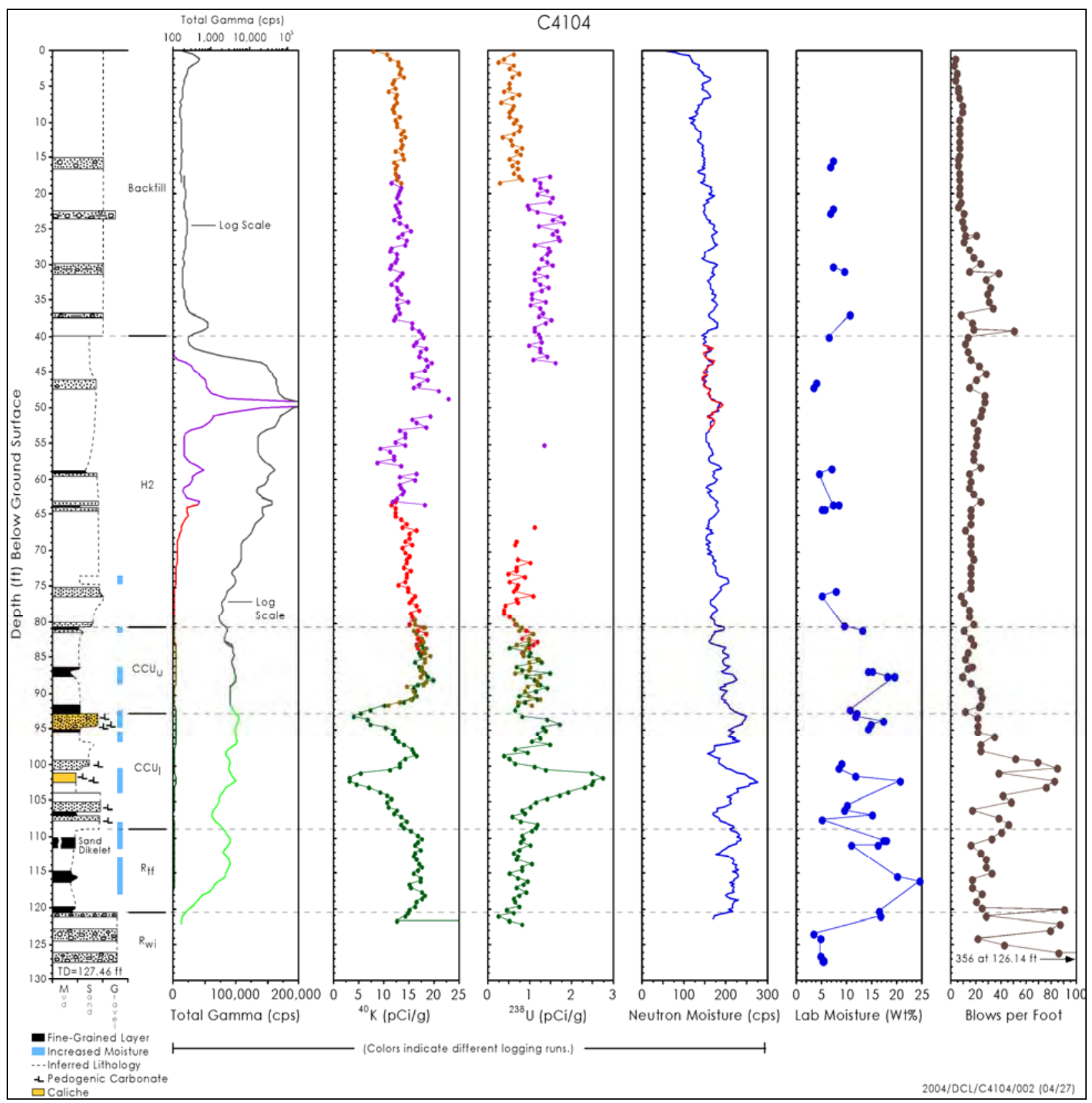

Figure 2.13. Summary Hydrogeologic Log for Borehole C4104. Zones of increased moisture are indicated as those with $>15$ wt\% water in core samples and/or show as distinct spikes on neutron-moisture log. Fine-grained layers are defined as those consisting predominantly of particles $<0.25 \mathrm{~mm}$ in diameter (i.e., fine sand and smaller). 
This unit appears to be rather homogeneous and lacks lithologic variation, except at the base. A steady increase in blow counts occurs towards the bottom of the hole, perhaps associated with compaction (Figure 2.12). The formation hardness drops off suddenly just above the base. This drop in blow counts is accompanied by a slight increase in natural gamma activity and moisture content, probably indicating a finer-grained bed (i.e., silty) is present at the base of the backfill.

\subsubsection{Hanford Formation}

Pleistocene cataclysmic flood deposits of the Hanford formation underlie backfill materials to a depth of $24.6 \mathrm{~m}(80.7 \mathrm{ft})$ in probe hole C4104. Only the sand-dominated Hanford formation $\mathrm{H} 2$ unit is represented; all of the coarse-grained Hanford formation H1 unit was removed during tank-farm construction, to be used later as backfill around the tanks.

\subsection{Hanford Formation H2 Unit}

The Hanford formation H2 unit is present between 40 to $80.7 \mathrm{ft}$ (12.2 to $24.6 \mathrm{~m}$ ) bgs. The H2 unit consists of predominantly fine-to-coarse-grained, gray to brownish-gray "salt and pepper" sand (Figure 2.14). The H2 unit is weakly to strongly calcareous and occasionally shows weak horizontal laminations. Dispersed within the Hanford formation $\mathrm{H} 2$ unit are at least two separate, relatively thin ( $\leq 0.5 \mathrm{ft}$ ), light olive-brown, compact, moderately to well-sorted, silty fine sand beds. These occur at depths starting at 58.6 and $63.5 \mathrm{ft}$ bgs (Figure 2.12). Other additional fine-grained beds may also be present between cored intervals. The base of the $\mathrm{H} 2$ unit, consisting of medium sand, lies in sharp contact with the underlying silty fine sand of the upper CCU at $80.7 \mathrm{ft}$ bgs in the middle of core S03072-10.

Moisture within cores from the $\mathrm{H} 2$ unit ranged from dry to slightly moist. One higher moisture zone at about $74 \mathrm{ft}$ bgs, near the base of the $\mathrm{H} 2$ unit, is indicated by a spike in the neutron moisture log (Figure 2.12). This higher moisture interval is probably associated with a fine-grained lens within the H2 unit. The penetration resistance (i.e., blow counts) is remarkably uniform over most of the $\mathrm{H} 2$ unit.

A total of 9 characterization samples were obtained from the Hanford formation $\mathrm{H} 2$ unit from probe hole C4104 (Table 2.7). Most of the samples from this unit consisted of medium- to coarse-grained sand; two of the samples [S03072-07A and S03072-08B] contained some silty fine sand.

\subsubsection{Cold Creek Unit (CCU)}

The Cold Creek unit in C4104 is 27.3-ft thick (Table 2.3). The top of the CCU lies at $80.7 \mathrm{ft}$ (24.6 m) bgs and bottom at about $108 \mathrm{ft}(32.9 \mathrm{~m})$. A total of 17 characterization samples were collected from the CCU, four from the upper CCU and 13 from the lower CCU (Table 2.7). The average moisture content increased significantly for the CCU, compared to overlying stratigraphic units (Table 2.6).

\subsection{Upper Cold Creek Unit $\left(\mathrm{CCU}_{\mathrm{u}}\right)$}

The contact between the Cold Creek unit and the overlying Hanford formation $\mathrm{H} 2$ unit lies at $80.7 \mathrm{ft}$ ( $24.6 \mathrm{~m}$ ) bgs. Both the upper and lower contacts of the $\mathrm{CCU}_{\mathrm{u}}$ were intersected during coring so the true thickness of the subunit is well established at $11.8-\mathrm{ft}$ thick (80.7 to $92.5 \mathrm{ft}$ bgs). 


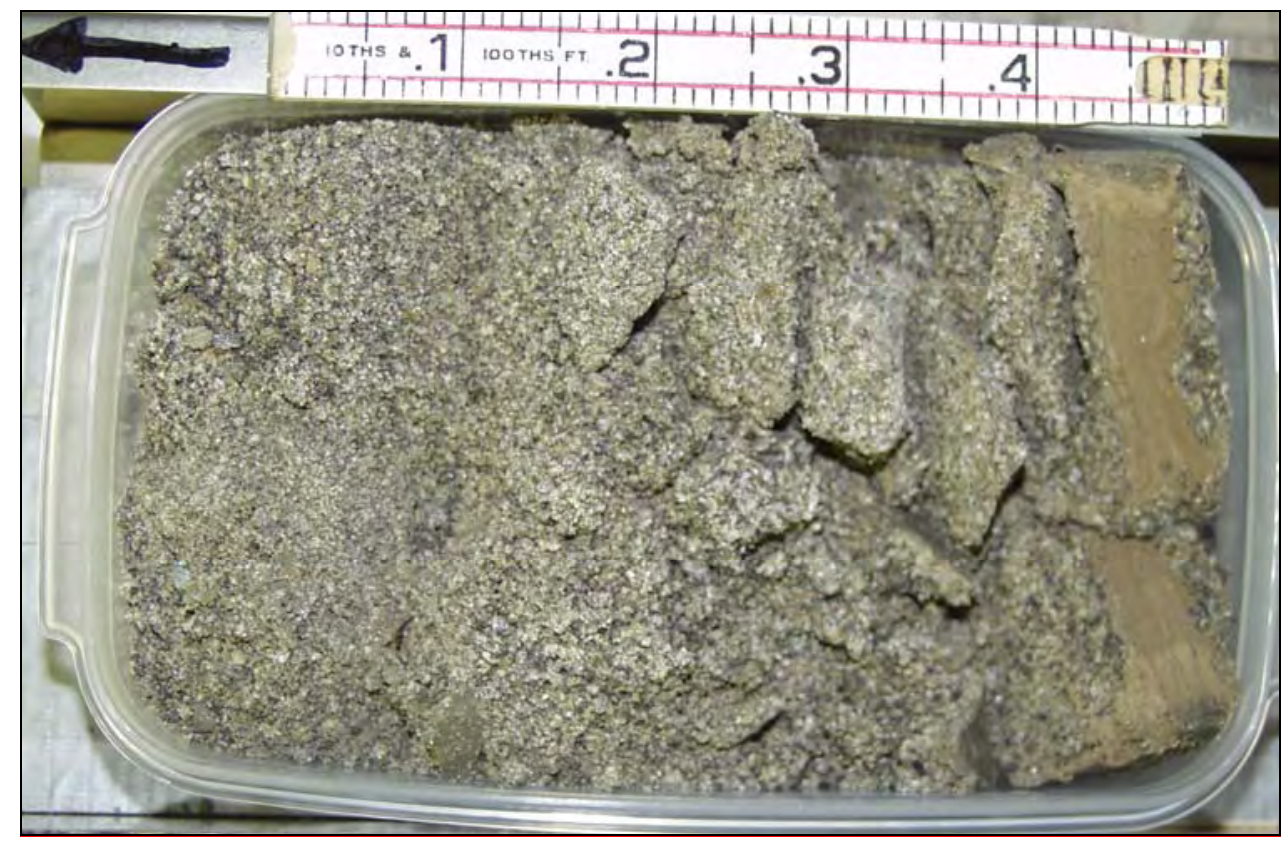

Figure 2.14. Hanford Formation H2 Unit in Borehole C4104. Core sample S03072-7A from a depth of 58.74 to $59.44 \mathrm{ft}$ bgs. This core consist of mostly a loose, moderately sorted, grayish-brown, medium- to coarse-grained, "salt and pepper"-like sand (S). At the top of the core (right) is a thin lens of well-sorted, olive-brown, silty fine sand (mS). Because of smaller grain sizes this lens is more cohesive and compact, allowing better preservation of the laminations that formed during deposition.

Four samples of the upper CCU were collected for physical, chemical, and radiological characterization (Table 2.7). Sediments from this unit consist of compacted and well-sorted silt to fine sand, which range from moderately to strongly calcareous. All the cores collected from the upper CCU in C4104 showed horizontal laminations, indicating the calcium carbonate is primarily of detrital origin, and not the result of soil development, as is the case with calcic soils of the underlying lower CCU. The structure of upper CCU in this borehole indicates a probable fluvial overbank origin and not a paleosol, as suggested in Reynolds (2003a), because any primary sedimentary structures (e.g., laminae) would have been destroyed during soil development. Moisture in the core samples ranged from slightly moist to moist. A typical example of a core from the upper CCU is shown in Figure 2.15.

\subsection{Lower Cold Creek Unit $\left(\mathrm{CCU}_{\mathrm{l}}\right)$}

The contact between the laminated silty sediments of the upper CCU and the calcic paleosol sequence of the lower CCU lies at $92.5 \mathrm{ft}$ (28.2 m) bgs. Sediments from this unit consist of mostly poorly sorted, massive mixtures of weathered, pale yellow sand, mud, and gravel, variably cemented with whitish pedogenic calcium carbonate. Some weak secondary pedogenic banding may also be apparent. The base of the lower CCU is defined by the depth of pedogenic weathering and calcic-soil development. The lowermost sample showing signs of pedogenic alteration was at $107.74 \mathrm{ft}$ bgs in core \#S03072-18. The next core, which started at depth of $110 \mathrm{ft}$ bgs is unaltered sandy silt of the Ringold Formation member of Taylor Flat. Based on geophysical logs and a drop in formation hardness (i.e., blow-count data), a contact of $108 \mathrm{ft}$ bgs is chosen for the base of the Cold Creek unit. 


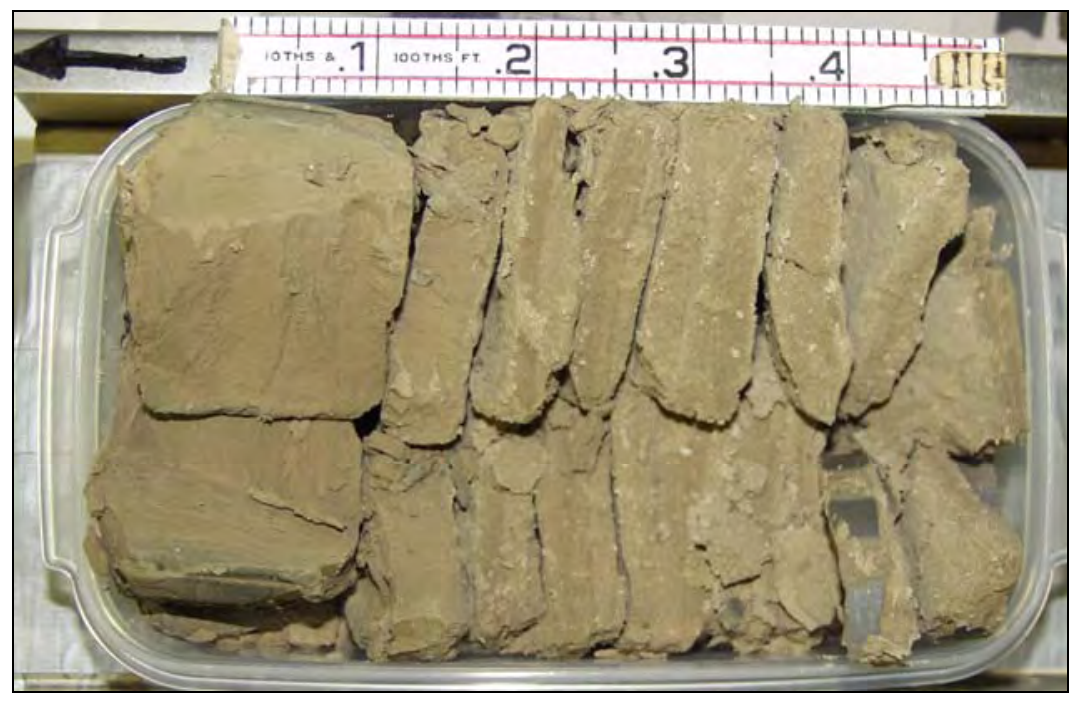

Figure 2.15. Upper Cold Creek Subunit $\left(\mathbf{C C U}_{\mathbf{u}}\right)$ in C4104. Core sample S03072-11A from 87.0 to $87.7 \mathrm{ft}$ bgs. Described as moist, well laminated, compacted, well-sorted, olive-brown, silt (M) to fine sandy silt (sM), and strongly calcareous. The high concentration of calcium carbonate appears to be the result of erosion and fluvial reworking of the underlying $C C U_{l}$ caliche layers, and not from in situ soil development. Top of core is to the right.

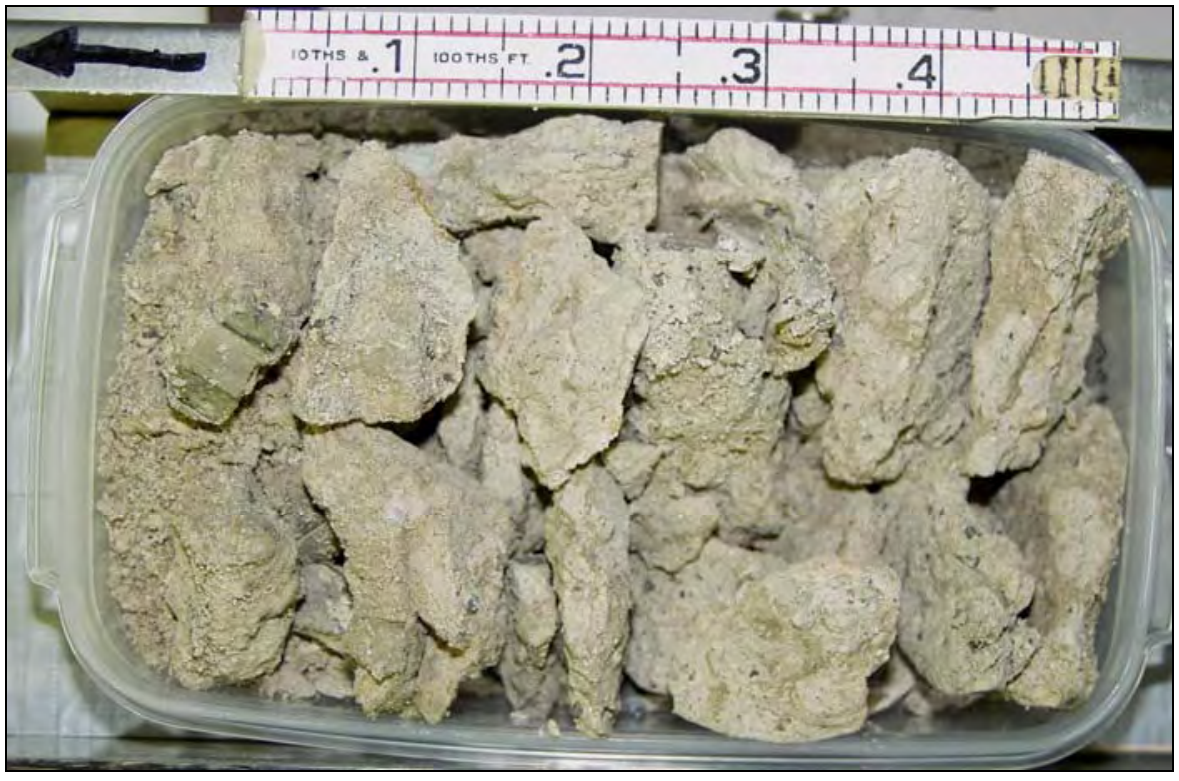

Figure 2.16. Lower Cold Creek Subunit $\left(\mathbf{C C U}_{\mathbf{l}}\right)$ in C4104. Core sample of highly cemented caliche near top of the lower CCU (93.23 to $93.88 \mathrm{ft}$ bgs). From core S03072-13A, described as moist, strongly calcareous and cemented, very poorly sorted, pale yellow, slightly gravelly muddy sand. Numerous dark basalt granules float in a matrix of sand, silt and clay. Caliche is highly fragmented due to the drilling process. The top of the core is to the right. 
A total of 13 samples of the lower CCU were collected for physical, chemical, and radiological characterization (Table 2.7). Moisture in the core samples ranged from slightly moist to moist. Judging from the blow-count data, it appears that the middle portion of the $\mathrm{CCU}_{1}$ is the most strongly cemented (Figure 2.12). A core photograph of the lower CCU is shown in Figure 2.16.

\subsubsection{Ringold Formation}

Almost $20 \mathrm{ft}$ of Ringold Formation sediments were penetrated within C4104 before the probe hole met refusal and was terminated at $127.46 \mathrm{ft}$ bgs. Two members of the Ringold Formation were present. Encountered first was the finer-grained Ringold Formation member of Taylor Flat $\left(\mathrm{R}_{\mathrm{tf}}\right)$, followed by the coarser-grained Ringold Formation member of Wooded Island $\left(\mathrm{R}_{\mathrm{wi}}\right)$ (Figure 2.12). A total of 10 samples were collected from splitspoon cores from the Ringold Formation in C4104 for physical, chemical, and radiological characterization (Table 2.7).

\subsection{Ringold Formation - Member of Taylor Flat $\left(\mathbf{R}_{\mathrm{tf}}\right)$}

The Ringold Formation member of Taylor Flat in probe hole C4104 extends from 108 to $120.9 \mathrm{ft}$ bgs and is 12.9-ft thick (Table 2.3). The $\mathrm{R}_{\mathrm{tf}}$ unit consists of mostly compacted, well-laminated, well-sorted, olive-brown to yellowish-brown sandy silt with lesser amounts of sand to slightly gravelly sand. The concentration of calcium carbonate appears to decrease with depth and distance from the overlying Cold Creek unit. A core photograph of the $\mathrm{R}_{\mathrm{tf}}$ is shown in Figure 2.17.

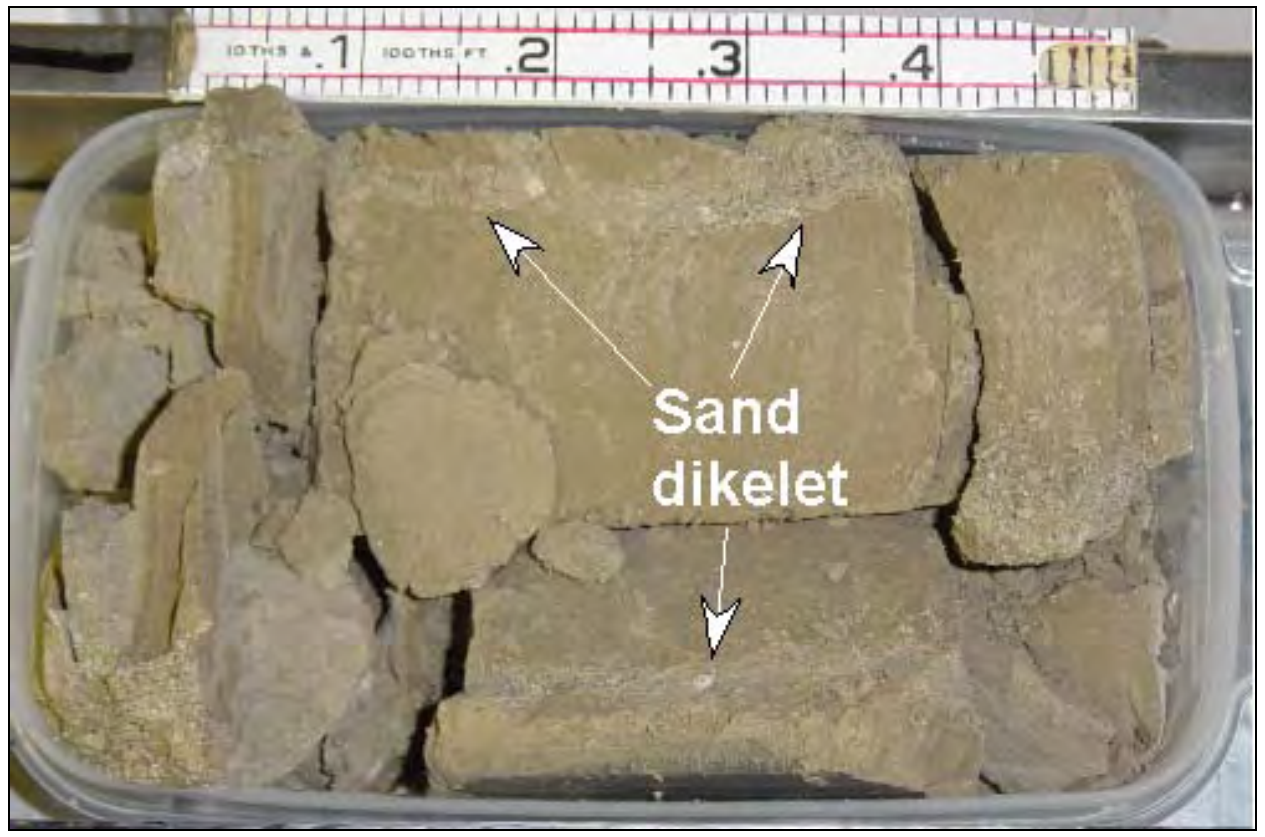

Figure 2.17. Ringold Formation Member of Taylor Flat $\left(\mathbf{R}_{\mathbf{t f}}\right)$ in C4104. Core sample S03072-19A from a depth of 110.65 to $111.30 \mathrm{ft}$ bgs. Described as moist, laminated, well-sorted, compact, olive-brown, fine sandy silt (sM). These sediments are non-calcareous, being well below the influence of calcic soil development associated with the overlying Cold Creek unit. A narrow (5mm) clastic dike, filled with well-sorted fine sand, cuts vertically across the bedding. Location of dikelet is shown schematically in Figure 2.12. The top of the core is to the right. 
A total of five characterization samples were collected from splitspoon cores from this unit. Observed moisture in core samples was slightly moist to moist and samples measured in the laboratory had the highest moisture of all the stratigraphic units measured with an average of $14.9+/-5.5 \mathrm{wt} \%$ water (Table 2.6).

\subsection{Ringold Formation - Member of Wooded Island $\left(\mathbf{R}_{\mathrm{wi}}\right)$}

The contact between fine-grained $\mathrm{R}_{\mathrm{tf}}$ unit with the underlying coarse-grained $\mathrm{R}_{\mathrm{wi}}$ unit lies at $120.9 \mathrm{ft}$ bgs. The borehole advanced only $6.6 \mathrm{ft}$ into the $\mathrm{R}_{\mathrm{wi}}$ unit before the borehole was abandoned at $127.46 \mathrm{ft}$ bgs. Based on core samples alone, all that can be said about the $\mathrm{R}_{\mathrm{wi}}$ unit is that it consists of a multi-lithologic sandy gravel (Figure 2.18). During drilling, much pulverization naturally occurred when trying to drive the splitspoon into clast-supported gravels that are larger than the diameter of the splitspoon. As a result, the drilling destroyed original structure and fabric of the material while adding fines and producing abundant angular rock fragments to the mix. Note that the roundness, sorting, texture, and color of the sediment recovered from this hole (Figure 2.18) are highly unrepresentative of the original material.

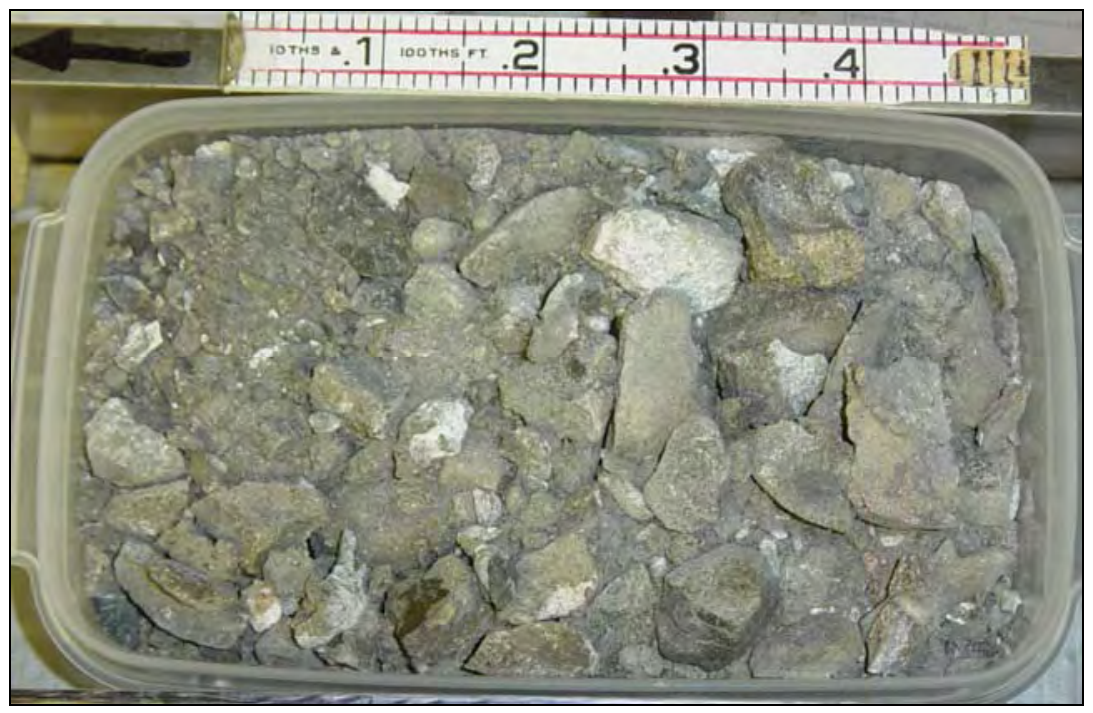

Figure 2.18. Ringold Formation Member of Wooded Island $\left(\mathbf{R}_{\mathrm{wi}}\right)$ in C4104. Core sample S03072-23A from a depth of 126.79 to the bottom of the hole at $127.46 \mathrm{ft}$ bgs. Described as a dry to slightly moist, non-calcareous, loose, very poorly sorted, dark gray, sandy gravel. Material was highly fragmented and pulverized during the drilling process. The top of the core is to right.

Based on past studies using other, less-destructive drilling methods as well as outcrop investigations, undisturbed Ringold Formation member of Wooded Island (Unit E) is described as a fluvial, clast-supported, bimodal, pebble to cobble gravel, with well-rounded clasts of basalt, quartzite, porphyritic volcanics, and greenstone, in a well-sorted matrix of quartzo-feldspathic sand (Lindsey 1995). The colors of most facies of the Ringold Formation are shades of brown due to a pervasive iron-oxide film, a weathering product that coats most sand and gravel clasts within the Ringold Formation to varying degrees. 
A total of five characterization samples were collected from splitspoon cores from the $\mathrm{R}_{\mathrm{wi}}$ unit. Observed moisture in core samples was dry to slightly moist. Samples measured in the laboratory corroborate the low-moisture content of this unit, which averaged about $4.3+/-0.8 \mathrm{wt} \%$ water (Table 2.6).

\subsubsection{Borehole C4105}

Borehole C4105 was drilled and sampled using a driven-probe technique between January 8 and March 12, 2003 (Reynolds 2003b). The borehole is closest to single-shell tank 241-T-106, where it lies approximately $28.1 \mathrm{ft}(8.6 \mathrm{~m})$ southwest (Figure 2.4$)$. The borehole is only slightly farther (36.78 ft [11.2 m]) from tank 241-T-109, located to the southeast. Total depth of the borehole was $130.9 \mathrm{ft}$ (39.9 m) bgs; the hole terminated within the vadose zone about $100 \mathrm{ft}$ (30 m) above the groundwater table. During drilling, a total of 22, 1.25-ft long splitspoon core samples were collected intermittently starting at a depth of about $14 \mathrm{ft}$ bgs (Table 2.8, Figure 2.19). All samples were overdriven beyond the 1.25 - $\mathrm{ft}$ length of the splitspoon, which resulted in over-compaction of most samples. In all, $30 \mathrm{ft}$ of core was collected from C4105, which accounts for about $23 \%$ of the total length of the hole. No samples or drill cuttings were collected between the 22 core runs because the hole was advanced in a closed configuration using a solid, removable tip. Surface elevation of the since-abandoned borehole was $675.02 \mathrm{ft}$ above mean sea level and geographic coordinates were N136720.758 m and E566761.692 m (Reynolds 2003b). Probe hole C4105 was decommissioned between March 14-18, 2003 by back-pulling the casing while filling the hole with dry bentonite.

Similar to borehole C4104, each splitspoon in C4105 contained two, 0.5-ft long stainless-steel core liners. A separate subsample was collected from each of the two liners for physical, chemical, and radiological characterization, from most of the 22 splitspoons collected. Two exceptions were from core runs \#3 and \#4, which contained smaller-diameter, shielded liners (1.93-in. inner diameter). In these core runs, only the lower half of the splitspoons was full, with the upper liner coming up empty. Recovery was generally $100 \%$ for the larger-diameter (2.51-inch inner diameter), non-shielded liners. Thus, a total of only 42 samples were collected for physical, chemical, and radiological characterization from C4105 (Table 2.8).

Splitspoon cores from probe hole C4105 were processed in a radiologically controlled PNNL laboratory. Most splitspoon cores were extracted, sampled, photographed, and geologically logged on February 24-25, 2003. Subsequent attempts to deepen the hole produced a final core sample (S03044-22), which was processed at PNNL about a month later (March 21, 2003). Core \#22 did not recover any new material beyond that collected by core \#21 so no additional samples were taken from core \#22. Geologic logging occurred after the contents of each 0.5 - $\mathrm{ft}$ stainless-steel core liner was emptied into an open plastic container, followed by photographing and subsampling for physical, chemical, and radiological characterization. Upon completion of these activities, the contents in the plastic containers were sealed shut and placed into cold storage for archival purposes. Geologic logs of the material within the core liners were generated by geologists Victoria Johnson (Kennedy / Jenks) and Bruce Bjornstad (PNNL). Kennedy / Jenks core logs are in Appendix E of Reynolds (2003b) while the PNNL core logs appear in Appendix B-2 of this report. 
Table 2.8. Splitspoon Core Samples From C4105. Two characterization samples (labeled "A" and "B") were collected from most splitspooned intervals.

\begin{tabular}{|c|c|c|c|c|c|c|c|c|}
\hline $\begin{array}{c}\text { Core } \\
\text { Sample } \\
\text { Id }\end{array}$ & COC\# & $\begin{array}{c}\text { Top } \\
\text { Depth } \\
\text { (ft) }\end{array}$ & $\begin{array}{c}\text { Bottom } \\
\text { Depth } \\
\text { (ft) }\end{array}$ & $\begin{array}{c}\text { Mid } \\
\text { Depth } \\
\text { (ft) }\end{array}$ & $\begin{array}{c}\text { Sampled } \\
\text { Interval } \\
\text { Thickness } \\
\text { (ft) }\end{array}$ & Lithology & $\begin{array}{c}\text { Strati- } \\
\text { graphic } \\
\text { Unit }\end{array}$ & Comments \\
\hline $\begin{array}{l}\text { C4105- } \\
14.16\end{array}$ & S03044-01 & 14.16 & 15.66 & 14.91 & 1.5 & $\begin{array}{l}\text { Silty sandy } \\
\text { gravel }\end{array}$ & backfill & \\
\hline $\begin{array}{l}\text { C4105- } \\
21.70\end{array}$ & S03044-02 & 21.70 & 23.05 & 22.38 & 1.35 & $\begin{array}{l}\text { Silty sandy } \\
\text { gravel }\end{array}$ & backfill & \\
\hline $\begin{array}{c}\text { C4105- } \\
35.74\end{array}$ & S03044-03 & 35.74 & 37.14 & 36.44 & 1.4 & $\begin{array}{l}\text { Silty sandy } \\
\text { gravel }\end{array}$ & backfill & $\begin{array}{l}\text { Small-diameter (2”) core } \\
\text { - upper liner empty }\end{array}$ \\
\hline $\begin{array}{c}\text { C4105- } \\
39.18\end{array}$ & S03044-04 & 39.18 & 40.53 & 39.86 & 1.35 & $\begin{array}{l}\text { Silty gravelly } \\
\text { sand }\end{array}$ & backfill & $\begin{array}{l}\text { Small-diameter (2”) core } \\
\text { - upper liner empty }\end{array}$ \\
\hline $\begin{array}{l}\text { C4105- } \\
47.30\end{array}$ & S03044-05 & 47.30 & 48.03 & 51.69 & 1.45 & Sand & $\mathrm{H} 2$ & \\
\hline $\begin{array}{l}\text { C4105- } \\
54.98\end{array}$ & S03044-06 & 54.98 & 56.53 & 55.76 & 1.55 & Gravelly sand & H2 & \\
\hline $\begin{array}{c}\text { C4105- } \\
68.95\end{array}$ & S03044-07 & 68.95 & 70.45 & 69.70 & 1.5 & Sand & $\mathrm{H} 2$ & \\
\hline $\begin{array}{c}\text { C4105- } \\
80.18\end{array}$ & S03044-08 & 80.18 & 81.58 & 80.88 & 1.4 & Sand & H2 & \\
\hline $\begin{array}{l}\text { C4105- } \\
85.36\end{array}$ & S03044-09 & 85.36 & 87.11 & 86.24 & 1.75 & Sandy silt & $\mathrm{CCU}_{\mathrm{u}}$ & \\
\hline $\begin{array}{c}\text { C4105- } \\
87.22\end{array}$ & S03044-10 & 87.22 & 88.52 & 87.87 & 1.3 & $\begin{array}{l}\text { Sand to silty } \\
\text { sand }\end{array}$ & $\mathrm{CCU}_{\mathrm{u}}$ & \\
\hline $\begin{array}{c}\text { C4105- } \\
92.24\end{array}$ & S03044-11 & 92.24 & 93.59 & 92.92 & 1.35 & $\begin{array}{l}\text { Gravelly } \\
\text { muddy sand }\end{array}$ & $\mathrm{CCU}_{\mathrm{l}}$ & \\
\hline $\begin{array}{c}\text { C4105- } \\
96.01\end{array}$ & S03044-12 & 96.01 & 97.46 & 96.74 & 1.45 & Muddy sand & $\mathrm{CCU}_{\mathrm{l}}$ & \\
\hline $\begin{array}{c}\text { C4105- } \\
99.33\end{array}$ & S03044-13 & 99.33 & 100.68 & 100.00 & 1.35 & Silty sand & $\mathrm{CCU}_{\mathrm{l}}$ & \\
\hline $\begin{array}{l}\text { C4105- } \\
101.02\end{array}$ & S03044-14 & 101.02 & 102.36 & 101.69 & 1.34 & Sandy silt & $\mathrm{CCU}_{\mathrm{l}}$ & \\
\hline
\end{tabular}


Table 2.8. (contd)

\begin{tabular}{|c|c|c|c|c|c|c|c|c|}
\hline $\begin{array}{l}\text { Core } \\
\text { Sample } \\
\text { Id }\end{array}$ & COC\# & $\begin{array}{c}\text { Top } \\
\text { Depth } \\
\text { (ft) }\end{array}$ & $\begin{array}{c}\text { Bottom } \\
\text { Depth } \\
\text { (ft) }\end{array}$ & $\begin{array}{c}\text { Mid } \\
\text { Depth } \\
\text { (ft) }\end{array}$ & $\begin{array}{c}\text { Sampled } \\
\text { Interval } \\
\text { Thickness } \\
\text { (ft) }\end{array}$ & Lithology & $\begin{array}{c}\text { Strati- } \\
\text { graphic } \\
\text { Unit }\end{array}$ & Comments \\
\hline $\begin{array}{l}\text { C4105- } \\
102.17\end{array}$ & S03044-15 & 102.17 & 103.52 & 102.85 & 1.35 & $\begin{array}{l}\text { Gravelly } \\
\text { sandy mud }\end{array}$ & $\mathrm{CCU}_{\mathrm{l}}$ & \\
\hline $\begin{array}{l}\text { C4105- } \\
105.89\end{array}$ & S03044-16 & 105.89 & 107.24 & 106.57 & 1.35 & $\begin{array}{l}\text { Sandy mud to } \\
\text { silt }\end{array}$ & $\mathrm{CCU}_{1}$ & \\
\hline $\begin{array}{l}\text { C4105- } \\
109.07\end{array}$ & S03044-17 & 109.07 & 110.37 & 109.72 & 1.3 & $\begin{array}{l}\text { Silt, sandy silt, } \\
\text { to silty sand }\end{array}$ & $\mathrm{CCU}_{\mathrm{l}}$ & \\
\hline $\begin{array}{l}\text { C4105- } \\
114.97\end{array}$ & S03044-18 & 114.97 & 116.30 & 115.64 & 1.33 & $\begin{array}{l}\text { Sand to sandy } \\
\text { silt }\end{array}$ & $\mathrm{R}_{\mathrm{tf}}$ & \\
\hline $\begin{array}{l}\text { C4105- } \\
119.85\end{array}$ & S03044-19 & 119.85 & 121.19 & 120.52 & 1.34 & $\begin{array}{l}\text { Sand, silty } \\
\text { sand, and } \\
\text { clayey silt }\end{array}$ & $\mathrm{R}_{\mathrm{tf}}$ & \\
\hline $\begin{array}{l}\text { C4105- } \\
122.90\end{array}$ & S03044-20 & 122.90 & 124.24 & 123.57 & 1.34 & Sandy gravel & $\mathrm{R}_{\mathrm{wi}}$ & \\
\hline $\begin{array}{l}\text { C4105- } \\
128.91\end{array}$ & S03044-21 & 128.91 & 130.12 & 129.51 & 1.21 & $\begin{array}{l}\text { Silty sandy } \\
\text { gravel }\end{array}$ & $\mathrm{R}_{\mathrm{wi}}$ & \\
\hline $\begin{array}{l}\text { C4105- } \\
128.58\end{array}$ & S03044-22 & 128.58 & 129.58 & 129.08 & 1.0 & $\begin{array}{l}\text { Silty sandy } \\
\text { gravel }\end{array}$ & $\mathrm{R}_{\mathrm{wi}}$ & $\begin{array}{l}\text { Re-drill of \#21?; mostly } \\
\text { not analyzed }\end{array}$ \\
\hline
\end{tabular}

No radiological contamination was detected with field instrumentation during the driving and sampling of probe hole C4105. However, HPGe spectral-gamma logging did detect cobalt-60 $\left({ }^{60} \mathrm{Co}\right)$ from $48.5 \mathrm{ft}$ to $122 \mathrm{ft}$ bgs (Reynolds 2003b). In addition, europium-154 $\left({ }^{154} \mathrm{Eu}\right)$ was detected between 48.5 to 51 and 57.5 to $66.5 \mathrm{ft}$ bgs. Because of contamination with these radionuclides, the total gamma signal is significantly greater than natural background and therefore not useful for interpreting lithology, especially between 48-80 ft bgs (Figure 2.19).

Because the hole was advanced via a solid probe, no grab samples were collected between core runs; thus, no geologic field log is available for this hole. Figure 2.19 presents a summary log for C4105 based on available geologic descriptions, core photographs, geophysical logs, laboratory measured gravimetric moisture, and blow-count data. The geology between core runs is inferred and interpreted based on these data. 


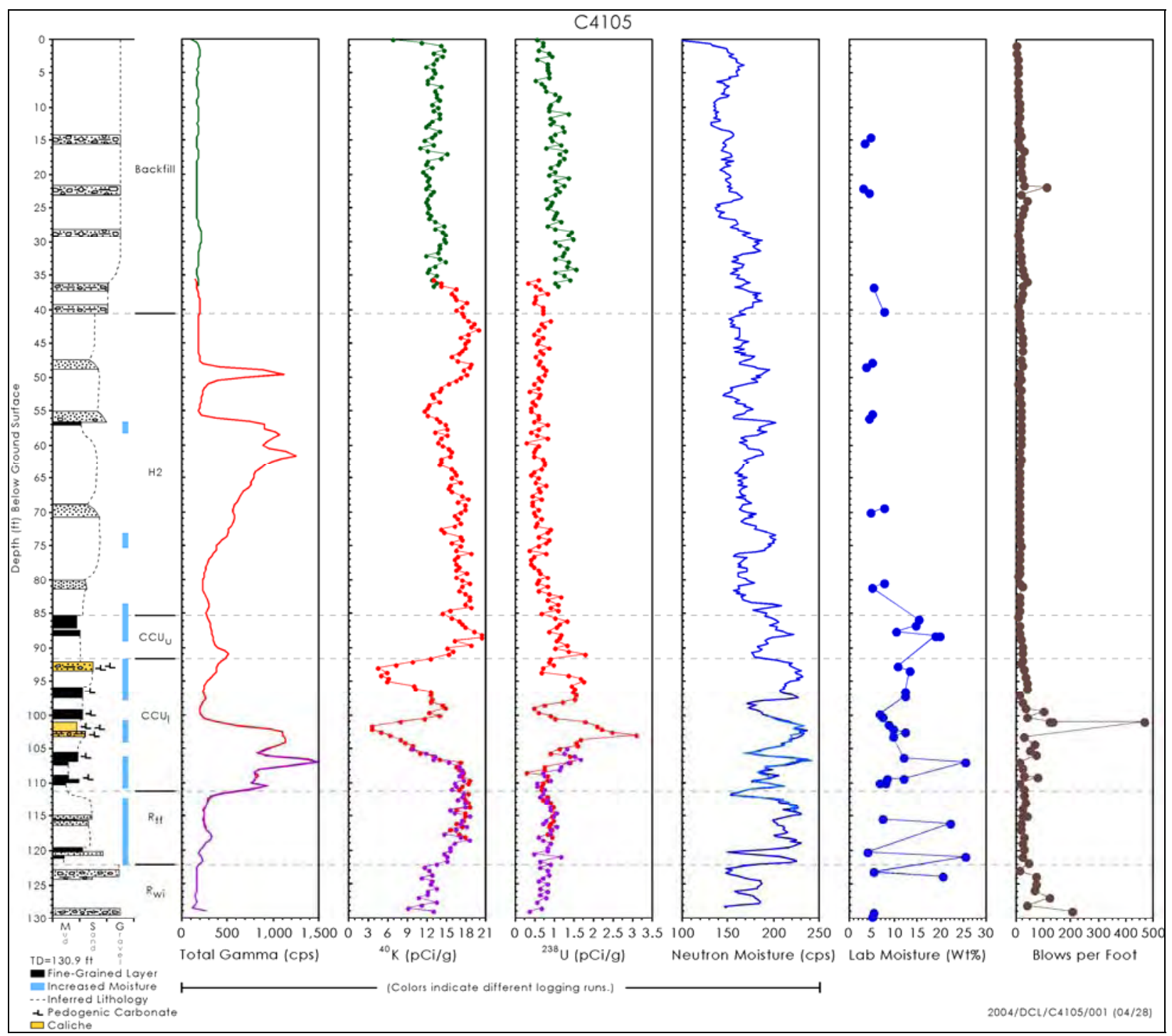

Figure 2.19. Summary Hydrogeologic Log for Borehole C4105. Penetration resistance (i.e., blow count) data is from Reynolds (2003b). Zones of increased moisture are indicated as those with $>15 \mathrm{wt} \%$ water in core samples and/or show as distinct spikes on neutron-moisture log. Fine-grained layers are defined as those consisting predominantly of particles $<0.25 \mathrm{~mm}$ in diameter (i.e., fine sand and smaller).

Four primary stratigraphic units were encountered by this borehole: 1) recent backfill materials, 2) the Hanford formation, 3) the Cold Creek unit, and 4) the Ringold Formation. The following is a brief description of the sampled materials from each of these stratigraphic units.

\subsubsection{Backfill}

The backfill extends from the ground surface to a depth of about $40.6 \mathrm{ft}(12.4 \mathrm{~m})$ where it lies in contact with the Hanford formation H2 unit (Figure 2.19). The exact depth of the base of the backfill is uncertain but tank construction is known to have occurred to depth of about 37-40 ft (Reynolds 2003b). 
Core run \#4, composed of a silty gravelly sand, is identical to samples of backfill above so the contact apparently lies below, but not much below, the $40.53 \mathrm{ft}$ depth. The contact is thus estimated at $40.6 \mathrm{ft}$ bgs.

The backfill material consist of predominantly gray to grayish brown, poorly to very poorly sorted, silty gravelly sand to sandy gravel, which is unconsolidated and weakly to moderately calcareous (Figure 2.20). Because of contamination with man-made radionuclides, the background gamma activity appears washed out through the backfill, which precludes using the total gamma log to interpret lithology (Figure 2.19).

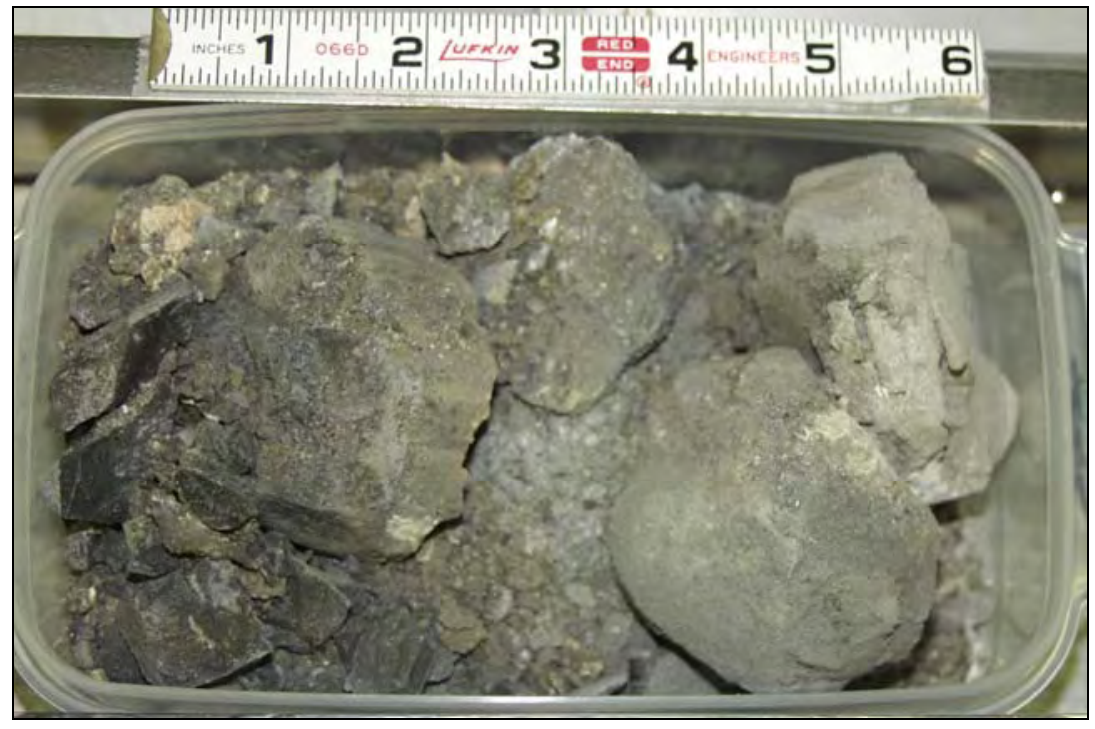

Figure 2.20. Backfill material from borehole C4105. Core sample S03044-2A from a depth of 22.38 to $23.05 \mathrm{ft}$ bgs. Described as a loose, dry to slightly moist, dark gray, very poorly sorted, silty sandy gravel (msG), weakly to moderately calcareous. Coarser gravel at this depth likely led to higher blow counts observed near this depth in Figure 2.19. Most clasts consist of basalt, pulverized during drilling. The top of the core is to the right.

Blow counts are uniformly low in the backfill, except for slightly harder zone at about $22 \mathrm{ft}$ bgs (Figure 2.19). Cores were described as dry to slightly moist immediately after opening in the laboratory. A total of six physical, chemical, and radiological characterization samples were collected from splitspoon cores of backfill material in probe hole C4105. The gravimetric moisture content was relatively low, averaging 4.8 +/- 1.7 wt\% water, in the backfill material from C4105 (Table 2.6).

\subsubsection{Hanford Formation}

About $45 \mathrm{ft}$ of Pleistocene cataclysmic flood deposits of the Hanford formation underlie backfill materials in C4105 (Table 2.3, Figure 2.19). Only the sand-dominated Hanford formation H2 is represented; all of the coarser-grained Hanford formation H1unit was removed during tank-farm construction and later used as backfill around the tanks. 


\subsection{Hanford Formation H2 Unit}

The Hanford formation H2 unit is present between 40.6 to $85.5 \mathrm{ft}$ bgs in C4105 (Figure 2.19). The Hanford formation $\mathrm{H} 2$ sediments consist of mostly fine- to coarse-grained sand with occasional layers of gravelly sand or silty fine sand. The fine to coarse sand beds are loose, massive to laminated, brownish gray to olive-brown, moderately to well-sorted, and weakly to moderately calcareous (Figure 2.21).

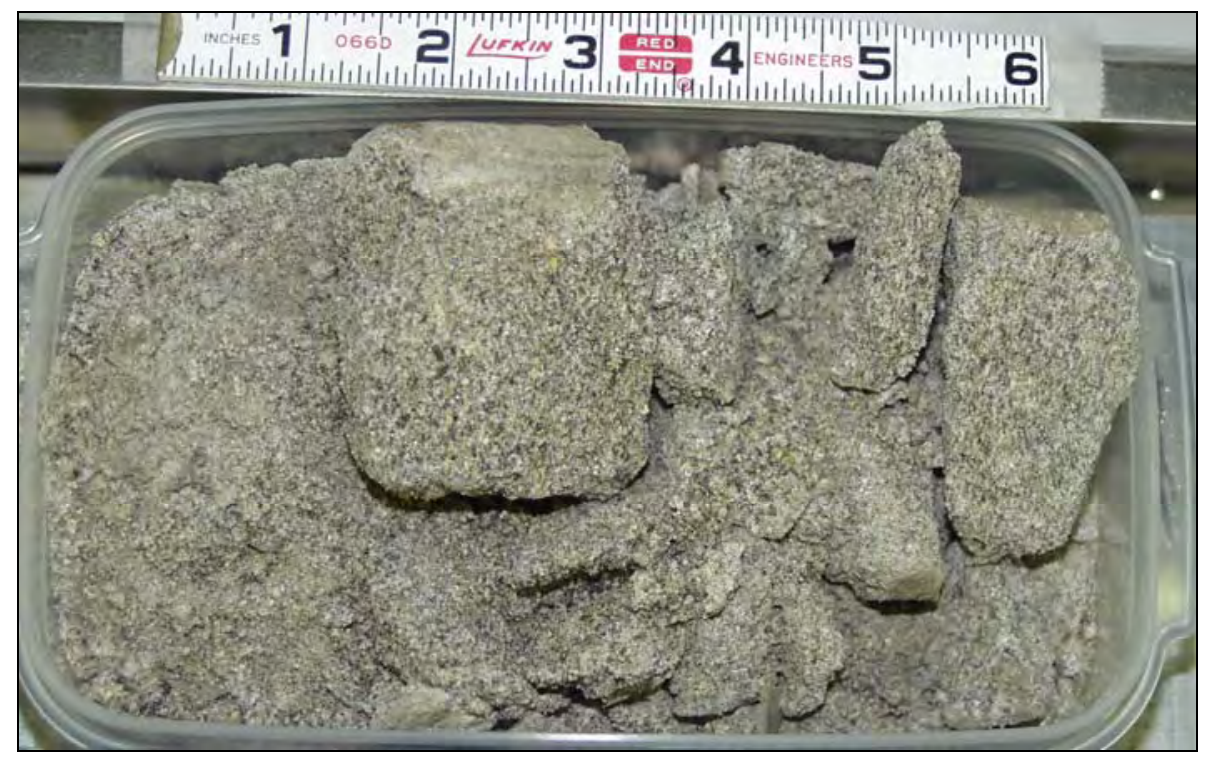

Figure 2.21. Hanford Formation H2 Unit in C4105. Core sample S03044-8A from a depth of 80.88 to $81.58 \mathrm{ft}$ bgs. Described as a slightly moist, loose, moderately sorted, laminated, moderately calcareous, fine to medium, "salt and pepper"-like, grayish-brown sand (S). About $20-30 \%$ of the sand grains are dark basalt rock fragments. Light colored grains are mostly quartz and feldspar. The top of the core is to the right.

There appear to be at least two fine-grained layers within the Hanford formation H2 unit in C4105 (Figure 2.19), which could cause lateral spreading of vadose zone moisture. One of these fine-grained layers was encountered at the bottom and in the nose cone of core \#6A at a depth of $\sim 56.5 \mathrm{ft}$ bgs. There is also a spike in the neutron-moisture log associated with this depth. Another fine-grained layer is suspected at a depth of $\sim 75 \mathrm{ft}$ bgs based on a second spike in the neutron-moisture log for the Hanford formation $\mathrm{H} 2$ unit.

A total of eight physical and chemical characterization samples were collected from within the $\mathrm{H} 2$ unit (Table 2.8).

\subsubsection{Cold Creek Unit}

The upper and lower contacts of the Cold Creek unit in C4105 are $85.5 \mathrm{ft}$ and $111 \mathrm{ft}$ bgs, respectively. The total thickness of the CCU in probe hole C4105 is $25.5 \mathrm{ft}$, slightly greater than that observed in companion hole C4104 (Table 2.3). While both subunits of the Cold Creek unit are clearly present and discernable, the relative thickness of the upper vs. lower subunits is very different for the two probe holes. 
The upper:lower thickness ratio for C4104 is close to 1.0, while this ratio in C4105 is 0.3. This is a remarkable difference considering the boreholes are only $87.7 \mathrm{ft}$ apart, but serves to illustrate the highly heterogeneous nature of the Cold Creek unit.

\subsection{Upper Cold Creek Unit $\left(\mathrm{CCU}_{\mathrm{u}}\right)$}

Sediments from this unit are mostly compacted, laminated, well-sorted, olive-brown, fine sandy silt to silty fine sand. Thin lenses, as coarse as medium-grained sand, were also observed. The subunit is moderately to strongly calcareous, apparently due to a high concentration of detrital calcium carbonate grains derived from the reworking of the underlying caliche-rich lower CCU. An image of one of the cores from C4105 is shown in Figure 2.22. The upper CCU in C4105 is relatively thin (only 6.5-ft thick) compared to adjacent boreholes (Table 2.3, Figure 2.5). This may reflect more erosional scouring of the upper CCU during Ice-Age flooding.

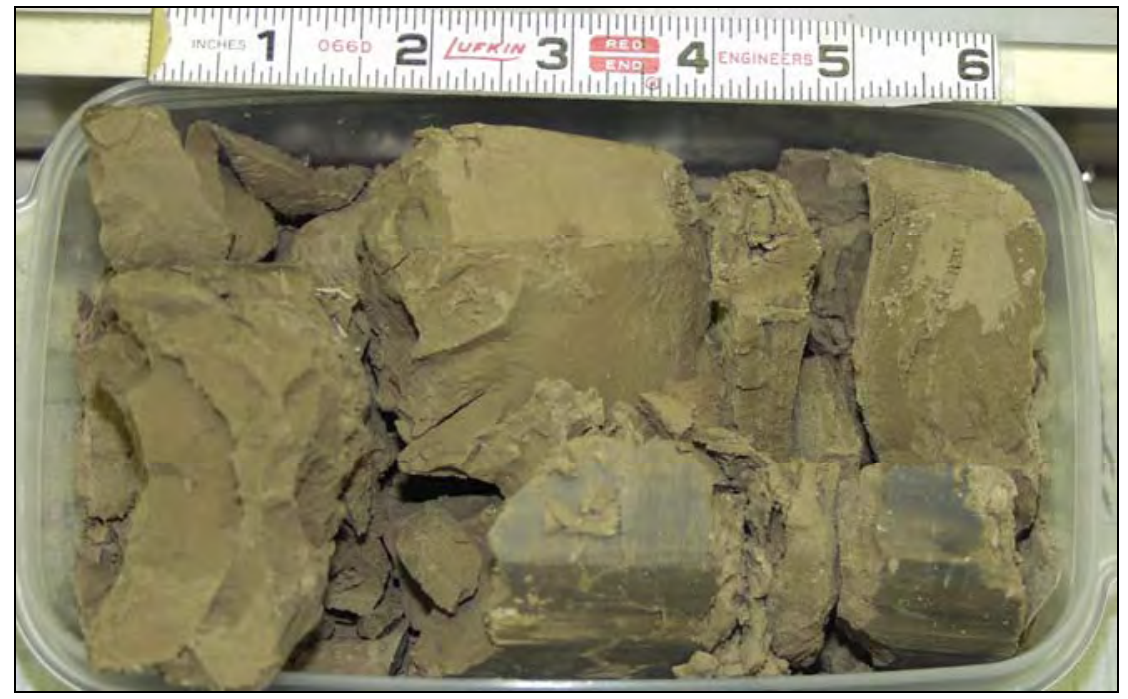

Figure 2.22. Upper Cold Creek Subunit in C4105. Core sample S03044-10A from a depth of 87.87 to $88.52 \mathrm{ft}$ bgs. Described as a homogeneous, moist, weakly laminated, compact, cohesive, well-sorted, moderately to strongly calcareous, olive-brown, silty fine sand $(\mathrm{mS})$. The top of the core is to the right.

A total of four physical and chemical characterization samples from splitspoon cores were collected from this unit in C4105. Upon opening in the laboratory, most of the sediment cores from the upper CCU were classified as moist. Gravimetric moisture content later measured in the laboratory confirmed a relatively high water content, which averaged 15.0 +/- 3.9 wt\%.

\subsection{Lower Cold Creek Unit $\left(\mathrm{CCU}_{\mathrm{l}}\right)$}

The top of the calcic paleosol sequence of the lower CCU lies at a depth of about $92 \mathrm{ft}$, based on a slight increase in penetration resistance and neutron moisture, and sudden decrease in potassium-40 activity (Figure 2.19). The lower CCU in C4105 is relatively thick (19 ft) with an extremely high degree of internal heterogeneity, especially with respect to grain-size distribution and degree of weathering and 
pedogenesis (Figure 2.23). Grain sizes within the lower CCU range from pebble gravel (mostly basalt) floating in a poorly sorted mixture of sand, silt, and/or clay to moderately to well-sorted sand and/or mud (i.e., silt and clay).

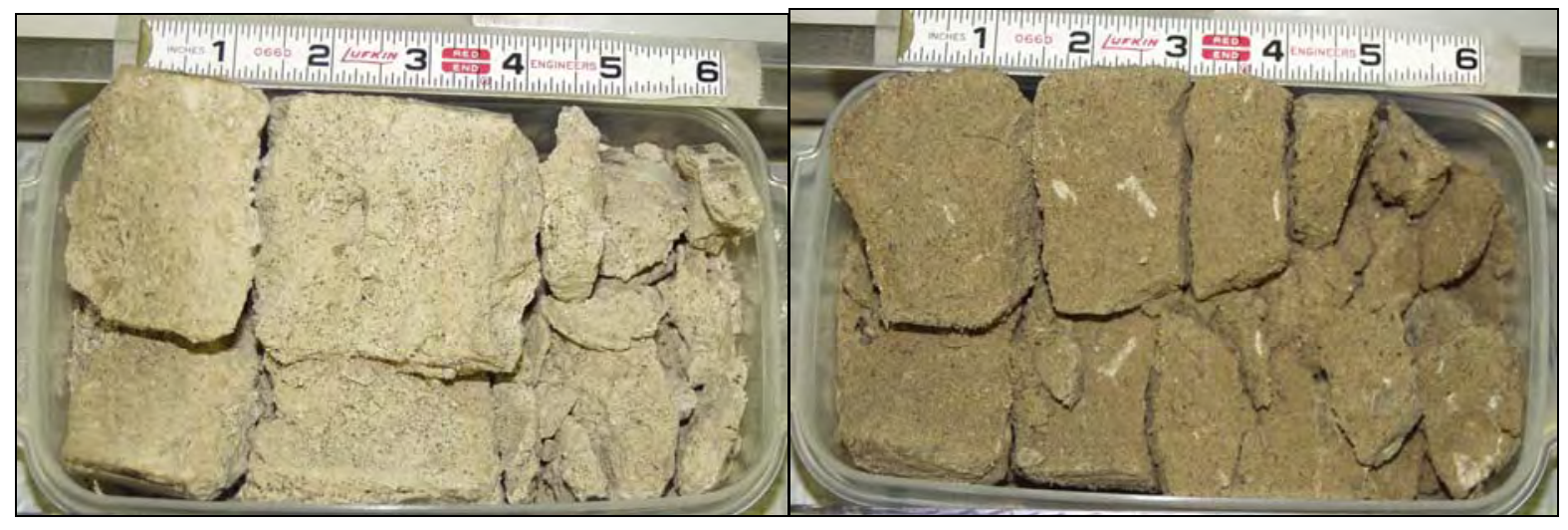

Figure 2.23. Lower Cold Creek Subunit within C4105. Left photo: Core sample S03044-15A from a depth of 102.85 to $103.52 \mathrm{ft}$ bgs. Described as slightly moist, very poorly sorted, moderately cemented, very strongly calcareous, massive, very pale brown, matrixsupported, slightly gravelly sandy mud (gsM). The subtle, diffuse color change at the left end of the core represents a physico-chemical transition between soil horizons.

Right photo: Core sample S03044-13A from a depth of 100.00 to $100.68 \mathrm{ft}$ bgs. Described as slightly moist, moderately sorted, moderately to strongly calcareous, weakly to moderately cemented, massive, olive-brown, silty fine-medium sand ( $\mathrm{mS}$ ). Irregular, white fragments are pedogenic, calcium carbonate (CaCO3) concretions. The top of the cores are to the right.

Multiple episodes of soil development occur internally within the lower CCU, with tightly cemented, calcic, pedogenic horizons separated by relatively unweathered zones displaying only a few stringers or nodules of secondary calcium carbonate, some of which retain original sedimentary structures. This indicates long periods of land-surface stability and soil development separated by intermittent pulses of sediment accumulation during lower CCU time. Strongly calcic horizons are whitish to pale brown or grayish-brown in color; less pedogenically altered horizons are generally olive-brown. Interpretation of the KUT logs from the T Tank Farm dry wells (Sobczyk 2001) suggests at least two cemented caliche horizons are present, separated by less pedogenically altered sediments.

The hardness of the lower CCU is quite variable, as indicated for the log of blow counts in Figure 2.19. One especially hard, thin cemented zone occurs about half way through the lower CCU at a depth of about $101 \mathrm{ft}$ bgs; this appears to be associated with the lower caliche horizon of Sobczyk (2001).

Most core samples from the lower CCU appeared only slightly moist upon opening. The lower CCU was extensively sampled in C4105; a total of 14 samples were collected for physical, chemical, and radiological characterization (Table 2.8). Gravimetric moisture averaged $11.3+/-4.6 \mathrm{wt} \%$ water. This appears to be a greater amount of moisture than was apparent from the initial visual estimate and reveals the limitation of estimating moisture based solely on visual inspection. 


\subsubsection{Ringold Formation}

A total of $18 \mathrm{ft}$ of Ringold Formation sediments were penetrated within C4105 before the probe hole met refusal and was terminated at $130.9 \mathrm{ft}(39.9 \mathrm{~m})$. As with other holes in and around the T Tank Farm, two members of the Ringold Formation are present within the vadose zone. Encountered first was the finer-grained Ringold Formation member of Taylor Flat $\left(\mathrm{R}_{\mathrm{tf}}\right)$, followed by the coarser-grained Ringold Formation member of Wooded Island $\left(\mathrm{R}_{\mathrm{wi}}\right.$ ), Unit $\mathrm{E}$ (Figure 2.19). A total of 8 samples were collected from splitspoon cores from the Ringold Formation in C4105 for physical, chemical, and radiological characterization (Table 2.8).

\subsection{Ringold Formation Member of Taylor Flat $\left(\mathbf{R}_{\mathrm{tf}}\right)$}

The Ringold Formation member of Taylor Flat in probe hole C4105 extends from 111 to $122 \mathrm{ft}$ bgs and is about $11 \mathrm{ft}$ thick (Table 2.3). The $\mathrm{R}_{\mathrm{tf}}$ unit is composed of interbedded layers of sand, silt, and clay (Figure 2.24). The strata are mostly fine-grained, compacted and cohesive, well-laminated, and wellsorted, in various shades of brown (gray, olive, and yellow). The concentration of calcium carbonate generally decreases with depth and distance from the overlying Cold Creek unit.

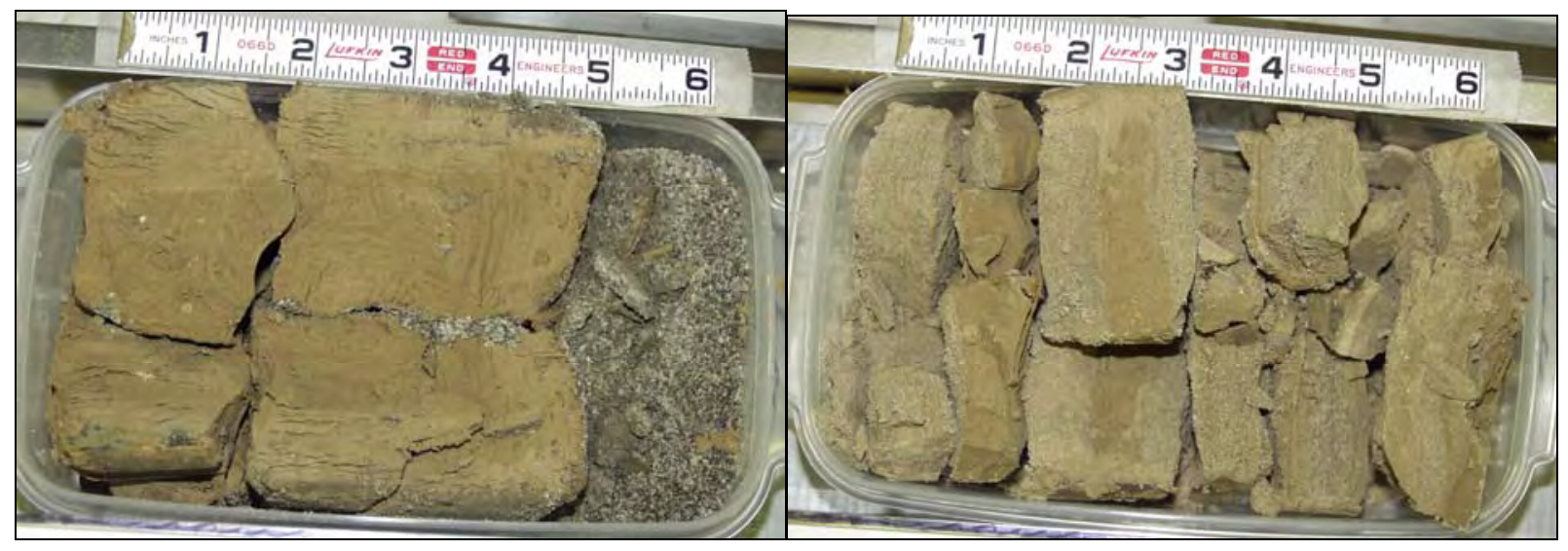

Figure 2.24. Ringold Formation Member of Taylor Flat $\left(\mathbf{R}_{\mathbf{t}}\right)$ in $\mathbf{C 4 1 0 5}$. Left photo: Core sample S03044-19A from a depth of 120.52 to 121.19 ft bgs. A sharp contact separates loose, dark gray, basaltic, noncalcareous, coarse sand (S) above, from massive, cohesive, stiff, moderately calcareous, yellowish-brown, clayey silt (M) below. Right photo: Core sample S03044-18A from a depth of 115.64 to $116.30 \mathrm{ft}$ bgs. Fine to medium sand (S) interlaminated with layers of fine sandy silt (sM) - strata in this core were moist, laminated, well-sorted, compact, and moderately calcareous, with an olive-brown color. The top of the cores is to the right.

Sediments from cores of the $\mathrm{R}_{\mathrm{tf}}$ unit in $\mathrm{C} 4105$ were all classified as moist. A total of 4 characterization samples were collected. Gravimetric moisture values on these samples are highly variable - two are relatively high while the other two are low. The average gravimetric moisture was $14.7+/-10.7 \mathrm{wt} \%$ water (Table 2.6). The neutron-moisture log (Figure 2.19), however, indicates that the $\mathrm{R}_{\mathrm{tf}}$ unit as a whole is relatively high in moisture, compared to other stratigraphic units. 


\subsection{Ringold Formation Member of Wooded Island $\left(\mathbf{R}_{\mathrm{wi}}\right)$}

The contact between fine-grained $\mathrm{R}_{\mathrm{tf}}$ unit and the underlying coarse-grained $\mathrm{R}_{\mathrm{wi}}$ unit lies at $122 \mathrm{ft}$ bgs. The borehole advanced only $\sim 9 \mathrm{ft}$ into the $\mathrm{R}_{\mathrm{wi}}$ unit before the borehole was abandoned at $130.9 \mathrm{ft}$ bgs. A core photograph from the $\mathrm{R}_{\mathrm{wi}}$ unit at C4105 is shown in Figure 2.25.

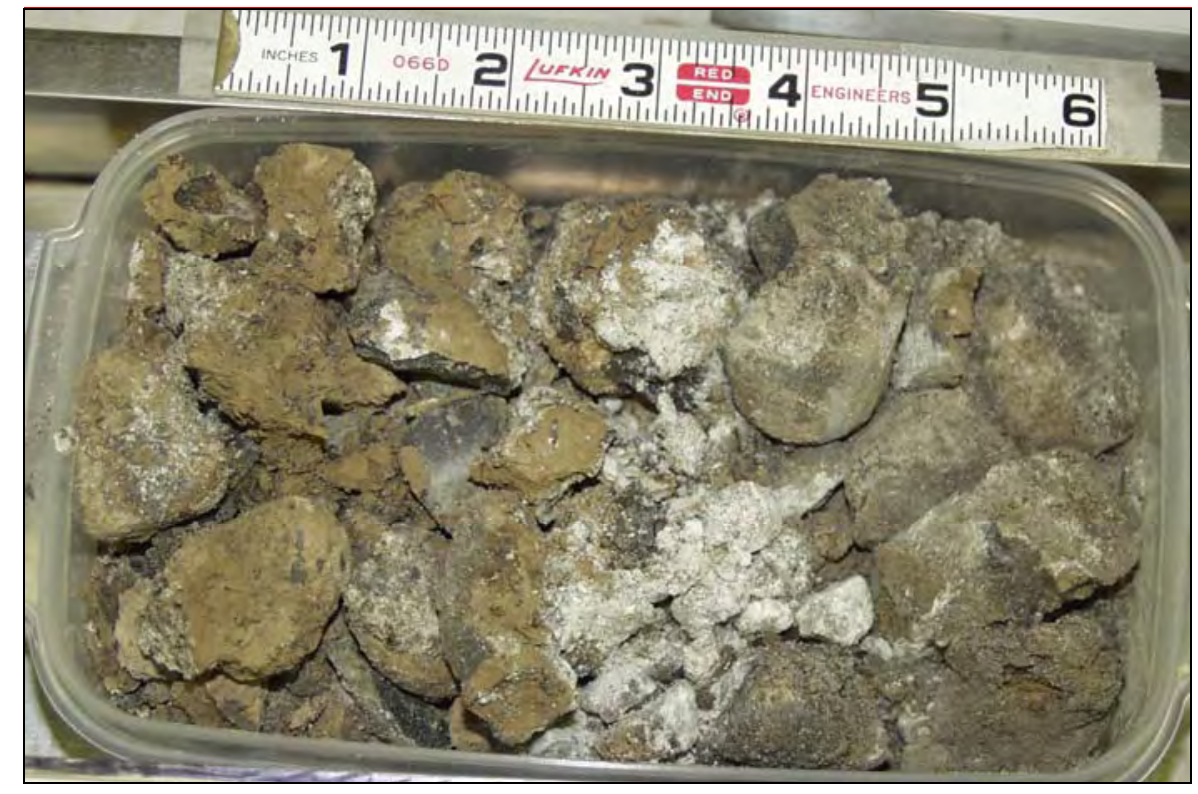

Figure 2.25. Ringold Formation, Member of Wooded Island $\left(\mathbf{R}_{\mathrm{wi}}\right)$ in $\mathbf{C 4 1 0 5}$. Core sample S03044-20A from a depth of 123.57 to 124.24 ft bgs. Upper part consists of pulverized, loose, very poorly sorted, non-calcareous, clast-supported, gray, sandy gravel. Lower part is a cohesive, poorly sorted, moderately calcareous, matrix-supported, yellowish-brown, silty gravel. In both parts, gravel clasts are pulverized and consist of 40-60\% basalt. The light colored material through the middle is the remains of a pulverized granitic or quartzite clast, crushed during drilling. The top of the core is to the right.

Observed moisture in core samples were slightly moist to moist. A total of four physical, chemical, and radiological characterization samples were collected from splitspoon cores from the $\mathrm{R}_{\mathrm{wi}}$ unit. The gravimetric moisture measured in these samples averaged about $9.1+/-7.6 \mathrm{wt} \%$ water (Table 2.6).

\subsubsection{Previous Characterization Studies at Borehole 299-W10-196}

Borehole 299-W10-196 was drilled to $179.6 \mathrm{ft}$ in late 1992 to early 1993 to investigate the vadosezone contaminant distribution in the vicinity of Tank 241-T-106 (Freeman-Pollard et al. 1994). Borehole 299-W10-196 is included in this analysis because it is another boring that has produced representative splitspoon samples for physical, chemical, and radiological characterization from T Tank Farm. A total of 43 splitspoon sediment samples were collected and analyzed back in 1993. Spectral-gamma geophysical logging was also performed. During sampling, two overlapping zones of radioactive contamination were encountered; one at 34.5 to $70 \mathrm{ft}$ and the other to $115 \mathrm{ft}$ bgs. The location of 299-W10-196 lies 12.99 feet north and $1.94 \mathrm{ft}$ west of borehole C4104 (Figure 2.4), described previously. Thus, the two boreholes are $13.13 \mathrm{ft}$ apart, based on Pythagoras' theorem. No core photos or archived sediment samples are available for 299-W10-196. A summary geohydrologic log for this hole is 
presented in Figure 2.26. The summary log was constructed using the geologist's log, total-gamma and neutron-moisture geophysical logs, blow-count data, and gravimetric moisture content measured in the laboratory, mostly reported in Freeman-Pollard et al. (1994).

\subsection{Discussion on Increased-Moisture Zones}

Zones of increased moisture in the vadose zone may be determined indirectly using the downhole, neutron-moisture geophysical log and/or, when available, gravimetric moisture measured directly from core samples in the laboratory. As discussed previously, borehole 299-W11-39 (Figure 2.9) was continuously cored and sampled between 20 to $93.5 \mathrm{ft}$ bgs. Lab moisture results in Figure 2.9 show a close correlation with the neutron moisture log. Therefore, the neutron moisture log appears to accurately reflect the relative moisture content, and can confidently be used as a substitute to estimate relative moisture conditions when core samples are unavailable.

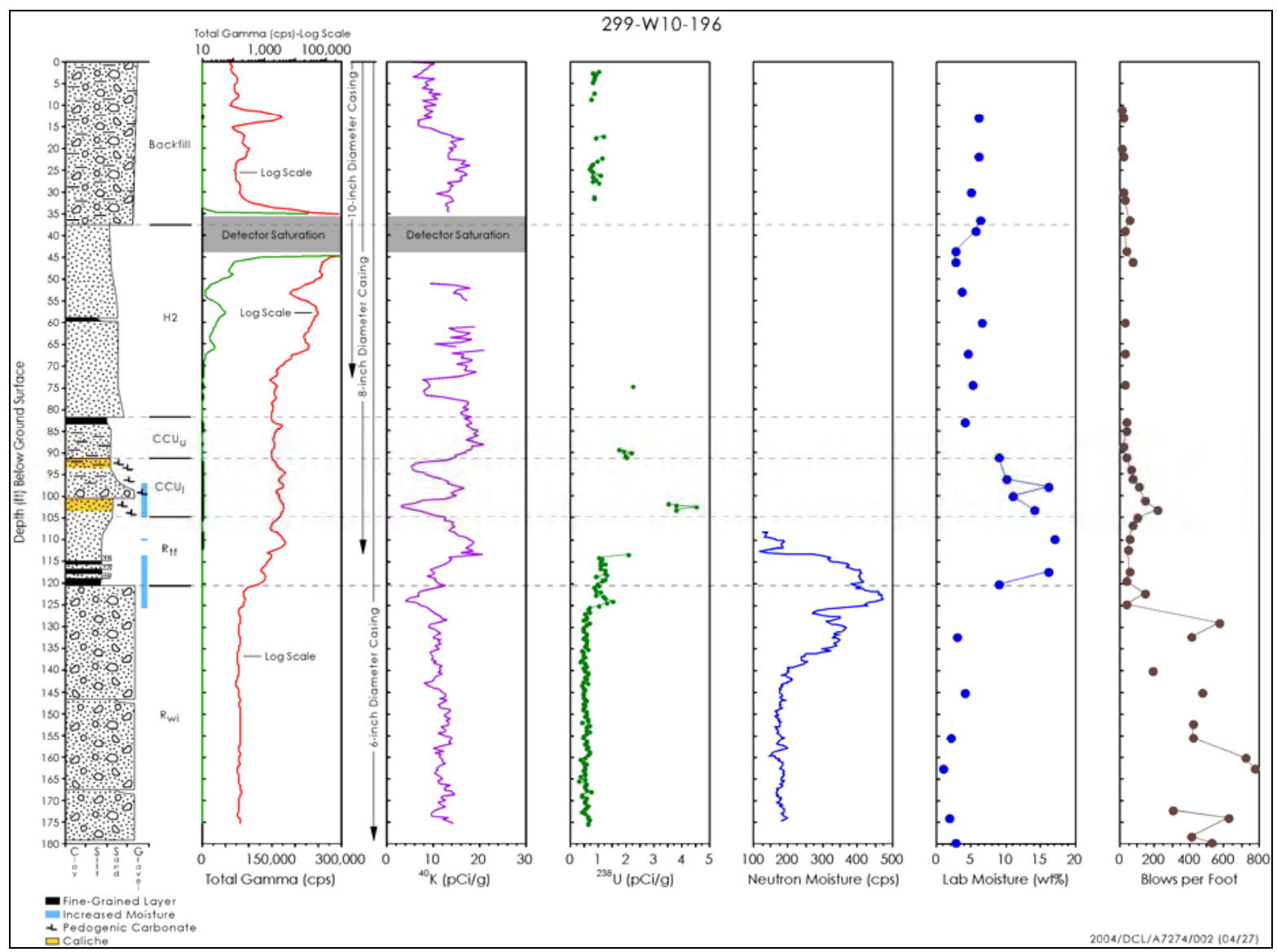

Figure 2.26. Summary Hydrogeologic Log for 299-W10-196. Zones of increased moisture are indicated as those with $>10 \mathrm{wt} \%$ water in core samples and/or show as distinct spikes on neutron-moisture log. Fine-grained layers are defined as those consisting predominantly of particles $<0.25 \mathrm{~mm}$ in diameter (i.e., fine sand and smaller).

The moisture distributions for the two recent boreholes are shown in Figures 2.12 and 2.19 for C4104 and C4105, respectively. Similarly, moisture distribution for the background well (299-W11-39) is shown in Figure 2.9. Zones with relatively high moisture (>15 wt\%) are illustrated via a light blue 
vertical bar immediately to the right of the lithologic log in these diagrams. In general, the highest concentrations of moisture in the vadose zone at $\mathrm{T}$ Tank Farm appear to lie within the Cold Creek unit and Ringold Formation member of Taylor Flat $\left(\mathrm{R}_{\mathrm{tf}}\right)$. Occasional, thin fine-grained lenses within the Hanford formation $\mathrm{H} 2$ unit also display higher moisture content.

Moisture also concentrates along boundaries between sudden, large contrasts in grain size. Commonly, a lower-permeability fine-grained silty layer may be present along the boundary, but is not required for a high-moisture zone to develop. Depending on the flux rate, moisture may collect and move laterally: 1) within finer-grained layers, 2) along interfaces between highly contrasting facies, or 3) along primary sedimentary structures (Bjornstad et al. 2003). Moisture may also move vertically along discordant clastic dikes, which are known to occur, especially within the Hanford formation (Fecht et al. 1999). During high-recharge events, moisture may move preferentially within the coarser-grained, vadose-zone strata, in contrast to fine-grained layers which transmit relatively more moisture under a low flux rate.

Figure 2.27 presents a statistical analysis of moisture conditions at different stratigraphic levels for each of the four borings documented in this report. Conclusions that can be drawn from these data include:

- Relatively low moisture contents are found in gravelly facies, which include backfill materials, Hanford formation H1 unit, and the Ringold Formation member of Wooded Island. Sand-dominated facies of the Hanford formation (H2 unit) are also relatively low in moisture content.

- Relatively higher moisture contents are found for fine-grained strata, which includes both the upper and lower Cold Creek subunits and Ringold Formation member of Taylor Flat, in all four boreholes. Moisture is naturally high in these strata and not necessarily from tank leaks.

- Average moisture content for the Hanford formation H2 unit and the upper CCU is about the same in the background hole as the probe holes within the T Tank farm. This suggests movement of water under both artificial and natural recharge is transient in nature and may be difficult to distinguish with depth in the vadose zone. 


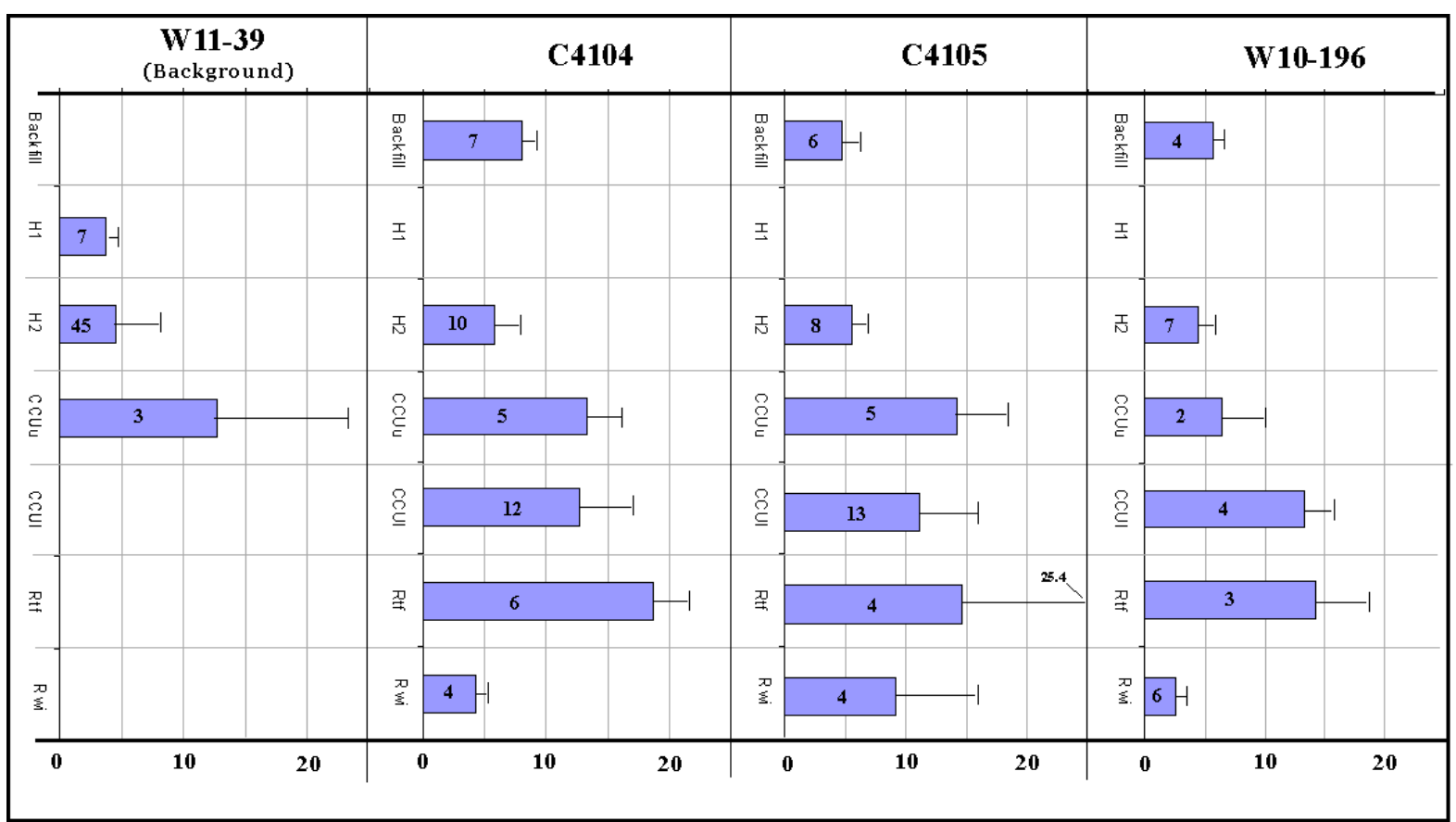

Figure 2.27. Average Moisture Content (wt\% water) from Different Stratigraphic Units in the Vicinity of the T Tank Farm. Numbers in shaded boxes are the number of analyses; bars to the right of the boxes are one standard deviation from the mean. 


\subsection{Geochemical Methods and Materials}

This section discusses the methods and philosophy used to determine which C4104 and C4105 borehole samples would be characterized and the parameters that would be measured and analyzed in the laboratory. It also describes the materials and methods used to conduct analyses of the physical, geochemical, and radioanalytical properties of the sediments, and the water potential (suction) measurements of the core liners in each sequential splitspoon sample from boreholes 299-W11-39 (a RCRA monitoring well) and C4104 .

\subsection{Sample Inventory}

Samples were identified using a project-specific prefix, in this case, C3117 (for the background borehole 299-W11-39), C4105 (for the borehole southwest of T-106), and C4104 (for the borehole south and a bit east of T-106), followed by a specific sample identification suffix such as -01, for each splitspoon. As noted in Section 2.3, the cores contained two liners identified by the letters A and B, where the A Liner was always in the deeper position closest to the drive shoe (i.e., the protective end attached to the bottom of the drive casing).

\subsection{Approach}

During a past investigation at WMA SX, a significant finding was that changes in sediment type and contaminant concentrations occurred within a distance of a few inches within a given liner. It was concluded that a more methodical scoping approach would be necessary to provide the technical justification for selecting samples for detailed characterization as defined in the data quality objectives process (DOE 1999). Subsequently, a method was developed that considered depth, geology (e.g., lithology, grain-size composition, and carbonate content, etc.), individual liner contaminant concentration (e.g., radionuclides, nitrate), moisture content, and overall sample quality. Inexpensive analyses and certain key parameters (i.e., moisture content, gamma energy analysis) were performed on sediment from each liner.

The objective of the first phase of the characterization was to quantify the extent of penetration of mobile contaminants into the vadose-zone sediment profile. Because of the potential for slough material in the upper liner, only the sediment from the A Liner was analyzed for most constituents except moisture and gamma energy. Measurable or significant drag-down effects (i.e., the process of moving contaminants down through the sediment column via pushing the casing) for contaminants were not noted, perhaps because the borehole was installed by pile driving closed end casing with periodic sampling through the retractable nose cone, and the main contaminants (i.e., uranium-238 and technetium-99) are associated mainly with the porewater (technetium-99) or are not exclusively concentrated on the sediment particles (uranium-238). Because drag-down is dominated by highly contaminated sediment particles, the contaminants in these boreholes had less chance of concentrating on particles.

During the geologic examination, the liner contents were subsampled for moisture content, gammaemission radiocounting, 1:1 water extracts (which provide soil $\mathrm{pH}$, electrical conductivity (EC), cation, and anion data), total carbon and inorganic carbon content, and $8 \mathrm{M}$ nitric acid extracts (which provide a measure of the total leachable sediment content of contaminants). The remaining sediment from each 
liner was then sealed and placed in cold storage. Later, additional aliquots of selected liners from clean borehole 299-W11-39 and C4105 were removed to measure particle size distribution and total chemical composition (for the clean borehole only). Additional aliquots of sediment from C4104 and C4105 were used to extract porewater using ultracentrifugation.

\subsection{Materials and Methods}

During subsampling of the selected core liner, every effort was made to minimize moisture loss and prevent cross contamination between samples. Depending on the sample matrix, very coarse pebble and larger material (i.e., >32 millimeter [mm]) was avoided during subsampling. Larger substrate was excluded to provide moisture contents representative of counting and 1:1 sediment:water extract samples. Therefore, the results from the subsample measurements may contain a possible bias toward higher concentrations for some analytes that would be preferentially associated with the smaller sized sediment fractions. The sediment in the lower Cold Creek unit (silt-dominated facies) contained no large pebbles or cobbles.

Procedures ASTM D2488-93 (1993) and PNL-MA-567-DO-1 (PNL 1990a) were followed for visual descriptions and geologic description of all splitspoon samples. The sediment classification scheme used for geologic identification of the sediment types is based on the modified Folk/Wentworth classification scheme described earlier (Section 2.3.1.3 and Figure 2.8). However, the particle size distribution for selected samples from the background well and borehole C4105 was also performed where further separation of the mud into discrete silt and clay size fractions was performed. Finally, selected sediments from C4105 were characterized for bulk sediment and clay-size separates mineralogy using X-ray diffraction.

\subsubsection{Moisture Content}

Gravimetric water contents of the sediment samples from each liner were determined using PNNL procedure PNL-MA-567-DO-1 (PNL 1990). This procedure is based on the American Society for Testing and Materials procedure Test Method for Laboratory Determination of Water (Moisture) Content of Soil and Rock (ASTM D2216-98 [ASTM 1998]). One representative subsample of at least 15 to 70 grams was taken from each liner. Sediment samples were placed in tared containers, weighed, and dried in an oven at $105^{\circ} \mathrm{C}\left(221^{\circ} \mathrm{F}\right)$ until constant weight was achieved, which took at least 24 hours. The containers then were removed from the oven, sealed, cooled, and weighed. At least two weighings, each after a 24-hour heating, were performed to ensure that all moisture was removed. All weighings were performed using a calibrated balance. A calibrated weight set was used to verify balance performance before weighing samples. The gravimetric water content was computed as the percentage change in soil weight before and after oven drying.

\section{1:1 Sediment:Water Extracts}

The water-soluble inorganic constituents were determined using a 1:1 sediment:deionized water extract method. This method was chosen because the sediment was too dry to easily extract vadose zone porewater. The extracts were prepared by adding an exact weight of deionized water to approximately 60 to 80 grams of sediment subsampled from each liner. The weight of deionized water needed was calculated based on the weight of the field-moist samples and their previously determined moisture contents. The sum of the existing moisture (porewater) and the deionized water was fixed at the mass of 
the dry sediment. The appropriate amount of deionized water was added to screw cap jars containing the sediment samples. The jars were sealed and briefly shaken by hand, then placed on a mechanical orbital shaker for one hour. The samples were allowed to settle until the supernatant liquid was fairly clear. The supernatant was carefully decanted and separated into unfiltered aliquots for electrical conductivity (EC) and $\mathrm{pH}$ determinations, and filtered aliquots (passed through $0.45 \mu \mathrm{m}$ membranes) for anion, cation, carbon, and radionuclide analyses. More details can be found in Rhoades (1996) within Methods of Soils Analysis Part 3 (ASA 1996a).

\subsubsection{1 $\quad \mathrm{pH}$ and Conductivity}

Two approximately 3-milliliter (mL) aliquots of the unfiltered 1:1 sediment:water extract supernatant were used for $\mathrm{pH}$ and conductivity measurements. The $\mathrm{pH}$ for the extracts was measured with a solid-state $\mathrm{pH}$ electrode and a $\mathrm{pH}$ meter calibrated with buffers 4, 7, and 10 . Electrical conductivity was measured and compared to potassium chloride standards with a range of $0.001 \mathrm{M}$ to $1.0 \mathrm{M}$.

\subsubsection{Anions and Small Organic Acids}

The 1:1 sediment:water extracts were analyzed for anions using an ion chromatograph. Fluoride, acetate, formate, chloride, nitrite, bromide, nitrate, carbonate, phosphate, sulfate, and oxalate were separated on a Dionex AS17 column with a gradient elution of $1 \mathrm{mM}$ to $35 \mathrm{mM}$ sodium hydroxide and measured using a conductivity detector. This methodology is based on U.S. Environmental Protection Agency (EPA) Method 300.0A (EPA 1984) with the exception of using the gradient elution of sodium hydroxide. Only small carbon chained organic acids elute with the inorganic anions using this procedure, and no attempts were made to measure other soluble organic components. Water extract chromatograms were visually scanned to assure there were no unidentified peaks caused by other constituents. No unexpected peaks were found in the water extracts from the background or contaminated sediments.

\subsubsection{Cations and Trace Metals}

Major cation analysis was performed using an inductively coupled plasma-optical emission spectrometry (ICP-OES) unit using high-purity calibration standards to generate calibration curves and verify continuing calibration during the analysis run. Dilutions of $100 \mathrm{x}, 50 \mathrm{x}, 10 \mathrm{x}$, and $5 \mathrm{x}$ were made of each 1:1 water extract for analysis to investigate and correct for matrix interferences. Details of this method are found in EPA Method 6010B (EPA 2000b). The second instrument used to analyze trace metals, including technetium-99 and uranium-238, was an inductively coupled plasma-mass spectrometer (ICP-MS) using PNNL-AGG-415 method (PNNL 1998). This method is quite similar to EPA Method 6020 (EPA 2000c).

\subsubsection{Alkalinity and Carbon}

The alkalinity and inorganic/organic carbon content of several of the 1:1 sediment-to-water extracts were measured using standard titration with acid and a carbon analyzer, respectively. The alkalinity procedure is equivalent to the method used in the U.S. Geological Survey (USGS) National Field Manual (USGS 2001). Inorganic and organic carbon in the water extracts were determined using a carbon analyzer and ASTM Method D4129-98 (ASTM 2003), "Standard Test Method for Total and Organic Carbon in Water by High Temperature Oxidation and by Coulometric Detection.” 


\subsubsection{Radioanalytical Analysis}

\subsubsection{Gamma Energy Analysis}

Gamma energy analysis (GEA) was performed on sediment, usually from the B core liners, for the two $\mathrm{T}$ boreholes. For C4104, sediment from both the A and the B liners was counted. All samples for gamma energy analysis were analyzed using $60 \%$-efficient intrinsic germanium gamma detectors. All germanium counters were efficiency calibrated for distinct geometries using mixed gamma standards traceable to the National Institute of Standards and Technology. Field-moist samples were placed in $150-\mathrm{cm}^{3}$ counting containers and analyzed for 100 minutes in a fixed geometry. All spectra were background-subtracted. Spectral analysis was conducted using libraries containing most mixed fission products, activation products, and natural decay products. Control samples were run throughout the analyses to ensure correct operation of the detectors. The controls contained isotopes with photo peaks spanning the full detector range and were monitored for peak position, counting rate, and full-width half-maximum. Details are found in Gamma Energy Analysis, Operation, and Instrument Verification using Genie2000 Support Software (PNNL 1997).

Selected 1:1 sediment:water extracts and ultracentrifuge obtained porewater from sediments from borehole C4104 were also placed in standard counting containers and counted for several hours in a calibrated geometry to obtain data on the concentrations of water-soluble gamma-emitting nuclides.

\subsubsection{Total Beta and Total Alpha Measurements on Water and Acid Extracts}

Gross alpha and beta measurement were made on both the water and acid extracts. For each extract, a 1-mL sample volume was placed in a 20-mL tared liquid scintillation vial and weighed. Fifteen mL of scintillation cocktail were then added and the samples were mixed and counted on a Wallac Model 1415 Liquid Scintillation Counter, as prescribed in procedure AGG-RRL-002, Liquid Scintillation Counting and Instrument Verification using the 1400 DSA ${ }^{T M}$ Support Software (PNNL-2000a). Results were converted to pCi per gram of dry sediment by using the known solution-to-solid ratios used to extract aliquots of the sediment.

\subsubsection{Strontium-90 and Actinides}

Sediment sample aliquots from C4104 and C4105 were leached with concentrated nitric acid at a ratio of $\sim 5$ parts acid to one part sediment. The slurries were heated to about $80^{\circ} \mathrm{C}\left(176^{\circ} \mathrm{F}\right)$ for several hours and then the fluid was separated by centrifugation and filtration through $0.2 \mu \mathrm{m}$ membranes. An aliquot of the filtered acid extract was diluted 50 percent with deionized water and submitted for Sr separation and analysis. A 3-5 mL aliquot of each acid leachate was spiked with ${ }^{85} \mathrm{Sr}$ tracer and passed through a SrSpec ${ }^{\circledR}$ column [Eichrom Technologies, Chicago, Illinois] to capture strontium. The columns were washed with 10 column volumes $(20 \mathrm{~mL})$ of $8 \mathrm{M}$ nitric acid. The strontium was eluted from the $\mathrm{SrSpec}{ }^{\circledR}$ column into glass liquid scintillation vials using $15 \mathrm{~mL}$ of deionized water. The vials were placed under a heat lamp overnight to evaporate the water to dryness. Fifteen $\mathrm{mL}$ of Optifluor ${ }^{\circledR}$ scintillation cocktail were added to each vial. Gamma spectroscopy was used to determine the chemical yield from the added

${ }^{85} \mathrm{Sr}$ tracer. The samples were then analyzed by liquid scintillation counting (LSC) to determine the amount of strontium-90 originally present in the sediment sample. The strontium-90 analytical procedure is documented in PNNL (2000b). 
A matrix spike, a blank spike, a duplicate, and blanks were run with each sample set to determine the efficiency of the separation procedure as well as the purity of reagents. For the most part, the separation procedure was straightforward. Chemical yields were generally good $(>90 \%)$ with some explainable exceptions. Matrix and blank spike yields were good (approximately 90-110\%), bias was consistent, and blanks were below detection limits.

Three 5-mL aliquots of select acid leachates were spiked with (plutonium-242) and americium-243 tracers and $50 \mu \mathrm{g}$ of neodymium (Nd) carrier. The spiked acid extracts were taken through an iron hydroxide precipitation (to precipitate actinides) by adding concentrated ammonium hydroxide until the solution $\mathrm{pH}$ was $>10$ and a red-brown precipitated formed. The slurry samples were centrifuged, the supernatant was discarded, and the precipitate was re-suspended in 2M nitric acid. Approximately $1 \mathrm{~mL}$ of saturated ascorbic acid solution was added drop-wise to the nitric acid extracts containing the re-dissolved actinides (this step reduces iron(III) to iron (II) and neptunium(V,VI) to neptunium(IV)). The actinide-bearing solutions were passed through a Tru-Spec ${ }^{\circledR}$ special exchange resin column (Eichrom Technologies, Chicago, Illinois) to capture the actinide species. $100 \mu \mathrm{L}$ of a $100 \mathrm{mg} / \mathrm{mL}$ sodium nitrite solution (in deionized water) was mixed with $5 \mathrm{~mL}$ of $2 \mathrm{M}$ nitric acid and added to the column. The column was washed with 10 pore volumes $(20 \mathrm{~mL})$ of this $2 \mathrm{M}$ nitric acid-nitrite reagent to flush other solutes out of the resin column.

Americium (Am) and californium (Cf) were eluted from the Tru-Spec ${ }^{\circledR}$ columns using $2 \mathrm{~mL}$ of $9 \mathrm{M}$ hydrochloric acid followed by $13 \mathrm{~mL}$ of $4 \mathrm{M}$ hydrochloric acid. Next, plutonium was eluted from the column and collected separately using $15 \mathrm{~mL}$ of $4 \mathrm{M}$ hydrochloric acid/0.1 M hydroquinone. Finally, neptunium was eluted from the column with $15 \mathrm{~mL}$ of $1 \mathrm{M}$ hydrochloric acid/0.03 M oxalic acid. The americium/californium-bearing eluent was dried under a heat lamp. The plutonium and neptunium eluent fractions were wet-ashed using 1-3 mL of concentrated nitric acid, approximately $1 \mathrm{~mL}$ of concentrated sulfuric acid, and $<1 \mathrm{~mL}$ of $30 \%$ hydrogen peroxide (added drop-wise in succession) on a hot plate at approximately $80^{\circ} \mathrm{C}$. After the addition of hydrogen peroxide, the plutonium- and neptunium-bearing eluents were evaporated to dryness. The americium, californium, plutonium, and neptunium precipitates were re-suspended in $5 \mathrm{~mL}$ of $4 \mathrm{M}$ hydrochloric acid. Approximately $1 \mathrm{~mL}$ of concentrated hydrofluoric acid was added to the suspensions to precipitate the actinide species as fluorides because most other metals do not form insoluble fluorides. The suspensions were allowed to equilibrate for approximately 30 minutes and were then filtered through $0.45 \mu \mathrm{m}$ Supor ${ }^{\circledR}$ filters. The filters, with captured americium and californium, plutonium, or neptunium precipitates were dried under a heat lamp, affixed to metal planchettes using double-stick tape, and counted using alpha energy analysis. A matrix spike, a blank spike, a duplicate, and blanks were run with each sample set to determine the efficiency of the separation procedure as well as the purity of reagents. For the most part, the separation procedure was straightforward. Chemical yields were generally good with some explainable exceptions; average yields for the americium and plutonium tracers were used to correct the data for yield of these individual actinides. The yield for californium was assumed to be identical to the yield of americium based on their chemical similarity. The yield for neptunium in the sediment acid extracts was assumed to be the same as that for the matrix spike where known activities of neptunium-237 were added to both blank reagents and one chemical extract of a sediment sample. The actinide analytical procedure is PNL (1995).

Matrix and blank spike yields were good (within the $\pm 20 \%$ range required by Hanford quality assurance protocols), bias was consistent, and blanks were below detection limits. 


\subsubsection{Porewater Composition}

Five splitspoon liner samples from borehole C4104 (8A, 11A, 13A, 20A, and 21A) and six splitspoon liner samples from borehole C4105 (7A, 10A, 11A, 16A, 19A, and 20A) were packed in drainable cells that were inserted into an ultracentrifuge. The samples were centrifuged for up to 8 hours at several thousand g's to squeeze the porewater out of the sediment. The porewaters were characterized for $\mathrm{pH}$, electrical conductivity, cation, trace metals, selected radionuclide and anions using the same techniques as used for the 1:1 sediment:water extracts.

\subsubsection{Carbon Content of Sediment}

The carbon content of borehole sediment samples was determined using ASTM Method D4129-98, Standard Methods for Total and Organic Carbon in Water Oxidation by High Temperature Oxidation and by Coulometric Detection (ASTM 2003). Total carbon in all samples was determined using a Coulometrics, Inc. Model 5051 Carbon Dioxide Coulometer with combustion at approximately $980^{\circ} \mathrm{C}$ $\left(1796^{\circ} \mathrm{F}\right)$. Ultra-pure oxygen was used to sweep the combustion products through a barium chromate catalyst tube for conversion to carbon dioxide. Evolved carbon dioxide was quantified through coulometric titration following absorption in a solution containing ethanolamine. Equipment output reported carbon content values in micrograms per sample. Soil samples for determining total carbon content were placed into pre-combusted, tared platinum combustion boats and weighed on a four-place analytical balance. After the combustion boats were placed into the furnace introduction tube, a oneminute waiting period was allowed so that the ultrapure oxygen carrier gas could remove (i.e., sparge) any carbon dioxide introduced to the coulometric system from the atmosphere during sample placement. After this system sparge, the sample was moved into the combustion furnace and the titration was begun. Sample titration readings were performed at 3 minutes after combustion began and again once stability was reached, usually within the next 2 minutes. The system background was determined by performing the entire process using an empty, pre-combusted platinum boat. Adequate system performance was confirmed by analyzing known quantities of a calcium carbonate standard.

Inorganic carbon contents for borehole sediment samples were determined using a Coulometrics, Inc., Model 5051 Carbon Dioxide Coulometer. Soil samples were weighed on a four-place analytical balance, and then placed into acid-treated glass tubes. Following placement of sample tubes into the system, a one-minute waiting period allowed the ultrapure oxygen carrier gas to remove any carbon dioxide introduced to the system from the atmosphere. Inorganic carbon was released through acid-assisted evolution ( $50 \%$ hydrochloric acid) with heating to $200^{\circ} \mathrm{C}\left(392^{\circ} \mathrm{F}\right)$. Samples were completely covered by the acid to allow full reaction to occur. Ultra-pure oxygen gas swept the resultant carbon dioxide through the equipment to determine inorganic carbon content by coulometric titration. Sample titration readings were performed 5 minutes following acid addition and again once stability was reached, usually within 10 minutes. Known quantities of calcium carbonate standards were analyzed to verify that the equipment was operating properly. Background values were determined. Inorganic carbon content was determined through calculations performed using the microgram per-sample output data and sample weights. Organic carbon was calculated by subtracting inorganic carbon from total carbon and using the remainder. 


\subsection{6 $\quad 8$ M Nitric Acid Extract}

Approximately 20 grams of oven-dried sediment was contacted with $8 \mathrm{M}$ nitric acid at a ratio of $\sim 5$ parts acid to one part sediment. The slurries were heated to about $80^{\circ} \mathrm{C}\left(176^{\circ} \mathrm{F}\right)$ for several hours and then the fluid was separated by centrifugation and filtration through $0.2 \mu \mathrm{m}$ membranes. The acid extracts were analyzed for major cations and trace metals using ICP and ICP-MS techniques, respectively. The acid digestion procedure is based on EPA SW-846 Method 3050B (EPA 2000a).

\subsubsection{Elemental Analysis}

The elemental composition of the bulk sediment from nine liners from the clean borehole, 299-W11-39, was determined by a commercial analytical laboratory using total fusion (using lithium metaborate/tetraborate) and inductively coupled plasma (ICP) and ICP-MS. The commercial lab used was ACTLAB-Skyline in Tucson, Arizona. Sample preparation involved grinding and mixing the sample in a Coors high-density alumina $\left(\mathrm{Al}_{2} \mathrm{O}_{3}\right)$ mortar and pestle. Fifty-six elements (i.e., beryllium, sodium through phosphorous, potassium through arsenic, rubidium through molybdenum, silver, indium through antimony, cesium through tungsten, thallium, lead , bismuth, thorium, and uranium) were analyzed on each sample. Nine geologic material standards that represent a wide range of geologic materials were fused and run along with the unknown sediments. Results for each element for the nine standards were reported along with the certified values from NIST, USGS, and other institutions that provide certified standards. We were satisfied with the accuracy on reported results for the standards and also found that the total oxide composition of the sediments from 299-W11-39 summed to close to 100\%, suggesting that the results were acceptable.

No elemental analyses were performed on the two contaminated $\mathrm{T}$ borehole sediments because the commercial laboratory can not test radioactive samples. We also have found that bulk elemental analysis of moderately radionuclide-contaminated sediments, such as the three TX borehole samples, do not vary significantly from uncontaminated samples (Serne et al. 2004).

\subsubsection{Particle Size Distribution}

The wet sieving/hydrometer method was used to determine the particle size distribution of selected samples from the background borehole, 299-W11-39 and the hydrometer method was used on selected samples from borehole C4105. No particle size measurements were made on samples from C4104. The hydrometer technique is described in ASA (1986a), Part 1, Method 15-5, "Hydrometer Method;” it concentrates on quantifying the relative amounts of silt and clay. The silt and clay separates were saved for later mineralogical analyses. Samples from the borehole that were used for the hydrometer method were never air- or oven-dried to minimize the effects of particle aggregation that can affect the separation of clay grains from the coarser material.

\subsubsection{Particle Density}

The particle density of bulk grains from the background borehole are usually determined using pychnometers as described in ASA (1986b) Part 1, Method 14-3, "Pychnometer Method," and oven-dried material. The particle density is an input needed to determine the particle size when using the hydrometer method. However, no direct particle density measurements were made for the 299-W11-39 or C4105 
sediments and the particle size data reported in this document used the quartz default value of 2.65 grams $/ \mathrm{cm}^{3}$ to calculate the particle size distribution. The error in using this simplifying assumption is not significant.

\subsubsection{Mineralogy}

The mineralogy of the whole rock and clay size fractions of the selected sediment samples was determined by XRD techniques. Each bulk sample was prepared for XRD analysis by crushing the sample into a fine powder using a mortar and pestle. The resultant powders were side packed into aluminum sample holders prior to being analyzed. Preparation of the clay fraction for XRD analysis began by dispersing the whole rock sediment using the following technique. Approximately $100 \mathrm{~g}$ of sediment was transferred into a $1.0 \mathrm{~L}$ bottle and mixed with $1.0 \mathrm{~L}$ of $0.001 \mathrm{M}$ solution of sodium hexametaphosphate. The suspensions were allowed to shake over night to ensure complete dispersion. The sand and silt fractions were separated from the clay fractions by repetitively using Stoke's settling law described in Jackson (1969). The lower limit of the silt fraction was taken at $\sim 2$ microns. The dispersed slurry was allowed to settle for $\sim 24$ hours and the unsettled slurry decanted. The settled solids were then re-suspended in $\sim 1$ liter of the sodium hexametaphosphate solution and the settling repeated several more times. All batches of settled solution containing the suspended clays for each sample depth were composited. Once the supernatant solution appeared to be clear, the clay separation was complete.

Each composited clay suspension was concentrated to an approximate volume of $30 \mathrm{mls}$ by adding a few drops of $10 \mathrm{~N} \mathrm{MgCl}_{2}$ to the dispersing solution. Concentrations of clay in the concentrated suspensions were determined by drying known volumes of the suspension and weighing the dried sediment. The density of the slurry was calculated from the volume pipetted and the final weight of dried sediment. Volumes of slurry equaling $250 \mathrm{mg}$ of clay were transferred into centrifuge tubes and saturated with $\mathrm{Mg}^{2+}$ using several more drops of the $10 \mathrm{~N} \mathrm{MgCl}_{2}$. After $\mathrm{Mg}$ saturation, the slurries were centrifuged to remove excess fluid. Two specimens were prepared for each dewatered-clay slurry by pipetting the concentrated slurry onto aluminum slides. One slide was allowed to air dry before examination by XRD. The other slide was saturated with ethylene glycol and stored in a desiccator over night before analysis by XRD.

All bulk and clay-sized samples were analyzed on a Scintag XRD unit equipped with a Pelter thermoelectrically cooled detector and a copper X-ray tube. Randomly oriented whole sediment samples were scanned from 2 to $65^{\circ} 2 \theta$ with a dwell time of 2 seconds. Slides of preferentially oriented clay were scanned from 2 to $45^{\circ} 2 \theta$ with a dwell time of 2 seconds. Scans were collected electronically and processed using the JADE ${ }^{\circledR}$ XRD pattern processing software. Some patterns were corrected for minor angular deviation using the quartz reflection. Identification of the mineral phases was based on mineral powder diffraction files published by the JCPDS International Center for Diffraction Data.

Semi quantification of mineral phases in the whole rock sediment samples were determined by the whole pattern fitting technique provided by JADE ${ }^{\circledR}$ XRD pattern processing software. The software allows the whole pattern fitting of the observed data and Reitveld refinement of crystal structures. A diffraction model is fit by non-linear least-square optimization in which certain parameters are varied to improve the fit between the two patterns. Success of the refinement process is measured by a ratio of the

weighted and calculated errors. This value, referred to as "goodness of fit", is expected to be close to one in an ideal refinement. 
Clay mineral abundances in the $<2$ micron fraction were calculated using the method outlined by Brindley and Brown (1980), which relies on external standards. The relationship of intensity and mass absorption to the weight fraction of an unknown phase is expressed as:

$$
\mathrm{I} / \mathrm{I}_{\mathrm{p}}=\mu_{\mathrm{p}} / \mu(\mathrm{wf})
$$

where:

I is the intensity of the unknown phase

$I_{p}$ is the intensity of the pure phase, $\mu_{p}$ is the mass absorption of the pure phase

$\mu$ is the average mass absorption of the unknown mixture

$\mathrm{wf}$ is the weight fraction of the unknown.

Pure mineral phases of illite, smectite, kaolinite, and chlorite were obtained from the Clay Mineral Society's source clays repository, (operated from the University of Missouri in Columbia, Missouri), and analyzed under the same conditions as the sediment samples. Quartz, feldspars, and calcite standards were purchased from the Excalibur Mineral Company (Peekskill, New York), ground and analyzed on the diffractometer to obtain intensities for pure nonclay phases. Based on previous data collected from Hanford sediments, an average mass absorption of $55 \mathrm{~cm}^{2} \mathrm{~g}^{-1}$ was assumed for the clay samples. Mass absorption values for standard reference minerals were calculated from published chemical data.

\subsubsection{Water Potential (Suction) Measurements}

Suction measurements were made on the core liners in each splitspoon sampler from borehole 299-W11-39 and on the disturbed unused sediment after geologic characterization and subsampling for the first phase of the characterization had been performed on C4104 samples using the filter paper method PNL-MA-567-SFA-2 (PNL 1990b), which is essentially the same as ASTM (2002). This method relies on three filter papers folded together into a small sandwich that rapidly equilibrates with the sediment sample. The middle filter paper does not contact sediment that might stick to the paper and bias the mass measurements. At equilibrium, the matric suction in the filter paper is the same as the matric suction of the sediment sample. The dry filter paper sandwiches were placed in the 299-W11-39 liners and the C4104 air-tight storage containers while still filled with the sediment and remained there for three weeks to allow sufficient time for the matric suction in the sediment to equilibrate with the matric suction in the filter paper. The mass of the wetted middle filter paper that has had no direct contact with the sediment was subsequently determined, and the suction of the sediment was determined from a calibration relationship between filter paper water content and matric suction. The filter paper method provides a good estimate of water potentials over the range from -0.01 to $-2 \mathrm{MPa}$ ( 1 to $200 \mathrm{~m}$ [3.3 to $656 \mathrm{ft}$ ] suction head) (Deka et al. 1995).

The relationships used for converting the water content of filter paper to matric suction for Whatman \#42 filter paper have been determined by Deka et al. (1995) and can be expressed as:

$$
\begin{aligned}
& \mathrm{Sm}=10^{(5.144-6.699 \mathrm{w})} / 10 \text { for } \mathrm{w}<0.5 \\
& \mathrm{Sm}=10^{(2.383-1.309 \mathrm{w})} / 10 \text { for } \mathrm{w}>0.5
\end{aligned}
$$

where:

Sm is the matric suction (m) and $\mathrm{w}$ is the gravimetric water content of the filter paper (gram/gram). 
Fifty-three core liner samples from borehole 299-W11-39 were analyzed for soil matric suction. The matric potential samples covered the borehole profile from 21.5 to $90.5 \mathrm{ft}$ bgs in $0.5 \mathrm{ft}$ increments. At C4104 each of the 23 A liner sediments were analyzed for soil matric suction after some exposure to air (potentially drying) during the geologic characterization and removing aliquots for characterization. We could not insert the filter paper sandwich in the C4104 core liners prior to characterization as we could for uncontaminated samples such as those from borehole 299-W11-39. 


\subsection{Results and Discussion}

This section presents the geochemical and physical characterization data collected on sediment from the background borehole 299-W11-39 and the two boreholes C4104 (near the 1993 borehole emplaced by Westinghouse Hanford Corporation, 299-W10-196) and C4105. The results for 299-W11-39 are presented in Section 4.1, and those for C4104 and C4105 are given in Sections 4.2, and 4.4, respectively. Comparison between the current data from C4104 with the distribution and concentrations of contaminants from 299-W10-196, found in Section 4.3, allows discussion on migration over the last ten years.

The first characterization activities emphasized tests that were inexpensive or that were key to determining the vertical distribution of mobile contaminants in the vadose zone sediments. Such information on the borehole sediments includes moisture content and total and inorganic carbon content, $\mathrm{pH}$, electrical conductivity (EC), and measurements of major cations, anions, and trace metals (including technetium-99 and uranium-238) in 1:1 sediment:water- and $8 \mathrm{M}$ nitric acid- extracts. A gamma energy analysis (GEA) of the sediments was also performed to search for any detectable man-made gamma emitting radionuclides. The particle size, bulk chemical composition, and alpha- and beta-emitting radionuclides of selected sediment samples were measured in the second characterization phase. The determination of particle size and bulk chemical composition aids in selecting contacts between major geologic units. These parameters also help to better define the background composition of the uncontaminated sediments for determining the vertical extent of mobile contaminants in the other boreholes. The measurement of beta- and alpha-emitting radionuclides (i.e., stronium-90 and transuranics, respectively) allows direct measurement of the vertical migration potential of these potentially risky contaminants.

\subsection{Vadose Zone Sediment from Borehole 299-W11-39}

\subsubsection{Moisture Content}

The moisture content of the sediment from the liners from the section of borehole 299-W11-39 that was continuously cored (20 to $94 \mathrm{ft}$ bgs) is listed in Table 4.1 and presented as a graph (Figure 2.9) in Chapter 2.0 Geology. Figure 2.9 shows both the field volumetric moisture obtained via neutron logging and the gravimetric moisture content of small aliquots of sediment taken during the geologic description activities. The moisture content profile correlates with the lithology described in Section 2.3.2 and shown in Figure 2.9. The first region with elevated moisture in the Hanford formation H2 unit is the thin mud lens at $\sim 50 \mathrm{ft}$ bgs. There is one other elevated moisture content spot in the Hanford formation $\mathrm{H} 2 \mathrm{unit}$ at 76 to $78 \mathrm{ft}$ bgs. The rest of the Hanford formation $\mathrm{H} 2$ unit is rather dry, with a mean gravimetric moisture content of $4.5 \mathrm{wt} \%$. Above the Hanford formation H2, the Hanford formation H1 unit is slightly drier, with a mean moisture content of $3.8 \mathrm{wt} \%$ and with no signs of any wetter, thin, fine-grained lenses. Below the Hanford formation strata, both the Cold Creek upper, $\mathrm{CCU}_{\mathrm{u}}$, (fine-grained) and the lower (carbonate-rich $\mathrm{CCU}_{\mathrm{l}}$ ) units are wetter than the Hanford formation units. The Ringold $\mathrm{R}_{\mathrm{tf}}$ unit that lies below the Cold Creek units also is quite moist, but the gravelly $\mathrm{R}_{\mathrm{wi}}$ unit is quite dry based on the field neutron logs. No core samples were obtained from borehole 299-W11-39 in the lower Cold Creek subunit or the Ringold units. 
Table 4.1. Gravimetric Moisture Content of Core Samples Obtained Between 20 and $92 \mathrm{ft}$ bgs in Borehole 299-W11-39

\begin{tabular}{|c|c|c|c|c|c|}
\hline $\begin{array}{c}\text { Depth } \\
\text { (ft bgs) }\end{array}$ & $\begin{array}{c}\text { Stratigraphic } \\
\text { Unit }\end{array}$ & $\begin{array}{c}\text { MC } \\
\% \text { Wt }\end{array}$ & $\begin{array}{c}\text { Depth } \\
\text { (ft bgs) }\end{array}$ & $\begin{array}{c}\text { Stratigraphic } \\
\text { Unit }\end{array}$ & $\begin{array}{c}\text { MC } \\
\% \mathrm{Wt}\end{array}$ \\
\hline 21.5 & H1 & $4.05 \%$ & 59.5 & $\mathrm{H} 2$ & $4.52 \%$ \\
\hline 23.5 & H1 & $3.94 \%$ & 60.5 & H2 & $6.78 \%$ \\
\hline 24.5 & H1 & $4.24 \%$ & 62 & H2 & $4.76 \%$ \\
\hline 25.5 & H1 & $3.33 \%$ & 63 & H2 & $4.60 \%$ \\
\hline 28 & H1 & $5.23 \%$ & |64.5 & H2 & $3.58 \%$ \\
\hline 32 & H1 & $2.89 \%$ & 65.5 & H2 & $3.25 \%$ \\
\hline 33 & H1 & $2.84 \%$ & 68 & H2 & $4.43 \%$ \\
\hline 34.5 & H2 & $6.90 \%$ & 69.5 & H2 & $3.64 \%$ \\
\hline 35.5 & H2 & $3.97 \%$ & 70.5 & H2 & $3.85 \%$ \\
\hline 37 & H2 & $3.84 \%$ & 72 & H2 & $4.82 \%$ \\
\hline 38 & H2 & $3.06 \%$ & |73 & $\mathrm{H} 2$ & $4.10 \%$ \\
\hline 39.5 & H2 & $3.60 \%$ & |74.5 & H2 & $3.91 \%$ \\
\hline 40.5 & H2 & $2.91 \%$ & |75.5 & H2 & $4.31 \%$ \\
\hline 42 & H2 & $3.25 \%$ & |77 & $\mathrm{H} 2$ & $12.78 \%$ \\
\hline 43 & H2 & $6.77 \%$ & 78 & H2 & $21.22 \%$ \\
\hline 44.5 & $\mathrm{H} 2$ & $4.58 \%$ & |79.5 & $\mathrm{H} 2$ & $5.26 \%$ \\
\hline 45.5 & H2 & $3.27 \%$ & 80.5 & H2 & $4.96 \%$ \\
\hline 47 & H2 & $3.00 \%$ & 82 & $\mathrm{H} 2$ & $5.60 \%$ \\
\hline 48 & H2 & $2.94 \%$ & 83 & $\mathrm{H} 2$ & $4.25 \%$ \\
\hline 49.5 & H2 & $13.25 \%$ & 84.5 & H2 & $4.12 \%$ \\
\hline 50.5 & $\mathrm{H} 2$ & $5.38 \%$ & 85.5 & $\mathrm{H} 2$ & $4.87 \%$ \\
\hline 52 & H2 & $3.28 \%$ & 87 & H2 & $5.15 \%$ \\
\hline 53 & H2 & $2.51 \%$ & 88 & H2 & $5.16 \%$ \\
\hline 54.5 & $\mathrm{H} 2$ & $3.00 \%$ & 89.5 & $\mathrm{CCU}_{\mathrm{u}}$ & $4.81 \%$ \\
\hline 55.5 & $\mathrm{H} 2$ & 7.65\% & 90.5 & $\mathrm{CCU}_{\mathrm{u}}$ & $22.84 \%$ \\
\hline 58 & H2 & $2.38 \%$ & 92 & $\mathrm{CCU}_{\mathrm{u}}$ & $13.28 \%$ \\
\hline
\end{tabular}




\subsubsection{1:1 Sediment:Water Extracts for Borehole 299-W11-39}

No subsampling of the background sediment from borehole 299-W11-39, aside from moisture content determination, was performed immediately after core opening. When cores were selected for geochemical characterization several months later, it was found that the samples had dried significantly.

Unlike past comparisons between background and contaminated sediments at the S-SX and B-BX-BY waste management areas (WMA), no attempt is made to estimate the chemical composition of uncontaminated vadose zone porewater from the 1:1 sediment:water extracts. Instead, the chemical data from the 1:1 water extracts for the background borehole (299-W11-39) and the three boreholes around tank T-106 were compared on a per gram of dry soil basis. The following sections discuss the results of the analyses for the 1:1 sediment:water extracts on the background sediment.

\subsubsection{1 $\quad \mathrm{pH}$ and Electrical Conductivity}

The $\mathrm{pH}$ and EC for the water extracts are shown in Table 4.2 and Figure 4.1. The $\mathrm{pH}$ is plotted as measured in the 1:1 sediment:water extracts but the EC is corrected for dilution and plotted as if it was actual porewater. The $\mathrm{pH}$ profile is rather featureless with all values between 7 and 7.5. The two water extracts from the upper Cold Creek unit have low values for EC compared to the Hanford formation sediments. During the SX and TX Tank Farm characterizations, three uncontaminated boreholes, 299-W22-48, 299-W22-50 and 299-W10-27, were cored and fully characterized. The pH and EC data for 299-W11-39 sediments agree more closely with the data for 299-W22-48 than 299-W22-50 (see Tables 5.15 and 5.38 in Serne et al. 2002a). The dilution-corrected EC values for this background well at the $\mathrm{T}$ Farm in the shallow regions (50 to $65 \mathrm{ft}$ bgs) of the Hanford formation $\mathrm{H} 2$ unit are more saline than values found outside the TX Tank Farm in well 299-W10-27. We suspect that the high EC values indicate the presence of Hanford liquid discharges. Dilution-corrected EC values at this T Tank Farm background well in the shallow Hanford formation $\mathrm{H} 2$ unit range between 60 and $70 \mathrm{mS} / \mathrm{cm}$, while the similar depth range at the TX tank farm background borehole range from 18 to $20 \mathrm{mS} / \mathrm{cm}$. At the T background borehole, dilution-corrected EC values at and below $78 \mathrm{ft}$ bgs show a similar range as the background values in other 200 West Area sediments. Thus the suspected presence of Hanford fluids is constrained to shallow depths above $78 \mathrm{ft}$ bgs.

Table 4.2. $\quad$ pH and EC Values for 1:1 Sediment:Water Extracts from 299-W11-39

\begin{tabular}{||l|l|l|l||}
\hline $\begin{array}{c}\text { Depth } \\
\text { (ft bgs) }\end{array}$ & Stratigraphic Unit & $\mathbf{p H}$ & $\begin{array}{c}\text { Conductivity } \\
\mathbf{m S} / \mathbf{c m}\end{array}$ \\
\hline 49.5 & $\mathrm{H} 2$ & 7.00 & 0.503 \\
\hline 60.5 & $\mathrm{H} 2$ & 7.51 & 0.379 \\
\hline 78 & $\mathrm{H} 2$ & 7.17 & 0.465 \\
\hline 92 & $\mathrm{CCU}_{\mathrm{u}}$ & 7.32 & 0.191 \\
\hline 92 (dup) & $\mathrm{CCU}_{\mathrm{u}}$ & 7.37 & 0.210 \\
\hline
\end{tabular}




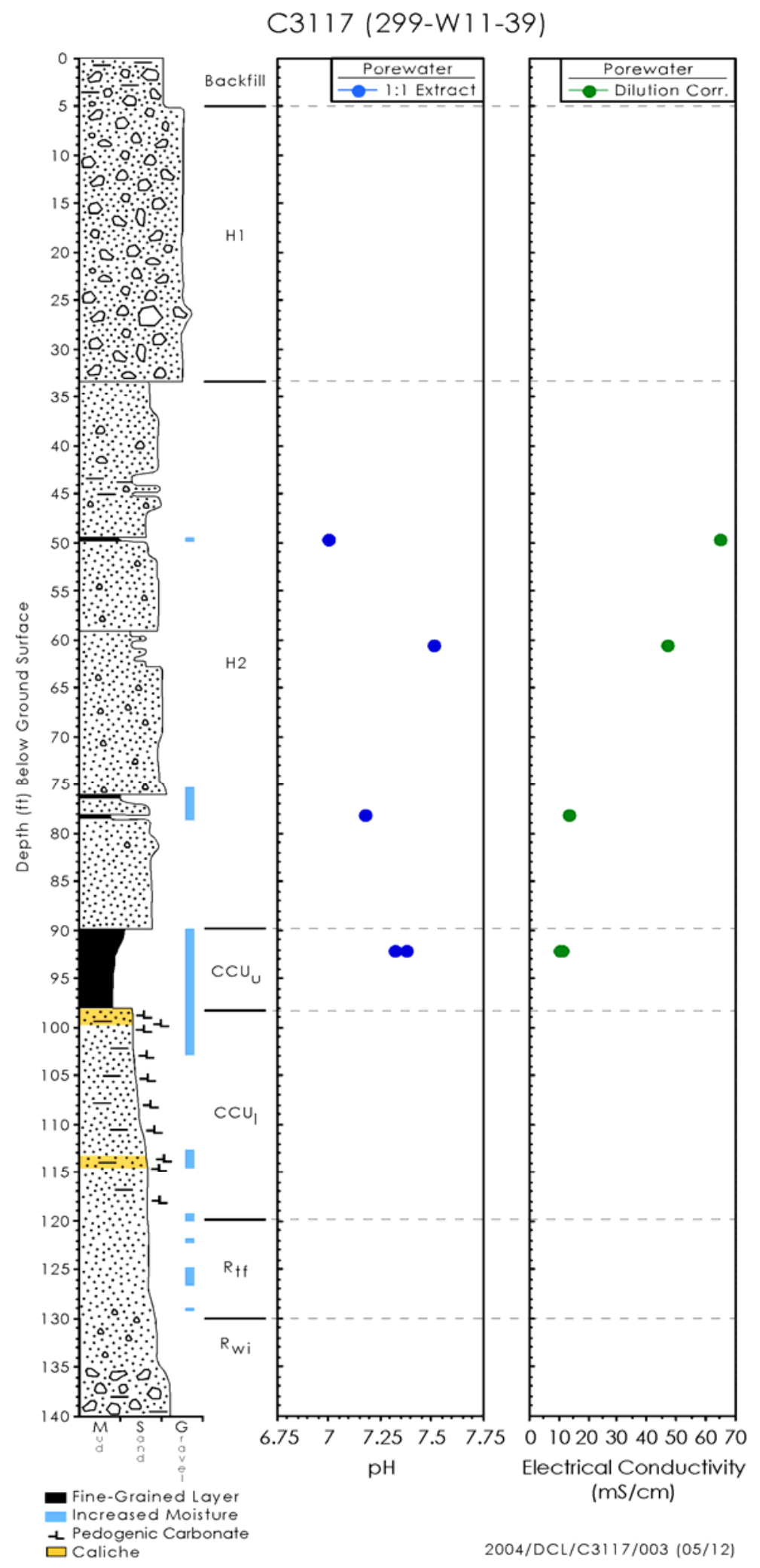

Figure 4.1. $\quad \mathrm{pH}$ and Electrical Conductivity Calculated From Sediment:Water Extracts for Borehole 299-W11-39 


\subsubsection{Water Extract Composition or the 1:1 Sediment:Water Extract for 299-W11-39}

The 1:1sediment:water extract anion composition from 299-W11-39 samples, in units of $\mu$ g per gram of dry sediment, is shown in Table 4.3 and Figure 4.2. We were going to assume that the values represented background values that can be compared to values for water extracts from the three boreholes, C4104, 299-W10-196, and C4105, near tank T-106 that leaked in 1973. However, as mentioned shallow depths at 299-W11-39 appear to be contaminated. Values in Table 4.3 that appear to be elevated compared to the others are shown in bold type and values that are low compared to the others are shown in italics. A comparison of the masses of water-extractable anions per gram of sediment from the background sediments from the Hanford formation H2 unit in 299-W11-39 shows that there are higher values in the T Tank Farm background sediment than for background sediments near the TX tank farm (Serne et al. 2004). The water-extractable chloride and sulfate for sediments in the upper portion of the Hanford formation H2 unit at 299-W11-39 (near T Tank Farm) are four times larger than comparable sediments outside the TX Tank Farm. The 299-W11-39 sediments leach about 15 to 60 times more nitrate than comparable background sediments near the TX Tank Farm. This corroborates the suspicion that some Hanford-related liquids likely have percolated into the upper portion of the Hanford formation $\mathrm{H} 2$ unit outside the northeast corner of the T Tank Farm. Thus, this well is not a good candidate for determining the background or natural conditions in the vadose zone.

Although not sampled at 299-W11-39, we expect that calcium-carbonate-rich $\mathrm{CCU}_{1}$ sediment below $\sim 98 \mathrm{ft}$ bgs will show elevated water-leachable solutes (see Serne et al. 2002a). The $\mathrm{CCU}_{\mathrm{l}}$ stratum is an old near-surface soil zone that translocated solutes during periods of active precipitation-evaporation. Thus, this stratum would be expected to contain larger quantities of leachable salts.

As found for the background sediment characterization for the TX Tank Farm, we find that the inorganic carbon (IC) values reported as carbonate are biased high compared to the carbonate values measured by standard alkalinity titration. None of the 299-W11-39 sediment:water extracts contain measurable amounts of nitrite or bromide, and the water-leachable phosphate values are below or right at the detection limit ( $0.25 \mu \mathrm{g} / \mathrm{g})$.

Table 4.4 shows the water-leachable composition for small organic molecules. With so few samples characterized we do not see any trends as was found for sediments from beneath the TX tank farm. There, in general, the Hanford formation sediments have slightly lower water-leachable concentrations of formate, acetate, and oxalate than the Cold Creek unit and Ringold Formation sediments. One possible cause for the differing concentrations of water-leachable organic molecules is the fact that the Hanford formation was deposited very rapidly and large volumes of sediment diluted any near surface organic matter that was present. The water-leachable amounts of small organic species at 299-W11-39 appear to be slightly lower than the comparable values at the background borehole near the TX Tank Farm.

Table 4.5 shows the water-leachable concentrations of divalent and monovalent cations, in units of $\mu \mathrm{g}$ per gram of dry sediment, for the background borehole 299-W11-39. Table 4.6 shows the waterleachable concentrations of aluminum (Al), silicon (Si), iron (Fe), manganese (Mn), zinc ( $\mathrm{Zn})$, phosphorous (P), and sulfur (S). The latter two were converted to their respective anions, phosphate and sulfate, and the data are plotted to compare with the ion chromatograph measured anion data in Figure 4.2. The comparison is quite good. 
The distributions of water leachable masses of several of the major cations versus depth are shown in Figure 4.3. Upon comparison with the comparable water leachable cation data at the background borehole at TX Tank Farm, we find that the water-leachable divalent cations, excepting barium, are low in 299-W11-39 in the Hanford H2 unit above $78 \mathrm{ft}$ bgs. Conversely, the water-leachable sodium shows higher values leached from the background sediments from the Hanford formation H2 unit at this T Tank Farm borehole in comparison to the background sediments at TX tank farm. Again, the concentrations of water-leachable cations are about a factor of 4 lower for calcium, magnesium, strontium, and potassium for Hanford formation H2 sediments from 299-W11-39. The water-leachable sodium at 299-W11-39 are as large as a factor of 10 higher than values for the background sediments near TX tank farm. Waterleachable cations in the upper subunit of the Cold Creek unit at the T Tank Farm background well are slightly elevated in comparison to the comparable sediments at the TX background borehole.

These findings further confirm that the upper portion of the Hanford formation $\mathrm{H} 2$ unit at the background borehole at the T Tank Farm contains discharged Hanford fluids enriched in sodium and nitrate. In fact, the low water-leachable magnesium and calcium and high sodium at $60.5 \mathrm{ft}$ bgs in borehole 299-W11-39 is the result of high sodium-bearing solution having replaced natural calcium and magnesium from the sediment cation exchange sites. Thus, at $60.5 \mathrm{ft}$ bgs in well 299-W11-39, considerable Hanford liquid likely percolated through this zone and flushed the natural divalent cations out of the sediment. There does not appear to be a fine-grained sediment lens at this depth, but the geologic stratigraphy does show this zone is finer grained sand than the sediments above and below this depth. Interestingly, the water-extractable nitrate in this zone is low compared to the sediments above and below, suggesting that it may have been flushed out after the high sodium nitrate liquids removed the divalent cations off the natural sediments. One can speculate that the sediments at $60.5 \mathrm{ft}$ bgs in borehole 299-W11-39 represent a preferential flow channel for unsaturated water flow and some flushing with natural recharge water has occurred since the Hanford fluids were present.

Little data are available for the Cold Creek units at borehole 299-W11-39 but we speculate that the findings for the background borehole at TX Tank Farm would apply at the T Tank Farm as well (see discussion in Section 4.1.2 in Serne et al. [2004]). Briefly, we would expect that water-soluble cations in the carbonate-rich $\mathrm{CCU}_{1}$ sediment would be higher than in the Hanford formation. This is to be expected because these divalent cations form moderately soluble carbonate solids. Although not characterized, the Ringold Formation sediments at 299-W11-39 would be expected to show slightly elevated waterleachable divalent cations because of carbonate coatings on the grains or detrital carbonates present in these older sediments.

The water-leachable metals (see Table 4.6) at 299-W11-39 do not differ significantly from values found in the background well for the TX Tank Farm with the exception of the elevated sulfur, reported as sulfate and discussed previously. The one exception is high water-soluble iron at $60.5 \mathrm{ft}$ bgs at 299-W11-39. We will thus rely more on the background data from the water extract of the TX borehole 299-W10-27 when comparing the data from the contaminated T boreholes. Table 4.7 and Figures 4.4 and 4.5 show the water-leachable concentrations for sediments from borehole 299-W11-39 for constituents that are present in tank leak fluids and, in the case of those shown in Figure 4.5, metals that have been found to be relatively mobile under some tanks in the S-SX and B-BX-BY WMAs (see Serne et al. 200b, 2002c, 2002d, 2002e, 2002f for further discussion). 
Table 4.3. Anion Composition of Water Extracts of 299-W11-39 Sediment (units $\mu \mathrm{g} / \mathrm{g}$ dry sediment)

\begin{tabular}{|c|c|c|c|c|c|c|c|c|c|}
\hline $\begin{array}{c}\text { Depth } \\
\text { (ft bgs) }\end{array}$ & Stratigraphic Unit & Fluoride & Chloride & Nitrate & $\begin{array}{c}\text { Alk as } \\
\mathrm{CO}_{3}\end{array}$ & Sulfate & Phosphate & Nitrite & Bromide \\
\hline 49.5 & $\mathrm{H} 2$ & 0.25 & 2.69 & 180.95 & $<50.472$ & 26.03 & $<0.242$ & $<0.081$ & $<0.138$ \\
\hline 60.5 & H2 & 0.52 & 7.79 & 44.76 & 81.77 & 47.45 & 0.28 & $<0.081$ & $<0.139$ \\
\hline 78 & H2 & 0.38 & 3.29 & 131.35 & 42.57 & 32.64 & $<0.256$ & $<0.085$ & $<0.146$ \\
\hline 92 & $\mathrm{CCU}_{\mathrm{u}}$ & 0.42 & 2.91 & 14.85 & 61.34 & 15.68 & 0.28 & $<0.083$ & $<0.143$ \\
\hline 92 (dup) & $\mathrm{CCU}_{\mathrm{u}}$ & 0.43 & 2.38 & 12.32 & 60.42 & 16.48 & 0.27 & $<0.083$ & $<0.142$ \\
\hline
\end{tabular}

Table 4.4. Small Molecular Weight Organic Content of Water Extracts of 299-W11-39 Sediment (units $\mu$ g/g dry sediment)

\begin{tabular}{||l|l|l|c|l||}
\hline \hline Depth (ft bgs) & Stratigraphic Unit & \multicolumn{1}{|c|}{ Formate } & Acetate & Oxalate \\
\hline 49.5 & $\mathrm{H} 2$ & 0.25 & 0.22 & 0.42 \\
\hline 60.5 & \multicolumn{1}{|c|}{$\mathbf{0 . 3 8}^{(\mathrm{a})}$} & $\mathbf{0 . 4 7}$ & $<0.22^{(\mathrm{b})}$ \\
\hline 78 & $\mathrm{H} 2$ & 0.15 & 0.22 & 0.41 \\
\hline 92 & $\mathrm{H} 2$ & 0.12 & 0.17 & 0.39 \\
\hline 92 (dup) & $\mathrm{CCU}_{\mathrm{u}}$ & 0.12 & 0.24 & 0.35 \\
\hline $\begin{array}{l}\text { (a) Bold values are higher than others for given constituent. } \\
\text { (b) Italicized values are lower than others for a given constituent. }\end{array}$ \\
\hline
\end{tabular}



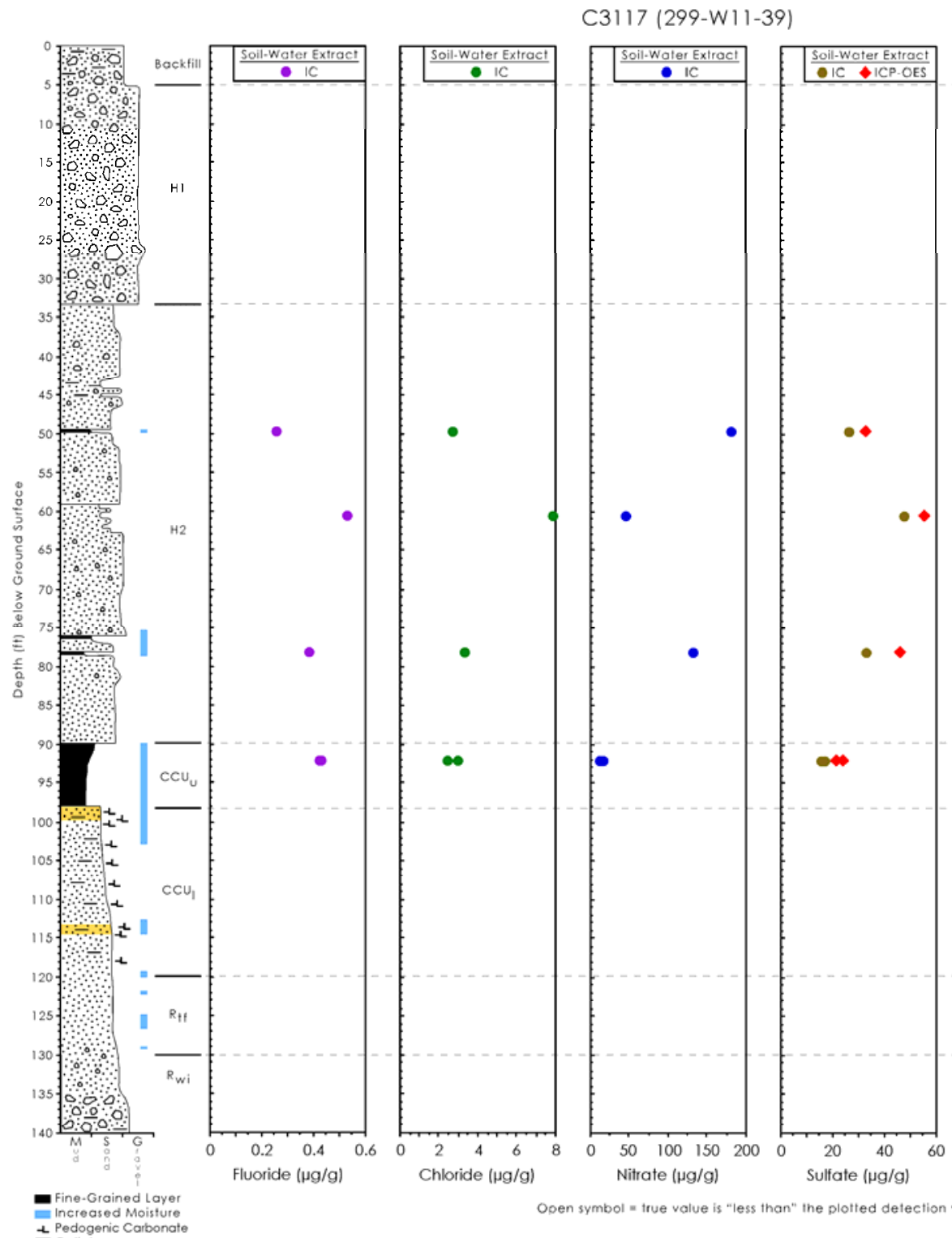

Increased Moisture

Open symbol = true value is "less than" the plotted detection value

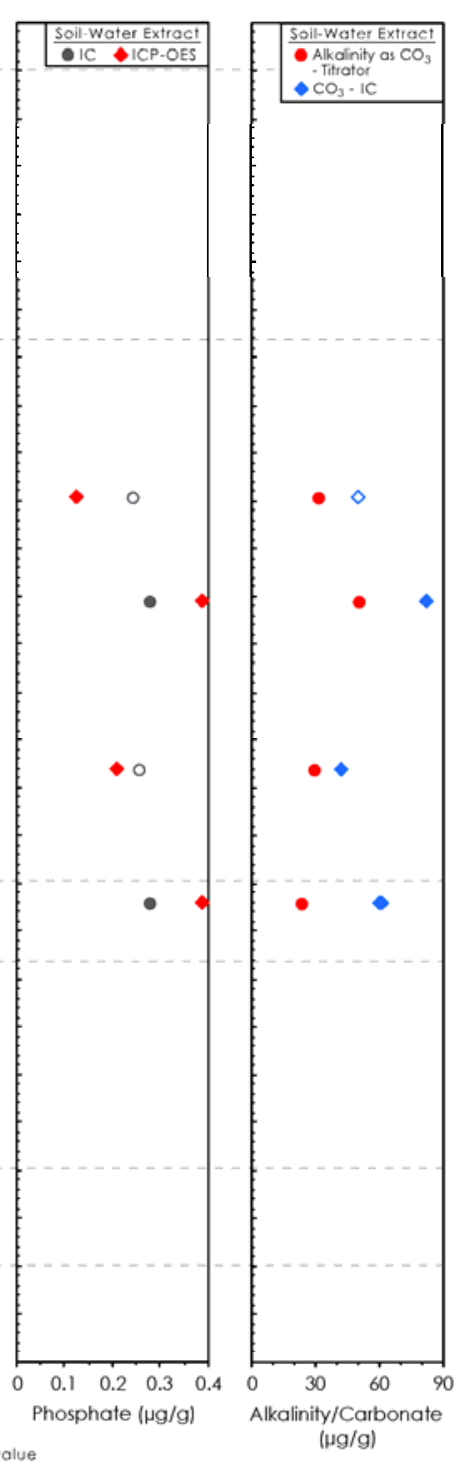

2004/DCL/C3117/004 (05/12)

Figure 4.2. Major Anions in 1:1 Sediment:Water Extracts from Borehole 299-W11-39 
Table 4.5. Water-Extractable Cations in Borehole 299-W11-39 Sediments ( $\mu \mathrm{g} / \mathrm{g}$ dry soil)

\begin{tabular}{|c|c|c|c|c|c|c|c|}
\hline $\begin{array}{c}\text { Depth } \\
\text { (ft bgs) }\end{array}$ & Stratigraphic Unit & Mg & Ca & Sr & Ba & $\mathbf{N a}$ & $\mathbf{K}$ \\
\hline 49.5 & $\mathrm{H} 2$ & 12.20 & 51.90 & 2.53E-01 & 9.41E-02 & 16.10 & 10.40 \\
\hline 60.5 & $\mathrm{H} 2$ & $0.82^{(b)}$ & 4.04 & $2.63 E-02$ & 2.51E-02 & $72.50^{(a)}$ & 4.17 \\
\hline 78 & $\mathrm{H} 2$ & 11.20 & 49.60 & 2.48E-01 & 4.34E-02 & 15.60 & 9.03 \\
\hline 92 & $\mathrm{CCU}_{\mathrm{u}}$ & 4.08 & 18.90 & 8.78E-02 & 2.97E-02 & 11.10 & 4.16 \\
\hline 92(dup) & $\mathrm{CCU}_{\mathrm{u}}$ & 4.03 & 18.90 & 8.85E-02 & 4.02E-02 & 11.10 & 4.38 \\
\hline
\end{tabular}

Table 4.6. Other Water-Extractable Species in Borehole 299-W11-39 Sediments ( $\mu \mathrm{g} / \mathrm{g}$ dry soil)

\begin{tabular}{|c|c|c|c|c|c|c|c|c|}
\hline $\begin{array}{c}\text { Depth } \\
\text { (ft bgs) }\end{array}$ & $\begin{array}{c}\text { Stratigraphic } \\
\text { Unit }\end{array}$ & Al & Si & $\mathbf{F e}$ & Mn & Zn & $\mathrm{P}$ as $\mathrm{PO}_{4}$ & $\mathrm{~S}$ as $\mathrm{SO}_{4}$ \\
\hline 49.5 & H2 & ND & 13.1 & 0.0126 & ND & 3.99E-02 & $(0.126)^{(\mathrm{c})}$ & 32.4 \\
\hline 60.5 & $\mathrm{H} 2$ & 3.61E-02 & 12.2 & $5.56 \mathrm{E}-02^{(\mathrm{a})}$ & ND & 4.88E-02 & 0.389 & 55.5 \\
\hline 78 & H2 & ND & 15.2 & $(1.14 \mathrm{E}-02)$ & ND & 3.28E-02 & 0.208 & 46.2 \\
\hline 92 & $\mathrm{CCU}_{\mathrm{u}}$ & ND & 12.2 & $(1.00 \mathrm{E}-02)$ & ND & 3.07E-02 & 0.405 & $21.7^{(b)}$ \\
\hline 92(dup) & $\mathrm{CCU}_{\mathrm{u}}$ & ND & 12.3 & (1.37E-02) & ND & 3.10E-02 & 0.389 & 23.9 \\
\hline \multicolumn{9}{|c|}{$\begin{array}{l}\text { (a) Bold values are higher than others for given constituent. } \\
\text { (b) Italicized values are lower than others for a given constituent. } \\
\text { (c) Parentheses signify values below level of quantitation but considered valid. } \\
\text { ND = not determined (not analyzed). }\end{array}$} \\
\hline
\end{tabular}


Table 4.7. Water-Extractable Mobile Trace Contaminants in Borehole 299-W11-39 Sediments ( $\mu$ g per gram dry soil)

\begin{tabular}{|c|c|c|c|c|c|c|}
\hline $\begin{array}{c}\text { Depth } \\
\text { (ft bgs) }\end{array}$ & $\begin{array}{c}\text { Stratigraphic } \\
\text { Unit }\end{array}$ & Tc-99 & $\mathrm{U}-238$ & $\mathrm{Cr}$ & $\begin{array}{c}\text { Mo } \\
\text { (ICP-MS) } \\
\end{array}$ & $\begin{array}{c}\text { Mo } \\
\text { (ICP) } \\
\end{array}$ \\
\hline 49.5 & $\mathrm{H} 2$ & $1.71 \mathrm{E}-01$ & $5.77 \mathrm{E}-04$ & $(4.34 \mathrm{E}-05)^{(\mathrm{c})}$ & $2.88 E-03^{(b)}$ & $(1.96 E-03)$ \\
\hline 60.5 & $\mathrm{H} 2$ & $<4.30 \mathrm{E}+00$ & $1.63 \mathrm{E}-03^{(\mathrm{a})}$ & (7.95E-04) & 8.71E-03 & $1.23 \mathrm{E}-02$ \\
\hline 78 & $\mathrm{H} 2$ & $1.81 \mathrm{E}-02$ & $4.41 \mathrm{E}-04$ & (7.00E-04) & 1.10E-02 & $1.14 \mathrm{E}-02$ \\
\hline 92 & $\mathrm{CCU}_{\mathrm{u}}$ & $<4.42 \mathrm{E}+00$ & $6.58 \mathrm{E}-04$ & (1.63E-03) & $7.86 \mathrm{E}-03$ & 9.29E-03 \\
\hline 92(dup) & $\mathrm{CCU}_{\mathrm{u}}$ & $<4.41 \mathrm{E}+00$ & $6.98 \mathrm{E}-04$ & $(7.42 \mathrm{E}-04)$ & 8.28E-03 & $1.01 \mathrm{E}-02$ \\
\hline \multicolumn{7}{|c|}{$\begin{array}{l}\text { (a) Bold values are higher than others for given constituent. } \\
\text { (b) Italicized values are lower than others for a given constituent. } \\
\text { (c) Parentheses signify values below level of quantitation but considered valid. }\end{array}$} \\
\hline
\end{tabular}

The values for water-leachable technetium-99, uranium, chromium, and molybdenum in the 299-W11-39 sediments are similar to the values in the background well at the TX Tank Farm in both the Hanford formation $\mathrm{H} 2$ and $\mathrm{CCU}_{\mathrm{u}}$ units. There may be slightly elevated water-leachable uranium in the 299-W11-39 sediments at $60.5 \mathrm{ft}$ bgs and low values for molybdenum at $49.5 \mathrm{ft}$ bgs but, in general, there are no obvious signs that these mobile indicators of tank liquids are present in the vadose zone at this location. However, we are fairly certain that sodium nitrate-bearing Hanford fluids are present in the vadose zone at this borehole.

The values presented in Tables 4.2 through Table 4.7 in this report and the TX report (Serne et al. 2004) will be compared to similar data for the three contaminated T boreholes C4104, C4105, and 299-W10-196, to evaluate whether significantly higher values are found in any borehole that would suggest tank fluids had percolated into the vadose zone where the boreholes were pushed. More reliance will be placed on the background values from the TX background borehole, 299-W10-27, than on the T tank farm borehole 299-W11-39. 


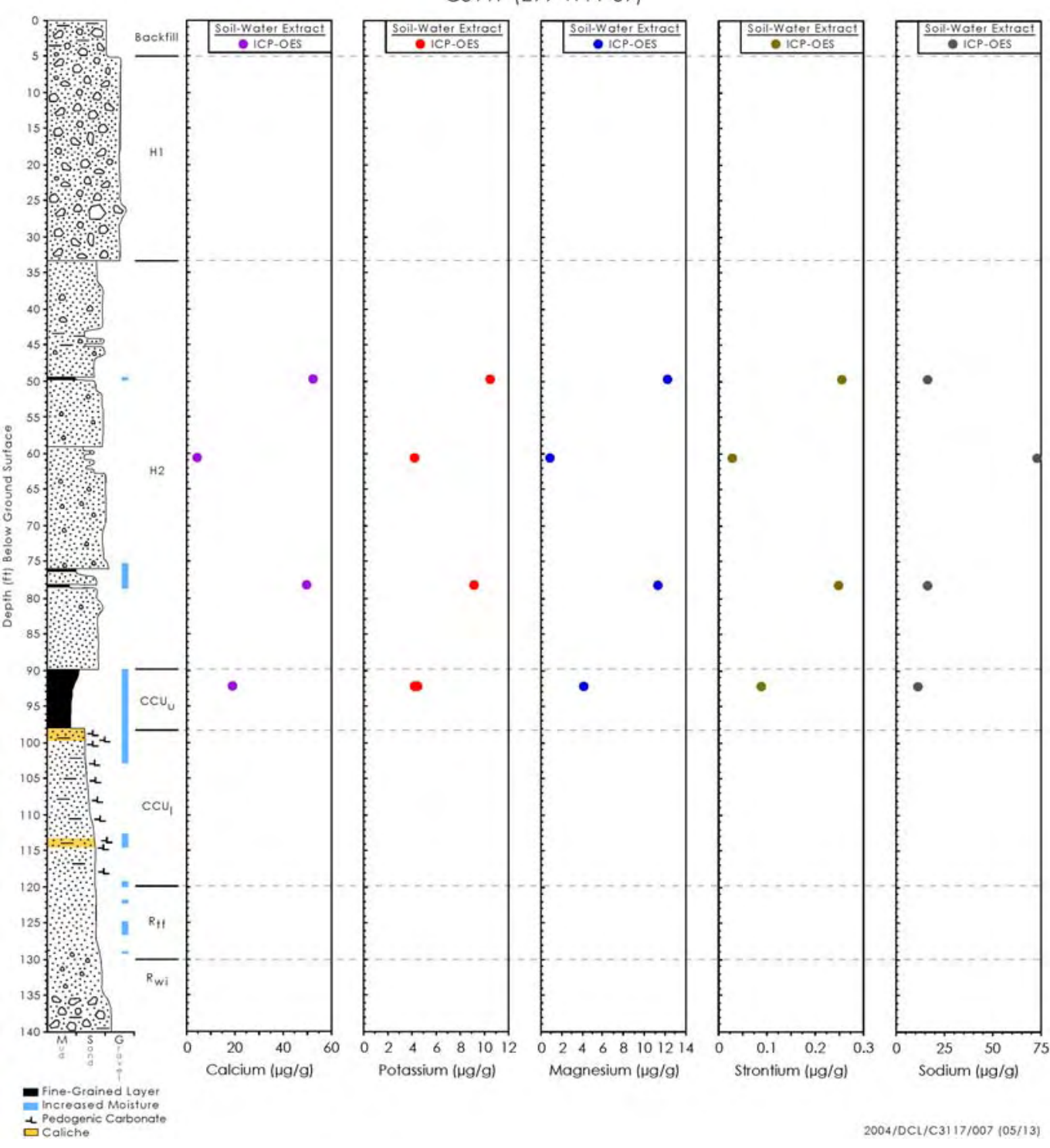

Figure 4.3. Cations in 1:1 Sediment:Water Extracts for Borehole 299-W11-39 


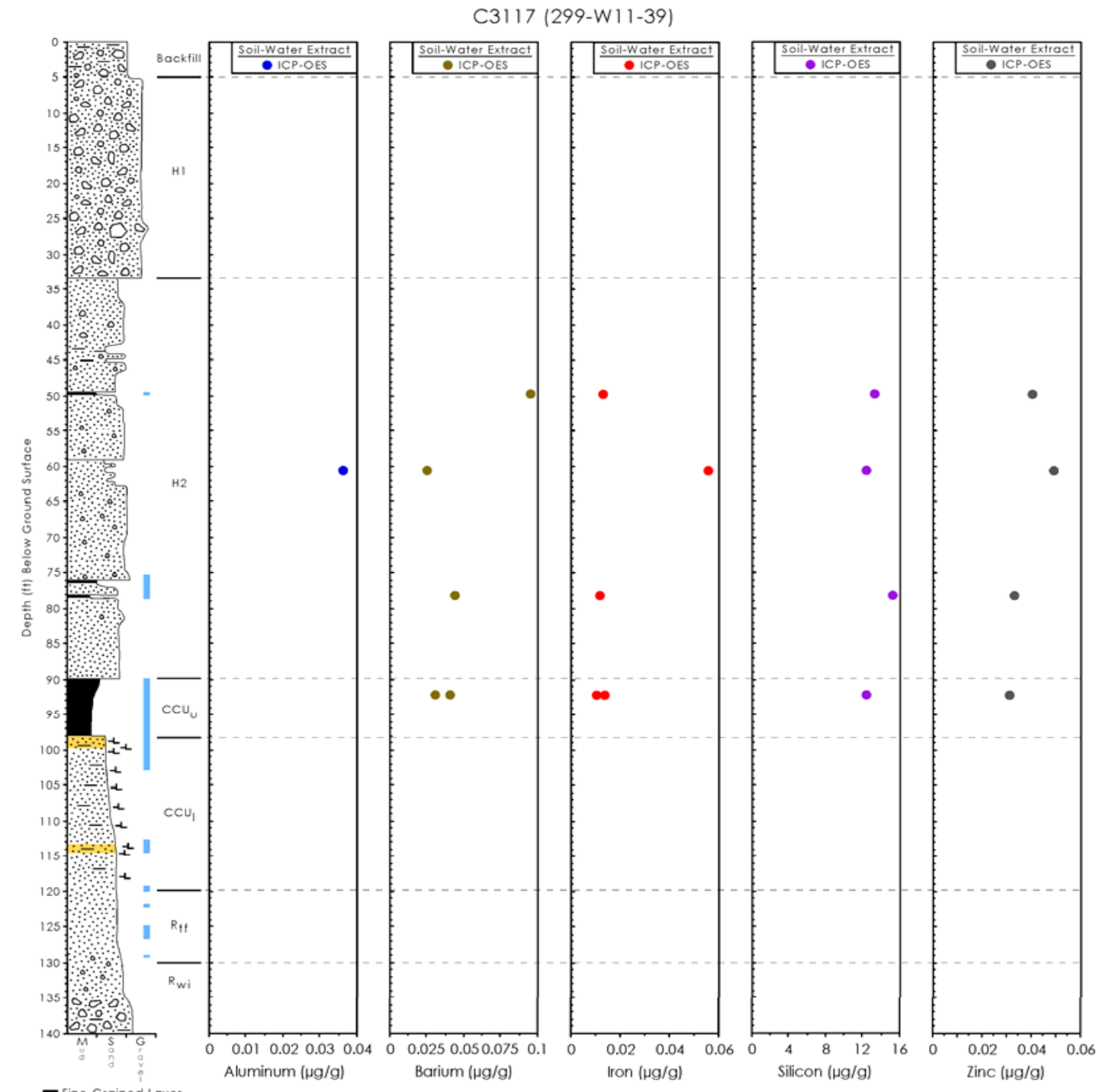

- Fine-Grained Layer
Increased Moisture
t Pedogeric Corbonate

2004/DCL/C3117/008 (05/13/

Figure 4.4. Aluminum, Barium, Iron, Silicon, and Zinc in 1:1 Sediment:Water Extracts from Borehole 299-W11-39 


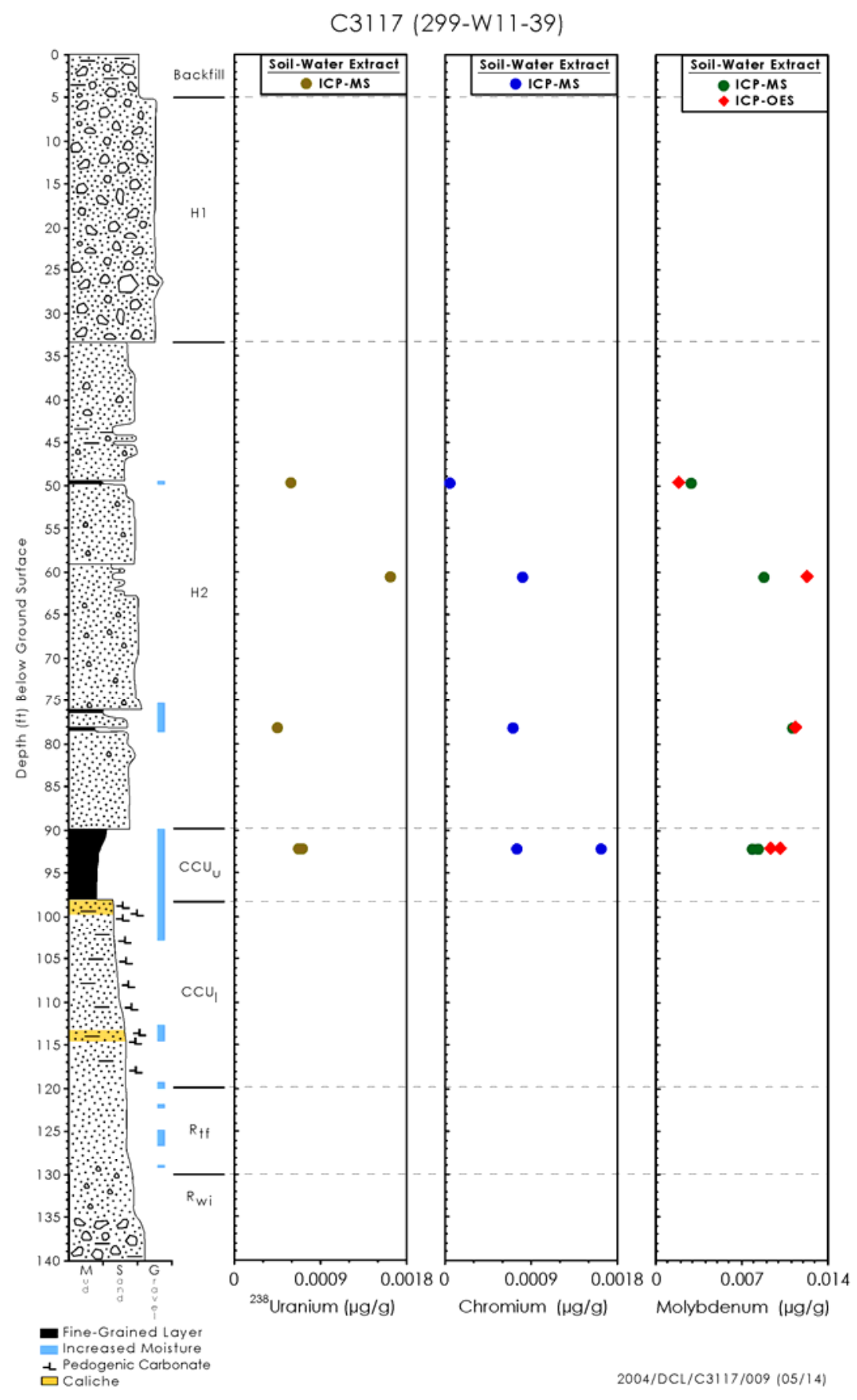

Figure 4.5. Trace Metals in 1:1 Sediment:Water Extracts Borehole 299-W11-39 


\subsubsection{M Nitric Acid-Extractable Amounts of Selected Elements}

The amount of material that could be extracted from the vadose zone sediment into $8 \mathrm{M}$ nitric acid is shown in Tables 4.8 through 4.10 and Figures 4.6 through 4.9. The $8 \mathrm{M}$ nitric acid extraction is a protocol used by the U.S. Environmental Protection Agency to estimate the maximum concentrations of regulated metals in contaminated sediment that would be biologically available. Aliquots of sediment from borehole 299-W11-39 were subjected to the acid extraction to establish baseline values to compare with acid extracts of potentially contaminated sediments from the three boreholes, C4104, C4105, and 299-W10-196.

The acid extract data in Tables 4.8 through 4.10 were compared to values for the background borehole at the TX Tank Farm to see if there were signs of elevated concentrations in the 299-W11-39 sediments. There is an obvious sign of elevated acid-extractable sodium (Na) in the 299-W11-39 sample at $60.5 \mathrm{ft}$ bgs that has been discussed in the water extract result section. This continues the evidence that Hanford-related liquids are or were present in the upper portion of the Hanford formation H2 unit at 299-W11-39. There may be elevated levels of acid-soluble potassium, zinc, iron, manganese and sulfate in the sediments from the $\mathrm{H} 2$ unit in borehole 299-W11-39 samples. The values appear to be slightly elevated but the potassium data may reflect differences in mineralogy more so than being an indication of Hanford-related liquid disposal.

Although no acid extract data from the high calcium-carbonate content $\mathrm{CCU}_{1}$ subunit are available, we project that high values for calcium (Ca), strontium (Sr), manganese (Mn), sodium (Na), uranium (U) and sulfate $\left(\mathrm{SO}_{4}{ }^{2-}\right.$ ) would be found. Samples from the Ringold Formation $\mathrm{R}_{\mathrm{tf}}$ unit may also contain detrital or carbonate coatings that would also readily dissolve in acid. Similar results were found for background sediments near the SX tank farm (Serne et al. 2002a and Lindenmeier et al. 2002).

A comparison of the water-leachable and acid-leachable contents of the uncontaminated sediments from borehole 299-W11-39 (see data shown in Tables 4.3 to 4.7 versus Tables 4.8 to 4.10 ) shows that less than $0.1 \%$ of the acid-extractable quantities of the following elements are water leachable: aluminum $(\mathrm{Al})$, barium $(\mathrm{Ba})$, iron $(\mathrm{Fe})$, manganese $(\mathrm{Mn})$, zinc $(\mathrm{Zn})$, chromium $(\mathrm{Cr})$, and phosphorus $(\mathrm{P})$ as phosphate. Less than $1 \%$ of the acid-extractable quantities of the following elements are water leachable: calcium (Ca), potassium (K), magnesium (Mg), strontium (Sr), and uranium (U). Less than $5 \%$ of the acid-extractable molybdenum (Mo) is water soluble and less than $15 \%$ of the acid-extractable sodium $(\mathrm{Na})$ is water soluble. The sample from $60.5 \mathrm{ft}$ bgs with obvious signs of elevated sodium concentrations, suggesting the presence of Hanford-generated liquids, has the highest percentage water versus acid leachable sodium. We have found that high percentages of water-soluble sodium versus acid-extractable concentrations are common where Hanford liquids are present (see various Serne et al. 2002 references, Lindenmeier et al. 2002, and Serne et al. 2004). At least $50 \%$ of the acid-extractable sulfur (S) as sulfate is water extractable. The sulfur in the sediments may be predominately present as slightly soluble gypsum and the phosphorous may be present predominantly as rather insoluble apatite-like minerals. The comparisons of water- to acid-soluble sulfur and phosphorous are shown in Figure 4.9.

\subsubsection{Bulk Chemical Composition of Sediment from 299-W11-39}

Five core samples were selected from this borehole and sent to a commercial analytical lab for bulk chemical composition analyses using fusion, followed by dissolution of the fused beads and analysis by 
ICP and ICP-MS. The carbon content of the samples was determined with a carbon analyzer (see Section 4.1.6). The total chemical composition of the samples is shown in Table 4.11 and total trace element compositions are shown in Table 4.12.

As found for most Hanford Site sediments, the bulk chemistry is dominated by silicon and aluminum oxides, with iron and calcium being next in abundance. There is also several percent of sodium, potassium, and magnesium present in all the sediments. Trace metals are often used to differentiate different lithologic units but the data in Table 4.12 include data for only the Hanford formation $\mathrm{H} 2$ unit and the upper Cold Creek unit and no significant trends are evident. For the background sediments at the TX Tank Farm, the minor trace metal data suggest that the fine-grained Cold Creek upper subunit is distinguishable from all other units by the presence of elevated lanthanide series elements. The other elements do not show striking differences in trace element concentrations with lithology (see Serne et al. 2004 for details).

\subsubsection{Radionuclide Content in Vadose Zone Sediment from 299-W11-39}

The sediment cores from borehole 299-W11-39 did not contain any man-made gamma radioactivity. The radioanalytical analyses performed on the sediment included direct gamma energy analysis and technetium-99 and uranium-238 analysis of the 1:1 sediment:water extracts and the sediment:acid extracts. The uranium and technetium water-extractable contents of the background sediments that were characterized are shown in Table 4.7 and the acid-extractable amounts are shown in Table 4.10. Both data sets suggest no elevated amounts are present. As mentioned in Serne et al. (2004) for the TX Tank Farm background sediments, sediments with high concentrations of calcium carbonate contain slightly higher concentrations of acid-leachable uranium, greater than one part per million (ppm) compared to 0.5

to $0.7 \mathrm{ppm}$ for non-calcareous sediment acid leachates. The gamma energy analysis data are not reported because there is nothing significant to report.

\subsubsection{Total Carbon, Calcium Carbonate, and Organic Carbon Content of Vadose Zone Sediment from Borehole 299-W11-39}

Table 4.13 shows the total carbon, inorganic carbon, and organic carbon contents of the vadose zone sediment at selected depths. The inorganic carbon was also converted to the equivalent calciumcarbonate content. The sediment in the shallow Hanford formation $\mathrm{H} 2$ unit is relatively low in calcium carbonate ( $<2 \mathrm{wt} \%)$ and organic carbon. At depth, the $\mathrm{H} 2$ unit shows slightly more calcium carbonate ( $\sim 4 \mathrm{wt} \%)$. The fine-grained $\mathrm{CCU}_{\mathrm{u}}$ sample contains $\sim 3.3 \mathrm{wt} \%$ calcium carbonate. These data for the identified stratigraphic units are quite similar to the data for the same units at the TX Tank Farm background borehole. No other strata were characterized at 299-W11-39.

At the background borehole near the TX Tank Farm, the coarser-grained $\mathrm{CCU}_{1}$ contains significant quantities ( $25 \mathrm{wt} \%$ ) of calcium carbonate and low organic carbon content. The $\mathrm{R}_{\mathrm{tf}}$ unit samples show highly variable calcium-carbonate contents as a function of depth. The coarse-grained $\mathrm{R}_{\mathrm{wi}}$ gravel has very little calcium carbonate and organic carbon. 
Table 4.8. Acid-Extractable Major Cations in Borehole 299-W11-39 Sediments ( $\mu \mathrm{g} / \mathrm{g}$ dry sediment)

\begin{tabular}{|c|c|c|c|c|c|c|c|}
\hline $\begin{array}{c}\text { Depth } \\
\text { (ft bgs) }\end{array}$ & $\begin{array}{c}\text { Stratigraphic } \\
\text { Unit }\end{array}$ & Ba & Ca & $\mathbf{K}$ & Mg & Sr & $\mathrm{Na}$ \\
\hline 49.5 & H2 & $6.77 \mathrm{E}+01$ & $9.13 E+03$ & $2.06 \mathrm{E}+03$ & $5.26 \mathrm{E}+03$ & 3.34E+01 & $\ldots \ldots$ \\
\hline 60.5 & H2 & $7.59 \mathrm{E}+01$ & $9.86 \mathrm{E}+03$ & $2.56 \mathrm{E}+03$ & $6.49 E+03$ & $4.11 \mathrm{E}+01$ & $-\ldots$ \\
\hline 78 & H2 & $9.53 \mathrm{E}+01$ & $1.63 \mathrm{E}+04$ & $3.58 \mathrm{E}+03$ & $8.11 E+03$ & $4.99 \mathrm{E}+01$ & - - - - \\
\hline 92 & $\mathrm{CCU}_{\mathrm{u}}$ & $1.04 \mathrm{E}+02$ & $1.48 \mathrm{E}+04$ & $2.93 E+03$ & $7.74 \mathrm{E}+03$ & $4.12 \mathrm{E}+01$ & $-\cdots$ \\
\hline 92(dup) & $\mathrm{CCU}_{\mathrm{u}}$ & $1.13 \mathrm{E}+02$ & $1.47 \mathrm{E}+04$ & $2.86 \mathrm{E}+03$ & $7.68 \mathrm{E}+03$ & $4.05 E+01$ & - . - - \\
\hline
\end{tabular}


Table 4.9. Acid-Extractable Content for Major Constituents in Borehole 299-W11-39 Sediments ( $\mu$ g/g dry sediment)

\begin{tabular}{||l|l|l|c|c|c|c|c|c||}
\hline \hline $\begin{array}{c}\text { Depth } \\
\text { (ft bgs) }\end{array}$ & \multicolumn{1}{|c|}{$\begin{array}{c}\text { Stratigraphic } \\
\text { Unit }\end{array}$} & \multicolumn{1}{|c|}{$\mathbf{A l}$} & $\mathbf{F e}$ & $\mathbf{M n}$ & $\mathbf{S i}$ & $\mathbf{P}$ & $\mathbf{S}$ & $\mathbf{Z n}$ \\
\hline 49.5 & $\mathrm{H} 2$ & $8.21 \mathrm{E}+03$ & $1.57 \mathrm{E}+04$ & $3.28 \mathrm{E}+02$ & $(1.11 \mathrm{E}+02)$ & $5.95 \mathrm{E}+02$ & $5.82 \mathrm{E}+01$ & $4.35 \mathrm{E}+01$ \\
\hline 60.5 & $\mathrm{H} 2$ & $1.20 \mathrm{E}+04$ & $1.87 \mathrm{E}+04$ & $3.74 \mathrm{E}+02$ & $(4.41 \mathrm{E}+01)$ & $7.40 \mathrm{E}+02$ & $(5.53 \mathrm{E}+01)$ & $5.41 \mathrm{E}+01$ \\
\hline 78 & $\mathrm{H} 2$ & $1.73 \mathrm{E}+04$ & $2.30 \mathrm{E}+04$ & $5.32 \mathrm{E}+02$ & $(8.60 \mathrm{E}+00)$ & $6.05 \mathrm{E}+02$ & $(5.80 \mathrm{E}+01)$ & $6.95 \mathrm{E}+01$ \\
\hline 92 & $\mathrm{CCU}_{\mathrm{u}}$ & $1.40 \mathrm{E}+04$ & $1.95 \mathrm{E}+04$ & $4.62 \mathrm{E}+02$ & $(8.61 \mathrm{E}+00)$ & $6.58 \mathrm{E}+02$ & $(4.81 \mathrm{E}+01)$ & $5.94 \mathrm{E}+01$ \\
\hline $92(d u p)$ & $\mathrm{CCU}_{\mathrm{u}}$ & $1.30 \mathrm{E}+04$ & $1.90 \mathrm{E}+04$ & $4.59 \mathrm{E}+02$ & $(9.70 \mathrm{E}+00)$ & $6.56 \mathrm{E}+02$ & $(5.24 \mathrm{E}+01)$ & $5.85 \mathrm{E}+01$ \\
\hline
\end{tabular}

Table 4.10. Acid-Extractable Mobile Trace Metals in Borehole 299-W11-39 Sediments ( $\mu$ g per gram dry sediment)

\begin{tabular}{|c|c|c|c|c|c|c|}
\hline $\begin{array}{l}\text { Depth } \\
\text { (ft bgs) }\end{array}$ & $\begin{array}{c}\text { Stratigraphic } \\
\text { Unit }\end{array}$ & Tc-99 & U-238 & $\begin{array}{c}\mathrm{Cr} \\
\text { (ICP-MS) }\end{array}$ & $\begin{array}{c}\mathrm{Cr} \\
\text { (ICP) }\end{array}$ & $\begin{array}{c}\text { Mo } \\
\text { (ICP-MS) }\end{array}$ \\
\hline 49.5 & $\mathrm{H} 2$ & $<2.33 \mathrm{E}+02$ & $4.45 \mathrm{E}-01$ & $1.13 \mathrm{E}+01$ & $1.16 \mathrm{E}+01$ & $1.53 \mathrm{E}-01$ \\
\hline 60.5 & $\mathrm{H} 2$ & $<2.75 \mathrm{E}+02$ & $6.25 \mathrm{E}-01$ & $1.83 \mathrm{E}+01$ & $1.90 \mathrm{E}+01$ & $2.00 \mathrm{E}-01$ \\
\hline 78 & $\mathrm{H} 2$ & $<2.51 \mathrm{E}+02$ & 9.18E-01 & $1.73 \mathrm{E}+01$ & $1.78 \mathrm{E}+01$ & 2.82E-01 \\
\hline 92 & $\mathrm{CCU}_{\mathrm{u}}$ & $<2.46 \mathrm{E}+02$ & $6.45 \mathrm{E}-01$ & $1.54 \mathrm{E}+01$ & $1.65 \mathrm{E}+01$ & 2.15E-01 \\
\hline 92(dup) & $\mathrm{CCU}_{\mathrm{u}}$ & $<2.38 \mathrm{E}+02$ & $6.11 \mathrm{E}-01$ & $1.52 \mathrm{E}+01$ & $1.60 \mathrm{E}+01$ & $1.94 \mathrm{E}-01$ \\
\hline
\end{tabular}




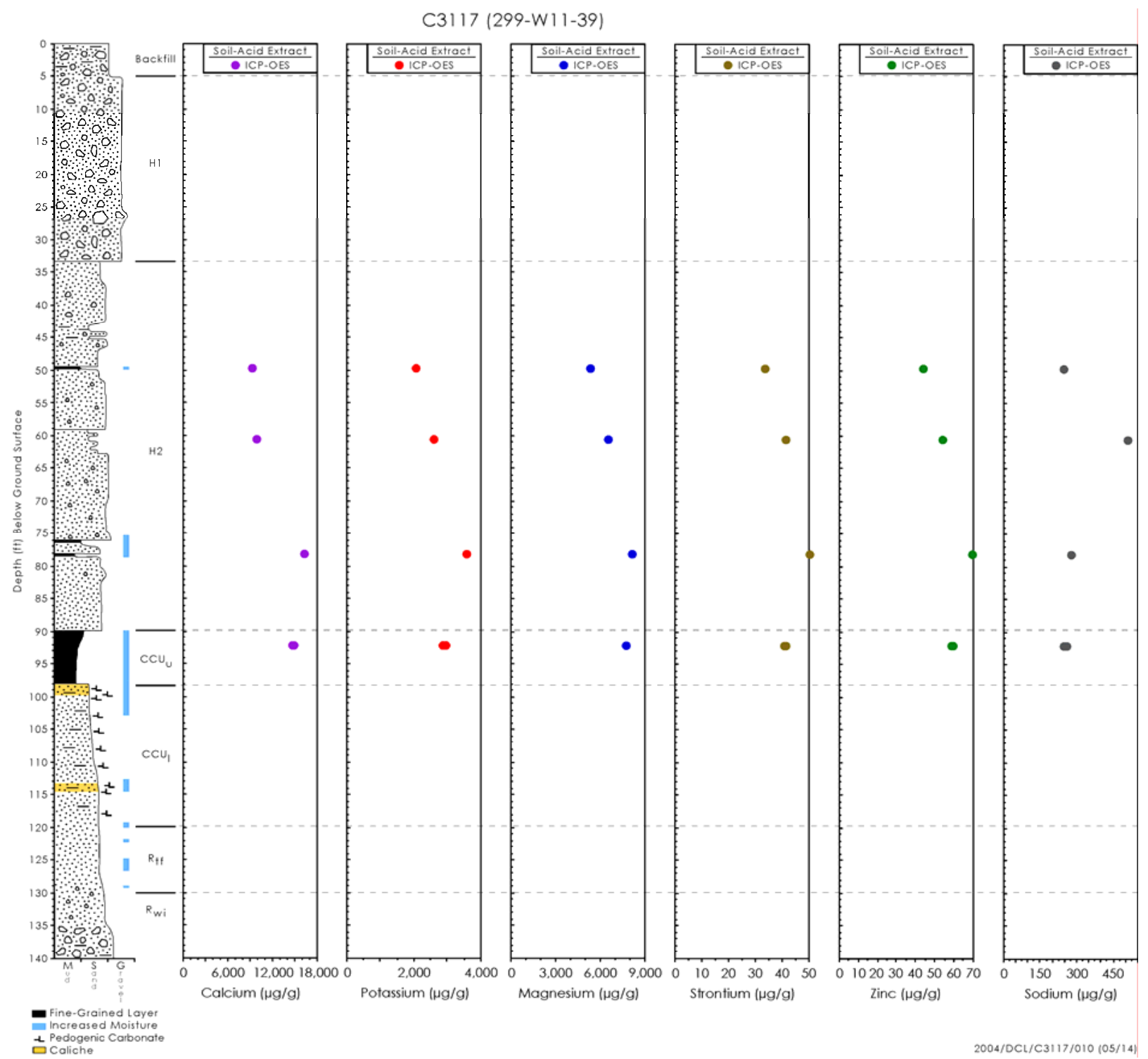

Figure 4.6. Acid-Extractable Concentrations of Major Cations in Borehole 299-W11-39 Sediment 
C3117 (299-W11-39)

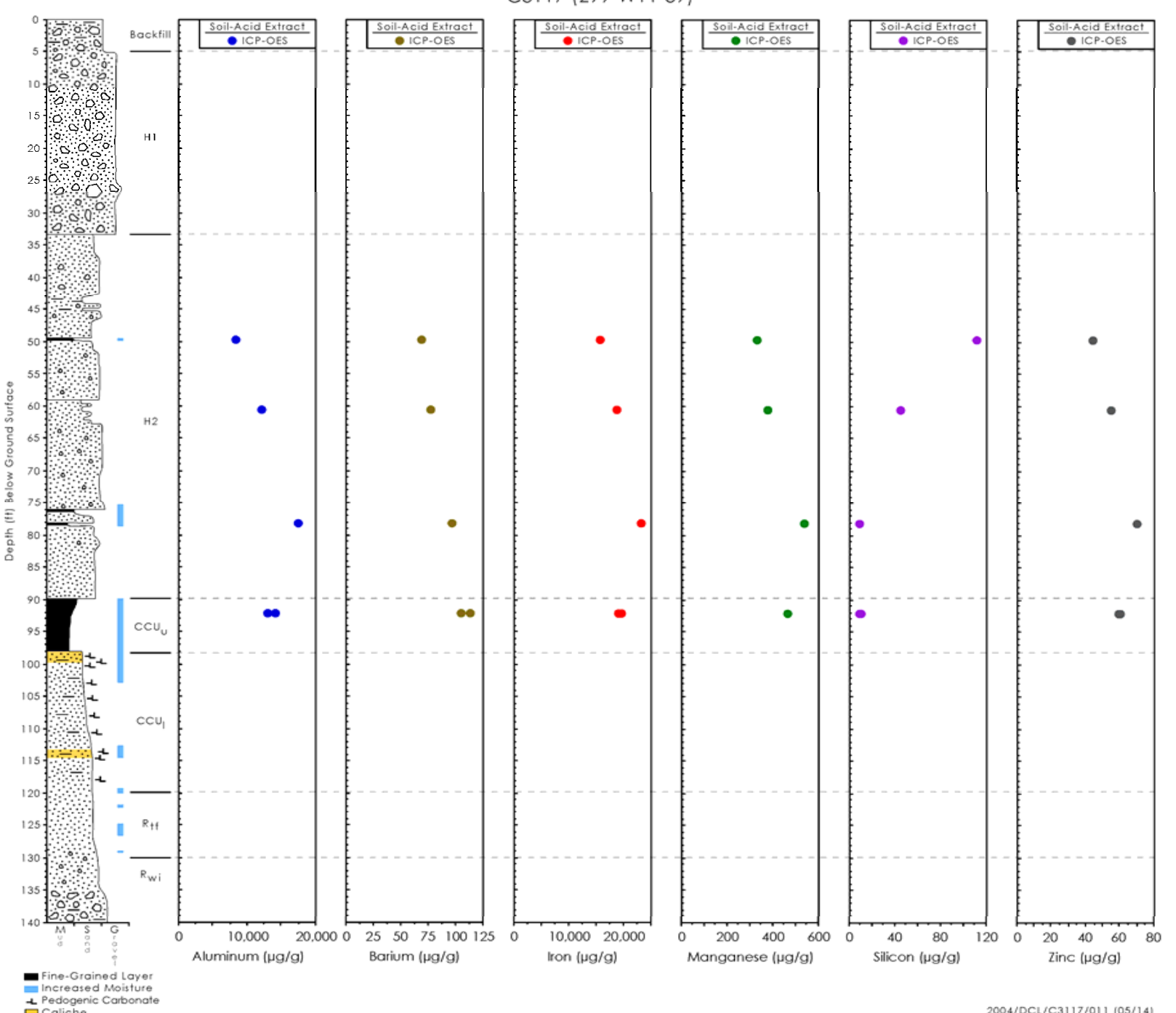

Figure 4.7. Acid-Extractable Concentrations of Aluminum, Barium, Iron, Manganese, Silicon and Zinc from Borehole 299-W11-39 Sediments 


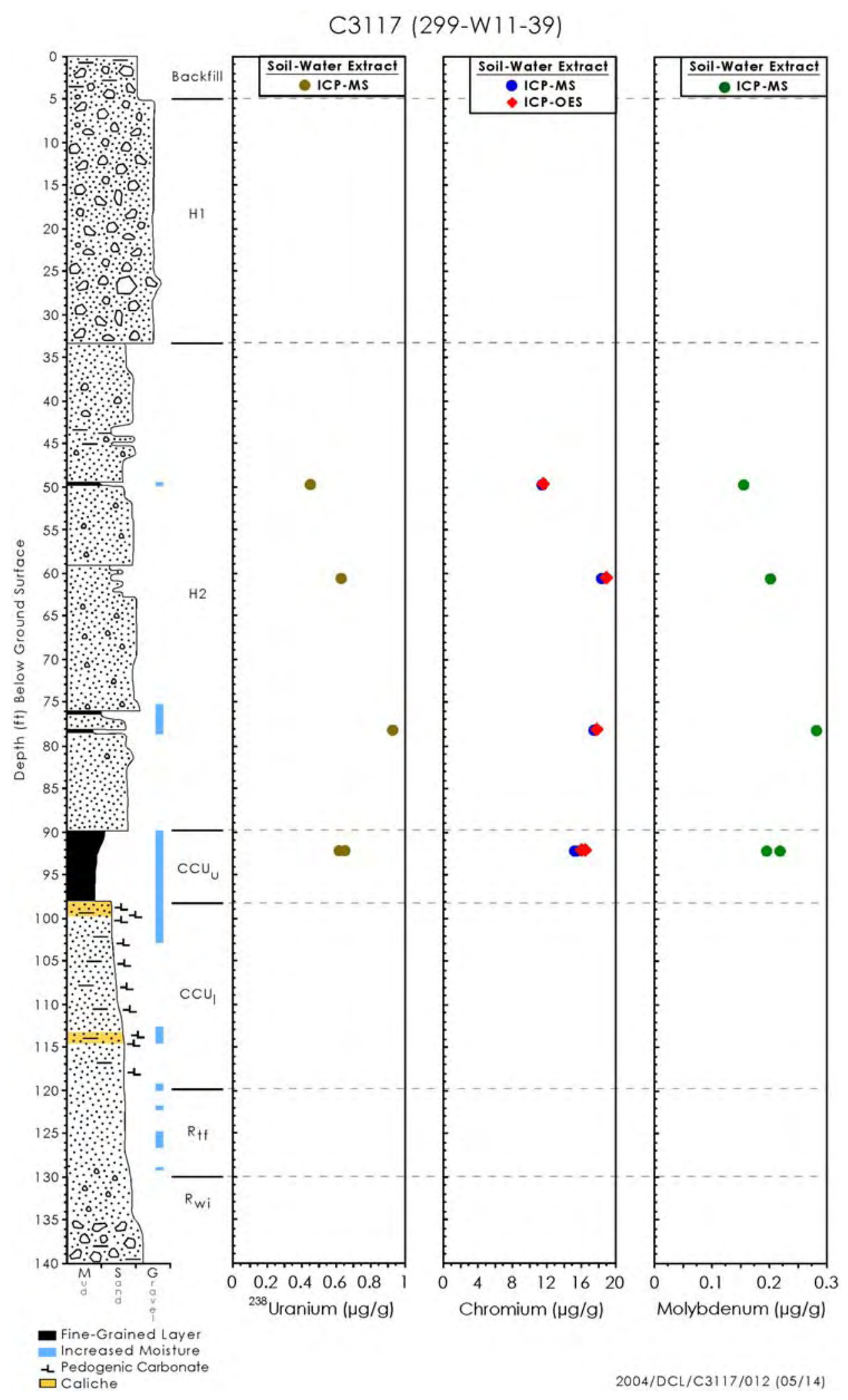

Figure 4.8. Concentration of Uranium-238, Chromium, and Molybdenum in 299-W11-39 Borehole Sediment that is Acid-Extractable. (Technetium-99 and Ruthenium were not detected in clean sediments; thus, they are not plotted). 
C3117 (299-W11-39)

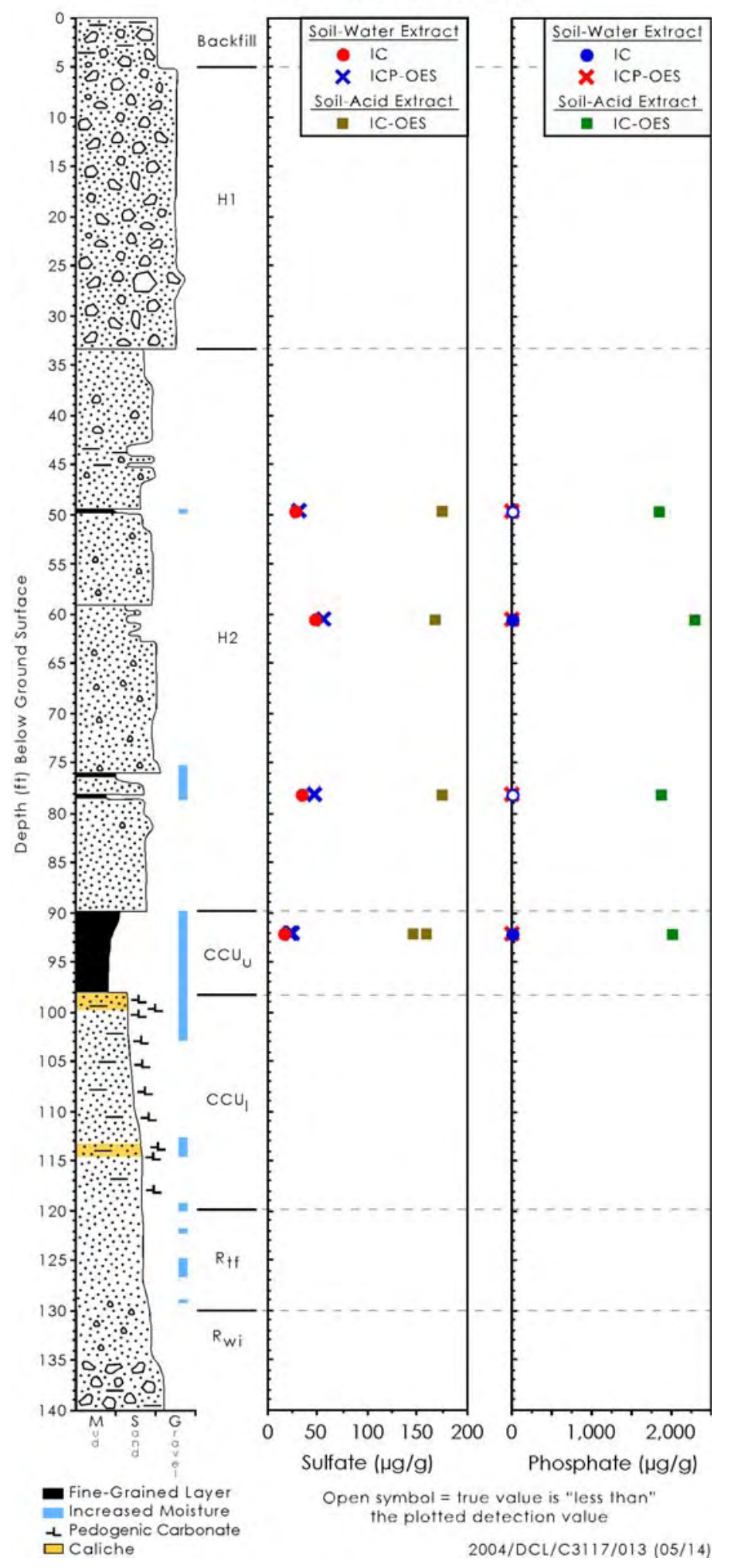

Figure 4.9. Comparison Between Acid-and Water-Extractable Sulfate and Phosphate in Vadose Zone Sediments from Borehole 299-W11-39 
Table 4.11. Total Chemical Composition of Borehole 299-W11-39 Sediments (as Weight \% Oxides)

\begin{tabular}{|c|c|c|c|c|c|}
\hline Depth (ft bgs) & 49.5 & 60.5 & 78 & 92 & 92 \\
\hline Unit & H2 & H2 & H2 & $\mathbf{C C U}_{\mathbf{u}}$ & $\mathbf{C C U}_{\mathbf{u}}$ \\
\hline $\mathrm{CO}_{2}$ & 0.81 & 0.66 & 1.76 & 1.43 & 1.50 \\
\hline $\mathrm{Na}_{2} \mathrm{O}$ & 2.57 & 2.64 & 1.53 & 1.86 & 1.86 \\
\hline $\mathrm{MgO}$ & 1.80 & 2.12 & 2.07 & 1.89 & 1.94 \\
\hline $\mathrm{Al}_{2} \mathrm{O}_{3}$ & 12.44 & 12.63 & 14.14 & 12.28 & 12.59 \\
\hline $\mathrm{SiO}_{2}$ & 66.29 & 64.31 & 61.62 & 64.62 & 64.47 \\
\hline $\mathrm{P}_{2} \mathrm{O}_{5}$ & 0.15 & 0.24 & 0.15 & 0.15 & 0.16 \\
\hline $\mathrm{SO}_{3}$ & NA & NA & NA & NA & NA \\
\hline $\mathrm{Cl}$ & NA & NA & NA & NA & NA \\
\hline $\mathrm{K}_{2} \mathrm{O}$ & 2.33 & 2.10 & 2.97 & 2.54 & 2.59 \\
\hline $\mathrm{CaO}$ & 3.56 & 4.06 & 3.09 & 3.19 & 3.14 \\
\hline $\mathrm{TiO}_{2}$ & 0.706 & 1.005 & 0.701 & 0.669 & 0.667 \\
\hline $\mathrm{V}_{2} \mathrm{O}_{5}$ & 0.019 & 0.025 & 0.016 & 0.014 & 0.014 \\
\hline $\mathrm{Cr}_{2} \mathrm{O}_{3}$ & 0.007 & 0.009 & 0.009 & 0.008 & 0.010 \\
\hline $\mathrm{MnO}$ & 0.092 & 0.109 & 0.097 & 0.100 & 0.103 \\
\hline $\mathrm{Fe}_{2} \mathrm{O}_{3}$ & 7.18 & 8.25 & 7.82 & 8.48 & 8.73 \\
\hline $\mathrm{CoO}$ & 0.002 & 0.002 & 0.002 & 0.002 & 0.002 \\
\hline $\mathrm{NiO}$ & 0.003 & 0.004 & 0.004 & 0.004 & 0.005 \\
\hline $\mathrm{CuO}$ & 0.008 & 0.005 & 0.005 & 0.005 & 0.005 \\
\hline $\mathrm{ZnO}$ & 0.007 & 0.010 & 0.010 & 0.007 & 0.009 \\
\hline $\mathrm{Rb}_{2} \mathrm{O}$ & 0.008 & 0.008 & 0.014 & 0.010 & 0.012 \\
\hline SrO & 0.042 & 0.042 & 0.023 & 0.028 & 0.028 \\
\hline $\mathrm{YO}_{2}$ & 0.003 & 0.004 & 0.005 & 0.004 & 0.005 \\
\hline $\mathrm{ZrO}_{2}$ & 0.020 & 0.030 & 0.030 & 0.037 & 0.037 \\
\hline
\end{tabular}


Table 4.11. (contd)

\begin{tabular}{||l|l|l|l|l|l||}
\hline \multicolumn{1}{|c|}{ Depth (ft bgs) } & \multicolumn{1}{|c|}{$\mathbf{4 9 . 5}$} & \multicolumn{1}{c|}{$\mathbf{6 0 . 5}$} & \multicolumn{1}{c|}{$\mathbf{7 8}$} & \multicolumn{1}{c|}{$\mathbf{9 2}$} & \multicolumn{1}{c|}{$\mathbf{9 2}$} \\
\hline Unit & $\mathbf{H 2}$ & $\mathbf{H 2}$ & $\mathbf{H 2}$ & $\mathbf{C C U}_{\mathbf{u}}$ & $\mathbf{C C U}_{\mathbf{u}}$ \\
\hline $\mathrm{BaO}$ & 0.086 & 0.080 & 0.077 & 0.076 & 0.077 \\
\hline $\mathrm{ThO}_{2}$ & $9.01 \mathrm{E}-04$ & $1.11 \mathrm{E}-03$ & $1.38 \mathrm{E}-03$ & $1.24 \mathrm{E}-03$ & $1.32 \mathrm{E}-03$ \\
\hline $\mathrm{UO}_{3}$ & $2.43 \mathrm{E}-04$ & $3.18 \mathrm{E}-04$ & $4.26 \mathrm{E}-04$ & $3.94 \mathrm{E}-04$ & $4.11 \mathrm{E}-04$ \\
\hline LOI & 2.12 & 1.89 & 4.90 & 3.22 & 3.14 \\
\hline Total (no LOI) & 98.13 & 98.34 & 96.14 & 97.41 & 97.96 \\
\hline Total (with LOI) & 99.44 & 99.58 & 99.28 & 99.20 & 99.59 \\
\hline $\begin{array}{l}\text { NA = Not analyzed. } \\
\text { LOI = Loss on Ignition. }\end{array}$ & & & & & \\
\hline
\end{tabular}

Table 4.12. Trace Element Composition of Borehole 299-W11-39 Sediments (as $\mu \mathrm{g}$ per gram dry sediment)

\begin{tabular}{|c|c|c|c|c|c|}
\hline $\begin{array}{c}\text { Depth } \\
\text { (ft bgs) }\end{array}$ & 49.5 & 60.5 & 78 & 92 & 92 \\
\hline Unit & H2 & H2 & H2 & $\mathbf{C C U}_{\mathbf{u}}$ & $\mathbf{C C U}_{\mathrm{u}}$ \\
\hline $\mathrm{Be}$ & 2 & 2 & 3 & 2 & 2 \\
\hline Sc & 12 & 15 & 13 & 11 & 11 \\
\hline $\mathrm{Ga}$ & 15 & 17 & 19 & 16 & 17 \\
\hline Ge & 1.2 & 1.4 & 1.8 & 1.4 & 1.9 \\
\hline As & 6 & 7 & 16 & 9 & 13 \\
\hline Se & $\mathrm{NA}^{(1)}$ & NA & NA & NA & NA \\
\hline $\mathrm{Nb}$ & 9.0 & 11.4 & 14.2 & 23.3 & 14.5 \\
\hline Mo & 3 & $<2$ & 2 & 2 & 3 \\
\hline Ag & $<0.1$ & $<0.1$ & $<0.1$ & $<0.1$ & $<0.1$ \\
\hline In & $<0.1$ & $<0.1$ & $<0.1$ & $<0.1$ & $<0.1$ \\
\hline Sn & 3 & 3 & 7 & 4 & 5 \\
\hline $\mathrm{Sb}$ & 0.7 & 0.7 & 1.5 & 1.4 & 1.9 \\
\hline Cs & 3.2 & 3.1 & 8.1 & 5.1 & 6.0 \\
\hline
\end{tabular}


Table 4.12. (contd)

\begin{tabular}{|c|c|c|c|c|c|}
\hline $\begin{array}{c}\text { Depth } \\
\text { (ft bgs) }\end{array}$ & 49.5 & 60.5 & 78 & 92 & 92 \\
\hline Unit & H2 & H2 & H2 & $\mathbf{C C U}_{\mathbf{u}}$ & $\mathbf{C C U}_{\mathrm{u}}$ \\
\hline $\mathrm{La}$ & 31.2 & 37.8 & 43.2 & 40.2 & 42.5 \\
\hline $\mathrm{Ce}$ & 61.2 & 69.3 & 82.9 & 77.0 & 80.8 \\
\hline $\mathrm{Pr}$ & 6.49 & 8.09 & 9.17 & 8.89 & 9.21 \\
\hline $\mathrm{Nd}$ & 24.5 & 32.0 & 36.5 & 35.5 & 37.0 \\
\hline Sm & 4.90 & 6.13 & 7.23 & 6.67 & 6.93 \\
\hline Eu & 1.25 & 1.43 & 1.47 & 1.36 & 1.43 \\
\hline Gd & 3.81 & 5.24 & 5.36 & 5.05 & 5.46 \\
\hline $\mathrm{Tb}$ & 0.65 & 0.89 & 1.02 & 0.95 & 1.01 \\
\hline Dy & 3.97 & 4.90 & 6.09 & 5.40 & 5.72 \\
\hline Ho & 0.78 & 0.96 & 1.16 & 1.04 & 1.10 \\
\hline Er & 2.19 & 2.87 & 3.49 & 3.27 & 3.47 \\
\hline Tm & 0.315 & 0.423 & 0.527 & 0.505 & 0.517 \\
\hline $\mathrm{Yb}$ & 2.17 & 2.77 & 3.55 & 3.18 & 3.36 \\
\hline $\mathrm{Lu}$ & 0.334 & 0.417 & 0.520 & 0.469 & 0.497 \\
\hline Hf & 3.8 & 5.9 & 5.9 & 7.4 & 7.4 \\
\hline Ta & 0.77 & 0.92 & 1.19 & 13.1 & 1.13 \\
\hline W & 2.0 & 2.9 & 2.7 & 2.2 & 2.3 \\
\hline $\mathrm{Tl}$ & 0.37 & 0.46 & 0.67 & 0.99 & 0.65 \\
\hline $\mathrm{Pb}$ & 10 & 27 & 19 & 9 & 18 \\
\hline $\mathrm{Bi}$ & 0.3 & 0.2 & 0.6 & 0.2 & 0.5 \\
\hline
\end{tabular}


Table 4.13. Total, Inorganic, and Organic Carbon Content of Vadose Zone Sediments from Borehole 299-W11-39

\begin{tabular}{|c|c|c|c|c|c|}
\hline $\begin{array}{c}\text { Depth } \\
\text { (ft) }\end{array}$ & $\begin{array}{c}\text { Stratigraphic } \\
\text { Unit }\end{array}$ & $\begin{array}{c}\text { Total } \\
\text { Carbon } \\
\% \\
\end{array}$ & $\begin{array}{c}\text { Inorganic } \\
\text { Carbon } \\
\% \\
\end{array}$ & $\begin{array}{c}\mathrm{IC} \\
\text { as } \mathrm{CaCO}_{3} \\
\% \\
\end{array}$ & $\begin{array}{c}\text { Organic } \\
\text { Carbon } \\
\text { (by difference) }\end{array}$ \\
\hline 49.5 & $\mathrm{H} 2$ & 0.25 & 0.22 & 1.83 & 0.03 \\
\hline 60.5 & H2 & 0.25 & 0.18 & 1.50 & 0.07 \\
\hline 78 & H2 & 0.52 & 0.48 & 4.00 & 0.04 \\
\hline 92 & $\mathrm{CCU}_{\mathrm{u}}$ & 0.47 & 0.39 & 3.25 & 0.08 \\
\hline 92(dup) & $\mathrm{CCU}_{\mathrm{u}}$ & 0.47 & 0.41 & 3.42 & 0.06 \\
\hline
\end{tabular}




\subsubsection{Particle Size Measurements on Vadose Zone Sediment}

Both the hydrometer and wet sieving methods were used to determine the particle size distributions of the selected samples from borehole 299-W11-39. Wet sieving results are shown in Table 4.14. The three samples of the Hanford formation $\mathrm{H} 2$ unit that were chosen for particle-size characterization represent zones with atypically high contents of fines. Samples for geochemical characterization were biased in favor of the fine-grained strata since these tend to contain more moisture and are more likely to have contaminants associated with them. Therefore, the values in Table 4.14 should not be used as representative of the bulk of the Hanford $\mathrm{H} 2$ unit. The $\mathrm{H} 2$ sample at $78 \mathrm{ft}$ bgs is the finest grained sediment of the three samples characterized. Based on the three $\mathrm{H} 2$ samples characterized, it appears that the fine-grained lens at this borehole get progressively more fine-grained with depth. The Cold Creek upper subunit is predominantly silt and has a particle size distribution very similar to the deepest Hanford formation $\mathrm{H} 2$ unit sample that was characterized, especially for the grains $<100$ microns. The Cold Creek upper sample has less larger-sized sand grains than the Hanford formation H2 unit.

In contrast, based on the data from the TX background borehole (see Serne et al. 2004 for details), the Cold Creek lower subunit (caliche) is very poorly sorted and has a wide range of particle sizes from gravel to silt and clay, as has been described previously for sediments below the SX tank farm (Serne et al. 2002a, 2002b, 2002c, 2002d). The hydrometer results and wet sieving results are combined in Figures 4.10 and Figure 4.11 as plots of "cumulative percent finer than" versus "particle size in microns”. The merged data for the two particle size methods are shown in Table 4.15.

At 299-W11-39 within the Hanford formation $\mathrm{H} 2$ unit the sediments at $~ 50, ~ 60$, and 76 to $78 \mathrm{ft}$ bgs are more fine-grained than the remainder of the 55 -ft thick unit. The median grain size of these $\mathrm{H} 2 \mathrm{unit}$ samples are $\sim 250, \sim 100$, and $\sim 25$ microns, respectively. The sample from the Cold Creek upper subunit has a fine texture with the median grain size, $~ 30$ microns.

Table 4.14. Wet Sieve Particle Size Results for Borehole 299-W11-39 Sediments

\begin{tabular}{||l|l|l|l|l||}
\hline \hline \multirow{2}{*}{$\begin{array}{c}\text { Depth } \\
\text { (ft bgs) }\end{array}$} & \multirow{2}{*}{$\begin{array}{c}\text { Stratigraphic } \\
\text { Unit }\end{array}$} & \multicolumn{3}{|c||}{ Weight Percent } \\
\cline { 3 - 5 } & & Gravel & Sand & Silt/Clay \\
\hline 49.5 & $\mathrm{H} 2$ & 6.80 & 78.19 & 15.01 \\
\hline 60.5 & $\mathrm{H} 2$ & 5.53 & 57.89 & 36.58 \\
\hline 78 & $\mathrm{H} 2$ & 2.40 & 12.56 & 85.03 \\
\hline 92 & $\mathrm{CCU}_{\mathrm{u}}$ & 0.03 & 10.70 & 89.27 \\
\hline
\end{tabular}


Table 4.15. Particle Size Data for Borehole 299-W11-39 Sediments Using Two Techniques Reported as Cumulative Percent Finer Than

\begin{tabular}{|c|c|c|c|c|c|c|c|}
\hline Stratigraphic Unit & H2 & & H2 & & H2 & & $\mathbf{C C U}_{\mathbf{u}}$ \\
\hline Sample depth (ft bgs) & 49.5 & & 60.5 & & 78 & & 92 \\
\hline \multicolumn{8}{|l|}{ Wet Sieve } \\
\hline$\mu \mathrm{m}$ & $\begin{array}{c}\% \\
\text { finer } \\
\text { than }\end{array}$ & $\mu \mathrm{m}$ & $\begin{array}{c}\% \\
\text { finer } \\
\text { than }\end{array}$ & $\mu \mathrm{m}$ & $\begin{array}{c}\% \\
\text { finer } \\
\text { than }\end{array}$ & $\mu \mathrm{m}$ & $\begin{array}{c}\% \\
\text { finer } \\
\text { than }\end{array}$ \\
\hline 2000 & 93.20 & 2000 & 94.47 & 2000 & 97.60 & 2000 & 99.97 \\
\hline 1000 & 81.64 & 1000 & 90.15 & 1000 & 95.39 & 1000 & 99.95 \\
\hline 500 & 66.46 & 500 & 79.94 & 500 & 92.99 & 500 & 99.92 \\
\hline 250 & 50.02 & 250 & 65.53 & 250 & 91.99 & 250 & 99.91 \\
\hline 105 & 23.21 & 105 & 52.24 & 105 & 89.86 & 105 & 99.32 \\
\hline 74 & 18.59 & 74 & 46.37 & 74 & 88.74 & 74 & 97.25 \\
\hline 53 & 15.01 & 53 & 36.58 & 53 & 85.03 & 53 & 89.26 \\
\hline \multicolumn{8}{|l|}{ Hydrometer } \\
\hline 83.23 & 17.20 & 85.98 & 39.02 & 92.17 & 81.73 & 95.57 & 80.40 \\
\hline 58.11 & 13.76 & 59.83 & 32.08 & 64.50 & 75.82 & 66.27 & 71.13 \\
\hline 33.26 & 10.32 & 33.69 & 21.68 & 36.32 & 62.03 & 36.78 & 53.34 \\
\hline 18.06 & 8.02 & 18.14 & 14.74 & 19.38 & 47.26 & 19.38 & 37.11 \\
\hline 10.38 & 6.88 & 10.38 & 10.40 & 10.92 & 35.45 & 10.92 & 27.83 \\
\hline 7.31 & 5.16 & 7.31 & 7.80 & 7.63 & 28.56 & 7.60 & 20.87 \\
\hline 5.97 & 4.59 & 5.94 & 6.07 & 6.19 & 25.60 & 6.18 & 19.33 \\
\hline 5.17 & 4.59 & 5.14 & 6.07 & 5.35 & 24.62 & 5.35 & 19.33 \\
\hline 1.48 & 3.44 & 1.48 & 6.07 & 1.50 & 12.80 & 1.50 & 9.28 \\
\hline
\end{tabular}

\subsubsection{Matric Suction Potential Measurements}

Water potential measurements have been included in the Hanford Tank Farm Vadose Zone Characterization Program to document the energy state of porewaters in the tank farm sediments. At the tank farms, vegetation is absent, surface soils are coarse-textured, and the potential for drainage (recharge) is high (Gee 1987; Gee et al. 1992). However, actual drainage rates are generally unknown. Attempts are currently being made to status the soil water matrix potential and use the analysis to confirm the occurrence of recharge within the Hanford Site tank farms. 
The status of soil water can be defined by either the amount of water in the soil (water content) or by the force that holds water to the soil matrix (i.e., the matric potential or suction) (Or and Wraith 2002). In recent studies, Serne et al. (2002b, 2002c, 2002e, and 2002f and Lindenmeier et al. 2002) measured both water content (gravimetrically) and matric water potential (filter paper method, ASTM 2002) on core samples obtained from boreholes in the SX and B-BX tank farm environs. The same measurements were made at borehole 299-W11-39 near to the T tank farm. All cores from the Hanford formation H2 unit that were obtained were analyzed. Unfortunately, at 299-W11-39, continuous coring was not performed all the way to the water table so that the entire profile of matric potential is not available.

Table 4.16 and Figure 4.12 show the matric potentials as a function of depth. Also plotted in Figure 4.12 is the gravity head expressed in pressure units (MPa). The gravity head is zero at the water table and increases linearly with height to the soil surface. For the core samples available from 299-W11-39, the water potentials are generally much less than the gravity potential from the shallowest core at $50 \mathrm{ft}$ bgs down to the deepest core taken at $90 \mathrm{ft}$ bgs, all within the Hanford formation $\mathrm{H} 2 \mathrm{unit}$. Two of the samples ( 24.5 and $32 \mathrm{ft}$ bgs) showed very high matric potentials that appear to be erroneous because of inadvertent drying of the samples or weighing errors. The green line, labeled "theoretical value” in Figure 4.12 is the theoretical line that represents the steady state unit gradient condition. This condition represents the profile for matric potential in a sediment profile that is neither draining nor drier than (actively evapotranspiring) a profile at equilibrium. Matric potential values to the left of the unit gradient line suggest a draining profile. The general trend for the data from 299-W11-39 is that the water potentials are consistent with a draining profile. 


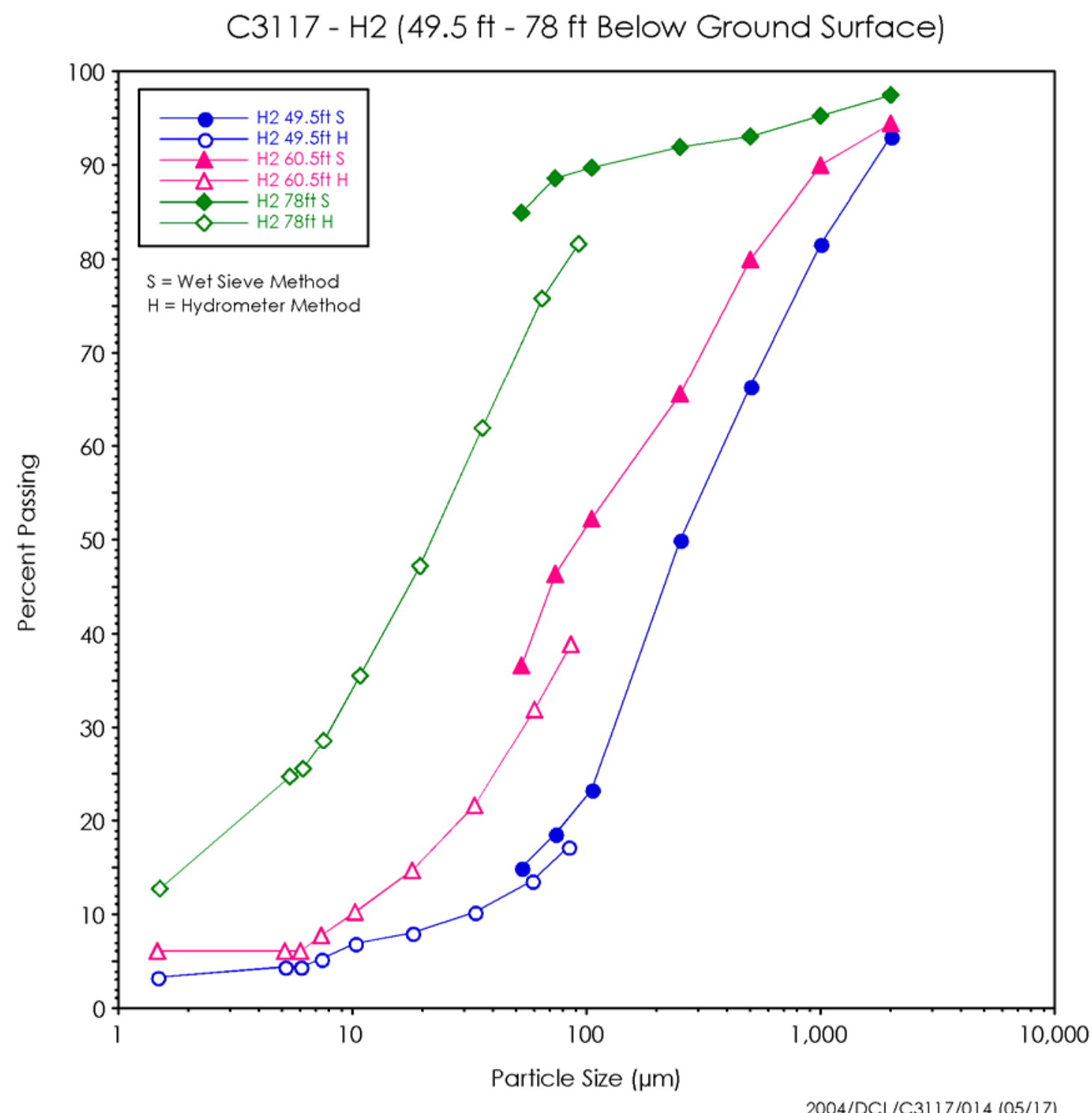

Figure 4.10. Particle Size Distribution of Hanford formation H2 Unit Subsamples from Borehole 299-W11-39 


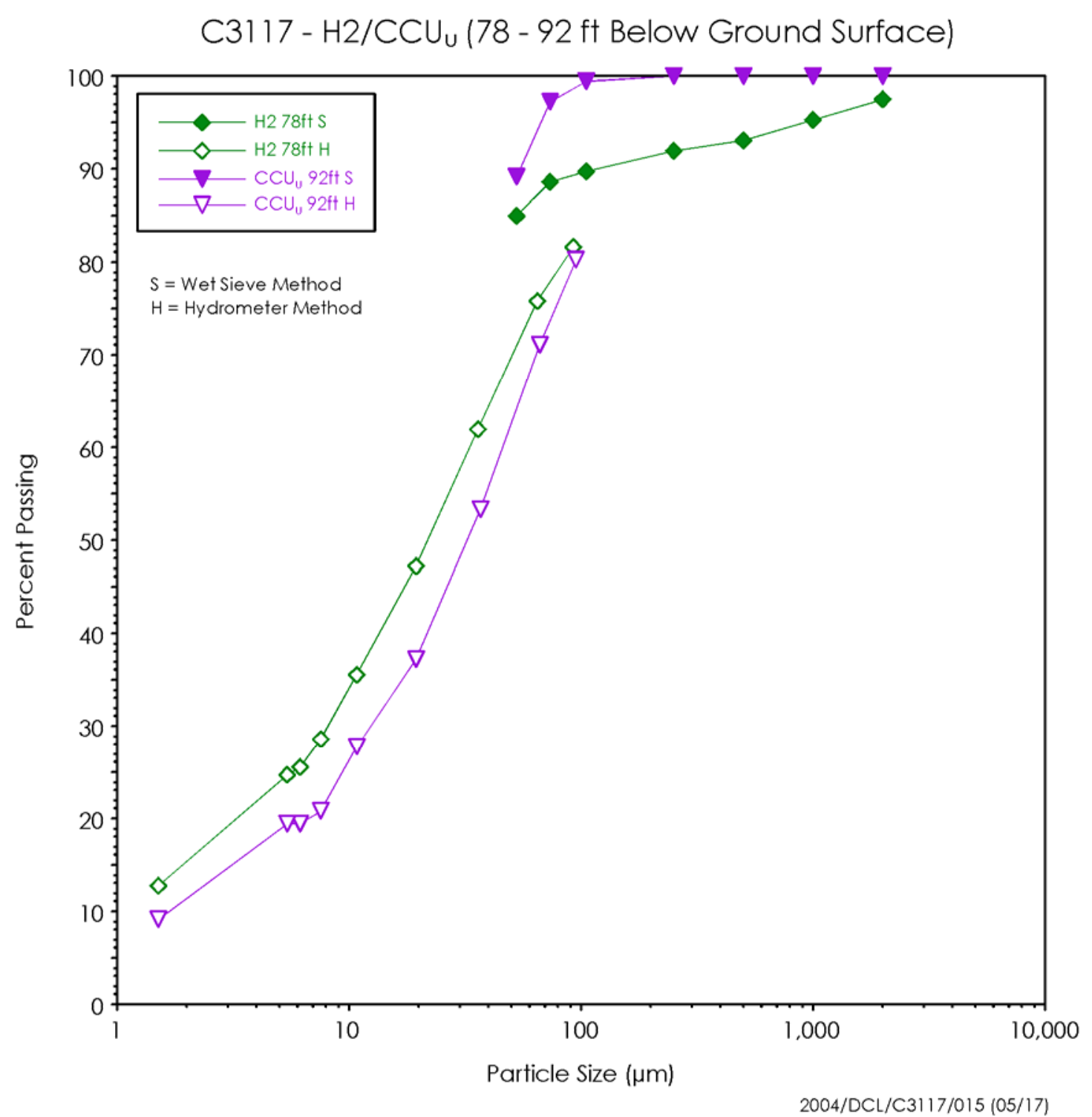

Figure 4.11. Particle Size Distribution of Deepest $\mathrm{H} 2$ and the Cold Creek Unit Subsample from Borehole 299-W11-39 
Table 4.16. Matric Potential as Measured by Filter Paper Method for Borehole 299-W11-39 Core Sediments

\begin{tabular}{|c|c|c|c|c|c|c|c|}
\hline $\begin{array}{l}\text { Depth } \\
\text { (ft bgs) }\end{array}$ & $\begin{array}{c}\text { Stratigraphic } \\
\text { Unit }\end{array}$ & $\begin{array}{c}\text { Matric } \\
\text { Potential } \\
\text { (MPa) }\end{array}$ & $\begin{array}{c}\text { Theoretical } \\
\text { Potential } \\
\text { (MPa) }\end{array}$ & $\begin{array}{l}\text { Depth } \\
\text { (ft bgs) }\end{array}$ & $\begin{array}{c}\text { Stratigraphic } \\
\text { Unit }\end{array}$ & $\begin{array}{c}\text { Matric } \\
\text { Potential } \\
\text { (MPa) }\end{array}$ & $\begin{array}{c}\text { Theoretical } \\
\text { Potential } \\
\text { (MPa) }\end{array}$ \\
\hline 21.5 & H1 & 0.5739 & 0.6660 & 61 & $\mathrm{H} 2$ & 0.5841 & 0.5426 \\
\hline 23.5 & H1 & 0.2323 & 0.6599 & 62 & $\mathrm{H} 2$ & 0.3275 & 0.5395 \\
\hline 24.5 & H1 & 24.7628 & 0.6569 & 63 & $\mathrm{H} 2$ & 0.2940 & 0.5350 \\
\hline 25.5 & H1 & 0.8605 & 0.6538 & 64.5 & $\mathrm{H} 2$ & 1.0402 & 0.5319 \\
\hline 28 & H1 & 0.4417 & 0.6462 & 65.5 & $\mathrm{H} 2$ & 0.6304 & 0.5243 \\
\hline 32 & H1 & 30.7442 & 0.6340 & 68 & $\mathrm{H} 2$ & 0.4973 & 0.5197 \\
\hline 33 & H1 & 0.4608 & 0.6310 & 69.5 & $\mathrm{H} 2$ & 0.5011 & 0.5167 \\
\hline 34.5 & H2 & 0.0458 & 0.6264 & 70.5 & $\mathrm{H} 2$ & 0.7290 & 0.5121 \\
\hline 35.5 & H2 & 0.1342 & 0.6233 & 72 & $\mathrm{H} 2$ & 0.5080 & 0.5090 \\
\hline 37 & H2 & 0.3983 & 0.6188 & 73 & $\mathrm{H} 2$ & 0.7863 & 0.5045 \\
\hline 38 & H2 & 0.3546 & 0.6157 & 74.5 & $\mathrm{H} 2$ & 1.3094 & 0.5014 \\
\hline 39.5 & $\mathrm{H} 2$ & 0.3484 & 0.6112 & 75.5 & $\mathrm{H} 2$ & 0.1255 & 0.4969 \\
\hline 40.5 & $\mathrm{H} 2$ & 0.2606 & 0.6081 & 77 & $\mathrm{H} 2$ & 0.1393 & 0.4938 \\
\hline 42 & H2 & 0.1271 & 0.6035 & 78 & $\mathrm{H} 2$ & 0.6234 & 0.4892 \\
\hline 43 & $\mathrm{H} 2$ & 0.0242 & 0.6005 & 79.5 & $\mathrm{H} 2$ & 0.3012 & 0.4862 \\
\hline 44.5 & $\mathrm{H} 2$ & 0.4290 & 0.5959 & 80.5 & $\mathrm{H} 2$ & 0.3286 & 0.4816 \\
\hline 45.5 & H2 & 0.2525 & 0.5929 & 82 & $\mathrm{H} 2$ & 0.2675 & 0.4786 \\
\hline 47 & $\mathrm{H} 2$ & 0.8913 & 0.5883 & 83 & $\mathrm{H} 2$ & 0.0984 & 0.4740 \\
\hline
\end{tabular}


Table 4.16. (contd)

\begin{tabular}{|c|c|c|c|c|c|c|c|}
\hline $\begin{array}{c}\text { Depth } \\
\text { (ft bgs) }\end{array}$ & $\begin{array}{c}\text { Stratigraphic } \\
\text { Unit }\end{array}$ & $\begin{array}{c}\text { Matric Potential } \\
(\mathrm{MPa})\end{array}$ & $\begin{array}{c}\text { Theoretical Potential } \\
\text { (MPa) }\end{array}$ & $\begin{array}{l}\text { Depth } \\
\text { (ft bgs) }\end{array}$ & $\begin{array}{c}\text { Stratigraphic } \\
\text { Unit }\end{array}$ & $\begin{array}{l}\text { Matric Potential } \\
\text { (MPa) }\end{array}$ & $\begin{array}{c}\text { Theoretical } \\
\text { Potential } \\
\text { (MPa) }\end{array}$ \\
\hline 48 & $\mathrm{H} 2$ & 0.6162 & 0.5852 & 84.5 & $\mathrm{H} 2$ & 0.1043 & 0.4709 \\
\hline 49.5 & $\mathrm{H} 2$ & 0.0181 & 0.5807 & 85.5 & $\mathrm{H} 2$ & 0.1943 & 0.4664 \\
\hline 50.5 & $\mathrm{H} 2$ & 0.1240 & 0.5776 & 87 & $\mathrm{H} 2$ & 0.0421 & 0.4633 \\
\hline 52 & $\mathrm{H} 2$ & 1.1808 & 0.5731 & 88 & $\mathrm{CCU}_{\mathrm{u}}$ & 0.2636 & 0.4588 \\
\hline 53 & $\mathrm{H} 2$ & 0.3958 & 0.5700 & 89.5 & $\mathrm{CCU}_{\mathrm{u}}$ & 0.4610 & 0.4557 \\
\hline 54.5 & $\mathrm{H} 2$ & 0.3205 & 0.5654 & 90.5 & $\mathrm{CCU}_{\mathrm{u}}$ & 0.0904 & 0.4511 \\
\hline 55.5 & $\mathrm{H} 2$ & 0.9970 & 0.5624 & 92 & $\mathrm{CCU}_{1}$ & no samples & no samples \\
\hline 58 & $\mathrm{H} 2$ & 0.5460 & 0.5548 & & $\mathrm{R}_{\mathrm{tf}}$ & no samples & no samples \\
\hline 59.5 & $\mathrm{H} 2$ & 0.9148 & 0.5502 & & $\mathrm{R}_{\mathrm{wi}}$ & no samples & no samples \\
\hline 60.5 & $\mathrm{H} 2$ & 0.1540 & 0.5471 & 240.01 & water table & 0 & 0 \\
\hline
\end{tabular}




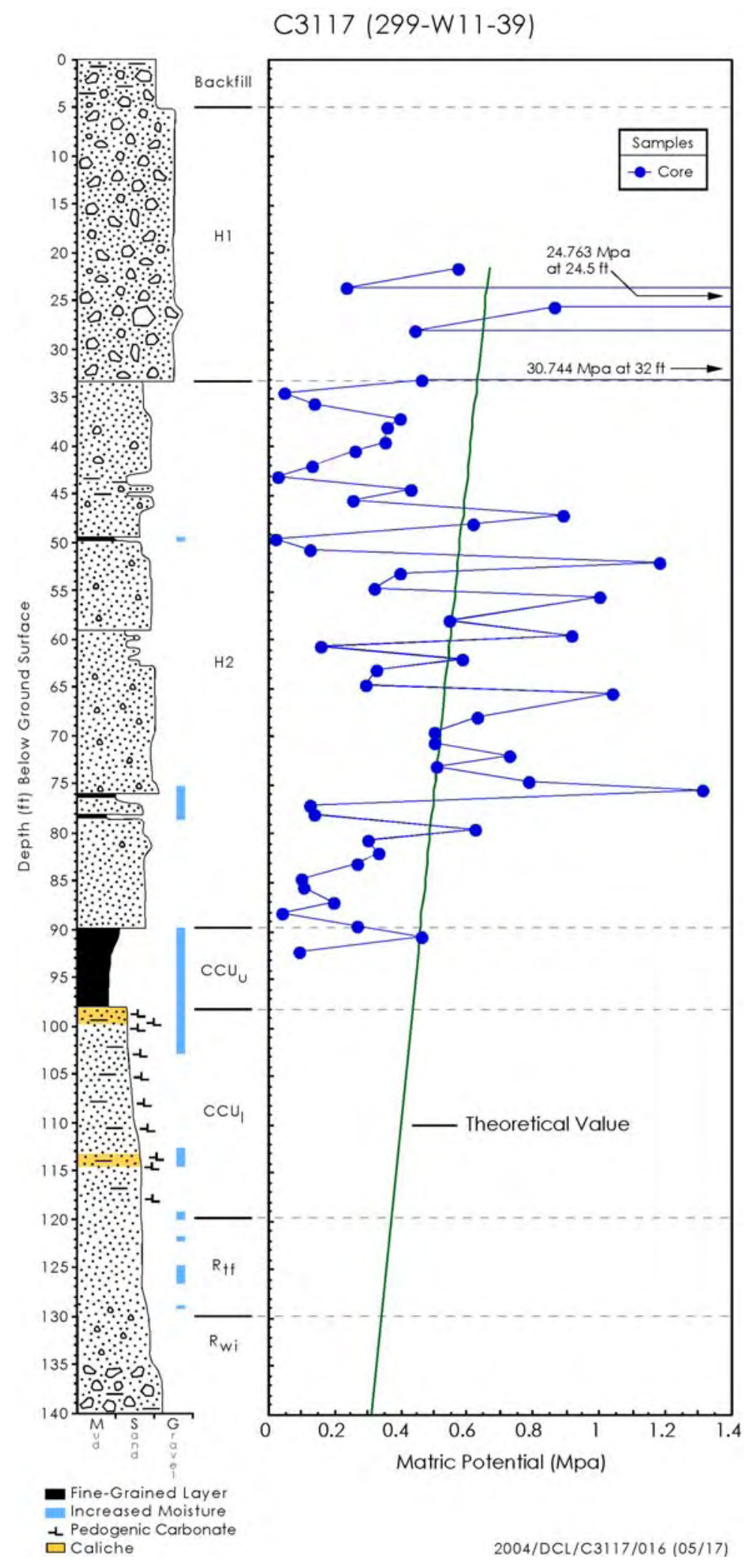

Figure 4.12. Matric Water Potential Measured by Filter Paper Technique on Core Samples from Borehole 299-W11-39 


\subsection{Vadose Zone Sediment from Borehole C4104}

Borehole C4104 was pushed into the vadose zone sediment approximately $19 \mathrm{ft}$ southeast of the edge of tank T-106 and $13 \mathrm{ft}$ to the south of 299-W10-196 borehole (drilled in 1993) (see Figure 4.29 in Section 4.3). Borehole C4104 was drilled to evaluate whether movement of contaminants deeper into the vadose zone profile occurred since 1993 and to add data for the horizontal extent of migration of contaminants from the 1973 leak from T-106. The C4104 borehole reached a depth of $127.46 \mathrm{ft}$ bgs at which point it met refusal. In 1993, using a different drilling technique, borehole 299-W10-196 reached a depth of $\sim 180 \mathrm{ft}$ bgs.

\subsubsection{Moisture Content}

The moisture content of the 44 core liners as a function of depth and lithology are shown in Table 4.17 and Figure 2.12. The backfill samples have a mean moisture content of $8.7 \%$ by weight with a wetter zone at the bottom of the backfill, perhaps caused by a low permeability compacted zone. The Hanford formation $\mathrm{H} 2$ samples have a mean moisture content of $6.3 \%$ by weight with little variation, because the discrete sampling missed sampling finer-grained samples that have slightly higher moisture contents. The Cold Creek subunits have higher moisture with averages for the two subunits of $14.2 \%$ and $12.3 \%$ by weight. Both show some variability with wetter samples in the middle of the units caused by the presence of higher percentages of mud. The average moisture contents of Ringold Formation sediments at C4104 are 17.6 and $6.9 \%$ by weight for the $\mathrm{R}_{\mathrm{tf}}$ and $\mathrm{R}_{\mathrm{wi}}$ subunits, respectively.

The average moisture content of the 299-W11-39 background borehole Hanford formation $\mathrm{H} 2$ subunit is $4.3 \%$ after deleting three samples from thin fine-grained lenses. The C4104 H2 subunit sediment moisture content is about $2 \%$ by weight larger than the average for the same stratigraphic unit in the background borehole. Whether this is significant and an indication of the various tank farm operations that encourage higher moisture infiltration cannot be determined because of the small sample population obtained. The high moisture contents in the two Cold Creek subunits and the Ringold Taylor Flats unit in C4104 sediments indicate the presence of finer grained and potentially lower permeability sediments below the Hanford formation H2 unit sands.

\subsubsection{1:1 Sediment:Water Extracts and Porewater Samples for Borehole C4104}

All the A liners (the deeper of the two liners) and selected B liners (the shallower of the two liners) from the 23 cores were characterized by performing 1:1 sediment:water extracts. Further, sediments from five of the A liners were packed into special cells with drains, placed in an ultracentrifuge, and spun for $\sim 18$ hours to separate native porewater from the sediments. The first suite of tables presents the mass of a given constituent leached per gram of sediment as measured in the water extracts to allow direct comparison to the same data for the background sediments from boreholes 299-W11-39 and 299-W10-27. Other tables and figures show dilution-corrected values that represent concentrations in vadose zone porewater. In the latter figures the actual porewater concentrations are also plotted to allow comparison between the derived porewaters and actual porewaters. As discussed in several other Vadose Zone Characterization Project reports, the dilution-corrected 1:1 sediment:water extracts are a reasonable estimate of the actual vadose zone porewater, especially when highly saline tank fluids are present (see Serne et al. 2002b, 2002c, 2002e, 2002f). 
Table 4.17. Moisture Content for Borehole C4104 Core Sediments

\begin{tabular}{|c|c|c|c|c|}
\hline Sample No. & $\begin{array}{c}\text { Depth } \\
\text { (ft bgs) }\end{array}$ & $\begin{array}{c}\text { Stratigraphic } \\
\text { Unit }\end{array}$ & Lithology & $\begin{array}{c}\text { Moisture } \\
\text { Content } \\
\% \mathrm{Wt} \\
\end{array}$ \\
\hline S03072-1B & 15.38 & Bkfl & \multirow{2}{*}{ Gravelly sand } & $7.16 \%$ \\
\hline S03072-1A & 16.18 & Bkfl & & $6.72 \%$ \\
\hline S03072-2B & 22.02 & Bkfl & \multirow{2}{*}{ Silty sandy gravel } & $7.28 \%$ \\
\hline S03072-2A & 22.69 & Bkfl & & $6.55 \%$ \\
\hline S03072-3B & 30.07 & Bkfl & \multirow{2}{*}{ Silty gravelly sand } & $7.25 \%$ \\
\hline S03072-3A & 30.74 & Bkfl & & $9.50 \%$ \\
\hline S03072-4B & 36.23 & Bkfl & \multirow{2}{*}{ Silty gravelly sand } & no sample \\
\hline S03072-4A & 36.88 & Bkfl & & $10.50 \%$ \\
\hline 4 (NOSE CONE) & 37.40 & Bkfl & Slightly gravelly sand & $16.68 \%$ \\
\hline S03072-5B & 39.34 & Bkfl & \multirow{2}{*}{ Gravelly sand } & no sample \\
\hline S03072-5A & 40.01 & Bkfl & & $6.42 \%$ \\
\hline S03072-6B & 46.33 & $\mathrm{H} 2$ & \multirow{2}{*}{ Sand } & $4.00 \%$ \\
\hline S03072-6A & 46.98 & $\mathrm{H} 2$ & & $3.30 \%$ \\
\hline S03072-7B & 58.39 & $\mathrm{H} 2$ & \multirow{3}{*}{ Silty sand to sand } & $7.00 \%$ \\
\hline S03072-7B Dup & 58.39 & $\mathrm{H} 2$ & & $8.33 \%$ \\
\hline S03072-7A & 59.09 & $\mathrm{H} 2$ & & $4.50 \%$ \\
\hline S03072-8B & 63.38 & $\mathrm{H} 2$ & \multirow{4}{*}{ Sand to silty sand } & $7.29 \%$ \\
\hline S03072-8B Dup & 63.38 & $\mathrm{H} 2$ & & $8.44 \%$ \\
\hline S03072-8A & 64.03 & $\mathrm{H} 2$ & & $4.99 \%$ \\
\hline S03072-8A Dup & 64.03 & $\mathrm{H} 2$ & & $5.53 \%$ \\
\hline S03072-9B & 75.38 & H2 & \multirow{2}{*}{ Sand to silty sand } & $7.78 \%$ \\
\hline S03072-9A & 76.03 & $\mathrm{H} 2$ & & $5.10 \%$ \\
\hline S03072-10B & 80.38 & H2 & \multirow{2}{*}{ Sand to silty sand } & $9.34 \%$ \\
\hline S03072-10A & 81.04 & $\mathrm{CCU}_{\mathrm{u}}$ & & $13.03 \%$ \\
\hline S03072-11B & 86.65 & $\mathrm{CCU}_{\mathrm{u}}$ & \multirow{4}{*}{ Silt to silty sand } & $14.08 \%$ \\
\hline S03072-11B Dup & 86.65 & $\mathrm{CCU}_{\mathrm{u}}$ & & $15.09 \%$ \\
\hline S03072-11A & 87.35 & $\mathrm{CCU}_{\mathrm{u}}$ & & $17.97 \%$ \\
\hline S03072-11A Dup & 87.35 & $\mathrm{CCU}_{\mathrm{u}}$ & & $19.50 \%$ \\
\hline
\end{tabular}


Table 4.17. (contd)

\begin{tabular}{|c|c|c|c|c|}
\hline Sample No. & $\begin{array}{c}\text { Depth } \\
\text { (ft bgs) }\end{array}$ & Stratigraphic Unit & Lithology & $\begin{array}{c}\text { Moisture Content } \\
\% \mathrm{Wt} \\
\end{array}$ \\
\hline S03072-12B & 91.96 & $\mathrm{CCU}_{\mathrm{u}}$ & \multirow{2}{*}{$\begin{array}{l}\text { Silty sand to gravelly muddy } \\
\text { sand }\end{array}$} & $10.52 \%$ \\
\hline S03072-12A & 92.61 & $\mathrm{CCU}_{1}$ & & $11.90 \%$ \\
\hline S03072-13B & 92.91 & $\mathrm{CCU}_{1}$ & \multirow{2}{*}{ Slightly gravelly muddy sand } & $11.74 \%$ \\
\hline S03072-13A & 93.56 & $\mathrm{CCU}_{1}$ & & $17.21 \%$ \\
\hline S03072-14B & 94.11 & $\mathrm{CCU}_{\mathrm{l}}$ & \multirow{2}{*}{$\begin{array}{l}\text { Gravelly muddy sand to silty } \\
\text { sand }\end{array}$} & $14.75 \%$ \\
\hline S03072-14A & 94.67 & $\mathrm{CCU}_{\mathrm{l}}$ & & $14.19 \%$ \\
\hline S03072-15B & 99.70 & $\mathrm{CCU}_{1}$ & \multirow{2}{*}{ Slightly silty sand to sand } & $8.77 \%$ \\
\hline S03072-15A & 100.37 & $\mathrm{CCU}_{\mathrm{l}}$ & & $8.40 \%$ \\
\hline S03072-16B & 101.33 & $\mathrm{CCU}_{\mathrm{l}}$ & \multirow{2}{*}{ Sandy mud } & $11.53 \%$ \\
\hline S03072-16A & 101.98 & $\mathrm{CCU}_{\mathrm{l}}$ & & $20.64 \%$ \\
\hline S03072-17B & 105.39 & $\mathrm{CCU}_{1}$ & \multirow{2}{*}{ Slightly gravelly sand } & $10.03 \%$ \\
\hline S03072-17A & 106.09 & $\mathrm{CCU}_{1}$ & & $9.54 \%$ \\
\hline S03072-18B & 106.77 & $\mathrm{CCU}_{\mathrm{l}}$ & \multirow{2}{*}{ Sandy silt to sand } & $14.93 \%$ \\
\hline S03072-18A & 107.42 & $\mathrm{CCU}_{1}$ & & $4.99 \%$ \\
\hline S03072-19B & 110.33 & $\mathrm{R}_{\mathrm{tf}}$ & \multirow{4}{*}{ Sandy silt } & $17.31 \%$ \\
\hline S03072-19B Dup & 110.33 & $\mathrm{R}_{\mathrm{tf}}$ & & $17.90 \%$ \\
\hline S03072-19A & 110.98 & $\mathrm{R}_{\mathrm{tf}}$ & & $16.14 \%$ \\
\hline S03072-19A Dup & 110.98 & $\mathrm{R}_{\mathrm{tf}}$ & & $10.74 \%$ \\
\hline S03072-20B & 115.25 & $\mathrm{R}_{\mathrm{tf}}$ & \multirow{2}{*}{ Sandy silt to silty sand } & $19.93 \%$ \\
\hline S03072-20A & 116.02 & $\mathrm{R}_{\mathrm{tf}}$ & & $24.53 \%$ \\
\hline S03072-21B & 120.30 & $\mathrm{R}_{\mathrm{tf}}$ & \multirow{2}{*}{ Silty sand to sand to sandy gravel } & $16.39 \%$ \\
\hline S03072-21A & 120.97 & $\mathrm{R}_{\mathrm{wi}}$ & & $16.78 \%$ \\
\hline S03072-22B & 123.32 & $\mathrm{R}_{\mathrm{wi}}$ & \multirow{2}{*}{ Sandy gravel } & $3.22 \%$ \\
\hline S03072-22A & 124.05 & $\mathrm{R}_{\mathrm{wi}}$ & & $4.64 \%$ \\
\hline S03072-23B & 126.46 & $\mathrm{R}_{\mathrm{wi}}$ & \multirow{2}{*}{ Sandy gravel } & $4.66 \%$ \\
\hline S03072-23A & 127.13 & $\mathrm{R}_{\mathrm{wi}}$ & & $5.26 \%$ \\
\hline
\end{tabular}




\subsubsection{1 $\quad \mathrm{pH}$ and Electrical Conductivity}

The 1:1 sediment:water extract and actual porewater $\mathrm{pH}$ and EC data for borehole C4104 are shown in Table 4.18. Both the measured value and dilution-corrected EC values are shown. Figure 4.13 shows the 1:1 sediment:water extract $\mathrm{pH}$ value and dilution-corrected EC as a function of depth and stratigraphy. A comparison of the data in Table 4.18 with the $\mathrm{pH}$ and EC of the two background boreholes, 299-W11-39 (suspected to contain some Hanford process waste fluids) and 299-W10-27 (near the north east corner of the TX Tank Farm), shows obvious signs of caustic fluid interaction with the C4104 sediments between the depths of 47 to $92.6 \mathrm{ft}$ bgs. As found at boreholes in the SX Tank Farm sediment water extract, $\mathrm{pH}$ values range from 8.6 to almost 10 where caustic fluids have percolated through the vadose zone. The borehole C4104 EC values for the 1:1 water extracts, dilution-corrected (calculated) porewaters and actual porewaters show elevated values from 47 to the bottom of the borehole near $127 \mathrm{ft}$ bgs. At $46 \mathrm{ft}$ bgs EC of the extracts and porewaters are 6 times higher than background values and differences reach values of $\sim 40$ times larger than background at $116 \mathrm{ft}$ bgs. The dilution-corrected (calculated) C4104 sediment porewaters are also quite elevated between 59 and $76 \mathrm{ft}$ bgs. These data show that tank liquors from T-106 are present in the sediments from C4104. The highest values of dilution-corrected porewater EC found at C4104 (33.4 mS/cm at $116 \mathrm{ft}$ bgs) are equivalent to a pore solution of $0.21 \mathrm{M} \mathrm{KCl}$, the salt solution used to calibrate the conductivity probe. The leaks near the SX108-109 and BX-102 tanks had peak vadose zone porewater concentrations that were equivalent to much more concentrated waste fluids, 7 to 17 and 0.7 to $1 \mathrm{M} \mathrm{KCl}$ solutions, respectively. The maximum dilution-corrected EC value found at the TX Tank Farm occurred in borehole C3831 [43.3 mS/cm], higher than the dilution-corrected EC at C4104 (for details see Serne et al. 2004).

The water extract values for the major cations and anions and several trace constituents are discussed in this section. The anion data are tabulated in Tables 4.19 and 4.20 and Figure 4.14 in units of mass per gram of dry sediment. The data for the water extracts of borehole C4104 for all the anions but bromide differ significantly at some depth in the profile from the same data as for the uncontaminated sediments from borehole 299-W10-27 (near the TX Tank Farm) or 299-W11-27 (near T Tank Farm; but are suspect with signs of Hanford fluids).

There are obvious signs of elevated fluoride, chloride, nitrate, alkalinity, sulfate, phosphate and nitrite in the water extracts of C4104 sediments. The water-extractable fluoride is high in most of the sediment profile and has the highest values between 58 and $81 \mathrm{ft} \mathrm{bgs} \mathrm{where} \mathrm{there} \mathrm{is} \mathrm{a} \mathrm{zone} \mathrm{with} 10$ to 20 times as much fluoride as in background sediments. The water-extractable chloride in C4104 is also elevated in most of the sediment profile by 5 to 10 times and shows the most concentrated zone is between the depths of 115 to $121 \mathrm{ft}$ bgs where concentrations are 20 to 40 times background values. The water-extractable nitrate values are elevated from $64 \mathrm{ft}$ bgs to the bottom of the borehole. Starting at $64 \mathrm{ft}$ bgs, the waterextractable nitrate is 10 times larger than background; at $87 \mathrm{ft}$ bgs, the nitrate values exceed 100 times background and at $111 \mathrm{ft}$ bgs, the water-extractable nitrate is greater than 250 times the values found in background sediments. At $116 \mathrm{ft}$ bgs, water-extractable nitrate peaks at 1000 time background sediment values. The water-extractable sulfate in the C4104 sediment profile is elevated but erratic in nature, with an obvious elevated zone between 81 and $116 \mathrm{ft}$ bgs where values are consistently 30 times larger than background sediments. The water-extractable phosphate values are elevated by a factor of 10 compared to background sediments from 40 to $115 \mathrm{ft}$ bgs. There is a small zone of elevated nitrite in the C4104 sediments between 111 to $116 \mathrm{ft}$ bgs. The alkalinity of the C4104 sediment water extracts is elevated between the depths of 40 to $111 \mathrm{ft}$. 
Table 4.18. $\quad$ pH and EC Data for Sediment:Water Extracts and Actual Porewater from Borehole C4104

\begin{tabular}{|c|c|c|c|c|c|}
\hline Sample No. & $\begin{array}{c}\text { Depth } \\
\text { (ft bgs) }\end{array}$ & $\begin{array}{c}\text { Stratigraphic } \\
\text { Unit }\end{array}$ & pH & $\begin{array}{c}\text { Conductivity } \\
\mathrm{mS} / \mathrm{cm}\end{array}$ & $\begin{array}{l}\text { Calculated (mS/cm) } \\
\text { (in Pore Water) }\end{array}$ \\
\hline $1 \mathrm{~A}$ & 16.18 & Bckfl & 7.59 & 0.148 & 2.203 \\
\hline $2 \mathrm{~A}$ & 22.69 & Bckfl & 7.61 & 0.237 & 3.619 \\
\hline $3 \mathrm{~A}$ & 30.74 & Bckfl & 7.97 & 0.214 & 2.253 \\
\hline $4 \mathrm{~A}$ & 36.88 & Bckfl & 7.57 & 0.468 & 4.456 \\
\hline 4 (NOSE CONE) & 37.40 & Bckfl & 7.94 & 0.27 & 1.61 \\
\hline $5 \mathrm{~A}$ & 40.01 & Bckfl & 8.65 & 0.37 & 5.767 \\
\hline 5A dup & 40.01 & Bckfl & 8.23 & 0.397 & 9.482 \\
\hline $6 \mathrm{~B}$ & 46.33 & $\mathrm{H} 2$ & 8.39 & 0.579 & 16.878 \\
\hline $6 \mathrm{~A}$ & 46.98 & $\mathrm{H} 2$ & 9.66 & 0.755 & 22.879 \\
\hline $7 \mathrm{~B}$ & 58.39 & $\mathrm{H} 2$ & 8.96 & 1.132 & 13.559 \\
\hline 7B Dup & 58.39 & $\mathrm{H} 2$ & 8.73 & 1.267 & 15.227 \\
\hline $7 \mathrm{~A}$ & 59.09 & H2 & 9.75 & 1.097 & 24.375 \\
\hline $8 B$ & 63.38 & $\mathrm{H} 2$ & 8.79 & 0.974 & 12.119 \\
\hline 8A UFA & 64.03 & $\mathrm{H} 2$ & 9.57 & & 9.978 \\
\hline $8 \mathrm{~A}$ & 64.03 & $\mathrm{H} 2$ & 9.77 & 1.198 & 24.017 \\
\hline 8A Dup & 64.03 & H2 & 9.69 & 1.34 & 24.253 \\
\hline $9 \mathrm{~A}$ & 76.03 & H2 & 9.63 & 1.133 & 22.196 \\
\hline $10 \mathrm{~A}$ & 81.04 & $\mathrm{CCU}_{\mathrm{u}}$ & 9.1 & 0.962 & 7.394 \\
\hline 11A UFA & 87.35 & $\mathrm{CCU}_{\mathrm{u}}$ & 8.39 & & 6.523 \\
\hline $11 \mathrm{~A}$ & 87.35 & $\mathrm{CCU}_{\mathrm{u}}$ & 8.94 & 1.395 & 7.841 \\
\hline 11A Dup & 87.35 & $\mathrm{CCU}_{\mathrm{u}}$ & 8.82 & 1.512 & 7.755 \\
\hline $12 \mathrm{~A}$ & 92.61 & $\mathrm{CCU}_{\mathrm{l}}$ & 9.14 & 1.992 & 16.744 \\
\hline 13A UFA & 93.56 & $\mathrm{CCU}_{1}$ & 8.29 & & 9.007 \\
\hline $13 \mathrm{~A}$ & 93.56 & $\mathrm{CCU}_{\mathrm{l}}$ & 8.46 & 2.919 & 16.958 \\
\hline $14 \mathrm{~A}$ & 94.67 & $\mathrm{CCU}_{\mathrm{l}}$ & 8.39 & 2.482 & 17.482 \\
\hline
\end{tabular}


Table 4.18. (contd)

\begin{tabular}{|c|c|c|c|c|c|}
\hline Sample No. & Depth (ft bgs) & Stratigraphic Unit & pH & $\begin{array}{c}\text { Conductivity } \\
\mathrm{mS} / \mathrm{cm}\end{array}$ & $\begin{array}{l}\text { Calculated (mS/cm) } \\
\text { (in Pore Water) }\end{array}$ \\
\hline 15B & 99.70 & $\mathrm{CCU}_{1}$ & 7.93 & 0.891 & 10.121 \\
\hline $15 \mathrm{~A}$ & 100.37 & $\mathrm{CCU}_{1}$ & 8.32 & 1.543 & 18.379 \\
\hline $16 \mathrm{~B}$ & 101.33 & $\mathrm{CCU}_{1}$ & 8.08 & 1.248 & 11.923 \\
\hline $16 \mathrm{~A}$ & 101.98 & $\mathrm{CCU}_{1}$ & 8.23 & 1.939 & 9.397 \\
\hline 17B & 105.39 & $\mathrm{CCU}_{1}$ & 7.85 & 0.89 & 10.881 \\
\hline $17 \mathrm{~A}$ & 106.09 & $\mathrm{CCU}_{1}$ & 7.77 & 0.932 & 9.77 \\
\hline $18 \mathrm{~A}$ & 107.42 & $\mathrm{CCU}_{1}$ & 7.88 & 1.082 & 21.696 \\
\hline $19 \mathrm{~A}$ & 110.98 & $\mathrm{R}_{\mathrm{tf}}$ & 7.69 & 2.503 & 15.51 \\
\hline 19A Dup & 110.98 & $\mathrm{R}_{\mathrm{tf}}$ & 7.66 & 2.268 & 21.127 \\
\hline $20 B$ & 115.25 & $\mathrm{R}_{\mathrm{tf}}$ & 7.49 & 3.309 & 16.353 \\
\hline 20A UFA & 116.02 & $\mathrm{R}_{\mathrm{tf}}$ & 7.3 & & 29.72 \\
\hline $20 \mathrm{~A}$ & 116.02 & $\mathrm{R}_{\mathrm{tf}}$ & 7.16 & 8.192 & 33.412 \\
\hline 21B & 120.30 & $\mathrm{R}_{\mathrm{tf}}$ & 7.35 & 1.103 & 9.027 \\
\hline 21A UFA & 120.97 & $\mathrm{R}_{\mathrm{wi}}$ & 7.44 & & 8.846 \\
\hline $21 \mathrm{~A}$ & 120.97 & $\mathrm{R}_{\mathrm{wi}}$ & 7.45 & 1.653 & 9.856 \\
\hline 22B & 123.32 & $\mathrm{R}_{\mathrm{wi}}$ & 7.45 & 0.4 & 19.74 \\
\hline $22 \mathrm{~A}$ & 124.05 & $\mathrm{R}_{\mathrm{wi}}$ & 7.27 & 0.536 & 11.546 \\
\hline $23 \mathrm{~A}$ & 127.13 & $\mathrm{R}_{\mathrm{wi}}$ & 7.49 & 0.431 & 8.197 \\
\hline
\end{tabular}




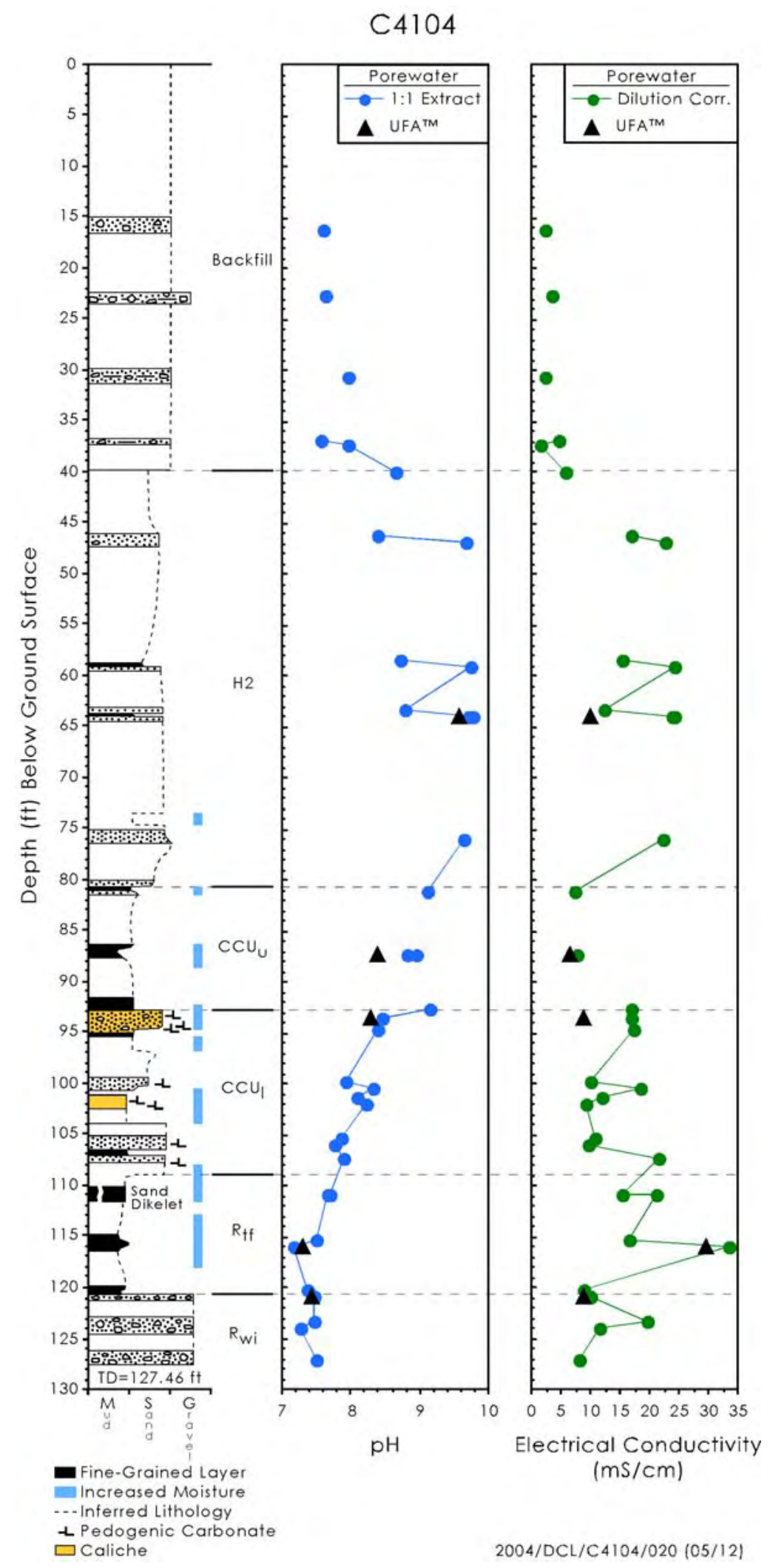

Figure 4.13. Borehole C4104 Sediment:Water Extract pH, Actual, and Calculated Porewater Electrical Conductivity 
The agreement between measuring the water extracts for phosphate and sulfate directly with the ion chromatograph and indirectly by converting the ICP measurements for phosphorous and sulfur is very good. Besides validating the ion chromatography data, we can state that the water-extractable sulfur and phosphorous species are in fact sulfate and phosphate.

The water-extractable small organic molecules in the C4104 borehole sediments are shown in Table 4.20. The depth profiles are erratic and there are several samples that appear to show elevated values especially for acetate and oxalate. There appears to be a zone of elevated acetate between 59 and $76 \mathrm{ft}$ bgs and two discrete samples with high values of water-extractable oxalate, at 63 and $116 \mathrm{ft}$ bgs. The formate value for the $116 \mathrm{ft}$ bgs sample is also elevated. We are not confident that these data are meaningful and are concerned that analytical difficulties from the highly variable matrix from sample to sample may be causing some spurious peaks in the ion chromatograph that relies solely on conductivity measurements as a function of time to quantitate analytes.

The water-extractable major cations in the C4104 borehole sediments are tabulated in Table 4.21 and the distribution with depth is shown in Figure 4.15. The distribution of the divalent-alkaline-earth cations (magnesium, calcium, and strontium and to some extent barium), shows low water-extractable quantities between 40 and $93 \mathrm{ft}$ bgs. Conversely, the distribution of water-extractable sodium is higher than the mass that is water-leachable from uncontaminated sediments in the profile from 23 to $116 \mathrm{ft}$ bgs. These trends suggest that tank fluids that are high in sodium did seep into the vadose zone near this borehole. The sodium pushed the natural divalent cations off the sediment cation exchange sites in the sediments between 40 and $93 \mathrm{ft}$ bgs. We have observed the same cation distribution and ion exchange fronts where divalent cations and sometimes potassium are depleted in the shallow sediments, and high levels of water-extractable sodium are present at both the SX and BX tank farms where tank fluids have been confirmed as being present (see Serne et al. 2002b, 2002c, 2002e, 2002f for details). At and right below the leading edge of the sodium plume, one finds elevated levels of the divalent cations that were displaced. We observe the high levels of divalent cations in the C4104 samples between $115 \mathrm{ft}$ bgs to the bottom of the borehole at $127 \mathrm{ft}$ bgs. For the three more common divalent cations (calcium, magnesium, and strontium), the highest concentrations occur in the $116 \mathrm{ft}$ sample. The water-extractable sodium concentration approaches background levels below $116 \mathrm{ft}$ bgs. The maximum penetration of the cationexchange front is located between 116 and $120 \mathrm{ft}$. No samples were obtained between these two depths to locate the exact penetration depth of the cation exchange interactions.

The water-extractable aluminum, silicon, iron, manganese, zinc, copper, phosphorous, and sulfur in the C4104 borehole sediments are shown in Table 4.22 and Figure 4.16. The phosphorous and sulfur data were converted to water-extractable phosphate and sulfate and plotted with the anion data in Figure 4.14. In general, the agreement between direct measurement of the two anions by ion chromatography and the converted ICP measurements of water-extractable P and S are very good. The water-soluble aluminum and iron data show elevated values between the depths of 40 and 76 and 46.3 to $111 \mathrm{ft}$ bgs, respectively. We speculate that these elevated values indicate some chemical reaction between alkaline tank fluids and native sediments that formed precipitates of aluminum and iron that are more water soluble than aluminum- and iron-rich phases in the native sediments. The manganese water extract data are slightly elevated from 59 to $116 \mathrm{ft}$ bgs with very high values between 111 and $116 \mathrm{ft}$ bgs. The water-extractable zinc and copper values appear to be elevated between 81 and $116 \mathrm{ft}$ bgs. The water-extractable sulfur (reported as sulfate) values between the depths of $37 \mathrm{ft}$ bgs and the bottom of the borehole at $127 \mathrm{ft} \mathrm{bgs}$ also appear to be elevated in comparison with the sulfate that is water-extractable from background sediments in borehole 299-W10-27. Water-extractable sulfate values in C4104 sediments are 10 to 
70 times greater than background values over the depth range $81 \mathrm{ft}$ bgs to the bottom of the hole. Zinc and copper can form soluble aqueous complexes with sulfate; this might be the cause for the elevated transition metals concentrations in the water extracts.

The water extract data for potentially mobile metals such as technetium-99, uranium-238, chromium, molybdenum and ruthenium (Ru) are shown in Table 4.23 and Figure 4.17. Water-leachable technetium-99 is present in the C4104 sediment from $40 \mathrm{ft}$ bgs to the bottom of the borehole. The bulk of the technetium plume resides between the depths of 115 and $121 \mathrm{ft}$ bgs in the Ringold Taylor Flats unit. The maximum water-leachable technetium in this zone ranges from 500 to $1160 \mathrm{pCi} / \mathrm{g}$. This range is larger than values found at contaminated boreholes in the TX ( 20 to $130 \mathrm{pCi} / \mathrm{g}$ ), BX and B tank farms ( 5 to $20 \mathrm{pCi} / \mathrm{g}$ ), and higher than the values found at the 299-W23-19 borehole near SX-115 (100 to $500 \mathrm{pCi} / \mathrm{g}$ ) but lower than the water-leachable technetium-99 found in boreholes near the SX-108 and SX-109 tanks (1,000 to 10,000 pCi/g) as described in Serne et al. (2002b, 2002c, 2002d, 2002e, 2002f) and Serne et al. (2004).

Elevated water-leachable uranium-238 is found in the zone between 58 and $93 \mathrm{ft}$ bgs at borehole C4104 and the values range from 0.2 to $1.0 \mu \mathrm{g} / \mathrm{g}$. The water-extractable uranium concentrations at C4104 are low compared to values found in the contaminated sediment east of the BX-102 tank where values reached $500 \mu \mathrm{g} / \mathrm{g}$. Elevated concentrations of water-leachable chromium, molybdenum and ruthenium are found in the sediments from borehole C4104. Ruthenium, similar to the technetium-99 profile, appears to be more mobile than chromium and molybdenum based on the fact that chromium and molybdenum profiles reach only $116 \mathrm{ft}$ bgs and the peak concentrations of both elements found between 81 to 95 and 87 to $102 \mathrm{ft}$ bgs, respectively. Both the ruthenium and technetium-99 distributions reach the bottom of the borehole ( $127 \mathrm{ft}$ bgs) and their peak concentrations are found between 111 and 116 and 116 and $121 \mathrm{ft}$ bgs, respectively. The technetium-99 data suggest that tank fluids may have percolated down through the entire Hanford formation $\mathrm{H} 2$ unit, the fine-grained $\mathrm{CCU}_{\mathrm{u}}$ mud, and the caliche-bearing $\mathrm{CCU}_{1}$ unit, and currently reside in the lower portion of the fine-grained Ringold Taylor Flat unit and coarser grained Ringold Wooded Island unit. 
Table 4.19. Water-Extractable Anions in Borehole C4104 Vadose Zone Sediments ( $\mu \mathrm{g} / \mathrm{g}$ dry sediment)

\begin{tabular}{|c|c|c|c|c|c|c|c|c|c|c|}
\hline Sample No. & $\begin{array}{c}\text { Depth } \\
\text { (ft bgs) }\end{array}$ & $\begin{array}{c}\text { Stratigraphic } \\
\text { Unit }\end{array}$ & Fluoride & Chloride & Nitrate & $\mathrm{CO}_{3}$ & Sulfate & Phosphate & Nitrite & Bromide \\
\hline $1 \mathrm{~A}$ & 16.18 & Bckfl & 0.73 & 0.39 & 2.34 & $<50.028$ & 3.2 & 0.28 & $<0.250$ & $<0.230$ \\
\hline $2 \mathrm{~A}$ & 22.69 & Bckfl & 0.81 & 0.26 & 2.72 & 89.68 & 3.49 & 3.98 & $<0.250$ & $<0.230$ \\
\hline $3 \mathrm{~A}$ & 30.74 & Bckfl & 1.22 & 0.86 & 1.77 & 95.42 & 9.22 & $<0.257$ & $<0.250$ & $<0.230$ \\
\hline $4 \mathrm{~A}$ & 36.88 & Bckfl & 0.63 & 58.51 & 0.79 & <49.997 & 75.25 & $<0.257$ & $<0.250$ & 0.31 \\
\hline 4 (NOSE CONE) & 37.40 & Bckfl & 1.00 & 5.00 & 0.77 & 87.81 & 33.15 & $<0.51$ & $<0.45$ & $<0.48$ \\
\hline $5 \mathrm{~A}$ & 40.01 & Bckfl & 0.77 & 0.56 & 2.05 & 191.14 & 5.97 & 0.82 & $<0.250$ & $<0.230$ \\
\hline 5A dup & 40.01 & Bckfl & 1.17 & 1.65 & 1.05 & 220.46 & 19.71 & 0.62 & $<0.45$ & $<0.48$ \\
\hline $6 \mathrm{~B}$ & 46.33 & H2 & 2.01 & 4.62 & $<0.43$ & 335.73 & 29.17 & 0.96 & $<0.45$ & $<0.48$ \\
\hline $6 \mathrm{~A}$ & 46.98 & H2 & 1.29 & 0.72 & 3.47 & 409.2 & 7.63 & 1.43 & $<0.250$ & $<0.230$ \\
\hline $7 \mathrm{~B}$ & 58.39 & $\mathrm{H} 2$ & 5.20 & 7.44 & 4.08 & 594.06 & 63.64 & 2.98 & 0.70 & $<0.48$ \\
\hline 7B Dup & 58.39 & $\mathrm{H} 2$ & 5.98 & 7.08 & 5.60 & 729.65 & 65.37 & 3.42 & $<0.45$ & $<0.48$ \\
\hline $7 \mathrm{~A}$ & 59.09 & $\mathrm{H} 2$ & 2.96 & 1.24 & 7.71 & 543.13 & 14.98 & 2.87 & 0.52 & $<0.230$ \\
\hline $8 \mathrm{~B}$ & 63.38 & $\mathrm{H} 2$ & 8.40 & 9.70 & $<0.44$ & 737.46 & 62.20 & 5.31 & $<0.45$ & $<0.48$ \\
\hline $8 \mathrm{~A}$ & 64.03 & $\mathrm{H} 2$ & 9.35 & 1.64 & 17.85 & 578.8 & 14.44 & 5.13 & 0.34 & $<0.230$ \\
\hline 8A Dup & 64.03 & $\mathrm{H} 2$ & 10.25 & 2.02 & 20.6 & 645.53 & 15.78 & 5.2 & 0.44 & $<0.230$ \\
\hline $9 \mathrm{~A}$ & 76.03 & $\mathrm{H} 2$ & 7.66 & 2.73 & 24.71 & 541.46 & 18.61 & 2.72 & $<0.250$ & $<0.230$ \\
\hline $10 \mathrm{~A}$ & 81.04 & $\mathrm{CCU}_{\mathrm{u}}$ & 5.55 & 5.26 & 78.22 & 356.56 & 151.96 & 1.15 & 0.48 & $<0.230$ \\
\hline $11 \mathrm{~A}$ & 87.35 & $\mathrm{CCU}_{\mathrm{u}}$ & 0.56 & 3.47 & 168.18 & 216.65 & 327.44 & 1.73 & 0.74 & $<0.232$ \\
\hline 11A Dup & 87.35 & $\mathrm{CCU}_{\mathrm{u}}$ & 0.54 & 4.39 & 196.66 & 213.82 & 392.02 & 1.56 & 0.76 & $<0.230$ \\
\hline $12 \mathrm{~A}$ & 92.61 & $\mathrm{CCU}_{\mathrm{l}}$ & 2.62 & 2.31 & 220.37 & 376.11 & 388.18 & 0.93 & 0.31 & $<0.230$ \\
\hline
\end{tabular}


Table 4.19. (contd)

\begin{tabular}{|c|c|c|c|c|c|c|c|c|c|c|}
\hline Sample No. & $\begin{array}{c}\text { Depth } \\
\text { (ft bgs) }\end{array}$ & \begin{tabular}{|c|}
$\begin{array}{c}\text { Stratigraphic } \\
\text { Unit }\end{array}$ \\
\end{tabular} & Fluoride & Chloride & Nitrate & $\mathrm{CO}_{3}$ & Sulfate & Phosphate & Nitrite & Bromide \\
\hline $13 \mathrm{~A}$ & 93.56 & $\mathrm{CCU}_{1}$ & 2.94 & 4.36 & 510.87 & 294.28 & 758.3 & 2.06 & $<0.250$ & $<0.230$ \\
\hline $14 \mathrm{~A}$ & 94.67 & $\mathrm{CCU}_{\mathrm{l}}$ & 2.73 & 5.24 & 528.93 & 173.35 & 539.75 & 0.82 & 0.32 & $<0.230$ \\
\hline $15 B$ & 99.70 & $\mathrm{CCU}_{\mathrm{l}}$ & 2.11 & 2.88 & 179.76 & 71.84 & 192.19 & 0.62 & $<0.45$ & $<0.48$ \\
\hline $15 \mathrm{~A}$ & 100.37 & $\mathrm{CCU}_{\mathrm{l}}$ & 1.41 & 3.5 & 276.47 & 108 & 352.24 & 1.41 & 0.7 & $<0.230$ \\
\hline $16 \mathrm{~B}$ & 101.33 & $\mathrm{CCU}_{\mathrm{l}}$ & $<0.12$ & 2.33 & 138.24 & 139.10 & $\operatorname{High}^{(a)}$ & 1.57 & $<0.45$ & $<0.48$ \\
\hline $16 \mathrm{~A}$ & 101.98 & $\mathrm{CCU}_{\mathrm{l}}$ & 2.38 & 3.08 & 239.88 & 209.23 & 519.87 & 1.04 & $<0.250$ & $<0.230$ \\
\hline $17 \mathrm{~B}$ & 105.39 & $\mathrm{CCU}_{\mathrm{l}}$ & 2.08 & 2.83 & 177.97 & 71.58 & 190.15 & 0.70 & $<0.45$ & $<0.48$ \\
\hline $17 \mathrm{~A}$ & 106.09 & $\mathrm{CCU}_{1}$ & 1.47 & 2.4 & 192.71 & 121.33 & 155.86 & 0.33 & 0.43 & $<0.230$ \\
\hline $18 \mathrm{~A}$ & 107.42 & $\mathrm{CCU}_{\mathrm{l}}$ & 1.43 & 1.41 & 87.41 & 128.03 & 96.72 & 0.8 & $<0.250$ & $<0.230$ \\
\hline $19 \mathrm{~A}$ & 110.98 & $\mathrm{R}_{\mathrm{tf}}$ & 0.71 & 5.86 & 548.12 & 182.96 & 667.59 & 3.16 & 1.56 & $<0.230$ \\
\hline 19A Dup & 110.98 & $\mathrm{R}_{\mathrm{tf}}$ & 0.75 & 5.48 & 477.37 & 164.76 & 592.47 & 2.03 & 1.42 & $<0.230$ \\
\hline $20 \mathrm{~B}$ & 115.25 & $\mathrm{R}_{\mathrm{tf}}$ & 0.87 & 28.82 & 1305.59 & $<50.01$ & 397.49 & 2.48 & 15.67 & $<0.48$ \\
\hline $20 \mathrm{~A}$ & 116.02 & $\mathrm{R}_{\mathrm{tf}}$ & 0.39 & 44.14 & 2565.63 & $<50.014$ & 570.35 & $<0.257$ & 486.1 & $<0.230$ \\
\hline $21 B$ & 120.30 & $\mathrm{R}_{\mathrm{tf}}$ & 0.47 & 14.89 & 562.95 & $<50.00$ & 20.07 & $<0.51$ & $<0.45$ & $<0.48$ \\
\hline $21 \mathrm{~A}$ & 120.97 & $\mathrm{R}_{\mathrm{wi}}$ & 0.37 & 23.44 & 718.61 & $<50.038$ & 25.74 & $<0.257$ & 3.11 & $<0.230$ \\
\hline $22 \mathrm{~B}$ & 123.32 & $\mathrm{R}_{\mathrm{wi}}$ & 1.34 & 6.39 & 111.65 & $<50.58$ & 22.69 & $<0.51$ & $<0.46$ & $<0.49$ \\
\hline $22 \mathrm{~A}$ & 124.05 & $\mathrm{R}_{\mathrm{wi}}$ & 0.69 & 8.15 & 245.03 & $<49.988$ & 15.34 & $<0.257$ & $<0.250$ & $<0.230$ \\
\hline $23 \mathrm{~A}$ & 127.13 & $\mathrm{R}_{\mathrm{wi}}$ & 1.88 & 6.09 & 140.55 & $<50.008$ & 23.73 & $<0.257$ & $<0.250$ & $<0.230$ \\
\hline
\end{tabular}



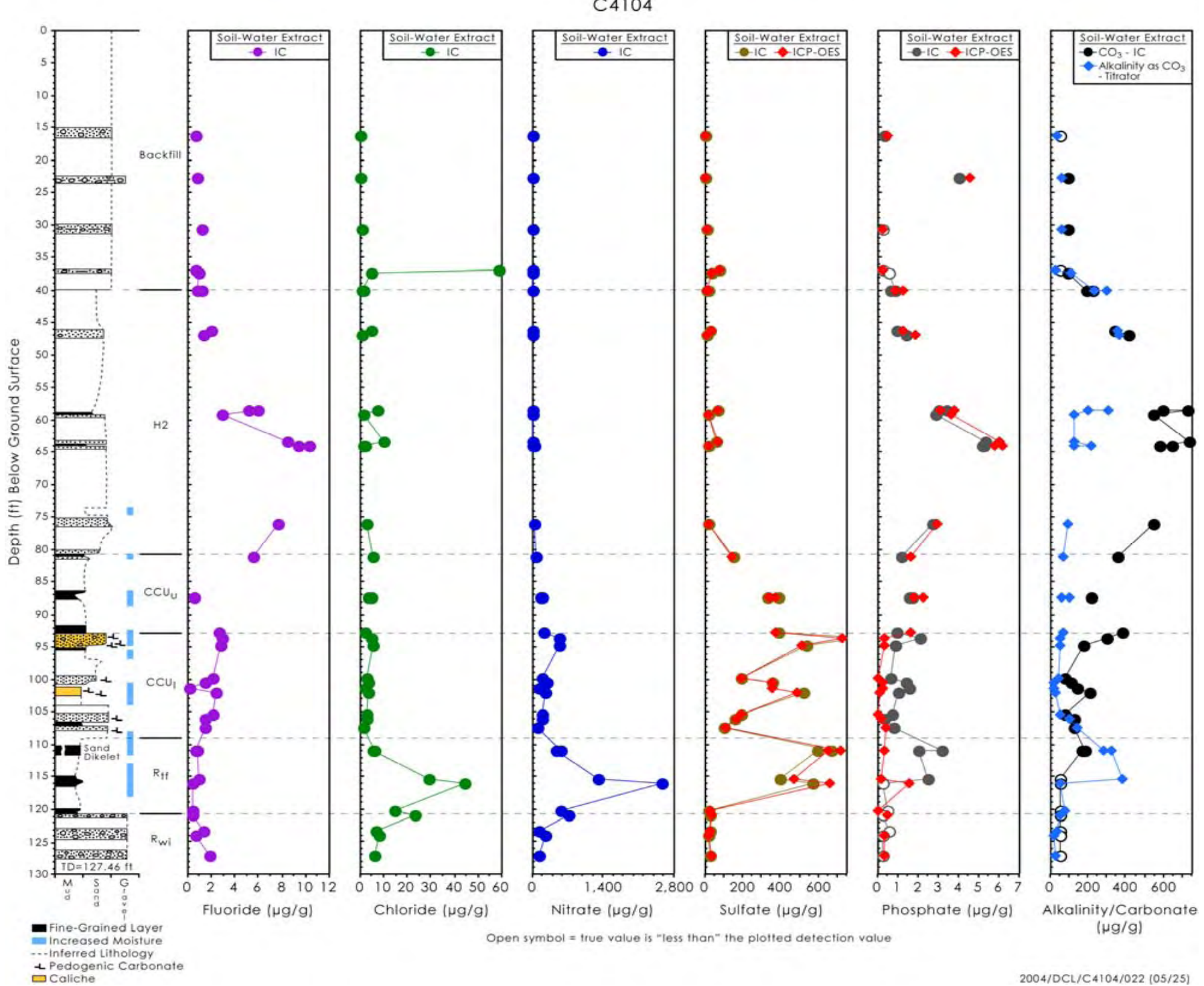

Figure 4.14. Borehole C4104 Water-Extractable Anions ( $\mu \mathrm{g} / \mathrm{g}$ dry sediment) 
Table 4.20. Water-Extractable Organics in C4104 Vadose Zone Sediments ( $\mu \mathrm{g} / \mathrm{g})$

\begin{tabular}{|c|c|c|c|c|c|}
\hline Sample No. & Depth (ft bgs) & Stratigraphic Unit & Formate & Acetate & Oxalate \\
\hline $1 \mathrm{~A}$ & 16.18 & Bckfl & $<0.300$ & 0.73 & $<0.200$ \\
\hline $2 \mathrm{~A}$ & 22.69 & Bckfl & $<0.300$ & 1.51 & 0.24 \\
\hline $3 \mathrm{~A}$ & 30.74 & Bckfl & $<0.300$ & $<0.160$ & 0.32 \\
\hline $4 \mathrm{~A}$ & 36.88 & Bckfl & $<0.300$ & $<0.160$ & $<0.200$ \\
\hline 4 (NOSE CONE) & 37.40 & Bckfl & $<0.41$ & $<1.38$ & $<0.35$ \\
\hline $5 \mathrm{~A}$ & 40.01 & Bckfl & $<0.300$ & $<0.160$ & $<0.200$ \\
\hline $5 \mathrm{~A}$ dup & 40.01 & Bckfl & $<0.40$ & $<1.37$ & $<0.34$ \\
\hline $6 \mathrm{~B}$ & 46.33 & $\mathrm{H} 2$ & $<0.40$ & $<1.37$ & 1.63 \\
\hline $6 \mathrm{~A}$ & 46.98 & $\mathrm{H} 2$ & $<0.300$ & 5.38 & 0.32 \\
\hline $7 \mathrm{~B}$ & 58.39 & $\mathrm{H} 2$ & $<0.40$ & $<1.37$ & $<0.35$ \\
\hline 7B Dup & 58.39 & $\mathrm{H} 2$ & $<0.40$ & $<1.37$ & $<0.35$ \\
\hline $7 \mathrm{~A}$ & 59.09 & $\mathrm{H} 2$ & 0.35 & 6.41 & 0.44 \\
\hline $8 \mathrm{~B}$ & 63.38 & $\mathrm{H} 2$ & $<0.41$ & 1.62 & 13.18 \\
\hline $8 \mathrm{~A}$ & 64.03 & $\mathrm{H} 2$ & 0.4 & 5.53 & 0.43 \\
\hline 8A Dup & 64.03 & $\mathrm{H} 2$ & 0.39 & 6.26 & 0.39 \\
\hline $9 \mathrm{~A}$ & 76.03 & $\mathrm{H} 2$ & $<0.300$ & 8.77 & 0.31 \\
\hline $10 \mathrm{~A}$ & 81.04 & $\mathrm{CCU}_{\mathrm{u}}$ & $<0.300$ & 0.34 & 0.31 \\
\hline $11 \mathrm{~A}$ & 87.35 & $\mathrm{CCU}_{\mathrm{u}}$ & 0.42 & 2.54 & 0.43 \\
\hline 11A Dup & 87.35 & $\mathrm{CCU}_{\mathrm{u}}$ & $<0.300$ & $<0.160$ & 0.36 \\
\hline $12 \mathrm{~A}$ & 92.61 & $\mathrm{CCU}_{\mathrm{l}}$ & 1.59 & $<0.160$ & 2.49 \\
\hline $13 \mathrm{~A}$ & 93.56 & $\mathrm{CCU}_{1}$ & 0.43 & 1.71 & 0.29 \\
\hline $14 \mathrm{~A}$ & 94.67 & $\mathrm{CCU}_{\mathrm{l}}$ & 2.01 & 1.11 & 0.93 \\
\hline $15 B$ & 99.70 & $\mathrm{CCU}_{1}$ & $<0.40$ & $<1.37$ & 0.44 \\
\hline $15 \mathrm{~A}$ & 100.37 & $\mathrm{CCU}_{\mathrm{l}}$ & 0.44 & 0.83 & 0.55 \\
\hline $16 \mathrm{~B}$ & 101.33 & $\mathrm{CCU}_{\mathrm{l}}$ & $<0.40$ & 0.22 & 0.41 \\
\hline $16 \mathrm{~A}$ & 101.98 & $\mathrm{CCU}_{1}$ & $<0.300$ & 1.15 & 0.6 \\
\hline $17 \mathrm{~B}$ & 105.39 & $\mathrm{CCU}_{\mathrm{l}}$ & $<0.40$ & $<1.37$ & 0.42 \\
\hline $17 \mathrm{~A}$ & 106.09 & $\mathrm{CCU}_{\mathrm{l}}$ & $<0.300$ & $<0.160$ & 1.76 \\
\hline $18 \mathrm{~A}$ & 107.42 & $\mathrm{CCU}_{1}$ & $<0.300$ & $<0.160$ & 0.23 \\
\hline $19 \mathrm{~A}$ & 110.98 & $\mathrm{R}_{\mathrm{tf}}$ & $<0.300$ & 0.41 & 0.27 \\
\hline 19A Dup & 110.98 & $\mathrm{R}_{\mathrm{tf}}$ & $<0.300$ & 0.27 & 0.25 \\
\hline $20 \mathrm{~B}$ & 115.25 & $\mathrm{R}_{\mathrm{tf}}$ & $<0.40$ & $<1.37$ & $<0.35$ \\
\hline $20 \mathrm{~A}$ & 116.02 & $\mathrm{R}_{\mathrm{tf}}$ & 4.23 & $<0.160$ & 8.14 \\
\hline $21 B$ & 120.30 & $\mathrm{R}_{\mathrm{tf}}$ & $<0.40$ & $<1.37$ & $<0.35$ \\
\hline $21 \mathrm{~A}$ & 120.97 & $\mathrm{R}_{\mathrm{wi}}$ & $<0.300$ & $<0.160$ & $<0.200$ \\
\hline $22 \mathrm{~B}$ & 123.32 & $\mathrm{R}_{\mathrm{wi}}$ & $<0.41$ & $<1.39$ & 1.70 \\
\hline $22 \mathrm{~A}$ & 124.05 & $\mathrm{R}_{\mathrm{wi}}$ & $<0.300$ & $<0.160$ & $<0.200$ \\
\hline $23 \mathrm{~A}$ & 127.13 & $\mathrm{R}_{\mathrm{wi}}$ & $<0.300$ & 0.27 & $<0.200$ \\
\hline
\end{tabular}


Table 4.21. Water-Extractable Cations in C4104 Vadose Zone Sediments ( $\mu \mathrm{g} / \mathrm{g}$ dry sediment)

\begin{tabular}{|c|c|c|c|c|c|c|c|c|}
\hline Sample No. & $\begin{array}{c}\text { Depth } \\
\text { (ft bgs) }\end{array}$ & $\begin{array}{l}\text { Strat } \\
\text { Unit }\end{array}$ & Ca & Mg & Ba & Sr & $\mathrm{Na}$ & $\mathbf{K}$ \\
\hline $1 \mathrm{~A}$ & 16.18 & Bckfl & $1.0 \mathrm{E}+01$ & $2.7 \mathrm{E}+00$ & 2.1E-02 & 5.8E-02 & $1.2 \mathrm{E}+01$ & $(4.0 \mathrm{E}+00)$ \\
\hline $2 \mathrm{~A}$ & 22.69 & Bckfl & $4.2 \mathrm{E}+00$ & $1.0 \mathrm{E}+00$ & $3.5 \mathrm{E}-02$ & $(2.7 \mathrm{E}-02)^{(\mathrm{a})}$ & $3.8 \mathrm{E}+01$ & $(4.6 \mathrm{E}+00)$ \\
\hline $3 \mathrm{~A}$ & 30.74 & Bckfl & $5.4 \mathrm{E}+00$ & $1.7 \mathrm{E}+00$ & $2.7 \mathrm{E}-02$ & $(3.7 \mathrm{E}-02)$ & $4.1 \mathrm{E}+01$ & $(4.1 \mathrm{E}+00)$ \\
\hline $4 \mathrm{~A}$ & 36.88 & Bckfl & $2.6 \mathrm{E}+01$ & $3.5 \mathrm{E}+00$ & $3.4 \mathrm{E}-02$ & $1.2 \mathrm{E}-01$ & $5.6 \mathrm{E}+01$ & $(9.6 \mathrm{E}+00)$ \\
\hline 4 (NOSE CONE) & 37.40 & Bckfl & $7.2 \mathrm{E}+00$ & $1.7 \mathrm{E}+00$ & $(2.6 \mathrm{E}-02)$ & $(4.9 \mathrm{E}-02)$ & $5.4 \mathrm{E}+01$ & $(7.2 \mathrm{E}+00)$ \\
\hline $5 \mathrm{~A}$ & 40.01 & Bckfl & $1.2 \mathrm{E}+00$ & 3.7E-01 & $(3.9 \mathrm{E}-03)$ & $(1.1 \mathrm{E}-02)$ & $9.9 \mathrm{E}+01$ & $(3.4 \mathrm{E}+00)$ \\
\hline 5A dup & 40.01 & Bckfl & 8.2E-01 & $(2.0 \mathrm{E}-01)$ & 8.5E-03 & $(9.1 \mathrm{E}-03)$ & $8.3 \mathrm{E}+01$ & $(2.7 \mathrm{E}+00)$ \\
\hline $6 \mathrm{~B}$ & 46.33 & $\mathrm{H} 2$ & $1.8 \mathrm{E}+00$ & $1.5 \mathrm{E}+00$ & $(3.4 \mathrm{E}-02)$ & $(1.4 \mathrm{E}-02)$ & $1.4 \mathrm{E}+02$ & $(4.4 \mathrm{E}+00)$ \\
\hline $6 \mathrm{~A}$ & 46.98 & $\mathrm{H} 2$ & 4.1E-01 & $(5.8 \mathrm{E}-02)$ & 8.3E-03 & $(4.9 \mathrm{E}-03)$ & $1.8 \mathrm{E}+02$ & $(1.6 \mathrm{E}+00)$ \\
\hline $7 \mathrm{~B}$ & 58.39 & $\mathrm{H} 2$ & $(7.4 \mathrm{E}-01)$ & $(1.5 \mathrm{E}-01)$ & (7.3E-03) & (5.6E-03) & $3.0 \mathrm{E}+02$ & $(4.0 \mathrm{E}+00)$ \\
\hline 7B Dup & 58.39 & $\mathrm{H} 2$ & $1.7 \mathrm{E}+00$ & $2.2 \mathrm{E}+00$ & $(4.9 \mathrm{E}-02)$ & $(1.6 \mathrm{E}-02)$ & $3.5 \mathrm{E}+02$ & $(6.0 \mathrm{E}+00)$ \\
\hline $7 \mathrm{~A}$ & 59.09 & $\mathrm{H} 2$ & $1.3 \mathrm{E}+00$ & (8.3E-02) & $2.0 \mathrm{E}-02$ & $(8.9 \mathrm{E}-03)$ & $2.6 \mathrm{E}+02$ & $(1.9 \mathrm{E}+00)$ \\
\hline $8 \mathrm{~B}$ & 63.38 & $\mathrm{H} 2$ & $1.8 \mathrm{E}+00$ & 4.2E-01 & $(1.1 \mathrm{E}-02)$ & $(9.9 \mathrm{E}-03)$ & $4.1 \mathrm{E}+02$ & $(4.4 \mathrm{E}+00)$ \\
\hline $8 \mathrm{~A}$ & 64.03 & $\mathrm{H} 2$ & $1.0 \mathrm{E}+00$ & $(8.0 \mathrm{E}-02)$ & 2.3E-02 & $(5.3 \mathrm{E}-03)$ & $2.9 \mathrm{E}+02$ & $(2.3 \mathrm{E}+00)$ \\
\hline 8A Dup & 64.03 & $\mathrm{H} 2$ & 9.5E-01 & $(7.4 \mathrm{E}-02)$ & $4.0 \mathrm{E}-02$ & $(6.2 \mathrm{E}-03)$ & $3.0 \mathrm{E}+02$ & $(2.4 \mathrm{E}+00)$ \\
\hline $9 \mathrm{~A}$ & 76.03 & $\mathrm{H} 2$ & 7.3E-01 & (1.3E-01) & 2.4E-02 & $(5.8 \mathrm{E}-03)$ & $2.6 \mathrm{E}+02$ & $(2.4 \mathrm{E}+00)$ \\
\hline $10 \mathrm{~A}$ & 81.04 & $\mathrm{CCU}_{\mathrm{u}}$ & $1.3 \mathrm{E}+00$ & $(3.5 \mathrm{E}-01)$ & $1.8 \mathrm{E}-02$ & $(8.2 \mathrm{E}-03)$ & $2.6 \mathrm{E}+02$ & $(3.1 \mathrm{E}+00)$ \\
\hline $11 \mathrm{~A}$ & 87.35 & $\mathrm{CCU}_{\mathrm{u}}$ & $2.9 \mathrm{E}+00$ & 6.3E-01 & 2.5E-02 & $(1.7 \mathrm{E}-02)$ & $3.3 \mathrm{E}+02$ & $(3.1 \mathrm{E}+00)$ \\
\hline 11A Dup & 87.35 & $\mathrm{CCU}_{\mathrm{u}}$ & $3.4 \mathrm{E}+00$ & 7.2E-01 & $1.5 \mathrm{E}-02$ & $(2.0 \mathrm{E}-02)$ & $3.6 \mathrm{E}+02$ & $(3.7 \mathrm{E}+00)$ \\
\hline $12 \mathrm{~A}$ & 92.61 & $\mathrm{CCU}_{\mathrm{l}}$ & $3.5 \mathrm{E}+00$ & 5.3E-01 & 2.6E-02 & $(2.0 \mathrm{E}-02)$ & $4.4 \mathrm{E}+02$ & $(3.7 \mathrm{E}+00)$ \\
\hline $13 \mathrm{~A}$ & 93.56 & $\mathrm{CCU}_{\mathrm{l}}$ & $1.4 \mathrm{E}+01$ & $3.6 \mathrm{E}+00$ & $3.0 \mathrm{E}-02$ & 7.1E-02 & $6.4 \mathrm{E}+02$ & $(6.5 E+00)$ \\
\hline $14 \mathrm{~A}$ & 94.67 & $\mathrm{CCU}_{1}$ & $1.1 \mathrm{E}+01$ & $2.3 \mathrm{E}+00$ & 2.2E-02 & $5.2 \mathrm{E}-02$ & $5.3 \mathrm{E}+02$ & $(6.2 \mathrm{E}+00)$ \\
\hline 15B & 99.70 & $\mathrm{CCU}_{\mathrm{l}}$ & $7.6 \mathrm{E}+00$ & $2.8 \mathrm{E}+00$ & $(1.2 \mathrm{E}-02)$ & $(4.5 \mathrm{E}-02)$ & $1.9 \mathrm{E}+02$ & $(3.4 \mathrm{E}+00)$ \\
\hline $15 \mathrm{~A}$ & 100.37 & $\mathrm{CCU}_{1}$ & $1.3 \mathrm{E}+01$ & $3.7 \mathrm{E}+00$ & 4.4E-02 & 7.1E-02 & $3.2 \mathrm{E}+02$ & $(5.4 \mathrm{E}+00)$ \\
\hline $16 \mathrm{~B}$ & 101.33 & $\mathrm{CCU}_{\mathrm{l}}$ & $8.5 \mathrm{E}+00$ & $2.6 \mathrm{E}+00$ & $(1.7 \mathrm{E}-02)$ & $(5.1 \mathrm{E}-02)$ & $2.8 \mathrm{E}+02$ & $(3.4 \mathrm{E}+00)$ \\
\hline $16 \mathrm{~A}$ & 101.98 & $\mathrm{CCU}_{\mathrm{l}}$ & $2.0 \mathrm{E}+01$ & $6.8 \mathrm{E}+00$ & 2.6E-02 & $1.2 \mathrm{E}-01$ & $4.0 \mathrm{E}+02$ & $(6.7 \mathrm{E}+00)$ \\
\hline 17B & 105.39 & $\mathrm{CCU}_{1}$ & $7.8 \mathrm{E}+00$ & $2.8 \mathrm{E}+00$ & (1.3E-02) & $(4.6 \mathrm{E}-02)$ & $1.9 \mathrm{E}+02$ & $(3.2 \mathrm{E}+00)$ \\
\hline 17A & 106.09 & $\mathrm{CCU}_{1}$ & $9.9 \mathrm{E}+00$ & $3.4 \mathrm{E}+00$ & $3.1 \mathrm{E}-02$ & $6.0 \mathrm{E}-02$ & $1.9 \mathrm{E}+02$ & $(4.4 \mathrm{E}+00)$ \\
\hline $18 \mathrm{~A}$ & 107.42 & $\mathrm{CCU}_{\mathrm{l}}$ & $3.5 \mathrm{E}+00$ & $1.2 \mathrm{E}+00$ & 2.8E-02 & 2.3E-02 & $1.3 \mathrm{E}+02$ & $(2.3 \mathrm{E}+00)$ \\
\hline 19A & 110.98 & $\mathrm{R}_{\mathrm{tf}}$ & 4.4E+01 & $1.3 \mathrm{E}+01$ & $2.4 \mathrm{E}-02$ & 2.2E-01 & $5.0 \mathrm{E}+02$ & $(8.6 \mathrm{E}+00)$ \\
\hline 19A Dup & 110.98 & $\mathrm{R}_{\mathrm{tf}}$ & $3.7 \mathrm{E}+01$ & $1.1 \mathrm{E}+01$ & 2.2E-02 & $1.8 \mathrm{E}-01$ & $4.6 \mathrm{E}+02$ & $(8.0 \mathrm{E}+00)$ \\
\hline 20B & 115.25 & $\mathrm{R}_{\mathrm{tf}}$ & $1.5 \mathrm{E}+02$ & $6.0 \mathrm{E}+01$ & $(4.5 \mathrm{E}-02)$ & 8.4E-01 & $5.3 \mathrm{E}+02$ & $(1.6 \mathrm{E}+01)$ \\
\hline $20 \mathrm{~A}$ & 116.02 & $\mathrm{R}_{\mathrm{tf}}$ & $8.2 \mathrm{E}+02$ & $3.1 \mathrm{E}+02$ & 7.4E-02 & $4.8 \mathrm{E}+00$ & $6.2 \mathrm{E}+02$ & $2.5 \mathrm{E}+01$ \\
\hline 21B & 120.30 & $\mathrm{R}_{\mathrm{tf}}$ & $1.2 \mathrm{E}+02$ & $4.1 \mathrm{E}+01$ & $(1.4 \mathrm{E}-01)$ & 7.5E-01 & $1.7 \mathrm{E}+01$ & $(8.8 \mathrm{E}+00)$ \\
\hline $21 \mathrm{~A}$ & 120.97 & $\mathrm{R}_{\mathrm{wi}}$ & $1.9 \mathrm{E}+02$ & $6.2 \mathrm{E}+01$ & $1.8 \mathrm{E}-01$ & $1.2 \mathrm{E}+00$ & $1.6 \mathrm{E}+01$ & $(1.0 \mathrm{E}+01)$ \\
\hline 22B & 123.32 & $\mathrm{R}_{\mathrm{wi}}$ & $3.3 \mathrm{E}+01$ & $1.4 \mathrm{E}+01$ & $(5.0 \mathrm{E}-02)$ & 2.9E-01 & $2.1 \mathrm{E}+01$ & $(4.9 \mathrm{E}+00)$ \\
\hline $22 \mathrm{~A}$ & 124.05 & $\mathrm{R}_{\mathrm{wi}}$ & $5.4 \mathrm{E}+01$ & $1.9 \mathrm{E}+01$ & $1.0 \mathrm{E}-01$ & 4.3E-01 & $1.6 \mathrm{E}+01$ & $(5.9 \mathrm{E}+00)$ \\
\hline $23 \mathrm{~A}$ & 127.13 & $\mathrm{R}_{\mathrm{wi}}$ & $2.8 \mathrm{E}+01$ & $9.5 \mathrm{E}+00$ & 9.5E-02 & 2.8E-01 & $3.5 \mathrm{E}+01$ & $(7.4 \mathrm{E}+00)$ \\
\hline
\end{tabular}


Table 4.22. Water-Extractable Concentrations of Other Metals in C4104 Vadose Zone Sediments ( $\mu$ g/g dry sediment)

\begin{tabular}{|c|c|c|c|c|c|c|c|c|c|c|}
\hline Sample No. & $\begin{array}{c}\text { Depth } \\
\text { (ft bgs) }\end{array}$ & $\begin{array}{c}\text { Stratigraphic } \\
\text { Unit }\end{array}$ & Al & Si & $\mathbf{F e}$ & Mn & Zn & $\mathrm{P}$ as $\mathrm{PO}_{4}$ & $\mathrm{~S}$ as $\mathrm{SO}_{4}$ & $\mathrm{Cu}$ \\
\hline $1 \mathrm{~A}$ & 16.18 & Bckfl & $(3.1 \mathrm{E}-02)^{(\mathrm{a})}$ & $1.3 \mathrm{E}+01$ & 5.3E-02 & 1.3E-02 & $(4.3 \mathrm{E}-02)$ & $(4.8 \mathrm{E}-01)$ & $(3.9 \mathrm{E}+00)$ & $(2.3 E-01)$ \\
\hline $2 \mathrm{~A}$ & 22.69 & Bckfl & (5.5E-02) & $1.3 \mathrm{E}+01$ & $1.2 \mathrm{E}-01$ & $1.2 \mathrm{E}-02$ & $(7.1 \mathrm{E}-02)$ & $4.54 \mathrm{E}+00$ & $(3.1 \mathrm{E}+00)$ & $(2.2 \mathrm{E}-01)$ \\
\hline $3 \mathrm{~A}$ & 30.74 & Bckfl & (3.9E-02) & $1.3 \mathrm{E}+01$ & 3.3E-01 & $1.1 \mathrm{E}-02$ & $(4.7 E-02)$ & $(2.4 \mathrm{E}-01)$ & $9.84 \mathrm{E}+00$ & $(2.0 \mathrm{E}-01)$ \\
\hline $4 \mathrm{~A}$ & 36.88 & Bckfl & $(1.0 \mathrm{E}-02)$ & $8.5 \mathrm{E}+00$ & $(2.9 \mathrm{E}-02)$ & $1.6 \mathrm{E}-02$ & $(4.2 \mathrm{E}-02)$ & $(2.2 \mathrm{E}-01)$ & $7.29 \mathrm{E}+01$ & $(1.6 \mathrm{E}-01)$ \\
\hline 4 (NOSE CONE) & 37.40 & Bckfl & $(4.5 E-02)$ & $(6.9 \mathrm{E}+00)$ & $(3.3 \mathrm{E}-02)$ & $\mathrm{ND}^{(\mathrm{b})}$ & $(4.0 \mathrm{E}-02)$ & ND & $3.38 \mathrm{E}+01$ & $(2.8 \mathrm{E}-02)$ \\
\hline $5 \mathrm{~A}$ & 40.01 & Bckfl & $(7.2 \mathrm{E}-02)$ & $1.2 \mathrm{E}+01$ & $(4.3 E-02)$ & 5.3E-03 & $(3.7 E-02)$ & $1.22 \mathrm{E}+00$ & $6.28 \mathrm{E}+00$ & $(1.5 \mathrm{E}-01)$ \\
\hline 5A dup & 40.01 & Bckfl & $1.3 \mathrm{E}-01$ & $(9.6 \mathrm{E}+00)$ & $(2.1 \mathrm{E}-01)$ & ND & $(4.5 E-02)$ & (8.7E-01) & $1.96 \mathrm{E}+01$ & $(2.9 \mathrm{E}-02)$ \\
\hline $6 \mathrm{~B}$ & 46.33 & $\mathrm{H} 2$ & $2.8 \mathrm{E}+00$ & $(1.6 \mathrm{E}+01)$ & $4.8 \mathrm{E}+00$ & $(4.9 \mathrm{E}-02)$ & $(3.5 E-02)$ & $(1.3 \mathrm{E}+00)$ & $3.07 \mathrm{E}+01$ & $(2.6 \mathrm{E}-02)$ \\
\hline $6 \mathrm{~A}$ & 46.98 & $\mathrm{H} 2$ & 3.1E-01 & 1.3E+01 & 1.7E-01 & 7.0E-03 & $(3.3 E-02)$ & $1.82 \mathrm{E}+00$ & 7.27E+00 & (1.3E-01) \\
\hline $7 \mathrm{~B}$ & 58.39 & $\mathrm{H} 2$ & $1.4 \mathrm{E}-01$ & $(1.0 \mathrm{E}+01)$ & $(5.4 \mathrm{E}-02)$ & (6.0E-03) & $(2.1 \mathrm{E}-02)$ & $(3.1 \mathrm{E}+00)$ & $6.63 \mathrm{E}+01$ & (5.4E-02) \\
\hline 7B Dup & 58.39 & $\mathrm{H} 2$ & $5.7 \mathrm{E}+00$ & $(2.8 \mathrm{E}+01)$ & $8.4 \mathrm{E}+00$ & $(1.0 \mathrm{E}-01)$ & $(5.6 \mathrm{E}-02)$ & $(3.7 \mathrm{E}+00)$ & $6.64 \mathrm{E}+01$ & $(7.2 \mathrm{E}-02)$ \\
\hline $7 \mathrm{~A}$ & 59.09 & $\mathrm{H} 2$ & $(2.4 \mathrm{E}-01)$ & $1.4 \mathrm{E}+01$ & 2.9E-01 & 1.5E-02 & $(6.3 \mathrm{E}-02)$ & $3.62 \mathrm{E}+00$ & 1.49E+01 & $(9.4 \mathrm{E}-02)$ \\
\hline $8 B$ & 63.38 & $\mathrm{H} 2$ & 4.6E-01 & $(1.2 \mathrm{E}+01)$ & 9.1E-01 & (6.7E-02) & $(9.7 \mathrm{E}-02)$ & $5.97 \mathrm{E}+00$ & 6.63E+01 & (3.3E-01) \\
\hline $8 \mathrm{~A}$ & 64.03 & $\mathrm{H} 2$ & $(1.4 \mathrm{E}-01)$ & $1.6 \mathrm{E}+01$ & 2.3E-01 & 2.2E-02 & $(3.6 \mathrm{E}-02)$ & $6.17 \mathrm{E}+00$ & $1.45 \mathrm{E}+01$ & $(1.1 \mathrm{E}-01)$ \\
\hline 8A Dup & 64.03 & $\mathrm{H} 2$ & $(1.4 \mathrm{E}-01)$ & $1.7 \mathrm{E}+01$ & 2.1E-01 & 1.9E-02 & $1.4 \mathrm{E}-01$ & $5.80 \mathrm{E}+00$ & $1.49 \mathrm{E}+01$ & (9.7E-02) \\
\hline $9 \mathrm{~A}$ & 76.03 & $\mathrm{H} 2$ & $(9.3 E-02)$ & $1.8 \mathrm{E}+01$ & 5.6E-02 & 5.8E-03 & $(8.7 \mathrm{E}-02)$ & $2.96 \mathrm{E}+00$ & $1.71 \mathrm{E}+01$ & $(5.7 \mathrm{E}-02)$ \\
\hline $10 \mathrm{~A}$ & 81.04 & $\mathrm{CCU}_{\mathrm{u}}$ & $(4.1 \mathrm{E}-02)$ & $1.8 \mathrm{E}+01$ & 1.2E-01 & 2.5E-02 & 1.6E-01 & $1.61 \mathrm{E}+00$ & $1.43 \mathrm{E}+02$ & $(1.8 \mathrm{E}-01)$ \\
\hline $11 \mathrm{~A}$ & 87.35 & $\mathrm{CCU}_{\mathrm{u}}$ & $(1.6 \mathrm{E}-01)$ & $1.1 \mathrm{E}+01$ & $2.3 \mathrm{E}+00$ & 2.5E-01 & 2.2E-01 & $2.22 \mathrm{E}+00$ & $3.35 \mathrm{E}+02$ & $6.1 \mathrm{E}-01$ \\
\hline 11A Dup & 87.35 & $\mathrm{CCU}_{\mathrm{u}}$ & $(8.3 E-02)$ & $1.0 \mathrm{E}+01$ & $2.6 \mathrm{E}+00$ & 4.1E-01 & 1.9E-01 & $1.80 \mathrm{E}+00$ & $3.75 \mathrm{E}+02$ & 5.0E-01 \\
\hline $12 \mathrm{~A}$ & 92.61 & $\mathrm{CCU}_{1}$ & $(2.2 \mathrm{E}-02)$ & $1.2 \mathrm{E}+01$ & $1.7 \mathrm{E}+00$ & 1.7E-01 & 1.7E-01 & 1.63E+00 & $3.69 \mathrm{E}+02$ & 8.2E-01 \\
\hline $13 \mathrm{~A}$ & 93.56 & $\mathrm{CCU}_{\mathrm{l}}$ & (5.3E-02) & $3.7 \mathrm{E}+01$ & 3.3E-01 & 5.1E-01 & 2.2E-01 & (3.2E-01) & 7.23E+02 & $1.4 \mathrm{E}+00$ \\
\hline $14 \mathrm{~A}$ & 94.67 & $\mathrm{CCU}_{\mathrm{l}}$ & $(2.4 \mathrm{E}-02)$ & $2.0 \mathrm{E}+01$ & 9.8E-01 & 3.9E-01 & 1.3E-01 & (2.9E-01) & $5.16 \mathrm{E}+02$ & 6.0E-01 \\
\hline 15B & 99.70 & $\mathrm{CCU}_{1}$ & ND & $(2.0 \mathrm{E}+01)$ & $(5.5 \mathrm{E}-02)$ & $(8.2 \mathrm{E}-02)$ & $(1.4 \mathrm{E}-01)$ & (4.5E-02) & $1.88 \mathrm{E}+02$ & $(4.9 \mathrm{E}-01)$ \\
\hline $15 \mathrm{~A}$ & 100.37 & $\mathrm{CCU}_{\mathrm{l}}$ & (6.3E-03) & $(2.7 \mathrm{E}+01)$ & (8.7E-02) & $(7.8 \mathrm{E}-02)$ & $(1.5 \mathrm{E}-01)$ & (2.4E-01) & $3.57 \mathrm{E}+02$ & 7.2E-01 \\
\hline $16 \mathrm{~B}$ & 101.33 & $\mathrm{CCU}_{\mathrm{l}}$ & $(6.3 E-03)$ & $(2.7 \mathrm{E}+01)$ & $(8.7 E-02)$ & $(7.8 \mathrm{E}-02)$ & $(1.5 \mathrm{E}-01)$ & (2.4E-01) & $3.57 \mathrm{E}+02$ & 7.2E-01 \\
\hline $16 \mathrm{~A}$ & 101.98 & $\mathrm{CCU}_{1}$ & $(1.8 \mathrm{E}-02)$ & $3.0 \mathrm{E}+01$ & 2.9E-01 & 2.4E-01 & 1.7E-01 & $(8.5 \mathrm{E}-02)$ & $4.91 \mathrm{E}+02$ & $1.1 \mathrm{E}+00$ \\
\hline
\end{tabular}


Table 4.22. (contd)

\begin{tabular}{|c|c|c|c|c|c|c|c|c|c|c|}
\hline Sample No. & $\begin{array}{c}\text { Depth } \\
\text { (ft bgs) }\end{array}$ & Stratigraphic Unit & Al & Si & $\mathbf{F e}$ & Mn & $\mathbf{Z n}$ & $\mathrm{P}$ as $\mathrm{PO}_{4}$ & $\mathrm{~S}$ as $\mathrm{SO}_{4}$ & $\mathbf{C u}$ \\
\hline 17B & 105.39 & $\mathrm{CCU}_{\mathrm{l}}$ & $(2.0 \mathrm{E}-02)^{(\mathrm{a})}$ & $(2.0 \mathrm{E}+01)$ & (8.8E-02) & (8.3E-02) & (1.5E-01) & ND & $1.89 \mathrm{E}+02$ & (4.9E-01) \\
\hline 17A & 106.09 & $\mathrm{CCU}_{\mathrm{l}}$ & $(1.4 \mathrm{E}-02)$ & $2.4 \mathrm{E}+01$ & (1.4E-01) & $6.3 \mathrm{E}-02$ & $1.3 \mathrm{E}-01$ & $(2.0 \mathrm{E}-01)$ & $1.67 \mathrm{E}+02$ & (3.0E-01) \\
\hline $18 \mathrm{~A}$ & 107.42 & $\mathrm{CCU}_{\mathrm{l}}$ & $(4.2 \mathrm{E}-02)$ & $2.4 \mathrm{E}+01$ & (1.2E-01) & 4.3E-02 & $1.8 \mathrm{E}-01$ & (3.8E-01) & $1.04 \mathrm{E}+02$ & (1.6E-01) \\
\hline $19 \mathrm{~A}$ & 110.98 & $\mathrm{R}_{\mathrm{tf}}$ & (5.7E-02) & $2.3 \mathrm{E}+01$ & (4.7E-01) & $1.2 \mathrm{E}+00$ & 2.4E-01 & $(2.9 \mathrm{E}-01)$ & $7.19 \mathrm{E}+02$ & $6.9 \mathrm{E}-01$ \\
\hline 19A Dup & 110.98 & $\mathrm{R}_{\mathrm{tf}}$ & (3.9E-02) & $2.3 \mathrm{E}+01$ & (4.5E-01) & $1.1 \mathrm{E}+00$ & $2.1 \mathrm{E}-01$ & $(2.8 \mathrm{E}-01)$ & $6.53 \mathrm{E}+02$ & 6.1E-01 \\
\hline $20 \mathrm{~B}$ & 115.25 & $\mathrm{R}_{\mathrm{tf}}$ & ND & $(1.2 \mathrm{E}+01)$ & (8.3E-02) & $2.1 \mathrm{E}+00$ & $(4.6 \mathrm{E}-01)$ & $(1.6 \mathrm{E}-01)$ & $4.69 \mathrm{E}+02$ & $9.8 \mathrm{E}-01$ \\
\hline $20 \mathrm{~A}$ & 116.02 & $\mathrm{R}_{\mathrm{tf}}$ & ND & $2.3 \mathrm{E}+01$ & (1.1E-01) & $2.9 \mathrm{E}+00$ & $4.4 \mathrm{E}-01$ & $(1.5 \mathrm{E}+00)$ & $6.64 \mathrm{E}+02$ & $1.0 \mathrm{E}+00$ \\
\hline $21 \mathrm{~B}$ & 120.30 & $\mathrm{R}_{\mathrm{tf}}$ & ND & $(1.2 \mathrm{E}+01)$ & (7.6E-03) & ND & $(2.6 \mathrm{E}-02)$ & $(4.4 \mathrm{E}-02)$ & $2.20 \mathrm{E}+01$ & ND \\
\hline $21 \mathrm{~A}$ & 120.97 & $\mathrm{R}_{\mathrm{wi}}$ & ND & $1.9 \mathrm{E}+01$ & $(7.1 \mathrm{E}-03)$ & $(1.4 \mathrm{E}-03)$ & $(7.7 \mathrm{E}-02)$ & (4.8E-01) & $(3.7 \mathrm{E}+01)$ & ND \\
\hline $22 B$ & 123.32 & $\mathrm{R}_{\mathrm{wi}}$ & $(1.3 \mathrm{E}-02)$ & $(7.2 \mathrm{E}+00)$ & (1.2E-02) & (5.3E-03) & $(2.9 \mathrm{E}-02)$ & ND & $2.72 \mathrm{E}+01$ & $(1.8 \mathrm{E}-02)$ \\
\hline $22 \mathrm{~A}$ & 124.05 & $\mathrm{R}_{\mathrm{wi}}$ & ND & $1.7 \mathrm{E}+01$ & (2.2E-02) & (2.1E-03) & (6.6E-02) & $(2.8 \mathrm{E}-01)$ & $(2.1 \mathrm{E}+01)$ & $(9.6 \mathrm{E}-03)$ \\
\hline $23 \mathrm{~A}$ & 127.13 & $\mathrm{R}_{\mathrm{wi}}$ & $(4.0 \mathrm{E}-02)$ & $1.5 \mathrm{E}+01$ & (1.7E-02) & (5.8E-03) & $(5.8 \mathrm{E}-02)$ & $(2.9 \mathrm{E}-01)$ & $(3.0 \mathrm{E}+01)$ & $(2.1 \mathrm{E}-02)$ \\
\hline $\begin{array}{l}\text { (a) } \\
\text { (b) }\end{array}$ & es signil & rues berow ate I & 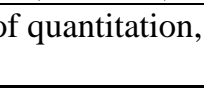 & 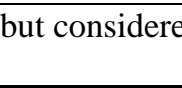 & d valid. & & & & & \\
\hline
\end{tabular}


Table 4.23. Water-Extractable Concentrations of Mobile Metals in C4104 Vadose Sediments ( $\mu$ g/g dry sediment)

\begin{tabular}{|c|c|c|c|c|c|c|c|c|c|c|c|}
\hline Sample & $\begin{array}{c}\text { Depth } \\
\text { (ft bgs) }\end{array}$ & $\begin{array}{c}\text { Tc-99 } \\
\text { (pCi/g soil) }\end{array}$ & U-238 & $\begin{array}{c}\mathrm{Cr} \\
\text { (ICP-MS) }\end{array}$ & $\begin{array}{c}\text { Cr } \\
\text { ICP }\end{array}$ & $\begin{array}{c}\text { Mo-98 } \\
\text { (ICP-MS) }\end{array}$ & $\begin{array}{c}\text { Mo-100 } \\
\text { (ICP-MS) }\end{array}$ & $\begin{array}{c}\text { Mo } \\
\text { (ICP) }\end{array}$ & $\begin{array}{c}\text { Ru-101 } \\
\text { (ICP-MS) }\end{array}$ & $\begin{array}{c}\text { Ru-102 } \\
\text { (ICP-MS) }\end{array}$ & $\begin{array}{c}\text { Ru-104 } \\
\text { (ICP-MS) }\end{array}$ \\
\hline $1 \mathrm{~A}$ & 16.18 & $<1.70 \mathrm{E}-01$ & 2.05E-03 & (3.60E-04) & $(9.8 \mathrm{E}-03)$ & 5.65E-03 & (2.99E-03) & (2.1E-02) & $(6.85 \mathrm{E}-04)$ & $(6.80 \mathrm{E}-04)$ & (6.75E-04) \\
\hline $2 \mathrm{~A}$ & 22.69 & $<1.70 \mathrm{E}-01$ & $2.40 \mathrm{E}-03$ & $(4.28 \mathrm{E}-04)$ & $(1.3 \mathrm{E}-03)$ & 5.19E-03 & (2.76E-03) & (1.7E-02) & (9.60E-04) & (9.35E-04) & (9.85E-04) \\
\hline $3 \mathrm{~A}$ & 30.74 & $<1.70 \mathrm{E}-01$ & $2.98 \mathrm{E}-03$ & (2.03E-03) & ND & 1.19E-02 & 5.97E-03 & $(2.9 \mathrm{E}-02)$ & $(7.35 \mathrm{E}-04)$ & $(6.90 \mathrm{E}-04)$ & $(7.35 \mathrm{E}-04)$ \\
\hline $4 \mathrm{~A}$ & 36.88 & $(6.78 \mathrm{E}-02)^{(\mathrm{a})}$ & $1.60 \mathrm{E}-03$ & $(1.41 \mathrm{E}-03)$ & $(4.1 \mathrm{E}-03)$ & 2.79E-02 & 1.34E-02 & $(4.1 \mathrm{E}-02)$ & $(2.50 \mathrm{E}-05)$ & (6.00E-05) & $(1.15 \mathrm{E}-04)$ \\
\hline 4 (Nose Cone) & 37.40 & $1.02 \mathrm{E}-01$ & 3.99E-03 & $(1.23 \mathrm{E}-04)$ & $(8.6 \mathrm{E}-03)$ & 4.90E-02 & 2.29E-02 & (6.3E-02) & $(2.21 \mathrm{E}-05)$ & $(1.21 \mathrm{E}-05)$ & 1.43E-04 \\
\hline $5 \mathrm{~A}$ & 40.01 & 2.12E-01 & 8.49E-03 & $(6.47 \mathrm{E}-04)$ & $(4.8 \mathrm{E}-03)$ & $1.43 \mathrm{E}-02$ & $7.82 \mathrm{E}-03$ & $(2.4 \mathrm{E}-02)$ & $(2.61 \mathrm{E}-04)$ & $1.25 \mathrm{E}-04$ & $1.44 \mathrm{E}-04$ \\
\hline $5 \mathrm{~A}$ dup & 40.01 & $(0.00 \mathrm{E}+00)$ & 3.95E-03 & $(3.27 \mathrm{E}-03)$ & $(1.7 \mathrm{E}-03)$ & 5.43E-03 & $(3.60 \mathrm{E}-03)$ & (9.6E-03) & $(4.60 \mathrm{E}-04)$ & $(3.50 \mathrm{E}-04)$ & $(3.60 \mathrm{E}-04)$ \\
\hline $6 \mathrm{~B}$ & 46.33 & $5.53 \mathrm{E}+00$ & 6.13E-02 & 4.14E-03 & $(1.1 \mathrm{E}-02)$ & 5.36E-02 & 2.77E-02 & (6.6E-02) & $1.25 \mathrm{E}-03$ & 5.93E-04 & $6.41 \mathrm{E}-04$ \\
\hline $6 \mathrm{~A}$ & 46.98 & $2.02 \mathrm{E}+00$ & 3.89E-02 & $5.28 \mathrm{E}-03$ & $(8.4 \mathrm{E}-03)$ & 8.56E-03 & 5.07E-03 & $(1.5 \mathrm{E}-02)$ & (1.58E-03) & $(8.64 \mathrm{E}-04)$ & $(8.31 \mathrm{E}-04)$ \\
\hline $7 \mathrm{~B}$ & 58.39 & $1.52 \mathrm{E}+01$ & 8.34E-01 & $1.61 \mathrm{E}-02$ & (2.3E-02) & $1.07 \mathrm{E}-01$ & $6.25 \mathrm{E}-02$ & (1.2E-01) & $9.52 \mathrm{E}-03$ & 4.54E-03 & 4.32E-03 \\
\hline 7B Dup & 58.39 & $1.38 \mathrm{E}+01$ & $1.06 \mathrm{E}+00$ & $3.26 \mathrm{E}-02$ & 3.8E-02 & $1.10 \mathrm{E}-01$ & $6.49 \mathrm{E}-02$ & (1.2E-01) & $1.05 \mathrm{E}-02$ & $5.16 \mathrm{E}-03$ & 4.84E-03 \\
\hline $7 \mathrm{~A}$ & 59.09 & $2.19 \mathrm{E}+00$ & 4.74E-01 & 3.03E-02 & (3.2E-02) & $1.30 \mathrm{E}-02$ & 1.34E-02 & $(1.4 \mathrm{E}-02)$ & (3.23E-03) & (1.65E-03) & (1.64E-03) \\
\hline $8 B$ & 63.38 & $1.32 \mathrm{E}+01$ & 7.18E-01 & $5.30 \mathrm{E}-02$ & 6.6E-02 & $1.30 \mathrm{E}-01$ & 8.30E-02 & (1.5E-01) & $1.11 \mathrm{E}-02$ & 5.33E-03 & $5.11 \mathrm{E}-03$ \\
\hline $8 \mathrm{~A}$ & 64.03 & $4.28 \mathrm{E}+00$ & $1.12 \mathrm{E}-01$ & 4.29E-01 & 4.3E-01 & $1.75 \mathrm{E}-02$ & 1.67E-02 & (1.2E-02) & (7.63E-03) & (3.96E-03) & $(4.70 \mathrm{E}-03)$ \\
\hline 8A Dup & 64.03 & $4.51 \mathrm{E}+00$ & $1.15 \mathrm{E}-01$ & $3.04 \mathrm{E}-01$ & $3.1 \mathrm{E}-01$ & $1.61 \mathrm{E}-02$ & $1.53 \mathrm{E}-02$ & $(1.8 \mathrm{E}-02)$ & $(7.26 \mathrm{E}-03)$ & (3.69E-03) & (4.53E-03) \\
\hline 9A & 76.03 & $2.01 \mathrm{E}+00$ & $9.08 \mathrm{E}-01$ & 5.31E-01 & 5.4E-01 & $2.88 \mathrm{E}-02$ & $3.04 \mathrm{E}-02$ & (2.8E-02) & $(5.08 \mathrm{E}-03)$ & $(2.64 \mathrm{E}-03)$ & $(2.75 \mathrm{E}-03)$ \\
\hline $10 \mathrm{~A}$ & 81.04 & $5.73 \mathrm{E}+00$ & $9.46 \mathrm{E}-01$ & $1.47 \mathrm{E}+00$ & $1.5 \mathrm{E}+00$ & 2.64E-01 & 2.69E-01 & 2.9E-01 & $2.36 \mathrm{E}-02$ & 1.17E-02 & 1.17E-02 \\
\hline $11 \mathrm{~A}$ & 87.35 & $4.43 \mathrm{E}+01$ & 2.07E-01 & $3.11 \mathrm{E}+00$ & $3.2 \mathrm{E}+00$ & 9.32E-01 & $1.09 \mathrm{E}+00$ & $1.0 \mathrm{E}+00$ & $8.90 \mathrm{E}-02$ & 4.35E-02 & 4.18E-02 \\
\hline 11A Dup & 87.35 & $4.06 \mathrm{E}+01$ & 2.29E-01 & $2.74 \mathrm{E}+00$ & $2.8 \mathrm{E}+00$ & $9.71 \mathrm{E}-01$ & $1.14 \mathrm{E}+00$ & $1.1 \mathrm{E}+00$ & $1.03 \mathrm{E}-01$ & 5.05E-02 & 4.89E-02 \\
\hline $12 \mathrm{~A}$ & 92.61 & $5.27 \mathrm{E}+01$ & 4.69E-01 & $1.83 \mathrm{E}+00$ & $1.8 \mathrm{E}+00$ & 3.23E-01 & 3.81E-01 & 3.5E-01 & $6.08 \mathrm{E}-02$ & 2.92E-02 & 2.91E-02 \\
\hline
\end{tabular}


Table 4.23. (contd)

\begin{tabular}{|c|c|c|c|c|c|c|c|c|c|c|c|}
\hline Sample & $\begin{array}{c}\text { Depth } \\
\text { (ft bgs) }\end{array}$ & $\begin{array}{c}\text { Tc-99 } \\
\text { (pCi/g soil) }\end{array}$ & U-238 & $\begin{array}{c}\mathrm{Cr} \\
\text { (ICP-MS) }\end{array}$ & $\begin{array}{c}\mathrm{Cr} \\
\text { ICP }\end{array}$ & $\begin{array}{c}\text { Mo-98 } \\
\text { (ICP-MS) }\end{array}$ & $\begin{array}{c}\text { Mo-100 } \\
\text { (ICP-MS) }\end{array}$ & $\begin{array}{c}\text { Mo } \\
\text { (ICP) }\end{array}$ & $\begin{array}{c}\text { Ru-101 } \\
\text { (ICP-MS) }\end{array}$ & $\begin{array}{c}\text { Ru-102 } \\
\text { (ICP-MS) }\end{array}$ & $\begin{array}{c}\text { Ru-104 } \\
\text { (ICP-MS) }\end{array}$ \\
\hline $13 \mathrm{~A}$ & 93.56 & $2.95 \mathrm{E}+02$ & 7.64E-03 & $6.72 \mathrm{E}+00$ & $6.8 \mathrm{E}+00$ & $1.55 \mathrm{E}+00$ & $1.89 \mathrm{E}+00$ & $1.7 \mathrm{E}+00$ & $1.85 \mathrm{E}-01$ & 8.86E-02 & 8.68E-02 \\
\hline $14 \mathrm{~A}$ & 94.67 & $1.04 \mathrm{E}+02$ & $6.81 \mathrm{E}-03$ & $2.17 \mathrm{E}+00$ & $2.4 \mathrm{E}+00$ & $5.47 \mathrm{E}-01$ & 6.59E-01 & 6.5E-01 & $1.15 \mathrm{E}-01$ & $5.48 \mathrm{E}-02$ & 5.38E-02 \\
\hline $15 \mathrm{~B}$ & 99.70 & $1.76 \mathrm{E}+02$ & $1.04 \mathrm{E}-02$ & $5.70 \mathrm{E}-01$ & $6.0 \mathrm{E}-01$ & 3.17E-01 & 3.54E-01 & $(3.4 \mathrm{E}-01)$ & 4.16E-02 & 2.09E-02 & $1.96 \mathrm{E}-02$ \\
\hline $15 \mathrm{~A}$ & 100.37 & $6.32 \mathrm{E}+01$ & 7.75E-03 & $6.75 \mathrm{E}-01$ & 6.9E-01 & $1.05 \mathrm{E}+00$ & $1.27 \mathrm{E}+00$ & $1.2 \mathrm{E}+00$ & $1.20 \mathrm{E}-01$ & $5.73 \mathrm{E}-02$ & $5.53 \mathrm{E}-02$ \\
\hline $16 \mathrm{~B}$ & 101.33 & $1.03 \mathrm{E}+02$ & 2.79E-02 & $2.43 \mathrm{E}+00$ & $2.6 \mathrm{E}+00$ & 7.43E-01 & 8.61E-01 & 8.3E-01 & 7.09E-02 & 3.57E-02 & 3.24E-02 \\
\hline $16 \mathrm{~A}$ & 101.98 & $1.18 \mathrm{E}+02$ & 2.38E-02 & $2.83 \mathrm{E}+00$ & $4.8 \mathrm{E}+00$ & $5.34 \mathrm{E}-01$ & $6.27 \mathrm{E}-01$ & 9.6E-01 & 7.64E-02 & $3.70 \mathrm{E}-02$ & 3.64E-02 \\
\hline 17B & 105.39 & $1.78 \mathrm{E}+02$ & $1.04 \mathrm{E}-02$ & $5.54 \mathrm{E}-01$ & 5.9E-01 & 3.15E-01 & 3.53E-01 & $(3.5 \mathrm{E}-01)^{(\mathrm{a})}$ & 4.24E-02 & $2.06 \mathrm{E}-02$ & $1.87 \mathrm{E}-02$ \\
\hline $17 \mathrm{~A}$ & 106.09 & $2.07 \mathrm{E}+02$ & 7.38E-03 & 9.32E-01 & 9.3E-01 & 3.43E-01 & 3.94E-01 & 4.0E-01 & 7.09E-02 & 3.37E-02 & $\mathrm{ND}^{(\mathrm{b})}$ \\
\hline $18 \mathrm{~A}$ & 107.42 & $9.80 \mathrm{E}+01$ & $2.66 \mathrm{E}-03$ & $6.25 \mathrm{E}-01$ & 6.4E-01 & $2.16 \mathrm{E}-01$ & $2.52 \mathrm{E}-01$ & 2.6E-01 & 2.77E-02 & $1.36 \mathrm{E}-02$ & ND \\
\hline 19A & 110.98 & $2.45 \mathrm{E}+02$ & $6.91 \mathrm{E}-03$ & $2.45 \mathrm{E}+00$ & $2.4 \mathrm{E}+00$ & $1.83 \mathrm{E}+00$ & $2.17 \mathrm{E}+00$ & $2.1 \mathrm{E}+00$ & 2.33E-01 & $1.09 \mathrm{E}-01$ & ND \\
\hline 19A Dup & 110.98 & $2.28 \mathrm{E}+02$ & $6.50 \mathrm{E}-03$ & $2.19 \mathrm{E}+00$ & $2.2 \mathrm{E}+00$ & $1.65 \mathrm{E}+00$ & $1.96 \mathrm{E}+00$ & $1.9 \mathrm{E}+00$ & 2.07E-01 & $9.82 \mathrm{E}-02$ & ND \\
\hline $20 \mathrm{~B}$ & 115.25 & $1.16 \mathrm{E}+03$ & $4.46 \mathrm{E}-03$ & 3.67E-01 & 3.7E-01 & $1.18 \mathrm{E}+00$ & $1.37 \mathrm{E}+00$ & $1.3 \mathrm{E}+00$ & 2.65E-01 & $1.26 \mathrm{E}-01$ & 1.19E-01 \\
\hline $20 \mathrm{~A}$ & 116.02 & $6.11 \mathrm{E}+03$ & 4.70E-03 & 8.66E-01 & 9.4E-01 & 3.15E-01 & $3.68 \mathrm{E}-01$ & $3.1 \mathrm{E}-01$ & $1.11 \mathrm{E}+00$ & $5.27 \mathrm{E}-01$ & $\mathrm{ND}$ \\
\hline $21 \mathrm{~B}$ & 120.30 & $5.06 \mathrm{E}+02$ & 8.79E-04 & (6.39E-04) & $(1.7 \mathrm{E}-03)$ & $1.42 \mathrm{E}-02$ & $7.00 \mathrm{E}-03$ & $(1.9 \mathrm{E}-02)$ & 4.06E-02 & $2.02 \mathrm{E}-02$ & 2.15E-02 \\
\hline $21 \mathrm{~A}$ & 120.97 & $5.72 \mathrm{E}+02$ & 7.41E-04 & $(1.78 \mathrm{E}-03)$ & (3.5E-03) & $1.57 \mathrm{E}-02$ & 8.69E-03 & $(2.6 \mathrm{E}-02)$ & 7.04E-02 & 3.32E-02 & ND \\
\hline $22 \mathrm{~B}$ & 123.32 & $1.13 \mathrm{E}+02$ & 7.13E-04 & $(3.75 \mathrm{E}-04)$ & $(2.0 \mathrm{E}-03)$ & $2.46 \mathrm{E}-02$ & $1.18 \mathrm{E}-02$ & $(3.0 \mathrm{E}-02)$ & $5.19 \mathrm{E}-03$ & 2.53E-03 & $3.12 \mathrm{E}-03$ \\
\hline $22 \mathrm{~A}$ & 124.05 & $2.64 \mathrm{E}+02$ & $1.45 \mathrm{E}-04$ & (6.25E-04) & (6.8E-03) & $9.50 \mathrm{E}-03$ & (4.97E-03) & $(2.5 \mathrm{E}-02)$ & $1.87 \mathrm{E}-02$ & $8.81 \mathrm{E}-03$ & ND \\
\hline $23 \mathrm{~A}$ & 127.13 & $6.13 \mathrm{E}+01$ & 2.69E-04 & $(9.55 \mathrm{E}-04)$ & $(4.0 \mathrm{E}-03)$ & $1.84 \mathrm{E}-02$ & 8.85E-03 & $(4.3 \mathrm{E}-02)$ & $6.65 \mathrm{E}-03$ & (3.07E-03) & ND \\
\hline \multicolumn{12}{|c|}{$\begin{array}{l}\text { (a) Parentheses signify values below the level of quantitation, but considered valid. } \\
\text { (b) } \\
\text { (bD = not determined. }\end{array}$} \\
\hline
\end{tabular}




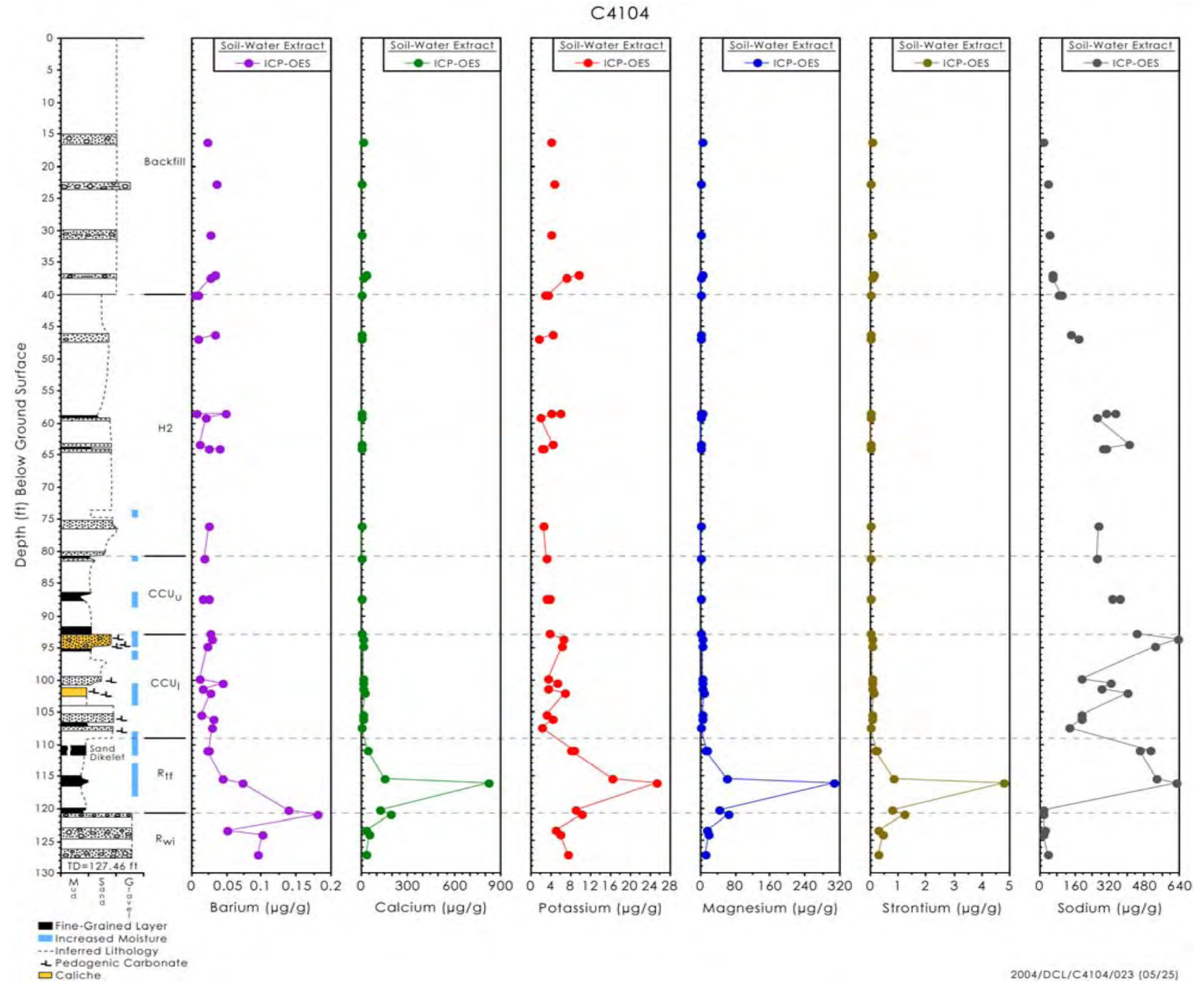

Figure 4.15. Water-Extractable Cations in C4104 Vadose Zone Sediments ( $\mu \mathrm{g} / \mathrm{g}$ ) 

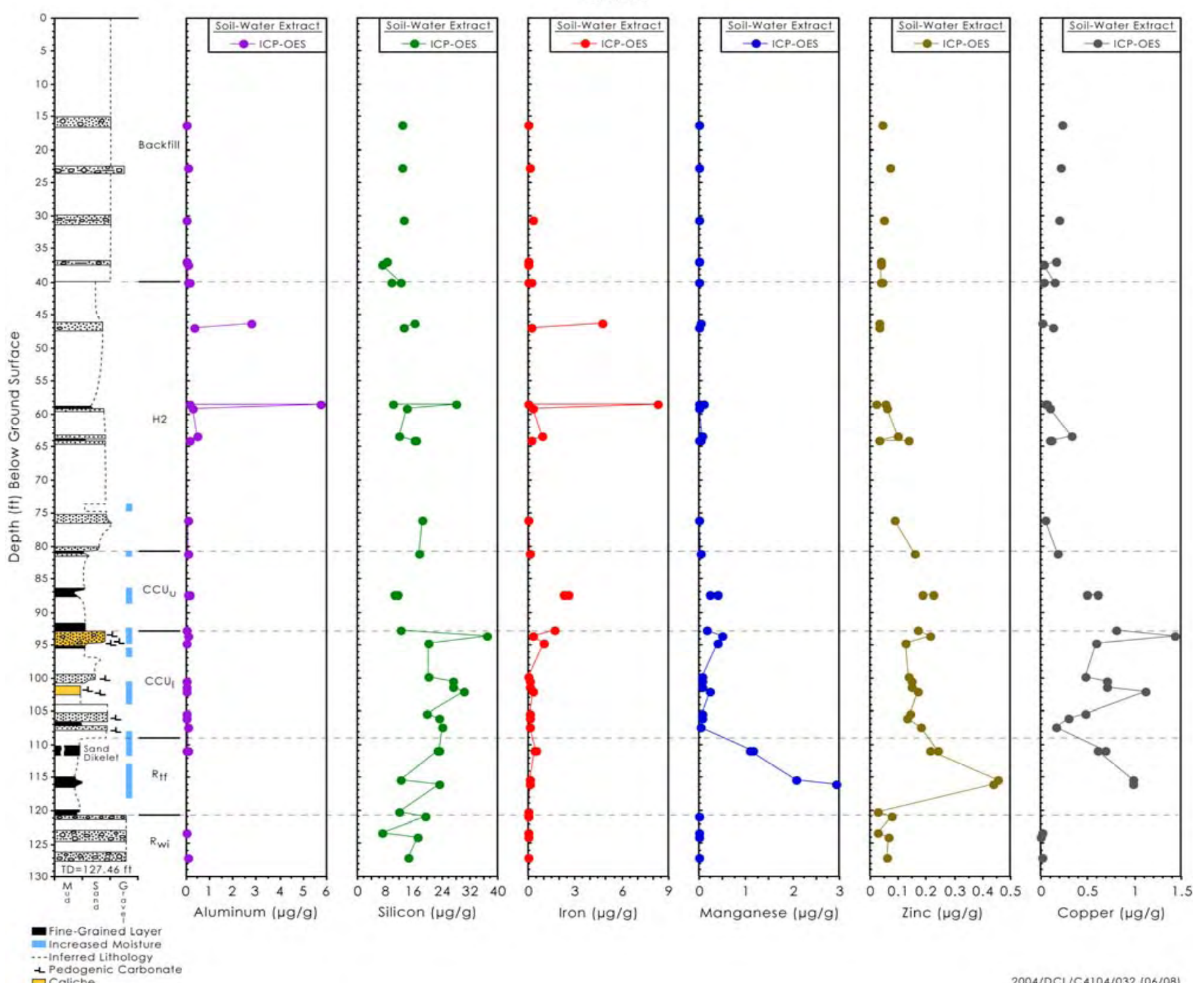

Figure 4.16. Water-Extractable Metals in C4104 Vadose Sediments ( $\mu \mathrm{g} / \mathrm{g}$ dry sediment) 
C4104
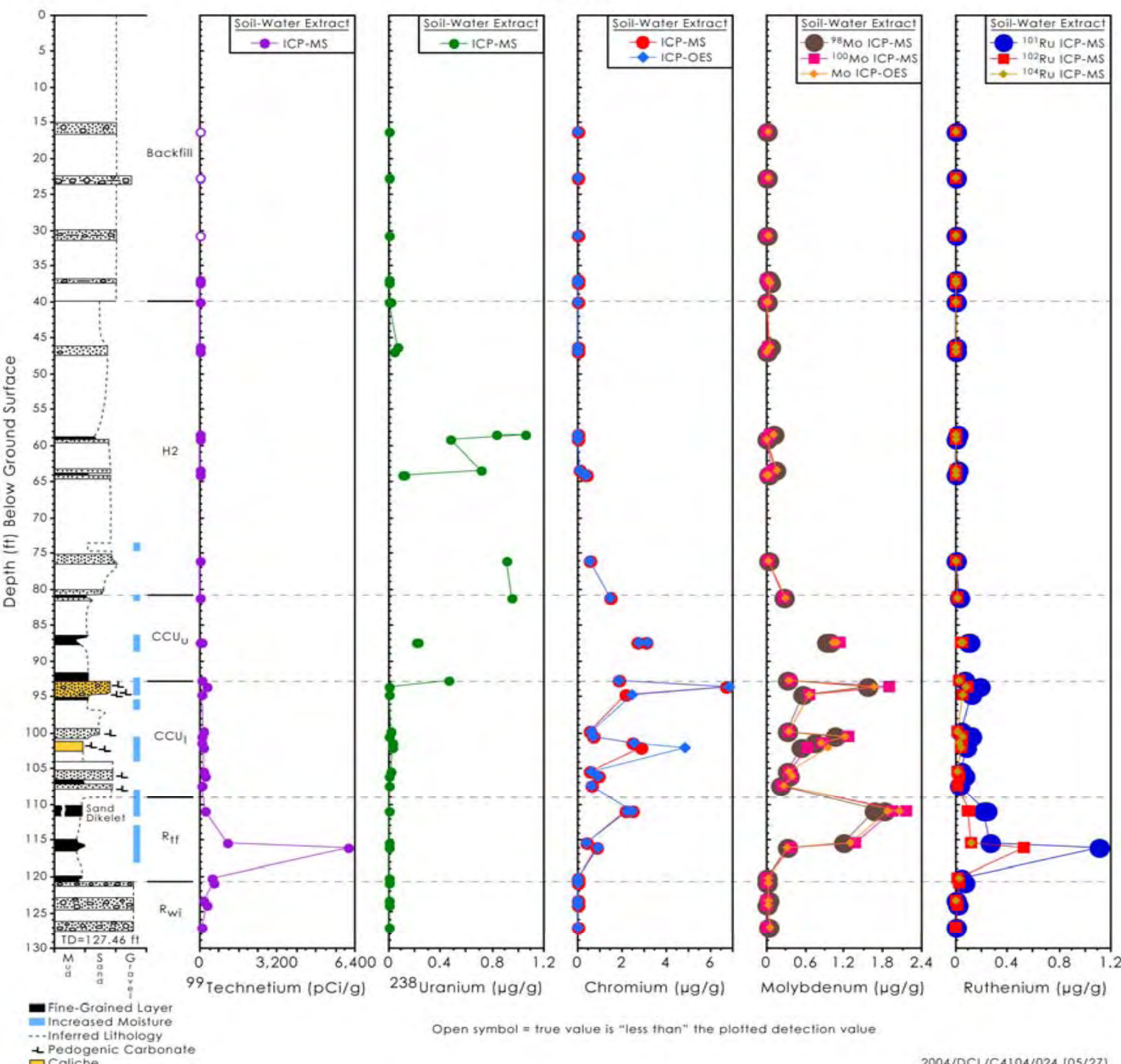

LPedogenic Carbona

Open symbot = true vatue is "less thon" the piolted detection vatue

2004/DCL/C4104/024 [05/27]

Figure 4.17. Distribution of Mobile Metals in Water Extracts of C4104 Vadose Zone Sediments 


\subsubsection{Vadose Zone Porewater Chemical Composition}

The 1:1 water extract data was recalculated to derive the porewater composition of the vadose zone sediments. From knowledge of the moisture content of the sediment samples taken from the liners of each core, we calculated the amount of deionized water that would be needed to make the water extract exactly one part water (total of native porewater and added deionized water) to one part by weight dry sediment. The ratio of the total volume of water in the extract to the native mass of porewater is the dilution factor. We assume that the deionized water acts solely as a diluent of the existing porewater and that the deionized water does not dissolve any of the solids in the sediments. Thus by correcting for the dilution, we can estimate the actual chemical composition of the native porewater in the partially saturated vadose zone sediments.

The assumption that none of the solid is dissolved during the water extraction process is simplistic. In comparisons of actual porewater that was obtained via ultracentrifugation of vadose zone sediments to the dilution-corrected calculated porewaters from both contaminated and uncontaminated sediments from the SX and B-BX Tank Farms (see Serne et al. 2002b, 2002c, 2002d, 2002e, 2002f), we have found that for highly contaminated sediments, the comparison is quite good. For slightly contaminated or uncontaminated sediments, the dilution-corrected water extract data is biased high by a factor of 2 to 7 for many constituents such that the true porewater is less saline. The five C4104 vadose zone sediment samples that were ultra-centrifuged yielded actual porewater and these are also presented in the following tables and figures. Thus, for the C4104 data set we have five actual porewaters, obtained by the ultracentrifugation technique, to compare with the derived porewaters from the $1: 1$ sediment:water extracts.

Tables 4.24 through 4.27 and Figures 4.18 through 4.21 show the derived porewater composition of key constituents as a function of depth and stratigraphy. Two regions of the C4104 vadose profile contain high concentration porewater - on a total dissolved salts basis - 59 to 76 and $116 \mathrm{ft}$ bgs. The cation and anion balance in both zones is not good based upon calculating the milliequivalents of cations and anions from data shown in Tables 4.24 and 4.25. In the shallower depths, there are too many anions with the carbonate or alkalinity values appearing to be biased high; in the deeper sample there are too many cations with the calcium data being suspect. The uncharged-balanced porewater at these two depth zones is approximated by the following compositions that are based on the actual porewaters, samples 8A UFA and 20A UFA, which were obtained by ultracentrifugation. The shallow zone (between 59 and $76 \mathrm{ft} \mathrm{bgs)}$ is dominated by sodium and carbonate/bicarbonate alkalinity with the approximate composition, in meq/L of sodium ( 150), calcium (0.7), magnesium (0.6), potassium (1.2), alkalinity ( 220), nitrate (9.2), fluoride (6.4), sulfate (5.6), chloride (3.0), and phosphate (1.8) meq/L, respectively.

The deeper saline porewater is dominated by the divalent cations calcium and magnesium and the anions nitrate and nitrite and represents tank liquor in the ion exchange front that is pushing the divalent cations off sediment exchange sites. The actual porewater from the 20A core liner had a chemical composition of calcium (190), magnesium (125), sodium (110), and potassium (1.7) meq/L and nitrate (212), nitrite (40), sulfate (37), chloride (5), and bicarbonate alkalinity (6) meq/L, respectively. This concentration is very dilute compared to the vadose zone porewaters found at the SX and BX tank farms where the total ionic strength of the porewaters were as high as 7,000 to 17,000 and $1,000 \mathrm{meq} / \mathrm{L}$, respectively. At the borehole emplaced near tank B-110, the most saline porewater was 150 to $160 \mathrm{meq} / \mathrm{L}$. At the TX tank farm, the most saline porewater was found to be in borehole C3831, near tank TX-107, with a total ionic strength of 850 meq/L, about 350 meq/L greater than concentrations in C4104 
sediments. For further information, see detailed discussions on derived and actual vadose zone porewater concentrations in Serne et al. (2002b, 2002c, 2002d, 2002e, and 2004).

The maximum concentration of technetium-99 in the C4104 vadose zone porewaters is found between the depths of 115 to $124 \mathrm{ft}$ bgs. Concentrations range between 3.5 and 25 million $\mathrm{pCi} / \mathrm{L}$ and the agreement between the derived porewater and actual porewater concentrations are excellent. This range in porewater concentrations exceeds the drinking water standard by 3500 to 25,000 times. The whole sediment profile from $46 \mathrm{ft}$ bgs to the bottom of the borehole has derived porewater technetium-99 concentrations that exceed the drinking water standard by at least 40 times.

Vadose zone porewater in C4104 sediments between the depths of 46 and $93 \mathrm{ft}$ bgs contain elevated levels of soluble uranium at concentrations greater than $1 \mathrm{mg} / \mathrm{L}$ (ppm). The agreement between the derived porewater concentrations and actual porewater is good for the $64 \mathrm{ft}$ bgs sample, but for all other comparisons the actual porewater concentrations are about one third as large as the derived porewaters (based on dilution correction of the 1:1 water extracts). The discrepancy likely is caused by the presence of readily soluble uranium precipitates or releasable uranium on surface adsorption sites that solubilize during the extraction process. The Hanford tank leak-derived uranium in the C4104 vadose zone is not as mobile as constituents such as technetium-99, ruthenium, chromium, and molybdenum. The C4104 vadose zone porewater chromium is most elevated between the depths of 76 to $116 \mathrm{ft}$ bgs. Peak porewater chromium concentrations range from 4 to $45 \mathrm{mg} / \mathrm{L}$ (ppm), and range between 80 and 1000 times larger than the drinking water standard. The actual porewater chromium concentrations are 1.5 to 2.5 times lower than the derived porewater concentrations signifying some of the chromium is sequestered in the sediments in an easily extractable form. The molybdenum and ruthenium porewater concentrations are highest between 94 and $115 \mathrm{ft}$ bgs but are somewhat variable. The actual porewater concentrations are somewhat lower than the derived porewater concentrations but not as disparate as the uranium and chromium comparisons. The ICP-MS data for the three molybdenum and ruthenium isotopes vary considerably because the instrument software and standards used to calibrate the instrument assume that the relative abundances of each isotope is the same as is naturally found, whereas during the fission process unnatural percentages of stable isotopes are generated. Thus, much of the variation in calculated concentrations of total molybdenum and ruthenium, based on each isotope, is an indication that fission-generated molybdenum and ruthenium are present. More detailed analysis of our raw data for fission product elements, where several stable isotopes are available, may be performed by "isotope signature" experts in the future to evaluate the percentages of the water-extractable isotopes that are natural versus fission produced. Such information may be able to aid in identifying the sources (e.g., which tank was the source of the fluids). 
Table 4.24. Calculated and Actual Porewater Cation Concentrations in C4104 Vadose Zone Sediments

\begin{tabular}{|c|c|c|c|c|c|c|c|c|}
\hline Sample No. & $\begin{array}{c}\text { Depth } \\
\text { (ft bgs) }\end{array}$ & Stratigraphic Unit & $\begin{array}{c}\text { Mg } \\
\mathrm{mg} / \mathrm{L}\end{array}$ & $\begin{array}{c}\text { Ca } \\
\text { mg/L }\end{array}$ & $\begin{array}{c}\mathrm{Sr} \\
\mu \mathrm{g} / \mathrm{L}\end{array}$ & $\begin{array}{c}\text { Ba } \\
\mathrm{mg} / \mathrm{L}\end{array}$ & $\begin{array}{c}\mathrm{Na} \\
\mathrm{mg} / \mathrm{L}\end{array}$ & $\begin{array}{c}\mathrm{K} \\
\mathrm{mg} / \mathrm{L}\end{array}$ \\
\hline $1 \mathrm{~A}$ & 16.18 & Bckfl & $4.0 \mathrm{E}+01$ & $1.5 \mathrm{E}+02$ & $8.6 \mathrm{E}+02$ & 3.2E-01 & $1.8 \mathrm{E}+02$ & $(6.0 \mathrm{E}+01)$ \\
\hline $2 \mathrm{~A}$ & 22.69 & Bckfl & $1.5 \mathrm{E}+01$ & $6.4 \mathrm{E}+01$ & $(4.1 \mathrm{E}+02)$ & 5.3E-01 & $5.8 \mathrm{E}+02$ & $(7.1 \mathrm{E}+01)$ \\
\hline $3 \mathrm{~A}$ & 30.74 & Bckfl & $1.8 \mathrm{E}+01$ & $5.7 \mathrm{E}+01$ & $(3.8 \mathrm{E}+02)$ & $2.8 \mathrm{E}-01$ & $4.3 \mathrm{E}+02$ & $(4.3 \mathrm{E}+01)$ \\
\hline $4 \mathrm{~A}$ & 36.88 & Bckfl & $3.3 \mathrm{E}+01$ & $2.5 \mathrm{E}+02$ & $1.1 \mathrm{E}+03$ & $3.2 \mathrm{E}-01$ & $5.4 \mathrm{E}+02$ & $(9.1 \mathrm{E}+01)$ \\
\hline 4 (NOSE CONE) & 37.40 & Bckfl & $1.0 \mathrm{E}+01$ & $4.2 \mathrm{E}+01$ & $(4.9 \mathrm{E}+01)$ & $(1.6 \mathrm{E}-01)$ & $3.2 \mathrm{E}+02$ & $(4.3 \mathrm{E}+01)$ \\
\hline $5 \mathrm{~A}$ & 40.01 & Bckfl & $8.8 \mathrm{E}+00$ & $3.0 \mathrm{E}+01$ & $(1.1 \mathrm{E}+01)$ & $(9.4 \mathrm{E}-02)$ & $2.4 \mathrm{E}+03$ & $(8.0 \mathrm{E}+01)$ \\
\hline $5 \mathrm{~A}$ dup & 40.01 & Bckfl & $(3.1 \mathrm{E}+00)$ & $1.3 \mathrm{E}+01$ & $(1.4 \mathrm{E}+02)$ & $1.3 \mathrm{E}-01$ & $1.3 \mathrm{E}+03$ & $(4.1 \mathrm{E}+01)$ \\
\hline $6 \mathrm{~B}$ & 46.33 & $\mathrm{H} 2$ & $4.3 \mathrm{E}+01$ & $5.2 \mathrm{E}+01$ & $(1.4 \mathrm{E}+01)$ & $(9.8 \mathrm{E}-01)$ & $4.2 \mathrm{E}+03$ & $(1.3 \mathrm{E}+02)$ \\
\hline $6 \mathrm{~A}$ & 46.98 & $\mathrm{H} 2$ & $(1.8 \mathrm{E}+00)$ & $1.3 \mathrm{E}+01$ & $(1.5 \mathrm{E}+02)$ & $2.5 \mathrm{E}-01$ & $5.4 \mathrm{E}+03$ & $(4.7 \mathrm{E}+01)$ \\
\hline $7 \mathrm{~B}$ & 58.39 & $\mathrm{H} 2$ & $(1.8 \mathrm{E}+00)$ & $(8.8 \mathrm{E}+00)$ & $(5.6 \mathrm{E}+00)$ & $(8.8 \mathrm{E}-02)$ & $3.6 \mathrm{E}+03$ & $(4.8 \mathrm{E}+01)$ \\
\hline 7B Dup & 58.39 & $\mathrm{H} 2$ & $2.6 \mathrm{E}+01$ & $2.0 \mathrm{E}+01$ & $(1.6 \mathrm{E}+01)$ & $(5.9 \mathrm{E}-01)$ & $4.2 \mathrm{E}+03$ & $(7.2 \mathrm{E}+01)$ \\
\hline $7 \mathrm{~A}$ & 59.09 & $\mathrm{H} 2$ & $(1.8 \mathrm{E}+00)$ & $2.9 \mathrm{E}+01$ & $(2.0 \mathrm{E}+02)$ & 4.4E-01 & $5.8 \mathrm{E}+03$ & $(4.3 \mathrm{E}+01)$ \\
\hline $8 B$ & 63.38 & $\mathrm{H} 2$ & $5.1 \mathrm{E}+00$ & $2.2 \mathrm{E}+01$ & $(9.9 \mathrm{E}+00)$ & $(1.4 \mathrm{E}-01)$ & $5.0 \mathrm{E}+03$ & $(5.4 \mathrm{E}+01)$ \\
\hline 8A UFA & 64.03 & $\mathrm{H} 2$ & $(7.7 E+00)$ & $(1.5 E+01)$ & $(3.6 E+02)$ & (8.0E-02) & $3.46 \mathrm{E}+03$ & $(4.6 E+01)$ \\
\hline $8 \mathrm{~A}$ & 64.03 & $\mathrm{H} 2$ & $(1.6 \mathrm{E}+00)$ & $2.0 \mathrm{E}+01$ & $(1.1 \mathrm{E}+02)$ & 4.7E-01 & $5.9 \mathrm{E}+03$ & $(4.6 \mathrm{E}+01)$ \\
\hline 8A Dup & 64.03 & $\mathrm{H} 2$ & $(1.3 \mathrm{E}+00)$ & $1.7 \mathrm{E}+01$ & $(1.1 \mathrm{E}+02)$ & 7.2E-01 & $5.5 \mathrm{E}+03$ & $(4.3 \mathrm{E}+01)$ \\
\hline $9 \mathrm{~A}$ & 76.03 & $\mathrm{H} 2$ & $(2.5 \mathrm{E}+00)$ & $1.4 \mathrm{E}+01$ & $(1.1 \mathrm{E}+02)$ & $4.8 \mathrm{E}-01$ & $5.2 \mathrm{E}+03$ & $(4.8 \mathrm{E}+01)$ \\
\hline $10 \mathrm{~A}$ & 81.04 & $\mathrm{CCU}_{\mathrm{u}}$ & $(2.7 \mathrm{E}+00)$ & $1.0 \mathrm{E}+01$ & $(6.3 E+01)$ & $1.4 \mathrm{E}-01$ & $2.0 \mathrm{E}+03$ & $(2.4 \mathrm{E}+01)$ \\
\hline
\end{tabular}


Table 4.24. (contd)

\begin{tabular}{|c|c|c|c|c|c|c|c|c|}
\hline Sample No. & $\begin{array}{c}\text { Depth } \\
\text { (ft bgs) }\end{array}$ & Stratigraphic Unit & $\begin{array}{c}\mathrm{Mg} \\
\mathrm{mg} / \mathrm{L}\end{array}$ & $\begin{array}{c}\mathrm{Ca} \\
\mathrm{mg} / \mathrm{L}\end{array}$ & $\begin{array}{c}\mathrm{Sr} \\
\mu \mathrm{g} / \mathrm{L}\end{array}$ & $\begin{array}{c}\text { Ba } \\
\mathrm{mg} / \mathrm{L}\end{array}$ & $\begin{array}{c}\mathrm{Na} \\
\mathrm{mg} / \mathrm{L}\end{array}$ & $\begin{array}{c}\mathrm{K} \\
\mathrm{mg} / \mathrm{L}\end{array}$ \\
\hline 11A UFA & 87.35 & $\mathrm{CCU}_{\mathrm{u}}$ & $1.49 \mathrm{E}+01$ & 6.17E+01 & $(2.9 E+02)$ & (5.0E-02) & $1.67 E+03$ & $1.4 \mathrm{E}+01$ \\
\hline $11 \mathrm{~A}$ & 87.35 & $\mathrm{CCU}_{\mathrm{u}}$ & $3.5 \mathrm{E}+00$ & $1.6 \mathrm{E}+01$ & $(9.6 \mathrm{E}+01)$ & $1.4 \mathrm{E}-01$ & $1.8 \mathrm{E}+03$ & $(1.7 \mathrm{E}+01)$ \\
\hline 11A Dup & 87.35 & $\mathrm{CCU}_{\mathrm{u}}$ & $3.7 \mathrm{E}+00$ & $1.7 \mathrm{E}+01$ & $(1.0 \mathrm{E}+02)$ & 7.9E-02 & $1.9 \mathrm{E}+03$ & $(1.9 \mathrm{E}+01)$ \\
\hline $12 \mathrm{~A}$ & 92.61 & $\mathrm{CCU}_{\mathrm{l}}$ & $4.5 \mathrm{E}+00$ & $2.9 \mathrm{E}+01$ & $(1.6 \mathrm{E}+02)$ & 2.2E-01 & $3.7 \mathrm{E}+03$ & $(3.1 \mathrm{E}+01)$ \\
\hline 13A UFA & 93.56 & $\mathrm{CCU}_{\mathrm{l}}$ & $3.66 \mathrm{E}+01$ & $1.16 \mathrm{E}+02$ & $(6.7 E+02)$ & (5.7E-02) & $2.51 E+03$ & $(1.7 E+01)$ \\
\hline $13 \mathrm{~A}$ & 93.56 & $\mathrm{CCU}_{\mathrm{l}}$ & $2.1 \mathrm{E}+01$ & $8.1 \mathrm{E}+01$ & $4.1 \mathrm{E}+02$ & $1.7 \mathrm{E}-01$ & $3.7 \mathrm{E}+03$ & $(3.8 \mathrm{E}+01)$ \\
\hline $14 \mathrm{~A}$ & 94.67 & $\mathrm{CCU}_{1}$ & $1.6 \mathrm{E}+01$ & $7.7 \mathrm{E}+01$ & $3.7 \mathrm{E}+02$ & $1.6 \mathrm{E}-01$ & $3.7 \mathrm{E}+03$ & $(4.4 \mathrm{E}+01)^{(\mathrm{a})}$ \\
\hline 15B & 99.70 & $\mathrm{CCU}_{1}$ & $3.1 \mathrm{E}+01$ & $8.7 \mathrm{E}+01$ & $(4.5 \mathrm{E}+01)$ & $(1.4 \mathrm{E}-01)$ & $2.1 \mathrm{E}+03$ & $(3.8 \mathrm{E}+01)$ \\
\hline $15 \mathrm{~A}$ & 100.37 & $\mathrm{CCU}_{\mathrm{l}}$ & $4.4 \mathrm{E}+01$ & $1.6 \mathrm{E}+02$ & $8.5 \mathrm{E}+02$ & $5.2 \mathrm{E}-01$ & $3.8 \mathrm{E}+03$ & $(6.4 \mathrm{E}+01)$ \\
\hline $16 B$ & 101.33 & $\mathrm{CCU}_{\mathrm{l}}$ & $2.5 \mathrm{E}+01$ & $8.1 \mathrm{E}+01$ & $(5.1 \mathrm{E}+01)$ & $(1.6 \mathrm{E}-01)$ & $2.7 \mathrm{E}+03$ & $(3.2 \mathrm{E}+01)$ \\
\hline $16 \mathrm{~A}$ & 101.98 & $\mathrm{CCU}_{1}$ & $3.3 \mathrm{E}+01$ & $9.8 \mathrm{E}+01$ & $5.8 \mathrm{E}+02$ & $1.3 \mathrm{E}-01$ & $1.9 \mathrm{E}+03$ & $(3.3 \mathrm{E}+01)$ \\
\hline 17B & 105.39 & $\mathrm{CCU}_{\mathrm{l}}$ & $3.4 \mathrm{E}+01$ & $9.5 \mathrm{E}+01$ & $(4.6 \mathrm{E}+01)$ & $(1.6 \mathrm{E}-01)$ & $2.3 \mathrm{E}+03$ & $(4.0 \mathrm{E}+01)$ \\
\hline $17 \mathrm{~A}$ & 106.09 & $\mathrm{CCU}_{\mathrm{I}}$ & $3.5 \mathrm{E}+01$ & $1.0 \mathrm{E}+02$ & $6.3 \mathrm{E}+02$ & 3.2E-01 & $2.0 \mathrm{E}+03$ & $(4.6 \mathrm{E}+01)$ \\
\hline $18 \mathrm{~A}$ & 107.42 & $\mathrm{CCU}_{1}$ & $2.5 \mathrm{E}+01$ & $7.1 \mathrm{E}+01$ & $4.7 \mathrm{E}+02$ & $5.6 \mathrm{E}-01$ & $2.7 \mathrm{E}+03$ & $(4.5 \mathrm{E}+01)$ \\
\hline $19 \mathrm{~A}$ & 110.98 & $\mathrm{R}_{\mathrm{tf}}$ & $8.1 \mathrm{E}+01$ & $2.7 \mathrm{E}+02$ & $1.4 \mathrm{E}+03$ & $1.5 \mathrm{E}-01$ & $3.1 \mathrm{E}+03$ & $(5.3 \mathrm{E}+01)$ \\
\hline 19A Dup & 110.98 & $\mathrm{R}_{\mathrm{tf}}$ & $1.0 \mathrm{E}+02$ & $3.4 \mathrm{E}+02$ & $1.7 \mathrm{E}+03$ & $2.1 \mathrm{E}-01$ & $4.3 \mathrm{E}+03$ & $(7.4 \mathrm{E}+01)$ \\
\hline $20 \mathrm{~B}$ & 115.25 & $\mathrm{R}_{\mathrm{tf}}$ & $3.0 \mathrm{E}+02$ & $7.5 \mathrm{E}+02$ & $8.4 \mathrm{E}+02$ & (2.2E-01) & $2.6 \mathrm{E}+03$ & $(8.1 \mathrm{E}+01)$ \\
\hline 20A UFA & 116.02 & $\mathrm{R}_{\mathrm{tf}}$ & $1.52 \mathrm{E}+03^{(\mathrm{b})}$ & $3.81 E+03$ & $2.3 E+04$ & (1.6E-01) & $2.54 E+03$ & $6.6 \mathrm{E}+01$ \\
\hline
\end{tabular}


Table 4.24. (contd)

\begin{tabular}{|c|c|c|c|c|c|c|c|c|}
\hline Sample No. & $\begin{array}{c}\text { Depth } \\
\text { (ft bgs) }\end{array}$ & Stratigraphic Unit & $\begin{array}{c}\mathrm{Mg} \\
\mathrm{mg} / \mathrm{L}\end{array}$ & $\begin{array}{c}\mathrm{Ca} \\
\mathrm{mg} / \mathrm{L}\end{array}$ & $\begin{array}{c}\mathrm{Sr} \\
\mu \mathrm{g} / \mathrm{L}\end{array}$ & $\begin{array}{c}\text { Ba } \\
\mathrm{mg} / \mathrm{L}\end{array}$ & $\begin{array}{c}\mathrm{Na} \\
\mathrm{mg} / \mathrm{L}\end{array}$ & $\begin{array}{c}\mathrm{K} \\
\mathrm{mg} / \mathrm{L}\end{array}$ \\
\hline $20 \mathrm{~A}$ & 116.02 & $\mathrm{R}_{\mathrm{tf}}$ & $1.3 \mathrm{E}+03$ & $3.3 \mathrm{E}+03$ & $2.0 \mathrm{E}+04$ & $3.0 \mathrm{E}-01$ & $2.5 E+03$ & $1.03 \mathrm{E}+02$ \\
\hline $21 B$ & 120.30 & $\mathrm{R}_{\mathrm{tf}}$ & $3.4 \mathrm{E}+02$ & $9.5 \mathrm{E}+02$ & $7.5 \mathrm{E}+02$ & $(1.1 \mathrm{E}+00)$ & $1.4 \mathrm{E}+02$ & $(7.2 \mathrm{E}+01)$ \\
\hline 21A UFA & 120.97 & $\mathrm{R}_{\mathrm{wi}}$ & $3.68 \mathrm{E}+02$ & $1.08 \mathrm{E}+03$ & $6.9 \mathrm{E}+03$ & (3.7E-01) & $1.75 E+02$ & $(3.2 \mathrm{E}+01)$ \\
\hline $21 \mathrm{~A}$ & 120.97 & $\mathrm{R}_{\mathrm{wi}}$ & $3.7 \mathrm{E}+02$ & $1.1 \mathrm{E}+03$ & $7.2 \mathrm{E}+03$ & $1.1 \mathrm{E}+00$ & $9.6 \mathrm{E}+01$ & $(6.1 \mathrm{E}+01)$ \\
\hline $22 \mathrm{~B}$ & 123.32 & $\mathrm{R}_{\mathrm{wi}}$ & $6.9 \mathrm{E}+02$ & $1.6 \mathrm{E}+03$ & $2.9 \mathrm{E}+02$ & $(2.4 \mathrm{E}+00)$ & $1.0 \mathrm{E}+03$ & $(2.4 \mathrm{E}+02)$ \\
\hline $22 \mathrm{~A}$ & 124.05 & $\mathrm{R}_{\mathrm{wi}}$ & $4.0 \mathrm{E}+02$ & $1.2 \mathrm{E}+03$ & $9.2 \mathrm{E}+03$ & $2.2 \mathrm{E}+00$ & $3.4 \mathrm{E}+02$ & $(1.3 \mathrm{E}+02)$ \\
\hline $23 \mathrm{~A}$ & 127.13 & $\mathrm{R}_{\mathrm{wi}}$ & $1.8 \mathrm{E}+02$ & $5.4 \mathrm{E}+02$ & $5.3 \mathrm{E}+03$ & $1.8 \mathrm{E}+00$ & $6.6 \mathrm{E}+02$ & $(1.4 \mathrm{E}+02)$ \\
\hline $\begin{array}{l}\text { Parenth } \\
\text { Bold val }\end{array}$ & $\begin{array}{l}\text { nify valu } \\
\text { gnate the }\end{array}$ & ow level of quantitati & $\begin{array}{l}\text { but consid } \\
\text { d by ultrac }\end{array}$ & $\begin{array}{l}\text { valid. } \\
\text { ifugation }\end{array}$ & he sediment & & & \\
\hline
\end{tabular}


Table 4.25. Calculated and Actual Porewater Anion Concentrations in C4104 Vadose Zone Sediments

\begin{tabular}{|c|c|c|c|c|c|c|c|c|c|c|}
\hline Sample & $\begin{array}{c}\text { Depth } \\
\text { (ft bgs) }\end{array}$ & $\begin{array}{c}\text { Fluoride } \\
\text { mg/L }\end{array}$ & $\begin{array}{c}\text { Chloride } \\
\text { mg/L }\end{array}$ & $\begin{array}{l}\text { Nitrate } \\
\text { mg/L }\end{array}$ & $\begin{array}{c}\mathrm{CO}_{3} \\
\mathrm{mg} / \mathrm{L}\end{array}$ & $\begin{array}{c}\text { Alk } \\
\text { mg/L }\end{array}$ & $\begin{array}{l}\text { Sulfate } \\
\text { mg/L }\end{array}$ & $\begin{array}{c}\text { Phosphate } \\
\text { mg/L }\end{array}$ & $\begin{array}{c}\text { Nitrite } \\
\text { mg/L }\end{array}$ & $\begin{array}{c}\text { Oxalate } \\
\text { mg/L }\end{array}$ \\
\hline $1 \mathrm{~A}$ & 16.18 & 10.87 & 5.83 & 34.83 & $<744.107$ & 907.57 & 47.59 & 4.17 & $<3.721$ & $<2.975$ \\
\hline $2 \mathrm{~A}$ & 22.69 & 12.3 & 4.04 & 41.49 & 1369.08 & 1414.90 & 53.34 & 60.76 & $<3.817$ & 3.7 \\
\hline $3 \mathrm{~A}$ & 30.74 & 12.89 & 9.02 & 18.61 & 1004.79 & 992.21 & 97.11 & $<2.706$ & $<2.632$ & 3.32 \\
\hline $4 \mathrm{~A}$ & 36.88 & 6 & 557.09 & 7.52 & $<476.015$ & 452.40 & 716.47 & $<2.447$ & $<2.380$ & $<1.903$ \\
\hline 4 (Nose Cone) & 37.40 & 5.90 & 29.61 & 4.54 & 520.20 & 527.00 & 196.36 & $<3.01$ & $<2.69$ & $<2.06$ \\
\hline $5 \mathrm{~A}$ & 40.01 & 34.07 & 48.24 & 30.73 & 6427.54 & 3930.25 & 574.55 & 18.20 & $<13.15$ & $<10.06$ \\
\hline 5A dup & 40.01 & 12.06 & 8.78 & 31.96 & 2977.21 & 2777.45 & 92.93 & 12.83 & $<3.897$ & $<3.115$ \\
\hline $6 \mathrm{~B}$ & 46.33 & 47.87 & 110.17 & $<10.34$ & 8012.54 & 7017.11 & 696.21 & 23.02 & $<10.77$ & 38.97 \\
\hline $6 \mathrm{~A}$ & 46.98 & 39 & 21.96 & 105.03 & 12397.26 & 11496.31 & 231.11 & 43.27 & $<7.576$ & 9.64 \\
\hline $7 \mathrm{~B}$ & 58.39 & 62.23 & 89.14 & 48.89 & 7114.52 & 5554.70 & 762.20 & 35.65 & 8.39 & $<4.13$ \\
\hline 7B Dup & 58.39 & 71.81 & 85.03 & 67.24 & 8759.25 & 6390.71 & 784.72 & 41.09 & $<5.42$ & $<4.15$ \\
\hline $7 \mathrm{~A}$ & 59.09 & 65.76 & 27.61 & 171.29 & 12073.53 & 10910.91 & 333.1 & 63.88 & 11.48 & 9.68 \\
\hline $8 B$ & 63.38 & 103.80 & 119.88 & $<5.39$ & 9115.71 & 7775.60 & 768.79 & 65.62 & $<5.61$ & 162.92 \\
\hline 8A UFA & 64.03 & $122.70^{(a)}$ & 109.38 & 578.78 & ND & 6256.000 & 270.35 & $\mathbf{5 7 . 5 0}$ & 5.71 & 10.58 \\
\hline 8A UFA dup & 64.03 & 121.21 & 107.26 & 568.13 & ND & ND & 264.92 & 56.27 & 5.73 & 12.89 \\
\hline $8 \mathrm{~A}$ & 64.03 & 187.38 & 32.89 & 357.82 & 11601.67 & 11860.62 & 289.5 & 102.86 & 6.89 & 8.63 \\
\hline 8A Dup & 64.03 & 185.34 & 36.51 & 372.73 & 11677.33 & 10980.27 & 285.53 & 94.14 & 7.95 & 7.09 \\
\hline $9 \mathrm{~A}$ & 76.03 & 150.06 & 53.56 & 484.08 & 10609.23 & 9961.03 & 364.55 & 53.21 & $<4.898$ & 6.09 \\
\hline $10 \mathrm{~A}$ & 81.04 & 42.61 & 40.39 & 600.5 & 2737.36 & 2495.84 & 1166.62 & 8.86 & 3.69 & 2.4 \\
\hline 11A UFA & 87.35 & 0.81 & 28.08 & 1328.33 & ND & 283.560 & 2010.52 & 4.62 & 6.25 & 2.58 \\
\hline $11 \mathrm{~A}$ & 87.35 & 3.09 & 19.3 & 936.14 & 1205.94 & 1126.32 & 1822.6 & 9.62 & 4.13 & 2.37 \\
\hline 11A Dup & 87.35 & 2.79 & 22.51 & 1008.44 & 1096.41 & 1068.35 & 2010.2 & 8 & 3.87 & 1.85 \\
\hline $12 \mathrm{~A}$ & 92.61 & 22.03 & 19.4 & 1851.48 & 3159.96 & 3069.04 & 3261.36 & 7.78 & 2.59 & 20.95 \\
\hline
\end{tabular}


Table 4.25. (contd)

\begin{tabular}{|c|c|c|c|c|c|c|c|c|c|c|}
\hline Sample & $\begin{array}{c}\text { Depth } \\
\text { (ft bgs) }\end{array}$ & $\begin{array}{c}\text { Fluoride } \\
\text { mg/L }\end{array}$ & $\begin{array}{c}\text { Chloride } \\
\text { mg/L }\end{array}$ & $\begin{array}{c}\text { Nitrate } \\
\text { mg/L }\end{array}$ & $\begin{array}{r}\mathrm{CO}_{3} \\
\mathrm{mg} / \mathrm{L}\end{array}$ & $\begin{array}{c}\text { Alk } \\
\text { mg/L }\end{array}$ & $\begin{array}{c}\text { Sulfate } \\
\text { mg/L }\end{array}$ & $\begin{array}{c}\text { Phosphate } \\
\text { mg/L }\end{array}$ & $\begin{array}{c}\text { Nitrite } \\
\text { mg/L }\end{array}$ & $\begin{array}{c}\text { Oxalate } \\
\text { mg/L }\end{array}$ \\
\hline 13A UFA & 93.56 & 2.72 & 25.54 & 2728.47 & ND & 258.400 & 3158.98 & 7.58 & 5.85 & 2.94 \\
\hline $13 \mathrm{~A}$ & 93.56 & 17.1 & 25.3 & 2967.92 & 1709.62 & 1237.72 & 4405.37 & 11.96 & $<1.452$ & 1.71 \\
\hline $14 \mathrm{~A}$ & 94.67 & 19.26 & 36.94 & 3726.31 & 1221.23 & 1087.77 & 3802.53 & 5.75 & 2.28 & 6.52 \\
\hline $15 B$ & 99.70 & 24.02 & 32.69 & 2042.16 & 816.12 & 942.32 & 2183.30 & 7.09 & $<5.12$ & 4.97 \\
\hline $15 \mathrm{~A}$ & 100.37 & 16.81 & 41.65 & 3293.07 & 1286.36 & 1264.15 & 4195.61 & 16.81 & 8.4 & 6.53 \\
\hline $16 \mathrm{~B}$ & 101.33 & $<1.12$ & 22.28 & 1320.30 & 1328.54 & 1136.87 & ND & 14.98 & $<4.31$ & 3.93 \\
\hline 16A UFA & 101.98 & 2.87 & 70.05 & 2415.10 & ND & ND & 2746.83 & 5.78 & 15.25 & 2.93 \\
\hline $16 \mathrm{~A}$ & 101.98 & 11.51 & 14.92 & 1162.09 & 1013.59 & 832.90 & 2518.48 & 5.04 & $<1.212$ & 2.9 \\
\hline 17B & 105.39 & 25.48 & 34.60 & 2175.71 & 875.09 & 981.01 & 2324.54 & 8.61 & $<5.51$ & 5.17 \\
\hline $17 \mathrm{~A}$ & 106.09 & 15.42 & 25.2 & 2020.04 & 1271.77 & 1054.37 & 1633.74 & 3.47 & 4.56 & 18.4 \\
\hline $18 \mathrm{~A}$ & 107.42 & 28.58 & 28.3 & 1752.29 & 2566.7 & 2191.62 & 1938.85 & 15.98 & $<5.013$ & 4.57 \\
\hline $19 \mathrm{~A}$ & 110.98 & 4.42 & 36.32 & 3395.02 & 1133.24 & 539.83 & 4135.02 & 19.59 & 9.69 & 1.66 \\
\hline 19A Dup & 110.98 & 6.96 & 50.99 & 4443.75 & 1533.73 & 767.29 & 5515.2 & 18.87 & 13.26 & 2.29 \\
\hline $20 \mathrm{~B}$ & 115.25 & 4.32 & 142.41 & 6450.54 & $<247.11$ & 265.49 & 1963.87 & 12.24 & 77.44 & $<1.71$ \\
\hline 20A UFA & 116.02 & 0.54 & 177.49 & 13144.07 & ND & 163.880 & 1813.56 & $<2.570$ & 1783.28 & 28.95 \\
\hline $20 \mathrm{~A}$ & 116.02 & 1.58 & 180 & 10461.15 & $<203.928$ & 300.41 & 2325.54 & $<1.048$ & 1982.02 & 33.19 \\
\hline $21 \mathrm{~B}$ & 120.30 & 3.83 & 121.81 & 4606.81 & $<409.18$ & 283.81 & 164.28 & $<4.13$ & $<3.69$ & $<2.82$ \\
\hline 21A UFA & 120.97 & 0.56 & 133.13 & 4717.59 & ND & 190.400 & 100.42 & $<2.570$ & 17.51 & 1.49 \\
\hline $21 \mathrm{~A}$ & 120.97 & 2.21 & 139.67 & 4281.6 & $<298.135$ & 188.90 & 153.34 & $<1.532$ & 18.51 & $<1.192$ \\
\hline $22 B$ & 123.32 & 65.15 & 311.72 & 5446.45 & $<2467.48$ & 2382.60 & 1106.87 & $<24.92$ & $<22.26$ & 82.72 \\
\hline $22 \mathrm{~A}$ & 124.05 & 14.93 & 175.69 & 5279.57 & $<1077.085$ & 580.07 & 330.6 & $<5.536$ & $<5.385$ & $<4.306$ \\
\hline $23 \mathrm{~A}$ & 127.13 & 35.77 & 115.83 & 2672.7 & $<950.976$ & 738.11 & 451.35 & $<4.888$ & $<4.755$ & $<3.802$ \\
\hline
\end{tabular}


Table 4.26. Calculated and Actual Porewater Concentrations of Selected Constituents in C4104 Vadose Zone Sediments

\begin{tabular}{|c|c|c|c|c|c|c|c|c|c|}
\hline Sample & $\begin{array}{c}\text { Depth } \\
\text { (ft bgs) }\end{array}$ & $\begin{array}{c}\text { Al } \\
\mu g / L\end{array}$ & $\begin{array}{c}\mathrm{Si} \\
\mathrm{mg} / \mathrm{L}\end{array}$ & $\begin{array}{c}\mathrm{Fe} \\
\mu \mathrm{g} / \mathrm{L}\end{array}$ & $\begin{array}{c}\mathrm{Mn} \\
\mu \mathrm{g} / \mathrm{L}\end{array}$ & $\begin{array}{c}\mathrm{Zn} \\
\mathrm{mg} / \mathrm{L}\end{array}$ & $\begin{array}{c}\mathrm{PO}_{4} \text { (ICP) } \\
\mathrm{mg} / \mathrm{L}\end{array}$ & $\begin{array}{c}\mathrm{SO}_{4}(\mathrm{ICP}) \\
\mathrm{mg} / \mathrm{L}\end{array}$ & $\begin{array}{c}\mathrm{Ni} \\
\mathrm{mg} / \mathrm{L}\end{array}$ \\
\hline $1 \mathrm{~A}$ & 16.18 & $(4.6 \mathrm{E}+02)^{(\mathrm{a})}$ & $1.9 \mathrm{E}+02$ & $7.8 \mathrm{E}+02$ & $1.9 \mathrm{E}+02$ & $(6.4 \mathrm{E}-01)$ & $7.12 \mathrm{E}+00$ & $5.74 \mathrm{E}+01$ & $1.2 \mathrm{E}+00$ \\
\hline $2 \mathrm{~A}$ & 22.69 & $(8.4 \mathrm{E}+02)$ & $1.9 \mathrm{E}+02$ & $1.8 \mathrm{E}+03$ & $1.9 \mathrm{E}+02$ & $(1.1 \mathrm{E}+00)$ & $6.93 \mathrm{E}+01$ & $4.79 \mathrm{E}+01$ & 9.2E-01 \\
\hline $3 \mathrm{~A}$ & 30.74 & $(4.1 \mathrm{E}+02)$ & $1.4 \mathrm{E}+02$ & $3.4 \mathrm{E}+03$ & $1.2 \mathrm{E}+02$ & $(5.0 \mathrm{E}-01)$ & $2.57 \mathrm{E}+00$ & $1.04 \mathrm{E}+02$ & 5.6E-01 \\
\hline $4 \mathrm{~A}$ & 36.88 & $(9.7 \mathrm{E}+01)$ & $8.1 \mathrm{E}+01$ & $(2.7 \mathrm{E}+02)$ & $1.6 \mathrm{E}+02$ & $(4.0 \mathrm{E}-01)$ & $2.09 \mathrm{E}+00$ & $6.95 \mathrm{E}+02$ & $(4.5 \mathrm{E}-01)$ \\
\hline 4 (Nose Cone) & 37.40 & $(2.7 \mathrm{E}+02)$ & $(4.1 \mathrm{E}+01)$ & $(2.0 \mathrm{E}+02)$ & $\mathrm{ND}^{(\mathrm{b})}$ & $(2.4 \mathrm{E}-01)$ & ND & $2.00 \mathrm{E}+02$ & $(1.2 \mathrm{E}-01)$ \\
\hline $5 \mathrm{~A}$ & 40.01 & $3.2 \mathrm{E}+03$ & $(2.3 \mathrm{E}+02)$ & $(5.0 \mathrm{E}+03)$ & ND & $(1.1 \mathrm{E}+00)$ & $2.07 \mathrm{E}+01$ & $4.67 \mathrm{E}+02$ & (3.3E-01) \\
\hline 5A dup & 40.01 & $(1.1 \mathrm{E}+03)$ & $1.9 \mathrm{E}+02$ & $(6.7 \mathrm{E}+02)$ & $8.2 \mathrm{E}+01$ & $(5.8 \mathrm{E}-01)$ & $1.90 \mathrm{E}+01$ & $9.78 \mathrm{E}+01$ & (5.3E-01) \\
\hline $6 \mathrm{~B}$ & 46.33 & $8.2 \mathrm{E}+04$ & $(4.8 \mathrm{E}+02)$ & $1.4 \mathrm{E}+05$ & $(1.4 \mathrm{E}+03)$ & $(1.0 \mathrm{E}+00)$ & $3.71 \mathrm{E}+01$ & $8.96 \mathrm{E}+02$ & $(7.6 \mathrm{E}-01)$ \\
\hline $6 \mathrm{~A}$ & 46.98 & $9.3 E+03$ & $4.0 \mathrm{E}+02$ & $5.1 \mathrm{E}+03$ & $2.1 \mathrm{E}+02$ & $(1.0 \mathrm{E}+00)$ & $5.52 \mathrm{E}+01$ & $2.20 \mathrm{E}+02$ & $(1.1 \mathrm{E}+00)$ \\
\hline 7B & 58.39 & $1.7 \mathrm{E}+03$ & $(1.2 \mathrm{E}+02)$ & $(6.4 \mathrm{E}+02)$ & $(7.2 E+01)$ & $(2.5 \mathrm{E}-01)$ & $3.70 \mathrm{E}+01$ & $7.94 \mathrm{E}+02$ & $(9.7 \mathrm{E}-01)$ \\
\hline 7B Dup & 58.39 & $6.9 \mathrm{E}+04$ & $(3.4 \mathrm{E}+02)$ & $1.0 \mathrm{E}+05$ & $(1.2 \mathrm{E}+03)$ & $(6.7 \mathrm{E}-01)$ & $4.50 \mathrm{E}+01$ & $7.98 \mathrm{E}+02$ & $(1.0 \mathrm{E}+00)$ \\
\hline $7 \mathrm{~A}$ & 59.09 & $(5.3 E+03)$ & $3.2 \mathrm{E}+02$ & $6.4 \mathrm{E}+03$ & $3.4 \mathrm{E}+02$ & $(1.4 \mathrm{E}+00)$ & $8.05 E+01$ & $3.31 \mathrm{E}+02$ & $(7.2 \mathrm{E}-01)$ \\
\hline $8 \mathrm{~B}$ & 63.38 & $5.7 \mathrm{E}+03$ & $(1.5 \mathrm{E}+02)$ & $1.1 \mathrm{E}+04$ & $(8.3 E+02)$ & $(1.2 \mathrm{E}+00)$ & $7.38 \mathrm{E}+01$ & $8.19 \mathrm{E}+02$ & $(2.7 \mathrm{E}+00)$ \\
\hline 8A UFA & 64.03 & $(3.4 \mathrm{E}+01)^{(\mathrm{c})}$ & ND & $(2.7 \mathrm{E}+03)$ & ND & $(1.26 E+01)$ & $(7.23 E+01)$ & $(3.19 \mathrm{E}+02)$ & $(4.37 E+00)$ \\
\hline $8 \mathrm{~A}$ & 64.03 & $(2.7 \mathrm{E}+03)$ & $3.3 \mathrm{E}+02$ & $4.7 \mathrm{E}+03$ & $4.4 \mathrm{E}+02$ & $(7.1 \mathrm{E}-01)$ & $1.24 \mathrm{E}+02$ & $2.91 \mathrm{E}+02$ & $1.0 \mathrm{E}+00$ \\
\hline 8A Dup & 64.03 & $(2.5 E+03)$ & $3.0 \mathrm{E}+02$ & $3.8 \mathrm{E}+03$ & $3.4 \mathrm{E}+02$ & $2.5 \mathrm{E}+00$ & $1.05 \mathrm{E}+02$ & $2.69 \mathrm{E}+02$ & (7.7E-01) \\
\hline $9 \mathrm{~A}$ & 76.03 & $(1.8 \mathrm{E}+03)$ & $3.6 \mathrm{E}+02$ & $1.1 \mathrm{E}+03$ & $1.1 \mathrm{E}+02$ & $(1.7 \mathrm{E}+00)$ & $5.81 \mathrm{E}+01$ & $3.35 E+02$ & $(5.0 \mathrm{E}-01)$ \\
\hline $10 \mathrm{~A}$ & 81.04 & $(3.1 \mathrm{E}+02)$ & $1.4 \mathrm{E}+02$ & $9.2 \mathrm{E}+02$ & $1.9 \mathrm{E}+02$ & $1.2 \mathrm{E}+00$ & $1.23 \mathrm{E}+01$ & $1.10 \mathrm{E}+03$ & 6.2E-01 \\
\hline 11A UFA & 87.35 & $3.7 \mathrm{E}+03$ & 53.136178 & $6.9 \mathrm{E}+03$ & $1.3 \mathrm{E}+03$ & $1.33 E+00$ & $(1.99 \mathrm{E}+00)$ & $2.12 E+03$ & $1.57 \mathrm{E}+00$ \\
\hline $11 \mathrm{~A}$ & 87.35 & $(8.8 \mathrm{E}+02)$ & $6.3 \mathrm{E}+01$ & $1.3 \mathrm{E}+04$ & $1.4 \mathrm{E}+03$ & $1.2 \mathrm{E}+00$ & $1.24 \mathrm{E}+01$ & $1.87 \mathrm{E}+03$ & $1.2 \mathrm{E}+00$ \\
\hline 11A Dup & 87.35 & $(4.3 E+02)$ & $5.3 \mathrm{E}+01$ & $1.3 \mathrm{E}+04$ & $2.1 \mathrm{E}+03$ & 9.7E-01 & $9.24 \mathrm{E}+00$ & $1.92 \mathrm{E}+03$ & $1.1 \mathrm{E}+00$ \\
\hline $12 \mathrm{~A}$ & 92.61 & $(1.8 \mathrm{E}+02)$ & $1.0 \mathrm{E}+02$ & $1.4 \mathrm{E}+04$ & $1.4 \mathrm{E}+03$ & $1.4 \mathrm{E}+00$ & $1.37 \mathrm{E}+01$ & $3.10 \mathrm{E}+03$ & $2.1 \mathrm{E}+00$ \\
\hline 13A UFA & 93.56 & $(6.9 E+01)$ & 22.855933 & $(1.8 E+03)$ & $(1.6 E+03)$ & $6.42 \mathrm{E}+00$ & ND & $3.07 E+03$ & $(3.81 E+00)$ \\
\hline $13 \mathrm{~A}$ & 93.56 & $(3.1 \mathrm{E}+02)$ & $2.1 \mathrm{E}+02$ & $1.9 \mathrm{E}+03$ & $3.0 \mathrm{E}+03$ & $1.3 \mathrm{E}+00$ & $1.87 \mathrm{E}+00$ & $4.20 \mathrm{E}+03$ & $5.1 \mathrm{E}+00$ \\
\hline
\end{tabular}


Table 4.26. (contd)

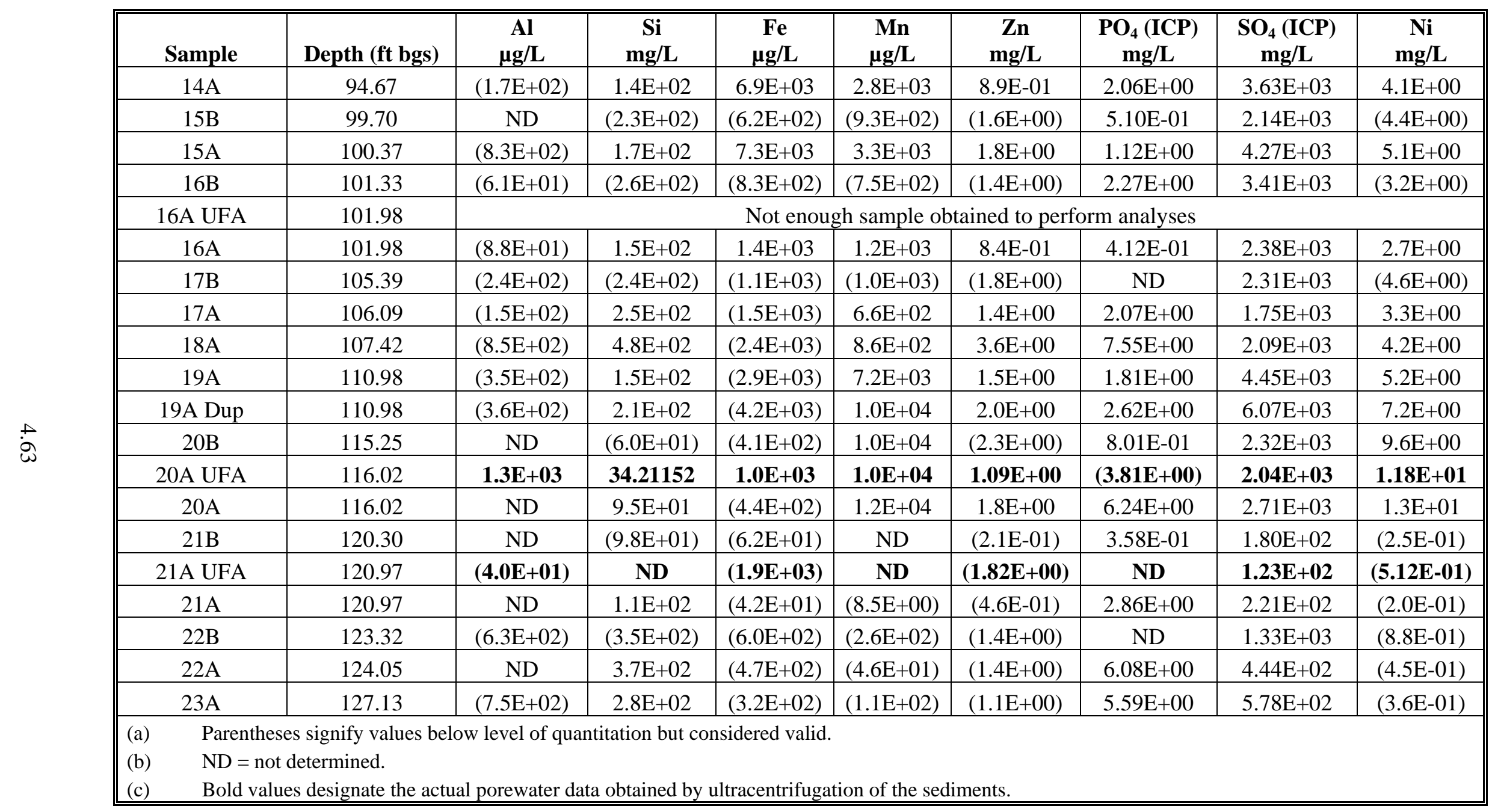


Table 4.27. Calculated and Actual Porewater Concentrations of Potentially Mobile Constituents in C4104 Vadose Sediments

\begin{tabular}{|c|c|c|c|c|c|c|c|c|c|c|c|c|}
\hline \multicolumn{2}{|c|}{ Units } & \multirow{2}{*}{$\begin{array}{c}\text { pCi/L } \\
\text { Tc-99 }^{(a)} \\
(\text { ICP-MS) }\end{array}$} & \multirow{2}{*}{$\begin{array}{c}\mu \mathrm{g} / \mathrm{L} \\
\mathrm{U}-238 \\
(\mathrm{ICP}-\mathrm{MS})\end{array}$} & \multirow{2}{*}{$\begin{array}{c}\mu \mathrm{g} / \mathrm{L} \\
\mathrm{Cr} \\
\text { ICP-OES }\end{array}$} & \multirow{2}{*}{$\begin{array}{c}\mu \mathrm{g} / \mathrm{L} \\
\mathrm{Cr} \\
(\mathrm{ICP}-\mathrm{MS})\end{array}$} & \multirow{2}{*}{$\begin{array}{c}\mu \mathrm{g} / \mathrm{L} \\
\text { Mo } \\
\text { ICP-OES }\end{array}$} & \multirow{2}{*}{$\begin{array}{c}\mu \mathrm{g} / \mathrm{L} \\
\text { Mo } 95 \\
\text { (ICP-MS) }\end{array}$} & \multirow{2}{*}{$\begin{array}{c}\mu \mathrm{g} / \mathrm{L} \\
\text { Mo } 98 \\
\text { (ICP-MS) }\end{array}$} & \multirow{2}{*}{$\begin{array}{c}\mu \mathrm{g} / \mathrm{L} \\
\text { Mo 100 } \\
\text { (ICP-MS) }\end{array}$} & \multirow{2}{*}{$\begin{array}{c}\mu \mathrm{g} / \mathrm{L} \\
\text { Ru 101 } \\
\text { (ICP-MS) }\end{array}$} & \multirow{2}{*}{$\begin{array}{c}\mu g / L \\
\text { Ru 102 } \\
\text { (ICP-MS) }\end{array}$} & \multirow{2}{*}{$\begin{array}{c}\mu \mathrm{g} / \mathrm{L} \\
\text { Ru 104 } \\
\text { (ICP-MS) }\end{array}$} \\
\hline Sample & $\begin{array}{c}\text { Depth } \\
\text { (ft bgs) }\end{array}$ & & & & & & & & & & & \\
\hline $1 \mathrm{~A}$ & 16.18 & $<2.52 \mathrm{E}+03$ & $3.05 \mathrm{E}+01$ & $(1.5 \mathrm{E}+02)$ & $(5.36 \mathrm{E}+00)$ & $(3.1 \mathrm{E}+02)$ & $9.00 \mathrm{E}+01$ & $8.41 \mathrm{E}+01$ & $(4.44 \mathrm{E}+01)$ & $(1.02 \mathrm{E}+01)$ & $(1.01 \mathrm{E}+01)$ & $(1.00 \mathrm{E}+01)$ \\
\hline $2 \mathrm{~A}$ & 22.69 & $<2.59 \mathrm{E}+03$ & $3.66 \mathrm{E}+01$ & $(2.0 \mathrm{E}+01)$ & $(6.53 \mathrm{E}+00)$ & $(2.6 \mathrm{E}+02)$ & $8.73 \mathrm{E}+01$ & $7.92 \mathrm{E}+01$ & $(4.22 \mathrm{E}+01)$ & $(1.47 \mathrm{E}+01)$ & $(1.43 \mathrm{E}+01)$ & $(1.50 \mathrm{E}+01)$ \\
\hline $3 \mathrm{~A}$ & 30.74 & $<1.79 \mathrm{E}+03$ & $3.14 \mathrm{E}+01$ & ND & $(2.14 \mathrm{E}+01)$ & $(3.1 \mathrm{E}+02)$ & $1.35 \mathrm{E}+02$ & $1.25 \mathrm{E}+02$ & $6.29 \mathrm{E}+01$ & $(7.74 \mathrm{E}+00)$ & $(7.26 \mathrm{E}+00)$ & $(7.74 \mathrm{E}+00)$ \\
\hline $4 \mathrm{~A}$ & 36.88 & $(6.46 \mathrm{E}+02)$ & $1.52 \mathrm{E}+01$ & $(3.9 \mathrm{E}+01)$ & $(1.34 \mathrm{E}+01)$ & $(3.9 \mathrm{E}+02)$ & $2.94 \mathrm{E}+02$ & $2.65 \mathrm{E}+02$ & $1.28 \mathrm{E}+02$ & $(2.38 \mathrm{E}-01)$ & $(5.71 \mathrm{E}-01)$ & $(1.09 \mathrm{E}+00)$ \\
\hline 4 (Nose Cone) & 37.40 & $6.07 \mathrm{E}+02$ & $2.36 \mathrm{E}+01$ & $(5.1 \mathrm{E}+01)$ & $(7.27 \mathrm{E}-01)$ & $(6.3 \mathrm{E}+01)$ & $3.17 \mathrm{E}+02$ & $2.90 \mathrm{E}+02$ & $1.36 \mathrm{E}+02$ & $(1.31 \mathrm{E}-01)$ & $(7.15 \mathrm{E}-02)$ & 8.47E-01 \\
\hline $5 \mathrm{~A}$ & 40.01 & $5.06 \mathrm{E}+03$ & $2.03 \mathrm{E}+02$ & $(1.1 \mathrm{E}+02)$ & $(1.55 \mathrm{E}+01)$ & $(2.4 \mathrm{E}+01)$ & $3.94 \mathrm{E}+02$ & $3.42 \mathrm{E}+02$ & $1.87 \mathrm{E}+02$ & $(6.23 E+00)$ & $2.99 \mathrm{E}+00$ & $3.44 \mathrm{E}+00$ \\
\hline 5A dup & 40.01 & $(0.00 \mathrm{E}+00)$ & $6.15 \mathrm{E}+01$ & $(2.6 \mathrm{E}+01)$ & $(5.09 \mathrm{E}+01)$ & $(1.5 \mathrm{E}+02)$ & $1.06 \mathrm{E}+02$ & $8.46 \mathrm{E}+01$ & $(5.60 \mathrm{E}+01)$ & $(7.17 \mathrm{E}+00)$ & $(5.46 \mathrm{E}+00)$ & $(5.61 \mathrm{E}+00)$ \\
\hline $6 \mathrm{~B}$ & 46.33 & $1.61 \mathrm{E}+05$ & $1.79 \mathrm{E}+03$ & $(3.1 \mathrm{E}+02)$ & $1.21 \mathrm{E}+02$ & $(6.6 \mathrm{E}+01)$ & $1.77 \mathrm{E}+03$ & $1.56 \mathrm{E}+03$ & $8.07 \mathrm{E}+02$ & $3.65 \mathrm{E}+01$ & $1.73 \mathrm{E}+01$ & $1.87 \mathrm{E}+01$ \\
\hline $6 \mathrm{~A}$ & 46.98 & $6.12 \mathrm{E}+04$ & $1.18 \mathrm{E}+03$ & $(2.5 \mathrm{E}+02)$ & $1.60 \mathrm{E}+02$ & $(4.5 E+02)$ & $3.03 \mathrm{E}+02$ & $2.59 \mathrm{E}+02$ & $1.54 \mathrm{E}+02$ & $(4.80 \mathrm{E}+01)$ & $(2.62 \mathrm{E}+01)$ & $(2.52 \mathrm{E}+01)$ \\
\hline $7 \mathrm{~B}$ & 58.39 & $1.82 \mathrm{E}+05$ & $9.99 \mathrm{E}+03$ & $(2.8 \mathrm{E}+02)$ & $1.93 \mathrm{E}+02$ & $(1.2 \mathrm{E}+02)$ & $1.48 \mathrm{E}+03$ & $1.28 \mathrm{E}+03$ & $7.48 \mathrm{E}+02$ & $1.14 \mathrm{E}+02$ & $5.43 \mathrm{E}+01$ & $5.17 \mathrm{E}+01$ \\
\hline 7B Dup & 58.39 & $1.66 \mathrm{E}+05$ & $1.27 \mathrm{E}+04$ & $4.6 \mathrm{E}+02$ & $3.92 \mathrm{E}+02$ & $(1.2 \mathrm{E}+02)$ & $1.55 \mathrm{E}+03$ & $1.32 \mathrm{E}+03$ & $7.80 \mathrm{E}+02$ & $1.26 \mathrm{E}+02$ & $6.19 \mathrm{E}+01$ & $5.81 \mathrm{E}+01$ \\
\hline $7 \mathrm{~A}$ & 59.09 & $4.86 \mathrm{E}+04$ & $1.05 \mathrm{E}+04$ & $(7.1 \mathrm{E}+02)$ & $6.74 \mathrm{E}+02$ & $(3.1 \mathrm{E}+02)$ & $4.31 \mathrm{E}+02$ & $2.90 \mathrm{E}+02$ & $2.97 \mathrm{E}+02$ & $(7.17 \mathrm{E}+01)$ & $(3.67 \mathrm{E}+01)$ & $(3.65 E+01)$ \\
\hline $8 \mathrm{~B}$ & 63.38 & $1.63 \mathrm{E}+05$ & $8.87 \mathrm{E}+03$ & $8.2 \mathrm{E}+02$ & $6.55 \mathrm{E}+02$ & $(1.5 \mathrm{E}+02)$ & $1.93 \mathrm{E}+03$ & $1.61 \mathrm{E}+03$ & $1.03 \mathrm{E}+03$ & $1.37 \mathrm{E}+02$ & $6.59 \mathrm{E}+01$ & $6.32 \mathrm{E}+01$ \\
\hline 8A UFA & 64.03 & $9.50 \mathrm{E}+04^{(\mathrm{c})}$ & $2.80 \mathrm{E}+03$ & $5.2 \mathrm{E}+03$ & $3.61 \mathrm{E}+03$ & $(8.1 \mathrm{E}+02)$ & $4.81 \mathrm{E}+02$ & $3.57 \mathrm{E}+02$ & $2.82 E+02$ & $1.27 \mathrm{E}+02$ & $6.03 E+01$ & $5.59 \mathrm{E}+01$ \\
\hline $8 \mathrm{~A}$ & 64.03 & $8.59 \mathrm{E}+04$ & $2.24 \mathrm{E}+03$ & $8.6 \mathrm{E}+03$ & $8.59 \mathrm{E}+03$ & $(2.3 E+02)$ & $5.01 \mathrm{E}+02$ & $3.50 \mathrm{E}+02$ & $3.36 \mathrm{E}+02$ & $(1.53 \mathrm{E}+02)$ & $(7.94 \mathrm{E}+01)$ & $(9.42 \mathrm{E}+01)$ \\
\hline 8A Dup & 64.03 & $8.17 \mathrm{E}+04$ & $2.08 \mathrm{E}+03$ & $5.7 \mathrm{E}+03$ & $5.50 \mathrm{E}+03$ & $(3.2 \mathrm{E}+02)$ & $4.23 \mathrm{E}+02$ & $2.92 \mathrm{E}+02$ & $2.76 \mathrm{E}+02$ & $(1.31 \mathrm{E}+02)$ & $(6.67 \mathrm{E}+01)$ & $(8.19 E+01)$ \\
\hline $9 \mathrm{~A}$ & 76.03 & $3.94 \mathrm{E}+04$ & $1.78 \mathrm{E}+04$ & $1.0 \mathrm{E}+04$ & $1.04 \mathrm{E}+04$ & $(5.5 \mathrm{E}+02)$ & $8.70 \mathrm{E}+02$ & $5.65 \mathrm{E}+02$ & $5.96 \mathrm{E}+02$ & $(9.96 \mathrm{E}+01)$ & $(5.17 \mathrm{E}+01)$ & $(5.39 \mathrm{E}+01)$ \\
\hline $10 \mathrm{~A}$ & 81.04 & $4.40 \mathrm{E}+04$ & $7.27 \mathrm{E}+03$ & $1.1 \mathrm{E}+04$ & $1.13 \mathrm{E}+04$ & $2.3 \mathrm{E}+03$ & $3.06 \mathrm{E}+03$ & $2.03 \mathrm{E}+03$ & $2.06 \mathrm{E}+03$ & $1.81 \mathrm{E}+02$ & $8.95 \mathrm{E}+01$ & $8.95 \mathrm{E}+01$ \\
\hline 11A UFA & 87.35 & 3.11E+05 & $4.48 \mathrm{E}+02$ & $1.2 \mathrm{E}+04$ & $1.14 E+04$ & $4.5 \mathrm{E}+03$ & $6.32 E+03$ & $3.88 E+03$ & $4.52 E+03$ & $3.32 E+02$ & $1.65 E+02$ & $1.57 \mathrm{E}+02$ \\
\hline $11 \mathrm{~A}$ & 87.35 & $2.47 \mathrm{E}+05$ & $1.15 \mathrm{E}+03$ & $1.8 \mathrm{E}+04$ & $1.73 \mathrm{E}+04$ & $5.7 \mathrm{E}+03$ & $8.43 E+03$ & $5.19 \mathrm{E}+03$ & $6.05 \mathrm{E}+03$ & $4.95 \mathrm{E}+02$ & $2.42 \mathrm{E}+02$ & $2.33 \mathrm{E}+02$ \\
\hline 11A Dup & 87.35 & $2.08 \mathrm{E}+05$ & $1.17 \mathrm{E}+03$ & $1.4 \mathrm{E}+04$ & $1.40 \mathrm{E}+04$ & $5.5 \mathrm{E}+03$ & $8.14 \mathrm{E}+03$ & $4.98 \mathrm{E}+03$ & $5.85 \mathrm{E}+03$ & $5.29 \mathrm{E}+02$ & $2.59 \mathrm{E}+02$ & $2.51 \mathrm{E}+02$ \\
\hline $12 \mathrm{~A}$ & 92.61 & $4.43 \mathrm{E}+05$ & $3.94 \mathrm{E}+03$ & $1.5 \mathrm{E}+04$ & $1.54 \mathrm{E}+04$ & $2.9 \mathrm{E}+03$ & $4.45 \mathrm{E}+03$ & $2.72 \mathrm{E}+03$ & $3.20 \mathrm{E}+03$ & $5.11 \mathrm{E}+02$ & $2.45 \mathrm{E}+02$ & $2.45 \mathrm{E}+02$ \\
\hline 13A UFA & 93.56 & $1.06 \mathrm{E}+06$ & $1.40 \mathrm{E}+01$ & $1.7 \mathrm{E}+04$ & $1.50 \mathrm{E}+04$ & $(6.0 \mathrm{E}+03)$ & $8.26 E+03$ & $4.95 E+03$ & $5.89 E+03$ & 8.19E+02 & $3.94 \mathrm{E}+02$ & $3.64 \mathrm{E}+02$ \\
\hline $13 \mathrm{~A}$ & 93.56 & $1.71 \mathrm{E}+06$ & $4.44 \mathrm{E}+01$ & $4.0 \mathrm{E}+04$ & $3.90 \mathrm{E}+04$ & $9.7 \mathrm{E}+03$ & $1.49 \mathrm{E}+04$ & $9.00 \mathrm{E}+03$ & $1.10 \mathrm{E}+04$ & $1.08 \mathrm{E}+03$ & $5.15 \mathrm{E}+02$ & $5.04 \mathrm{E}+02$ \\
\hline $14 \mathrm{~A}$ & 94.67 & $7.32 \mathrm{E}+05$ & $4.80 \mathrm{E}+01$ & $1.7 \mathrm{E}+04$ & $1.53 \mathrm{E}+04$ & $4.6 \mathrm{E}+03$ & $6.35 \mathrm{E}+03$ & $3.85 \mathrm{E}+03$ & $4.65 \mathrm{E}+03$ & $8.11 \mathrm{E}+02$ & $3.86 \mathrm{E}+02$ & $3.79 \mathrm{E}+02$ \\
\hline $15 \mathrm{~B}$ & 99.70 & $2.00 \mathrm{E}+06$ & $1.18 \mathrm{E}+02$ & $6.8 \mathrm{E}+03$ & $6.48 \mathrm{E}+03$ & $(3.4 \mathrm{E}+02)$ & $5.78 \mathrm{E}+03$ & $3.60 \mathrm{E}+03$ & $4.02 \mathrm{E}+03$ & $4.73 E+02$ & $2.38 \mathrm{E}+02$ & $2.22 \mathrm{E}+02$ \\
\hline $15 \mathrm{~A}$ & 100.37 & $7.53 \mathrm{E}+05$ & $9.24 \mathrm{E}+01$ & $8.3 \mathrm{E}+03$ & $8.04 \mathrm{E}+03$ & $1.4 \mathrm{E}+04$ & $2.07 \mathrm{E}+04$ & $1.25 \mathrm{E}+04$ & $1.51 \mathrm{E}+04$ & $1.43 E+03$ & $6.82 \mathrm{E}+02$ & $6.59 \mathrm{E}+02$ \\
\hline
\end{tabular}


Table 4.27. (contd)

\begin{tabular}{|c|c|c|c|c|c|c|c|c|c|c|c|c|}
\hline \multicolumn{2}{|c|}{ Units } & \multirow{2}{*}{$\begin{array}{c}\mathrm{pCi} / \mathbf{L} \\
\text { Tc-99 } \\
\text { (ICP-MS) }^{(\mathrm{a})} \\
\end{array}$} & \multirow{2}{*}{$\begin{array}{c}\mu \mathrm{g} / \mathrm{L} \\
\mathrm{U}-238 \\
(\mathrm{ICP}-\mathrm{MS})\end{array}$} & \multirow{2}{*}{$\begin{array}{c}\mu \mathrm{g} / \mathrm{L} \\
\mathrm{Cr} \\
\mathrm{ICP}-\mathrm{OES} \\
\end{array}$} & \multirow{2}{*}{$\begin{array}{c}\mu \mathrm{g} / \mathrm{L} \\
\mathrm{Cr} \\
(\mathrm{ICP}-\mathrm{MS}) \\
\end{array}$} & \multirow{2}{*}{$\begin{array}{c}\mu \mathrm{g} / \mathrm{L} \\
\text { Mo } \\
\text { ICP-OES }\end{array}$} & \multirow{2}{*}{$\begin{array}{c}\mu \mathrm{g} / \mathrm{L} \\
\text { Mo 95 } \\
\text { (ICP-MS) }\end{array}$} & \multirow{2}{*}{$\begin{array}{c}\mu \mathrm{g} / \mathrm{L} \\
\text { Mo 98 } \\
\text { (ICP-MS) }\end{array}$} & \multirow{2}{*}{$\begin{array}{c}\mu \mathrm{g} / \mathrm{L} \\
\text { Mo 100 } \\
\text { (ICP-MS) }\end{array}$} & \multirow{2}{*}{$\begin{array}{c}\mu \mathrm{g} / \mathrm{L} \\
\text { Ru 101 } \\
\text { (ICP-MS) }\end{array}$} & \multirow{2}{*}{$\begin{array}{c}\mu \mathrm{g} / \mathrm{L} \\
\mathrm{Ru} \mathrm{102} \\
\text { (ICP-MS) }\end{array}$} & \multirow{2}{*}{$\begin{array}{c}\mu g / L \\
\text { Ru 104 } \\
\text { (ICP-MS) }\end{array}$} \\
\hline Sample & $\begin{array}{c}\text { Depth } \\
\text { (ft bgs) }\end{array}$ & & & & & & & & & & & \\
\hline $16 \mathrm{~B}$ & 101.33 & $9.86 \mathrm{E}+05$ & $2.66 \mathrm{E}+02$ & $2.5 \mathrm{E}+04$ & $2.32 \mathrm{E}+04$ & $8.3 \mathrm{E}+02$ & $1.16 \mathrm{E}+04$ & $7.10 \mathrm{E}+03$ & $8.22 \mathrm{E}+03$ & $6.78 \mathrm{E}+02$ & $3.41 \mathrm{E}+02$ & $3.09 \mathrm{E}+02$ \\
\hline 16A UFA & 101.98 & \multicolumn{11}{|c|}{ Not enough sample obtained to perform all analyses } \\
\hline $16 \mathrm{~A}$ & 101.98 & $5.73 \mathrm{E}+05$ & $1.15 \mathrm{E}+02$ & $2.3 \mathrm{E}+04$ & $1.37 \mathrm{E}+04$ & $4.6 \mathrm{E}+03$ & $4.27 \mathrm{E}+03$ & $2.58 \mathrm{E}+03$ & $3.04 \mathrm{E}+03$ & $3.70 \mathrm{E}+02$ & $1.79 \mathrm{E}+02$ & $1.77 \mathrm{E}+02$ \\
\hline 17B & 105.39 & $2.18 \mathrm{E}+06$ & $1.27 \mathrm{E}+02$ & $7.2 \mathrm{E}+03$ & $6.77 \mathrm{E}+03$ & $(3.5 \mathrm{E}+02)$ & $6.22 \mathrm{E}+03$ & $3.85 \mathrm{E}+03$ & $4.32 \mathrm{E}+03$ & $5.18 \mathrm{E}+02$ & $2.51 \mathrm{E}+02$ & $2.29 \mathrm{E}+02$ \\
\hline $17 \mathrm{~A}$ & 106.09 & $2.17 \mathrm{E}+06$ & $7.74 \mathrm{E}+01$ & $9.7 \mathrm{E}+03$ & $9.77 \mathrm{E}+03$ & $4.2 \mathrm{E}+03$ & NR & $3.60 \mathrm{E}+03$ & $4.13 \mathrm{E}+03$ & $7.43 \mathrm{E}+02$ & $3.53 \mathrm{E}+02$ & NR \\
\hline $18 \mathrm{~A}$ & 107.42 & $1.96 \mathrm{E}+06$ & $5.34 \mathrm{E}+01$ & $1.3 \mathrm{E}+04$ & $1.25 \mathrm{E}+04$ & $5.3 \mathrm{E}+03$ & NR & $4.32 \mathrm{E}+03$ & $5.05 \mathrm{E}+03$ & $5.56 \mathrm{E}+02$ & $2.72 \mathrm{E}+02$ & NR \\
\hline $19 \mathrm{~A}$ & 110.98 & $1.52 \mathrm{E}+06$ & $4.28 \mathrm{E}+01$ & $1.5 \mathrm{E}+04$ & $1.51 \mathrm{E}+04$ & $1.3 \mathrm{E}+04$ & NR & $1.13 \mathrm{E}+04$ & $1.35 \mathrm{E}+04$ & $1.44 \mathrm{E}+03$ & $6.76 \mathrm{E}+02$ & NR \\
\hline 19A Dup & 110.98 & $2.12 \mathrm{E}+06$ & $6.05 \mathrm{E}+01$ & $2.1 \mathrm{E}+04$ & $2.04 \mathrm{E}+04$ & $1.7 \mathrm{E}+04$ & NR & $1.54 \mathrm{E}+04$ & $1.83 \mathrm{E}+04$ & $1.93 \mathrm{E}+03$ & $9.14 \mathrm{E}+02$ & NR \\
\hline $20 \mathrm{~B}$ & 115.25 & $5.71 \mathrm{E}+06$ & $2.20 \mathrm{E}+01$ & $1.8 \mathrm{E}+03$ & $1.81 \mathrm{E}+03$ & $1.3 \mathrm{E}+03$ & $9.62 \mathrm{E}+03$ & $5.85 \mathrm{E}+03$ & $6.79 \mathrm{E}+03$ & $1.31 \mathrm{E}+03$ & $6.22 \mathrm{E}+02$ & $5.88 \mathrm{E}+02$ \\
\hline 20A UFA & 116.02 & $2.42 \mathrm{E}+07$ & $4.86 \mathrm{E}+00$ & $2.3 \mathrm{E}+03$ & $(2.24 E+03)$ & $1.3 E+03$ & $(1.99 \mathrm{E}+03)$ & $(1.22 \mathrm{E}+03)$ & $(1.45 E+03)$ & $(4.74 E+03)$ & $(2.36 \mathrm{E}+03)$ & $(2.30 \mathrm{E}+03)$ \\
\hline $20 \mathrm{~A}$ & 116.02 & $2.49 \mathrm{E}+07$ & $1.92 \mathrm{E}+01$ & $3.8 \mathrm{E}+03$ & $3.53 \mathrm{E}+03$ & $1.3 \mathrm{E}+03$ & NR & $1.29 \mathrm{E}+03$ & $1.50 \mathrm{E}+03$ & $4.54 \mathrm{E}+03$ & $2.15 \mathrm{E}+03$ & NR \\
\hline $21 \mathrm{~B}$ & 120.30 & $4.14 \mathrm{E}+06$ & $7.20 \mathrm{E}+00$ & $(1.4 \mathrm{E}+01)$ & $(5.23 \mathrm{E}+00)$ & $(1.9 \mathrm{E}+01)$ & $1.25 \mathrm{E}+02$ & $1.17 \mathrm{E}+02$ & $5.73 \mathrm{E}+01$ & $3.32 \mathrm{E}+02$ & $1.66 \mathrm{E}+02$ & $1.76 \mathrm{E}+02$ \\
\hline 21A UFA & 120.97 & $3.07 E+06$ & $1.60 \mathrm{E}+00$ & NR & $2.00 \mathrm{E}+00$ & NR & $4.09 \mathrm{E}+01$ & $3.28 \mathrm{E}+01$ & $2.47 \mathrm{E}+01$ & $3.66 \mathrm{E}+02$ & $1.77 \mathrm{E}+02$ & $1.84 \mathrm{E}+02$ \\
\hline $21 \mathrm{~A}$ & 120.97 & $3.41 \mathrm{E}+06$ & $4.42 \mathrm{E}+00$ & $(2.1 \mathrm{E}+01)$ & $(1.06 \mathrm{E}+01)$ & $(1.5 \mathrm{E}+02)$ & NR & $9.35 \mathrm{E}+01$ & $5.18 \mathrm{E}+01$ & $4.19 \mathrm{E}+02$ & $1.98 \mathrm{E}+02$ & NR \\
\hline $22 \mathrm{~B}$ & 123.32 & $5.50 \mathrm{E}+06$ & $3.48 \mathrm{E}+01$ & $(9.9 \mathrm{E}+01)$ & $(1.83 \mathrm{E}+01)$ & $(3.0 \mathrm{E}+01)$ & $1.31 \mathrm{E}+03$ & $1.20 \mathrm{E}+03$ & $5.76 \mathrm{E}+02$ & $2.53 \mathrm{E}+02$ & $1.24 \mathrm{E}+02$ & $1.52 \mathrm{E}+02$ \\
\hline $22 \mathrm{~A}$ & 124.05 & $5.70 \mathrm{E}+06$ & $3.12 \mathrm{E}+00$ & $(1.5 \mathrm{E}+02)$ & $(1.35 \mathrm{E}+01)$ & $(5.3 \mathrm{E}+02)$ & NR & $2.05 \mathrm{E}+02$ & $(1.07 \mathrm{E}+02)$ & $4.03 \mathrm{E}+02$ & $1.90 \mathrm{E}+02$ & NR \\
\hline $23 \mathrm{~A}$ & 127.13 & $1.17 \mathrm{E}+06$ & $5.12 \mathrm{E}+00$ & $(7.6 \mathrm{E}+01)$ & $(1.82 \mathrm{E}+01)$ & $(8.2 \mathrm{E}+02)$ & NR & $3.49 \mathrm{E}+02$ & $1.68 \mathrm{E}+02$ & $1.26 \mathrm{E}+02$ & $(5.84 \mathrm{E}+01)$ & NR \\
\hline $\begin{array}{l}\text { (b) } \\
\text { (c) }\end{array}$ & heses sig & ify values b & low level o & quantitatior & but conside & ed valid. & & & & & & \\
\hline
\end{tabular}




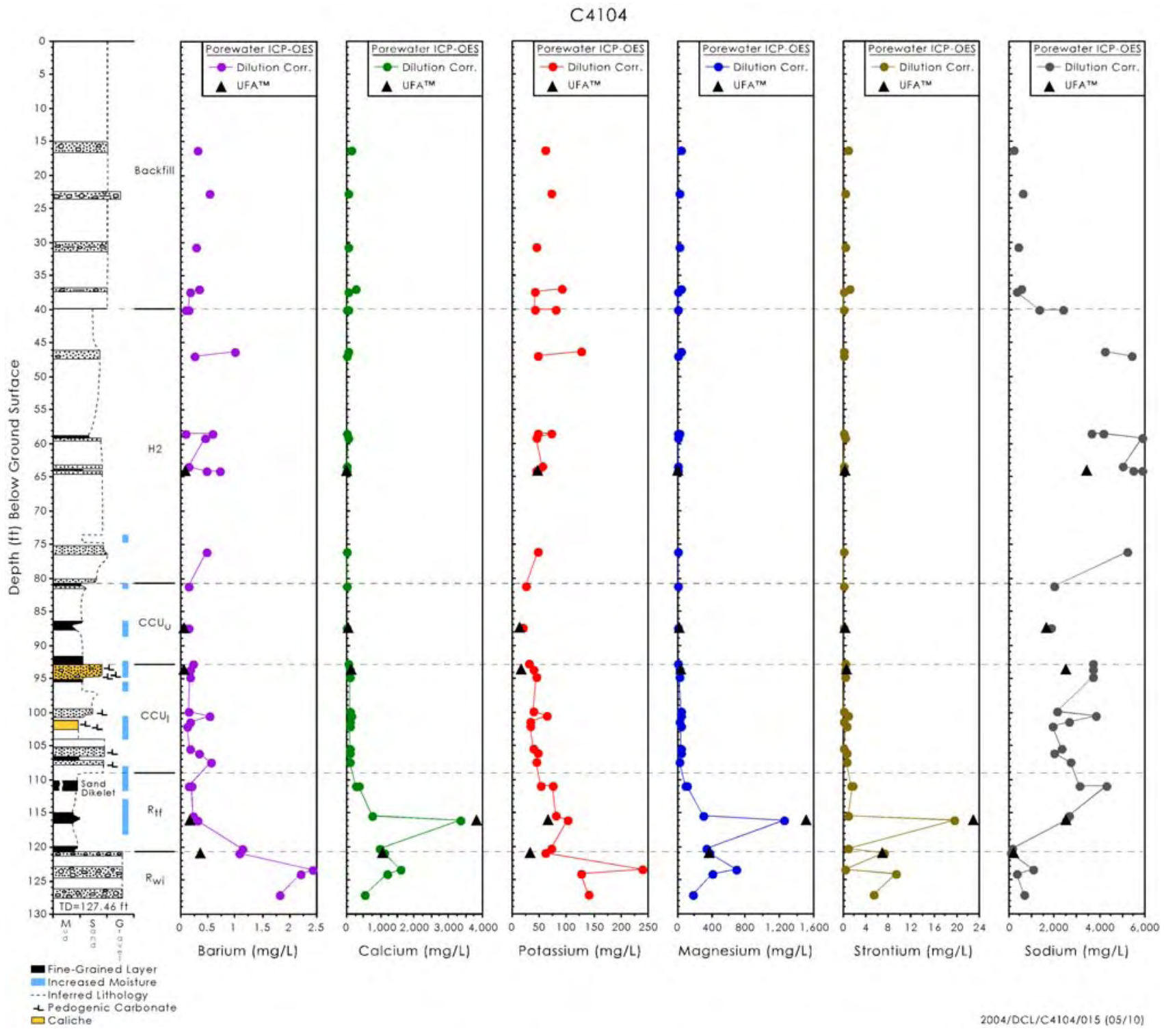

Figure 4.18. Derived and Actual Porewater Composition of Major Cations in C4104 Vadose Zone Sediments 

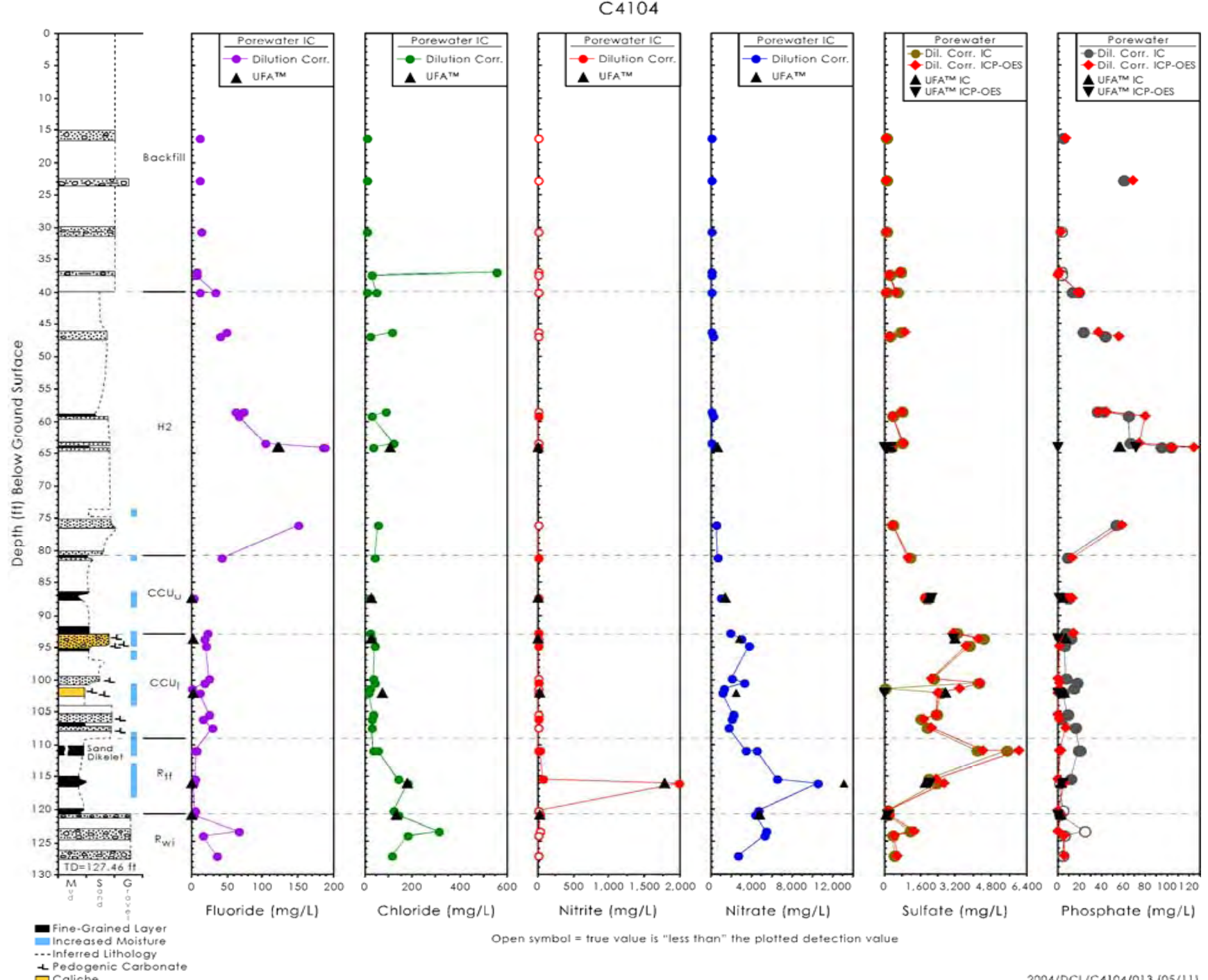

Figure 4.19. Derived and Actual Porewater Anion Composition in C4104 Vadose Zone Sediments 

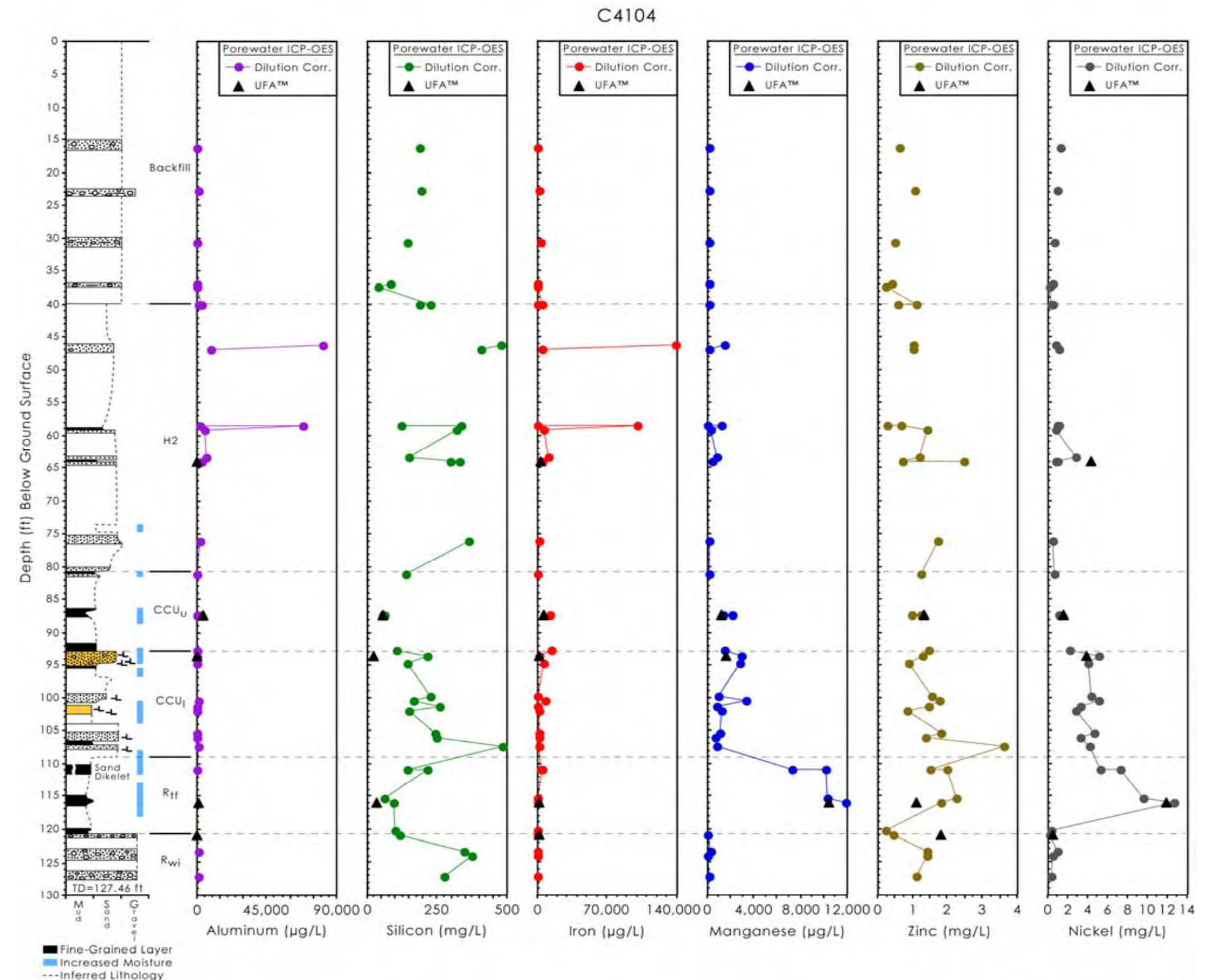

tPedogenic Carbonal

2004/DCL/C4104/031 (06/07)

Figure 4.20. Derived and Actual Porewater Composition for Selected Metals in C4104 Vadose Zone Sediments 


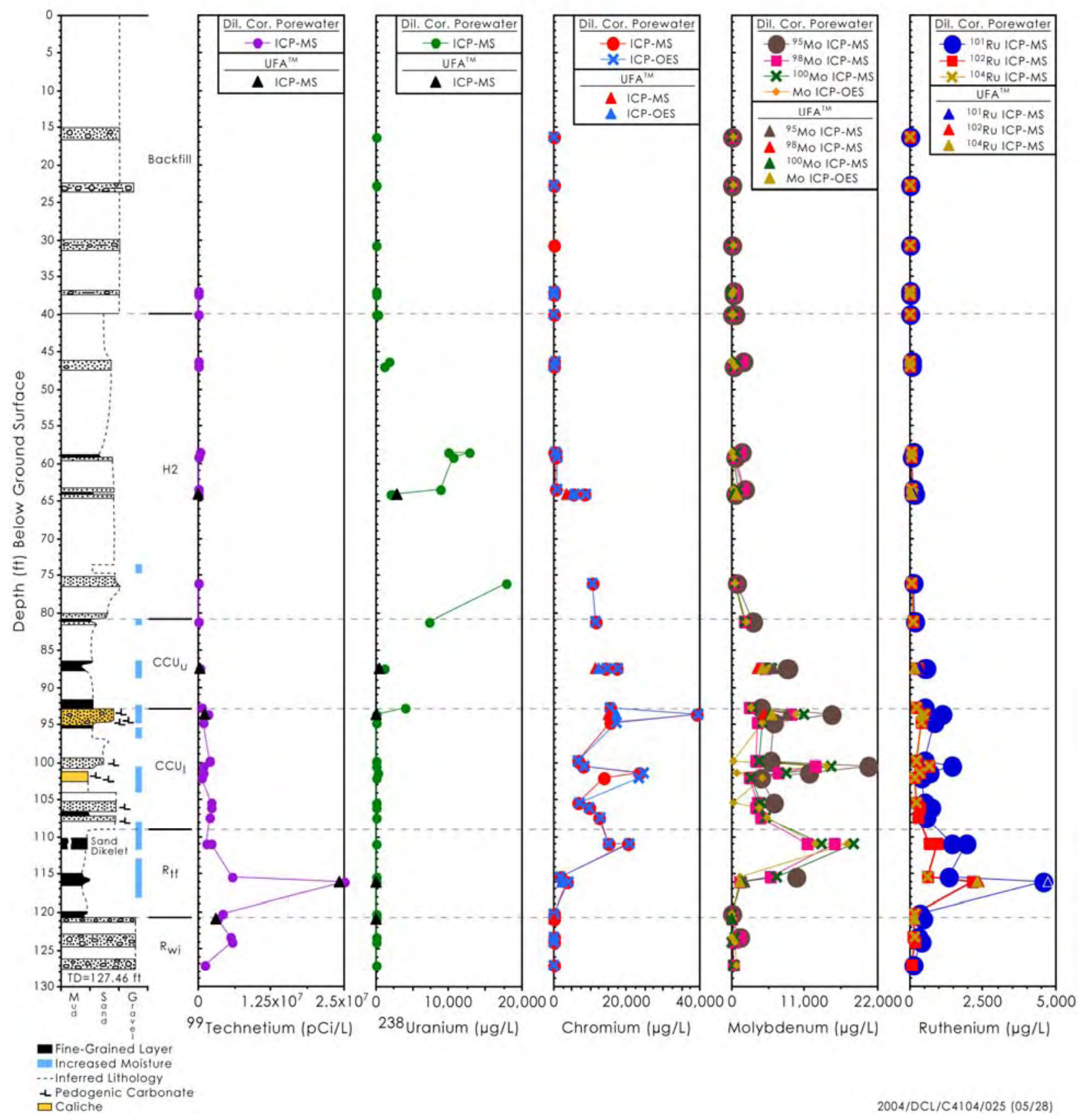

Figure 4.21. Derived and Actual Porewater Composition of Mobile Metals in C4104 Vadose Zone Sediments 


\subsubsection{M Nitric Acid-Extractable Amounts of Selected Elements in C4104 Sediments}

The same cores that were characterized for water-extractable constituents were also characterized to see how much of the various constituents could be leached with hot $8 \mathrm{M}$ nitric acid. A comparison between the quantities that were acid extractable with those that are water extractable often indicates the relative mobility of a given constituent and can sometimes differentiate man-disposed from naturally occurring constituents.

Finally, a comparison of the acid-extractable quantities in suspected contaminated sediments with acid-extractable amounts in uncontaminated sediments can be used to delineate the presence of less mobile contaminants. The quantities of various constituents in the C4104 vadose zone sediments that were acid extractable are shown in Tables 4.28 through 4.31 and Figures 4.22 through 4.25.

Upon comparing the acid extract data for borehole C4104 with similar lithologies in the uncontaminated boreholes 299-W10-27 and 299-W11-39, most of the variation in mass leached per gram of sediment versus depth is found to be lithology related. That is, for most constituents there is no sign of elevated values of acid-leachable constituents in borehole C4104 sediments, with the exception of acidextractable sodium and sulfate in most of the profile. Acid-soluble sodium is elevated from 36 to $102 \mathrm{ft}$ bgs, where elevated sodium is likely from the sodium-rich tank leak fluids. Acid-soluble sulfate is also elevated throughout most of the profile, indicating that the tank fluids also contained significant quantities of sulfate. Our data set for acid-extractable trace metals such as nickel, zinc, copper and silver is so sparse in uncontaminated sediments that it is difficult to determine if the elevated acid-extractable concentrations of these elements at $65 \mathrm{ft}$ bgs (see the "spikes" in concentrations in Figure 4.24) is an indication of tank fluids or just the fact that this sediment sample contains some silt.

The acid-extractable technetium-99 profile in the C4104 borehole sediments is elevated throughout most of the profile and correlates well with the water extract profile, although the acid extract values are larger for every sample. The acid extract technetium-99 data are variable and, as shown in Table 4.31, are mostly qualified with parentheses to indicate that the values are below our level of quantification. As found in sediments at borehole 299-E33-46 (see Serne et al. 2002f), measuring technetium-99 at low levels by acid extraction yields results that are not as reliable as when measured by water extraction. We thus place more confidence in the technetium-99 data shown in Table 4.23. We are investigating whether the difference in the amount of technetium-99 that is acid- versus water-extractable is real or the result of an analytical bias.

The acid-extractable uranium concentrations from the C4104 sediments clearly indicate elevated values between 58 and $94 \mathrm{ft}$ bgs, although natural sediment concentrations in the Cold Creek lower subunit (caliche) often approach the values found in the samples that are considered to be elevated. Thus the acid extractable uranium values in this zone (1 to $2.5 \mu \mathrm{g} / \mathrm{g}$ ) are not an indication that the tank leak contained high concentrations of uranium.

The acid-extractable chromium and molybdenum values in the sample at $58.4 \mathrm{ft}$ bgs are the largest observed for these metals. The rest of the sediment profile does not show atypically high values of acidextractable chromium but the acid-extractable molybdenum values between 58 and $115 \mathrm{ft}$ bgs do appear to be quite variable and larger than quantities that are acid extractable from background sediments.

The acid-extractable ruthenium values are also variable and higher than found in background sediments and are likely indicative of fission-product material. Table 4.30 shows the acid-extractable 
concentrations of several trace metals that are usually not quantified in background sediments. The data are presented for completeness but no assessment has been made on whether the values are indicative that the T-106 tank leak fluids contained significant quantities of these metals.

The comparison of the water to acid-extractable quantities of each constituent was performed by taking the data in Tables 4.21 to 4.23 and dividing by the data in Tables 4.28 through 4.31 . The data are not presented herein but show distinct regions where the water to acid extractable percentages are much larger than found for uncontaminated borehole (299-W10-27) sediments. For uncontaminated sediments, less than $0.1 \%$ of the acid-extractable quantities of the following elements are water leachable: aluminum, barium, iron, manganese, chromium, and phosphorus (P) as phosphate. Less than $0.5 \%$ of the acidextractable quantities of the following elements are water leachable: calcium, potassium, magnesium, strontium, zinc, and uranium. Less than $20 \%$ of the acid-extractable sodium, sulfur, and molybdenum are water-extractable.

For C4104 sediments, greater than $0.3 \%$ of the acid-extractable calcium, magnesium, and strontium are water extractable from $111 \mathrm{ft}$ bgs to the bottom of the borehole. More than $0.3 \%$ of the acidextractable manganese is water extractable from 111 to $120 \mathrm{ft}$ bgs. More than $0.3 \%$ of the acidextractable zinc is water extractable from 64 to $116 \mathrm{ft}$ bgs. Greater than 2\% of the acid-extractable copper and chromium is water extractable over the depths of 94 to 116 and 46 to $116 \mathrm{ft}$ bgs, respectively. Greater than 5\% of the acid-extractable uranium is also water extractable between the depths of 46 to 92.6 $\mathrm{ft}$ bgs. Of the acid-extractable ruthenium and molybdenum, greater than $10 \%$ is also water extractable from 46 to $116 \mathrm{ft}$ bgs. For sulfate, greater than $10 \%$ of acid-extractable amount is also water extractable over the depth interval 63.4 to $116 \mathrm{ft}$ bgs. Greater than 20\% of the acid-extractable sodium is also water extractable from 87 to $116 \mathrm{ft}$ bgs. So, several elements show a higher percentage of water extractability than expected for uncontaminated sediments. Thus, at C4104 there are clear indications of tank fluids present in the vadose zone profile and the following qualitative measure of mobility is inferred: technetium-99 and ruthenium are slightly more mobile than molybdenum, sulfate, and chromium. Zinc and uranium are less mobile than these noted species.

Figure 4.26 shows that there is some sulfate present in the Cold Creek lower subunit (caliche) sediments that is not readily water extractable, suggesting the presence of significant quantities of a rather insoluble sulfate phase. Conversely, the sulfate data may reflect high concentrations of gypsum in the caliche such that saturation is maintained in the 1:1 water extracts such that all of the sulfate is not dissolved into the water extract. Figure 4.26 also shows that the vast majority of the sediment phosphate content is not water extractable in comparison with the amounts that are acid extractable. The same trend was observed for the uncontaminated sediments from borehole 299-W10-27. Alternatively, some of the acid-extractable phosphorous may be present in a form other than phosphate such that when we convert the acid-extractable phosphorous number to phosphate (essentially multiply by 3), we are inflating the acid-extractable phosphate value. 
Table 4.28. Acid-Extractable Cations from C4104 Vadose Zone Sediments ( $\mu \mathrm{g} / \mathrm{g}$ dry sediment)

\begin{tabular}{|c|c|c|c|c|c|c|c|c|}
\hline Sample No. & $\begin{array}{c}\text { Depth } \\
\text { (ft bgs) }\end{array}$ & $\begin{array}{c}\text { Stratigraphic } \\
\text { Unit }\end{array}$ & Mg & Ca & $\mathrm{Sr}$ & Ba & $\mathrm{Na}$ & $\mathbf{K}$ \\
\hline $1 \mathrm{~A}$ & 16.18 & Bckfl & $5.3 \mathrm{E}+03$ & $9.6 \mathrm{E}+03$ & $3.3 \mathrm{E}+01$ & $9.2 \mathrm{E}+01$ & $-\ldots$ & $1.2 \mathrm{E}+03$ \\
\hline $2 \mathrm{~A}$ & 22.69 & Bckfl & $4.5 \mathrm{E}+03$ & $6.3 \mathrm{E}+03$ & $3.0 \mathrm{E}+01$ & $9.1 \mathrm{E}+01$ & $\ldots$ & $1.4 \mathrm{E}+03$ \\
\hline $3 \mathrm{~A}$ & 30.74 & Bckfl & $5.0 \mathrm{E}+03$ & $8.9 \mathrm{E}+03$ & $3.3 \mathrm{E}+01$ & $8.0 \mathrm{E}+01$ & $\ldots$ & $1.1 \mathrm{E}+03$ \\
\hline $4 \mathrm{~A}$ & 36.88 & Bckfl & $5.2 \mathrm{E}+03$ & $1.3 \mathrm{E}+04$ & $4.5 \mathrm{E}+01$ & $1.1 \mathrm{E}+02$ & $-\ldots$ & $1.2 \mathrm{E}+03$ \\
\hline 4 (Nose Cone) & 37.40 & Bckfl & $5.9 \mathrm{E}+03$ & $9.5 \mathrm{E}+03$ & $4.2 \mathrm{E}+01$ & $9.5 \mathrm{E}+01$ & $\ldots$ & $1.7 \mathrm{E}+03$ \\
\hline $5 \mathrm{~A}$ & 40.01 & Bckfl & $5.5 \mathrm{E}+03$ & $8.9 \mathrm{E}+03$ & $4.0 \mathrm{E}+01$ & $9.6 \mathrm{E}+01$ & $-\ldots$ & $1.7 \mathrm{E}+03$ \\
\hline 5A dup & 40.01 & Bckfl & $5.4 \mathrm{E}+03$ & $8.8 \mathrm{E}+03$ & $3.8 \mathrm{E}+01$ & $8.1 \mathrm{E}+01$ & $\ldots$ & $1.5 \mathrm{E}+03$ \\
\hline $6 \mathrm{~B}$ & 46.33 & $\mathrm{H} 2$ & $5.5 \mathrm{E}+03$ & $8.9 \mathrm{E}+03$ & $4.0 \mathrm{E}+01$ & $9.6 \mathrm{E}+01$ & $-\cdots$ & $1.7 \mathrm{E}+03$ \\
\hline $6 \mathrm{~A}$ & 46.98 & $\mathrm{H} 2$ & $5.0 \mathrm{E}+03$ & $9.6 \mathrm{E}+03$ & $3.9 \mathrm{E}+01$ & $6.7 \mathrm{E}+01$ & $\ldots$ & $1.2 \mathrm{E}+03$ \\
\hline 7B Dup & 58.39 & $\mathrm{H} 2$ & $4.9 \mathrm{E}+03$ & $1.0 \mathrm{E}+04$ & $4.8 \mathrm{E}+01$ & $5.6 \mathrm{E}+02$ & $\ldots$ & $1.6 \mathrm{E}+03$ \\
\hline $7 \mathrm{~A}$ & 59.09 & $\mathrm{H} 2$ & $4.1 \mathrm{E}+03$ & $7.5 \mathrm{E}+03$ & $2.9 \mathrm{E}+01$ & $6.3 \mathrm{E}+01$ & $-\cdots$ & $1.0 \mathrm{E}+03$ \\
\hline $8 \mathrm{~B}$ & 63.38 & $\mathrm{H} 2$ & $5.0 \mathrm{E}+03$ & $9.1 \mathrm{E}+03$ & $3.8 \mathrm{E}+01$ & $1.5 \mathrm{E}+02$ & $-\cdots$ & $1.2 \mathrm{E}+03$ \\
\hline $8 \mathrm{~A}$ & 64.03 & $\mathrm{H} 2$ & $4.3 \mathrm{E}+03$ & $1.6 \mathrm{E}+04$ & $4.2 \mathrm{E}+01$ & $6.7 \mathrm{E}+01$ & - - - & $1.1 \mathrm{E}+03$ \\
\hline 8A Dup & 64.03 & $\mathrm{H} 2$ & $4.6 \mathrm{E}+03$ & $1.4 \mathrm{E}+04$ & $4.1 \mathrm{E}+01$ & $6.4 \mathrm{E}+01$ & $-\ldots$ & $1.1 \mathrm{E}+03$ \\
\hline $9 \mathrm{~A}$ & 76.03 & $\mathrm{H} 2$ & $5.3 \mathrm{E}+03$ & $2.2 \mathrm{E}+04$ & $5.3 \mathrm{E}+01$ & $6.2 \mathrm{E}+01$ & $\ldots$ & $1.3 \mathrm{E}+03$ \\
\hline $10 \mathrm{~A}$ & 81.04 & $\mathrm{H} 2$ & $6.6 \mathrm{E}+03$ & $1.6 \mathrm{E}+04$ & $4.6 \mathrm{E}+01$ & $8.4 \mathrm{E}+01$ & $\ldots$ & $2.1 \mathrm{E}+03$ \\
\hline $11 \mathrm{~A}$ & 87.35 & $\mathrm{CCU}_{\mathrm{u}}$ & $8.0 \mathrm{E}+03$ & $1.5 \mathrm{E}+04$ & $4.4 \mathrm{E}+01$ & $1.0 \mathrm{E}+02$ & - - - & $2.4 \mathrm{E}+03$ \\
\hline 11A Dup & 87.35 & $\mathrm{CCU}_{\mathrm{u}}$ & $8.2 \mathrm{E}+03$ & $1.5 \mathrm{E}+04$ & $4.6 \mathrm{E}+01$ & $1.1 \mathrm{E}+02$ & $\ldots$ & $2.6 \mathrm{E}+03$ \\
\hline $12 \mathrm{~A}$ & 92.61 & $\mathrm{CCU}_{\mathrm{u}}$ & $8.0 \mathrm{E}+03$ & $2.8 \mathrm{E}+05$ & $3.7 \mathrm{E}+02$ & $1.1 \mathrm{E}+02$ & - - - & $6.2 \mathrm{E}+02$ \\
\hline $13 \mathrm{~A}$ & 93.56 & $\mathrm{CCU}_{\mathrm{I}}$ & $1.8 \mathrm{E}+04$ & $1.8 \mathrm{E}+05$ & $4.5 \mathrm{E}+02$ & $1.1 \mathrm{E}+02$ & $\ldots$ & $7.1 \mathrm{E}+02$ \\
\hline $14 \mathrm{~A}$ & 94.67 & $\mathrm{CCU}_{\mathrm{l}}$ & $8.7 \mathrm{E}+03$ & $4.5 \mathrm{E}+04$ & $1.2 \mathrm{E}+02$ & $9.0 \mathrm{E}+01$ & $-\cdots$ & $1.3 \mathrm{E}+03$ \\
\hline 15B & 99.70 & $\mathrm{CCU}_{1}$ & $5.7 \mathrm{E}+03$ & $1.7 \mathrm{E}+04$ & $7.8 \mathrm{E}+01$ & $1.4 \mathrm{E}+02$ & $\ldots$ & $1.0 \mathrm{E}+03$ \\
\hline $15 \mathrm{~A}$ & 100.37 & $\mathrm{CCU}_{\mathrm{l}}$ & $4.8 \mathrm{E}+03$ & $4.6 \mathrm{E}+04$ & $9.2 \mathrm{E}+01$ & $8.2 \mathrm{E}+01$ & - - - & $1.1 \mathrm{E}+03$ \\
\hline $16 \mathrm{~B}$ & 101.33 & $\mathrm{CCU}_{\mathrm{l}}$ & $1.4 \mathrm{E}+04$ & $2.4 \mathrm{E}+05$ & $3.3 \mathrm{E}+02$ & $2.0 \mathrm{E}+02$ & $\ldots$ & $1.1 \mathrm{E}+03$ \\
\hline $16 \mathrm{~A}$ & 101.98 & $\mathrm{CCU}_{\mathrm{l}}$ & $2.3 \mathrm{E}+04$ & $2.4 \mathrm{E}+05$ & $3.7 \mathrm{E}+02$ & $1.4 \mathrm{E}+02$ & $\ldots$ & $8.1 \mathrm{E}+02$ \\
\hline 17B & 105.39 & $\mathrm{CCU}_{1}$ & $8.8 \mathrm{E}+03$ & $8.7 \mathrm{E}+04$ & $2.1 \mathrm{E}+02$ & $1.2 \mathrm{E}+02$ & $\ldots$ & $7.8 \mathrm{E}+02$ \\
\hline $17 \mathrm{~A}$ & 106.09 & $\mathrm{CCU}_{1}$ & $5.0 \mathrm{E}+03$ & $4.4 \mathrm{E}+04$ & $9.1 \mathrm{E}+01$ & $8.9 \mathrm{E}+01$ & - - - & $6.3 \mathrm{E}+02$ \\
\hline $18 \mathrm{~A}$ & 107.42 & $\mathrm{CCU}_{1}$ & $4.9 \mathrm{E}+03$ & $6.9 \mathrm{E}+03$ & $3.4 \mathrm{E}+01$ & $7.9 \mathrm{E}+01$ & $\ldots$ & $5.9 \mathrm{E}+02$ \\
\hline $19 \mathrm{~A}$ & 110.98 & $\mathrm{CCU}_{1}$ & $7.1 \mathrm{E}+03$ & $7.9 \mathrm{E}+03$ & $3.9 \mathrm{E}+01$ & $1.1 \mathrm{E}+02$ & $-\cdots$ & $1.3 \mathrm{E}+03$ \\
\hline 19A Dup & 110.98 & $\mathrm{R}_{\mathrm{tf}}$ & $6.5 \mathrm{E}+03$ & $9.1 \mathrm{E}+03$ & $3.6 \mathrm{E}+01$ & $9.0 \mathrm{E}+01$ & $\ldots$ & $1.2 \mathrm{E}+03$ \\
\hline
\end{tabular}


Table 4.28. (contd)

\begin{tabular}{|c|c|c|c|c|c|c|c|c|}
\hline Sample No. & $\begin{array}{l}\text { Depth } \\
\text { (ft bgs) }\end{array}$ & $\begin{array}{c}\text { Stratigraphic } \\
\text { Unit }\end{array}$ & Mg & Ca & $\mathrm{Sr}$ & Ba & $\mathrm{Na}$ & $\mathbf{K}$ \\
\hline $20 \mathrm{~A}$ & 116.02 & $\mathrm{R}_{\mathrm{tf}}$ & $8.6 \mathrm{E}+03$ & $9.6 \mathrm{E}+03$ & $4.5 \mathrm{E}+01$ & $1.0 \mathrm{E}+02$ & $\ldots$ & $1.7 \mathrm{E}+03$ \\
\hline $21 \mathrm{~B}$ & 120.30 & $\mathrm{R}_{\mathrm{tf}}$ & $6.6 \mathrm{E}+03$ & $3.2 \mathrm{E}+04$ & $4.3 \mathrm{E}+01$ & $1.1 \mathrm{E}+02$ & $-\quad-\quad-$ & $1.2 \mathrm{E}+03$ \\
\hline $21 \mathrm{~A}$ & 120.97 & $\mathrm{R}_{\mathrm{tf}}$ & $6.2 \mathrm{E}+03$ & $1.8 \mathrm{E}+04$ & $4.4 \mathrm{E}+01$ & $8.7 \mathrm{E}+01$ & $\ldots$ & $1.4 \mathrm{E}+03$ \\
\hline $22 \mathrm{~B}$ & 123.32 & $\mathrm{R}_{\mathrm{wi}}$ & $4.6 \mathrm{E}+03$ & $5.8 \mathrm{E}+03$ & $4.5 \mathrm{E}+01$ & $2.5 \mathrm{E}+02$ & $-\cdots$ & $1.0 \mathrm{E}+03$ \\
\hline $22 \mathrm{~A}$ & 124.05 & $\mathrm{R}_{\mathrm{wi}}$ & $4.1 \mathrm{E}+03$ & $3.7 \mathrm{E}+03$ & $2.7 \mathrm{E}+01$ & $8.0 \mathrm{E}+01$ & - - - & $4.4 \mathrm{E}+02$ \\
\hline $23 \mathrm{~A}$ & 127.13 & $\mathrm{R}_{\mathrm{wi}}$ & $3.2 \mathrm{E}+03$ & $4.5 \mathrm{E}+03$ & $3.9 \mathrm{E}+01$ & $1.6 \mathrm{E}+02$ & $\ldots$ & $9.0 \mathrm{E}+02$ \\
\hline
\end{tabular}


Table 4.29. Acid-Extractable Constituents in C4104 Vadose Zone Sediments ( $\mu \mathrm{g} / \mathrm{g}$ dry sediment)

\begin{tabular}{|c|c|c|c|c|c|c|c|}
\hline Sample No. & Depth (ft bgs) & Stratigraphic Unit & Al & $\mathbf{F e}$ & Mn & $\mathrm{P}$ as $\mathrm{PO}_{4}$ & $\mathrm{~S}$ as $\mathrm{SO}_{4}$ \\
\hline $1 \mathrm{~A}$ & 16.18 & Bckfl & $7.0 \mathrm{E}+03$ & $2.1 \mathrm{E}+04$ & $3.4 \mathrm{E}+02$ & $3.67 \mathrm{E}+03$ & $7.32 \mathrm{E}+02$ \\
\hline $2 \mathrm{~A}$ & 22.69 & Bckfl & $7.0 \mathrm{E}+03$ & $1.9 \mathrm{E}+04$ & $3.5 \mathrm{E}+02$ & $3.43 E+03$ & $5.29 \mathrm{E}+02$ \\
\hline $3 \mathrm{~A}$ & 30.74 & Bckfl & $6.86 \mathrm{E}+03$ & $2.03 E+04$ & $3.59 \mathrm{E}+02$ & $3.04 \mathrm{E}+03$ & $4.82 \mathrm{E}+02$ \\
\hline $4 \mathrm{~A}$ & 36.88 & Bckfl & $7.75 E+03$ & $2.30 \mathrm{E}+04$ & $3.56 \mathrm{E}+02$ & $3.68 \mathrm{E}+03$ & $8.10 \mathrm{E}+02$ \\
\hline 4 (Nose Cone) & 37.40 & Bckfl & $6.5 \mathrm{E}+03$ & $1.9 \mathrm{E}+04$ & $2.7 \mathrm{E}+02$ & $2.56 \mathrm{E}+03$ & $3.37 \mathrm{E}+02$ \\
\hline $5 \mathrm{~A}$ & 40.01 & Bckfl & $9.2 \mathrm{E}+03$ & $2.1 \mathrm{E}+04$ & $3.6 \mathrm{E}+02$ & $2.40 \mathrm{E}+03$ & $3.72 \mathrm{E}+02$ \\
\hline 5A dup & 40.01 & Bckfl & $7.7 \mathrm{E}+03$ & $1.7 \mathrm{E}+04$ & $3.0 \mathrm{E}+02$ & $2.06 \mathrm{E}+03$ & $6.34 \mathrm{E}+02$ \\
\hline $6 \mathrm{~B}$ & 46.33 & $\mathrm{H} 2$ & $9.1 \mathrm{E}+03$ & $1.9 \mathrm{E}+04$ & $3.3 \mathrm{E}+02$ & $2.06 \mathrm{E}+03$ & $3.20 \mathrm{E}+02$ \\
\hline $6 \mathrm{~A}$ & 46.98 & $\mathrm{H} 2$ & $6.8 \mathrm{E}+03$ & $1.4 \mathrm{E}+04$ & $2.7 \mathrm{E}+02$ & $2.45 \mathrm{E}+03$ & $6.18 \mathrm{E}+02$ \\
\hline 7B Dup & 58.39 & $\mathrm{H} 2$ & $8.8 \mathrm{E}+03$ & $2.4 \mathrm{E}+04$ & $3.4 \mathrm{E}+02$ & $2.05 \mathrm{E}+03$ & $7.85 \mathrm{E}+02$ \\
\hline $7 \mathrm{~A}$ & 59.09 & $\mathrm{H} 2$ & $5.7 \mathrm{E}+03$ & $1.5 \mathrm{E}+04$ & $2.7 \mathrm{E}+02$ & $2.60 \mathrm{E}+03$ & $5.74 \mathrm{E}+02$ \\
\hline $8 \mathrm{~B}$ & 63.38 & $\mathrm{H} 2$ & $7.6 \mathrm{E}+03$ & $2.0 \mathrm{E}+04$ & $3.1 \mathrm{E}+02$ & $2.69 \mathrm{E}+03$ & $4.73 \mathrm{E}+02$ \\
\hline $8 \mathrm{~A}$ & 64.03 & $\mathrm{H} 2$ & $6.1 \mathrm{E}+03$ & $1.5 \mathrm{E}+04$ & $2.5 \mathrm{E}+02$ & $2.69 \mathrm{E}+03$ & $1.03 \mathrm{E}+03$ \\
\hline 8A Dup & 64.03 & $\mathrm{H} 2$ & $6.6 \mathrm{E}+03$ & $1.6 \mathrm{E}+04$ & $2.8 \mathrm{E}+02$ & $2.69 E+03$ & $9.15 \mathrm{E}+02$ \\
\hline $9 \mathrm{~A}$ & 76.03 & $\mathrm{H} 2$ & $6.6 \mathrm{E}+03$ & $1.4 \mathrm{E}+04$ & $2.7 \mathrm{E}+02$ & $1.82 \mathrm{E}+03$ & $1.32 \mathrm{E}+03$ \\
\hline $10 \mathrm{~A}$ & 81.04 & $\mathrm{H} 2$ & $1.0 \mathrm{E}+04$ & $1.8 \mathrm{E}+04$ & $3.9 \mathrm{E}+02$ & $2.18 \mathrm{E}+03$ & $1.06 \mathrm{E}+03$ \\
\hline $11 \mathrm{~A}$ & 87.35 & $\mathrm{CCU}_{\mathrm{u}}$ & $1.5 \mathrm{E}+04$ & $2.2 \mathrm{E}+04$ & $4.9 \mathrm{E}+02$ & $2.21 \mathrm{E}+03$ & $1.30 \mathrm{E}+03$ \\
\hline 11A Dup & 87.35 & $\mathrm{CCU}_{\mathrm{u}}$ & $1.6 \mathrm{E}+04$ & $2.2 \mathrm{E}+04$ & $4.9 \mathrm{E}+02$ & $2.23 E+03$ & $1.27 \mathrm{E}+03$ \\
\hline $12 \mathrm{~A}$ & 92.61 & $\mathrm{CCU}_{\mathrm{u}}$ & $5.1 \mathrm{E}+03$ & $9.3 \mathrm{E}+03$ & $1.2 \mathrm{E}+02$ & $1.38 \mathrm{E}+03$ & $1.66 \mathrm{E}+04$ \\
\hline $13 \mathrm{~A}$ & 93.56 & $\mathrm{CCU}_{\mathrm{l}}$ & $6.5 \mathrm{E}+03$ & $1.1 \mathrm{E}+04$ & $1.5 \mathrm{E}+02$ & $1.28 \mathrm{E}+03$ & $1.15 \mathrm{E}+04$ \\
\hline $14 \mathrm{~A}$ & 94.67 & $\mathrm{CCU}_{\mathrm{l}}$ & $9.6 \mathrm{E}+03$ & $1.6 \mathrm{E}+04$ & $2.8 \mathrm{E}+02$ & $1.97 \mathrm{E}+03$ & $3.12 \mathrm{E}+03$ \\
\hline $15 B$ & 99.70 & $\mathrm{CCU}_{\mathrm{l}}$ & $7.2 \mathrm{E}+03$ & $1.4 \mathrm{E}+04$ & $2.4 \mathrm{E}+02$ & $1.32 \mathrm{E}+03$ & $1.11 \mathrm{E}+03$ \\
\hline $15 \mathrm{~A}$ & 100.37 & $\mathrm{CCU}_{\mathrm{l}}$ & $9.7 \mathrm{E}+03$ & $1.4 \mathrm{E}+04$ & $2.2 \mathrm{E}+02$ & $1.30 \mathrm{E}+03$ & $3.00 \mathrm{E}+03$ \\
\hline $16 \mathrm{~B}$ & 101.33 & $\mathrm{CCU}_{\mathrm{l}}$ & $8.6 \mathrm{E}+03$ & $1.1 \mathrm{E}+04$ & $1.6 \mathrm{E}+02$ & $1.38 \mathrm{E}+03$ & $8.33 \mathrm{E}+03$ \\
\hline $16 \mathrm{~A}$ & 101.98 & $\mathrm{CCU}_{\mathrm{l}}$ & $5.5 \mathrm{E}+03$ & $6.9 \mathrm{E}+03$ & $1.0 \mathrm{E}+02$ & $1.23 \mathrm{E}+03$ & $1.42 \mathrm{E}+04$ \\
\hline
\end{tabular}


Table 4.29. (contd)

\begin{tabular}{||c|c|c|c|c|c|c|c||}
\hline \hline Sample No. & Depth (ft bgs) & Stratigraphic Unit & Al & Fe & Mn & $\mathbf{P}_{\text {as PO }} \mathbf{P O}_{\mathbf{4}}$ & $\mathbf{S}_{\text {as }} \mathbf{S O}_{\mathbf{4}}$ \\
\hline $17 \mathrm{~B}$ & 105.39 & $\mathrm{CCU}_{\mathrm{l}}$ & $8.0 \mathrm{E}+03$ & $1.5 \mathrm{E}+04$ & $2.3 \mathrm{E}+02$ & $1.75 \mathrm{E}+03$ & $3.13 \mathrm{E}+03$ \\
\hline $17 \mathrm{~A}$ & 106.09 & $\mathrm{CCU}_{\mathrm{l}}$ & $5.6 \mathrm{E}+03$ & $1.2 \mathrm{E}+04$ & $2.4 \mathrm{E}+02$ & $2.13 \mathrm{E}+03$ & $2.84 \mathrm{E}+03$ \\
\hline $18 \mathrm{~A}$ & 107.42 & $\mathrm{CCU}_{\mathrm{l}}$ & $6.2 \mathrm{E}+03$ & $1.3 \mathrm{E}+04$ & $2.2 \mathrm{E}+02$ & $1.86 \mathrm{E}+03$ & $6.31 \mathrm{E}+02$ \\
\hline $19 \mathrm{~A}$ & 110.98 & $\mathrm{CCU}_{\mathrm{l}}$ & $9.8 \mathrm{E}+03$ & $1.8 \mathrm{E}+04$ & $4.9 \mathrm{E}+02$ & $2.29 \mathrm{E}+03$ & $1.12 \mathrm{E}+03$ \\
\hline $19 \mathrm{~A}$ Dup & 110.98 & $\mathrm{R}_{\mathrm{tf}}$ & $8.5 \mathrm{E}+03$ & $1.6 \mathrm{E}+04$ & $4.4 \mathrm{E}+02$ & $2.14 \mathrm{E}+03$ & $1.13 \mathrm{E}+03$ \\
\hline $20 \mathrm{~B}$ & 115.25 & $\mathrm{R}_{\mathrm{tf}}$ & $1.3 \mathrm{E}+04$ & $2.3 \mathrm{E}+04$ & $5.5 \mathrm{E}+02$ & $1.94 \mathrm{E}+03$ & $8.65 \mathrm{E}+02$ \\
\hline $20 \mathrm{~A}$ & 116.02 & $\mathrm{R}_{\mathrm{tf}}$ & $1.1 \mathrm{E}+04$ & $2.0 \mathrm{E}+04$ & $5.4 \mathrm{E}+02$ & $2.48 \mathrm{E}+03$ & $1.17 \mathrm{E}+03$ \\
\hline $21 \mathrm{~B}$ & 120.30 & $\mathrm{R}_{\mathrm{tf}}$ & $9.2 \mathrm{E}+03$ & $1.9 \mathrm{E}+04$ & $4.0 \mathrm{E}+02$ & $1.99 \mathrm{E}+03$ & $7.52 \mathrm{E}+02$ \\
\hline $21 \mathrm{~A}$ & 120.97 & $\mathrm{R}_{\mathrm{tf}}$ & $8.8 \mathrm{E}+03$ & $1.5 \mathrm{E}+04$ & $4.4 \mathrm{E}+02$ & $2.07 \mathrm{E}+03$ & $9.68 \mathrm{E}+02$ \\
\hline $2 \mathrm{~B}$ & 123.32 & $\mathrm{R}_{\mathrm{wi}}$ & $6.4 \mathrm{E}+03$ & $2.4 \mathrm{E}+04$ & $3.0 \mathrm{E}+02$ & $2.28 \mathrm{E}+03$ & $4.88 \mathrm{E}+02$ \\
\hline $22 \mathrm{~A}$ & 124.05 & $\mathrm{R}_{\mathrm{wi}}$ & $4.2 \mathrm{E}+03$ & $1.3 \mathrm{E}+04$ & $1.9 \mathrm{E}+02$ & $2.27 \mathrm{E}+03$ & $4.87 \mathrm{E}+02$ \\
\hline $23 \mathrm{~A}$ & 127.13 & $\mathrm{R}_{\mathrm{wi}}$ & $5.0 \mathrm{E}+03$ & $1.5 \mathrm{E}+04$ & $1.9 \mathrm{E}+02$ & $2.44 \mathrm{E}+03$ & $5.58 \mathrm{E}+02$ \\
\hline
\end{tabular}


Table 4.30. Acid-Extractable Trace Metals in C4104 Vadose Zone Sediments ( $\mu \mathrm{g} / \mathrm{g}$ dry sediment)

\begin{tabular}{|c|c|c|c|c|c|c|c|c|c|}
\hline \multirow{3}{*}{ Sample No. } & \multirow{3}{*}{$\begin{array}{c}\text { Depth } \\
\text { (ft bgs) }\end{array}$} & \multirow{3}{*}{$\begin{array}{c}\text { Stratigraphic } \\
\text { Unit }\end{array}$} & ICP-OES & ICP-OES & ICP-OES & ICP-OES & ICP-MS & ICP-MS & ICP-MS \\
\hline & & & $\mathrm{Ni}$ & Zn & $\mathrm{Cu}$ & V & Ag-109 & Cd-114 & Pb-208 \\
\hline & & & $(\mu \mathrm{g} / \mathrm{g})$ & $(\mu \mathrm{g} / \mathrm{g})$ & $(\mu \mathrm{g} / \mathrm{g})$ & $(\mu \mathrm{g} / \mathrm{g})$ & $(\mu \mathrm{g} / \mathrm{g})$ & $(\mu \mathrm{g} / \mathrm{g})$ & $(\mu \mathrm{g} / \mathrm{g})$ \\
\hline $1 \mathrm{~A}$ & 16.18 & Bckfl & $1.3 \mathrm{E}+01$ & $4.4 \mathrm{E}+01$ & $2.0 \mathrm{E}+01$ & $2.9 \mathrm{E}+01$ & 3.62E-02 & $9.80 \mathrm{E}-02$ & $4.37 \mathrm{E}+00$ \\
\hline $2 \mathrm{~A}$ & 22.69 & Bckfl & $1.0 \mathrm{E}+01$ & $4.3 \mathrm{E}+01$ & $1.6 \mathrm{E}+01$ & $2.7 \mathrm{E}+01$ & 2.13E-02 & $9.08 \mathrm{E}-02$ & $4.22 \mathrm{E}+00$ \\
\hline $3 \mathrm{~A}$ & 30.74 & Bckfl & $1.10 \mathrm{E}+01$ & $3.95 \mathrm{E}+01$ & $1.72 \mathrm{E}+01$ & $2.91 \mathrm{E}+01$ & 3.44E-02 & 8.42E-02 & $3.58 \mathrm{E}+00$ \\
\hline $4 \mathrm{~A}$ & 36.88 & Bckfl & $1.25 \mathrm{E}+01$ & $4.78 \mathrm{E}+01$ & $2.23 \mathrm{E}+01$ & $3.36 \mathrm{E}+01$ & 1.94E-01 & $9.29 \mathrm{E}-02$ & $7.86 \mathrm{E}+00$ \\
\hline 4 (Nose Cone) & 37.40 & Bckfl & $(1.1 \mathrm{E}+01)^{(\mathrm{a})}$ & $3.4 \mathrm{E}+01$ & $(1.2 \mathrm{E}+01)$ & $3.5 \mathrm{E}+01$ & 4.24E-02 & $9.58 \mathrm{E}-02$ & $3.91 \mathrm{E}+01$ \\
\hline $5 \mathrm{~A}$ & 40.01 & Bckfl & $(1.3 \mathrm{E}+01)$ & $4.6 \mathrm{E}+01$ & $(1.2 \mathrm{E}+01)$ & $(3.4 \mathrm{E}+01)$ & $(2.37 \mathrm{E}-02)$ & (9.49E-02) & $1.40 \mathrm{E}+02$ \\
\hline 5A dup & 40.01 & Bckfl & $1.4 \mathrm{E}+01$ & $4.1 \mathrm{E}+01$ & $2.0 \mathrm{E}+01$ & $2.4 \mathrm{E}+01$ & 7.11E-02 & $6.44 \mathrm{E}-02$ & $4.28 \mathrm{E}+01$ \\
\hline $6 \mathrm{~B}$ & 46.33 & $\mathrm{H} 2$ & $(4.3 \mathrm{E}+01)$ & $4.2 \mathrm{E}+01$ & $(1.9 \mathrm{E}+01)$ & $2.9 \mathrm{E}+01$ & $6.08 \mathrm{E}-02$ & $1.07 \mathrm{E}-01$ & $4.49 \mathrm{E}+00$ \\
\hline $6 \mathrm{~A}$ & 46.98 & $\mathrm{H} 2$ & $1.3 \mathrm{E}+01$ & $3.6 \mathrm{E}+01$ & $1.7 \mathrm{E}+01$ & $1.7 \mathrm{E}+01$ & $3.21 \mathrm{E}-02$ & $1.50 \mathrm{E}-01$ & $3.08 \mathrm{E}+00$ \\
\hline 7B Dup & 58.39 & $\mathrm{H} 2$ & $(2.6 \mathrm{E}+01)$ & $9.8 \mathrm{E}+01$ & $8.2 \mathrm{E}+01$ & $2.8 \mathrm{E}+01$ & $1.20 \mathrm{E}+00$ & 2.22E-01 & $1.25 \mathrm{E}+01$ \\
\hline $7 \mathrm{~A}$ & 59.09 & $\mathrm{H} 2$ & $1.1 \mathrm{E}+01$ & $3.3 \mathrm{E}+01$ & $1.6 \mathrm{E}+01$ & $1.8 \mathrm{E}+01$ & 2.30E-02 & 5.61E-02 & $3.46 \mathrm{E}+00$ \\
\hline $8 \mathrm{~B}$ & 63.38 & $\mathrm{H} 2$ & $(4.5 E+01)$ & $1.6 \mathrm{E}+02$ & $1.9 \mathrm{E}+02$ & $3.0 \mathrm{E}+01$ & 7.48E-01 & $1.01 \mathrm{E}-01$ & $4.08 \mathrm{E}+00$ \\
\hline $8 \mathrm{~A}$ & 64.03 & $\mathrm{H} 2$ & $8.0 \mathrm{E}+00$ & $3.6 \mathrm{E}+01$ & $1.9 \mathrm{E}+01$ & $1.7 \mathrm{E}+01$ & 2.26E-02 & 7.29E-02 & $3.37 \mathrm{E}+00$ \\
\hline 8A Dup & 64.03 & $\mathrm{H} 2$ & $8.9 \mathrm{E}+00$ & $3.7 \mathrm{E}+01$ & $1.6 \mathrm{E}+01$ & $2.1 \mathrm{E}+01$ & 2.67E-02 & $7.90 \mathrm{E}-02$ & $3.35 \mathrm{E}+00$ \\
\hline $9 \mathrm{~A}$ & 76.03 & $\mathrm{H} 2$ & $1.1 \mathrm{E}+01$ & $3.6 \mathrm{E}+01$ & $1.6 \mathrm{E}+01$ & $1.4 \mathrm{E}+01$ & 2.37E-02 & 6.89E-02 & $3.18 \mathrm{E}+00$ \\
\hline $10 \mathrm{~A}$ & 81.04 & $\mathrm{H} 2$ & $1.6 \mathrm{E}+01$ & $5.3 \mathrm{E}+01$ & $2.0 \mathrm{E}+01$ & $2.1 \mathrm{E}+01$ & $5.45 \mathrm{E}-02$ & $1.12 \mathrm{E}-01$ & $6.75 \mathrm{E}+00$ \\
\hline $11 \mathrm{~A}$ & 87.35 & $\mathrm{CCU}_{\mathrm{u}}$ & $1.9 \mathrm{E}+01$ & $6.2 \mathrm{E}+01$ & $3.2 \mathrm{E}+01$ & $2.6 \mathrm{E}+01$ & $5.42 \mathrm{E}-02$ & $1.45 \mathrm{E}-01$ & $1.01 \mathrm{E}+01$ \\
\hline 11A Dup & 87.35 & $\mathrm{CCU}_{\mathrm{u}}$ & $1.7 \mathrm{E}+01$ & $6.3 \mathrm{E}+01$ & $2.9 \mathrm{E}+01$ & $2.7 \mathrm{E}+01$ & 5.55E-02 & $1.50 \mathrm{E}-01$ & $1.03 \mathrm{E}+01$ \\
\hline $12 \mathrm{~A}$ & 92.61 & $\mathrm{CCU}_{\mathrm{u}}$ & $8.2 \mathrm{E}+00$ & $2.2 \mathrm{E}+01$ & $(5.6 \mathrm{E}+00)$ & $(6.1 \mathrm{E}+00)$ & $2.00 \mathrm{E}-02$ & 3.54E-01 & $2.25 \mathrm{E}+00$ \\
\hline $13 \mathrm{~A}$ & 93.56 & $\mathrm{CCU}_{\mathrm{I}}$ & $1.0 \mathrm{E}+01$ & $2.6 \mathrm{E}+01$ & $(1.1 \mathrm{E}+01)$ & $(5.5 \mathrm{E}+00)$ & $1.46 \mathrm{E}-02$ & $2.96 \mathrm{E}-01$ & $2.91 \mathrm{E}+00$ \\
\hline $14 \mathrm{~A}$ & 94.67 & $\mathrm{CCU}_{\mathrm{I}}$ & $1.6 \mathrm{E}+01$ & $4.4 \mathrm{E}+01$ & $1.9 \mathrm{E}+01$ & $2.7 \mathrm{E}+01$ & 2.37E-02 & $1.60 \mathrm{E}-01$ & $5.13 \mathrm{E}+00$ \\
\hline $15 B$ & 99.70 & $\mathrm{CCU}_{\mathrm{I}}$ & $(1.9 \mathrm{E}+01)$ & $4.9 \mathrm{E}+01$ & $(2.1 \mathrm{E}+01)$ & $(1.4 \mathrm{E}+01)$ & $9.49 \mathrm{E}-01$ & $3.01 \mathrm{E}-01$ & $4.63 \mathrm{E}+00$ \\
\hline $15 \mathrm{~A}$ & 100.37 & $\mathrm{CCU}_{\mathrm{I}}$ & $1.6 \mathrm{E}+01$ & $3.2 \mathrm{E}+01$ & $(1.3 \mathrm{E}+01)$ & $2.9 \mathrm{E}+01$ & $1.40 \mathrm{E}-02$ & $2.42 \mathrm{E}-01$ & $3.51 \mathrm{E}+00$ \\
\hline
\end{tabular}


Table 4.30. (contd)

\begin{tabular}{|c|c|c|c|c|c|c|c|c|c|}
\hline \multirow[b]{2}{*}{ Sample No. } & \multirow[b]{2}{*}{$\begin{array}{c}\text { Depth } \\
\text { (ft bgs) }\end{array}$} & \multirow[b]{2}{*}{$\begin{array}{c}\text { Stratigraphic } \\
\text { Unit }\end{array}$} & \multirow{2}{*}{$\begin{array}{c}\text { ICP-OES } \\
\begin{array}{c}\mathrm{Ni} \\
(\mu \mathrm{g} / \mathrm{g})\end{array} \\
\end{array}$} & \multirow{2}{*}{$\begin{array}{c}\text { ICP-OES } \\
\begin{array}{c}\mathrm{Zn} \\
(\mu \mathrm{g} / \mathrm{g})\end{array}\end{array}$} & \multirow{2}{*}{$\begin{array}{c}\text { ICP-OES } \\
\begin{array}{c}\mathrm{Cu} \\
(\mu \mathrm{g} / \mathrm{g})\end{array}\end{array}$} & \multirow{2}{*}{$\begin{array}{c}\text { ICP-OES } \\
\begin{array}{c}\mathrm{V} \\
(\mu \mathrm{g} / \mathrm{g})\end{array}\end{array}$} & \multirow{2}{*}{$\begin{array}{c}\text { ICP-MS } \\
\text { Ag-109 } \\
(\mu \mathrm{g} / \mathrm{g}) \\
\end{array}$} & \multirow{2}{*}{$\begin{array}{c}\text { ICP-MS } \\
\text { Cd-114 } \\
(\mu \mathrm{g} / \mathrm{g}) \\
\end{array}$} & \multirow{2}{*}{$\begin{array}{c}\text { ICP-MS } \\
\text { Pb-208 } \\
(\mu \mathrm{g} / \mathrm{g}) \\
\end{array}$} \\
\hline & & & & & & & & & \\
\hline $16 \mathrm{~B}$ & 101.33 & $\mathrm{CCU}_{\mathrm{l}}$ & $(1.3 \mathrm{E}+01)$ & $2.8 \mathrm{E}+01$ & $(2.5 \mathrm{E}+01)$ & ND & $7.80 \mathrm{E}-01$ & 2.72E-01 & $3.53 \mathrm{E}+00$ \\
\hline $16 \mathrm{~A}$ & 101.98 & $\mathrm{CCU}_{1}$ & $1.1 \mathrm{E}+01$ & $2.0 \mathrm{E}+01$ & $(1.1 \mathrm{E}+01)$ & ND & $1.74 \mathrm{E}-02$ & 3.15E-01 & $1.88 \mathrm{E}+00$ \\
\hline 17B & 105.39 & $\mathrm{CCU}_{\mathrm{I}}$ & $(1.3 \mathrm{E}+01)$ & $3.5 \mathrm{E}+01$ & $(1.3 \mathrm{E}+01)$ & $(1.5 \mathrm{E}+01)$ & $3.80 \mathrm{E}-01$ & $1.41 \mathrm{E}-01$ & $3.58 \mathrm{E}+00$ \\
\hline $17 \mathrm{~A}$ & 106.09 & $\mathrm{CCU}_{\mathrm{I}}$ & $1.0 \mathrm{E}+01$ & $3.5 \mathrm{E}+01$ & $1.4 \mathrm{E}+01$ & $1.3 \mathrm{E}+01$ & 7.61E-02 & $9.89 \mathrm{E}-02$ & $3.34 \mathrm{E}+00$ \\
\hline $18 \mathrm{~A}$ & 107.42 & $\mathrm{CCU}_{1}$ & $9.4 \mathrm{E}+00$ & $3.1 \mathrm{E}+01$ & $1.5 \mathrm{E}+01$ & $1.6 \mathrm{E}+01$ & 2.34E-02 & 6.39E-02 & $2.94 \mathrm{E}+00$ \\
\hline $19 \mathrm{~A}$ & 110.98 & $\mathrm{CCU}_{\mathrm{l}}$ & $2.2 \mathrm{E}+01$ & $6.1 \mathrm{E}+01$ & $3.5 \mathrm{E}+01$ & $2.6 \mathrm{E}+01$ & $2.43 \mathrm{E}-02$ & $1.80 \mathrm{E}-01$ & $1.04 \mathrm{E}+01$ \\
\hline 19A Dup & 110.98 & $\mathrm{R}_{\mathrm{tf}}$ & $2.0 \mathrm{E}+01$ & $5.4 \mathrm{E}+01$ & $3.1 \mathrm{E}+01$ & $2.2 \mathrm{E}+01$ & $3.19 \mathrm{E}-02$ & 1.63E-01 & $8.80 \mathrm{E}+00$ \\
\hline 20B & 115.25 & $\mathrm{R}_{\mathrm{tf}}$ & $(2.2 \mathrm{E}+01)$ & $6.5 \mathrm{E}+01$ & $(2.0 \mathrm{E}+01)$ & $2.9 \mathrm{E}+01$ & 8.10E-02 & 3.42E-01 & $1.02 \mathrm{E}+01$ \\
\hline $20 \mathrm{~A}$ & 116.02 & $\mathrm{R}_{\mathrm{tf}}$ & $2.5 \mathrm{E}+01$ & $7.0 \mathrm{E}+01$ & $3.7 \mathrm{E}+01$ & $3.6 \mathrm{E}+01$ & $4.21 \mathrm{E}-01$ & 2.05E-01 & $1.14 \mathrm{E}+01$ \\
\hline 21B & 120.30 & $\mathrm{R}_{\mathrm{tf}}$ & $(1.7 \mathrm{E}+01)$ & $5.0 \mathrm{E}+01$ & $(1.6 \mathrm{E}+01)$ & $(2.4 \mathrm{E}+01)$ & $2.47 \mathrm{E}-01$ & 2.53E-01 & $6.01 \mathrm{E}+00$ \\
\hline $21 \mathrm{~A}$ & 120.97 & $\mathrm{R}_{\mathrm{tf}}$ & $2.0 \mathrm{E}+01$ & $4.9 \mathrm{E}+01$ & $2.6 \mathrm{E}+01$ & $1.8 \mathrm{E}+01$ & 2.35E-02 & $9.08 \mathrm{E}-02$ & $6.13 \mathrm{E}+00$ \\
\hline 22B & 123.32 & $\mathrm{R}_{\mathrm{wi}}$ & $(1.6 \mathrm{E}+01)$ & $4.8 \mathrm{E}+01$ & $2.3 \mathrm{E}+01$ & $4.2 \mathrm{E}+01$ & $5.24 \mathrm{E}-01$ & 8.63E-02 & $3.57 \mathrm{E}+00$ \\
\hline $22 \mathrm{~A}$ & 124.05 & $\mathrm{R}_{\mathrm{wi}}$ & $9.3 \mathrm{E}+00$ & $2.8 \mathrm{E}+01$ & $1.6 \mathrm{E}+01$ & $8.9 \mathrm{E}+00$ & $2.71 \mathrm{E}-02$ & 4.97E-02 & $2.44 \mathrm{E}+00$ \\
\hline $23 \mathrm{~A}$ & 127.13 & $\mathrm{R}_{\mathrm{wi}}$ & $6.6 \mathrm{E}+00$ & $3.0 \mathrm{E}+01$ & $1.8 \mathrm{E}+01$ & $1.6 \mathrm{E}+01$ & $1.74 \mathrm{E}-02$ & $6.22 \mathrm{E}-02$ & $2.12 \mathrm{E}+00$ \\
\hline ND & ned. & & & d valid. & & & & & \\
\hline
\end{tabular}


Table 4.31. Acid-Extractable Mobile Metals in C4104 Vadose Zone Sediments

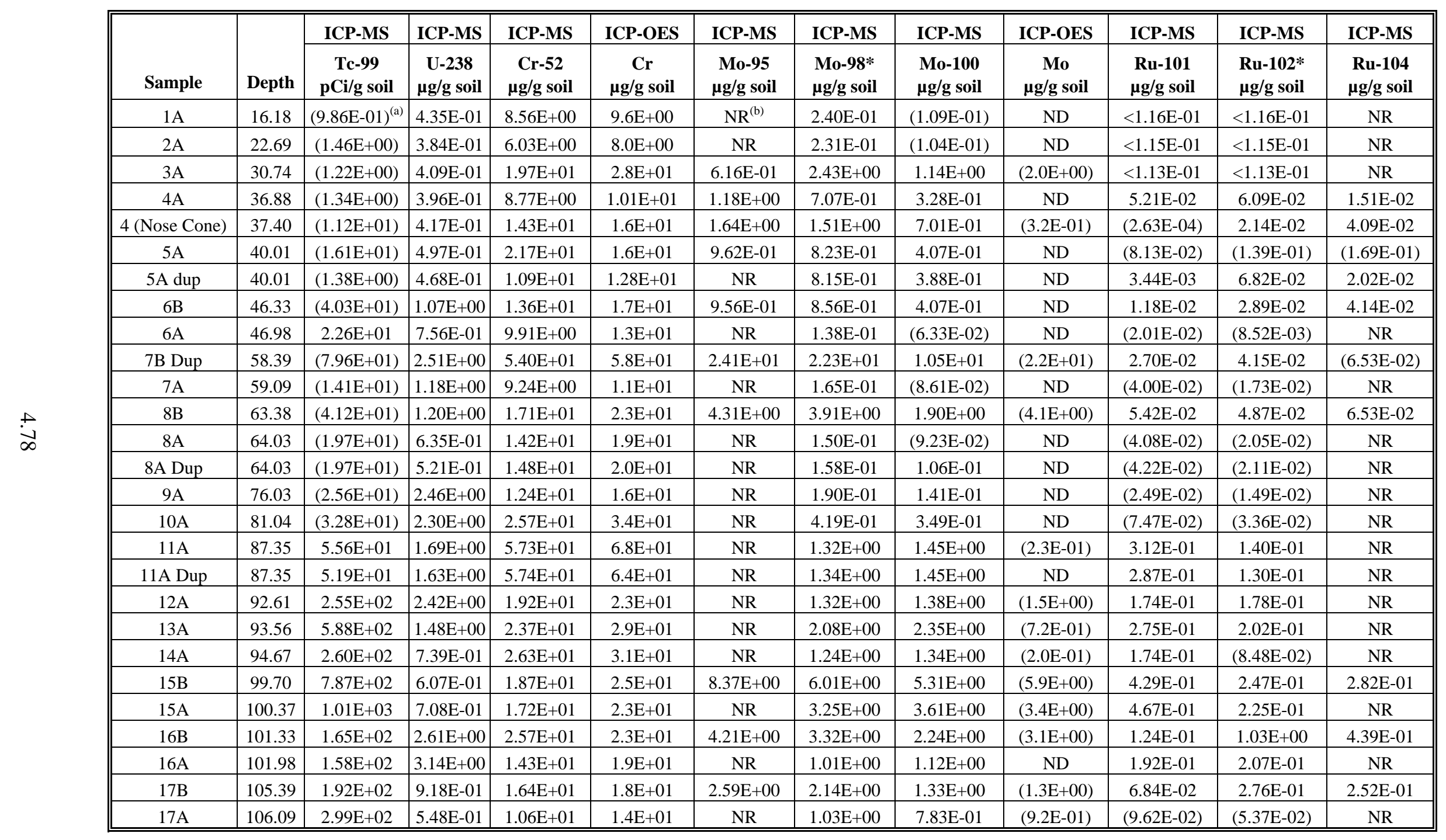


Table 4.31. (contd)

\begin{tabular}{|c|c|c|c|c|c|c|c|c|c|c|c|c|}
\hline \multirow[b]{2}{*}{ Sample } & \multirow[b]{2}{*}{ Depth } & ICP-MS & ICP-MS & ICP-MS & ICP-OES & ICP-MS & ICP-MS & ICP-MS & ICP-OES & ICP-MS & ICP-MS & ICP-MS \\
\hline & & $\begin{array}{c}\text { Tc-99 } \\
\text { pCi/g soil }\end{array}$ & $\begin{array}{c}\text { U-238 } \\
\mu g / g \text { soil }\end{array}$ & $\begin{array}{c}\text { Cr-52 } \\
\mu g / g \text { soil }\end{array}$ & $\begin{array}{c}\mathrm{Cr} \\
\mu \mathrm{g} / \mathrm{g} \text { soil }\end{array}$ & $\begin{array}{c}\text { Mo-95 } \\
\mu g / g \text { soil }\end{array}$ & $\begin{array}{c}\text { Mo-98* } \\
\mu g / g \text { soil }\end{array}$ & $\begin{array}{c}\text { Mo-100 } \\
\mu \mathrm{g} / \mathrm{g} \text { soil }\end{array}$ & $\begin{array}{c}\text { Mo } \\
\mu \mathrm{g} / \mathrm{g} \text { soil }\end{array}$ & $\begin{array}{c}\text { Ru-101 } \\
\mu g / g \text { soil }\end{array}$ & $\begin{array}{l}\text { Ru-102* } \\
\mu g / g \text { soil }\end{array}$ & $\begin{array}{c}\text { Ru-104 } \\
\mu g / g \text { soil }\end{array}$ \\
\hline $18 \mathrm{~A}$ & 107.42 & $1.25 \mathrm{E}+02$ & 4.12E-01 & $9.12 \mathrm{E}+00$ & $1.0 \mathrm{E}+01$ & NR & 4.26E-01 & 3.95E-01 & ND & (4.57E-02) & $(2.04 \mathrm{E}-02)$ & NR \\
\hline $19 \mathrm{~A}$ & 110.98 & $2.70 \mathrm{E}+02$ & 4.55E-01 & $2.47 \mathrm{E}+01$ & $3.3 \mathrm{E}+01$ & NR & $1.60 \mathrm{E}+00$ & $1.73 E+00$ & $(2.9 \mathrm{E}-01)$ & 2.85E-01 & $1.26 \mathrm{E}-01$ & NR \\
\hline 19A Dup & 110.98 & $1.67 \mathrm{E}+02$ & 4.04E-01 & $1.86 \mathrm{E}+01$ & $2.6 \mathrm{E}+01$ & NR & $1.14 \mathrm{E}+00$ & $1.24 \mathrm{E}+00$ & (3.9E-01) & $2.12 \mathrm{E}-01$ & $(1.00 \mathrm{E}-01)$ & NR \\
\hline $20 \mathrm{~B}$ & 115.25 & $2.90 \mathrm{E}+03$ & 6.95E-01 & $2.57 \mathrm{E}+01$ & $3.5 \mathrm{E}+01$ & $3.98 \mathrm{E}+00$ & $2.77 \mathrm{E}+00$ & $2.56 \mathrm{E}+00$ & $(9.4 \mathrm{E}-01)$ & 6.69E-01 & 3.64E-01 & 3.64E-01 \\
\hline $20 \mathrm{~A}$ & 116.02 & $4.67 \mathrm{E}+03$ & 6.63E-01 & $1.79 \mathrm{E}+01$ & $2.7 \mathrm{E}+01$ & NR & 6.19E-01 & 4.62E-01 & ND & $1.08 \mathrm{E}+00$ & $5.08 \mathrm{E}-01$ & NR \\
\hline $21 \mathrm{~B}$ & 120.30 & $6.45 \mathrm{E}+02$ & 5.64E-01 & $1.50 \mathrm{E}+01$ & $1.9 \mathrm{E}+01$ & $2.00 \mathrm{E}+00$ & $1.83 \mathrm{E}+00$ & 8.48E-01 & (6.6E-01) & 4.71E-02 & 8.23E-02 & 6.57E-02 \\
\hline $21 \mathrm{~A}$ & 120.97 & $1.34 \mathrm{E}+03$ & 3.87E-01 & $1.13 \mathrm{E}+01$ & $1.5 \mathrm{E}+01$ & NR & 2.31E-01 & 1.05E-01 & ND & (9.87E-02) & (4.65E-02) & NR \\
\hline $22 B$ & 123.32 & $2.38 \mathrm{E}+02$ & $3.86 \mathrm{E}-01$ & $2.28 \mathrm{E}+01$ & $3.5 \mathrm{E}+01$ & $8.65 E+00$ & $8.22 \mathrm{E}+00$ & $3.88 \mathrm{E}+00$ & $(8.1 \mathrm{E}+00)$ & $1.14 \mathrm{E}-02$ & $1.64 \mathrm{E}-02$ & $4.52 \mathrm{E}-02$ \\
\hline $22 \mathrm{~A}$ & 124.05 & $2.53 \mathrm{E}+02$ & 3.15E-01 & $5.04 \mathrm{E}+00$ & $6.7 \mathrm{E}+00$ & NR & 3.67E-01 & 1.63E-01 & ND & $(1.24 \mathrm{E}-02)$ & (3.45E-03) & NR \\
\hline $23 \mathrm{~A}$ & 127.13 & $2.34 \mathrm{E}+02$ & 3.45E-01 & $4.45 \mathrm{E}+00$ & $5.8 \mathrm{E}+00$ & NR & 3.15E-01 & $1.46 \mathrm{E}-01$ & ND & (1.18E-02) & $(2.59 \mathrm{E}-03)$ & NR \\
\hline $\begin{array}{l}\text { (a) } \\
\text { (b) }\end{array}$ & 保 & $\begin{array}{l}\text { gnify valu } \\
\text { rted/deter }\end{array}$ & $\begin{array}{l}\text { elow leve } \\
\text { ed. }\end{array}$ & juantitati & t consid & valid. & & & & & & \\
\hline
\end{tabular}




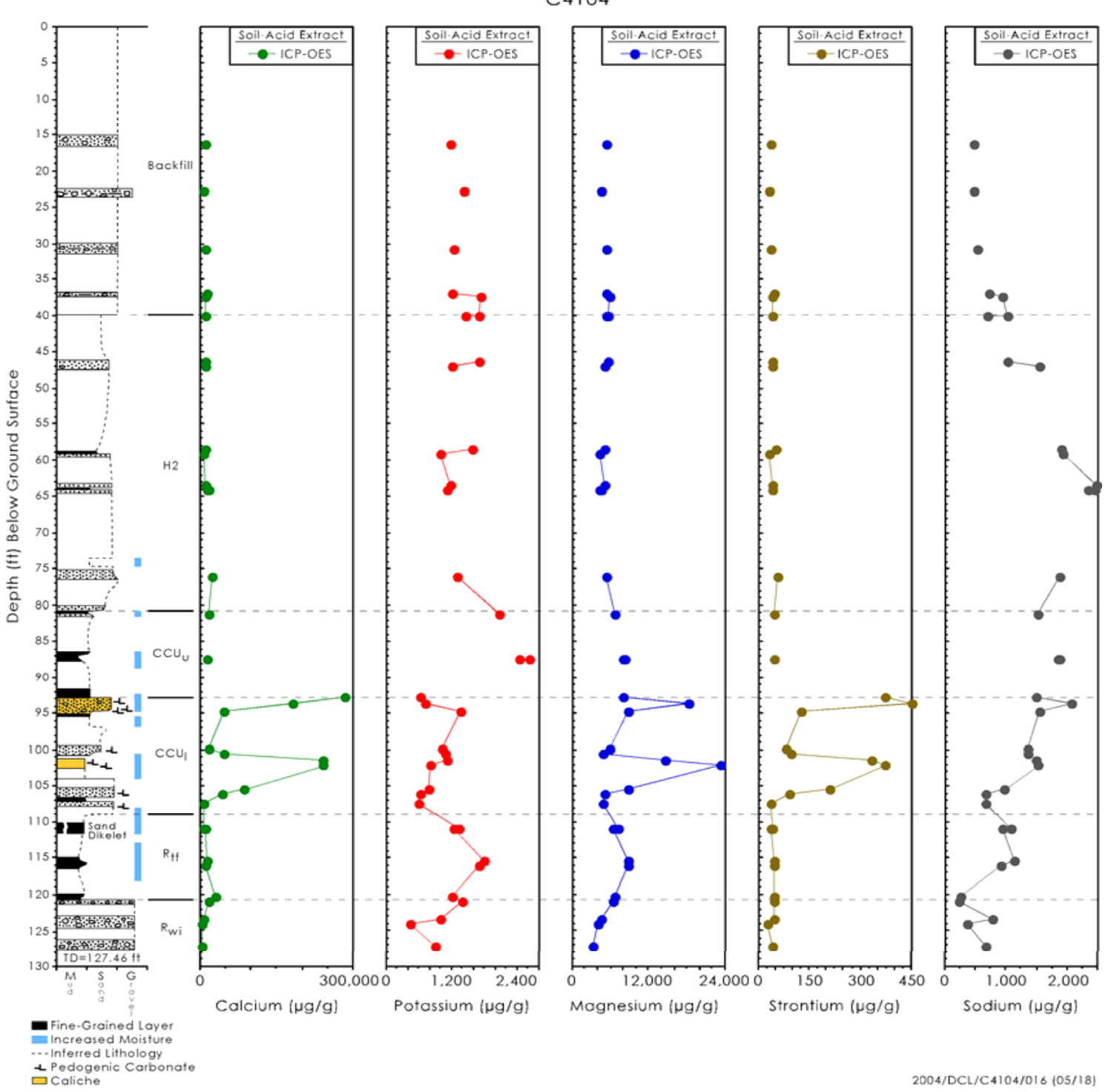

Figure 4.22. Acid-Extractable Cations in C4104 Vadose Zone Sediments ( $\mu \mathrm{g} / \mathrm{g}$ dry sediment) 


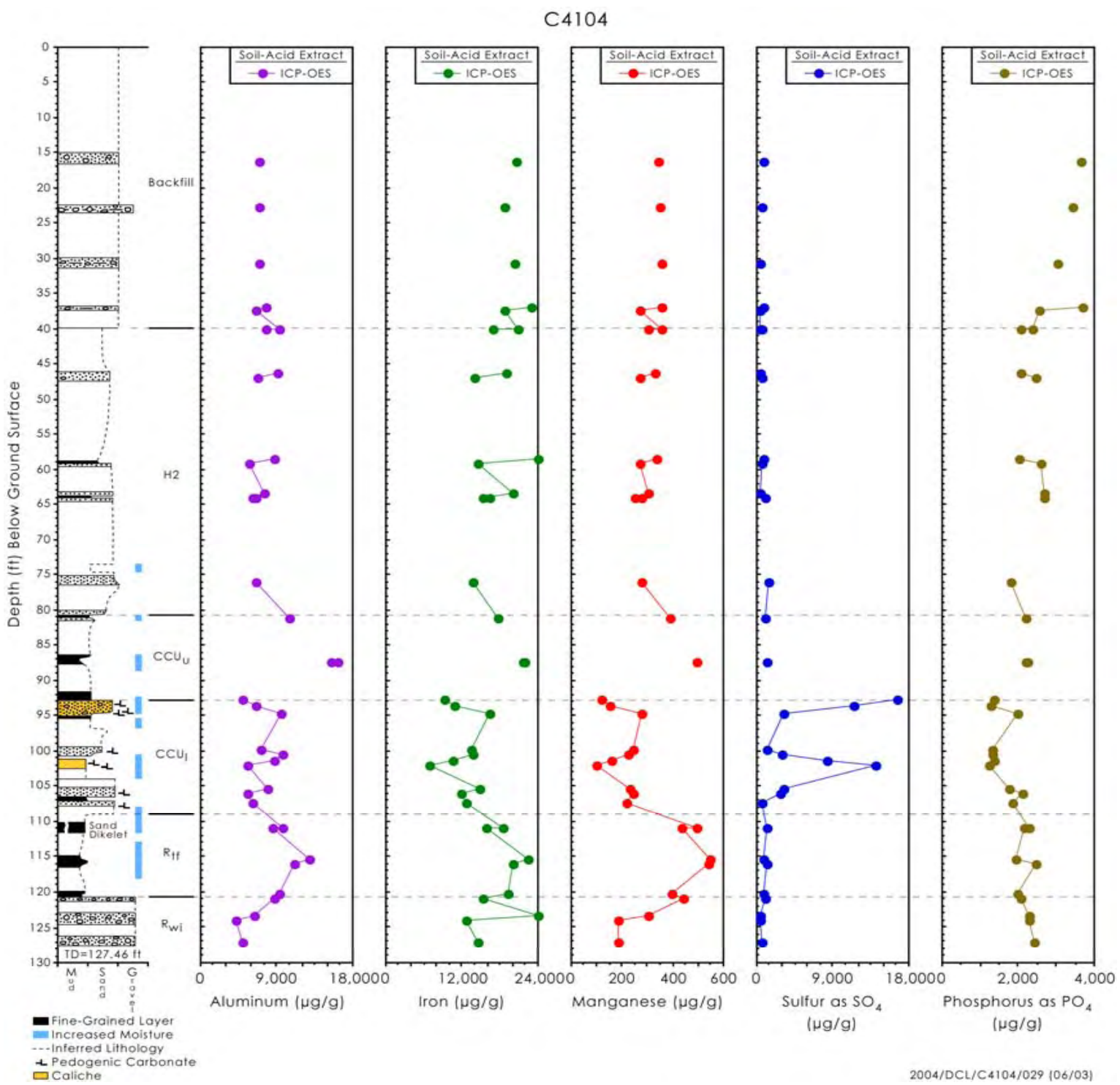

Figure 4.23. Acid-Extractable Major Metals in C4104 Vadose Zone Sediments ( $\mu \mathrm{g} / \mathrm{g}$ dry sediment) 
C4104
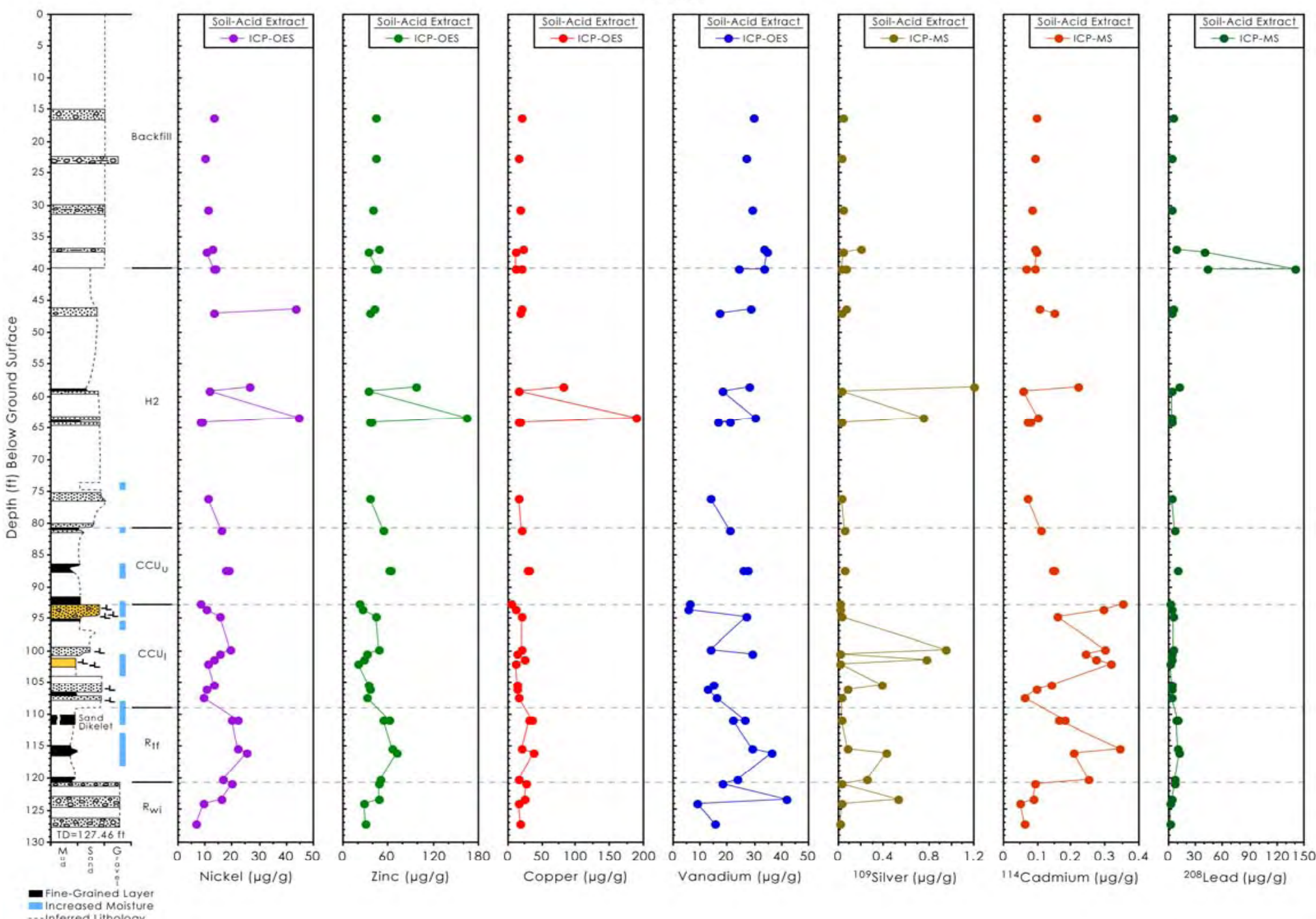

tPedogenic Carbona

$2004 / 0$ CL/C4104/030 106/03)

Figure 4.24. Acid-Extractable Trace Metals in C4104 Vadose Zone Sediments ( $\mu g / g$ dry sediment) 


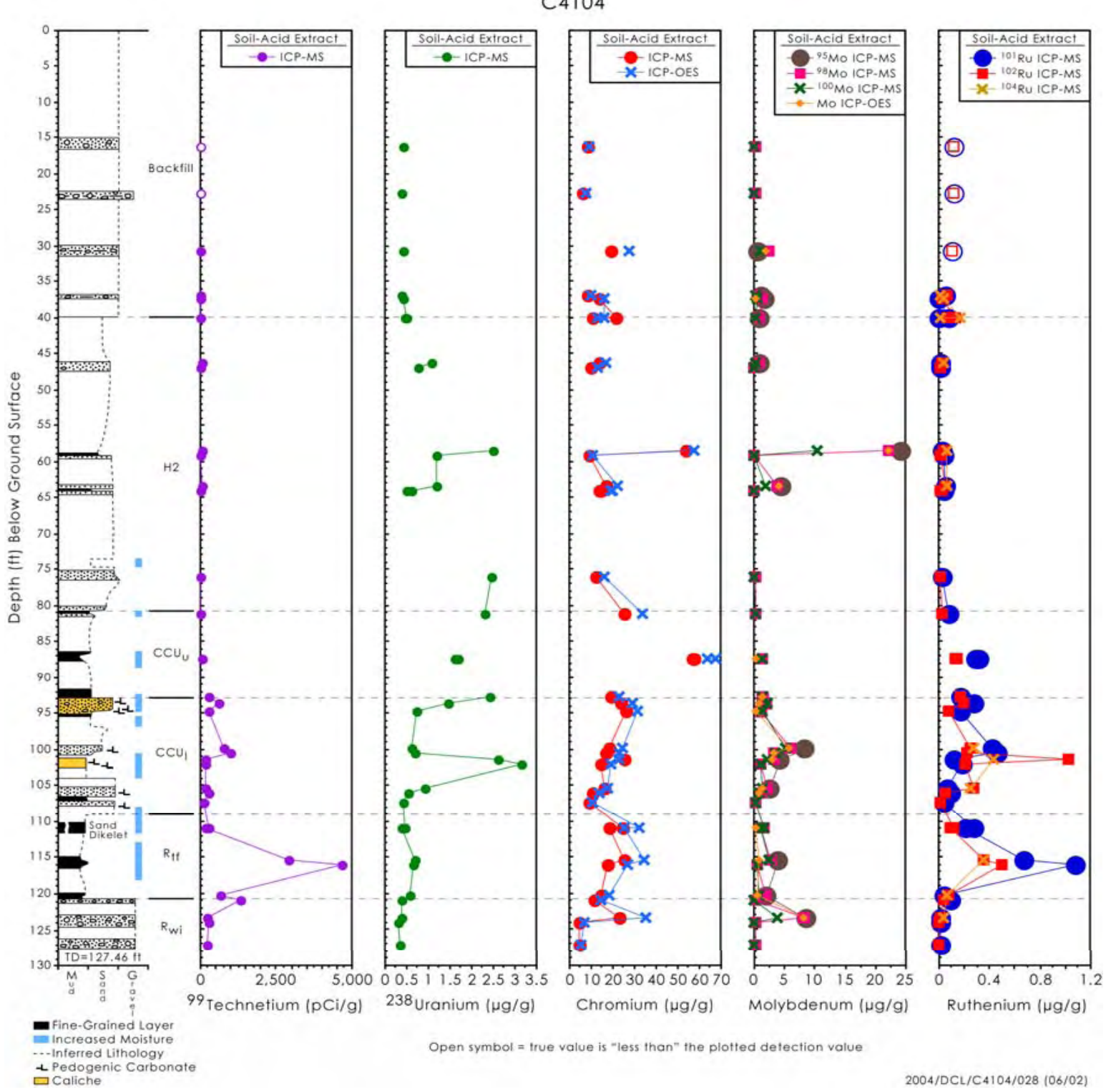

Figure 4.25. Acid-Extractable Mobile Metals in C4104 Vadose Zone Sediments (units vary) 
C4104

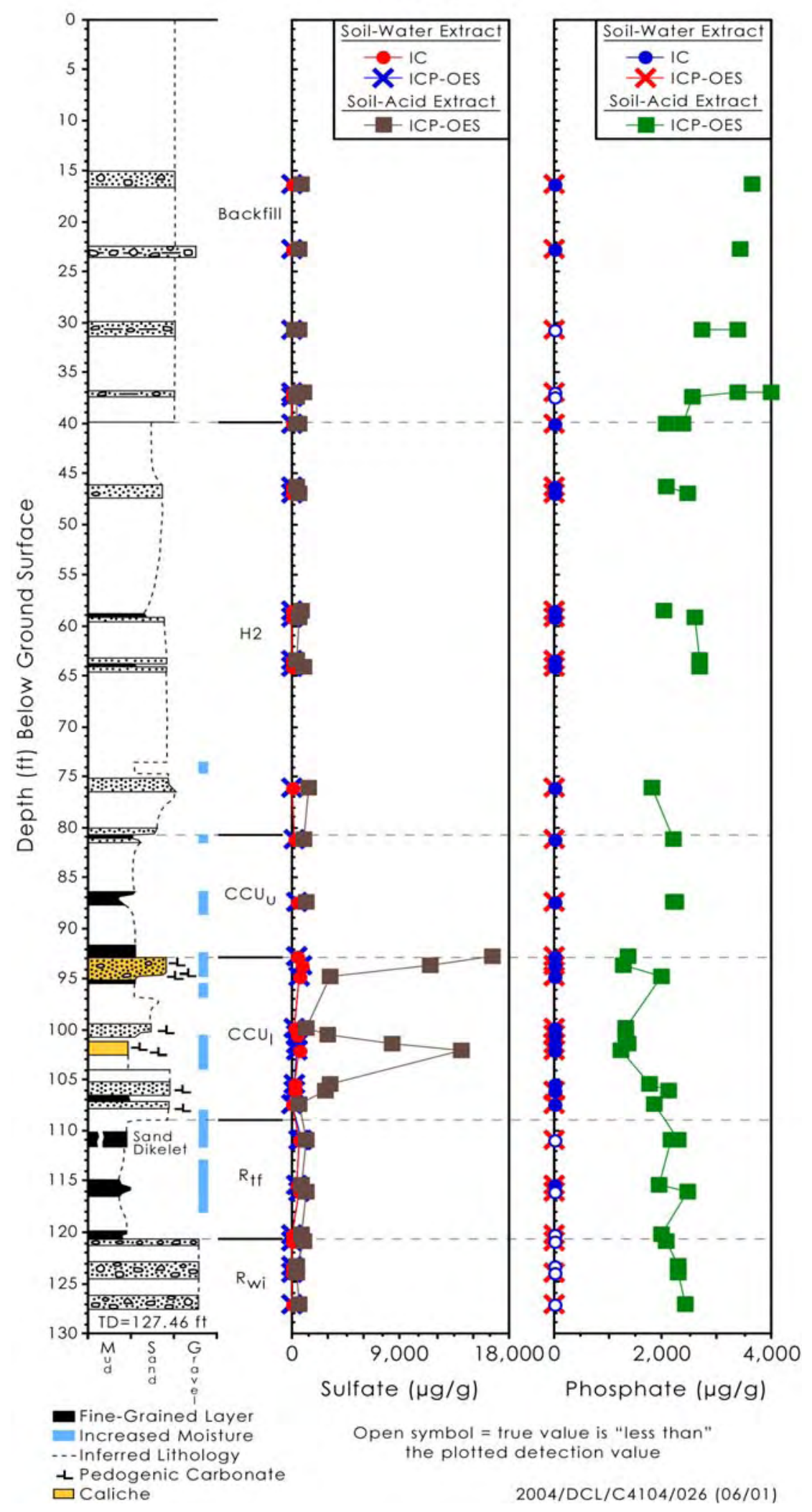

Figure 4.26. Water- Versus Acid-Extractable Sulfate and Phosphate in C4104 Vadose Zone Sediments 


\subsubsection{Radionuclide Content in Vadose Zone Sediment from C4104}

Aside from the technetium-99 and uranium data presented in the water and acid extracts already discussed, the direct measurement of bulk sediment samples for gamma-emitting radionuclides shows that natural potassium-40, and the fission products cobalt-60, cesium-137, and europium-152, -154, and -155 isotopes are present. The gamma energy analyses data are shown in Table 4.32 and Figure 4.27. The spectral gamma log results in Figure 4.27 indicate that there is slightly elevated uranium present between 45 and $64 \mathrm{ft}$ bgs as does the acid extract data in Table 4.31. The water-extractable uranium shows elevated values, compared to other depths and the background sediments from 299-W11-39, between the depths of 58.5 and $92.6 \mathrm{ft}$ bgs, but the levels are not large on a per gram of sediment basis $(\sim 1 \mu \mathrm{g} / \mathrm{g})$. The equivalent and actual porewater dissolved uranium concentrations are $\sim 20,000 \mu \mathrm{g} / \mathrm{L}$, which is almost 1000 times higher than the drinking water standard. Because the Cold Creek units contain caliche, which is naturally elevated in uranium that is somewhat water leachable and significantly more acid leachable than other types of sediments, the elevated uranium concentrations below $81 \mathrm{ft}$ bgs in C4104 sediments may be a natural occurrence more so than signs of elevated uranium from the T-106 tank leak.

As shown in Figure 4.27, the europium isotopes are found between 45 and $65 \mathrm{ft}$ bgs in the upper portion of the Hanford $\mathrm{H} 2$ unit, suggesting moderate migration has occurred from the origin of the leak from tank T-106. The field spectral gamma log of the continuous profile shows that the discrete sampling approach missed the region of highest europium-154 activity (values reach 2,000 pCi/g) at 48 to $52 \mathrm{ft}$ bgs. The field spectral gamma logging data do not include data for europium-152 or europium-155 but we suspect that their highest activities also occur in the thin zone (50+/-2) ft bgs. The cesium-137 data show a thin region between 45 and $52 \mathrm{ft}$ bgs that has activities ranging between 10 and $40 \mathrm{pCi} / \mathrm{g}$, as captured by the continuous spectral gamma log. The discrete splitspoon samples showed very low cesium-137 activities. The high europium-154 activity hindered the spectral gamma logging tool from quantitating the cesium-137 activity between 47 and $52 \mathrm{ft}$ bgs. It is possible that both radioelements, cesium and europium, migrated about the same distance from the leak source. Neither the radio-europium nor cesium-137 in the C4104 sediments leaches at measurable concentrations when extracted with water at one part sediment to one part water. No measurable radio-europium or cesium-137 was found the four actual porewaters (between the depths of 87 and $121 \mathrm{ft}$ bgs) for which adequate volumes were obtained to facilitate counting. It should be noted that neither radio-europium nor radio-cesium were found by directly counting the sediments at the depths from which actual porewater was obtained; thus, the actual porewater data set is inconclusive regarding the potential for water leachability of these two contaminants.

Both the continuous spectral gamma log and the discrete splitspoon samples show a thick plume of cobalt-60 from about 48 to $118 \mathrm{ft}$ bgs based on a $10 \mathrm{pCi} / \mathrm{g}$ cut-off value. The cobalt-60 activity is slightly higher between 95 and $103 \mathrm{ft}$ bgs where values exceed $30 \mathrm{pCi} / \mathrm{g}$. As found at other Hanford vadose zone sites and in the groundwater, cobalt-60 can be mobile compared to other cationic fission products such as strontium-90, cesium-137, europium isotopes, and actinides. Further, substantial percentages of the cobalt-60 found by directly counting field-moist sediment are water extractable, and cobalt-60 was found in three of the four actual porewaters obtained between the depths of 87 and $121 \mathrm{ft} \mathrm{bgs.} \mathrm{More} \mathrm{discussion}$ on the cobalt-60 data that includes calculation of in situ $K_{d}$ values is found in Section 6.6.

Strontium-90 and actinide measurements were made on selected sediments from the shallow H2 unit based on data available from the 299-W10-196 borehole characterization. The results are shown in Table 4.33. Because it is possible to measure strontium-90 and technetium-99 on the same acid extract needed to prepare sediment for strontium-90 measurements, technetium-99 was also determined by wet chemical separation/radiocounting. The comparison between technetium-99 values determined by the 
wet chemical separation/radiocounting with the ICP-MS technique is also shown in Table 4.33. The data in Table 4.33 show that there is a zone of elevated strontium-90 (>1,000 pCi/g) between 47 and $59 \mathrm{ft}$ bgs. Below this depth, the strontium-90 concentrations range from 10 to $350 \mathrm{pCi} / \mathrm{g}$. Below $59 \mathrm{ft}$ bgs, every sediment sample that contains $>100 \mathrm{pCi} / \mathrm{g}$ of strontium-90 is associated with a fine-grained thin lens or with sediment enriched in calcium carbonate. Strontium is known to bind to sediments by ion exchange reactions with fine-grained particles such as silt and clay and to be enriched in calcite-rich sediments perhaps by co-precipitation in the calcite structure or by substitution for calcium ions. No attempt was made to measure strontium-90 in the water extracts of the sediment, but the sediment profile suggests that low concentrations of strontium-90 have migrated throughout the sediments obtained. The fine-grained lens and caliche rich sediments appear to act as sinks for strontium-90.

The comparison of the technetium-99 data measured by two different techniques (see the 4th and 5th columns, Rad Acid and ICP-MS Acid, respectively, in Table 4.33) suggests that this radionuclide is quite mobile; it occurs in all the sediments below $47 \mathrm{ft}$ bgs and shows a bimodal distribution with peaks at 90 to 100 and 116 to $121 \mathrm{ft}$ bgs. Both zones appear to be fine-grained sediments (with higher moisture content than the overlying Hanford sands) in the upper Cold Creek subunit and the Ringold Taylor Flats member, respectively. The agreement between the wet chemical separation/radiocounting versus the ICP-MS measurements on acid extracts is satisfactory for most samples, especially considering that separate aliquots of sediment were used. The water-extractable concentrations of technetium-99 appear to be consistently lower than the acid-extractable concentrations, suggesting that some technetium-99 is associated with the sediment. This observation has not been as evident at any other borehole studied to date. If real, technetium-99 below the T-106 tank may not travel essentially un-retarded as is generally assumed in fate and transport analyses. Further studies with the tank T-106 Tc contaminated sediments are planned to better establish whether the technetium-99 is interacting with the sediments.

The actinide measurements show some neptunium, plutonium and americium is present near $47 \mathrm{ft}$ bgs. There is a faint indication that up to $10 \mathrm{pCi} / \mathrm{g}$ of plutonium-239 and americium-241 has migrated to $64 \mathrm{ft}$ bgs and up to $5 \mathrm{pCi} / \mathrm{g}$ has reached as deep as $87 \mathrm{ft}$ bgs. More discussion is found in Section 4.3.5 where the recent C4104 borehole data is compared to the 1993 vadose zone distribution at 299-W10-196 that is $\sim 13 \mathrm{ft}$ closer to tank T-106.

Gross alpha and beta measurement were made on some of the sediment:acid and sediment:water extracts. The gross alpha acid extract data agreed with the wet chemical separation/alpha spectroscopy counting actinide data shown in Table 4.33 fairly well, as should occur. The gross alpha data on water extracts did not show much activity and was rather featureless with near background values. The gross beta acid extracts showed high values shallow in the profile where the strontium-90 is found and deep in the profile where the technetium-99 is found. The gross beta data for water extracts qualititatively correlates somewhat with the water-extractable technetium-99 data shown in Table 4.33, but there is little quantitative agreement between the gross beta values and the independent analyses of specific betaemitting radionuclides. As is commonly found and standard protocol, gross alpha and gross beta measurements are only useful as a screening tool. 
Table 4.32. Gamma Emitting Radionuclides in C4104 Vadose Zone Sediments (pCi/g)

\begin{tabular}{|c|c|c|c|c|c|c|c|c|c|}
\hline Sample & $\begin{array}{l}\text { Depth } \\
\text { ft bgs }\end{array}$ & $\begin{array}{c}\text { Units } \\
\text { Stratioranhic Unit }\end{array}$ & $\begin{array}{c}\text { K-40 } \\
\text { pCi/g sed. }\end{array}$ & $\begin{array}{c}\text { Co-60 } \\
\text { pCi/g sed. }\end{array}$ & $\begin{array}{c}\text { Cs-137 } \\
\text { pCi/g sed. }\end{array}$ & $\begin{array}{c}\text { Eu-152 } \\
\text { pCi/g sed. }\end{array}$ & $\begin{array}{c}\text { Eu-154 } \\
\text { pCi/g sed. }\end{array}$ & $\begin{array}{c}\text { Eu-155 } \\
\text { pCi/g sed. }\end{array}$ & $\begin{array}{c}\text { U-238 } \\
\text { pCi/g sed. }\end{array}$ \\
\hline $1 \mathrm{~B}$ & 15.38 & Bckfl & 14.93 & $<0.11$ & $<0.18$ & $<0.42$ & $<0.28$ & $<0.599$ & $<3.25$ \\
\hline $2 \mathrm{~B}$ & 22.02 & Bckfl & 10.43 & $<0.12$ & $<0.15$ & $<0.46$ & $<0.33$ & $<0.576$ & $<3.23$ \\
\hline $3 B$ & 30.07 & Bckfl & 11.49 & $<0.11$ & $<0.14$ & $<0.40$ & $<0.28$ & $<0.480$ & $<2.68$ \\
\hline $5 \mathrm{~A}$ & 40.01 & Bckfl & 19.16 & 1.47 & $<0.54$ & $<1.17$ & 6.69 & 3.83 & $<7.35$ \\
\hline 5A dup & 40.01 & Bckfl & 15.28 & 1.80 & $<0.51$ & $<1.32$ & 6.87 & ND & ND \\
\hline $6 \mathrm{~B}$ & 46.33 & Bckfl & 14.95 & 9.54 & 2.71 & 13.65 & 497.28 & 284 & $<33.70$ \\
\hline $6 \mathrm{~A}$ & 46.98 & Bckfl & 17.01 & 11.04 & 2.59 & 15.13 & 530.28 & ND & ND \\
\hline $7 \mathrm{~B}$ & 58.39 & $\mathrm{H} 2$ & 15.72 & 16.06 & 1.19 & 21.25 & 763.42 & 369.7 & $<28.40$ \\
\hline 7A & 59.09 & $\mathrm{H} 2$ & 13.72 & 9.93 & 1.16 & 11.55 & 375.48 & ND & ND \\
\hline $8 \mathrm{~B}$ & 63.38 & $\mathrm{H} 2$ & 16.10 & 29.44 & 2.40 & 22.73 & 719.03 & 336.4 & $<32.80$ \\
\hline 8B Dup & 63.38 & $\mathrm{H} 2$ & 14.22 & 16.60 & 0.49 & 8.89 & 305.86 & 156.1 & $<19.00$ \\
\hline $8 \mathrm{~A}$ & 64.03 & $\mathrm{H} 2$ & 14.36 & 27.99 & $<1.43$ & 5.30 & 168.02 & ND & ND \\
\hline 8ADup & 64.03 & $\mathrm{H} 2$ & 10.33 & 21.63 & $<0.52$ & 4.10 & 129.37 & ND & ND \\
\hline $9 \mathrm{~B}$ & 75.38 & $\mathrm{H} 2$ & 13.60 & 24.40 & $<0.39$ & 0.95 & 30.33 & 14.96 & $<6.73$ \\
\hline $9 \mathrm{~A}$ & 76.03 & $\mathrm{H} 2$ & 14.75 & 12.22 & $<0.65$ & $<1.58$ & 8.56 & ND & ND \\
\hline $10 \mathrm{~B}$ & 80.38 & $\mathrm{H} 2$ & 13.68 & 25.99 & $<0.44$ & $<0.72$ & 14.48 & 7.62 & $<6.82$ \\
\hline $10 \mathrm{~A}$ & 81.04 & $\mathrm{CCU}_{\mathrm{u}}$ & 15.24 & 12.01 & $<0.68$ & $<1.77$ & 7.29 & ND & ND \\
\hline $11 \mathrm{~B}$ & 86.65 & $\mathrm{CCU}_{\mathrm{u}}$ & 16.23 & 34.36 & $<0.36$ & $<0.58$ & $<0.58$ & $<0.952$ & $<5.30$ \\
\hline 11B Dup & 86.65 & $\mathrm{CCU}_{\mathrm{u}}$ & 19.40 & 43.03 & $<0.41$ & $<0.63$ & $<0.63$ & $<0.952$ & $<5.49$ \\
\hline 11A Soil & 87.35 & $\mathrm{CCU}_{\mathrm{l}}$ & 16.31 & 35.59 & $<0.40$ & $<1.18$ & $<0.96$ & ND & ND \\
\hline 11A Dup & 87.35 & $\mathrm{CCU}_{\mathrm{l}}$ & 17.48 & 32.97 & $<0.76$ & $<1.73$ & $<0.89$ & ND & ND \\
\hline $12 \mathrm{~B}$ & 91.96 & $\mathrm{CCU}_{\mathrm{l}}$ & 9.98 & 23.78 & $<0.38$ & $<0.51$ & $<0.51$ & $<0.893$ & $<5.33$ \\
\hline $12 \mathrm{~A}$ & 92.61 & $\mathrm{CCU}_{\mathrm{l}}$ & 9.89 & 29.99 & $<0.87$ & $<2.05$ & $<1.21$ & ND & ND \\
\hline $13 \mathrm{~B}$ & 92.91 & $\mathrm{CCU}_{\mathrm{l}}$ & 3.19 & 51.22 & $<0.41$ & $<0.60$ & $<0.60$ & $<0.942$ & $<5.46$ \\
\hline $13 \mathrm{~A}$ & 93.56 & $\mathrm{CCU}_{1}$ & 3.55 & 38.34 & $<0.41$ & $<1.27$ & $<0.95$ & ND & ND \\
\hline $14 \mathrm{~B}$ & 94.11 & $\mathrm{CCU}_{\mathrm{l}}$ & 11.95 & 42.44 & $<0.40$ & $<0.63$ & $<0.63$ & $<0.971$ & $<5.63$ \\
\hline
\end{tabular}


Table 4.32. (contd)

\begin{tabular}{|c|c|c|c|c|c|c|c|c|c|}
\hline \multirow{2}{*}{ Sample } & \multirow{2}{*}{$\begin{array}{l}\text { Depth } \\
\text { ft bgs }\end{array}$} & Units & \multirow{2}{*}{$\begin{array}{c}\text { K-40 } \\
\text { pCi/g sed. }\end{array}$} & \multirow{2}{*}{$\begin{array}{c}\text { Co-60 } \\
\text { pCi/g sed. }\end{array}$} & \multirow{2}{*}{$\begin{array}{c}\text { Cs-137 } \\
\text { pCi/g sed. }\end{array}$} & \multirow{2}{*}{$\begin{array}{c}\text { Eu-152 } \\
\text { pCi/g sed. }\end{array}$} & \multirow{2}{*}{$\begin{array}{c}\text { Eu-154 } \\
\text { pCi/g sed. }\end{array}$} & \multirow{2}{*}{$\begin{array}{c}\text { Eu-155 } \\
\text { pCi/g sed. }\end{array}$} & \multirow{2}{*}{$\begin{array}{c}\text { U-238 } \\
\text { pCi/g sed. }\end{array}$} \\
\hline & & Stratigraphic Unit & & & & & & & \\
\hline $14 \mathrm{~A}$ & 94.67 & $\mathrm{CCU}_{\mathrm{l}}$ & 12.63 & 41.70 & $<0.92$ & $<2.13$ & $<1.05$ & ND & ND \\
\hline $15 B$ & 99.70 & $\mathrm{CCU}_{\mathrm{l}}$ & 12.59 & 29.06 & $<0.42$ & $<0.52$ & $<0.52$ & $<0.920$ & $<5.32$ \\
\hline $16 \mathrm{~B}$ & 101.33 & $\mathrm{CCU}_{\mathrm{l}}$ & 4.03 & 26.50 & $<0.34$ & $<0.57$ & $<0.57$ & $<0.959$ & 3.22 \\
\hline $17 \mathrm{~B}$ & 105.39 & $\mathrm{R}_{\mathrm{tf}}$ & 8.76 & 11.45 & $<0.22$ & $<0.39$ & $<0.39$ & $<0.657$ & $<3.75$ \\
\hline 18B & 106.77 & $\mathrm{R}_{\mathrm{tf}}$ & 8.89 & 17.57 & $<0.32$ & $<0.42$ & $<0.42$ & $<0.813$ & $<4.59$ \\
\hline 19B & 110.33 & $\mathrm{R}_{\mathrm{tf}}$ & 14.79 & 24.06 & $<0.27$ & $<0.44$ & $<0.44$ & $<0.650$ & $<3.78$ \\
\hline 19B Dup & 110.33 & $\mathrm{R}_{\mathrm{tf}}$ & 12.81 & 22.90 & $<0.33$ & $<0.44$ & $<0.44$ & $<0.833$ & $<4.79$ \\
\hline $20 \mathrm{~B}$ & 115.25 & $\mathrm{R}_{\mathrm{tf}}$ & 18.52 & 22.25 & $<0.40$ & $<0.68$ & $<0.68$ & $<1.150$ & $<6.47$ \\
\hline $21 \mathrm{~B}$ & 120.30 & $\mathrm{R}_{\mathrm{tf}}$ & 10.26 & $<0.14$ & $<0.15$ & $<0.33$ & $<0.33$ & $<0.554$ & $<3.21$ \\
\hline $22 \mathrm{~B}$ & 123.32 & $\mathrm{R}_{\mathrm{wi}}$ & 14.24 & $<0.22$ & $<0.26$ & $<0.43$ & $<0.43$ & $<0.872$ & $<4.77$ \\
\hline 23B & 126.46 & $\mathrm{R}_{\mathrm{wi}}$ & 12.21 & 0.13 & $<0.23$ & $<0.50$ & $<0.50$ & $<\mathbf{0 . 8 9 7}$ & $<4.99$ \\
\hline \multicolumn{10}{|c|}{ (a) Bold type signifies less than detection limit values } \\
\hline
\end{tabular}


Table 4.33. Sr-90, Tc-99, and Actinides in C4104 Vadose Zone Sediments

\begin{tabular}{|c|c|c|c|c|c|c|c|c|c|}
\hline Method & & Rad & Rad & ICP-MS & ICP-MS & Rad & Rad & Rad & Rad \\
\hline Leachant & & Acid & Acid & Acid & Water & Acid & Acid & Acid & Acid \\
\hline \multirow[t]{2}{*}{ Sample } & Depth & Sr-90 (pCi/ & [c-99 (pCi/s & Tc-99 (pCi/g) & Tc-99 (pCi/g) & Np-237 & Pu-239 & Am-241 & Cm-243 \\
\hline & ft bgs & & & & & $(\mathrm{pCi} / \mathrm{g})$ & $(\mathrm{pCi} / \mathrm{g})$ & $(\mathrm{pCi} / \mathrm{g})$ & $(\mathrm{pCi} / \mathrm{g})$ \\
\hline $5 \mathrm{~A}$ & 40.01 & 17.85 & $-10.80^{(c)}$ & $(8.74 \mathrm{E}+00)^{(\mathrm{a})}$ & 0.21 & $<3.01 \mathrm{E}-01$ & $<5.52 \mathrm{E}-01$ & $<1.10 \mathrm{E}+00$ & $0.00 \mathrm{E}+00$ \\
\hline $6 \mathrm{~B}$ & 46.33 & $\mathrm{NA}^{(\mathrm{b})}$ & NA & NA & NA & $<7.50 \mathrm{E}-01$ & $3.26 \mathrm{E}+01$ & $<6.24 \mathrm{E}+01$ & NA \\
\hline $6 \mathrm{~A}$ & 46.98 & 32393 & 75.38 & 22.58 & 2.02 & $3.90 \mathrm{E}+01$ & $9.61 \mathrm{E}+01$ & $1.33 \mathrm{E}+02$ & $1.56 \mathrm{E}+00$ \\
\hline $7 \mathrm{~B}$ & 58.39 & NA & NA & NA & NA & $<5.91 \mathrm{E}-01$ & $8.40 \mathrm{E}+01$ & $<5.14 \mathrm{E}+01$ & NA \\
\hline 7A & 59.09 & 2664 & 47.65 & $(14.11)$ & 2.19 & $<6.01 \mathrm{E}-01$ & $9.20 \mathrm{E}+01$ & $<5.52 \mathrm{E}+01$ & NA \\
\hline $8 \mathrm{~B}$ & 63.38 & NA & NA & NA & NA & $1.64 \mathrm{E}+00$ & $1.17 \mathrm{E}+01$ & $1.46 \mathrm{E}+01$ & $<2.11 \mathrm{E}-01$ \\
\hline $8 \mathrm{~B}$ & 63.38 & NA & NA & NA & NA & $9.80 \mathrm{E}-02$ & $9.27 \mathrm{E}+00$ & $<3.61 \mathrm{E}+01$ & NA \\
\hline $8 \mathrm{~A}$ & 64.03 & 185.33 & 32.66 & $(19.67)$ & 4.28 & $<1.24 \mathrm{E}+01$ & $3.84 \mathrm{E}+01$ & $6.27 \mathrm{E}+01$ & $<7.89 \mathrm{E}-01$ \\
\hline 8A Dup & 64.03 & 194.63 & 55.89 & $(19.70)$ & 4.51 & $<3.86 \mathrm{E}+00$ & $1.42 \mathrm{E}+01$ & $1.50 \mathrm{E}+01$ & $<4.83 \mathrm{E}-02$ \\
\hline $9 \mathrm{~A}$ & 76.03 & 115.75 & 53.64 & $(25.58)$ & 2.01 & $<7.07 \mathrm{E}-01$ & $1.37 \mathrm{E}+00$ & $1.56 \mathrm{E}+00$ & $0.00 \mathrm{E}+00$ \\
\hline $10 \mathrm{~A}$ & 81.04 & 151.68 & 10.93 & $(32.80)$ & 5.73 & $<1.03 \mathrm{E}-01$ & $<2.59 \mathrm{E}-01$ & $<2.59 \mathrm{E}-01$ & $0.00 \mathrm{E}+00$ \\
\hline $11 \mathrm{~A}$ & 87.35 & 160.25 & 150.31 & 55.65 & 44.30 & $<2.89 \mathrm{E}+00$ & $6.06 \mathrm{E}+00$ & $6.15 \mathrm{E}+00$ & $<5.42 \mathrm{E}-01$ \\
\hline 11A Dup & 87.35 & 186.76 & 245.48 & 51.87 & 40.62 & $<1.24 \mathrm{E}+00$ & $4.66 \mathrm{E}+00$ & $4.19 \mathrm{E}+00$ & $<3.11 \mathrm{E}-01$ \\
\hline $12 \mathrm{~A}$ & 92.61 & 349.45 & 350.40 & 255.24 & 52.70 & $<0.00 \mathrm{E}+00$ & $<0.00 \mathrm{E}+00$ & $<0.00 \mathrm{E}+00$ & $0.00 \mathrm{E}+00$ \\
\hline $13 \mathrm{~A}$ & 93.56 & 73.42 & 235.74 & 587.99 & 295.19 & $<1.61 \mathrm{E}+00$ & $<1.61 \mathrm{E}+00$ & $<9.54 \mathrm{E}-01$ & $0.00 \mathrm{E}+00$ \\
\hline $14 \mathrm{~A}$ & 94.67 & 22.86 & 889.95 & 260.46 & 103.91 & $<3.91 \mathrm{E}-01$ & $<0.00 \mathrm{E}+00$ & $<4.89 \mathrm{E}-02$ & $0.00 \mathrm{E}+00$ \\
\hline $15 \mathrm{~A}$ & 100.37 & 57.60 & 1361.31 & $1.01 \mathrm{E}+03$ & 63.18 & $<4.69 \mathrm{E}-02$ & $<0.00 \mathrm{E}+00$ & $<0.00 \mathrm{E}+00$ & $0.00 \mathrm{E}+00$ \\
\hline $16 \mathrm{~A}$ & 101.98 & 278.90 & 346.65 & 158.29 & 118.19 & NA & NA & NA & NA \\
\hline 17A & 106.09 & 34.09 & 465.80 & 299.23 & 207.35 & NA & NA & NA & NA \\
\hline $18 \mathrm{~A}$ & 107.42 & 10.97 & 204.27 & 124.77 & 98.00 & NA & NA & NA & NA \\
\hline $19 \mathrm{~A}$ & 110.98 & 124.13 & 369.88 & 269.67 & 245.25 & NA & NA & NA & NA \\
\hline 19A Dup & 110.98 & 113.53 & 196.77 & 166.96 & 228.27 & NA & NA & NA & NA \\
\hline
\end{tabular}


Table 4.33. (contd)

\begin{tabular}{||l|l|c|c|c|c|c|c|c|c||}
\hline \begin{tabular}{|l|} 
Method \\
Leachant
\end{tabular} & & Rad & Rad & ICP-MS & ICP-MS & Rad & Rad & Rad & Rad \\
\hline Sample & Depth & Sr-90 (pCi/g) & Tc-99 (pCi/g) & Tc-99 (pCi/g) & Tc-99 (pCi/g) & Np-237 & Pu-239 & Am-241 & Cm-243 \\
\hline & ft bgs & & & & & (pCi/g) & (pCi/g) & (pCi/g) & (pCi/g) \\
\hline 20A & 116.02 & 26.12 & 8116.19 & $4.67 E+03$ & 6109.00 & NA & NA & NA & NA \\
\hline 21A & 120.97 & 8.83 & 1789.95 & $1.34 E+03$ & 572.42 & NA & NA & NA & NA \\
\hline 22A & 124.05 & 13.50 & 239.49 & 253.18 & 264.35 & NA & NA & NA & NA \\
\hline 23A & 127.13 & 26.72 & 336.91 & 233.66 & 61.29 & NA & NA & NA & NA \\
\hline $\begin{array}{l}\text { (a) } \\
\text { (b) } \\
\text { (c) }\end{array}$
\end{tabular}




\subsubsection{Total Carbon, Calcium Carbonate, and Organic Carbon Content of Vadose Zone Sediment from Borehole C4104}

The total, inorganic, and organic carbon contents of the C4104 sediments are reported in Table 4.34. Three of the samples from the lower Cold Creek subunit (caliche) obtained at 92.6, 93.6, and $102 \mathrm{ft}$ bgs, contain significant amounts of calcium-carbonate equivalent material (ranging from 36 to 55\% by weight.) The wide range in calcium-carbonate contents reflects the variability in weathering processes and time for paleosol horizon development. The sediment from the upper Cold Creek subunit also contains a few percent calcium-carbonate content. As is found in most vadose sediments from the Hanford Reservation, there is very little $(<0.1 \%$ by weight) organic carbon in the vadose zone sediments. The lower Cold Creek subunit may contain the most organic carbon, up to $0.1 \%$ by weight. However, because the organic carbon is determined from the difference in total and inorganic carbon content, which are measured on two separate aliquots of sediment, small differences in composition of the two aliquots in this highly variable strata can lead to the appearance of organic carbon when, in fact, sample inhomogeniety is the cause of the difference in the total and inorganic values. The backfill and Hanford $\mathrm{H} 2$ unit contain a few percent calcium-carbonate content and low organic carbon content.

\subsubsection{Matric Potential of C4104 Vadose Zone Sediments}

Water potential measurements have been included in the Hanford Tank Farm Vadose Zone Characterization Program to document the energy state of porewaters in the tank farm sediments. At the tank farms, vegetation is absent, surface soils are coarse-textured, and the potential for drainage (recharge) is high (Gee 1987; Gee et al. 1992). However, actual drainage rates are generally unknown. Attempts are currently being made to determine the soil water matrix potential and use the analysis to confirm the occurrence of recharge within the Hanford Site tank farms.

The status of soil water can be defined by either the amount of water in the soil (water content) or by the force that holds water to the soil matrix (i.e., the matric potential or suction) (Or and Wraith 2002). In recent studies, Serne et al. (2002b, 2002c, 2002e, and 2002f) and Lindenmeier et al. (2002) measured both water content (gravimetrically) and matric water potential (filter paper method, ASTM 2002) on core samples obtained from boreholes in the SX and B-BX tank farm environs. The same measurements were made at borehole C4104 on the sediments in each A liner several weeks after the samples had been opened and sub-sampled. Sandwiched filter papers were added to the air tight plastic storage containers that contained the residual sediment. The data are presented in Table 4.35 and Figure 4.28. To generate the theoretical unit gradient line (gravity head) shown in Figure 4.28, we estimated the water table to be present at an elevation of $448.32 \mathrm{ft}$ above mean seal level or $227 \mathrm{ft}$ bgs, based on nearby groundwater monitoring wells.

The gravity head is zero at the water table and increases linearly with height to the soil surface. For the core samples available from C4104, the measured water potentials are quite erratic and about two thirds of the datum are generally greater than the gravity potential, especially in the deeper samples. Two of the samples $8 \mathrm{~A}$ and 16A have very high matric potentials (signifying very dry conditions). About one third of the matric potentials are very low in comparison of the gravity head. The green line labeled "theoretical value" in Figure 4.28 is the theoretical line that represents the steady-state unit gradient condition, which represents the profile for matric potential in a sediment profile that is neither draining nor drier than (actively evapotranspiring) equilibrium. Matric potential values to the left of the unit gradient line suggest a draining profile. The general trend for the data from C4104 is that the water potentials are erratic and should not be used to infer whether the profile is draining or actively evapotranspiring water. 
It appears that inadvertent drying occurred in many of the samples during the core processing, wherein samples were photographed and quantitatively transferred by means of aliquots for geochemical characterization. Our standard procedure is to insert the matric potential filter papers into the core liner ends, sometimes up to several weeks prior to opening for characterization, to avoid opportunity for drying.

\subsection{Comparison of Contaminant Distributions in C4104 and 299-W10-196 Vadose Zone Sediments}

The main objective of drilling the C4104 borehole was to provide sediment from the vadose zone as close as possible to borehole 299-W10-196 that was installed in 1993 to assess the migration of contaminants from the 1973 tank leak at T-106. As mentioned previously, C4104 could not be placed any closer than $\sim 13 \mathrm{ft}$ because of tank farm infrastructure obstructions. Figures 4.29 and 4.30 show detailed maps of the three contaminated boreholes discussed in this report. The C4104 borehole is situated $\sim 13 \mathrm{ft}$ to the east of 299-W10-196 and is farther away from Tank T-106. The drilling techniques differed (see Section 2.3.5) such that C4104 met refusal at a shallower depth $\sim 127 \mathrm{ft}$ bgs than was reached at 299-W10-196 ( 180 ft bgs). The following discussion compares the vertical distribution and concentrations of various constituents per gram of dry sediment for both boreholes. No water extracts or attempts were made to obtain estimates of the porewater within the sediments at 299-W10-196 in 1993; thus, the only comparisons that can be made are for the total concentration of constituents in the sediments of each borehole. The activities of short-lived radionuclides found in borehole 299-W10-196 were decay-corrected to 2003 when borehole C4104 was emplaced so that the comparisons represent the present day conditions (assuming that significant migration of radionuclides has not occurred in borehole 299-W10-196 over the last ten years).

\subsubsection{Technetium-99}

Technetium-99 is one of Hanford's highest potential risk-causing contaminants because it does not usually interact (precipitate or adsorb) with vadose zone sediments. Therefore, attention was given to measuring the technetium-99 concentrations in the C4104 vadose zone sediments. Although different analytical methods were used to measure technetium-99 in the sediments from the new (C4104) and old (299-W10-196) boreholes, previous studies on vadose zone sediments from WMA SX (see Serne et al. 2002c) and measurements in this report show that the two methods yield comparable results. Assuming that the original tank leak plume had fully interacted with the sediments at both boreholes based on the large volume of the 1973 leak (115,000 gal; Freeman-Pollard et al. 1993), any differences in technetium-99 content in the sediments from the same lithology and same approximate depth should be an indication of either horizontal or vertical migration, or both, over the ten-year span between the measurements. If no differences in technetium-99 content are found between the two boreholes, it would be an indication that the vadose zone sediments are capable of significant sequestration of contaminants very near to the tank. Based on the available data that shows technetium-99, in general, to not interact significantly with Hanford vadose zone sediments, we can dismiss the latter hypothesis. 


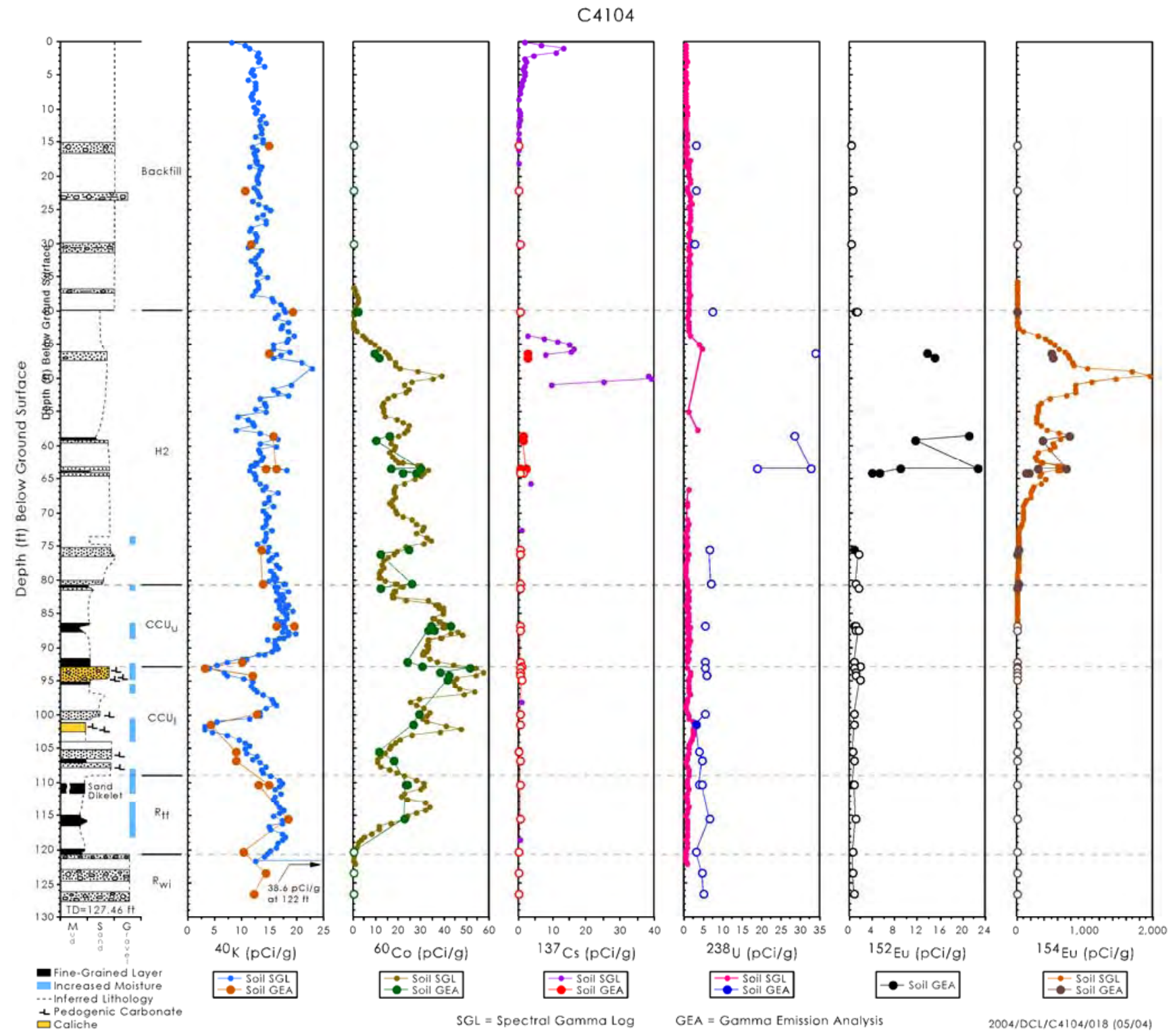

Figure 4.27. Comparison of Lab Gamma Energy Analysis (GEA) and Field Log for Natural Gamma Emitters in Borehole C4104 
Table 4.34. Carbon Contents of Vadose Zone Sediments in Borehole C4104

\begin{tabular}{|c|c|c|c|c|c|c|}
\hline \multirow{2}{*}{$\begin{array}{c}\text { Sample } \\
\text { ID } \\
\end{array}$} & \multirow{2}{*}{$\begin{array}{c}\text { Stratigraphic } \\
\text { Unit }\end{array}$} & \multirow{2}{*}{$\begin{array}{r}\text { Depth } \\
\text { (ft bgs) } \\
\end{array}$} & \multirow{2}{*}{$\begin{array}{c}\text { Total } \\
\text { Carbon \% } \\
\end{array}$} & \multirow{2}{*}{$\begin{array}{c}\text { Inorganic Carbon } \\
\% \\
\end{array}$} & \multirow{2}{*}{$\begin{array}{c}\mathrm{IC} \text { as } \\
\mathrm{CaCO}_{3} \\
\% \\
\end{array}$} & \multirow{2}{*}{$\begin{array}{c}\begin{array}{c}\text { Organic } \\
\text { Carbon \% }\end{array} \\
\text { (by diff.) } \\
\end{array}$} \\
\hline & & & & & & \\
\hline $1 \mathrm{~A}$ & Bkfl & 16.18 & 0.21 & 0.13 & 1.08 & 0.08 \\
\hline $2 \mathrm{~A}$ & Bkfl & 22.69 & 0.14 & 0.05 & 0.42 & 0.09 \\
\hline $3 \mathrm{~A}$ & Bkfl & 30.74 & 0.17 & 0.10 & 0.83 & 0.07 \\
\hline $4 \mathrm{~A}$ & Bkfl & 36.88 & 0.46 & 0.34 & 2.83 & 0.12 \\
\hline $5 \mathrm{~A}$ & Bkfl & 40.01 & 0.25 & 0.17 & 1.42 & 0.08 \\
\hline $6 \mathrm{~A}$ & $\mathrm{H} 2$ & 46.98 & 0.19 & 0.15 & 1.25 & 0.04 \\
\hline 7A & H2 & 59.09 & 0.18 & 0.13 & 1.08 & 0.05 \\
\hline $8 \mathrm{~A}$ & $\mathrm{H} 2$ & 64.03 & 0.34 & 0.27 & 2.25 & 0.07 \\
\hline 8A Dup & $\mathrm{H} 2$ & 64.03 & 0.49 & 0.41 & 3.42 & 0.08 \\
\hline $9 \mathrm{~A}$ & $\mathrm{H} 2$ & 76.03 & 0.49 & 0.39 & 3.25 & 0.10 \\
\hline $10 \mathrm{~A}$ & $\mathrm{CCU}_{\mathrm{u}}$ & 81.04 & 0.41 & 0.34 & 2.83 & 0.07 \\
\hline $11 \mathrm{~A}$ & $\mathrm{CCU}_{\mathrm{u}}$ & 87.35 & 0.46 & 0.38 & 3.17 & 0.08 \\
\hline 11A Dup & $\mathrm{CCU}_{\mathrm{u}}$ & 87.35 & 0.43 & 0.34 & 2.83 & 0.09 \\
\hline $12 \mathrm{~A}$ & $\mathrm{CCU}_{1}$ & 92.61 & 4.70 & 4.36 & 36.33 & 0.34 \\
\hline $13 \mathrm{~A}$ & $\mathrm{CCU}_{\mathrm{l}}$ & 93.56 & 5.65 & 5.22 & 43.50 & 0.43 \\
\hline $14 \mathrm{~A}$ & $\mathrm{CCU}_{\mathrm{l}}$ & 94.67 & 1.34 & 1.21 & 10.08 & 0.13 \\
\hline $15 \mathrm{~A}$ & $\mathrm{CCU}_{1}$ & 100.37 & 1.30 & 1.24 & 10.33 & 0.06 \\
\hline $16 \mathrm{~A}$ & $\mathrm{CCU}_{1}$ & 101.98 & 6.94 & 6.61 & 55.08 & 0.33 \\
\hline 17A & $\mathrm{CCU}_{\mathrm{l}}$ & 106.09 & 0.57 & 0.52 & 4.33 & 0.05 \\
\hline $18 \mathrm{~A}$ & $\mathrm{CCU}_{1}$ & 107.42 & 0.17 & 0.13 & 1.08 & 0.04 \\
\hline $19 \mathrm{~A}$ & $\mathrm{R}_{\mathrm{tf}}$ & 110.98 & 0.17 & 0.14 & 1.17 & 0.03 \\
\hline 19A Dup & $\mathrm{R}_{\mathrm{tf}}$ & 110.98 & 0.18 & 0.16 & 1.33 & 0.02 \\
\hline $20 \mathrm{~A}$ & $\mathrm{R}_{\mathrm{tf}}$ & 116.02 & 0.18 & 0.13 & 1.08 & 0.05 \\
\hline $21 \mathrm{~A}$ & $\mathrm{R}_{\mathrm{wi}}$ & 120.97 & 0.38 & 0.34 & 2.83 & 0.04 \\
\hline $22 \mathrm{~A}$ & $\mathrm{R}_{\mathrm{wi}}$ & 124.05 & 0.03 & 0.01 & 0.08 & 0.02 \\
\hline $23 \mathrm{~A}$ & $\mathrm{R}_{\mathrm{wi}}$ & 127.13 & 0.03 & 0.01 & 0.08 & 0.02 \\
\hline
\end{tabular}


Table 4.35. Matric Potential of Vadose Zone Sediments in Borehole C4104

\begin{tabular}{||l|l|l||}
\hline \multicolumn{1}{|c|}{$\begin{array}{c}\text { Sample } \\
\text { ID }\end{array}$} & \multicolumn{1}{|c|}{$\begin{array}{c}\text { Depth } \\
\text { (ft bgs) }\end{array}$} & \multicolumn{1}{|c|}{$\begin{array}{c}\text { Matric Potential } \\
\text { (Mpa) }\end{array}$} \\
\hline S03072-1A & 16.18 & 0.4493 \\
\hline S03072-2A & 22.69 & 0.6615 \\
\hline S03072-3A & 30.74 & 0.1741 \\
\hline S03072-4A & 36.88 & 0.0284 \\
\hline S03072-5A & 40.01 & 4.8378 \\
\hline S03072-6A & 46.98 & 3.0258 \\
\hline S03072-7A & 59.09 & 0.8797 \\
\hline S03072-8A & 64.03 & 10.7565 \\
\hline S03072-9A & 76.03 & 0.5383 \\
\hline S03072-10A & 81.04 & 0.0556 \\
\hline S03072-11A & 87.35 & 3.2114 \\
\hline S03072-12A & 92.61 & 0.2439 \\
\hline S03072-13A & 93.56 & 3.2712 \\
\hline S03072-14A & 94.67 & 0.3552 \\
\hline S03072-15A & 100.37 & 0.5071 \\
\hline S03072-16A & 101.98 & 201.0024 \\
\hline S03072-17A & 106.09 & 0.2936 \\
\hline S03072-18A & 107.42 & 2.0735 \\
\hline S03072-19A & 110.98 & 0.1981 \\
\hline S03072-20A & 116.02 & 3.1299 \\
\hline S03072-21A & 120.97 & 1.5127 \\
\hline S03072-22A & 124.05 & 0.9985 \\
\hline S03072-23A & 127.13 & \\
\hline Water Table & 227.00 & \\
\hline \hline
\end{tabular}


C4104

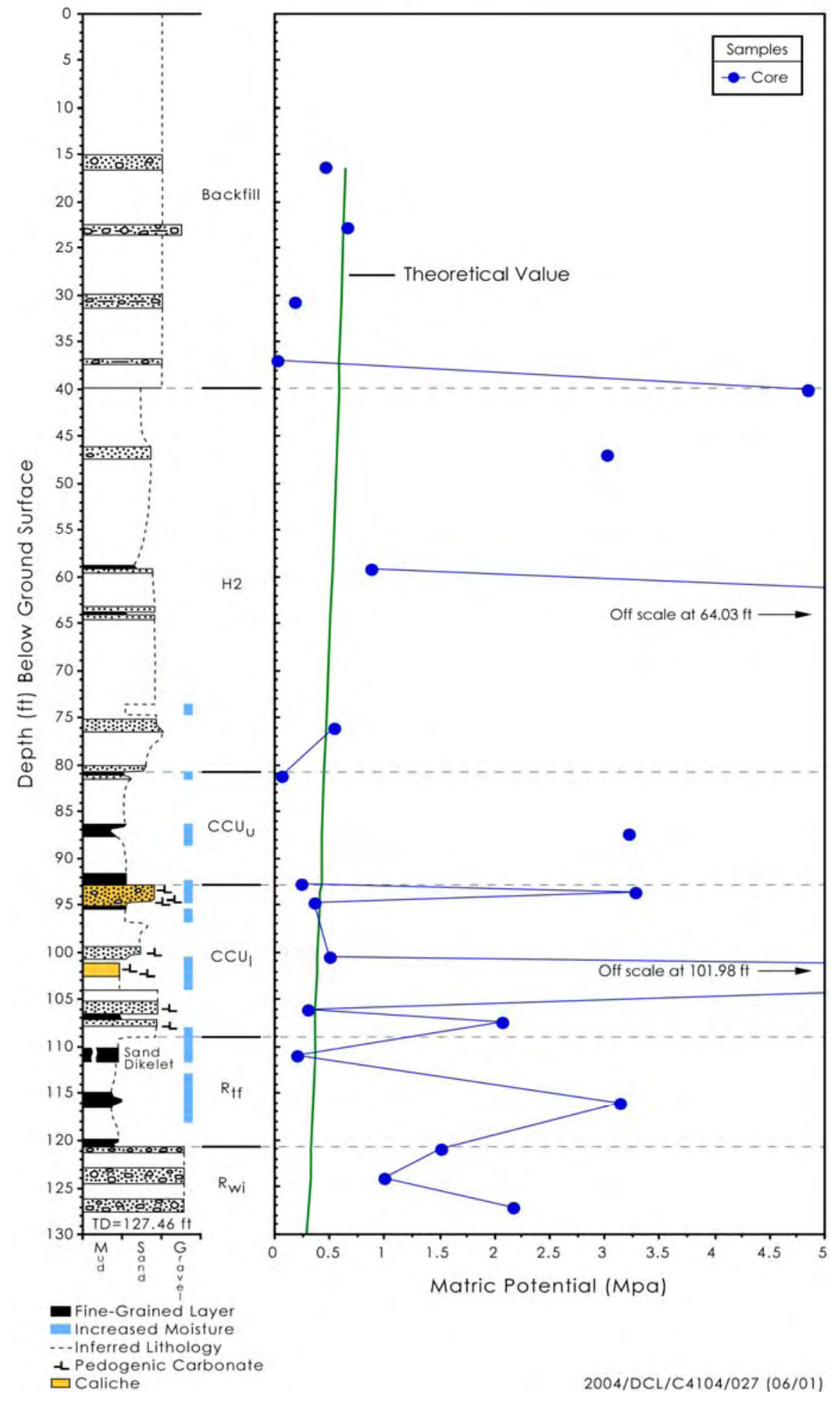

Figure 4.28. Matric Potential for C4104 Core Samples (measured after cores were subsampled) 
Tank 241-T-106 and Well Locations

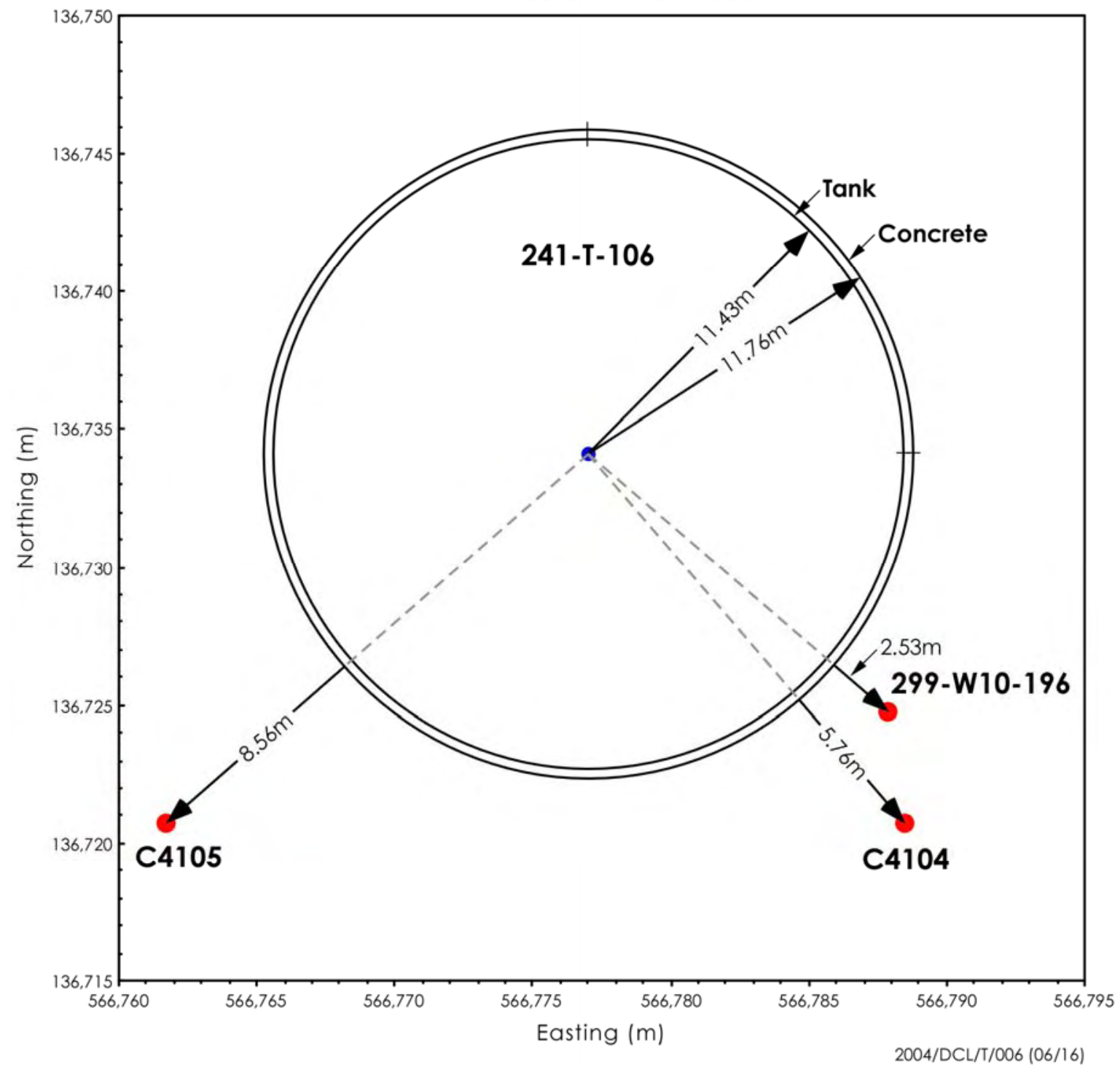

\begin{tabular}{|cclll|}
\hline \multicolumn{5}{|c|}{ Distance: } \\
Meters & Feet & From: & To: \\
4.00 & 13.13 & C4104 & $299-W 10-196$ \\
26.73 & 87.70 & C4104 & C4105 \\
2.53 & 8.32 & Edge of T-106 Concrete & $299-W 10-196$ \\
5.76 & 18.91 & Edge of T-106 Concrete & C4104 \\
8.56 & 28.09 & Edge of T-106 Concrete & C4105 \\
\hline Center Point of: & Easting (m) & Northing (m) & Reference \\
$241-T-106$ & 566777.006 & 136734.118 & WIDS Gen. Summary Rpt. \\
$299-W 10-196$ & 566787.830 & 136724.780 & KEH Survey Report (1993) \\
C4104 & 566788.421 & 136720.823 & RPP-17275, Rev 0 (2003) \\
C4105 & 566761.692 & 136720.758 & RPP-16340, Rev 0 (2003) \\
\hline
\end{tabular}

Figure 4.29. Location of the Three Contaminated Boreholes Around Tank T-106 
Tanks 241-T-106 and 241-T-109 and Well Locations

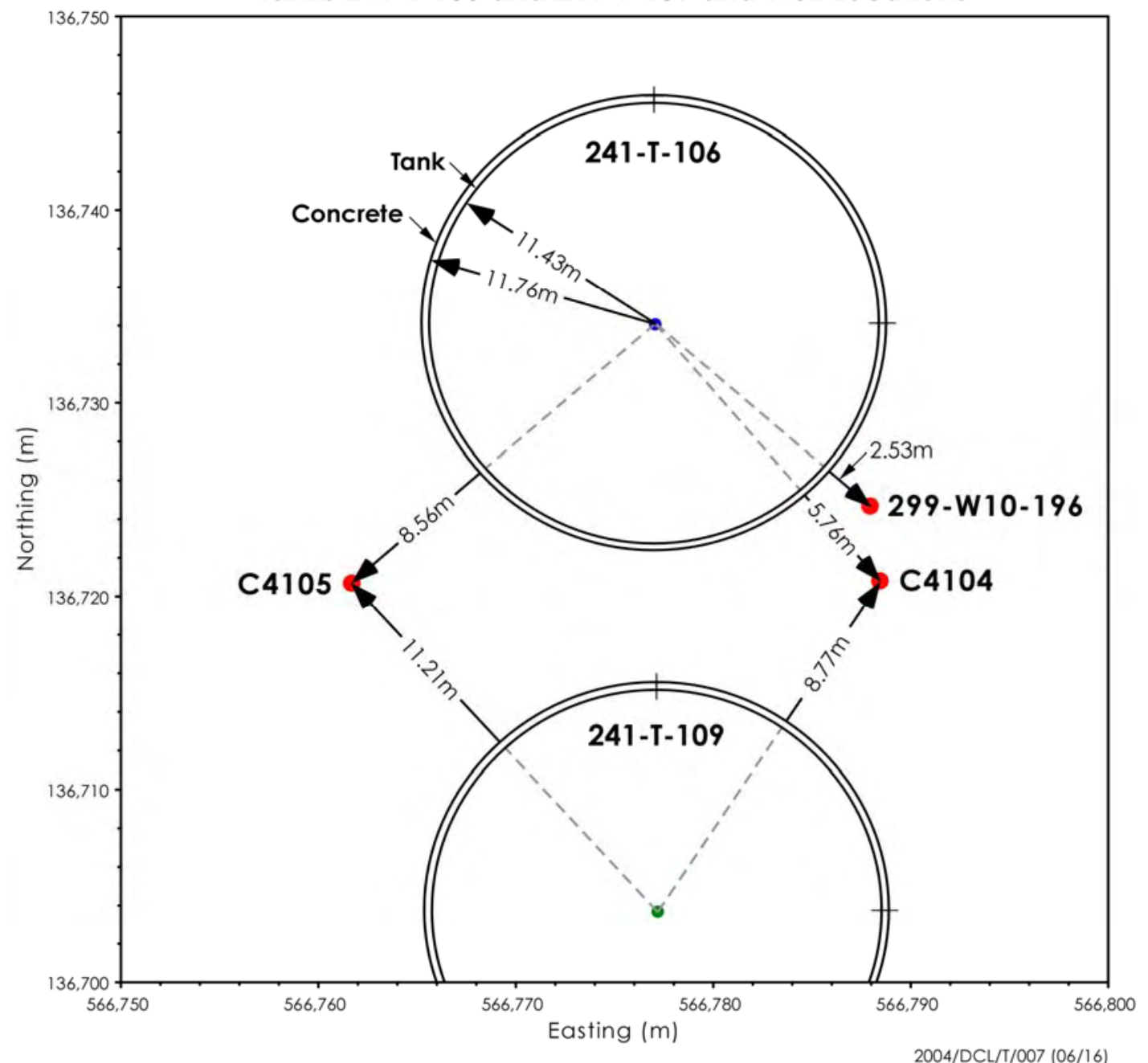

\begin{tabular}{|cclll|}
\hline \multicolumn{5}{|c|}{ Distance: } \\
Meters & Feet & From: & To: \\
4.00 & 13.13 & C4104 & $299-W 10-196$ \\
26.73 & 87.70 & C4104 & C4105 \\
2.53 & 8.32 & Edge of T-106 Concrete & $299-$ W10-196 \\
5.76 & 18.91 & Edge of T-106 Concrete & C4104 \\
8.56 & 28.09 & Edge of T-106 Concrete & C4105 \\
8.77 & 28.79 & Edge of T-109 Concrete & C4104 \\
11.21 & 36.78 & Edge of T-109 Concrete & C4105 \\
\hline Center Point of: & Easting (m) & Northing (m) & Reference \\
$241-T-106$ & 566777.006 & 136734.118 & WIDS Gen. Summary Rpt. \\
$299-$ 10-196 & 566787.830 & 136724.780 & KEH Survey Report (1993) \\
C4104 & 566788.421 & 136720.823 & RPP-17275, Rev 0 (2003) \\
C4105 & 566761.692 & 136720.758 & RPP-16340, Rev 0 (2003) \\
$241-T-109$ & 566777.079 & 136703.705 & WIDS Gen. Summary Rpt. \\
\hline
\end{tabular}

Figure 4.30. Location of the Three Contaminated Boreholes in Relationship to Tanks T-106 and T-109 
Table 4.36 and Figure 4.31 show the technetium-99 data for the two borehole vadose zone sediments. The data show that technetium-99 present between the depths of 95 to $105 \mathrm{ft}$ bgs in the Cold Creek lower subunit in borehole 299-W10-196 in 1993 is not present in borehole C4104 at similar depths in 2004. Unfortunately, the sampling and frequency of technetium-99 measurement in 1993 for borehole 299-W10-196 was too coarse to determine the shape of the technetium-99 plume. A key technetium-99 measurement for a sample between 105 and $117 \mathrm{ft}$ bgs was inexplicably not reported/available in the 299-W10-196 report. Without at least one datum for the technetium-99 content between these depths, we can not estimate the shape of the plume or the quantity of technetium-99 that was present in 1993. The distribution of nitrate that is extractable from the 299-W10-196 sediments does suggest that technetium99 in the zone around $105 \mathrm{ft}$ bgs should be higher than any of the values reported, based on the fact that nitrate and technetium-99 generally track each other and the sample at $105 \mathrm{ft}$ bgs has the highest nitrate value found in borehole 299-W10-196.

One plausible explanation of the differences in the shape (vertical distribution) of the technetium-99 plume between the observed profiles in 299-W10-196 and C4104 is that the upper portion of the technetium-99 1993 plume has vertically migrated from the Cold Creek lower subunit into the moist and fine-grained Ringold Formation Taylor Flat member during the ten years that has elapsed since the 299-W10-196 borehole was drilled and measurements performed. Depending upon what the technetium99 concentration was in the peak of the plume (between 105 and $115 \mathrm{ft}$ bgs; the zone where data are missing) in borehole 299-W10-196, the masses of technetium-99 in the two boreholes appear to be quite similar. The sediments below $120 \mathrm{ft}$ bgs in both boreholes is the drier and coarser-grained Ringold Formation Wooded Island member. This stratum may be acting as a hydrologic barrier to the migration of unsaturated fluids that have accumulated in the finer grained $\mathrm{R}_{\mathrm{tf}}$ strata.

\subsubsection{Nitrate}

As mentioned, nitrate is another constituent that, in general, does not interact with sediments such that it also travels with the tank leak fluids and is indicative of the direction and distance that a leak has traveled through the vadose zone. At all of the tank farms that have been studied to date, there is a strong correlation between the nitrate and technetium-99 distributions in the vadose zone sediment and in porewater. Table 4.37 and Figure 4.32 show the total water-extractable nitrate present in the vadose sediments from the two boreholes shortly after they were drilled. Both boreholes have the bulk of the nitrate present in the Ringold Taylor Flat member between 110 and $122 \mathrm{ft}$ bgs, suggesting that this finegrained zone is acting as an aquitard to further vertical migration. Both profiles show some nitrate is present in the next shallowest layer, the $\mathrm{CCU}_{1}$ (caliche). Unlike the technetium-99 profile, there does not appear to be much difference in the position of the shallow edge of the nitrate plume to suggest vertical migration over the past ten years. However, the sampling frequency for the nitrate at 299-W10-196 is very sparse in the zone of interest. Further, neither borehole is sampled frequently enough to identify the exact depth of maximum concentration. Available data suggest that the maximum concentration in C4104 is about 6-ft deeper than at 299-W10-196; perhaps indicating that there has been some vertical migration. The concentrations of nitrate found in the sediments vary somewhat with peak concentrations of 4,400 and 2,600 $\mu \mathrm{g} / \mathrm{g}$, in 299-W10-196 and C4104, respectively.

Table 4.37 also shows the nitrite data and suggests that higher concentrations of nitrite were present in 1993 in borehole 299-W10-196 sediments, especially in the Hanford formation H2 unit and the Cold Creek units. We have found that nitrite in tank leak fluids appears to oxidize to nitrate in the vadose zone with time; perhaps the data corroborate oxidation of nitrite as having occurred during the past ten years. 
Table 4.36. Comparison of Tc-99 Contents in Sediments from C4104 and 299-W10-196

\begin{tabular}{|c|c|c|c|c|c|}
\hline \multirow[b]{2}{*}{ C4104 } & \multirow{2}{*}{$\begin{array}{l}\text { Depth } \\
\text { (ft bgs) }\end{array}$} & \multicolumn{2}{|c|}{$\mathrm{pCi} / \mathrm{g}$} & \multirow{2}{*}{$\begin{array}{l}\text { 299-W10-196 Depth } \\
\text { (ft bgs) }\end{array}$} & \multirow{2}{*}{$\begin{array}{c}\mathrm{pCi} / \mathrm{g} \\
\text { Rad }\end{array}$} \\
\hline & & Rad & ICP-MS & & \\
\hline $1 \mathrm{~B}$ & 15.38 & --- & --- & 13 & $<0.32$ \\
\hline $1 \mathrm{~A}$ & 16.18 & --- & $<0.17$ & --- & --- \\
\hline $2 B$ & 22.02 & --- & & 21.8 & $<0.42$ \\
\hline $2 \mathrm{~A}$ & 22.69 & --- & $<0.17$ & --- & --- \\
\hline $3 B$ & 30.07 & --- & & 30 & 0.17 \\
\hline $3 \mathrm{~A}$ & 30.74 & --- & $<0.17$ & --- & --- \\
\hline $4 \mathrm{~B}$ & 36.23 & --- & --- & 36.4 & $<17$ \\
\hline $4 \mathrm{~A}$ & 36.88 & --- & $(0.07)^{(a)}$ & --- & --- \\
\hline 4 Nose Cone & 37.40 & --- & 0.1 & 38.9 & $<17$ \\
\hline $5 B$ & 39.34 & --- & --- & 38.9 & $<17$ \\
\hline $5 \mathrm{~A}$ & 40.01 & 3.0 & 0.0 & --- & --- \\
\hline 5A dup & 40.01 & --- & 0.2 & 43.4 & 135 \\
\hline $6 \mathrm{~B}$ & 46.33 & --- & 5.5 & 46.1 & 137 \\
\hline $6 \mathrm{~A}$ & 46.98 & 89.2 & 2.0 & --- & --- \\
\hline 7B & 58.39 & --- & 15.2 & 52.8 & 119 \\
\hline 7B Dup & 58.39 & --- & 13.8 & 52.8 & 198 \\
\hline $7 \mathrm{~A}$ & 59.09 & 61.4 & 2.2 & 59.8 & 138 \\
\hline $8 B$ & 63.38 & --- & 13.2 & --- & --- \\
\hline $8 \mathrm{~A}$ & 64.03 & 46.5 & 4.3 & --- & --- \\
\hline 8ADup & 64.03 & 69.7 & 4.5 & 67.1 & 390 \\
\hline $9 B$ & 75.38 & --- & --- & 74 & 35 \\
\hline $9 \mathrm{~A}$ & 76.03 & 67.4 & 2.0 & --- & --- \\
\hline $10 \mathrm{~A}$ & 81.04 & 24.7 & 5.7 & 82.7 & 39 \\
\hline $11 \mathrm{~A}$ & 87.35 & 164.1 & 44.3 & --- & --- \\
\hline 11A Dup & 87.35 & 259.3 & 40.6 & 90.8 & 350 \\
\hline $12 B$ & 91.96 & --- & --- & 90.8 & 160 \\
\hline $12 \mathrm{~A}$ & 92.61 & 364.2 & 52.7 & --- & --- \\
\hline
\end{tabular}


Table 4.36. (contd)

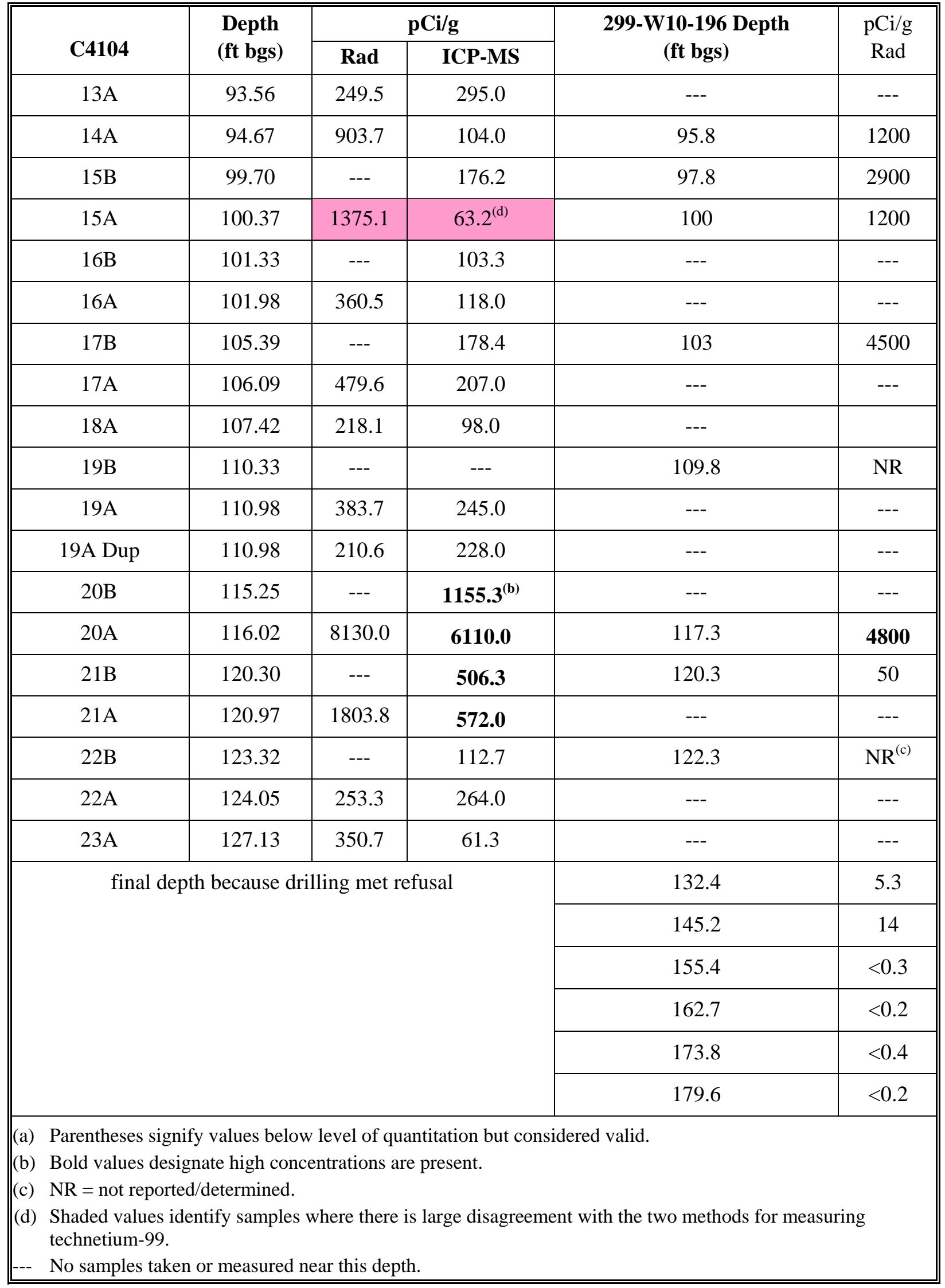




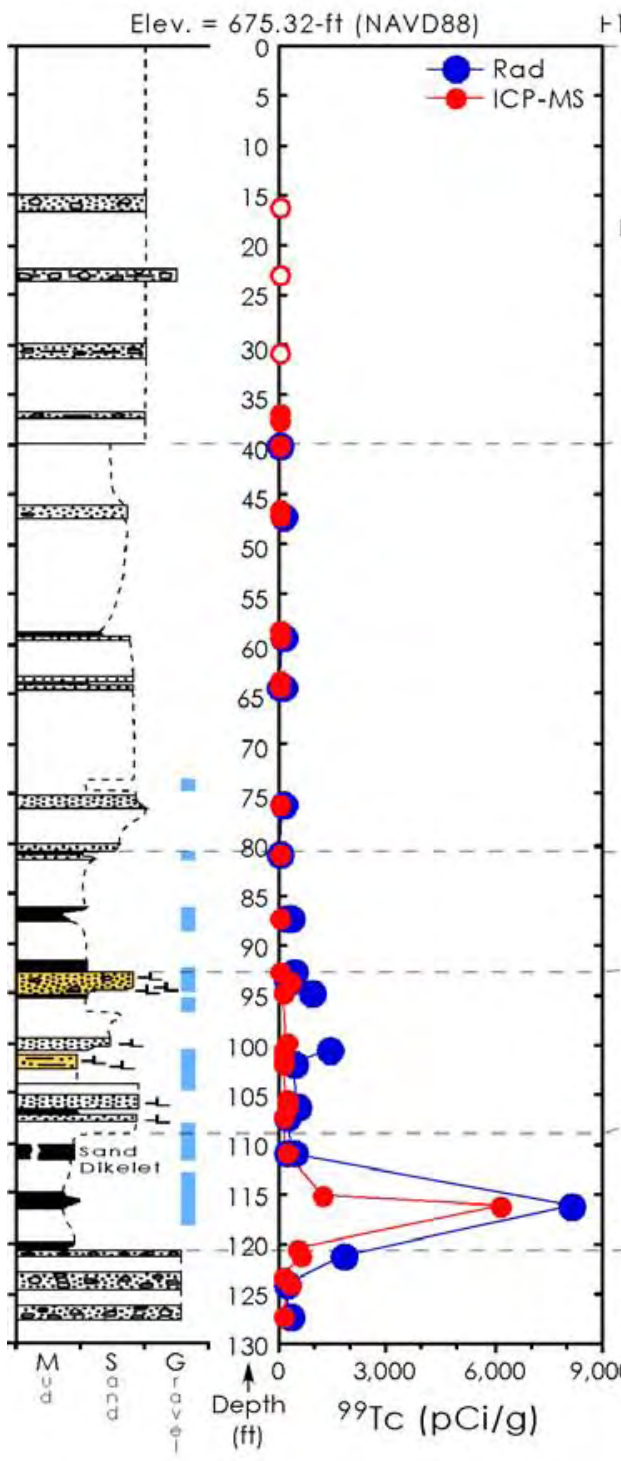

+13.13-ft- Elev. $=675.36-\mathrm{ft}\left(\mathrm{NAVD}^{*}\right)$

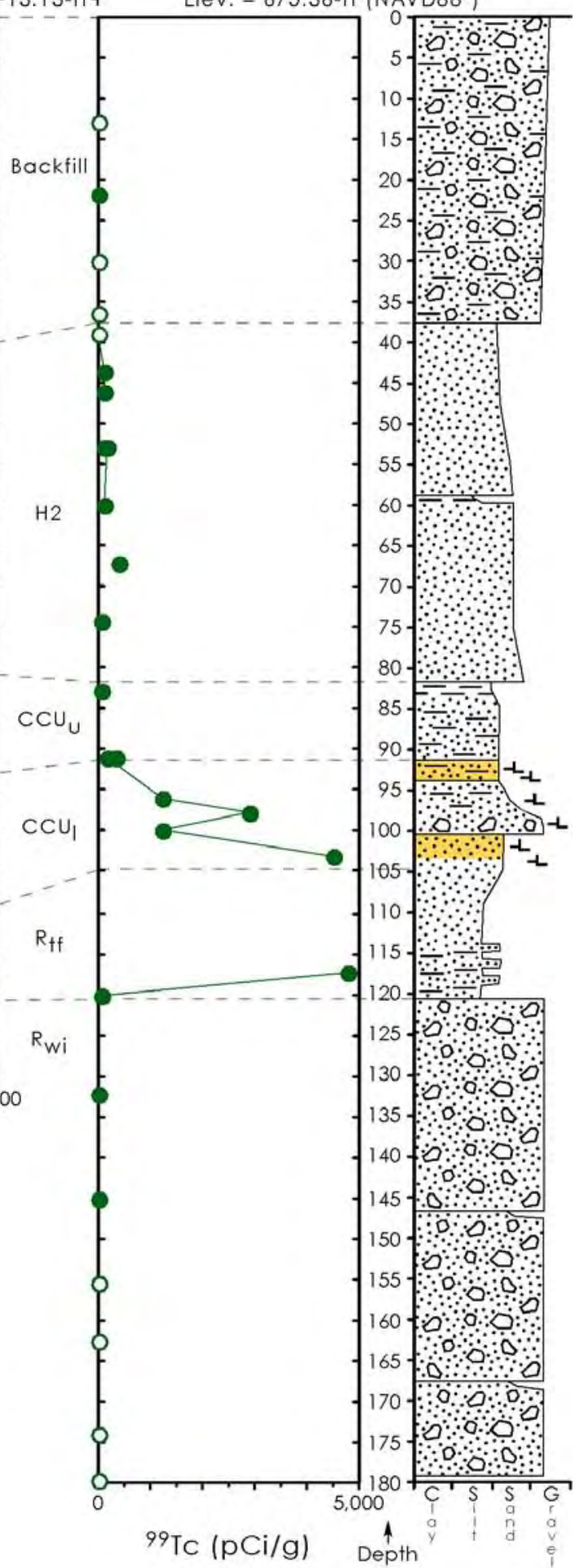

(ft) NGVD' 29 vertical Datum and was converted using NAVD88 vertical Datum.

2004/DCL/C4104/019 (05/05)

Figure 4.31. Comparison of Tc-99 Content in Boreholes C4104 (in 2003) and 299-W10-196 (in 1993) 
Table 4.37. Comparison of Nitrate and Nitrite Contents in Sediments from C4104 and 299-W10-196

\begin{tabular}{|c|c|c|c|c|c|c|}
\hline \multirow[b]{2}{*}{ Sample No. } & \multirow[b]{2}{*}{$\begin{array}{c}\text { Depth } \\
\text { (ft bgs) }\end{array}$} & \multicolumn{2}{|c|}{ C4104 (2003) } & \multirow[b]{2}{*}{$\begin{array}{c}\text { Depth } \\
\text { (ft bgs) }\end{array}$} & \multicolumn{2}{|c|}{ 299-W10-196 (1993) } \\
\hline & & $\begin{array}{c}\text { Nitrate } \\
(\mu g / g)\end{array}$ & $\begin{array}{c}\text { Nitrite } \\
(\mu \mathrm{g} / \mathrm{g})\end{array}$ & & $\begin{array}{l}\text { Nitrate } \\
(\mu g / g)\end{array}$ & $\begin{array}{c}\text { Nitrite } \\
(\mu g / g)\end{array}$ \\
\hline $1 \mathrm{~A}$ & 16.18 & 2.34 & $<0.250$ & 13 & $(5.32 \mathrm{E}+00)^{(\mathrm{a})}$ & $(6.58 \mathrm{E}-01)$ \\
\hline $2 \mathrm{~A}$ & 22.69 & 2.72 & $<0.250$ & 21.8 & $(5.76 \mathrm{E}+00)$ & $<6.58 \mathrm{E}-01$ \\
\hline $3 \mathrm{~A}$ & 30.74 & 1.77 & $<0.250$ & 30 & 3.54 & 0.00 \\
\hline $4 \mathrm{~A}$ & 36.88 & 0.79 & $<0.250$ & 36.4 & 18.16 & $\mathrm{NR}^{(\mathrm{b})}$ \\
\hline (Nose Cone) & 37.40 & 0.77 & $<0.45$ & 38.9 & 21.26 & NR \\
\hline $5 \mathrm{~A}$ & 40.01 & 2.05 & $<0.250$ & --- & --- & --- \\
\hline 5A dup & 40.01 & 1.05 & $<0.45$ & 43.4 & 230.36 & 88.83 \\
\hline $6 \mathrm{~B}$ & 46.33 & $<0.43$ & $<0.45$ & 46.1 & 256.50 & 9.87 \\
\hline $6 \mathrm{~A}$ & 46.98 & 3.47 & $<0.250$ & --- & --- & --- \\
\hline $7 \mathrm{~B}$ & 58.39 & 4.08 & 0.70 & 52.8 & 242.32 & 30.27 \\
\hline 7B Dup & 58.39 & 5.60 & $<0.45$ & 52.8 & 295.48 & 32.24 \\
\hline $7 \mathrm{~A}$ & 59.09 & 7.71 & 0.52 & --- & --- & --- \\
\hline $8 B$ & 63.38 & $<0.44$ & $<0.45$ & --- & --- & --- \\
\hline $8 \mathrm{~A}$ & 64.03 & 17.85 & 0.34 & --- & --- & --- \\
\hline 8A Dup & 64.03 & 20.6 & 0.44 & --- & --- & --- \\
\hline $9 \mathrm{~A}$ & 76.03 & 24.71 & $<0.250$ & --- & --- & --- \\
\hline $10 \mathrm{~A}$ & 81.04 & 78.22 & 0.48 & 82.7 & 29.24 & $<6.58 \mathrm{E}-01$ \\
\hline $11 \mathrm{~A}$ & 87.35 & 168.18 & 0.74 & --- & --- & --- \\
\hline 11A Dup & 87.35 & 196.66 & 0.76 & 90.8 & 109.42 & $<1.32 \mathrm{E}+00$ \\
\hline $12 \mathrm{~A}$ & 92.61 & 220.37 & 0.31 & 90.8 & 104.11 & $<1.32 \mathrm{E}+00$ \\
\hline $13 \mathrm{~A}$ & 93.56 & 510.87 & $<0.250$ & --- & --- & --- \\
\hline $14 \mathrm{~A}$ & 94.67 & 528.93 & 0.32 & 95.8 & 422.62 & 87.51 \\
\hline $15 B$ & 99.70 & 179.76 & $<0.45$ & 97.8 & 970.17 & 214.84 \\
\hline $15 \mathrm{~A}$ & 100.37 & 276.47 & 0.7 & 100 & 598.05 & 155.95 \\
\hline $16 \mathrm{~B}$ & 101.33 & 138.24 & $<0.45$ & --- & --- & --- \\
\hline $16 \mathrm{~A}$ & 101.98 & 239.88 & $<0.250$ & --- & --- & --- \\
\hline 17B & 105.39 & 177.97 & $<0.45$ & --- & --- & --- \\
\hline $17 \mathrm{~A}$ & 106.09 & 192.71 & 0.43 & --- & --- & --- \\
\hline $18 \mathrm{~A}$ & 107.42 & 87.41 & $<0.250$ & 109.8 & 4430.00 & NR \\
\hline 19A & 110.98 & 548.12 & 1.56 & --- & --- & --- \\
\hline 19A Dup & 110.98 & 477.37 & 1.42 & --- & --- & --- \\
\hline
\end{tabular}


Table 4.37. (contd)

\begin{tabular}{|c|c|c|c|c|c|c|}
\hline \multirow[b]{2}{*}{ Sample No. } & \multirow[b]{2}{*}{$\begin{array}{c}\text { Depth } \\
\text { (ft bgs) }\end{array}$} & \multicolumn{2}{|c|}{ C4104 (2003) } & \multirow[b]{2}{*}{$\begin{array}{l}\text { Depth } \\
\text { (ft bgs) }\end{array}$} & \multicolumn{2}{|c|}{ 299-W10-196 (1993) } \\
\hline & & $\begin{array}{c}\text { Nitrate } \\
(\mu g / g)\end{array}$ & $\begin{array}{c}\text { Nitrite } \\
(\mu \mathrm{g} / \mathrm{g})\end{array}$ & & $\begin{array}{c}\text { Nitrate } \\
(\mu g / g)\end{array}$ & $\begin{array}{l}\text { Nitrite } \\
(\mu g / g)\end{array}$ \\
\hline 20B & 115.25 & 1305.59 & 15.67 & --- & --- & --- \\
\hline $20 \mathrm{~A}$ & 116.02 & 2565.63 & 486.1 & 117.3 & 2906.08 & NR \\
\hline $21 \mathrm{~B}$ & 120.30 & 562.95 & $<0.45$ & 120.3 & 51.39 & NR \\
\hline $21 \mathrm{~A}$ & 120.97 & 718.61 & 3.11 & --- & --- & --- \\
\hline 22B & 123.32 & 111.65 & $<0.46$ & --- & --- & --- \\
\hline $22 \mathrm{~A}$ & 124.05 & 245.03 & $<0.250$ & --- & --- & --- \\
\hline $23 \mathrm{~A}$ & 127.13 & 140.55 & $<0.250$ & --- & --- & --- \\
\hline \multirow{5}{*}{\multicolumn{4}{|c|}{ final depth because drilling met refusal }} & 145.2 & 70.44 & 8.23 \\
\hline & & & & 155.4 & 11.03 & NR \\
\hline & & & & 162.7 & NR & NR \\
\hline & & & & 173.8 & NR & NR \\
\hline & & & & 179.6 & NR & NR \\
\hline \multicolumn{7}{|c|}{$\begin{array}{l}\text { (a) Parentheses signify values below level of quantitation but considered valid. } \\
\text { (b) NR = not reported/ determined. } \\
\text {--- no samples near this depth. }\end{array}$} \\
\hline
\end{tabular}




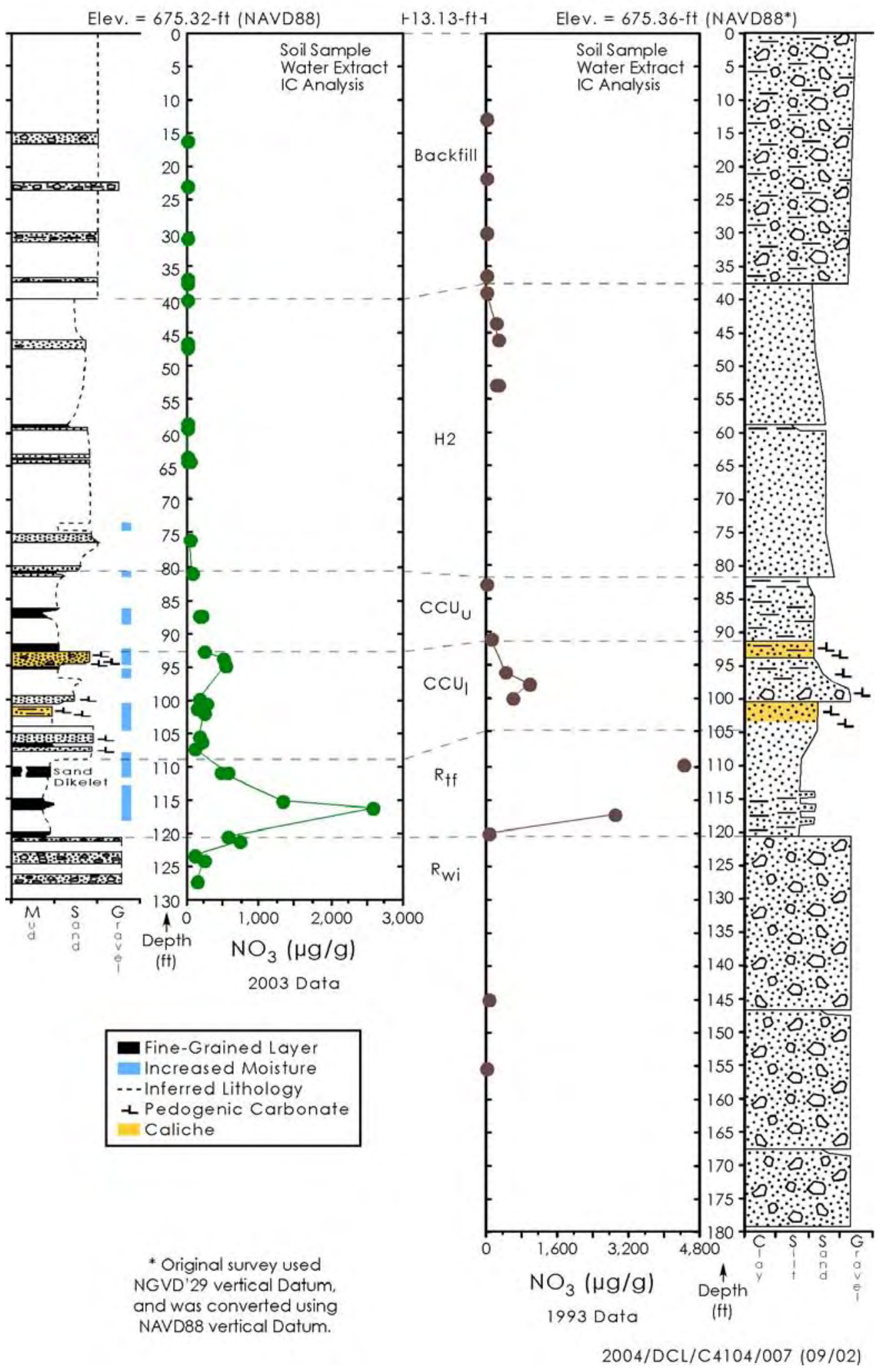

Figure 4.32. Comparison of Nitrate Content in Boreholes C4104 (in 2003) and 299-W10-196 (in 1993) 


\subsubsection{Cobalt-60}

A third fairly mobile contaminant in many Hanford vadose zone sediment-waste solution environments is cobalt-60. Figure 4.33 compares the cobalt-60 data from direct measurement of sediment samples for the two boreholes decay-corrected to 2003 when the C4104 borehole measurements were taken. Further, both Co-60 plots show the spectral gamma logging results that allow a near continuous measurement. The spectral gamma logs for 299-W10-196 for two time periods, April 1993 and July 21-23, 1998 are available on the DOE-Grand Junction web site (www.gjo.doe.gov/programs/hanf) ${ }^{(a)}$. These data were decay-corrected to May 2003, the time at which the C4104 data were collected.

Thus, Figure 4.33 allows us to compare the various data sets at one common time in hopes of determining if there are obvious signs of changes in the vertical distribution of cobalt-60 in each borehole. The plots in Figure 4.33 do suggest that cobalt-60 has migrated somewhat deeper into the sediment profile within the Ringold Taylor Flat member at borehole C4104 when compared to the profile in 1993 or 1998 for borehole 299-W10-196. At the 299-W10-196 borehole, the cobalt-60 deepest peak is found at $111 \mathrm{ft}$ bgs in both 1993 and 1998, whereas in borehole C4104 in 2003, the deepest cobalt-60 peak is found at $\sim 113 \mathrm{ft}$ bgs. The cobalt-60 activities, after decay correction to 2003 , for both borehole profiles are in close agreement, especially for the lab-generated data on discrete samples. This suggests that the total mass of cobalt-60 has not changed in the sediments and that the leading edge of the plume has redistributed only a few feet deeper into the profile in the past ten years.

The comparison of the two spectral gamma logs for borehole 299-W10-196 between 1993 and 1998 when decay-corrected to a common time (see blue and tan lines on right side of Figure 4.33, below the bar labeled "Detector Saturation") suggest that there has been significant migration into the zone around the casing in several places ( 77, 83, 94, and 100 to $110 \mathrm{ft}$ bgs). However, the discussion in the report that accompanies the data plots (DOE-GJO 1999b) states that some of the apparent increase in cobalt-60 may be caused by bentonite sealing material added after April 1993 to complete the borehole. The exact wording in DOE-GJO (1999b) is "the increase in the Co-60 concentrations between 74 and $85 \mathrm{ft}$ is most likely the result of the wicking effect of the bentonite seal placed along this interval, suggesting that there probably has not been any migration of the Co-60 contamination through the formation in this region between 1994 and 1998.” No comparison is made on the lower activity peaks between 95 and $110 \mathrm{ft}$ bgs that also show apparent increase in cobalt-60 activity between 1994 and 1998. DOE-GJO (1999b) does state that the 1993 and 1998 data were collected with different detectors and used different counting times such that direct comparison is not possible.

\subsubsection{Uranium}

A fourth constituent that is often mobile and a potential risk at Hanford is uranium. Figure 4.34 shows the concentrations of uranium that are acid leachable from sediment from both boreholes. The total acid-extractable uranium is no more than 10 times the background values found in the various strata at the clean boreholes near TX tank farm (299-W10-27; see Serne et al. [2004] and for the baseline borehole for $\mathrm{T}$ tank farm, see Table 4.10, this report). The acid-extractable uranium in the background boreholes ranges from 0.5 to $1.0 \mu \mathrm{g} / \mathrm{g}$ and the values found in borehole 299-W10-196 in 1993 peak at $12 \mu \mathrm{g} / \mathrm{g}$. The acid-extractable uranium at C4104 peaks at $\sim 3.5 \mu \mathrm{g} / \mathrm{g}$. In 1993, there were two zones of sediment with $\sim 12 \mu \mathrm{g} / \mathrm{g}$ uranium. One zone was between 44 and $55 \mathrm{ft}$ bgs and the deeper zone was at the bottom of the Cold Creek caliche layer at $104 \mathrm{ft}$ bgs, although the next sample characterized was at

(a) Hanford 200 Areas Vadose Zone Characterization Project, DOE Grand Junction Office, Grand Junction, Colorado. Available at URL: http://www.gjo.doe.gov/programs/hanf, as accessed September 25, 2004. 
$118 \mathrm{ft}$ bgs; thus, the entire deep zone is not well defined. In 2003 at borehole C4104, there is no obvious indication of elevated uranium in the Hanford formation $\mathrm{H} 2$ unit near the bottom of the tank and the high value at $103 \mathrm{ft}$ bgs in the Cold Creek caliche layer may actually be natural. The GEA data, based on the uranium daughter product thorium-234, suggests slightly elevated uranium concentrations are present in borehole C4104 between the depths of 50 and $65 \mathrm{ft}$ bgs, slightly deeper than the shallower elevated zone in borehole 299-W10-196 at the 1993 sampling.

It is thus not easy to evaluate the uranium data set for the two boreholes to determine whether there are obvious signs of uranium migration over the ten-year period between drilling the two boreholes. The lower concentrations of acid-extractable uranium in the C4104 borehole are likely an indication that uranium reacts with the sediments and was readily removed from the leaking tank fluid from T-106 such that sediments $13 \mathrm{ft}$ farther away from the leak (as is C4104) contain reacted tank pore fluids that have lower concentrations of uranium. Therefore, uranium concentrations decrease rapidly with distance from the tank. As shown in Section 4.4, uranium concentrations in borehole C4105, $88 \mathrm{ft}$ farther west from C4104, are much lower and hard to distinguish from natural background levels. This observation also suggests that uranium is interacting with the sediments and being removed from solution in the vadose zone sediments.

\subsubsection{Cesium-137}

The cesium-137 activity found in the sediments at both boreholes was directly measured on aliquots of sediment removed from the splitspoon samplers and also continuously logged through the metal casings using spectral gamma logging instrumentation. The cesium-137 profiles (corrected to May 2003) are shown in Figure 4.35. In 1993 at the 299-W10-196 borehole, there was a shallow zone of elevated cesium-137 between the depths of 33 and $58.6 \mathrm{ft}$ bgs, mostly defined by field logging measurements where the detector was saturated but supplanted by a few lab samples that were above the detection limit of $\sim 0.3 \mathrm{pCi} / \mathrm{g}$. The activity level in the lab measured samples was $\sim 1,000 \mathrm{pCi} / \mathrm{g}$ at $43.4 \mathrm{ft}$ bgs and $\sim 4 \mathrm{pCi} / \mathrm{g}$ at $58.6 \mathrm{ft}$ bgs, after decay correction to 2003. The field gamma logs for borehole 299-W10-196 also show elevated cesium-137 between 63 and $66 \mathrm{ft}$ bgs. In 2003 at borehole C4104, the cesium-137 activity in samples measured in the lab was $~ 3$ or less pCi/g throughout the entire profile (see Table 4.32 for data). The maximum concentration of cesium-137 in borehole C4104 was found at $~ 50 \mathrm{ft}$ bgs based on the field log, which is somewhat deeper than the zone of detector saturation at 299-W10-196. Based on the field spectral gamma log, the maximum cesium-137 activity at C4104 is $40 \mathrm{pCi} / \mathrm{g}$, much lower than the decay-corrected values found $13 \mathrm{ft}$ closer to the tank at 299-W10-196.

We interpret the cesium-137 data as corroborating the hypothesis that cesium-137 is highly adsorbed in Hanford sediments when the ionic strength of the waste fluids is less than $5 \mathrm{M}$ as discussed in Zachara et al. (2002) and Knepp (2002). As described in Section 4.2.2.1, the water extract electrical conductivity is not high and the calculated porewater concentrations are no greater than 0.4 M. Thus at 299-W10-196, cesium-137 did not migrate deeper than $\sim 66 \mathrm{ft}$ bgs and within an additional $13 \mathrm{ft}$ of horizontal migration, the fluids that populated the 299-W10-196 sediments with up to 1,000 pCi/g cesium-137 had only enough radiocesium available to populate the sediments at C4104 with a few tens of pCi/g cesium-137. 


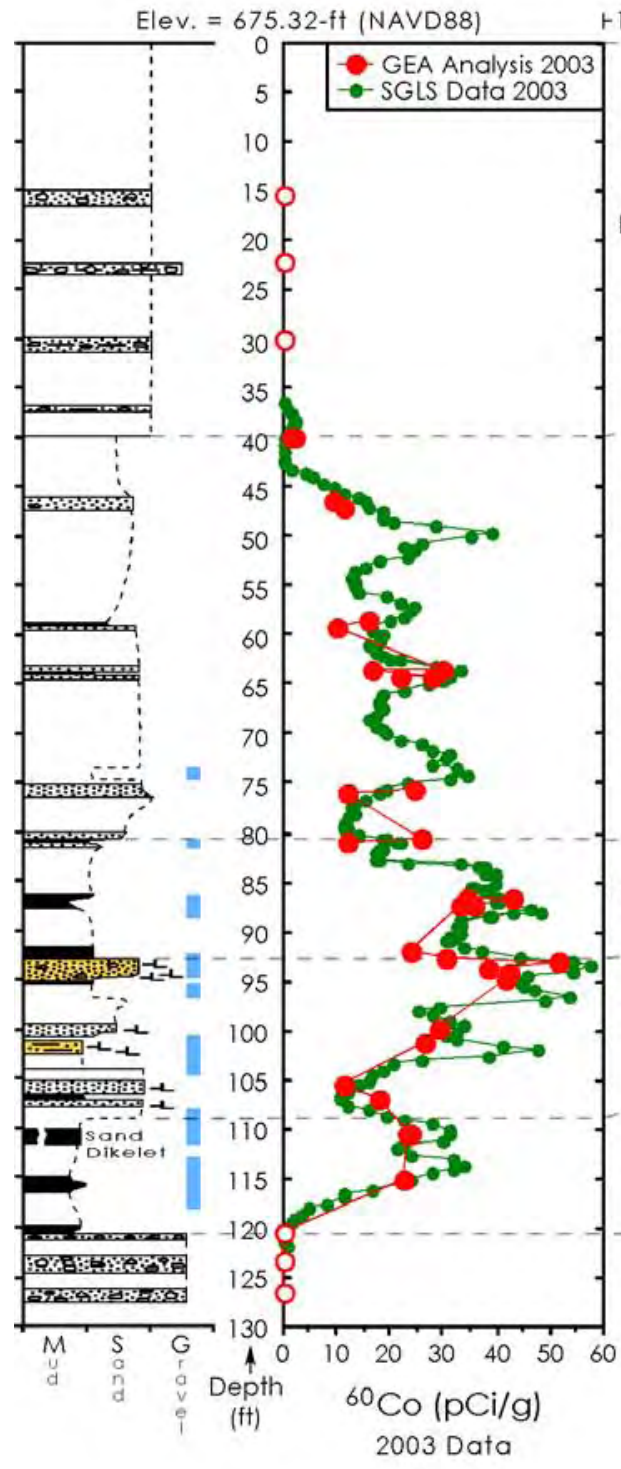

$+13.13-\mathrm{ftt}^{2} \quad$ Elev. $=675.36-\mathrm{ft}($ NAVD88*)

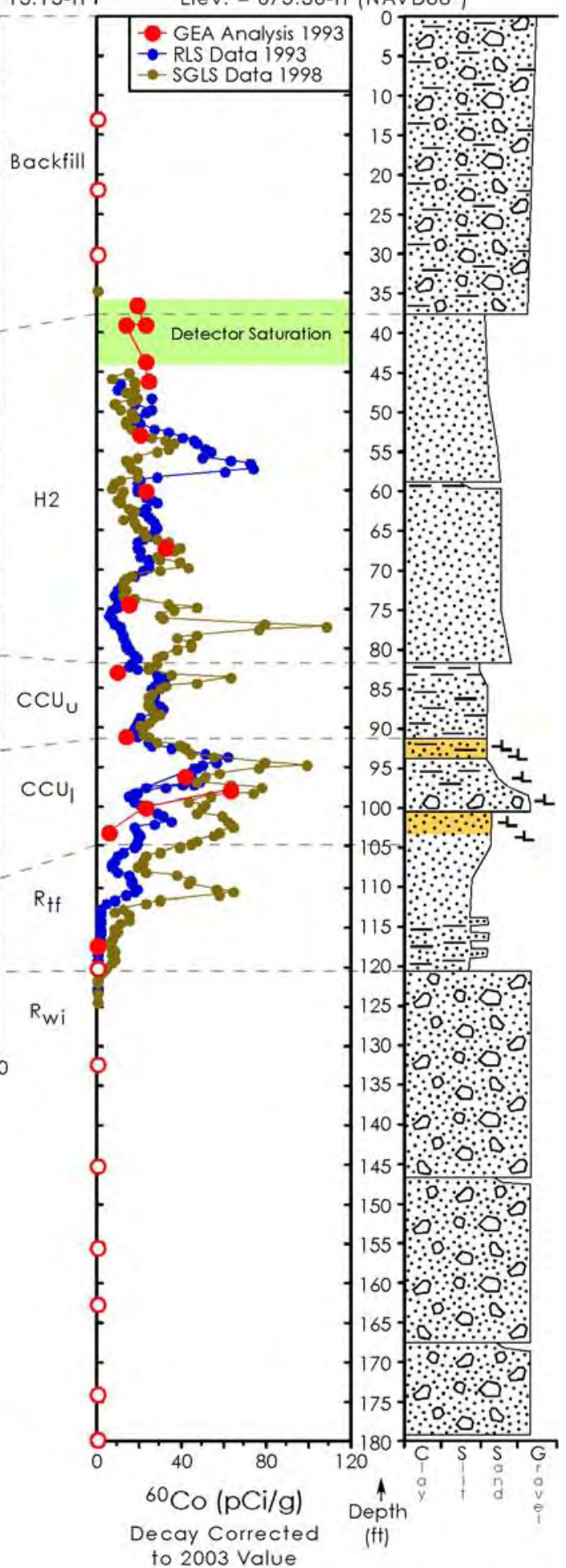
NGVD'29 vertical Datum and was converted using NAVD88 vertical Datum.

Figure 4.33. Comparison of Cobalt-60 in Boreholes C4104 (in 2003) and 299-W10-196 (in 1993) But Decay-Corrected to 05/2003 


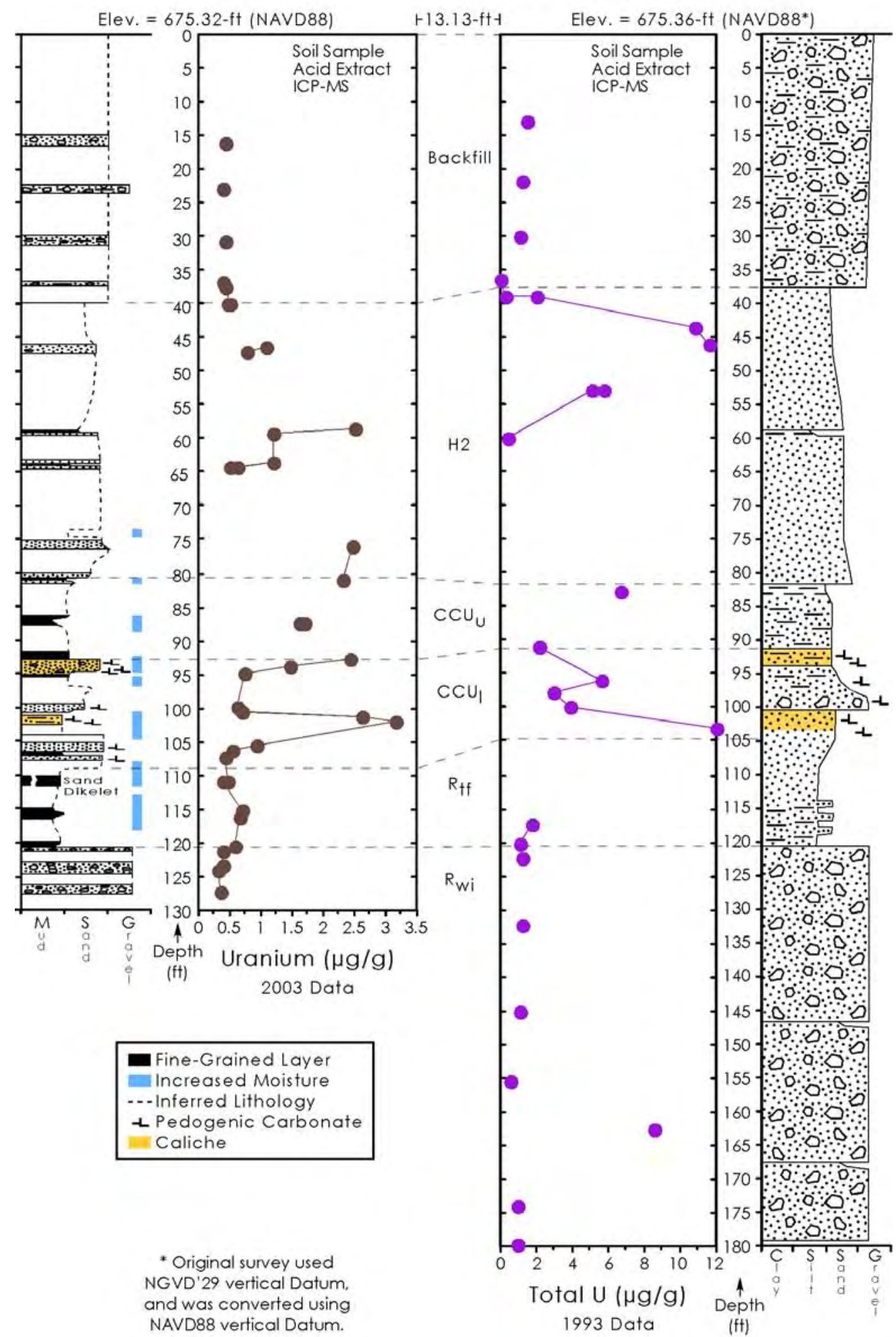

2004/DCL/C4104/008 (09/03)

Figure 4.34. Comparison of Acid-Extractable Uranium in Boreholes C4104 (in 2003) and 299-W10-196 (in 1993) 
C4104

299-W10-196

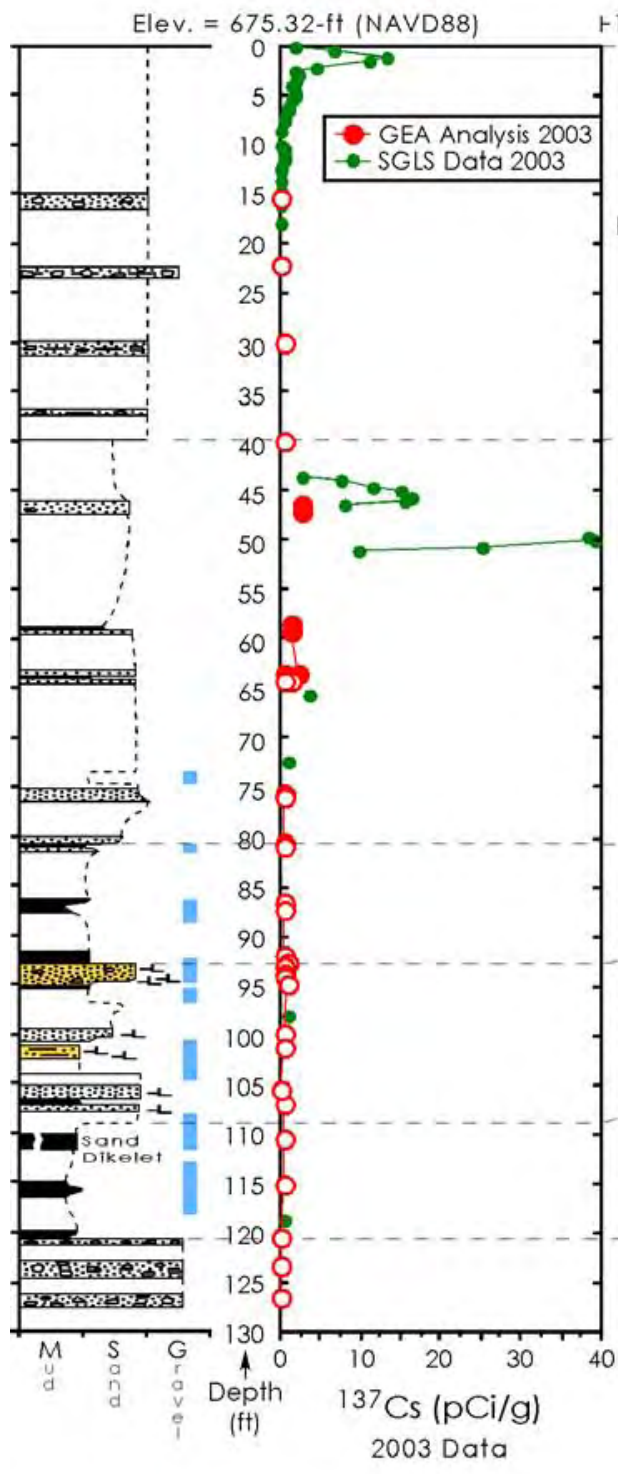

$113.13-\mathrm{ft}-\mathrm{t}$

Elev. $=675.36-\mathrm{ft}\left(\right.$ NAVD88 $\left.^{*}\right)$

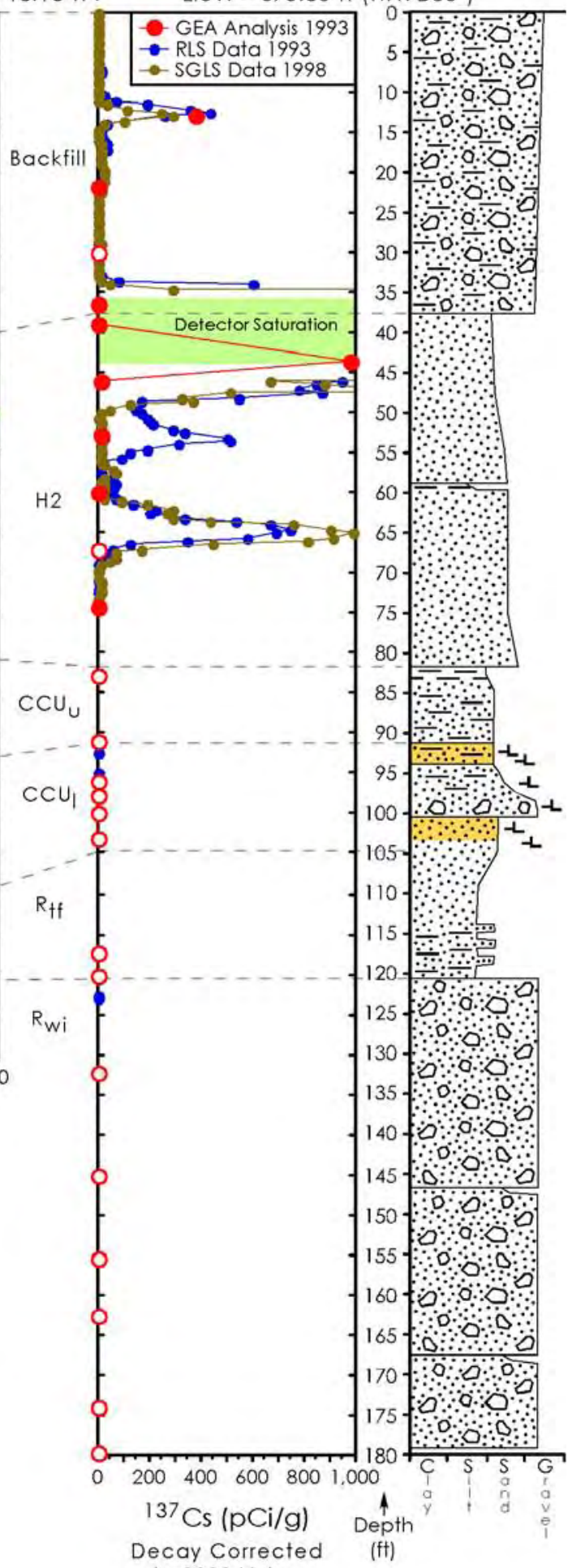

ecay Corrected

to 2003 Value

2004/DCL/C4104/034 (09/08)

Figure 4.35. Comparison of Cesium-137 in Boreholes C4104 (in 2003) and 299-W10-196 (in 1993) but Decay Corrected to 05/2003 


\subsubsection{Europium-154 and Europium-152}

There were measurable amounts of the fission product europium-152, europium-154, and europium-155 found in C4104 and europium-152 and europium-154 was also found in 1993 and 1998 in the Hanford formation $\mathrm{H} 2$ unit in borehole 299-W10-196 based on the spectral gamma field log. All the lab and field logging data for europium isotopes are shown in Figures 4.36 and 4.37. Only two sediment samples from 299-W10-196 contained measurable europium-154 and europium-152 above detection limits in the lab analyses in the 1993 project, but the sample density was not very good. The spectral gamma field logs for borehole 299-W10-196 do show a discernable plume of both europium isotopes right below the zone where the detector was saturated.

As shown in Figures 4.36 and 4.37 and Table 4.32, the discrete core sampling at borehole C4104 also did not capture the europium-154 and europium-152 plumes maxima as shown by the near continuous spectral gamma logs. At C4104, the europium-154 and europium-152 plumes have a very thin (a few ft) maxima centered around the 50-ft bgs depth with concentrations $\sim 2,000$ and $\sim 50 \mathrm{pCi} / \mathrm{g}$, respectively. The comparison of europium-154 activities per gram of sediment for the two boreholes, corrected to 2003, is shown in Figure 4.36. If one looks at only the data obtained from the discrete sediment samples collected and analyzed in the lab, an illogical conclusion would be drawn that suggests the C4104 europium-154 activities are much greater than the europium-154 activities found at 299-W10-196. That is, one would not expect a borehole that is farther away from the source to show higher concentrations than sediments from a borehole closer to the source. However, if one focuses on comparing only the near continuous spectral gamma logging data, it becomes clear that both boreholes have essentially the same europium-154 distributions (when decay-corrected to 2003). Both the activity levels, depth of penetration and shape of the distributions are similar. The same is true for the europium-152 distributions in the two boreholes (see Figure 4.37), excepting that the activity maxima are $\sim 50 \mathrm{pCi} / \mathrm{g}$. Therefore, it can be concluded that europium has not moved in the vertical direction in the sediments around both boreholes over the past ten years. Because the activities observed in the sediments around each borehole are similar, we can not rule out horizontal migration of fluids containing similar europium activities. However, because no europium radioisotopes are found in water extracts of the sediments, we believe that europium isotopes have not transported in the sediments surrounding the two boreholes since the initial leak event. It does appear that europium may have migrated farther from the tank leak than cesium-137 because there is significant reduction in cesium-137 activities in the sediments between the two boreholes. At 299-W10-196, the sediments between 35.5 and $44 \mathrm{ft}$ bgs contained enough cesium-137 to saturate the logging gamma detector up through at least 1998 (DOE-GJO [1999b]. DOE-GJO (1999b) estimated the cesium-137 activity at $>30,000 \mathrm{pCi} / \mathrm{g}$ in this zone), whereas at C4104, the sediments in this region contain only a few tens of $\mathrm{pCi} / \mathrm{g}$. Thus, there is significant reduction in the cesium-137 in both the horizontal and vertical directions below the tank bottom over the 13-ft distance between the two boreholes. However, the europium radioisotopes show essentially the same activities and vertical profiles at both boreholes. Thus, europium must have migrated over the $13 \mathrm{ft}$ distance between the two boreholes more readily than the cesium- 137 .

It appears that the sampling frequency for both boreholes, especially borehole 299-W10-196, almost entirely missed the zone where high activities of europium reside. The data also suggest that there must have been substantial horizontal migration of tank fluid containing both europium-152 and europium-154 between 1973 (the time of the leak) and 1993. Other field spectral gamma data suggest that there was rapid horizontal spreading of the tank fluids during the first year and that further horizontal and vertical spreading of gamma emitters could not be shown to be occurring beyond 1974 (see details presented in Routson et al. 1979 and Freeman-Pollard et al. 1993). 
C4104

299-W10-196

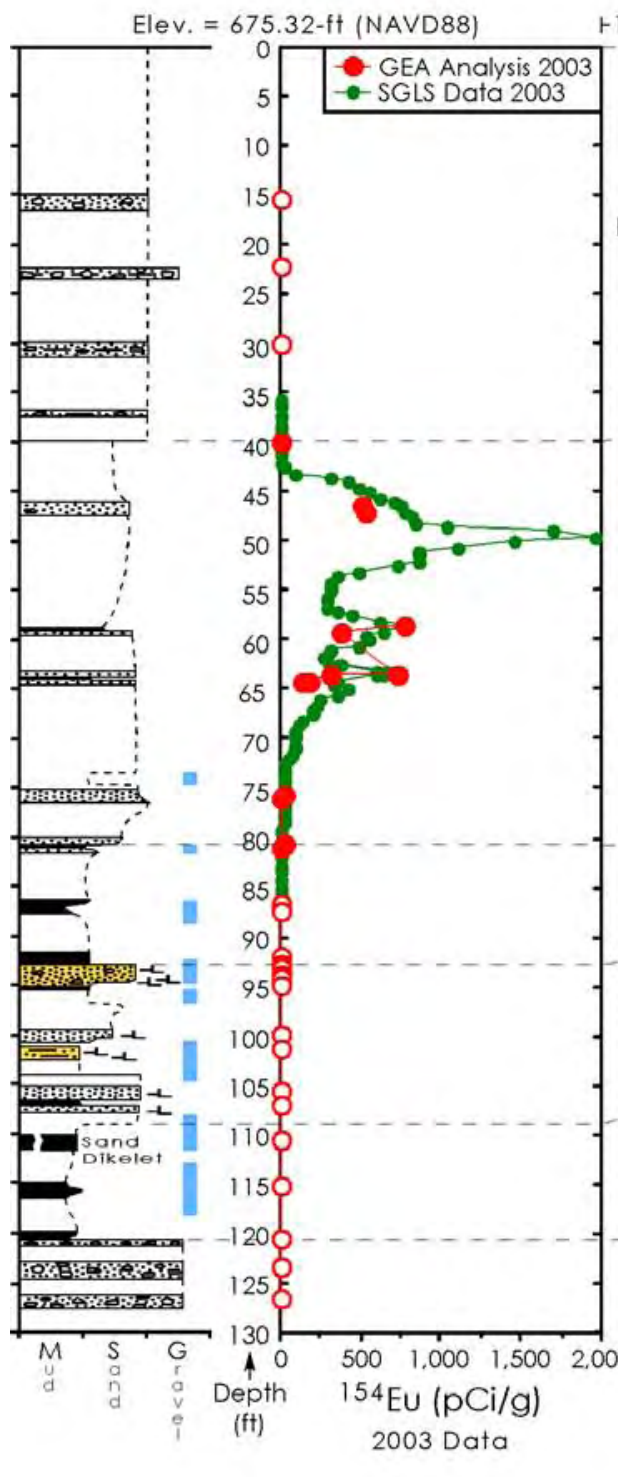

$113.13-\mathrm{ftt}^{-1} \quad$ Elev. $=675.36-\mathrm{ft}\left(\right.$ NAVD88 ${ }^{*}$ )

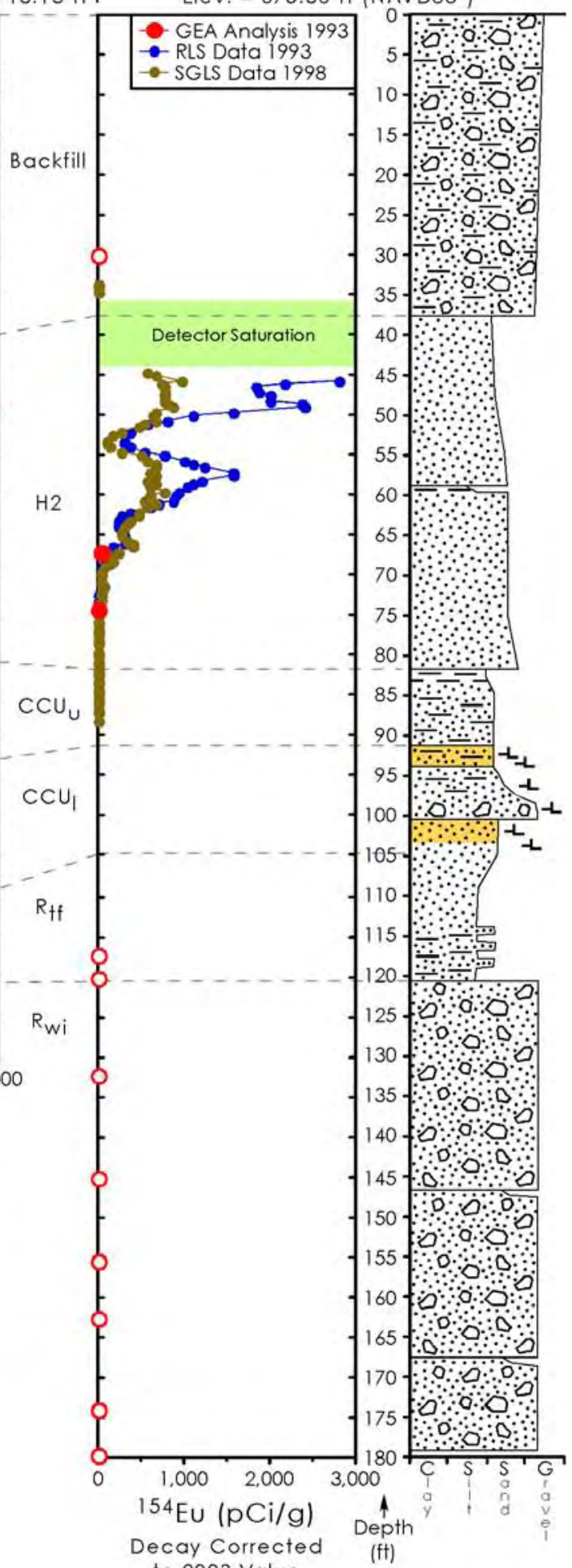

NGVD' 29 vertical Datum and was converted using NAVD88 vertical Datum.

to 2003 value

2004/DCL/C4104/035 (09/08)

Figure 4.36. Comparison of Europium-154 in Boreholes C4104 (in 2003) and 299-W10-196 (in 1993) but Decay Corrected to 05/2003 
C4104

299-W $10-196$

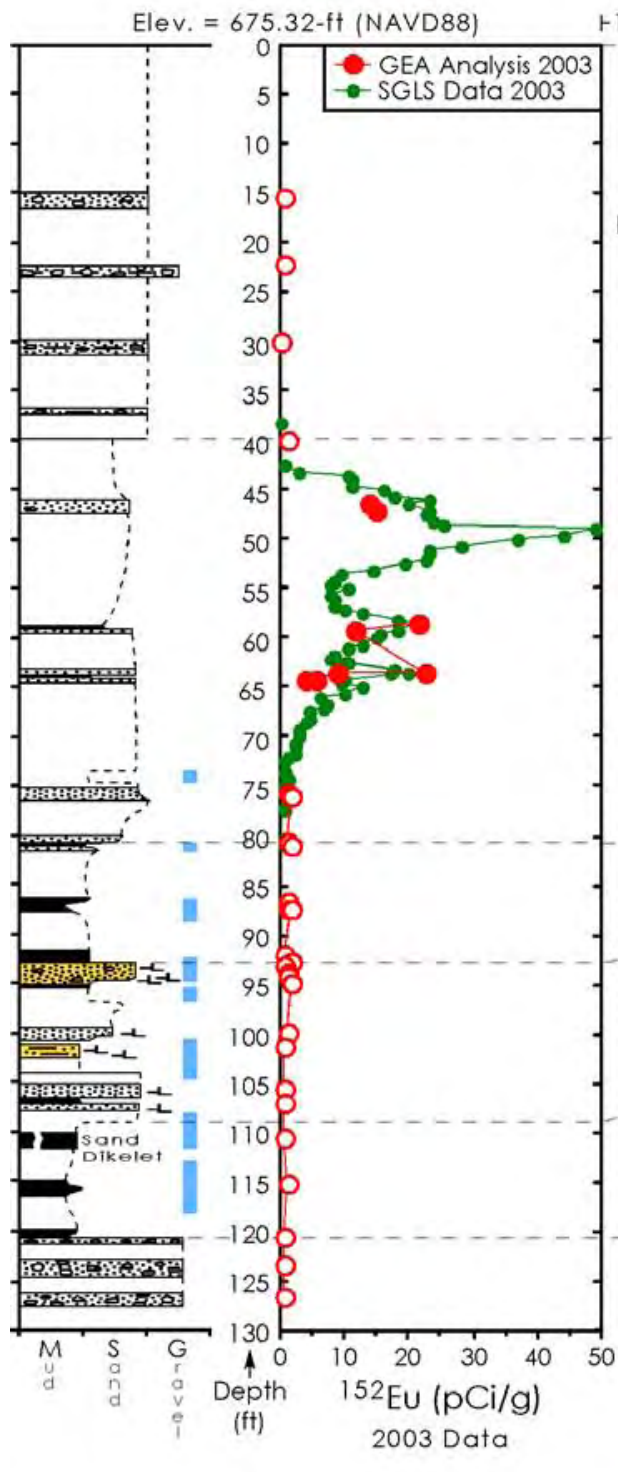

113.13- $\mathrm{ftt} \quad$ Elev. $=675.36-\mathrm{ft}\left(\right.$ NAVD88 $\left.{ }^{*}\right)$

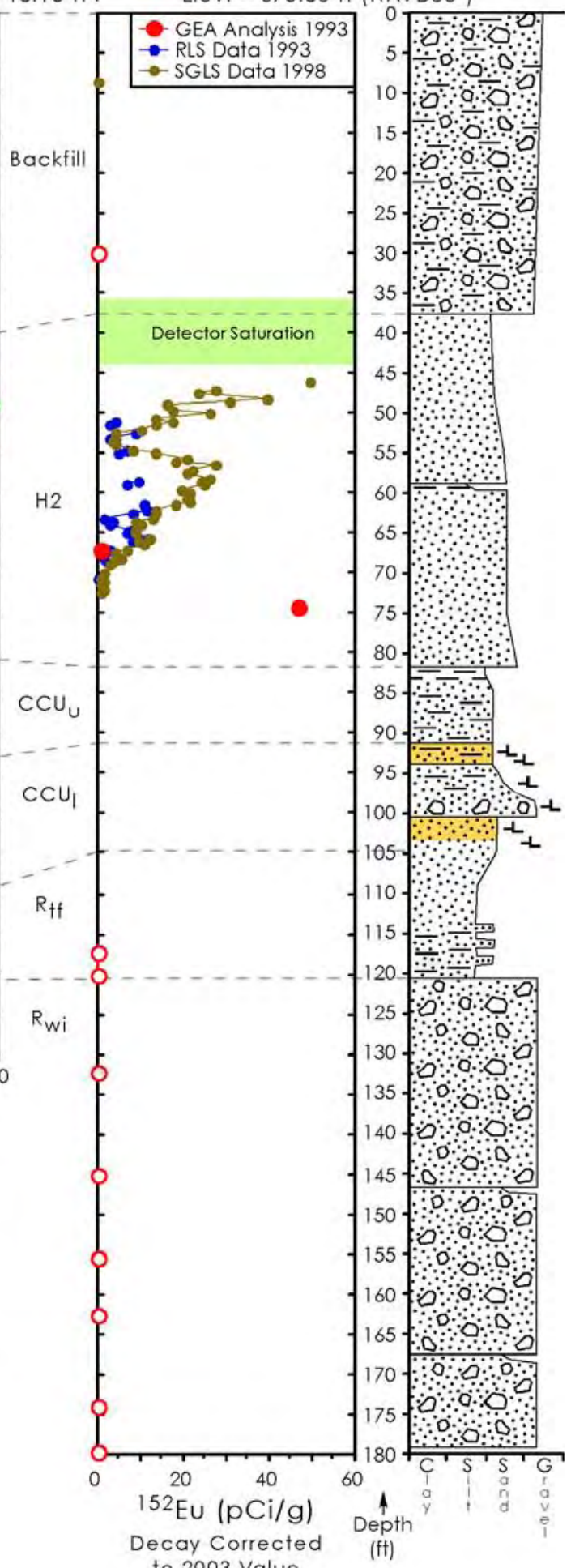

NGVD' 29 vertical Datum and was converted using NAVD88 vertical Datum.

Figure 4.37. Comparison of Europium-152 in Boreholes C4104 (in 2003) and 299-W10-196 (in 1993) but Decay Corrected to 05/2003 


\subsubsection{Sodium}

The acid-extractable sodium concentrations in the two boreholes are shown in Table 4.38 and Figure 4.38. The overall concentrations in the two profiles are quite similar (high concentrations vary between 1,000 and 2,300 $\mu \mathrm{g} / \mathrm{g}$ ). Again, there is a large gap in available data for the 299-W10-196 borehole between 60 and $80 \mathrm{ft}$ bgs, where the data at C4104 reaches its maxima. Acid-extractable sodium in background sediments varies from $\sim 250 \mu \mathrm{g} / \mathrm{g}$ in the Hanford $\mathrm{H} 2 \mathrm{unit}$, to $\sim 300 \mu \mathrm{g} / \mathrm{g}$ in the $\mathrm{CCU}_{\mathrm{u}}$ unit, $\sim 600 \mu \mathrm{g} / \mathrm{g}$ in the $\mathrm{CCU}_{\mathrm{l}}$ unit, $\sim 270 \mu \mathrm{g} / \mathrm{g}$ in the $\mathrm{R}_{\mathrm{tf}}$ unit and up to $900 \mu \mathrm{g} / \mathrm{g}$ in the $\mathrm{R}_{\mathrm{wi}}$ unit. Thus, the upswing in the acid- extractable profiles in the $\mathrm{R}_{\mathrm{wi}}$ strata in the figure is not a sign of tank-leak-derived sodium; instead, it is caused by the sediments themselves. The high values of sodium in the Hanford H2 unit is caused by the T-106 tank leak fluids displacing native pore fluids and replacing natural calcium and magnesium on the sediment exchange sites. The acid-extractable cations (sodium, magnesium and calcium) are not the best indicator of the ion exchange process and its plume front. A much better indicator is the water-extractable cation distribution, as discussed in Section 4.2.2, where it was determined that the ion exchange front (maximum depth at which the sodium from the tank leak has reached and place where the stripped calcium and magnesium reside) reached $\sim 116 \mathrm{ft}$ bgs in borehole C4104. In Figure 4.38, the C4104 acid-extractable sodium profile shows a significant drop in concentration at this depth. For the 299-W10-196 borehole there is a corresponding drop off in concentration between 110 and $118 \mathrm{ft}$ bgs, suggesting that both boreholes have the same ion-exchangefront location. Because the 299-10-196 sample density has a large gap between 60 and $80 \mathrm{ft}$ bgs and this zone contains the largest concentrations of acid-extractable sodium in C4104, the shapes of the two curves are sensitive to the differing scales on the X-axes. What appears in Figure 4.38 as some downward flushing of the shallow edge of the plume in C4104 versus 299-W10-196 is not borne out by the data shown in Table 4.38. We do not see any significant differences in the acid-extractable sodium versus depth between the two boreholes that would suggest that the sodium distribution has changed over the 10-year span between the drilling and characterization of the two boreholes. Again, a better metric would have been to measure the water- extractable sodium, but no water extracts were performed for cation determination in 1993 for borehole 299-W10-196 sediments.

\subsubsection{Calcium}

The acid-soluble calcium concentration profiles as a function of depth are tabulated in Table 4.38 and shown in Figure 4.39. Again, a much more informative calcium measurement would have been available if a water extract of the sediments and cation analysis had been performed. The water extract data for the C4104 sediments was performed and used to evaluate the interaction of the relatively high sodiumbearing tank fluids with the natural sediments (see Section 4.2.2). The acid-extractable calcium concentrations in both boreholes are dominated by dissolution of caliche within the Cold Creek lower subunit. The percentage of caliche in this unit on a per gram of sediment basis can be quite variable and strong acid readily dissolves the caliche, which consists predominately of the mineral calcite, also known as calcium carbonate.

\subsubsection{Sulfate}

The water-extractable sulfate content of the sediments from C4104 and 299-W10-196 are listed in Table 4.39 and Figure 4.40. There appears to be some slightly elevated concentrations of sulfate in the C4104 sediments near 37 and 75 to $80 \mathrm{ft}$ bgs within the Hanford H2 unit, but by far the highest concentrations in both boreholes' sediments occurs in the Cold Creek lower subunit (caliche) and the upper portion of the Ringold Unit Taylor Flat member. The maximum water-extractable sulfate concentrations are in the 500 to $800 \mu \mathrm{g} / \mathrm{g}$ range and are significantly elevated over the natural sediment 
concentrations that range from 5 to $20 \mu \mathrm{g} / \mathrm{g}$. The vertical profile at C4104 does appear to show high concentrations down to $115 \mathrm{ft}$ bgs, while in 1993 the elevated concentrations may be several feet shallower. Unfortunately, sampling frequency between 110 and $120 \mathrm{ft}$ at the 299-W10-196 borehole was limited. Thus, it is difficult to ascertain migration of constituents on the order of a few feet.

\subsubsection{Actinides}

The $8 \mathrm{M}$ nitric acid-extractable actinides for sediments from the two boreholes are listed in Table 4.40. There are low but measurable concentrations of neptunium [Np-237] in both boreholes between 45 to $60 \mathrm{ft}$ bgs at concentrations between 2 and $40 \mathrm{pCi} / \mathrm{g}$. There is not much difference in the activity level or depths where detectable neptunium is observed. In oxidizing environments, Np-237 is often considered somewhat mobile (Cantrell et al. 2003, Kaplan and Serne 2000, and Routson et al. 1976).

Plutonium-239/240 is detectable in both boreholes. At 299-W10-196, the plutonium was found to range in concentration from 1 to $1,000 \mathrm{pCi} / \mathrm{g}$ over the depth interval 36 to $74 \mathrm{ft}$ bgs. Values above $100 \mathrm{pCi} / \mathrm{g}$ were observed between 40 and $60 \mathrm{ft}$ bgs and may extend all the way down to $64 \mathrm{ft}$ bgs. At C4104, the plutonium concentrations are lower ( 2 to $96 \mathrm{pCi} / \mathrm{g}$ ) over the depth range 47 to $60 \mathrm{ft}$ bgs. It appears that there has not been significant vertical migration of plutonium in the vicinity of the two boreholes in the ten years between drilling C4104 and 299-W10-196. It also appears that plutonium concentrations drop measurably over the $13 \mathrm{ft}$ interval between the two boreholes, suggesting that plutonium is interacting with the vadose zone sediments based on the concentration decrease in the horizontal direction.

The americium (Am-241) activities in the two borehole sediments exceed the plutonium-239 activities and Am-241 is detected between 47 and 60 and 39 to $74 \mathrm{ft}$ bgs at C4104 and 299-W10-196, respectively. Curium (Cm-243) was found in the C4104 sample at $46.98 \mathrm{ft}$ bgs and was below detection limits in all other samples that were analyzed. No curium measurements were reported for the 299-W10-196 borehole sediments.

The bulk of the actinides are found at $47 \mathrm{ft}$ bgs in C4104 sediments and at 43 to $46 \mathrm{ft}$ bgs at 299-W10-196. There does not seem to be deeper penetration of any of the actinides at C4104 over the past 10 years when compared to profiles at 299-W10-196. The higher concentrations of plutonium and americium at 299-W10-196, which is 13 feet closer to tank T-106, suggest that both plutonium and americium interacted readily with the sediments once the initial leak event rapidly spread the contaminated fluids both horizontally and vertically into the vadose zone. 
Table 4.38. Acid-Extractable Calcium and Sodium Concentrations in the Two Borehole Sediments ( $\mu \mathrm{g} / \mathrm{g}$ dry sediment)

\begin{tabular}{|c|c|c|c|c|c|c|}
\hline \multirow[b]{2}{*}{ Sample No. } & \multirow[b]{2}{*}{$\begin{array}{c}\text { Depth } \\
\text { (ft bgs) }\end{array}$} & \multicolumn{2}{|c|}{ C4104 (2003) } & \multirow[b]{2}{*}{$\begin{array}{c}\text { Depth } \\
\text { (ft bgs) }\end{array}$} & \multicolumn{2}{|c|}{ 299-W10-196 (1993) } \\
\hline & & $\begin{array}{c}\text { Ca } \\
(\mu g / g)\end{array}$ & $\begin{array}{c}\mathrm{Na} \\
(\mu \mathrm{g} / \mathrm{g})\end{array}$ & & $\begin{array}{c}\text { Ca } \\
(\mu g / g)\end{array}$ & $\begin{array}{c}\mathrm{Na} \\
(\mu \mathrm{g} / \mathrm{g})\end{array}$ \\
\hline $1 \mathrm{~A}$ & 16.18 & $9.60 \mathrm{E}+03$ & $4.70 \mathrm{E}+02$ & 13 & $8.67 \mathrm{E}+03$ & $2.87 E+02$ \\
\hline $2 \mathrm{~A}$ & 22.69 & $6.30 \mathrm{E}+03$ & $4.80 \mathrm{E}+02$ & 21.8 & $7.98 \mathrm{E}+03$ & $3.08 \mathrm{E}+02$ \\
\hline 3A & 30.74 & $8.90 \mathrm{E}+03$ & $5.50 \mathrm{E}+02$ & --- & --- & --- \\
\hline $4 \mathrm{~A}$ & 36.88 & $1.30 \mathrm{E}+04$ & $7.60 \mathrm{E}+02$ & 36.4 & $1.02 \mathrm{E}+04$ & $4.91 \mathrm{E}+02$ \\
\hline 4 (Nose Cone) & 37.4 & $9.50 \mathrm{E}+03$ & $9.40 \mathrm{E}+02$ & 38.9 & $8.15 E+03$ & $1.18 \mathrm{E}+03$ \\
\hline $5 \mathrm{~A}$ & 40.01 & $8.90 \mathrm{E}+03$ & $1.00 \mathrm{E}+03$ & --- & --- & --- \\
\hline $5 \mathrm{~A}$ dup & 40.01 & $8.80 \mathrm{E}+03$ & $6.90 \mathrm{E}+02$ & 43.4 & $6.81 \mathrm{E}+03$ & $1.96 \mathrm{E}+03$ \\
\hline $6 B$ & 46.33 & $8.90 \mathrm{E}+03$ & $1.00 \mathrm{E}+03$ & 46.1 & $5.30 \mathrm{E}+03$ & $1.56 \mathrm{E}+03$ \\
\hline $6 \mathrm{~A}$ & 46.98 & $9.60 \mathrm{E}+03$ & $1.50 \mathrm{E}+03$ & 52.8 & $6.79 \mathrm{E}+03$ & $1.62 \mathrm{E}+03$ \\
\hline 7B Dup & 58.39 & $1.00 \mathrm{E}+04$ & $1.90 \mathrm{E}+03$ & 52.8 & $6.32 E+03$ & $1.68 \mathrm{E}+03$ \\
\hline $7 \mathrm{~A}$ & 59.09 & $7.50 \mathrm{E}+03$ & $1.90 \mathrm{E}+03$ & 59.8 & $9.24 \mathrm{E}+03$ & $2.17 \mathrm{E}+03$ \\
\hline $8 \mathrm{~B}$ & 63.38 & $9.10 \mathrm{E}+03$ & $2.50 \mathrm{E}+03$ & --- & --- & --- \\
\hline $8 \mathrm{~A}$ & 64.03 & $1.60 \mathrm{E}+04$ & $2.40 \mathrm{E}+03$ & --- & --- & --- \\
\hline 8A Dup & 64.03 & $1.40 \mathrm{E}+04$ & $2.30 \mathrm{E}+03$ & --- & --- & --- \\
\hline $9 \mathrm{~A}$ & 76.03 & $2.20 \mathrm{E}+04$ & $1.90 \mathrm{E}+03$ & --- & --- & --- \\
\hline $10 \mathrm{~A}$ & 81.04 & $1.60 \mathrm{E}+04$ & $1.50 \mathrm{E}+03$ & 82.7 & $2.06 \mathrm{E}+04$ & $3.79 \mathrm{E}+02$ \\
\hline $11 \mathrm{~A}$ & 87.35 & $1.50 \mathrm{E}+04$ & $1.90 \mathrm{E}+03$ & --- & --- & --- \\
\hline 11A Dup & 87.35 & $1.50 \mathrm{E}+04$ & $1.80 \mathrm{E}+03$ & 90.8 & $2.70 \mathrm{E}+04$ & $7.41 \mathrm{E}+02$ \\
\hline $12 \mathrm{~A}$ & 92.61 & $2.80 \mathrm{E}+05$ & $1.50 \mathrm{E}+03$ & 90.8 & $2.87 \mathrm{E}+04$ & $7.25 \mathrm{E}+02$ \\
\hline $13 \mathrm{~A}$ & 93.56 & $1.80 \mathrm{E}+05$ & $2.10 \mathrm{E}+03$ & --- & --- & --- \\
\hline $14 \mathrm{~A}$ & 94.67 & $4.50 \mathrm{E}+04$ & $1.50 \mathrm{E}+03$ & 95.8 & $1.19 \mathrm{E}+05$ & $1.43 E+03$ \\
\hline $15 B$ & 99.7 & $1.70 \mathrm{E}+04$ & $1.40 \mathrm{E}+03$ & 97.8 & $6.36 \mathrm{E}+04$ & $1.68 \mathrm{E}+03$ \\
\hline $15 \mathrm{~A}$ & 100.37 & $4.60 \mathrm{E}+04$ & $1.40 \mathrm{E}+03$ & 100 & $9.61 \mathrm{E}+04$ & $1.30 \mathrm{E}+03$ \\
\hline $16 B$ & 101.33 & $2.40 \mathrm{E}+05$ & $1.50 \mathrm{E}+03$ & 103 & $1.85 \mathrm{E}+05$ & $6.99 \mathrm{E}+02$ \\
\hline $16 \mathrm{~A}$ & 101.98 & $2.40 \mathrm{E}+05$ & $1.50 \mathrm{E}+03$ & --- & --- & --- \\
\hline 17B & 105.39 & $8.70 \mathrm{E}+04$ & $9.60 \mathrm{E}+02$ & --- & --- & --- \\
\hline
\end{tabular}


Table 4.38. (contd)

\begin{tabular}{|c|c|c|c|c|c|c|}
\hline \multirow[b]{2}{*}{ Sample No. } & \multirow[b]{2}{*}{$\begin{array}{c}\text { Depth } \\
\text { (ft bgs) }\end{array}$} & \multicolumn{2}{|c|}{ C4104 (2003) } & \multicolumn{3}{|c|}{ 299-W10-196 (1993) } \\
\hline & & $\begin{array}{c}\text { Ca } \\
(\mu g / g)\end{array}$ & $\begin{array}{c}\text { Na } \\
(\mu \mathrm{g} / \mathrm{g})\end{array}$ & $\begin{array}{r}\text { Depth } \\
\text { (ft bgs) }\end{array}$ & $\begin{array}{c}\text { Ca } \\
(\mu g / g)\end{array}$ & $\begin{array}{c}\text { Na } \\
(\mu g / g)\end{array}$ \\
\hline $17 \mathrm{~A}$ & 106.09 & $4.40 \mathrm{E}+04$ & $6.60 \mathrm{E}+02$ & --- & --- & --- \\
\hline $18 \mathrm{~A}$ & 107.42 & $6.90 \mathrm{E}+03$ & $6.60 \mathrm{E}+02$ & 109.8 & $3.24 \mathrm{E}+04$ & $8.80 \mathrm{E}+02$ \\
\hline $19 \mathrm{~A}$ & 110.98 & $7.90 \mathrm{E}+03$ & $1.10 \mathrm{E}+03$ & --- & --- & --- \\
\hline 19A Dup & 110.98 & $9.10 \mathrm{E}+03$ & $9.50 \mathrm{E}+02$ & --- & --- & --- \\
\hline $20 B$ & 115.25 & $1.50 \mathrm{E}+04$ & $1.10 \mathrm{E}+03$ & --- & --- & --- \\
\hline $20 \mathrm{~A}$ & 116.02 & $9.60 \mathrm{E}+03$ & $9.10 \mathrm{E}+02$ & 117.3 & $1.07 \mathrm{E}+04$ & $1.06 \mathrm{E}+02$ \\
\hline $21 B$ & 120.3 & $3.20 \mathrm{E}+04$ & $2.50 \mathrm{E}+02$ & 120.3 & $8.37 \mathrm{E}+03$ & $2.12 \mathrm{E}+02$ \\
\hline $21 \mathrm{~A}$ & 120.97 & $1.80 \mathrm{E}+04$ & $2.10 \mathrm{E}+02$ & --- & --- & --- \\
\hline 22B & 123.32 & $5.80 \mathrm{E}+03$ & $7.70 \mathrm{E}+02$ & --- & --- & --- \\
\hline $22 \mathrm{~A}$ & 124.05 & $3.70 \mathrm{E}+03$ & $3.70 \mathrm{E}+02$ & --- & --- & --- \\
\hline $23 \mathrm{~A}$ & 127.13 & $4.50 \mathrm{E}+03$ & $6.60 \mathrm{E}+02$ & --- & --- & --- \\
\hline \multirow{5}{*}{\multicolumn{4}{|c|}{ Borehole C4104 met refusal }} & 132.4 & $2.79 \mathrm{E}+03$ & $3.20 \mathrm{E}+01$ \\
\hline & & & & 145.2 & $(8.60 \mathrm{E}+03)$ & $3.87 \mathrm{E}+02$ \\
\hline & & & & 155.4 & $2.25 \mathrm{E}+03$ & $4.26 \mathrm{E}+02$ \\
\hline & & & & 162.7 & $3.77 \mathrm{E}+03$ & $6.07 \mathrm{E}+02$ \\
\hline & & & & 173.8 & $6.48 \mathrm{E}+03$ & $9.75 \mathrm{E}+02$ \\
\hline
\end{tabular}




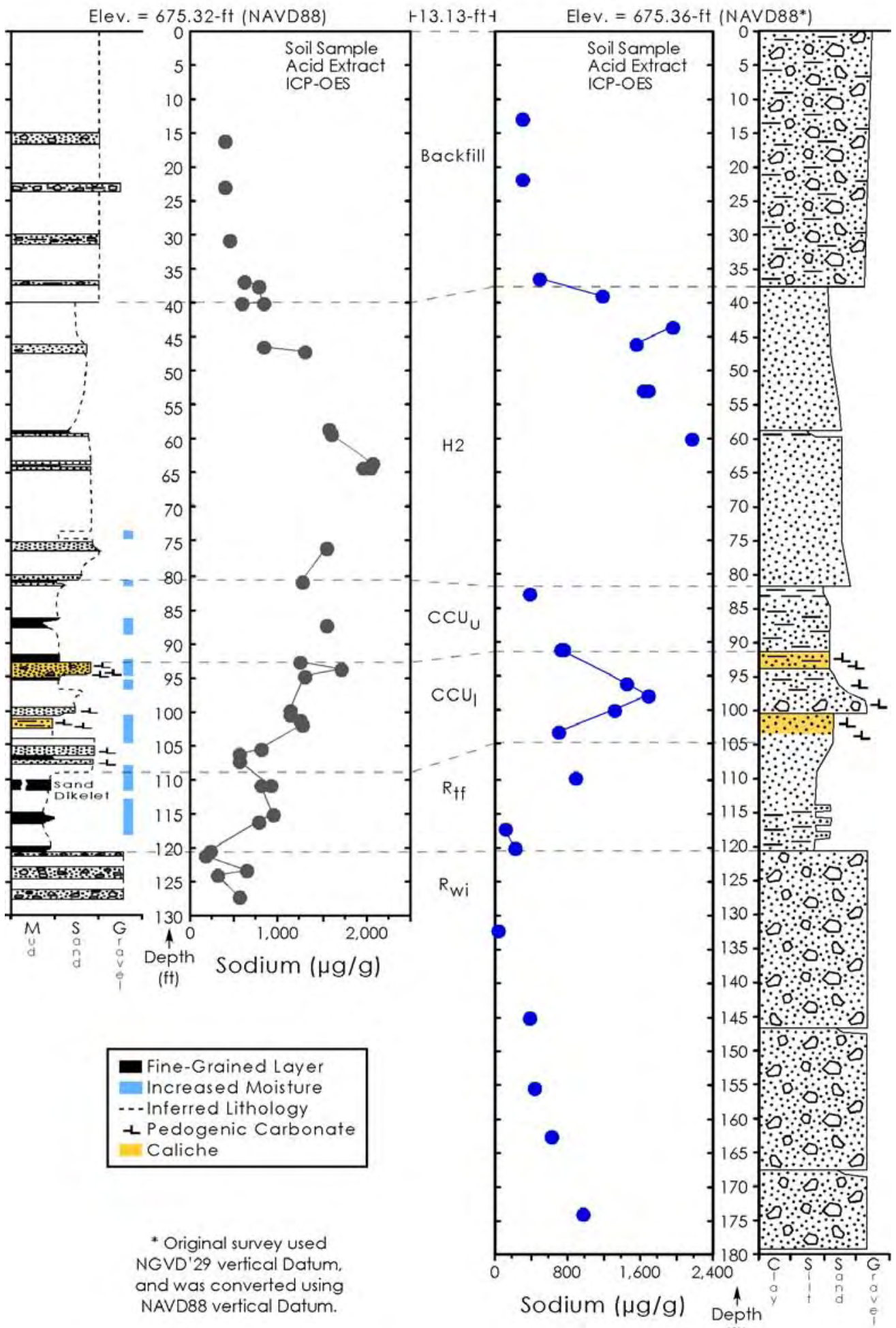

(ft)

2004/DCL/C4104/011 (09/07)

Figure 4.38. Comparison of Acid-Extractable Sodium in Boreholes C4104 (in 2003) and 299-W10-196 (in 1993) ( $\mu \mathrm{g} / \mathrm{g}$ dry sediment) 


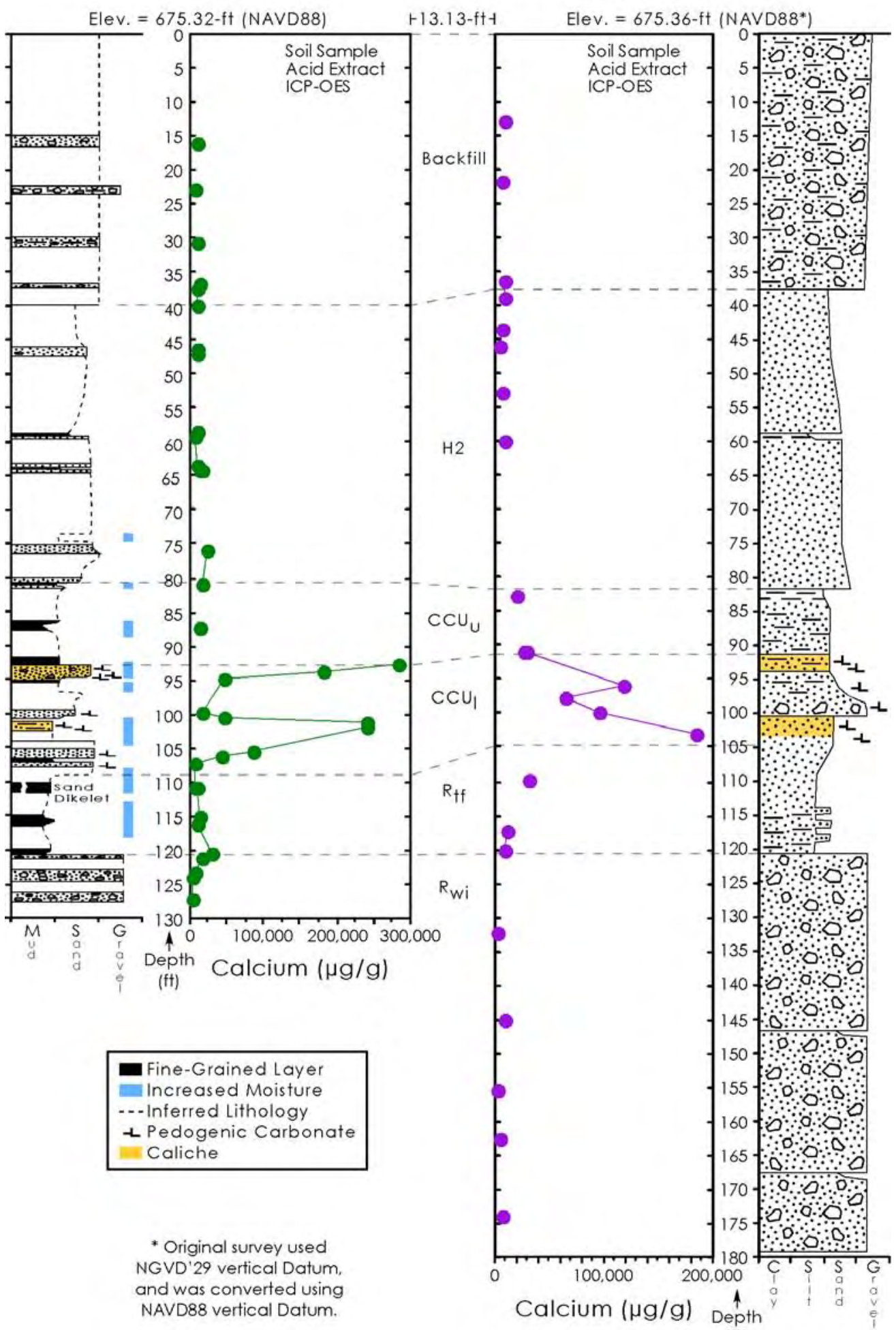

(ft)

2004/DCL/C4104/010 (09/07)

Figure 4.39. Comparison of Acid-Extractable Calcium in Boreholes C4104 (in 2003) and 299-W10-196 (in 1993) 
Table 4.39. Comparison of Water-Extractable Sulfate from Sediments from Both Boreholes

\begin{tabular}{|c|c|c|c|c|}
\hline \multirow[b]{2}{*}{ Sample No. } & \multicolumn{2}{|c|}{ C4104 (2003) } & \multicolumn{2}{|c|}{ 299-W10-196 (1993) } \\
\hline & $\begin{array}{c}\text { Depth } \\
\text { (ft bgs) }\end{array}$ & $\begin{array}{c}\text { Sulfate } \\
(\mu \mathrm{g} / \mathrm{g})\end{array}$ & $\begin{array}{c}\text { Depth } \\
\text { (ft bgs) }\end{array}$ & $\begin{array}{c}\text { Sulfate } \\
(\mu g / g)\end{array}$ \\
\hline $1 \mathrm{~A}$ & 16.18 & 3.2 & 13 & 8 \\
\hline $2 \mathrm{~A}$ & 22.69 & 3.49 & 21.8 & 7 \\
\hline $3 \mathrm{~A}$ & 30.74 & 9.22 & 30 & 6 \\
\hline $4 \mathrm{~A}$ & 36.88 & 75.25 & 36.4 & 9.7 \\
\hline 4 (Nose Cone) & 37.40 & 33.15 & 38.9 & 12.3 \\
\hline $5 \mathrm{~A}$ & 40.01 & 5.97 & --- & --- \\
\hline 5A dup & 40.01 & 19.71 & 43.4 & 21.2 \\
\hline $6 B$ & 46.33 & 29.17 & 46.1 & 14.8 \\
\hline $6 \mathrm{~A}$ & 46.98 & 7.63 & 52.8 & 15.7 \\
\hline 7B & 58.39 & 63.64 & 52.8 & 19 \\
\hline 7B Dup & 58.39 & 65.37 & --- & --- \\
\hline $7 \mathrm{~A}$ & 59.09 & 14.98 & --- & --- \\
\hline 8B & 63.38 & 62.20 & --- & --- \\
\hline $8 \mathrm{~A}$ & 64.03 & 14.44 & --- & --- \\
\hline 8A Dup & 64.03 & 15.78 & --- & --- \\
\hline $9 \mathrm{~A}$ & 76.03 & 18.61 & --- & --- \\
\hline $10 \mathrm{~A}$ & 81.04 & 151.96 & 82.7 & 25 \\
\hline $11 \mathrm{~A}$ & 87.35 & 327.44 & --- & --- \\
\hline 11A Dup & 87.35 & 392.02 & 90.8 & 86 \\
\hline $12 \mathrm{~A}$ & 92.61 & 388.18 & 90.8 & 74 \\
\hline $13 \mathrm{~A}$ & 93.56 & 758.3 & --- & --- \\
\hline $14 \mathrm{~A}$ & 94.67 & 539.75 & 95.8 & 903 \\
\hline $15 B$ & 99.70 & 192.19 & 97.8 & 700 \\
\hline $15 \mathrm{~A}$ & 100.37 & 352.24 & 100 & 278 \\
\hline $16 \mathrm{~B}$ & 101.33 & $\operatorname{High}^{(a)}$ & --- & --- \\
\hline $16 \mathrm{~A}$ & 101.98 & 519.87 & --- & --- \\
\hline
\end{tabular}


Table 4.39. (contd)

\begin{tabular}{|c|c|c|c|c|c|}
\hline \multirow{2}{*}{\multicolumn{2}{|c|}{ Sample No. }} & \multicolumn{2}{|c|}{ C4104 (2003) } & \multicolumn{2}{|c|}{ 299-W10-196 (1993) } \\
\hline & & $\begin{array}{c}\text { Depth } \\
\text { (ft bgs) }\end{array}$ & $\begin{array}{c}\text { Sulfate } \\
(\mu g / g)\end{array}$ & $\begin{array}{c}\text { Depth } \\
\text { (ft bgs) }\end{array}$ & $\begin{array}{c}\text { Sulfate } \\
(\mu \mathrm{g} / \mathrm{g})\end{array}$ \\
\hline & 17B & 105.39 & 190.15 & --- & --- \\
\hline & $17 \mathrm{~A}$ & 106.09 & 155.86 & --- & --- \\
\hline & $18 \mathrm{~A}$ & 107.42 & 96.72 & 109.8 & 313 \\
\hline & $19 \mathrm{~A}$ & 110.98 & 667.59 & --- & --- \\
\hline & 19A Dup & 110.98 & 592.47 & --- & --- \\
\hline & 20B & 115.25 & 397.49 & --- & --- \\
\hline & $20 \mathrm{~A}$ & 116.02 & 570.35 & 117.3 & 18 \\
\hline & $21 \mathrm{~B}$ & 120.30 & 20.07 & 120.3 & 19 \\
\hline & $21 \mathrm{~A}$ & 120.97 & 25.74 & --- & --- \\
\hline & 22B & 123.32 & 22.69 & --- & --- \\
\hline & $22 \mathrm{~A}$ & 124.05 & 15.34 & --- & --- \\
\hline & $23 \mathrm{~A}$ & 127.13 & 23.73 & --- & --- \\
\hline \multirow{6}{*}{\multicolumn{2}{|c|}{ final d }} & -drilling $\mathrm{I}$ & isal & 132.4 & 18 \\
\hline & & & & 145.2 & 10.2 \\
\hline & & & & 155.4 & 10 \\
\hline & & & & 162.7 & 13 \\
\hline & & & & 173.8 & 21 \\
\hline & & & & 179.6 & 17 \\
\hline (a) & \multicolumn{5}{|c|}{ Value was larger than standards used to calibrate instrument. } \\
\hline (b) & \multicolumn{5}{|c|}{--- = Sample frequency was low; thus, no samples at comparable depths. } \\
\hline
\end{tabular}


Table 4.40. Comparison of Strong Acid-Extractable Actinides from Sediments from Both Boreholes

\begin{tabular}{|c|c|c|c|c|c|c|c|c|c|c|}
\hline \multicolumn{6}{|c|}{ C4104 (2003) } & \multicolumn{5}{|c|}{ 299-W10-196 (1993) } \\
\hline Sample & $\begin{array}{l}\text { Depth } \\
\text { ft bgs }\end{array}$ & $\begin{array}{c}\text { Np-237 } \\
\text { pCi/g }\end{array}$ & $\begin{array}{c}\text { Pu-239/240 } \\
\text { pCi/g }\end{array}$ & $\begin{array}{c}\mathrm{Am}-241 \\
\mathrm{pCi} / \mathrm{g}\end{array}$ & $\begin{array}{c}\mathrm{Cm}-243 \\
\mathrm{pCi} / \mathrm{g}\end{array}$ & $\begin{array}{l}\text { Depth } \\
\text { ft bgs }\end{array}$ & $\begin{array}{c}\text { Np-237 } \\
\text { pCi/g }\end{array}$ & $\begin{array}{c}\mathrm{Pu}-239 / 240 \\
\text { pCi/g }\end{array}$ & $\begin{array}{c}\text { Am-241 } \\
\text { pCi/g }\end{array}$ & $\begin{array}{r}\text { Pu-238 } \\
\text { pCi/g }\end{array}$ \\
\hline --- & --- & --- & --- & --- & --- & 13 & $<1.00 \mathrm{E}-02$ & $(5.00 \mathrm{E}-02)$ & $<1.00 \mathrm{E}-02$ & $<1.00 \mathrm{E}-02$ \\
\hline--- & --- & --- & --- & --- & --- & 21.8 & $(1.40 \mathrm{E}-01)^{(\mathrm{a})}$ & $<1.00 \mathrm{E}-02$ & $<1.00 \mathrm{E}-02$ & $<0.00 \mathrm{E}+00$ \\
\hline--- & --- & -- & -- & - & --- & 30 & (2.50E-02) & $<3.00 \mathrm{E}-02$ & $<3.00 \mathrm{E}-02$ & $<3.00 \mathrm{E}-02$ \\
\hline--- & --- & --- & --- & --- & --- & 36.4 & 3.86E-01 & $2.72 \mathrm{E}+02^{(\mathrm{b})}$ & & $4.29 \mathrm{E}+01$ \\
\hline--- & --- & --- & --- & --- & --- & |38.9 & $<4.30 \mathrm{E}-02$ & $3.49 \mathrm{E}+01$ & $5.36 \mathrm{E}+02$ & $4.20 \mathrm{E}+00$ \\
\hline--- & --- & --- & --- & --- & --- & 38.9 & 5.50E-02 & $4.00 \mathrm{E}+01$ & $1.57 \mathrm{E}+02$ & $5.29 \mathrm{E}+00$ \\
\hline $5 \mathrm{~A}$ & 40.01 & $<3.01 \mathrm{E}-01$ & $<5.52 \mathrm{E}-01$ & $<1.10 \mathrm{E}+00$ & $0.00 \mathrm{E}+00$ & 43.4 & $1.64 \mathrm{E}+01$ & $1.17 \mathrm{E}+03$ & $1.95 \mathrm{E}+03$ & $2.28 \mathrm{E}+02$ \\
\hline $6 \mathrm{~A}$ & 46.98 & $3.90 \mathrm{E}+01$ & $9.61 \mathrm{E}+01$ & $1.33 \mathrm{E}+02$ & $1.56 \mathrm{E}+00$ & | 46.1 & $6.75 \mathrm{E}+00$ & $5.18 \mathrm{E}+02$ & $7.50 \mathrm{E}+02$ & $9.26 \mathrm{E}+01$ \\
\hline-- & --- & --- & --- & --- & --- & 52.8 & $1.44 \mathrm{E}+00$ & $1.76 \mathrm{E}+02$ & $5.15 \mathrm{E}+02$ & $2.75 \mathrm{E}+01$ \\
\hline-- & --- & --- & --- & --- & --- & 52.8 & $2.08 \mathrm{E}+00$ & $2.14 \mathrm{E}+02$ & $5.55 E+02$ & $3.56 \mathrm{E}+01$ \\
\hline $7 \mathrm{~A}$ & 59.09 & $1.64 \mathrm{E}+00$ & $1.17 \mathrm{E}+01$ & $1.46 \mathrm{E}+01$ & $<2.11 \mathrm{E}-01$ & 59.8 & $9.20 \mathrm{E}-02$ & $1.36 \mathrm{E}+02$ & $5.59 \mathrm{E}+02$ & $1.83 \mathrm{E}+01$ \\
\hline $8 \mathrm{~A}$ & 64.03 & $<1.24 \mathrm{E}+01$ & $3.84 \mathrm{E}+01$ & $6.27 \mathrm{E}+01$ & $<7.89 \mathrm{E}-01$ & |--- & --- & --- & -- & --- \\
\hline 8A Dup & 64.03 & $<3.86 \mathrm{E}+00$ & $1.42 \mathrm{E}+01$ & $1.50 \mathrm{E}+01$ & $<4.83 \mathrm{E}-02$ & |67.1 & $<2.00 \mathrm{E}-02$ & $2.60 \mathrm{E}+00$ & $7.30 \mathrm{E}+00$ & $1.90 \mathrm{E}-01$ \\
\hline $9 \mathrm{~A}$ & 76.03 & $<7.07 \mathrm{E}-01$ & $1.37 \mathrm{E}+00$ & $1.56 \mathrm{E}+00$ & $0.00 \mathrm{E}+00$ & 74 & $<1.00 \mathrm{E}-02$ & $1.10 \mathrm{E}+00$ & $2.90 \mathrm{E}+00$ & $9.10 \mathrm{E}-01$ \\
\hline $10 \mathrm{~A}$ & 81.04 & $<1.03 E-01$ & $<2.59 \mathrm{E}-01$ & $<2.59 \mathrm{E}-01$ & $0.00 \mathrm{E}+00$ & 82.7 & $<0.00 \mathrm{E}+00$ & 1.30E-01 & $<4.90 \mathrm{E}-01$ & $<2.00 \mathrm{E}-02$ \\
\hline $11 \mathrm{~A}$ & 87.35 & $<2.89 \mathrm{E}+00$ & $6.06 \mathrm{E}+00$ & $6.15 E+00$ & $<5.42 \mathrm{E}-01$ & |--- & --- & --- & -- & --- \\
\hline 11A Dup & 87.35 & $<1.24 \mathrm{E}+00$ & $4.66 \mathrm{E}+00$ & $4.19 \mathrm{E}+00$ & $<3.11 \mathrm{E}-01$ & 90.8 & $<0.00 \mathrm{E}+00$ & 3.00E-02 & $<2.00 \mathrm{E}-02$ & $<0.00 \mathrm{E}+00$ \\
\hline
\end{tabular}


Table 4.40. (contd)

\begin{tabular}{|c|c|c|c|c|c|c|c|c|c|c|}
\hline \multicolumn{6}{|c|}{ C4101 (2003) } & \multicolumn{5}{|c|}{ 299-W10-196 (1993) } \\
\hline Sample & $\begin{array}{l}\text { Depth } \\
\text { ft bgs }\end{array}$ & $\begin{array}{c}\text { Np-237 } \\
\text { pCi/g }\end{array}$ & $\begin{array}{c}\mathrm{Pu}-239 / 240 \\
\mathrm{pCi} / \mathrm{g}\end{array}$ & $\begin{array}{c}\text { Am-241 } \\
\mathrm{pCi} / \mathrm{g}\end{array}$ & $\begin{array}{c}\mathrm{Cm}-243 \\
\mathrm{pCi} / \mathrm{g}\end{array}$ & $\begin{array}{l}\text { Depth } \\
\text { ft bgs }\end{array}$ & $\begin{array}{c}\text { Np-237 } \\
\text { pCi/g }\end{array}$ & $\begin{array}{c}\mathrm{Pu}-239 / 240 \\
\mathrm{pCi} / \mathrm{g}\end{array}$ & $\begin{array}{c}\text { Am-241 } \\
\text { pCi/g }\end{array}$ & $\begin{array}{c}\text { Pu-238 } \\
\text { pCi/g }\end{array}$ \\
\hline $12 \mathrm{~A}$ & 92.61 & $<0.00 \mathrm{E}+00$ & $<0.00 \mathrm{E}+00$ & $<0.00 \mathrm{E}+00$ & $0.00 \mathrm{E}+00$ & 90.8 & $<0.00 \mathrm{E}+00$ & $<1.00 \mathrm{E}-02$ & $<0.00 \mathrm{E}+00$ & $<1.00 \mathrm{E}-02$ \\
\hline $13 \mathrm{~A}$ & 93.56 & $<1.61 \mathrm{E}+00$ & $<1.61 \mathrm{E}+00$ & $<9.54 \mathrm{E}-01$ & $0.00 \mathrm{E}+00$ & |-- & --- & -- & --- & --- \\
\hline $14 \mathrm{~A}$ & 94.67 & $<3.91 \mathrm{E}-01$ & $<0.00 \mathrm{E}+00$ & $<4.89 \mathrm{E}-02$ & $0.00 \mathrm{E}+00$ & 95.8 & $<0.00 \mathrm{E}+00$ & $4.60 \mathrm{E}+00$ & $<6.20 \mathrm{E}-01$ & 3.00E-02 \\
\hline $15 \mathrm{~A}$ & 100.37 & $<4.69 \mathrm{E}-02$ & $<0.00 \mathrm{E}+00$ & $<0.00 \mathrm{E}+00$ & $0.00 \mathrm{E}+00$ & 97.8 & $<0.00 \mathrm{E}+00$ & $2.10 \mathrm{E}+00$ & $<3.40 \mathrm{E}-01$ & $<1.00 \mathrm{E}-02$ \\
\hline $16 \mathrm{~A}$ & 101.98 & $\mathrm{NA}^{(\mathrm{c})}$ & NA & NA & NA & 100 & $<0.00 \mathrm{E}+00$ & 2.00E-02 & $<2.00 \mathrm{E}-02$ & $<0.00 \mathrm{E}+00$ \\
\hline $17 \mathrm{~A}$ & 106.09 & NA & NA & NA & NA & 103 & $<0.00 \mathrm{E}+00$ & $<1.00 \mathrm{E}-02$ & $<1.00 \mathrm{E}-02$ & $<0.00 \mathrm{E}+00$ \\
\hline $19 A$ & 110.98 & NA & NA & NA & NA & || 109.8 & $(2.50 \mathrm{E}-02)$ & $<1.00 \mathrm{E}-02$ & $<1.00 \mathrm{E}-02$ & $<0.00 \mathrm{E}+00$ \\
\hline $20 \mathrm{~A}$ & 116.02 & NA & NA & NA & NA & $\mid 117.3$ & $(1.50 \mathrm{E}-01)$ & $<4.00 \mathrm{E}-02$ & $<2.00 \mathrm{E}-02$ & $<5.00 \mathrm{E}-02$ \\
\hline $21 \mathrm{~A}$ & 120.97 & NA & NA & NA & NA & 120.3 & $<1.00 \mathrm{E}-02$ & $<2.00 \mathrm{E}-02$ & $<2.00 \mathrm{E}-02$ & $<2.00 \mathrm{E}-02$ \\
\hline $22 \mathrm{~A}$ & 124.05 & NA & NA & NA & NA & || 122.3 & $<1.00 \mathrm{E}-02$ & $<2.00 \mathrm{E}-02$ & $<2.00 \mathrm{E}-02$ & $<2.00 \mathrm{E}-02$ \\
\hline \multicolumn{6}{|c|}{ final depth -drilling met refusal } & 132.4 & $<2.00 \mathrm{E}-02$ & $<3.00 \mathrm{E}-02$ & $<3.00 \mathrm{E}-02$ & $<5.00 \mathrm{E}-02$ \\
\hline & & & & & & 145.2 & $<5.00 \mathrm{E}-02$ & $<2.00 \mathrm{E}-02$ & $<2.00 \mathrm{E}-02$ & $<3.00 \mathrm{E}-02$ \\
\hline & & & & & & 155.4 & $<2.00 \mathrm{E}-02$ & $<3.00 \mathrm{E}-02$ & $<3.00 \mathrm{E}-02$ & $<4.00 \mathrm{E}-02$ \\
\hline & & & & & & 162.7 & $\mid<2.00 \mathrm{E}-02$ & $\mid<4.00 \mathrm{E}-02$ & $\mid<5.00 \mathrm{E}-02$ & $<5.00 \mathrm{E}-02$ \\
\hline & & & & & & 173.8 & $<1.70 \mathrm{E}-02$ & $<3.00 \mathrm{E}-02$ & $<3.00 \mathrm{E}-02$ & $<5.00 \mathrm{E}-02$ \\
\hline & & & & & & 179.6 & $<2.00 \mathrm{E}-02$ & $<3.00 \mathrm{E}-02$ & $<2.00 \mathrm{E}-02$ & $<3.00 \mathrm{E}-02$ \\
\hline $\begin{array}{l}\text { (a) } \\
\text { (b) } \\
\text { (c) } \\
\text { (d) }\end{array}$ & \multicolumn{10}{|c|}{$\begin{array}{l}\text { Parentheses signify values below level of quantitation but considered valid. } \\
\text { Bold values designate high concentrations relative to other analyses. } \\
\text { NA = not analyzed because constituents are not expected to migrate this deep and analysis costly. } \\
\text {--- sampling frequency such that no samples were taken near these depths. }\end{array}$} \\
\hline
\end{tabular}




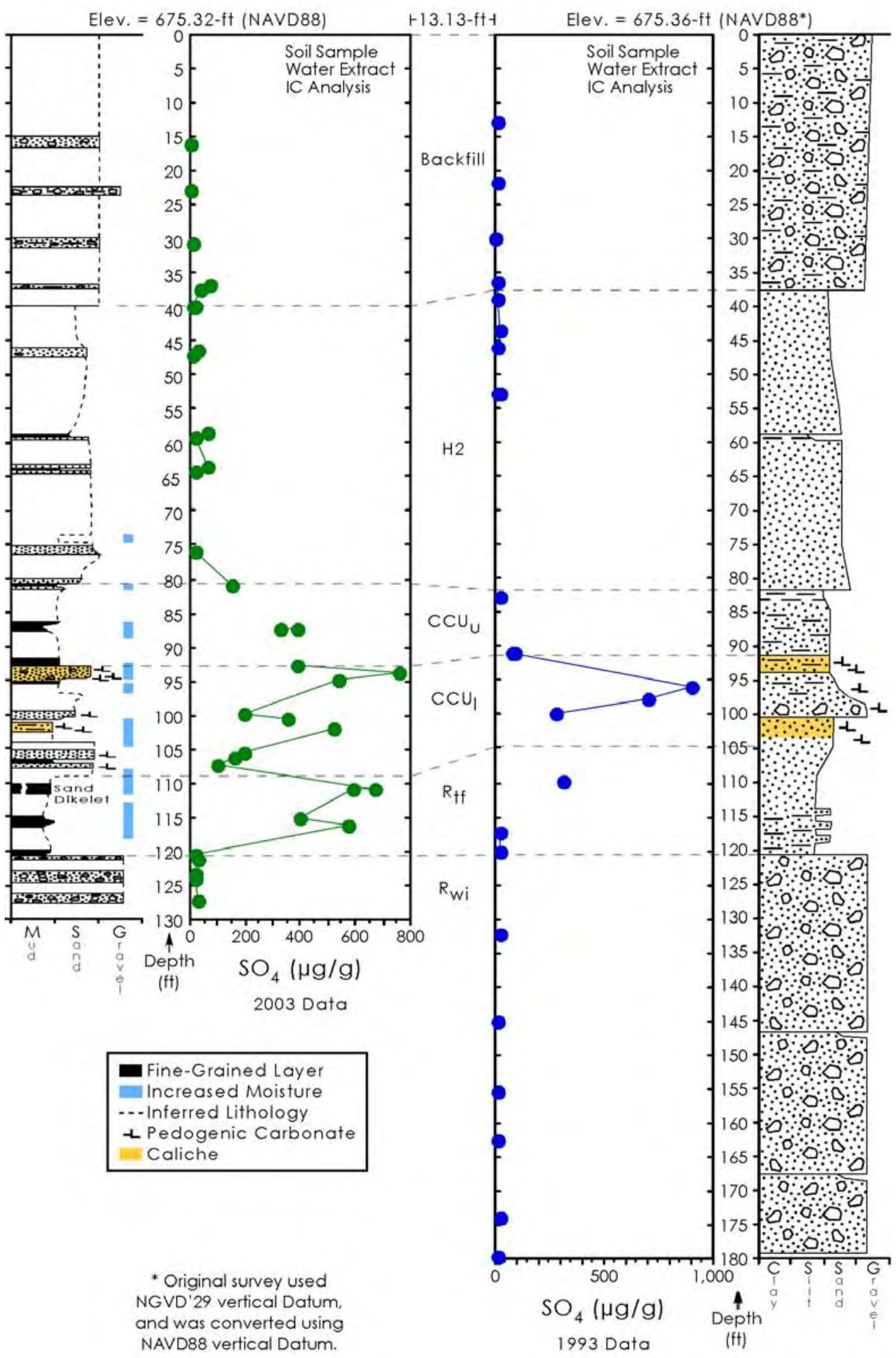

2004/DCL/C4104/009 (09/03)

Figure 4.40. Comparison of Water-Extractable Sulfate in Boreholes C4104 (in 2003) and 299-W10-196 (in 1993). 


\subsection{Vadose Zone Sediment from Borehole C4105}

To evaluate the extent of vertical and horizontal migration of contaminants, borehole C4105 was pushed into the vadose zone sediment approximately $87.70 \mathrm{ft}$ west of C4104 and is approximately $28.1 \mathrm{ft}$ southwest of the edge of tank T-106 as shown in Figures 4.29 and 4.30, the down dip direction for vadose zone fluid migration. By comparing the distributions of constituents in the vadose zone sediments from boreholes C4105 and C4104, semi-quantitative measures of mobility can be performed. Borehole C4105 reached a depth of $130.9 \mathrm{ft}$ bgs at which point driving the probe met refusal.

\subsubsection{Moisture Content}

The moisture content of the 44 cores liners as a function of depth and lithology are shown in Table 4.41 and Figure 2.19. The backfill samples have a mean moisture content of $4.7 \pm 1.7 \%$ by weight with a wet zone at the very bottom at $40.3 \mathrm{ft}$ bgs. The backfill samples at C4105 are $4.5 \%$ drier than the backfill at C4104. The Hanford formation H2 samples from borehole C4105 have a mean moisture content of $5.3 \pm 1.4 \%$ by weight. The Hanford formation $\mathrm{H} 2$ sediments in borehole C4105 are on average $1 \%$ by weight drier than the $\mathrm{H} 2$ sediments at borehole C4104. The fact that the backfill and Hanford formation $\mathrm{H} 2$ unit are drier at borehole C4105 in comparison to borehole C4104 sediments may reflect the fact that moisture that is deflected off the tank domes infiltrates along a circular path just outside the tank circumference, which is in the vicinity of where borehole C4104 was drilled. Borehole C4105 is significantly farther away from the edges of the nearby tanks T-106 and T-109. At borehole C4105, the Cold Creek upper subunit's moisture content is $\sim 15.7 \pm 3.8 \%$ by weight, slightly wetter than the same unit at C4104 and about typical for a fine-grained sediment in the vadose zone at Hanford. The Cold Creek lower subunit (caliche) at C4105 has an average moisture content of $10.6 \pm 4.4 \% \mathrm{wt}$, slightly less than the average for this unit at borehole C4104. The average moisture content of the Ringold Formation Taylor Flat member at C4105 is $14.7 \pm 10.7 \%$ and is quite variable. At borehole C4104, this unit is also quite moist (average 17.6\%) and also variable because of a wide range in particle sizes. The Ringold Formation Wooded Island member at $\mathrm{C} 4105$ has an average moisture content of $9.2 \pm 6.6 \%$. The variability reflects the wide range of particle sizes present versus depth. The same unit at C4104 is a bit drier with an average moisture content of $6.9 \%$.

The average moisture content of the $\mathrm{H} 2$ unit samples measured in background boreholes is 3.8\% for samples that are not fine-grained thin lens. Both C4104 and C4105 contain greater moisture percentages that may reflect the various tank farm operations (e.g., gravel cover) that encourage higher moisture infiltration.

\subsubsection{1:1 Sediment:Water Extracts for Borehole C4105}

The A liners from the 19 and two B liners (run in duplicate) cores were characterized after the geologic descriptions by performing 1:1 water:sediment extracts. In total, 23 separate sediment samples were characterized. The following tables and figures present the mass of a given constituent leached per gram of sediment as measured in the water extracts to allow direct comparison to the same data for the background borehole sediments from borehole 299-W10-27 (because the T tank farm background borehole 299-W11-39 may contain Hanford related fluids) and the other two contaminated boreholes. Other figures show dilution-corrected values that represent concentrations in vadose zone porewater in borehole C4105. Six of the C4105 sediments were also ultracentrifuged and actual porewater was extracted. As discussed in several other Vadose Zone Characterization Project reports, the dilutioncorrected 1:1 water:sediment extracts are a reasonable derivation of the actual vadose zone porewater 
(see Serne et al. 2002b, 2002c, 2002d, 2002e, 2002f). The six ultra-centrifuged sediments yielded actual porewater that is compared with the derived porewaters based on the 1:1 sediment to water extracts.

\subsubsection{1 pH and Electrical Conductivity (EC)}

The 1:1 sediment:water extract $\mathrm{pH}$ and EC data are shown in Table 4.42. Both the extract and dilution-corrected EC values are shown as is the EC for the actual porewaters obtained by ultracentrifugation of the six selected sediments. Figure 4.41 shows the 1:1 sediment:water extract and actual porewater $\mathrm{pH}$ values and dilution-corrected and actual EC values as a function of depth and stratigraphy. A comparison of the data in Table 4.42 with the $\mathrm{pH}$ and EC of the 299-W10-27 extracts (see Serne et al. 2004) shows atypical high salinity is present from $86.7 .3 \mathrm{ft}$ bgs to the bottom of the C4105 borehole. The EC values for 1:1 water extracts from the Cold Creek units' sediments at C4105 range from 1.2 to $3.1 \mathrm{mS} / \mathrm{cm}$, which is about 10 to 30 times higher than found in dilution corrected porewaters from nearby background sediments. The six actual porewater EC values are quite similar, or in some cases slightly lower than the dilution-corrected (derived) porewater conductivities. Thus, there is some possibility that small amounts of precipitates and coatings on the grains may have re-dissolved during the extraction process in some sediment samples. The highest values of dilution-corrected porewater EC in borehole C4105 occur in two zones, between 87 to $110 \mathrm{ft}$ bgs and at $123 \mathrm{ft}$ bgs. The dilution-corrected EC and actual porewater values for these two zones are equivalent to a pore solution of 0.10 to $0.175 \mathrm{M} \mathrm{KCl}$, the salt solution used to calibrate the conductivity cell. The leaks near the SX108-109 and BX-102 tanks had peak vadose zone porewater concentrations that were equivalent to much more concentrated waste fluids, 7 to 17 and 0.7 to $1 \mathrm{M} \mathrm{KCl}$ solutions, respectively. The maximum dilution-corrected EC at borehole C4104 ranged from 25 to $30 \mathrm{mS} / \mathrm{cm}$ in two zones: one in the Hanford formation $\mathrm{H} 2$ unit and one zone in the Ringold Formation Taylor Flats member that contained the highest concentration of nitrate and technetium-99. The EC values at C4105 are less than half the values in sediments at C4104 and there is no evidence of elevated values in the H2 unit at C4105.

The $\mathrm{pH}$ value of the actual porewater and 1:1 sediment:water extract at $70 \mathrm{ft}$ bgs may be elevated above the values expected for uncontaminated sediments, but the values, 8.05 to 8.5, are much lower than the values 9.6 to 9.8 found at the same depth at borehole C4104.

\subsubsection{Composition of the 1:1 Sediment:Water Extract and Porewaters for Borehole C4105}

The water extract values for the major cations and anions and several trace constituents are discussed in this section. The anion data are tabulated in Tables 4.43 and 4.44 and Figure 4.42 in units of mass per gram of dry sediment. The data for the water extracts of borehole C4105 for fluoride are elevated slightly in comparison to the background sediment at 299-W10-27 in the backfill but for the other strata the water-extractable fluoride is not elevated. Compared to the C4104 water extract fluoride data, C4105 sediments contain a hundredfold less fluoride in the Hanford formation $\mathrm{H} 2$ unit and about 3 times less in the Cold Creek lower subunit. From a comparison of the two contaminated boreholes with background sediments, it appears that there was fluoride in the T-106 waste that leaked and it is somewhat reactive with sediments such that the leading edge of the fluoride plume has been dissipated mostly in the Hanford $\mathrm{H} 2$ unit (based on the hundredfold lower values at C4105).

The chloride concentrations in the borehole C4105 sediments are elevated in comparison to the background sediments in all strata except the Hanford formation $\mathrm{H} 2$ unit. The chloride concentrations are as much as 40,60,100, and 4 times larger than in background sediments from the Cold Creek upper, Cold Creek lower, Ringold Formation Taylor Flat member and Ringold Formation Wooded Island member, respectively. The chloride concentrations in the C4105 sediments from the Hanford formation H2 unit 
are lower than for sediment chloride concentrations at C4104 by a factor of 10 to 20. However, deeper within the Cold Creek Unit (both subunits), the chloride concentrations at C4105 are between 5 and 10 times larger than at C4104. Within the Ringold Formation (both subunits), the chloride concentrations in the two contaminated boreholes are about the same and significantly elevated compared to background sediments.

The chloride distributions for the two contaminated boreholes are perplexing. One possible conceptual model is that the T-106 tank leak fluid contained elevated chloride that percolated into the vadose zone throughout all the strata penetrated by borehole C4104 with a strong vertical component. At C4105, the chloride plume is not found in the Hanford formation but is found at larger concentrations than at C4104 in the Cold Creek units, suggesting a significant horizontal spreading between the two boreholes in both Cold Creek units. The chloride concentrations are elevated, but similar at the two contaminated boreholes in the Ringold Formation. One hydrologic conceptual model that would lead to this distribution of mobile constituents is that the T-106 leak penetrated the Hanford formation with a strong vertical component and then the plume moved predominately in the horizontal direction towards borehole C4105 (down-dip direction) with a slower percolation of fluids into the deeper Ringold Formation at both boreholes. Diffusion might also have transported the mobile contaminants into the Ringold. After the leak dissipated, enhanced recharge (because of the gravel cover and umbrella effect from the tank dome) may have pushed the tank fluids in the Hanford formation near C4104 into the Cold Creek where horizontal migration pushed the heart of the mobile salts towards C4105. Slow percolation and diffusion continued to distribute contaminants into the deeper Ringold strata at both boreholes. This hydrologic conceptual model could account for the center of mass of the mobile anions being closer to C4105 than C4104 in the Cold Creek sediments.

The water-extractable nitrate data for borehole C4105 sediments show slightly elevated values in comparison to background sediments in the deeper portion of the Hanford formation $\mathrm{H} 2$ unit and significantly higher concentrations (>1000 x) than background in both Cold Creek subunits. The nitrate concentrations in C4105 sediments within the Ringold Formation (both subunits) are also elevated versus background by factors of 500 and 100 in $\mathrm{R}_{\mathrm{tf}}$ and $\mathrm{R}_{\mathrm{wi}}$, respectively. The comparison of the nitrate concentrations in the two contaminated boreholes suggests that in the Hanford formation tank leak fluid percolated into the sediments at $\mathrm{C} 4104$ starting at about $80 \mathrm{ft}$ bgs but did not flow horizontally all the way to C4105. However, in the Cold Creek upper subunit, the nitrate concentrations at C4105 exceed the concentrations at $\mathrm{C} 4104$ by a factor of 10, thus suggesting a large component of horizontal spreading in these strata. In the $\mathrm{CCU}_{1}$ subunit there is somewhat larger concentrations of nitrate in $\mathrm{C} 4105$ sediments suggesting perhaps some vertical penetration of high concentration nitrate that originally spread horizontally in the overlying $\mathrm{CCU}_{\mathrm{u}}$ stratum. There is more nitrate (by a factor of 1 to 5 times) in the C4105 sediments in the $\mathrm{R}_{\mathrm{tf}}$ stratum than at C4104, but in the deepest stratum penetrated, the top of Ringold Formation Wooded Island member, the nitrate concentrations in both contaminated boreholes are similar (several hundred $\mu \mathrm{g} / \mathrm{g}$ ). The nitrate and chloride data both support a flow conceptual model that suggests vertical percolation through the $\mathrm{H} 2$ unit near T-106 and then a strong horizontal spreading within the $\mathrm{CCU}_{\mathrm{u}}$ unit followed by more slow vertical percolation, perhaps via diffusion, into the deeper strata.

The carbonate contents of the C4105 sediments in the backfill are 3 times greater than in background sediments, but in all the rest of strata at C4105 the carbonate content does not differ from values in the background sediment. Compared to sediments at C4104, the sediments at C4105 contain much lower water-leachable carbonate over the depths from 81 to the bottom of the borehole ( 131) ft bgs. The cause for the high water-leachable carbonate at C4104 is the likely interaction of the alkaline tank leak fluids with the sediments. It appears that most of the caustic reactions occur closer to tank T-106 and on the east side of tank as opposed to the south-west side of the tank. 
Table 4.41. Moisture Content of Borehole C4105 Cores

\begin{tabular}{|c|c|c|c|c|}
\hline \multirow[b]{2}{*}{ Sample No. } & \multirow{2}{*}{$\begin{array}{c}\text { Depth } \\
\text { (ft bgs) }\end{array}$} & \multirow{2}{*}{$\begin{array}{c}\text { Stratigraphic } \\
\text { Unit }\end{array}$} & \multirow[b]{2}{*}{ Lithology } & $\begin{array}{c}\text { Moisture } \\
\text { Content }\end{array}$ \\
\hline & & & & $\% \mathrm{Wt}$ \\
\hline S03044-1B & 14.5 & Bkfl & \multirow{2}{*}{ Silty sandy gravel } & $4.63 \%$ \\
\hline S03044-1A & 15.3 & Bkfl & & $3.32 \%$ \\
\hline S03044-2B & 22.0 & Bkfl & \multirow{2}{*}{ Silty sandy gravel } & $2.91 \%$ \\
\hline S03044-2A & 22.7 & Bkfl & & $4.21 \%$ \\
\hline S03044-3B & 36.1 & Bkfl & \multirow{2}{*}{ Silty sandy gravel } & no sample \\
\hline S03044-3A & 36.8 & Bkfl & & $5.36 \%$ \\
\hline S03044-4B & 39.5 & Bkfl & \multirow{2}{*}{ Silty gravelly sand } & no sample \\
\hline S03044-4A & 40.2 & Bkfl & & $7.62 \%$ \\
\hline S03044-5B & 47.7 & $\mathrm{H} 2$ & \multirow{2}{*}{ Sand } & $5.02 \%$ \\
\hline S03044-5A & 48.4 & $\mathrm{H} 2$ & & $3.73 \%$ \\
\hline S03044-6B & 55.4 & H2 & \multirow{2}{*}{ Gravelly sand } & $4.91 \%$ \\
\hline S03044-6A & 56.1 & $\mathrm{H} 2$ & & $4.33 \%$ \\
\hline S03044-7B & 69.3 & H2 & \multirow{2}{*}{ Sand } & $7.53 \%$ \\
\hline S03044-7A & 70.1 & $\mathrm{H} 2$ & & $4.57 \%$ \\
\hline S03044-8B & 80.5 & $\mathrm{H} 2$ & \multirow{2}{*}{ Sand } & $7.50 \%$ \\
\hline S03044-8A & 81.2 & $\mathrm{H} 2$ & & $4.89 \%$ \\
\hline S03044-9B & 85.8 & $\mathrm{CCU}_{\mathrm{u}}$ & \multirow{2}{*}{ Sandy silt } & $15.20 \%$ \\
\hline S03044-9A & 86.7 & $\mathrm{CCU}_{\mathrm{u}}$ & & $14.44 \%$ \\
\hline S03044-10B & 87.5 & $\mathrm{CCU}_{\mathrm{u}}$ & \multirow{3}{*}{ Sand to silty sand } & $10.25 \%$ \\
\hline S03044-10A & 88.2 & $\mathrm{CCU}_{\mathrm{u}}$ & & $19.87 \%$ \\
\hline S03044-10A DUP & 88.2 & $\mathrm{CCU}_{\mathrm{u}}$ & & $18.81 \%$ \\
\hline S03044-11B & 92.6 & $\mathrm{CCU}_{\mathrm{l}}$ & \multirow{2}{*}{$\begin{array}{l}\text { Gravelly Muddy } \\
\text { Sand }\end{array}$} & $10.51 \%$ \\
\hline S03044-11A & 93.3 & $\mathrm{CCU}_{1}$ & & $13.28 \%$ \\
\hline S03044-12B & 96.4 & $\mathrm{CCU}_{1}$ & \multirow{2}{*}{ Muddy sand } & $12.11 \%$ \\
\hline S03044-12A & 97.1 & $\mathrm{CCU}_{\mathrm{l}}$ & & $12.11 \%$ \\
\hline
\end{tabular}


Table 4.41. (contd)

\begin{tabular}{|c|c|c|c|c|}
\hline Sample No. & $\begin{array}{c}\text { Depth } \\
\text { (ft bgs) }\end{array}$ & $\begin{array}{c}\text { Stratigraphic } \\
\text { Unit }\end{array}$ & Lithology & $\begin{array}{c}\text { Moisture } \\
\text { Content }\end{array}$ \\
\hline S03044-13B & 99.7 & $\mathrm{CCU}_{\mathrm{l}}$ & \multirow{3}{*}{ Silty sand } & $6.69 \%$ \\
\hline S03044-13B DUP & 99.7 & $\mathrm{CCU}_{1}$ & & $6.74 \%$ \\
\hline S03044-13A & 100.3 & $\mathrm{CCU}_{1}$ & & $7.43 \%$ \\
\hline S03044-14B & 101.4 & $\mathrm{CCU}_{\mathrm{l}}$ & \multirow{2}{*}{ Sandy silt } & $8.63 \%$ \\
\hline S03044-14A & 102.0 & $\mathrm{CCU}_{\mathrm{l}}$ & & $9.54 \%$ \\
\hline S03044-15B & 102.5 & $\mathrm{CCU}_{1}$ & \multirow{2}{*}{$\begin{array}{l}\text { Gravelly sandy } \\
\text { mud }\end{array}$} & $12.26 \%$ \\
\hline S03044-15A & 103.2 & $\mathrm{CCU}_{1}$ & & $9.61 \%$ \\
\hline S03044-16B & 106.2 & $\mathrm{CCU}_{1}$ & \multirow{2}{*}{ Sandy mud to silt } & $11.82 \%$ \\
\hline S03044-16A & 106.9 & $\mathrm{CCU}_{\mathrm{l}}$ & & $25.36 \%$ \\
\hline S03044-17B & 109.4 & $\mathrm{CCU}_{1}$ & \multirow{4}{*}{$\begin{array}{l}\text { Silt, sandy silt, to } \\
\text { silty sand }\end{array}$} & $11.82 \%$ \\
\hline S03044-17B DUP & 109.4 & $\mathrm{CCU}_{1}$ & & $8.40 \%$ \\
\hline S03044-17A & 110.0 & $\mathrm{CCU}_{1}$ & & $6.67 \%$ \\
\hline S03044-17A DUP & 110.0 & $\mathrm{CCU}_{1}$ & & $7.87 \%$ \\
\hline S03044-18B & 115.3 & $\mathrm{R}_{\mathrm{tf}}$ & \multirow{2}{*}{ Sand to sandy silt } & $7.42 \%$ \\
\hline S03044-18A & 116.0 & $\mathrm{R}_{\mathrm{tf}}$ & & $21.98 \%$ \\
\hline S03044-19B & 120.2 & $\mathrm{R}_{\mathrm{tf}}$ & \multirow{2}{*}{$\begin{array}{l}\text { Sand, silty sand, } \\
\text { and clayey silt }\end{array}$} & $3.85 \%$ \\
\hline S03044-19A & 120.9 & $\mathrm{R}_{\mathrm{tf}}$ & & $25.49 \%$ \\
\hline S03044-20B & 123.2 & $\mathrm{R}_{\mathrm{wi}}$ & \multirow{2}{*}{ Sandy gravel } & $5.32 \%$ \\
\hline S03044-20A & 123.9 & $\mathrm{R}_{\mathrm{wi}}$ & & $20.61 \%$ \\
\hline S03044-21B & 129.2 & $\mathrm{R}_{\mathrm{wi}}$ & \multirow{2}{*}{ Silty sandy gravel } & $5.33 \%$ \\
\hline S03044-21A & 129.8 & $\mathrm{R}_{\mathrm{wi}}$ & & $5.13 \%$ \\
\hline S03044-22 & 129.3 & $\mathrm{R}_{\mathrm{wi}}$ & Silty sandy gravel & $9.60 \%$ \\
\hline
\end{tabular}


Table 4.42. $\quad$ pH and EC Data for Sediment-Water Extracts and Actual Porewater from Borehole C4105

\begin{tabular}{|c|c|c|c|c|c|}
\hline Sample No. & $\begin{array}{l}\text { Depth } \\
\text { (ft bgs) }\end{array}$ & $\begin{array}{c}\text { Stratigraphic } \\
\text { Unit }\end{array}$ & pH & $\begin{array}{c}\text { Conductivity } \\
\mathrm{mS} / \mathrm{cm}\end{array}$ & $\begin{array}{l}\text { Calculated (mS/cm) } \\
\text { (in Pore Water) }\end{array}$ \\
\hline $1 \mathrm{~A}$ & 15.3 & Bkfl & 7.63 & 0.149 & 4.494 \\
\hline $2 \mathrm{~A}$ & 22.7 & Bkfl & 7.74 & 0.193 & 4.588 \\
\hline $3 \mathrm{~A}$ & 36.8 & Bkfl & 7.89 & 0.324 & 6.046 \\
\hline $4 \mathrm{~A}$ & 40.2 & Bkfl & 7.82 & 0.504 & 6.610 \\
\hline $5 \mathrm{~A}$ & 48.4 & $\mathrm{H} 2$ & 7.56 & 0.131 & 3.516 \\
\hline $6 \mathrm{~A}$ & 56.1 & H2 & 7.50 & 0.135 & 3.120 \\
\hline 7A UFA & 70.1 & $\mathrm{H} 2$ & 8.51 & & 3.57 \\
\hline $7 \mathrm{~A}$ & 70.1 & $\mathrm{H} 2$ & 8.05 & 0.292 & 6.393 \\
\hline $8 \mathrm{~A}$ & 81.2 & $\mathrm{H} 2$ & 7.57 & 0.220 & 4.502 \\
\hline 9A & 86.7 & $\mathrm{CCU}_{\mathrm{u}}$ & 7.48 & 2.202 & 15.270 \\
\hline 10A UFA & 88.2 & $\mathrm{CCU}_{\mathrm{u}}$ & 7.25 & & 14.19 \\
\hline $10 \mathrm{~A}$ & 88.2 & $\mathrm{CCU}_{\mathrm{u}}$ & 7.46 & 3.089 & 15.596 \\
\hline 10A DUP & 88.2 & $\mathrm{CCU}_{\mathrm{u}}$ & 7.47 & 2.848 & 15.140 \\
\hline 11A UFA & 93.3 & $\mathrm{CCU}_{\mathrm{l}}$ & 7.36 & & 12.23 \\
\hline $11 \mathrm{~A}$ & 93.3 & $\mathrm{CCU}_{1}$ & 7.44 & 2.407 & 18.126 \\
\hline $12 \mathrm{~A}$ & 97.1 & $\mathrm{CCU}_{\mathrm{l}}$ & 7.39 & 1.396 & 11.523 \\
\hline $13 \mathrm{~A}$ & 100.3 & $\mathrm{CCU}_{1}$ & 7.54 & 1.008 & 13.573 \\
\hline $14 \mathrm{~A}$ & 102.0 & $\mathrm{CCU}_{\mathrm{l}}$ & 7.53 & 1.565 & 16.426 \\
\hline $15 \mathrm{~A}$ & 103.2 & $\mathrm{CCU}_{1}$ & 7.57 & 1.689 & 17.580 \\
\hline 16A UFA & 106.9 & $\mathrm{CCU}_{1}$ & 7.74 & & 10.16 \\
\hline $16 \mathrm{~A}$ & 106.9 & $\mathrm{CCU}_{1}$ & 7.58 & 2.684 & 10.590 \\
\hline $17 \mathrm{~A}$ & 110.0 & $\mathrm{CCU}_{1}$ & 7.45 & 1.199 & 17.980 \\
\hline 17A DUP & 110.0 & $\mathrm{CCU}_{\mathrm{l}}$ & 7.52 & 1.168 & 14.841 \\
\hline $18 \mathrm{~A}$ & 116.0 & $\mathrm{R}_{\mathrm{tf}}$ & 7.78 & 1.009 & 4.590 \\
\hline 19A UFA & 120.9 & $\mathrm{R}_{\mathrm{tf}}$ & 7.47 & & 5.005 \\
\hline $19 \mathrm{~A}$ & 120.9 & $\mathrm{R}_{\mathrm{tf}}$ & 7.48 & 1.270 & 4.986 \\
\hline 20A UFA & 123.9 & $\mathrm{R}_{\mathrm{wi}}$ & 7.27 & & 16.17 \\
\hline $20 \mathrm{~A}$ & 123.9 & $\mathrm{R}_{\mathrm{wi}}$ & 7.65 & 0.630 & 18.979 \\
\hline $21 \mathrm{~A}$ & 129.8 & $\mathrm{R}_{\mathrm{wi}}$ & 7.52 & 0.511 & 10.043 \\
\hline
\end{tabular}




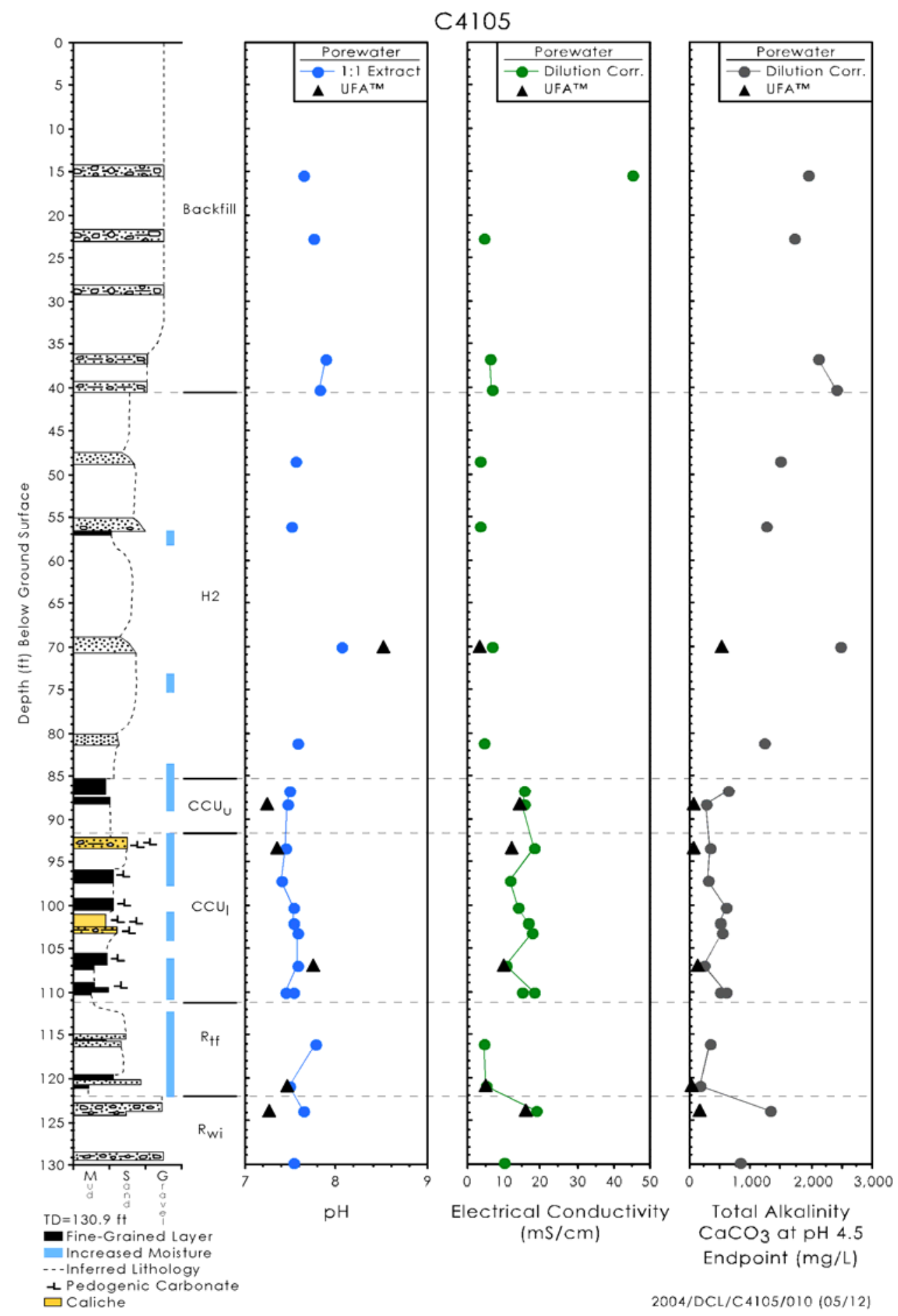

Figure 4.41. Borehole C4105 Sediment-to-Water Extract and Actual Porewater $\mathbf{p H}$ and Calculated and Actual Porewater EC and Total Alkalinity 
The sulfate content of the sediments in borehole C4105 is elevated compared to background sediments all the way down to the Ringold Formation Wooded Island member. In the backfill and Hanford formation $\mathrm{H} 2$ unit the C4105 sediments contain 2 to 4 times as much water-soluble sulfate as found in background sediments. In the Cold Creek unit and the Ringold Formation penetrated by the C4105 borehole, the water-soluble sulfate contents exceed background values by factors of 3 to 100 times, with the most elevated concentrations found in Cold Creek upper subunit and in a portion of the Cold Creek lower unit between 102 and $110 \mathrm{ft}$ bgs. Compared to the water-soluble sulfate in C4104, the sulfate in the C4105 sediments is lower in the Cold Creek units and much lower in the Ringold Formation Taylor Flats member. It appears that the tank-fluid-derived sulfate penetrated deeper in the profile at C4104 at higher concentrations, which suggests some interaction of sulfate with sediments, because mobile nitrate and chloride penetrates deeper and remains at high concentrations over a longer horizontal path length towards C4105 and beyond.

The water-soluble phosphate concentrations in the C4105 sediments do not differ significantly from background values in uncontaminated sediments excepting in the Cold Creek lower subunit (caliche) where there seems to be elevated values in some samples; however, differences in calcium-carbonate content and soil development reactions may be the cause as opposed to the presence of tank-derived phosphate. The water-soluble phosphate concentrations in the C4105 borehole sediment in the Hanford formation $\mathrm{H} 2$ unit are not elevated and are much lower compared to the sediments from this unit in C4104, which suggests that phosphate is significantly immobilized in Hanford sediments and that the T106 leak must have been closer to C4104 than C4105, again suggesting that the leak occurred on the eastern portion of the tank.

The water-soluble nitrite data for C4105 sediments show background values exist down to the Cold Creek units where values from 1 to $55 \mu \mathrm{g} / \mathrm{g}$ are found. Values between 0.5 and $22 \mu \mathrm{g} / \mathrm{g}$ are found in the Ringold Formation Taylor Flats member. At C4104, nitrite values are elevated only in the Ringold Formation Taylor Flats member. We suspect that nitrite is being oxidized in the vadose zone once it leaves the tank and that some of the analytical data is compromised by the presence of large concentrations of nitrate in the chromatogram, which interferes in the resolution of the two peaks from each other to allow accurate quantification.

Unlike the sediments from C4104, which show a small acetate plume in the Hanford formation H2 sediments, the water-soluble formate, acetate, and oxalate data for sediment from borehole C4105 do not show any distinct patterns and values do not differ significantly from values in uncontaminated sediments from the T and TX tank farm regions. The water-extractable small organic molecules in the C4105 borehole sediments are shown in Table 4.44.

The water-extractable major cations in the borehole C4105 sediments are shown in Table 4.45 and the distribution with depth is shown in Figure 4.43. The distribution of the divalent alkaline earth cations (magnesium, calcium, and strontium but not barium) shows lower than background sediment water-extractable quantities at $70 \mathrm{ft}$ bgs; however, throughout the rest of the backfill and Hanford formation $\mathrm{H} 2$ unit the values are similar to uncontaminated sediments. High divalent cation water extracts are found in the Cold Creek unit and Ringold Formation. The largest divalent cation concentrations at C4105 are found in the Cold Creek upper subunit where values exceed background sediment values by factors of 20 to 45 times. In the Cold Creek lower subunit, water-extractable divalent cations exceed the concentrations leachable from background sediments by factors that range from 5 to 20 times. In the Ringold Formation Taylor Flat member, the water-extractable divalent cations exceed the concentrations leachable from background sediments by factors of 8 to 25 times, while in the Ringold 
Formation Wooded Island member the water-extractable divalent cations in borehole C4105 sediments exceed values in background sediments by factors of 1 to 5 times. In the Hanford $\mathrm{H} 2 \mathrm{unit}$ at $70 \mathrm{ft}$ bgs, the water-extractable sodium is 6 to 10 times larger than in background sediments. In the two Cold Creek subunits, water-extractable sodium at borehole C4105 exceeds the concentrations leachable from background sediments from the Cold Creek subunits by factors of 3 to 20 times. In the Ringold Formation at C4105, the sodium that leaches into water is 1 to 3 times larger than the sodium that water leaches from background sediments.

These trends suggest that tank fluids that contained sodium did seep into the vadose zone near borehole C4104 and that the enriched sodium plume traveled mainly in the Cold Creek and upper portion of the Ringold Formation to reach borehole C4105. There is a distinct marker of tank fluid at the 70-ft bgs depth in the Hanford formation $\mathrm{H} 2$ unit at borehole C4105. The divalent cations that water leach at C4105 exceed the values leached from the comparable strata and depth at C4104 by factors of 3 to 10 times in the Hanford formation $\mathrm{H} 2$ unit, by a factor of about 100 times in the Cold Creek upper subunit, by factors of 5 to 35 in the Cold Creek lower subunit, and by factors of 1 to 20 in the Ringold Formation Taylor Flats member. In the Ringold Formation Wooded Island member, the divalent cations are similar in the two boreholes. On the other hand, the water-extractable sodium contents in the C4105 sediments are less than the sodium that water extracts from the C4104 sediments by factors of 10 to 30 in the Hanford formation $\mathrm{H} 2$ unit, by a factor of 3 to 5 in the Cold Creek upper subunit, by factors of 5 to 10 in the Cold Creek upper subunit and by factors of 1 to 20 times in the $R_{t f}$ unit. Deeper in the $R_{w i}$ unit, the sodium quantities that water leached from sediments from both boreholes are similar. These distributions agree with the hydrologic conceptual model wherein the T-106 tank leak with high soluble sodium percolates both vertically below tank T-106 into the sediments near borehole C4104 and also horizontally towards borehole C4105 in the Cold Creek upper subunit. As the T-106 tank fluids migrated, the sodium displaced the natural divalent cations and some of the natural potassium off the sediment cation exchange sites in the sediments between boreholes C4104 and C4105. The displaced divalent cations migrated horizontally into the area of borehole C4105 mainly in both Cold Creek units and the upper portion of $\mathrm{R}_{\mathrm{tf}}$. Similarly, some of the divalent cations were pushed vertically near borehole C4104 down mainly into the lower portion of the $\mathrm{R}_{\mathrm{tf}}$ and somewhat into the $\mathrm{R}_{\mathrm{wi}}$ unit.

We have observed the same cation distribution and ion exchange fronts where divalent cations and sometimes potassium are depleted and high levels of water-extractable sodium are present in the shallow sediments at both the SX and BX tank farms, where tank fluids have been confirmed as being present (for details, see Serne et al. 2002b, 2002c, 2002d, 2002e, and 2002f). Right below the leading edge of the sodium plume, one finds elevated levels of divalent cations that were displaced. The data for the two boreholes near Tank T-106 show that horizontal plume migration can be as significant as vertical percolation. Borehole C4105 is about $88 \mathrm{ft}$ due west of C4104; thus, the ion exchange front has traveled horizontally as far as the ion exchange front penetrated vertically at C4104. 
Table 4.43. Water-Extractable Anions in Borehole C4105 Vadose Zone Sediments ( $\mu \mathrm{g} / \mathrm{g}$ dry sediment)

\begin{tabular}{|c|c|c|c|c|c|c|c|c|c|c|}
\hline Sample No. & Depth (ft bgs) & $\begin{array}{c}\text { Stratigraphic } \\
\text { Unit }\end{array}$ & Fluoride & Chloride & Nitrate & $\mathrm{CO}_{3}$ & Sulfate & Phosphate & Nitrite & Bromide \\
\hline $1 \mathrm{~A}$ & 15.3 & Bkfl & 0.86 & 0.53 & 1.59 & 52.41 & 3.86 & $<0.240$ & $<0.080$ & $<0.137$ \\
\hline $2 \mathrm{~A}$ & 22.7 & Bkfl & 1.23 & 3.08 & 0.77 & $<49.981$ & 12.42 & 0.4 & $<0.080$ & $<0.137$ \\
\hline $3 \mathrm{~A}$ & 36.8 & Bkfl & 2.07 & 5.45 & 0.5 & 96.27 & 29.55 & 0.49 & $<0.080$ & $<0.137$ \\
\hline $4 \mathrm{~A}$ & 40.2 & Bkfl & 0.04 & 8.88 & 1.4 & 121.06 & 47.72 & $<0.240$ & 1 & $<0.137$ \\
\hline $5 \mathrm{~A}$ & 48.4 & $\mathrm{H} 2$ & 0.33 & 0.48 & 1.5 & $<50.020$ & 6.92 & $<0.240$ & $<0.080$ & $<0.137$ \\
\hline $6 \mathrm{~A}$ & 56.1 & $\mathrm{H} 2$ & 0.46 & 0.39 & 2.17 & $<50.000$ & 11.6 & $<0.240$ & $<0.080$ & $<0.137$ \\
\hline $7 \mathrm{~A}$ & 70.1 & $\mathrm{H} 2$ & 0.47 & 0.76 & 15.44 & 93 & 20.06 & 0.52 & $<0.080$ & $<0.137$ \\
\hline $8 \mathrm{~A}$ & 81.2 & $\mathrm{H} 2$ & 0.52 & 0.82 & 9.37 & $<50.013$ & 38.81 & $<0.240$ & $<0.080$ & $<0.137$ \\
\hline $9 \mathrm{~A}$ & 86.7 & $\mathrm{CCU}_{\mathrm{u}}$ & 0.09 & 20.2 & 1033.6 & $<50.061$ & 210.71 & 0.3 & 0.48 & $<0.137$ \\
\hline $10 \mathrm{~A}$ & 88.2 & $\mathrm{CCU}_{\mathrm{u}}$ & 0.06 & 30.27 & 1613 & $<50.160$ & 239.59 & 0.32 & 1.57 & $<0.137$ \\
\hline 10A DUP & 88.2 & $\mathrm{CCU}_{\mathrm{u}}$ & 0.06 & 26.87 & 1410.4 & $<50.010$ & 215.52 & $<0.240$ & 1.65 & $<0.137$ \\
\hline $11 \mathrm{~A}$ & 93.3 & $\mathrm{CCU}_{\mathrm{l}}$ & 0.04 & 17.98 & 1066.3 & $<50.000$ & 302.82 & 0.26 & 1.73 & $<0.137$ \\
\hline $12 \mathrm{~A}$ & 97.1 & $\mathrm{CCU}_{\mathrm{l}}$ & 0.59 & 20.99 & 768.82 & $<49.997$ & 27.07 & $<0.240$ & 1.59 & $<0.137$ \\
\hline $13 \mathrm{~A}$ & 100.3 & $\mathrm{CCU}_{\mathrm{l}}$ & 0.54 & 14.47 & 458.07 & $<50.005$ & 26.83 & $<0.240$ & 1.71 & $<0.137$ \\
\hline $14 \mathrm{~A}$ & 102.0 & $\mathrm{CCU}_{\mathrm{l}}$ & 0.07 & 13.18 & 625.18 & $<50.042$ & 222.66 & 0.27 & 1.51 & $<0.137$ \\
\hline $15 \mathrm{~A}$ & 103.2 & $\mathrm{CCU}_{\mathrm{l}}$ & 0.86 & 12.75 & 609.71 & $<50.002$ & 263.51 & 0.32 & 2.21 & $<0.137$ \\
\hline $16 \mathrm{~A}$ & 106.9 & $\mathrm{CCU}_{\mathrm{l}}$ & 1.01 & 12.53 & 949.66 & $<50.020$ & 816.59 & 2.48 & 5.47 & $<0.137$ \\
\hline $17 \mathrm{~A}$ & 110.0 & $\mathrm{CCU}_{\mathrm{l}}$ & 0.44 & 5.64 & 432.34 & $<50.024$ & 151.23 & 0.29 & 55.1 & $<0.137$ \\
\hline 17A DUP & 110.0 & $\mathrm{CCU}_{\mathrm{l}}$ & 0.47 & 5.79 & 425.27 & $<50.008$ & 122.22 & 0.27 & 55.16 & $<0.137$ \\
\hline $18 \mathrm{~A}$ & 116.0 & $\mathrm{R}_{\mathrm{tf}}$ & 0.49 & 27.25 & 402.24 & $<50.004$ & 28.73 & $<0.240$ & 22.14 & $<0.137$ \\
\hline $19 \mathrm{~A}$ & 120.9 & $\mathrm{R}_{\mathrm{tf}}$ & 0.56 & 28.58 & 599.23 & $<50.041$ & 45.06 & $<0.240$ & 0.44 & $<0.137$ \\
\hline $20 \mathrm{~A}$ & 123.9 & $\mathrm{R}_{\mathrm{wi}}$ & 0.6 & 10.7 & 261.34 & $<49.948$ & 22.02 & $<0.240$ & 0.09 & $<0.137$ \\
\hline $21 \mathrm{~A}$ & 129.8 & $\mathrm{R}_{\mathrm{wi}}$ & 1.06 & 9.38 & 194.83 & $<50.457$ & 12.01 & $<0.242$ & 0.23 & $<0.138$ \\
\hline
\end{tabular}



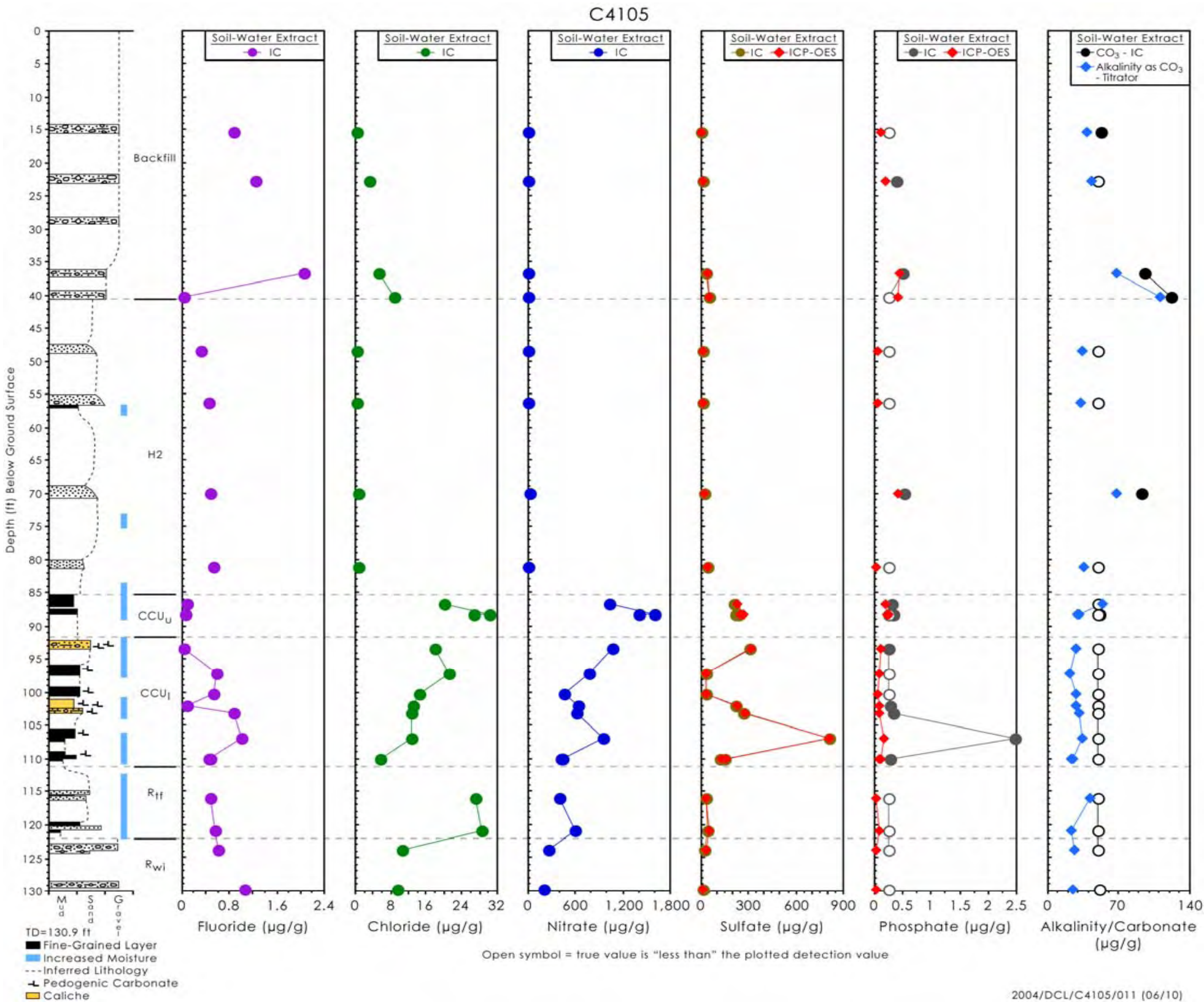

L Pedogenic Carbona

Figure 4.42. C4105 Borehole Water-Extractable Anions ( $\mu \mathrm{g} / \mathrm{g}$ dry sediment) 
The water-extractable aluminum, silicon, iron, manganese, zinc, phosphorous, and sulfur in the C4105 borehole sediments are shown in Table 4.46 and Figure 4.44. The phosphorous and sulfur data were converted to water-extractable phosphate and sulfate and plotted with the anion data in Figure 4.42. In general, the agreement between direct measurement of the two anions by ion chromatography and the converted ICP measurements of water-extractable phosphorous and sulfur are very good. The borehole C4105 water-soluble aluminum data show an elevated value only in the Hanford formation H2 sample at $70 \mathrm{ft}$ bgs. The water-soluble iron value for this sample is also high. We speculate that these elevated values indicate some chemical reaction between tank fluids and native sediments that formed precipitates of aluminum and iron that are more water soluble than the natural aluminum and iron phases present in the native sediments. Besides the high water-soluble aluminum and iron in this one sample, the only other indication of tank fluid interactions is the high sulfate found in the water extracts, especially in both Cold Creek units and the Ringold Formation Taylor Flat member. All other water-extractable metals data are within the range of values found for uncontaminated sediments.

When compared to the water-extractable metals in C4104 borehole sediments, the C4105 sediments have about the same amount of elevated sulfate but less water-extractable manganese and zinc in the Cold Creek units and upper Ringold Formation $\left(\mathrm{R}_{\mathrm{tf}}\right)$. There is also elevated phosphate in the Hanford formation $\mathrm{H} 2$ unit at $\mathrm{C} 4104$ that is not observed in any of the C4105 samples. The comparison between the two boreholes suggests that tank-derived phosphate, manganese, and zinc reacts with the sediments near the tank and these species do not reach the downgradient sediments at C4105.

The water-extractable data for potentially mobile metals such as technetium-99, uranium-238, chromium, molybdenum, and ruthenium in borehole C4105 sediments are shown in Table 4.47 and Figure 4.45. In borehole C4105 sediments, technetium-99 is present between $70 \mathrm{ft}$ bgs and the bottom of the borehole. The maximum concentrations of technetium-99 are found between 86.7 and $93.3 \mathrm{ft}$ bgs in the Cold Creek upper subunit (the fine-grained sediment) although significant concentrations are found all the way down to the bottom of the $\mathrm{R}_{\mathrm{tf}}$ unit. There is no sign of elevated water-soluble uranium in the C4105 sediments, but there are elevated concentrations of water-soluble chromium, molybdenum, and ruthenium from $70 \mathrm{ft}$ bgs to the bottom of the $\mathrm{CCU}_{1}$ unit at $110 \mathrm{ft}$ bgs.

The water-extractable technetium-99 concentrations in the sediments from C4105 are greater than the concentrations in sediments from C4104 in the two Cold Creek units by factors of 4 to 30. Deeper in the two Ringold Formation units, the sediments at C4104 contain more water-soluble technetium-99 than the sediments from $\mathrm{C} 4105$ by factors of 1 to 10 . We interpret the technetium-99 distributions between the two boreholes to reflect the rapid horizontal migration of the plume in the Cold Creek units and a rapid vertical migration of tank fluids near the tank. Slow flushing by enhanced recharge appears to lead to more horizontal movement of the tank fluids downgradient towards C4105 within the Cold Creek units.

The water-extractable chromium, molybdenum, and ruthenium values for borehole C4105 in comparison with water extracts from sediments from C4104 follow a similar pattern to the technetium-99 distribution in most of the geologic strata. Within the Hanford formation $\mathrm{H} 2$ unit there is slightly higher concentrations of these three elements in sediments at C4104 likely because of the proximity to the tank and the fact that very little tank leak fluids reached the $\mathrm{H} 2$ unit by shallow horizontal migration. In the Cold Creek upper subunit, there are considerably higher concentrations of water-leachable chromium and ruthenium in the sediments at C4105 as opposed to the sediments at C4104, which is closer to the leak source. Molybdenum is an exception where the C4104 sediments contain higher concentrations of water leachable molybdenum. In the Cold Creek lower subunit (caliche), all three of these metals show similar water-leachable concentrations and large variability that is likely indicative of the heterogeneity in the 
amount of caliche cementation versus depth in this $~ 20$-ft thick stratum. Within the Ringold Formation Taylor Flats member, the concentrations of these three water-leachable metals are much larger in the sediments from C4104 than in same strata at C4105. The water-leachable concentrations of these three elements in the Ringold Formation Wooded Island member are either not elevated or are slightly elevated compared to the background sediments, and there are no significant differences between borehole locations. The data for chromium, molybdenum, and ruthenium support the conceptual model that a large portion of the leak plume migrated horizontally in the Cold Creek upper subunit at least as far as C4105. Because the concentrations in sediment from borehole C4104 in this stratum are much lower, it appears that natural (or enhanced) recharge near the borehole has flushed the center of mass of the plume horizontally and farther away from the tank. There is also a component of the plume that migrated vertically to deeper depths at C4104 likely because of its proximity to the tank leak location. At the more distant borehole, C4105, tank plume contaminants appear to be slowly diffusing or advecting deeper below the $\mathrm{CCU}_{\mathrm{u}}$ strata, but the concentrations remain lower than the values found at C4104.

In summary, the maximum water-soluble technetium-99 concentrations occur at the more distant borehole, C4105 in the Cold Creek upper subunit between 86 to $93 \mathrm{ft}$ bgs (1,000 to 1,650 pCi/g) and at borehole C4104 deeper in the profile (within the Ringold Formation Taylor Flats member between 115 and $116 \mathrm{ft}$ bgs at concentrations of 1,000 to $6,000 \mathrm{pCi} / \mathrm{g}$. These technetium-99 concentrations are considerably larger than concentrations found below the TX, B, and BX tank farms, but lower than values found below the SX tank farm. There are slightly elevated water-soluble uranium concentrations in the deeper portion of the Hanford H2 unit at C4104 but no signs of elevated water-leachable uranium throughout the C4105 profile. The maximum water-soluble uranium concentrations at C4104 range from 0.5 to $1 \mu \mathrm{g} / \mathrm{g}$. These values are lower than found at borehole C3832 near Tank TX-104 and east of the BX-102 tank. The maximum water-soluble chromium concentrations are found in both boreholes in both the $\mathrm{CCU}_{\mathrm{u}}$ and $\mathrm{CCU}_{1}$ units at concentrations that range from 2 to 4 and 2 to $6 \mu \mathrm{g} / \mathrm{g}$, respectively. 
Table 4.44. Water-Extractable Organics in C4105 Vadose Zone Sediments ( $\mu \mathrm{g} / \mathrm{g}$ )

\begin{tabular}{|c|c|c|c|c|c|}
\hline $\begin{array}{c}\text { Sample } \\
\text { No. }\end{array}$ & $\begin{array}{c}\text { Depth } \\
\text { (ft bgs) }\end{array}$ & $\begin{array}{c}\text { Stratigraphic } \\
\text { Unit }\end{array}$ & Acetate & Formate & Oxalate \\
\hline $1 \mathrm{~A}$ & 15.3 & Bkfl & 0.28 & $<0.113$ & 0.31 \\
\hline $2 \mathrm{~A}$ & 22.7 & Bkfl & 0.33 & $<0.113$ & 0.36 \\
\hline $3 \mathrm{~A}$ & 36.8 & Bkfl & 0.28 & $<0.113$ & 1.53 \\
\hline $4 \mathrm{~A}$ & 40.2 & Bkfl & 0.81 & 0.62 & 2.82 \\
\hline $5 \mathrm{~A}$ & 48.4 & $\mathrm{H} 2$ & 0.28 & $<0.113$ & $<0.214$ \\
\hline $6 \mathrm{~A}$ & 56.1 & $\mathrm{H} 2$ & 0.23 & $<0.113$ & $<0.214$ \\
\hline 7A & 70.1 & $\mathrm{H} 2$ & 1.14 & $<0.113$ & $<0.214$ \\
\hline $8 \mathrm{~A}$ & 81.2 & $\mathrm{H} 2$ & 0.24 & $<0.113$ & $<0.214$ \\
\hline $9 \mathrm{~A}$ & 86.7 & $\mathrm{CCU}_{\mathrm{u}}$ & 0.18 & 0.7 & $<0.214$ \\
\hline $10 \mathrm{~A}$ & 88.2 & $\mathrm{CCU}_{\mathrm{u}}$ & 0.25 & 1.05 & 0.79 \\
\hline 10A DUP & 88.2 & $\mathrm{CCU}_{\mathrm{u}}$ & 0.37 & 0.89 & 0.75 \\
\hline $11 \mathrm{~A}$ & 93.3 & $\mathrm{CCU}_{\mathrm{l}}$ & 0.33 & 0.68 & 0.74 \\
\hline $12 \mathrm{~A}$ & 97.1 & $\mathrm{CCU}_{1}$ & 0.22 & 0.18 & 0.25 \\
\hline $13 \mathrm{~A}$ & 100.3 & $\mathrm{CCU}_{1}$ & 0.16 & 0.13 & $<0.214$ \\
\hline $14 \mathrm{~A}$ & 102.0 & $\mathrm{CCU}_{1}$ & 1.87 & 0.43 & 0.89 \\
\hline $15 \mathrm{~A}$ & 103.2 & $\mathrm{CCU}_{1}$ & 0.78 & 0.48 & 0.63 \\
\hline $16 \mathrm{~A}$ & 106.9 & $\mathrm{CCU}_{\mathrm{l}}$ & 0.53 & 1.5 & 2.24 \\
\hline $17 \mathrm{~A}$ & 110.0 & $\mathrm{CCU}_{1}$ & $<0.160$ & 0.48 & 1.06 \\
\hline 17A DUP & 110.0 & $\mathrm{CCU}_{\mathrm{l}}$ & 0.29 & 0.57 & 0.93 \\
\hline $18 \mathrm{~A}$ & 116.0 & $\mathrm{R}_{\mathrm{tf}}$ & 0.37 & 0.25 & $<0.214$ \\
\hline $19 \mathrm{~A}$ & 120.9 & $\mathrm{R}_{\mathrm{tf}}$ & 0.34 & 0.2 & $<0.214$ \\
\hline $20 \mathrm{~A}$ & 123.9 & $\mathrm{R}_{\mathrm{wi}}$ & 0.27 & 0.17 & $<0.214$ \\
\hline $21 \mathrm{~A}$ & 129.8 & $\mathrm{R}_{\mathrm{wi}}$ & 0.39 & 0.2 & 0.36 \\
\hline
\end{tabular}


Table 4.45. Water-Extractable Cations in C4105 Borehole Vadose Zone Sediments ( $\mu \mathrm{g} / \mathrm{g}$ dry sediment)

\begin{tabular}{|c|c|c|c|c|c|c|c|c|}
\hline Sample No. & $\begin{array}{c}\text { Depth (ft } \\
\text { bgs) }\end{array}$ & $\begin{array}{c}\text { Stratigraphic } \\
\text { Unit }\end{array}$ & Ca & Mg & Ba & $\mathrm{Sr}$ & $\mathrm{Na}$ & $\mathbf{K}$ \\
\hline $1 \mathrm{~A}$ & 15.3 & Bkfl & $8.91 \mathrm{E}+00$ & $2.52 \mathrm{E}+00$ & $1.59 \mathrm{E}-02$ & 4.16E-02 & $1.40 \mathrm{E}+01$ & $(3.69 \mathrm{E}+00)^{(\mathrm{a}}$ \\
\hline $2 \mathrm{~A}$ & 22.7 & Bkfl & $6.00 \mathrm{E}+00$ & $1.18 \mathrm{E}+00$ & $1.26 \mathrm{E}-02$ & 2.89E-02 & $2.76 \mathrm{E}+01$ & $(4.49 \mathrm{E}+00)$ \\
\hline $3 \mathrm{~A}$ & 36.8 & Bkfl & $1.12 \mathrm{E}+01$ & $3.18 \mathrm{E}+00$ & $2.00 \mathrm{E}-02$ & $5.48 \mathrm{E}-02$ & $4.79 \mathrm{E}+01$ & $8.29 \mathrm{E}+00$ \\
\hline $4 \mathrm{~A}$ & 40.2 & Bkfl & $3.44 \mathrm{E}+01$ & $9.10 \mathrm{E}+00$ & $6.39 \mathrm{E}-02$ & $1.69 \mathrm{E}-01$ & $5.82 \mathrm{E}+01$ & $1.48 \mathrm{E}+01$ \\
\hline $5 \mathrm{~A}$ & 48.4 & $\mathrm{H} 2$ & $7.20 \mathrm{E}+00$ & $1.63 \mathrm{E}+00$ & $1.26 \mathrm{E}-02$ & 3.63E-02 & $1.23 \mathrm{E}+01$ & $(4.08 \mathrm{E}+00)$ \\
\hline $6 \mathrm{~A}$ & 56.1 & $\mathrm{H} 2$ & $9.20 \mathrm{E}+00$ & $2.09 \mathrm{E}+00$ & $1.05 \mathrm{E}-02$ & 4.61E-02 & $9.84 \mathrm{E}+00$ & $(3.80 \mathrm{E}+00)$ \\
\hline $7 \mathrm{~A}$ & 70.1 & $\mathrm{H} 2$ & 8.87E-01 & $1.77 \mathrm{E}-01$ & 2.99E-02 & $(4.85 \mathrm{E}-03)$ & $6.15 \mathrm{E}+01$ & $(1.71 \mathrm{E}+00)$ \\
\hline $8 \mathrm{~A}$ & 81.2 & $\mathrm{H} 2$ & $1.81 \mathrm{E}+01$ & $4.33 \mathrm{E}+00$ & $2.52 \mathrm{E}-02$ & $1.06 \mathrm{E}-01$ & $1.34 \mathrm{E}+01$ & $(4.30 \mathrm{E}+00)$ \\
\hline $9 \mathrm{~A}$ & 86.7 & $\mathrm{CCU}_{\mathrm{u}}$ & $2.75 \mathrm{E}+02$ & $6.00 \mathrm{E}+01$ & 5.89E-02 & $1.13 \mathrm{E}+00$ & $6.63 \mathrm{E}+01$ & $1.31 \mathrm{E}+01$ \\
\hline $10 \mathrm{~A}$ & 88.2 & $\mathrm{CCU}_{\mathrm{u}}$ & $4.17 \mathrm{E}+02$ & $9.20 \mathrm{E}+01$ & 6.62E-02 & $1.72 \mathrm{E}+00$ & $7.60 \mathrm{E}+01$ & $1.47 \mathrm{E}+01$ \\
\hline 10A DUP & 88.2 & $\mathrm{CCU}_{\mathrm{u}}$ & $3.84 \mathrm{E}+02$ & $8.16 \mathrm{E}+01$ & $7.28 \mathrm{E}-02$ & $1.59 \mathrm{E}+00$ & $7.24 \mathrm{E}+01$ & $1.54 \mathrm{E}+01$ \\
\hline $11 \mathrm{~A}$ & 93.3 & $\mathrm{CCU}_{1}$ & $2.36 \mathrm{E}+02$ & $6.30 \mathrm{E}+01$ & 6.25E-02 & $1.31 \mathrm{E}+00$ & $1.55 \mathrm{E}+02$ & $1.07 \mathrm{E}+01$ \\
\hline $12 \mathrm{~A}$ & 97.1 & $\mathrm{CCU}_{\mathrm{l}}$ & $1.36 \mathrm{E}+02$ & $6.63 \mathrm{E}+01$ & $1.68 \mathrm{E}-01$ & $1.05 \mathrm{E}+00$ & $2.88 \mathrm{E}+01$ & $7.48 \mathrm{E}+00$ \\
\hline $13 \mathrm{~A}$ & 100.3 & $\mathrm{CCU}_{\mathrm{l}}$ & $8.10 \mathrm{E}+01$ & $4.05 \mathrm{E}+01$ & $1.11 \mathrm{E}-01$ & 6.27E-01 & $2.78 \mathrm{E}+01$ & $7.61 \mathrm{E}+00$ \\
\hline $14 \mathrm{~A}$ & 102.0 & $\mathrm{CCU}_{1}$ & $1.52 \mathrm{E}+02$ & $5.56 \mathrm{E}+01$ & 7.74E-02 & $1.05 \mathrm{E}+00$ & $6.95 \mathrm{E}+01$ & $8.37 \mathrm{E}+00$ \\
\hline $15 \mathrm{~A}$ & 103.2 & $\mathrm{CCU}_{1}$ & $1.35 \mathrm{E}+02$ & $5.69 \mathrm{E}+01$ & 5.69E-02 & $9.47 \mathrm{E}-01$ & $1.17 \mathrm{E}+02$ & $8.76 \mathrm{E}+00$ \\
\hline $16 \mathrm{~A}$ & 106.9 & $\mathrm{CCU}_{\mathrm{l}}$ & $2.65 \mathrm{E}+02$ & $1.31 \mathrm{E}+02$ & 4.55E-02 & $1.68 \mathrm{E}+00$ & $1.85 \mathrm{E}+02$ & $1.34 \mathrm{E}+01$ \\
\hline $17 \mathrm{~A}$ & 110.0 & $\mathrm{CCU}_{\mathrm{l}}$ & $1.11 \mathrm{E}+02$ & $4.96 \mathrm{E}+01$ & $5.00 \mathrm{E}-02$ & $6.91 \mathrm{E}-01$ & $3.40 \mathrm{E}+01$ & $9.37 \mathrm{E}+00$ \\
\hline 17A DUP & 110.0 & $\mathrm{CCU}_{\mathrm{l}}$ & $1.08 \mathrm{E}+02$ & $4.67 \mathrm{E}+01$ & 5.16E-02 & 6.70E-01 & $2.69 \mathrm{E}+01$ & $1.03 \mathrm{E}+01$ \\
\hline $18 \mathrm{~A}$ & 116.0 & $\mathrm{R}_{\mathrm{tf}}$ & $1.05 \mathrm{E}+02$ & $3.64 \mathrm{E}+01$ & 1.15E-01 & 7.11E-01 & $1.28 \mathrm{E}+01$ & $9.72 \mathrm{E}+00$ \\
\hline $19 \mathrm{~A}$ & 120.9 & $\mathrm{R}_{\mathrm{tf}}$ & $1.37 \mathrm{E}+02$ & $4.90 \mathrm{E}+01$ & $1.18 \mathrm{E}-01$ & $1.03 \mathrm{E}+00$ & $1.54 \mathrm{E}+01$ & $7.17 \mathrm{E}+00$ \\
\hline $20 \mathrm{~A}$ & 123.9 & $\mathrm{R}_{\mathrm{wi}}$ & $6.13 \mathrm{E}+01$ & $2.17 \mathrm{E}+01$ & 7.35E-02 & 4.66E-01 & $1.27 \mathrm{E}+01$ & $(4.36 \mathrm{E}+00)$ \\
\hline $21 \mathrm{~A}$ & 129.8 & $\mathrm{R}_{\mathrm{wi}}$ & $3.48 \mathrm{E}+01$ & $1.13 \mathrm{E}+01$ & $5.51 \mathrm{E}-02$ & 2.89E-01 & $2.72 \mathrm{E}+01$ & $1.01 \mathrm{E}+01$ \\
\hline 22 & 129.3 & $\mathrm{R}_{\mathrm{wi}}$ & $5.60 \mathrm{E}+01$ & $2.38 \mathrm{E}+01$ & $1.50 \mathrm{E}-01$ & $5.21 \mathrm{E}-01$ & $5.13 \mathrm{E}+01$ & $1.51 \mathrm{E}+01$ \\
\hline
\end{tabular}


Table 4.46. Water-Extractable Concentrations of Other Metals in C4105 Vadose Zone Sediments ( $\mu \mathrm{g} / \mathrm{g}$ dry sediment)

\begin{tabular}{|c|c|c|c|c|c|c|c|c|c|c|}
\hline Sample No. & $\begin{array}{c}\text { Depth } \\
\text { (ft bgs) }\end{array}$ & Stratigraphic Unit & Al & Si & $\mathbf{F e}$ & Mn & Zn & $\mathrm{P}$ as $\mathrm{PO}_{4}$ & $\mathrm{~S}$ as $\mathrm{SO}_{4}$ & $\mathbf{C u}$ \\
\hline $1 \mathrm{~A}$ & 15.3 & Bkfl & (2.03E-02) & $1.19 \mathrm{E}+01$ & $(2.90 \mathrm{E}-02)^{(\mathrm{a})}$ & $\mathrm{ND}^{(\mathrm{b})}$ & $(2.38 \mathrm{E}-02)$ & $(1.08 \mathrm{E}-01)$ & $5.16 \mathrm{E}+00$ & ND \\
\hline $2 \mathrm{~A}$ & 22.7 & Bkfl & $(2.92 \mathrm{E}-02)$ & $1.09 \mathrm{E}+01$ & $(2.64 \mathrm{E}-02)$ & ND & $(2.02 \mathrm{E}-02)$ & $(2.08 \mathrm{E}-01)$ & $1.45 \mathrm{E}+01$ & ND \\
\hline $3 \mathrm{~A}$ & 36.8 & Bkfl & $6.27 \mathrm{E}-02$ & $1.09 \mathrm{E}+01$ & (3.90E-02) & $(2.90 \mathrm{E}-03)$ & $(1.66 \mathrm{E}-02)$ & (4.41E-01) & $3.91 \mathrm{E}+01$ & ND \\
\hline $4 \mathrm{~A}$ & 40.2 & Bkfl & $6.04 \mathrm{E}-02$ & $9.31 \mathrm{E}+00$ & (2.38E-02) & $(4.12 \mathrm{E}-02)$ & $(2.42 \mathrm{E}-02)$ & $(4.21 \mathrm{E}-01)$ & $5.50 \mathrm{E}+01$ & $(5.36 \mathrm{E}-02)$ \\
\hline $5 \mathrm{~A}$ & 48.4 & $\mathrm{H} 2$ & (1.79E-02) & $1.00 \mathrm{E}+01$ & $(1.68 \mathrm{E}-02)$ & ND & $(2.10 \mathrm{E}-02)$ & (6.53E-02) & $7.47 \mathrm{E}+00$ & ND \\
\hline $6 \mathrm{~A}$ & 56.1 & $\mathrm{H} 2$ & (6.58E-03) & $1.19 \mathrm{E}+01$ & $(1.51 \mathrm{E}-02)$ & ND & $(1.75 \mathrm{E}-02)$ & (7.03E-02) & $1.21 \mathrm{E}+01$ & ND \\
\hline $7 \mathrm{~A}$ & 70.1 & $\mathrm{H} 2$ & 1.74E-01 & $1.39 \mathrm{E}+01$ & 2.63E-01 & $(4.10 \mathrm{E}-03)$ & $(2.46 \mathrm{E}-02)$ & (4.06E-01) & $2.00 \mathrm{E}+01$ & (6.31E-03) \\
\hline $8 \mathrm{~A}$ & 81.2 & $\mathrm{H} 2$ & (3.55E-03) & $1.20 \mathrm{E}+01$ & $(1.15 \mathrm{E}-02)$ & (1.07E-03) & $(2.07 \mathrm{E}-02)$ & $(2.64 \mathrm{E}-02)$ & $3.89 \mathrm{E}+01$ & $(2.70 \mathrm{E}-02)$ \\
\hline $9 \mathrm{~A}$ & 86.7 & $\mathrm{CCU}_{\mathrm{u}}$ & ND & $1.18 \mathrm{E}+01$ & ND & $(1.46 \mathrm{E}-03)$ & (3.64E-02) & $(1.82 \mathrm{E}-01)$ & $2.28 \mathrm{E}+02$ & $(1.10 \mathrm{E}-01)$ \\
\hline $10 \mathrm{~A}$ & 88.2 & $\mathrm{CCU}_{\mathrm{u}}$ & ND & $1.25 \mathrm{E}+01$ & ND & ND & (3.63E-02) & (2.17E-01) & $2.71 \mathrm{E}+02$ & $(3.16 \mathrm{E}-02)$ \\
\hline 10A DUP & 88.2 & $\mathrm{CCU}_{\mathrm{u}}$ & ND & $1.23 \mathrm{E}+01$ & ND & ND & (3.67E-02) & $(2.41 \mathrm{E}-01)$ & $2.43 \mathrm{E}+02$ & (3.09E-02) \\
\hline $11 \mathrm{~A}$ & 93.3 & $\mathrm{CCU}_{\mathrm{I}}$ & ND & $1.74 \mathrm{E}+01$ & $(0.00 \mathrm{E}+00)$ & (7.09E-03) & $(4.04 \mathrm{E}-02)$ & (1.13E-01) & $3.19 \mathrm{E}+02$ & 3.66E-01 \\
\hline $12 \mathrm{~A}$ & 97.1 & $\mathrm{CCU}_{1}$ & ND & $2.59 \mathrm{E}+01$ & (4.99E-03) & ND & (2.83E-02) & (8.81E-02) & $3.54 \mathrm{E}+01$ & (1.13E-02) \\
\hline $13 \mathrm{~A}$ & 100.3 & $\mathrm{CCU}_{1}$ & ND & $1.90 \mathrm{E}+01$ & $(4.41 \mathrm{E}-03)$ & (1.97E-03) & (2.33E-02) & (4.76E-02) & $3.13 \mathrm{E}+01$ & $(4.32 \mathrm{E}-03)$ \\
\hline $14 \mathrm{~A}$ & 102.0 & $\mathrm{CCU}_{\mathrm{I}}$ & ND & $3.33 \mathrm{E}+01$ & ND & $(4.00 \mathrm{E}-03)$ & (3.54E-02) & (9.35E-02) & $2.33 \mathrm{E}+02$ & $(1.21 \mathrm{E}-01)$ \\
\hline $15 \mathrm{~A}$ & 103.2 & $\mathrm{CCU}_{1}$ & ND & $3.07 \mathrm{E}+01$ & ND & (3.07E-02) & (5.60E-02) & $(7.50 \mathrm{E}-02)$ & $2.76 \mathrm{E}+02$ & 3.27E-01 \\
\hline $16 \mathrm{~A}$ & 106.9 & $\mathrm{CCU}_{1}$ & ND & $2.85 \mathrm{E}+01$ & $1.05 \mathrm{E}-01$ & 5.43E-01 & 1.23E-01 & (1.58E-01) & $8.08 \mathrm{E}+02$ & 4.11E-01 \\
\hline $17 \mathrm{~A}$ & 110.0 & $\mathrm{CCU}_{1}$ & ND & $1.55 \mathrm{E}+01$ & $(2.53 \mathrm{E}-02)$ & $(8.51 \mathrm{E}-02)$ & (3.16E-02) & (1.05E-01) & $1.58 \mathrm{E}+02$ & $(6.60 \mathrm{E}-02)$ \\
\hline 17A DUP & 110.0 & $\mathrm{CCU}_{\mathrm{I}}$ & ND & $1.41 \mathrm{E}+01$ & (9.13E-03) & (4.18E-02) & $(2.56 \mathrm{E}-02)$ & (8.89E-02) & $1.28 \mathrm{E}+02$ & (3.07E-02) \\
\hline $18 \mathrm{~A}$ & 116.0 & $\mathrm{R}_{\mathrm{tf}}$ & ND & $1.60 \mathrm{E}+01$ & (5.11E-03) & 3.19E-01 & $(2.33 \mathrm{E}-02)$ & $(4.17 \mathrm{E}-02)$ & $3.51 \mathrm{E}+01$ & $(1.37 \mathrm{E}-03)$ \\
\hline $19 \mathrm{~A}$ & 120.9 & $\mathrm{R}_{\mathrm{tf}}$ & ND & $2.16 \mathrm{E}+01$ & (5.18E-03) & ND & (2.32E-02) & $(9.10 \mathrm{E}-02)$ & $5.31 \mathrm{E}+01$ & (4.09E-03) \\
\hline $20 \mathrm{~A}$ & 123.9 & $\mathrm{R}_{\mathrm{wi}}$ & ND & $1.62 \mathrm{E}+01$ & (5.59E-03) & (6.03E-03) & (1.77E-02) & (4.07E-02) & $2.60 \mathrm{E}+01$ & ND \\
\hline $21 \mathrm{~A}$ & 129.8 & $\mathrm{R}_{\mathrm{wi}}$ & ND & $1.12 \mathrm{E}+01$ & (6.74E-03) & (9.54E-03) & $(1.94 \mathrm{E}-02)$ & (3.90E-02) & $1.49 \mathrm{E}+01$ & ND \\
\hline 22 & 129.3 & $\mathrm{R}_{\mathrm{wi}}$ & ND & $9.91 \mathrm{E}+00$ & $(1.24 \mathrm{E}-02)$ & 2.59E-01 & 1.08E-01 & (2.13E-01) & $4.20 \mathrm{E}+01$ & $(2.41 \mathrm{E}-02)$ \\
\hline (b) & $\begin{array}{l}\text { es sign } \\
\text { detern }\end{array}$ & ow le & & ed valid. & & & & & & \\
\hline
\end{tabular}


Table 4.47. Water-Extractable Concentrations of Mobile Metals in C4105 Vadose Sediments ( $\mu \mathrm{g} / \mathrm{g}$ dry sediment)

\begin{tabular}{|c|c|c|c|c|c|c|c|c|c|c|c|c|}
\hline \multirow{2}{*}{$\begin{array}{c}\text { Sample } \\
\text { No. } \\
\end{array}$} & \multirow{2}{*}{$\begin{array}{c}\text { Depth } \\
\text { (ft } \\
\text { bgs) }\end{array}$} & \multirow{2}{*}{$\begin{array}{c}\text { Stratigraphic } \\
\text { Unit }\end{array}$} & Tc 99 & \multirow[b]{2}{*}{$\mathrm{U}-238$} & \multirow{2}{*}{$\begin{array}{c}\mathrm{Cr} \\
\text { (ICP-MS) }\end{array}$} & \multirow{2}{*}{$\begin{array}{c}\mathrm{Cr} \\
\mathrm{ICP} \\
\end{array}$} & \multirow{2}{*}{$\begin{array}{c}\text { Mo-98 } \\
\text { (ICP-MS) }\end{array}$} & \multirow{2}{*}{$\begin{array}{c}\text { Mo-100 } \\
\text { (ICP-MS) }\end{array}$} & \multirow{2}{*}{$\begin{array}{c}\text { Mo } \\
\text { (ICP) }\end{array}$} & \multirow{2}{*}{$\begin{array}{c}\text { Ru-101 } \\
\text { (ICP-MS) }\end{array}$} & \multirow{2}{*}{$\begin{array}{c}\text { Ru-102 } \\
\text { (ICP-MS) }\end{array}$} & \multirow{2}{*}{$\begin{array}{c}\text { Ru-104 } \\
\text { (ICP-MS) }\end{array}$} \\
\hline & & & pCi/g soil & & & & & & & & & \\
\hline $1 \mathrm{~A}$ & 15.3 & Bkfl & $(0.00)^{(\mathrm{a})}$ & 1.99E-03 & $(1.52 \mathrm{E}-04)$ & $(1.51 \mathrm{E}-03)$ & $1.09 \mathrm{E}-02$ & $5.08 \mathrm{E}-03$ & $(1.30 \mathrm{E}-02)$ & (3.00E-06) & $(2.10 \mathrm{E}-05)$ & (3.30E-05) \\
\hline $2 \mathrm{~A}$ & 22.7 & Bkfl & $(0.00)$ & $1.32 \mathrm{E}-03$ & $(1.63 \mathrm{E}-04)$ & $(1.13 \mathrm{E}-03)$ & $1.92 \mathrm{E}-02$ & 9.07E-03 & $2.08 \mathrm{E}-02$ & $<1.00 \mathrm{E}-03$ & $<5.00 \mathrm{E}-04$ & $<1.00 \mathrm{E}-03$ \\
\hline $3 \mathrm{~A}$ & 36.8 & Bkfl & $(0.02)$ & 2.89E-03 & $1.24 \mathrm{E}-03$ & $(1.64 \mathrm{E}-03)$ & $6.90 \mathrm{E}-02$ & $3.26 \mathrm{E}-02$ & 7.39E-02 & $<1.00 \mathrm{E}-03$ & $<5.00 \mathrm{E}-04$ & $<1.00 \mathrm{E}-03$ \\
\hline $4 \mathrm{~A}$ & 40.2 & Bkfl & $(0.05)$ & $4.02 \mathrm{E}-03$ & $1.03 \mathrm{E}-03$ & $(2.17 \mathrm{E}-03)$ & $3.16 \mathrm{E}-02$ & $1.53 \mathrm{E}-02$ & $3.51 \mathrm{E}-02$ & $<1.00 \mathrm{E}-03$ & $<5.00 \mathrm{E}-04$ & $(2.10 \mathrm{E}-05)$ \\
\hline $5 \mathrm{~A}$ & 48.4 & $\mathrm{H} 2$ & $<0.170$ & 5.23E-04 & $(1.07 \mathrm{E}-04)$ & $(1.08 \mathrm{E}-03)$ & 8.37E-03 & 4.01E-03 & $(9.98 \mathrm{E}-03)$ & $<1.00 \mathrm{E}-03$ & $<5.00 \mathrm{E}-04$ & $<1.00 \mathrm{E}-03$ \\
\hline $6 \mathrm{~A}$ & 56.1 & $\mathrm{H} 2$ & $(0.10)$ & 4.23E-04 & $9.15 \mathrm{E}-03$ & $(1.14 \mathrm{E}-02)$ & $1.68 \mathrm{E}-02$ & 1.53E-02 & $(1.73 \mathrm{E}-02)$ & (1.09E-04) & $(4.65 \mathrm{E}-05)$ & $(6.58 \mathrm{E}-05)$ \\
\hline $7 \mathrm{~A}$ & 70.1 & $\mathrm{H} 2$ & $9.04 \mathrm{E}+00$ & $1.38 \mathrm{E}-03$ & 1.09E-01 & $1.27 \mathrm{E}-01$ & $9.47 \mathrm{E}-02$ & $1.15 \mathrm{E}-01$ & $1.10 \mathrm{E}-01$ & 3.63E-03 & $1.72 \mathrm{E}-03$ & $1.76 \mathrm{E}-03$ \\
\hline $8 \mathrm{~A}$ & 81.2 & $\mathrm{H} 2$ & $6.04 \mathrm{E}+00$ & $1.31 \mathrm{E}-03$ & 7.19E-02 & 7.99E-02 & 7.83E-03 & $3.90 \mathrm{E}-03$ & $(8.19 \mathrm{E}-03)$ & $3.42 \mathrm{E}-03$ & 1.62E-03 & $1.75 \mathrm{E}-03$ \\
\hline $9 \mathrm{~A}$ & 86.7 & $\mathrm{CCU}_{\mathrm{u}}$ & $1.05 \mathrm{E}+03$ & $1.29 \mathrm{E}-03$ & $4.15 \mathrm{E}+00$ & $4.71 \mathrm{E}+00$ & $6.18 \mathrm{E}-03$ & 5.57E-03 & $\mathrm{ND}^{(\mathrm{b})}$ & 2.96E-01 & $1.43 \mathrm{E}-01$ & 1.43E-01 \\
\hline $10 \mathrm{~A}$ & 88.2 & $\mathrm{CCU}_{\mathrm{u}}$ & $1.65 \mathrm{E}+03$ & $1.22 \mathrm{E}-03$ & $4.24 \mathrm{E}+00$ & $4.57 \mathrm{E}+00$ & 7.29E-03 & 8.00E-03 & ND & 5.08E-01 & 2.42E-01 & $2.40 \mathrm{E}-01$ \\
\hline 10A DUP & 88.2 & $\mathrm{CCU}_{\mathrm{u}}$ & $1.41 \mathrm{E}+03$ & $1.22 \mathrm{E}-03$ & $3.40 \mathrm{E}+00$ & $3.66 \mathrm{E}+00$ & 7.35E-03 & 7.27E-03 & ND & 4.14E-01 & 2.01E-01 & $1.98 \mathrm{E}-01$ \\
\hline $11 \mathrm{~A}$ & 93.3 & $\mathrm{CCU}_{\mathrm{l}}$ & $8.12 \mathrm{E}+02$ & $3.27 \mathrm{E}-03$ & $1.28 \mathrm{E}+00$ & $1.60 \mathrm{E}+00$ & 3.02E-02 & $1.71 \mathrm{E}-02$ & $1.96 \mathrm{E}-02$ & 2.97E-01 & $1.42 \mathrm{E}-01$ & 1.43E-01 \\
\hline $12 \mathrm{~A}$ & 97.1 & $\mathrm{CCU}_{\mathrm{l}}$ & $4.97 \mathrm{E}+02$ & $1.67 \mathrm{E}-03$ & $3.76 \mathrm{E}-02$ & 4.29E-02 & $3.87 \mathrm{E}-02$ & $1.95 \mathrm{E}-02$ & $2.50 \mathrm{E}-02$ & $1.29 \mathrm{E}-01$ & 6.19E-02 & $6.12 \mathrm{E}-02$ \\
\hline $13 \mathrm{~A}$ & 100.3 & $\mathrm{CCU}_{\mathrm{l}}$ & $4.07 \mathrm{E}+02$ & 2.02E-03 & 1.49E-02 & $1.55 \mathrm{E}-02$ & 1.92E-02 & $9.58 \mathrm{E}-03$ & $(7.67 \mathrm{E}-03)$ & 5.41E-02 & 2.62E-02 & $2.60 \mathrm{E}-02$ \\
\hline $14 \mathrm{~A}$ & 102.0 & $\mathrm{CCU}_{\mathrm{l}}$ & $8.21 \mathrm{E}+02$ & 3.82E-03 & $2.15 \mathrm{E}+00$ & $2.90 \mathrm{E}+00$ & $1.16 \mathrm{E}-01$ & $1.34 \mathrm{E}-01$ & $1.27 \mathrm{E}-01$ & $1.59 \mathrm{E}-01$ & 7.76E-02 & 7.83E-02 \\
\hline $15 \mathrm{~A}$ & 103.2 & $\mathrm{CCU}_{\mathrm{l}}$ & $7.83 \mathrm{E}+02$ & 3.99E-03 & $2.52 \mathrm{E}+00$ & $3.12 \mathrm{E}+00$ & 3.67E-01 & 4.50E-01 & 4.66E-01 & 2.03E-01 & 9.87E-02 & $9.86 \mathrm{E}-02$ \\
\hline $16 \mathrm{~A}$ & 106.9 & $\mathrm{CCU}_{\mathrm{l}}$ & $3.94 \mathrm{E}+02$ & $3.40 \mathrm{E}-03$ & $4.25 \mathrm{E}+00$ & $5.55 \mathrm{E}+00$ & $1.61 \mathrm{E}+00$ & $2.00 \mathrm{E}+00$ & $1.85 \mathrm{E}+00$ & 4.78E-01 & 2.33E-01 & 2.30E-01 \\
\hline $17 \mathrm{~A}$ & 110.0 & $\mathrm{CCU}_{1}$ & $5.12 \mathrm{E}+02$ & 8.35E-04 & $3.59 \mathrm{E}-01$ & 4.60E-01 & $1.91 \mathrm{E}-01$ & 2.07E-01 & $1.98 \mathrm{E}-01$ & $1.05 \mathrm{E}-01$ & 5.07E-02 & 5.06E-02 \\
\hline 17A DUP & 110.0 & $\mathrm{CCU}_{\mathrm{l}}$ & $5.44 \mathrm{E}+02$ & 8.26E-04 & $9.33 \mathrm{E}-02$ & $1.92 \mathrm{E}-01$ & $5.28 \mathrm{E}-02$ & 5.77E-02 & 5.72E-02 & 8.84E-02 & 4.35E-02 & 4.35E-02 \\
\hline $18 \mathrm{~A}$ & 116.0 & $\mathrm{R}_{\mathrm{tf}}$ & $1.94 \mathrm{E}+02$ & $1.26 \mathrm{E}-03$ & $(5.15 \mathrm{E}-04)$ & $(2.28 \mathrm{E}-03)$ & $1.74 \mathrm{E}-02$ & 8.87E-03 & $(9.64 \mathrm{E}-03)$ & $1.83 \mathrm{E}-02$ & 8.93E-03 & $9.44 \mathrm{E}-03$ \\
\hline $19 \mathrm{~A}$ & 120.9 & $\mathrm{R}_{\mathrm{tf}}$ & $6.34 \mathrm{E}+02$ & 7.49E-04 & 8.46E-03 & $(9.98 \mathrm{E}-03)$ & 8.39E-03 & 4.61E-03 & ND & 7.03E-02 & 3.35E-02 & 3.39E-02 \\
\hline $20 \mathrm{~A}$ & 123.9 & $\mathrm{R}_{\mathrm{wi}}$ & $2.07 \mathrm{E}+02$ & $3.68 \mathrm{E}-04$ & (6.78E-04) & $(2.00 \mathrm{E}-03)$ & 7.47E-03 & $3.71 \mathrm{E}-03$ & $(0.00 \mathrm{E}+00)$ & $2.14 \mathrm{E}-02$ & 1.03E-02 & $1.05 \mathrm{E}-02$ \\
\hline $21 \mathrm{~A}$ & 129.8 & $\mathrm{R}_{\mathrm{wi}}$ & $1.23 \mathrm{E}+02$ & $1.03 \mathrm{E}-04$ & (7.97E-04) & (2.29E-03) & $1.37 \mathrm{E}-02$ & 6.67E-03 & (1.08E-02) & $1.17 \mathrm{E}-02$ & $5.68 \mathrm{E}-03$ & $5.80 \mathrm{E}-03$ \\
\hline & & & & & & & & & & & & \\
\hline
\end{tabular}



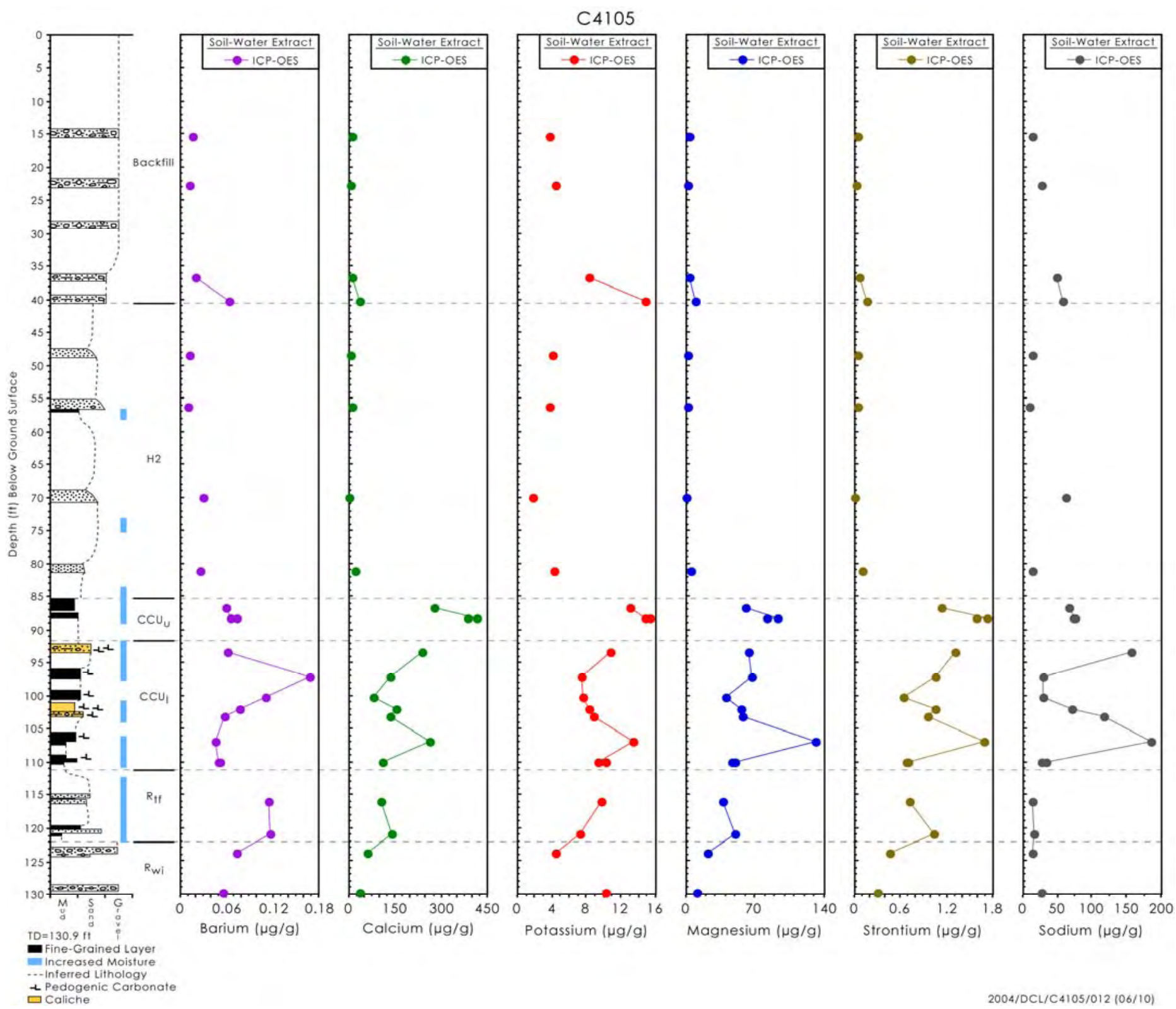

Figure 4.43. Water-Extractable Cations in Borehole C4105 Vadose Zone Sediments ( $\mu \mathrm{g} / \mathrm{g})$ 


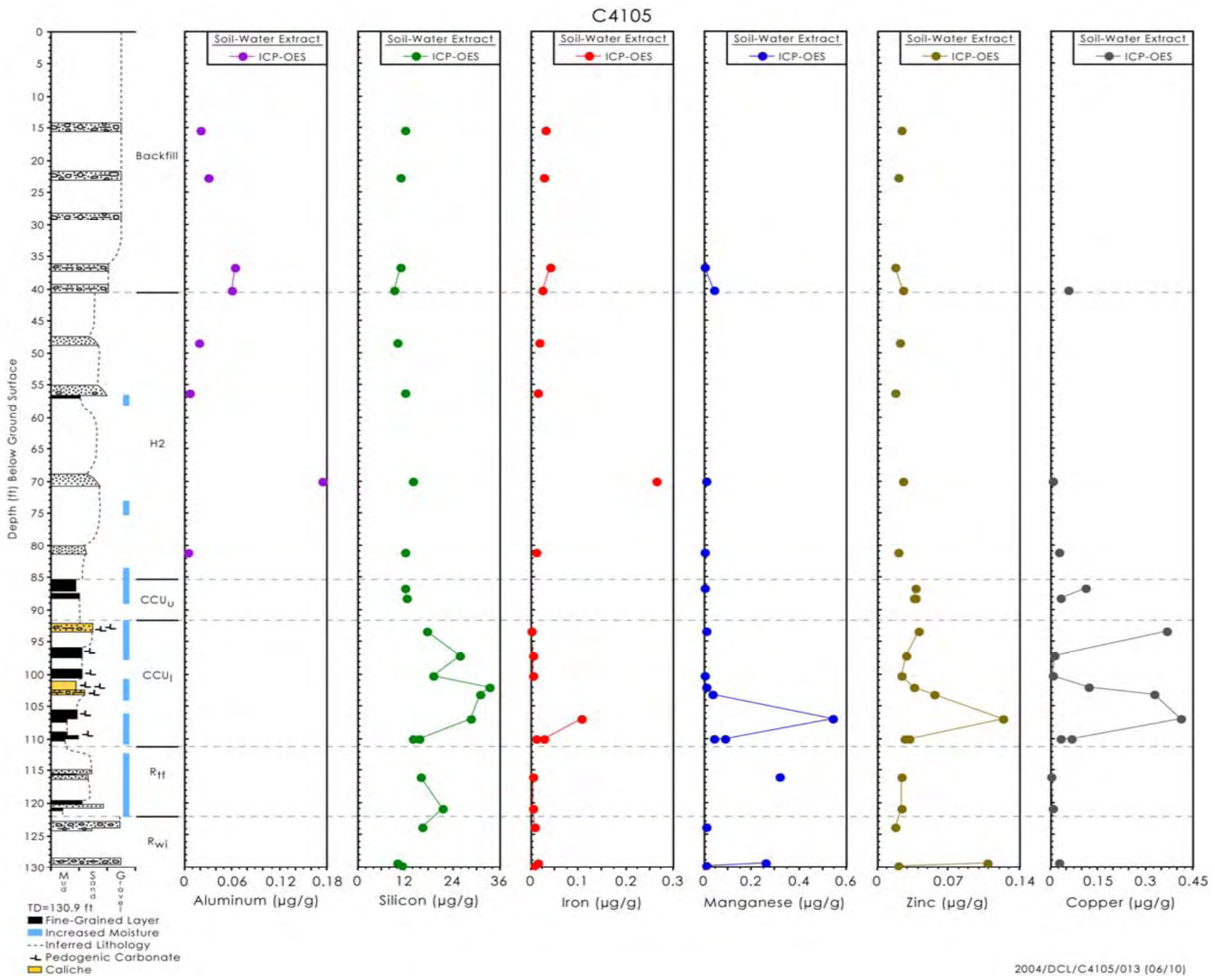

Figure 4.44. Water-Extractable Metals in C4105 Borehole Vadose Sediments ( $\mu \mathrm{g} / \mathrm{g}$ dry sediment) 

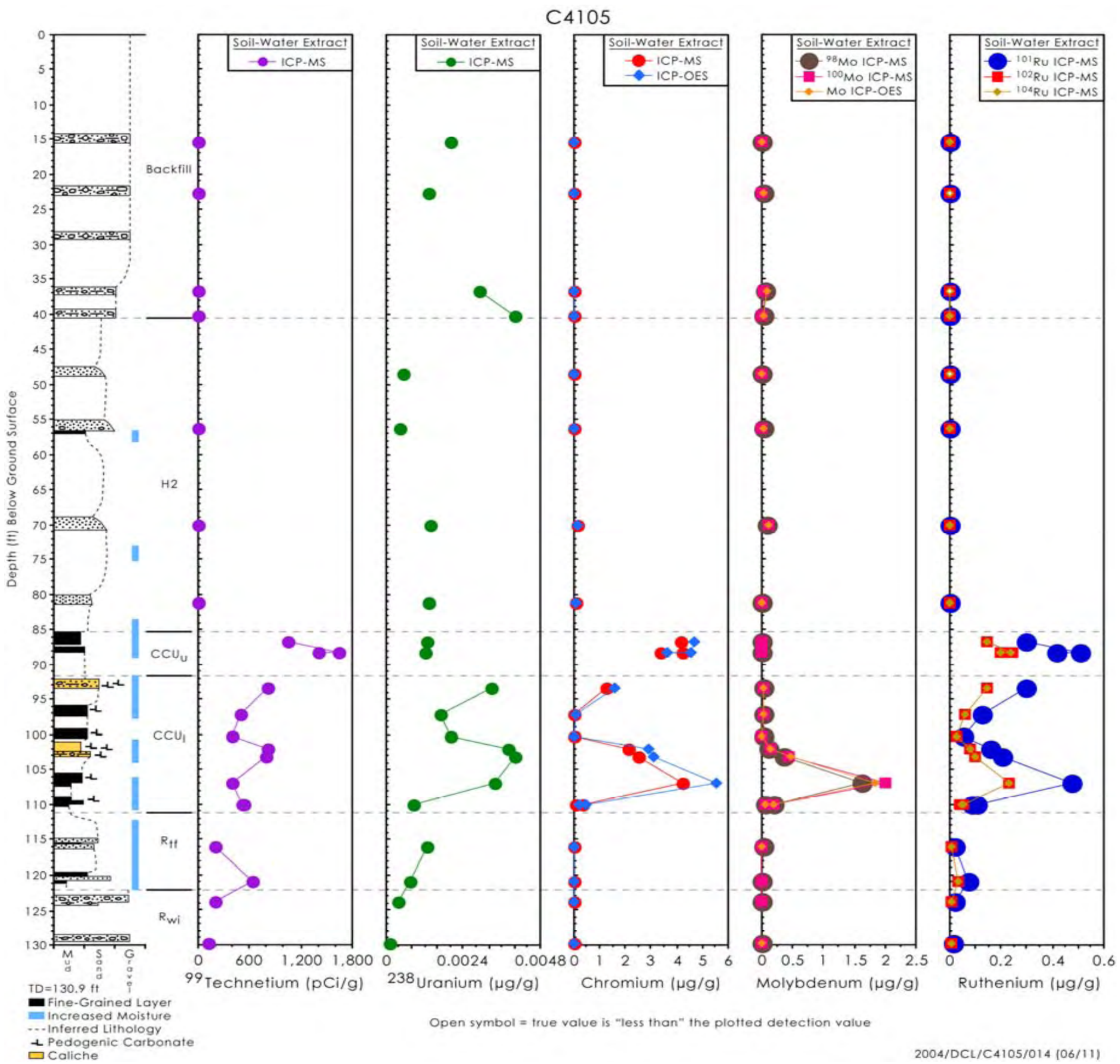

-.inferred Lithology

Open symbol $=$ true value is "less than" the plotted detection value

Ruthenium $(\mu \mathrm{g} / \mathrm{g}$ )

Figure 4.45. Distribution of Mobile Metals in Water Extracts of C4105 Vadose Zone Sediments 


\subsubsection{Derivation of Vadose Zone Porewater Chemical Composition}

The 1:1 water extract data was recalculated to derive an estimate of the composition of the vadose zone porewater. From knowledge of the moisture content of the sediment samples taken from the A liners of each core, we calculated the amount of deionized water that would be needed to make the water extract exactly one part water (total of native porewater and added deionized water) to one part by weight dry sediment. We also directly extracted porewater from six samples using an ultracentrifuge with a special liquid sampling cup so that we can compare the derived porewater compositions with actual porewater.

Tables 4.48 through 4.51 and Figures 4.46 through 4.49 show the derived porewater composition of key constituents as a function of depth and stratigraphy. The porewaters in the two Cold Creek units at C4105 have the most dissolved salts at 88 and 103 to $110 \mathrm{ft}$ bgs, respectively. The porewater in the Cold Creek upper subunit has a total concentration of $\sim 185 \mathrm{meq} / \mathrm{L}$ of cations and anions consisting of $44 \mathrm{meq} / \mathrm{L} \mathrm{Mg}, 120 \mathrm{meq} / \mathrm{L} \mathrm{Ca}, 18 \mathrm{meq} / \mathrm{L} \mathrm{Na}, 1.2 \mathrm{meq} / \mathrm{L} \mathrm{K}, 5 \mathrm{meq} / \mathrm{L} \mathrm{Cl}, 30 \mathrm{meq} / \mathrm{L}$ bicarbonate, $130 \mathrm{meq} / \mathrm{L}$ nitrate, and $20 \mathrm{meq} / \mathrm{L}$ sulfate. The saline porewater in the Cold Creek lower subunit contains $\sim 175 \mathrm{meq} / \mathrm{L}$ cations and anions consisting of $55 \mathrm{meq} / \mathrm{L} \mathrm{Mg}, 77 \mathrm{meq} / \mathrm{L} \mathrm{Ca,} 40 \mathrm{meq} / \mathrm{L} \mathrm{Na}, 3 \mathrm{meq} / \mathrm{L} \mathrm{K}, 0.3 \mathrm{meq} / \mathrm{L} \mathrm{F}$, $3 \mathrm{meq} / \mathrm{L} \mathrm{Cl}, 85 \mathrm{meq} / \mathrm{L}$ nitrate, $62 \mathrm{meq} / \mathrm{L}$ sulfate and $25 \mathrm{meq} / \mathrm{L}$ bicarbonate. It is difficult to get an accurate measure of carbonate from the water extraction of caliche bearing material so we rely more on the measurement of all the other cations and anions and use bicarbonate to force charge balance in these estimates of porewater concentrations. The actual porewaters from caliche-bearing sediments, obtained from ultracentrifugation, show that 1:1 sediment:water extracts inflate the calculated bicarbonate porewater concentration significantly from dissolution of the caliche. The porewaters from C4105 in the Cold Creek upper subunit are slightly more saline than comparable porewaters at C4104 (depths slightly more shallow and including the deep Hanford formation H2 unit) that contain 150 meq/L cations and anions that are predominately sodium bicarbonate. The chemical composition at C4105 shows more divalent cations from the ion exchange reactions and more nitrate and sulfate likely from the tank fluids than porewaters within the $\mathrm{C} 4104$ sediments from the same strata.

The C4105 porewater in the Cold Creek lower unit is more dilute ( 175 vs. 425 meq/L) than the porewater from the same strata in borehole C4104. Both contain a mix of divalent cations (from ion exchange and naturally from caliche) and sodium (from the tank leak) and a mix of nitrate-nitrite and sulfate (from the tank leak) and bicarbonate (from the sediment and reactions with the caustic tank fluids). The porewater chemical compositions at C4104 and C4105 are consistent with a plume migration model that has the tank fluid quickly penetrating vertically through the Hanford formation H2 unit into the Cold Creek units, with additional fluid migrating horizontally in the Cold Creek units downgradient towards C4105. With time, dilute recharge water has pushed the mobile nitrate out of the shallow C4104 sediments down to the Cold Creek strata where the mobile tank species are transported horizontally towards C4105.

The calculated and actual porewater concentrations in the vadose zone at C4104 and C4105 are dilute compared to the vadose zone porewaters found at the SX and BX tank farms where the total ionic strength of the porewaters were as high as 7,000 to 17,000 and1,000 meq/L, respectively (Serne et al. 2002c, 2002d, 2002e). At the borehole emplaced near tank B-110 the most saline porewater was 150 to $160 \mathrm{meq} / \mathrm{L}$, similar to the values in C4105 sediments. The porewater maximum salinities at borehole C3831 near tank TX-104 are $~ 3$ times more concentrated than the most saline vadose zone porewater at C4105. 
Technetium-99 in the C4105 porewaters are elevated from 70 ft bgs (in the deep Hanford formation $\mathrm{H} 2$ unit all the way to the bottom of the borehole at $\sim 130$ bgs. The values range from 200,000 to 8 million $\mathrm{pCi} / \mathrm{L}$. In general, the agreement between the actual porewater technetium-99 values and the derived values from the water extracts is quite good. This has been observed to be the case at most other tank farms where leak plumes have been characterized. The technetium-99 porewater concentrations in the shallower strata $\left(\mathrm{H} 2, \mathrm{CCU}_{\mathrm{u}}\right.$, and $\left.\mathrm{CCU}_{1}\right)$ at $\mathrm{C} 4105$ are similar to and actually exceed porewater concentrations at C4104 that is closer to the tank leak location. Deeper in the Ringold strata, the technetium-99 porewater concentrations at C4104 are larger by approximately a factor of 10 than the concentrations in the similar sediments at C4105. Again, these distributions support the aforementioned plume conceptual model.

The derived and actual porewater uranium concentrations for sediments at C4105 are low with maximum values less than $50 \mu \mathrm{g} / \mathrm{L}$. The actual porewater uranium values are in general slightly lower than the derived (from the 1:1 water extract) values so that the vadose zone porewaters are at or below the drinking water standard ( $30 \mu \mathrm{g} / \mathrm{L})$ and likely do not pose a risk. Porewater uranium concentrations at C4104 are much higher, especially in the Hanford formation $\mathrm{H} 2$ unit, but the two boreholes' uranium distributions suggest that uranium is interacting significantly with the sediments in such a way that it should not reach the groundwater at concentrations of importance in the foreseeable future.

The chromium porewater concentrations in the sediments from borehole C4105 range from 200 to $50,000 \mu \mathrm{g} / \mathrm{L}$ between 56 and $110 \mathrm{ft}$ bgs. There are two zones, one in each of the Cold Creek subunits where chromium concentrations exceed 10,000 $\mu \mathrm{g} / \mathrm{L}: 87$ to 93 and 102 to $107 \mathrm{ft}$ bgs, respectively. These chromium porewater concentrations and depth distributions are similar to zones in borehole C4104 sediments, excepting at C4104 the deeper high concentration zone reaches $116 \mathrm{ft}$ bgs. In the zones of high porewater chromium, the values for actual porewater often are about one-half the derived values from the water extracts. This suggests that some weak interaction with the sediments is occurring but the fact that concentrations do not vary significantly between the two boreholes suggests that chromium is not significantly interacting with sediments during the migration of the plume.

Within C4105 sediments, the molybdenum and ruthenium porewater concentrations are highest between 102 and 110 and 90 to $110 \mathrm{ft}$ bgs, respectively, but are somewhat variable. The actual porewater concentrations are somewhat lower than the derived porewater concentrations but not as disparate as the uranium and chromium comparisons. The ICP-MS data for the three molybdenum and three ruthenium isotopes vary considerably because the instrument's software and standards used to calibrate the instrument assume that the relative abundances of each isotope are the same as are naturally found. However, during the fission process unnatural percentages of stable isotopes are generated. Thus, much of the variation in calculated concentrations of total molybdenum and ruthenium for each isotope is an indication that fission-generated molybdenum and ruthenium are present. More detailed analysis of our raw data for fission product elements where several stable isotopes are available may be performed by "isotope signature" experts in the future to evaluate the percentages of the water-extractable isotopes that are natural versus fission-produced. Such information may be able to aid in pinpointing the sources (e.g., which tank was the source of the fluids). 
Table 4.48. Derived and Actual Porewater Cation Concentrations in C4105 Vadose Zone Sediments

\begin{tabular}{|c|c|c|c|c|c|c|c|c|}
\hline $\begin{array}{l}\text { Sample } \\
\text { ID }\end{array}$ & $\begin{array}{c}\text { Depth } \\
\text { (ft-bgs) }\end{array}$ & Stratigraphy & $\begin{array}{c}\mathrm{Mg} \\
\mathrm{mg} / \mathrm{L}\end{array}$ & $\begin{array}{c}\mathrm{Ca} \\
\mathrm{mg} / \mathrm{L}\end{array}$ & $\begin{array}{c}\mathrm{Sr} \\
\mathrm{mg} / \mathrm{L}\end{array}$ & $\begin{array}{c}\mathrm{Ba} \\
\mathrm{mg} / \mathrm{L}\end{array}$ & $\begin{array}{c}\mathrm{Na} \\
\mathrm{mg} / \mathrm{L}\end{array}$ & $\begin{array}{c}\mathrm{K} \\
\mathrm{mg} / \mathrm{L}\end{array}$ \\
\hline $1 \mathrm{~A}$ & 15.3 & Bkfl & $7.61 \mathrm{E}+01$ & $2.69 \mathrm{E}+02$ & $1.25 \mathrm{E}+00$ & 4.79E-01 & $4.23 E+02$ & $(1.11 \mathrm{E}+02)$ \\
\hline $2 \mathrm{~A}$ & 22.7 & Bkfl & $2.81 \mathrm{E}+01$ & $1.43 E+02$ & $6.88 \mathrm{E}-01$ & $3.00 \mathrm{E}-01$ & $6.57 \mathrm{E}+02$ & $(1.07 \mathrm{E}+02)$ \\
\hline $3 \mathrm{~A}$ & 36.8 & Bkfl & $5.94 \mathrm{E}+01$ & $2.09 \mathrm{E}+02$ & $1.02 \mathrm{E}+00$ & 3.73E-01 & $8.94 \mathrm{E}+02$ & $1.55 \mathrm{E}+02$ \\
\hline $4 \mathrm{~A}$ & 40.2 & Bkfl & $1.19 \mathrm{E}+02$ & $4.51 \mathrm{E}+02$ & $2.22 \mathrm{E}+00$ & 8.38E-01 & $7.63 \mathrm{E}+02$ & $1.94 \mathrm{E}+02$ \\
\hline $5 \mathrm{~A}$ & 48.4 & H2 & $4.38 \mathrm{E}+01$ & $1.93 \mathrm{E}+02$ & 9.75E-01 & 3.39E-01 & $3.31 \mathrm{E}+02$ & $(1.09 \mathrm{E}+02)$ \\
\hline $6 \mathrm{~A}$ & 56.1 & $\mathrm{H} 2$ & $4.82 \mathrm{E}+01$ & $2.13 \mathrm{E}+02$ & $1.07 \mathrm{E}+00$ & $2.42 \mathrm{E}-01$ & $2.27 \mathrm{E}+02$ & $(8.77 \mathrm{E}+01)$ \\
\hline 7A UFA & 70.1 & $\mathrm{H} 2$ & $1.00 \mathrm{E}+01^{(\mathrm{a})}$ & $2.80 \mathrm{E}+01$ & (1.20E-01) & (2.60E-01) & $7.10 \mathrm{E}+02$ & $(1.00 \mathrm{E}+01)$ \\
\hline 7A & 70.1 & $\mathrm{H} 2$ & $3.87 \mathrm{E}+00$ & $1.94 \mathrm{E}+01$ & $(1.06 \mathrm{E}-01)^{(\mathrm{b})}$ & 6.54E-01 & $1.35 E+03$ & $(3.75 E+01)$ \\
\hline $8 \mathrm{~A}$ & 81.2 & $\mathrm{H} 2$ & $8.85 \mathrm{E}+01$ & $3.71 \mathrm{E}+02$ & $2.17 \mathrm{E}+00$ & $5.16 \mathrm{E}-01$ & $2.74 \mathrm{E}+02$ & $(8.80 \mathrm{E}+01)$ \\
\hline $9 \mathrm{~A}$ & 86.7 & $\mathrm{CCU}_{\mathrm{u}}$ & $4.16 \mathrm{E}+02$ & $1.91 \mathrm{E}+03$ & $7.84 \mathrm{E}+00$ & 4.08E-01 & $4.59 \mathrm{E}+02$ & $9.08 \mathrm{E}+01$ \\
\hline 10A UFA & 88.2 & $\mathrm{CCU}_{\mathrm{u}}$ & $5.40 \mathrm{E}+02$ & $2.40 E+03$ & $9.50 E+00$ & 1.10E-01 & $4.10 \mathrm{E}+02$ & $4.60 \mathrm{E}+01$ \\
\hline $10 \mathrm{~A}$ & 88.2 & $\mathrm{CCU}_{\mathrm{u}}$ & $4.63 \mathrm{E}+02$ & $2.10 \mathrm{E}+03$ & $8.65 E+00$ & 3.33E-01 & $3.83 E+02$ & $7.41 \mathrm{E}+01$ \\
\hline 10A DUP & 88.2 & $\mathrm{CCU}_{\mathrm{u}}$ & 4.33E+02 & $2.04 \mathrm{E}+03$ & $8.45 \mathrm{E}+00$ & 3.87E-01 & $3.85 \mathrm{E}+02$ & $8.18 \mathrm{E}+01$ \\
\hline 11A UFA & 93.3 & $\mathrm{CCU}_{\mathrm{l}}$ & $3.90 \mathrm{E}+02$ & $1.20 \mathrm{E}+03$ & $6.50 \mathrm{E}+00$ & $1.20 \mathrm{E}-01$ & $8.50 \mathrm{E}+02$ & $3.10 \mathrm{E}+01$ \\
\hline $11 \mathrm{~A}$ & 93.3 & $\mathrm{CCU}_{\mathrm{l}}$ & $4.74 \mathrm{E}+02$ & $1.78 \mathrm{E}+03$ & $9.85 \mathrm{E}+00$ & 4.70E-01 & $1.17 \mathrm{E}+03$ & $8.08 \mathrm{E}+01$ \\
\hline $12 \mathrm{~A}$ & 97.1 & $\mathrm{CCU}_{\mathrm{l}}$ & $5.48 \mathrm{E}+02$ & $1.12 \mathrm{E}+03$ & $8.63 E+00$ & $1.39 \mathrm{E}+00$ & $2.38 \mathrm{E}+02$ & $6.17 \mathrm{E}+01$ \\
\hline $13 \mathrm{~A}$ & 100.3 & $\overline{\mathrm{CCU}_{\mathrm{l}}}$ & $5.45 \mathrm{E}+02$ & $1.09 \mathrm{E}+03$ & $8.44 \mathrm{E}+00$ & $1.50 \mathrm{E}+00$ & $3.75 E+02$ & $1.02 \mathrm{E}+02$ \\
\hline $14 \mathrm{~A}$ & 102.0 & $\mathrm{CCU}_{\mathrm{l}}$ & $5.83 E+02$ & $1.60 \mathrm{E}+03$ & $1.10 \mathrm{E}+01$ & 8.12E-01 & $7.29 \mathrm{E}+02$ & $8.78 \mathrm{E}+01$ \\
\hline $15 \mathrm{~A}$ & 103.2 & $\mathrm{CCU}_{\mathrm{l}}$ & $5.92 E+02$ & $1.40 \mathrm{E}+03$ & $9.86 \mathrm{E}+00$ & 5.92E-01 & $1.22 \mathrm{E}+03$ & $9.12 \mathrm{E}+01$ \\
\hline 16A UFA & 106.9 & $\mathrm{CCU}_{1}$ & $6.40 \mathrm{E}+02$ & $1.20 \mathrm{E}+03$ & $7.40 \mathrm{E}+00$ & 6.10E-02 & $6.90 \mathrm{E}+02$ & $2.70 \mathrm{E}+01$ \\
\hline $16 \mathrm{~A}$ & 106.9 & $\mathrm{CCU}_{\mathrm{l}}$ & $5.18 \mathrm{E}+02$ & $1.04 \mathrm{E}+03$ & $6.63 \mathrm{E}+00$ & 1.79E-01 & $7.29 \mathrm{E}+02$ & $5.30 \mathrm{E}+01$ \\
\hline
\end{tabular}


Table 4.48. (contd)

\begin{tabular}{|c|c|c|c|c|c|c|c|c|}
\hline $\begin{array}{c}\text { Sample } \\
\text { ID }\end{array}$ & $\begin{array}{c}\text { Depth } \\
\text { (ft-bgs) }\end{array}$ & Stratigraphy & $\begin{array}{r}\mathrm{Mg} \\
\mathrm{mg} / \mathrm{L} \\
\end{array}$ & $\begin{array}{c}\mathrm{Ca} \\
\mathrm{mg} / \mathrm{L} \\
\end{array}$ & $\begin{array}{c}\mathrm{Sr} \\
\mathrm{mg} / \mathrm{L}\end{array}$ & $\begin{array}{c}\text { Ba } \\
\mathrm{mg} / \mathrm{L} \\
\end{array}$ & $\begin{array}{c}\mathrm{Na} \\
\mathrm{mg} / \mathrm{L}\end{array}$ & $\begin{array}{c}\mathrm{K} \\
\mathrm{mg} / \mathrm{L} \\
\end{array}$ \\
\hline $17 \mathrm{~A}$ & 110.0 & $\mathrm{CCU}_{\mathrm{l}}$ & $7.44 \mathrm{E}+02$ & $1.67 \mathrm{E}+03$ & $1.04 \mathrm{E}+01$ & 7.49E-01 & $5.10 \mathrm{E}+02$ & $1.40 \mathrm{E}+02$ \\
\hline 17A DUP & 110.0 & $\mathrm{CCU}_{\mathrm{l}}$ & $5.94 \mathrm{E}+02$ & $1.38 \mathrm{E}+03$ & $8.51 E+00$ & $6.55 \mathrm{E}-01$ & $3.42 E+02$ & $1.30 \mathrm{E}+02$ \\
\hline $18 \mathrm{~A}$ & 116.0 & $\mathrm{R}_{\mathrm{tf}}$ & $1.66 \mathrm{E}+02$ & $4.78 \mathrm{E}+02$ & $3.24 \mathrm{E}+00$ & $5.24 \mathrm{E}-01$ & $5.84 \mathrm{E}+01$ & $4.42 \mathrm{E}+01$ \\
\hline 19A UFA & 120.9 & $\mathrm{R}_{\mathrm{tf}}$ & $2.40 \mathrm{E}+02$ & $6.30 \mathrm{E}+02$ & $4.40 E+00$ & $1.60 \mathrm{E}-01$ & $8.00 E+01$ & $1.80 \mathrm{E}+01$ \\
\hline $19 \mathrm{~A}$ & 120.9 & $\mathrm{R}_{\mathrm{tf}}$ & $1.92 \mathrm{E}+02$ & $5.36 \mathrm{E}+02$ & $4.05 \mathrm{E}+00$ & 4.62E-01 & $6.04 \mathrm{E}+01$ & $2.81 \mathrm{E}+01$ \\
\hline 20A UFA & 123.9 & $\mathrm{R}_{\mathrm{wi}}$ & $2.50 \mathrm{E}+02$ & $4.90 \mathrm{E}+02$ & $4.30 \mathrm{E}+00$ & $2.50 \mathrm{E}-01$ & $4.90 \mathrm{E}+02$ & $(2.00 E+01)$ \\
\hline $20 \mathrm{~A}$ & 123.9 & $\mathrm{R}_{\mathrm{wi}}$ & $6.54 \mathrm{E}+02$ & $1.85 \mathrm{E}+03$ & $1.40 \mathrm{E}+01$ & $2.22 \mathrm{E}+00$ & $3.84 \mathrm{E}+02$ & $(1.31 E+02)$ \\
\hline $21 \mathrm{~A}$ & 129.8 & $\mathrm{R}_{\mathrm{wi}}$ & $2.20 \mathrm{E}+02$ & $6.78 \mathrm{E}+02$ & $5.64 \mathrm{E}+00$ & $1.07 \mathrm{E}+00$ & $5.30 \mathrm{E}+02$ & $1.98 \mathrm{E}+02$ \\
\hline
\end{tabular}

(a) Bold values designate the actual porewater data obtained by ultracentrifugation of the sediments.

(b) Parentheses signify values below level of quantitation, but considered valid. 
Table 4.49. Derived and Actual Porewater Anion Concentrations in C4105 Vadose Zone Sediments

\begin{tabular}{|c|c|c|c|c|c|c|c|c|}
\hline Sample No. & $\begin{array}{c}\text { Depth } \\
\text { (ft bgs) }\end{array}$ & Stratigraphic Unit & $\begin{array}{c}\text { mg/L } \\
\text { Fluoride }\end{array}$ & $\begin{array}{c}\text { mg/L } \\
\text { Chloride }\end{array}$ & $\begin{array}{c}\mathrm{mg} / \mathrm{L} \\
\text { Nitrate }\end{array}$ & $\begin{array}{c}\mathrm{mg} / \mathrm{L} \\
\text { Alk as } \mathrm{CO}_{3}\end{array}$ & $\begin{array}{c}\text { mg/L } \\
\text { Sulfate }\end{array}$ & $\begin{array}{c}\mathrm{mg} / \mathrm{L} \\
\text { Phosphate }\end{array}$ \\
\hline $1 \mathrm{~A}$ & 15.3 & Bkfl & 26.10 & 16.06 & 47.98 & 1161.8 & 116.41 & $<7.244$ \\
\hline $2 \mathrm{~A}$ & 22.7 & Bkfl & 29.26 & 73.34 & 18.27 & 1028.0 & 295.44 & 9.42 \\
\hline $3 \mathrm{~A}$ & 36.8 & Bkfl & 38.65 & 101.68 & 9.36 & 1268.1 & 551.36 & 9.10 \\
\hline $4 \mathrm{~A}$ & 40.2 & Bkfl & 0.47 & 116.44 & 18.41 & 1452.1 & 625.95 & $<3.148$ \\
\hline $5 \mathrm{~A}$ & 48.4 & $\mathrm{H} 2$ & 8.96 & 12.89 & 40.30 & 892.7 & 185.63 & $<6.441$ \\
\hline $6 \mathrm{~A}$ & 56.1 & $\mathrm{H} 2$ & 10.67 & 8.95 & 50.04 & 746.8 & 268.07 & $<5.546$ \\
\hline 7A UFA & 70.1 & $\mathrm{H} 2$ & $<10.200$ & 72.58 & 676.94 & 320.76 & 435.83 & $<38.550$ \\
\hline $7 \mathrm{~A}$ & 70.1 & $\mathrm{H} 2$ & 10.26 & 16.55 & 338.09 & 1477.4 & 439.24 & 11.31 \\
\hline $8 \mathrm{~A}$ & 81.2 & $\mathrm{H} 2$ & 10.59 & 16.76 & 191.72 & 739.0 & 793.88 & $<4.911$ \\
\hline $9 \mathrm{~A}$ & 86.7 & $\mathrm{CCU}_{\mathrm{u}}$ & 0.61 & 139.93 & 7159.26 & 379.0 & 1459.41 & 2.06 \\
\hline 10A UFA & 88.2 & $\mathrm{CCU}_{\mathrm{u}}$ & $<\mathbf{0 . 6 8 0}$ & 177.48 & 8631.12 & 43.24 & 972.44 & $<2.570$ \\
\hline $10 \mathrm{~A}$ & 88.2 & $\mathrm{CCU}_{\mathrm{u}}$ & 0.28 & 152.36 & 8117.80 & 153.6 & 1205.81 & 1.60 \\
\hline 10A DUP & 88.2 & $\mathrm{CCU}_{\mathrm{u}}$ & 0.33 & 142.81 & 7496.64 & 787.4 & 1145.51 & $<1.276$ \\
\hline 11A UFA & 93.3 & $\mathrm{CCU}_{1}$ & $<1.360$ & 133.44 & 6661.75 & 33.26 & \begin{tabular}{|l|}
628.58 \\
\end{tabular} & $<5.140$ \\
\hline $11 \mathrm{~A}$ & 93.3 & $\mathrm{CCU}_{1}$ & 0.33 & 135.37 & 8029.71 & 156.6 & 2280.39 & 1.95 \\
\hline $12 \mathrm{~A}$ & 97.1 & $\mathrm{CCU}_{1}$ & 4.90 & 173.27 & 6346.65 & 204.0 & 223.49 & $<1.981$ \\
\hline $13 \mathrm{~A}$ & 100.3 & $\mathrm{CCU}_{\mathrm{l}}$ & 7.30 & 194.81 & 6167.65 & 180.4 & 361.19 & $<3.232$ \\
\hline $14 \mathrm{~A}$ & 102.0 & $\mathrm{CCU}_{1}$ & 0.70 & 138.27 & 6556.53 & 364.7 & 2335.17 & 2.82 \\
\hline $15 \mathrm{~A}$ & 103.2 & $\mathrm{CCU}_{\mathrm{l}}$ & 8.91 & 132.68 & 6345.83 & 299.3 & 2742.62 & 3.36 \\
\hline
\end{tabular}


Table 4.49. (contd)

\begin{tabular}{|c|c|c|c|c|c|c|c|c|}
\hline Sample No. & $\begin{array}{c}\text { Depth } \\
\text { (ft bgs) }\end{array}$ & Stratigraphic Unit & $\begin{array}{c}\text { mg/L } \\
\text { Fluoride }\end{array}$ & $\begin{array}{c}\text { mg/L } \\
\text { Chloride }\end{array}$ & $\begin{array}{c}\text { mg/L } \\
\text { Nitrate }\end{array}$ & $\begin{array}{c}\mathrm{mg} / \mathrm{L} \\
\text { Alk as } \mathrm{CO}_{3}\end{array}$ & $\begin{array}{c}\mathrm{mg} / \mathrm{L} \\
\text { Sulfate }\end{array}$ & $\begin{array}{c}\mathrm{mg} / \mathrm{L} \\
\text { Phosphate }\end{array}$ \\
\hline 16A UFA & 106.9 & $\mathrm{CCU}_{1}$ & 1.88 & 65.86 & 3715.65 & 81.26 & 2429.24 & 12.83 \\
\hline $16 \mathrm{~A}$ & 106.9 & $\mathrm{CCU}_{1}$ & 3.99 & 49.44 & 3745.45 & 326.4 & 3220.62 & 9.78 \\
\hline 17A & 110.0 & $\mathrm{CCU}_{1}$ & 6.57 & 84.51 & 6480.36 & 136.9 & 2266.80 & 4.34 \\
\hline 17A DUP & 110.0 & $\mathrm{CCU}_{1}$ & 5.99 & 73.51 & 5402.62 & 495.0 & 1552.70 & 3.38 \\
\hline $18 \mathrm{~A}$ & 116.0 & $\mathrm{R}_{\mathrm{tf}}$ & 2.24 & 123.93 & 1829.73 & 363.4 & 130.68 & $<1.092$ \\
\hline 19A UFA & 120.9 & $\mathrm{R}_{\mathrm{tf}}$ & 1.07 & 131.45 & 2676.47 & 28.99 & 127.8 & $<2.570$ \\
\hline $19 \mathrm{~A}$ & 120.9 & $\mathrm{R}_{\mathrm{tf}}$ & 2.21 & 112.13 & 2350.83 & 301.9 & 176.77 & $<0.942$ \\
\hline 20A UFA & 123.9 & $\mathrm{R}_{\mathrm{wi}}$ & $<6.800$ & 178.6 & 3056.6 & 95.04 & 244.97 & $<25.700$ \\
\hline $20 \mathrm{~A}$ & 123.9 & $\mathrm{R}_{\mathrm{wi}}$ & 18.00 & 322.82 & 7881.34 & 190.2 & 664.19 & $<7.230$ \\
\hline $21 \mathrm{~A}$ & 129.8 & $\mathrm{R}_{\mathrm{wi}}$ & 20.55 & 182.75 & 3794.47 & 93.3 & 233.91 & $<4.717$ \\
\hline
\end{tabular}


Table 4.50. Derived and Actual Porewater Concentrations of Selected Constituents in C4105 Vadose Zone Sediments

\begin{tabular}{|c|c|c|c|c|c|c|c|c|c|}
\hline \multirow{2}{*}{$\begin{array}{c}\text { Sample } \\
\text { No. }\end{array}$} & \multicolumn{2}{|c|}{ Units } & \multirow{2}{*}{$\begin{array}{c}\mu g / L \\
\text { Al } \\
\end{array}$} & \multirow{2}{*}{$\begin{array}{c}\mathrm{mg} / \mathrm{L} \\
\mathrm{Si} \\
\end{array}$} & \multirow{2}{*}{$\begin{array}{c}\mu g / L \\
\text { Fe } \\
\end{array}$} & \multirow{2}{*}{$\begin{array}{c}\mu g / L \\
\text { Mn } \\
\end{array}$} & \multirow{2}{*}{$\begin{array}{c}\mathrm{mg} / \mathrm{L} \\
\mathrm{Zn} \\
\end{array}$} & \multirow{2}{*}{$\begin{array}{c}\mathrm{mg} / \mathrm{L} \\
\mathrm{PO}_{4} \text { (ICP) }\end{array}$} & \multirow{2}{*}{$\begin{array}{c}\mathrm{mg} / \mathrm{L} \\
\mathrm{SO}_{4}(\mathrm{ICP}) \\
\end{array}$} \\
\hline & Depth (ft bgs) & Stratigraphic Unit & & & & & & & \\
\hline $1 \mathrm{~A}$ & 15.3 & Bkfl & $(6.13 E+02)^{(a)}$ & $3.59 E+02$ & $(8.75 E+02)$ & $\mathrm{ND}^{(\mathrm{b})}$ & (7.18E-01) & $(3.26 E+00)$ & $1.56 \mathrm{E}+02$ \\
\hline $2 \mathrm{~A}$ & 22.7 & Bkfl & $(6.95 E+02)$ & $2.59 \mathrm{E}+02$ & $(6.27 \mathrm{E}+02)$ & ND & $(4.81 \mathrm{E}-01)$ & $(4.94 \mathrm{E}+00)$ & $3.45 E+02$ \\
\hline $3 \mathrm{~A}$ & 36.8 & Bkfl & $1.17 \mathrm{E}+03$ & $2.03 E+02$ & $(7.28 \mathrm{E}+02)$ & $(5.41 \mathrm{E}+01)$ & (3.09E-01) & $(8.23 E+00)$ & $7.30 \mathrm{E}+02$ \\
\hline $4 \mathrm{~A}$ & 40.2 & Bkfl & $7.92 E+02$ & $1.22 \mathrm{E}+02$ & $(3.13 E+02)$ & $(5.40 \mathrm{E}+02)$ & (3.17E-01) & $(5.52 E+00)$ & $7.21 E+02$ \\
\hline $5 \mathrm{~A}$ & 48.4 & $\mathrm{H} 2$ & $(4.80 \mathrm{E}+02)$ & $2.69 \mathrm{E}+02$ & $(4.51 E+02)$ & ND & (5.64E-01) & $(1.75 E+00)$ & $2.00 \mathrm{E}+02$ \\
\hline $6 \mathrm{~A}$ & 56.1 & $\mathrm{H} 2$ & $(1.52 \mathrm{E}+02)$ & $2.74 \mathrm{E}+02$ & $(3.48 E+02)$ & ND & $(4.04 \mathrm{E}-01)$ & $(1.62 \mathrm{E}+00)$ & $2.79 \mathrm{E}+02$ \\
\hline 7A UFA & 70.1 & $\mathrm{H} 2$ & $(7.5 \mathrm{E}+02)^{(\mathrm{c})}$ & $(3.7 E+01)$ & $(3.5 E+02)$ & $(5.2 E+02)$ & $1.96 \mathrm{E}+00$ & $(8.80 \mathrm{E}-01)$ & $4.99 E+02$ \\
\hline $7 \mathrm{~A}$ & 70.1 & $\mathrm{H} 2$ & $3.80 \mathrm{E}+03$ & $3.04 \mathrm{E}+02$ & $5.76 \mathrm{E}+03$ & $(8.98 E+01)$ & (5.39E-01) & $(8.89 E+00)$ & $4.38 \mathrm{E}+02$ \\
\hline $8 \mathrm{~A}$ & 81.2 & $\mathrm{H} 2$ & $(7.27 \mathrm{E}+01)$ & $2.44 \mathrm{E}+02$ & $(2.35 \mathrm{E}+02)$ & $(2.20 \mathrm{E}+01)$ & $(4.23 E-01)$ & (5.40E-01) & $7.96 \mathrm{E}+02$ \\
\hline $9 \mathrm{~A}$ & 86.7 & $\mathrm{CCU}_{\mathrm{u}}$ & ND & $8.15 \mathrm{E}+01$ & ND & $(1.01 \mathrm{E}+01)$ & (2.52E-01) & $(1.26 \mathrm{E}+00)$ & $1.58 \mathrm{E}+03$ \\
\hline 10A UFA & 88.2 & $\mathrm{CCU}_{\mathrm{u}}$ & ND & $2.27 \mathrm{E}+01$ & $(6.7 E+01)$ & $8.6 \mathrm{E}+01$ & $1.38 \mathrm{E}-01$ & $(1.28 E+00)$ & $1.13 E+03$ \\
\hline $10 \mathrm{~A}$ & 88.2 & $\mathrm{CCU}_{\mathrm{u}}$ & ND & $6.27 \mathrm{E}+01$ & ND & ND & (1.83E-01) & $(1.09 E+00)$ & $1.36 \mathrm{E}+03$ \\
\hline 10A DUP & 88.2 & $\mathrm{CCU}_{\mathrm{u}}$ & ND & $6.55 \mathrm{E}+01$ & ND & ND & (1.95E-01) & $(1.28 \mathrm{E}+00)$ & $1.29 \mathrm{E}+03$ \\
\hline 11A UFA & 93.3 & $\mathrm{CCU}_{\mathrm{l}}$ & ND & $2.08 \mathrm{E}+01$ & $(8.0 \mathrm{E}+01)$ & $2.7 \mathrm{E}+02$ & 3.20E-01 & $(1.04 E+00)$ & $6.99 E+02$ \\
\hline $11 \mathrm{~A}$ & 93.3 & $\mathrm{CCU}_{1}$ & ND & $1.31 \mathrm{E}+02$ & $(0.00 \mathrm{E}+00)$ & $(5.34 \mathrm{E}+01)$ & (3.04E-01) & (8.47E-01) & $2.40 \mathrm{E}+03$ \\
\hline $12 \mathrm{~A}$ & 97.1 & $\mathrm{CCU}_{1}$ & ND & $2.14 \mathrm{E}+02$ & $(4.12 \mathrm{E}+01)$ & ND & $(2.34 \mathrm{E}-01)$ & (7.27E-01) & $2.92 \mathrm{E}+02$ \\
\hline $13 \mathrm{~A}$ & 100.3 & $\mathrm{CCU}_{1}$ & ND & $2.56 \mathrm{E}+02$ & $(5.93 E+01)$ & $(2.65 \mathrm{E}+01)$ & (3.14E-01) & $(6.41 \mathrm{E}-01)$ & $4.21 \mathrm{E}+02$ \\
\hline $14 \mathrm{~A}$ & 102.0 & $\mathrm{CCU}_{\mathrm{l}}$ & ND & $3.49 E+02$ & ND & $(4.19 \mathrm{E}+01)$ & (3.71E-01) & $(9.81 \mathrm{E}-01)$ & $2.45 E+03$ \\
\hline $15 \mathrm{~A}$ & 103.2 & $\mathrm{CCU}_{1}$ & ND & $3.20 \mathrm{E}+02$ & ND & $(3.20 \mathrm{E}+02)$ & (5.83E-01) & $(7.81 \mathrm{E}-01)$ & $2.87 \mathrm{E}+03$ \\
\hline 16A UFA & 106.9 & $\mathrm{CCU}_{1}$ & ND & $3.64 \mathrm{E}+01$ & $1.2 \mathrm{E}+02$ & $2.3 E+03$ & 4.03E-01 & $(1.33 E+00)$ & $2.75 E+03$ \\
\hline $16 \mathrm{~A}$ & 106.9 & $\mathrm{CCU}_{1}$ & ND & $1.13 E+02$ & $4.16 \mathrm{E}+02$ & $2.14 \mathrm{E}+03$ & 4.85E-01 & (6.25E-01) & $3.18 E+03$ \\
\hline
\end{tabular}


Table 4.50. (contd)

\begin{tabular}{|c|c|c|c|c|c|c|c|c|c|}
\hline \multirow{2}{*}{$\begin{array}{l}\text { Sample } \\
\text { No. }\end{array}$} & \multicolumn{2}{|c|}{ Units } & \multirow{2}{*}{$\mu \mathrm{\mu g} / \mathrm{L}$} & \multirow{2}{*}{$\begin{array}{c}\mathrm{mg} / \mathrm{L} \\
\mathrm{Si}\end{array}$} & \multirow{2}{*}{$\mu \mathrm{gg} / \mathrm{L}$} & \multirow{2}{*}{$\mu \mathrm{gg} / \mathrm{L}$} & \multirow{2}{*}{$\mathrm{mg} / \mathrm{L}$} & \multirow{2}{*}{$\begin{array}{c}\mathrm{mg} / \mathrm{L} \\
\mathrm{PO}_{4}(\mathrm{ICP}) \\
\end{array}$} & \multirow{2}{*}{$\begin{array}{c}\mathrm{mg} / \mathrm{L} \\
\mathrm{SO}_{4}(\mathrm{ICP}) \\
\end{array}$} \\
\hline & Depth (ft bgs) & Stratigraphic Unit & & & & & & & \\
\hline $17 \mathrm{~A}$ & 110.0 & $\mathrm{CCU}_{\mathrm{l}}$ & ND & $2.32 \mathrm{E}+02$ & $(3.80 \mathrm{E}+02)$ & $(1.28 \mathrm{E}+03)$ & $(4.74 \mathrm{E}-01)$ & $(1.58 \mathrm{E}+00)$ & $2.37 \mathrm{E}+03$ \\
\hline 17A DUP & 110.0 & $\mathrm{CCU}_{1}$ & ND & $1.79 \mathrm{E}+02$ & $(1.16 \mathrm{E}+02)$ & $(5.31 \mathrm{E}+02)$ & $(3.26 \mathrm{E}-01)$ & $(1.13 \mathrm{E}+00)$ & $1.63 \mathrm{E}+03$ \\
\hline $18 \mathrm{~A}$ & 116.0 & $\mathrm{R}_{\mathrm{tf}}$ & ND & $7.30 \mathrm{E}+01$ & $(2.33 E+01)$ & $1.45 \mathrm{E}+03$ & $(1.06 \mathrm{E}-01)$ & $(1.90 \mathrm{E}-01)$ & $1.60 \mathrm{E}+02$ \\
\hline 19A UFA & 120.9 & $\mathrm{R}_{\mathrm{tf}}$ & ND & $2.49 \mathrm{E}+01$ & $(3.4 \mathrm{E}+01)$ & $1.0 \mathrm{E}+03$ & 8.90E-02 & $(5.13 E-01)$ & $1.54 \mathrm{E}+02$ \\
\hline 19A & 120.9 & $\mathrm{R}_{\mathrm{tf}}$ & ND & $8.47 \mathrm{E}+01$ & $(2.03 E+01)$ & ND & $(9.08 \mathrm{E}-02)$ & $(3.57 \mathrm{E}-01)$ & $2.09 \mathrm{E}+02$ \\
\hline 20A UFA & 123.9 & $\mathrm{R}_{\mathrm{wi}}$ & ND & $(2.8 \mathrm{E}+01)$ & $(2.2 E+02)$ & $(9.4 \mathrm{E}+01)$ & 1.03E-01 & $(9.27 E-01)$ & $3.00 \mathrm{E}+02$ \\
\hline $20 \mathrm{~A}$ & 123.9 & $\mathrm{R}_{\mathrm{wi}}$ & ND & $4.89 \mathrm{E}+02$ & $(1.68 \mathrm{E}+02)$ & $(1.82 \mathrm{E}+02)$ & (5.33E-01) & $(1.23 E+00)$ & $7.84 \mathrm{E}+02$ \\
\hline $21 \mathrm{~A}$ & 129.8 & $\mathrm{R}_{\mathrm{wi}}$ & ND & $2.18 \mathrm{E}+02$ & $(1.31 \mathrm{E}+02)$ & $(1.86 \mathrm{E}+02)$ & (3.79E-01) & (7.59E-01) & $2.90 \mathrm{E}+02$ \\
\hline \multicolumn{10}{|c|}{$\begin{array}{l}\text { (a) Parentheses signify values below level of quantitation but considered valid. } \\
\text { (b) } \mathrm{ND}=\text { not determined. }\end{array}$} \\
\hline
\end{tabular}


Table 4.51. Derived and Actual Porewater Concentrations of Potentially Mobile Constituents in C4105 Vadose Sediments

\begin{tabular}{|c|c|c|c|c|c|c|c|c|c|c|c|c|}
\hline \multicolumn{2}{|c|}{ Units } & \multirow{2}{*}{$\begin{array}{c}\mathbf{p C i} / \mathbf{L} \\
\text { Tc-99 }^{(\mathrm{a})}\end{array}$} & \multirow{2}{*}{$\begin{array}{c}\mu \mathrm{g} / \mathrm{L} \\
\mathrm{U}-238 \\
\end{array}$} & \multirow{2}{*}{$\begin{array}{c}\mu \mathrm{g} / \mathrm{L} \\
\mathrm{Cr}\end{array}$} & \multirow{2}{*}{$\begin{array}{c}\mu \mathrm{g} / \mathrm{L} \\
\mathrm{Cr}\end{array}$} & \multirow{2}{*}{$\begin{array}{c}\mu \mathrm{g} / \mathrm{L} \\
\text { Mo }\end{array}$} & \multirow{2}{*}{$\begin{array}{c}\mu \mathrm{g} / \mathrm{L} \\
\text { Mo } 95 \\
\end{array}$} & \multirow{2}{*}{$\begin{array}{c}\mu \mathrm{g} / \mathrm{L} \\
\text { Mo } 98 \\
\end{array}$} & \multirow{2}{*}{$\begin{array}{c}\mu \mathrm{g} / \mathrm{L} \\
\text { Mo } 100\end{array}$} & \multirow{2}{*}{$\begin{array}{c}\mu \mathrm{g} / \mathrm{L} \\
\text { Ru } 101\end{array}$} & \multirow{2}{*}{$\begin{array}{c}\mu g / L \\
\text { Ru } 102 \\
\end{array}$} & \multirow{2}{*}{$\begin{array}{c}\mu \mathrm{g} / \mathrm{L} \\
\text { Ru } 104 \\
\end{array}$} \\
\hline & Depth & & & & & & & & & & & \\
\hline Sample & (ft bgs) & (ICP-MS) & (ICP-MS) & ICP-OES & (ICP-MS) & ICP-OES & (ICP-MS) & (ICP-MS) & (ICP-MS) & (ICP-MS) & (ICP-MS) & (ICP-MS) \\
\hline $1 \mathrm{~A}$ & 15.3 & $(0.00)^{(\mathrm{a})}$ & $6.01 \mathrm{E}+01$ & $(4.55 \mathrm{E}+01)$ & $(4.59 \mathrm{E}+00)$ & $(3.92 \mathrm{E}+02)$ & $3.56 \mathrm{E}+02$ & $3.28 \mathrm{E}+02$ & $1.53 \mathrm{E}+02$ & $(9.05 \mathrm{E}-02)$ & (6.34E-01) & (9.96E-01) \\
\hline $2 \mathrm{~A}$ & 22.7 & $(0.00)$ & $3.13 \mathrm{E}+01$ & $(2.70 \mathrm{E}+01)$ & $(3.87 \mathrm{E}+00)$ & $4.94 \mathrm{E}+02$ & $4.93 \mathrm{E}+02$ & $4.56 \mathrm{E}+02$ & $2.16 \mathrm{E}+02$ & $<2.38 \mathrm{E}+01$ & $<1.19 \mathrm{E}+01$ & $<2.38 \mathrm{E}+01$ \\
\hline $3 \mathrm{~A}$ & 36.8 & $(316.49)$ & $5.39 \mathrm{E}+01$ & $(3.06 \mathrm{E}+01)$ & $2.32 \mathrm{E}+01$ & $1.38 \mathrm{E}+03$ & $1.39 \mathrm{E}+03$ & $1.29 \mathrm{E}+03$ & $6.08 \mathrm{E}+02$ & $<1.87 \mathrm{E}+01$ & $<9.33 \mathrm{E}+00$ & $<1.87 \mathrm{E}+01$ \\
\hline $4 \mathrm{~A}$ & 40.2 & $(667.29)$ & $5.27 \mathrm{E}+01$ & $(2.84 \mathrm{E}+01)$ & $1.35 \mathrm{E}+01$ & $4.60 \mathrm{E}+02$ & $4.49 \mathrm{E}+02$ & $4.15 \mathrm{E}+02$ & $2.01 \mathrm{E}+02$ & $<1.31 \mathrm{E}+01$ & $<6.56 \mathrm{E}+00$ & $(2.75 \mathrm{E}-01)$ \\
\hline $5 \mathrm{~A}$ & 48.4 & $<4551.4$ & $1.40 \mathrm{E}+01$ & $(2.90 \mathrm{E}+01)$ & $(2.87 \mathrm{E}+00)$ & $(2.68 \mathrm{E}+02)$ & $2.41 \mathrm{E}+02$ & $2.24 \mathrm{E}+02$ & $1.08 \mathrm{E}+02$ & $<2.68 \mathrm{E}+01$ & $<1.34 \mathrm{E}+01$ & $<2.68 \mathrm{E}+01$ \\
\hline $6 \mathrm{~A}$ & 56.1 & (2351.69) & $9.78 \mathrm{E}+00$ & $(2.64 \mathrm{E}+02)$ & $2.11 \mathrm{E}+02$ & $(3.99 \mathrm{E}+02)$ & $5.27 \mathrm{E}+02$ & $3.89 \mathrm{E}+02$ & $3.54 \mathrm{E}+02$ & $(2.51 \mathrm{E}+00)$ & $(1.07 \mathrm{E}+00)$ & $(1.52 \mathrm{E}+00)$ \\
\hline 7A UFA & 70.1 & $3.07 \mathrm{E}+05^{(\mathrm{c})}$ & $5.72 \mathrm{E}+00$ & $(5.3 E+02)$ & $5.53 \mathrm{E}+02$ & $(1.7 E+03)$ & $2.70 \mathrm{E}+03$ & $1.65 \mathrm{E}+03$ & $1.96 \mathrm{E}+03$ & $9.08 E+01$ & $(3.83 E+01)$ & $(3.91 E+01)$ \\
\hline $7 \mathrm{~A}$ & 70.1 & $1.98 \mathrm{E}+05$ & $3.01 \mathrm{E}+01$ & $2.77 \mathrm{E}+03$ & $2.38 \mathrm{E}+03$ & $2.41 \mathrm{E}+03$ & $3.32 \mathrm{E}+03$ & $2.07 \mathrm{E}+03$ & $2.52 \mathrm{E}+03$ & $7.95 \mathrm{E}+01$ & $3.77 \mathrm{E}+01$ & $3.86 \mathrm{E}+01$ \\
\hline $8 \mathrm{~A}$ & 81.2 & $1.24 \mathrm{E}+05$ & $2.68 \mathrm{E}+01$ & $1.63 \mathrm{E}+03$ & $1.47 \mathrm{E}+03$ & $(1.67 \mathrm{E}+02)$ & $1.77 \mathrm{E}+02$ & $1.60 \mathrm{E}+02$ & $7.97 \mathrm{E}+01$ & $7.00 \mathrm{E}+01$ & $3.31 \mathrm{E}+01$ & $3.58 \mathrm{E}+01$ \\
\hline $9 \mathrm{~A}$ & 86.7 & $7.30 \mathrm{E}+06$ & $8.96 \mathrm{E}+00$ & $3.26 \mathrm{E}+04$ & $2.87 \mathrm{E}+04$ & $\mathrm{ND}^{(\mathrm{b})}$ & $4.49 \mathrm{E}+01$ & $4.28 \mathrm{E}+01$ & $3.86 \mathrm{E}+01$ & $2.05 \mathrm{E}+03$ & $9.91 \mathrm{E}+02$ & $9.93 \mathrm{E}+02$ \\
\hline 10A UFA & 88.2 & $8.68 \mathrm{E}+06$ & $3.99 \mathrm{E}+00$ & $1.4 \mathrm{E}+04$ & $1.46 \mathrm{E}+04$ & $(4.8 \mathrm{E}+01)$ & $(1.19 \mathrm{E}+01)$ & $(9.60 \mathrm{E}+00)$ & $2.85 \mathrm{E}+01$ & $2.71 \mathrm{E}+03$ & $1.29 \mathrm{E}+03$ & $1.27 \mathrm{E}+03$ \\
\hline $10 \mathrm{~A}$ & 88.2 & $8.29 \mathrm{E}+06$ & $6.15 \mathrm{E}+00$ & $2.30 \mathrm{E}+04$ & $2.13 \mathrm{E}+04$ & ND & $3.97 \mathrm{E}+01$ & $3.67 \mathrm{E}+01$ & $4.03 \mathrm{E}+01$ & $2.56 \mathrm{E}+03$ & $1.22 \mathrm{E}+03$ & $1.21 \mathrm{E}+03$ \\
\hline 10A DUP & 88.2 & $7.47 \mathrm{E}+06$ & $6.49 \mathrm{E}+00$ & $1.94 \mathrm{E}+04$ & $1.80 \mathrm{E}+04$ & ND & $4.20 \mathrm{E}+01$ & $3.91 \mathrm{E}+01$ & $3.87 \mathrm{E}+01$ & $2.20 \mathrm{E}+03$ & $1.07 \mathrm{E}+03$ & $1.05 \mathrm{E}+03$ \\
\hline 11A UFA & 93.3 & $4.37 \mathrm{E}+06$ & $3.89 \mathrm{E}+00$ & $5.0 \mathrm{E}+03$ & $4.95 \mathrm{E}+03$ & $(9.6 \mathrm{E}+01)$ & 4.77E+01 & $4.21 \mathrm{E}+01$ & $3.64 \mathrm{E}+01$ & $1.50 \mathrm{E}+03$ & $7.14 \mathrm{E}+02$ & $6.97 \mathrm{E}+02$ \\
\hline $11 \mathrm{~A}$ & 93.3 & $6.11 \mathrm{E}+06$ & $2.46 \mathrm{E}+01$ & $1.20 \mathrm{E}+04$ & $9.65 \mathrm{E}+03$ & $1.48 \mathrm{E}+02$ & $2.43 \mathrm{E}+02$ & $2.27 \mathrm{E}+02$ & $1.28 \mathrm{E}+02$ & $2.24 \mathrm{E}+03$ & $1.07 \mathrm{E}+03$ & $1.08 \mathrm{E}+03$ \\
\hline $12 \mathrm{~A}$ & 97.1 & $4.10 \mathrm{E}+06$ & $1.38 \mathrm{E}+01$ & $3.55 \mathrm{E}+02$ & $3.10 \mathrm{E}+02$ & $2.07 \mathrm{E}+02$ & $3.48 \mathrm{E}+02$ & $3.20 \mathrm{E}+02$ & $1.61 \mathrm{E}+02$ & $1.06 \mathrm{E}+03$ & $5.11 \mathrm{E}+02$ & $5.05 \mathrm{E}+02$ \\
\hline $13 \mathrm{~A}$ & 100.3 & $5.48 \mathrm{E}+06$ & $2.72 \mathrm{E}+01$ & $2.09 \mathrm{E}+02$ & $2.00 \mathrm{E}+02$ & $(1.03 E+02)$ & $2.78 \mathrm{E}+02$ & $2.58 \mathrm{E}+02$ & $1.29 \mathrm{E}+02$ & $7.29 \mathrm{E}+02$ & $3.52 \mathrm{E}+02$ & $3.51 \mathrm{E}+02$ \\
\hline $14 \mathrm{~A}$ & 102.0 & $8.61 \mathrm{E}+06$ & $4.01 \mathrm{E}+01$ & $3.04 \mathrm{E}+04$ & $2.25 \mathrm{E}+04$ & $1.34 \mathrm{E}+03$ & $1.86 \mathrm{E}+03$ & $1.21 \mathrm{E}+03$ & $1.41 \mathrm{E}+03$ & $1.67 \mathrm{E}+03$ & $8.14 \mathrm{E}+02$ & $8.21 \mathrm{E}+02$ \\
\hline $15 \mathrm{~A}$ & 103.2 & $8.15 \mathrm{E}+06$ & $4.15 \mathrm{E}+01$ & $3.25 \mathrm{E}+04$ & $2.62 \mathrm{E}+04$ & $4.85 \mathrm{E}+03$ & $6.93 \mathrm{E}+03$ & $3.82 \mathrm{E}+03$ & $4.68 \mathrm{E}+03$ & $2.11 \mathrm{E}+03$ & $1.03 \mathrm{E}+03$ & $1.03 \mathrm{E}+03$ \\
\hline 16A UFA & 106.9 & $4.49 \mathrm{E}+06$ & $1.10 \mathrm{E}+01$ & $4.3 \mathrm{E}+04$ & $4.37 \mathrm{E}+04$ & $1.0 \mathrm{E}+04$ & $1.55 \mathrm{E}+04$ & $9.51 \mathrm{E}+03$ & $1.15 \mathrm{E}+04$ & $3.15 \mathrm{E}+03$ & $1.52 \mathrm{E}+03$ & $1.49 \mathrm{E}+03$ \\
\hline $16 \mathrm{~A}$ & 106.9 & $1.55 \mathrm{E}+06$ & $1.34 \mathrm{E}+01$ & $2.19 \mathrm{E}+04$ & $1.68 \mathrm{E}+04$ & $7.29 \mathrm{E}+03$ & $1.01 \mathrm{E}+04$ & $6.35 \mathrm{E}+03$ & $7.90 \mathrm{E}+03$ & $1.88 \mathrm{E}+03$ & $9.17 \mathrm{E}+02$ & $9.07 \mathrm{E}+02$ \\
\hline
\end{tabular}


Table 4.51. (contd)

\begin{tabular}{|c|c|c|c|c|c|c|c|c|c|c|c|c|}
\hline \multicolumn{2}{|c|}{ Units } & pCi/L & $\mu g / L$ & $\mu g / L$ & $\mu g / L$ & $\mu g / L$ & $\mu g / L$ & $\mu g / L$ & $\mu g / L$ & $\mu g / L$ & $\mu g / L$ & $\mu g / L$ \\
\hline \multirow[b]{2}{*}{ Sample } & \multirow{2}{*}{$\begin{array}{r}\text { Depth } \\
\text { (ft bgs) }\end{array}$} & Tc-99 ${ }^{(a)}$ & U-238 & $\mathrm{Cr}$ & $\mathrm{Cr}$ & Mo & Mo 95 & Mo 98 & Mo 100 & Ru 101 & Ru 102 & Ru 104 \\
\hline & & (ICP-MS) & (ICP-MS) & ICP-OES & (ICP-MS) & ICP-OES & (ICP-MS) & (ICP-MS) & (ICP-MS) & (ICP-MS) & (ICP-MS) & (ICP-MS) \\
\hline $17 \mathrm{~A}$ & 110.0 & $7.67 \mathrm{E}+06$ & $1.25 \mathrm{E}+01$ & $6.89 \mathrm{E}+03$ & $5.38 \mathrm{E}+03$ & $2.97 \mathrm{E}+03$ & $4.26 \mathrm{E}+03$ & $2.86 \mathrm{E}+03$ & $3.10 \mathrm{E}+03$ & $1.58 \mathrm{E}+03$ & $7.60 \mathrm{E}+02$ & $7.59 \mathrm{E}+02$ \\
\hline 17A DUP & 110.0 & $6.91 \mathrm{E}+06$ & $1.05 \mathrm{E}+01$ & $2.44 \mathrm{E}+03$ & $1.19 \mathrm{E}+03$ & $7.26 \mathrm{E}+02$ & $9.59 \mathrm{E}+02$ & $6.70 \mathrm{E}+02$ & $7.33 \mathrm{E}+02$ & $1.12 \mathrm{E}+03$ & $5.52 \mathrm{E}+02$ & $5.53 \mathrm{E}+02$ \\
\hline $18 \mathrm{~A}$ & 116.0 & $8.85 \mathrm{E}+05$ & $5.73 \mathrm{E}+00$ & $(1.04 \mathrm{E}+01)$ & $(2.34 \mathrm{E}+00)$ & $(4.39 E+01)$ & $8.66 \mathrm{E}+01$ & $7.93 \mathrm{E}+01$ & $4.03 \mathrm{E}+01$ & $8.33 \mathrm{E}+01$ & $4.06 \mathrm{E}+01$ & $4.30 \mathrm{E}+01$ \\
\hline 19A UFA & 120.9 & $2.18 \mathrm{E}+06$ & $2.06 \mathrm{E}+00$ & $(3.8 \mathrm{E}+01)$ & $1.47 \mathrm{E}+01$ & $(4.7 \mathrm{E}+01)$ & $1.67 \mathrm{E}+01$ & $(1.15 E+01)$ & $1.29 \mathrm{E}+01$ & $2.80 \mathrm{E}+02$ & $1.32 \mathrm{E}+02$ & $1.32 \mathrm{E}+02$ \\
\hline $19 \mathrm{~A}$ & 120.9 & $2.49 \mathrm{E}+06$ & $2.94 \mathrm{E}+00$ & $(3.92 \mathrm{E}+01)$ & $3.32 \mathrm{E}+01$ & ND & $3.53 \mathrm{E}+01$ & $3.29 \mathrm{E}+01$ & $1.81 \mathrm{E}+01$ & $2.76 \mathrm{E}+02$ & $1.31 \mathrm{E}+02$ & $1.33 \mathrm{E}+02$ \\
\hline 20A UFA & 123.9 & $2.57 E+06$ & $1.90 \mathrm{E}+00$ & $(1.2 E+02)$ & $(3.96 E+01)$ & $(1.4 \mathrm{E}+02)$ & $(5.04 \mathrm{E}+01)$ & $(4.30 \mathrm{E}+01)$ & $(2.48 \mathrm{E}+01)$ & $3.22 \mathrm{E}+02$ & $1.51 \mathrm{E}+02$ & $1.50 \mathrm{E}+02$ \\
\hline $20 \mathrm{~A}$ & 123.9 & $6.25 \mathrm{E}+06$ & $1.11 \mathrm{E}+01$ & $(6.04 \mathrm{E}+01)$ & $(2.05 \mathrm{E}+01)$ & $(0.00 \mathrm{E}+00)$ & $2.45 \mathrm{E}+02$ & $2.25 \mathrm{E}+02$ & $1.12 \mathrm{E}+02$ & $6.45 \mathrm{E}+02$ & $3.11 \mathrm{E}+02$ & $3.17 \mathrm{E}+02$ \\
\hline $21 \mathrm{~A}$ & 129.8 & $2.40 \mathrm{E}+06$ & $2.00 \mathrm{E}+00$ & $(4.46 \mathrm{E}+01)$ & $(1.55 \mathrm{E}+01)$ & $(2.11 \mathrm{E}+02)$ & $2.84 \mathrm{E}+02$ & $2.66 \mathrm{E}+02$ & $1.30 \mathrm{E}+02$ & $2.28 \mathrm{E}+02$ & $1.11 \mathrm{E}+02$ & $1.13 \mathrm{E}+02$ \\
\hline $\begin{array}{l}\text { (a) } \\
\text { (b) } \\
\text { (c) }\end{array}$ & & mined. & & & but concis & ad yolid & 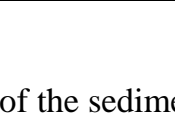 & & & & & \\
\hline
\end{tabular}




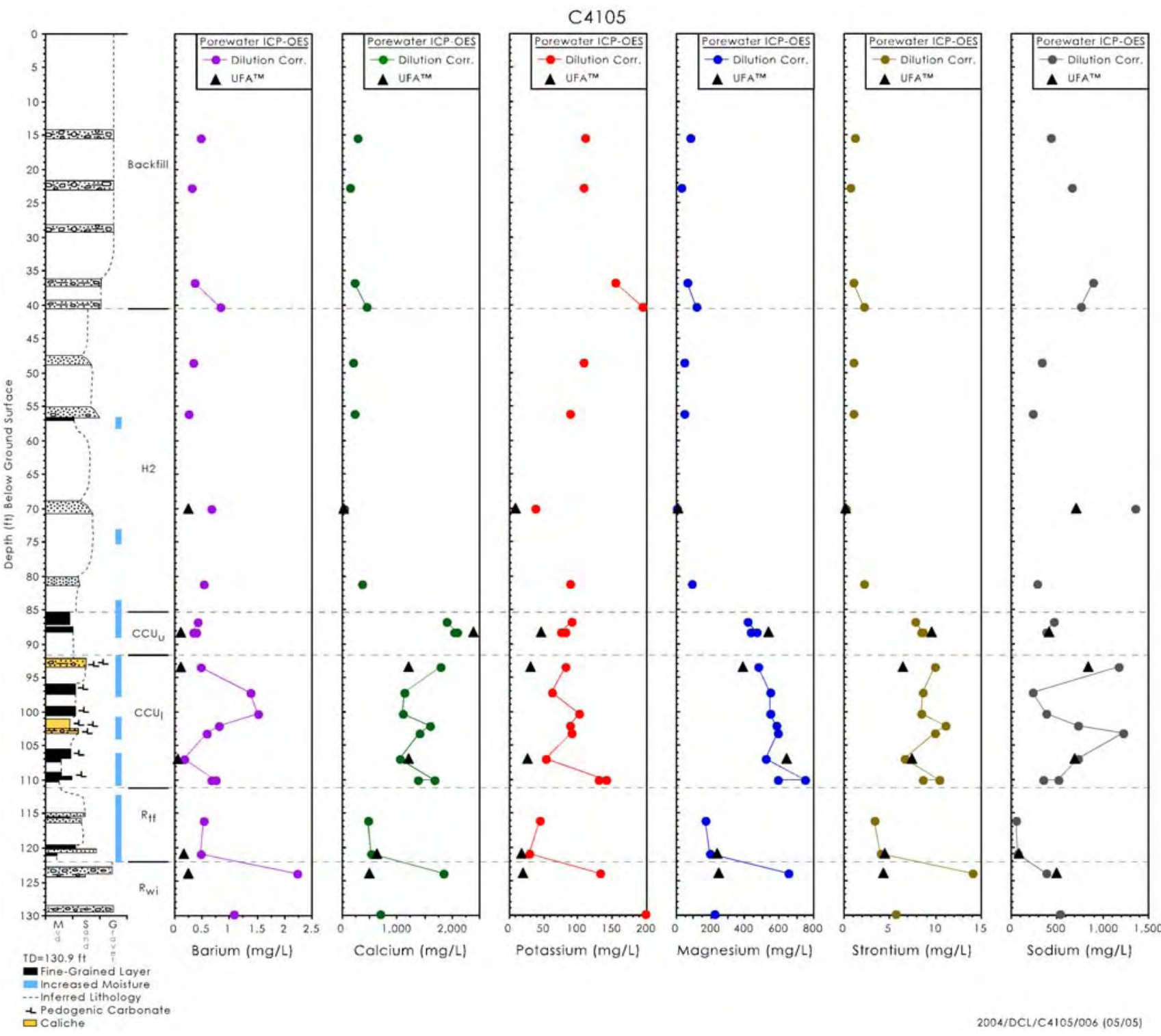

Figure 4.46. Porewater Composition of Major Cations in C4105 Vadose Zone Sediments 

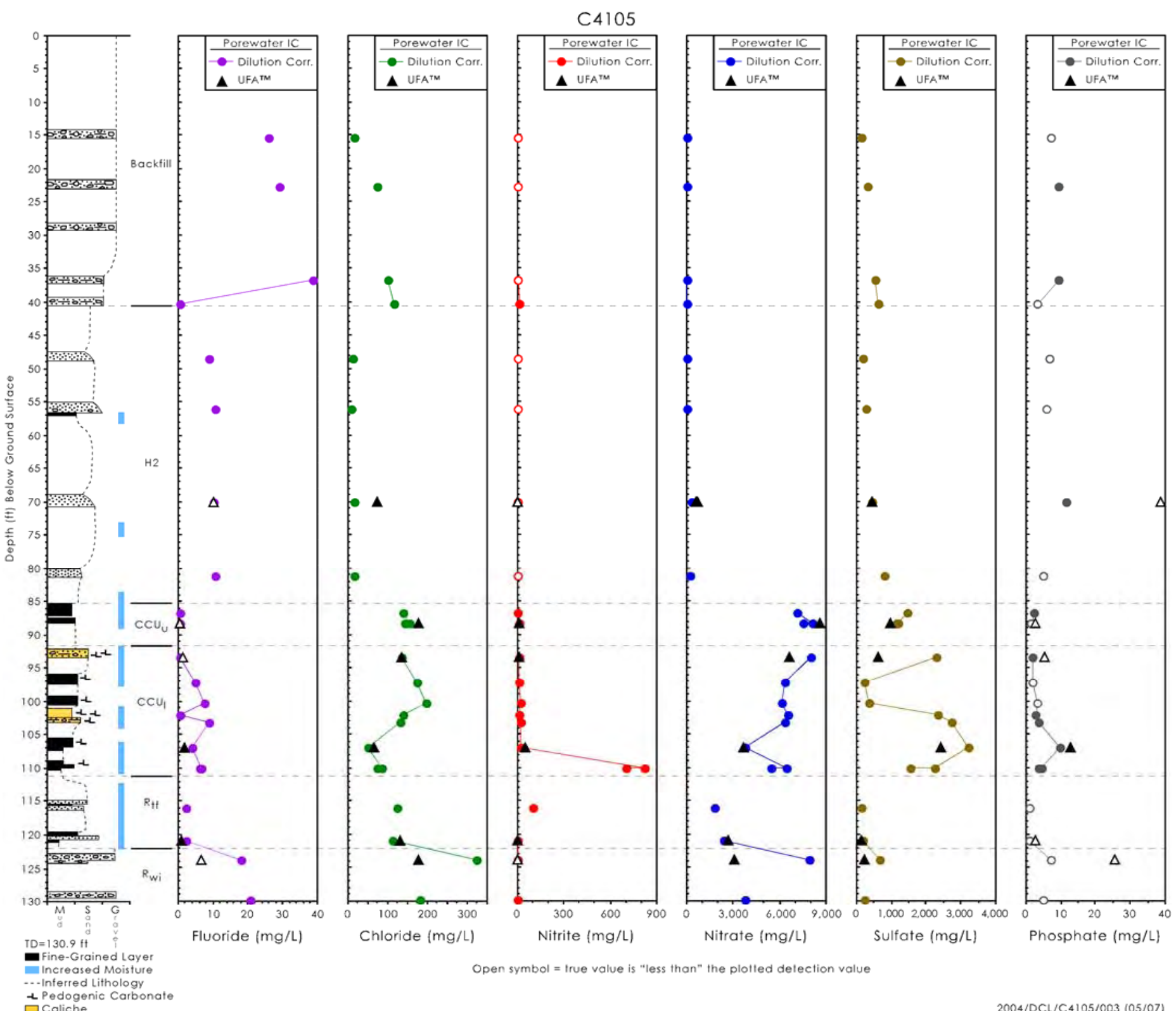

Figure 4.47. Porewater Anion Composition in C4105 Vadose Zone Sediments 

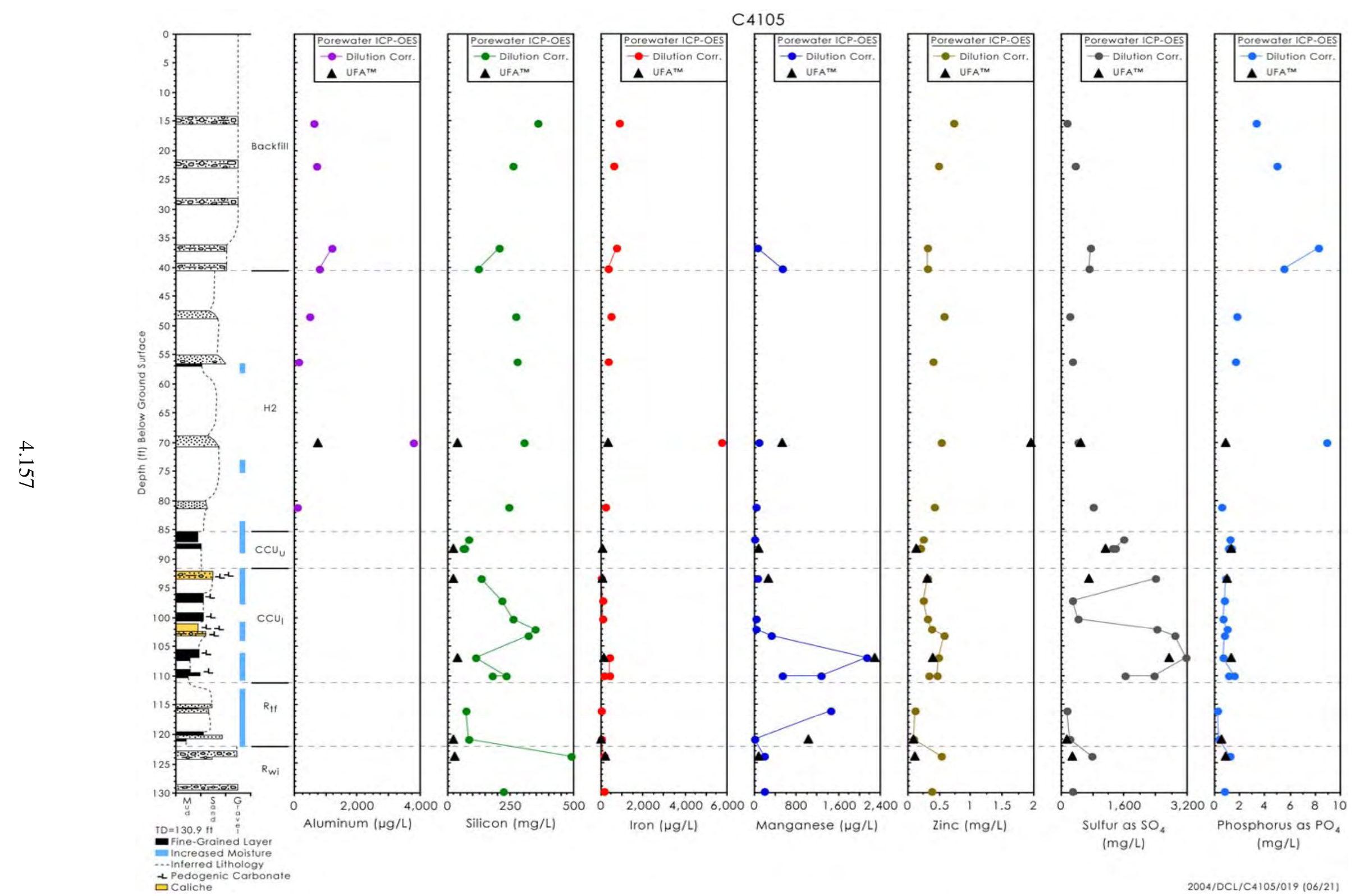

tPedogenic Carbona

2004/DCL/C4105/019 (06/21)

Figure 4.48. Porewater Composition for Selected Metals in C4105 Vadose Zone Sediments 

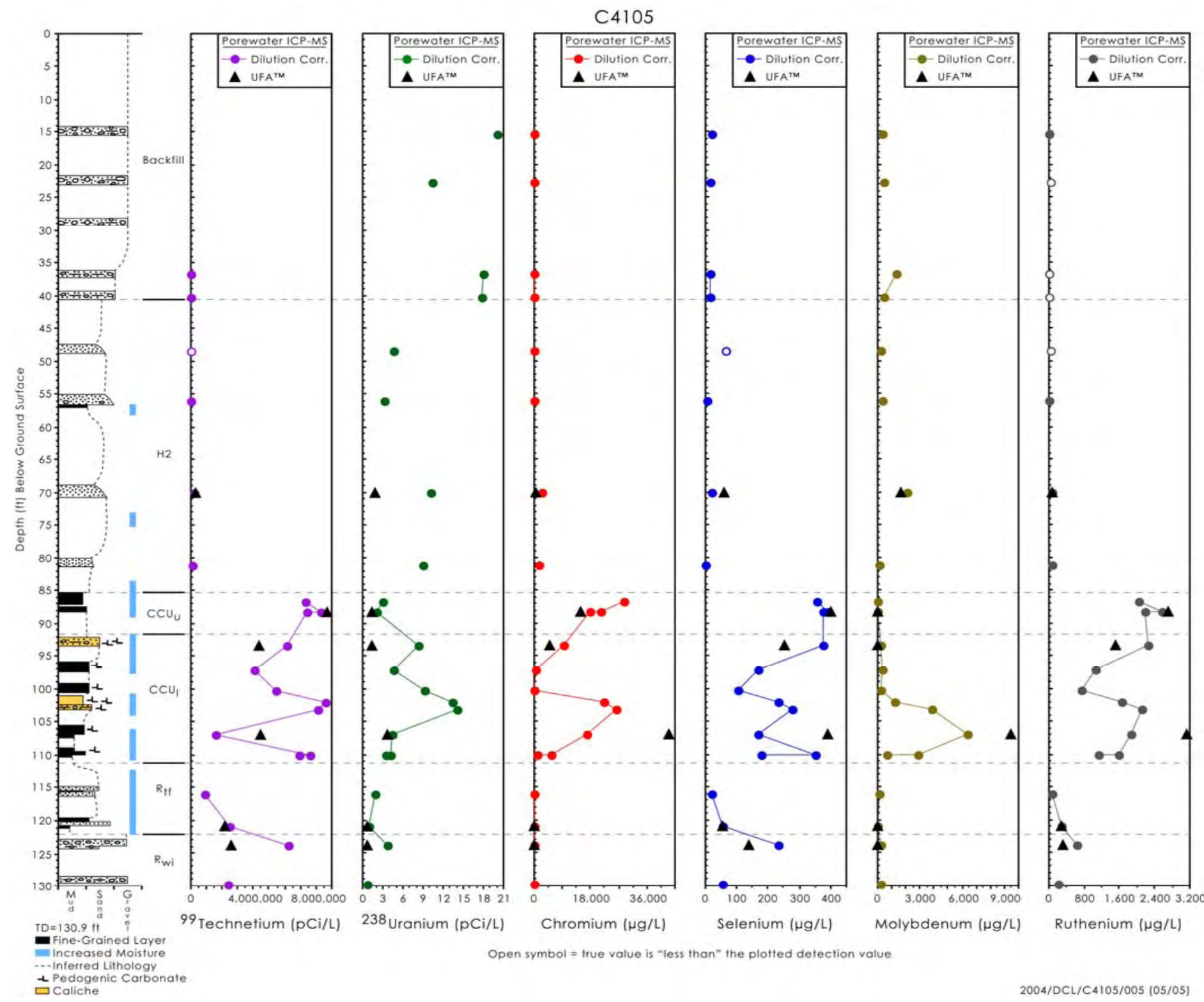

Figure 4.49. Porewater Composition of Mobile Metals in C4105 Vadose Zone Sediments 


\subsubsection{M Nitric Acid-Extractable Amounts of Selected Elements in C4105 Sediments}

The same cores that were characterized for water-extractable constituents were also characterized to see how much of various constituents could be leached with hot $8 \mathrm{M}$ nitric acid. A comparison between the quantities that are acid extractable with those that are water extractable often indicates the relative mobility of a given constituent and can sometimes differentiate man-disposed from naturally occurring constituents. Finally, a comparison of the acid-extractable quantities in suspected contaminated sediments with acid-extractable amounts in uncontaminated sediments can be used to delineate the presence of less mobile contaminants.

The quantities of various constituents in the C4105 vadose zone sediments that were acid extractable are shown in Tables 4.52 to 4.55 and Figures 4.50 through 4.53. Upon comparing the acid extract data for borehole C4105 with similar lithologies in the uncontaminated borehole 299-W10-27, most of the variation in mass leached per gram of sediment versus depth in found to be lithology related. That is, for most major constituents there are no signs of elevated values of acid-leachable constituents in borehole C4105 sediments, excepting acid-extractable sodium in the backfill, one elevated acid-extractable calcium value at $81.2 \mathrm{ft}$ bgs near the bottom of the Hanford $\mathrm{H} 2$ unit, and sulfate throughout the profile. The high acid-extractable sodium in the shallow background sediments suggests some waste was released on the sediment surface or from pipelines. The elevated calcium near the bottom of the Hanford H2 unit may indicate that the ion exchange front from the tank waste plume has reached this borehole at this depth. The high sulfate throughout the sediment profile is confusing although the tank leak did contain sulfate. However, elevated concentrations should not be seen in the entire sediment profile. Elevated sulfate was also observed throughout the C4104 sediment profile so perhaps some of the high sulfate may be a localized natural phenomenon.

For the mobile fission products technetium-99, molybdenum, and ruthenium, the acid extracts show elevated concentrations at C4105 borehole from 86.7 to $130 \mathrm{ft}$ bgs (the bottom of the borehole), 93.3 to 110, and 86.7 to $110 \mathrm{ft}$ bgs, respectively.

Figure 4.54 shows that the vast majority of the sediment phosphate content is not water extractable in comparison with the amounts that are acid extractable. The same trend was observed for the uncontaminated sediments from boreholes 299-W10-27 and from contaminated C4104 sediments. Alternatively, some of the acid-extractable phosphorous may be present in a form other than phosphate such that when we convert the acid-extractable phosphorous number to phosphate (essentially multiplying by 3), we are inflating the acid-extractable value. Some of the sulfate that is acid extractable is also water extractable.

As mentioned, the ratio of water-extractable to acid-extractable quantities of constituents can identify samples that may contain leaked fluids from Hanford waste disposals. The comparison of the water to acid-extractable quantities of each constituent was performed by taking the data in Tables 4.45 through 4.47 and dividing by the data in Tables 4.52 through 4.55 . The data are not presented herein but show distinct regions where the water to acid extractable percentages are much larger than found for uncontaminated borehole (299-W10-27) sediments. For the uncontaminated sediments, less than $0.1 \%$ of the acid-extractable quantities of the following elements are water leachable: aluminum, barium, iron, manganese, chromium, and $\mathrm{P}$ as phosphate. Less than $0.5 \%$ of the acid-extractable quantities of the following elements are water leachable: calcium, potassium, magnesium, strontium, zinc, and uranium. Less than $20 \%$ of the acid-extractable sodium, sulfur, and molybdenum are water extractable in uncontaminated sediments. 
The comparison of water to acid extracts for borehole C4105 sediments suggests that there are unnaturally high percentages [i.e., Tc-99: 60 to 100\%; Mo: 3 to 50\%; Ru: 30 to 85\%] of water-leachable technetium-99, molybdenum, and ruthenium at depths of between 70 to 121,70 to 110 , and 87 to $121 \mathrm{ft}$ bgs ft bgs, respectively.

There is also high water-extractable sodium, sulfate, and chromium in the Cold Creek upper subunit and the bottom of the Cold Creek lower subunit. In both depth zones the percentage of water- to acidleachable concentrations for these species ranges from 15 to 30\% while in most other depth regions less than a few percent of these species is water leachable. The water- to acid-extractable uranium percentages for the C4105 sediments do not show any high values (all are $<1 \%$ ) such that we do not believe there is measurable quantities of tank derived uranium in the C4105 sediments.

The acid-extractable concentrations of major cations in the sediments at C4105 show significantly less sodium than the sediments at C4104 as would be expected if the tank leak fluids were interacting with the sediments and sodium were to get incorporated into or onto the sediments in a form that readily dissolves in strong acid. Both ion exchangeable and secondary mineral sodium would dissolve in the strong acid. There also appears to be slightly less acid soluble phosphate in the C4105 sediments than the C4104 sediments, suggesting that phosphate present in the T-106 tank fluid that leaked deposited measurable amounts in the vicinity of C4104. With the exception of the acid extract for C4104 sediments at $63.4 \mathrm{ft}$ bgs in the Hanford formation $\mathrm{H} 2$ unit, which has significantly higher values for zinc, copper and vanadium, there are no significant differences between the acid-extractable concentrations of most other metals between the two boreholes' sediments. A comparison of the acid-extractable, potentially mobile fission products technetium-99, chromium, molybdenum, ruthenium, and uranium shows that there is elevated technetium-99 values shallow in the Hanford formation H2 unit at C4104 that do not occur at C4105. There is higher acid-extractable uranium and chromium in sediments at C4104 than at C4105. There are also larger concentrations of acid extractable molybdenum between 58 and $64 \mathrm{ft}$ bgs in the C4104 sediments than found in the C4105 sediments. These comparisons suggest that a portion of the truly mobile constituents such as technetium-99 descended deeper from the tank bottom near C4104 while another portion spread out horizontally towards C4105 sediments. Other water extract data suggests that the Cold Creek upper subunit was the stratum that promoted most of the horizontal migration. Uranium must be interacting quite significantly with the sediments because it is not observed at elevated concentrations at C4105. Some interaction is also indicated for chromium and molybdenum because acid-extractable concentrations are less at C4105, which is farther from the leak source. 
Table 4.52. Acid-Extractable Cations from C4105 Vadose Zone Sediments ( $\mu$ g/g dry sediment)

\begin{tabular}{|c|c|c|c|c|c|c|c|c|}
\hline Sample No. & Depth (ft bgs) & $\begin{array}{c}\text { Stratigraphic } \\
\text { Unit }\end{array}$ & Mg & $\mathbf{C a}$ & $\mathrm{Sr}$ & Ba & $\mathrm{Na}$ & $\mathbf{K}$ \\
\hline $1 \mathrm{~A}$ & 15.3 & Bkfl & $3.73 E+03$ & $7.03 E+03$ & $2.88 \mathrm{E}+01$ & $6.86 \mathrm{E}+01$ & $-\quad-\quad-$ & $7.27 E+02$ \\
\hline $2 \mathrm{~A}$ & 22.7 & Bkfl & $4.25 E+03$ & $8.04 \mathrm{E}+03$ & $3.61 \mathrm{E}+01$ & $1.20 \mathrm{E}+02$ & $-\quad-$ & $9.93 \mathrm{E}+02$ \\
\hline $3 \mathrm{~A}$ & 36.8 & Bkfl & $4.32 E+03$ & $9.09 E+03$ & $3.94 \mathrm{E}+01$ & $1.21 \mathrm{E}+02$ & $-\quad-\quad-$ & $1.03 E+03$ \\
\hline $4 \mathrm{~A}$ & 40.2 & Bkfl & $4.95 \mathrm{E}+03$ & $1.03 E+04$ & $4.01 \mathrm{E}+01$ & $1.53 \mathrm{E}+02$ & $-\quad-\quad-$ & $1.30 \mathrm{E}+03$ \\
\hline $5 \mathrm{~A}$ & 48.4 & $\mathrm{H} 2$ & $4.67 \mathrm{E}+03$ & $8.66 \mathrm{E}+03$ & $3.27 \mathrm{E}+01$ & $7.06 \mathrm{E}+01$ & $-\quad-$ & $1.09 \mathrm{E}+03$ \\
\hline $6 \mathrm{~A}$ & 56.1 & $\mathrm{H} 2$ & $3.94 \mathrm{E}+03$ & $8.16 \mathrm{E}+03$ & $2.89 \mathrm{E}+01$ & $6.16 \mathrm{E}+01$ & $-\quad-\quad-$ & $8.03 E+02$ \\
\hline $7 \mathrm{~A}$ & 70.1 & $\mathrm{H} 2$ & $4.65 E+03$ & $9.35 E+03$ & $3.67 \mathrm{E}+01$ & $5.74 \mathrm{E}+01$ & $-\quad-\quad-$ & $1.10 \mathrm{E}+03$ \\
\hline $8 \mathrm{~A}$ & 81.2 & $\mathrm{H} 2$ & $5.52 \mathrm{E}+03$ & $2.22 \mathrm{E}+04$ & $6.20 \mathrm{E}+01$ & $7.11 \mathrm{E}+01$ & $-\quad-\quad-$ & $1.23 E+03$ \\
\hline $9 \mathrm{~A}$ & 86.7 & $\mathrm{CCU}_{\mathrm{u}}$ & $7.37 \mathrm{E}+03$ & $1.42 \mathrm{E}+04$ & 4.13E+01 & $1.28 \mathrm{E}+02$ & $-\quad-$ & $2.09 \mathrm{E}+03$ \\
\hline $10 \mathrm{~A}$ & 88.2 & $\mathrm{CCU}_{\mathrm{u}}$ & $9.02 \mathrm{E}+03$ & $1.70 \mathrm{E}+04$ & $5.08 \mathrm{E}+01$ & $1.61 \mathrm{E}+02$ & $-\ldots$ & $2.51 E+03$ \\
\hline 10A DUP & 88.2 & $\mathrm{CCU}_{\mathrm{u}}$ & $8.59 E+03$ & $1.53 E+04$ & $4.69 \mathrm{E}+01$ & $1.54 \mathrm{E}+02$ & --- & $2.31 E+03$ \\
\hline $11 \mathrm{~A}$ & 93.3 & $\mathrm{CCU}_{1}$ & $8.14 \mathrm{E}+03$ & $1.97 \mathrm{E}+05$ & $2.89 \mathrm{E}+02$ & $1.32 \mathrm{E}+02$ & $-\quad-$ & $7.11 \mathrm{E}+02$ \\
\hline $12 \mathrm{~A}$ & 97.1 & $\mathrm{CCU}_{1}$ & $9.58 \mathrm{E}+03$ & $6.81 \mathrm{E}+04$ & $2.13 E+02$ & $1.00 \mathrm{E}+02$ & $-\quad-$ & $9.19 E+02$ \\
\hline $13 \mathrm{~A}$ & 100.3 & $\mathrm{CCU}_{1}$ & $5.40 \mathrm{E}+03$ & $3.22 \mathrm{E}+04$ & $1.05 \mathrm{E}+02$ & $8.42 \mathrm{E}+01$ & $-\quad-$ & $1.06 \mathrm{E}+03$ \\
\hline $14 \mathrm{~A}$ & 102.0 & $\mathrm{CCU}_{\mathrm{l}}$ & $1.38 E+04$ & $2.50 \mathrm{E}+05$ & $3.55 \mathrm{E}+02$ & $1.31 \mathrm{E}+02$ & $-\quad-\quad-$ & $6.62 \mathrm{E}+02$ \\
\hline $15 \mathrm{~A}$ & 103.2 & $\mathrm{CCU}_{\mathrm{l}}$ & $1.32 \mathrm{E}+04$ & $2.10 \mathrm{E}+05$ & $3.68 \mathrm{E}+02$ & $1.33 \mathrm{E}+02$ & $-\quad-\quad-$ & $8.58 \mathrm{E}+02$ \\
\hline $16 \mathrm{~A}$ & 106.9 & $\mathrm{CCU}_{\mathrm{l}}$ & $1.32 \mathrm{E}+04$ & $2.47 \mathrm{E}+04$ & $7.34 \mathrm{E}+01$ & $1.16 \mathrm{E}+02$ & $-\quad-$ & $1.84 \mathrm{E}+03$ \\
\hline $17 \mathrm{~A}$ & 110.0 & $\mathrm{CCU}_{1}$ & $6.26 \mathrm{E}+03$ & $6.70 \mathrm{E}+03$ & $3.65 \mathrm{E}+01$ & $7.96 \mathrm{E}+01$ & - . - - & $1.20 \mathrm{E}+03$ \\
\hline 17A DUP & 110.0 & $\mathrm{CCU}_{1}$ & $6.27 \mathrm{E}+03$ & $5.19 \mathrm{E}+03$ & $3.32 \mathrm{E}+01$ & $8.02 \mathrm{E}+01$ & - - - - & $1.10 \mathrm{E}+03$ \\
\hline $18 \mathrm{~A}$ & 116.0 & $\mathrm{R}_{\mathrm{tf}}$ & $9.76 \mathrm{E}+03$ & $1.52 \mathrm{E}+04$ & $4.58 \mathrm{E}+01$ & $1.10 \mathrm{E}+02$ & - - - - & $1.92 \mathrm{E}+03$ \\
\hline $19 \mathrm{~A}$ & 120.9 & $\mathrm{R}_{\mathrm{tf}}$ & $9.83 E+03$ & $1.52 \mathrm{E}+04$ & $5.29 \mathrm{E}+01$ & $1.13 \mathrm{E}+02$ & $-\quad-\quad-$ & $2.07 E+03$ \\
\hline $20 \mathrm{~A}$ & 123.9 & $\mathrm{R}_{\mathrm{wi}}$ & $8.29 \mathrm{E}+03$ & $2.61 \mathrm{E}+04$ & $5.92 \mathrm{E}+01$ & $1.07 \mathrm{E}+02$ & $-\ldots$ & $1.82 \mathrm{E}+03$ \\
\hline $21 \mathrm{~A}$ & 129.8 & $\mathrm{R}_{\mathrm{wi}}$ & $5.05 E+03$ & $6.14 \mathrm{E}+03$ & $3.47 \mathrm{E}+01$ & $8.52 \mathrm{E}+01$ & 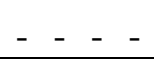 & $1.74 \mathrm{E}+03$ \\
\hline
\end{tabular}


Table 4.53. Acid-Extractable Constituents in C4105 Vadose Zone Sediments ( $\mu \mathrm{g} / \mathrm{g}$ dry sediment)

\begin{tabular}{|c|c|c|c|c|c|c|c|}
\hline Sample No. & Depth (ft bgs) & $\begin{array}{c}\text { Stratigraphic } \\
\text { Unit }\end{array}$ & Al & $\mathbf{F e}$ & Mn & $\mathrm{P}$ as $\mathrm{PO}_{4}$ & $\mathrm{~S}$ as $\mathrm{SO}_{4}$ \\
\hline $1 \mathrm{~A}$ & 15.3 & Bkfl & $6.42 \mathrm{E}+03$ & $1.79 \mathrm{E}+04$ & $2.68 \mathrm{E}+02$ & $3.13 E+03$ & $6.57 \mathrm{E}+02$ \\
\hline $2 \mathrm{~A}$ & 22.7 & Bkfl & $8.26 \mathrm{E}+03$ & $2.24 \mathrm{E}+04$ & $2.68 \mathrm{E}+02$ & $3.19 \mathrm{E}+03$ & $7.53 \mathrm{E}+02$ \\
\hline $3 \mathrm{~A}$ & 36.8 & Bkfl & $9.52 \mathrm{E}+03$ & $2.29 \mathrm{E}+04$ & $2.88 \mathrm{E}+02$ & $2.87 \mathrm{E}+03$ & $8.20 \mathrm{E}+02$ \\
\hline $4 \mathrm{~A}$ & 40.2 & Bkfl & $8.77 \mathrm{E}+03$ & $2.38 E+04$ & $3.34 \mathrm{E}+02$ & $3.16 \mathrm{E}+03$ & $1.01 \mathrm{E}+03$ \\
\hline $5 \mathrm{~A}$ & 48.4 & $\mathrm{H} 2$ & $7.37 \mathrm{E}+03$ & $1.63 \mathrm{E}+04$ & $2.57 \mathrm{E}+02$ & $2.25 \mathrm{E}+03$ & $6.91 \mathrm{E}+02$ \\
\hline $6 \mathrm{~A}$ & 56.1 & $\mathrm{H} 2$ & $6.17 \mathrm{E}+03$ & $1.68 \mathrm{E}+04$ & $2.28 \mathrm{E}+02$ & $2.81 \mathrm{E}+03$ & $6.82 \mathrm{E}+02$ \\
\hline $7 \mathrm{~A}$ & 70.1 & $\mathrm{H} 2$ & $7.48 \mathrm{E}+03$ & $1.55 \mathrm{E}+04$ & $2.82 \mathrm{E}+02$ & $1.77 \mathrm{E}+03$ & $6.91 \mathrm{E}+02$ \\
\hline $8 \mathrm{~A}$ & 81.2 & $\mathrm{H} 2$ & $8.06 \mathrm{E}+03$ & $1.59 \mathrm{E}+04$ & $2.68 \mathrm{E}+02$ & $1.79 \mathrm{E}+03$ & $1.62 \mathrm{E}+03$ \\
\hline $9 \mathrm{~A}$ & 86.7 & $\mathrm{CCU}_{\mathrm{u}}$ & $1.42 \mathrm{E}+04$ & $1.94 \mathrm{E}+04$ & $4.32 \mathrm{E}+02$ & $1.85 \mathrm{E}+03$ & $1.20 \mathrm{E}+03$ \\
\hline $10 \mathrm{~A}$ & 88.2 & $\mathrm{CCU}_{\mathrm{u}}$ & $1.76 \mathrm{E}+04$ & $2.30 \mathrm{E}+04$ & $5.09 \mathrm{E}+02$ & $1.81 \mathrm{E}+03$ & $1.39 \mathrm{E}+03$ \\
\hline 10A DUP & 88.2 & $\mathrm{CCU}_{\mathrm{u}}$ & $1.49 \mathrm{E}+04$ & $2.12 \mathrm{E}+04$ & $4.81 \mathrm{E}+02$ & $1.92 \mathrm{E}+03$ & $1.30 \mathrm{E}+03$ \\
\hline $11 \mathrm{~A}$ & 93.3 & $\mathrm{CCU}_{1}$ & $8.06 \mathrm{E}+03$ & $1.11 \mathrm{E}+04$ & $1.58 \mathrm{E}+02$ & $1.25 \mathrm{E}+03$ & $1.28 \mathrm{E}+04$ \\
\hline $12 \mathrm{~A}$ & 97.1 & $\mathrm{CCU}_{1}$ & $9.97 \mathrm{E}+03$ & $1.53 \mathrm{E}+04$ & $2.40 \mathrm{E}+02$ & $1.48 \mathrm{E}+03$ & $4.48 \mathrm{E}+03$ \\
\hline $13 \mathrm{~A}$ & 100.3 & $\mathrm{CCU}_{1}$ & $1.03 \mathrm{E}+04$ & $1.42 \mathrm{E}+04$ & $2.19 \mathrm{E}+02$ & $1.28 \mathrm{E}+03$ & $2.22 \mathrm{E}+03$ \\
\hline $14 \mathrm{~A}$ & 102.0 & $\mathrm{CCU}_{1}$ & $6.09 \mathrm{E}+03$ & $7.19 \mathrm{E}+03$ & $8.08 \mathrm{E}+01$ & $8.61 \mathrm{E}+02$ & $1.56 \mathrm{E}+04$ \\
\hline $15 \mathrm{~A}$ & 103.2 & $\mathrm{CCU}_{1}$ & $7.14 \mathrm{E}+03$ & $9.27 \mathrm{E}+03$ & $1.31 \mathrm{E}+02$ & $9.97 \mathrm{E}+02$ & $1.40 \mathrm{E}+04$ \\
\hline $16 \mathrm{~A}$ & 106.9 & $\mathrm{CCU}_{\mathrm{l}}$ & $1.72 \mathrm{E}+04$ & $2.35 E+04$ & $5.29 \mathrm{E}+02$ & $1.98 \mathrm{E}+03$ & $2.53 \mathrm{E}+03$ \\
\hline $17 \mathrm{~A}$ & 110.0 & $\mathrm{CCU}_{\mathrm{l}}$ & $1.03 \mathrm{E}+04$ & $1.68 \mathrm{E}+04$ & $3.29 \mathrm{E}+02$ & $1.35 \mathrm{E}+03$ & $5.96 \mathrm{E}+02$ \\
\hline 17A DUP & 110.0 & $\mathrm{CCU}_{\mathrm{l}}$ & $9.67 \mathrm{E}+03$ & $1.67 \mathrm{E}+04$ & $3.36 \mathrm{E}+02$ & $1.34 \mathrm{E}+03$ & $5.13 \mathrm{E}+02$ \\
\hline $18 \mathrm{~A}$ & 116.0 & $\mathrm{R}_{\mathrm{tf}}$ & $1.63 \mathrm{E}+04$ & $2.43 \mathrm{E}+04$ & $6.07 \mathrm{E}+02$ & $1.89 \mathrm{E}+03$ & $1.00 \mathrm{E}+03$ \\
\hline $19 \mathrm{~A}$ & 120.9 & $\mathrm{R}_{\mathrm{tf}}$ & $1.70 \mathrm{E}+04$ & $2.58 \mathrm{E}+04$ & $5.72 \mathrm{E}+02$ & $2.13 E+03$ & $1.03 \mathrm{E}+03$ \\
\hline $20 \mathrm{~A}$ & 123.9 & $\mathrm{R}_{\mathrm{wi}}$ & $1.64 \mathrm{E}+04$ & $2.20 \mathrm{E}+04$ & $4.41 \mathrm{E}+02$ & $2.57 \mathrm{E}+03$ & $1.74 \mathrm{E}+03$ \\
\hline $21 \mathrm{~A}$ & 129.8 & $\mathrm{R}_{\mathrm{wi}}$ & $9.89 \mathrm{E}+03$ & $1.64 \mathrm{E}+04$ & $2.54 \mathrm{E}+02$ & $1.77 \mathrm{E}+03$ & $4.69 \mathrm{E}+02$ \\
\hline
\end{tabular}


Table 4.54. Acid-Extractable Trace Metals in C4105 Vadose Zone Sediments

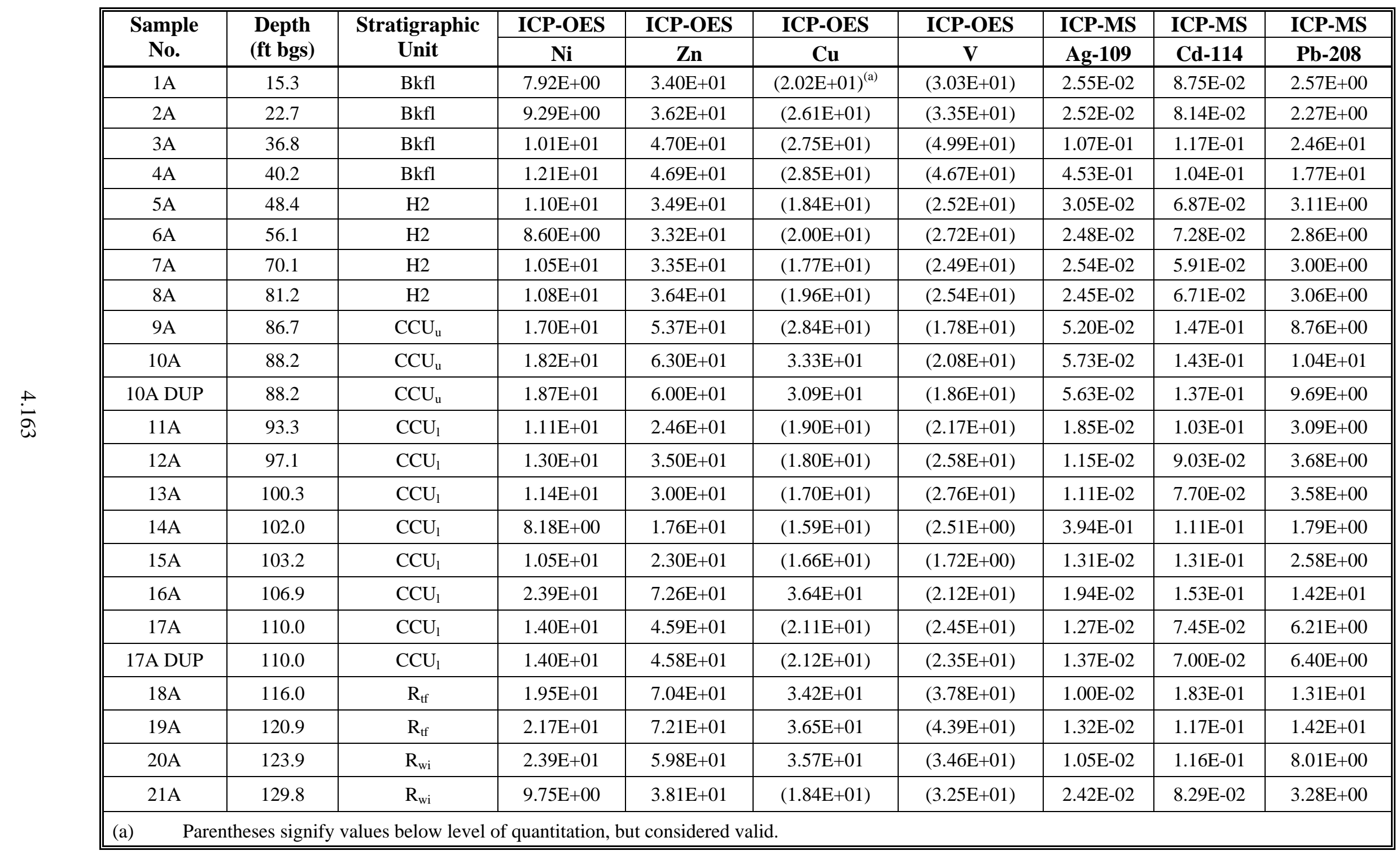


Table 4.55. Acid-Extractable Mobile Trace Metals in C4105 Vadose Zone Sediments

\begin{tabular}{|c|c|c|c|c|c|c|c|c|c|c|c|c|c|}
\hline \multirow{2}{*}{$\begin{array}{c}\text { Sample } \\
\text { No. }\end{array}$} & \multirow{2}{*}{$\begin{array}{c}\begin{array}{c}\text { Depth } \\
\text { (ft } \\
\text { bgs) }\end{array} \\
\end{array}$} & \multirow{2}{*}{$\begin{array}{c}\text { Stratigraphic } \\
\text { Unit }\end{array}$} & ICP-MS & ICP-MS & ICP-MS & ICP-OES & ICP-MS & ICP-MS & ICP-MS & ICP-OES & ICP-MS & ICP-MS & ICP-MS \\
\hline & & & Tc 99 & U 238 & Cr 52 & $\mathrm{Cr}$ & Mo 95 & Mo 98 & Mo 100 & Mo & Ru 101 & Ru 102 & Ru 104 \\
\hline $1 \mathrm{~A}$ & 15.3 & Bkfl & $(0.00 \mathrm{E}+00)^{(\mathrm{a})}$ & 4.76E-01 & $1.18 \mathrm{E}+01$ & $1.08 \mathrm{E}+01$ & $1.19 \mathrm{E}+00$ & $1.09 \mathrm{E}+00$ & $5.01 \mathrm{E}-01$ & $\mathrm{ND}^{(\mathrm{b})}$ & $<5.67 \mathrm{E}-02$ & (5.39E-03) & (1.19E-02) \\
\hline $2 \mathrm{~A}$ & 22.7 & Bkfl & $<4.68 \mathrm{E}+01$ & 4.16E-01 & $3.39 \mathrm{E}+01$ & $3.22 \mathrm{E}+01$ & $4.20 \mathrm{E}+00$ & $3.86 \mathrm{E}+00$ & $1.82 \mathrm{E}+00$ & $1.62 \mathrm{E}+00$ & $<5.52 \mathrm{E}-02$ & (1.44E-03) & (1.03E-02) \\
\hline $3 \mathrm{~A}$ & 36.8 & Bkfl & $(0.00 \mathrm{E}+00)$ & 4.21E-01 & $2.54 \mathrm{E}+01$ & $2.27 \mathrm{E}+01$ & $6.09 \mathrm{E}+00$ & $5.60 \mathrm{E}+00$ & $2.61 \mathrm{E}+00$ & $3.57 \mathrm{E}+00$ & $<6.04 \mathrm{E}-02$ & $(3.14 \mathrm{E}-03)$ & $1.53 \mathrm{E}-02$ \\
\hline $4 \mathrm{~A}$ & 40.2 & Bkfl & $(0.00 \mathrm{E}+00)$ & 4.46E-01 & $2.67 \mathrm{E}+01$ & $2.30 \mathrm{E}+01$ & $7.08 \mathrm{E}+00$ & $6.48 \mathrm{E}+00$ & $3.02 \mathrm{E}+00$ & $4.20 \mathrm{E}+00$ & $<6.01 \mathrm{E}-02$ & (2.89E-03) & $(1.50 \mathrm{E}-02)$ \\
\hline $5 \mathrm{~A}$ & 48.4 & $\mathrm{H} 2$ & $<4.28 \mathrm{E}+01$ & 4.38E-01 & $1.14 \mathrm{E}+01$ & $1.05 \mathrm{E}+01$ & 4.23E-01 & 3.79E-01 & 1.76E-01 & ND & $(0.00 \mathrm{E}+00)$ & (5.55E-03) & $1.32 \mathrm{E}-02$ \\
\hline $6 \mathrm{~A}$ & 56.1 & $\mathrm{H} 2$ & $(9.00 \mathrm{E}-01)$ & 4.04E-01 & $8.34 \mathrm{E}+00$ & $7.07 \mathrm{E}+00$ & $2.90 \mathrm{E}-01$ & 2.53E-01 & $1.29 \mathrm{E}-01$ & ND & (5.89E-03) & $(9.29 \mathrm{E}-03)$ & $1.57 \mathrm{E}-02$ \\
\hline $7 \mathrm{~A}$ & 70.1 & $\mathrm{H} 2$ & $(1.10 \mathrm{E}+01)$ & $3.68 \mathrm{E}-01$ & $1.27 \mathrm{E}+01$ & $1.15 \mathrm{E}+01$ & 5.82E-01 & 4.11E-01 & $3.52 \mathrm{E}-01$ & ND & $(1.72 \mathrm{E}-02)$ & $(1.60 \mathrm{E}-02)$ & 2.48E-02 \\
\hline $8 \mathrm{~A}$ & 81.2 & $\mathrm{H} 2$ & $(8.56 \mathrm{E}+00)$ & $5.14 \mathrm{E}-01$ & $1.26 \mathrm{E}+01$ & $1.18 \mathrm{E}+01$ & 2.79E-01 & 2.44E-01 & 1.19E-01 & ND & $(1.45 \mathrm{E}-02)$ & $(1.88 \mathrm{E}-02)$ & 3.35E-02 \\
\hline $9 \mathrm{~A}$ & 86.7 & $\mathrm{CCU}_{\mathrm{u}}$ & $1.06 \mathrm{E}+03$ & 6.79E-01 & $2.45 \mathrm{E}+01$ & $2.23 \mathrm{E}+01$ & 2.58E-01 & $2.25 \mathrm{E}-01$ & $1.04 \mathrm{E}-01$ & ND & $3.41 \mathrm{E}-01$ & $1.63 \mathrm{E}-01$ & $1.69 \mathrm{E}-01$ \\
\hline $10 \mathrm{~A}$ & 88.2 & $\mathrm{CCU}_{\mathrm{u}}$ & $7.34 \mathrm{E}+02$ & 7.17E-01 & $2.34 \mathrm{E}+01$ & $2.18 \mathrm{E}+01$ & $2.40 \mathrm{E}-01$ & 2.04E-01 & $9.20 \mathrm{E}-02$ & ND & 3.59E-01 & $1.73 \mathrm{E}-01$ & 1.83E-01 \\
\hline 10A DUP & 88.2 & $\mathrm{CCU}_{\mathrm{u}}$ & $1.87 \mathrm{E}+03$ & 6.60E-01 & $2.52 \mathrm{E}+01$ & $2.39 \mathrm{E}+01$ & 2.29E-01 & 2.00E-01 & $9.12 \mathrm{E}-02$ & ND & 4.84E-01 & 2.29E-01 & 2.40E-01 \\
\hline $11 \mathrm{~A}$ & 93.3 & $\mathrm{CCU}_{1}$ & $1.38 \mathrm{E}+03$ & 8.49E-01 & $1.50 \mathrm{E}+01$ & $1.35 \mathrm{E}+01$ & 4.18E-01 & $3.77 \mathrm{E}-01$ & $1.80 \mathrm{E}-01$ & ND & 4.47E-01 & $3.24 \mathrm{E}-01$ & 3.52E-01 \\
\hline $12 \mathrm{~A}$ & 97.1 & $\mathrm{CCU}_{1}$ & $5.41 \mathrm{E}+02$ & 8.42E-01 & $1.56 \mathrm{E}+01$ & $1.39 \mathrm{E}+01$ & $4.30 \mathrm{E}-01$ & $3.91 \mathrm{E}-01$ & $1.77 \mathrm{E}-01$ & ND & $1.14 \mathrm{E}-01$ & $(7.74 \mathrm{E}-02)$ & $1.34 \mathrm{E}-01$ \\
\hline $13 \mathrm{~A}$ & 100.3 & $\mathrm{CCU}_{\mathrm{l}}$ & $6.13 \mathrm{E}+02$ & 7.04E-01 & $1.28 \mathrm{E}+01$ & $1.16 \mathrm{E}+01$ & $3.47 \mathrm{E}-01$ & 3.15E-01 & $1.45 \mathrm{E}-01$ & ND & 6.36E-02 & (3.90E-02) & 6.37E-02 \\
\hline $14 \mathrm{~A}$ & 102.0 & $\mathrm{CCU}_{1}$ & $5.57 \mathrm{E}+02$ & $1.93 \mathrm{E}+00$ & $1.07 \mathrm{E}+01$ & $9.62 \mathrm{E}+00$ & $6.55 \mathrm{E}-01$ & 4.65E-01 & 4.02E-01 & ND & $2.01 \mathrm{E}-01$ & 2.66E-01 & 2.71E-01 \\
\hline $15 \mathrm{~A}$ & 103.2 & $\mathrm{CCU}_{\mathrm{l}}$ & $7.64 \mathrm{E}+02$ & $1.69 \mathrm{E}+00$ & $1.40 \mathrm{E}+01$ & $1.32 \mathrm{E}+01$ & $1.59 \mathrm{E}+00$ & $1.15 \mathrm{E}+00$ & $9.74 \mathrm{E}-01$ & ND & 2.99E-01 & 2.69E-01 & 3.25E-01 \\
\hline $16 \mathrm{~A}$ & 106.9 & $\mathrm{CCU}_{\mathrm{l}}$ & $8.17 \mathrm{E}+02$ & $1.02 \mathrm{E}+00$ & $3.20 \mathrm{E}+01$ & $3.16 \mathrm{E}+01$ & $3.67 \mathrm{E}+00$ & $2.38 \mathrm{E}+00$ & $2.46 \mathrm{E}+00$ & ND & 7.62E-01 & 3.76E-01 & 3.85E-01 \\
\hline $17 \mathrm{~A}$ & 110.0 & $\mathrm{CCU}_{\mathrm{l}}$ & $5.75 \mathrm{E}+02$ & 4.93E-01 & $1.55 \mathrm{E}+01$ & $1.55 \mathrm{E}+01$ & 4.79E-01 & 3.90E-01 & 2.45E-01 & ND & 1.32E-01 & (6.13E-02) & 7.16E-02 \\
\hline 17A DUP & 110.0 & $\mathrm{CCU}_{\mathrm{l}}$ & $4.48 \mathrm{E}+02$ & 3.78E-01 & $1.63 \mathrm{E}+01$ & $1.52 \mathrm{E}+01$ & 5.43E-01 & 4.29E-01 & 2.83E-01 & ND & 1.33E-01 & $(5.81 \mathrm{E}-02)$ & 7.11E-02 \\
\hline $18 \mathrm{~A}$ & 116.0 & $\mathrm{R}_{\mathrm{tf}}$ & $9.59 \mathrm{E}+01$ & 8.16E-01 & $1.65 \mathrm{E}+01$ & $1.50 \mathrm{E}+01$ & 3.83E-01 & 3.37E-01 & $1.51 \mathrm{E}-01$ & ND & $(1.05 \mathrm{E}-02)$ & (4.35E-03) & $1.74 \mathrm{E}-02$ \\
\hline $19 \mathrm{~A}$ & 120.9 & $\mathrm{R}_{\mathrm{tf}}$ & $5.73 \mathrm{E}+02$ & 8.76E-01 & $1.89 \mathrm{E}+01$ & $1.76 \mathrm{E}+01$ & 3.89E-01 & 3.45E-01 & $1.54 \mathrm{E}-01$ & ND & 7.47E-02 & (3.55E-02) & $5.18 \mathrm{E}-02$ \\
\hline $20 \mathrm{~A}$ & 123.9 & $\mathrm{R}_{\mathrm{wi}}$ & $5.44 \mathrm{E}+02$ & 7.51E-01 & $2.14 \mathrm{E}+01$ & $2.20 \mathrm{E}+01$ & $2.58 \mathrm{E}-01$ & 2.25E-01 & 1.03E-01 & ND & (5.27E-02) & (2.57E-02) & $3.94 \mathrm{E}-02$ \\
\hline $21 \mathrm{~A}$ & 129.8 & $\mathrm{R}_{\mathrm{wi}}$ & $4.44 \mathrm{E}+02$ & 3.56E-01 & $1.09 \mathrm{E}+01$ & $1.03 \mathrm{E}+01$ & 4.72E-01 & 4.22E-01 & $1.89 \mathrm{E}-01$ & ND & (3.06E-02) & (1.07E-02) & 2.45E-02 \\
\hline & & & & & & & & & & & & & \\
\hline
\end{tabular}



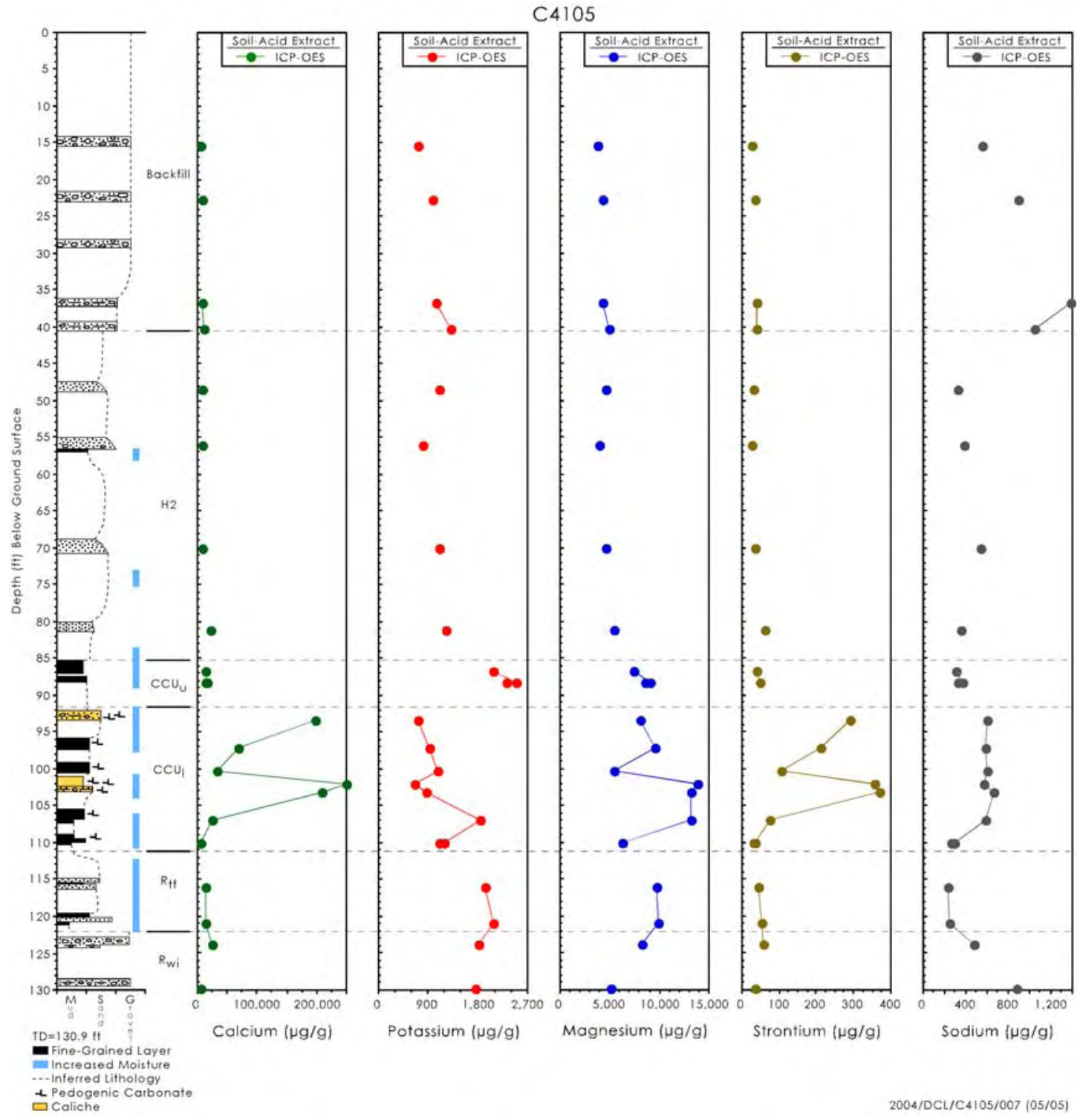

Figure 4.50. Acid-Extractable Cations in C4105 Vadose Zone Sediments ( $\mu \mathrm{g} / \mathrm{g}$ dry sediment) 


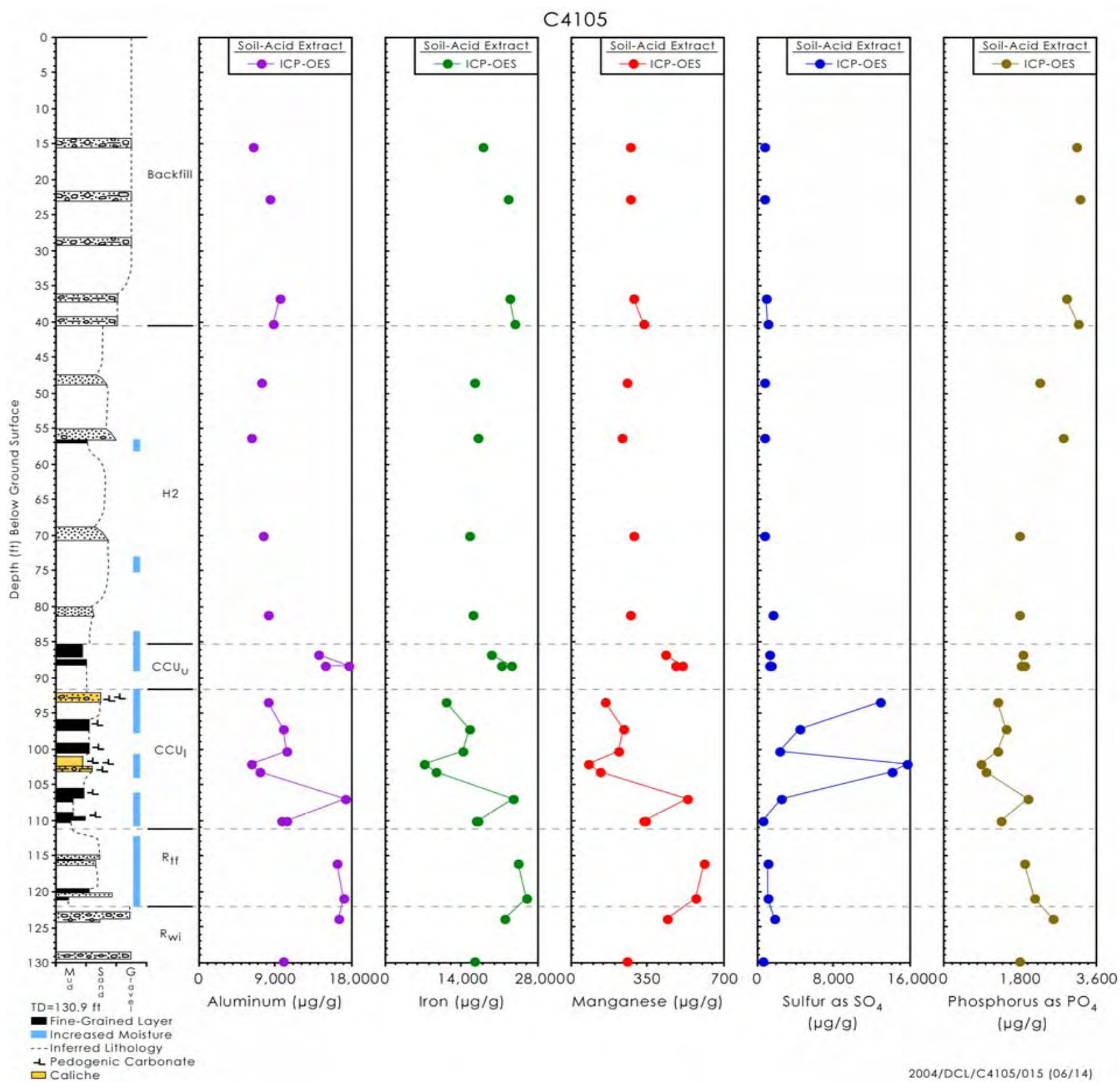

Figure 4.51. Acid-Extractable Metals in C3832 Vadose Zone Sediments ( $\mu$ g/g dry sediment) 


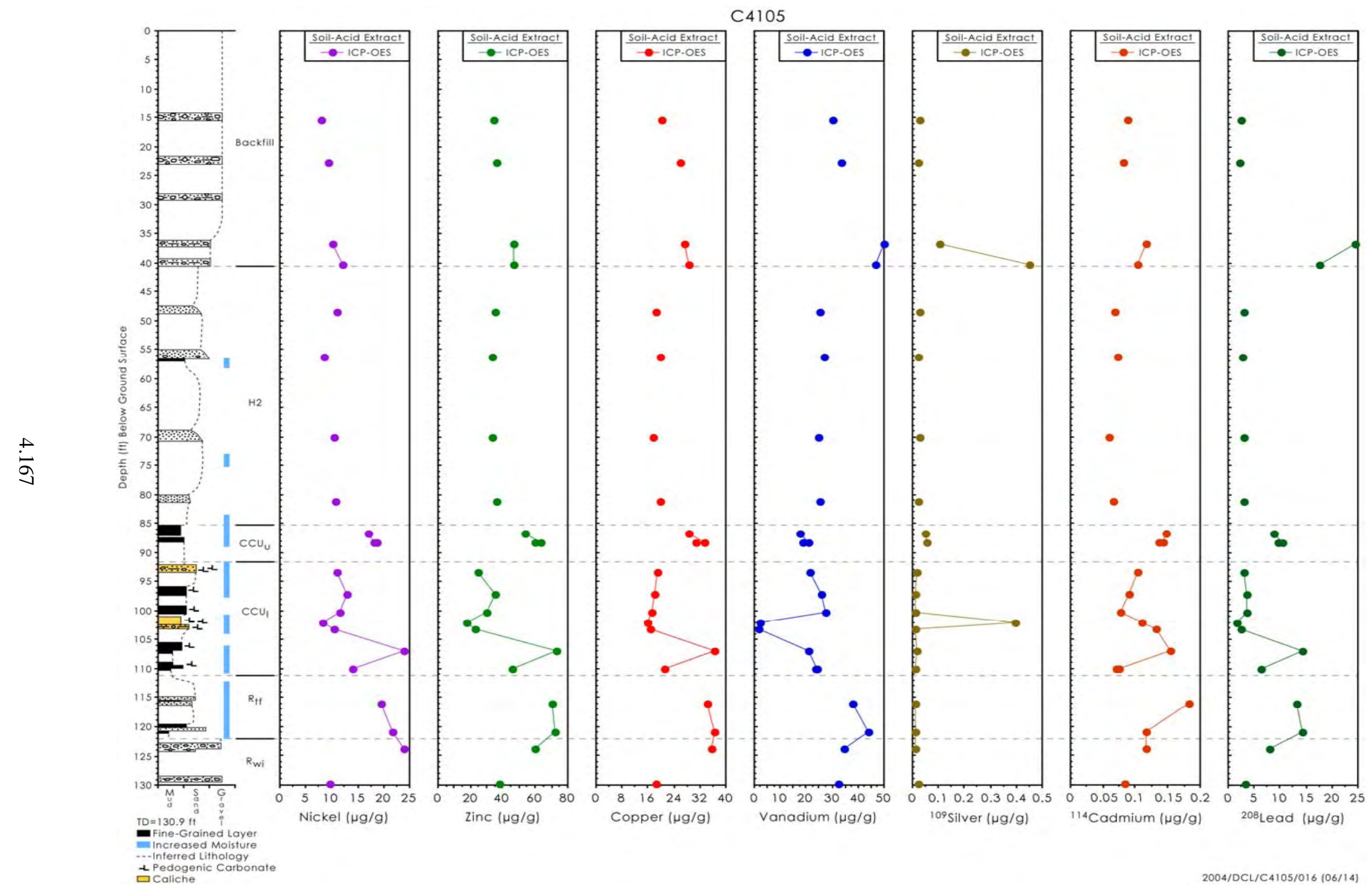

Figure 4.52. Acid-Extractable Trace Metals in C4105 Vadose Zone Sediments ( $\mu \mathrm{g} / \mathrm{g})$ 

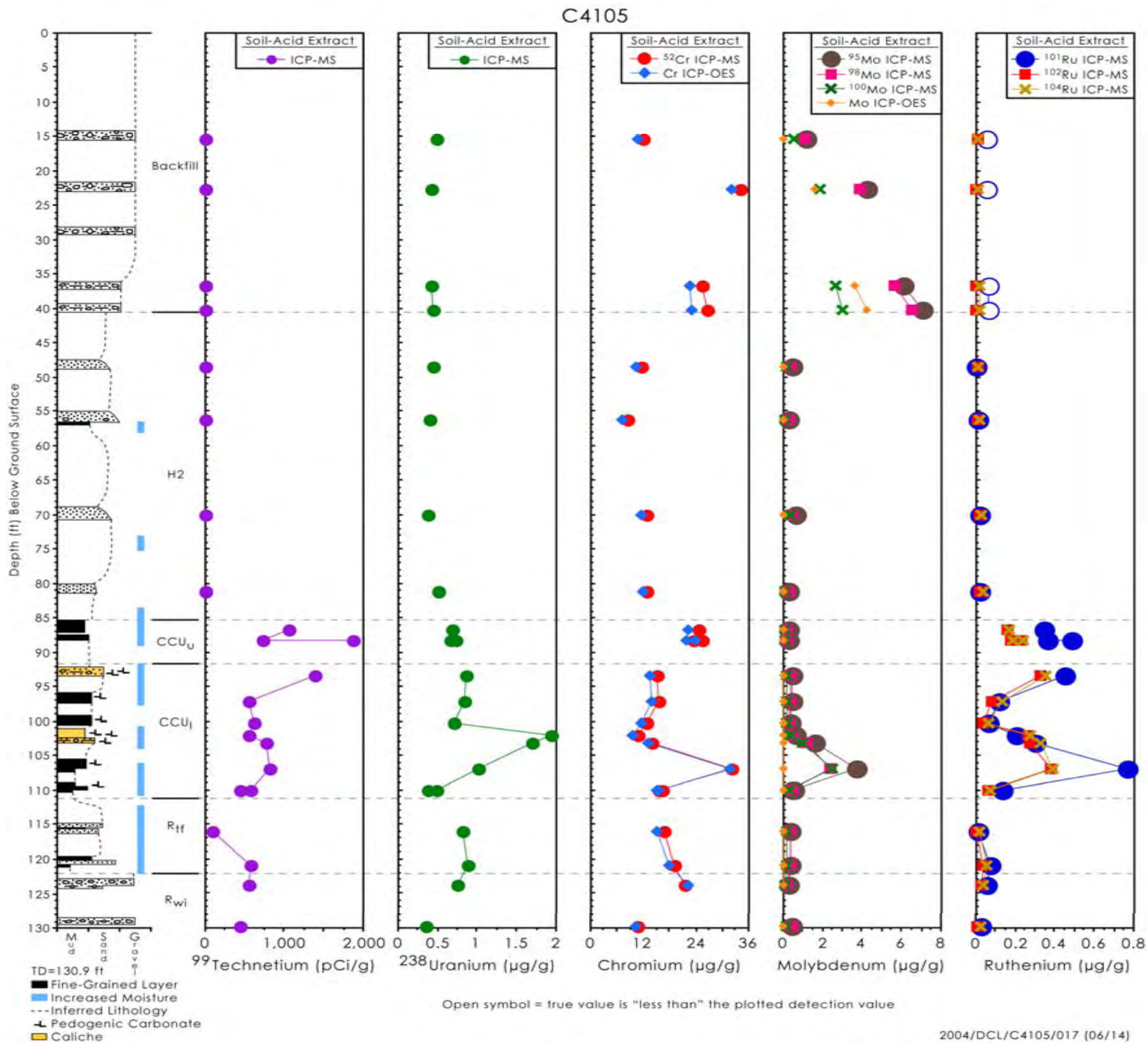

t Pedogenic Carbona

Open symbol = true value is "less than" the plotted detection value

Figure 4.53. Acid-Extractable Mobile Trace Metals in C4105 Vadose Zone Sediments (units vary) 


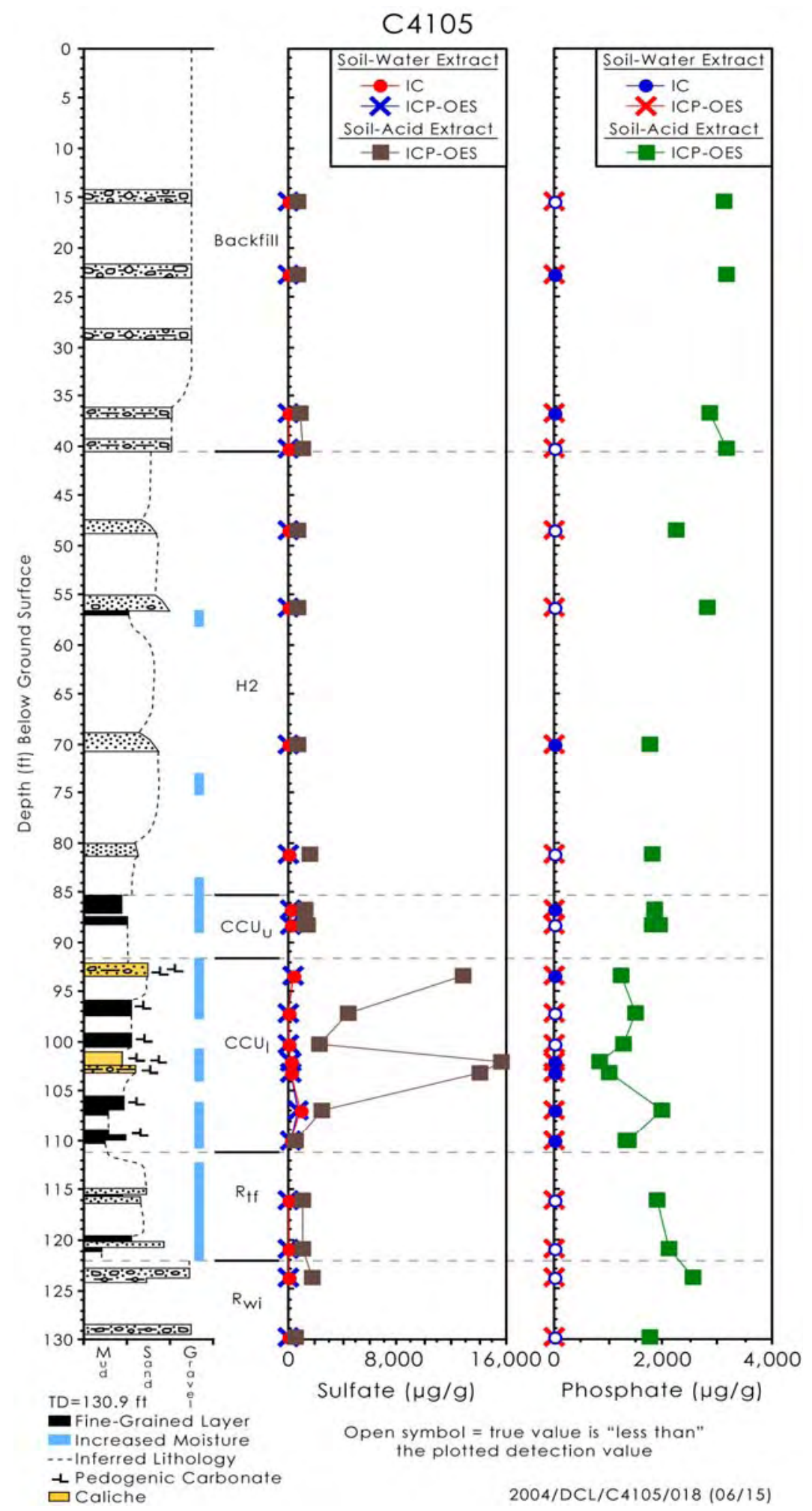

Figure 4.54. Water- versus Acid-Extractable Sulfates and Phosphate in C4105 Vadose Zone Sediments 


\subsubsection{Radionuclide Content in Vadose Zone Sediment from C4105}

Aside from the technetium-99 and uranium-238 data already presented, our gamma energy analyses of sediment from the C4105 "B core liners" found low concentrations of cobalt-60, cesium-137, and europium-155 (one value above detection limit) as tabulated in Table 4.56 and shown in Figure 4.55. Only the cobalt is present at concentrations high enough above background to identify a vertical distribution. Based on the field gamma log, cobalt-60 is present from 57 to $112 \mathrm{ft}$ bgs. The vertical extent of the cobalt-60 is defined by the contact between the Cold Creek lower subunit and the Ringold Formation Taylor Flat member. The field spectral gamma data suggests that our sparse sampling in the lower Hanford formation $\mathrm{H} 2$ unit (only three cores were obtained between 57 and $87 \mathrm{ft}$ bgs) may cause us to underestimate horizontal migration of tank leak fluids in the Hanford formation H2 unit and overemphasize the horizontal migration in the Cold Creek subunit. The cobalt-60 activities found in the C4105 sediments is 10 times lower than in the sediments from C4104 suggesting either some dilution occurs in the porewater or some adsorption occurs in the sediments as the plume travels between these boreholes. More discussion on cobalt-60 mobility is found in Section 6.6.

Aside from a small amount of surface cesium-137 contamination in the first 5 feet of backfill there are only three "random" places in the vertical profile where the field spectral gamma tool registered cesium-137 signal above background. The lab detector was able to measure cesium-137 with greater sensitivity but as shown in Figure 4.55 there is no trend to the lab data and all values are $<0.2 \mathrm{pCi} / \mathrm{g}$. The field logging and lab results for potassium-40 and uranium-238 show excellent agreement and the uranium data suggests that there is insignificant activities of Hanford tank leak uranium in C4105 sediments as suggested with the water and acid extract data.

Gross alpha and beta measurement were made on both the 1:1 sediment:water and sediment:acid extracts. With knowledge of the mass of dry sediment to extraction fluid used the data were converted to activity of gross beta and alpha leached per gram of dry sediment. None of the water or acid extracts of the C4105 showed gross alpha activities significantly greater than the detection limits for the procedure. For the total alpha analyses the detection limit for both extracts was 5 to $10 \mathrm{pCi} / \mathrm{g}$ dry sediment.

The total beta data for the acid and water extracts were significantly greater than the detection limit for samples from $86.7 \mathrm{ft}$ bgs to the bottom of the borehole, which is what was observed for the technetium-99 data. The comparison of the values in Table 4.57 show that the two independent measurement techniques track each other but the total beta values for the water extracts are somewhat higher than the direct measurement of technetium-99. Conversely, the acid extract total beta values are in general slightly lower than the ICP-MS direct measurement of technetium-99.

No detectable (above background values) strontium-90 was found in the acid extracts from the "A liner” samples from borehole C4105 sediments. 


\subsubsection{Total Carbon, Calcium Carbonate, and Organic Carbon Content of Vadose Zone Sediment from Borehole C4105}

The total, inorganic, and organic carbon contents of the C4105 sediments are reported in Table 4.58. The lower Cold Creek subunit (caliche) samples obtained between 93.3 to 97.1 and 102 to $103 \mathrm{ft}$ bgs contain significant amounts of calcium-carbonate equivalent material with 16 to $60 \%$ by weight. The sediment from the upper Cold Creek subunit and the deepest sample of Hanford H2 sediment at $81.2 \mathrm{ft}$ bgs also contain about $3 \%$ by weight calcium-carbonate content. As found in most vadose sediments from the Hanford Reservation, there is very little $(<0.1 \%$ by weight) organic carbon in the vadose zone sediments, excepting the sediments with the highest calcium carbonate content. These samples are difficult to measure for organic carbon so that values as high as $0.3 \%$ by weight are likely not accurate.

The caliche at borehole C4105 corresponds quite well to the high values (quantity) and depth of occurrence as the data from borehole C4104. This suggests that the caliche lenses are fairly continuous between these two boreholes. 
Table 4.56. Gamma Emitter Concentrations in Vadose Zone Sediments in Borehole C4105 (pCi/g)

\begin{tabular}{|c|c|c|c|c|c|c|c|}
\hline Sample No. & $\begin{array}{c}\text { Depth } \\
\text { (ft bgs) }\end{array}$ & $\begin{array}{c}\text { Stratigraphic } \\
\text { Unit }\end{array}$ & K-40 & Co-60 & Cs-137 & Eu-155 & U-238 \\
\hline $1 \mathrm{~B}$ & 14.5 & Bkfl & 9.65 & $<0.0374$ & 0.078 & $<0.149$ & $<0.78$ \\
\hline 2B & 22.0 & Bkfl & 10.24 & $<0.0316$ & $<0.0373$ & $<0.15$ & 2.33 \\
\hline $5 \mathrm{~B}$ & 47.7 & $\mathrm{H} 2$ & 18.11 & $<0.0354$ & $<0.0429$ & $<0.142$ & $<1.05$ \\
\hline $6 B$ & 55.4 & $\mathrm{H} 2$ & 11.26 & 0.283 & 0.033 & $<0.15$ & $<0.69$ \\
\hline $7 \mathrm{~B}$ & 69.3 & $\mathrm{H} 2$ & 18.25 & 3.989 & 0.039 & $<0.158$ & $<1.10$ \\
\hline $8 B$ & 80.5 & $\mathrm{H} 2$ & 16.48 & 1.071 & 0.095 & $<0.166$ & 2.05 \\
\hline $9 B$ & 85.8 & $\mathrm{CCU}_{\mathrm{u}}$ & 22.26 & 0.453 & 0.028 & 0.265 & $<1.06$ \\
\hline $10 \mathrm{~B}$ & 87.5 & $\mathrm{CCU}_{\mathrm{u}}$ & 18.89 & 0.659 & $<0.0467$ & $<0.167$ & 2.18 \\
\hline $11 \mathrm{~B}$ & 92.6 & $\mathrm{CCU}_{\mathrm{l}}$ & 12.80 & 2.707 & 0.121 & $<0.199$ & 2.20 \\
\hline $12 \mathrm{~B}$ & 96.4 & $\mathrm{CCU}_{1}$ & 11.48 & 0.555 & 0.039 & $<0.184$ & 6.58 \\
\hline $13 B$ & 99.7 & $\mathrm{CCU}_{\mathrm{l}}$ & 12.95 & 0.171 & 0.064 & $<0.194$ & $<1.09$ \\
\hline 13B DUP & 99.7 & $\mathrm{CCU}_{\mathrm{l}}$ & 12.95 & 0.164 & 0.041 & $<0.171$ & 1.66 \\
\hline $14 \mathrm{~B}$ & 101.4 & $\mathrm{CCU}_{1}$ & 4.41 & 1.307 & 0.044 & $<0.162$ & $<1.31$ \\
\hline $15 B$ & 102.5 & $\mathrm{CCU}_{\mathrm{l}}$ & 6.58 & 1.646 & 0.044 & $<0.205$ & $<1.42$ \\
\hline $16 \mathrm{~B}$ & 106.2 & $\mathrm{CCU}_{\mathrm{l}}$ & 12.03 & 6.910 & 0.061 & $<0.23$ & 3.01 \\
\hline 17B & 109.4 & $\mathrm{CCU}_{1}$ & 19.23 & 5.452 & $<0.0668$ & $<0.242$ & 2.39 \\
\hline 17B DUP & 109.4 & $\mathrm{CCU}_{\mathrm{l}}$ & 18.83 & 5.279 & 0.114 & $<0.19$ & $<1.20$ \\
\hline 18B & 115.3 & $\mathrm{CCU}_{\mathrm{l}}$ & 18.05 & 0.743 & 0.067 & $<0.179$ & 2.45 \\
\hline 19B & 120.2 & $\mathrm{R}_{\mathrm{tf}}$ & 13.17 & $<0.0344$ & 0.028 & $<0.139$ & $<1.01$ \\
\hline $20 \mathrm{~B}$ & 123.2 & $\mathrm{R}_{\mathrm{tf}}$ & 7.72 & 0.077 & 0.035 & $<0.154$ & $<0.87$ \\
\hline $21 B$ & 129.2 & $\mathrm{R}_{\mathrm{wi}}$ & 30.26 & $<0.06$ & 0.071 & $<0.217$ & 2.72 \\
\hline
\end{tabular}




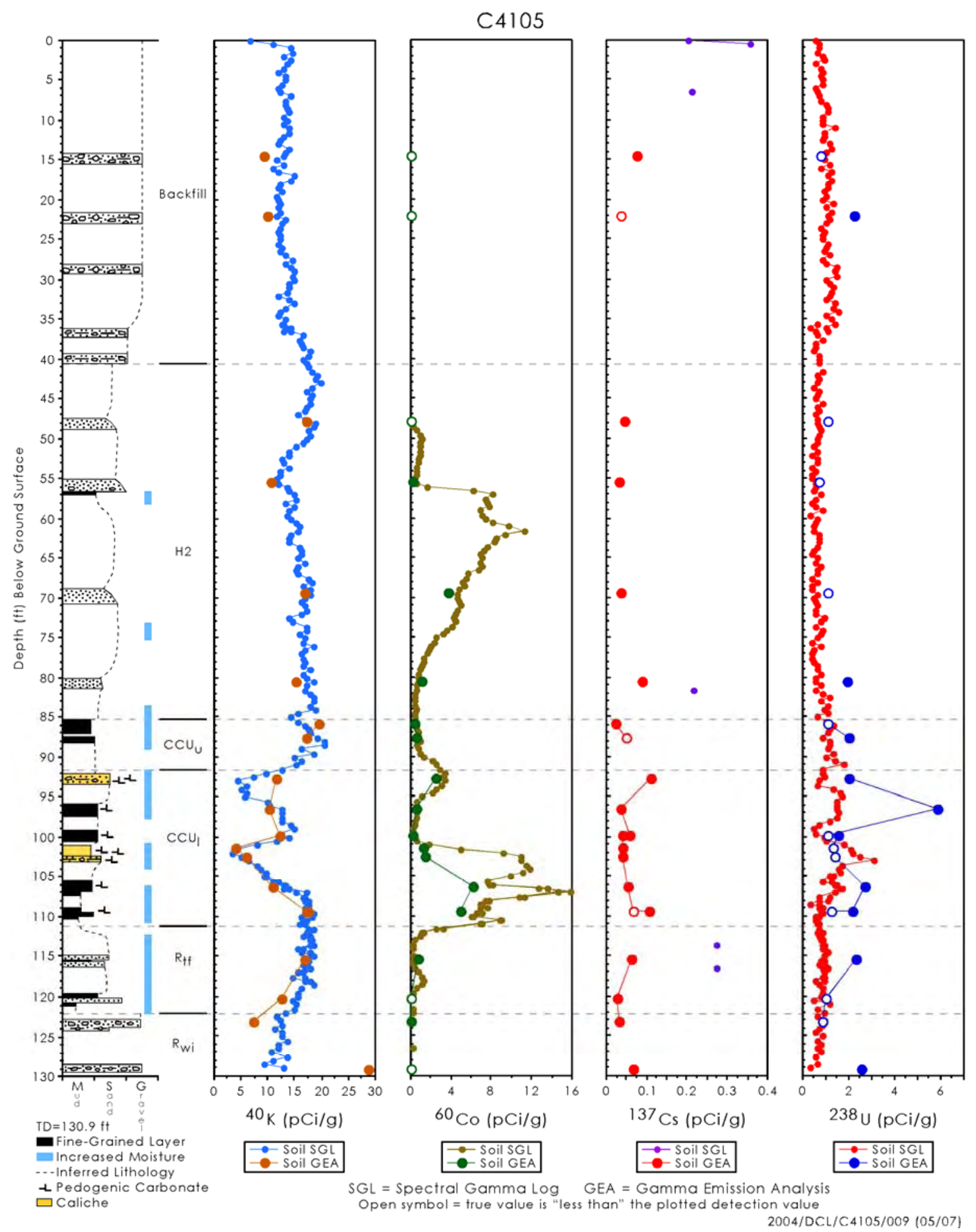

Figure 4.55. Comparison of Lab Gamma Energy Analysis (GEA) and Field Log for Natural Gamma Emitters 
Table 4.57. Total Beta Comparison to Technetium-99 Measurements in Water and Acid Extracts in Vadose Zone Sediments in Borehole C4105 (pCi/g)

\begin{tabular}{||c|c|c|c|c|c|c||}
\hline \hline \multirow{2}{*}{ Sample No. } & \multirow{2}{*}{ Depth (ft bgs) } & Stratigraphic Unit & \multicolumn{2}{c|}{ Water Extract } & \multicolumn{2}{c||}{ Acid Extract } \\
\cline { 4 - 7 } & 15.3 & $\mathrm{Tkfl}$ & $0.00 \mathrm{E}+00$ & $3.34 \mathrm{E}+00$ & $0.00 \mathrm{E}+00$ & $1.46 \mathrm{E}+01$ \\
\hline $1 \mathrm{~A}$ & 22.7 & $\mathrm{Bkfl}$ & $0.00 \mathrm{E}+00$ & $4.03 \mathrm{E}+00$ & $4.68 \mathrm{E}+01$ & $1.05 \mathrm{E}+01$ \\
\hline $2 \mathrm{~A}$ & 36.8 & $\mathrm{Bkfl}$ & $1.70 \mathrm{E}-02$ & $4.51 \mathrm{E}+00$ & $0.00 \mathrm{E}+00$ & $9.88 \mathrm{E}+00$ \\
\hline $3 \mathrm{~A}$ & 40.2 & $\mathrm{Bkfl}$ & $5.09 \mathrm{E}-02$ & $3.89 \mathrm{E}+00$ & $0.00 \mathrm{E}+00$ & $1.73 \mathrm{E}+01$ \\
\hline $4 \mathrm{~A}$ & 48.4 & $\mathrm{H} 2$ & $1.70 \mathrm{E}-01$ & $5.99 \mathrm{E}+00$ & $4.28 \mathrm{E}+01$ & $9.24 \mathrm{E}+00$ \\
\hline $5 \mathrm{~A}$ & 56.1 & $\mathrm{H} 2$ & $1.02 \mathrm{E}-01$ & $4.26 \mathrm{E}+00$ & $9.00 \mathrm{E}-01$ & $9.12 \mathrm{E}+00$ \\
\hline $6 \mathrm{~A}$ & 70.1 & $\mathrm{H} 2$ & $9.04 \mathrm{E}+00$ & $1.88 \mathrm{E}+01$ & $1.10 \mathrm{E}+01$ & $3.78 \mathrm{E}+01$ \\
\hline $7 \mathrm{~A}$ & 81.2 & $\mathrm{H} 2$ & $6.04 \mathrm{E}+00$ & $2.88 \mathrm{E}+01$ & $8.56 \mathrm{E}+00$ & $1.94 \mathrm{E}+01$ \\
\hline $8 \mathrm{~A}$ & 86.7 & $\mathrm{CCU}_{\mathrm{u}}$ & $1.05 \mathrm{E}+03$ & $1.21 \mathrm{E}+03$ & $1.06 \mathrm{E}+03$ & $7.26 \mathrm{E}+02$ \\
\hline $9 \mathrm{~A}$ & 88.2 & $\mathrm{CCU}_{\mathrm{u}}$ & $1.65 \mathrm{E}+03$ & $1.79 \mathrm{E}+03$ & $7.34 \mathrm{E}+02$ & $5.35 \mathrm{E}+02$ \\
\hline $10 \mathrm{~A}$ & 88.2 & $\mathrm{CCU}_{\mathrm{u}}$ & $1.41 \mathrm{E}+03$ & $1.56 \mathrm{E}+03$ & $1.87 \mathrm{E}+03$ & $1.27 \mathrm{E}+03$ \\
\hline $10 \mathrm{~A} \mathrm{DUP}$ & 93.3 & $\mathrm{CCU}_{\mathrm{l}}$ & $8.12 \mathrm{E}+02$ & $9.96 \mathrm{E}+02$ & $1.38 \mathrm{E}+03$ & $7.99 \mathrm{E}+02$ \\
\hline $11 \mathrm{~A}$ & 97.1 & $\mathrm{CCU}_{\mathrm{l}}$ & $4.97 \mathrm{E}+02$ & $5.02 \mathrm{E}+02$ & $5.41 \mathrm{E}+02$ & $4.85 \mathrm{E}+02$ \\
\hline $12 \mathrm{~A}$ & 100.3 & $\mathrm{CCU}_{\mathrm{l}}$ & $4.07 \mathrm{E}+02$ & $4.10 \mathrm{E}+02$ & $6.13 \mathrm{E}+02$ & $4.97 \mathrm{E}+02$ \\
\hline $13 \mathrm{~A}$ & 102.0 & $\mathrm{CCU}_{\mathrm{l}}$ & $8.21 \mathrm{E}+02$ & $1.07 \mathrm{E}+03$ & $5.57 \mathrm{E}+02$ & $2.92 \mathrm{E}+02$ \\
\hline $14 \mathrm{~A}$ & 103.2 & $\mathrm{CCU}_{\mathrm{l}}$ & $7.83 \mathrm{E}+02$ & $1.32 \mathrm{E}+03$ & $7.64 \mathrm{E}+02$ & $4.42 \mathrm{E}+02$ \\
\hline $15 \mathrm{~A}$ & 106.9 & $\mathrm{CCU}_{\mathrm{l}}$ & $3.94 \mathrm{E}+02$ & $1.43 \mathrm{E}+03$ & $8.17 \mathrm{E}+02$ & $7.53 \mathrm{E}+02$ \\
\hline $16 \mathrm{~A}$ & 110.0 & $\mathrm{CCU}_{\mathrm{l}}$ & $5.12 \mathrm{E}+02$ & $6.60 \mathrm{E}+02$ & $5.75 \mathrm{E}+02$ & $4.52 \mathrm{E}+02$ \\
\hline $17 \mathrm{~A}$ & 110.0 & $\mathrm{CCU}_{\mathrm{l}}$ & $5.44 \mathrm{E}+02$ & $6.47 \mathrm{E}+02$ & $4.48 \mathrm{E}+02$ & $4.28 \mathrm{E}+02$ \\
\hline $17 \mathrm{~A} \mathrm{DUP}$ & 116.0 & $\mathrm{R}_{\mathrm{tf}}$ & $1.94 \mathrm{E}+02$ & $2.02 \mathrm{E}+02$ & $9.59 \mathrm{E}+01$ & $5.95 \mathrm{E}+01$ \\
\hline $18 \mathrm{~A}$ & 120.9 & $\mathrm{R}_{\mathrm{tf}}$ & $6.34 \mathrm{E}+02$ & $6.33 \mathrm{E}+02$ & $5.73 \mathrm{E}+02$ & $3.23 \mathrm{E}+02$ \\
\hline $19 \mathrm{~A}$ & 123.9 & $\mathrm{R}_{\mathrm{wi}}$ & $2.07 \mathrm{E}+02$ & $2.06 \mathrm{E}+02$ & $5.44 \mathrm{E}+02$ & $3.29 \mathrm{E}+02$ \\
\hline $20 \mathrm{~A}$ & $\mathrm{R}_{\mathrm{wi}}$ & $1.23 \mathrm{E}+02$ & $1.22 \mathrm{E}+02$ & $4.44 \mathrm{E}+02$ & $3.18 \mathrm{E}+02$ \\
\hline $21 \mathrm{~A}$ & 129.8 & & & & & \\
\hline
\end{tabular}


Table 4.58. Carbon Contents of Vadose Zone Sediments in Borehole C4105

\begin{tabular}{|c|c|c|c|c|c|c|}
\hline $\begin{array}{c}\text { Sample } \\
\text { No. }\end{array}$ & $\begin{array}{l}\text { Depth } \\
\text { (ft bgs) }\end{array}$ & $\begin{array}{c}\text { Stratigraphic } \\
\text { Unit }\end{array}$ & $\begin{array}{c}\text { Total } \\
\text { Carbon } \\
\%\end{array}$ & $\begin{array}{c}\text { Inorganic } \\
\text { Carbon } \\
\% \\
\end{array}$ & $\begin{array}{c}\mathrm{IC} \text { as } \\
\mathrm{CaCO}_{3} \\
\%\end{array}$ & $\begin{array}{c}\text { Organic } \\
\text { Carbon } \\
\text { (by difference) }\end{array}$ \\
\hline $1 \mathrm{~A}$ & 15.3 & Bkfl & 0.12 & 0.08 & 0.67 & 0.04 \\
\hline $2 \mathrm{~A}$ & 22.7 & Bkfl & 0.15 & 0.07 & 0.58 & 0.08 \\
\hline $3 \mathrm{~A}$ & 36.8 & Bkfl & 0.16 & 0.06 & 0.50 & 0.10 \\
\hline $4 \mathrm{~A}$ & 40.2 & Bkfl & 0.29 & 0.10 & 0.83 & 0.19 \\
\hline $5 \mathrm{~A}$ & 48.4 & $\mathrm{H} 2$ & 0.18 & 0.12 & 1.00 & 0.06 \\
\hline $6 \mathrm{~A}$ & 56.1 & $\mathrm{H} 2$ & 0.16 & 0.10 & 0.83 & 0.06 \\
\hline $7 \mathrm{~A}$ & 70.1 & $\mathrm{H} 2$ & 0.19 & 0.13 & 1.08 & 0.06 \\
\hline $8 \mathrm{~A}$ & 81.2 & $\mathrm{H} 2$ & 0.38 & 0.32 & 2.66 & 0.06 \\
\hline $9 \mathrm{~A}$ & 86.7 & $\mathrm{CCU}_{\mathrm{u}}$ & 0.49 & 0.37 & 3.10 & 0.12 \\
\hline $10 \mathrm{~A}$ & 88.2 & $\mathrm{CCU}_{\mathrm{u}}$ & 0.53 & 0.47 & 3.91 & 0.06 \\
\hline $\begin{array}{l}10 A \\
\text { DUP }\end{array}$ & 88.2 & $\mathrm{CCU}_{\mathrm{u}}$ & 0.51 & 0.40 & 3.29 & 0.11 \\
\hline $11 \mathrm{~A}$ & 93.3 & $\mathrm{CCU}_{\mathrm{l}}$ & 5.41 & 5.22 & 43.47 & 0.19 \\
\hline $12 \mathrm{~A}$ & 97.1 & $\mathrm{CCU}_{1}$ & 2.15 & 1.96 & 16.30 & 0.19 \\
\hline $13 \mathrm{~A}$ & 100.3 & $\mathrm{CCU}_{\mathrm{l}}$ & 0.86 & 0.81 & 6.76 & 0.05 \\
\hline $14 \mathrm{~A}$ & 102.0 & $\mathrm{CCU}_{\mathrm{l}}$ & 7.33 & 7.02 & 58.50 & 0.31 \\
\hline $15 \mathrm{~A}$ & 103.2 & $\mathrm{CCU}_{1}$ & 5.80 & 5.68 & 47.34 & 0.12 \\
\hline $16 \mathrm{~A}$ & 106.9 & $\mathrm{CCU}_{1}$ & 0.82 & 0.71 & 5.95 & 0.11 \\
\hline $17 \mathrm{~A}$ & 110.0 & $\mathrm{CCU}_{\mathrm{l}}$ & 0.13 & 0.12 & 1.00 & 0.01 \\
\hline $\begin{array}{l}17 \mathrm{~A} \\
\text { DUP }\end{array}$ & 110.0 & $\mathrm{CCU}_{1}$ & 0.10 & 0.07 & 0.56 & 0.03 \\
\hline $18 \mathrm{~A}$ & 116.0 & $\mathrm{R}_{\mathrm{tf}}$ & 0.24 & 0.20 & 1.70 & 0.04 \\
\hline $19 \mathrm{~A}$ & 120.9 & $\mathrm{R}_{\mathrm{tf}}$ & 0.45 & 0.37 & 3.07 & 0.08 \\
\hline $20 \mathrm{~A}$ & 123.9 & $\mathrm{R}_{\mathrm{wi}}$ & 0.21 & 0.18 & 1.50 & 0.03 \\
\hline $21 \mathrm{~A}$ & 129.8 & $\mathrm{R}_{\mathrm{wi}}$ & 0.05 & 0.03 & 0.22 & 0.02 \\
\hline
\end{tabular}




\subsubsection{Particle Size Analyses}

Six of the samples from borehole C4105 were characterized for particle size distribution using the hydrometer method described in Section 3.3.8. One sample from each of the major lithologies was characterized as shown in Table 4.59 and plotted in Figure 4.56. The sample of the Hanford unit H2 has the least silt and clay and is predominately sand and gravel. The sample from the Ringold Formation Wooden Island member is also coarse with little silt and clay. The two samples from the Cold Creek lower subunit are fairly coarse also, especially at the top of the subunit where less than $35 \%$ of the mass is $<60$ microns. At the bottom of the Cold Creek lower unit $60 \%$ of the mass is $<60$ microns. The Ringold Formation Taylor Flats member sample is fine grained with $75 \%$ of the mass being $<60$ microns in size. The Cold Creek upper subunit is the finest grained material characterized and had more than $80 \%$ of the mass $<60$ microns in size.

Table 4.59. Particle Size Data for One Sample from Each Major Stratigraphic Unit in Borehole C4105 Sediments

\begin{tabular}{|c|c|c|c|c|c|c|c|c|c|c|c|}
\hline \multirow{2}{*}{$\begin{array}{c}\text { Sample } \\
\begin{array}{c}\text { Depth } \\
\text { (ft bgs) }\end{array}\end{array}$} & \multirow{2}{*}{$\begin{array}{c}\text { 7A } \\
\text { Strat } \\
\text { Unit }\end{array}$} & \multicolumn{2}{|c|}{$10 \mathrm{~A}$} & \multicolumn{2}{|c|}{$11 \mathrm{~A}$} & \multicolumn{2}{|c|}{$16 A$} & \multicolumn{2}{|c|}{ 19A } & \multicolumn{2}{|c|}{$20 \mathrm{~A}$} \\
\hline & & $\begin{array}{c}\text { Depth } \\
\text { (ft bgs) }\end{array}$ & $\begin{array}{l}\text { Strat } \\
\text { Unit }\end{array}$ & $\begin{array}{l}\text { Depth } \\
\text { (ft bgs) }\end{array}$ & $\begin{array}{l}\text { Strat } \\
\text { Unit }\end{array}$ & $\begin{array}{c}\text { Depth } \\
\text { (ft bgs) }\end{array}$ & $\begin{array}{l}\text { Strat } \\
\text { Unit }\end{array}$ & $\begin{array}{l}\text { Depth } \\
\text { (ft bgs) }\end{array}$ & $\begin{array}{l}\text { Strat } \\
\text { Unit }\end{array}$ & $\begin{array}{c}\text { Depth } \\
\text { (ft bgs) }\end{array}$ & $\begin{array}{l}\text { Strat } \\
\text { Unit }\end{array}$ \\
\hline 70.1 & H2 & 88.2 & $\mathbf{C C U}_{\mathbf{u}}$ & 93.3 & $\mathrm{CCU}_{\mathrm{I}}$ & 106.9 & $\mathbf{C C U}_{\mathrm{I}}$ & 120.9 & $\mathbf{R}_{\mathbf{t f}}$ & 123.9 & $\mathbf{R}_{\mathrm{wi}}$ \\
\hline$\mu \mathrm{m}$ & $\begin{array}{c}\% \\
\text { finer } \\
\text { than }\end{array}$ & $\mu \mathrm{m}$ & $\begin{array}{c}\% \% \\
\text { finer } \\
\text { than } \\
\end{array}$ & $\mu \mathrm{m}$ & $\begin{array}{c}\% \\
\text { finer } \\
\text { than }\end{array}$ & $\mu \mathrm{m}$ & $\begin{array}{c}\% \% \\
\text { finer } \\
\text { than }\end{array}$ & $\mu \mathrm{m}$ & $\begin{array}{c}\% \\
\text { finer } \\
\text { than }\end{array}$ & $\mu \mathrm{m}$ & $\begin{array}{c}\% \\
\text { finer } \\
\text { than }\end{array}$ \\
\hline 80.93 & 9.85 & 96.32 & 92.44 & 89.06 & 41.64 & 94.56 & 71.64 & 97.18 & 84.73 & 83.76 & 22.70 \\
\hline 56.71 & 7.22 & 67.02 & 83.96 & 61.79 & 35.03 & 64.95 & 58.96 & 67.63 & 77.23 & 58.72 & 19.77 \\
\hline 32.66 & 6.57 & 38.18 & 77.18 & 35.19 & 30.41 & 36.57 & 48.51 & 38.02 & 65.23 & 33.76 & 18.31 \\
\hline 17.85 & 5.91 & 20.30 & 62.76 & 19.00 & 25.78 & 19.12 & 30.60 & 20.03 & 48.74 & 18.21 & 13.18 \\
\hline 10.26 & 4.60 & 11.32 & 46.65 & 10.93 & 24.46 & 10.72 & 20.15 & 11.17 & 35.24 & 10.39 & 9.52 \\
\hline 7.22 & 3.28 & 7.83 & 38.16 & 7.66 & 22.47 & 7.45 & 14.18 & 7.73 & 26.99 & 7.30 & 7.32 \\
\hline 5.91 & 3.94 & 6.30 & 30.53 & 6.26 & 21.15 & 6.06 & 12.69 & 6.24 & 23.24 & 5.95 & 6.59 \\
\hline 5.09 & 2.63 & 5.44 & 29.68 & 5.38 & 19.83 & 5.20 & 9.70 & 5.37 & 20.99 & 5.14 & 5.86 \\
\hline 1.47 & 3.28 & 1.52 & 16.11 & 1.54 & 16.52 & 1.49 & 6.72 & 1.50 & 9.75 & 1.49 & 6.59 \\
\hline
\end{tabular}


C4105 (70.1 ft - $123.9 \mathrm{ft}$ Below Ground Surface)

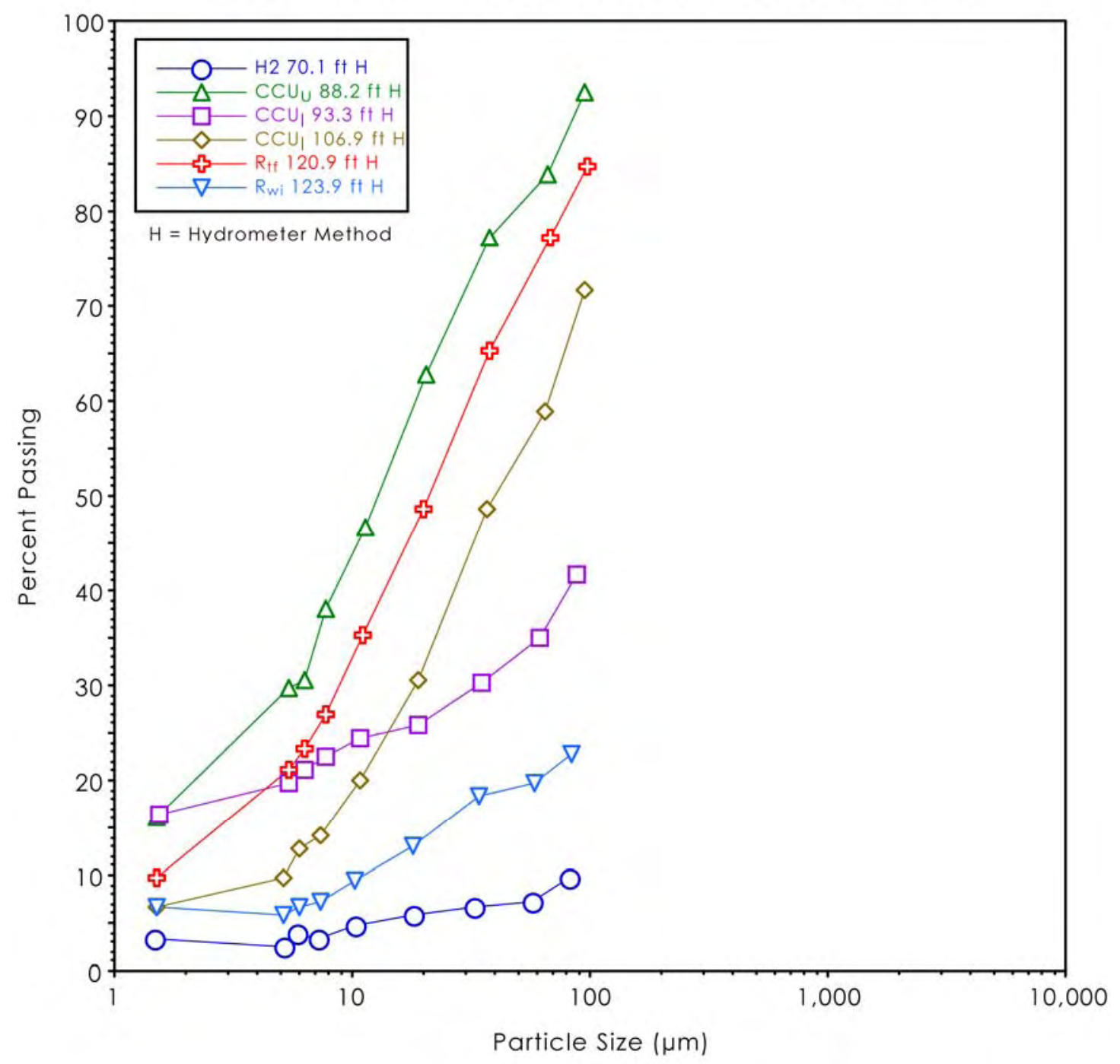

$2004 / D C L / C 4105 / 020(06 / 21)$

Figure 4.56. Particle Size Distribution for Selected Borehole C4105 Sediments

\subsubsection{Mineralogy of C4105 Sediments}

This section discusses the minerals identified in XRD patterns for vadose zone samples collected from borehole C4105. Phase identification was based on a comparison of the peak reflections and intensities observed in each pattern to the mineral Powder Diffraction Files (PDFTM) published by the Joint Committee on Powder Diffraction Standards (JCPDS) International Center for Diffraction Data (ICDD).

Each pattern is shown as a function of degrees $2 \theta$ based on CuK $\alpha$ radiation ( $\lambda=1.5406 \AA$ ). The vertical axis represents the intensity or relative intensity of the XRD peaks. The XRD patterns show for 
comparison purposes one or more schematic database (PDFTM) patterns considered for phase identification. The height of each line in the schematic PDF ${ }^{\mathrm{TM}}$ patterns represents the relative intensity of an XRD peak [i.e., the most intense (the highest) peak has a relative intensity (I/Io) of $100 \%$ ]. A crystalline phase typically must be present at greater than $5 \mathrm{wt} \%$ of the total sample mass (greater than $1 \mathrm{wt} \%$ under optimum conditions) to be readily detected by XRD.

XRD analysis of C4105 borehole samples 7A, 10A, 16A, 19A, and 20A show the sediments are mineralogically similar. The samples are dominated by quartz and feldspar (both plagioclase and alkali-feldspar), with lesser amounts of clay, calcite, and amphibole. Figure 4.57 is an example background subtracted XRD pattern of sample 10A ( $88.2 \mathrm{ft}$ bgs). Intensity for the primary quartz reflection $\left(26.6^{\circ} 2 \theta\right)$ was truncated to increase the pattern detail. All XRD patterns are shown in Appendix C. The main reflection for quartz is at $26.63^{\circ} 2 \theta$, followed by less intense reflections at 20.86, $36.53,39.46,42.43,50.12$, and $59.92^{\circ} 2 \theta$. The main reflections associated with feldspar minerals are between $27.34^{\circ} 2 \theta$ and $27.92^{\circ} 2 \theta$, with the higher $2 \theta$ values belonging to the plagioclase series. Clay minerals were identified on the X-ray tracings by the reflections at $6.3^{\circ} 2 \theta$ and $8.8^{\circ} 2 \theta$ and will be described in detail later in this section. The presence of an amphibole was established by the characteristic $100 \%$ reflection at $10.5^{\circ} 2 \theta$. In addition, minor amounts of calcite were identified in these samples by a diffraction peak positioned at $29.45^{\circ} 2 \theta$.

In contrast, $\mathrm{XRD}$ results from sample $11 \mathrm{~A}$ indicate the sediment is dominated by calcite. The major reflection for calcite $\left(29.40^{\circ} 2 \theta\right)$ dominates the pattern as shown in Figure 4.58. Lesser amounts of quartz, feldspar, amphibole, and clays were also identified by XRD, but at much lower concentrations than in the previously described sediments. The calcite domination is corroborated by the data shown in Table 4.58 for sample 11A.

Results from the semi quantification of the minerals in the bulk samples are provided in Table 4.60.

Quartz concentrations range from 27 to $54 \mathrm{wt} \%$, (excluding 11A) with an average quartz concentration of $38 \pm 10 \mathrm{wt} \%$. Plagioclase feldspar is present at concentrations between 12 to $43 \mathrm{wt} \%$ and potassium feldspar concentrations are between 4 to $15 \mathrm{wt} \%$. Plagioclase feldspar was more abundant than potassium feldspar in all C4105 samples. The amphibole phase comprised $<5 \mathrm{wt} \%$. Calcite concentrations measured $55 \mathrm{wt} \%$ in sample $11 \mathrm{~A}$, with all other samples having $<4 \mathrm{wt} \%$. Clay minerals, consisting primarily of a $6.3^{\circ} 2 \theta$ reflection (chlorite and smectite) as well as the $8.8^{\circ} 2 \theta$ reflection (mica), make up between 8 and $32 \mathrm{wt} \%$ of the sediment samples.

Table 4.60. Whole Rock Quantitative XRD Results Determined by JADE Whole Pattern Fitting on Sediment Samples Collected From Borehole C4105. Results are given in wt\%.

\begin{tabular}{|c|c|c|c|c|c|c|c||}
\hline $\begin{array}{c}\text { Sample } \\
\text { ID }\end{array}$ & $\begin{array}{c}\text { Depth } \\
\text { (ft bgs) }\end{array}$ & \multicolumn{1}{c}{ Quartz } & \multicolumn{2}{c|}{ Plagioclase } & \multicolumn{2}{c|}{ Microcline } & \multicolumn{2}{c|}{ Amphibole } & Calcite & $\begin{array}{c}\text { Clay } \\
\text { Minerals }\end{array}$ \\
\hline \hline 7A & 70.1 & 34 & 39 & 15 & 2 & 1 & 8 \\
\hline 10A & 88.2 & 41 & 17 & 6 & 4 & 2 & 29 \\
\hline 11A & 93.3 & 11 & 18 & 7 & $<1$ & 55 & 10 \\
\hline 16A & 106.9 & 35 & 19 & 6 & 5 & 3 & 33 \\
\hline 19A & 120.9 & 54 & 12 & 4 & $<1$ & 2 & 28 \\
\hline 20A & 123.9 & 27 & 43 & 12 & 4 & 4 & 11 \\
\hline
\end{tabular}


Detailed XRD examination of the clay fraction from each sediment sample (except 11A) was conducted and the results are presented below. XRD tracings of the Mg-saturated air dried and Mg-saturated ethylene glycol solvated $<2.0 \mu \mathrm{m}$ fractions are shown in Appendix C. The clay fraction is dominated by four clay minerals: smectite, chlorite, illite, and kaolinite with minor amounts of quartz and feldspar.

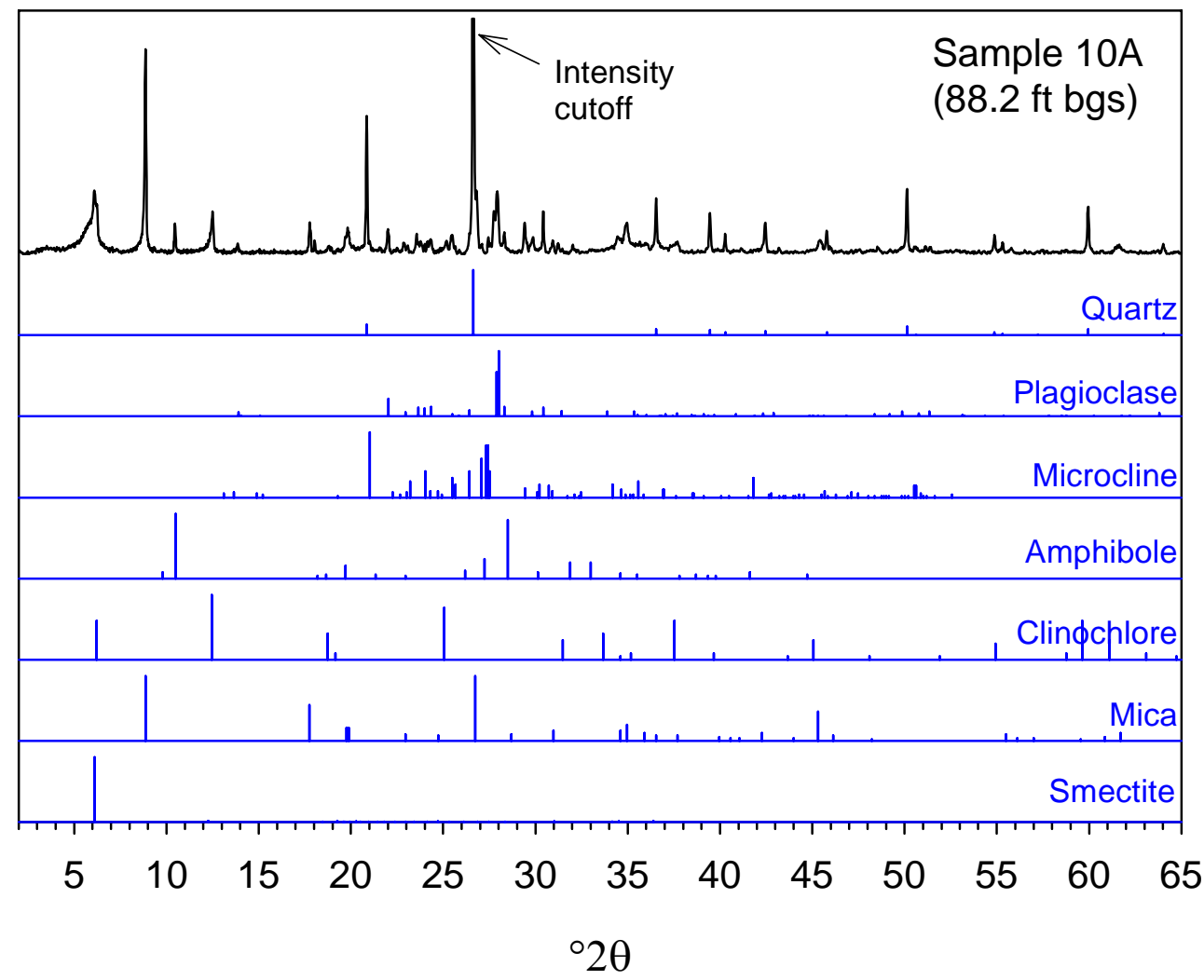

Figure 4.57. XRD Tracing for Sediment Sample 10A (88.2 ft bgs) Collected From Borehole C4105, With Matching PDFTM Files 


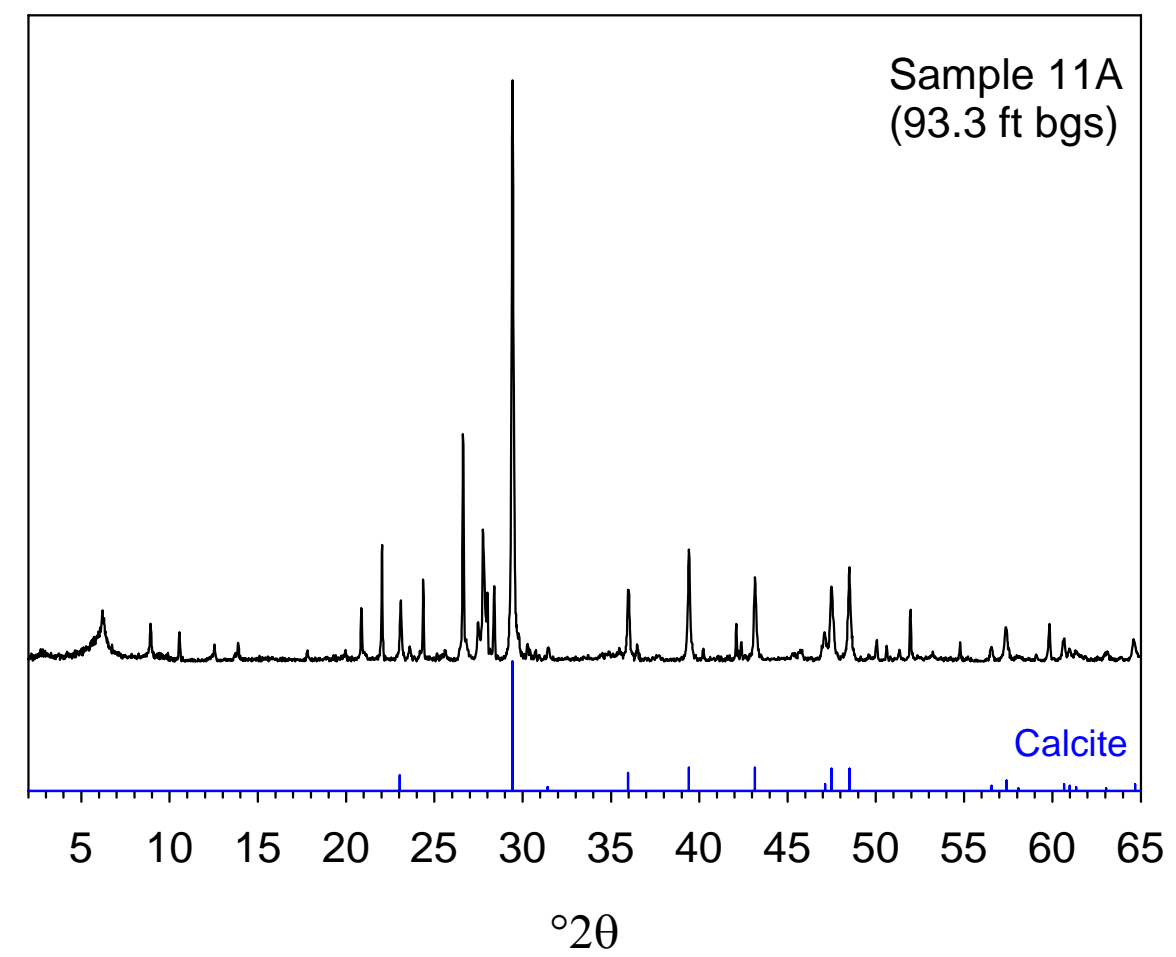

Figure 4.58. XRD Tracing for Sediment Sample 11A (93.3 ft bgs) Collected From Borehole C4105, With Calcite PDFTM File

Figure 4.59 provides an example XRD pattern of a typical clay assemblage (sample 19A) following two different treatments. Smectite is the fraction of the Mg-saturated sub-sample that gives a basal reflection at $5.85^{\circ} 2 \theta$ and expands to $5.28^{\circ} 2 \theta$ after solvation with ethylene glycol. Glycerol solvation treatments on two Mg-saturated clay slides (10A and 19A) were used to confirm the absence of vermiculite in the clay fraction. Vermiculite clay produces a basal reflection at $5.00^{\circ} 2 \theta$ in the presence of glycol; however, in the presence of glycerol, vermiculite retains a basal reflection of $6.10^{\circ} 2 \theta$. A significant change in intensity of the basal reflection at $6.10^{\circ} 2 \theta$ between the two treatments would indicate the presence of vermiculite. No observable intensity changes occurred on the basal reflection positioned at $6.10^{\circ} 2 \theta$ in either of the two clay samples examined.

Illite is the easiest of the four clay minerals to identify in these sediments. The basal reflections for illite are at $8.88,17.8$, and $26.7^{\circ} 2 \theta$. The various treatments, including cation saturation and solvation with ethylene glycol, do not affect the position of these reflections. Chlorite is identified by a basal series of diffraction peaks at $6.24,12.5,18.8$, and $25.2^{\circ} 2 \theta$, which are unaffected by cation saturation or ethylene glycol solvation. Kaolinite is difficult to identify in the presence of chlorite. Basal reflections characteristic of kaolinite are at 12.5 and $24.9^{\circ} 2 \theta$ and are superimposed on the even-ordered chlorite reflections. Kaolinite reflections are unaffected by cation saturation and ethylene glycol solvation. Positive identification of kaolinite in the presence of chlorite can be determined by differentiating kaolinite basal reflection at $24.9^{\circ} 2 \theta$ from the chlorite reflection at $25.2^{\circ} 2 \theta$ (Figure 4.59). Published reports characterizing clay fractions of Hanford formation sand-dominated sediment from other studies 
(Serne et al. 2002a, b, c, d, e, f and Lindenmeier et al. 2002) identified kaolinite using electron microscopy.

Trace amounts of quartz in the $<2.0 \mu \mathrm{m}$ fractions are evident by the diffraction peak located at $20.85^{\circ} 2 \theta$. The $100 \%$ reflection for quartz $\left(26.6^{\circ} 2 \theta\right)$ is hidden by the third-order basal reflection of illite located at $26.6^{\circ} 2 \theta$. Plagioclase feldspar is also identified in the clay fractions by the minor diffraction peak at $27.8^{\circ} 2 \theta$. Semi-quantification results of clay minerals in the $<2.0 \mu \mathrm{m}$ fractions are presented in Table 4.61. Total recoveries were normalized to $100 \%$. Smectite concentrations range from 26 to $56 \mathrm{wt} \%$ with an average of $41 \mathrm{wt} \%$. Illite concentration varies from 33 to $50 \mathrm{wt} \%$ with an average concentration of $42 \mathrm{wt} \%$. Chlorite and kaolinite are the least abundant of the clay minerals identified in the samples with concentrations equal to or less than 20 and $7 \mathrm{wt} \%$, respectively. Quartz and feldspar minerals were present as trace amounts in the clay fraction and therefore were not included in totals presented in Table 4.61.

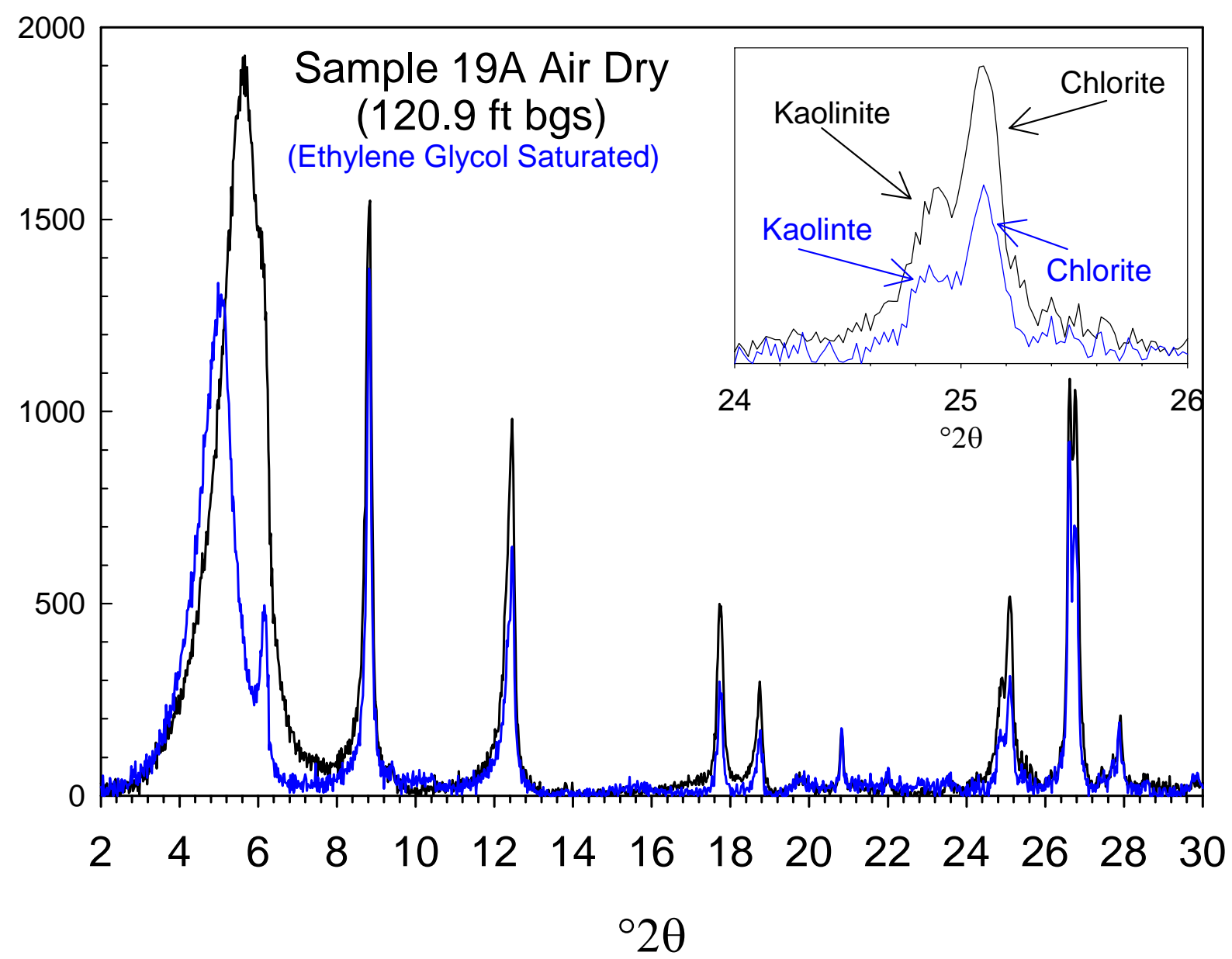

Figure 4.59. XRD Tracing of Clay Fraction from Sediment Sample 19A (120.9 ft bgs) Collected From Borehole C4105, With Matching PDF ${ }^{\mathrm{TM}}$ Files 
Table 4.61. Semi Quantitative XRD Results of Clay Minerals in $<2$ um Fraction of Sediment Samples Collected From Borehole C4105. Results are given in wt\%.

\begin{tabular}{||c|c|c|c|c|c||}
\hline Sample ID & $\begin{array}{c}\text { Depth } \\
\text { (ft bgs) }\end{array}$ & Smectite & Illite & Chlorite & Kaolinite \\
\hline 7A & 70.1 & 26 & 47 & 20 & 7 \\
\hline 10A & 88.2 & 35 & 50 & 10 & 5 \\
\hline 16A & 106.9 & 48 & 42 & 6 & 5 \\
\hline 19A & 120.9 & 56 & 33 & 7 & 5 \\
\hline 20A & 123.9 & 40 & 40 & 13 & 7 \\
\hline
\end{tabular}




\subsection{Groundwater Status Below the T Tank Farm}

This section summarizes historical as well as recent groundwater data from the uppermost, unconfined aquifer in the vicinity of WMA T. The data then are used to describe the nature and extent of contamination in the area. The primary focus is on relating ambient groundwater contamination to releases from waste storage and disposal facilities within or near the WMA. Accordingly, historical water levels and flow directions, and contaminant histories in key wells near the WMA are reviewed as background for understanding current groundwater contaminant distribution patterns and their relationship to possible waste management area sources.

Selected ratios of mobile contaminants in 1) the vadose zone sediments sampled by the two boreholes, C4104 and C4105 (see Section 4), 2) the groundwater, and 3) specific single-shell tanks at the time of suspected leaks are used to assess whether there are indications that the groundwater contamination is related to the current vadose zone contamination and to the tank leaks.

\subsection{Aquifer Properties}

This section provides information on the properties of the uppermost, unconfined aquifer in the immediate region of WMA T. Aquifer properties were determined from stratigraphic interpretations, current water level elevations, and aquifer testing.

Beneath the 200 West Area, the suprabasalt aquifer system contains the uppermost unconfined aquifer and the underlying Ringold confined aquifer. Deeper confined and semi-confined aquifer systems also exist beneath these sedimentary aquifers in the basalt flow tops, flow bottom zones, and sedimentary interbeds (DOE 1998). Groundwater flow, both vertically and horizontally, in the suprabasalt aquifers is less constrained than in the deeper basalt aquifers.

The suprabasalt aquifers below the Hanford Reservation have been impacted by past practice, liquid waste disposal operations and unplanned releases, in some instances from single-shell tank leaks. In the area of WMA T, large volumes of waste water disposed to ground between the 1940s and 1997 created large artificial groundwater mounds particularly beneath the 216-T pond system, north of WMA T, and beneath the 216-U pond, southwest of WMA T. The disposed liquids contained many of the contaminants that now move through the upper unconfined aquifer. Water mounding has declined significantly since the 1997 cessation of non-permitted liquid waste disposal.

The following discussion focuses on the uppermost, suprabasalt aquifer system within the Ringold and Hanford formations. The suprabasalt aquifers are the uppermost regionally extensive aquifers beneath the WMA T. Groundwater within this aquifer system is contained within the fluvial-lacustrine sediments of the Ringold Formation. Figure 5.1 shows a map of WMA T with the location of all wells discussed in this section. 


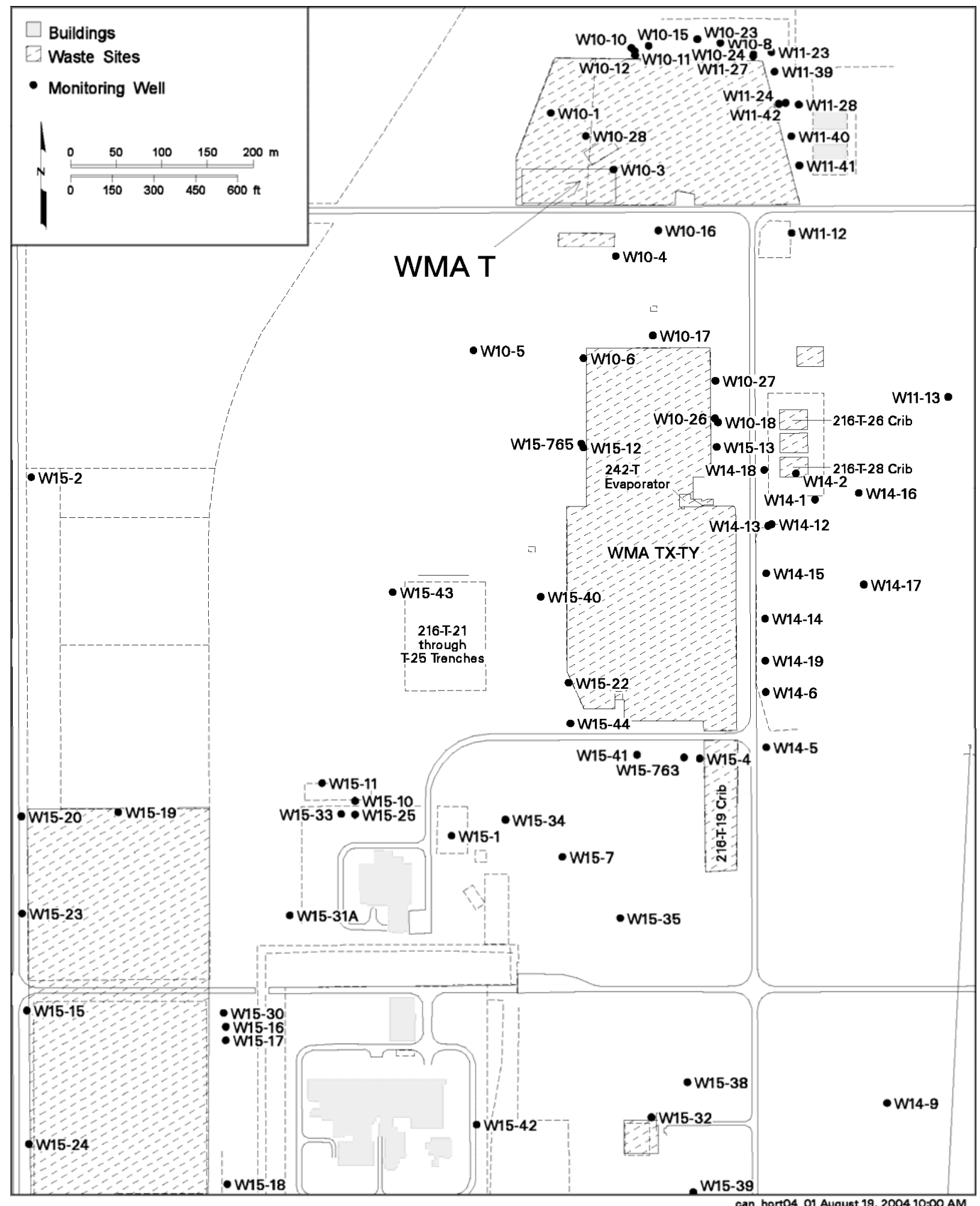

Figure 5.1. Well Location Map for Waste Management Area T 
Only one well, 299-W11-13, near WMA T extends to the top of basalt and has recent water level data. (Well 299-W11-13 is located about 270 meters southeast of the southeast corner of WMA T.) Based on the March 2003 water table elevation, the suprabasalt aquifer system is approximately 73 meters thick at this well.

The base of the uppermost, unconfined aquifer generally is regarded as the basalt surface and, where this is the case, the entire suprabasalt aquifer is unconfined. However, beneath WMA T (and beneath the entire 200 West Area), the silt and clay deposits of the Ringold Formation lower mud unit (hydrogeologic unit 8 of Williams et al. 2002) form a confining layer that separates the suprabasalt aquifer into the uppermost unconfined aquifer and the underlying Ringold confined aquifer (Williams et al. 2002). Thus, the uppermost, unconfined aquifer in the area of interest extends from the water table down to the top of the lower mud unit. The unconfined aquifer is about 50 meters thick at well 299-W10-24 (located at the northeast corner of WMA T), based on the August 2003 water level. The unconfined aquifer consists of sandy gravels and gravelly sands of the Ringold Formation member of Wooded Island unit $\mathrm{E}$ (hydrogeologic unit 5 of Williams et al. 2002). All wells in the WMA T monitoring networks are screened in hydrogeologic unit 5. Currently, the water table at WMA T is 136 to 137 meters above sea level.

Water levels in the uppermost unconfined aquifer raised as much as 13.5 meters (above the pre-Hanford natural water table) beneath WMA T because of artificial recharge from liquid waste disposal operations that were active since the mid 1940s and continued for 30-40 years. The largest volumes of discharge were to the 216-T pond system and the 216-U-10 pond. Figure 5.2 shows the liquid discharge history for the two ponds. The 216-T pond system is estimated to have received approximately 424 billion liters of effluent (Alexander et al. 1995); the 216-U pond received about 158 billion liters of effluent (Last 1994). The large-volume disposals to the ponds (and, lesser volumes to cribs and ditches) artificially recharged the uppermost unconfined aquifer, creating large water-table mounds.

Figure 5.3 shows the groundwater elevations in the area of WMA T since the late 1940s. The figure shows that the increase in water-table elevation was most rapid from 1949 to 1956 and was somewhat stabilized between the late 1960s and the late 1980s. Water levels began to decline in the late 1980s beneath WMA T when wastewater discharges in the 200 West Area were reduced. The decline in water levels may have implications for the groundwater monitoring network at the WMA T as discussed later.

Accompanying the changes in water level were changes in groundwater flow direction. Histograms (rose diagrams) showing groundwater flow directions beneath the $\mathrm{T}$ tank farm during different time periods are shown in Figure 5.4. The rose diagrams plot the solutions to numerous three-point analyses using water level information from various well triplets in the north central part of the 200 West Area. The petals of the rose diagrams point in the direction of groundwater flow and the length of the petals represents the percentage of measurements showing that groundwater flowed in the indicated direction.

Pre-Hanford Site groundwater flow direction was toward the east (Kipp and Mudd 1974). The rose diagram in Figure 5.4A shows that groundwater flow had changed toward the south in the area by the early 1950s. This shift resulted from disposal of large volumes of liquid to the 216-T pond system. 


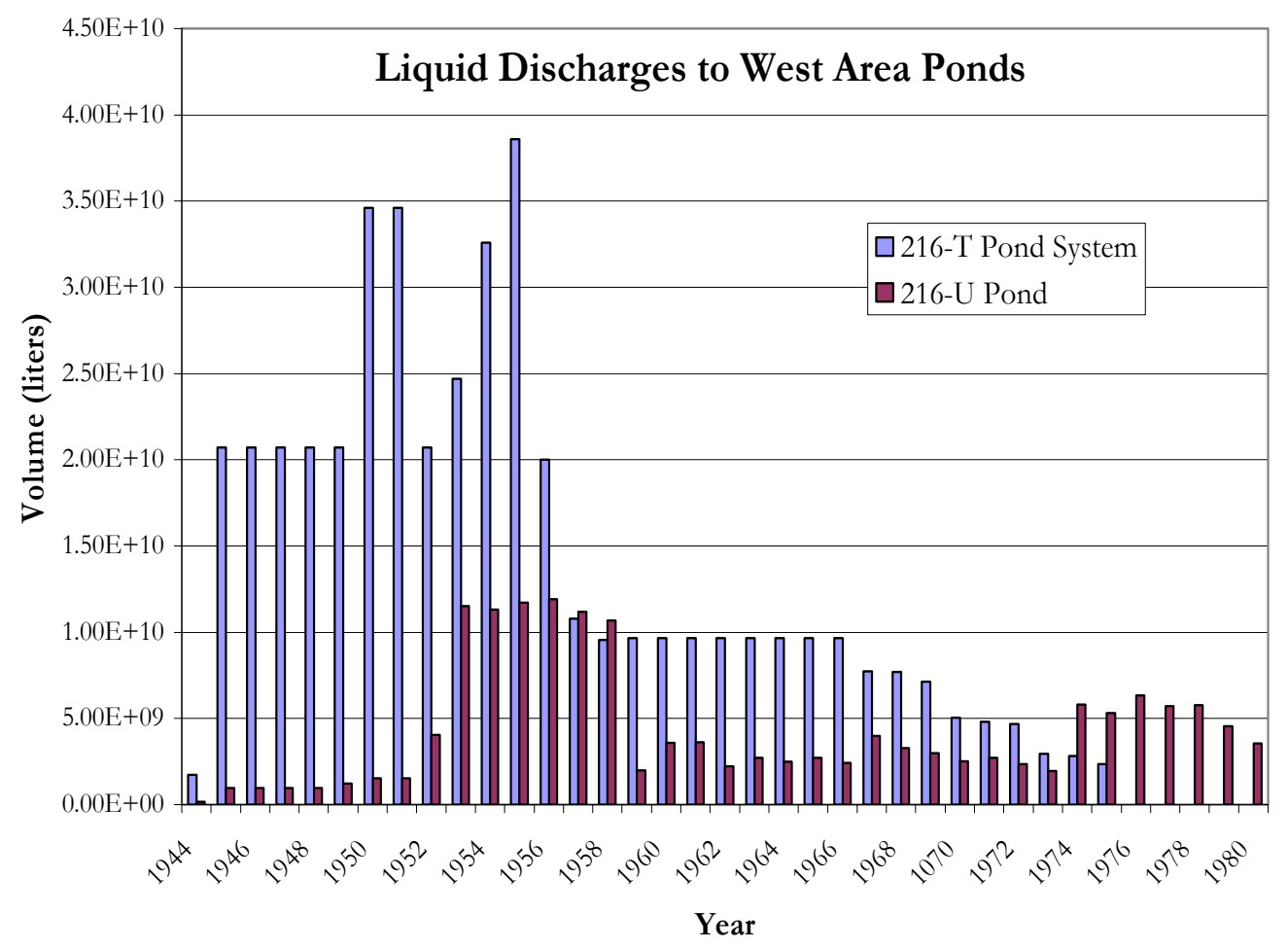

Figure 5.2. Discharge History for the 216-T Pond and the 216-U Pond. Data for the 216-T Pond are from Alexander et al. 1995; data for the 216-U pond are from Last 1994.

Hydrographs

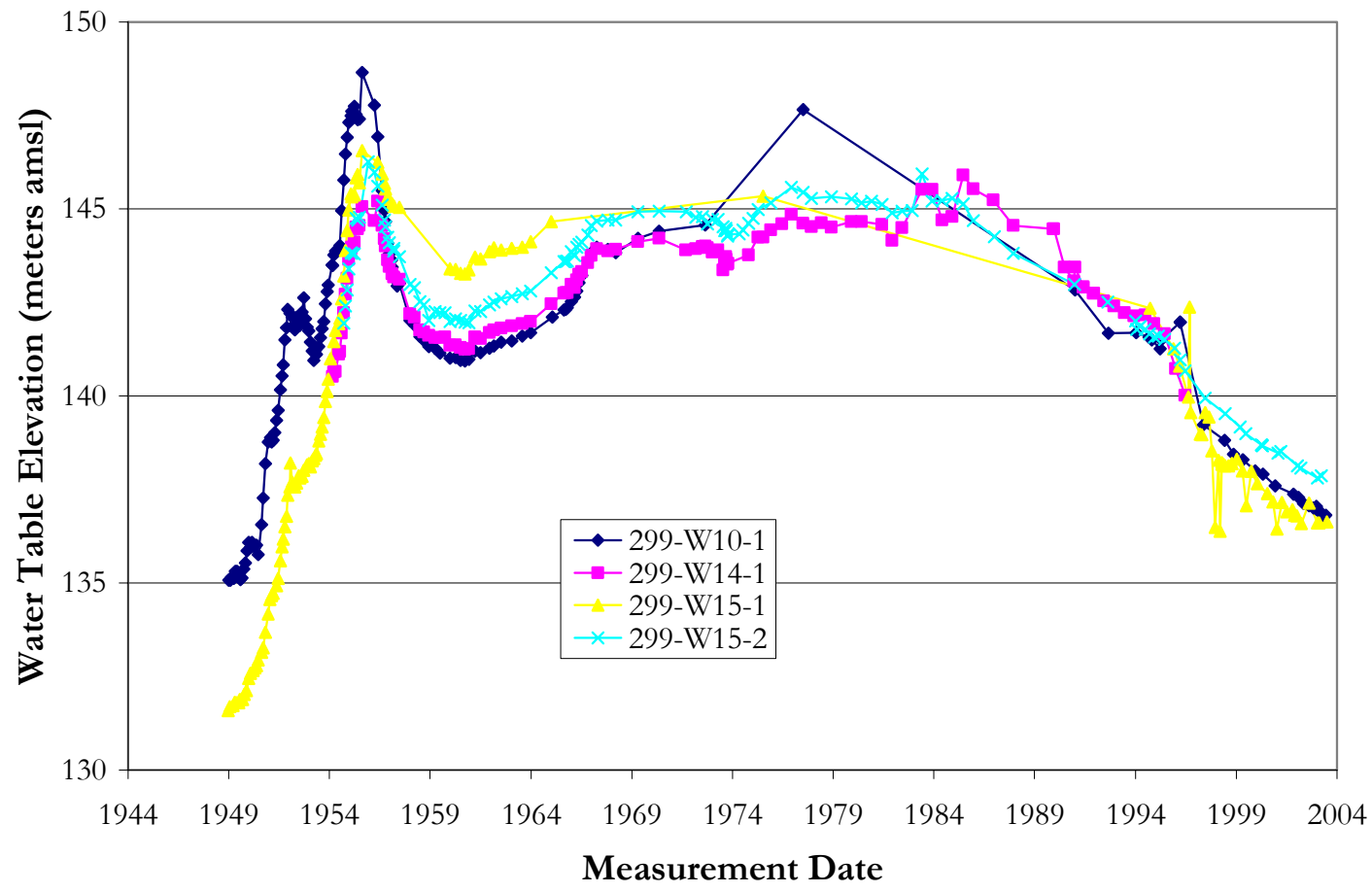

Figure 5.3. Hydrographs of Selected Wells in the North 200 West Area 
In 1956, groundwater flow direction changed again and started flowing towards the northeast due to the increasing influence of the groundwater mound under 216-U pond and a decreasing influence of the mound under 216-T pond (Figure 5.4B). Discharges to 216-T pond ended in 1976 but continued at $216-\mathrm{U}$ pond until 1984 . As discharges to the $216-\mathrm{U}$ pond declined in the early 1980 s, groundwater flow shifted to a more northerly direction as the groundwater mound began to decrease and discharges to the 216-U-14 ditch continued. The slight westerly component to the groundwater flow direction between early 1980s and mid 1990s (Figure 5.4C) is probably a result of the discharges to the 216-U-14 ditch, located southwest of WMA T. All non-permitted discharges to the ground ceased and the influence of the 216-U pond mound on the groundwater beneath the T tank farm diminished in 1995. Consequently, the flow direction changed again in about 1996 and began to return toward an easterly direction (Figure 5.4D).

These large shifts in groundwater flow direction have broad implications for contaminant distribution in the uppermost aquifer beneath WMA T. In the late 1940s and early 1950s, contamination was spread south in the aquifer. Then, in the late 1950s and until the mid-1990s, that same contamination returned to the north along with any new contamination that entered the aquifer after the 1950s. Today, groundwater contamination beneath the WMA and surrounding area is generally migrating east.

Recently, two trend-surface analyses, using August and September 2002 data, yielded groundwater flow directions of $98^{\circ}$ to $96^{\circ}$ (azimuth) and a water table gradient between of 0.00114 and 0.00132 (Spane et al. 2002). An earlier trend-surface analysis yielded a flow direction of $85^{\circ}$ and a water table gradient of 0.00172 (Spane et al. 2001a,b). All trend-surface analysis data are shown in Table 5.1. Although the flow direction may differ from well to well due to heterogeneous aquifer sediments, the groundwater flow direction at WMA T, as determined by the trend surface analyses, is consistent with the data shown in Figure 5.4D and the current regional groundwater map (Figure 5.5).

Borehole tracer dilution and tracer pumpback tests were conducted in three new RCRA monitoring wells at the T tank farm between fiscal years 1999 and 2001. These tests permitted some inferences about flow rate and aquifer homogeneity. The tests allowed direct observation of the effect of lateral groundwater flow through the screened interval of the wells and, thus, provided an indication of the variability of flow through the screened intervals. Details of the test methods, computations, and the results are included in Spane et al. (2001a,b and 2002).

A significant feature of the tracer dilution test results is evidence for downward, vertical hydraulic gradients within the upper portion of the aquifer in wells 299-W11-39 and 299-W11-40. Table 5.2 summarizes the test results for these wells. Vertical flow within 200 West Area wells was first indicated by tracer-dilution studies and later confirmed (for two wells at WMA TX-TY) by vertical tracer tests specifically designed to detect vertical flow within a borehole (Spane et al. 2001a, b). Downward vertical flow was subsequently confirmed by electromagnetic flowmeter surveys (Waldrop and Pearson 2000). 

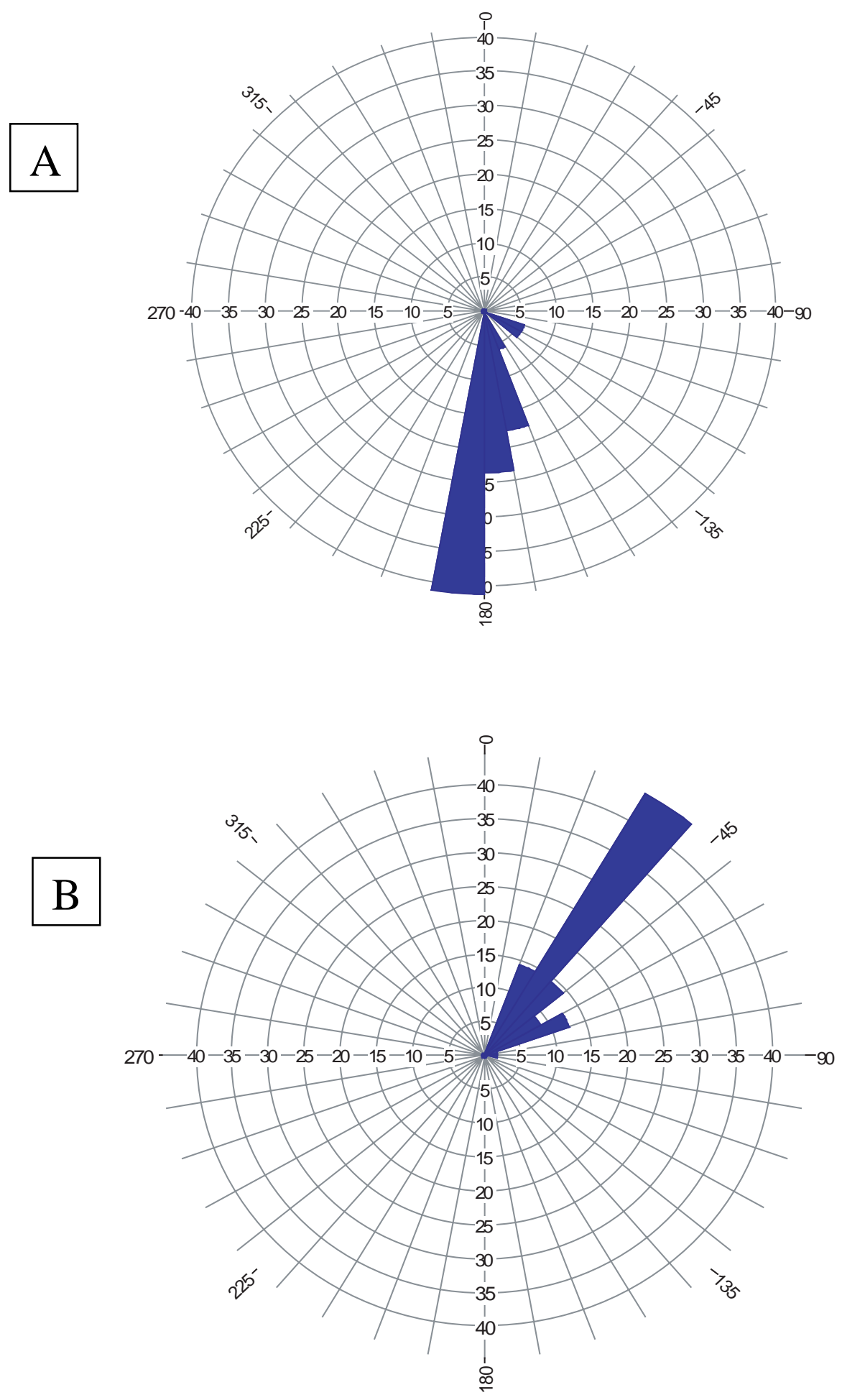

Figure 5.4. Groundwater Flow Directions in the North Part of 200 West Area. A. 1954 to 1956, 1 Well Triplet, 17 Measurements; B. 1957 to 1982, 2 Well Triplets, 56 Measurements. 

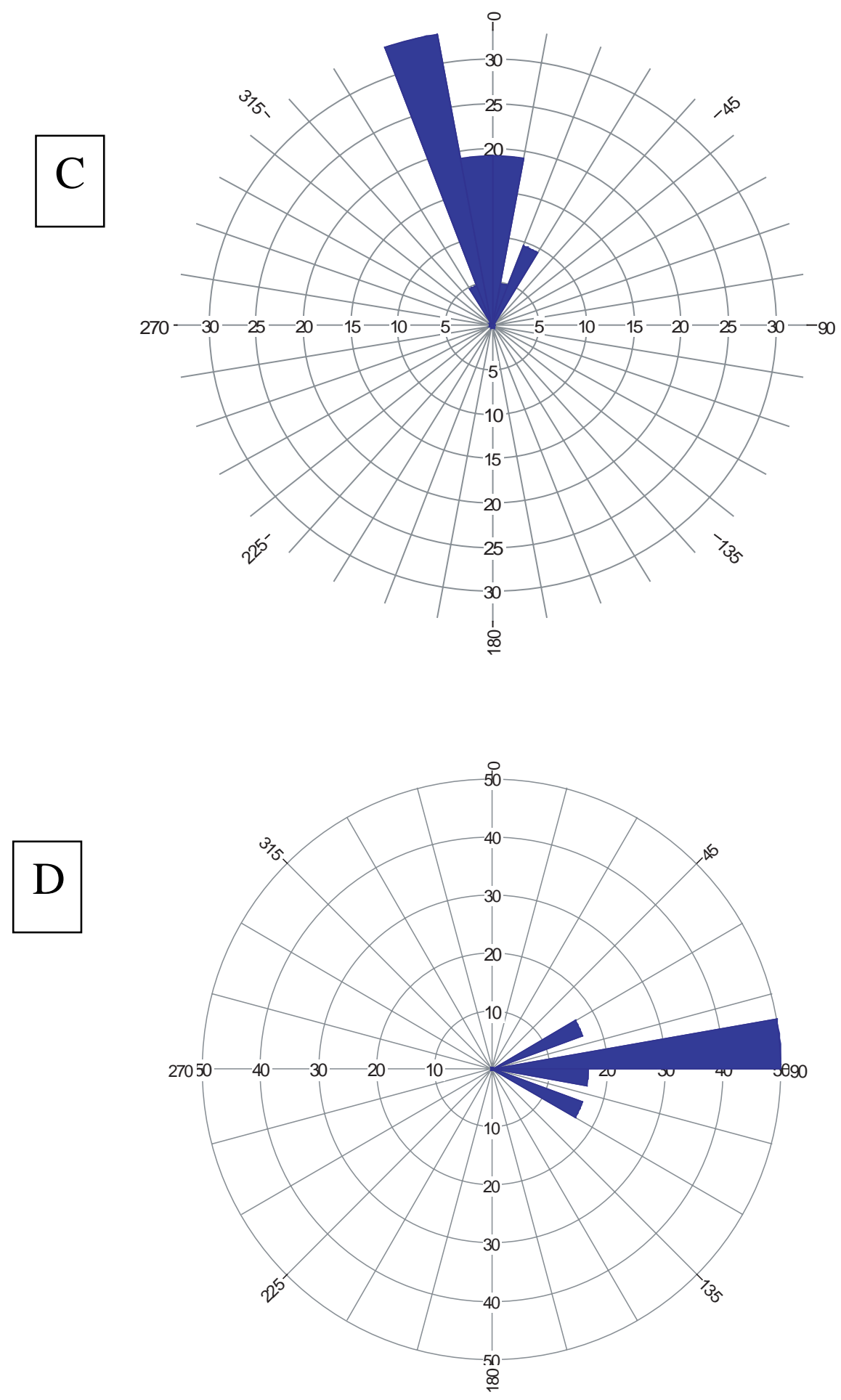

Figure 5.4. Groundwater Flow Directions in the North Part of 200 West Area. C. 1983 to 1995, 4 Well Triplets, 21 Measurements; D. 1997 to 2003, 3 Well Triplets, 6 Measurements. 
Table 5.1. Groundwater Flow Characterization Results Based on Trend Surface Analyses. (Data are from Spane et al. 2001a, 2001b, 2002.)

\begin{tabular}{|c|c|c|c|c|}
\hline Well & Measurement Date & \begin{tabular}{|c|} 
Groundwater Flow \\
Direction
\end{tabular} & $\begin{array}{l}\text { Hydraulic } \\
\text { Gradient }\end{array}$ & $\begin{array}{l}\text { Wells Used } \\
\text { in Analyses }\end{array}$ \\
\hline 299-W10-24 & 4/21/99 & $\mathrm{N} 85^{\circ} \mathrm{E}$ & 0.00172 & $\begin{array}{c}299-W 10-8 \\
299-W 10-12 \\
299-W 10-22 \\
299-W 10-24 \\
299-W 11-23 \\
299-W 11-27\end{array}$ \\
\hline 299-W11-39 & $\begin{array}{l}\text { 9/4/01 } \\
\text { 9/18/01 }\end{array}$ & $\begin{array}{l}\mathrm{N} 98^{\circ} \mathrm{E} \\
\mathrm{N} 96^{\circ} \mathrm{E}\end{array}$ & $\begin{array}{l}0.00115 \\
0.00114\end{array}$ & $\begin{array}{c}\text { 299-W10-1 } \\
\text { 299-W10-4 } \\
\text { 299-W10-24 } \\
\text { 299-W11-40 } \\
\text { 299-W11-41 } \\
\text { 299-W11-42 }\end{array}$ \\
\hline 299-W11-40 & $8 / 9 / 01$ & $\mathrm{~N} 96^{\circ} \mathrm{E}$ & 0.00132 & $\begin{array}{c}299-W 10-1 \\
299-W 10-4 \\
299-W 10-24 \\
299-W 11-39 \\
299-W 11-41 \\
299-W 11-42\end{array}$ \\
\hline
\end{tabular}

The existence of vertical flow in a well does not necessarily reflect actual groundwater flow conditions within the surrounding aquifer, but its presence implies a vertical flow gradient and has implications pertaining to the representativeness of groundwater samples collected from the wells. Thus, the vertical gradient detected in some wells, especially along the current downgradient edge of WMA T (eastern edge) may have an impact on contaminant distribution patterns in the area.

A second feature of the hydrologic test data is the suggestion of higher or lower hydraulic conductivity at certain depths within the screened interval of some wells relative to other depths. For example, tracer tests indicate that the upper 3 to 4 meters of the screened interval of well 299-W10-24 is less permeable than the lower part of the screened interval. However, a tracer test in nearby well 299-W11-39 indicated that the lower 3 meters of the screened interval are relatively impermeable compared to the rest of the interval. (Flow in the lower interval was described as stagnant in Spane et al. [2002].) Thus, apparent differences in permeability do not appear to correlate from well to well. 


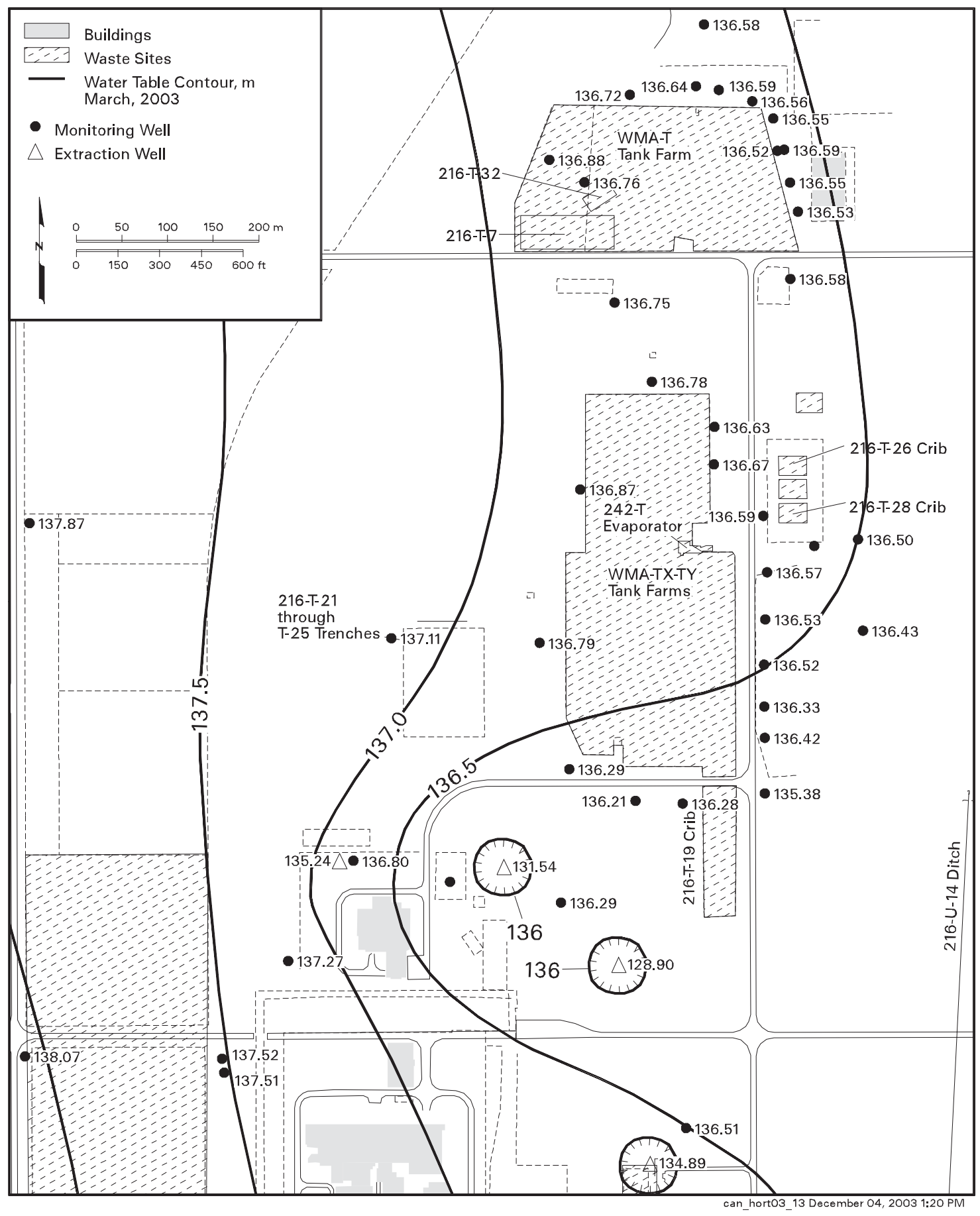

Figure 5.5. March 2003 Water Table Map for the Area Around Waste Management Area T 
Table 5.2. In-Well, Downward Vertical, Flow-Velocity Summary for Wells 299-W11-39 and 299-W11-40 at Waste Management Area T (Spane et al. 2002)

\begin{tabular}{||l|c|c||}
\hline \multirow{2}{*}{ Test Well } & \multicolumn{2}{|c||}{ Tracer Dilution Profile } \\
\cline { 2 - 3 } & Range (m/min) & Average (m/min) \\
\hline 299-W11-39 & $0.0003-0.002$ & 0.001 \\
\hline 299-W11-40 & $0.011-0.020$ & 0.017 \\
\hline
\end{tabular}

For the WMA T groundwater assessment, new hydraulic conductivity data were obtained from slug tests and drawdown tests conducted in 9 new wells drilled since 1999. Effective porosities were determined from tracer drift and tracer pumpback tests. Hydraulic properties are discussed in detail by Spane et al. (2001a, b), Spane (2002), and Spane et al. (2003) and are presented in Tables 5.3 and 5.4.

Table 5.3 shows horizontal groundwater flow velocities determined from tracer pump back tests. These horizontal velocities are greater than the calculated velocities in Table 5.4 for well 299-W11-40, which has downward vertical flow in the well. The vertical flow in the well probably resulted in overestimation of the measured flow velocity. Both the measured and calculated velocities are about the same for wells 299-W10-24, which has no vertical flow.

Overall, there is about an order of magnitude difference in the horizontal flow velocities in Table 5.4. The horizontal velocity in wells 299-W10-28 and 299-W11-42 are substantially greater than the velocities calculated for the other wells (Table 5.4). Very rapid recoveries during slug testing were noted (90\% recovery within 4 seconds for both wells), which suggests fairly permeable formations (Spane et al. 2002 and 2003). However, there is nothing in the geologist's logs or the geophysical logs to suggest that the formation in the screened interval of these wells is significantly different than the formation at nearby wells.

Table 5.3. $\quad$ Results from Tracer-Dilution and Tracer-Pumpback Tests in Wells at Waste Management Area T (Spane et al. 2001a, b and 2002)

\begin{tabular}{|c|c|c|c|}
\hline Well & $\begin{array}{c}\text { Effective } \\
\text { Porosity }^{(a)} \\
\end{array}$ & $\begin{array}{c}\text { Groundwater }^{(\mathbf{a})} \text { Flow } \\
\text { Velocity (m/d) }\end{array}$ & $\begin{array}{c}\text { Average In-Well Flow } \\
\text { Velocity }^{(b)}(\mathrm{m} / \mathrm{d})\end{array}$ \\
\hline 299-W10-24 & 0.072 & 0.029 & 0.012 \\
\hline $299-W 11-39^{(c)}$ & 0.045 & 0.022 & 0.014 \\
\hline $299-W 11-40^{(\mathrm{d})}$ & 1.1 & 0.002 & 0.176 \\
\hline \multicolumn{4}{|c|}{ (a) Data from tracer pump back tests. } \\
\hline \multicolumn{4}{|c|}{ (b) Data from tracer dilution tests. } \\
\hline \multicolumn{4}{|c|}{ (c) Slight downward vertical flow, data uncertain. } \\
\hline \multicolumn{4}{|c|}{ (d) Strong downward vertical flow, data highly uncertain. } \\
\hline
\end{tabular}


Table 5.4. Hydraulic Properties from Slug and Constant Rate Pumping Tests and Calculated Horizontal Flow Velocities at New Wells at Waste Management Area T

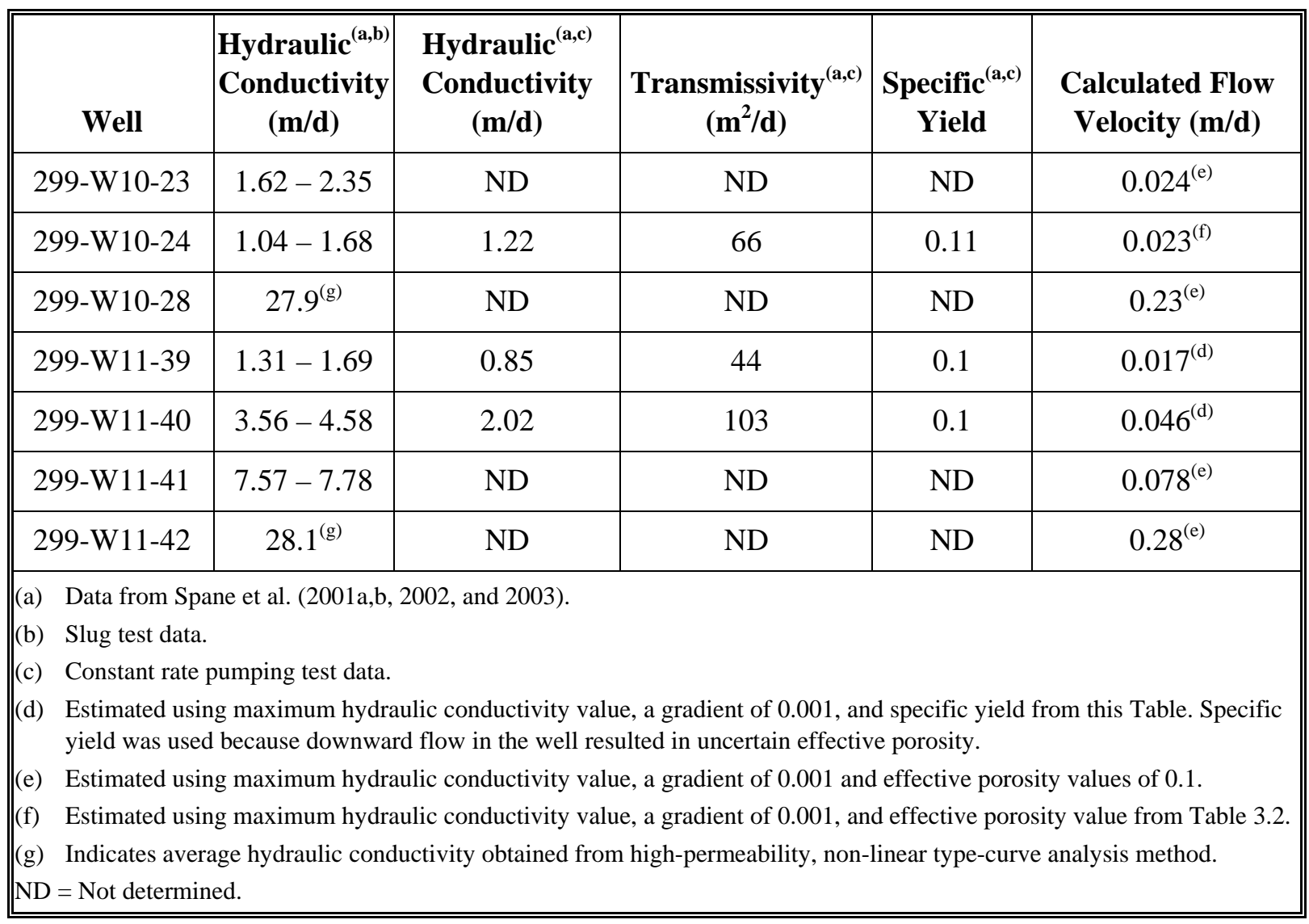

Taken as a whole, the geologist's logs, geophysical logs, development pumping data, and the hydrologic testing data all indicate heterogeneity in the aquifer properties within the screened intervals of several individual wells and among wells at WMA T. No widespread trends have been identified.

The hydrographs in Figure 5.6 show that water levels have declined by about 6.5 meters since 1991 beneath the T tank farm. This decline, resulting from decreasing effluent discharge in the 200 West Area, became much steeper in 1995 with the effective cessation of discharge to all non-permitted facilities in this area. Between 1998 and 2004 the average rate of water table decline has been between about 0.3 and 0.4 meter per year in all monitoring wells at WMA T. The rapid decrease in water levels after 1995 has resulted in monitoring wells going dry more quickly than previously predicted and has necessitated the drilling of 7 new monitoring wells since 1999.

The pre-Manhattan Project water table was estimated at approximately 123 to 125 meters above sea level in the area of T tank farms by Kipp and Mudd (1974). More recently, Bergeron and Wurstner (2000) modeled the elevation of the water table beneath the Hanford Site for the Immobilized Low-Activity Waste Performance Assessment. Their results predict a post-Hanford Site influenced water table elevation of about 130 to 132 meters above sea level in the T tank farm area. The difference between these two estimates may be due, in part, to the back extrapolation of very few data points by Kipp and Mudd (1974). However, the model results of Bergeron and Wurstner incorporated the increase 
in recharge due to increased irrigation in the Cold Creek Valley which would results in a higher water table. The model results probably better represent the future condition and suggest that the elevation of the current water table will continue to decrease another 5 to 7 meters in the T tank farm area.

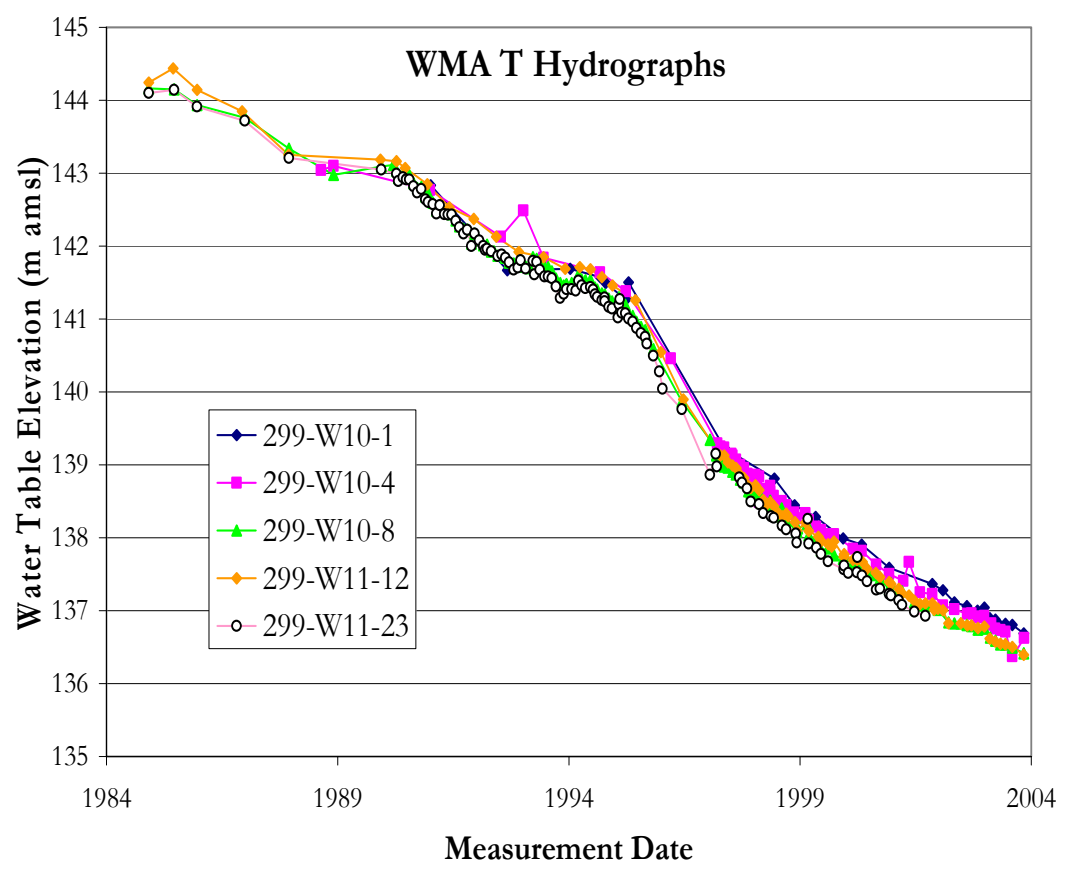

Figure 5.6. Historic Water Table Elevations in Selected Wells at WMA T. Well 299-W11-23 is now dry.

\subsection{Existing Groundwater Contamination}

This section discusses the current and historical groundwater contamination at WMA T. The evaluation of contamination includes descriptions of the types and concentrations of contaminants in the groundwater, the depth distribution of contaminants in the aquifer, and the areal extent of contamination in the area.

Monitoring results from new and existing wells, results of depth sampling during and after installation of new monitoring wells, and comparison of groundwater chemistry in old wells and their adjacent replacement wells, provide new insights into the occurrence and nature of groundwater contamination in the $\mathrm{T}$ tank farm area. The information given in this section is taken largely from Horton et al. (2002) and is updated with more current groundwater data.

Groundwater at the T tank farm contains elevated concentrations of carbon tetrachloride, chromium, nitrate, technetium-99, and tritium. This contamination is a result of mixing of wastes from a number of past waste-disposal activities, including: 1) the disposal of process water and steam condensate at nearby ponds, cribs, and trenches, 2) the disposal of plutonium processing waste at cribs and trenches associated with the Plutonium Finishing Plant, and 3) leaks from single-shell tanks and transfer lines within the T tank farm. 


\subsubsection{Extent of Contamination - Depth Distribution}

Determining the vertical extent of contaminants within the uppermost aquifer is part of the RCRA groundwater quality assessments currently underway at WMA T. A variety of data sources including discrete depth sampling during drilling, comparison of adjacent wells that sample different parts of the aquifer, and detailed specific conductance profiling provide important information about the depth distribution of contaminants.

\subsubsection{Specific Conductance Profiling}

In September 2002, specific conductance measurements were taken at 0.5 to 1 meter intervals throughout the screened intervals of four groundwater monitoring wells around the T tank farm. Significant differences in specific conductance with depth were found in three of these wells. The remaining well (299-W10-24) showed no variation of specific conductance with depth.

Figure 5.7 shows a plot of specific conductance versus depth in well 299-W10-28, an upgradient well at WMA T. The specific conductance data show a marked increase with increasing depth through the upper 4 meters of the screened interval below which specific conductance remains unchanged. In general, specific conductance reflects nitrate (and sodium and calcium) concentration in the T tank farm area. At well 299-W10-28, the data suggest that the nitrate concentration increases from the water table to about 4 meters depth within the aquifer. Also shown on the figure are the values of specific conductance measured after purging the well for the four routine quarterly groundwater samples taken prior to the specific conductance profile. The red squares to the left of the curve, representing the pumped values, are at the depth of the pump intake. The pumped values are all less than the measured ambient values and appear to be an average of the low conductance water at the water table surface and the relatively high conductance water deeper in the screened interval.

A specific conductance profile measured in well 299-W11-39, a downgradient well at WMA T, has a shape very similar to that of well 299-W10-28, in Figure 5.7, although the absolute values of the specific conductance are much smaller and the magnitude of the change is much less for well 299-W11-39. A specific conductance profile measured in well 299-W11-42 (Figure 5.8), another downgradient well at WMA T, also looks similar to that of well 299-W10-28 except that the increase in specific conductance occurs between 6 and 9 meters below the water table and, again, the magnitude of the change is much less than that shown for well 299-W10-28. The data from well 299-W11-42 allow for a continued increase in specific conductance below the screened interval.

Comparison of nitrate concentrations in well 299-W11-28 (now dry) with replacement well 299-W11-42 indicate that the nitrate concentration is relatively low at the water table and increases at some depth in the aquifer (see Section 5.2.1.3, "Sampling During Drilling”). The specific conductance profile in well 299-W11-42 supports the interpretation of the nitrate data. These data also are interpreted to reflect the regional nitrate trend found in the WMA T area and suggest that the main part of the regional plume is located at some depth below the water table. 


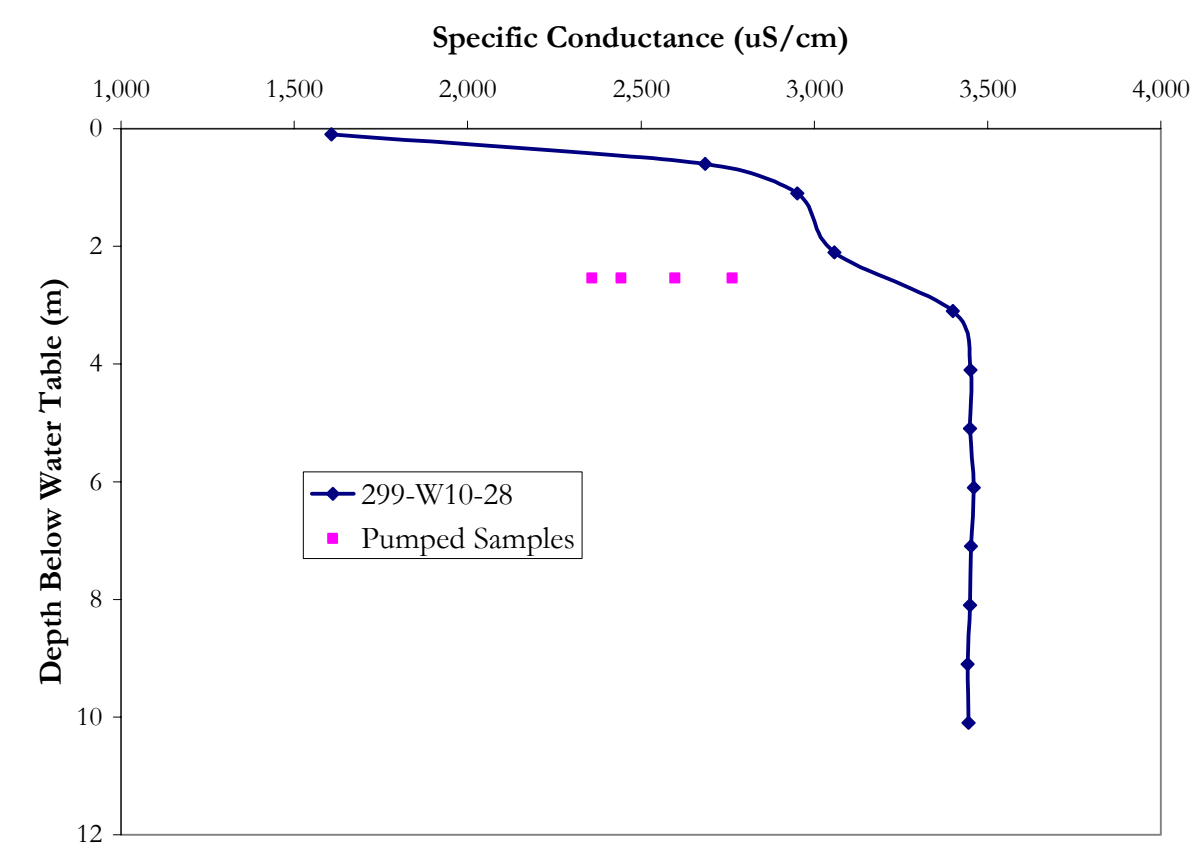

Figure 5.7. Specific Conductance versus Depth Below the Water Table in Well 299-W10-28. The red squares to the left of the curve are at the depth of the pump intake.

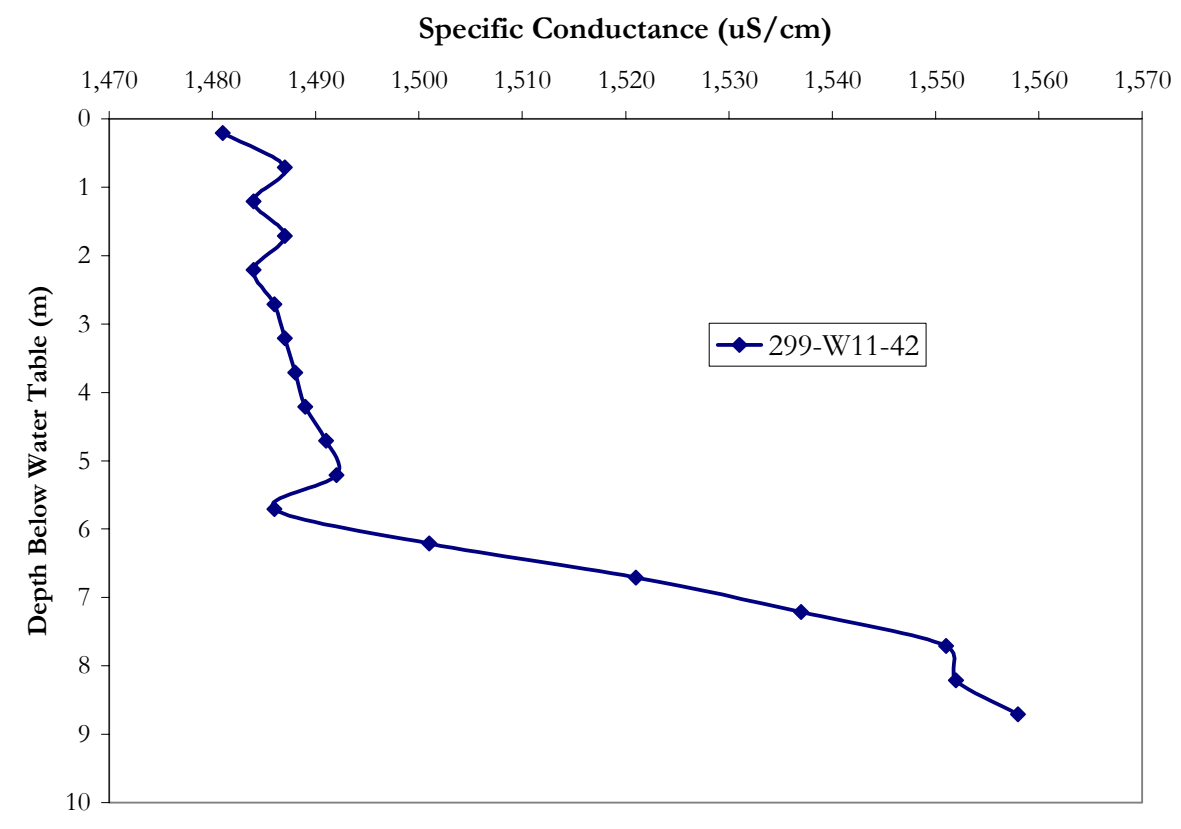

Figure 5.8. Specific Conductance versus Depth Below the Water Table in Well 299-W11-42 


\subsubsection{Comparison of Chemical Data From New and Replaced Wells}

Replacement wells, when located immediately adjacent to the older wells, offer an opportunity to look for vertical variation within the upper part of the aquifer. Three well pairs at $\mathrm{T}$ tank farm show variable vertical stratification of contaminants in the upper part of the aquifer.

In each case, the old well and its replacement well are separated by only a few meters. In addition, in each case, the older well was last sampled when there was a fraction of a meter of water within the screened interval and the replacement well was sampled with a pump placed at least 3 meters below the water table within a 10.7-meter screened interval. Thus, the last samples from the old well represent the top of the aquifer and the samples from the replacement well represent a composite of water pumped from the length of the screened interval that includes both the water table and deeper parts of the aquifer.

Wells 299-W11-27 and 299-W10-24 are about 3 meters apart and are located near the northeastern corner of WMA T. Well 299-W10-24 is the replacement well for well 299-W11-27 that went dry in early 1999. The last sampling of well 299-W11-27 took place in March 1999 and sampling of replacement well 299-W10-24 started in December 1998, allowing a sampling overlap between the two adjacent wells. The last samples collected from well 299-W11-27 represent the top of the aquifer. The samples collected from well 299-W10-24 represent water throughout the screened interval, which extends from the water table to 10 meters below the water table. The sample pump was at 5.0 meters below the water table when sampling began.

Well 299-W11-27 reached a peak technetium-99 concentration of 21,700 pCi/L in February 1997 and dropped to 6,000 pCi/L for the last sampling in March 1999 before going dry. This sample represented the technetium-99 concentration at the top of the aquifer. The first analysis of technetium-99, from the December 1998 sampling of replacement well 299-W10-24, contained 2,090 pCi/L technetium-99, about $4,000 \mathrm{pCi} / \mathrm{L}$ less than the older, dry well (Figure 5.9). The sample from well 299-W10-24 represented the technetium-99 concentration throughout the upper 10 meters of the aquifer after ambient water was purged from the well. The interpretation is that, in early 1999, the technetium concentration at the water table at the northeast corner of $\mathrm{T}$ tank farm was $6,000 \mathrm{pCi} / \mathrm{L}$ and the concentration decreased with depth in the aquifer.

Well 299-W11-39 is the replacement well for now dry well 299-W11-23; both are located near the northeast corner of the $\mathrm{T}$ tank farm. Comparison of technetium-99 concentration in the two wells indicates essentially no difference between the last samples from well 299-W11-23 and the first samples from 299-W11-39 (Figure 5.9). The situation here, however, is complicated by the downward in-well flow and very tight formation at the bottom of the well screen in well 299-W11-39. One possibility is that there are no vertical technetium-99 concentration gradients at these wells. A second possibility is that the tight formation near the bottom of well 299-W11-39 does not contribute sufficient water to the pumped sample to effectively dilute a high technetium-99 concentration in water from near the water table. Because other evidence suggests a technetium-99 concentration gradient in the area, the second possibility is preferred. 


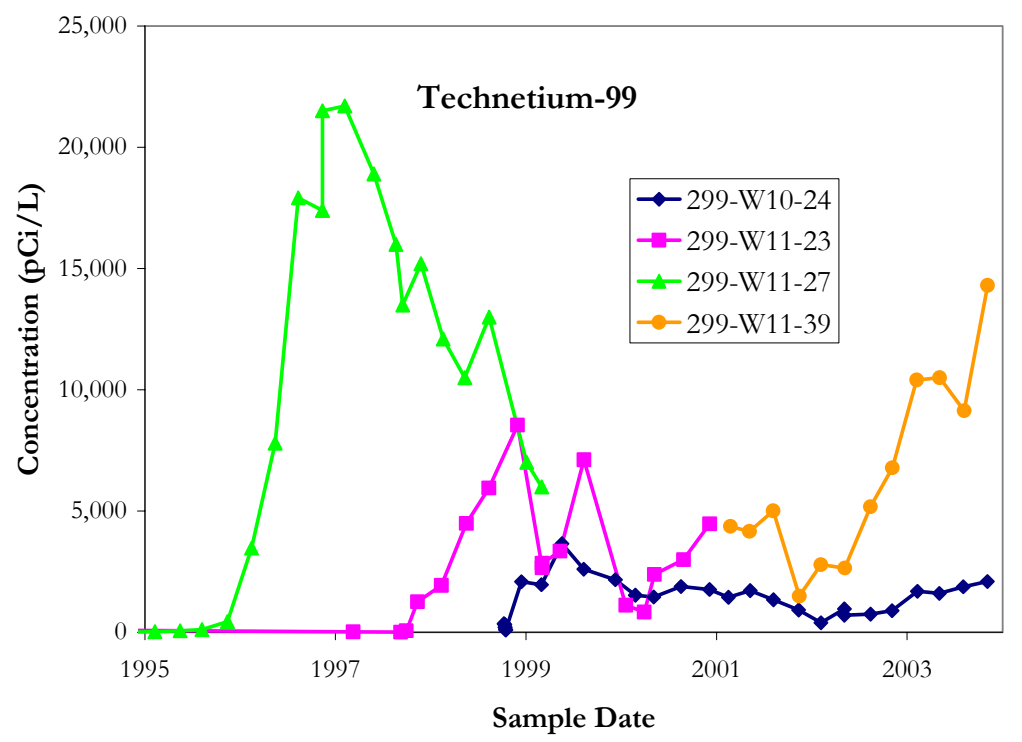

Figure 5.9. Technetium-99 Concentrations in Two Well Pairs at the Northeast Corner of T Tank Farm

Figure 5.10 shows the concentration of nitrate versus time for two well pairs at $\mathrm{T}$ tank farm. The well pair 299-W11-28 and 299-W11-42 is located near the center of the downgradient side of WMA T. Well 299-W11-42 is the replacement well for now dry well 299-W11-28. For both well pairs in the figure, the replacement well, which samples the upper 10 meters of the aquifer, has higher concentrations of nitrate than did the older well as it went dry. These data suggest that nitrate concentration in groundwater beneath WMA T is relatively low at the water table and increases with depth in the aquifer. This is consistent with the specific conductance profiles.

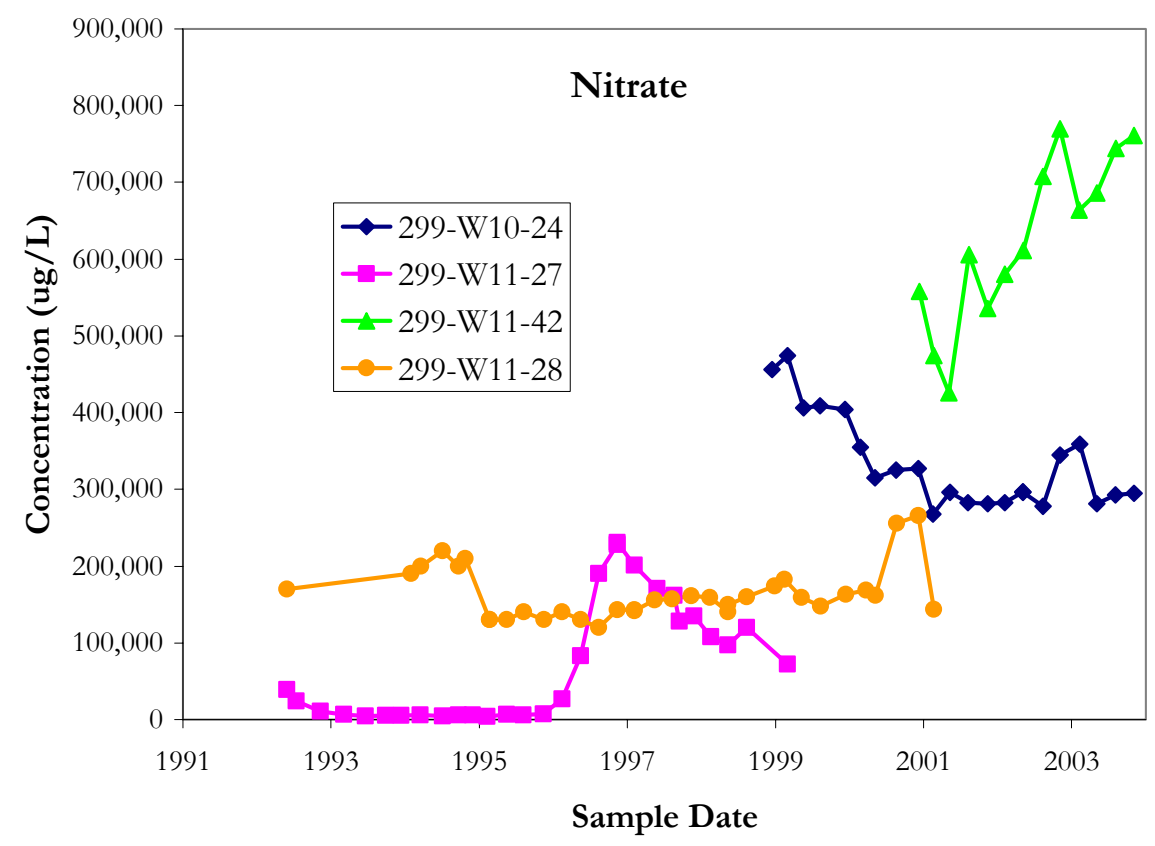

Figure 5.10. Nitrate Concentration in Two Well Pairs Downgradient of WMA T 
Figure 5.11 shows the chromium concentration versus time for two well pairs at the $\mathrm{T}$ tank farm. These data indicate that the chromium concentrations in the area are relatively low at the water table and higher at some depth in the aquifer. The well pair 299-W11-23 and 299-W11-39 shows essentially the same trend although the older well, 299-W11-23, had a carbon steel casing so that some of the chromium data may be questionable.

Finally, the same kind of information is shown in Figure 5.12 for fluoride. Like chromium, the fluoride concentration appears to be larger at some depth below the water table than it is at the water table. As will be discussed later (Section 5.2.2, "Extent of Contamination”), both chromium and fluoride appear to have a source in one or more of the upgradient cribs at WMA T.

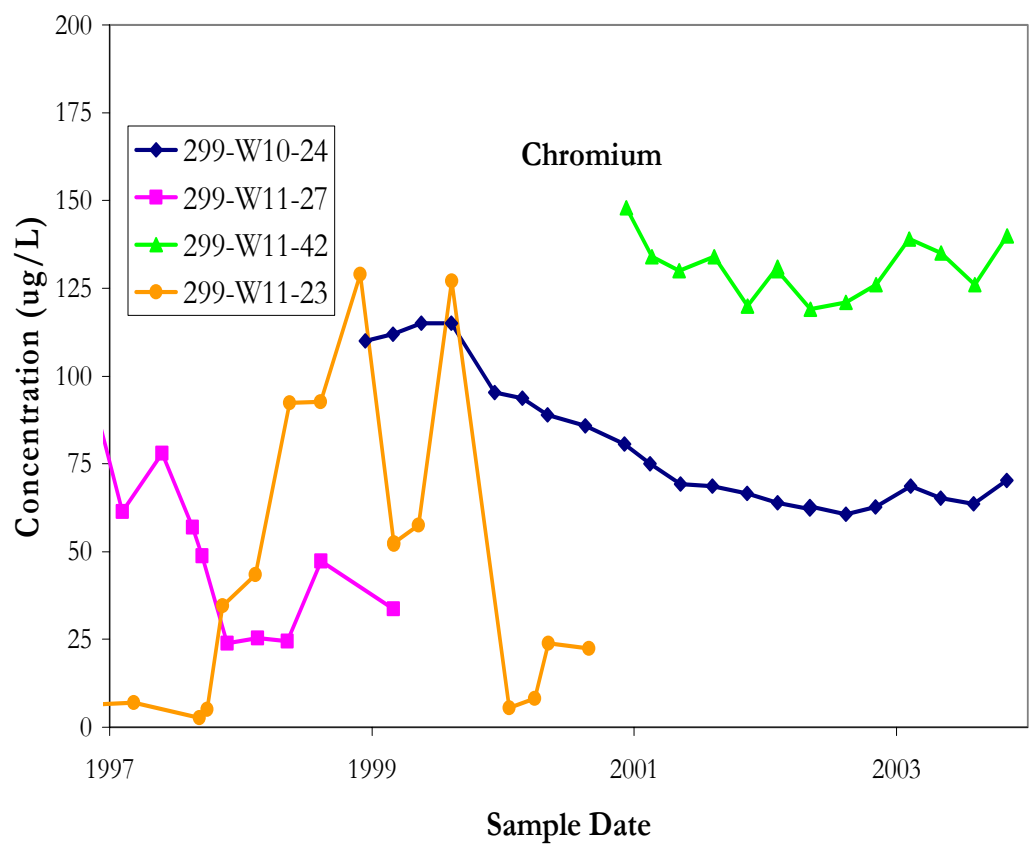

Figure 5.11. Concentrations of Chromium in Filtered Samples from Two Downgradient Well Pairs Near the T Tank Farm 


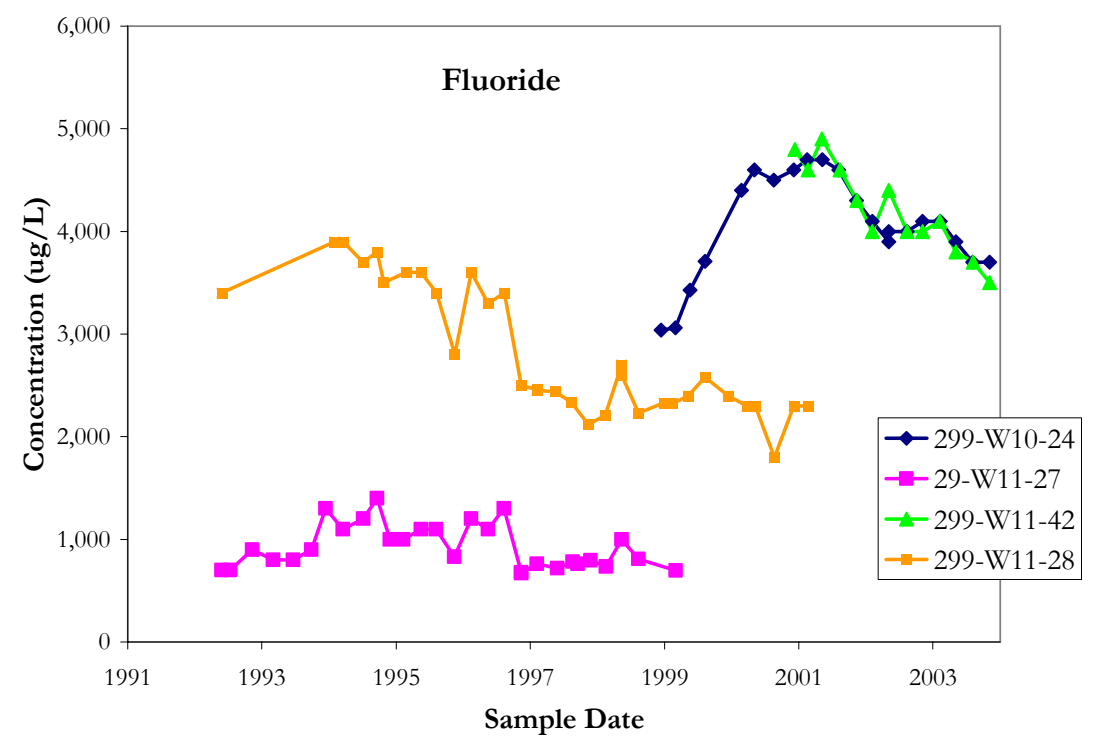

Figure 5.12. Concentrations of Fluoride in Two Downgradient Well Pairs Near the T Tank Farm

\subsubsection{Sampling During Drilling}

Groundwater and saturated sediments brought to the surface during drilling can give an indication of vertical chemical variations within the aquifer. New well 299-W10-24 was sampled in this way in 1998. Well 299-W10-24 was drilled at the northeast corner of T tank farm and through the lower mud unit of the Ringold Formation (hydrogeologic unit 8) prior to being completed as a top-of-the-aquifer monitoring well. The well was sampled with a pump-and-packer assembly at 5 depths in the aquifer (Horton et al. 2002).

The results from the pump-and-packer samples are shown in Figure 5.13. The maximum technetium-99 concentration occurs at the water table, whereas the maximum concentrations of tritium, nitrate, and carbon tetrachloride were found at about 20 meters or greater below the water table. The Ringold formation lower mud unit (hydrogeologic unit 8), a local aquitard, occurs between 52 and 53 meters below the water table in well 299-W10-24. Concentrations of all four key contaminants in Figure 5.13 decrease across the lower mud unit. 

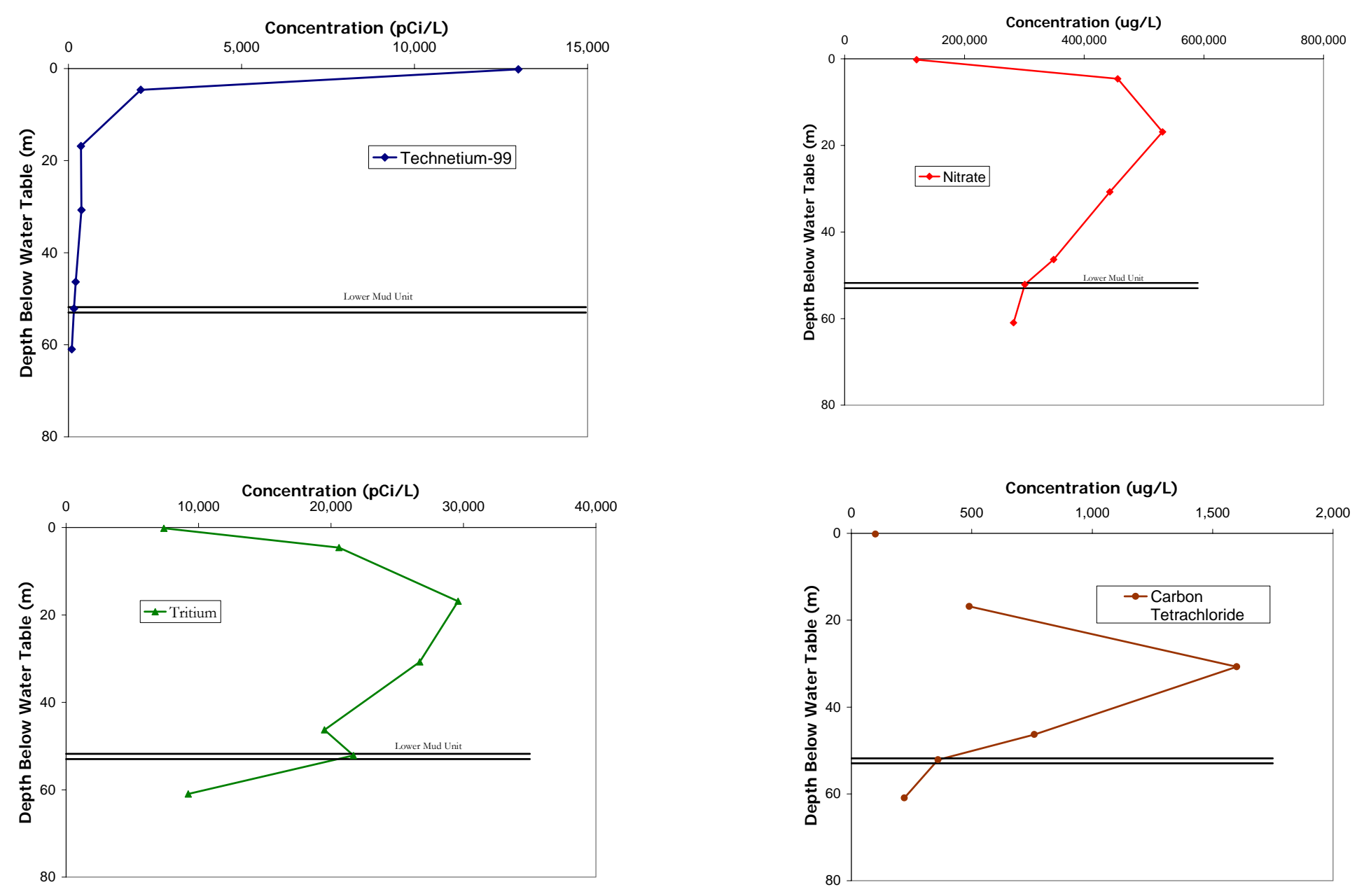

Figure 5.13. Depth Distribution of Key Contaminants in Well 299-W10-24. The sample at the water table was collected with a Kabis from well 299-W11-27; the sample at about 5 meters depth is a pumped sample from the screened interval after well completion. 
A few other samples were collected from two wells at WMA T during drilling and analyzed for a limited suite of constituents. Selected results are shown in Table 5.5. The data from well 299-W11-42 (downgradient well) in Table 5.5 are consistent with other data suggesting that specific conductance and nitrate increase with increasing depth to some distance below the water table. The data from well 299-W10-28 (upgradient well) do not reflect this trend. The nitrate concentration in well 299-W10-28 was the highest on the Hanford Site in 2003, second only to another upgradient well at WMA T, 299-W10-4 (Hartman et al. 2004). The high nitrate values upgradient of WMA T probably are due to contamination from nearby cribs that may not have had a chance to disperse in the aquifer. The downgradient, and deeper, nitrate contamination is most likely part of the regional nitrate plume in the 200 West Area.

Table 5.5. Nitrate and Specific Conductance in Samples Collected During Drilling at WMA T

\begin{tabular}{|c|c|c|}
\hline $\begin{array}{c}\text { Depth Below the Water } \\
\text { Table (m) }\end{array}$ & $\begin{array}{c}\text { Nitrate Concentration } \\
(\mu \mathrm{g} / \mathrm{L})\end{array}$ & $\begin{array}{c}\text { Specific Conductance } \\
(\mu \mathrm{S} / \mathrm{cm})\end{array}$ \\
\hline \multicolumn{3}{|c|}{$299-W 10-28^{1}$} \\
\hline 8.2 & 562,420 & 1,381 \\
\hline 16.8 & 274,700 & 784 \\
\hline \multicolumn{3}{|c|}{$299-W 11-42^{2}$} \\
\hline 0.6 & Not Measured & 580 \\
\hline 2.1 & Not Measured & 688 \\
\hline 3.6 & Not Measured & 660 \\
\hline 5.2 & 302,000 & 758 \\
\hline 8.2 & Not Measured & 1392 \\
\hline 9.8 & Not Measured & 1419 \\
\hline 11.3 & Not Measured & 1420 \\
\hline 12.8 & 576,000 & 1400 \\
\hline $\begin{array}{l}\text { 1. }=\text { Laboratory Analyses (Horto } \\
\text { 2. }=\text { Field Analyses (Horton and }\end{array}$ & do02) & \\
\hline
\end{tabular}

\subsubsection{Extent of Contamination - Geographic Distribution}

This section summarizes the areal distribution of contaminants in groundwater at WMA T. The contaminants of concern for WMA T are nitrate, fluoride, chromium, carbon tetrachloride, trichloroethene, technetium-99, and tritium. Spatial variation in contaminant concentrations may provide some clues about source areas. Because concentrations change over time, a time-period must be chosen to examine spatial distribution patterns. For this purpose, the most recent data (average of fiscal year 2003 sampling events) were chosen. The data are tabulated in Table 5.6. Data were then plotted and 
inspected for distribution patterns or groupings. Contour maps of contaminant concentrations were drawn to identify spatial patterns that might be indicative of source areas. The maps are shown in the series of Figures 5.14 through 5.20.

Table 5.6. Average Concentration of Mobile Contaminants in Groundwater in the Vicinity of Waste Management Areas T for Fiscal Year $2003^{(a)}$

\begin{tabular}{|c|c|c|c|c|c|c|c|}
\hline Wells & $\begin{array}{c}\mathrm{NO}_{3} \\
(\mu \mathrm{g} / \mathrm{L})\end{array}$ & $\begin{array}{c}\text { F } \\
(\mu \mathrm{g} / \mathrm{L})\end{array}$ & $\begin{array}{c}\mathrm{Cr} \\
(\mu \mathrm{g} / \mathrm{L})\end{array}$ & $\begin{array}{c}\mathrm{CCl}_{4} \\
(\mu \mathrm{g} / \mathrm{L})\end{array}$ & $\begin{array}{c}\text { Trichloroethene } \\
(\mu \mathrm{g} / \mathrm{L})\end{array}$ & $\begin{array}{c}\text { Tc-99 } \\
(\mathrm{pCi} / \mathrm{L})\end{array}$ & $\begin{array}{l}\text { Tritium } \\
\text { (pCi/L) }\end{array}$ \\
\hline 299-W10-1 ${ }^{(b)}$ & 131,000 & 395 & 21 & 540 & 5 & 67 & 1,360 \\
\hline $299-W 10-4^{(\mathrm{c})}$ & $1,985,000$ & 2,400 & 327 & 1,550 & 10 & 574 & 8,285 \\
\hline 299-W10-8 & 170,500 & 3,700 & 45 & NA & NA & 66 & 6,412 \\
\hline $299-W 10-22^{(\mathrm{d})}$ & 168,000 & 700 & 60 & 810 & 6 & 150 & 11,200 \\
\hline $299-W 10-23^{(b)}$ & 312,750 & 4,150 & 81 & 1,500 & 10 & 189 & 12,050 \\
\hline 299-W10-24 & 319,500 & 3,950 & 65 & NA & NA & 1,519 & 5,525 \\
\hline 299-W10-28 & $1,835,000$ & 1,375 & 133 & NA & NA & 176 & 4,232 \\
\hline $299-W 11-7^{(\mathrm{d})}$ & 164,000 & 840 & 11 & 1,400 & 8 & 404 & 19,650 \\
\hline 299-W11-12 & 145,000 & 510 & 47 & NA & NA & 226 & 52,100 \\
\hline 299-W11-39 & 89,000 & 1,650 & 70 & NA & NA & 9,208 & 2,918 \\
\hline $299-W 11-40^{(\mathrm{e})}$ & 281,000 & 2,780 & 66 & NA & NA & 513 & 17,040 \\
\hline 299-W11-41 & 579,600 & 2,720 & 140 & NA & NA & 1,934 & 21,940 \\
\hline 299-W11-42 & 716,000 & 3,900 & 132 & NA & NA & 1,314 & 8,230 \\
\hline $\begin{array}{l}\text { (a) Average conce } \\
\text { (b) One analysis } f \\
\text { (c) Average of tw } \\
\text { (d) Average of tw } \\
\text { (e) Average of fiv } \\
\text { NA = Not analyzed }\end{array}$ & $\begin{array}{l}\text { ation of four, } \\
\text { prganics. } \\
\text { nalyses for org } \\
\text { nalyses for all } \\
\text { nalyses. }\end{array}$ & $\begin{array}{l}\text { arterly sam } \\
\text { hics. } \\
\text { nstituents. }\end{array}$ & s unless sp & fied othery & & & \\
\hline
\end{tabular}

Carbon tetrachloride is present in the unconfined aquifer beneath most of the 200 West Area (Figure 5.14). The highest carbon tetrachloride concentration near WMA T in fiscal year 2003 was 1,550 $\mu \mathrm{g} / \mathrm{L}$ in well 299-W10-4, south of the waste management area. High concentrations were also found north (299-W10-23) and east (299-W11-7) of the waste management area. The carbon tetrachloride is believed to be from pre-1973 waste from the Plutonium Finishing Plant and not from the WMA T area. 


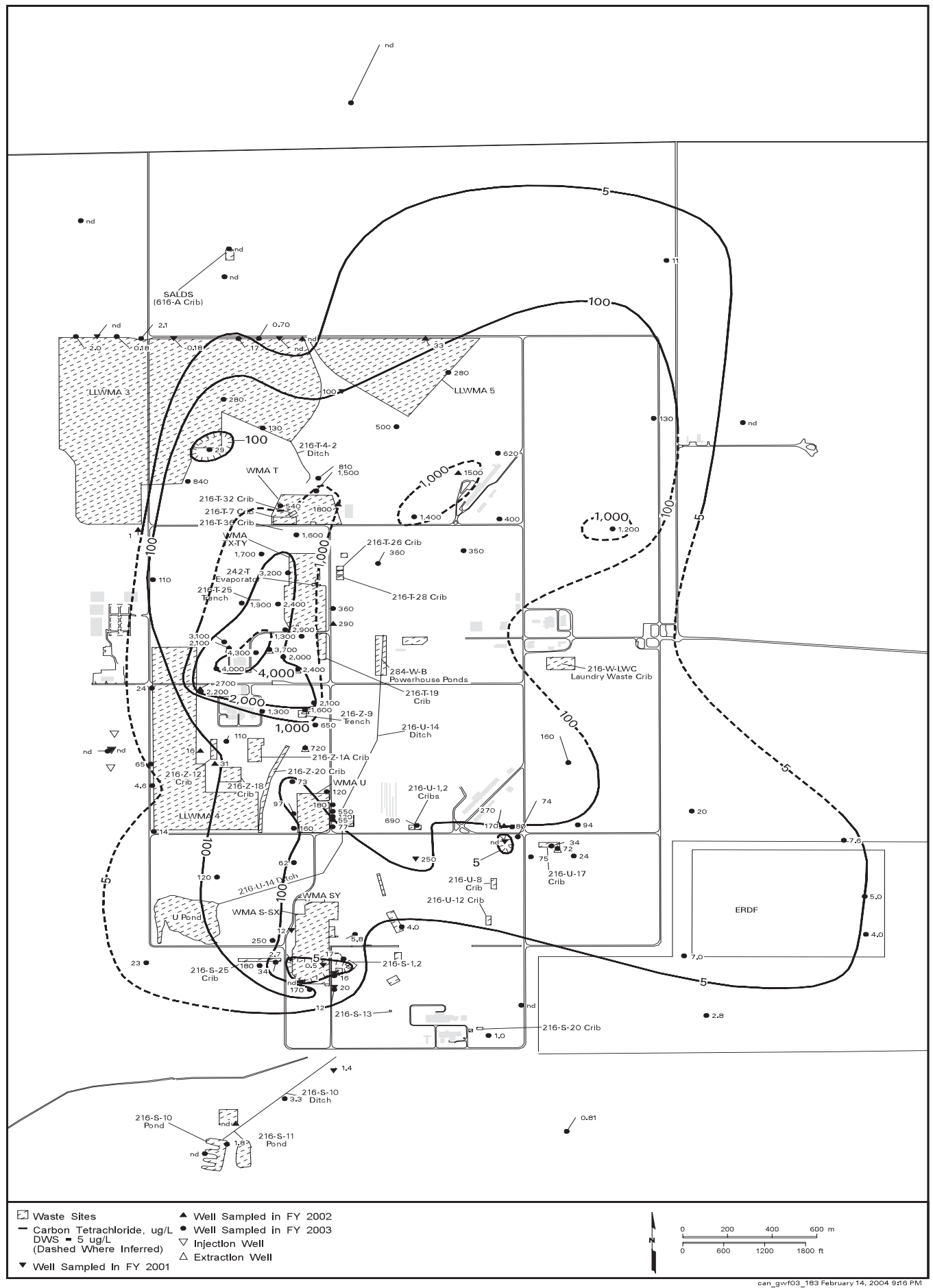

Figure 5.14. Average Concentrations of Carbon Tetrachloride in the 200 West Area, Top of the Unconfined Aquifer (from Hartman et al. 2003) 
The major sources for trichloroethene are disposal sites associated with the Plutonium Finishing Plant. A second potential source is disposal near T Plant (Hartman et al. 2003). The maximum trichloroethene concentration found near WMA T in 2003 was $10 \mu \mathrm{g} / \mathrm{L}$ both north (well 299-W10-23) and south (well 299-W10-4) of the WMA. The waste management area is not considered a source for trichloroethene. Figure 5.15 shows the average concentrations of trichloroethene in the north part of the 200 West Area.

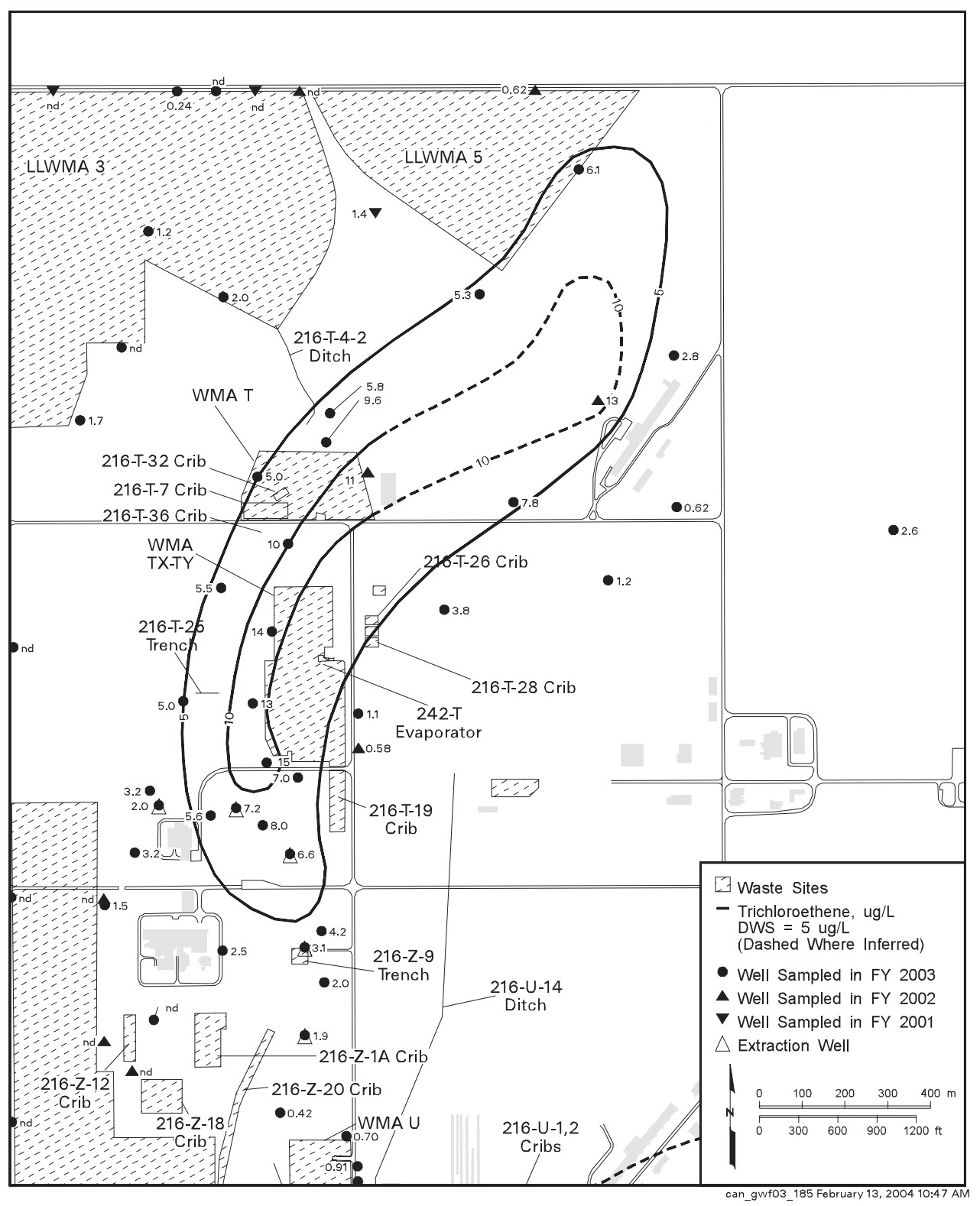

Figure 5.15. Average Concentrations of Trichloroethene in the North Part of the 200 West Area, Top of the Unconfined Aquifer (from Hartman et al. 2003) 
A tritium plume lies beneath much of the north half of the 200 West Area (Figure 5.16). The plume geometry suggests that the major tritium source is near the 242-T evaporator, the TY tank farm, and nearby cribs (Hartman et al. 2003). Other contributing sources are likely present in the vicinity of the $\mathrm{T}$ tank farm and include associated cribs and trenches and, potentially, tank leaks.

The highest tritium concentration near WMA T in 2003 was 52,100 pCi/L in well 299-W11-12, located at the southeast corner of the waste management area. Waste Management Area $\mathrm{T}$ is not thought to be a major contributor of tritium to groundwater in the area.

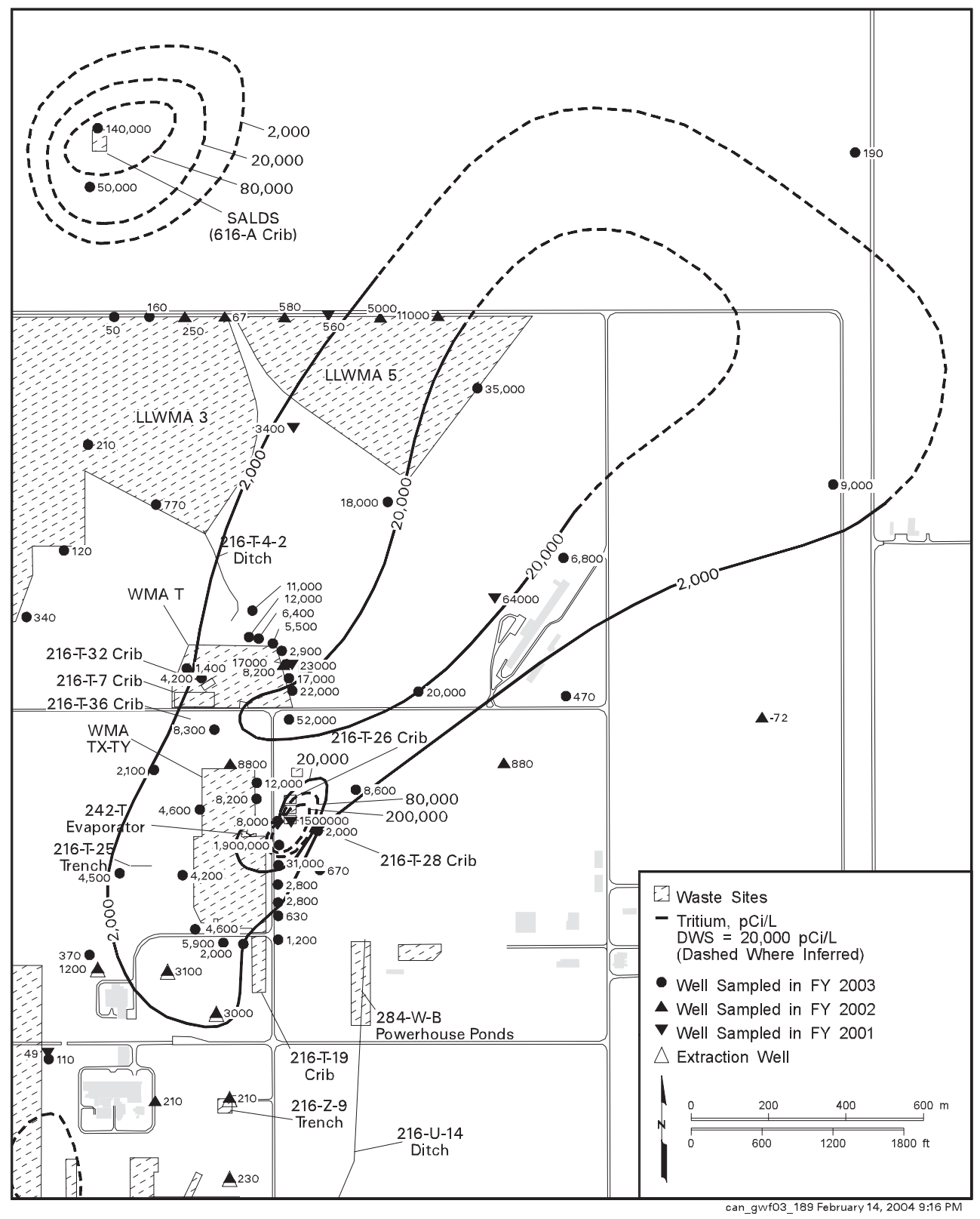

Figure 5.16. Average Concentrations of Tritium in the North Part of 200 West Area, Top of the Unconfined Aquifer (from Hartman et al. 2003) 
A regional nitrate plume underlies WMA T and much of the north part of the 200 West Area (Figure 5.17). However, unlike carbon tetrachloride, trichloroethene, and tritium, there also appears to be a source of nitrate local and upgradient to Waste Management Area T. All monitoring wells in the WMA T monitoring network have nitrate concentrations in excess of the $45,000 \mu \mathrm{g} / \mathrm{L}$ maximum contaminant level. The highest nitrate concentrations at the Hanford Site in fiscal year 2003 were from two upgradient wells at WMA T: 1,985,000 $\mu \mathrm{g} / \mathrm{L}$ in well 299-W10-4 and 1,835,000 $\mu \mathrm{g} / \mathrm{L}$ in well 299W10-28. The nitrate concentration began to increase in well 299-W10-4 in about 1997 when the groundwater flow direction changed from northerly to easterly (Figure 5.18). Concentrations continued to rise until just recently. Since it was drilled in 2001, the nitrate concentration in well 299-W10-28 has always been high and parallel to concentrations in well 299-W10-4. The most likely source for the nitrate in this area is one or more of the past-practice liquid disposal facilities up gradient of the $\mathrm{T}$ tank farm (Table 5.7).

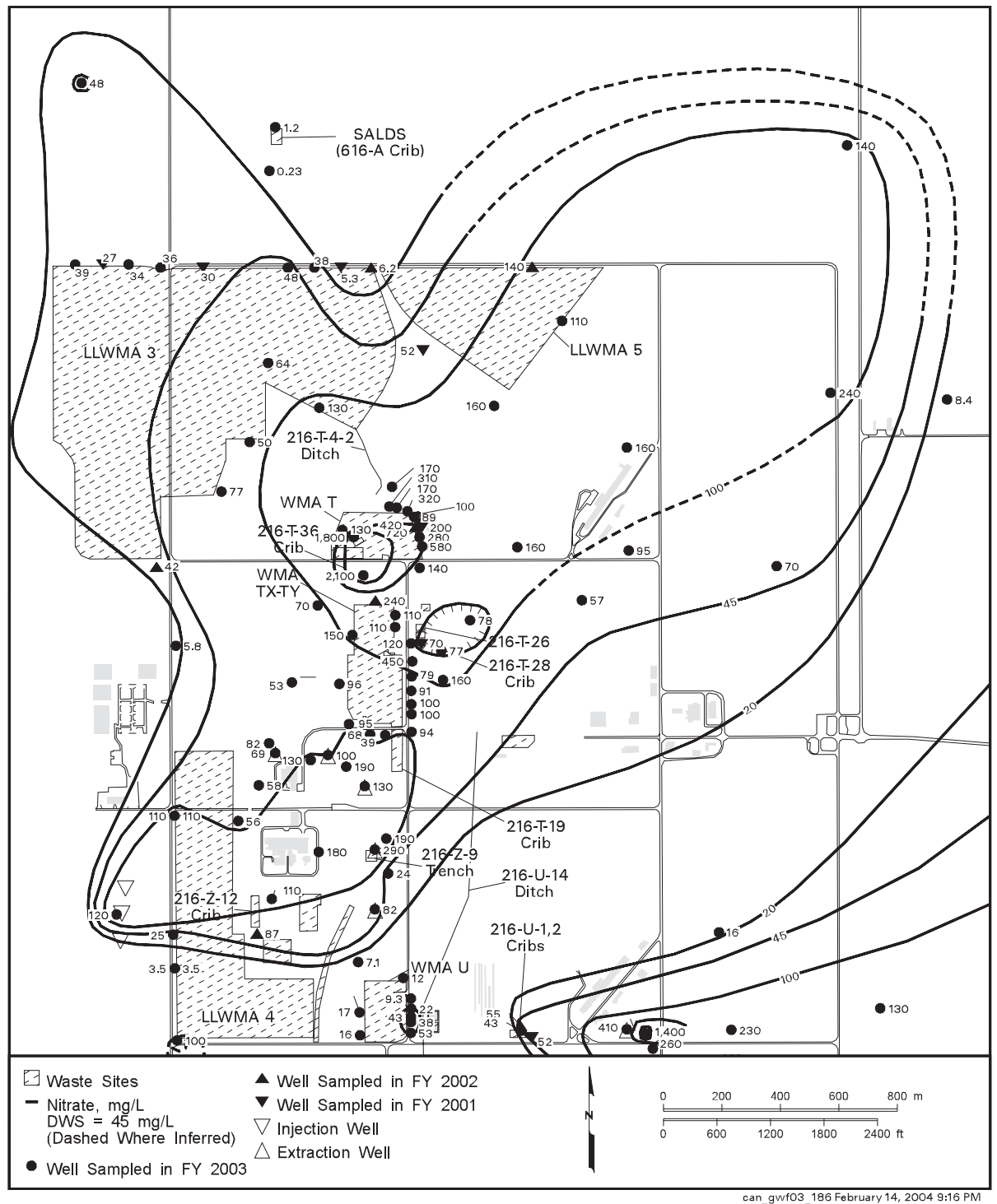

Figure 5.17. Average Concentrations of Nitrate in the North Part of 200 West Area, Top of the Unconfined Aquifer (from Hartman et al. 2003) 
Table 5.7. Partial Inventories for Past-Practice Facilities Upgradient of WMA T

\begin{tabular}{|c|c|c|c|c|c|}
\hline Facility & $\begin{array}{c}\text { Date of } \\
\text { Operation }\end{array}$ & $\begin{array}{l}\text { Effluent Volume } \\
(\mathrm{L})^{(1)}\end{array}$ & $\begin{array}{l}\text { Nitrate } \\
(\mathbf{K g})^{(2)}\end{array}$ & $\begin{array}{l}\text { Fluoride } \\
\text { (Kg) }^{(3)}\end{array}$ & $\begin{array}{l}\text { Chromium } \\
\qquad(\mathrm{Kg})^{(3)}\end{array}$ \\
\hline 216-T-5 crib & 1955 & $2,600,000$ & 140,000 & 573 & 220 \\
\hline $\begin{array}{l}\text { 216-T-7 crib and } \\
\text { tile field }\end{array}$ & 1948 - 1955 & $110,000,000$ & $2,300,000$ & 19,900 & 3,920 \\
\hline 216-T-32 crib & 1946 - 1952 & $29,000,000$ & $1,200,000$ & 16,000 & 2,490 \\
\hline 216-T-36 & 1966 - 1967 & $\begin{array}{c}522,000 \\
\text { decontamination } \\
\text { waste and } \\
\text { condensate }\end{array}$ & Not Available & Not Available & Not Available \\
\hline \multicolumn{6}{|c|}{$\begin{array}{l}\text { 1. Data from Williams } 2000 \text {. } \\
\text { 2. Data from DOE/RL-91-61. } \\
\text { 3. Data from Simpson et al. } 2001 \text {. }\end{array}$} \\
\hline
\end{tabular}

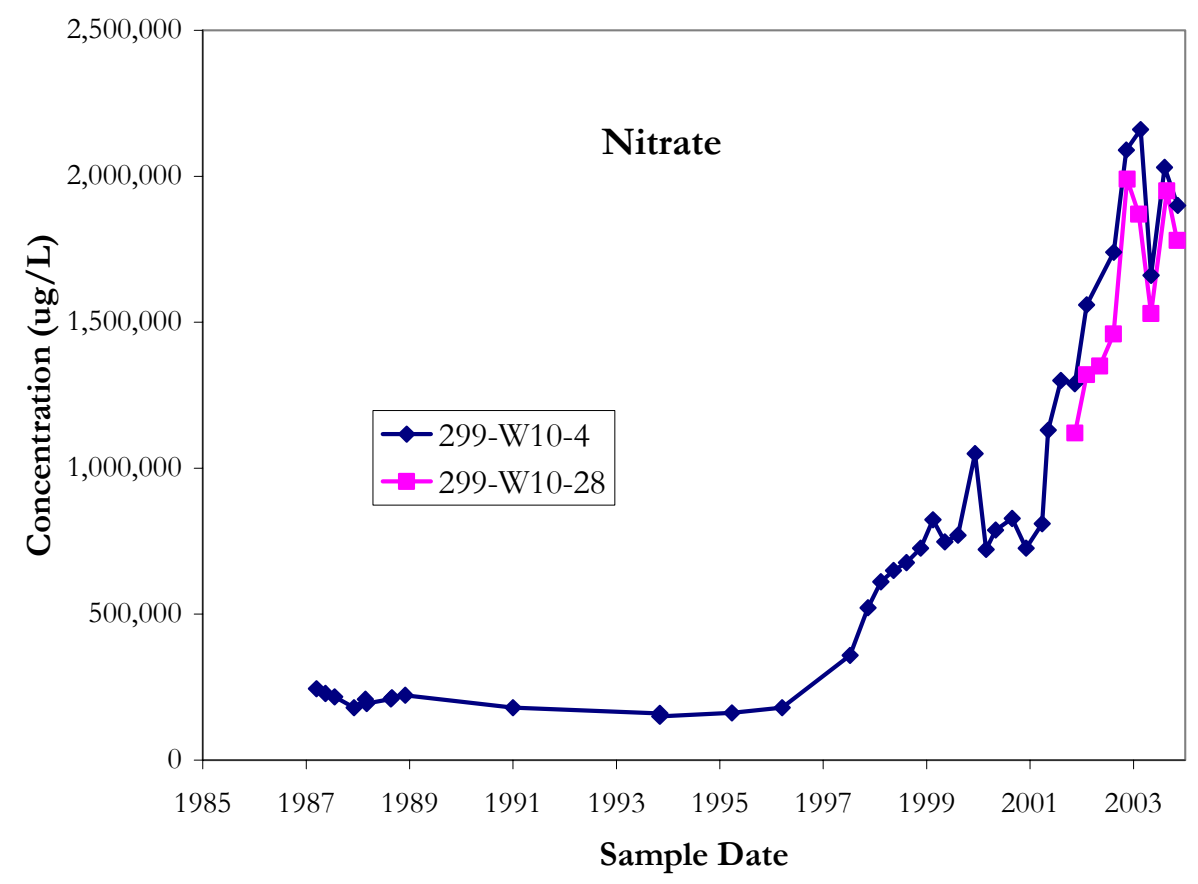

Figure 5.18. Nitrate Concentration versus Time in Upgradient Wells at WMA T

A plume map depicting the fiscal year 2003 average chromium concentration in wells near WMA T is shown in Figure 5.19. The highest chromium concentrations are in upgradient wells 299-W10-28 and 299-W10-4 where chromium reached 215 and $347 \mu \mathrm{g} / \mathrm{L}$ respectively in 2003. Figure 5.20 shows trend 
plots for chromium in those wells. (Chromium was also elevated in well 299-W10-3, located inside the tank farm fence between the 216-T-7 crib and tile field and the 216-T-32 crib and upgradient of the tank farm. This well was sampled only in 2000 during its decommissioning when the chromium concentration was $257 \mu \mathrm{g} / \mathrm{L}$.) Prior to about 1997 when groundwater flow direction was toward the north, several wells on the north (then downgradient) side of the waste management area had relatively high chromium concentrations. Also, prior to 1997, well 299-W10-1, which was parallel to the tank farm with respect to groundwater flow direction but downgradient of the 216-T-5 trench, the 216-T-7 crib and tile field, and the 216-T-32 crib, had chromium concentrations exceeding $200 \mu \mathrm{g} / \mathrm{L}$. After the flow direction changed toward the east in about 1997, chromium concentrations dropped to $<40 \mu \mathrm{g} / \mathrm{L}$ in well 299-W10-1, decreased in all of the northern wells (Figure 5.21), and began increasing in well 299-W10-4. The most likely source for the chromium west and north of Waste Management Area $\mathrm{T}$ is one or more of the disposal facilities upgradient of the WMA (Table 5.7). Chromium from these facilities would have been moving north across well 299-W10-1 prior to 1997 and then east across the northern wells and the rest of the waste management area after 1997.

Finally, since December 2000, chromium has exceeded the maximum contaminant level in two downgradient wells, 299-W11-41 (average for fiscal year 2003, $141 \mu \mathrm{g} / \mathrm{L}$ ) and 299-W11-42 (average for fiscal year 2003, $132 \mu \mathrm{g} / \mathrm{L}$ ). These wells are located downgradient of the disposal facilities east of WMA T but appear to be too far away for chromium to have migrated from west of the WMA to the wells since the 1996 change in groundwater flow direction, given a flow rate of 0.025 meter per day.

Fluoride concentrations exceeded the drinking water standard of 4,000 $\mu \mathrm{g} / \mathrm{L}$ in three wells at Waste Management Area T in 2003 and exceeded the secondary drinking water standard of 2,000 $\mu \mathrm{g} / \mathrm{L}$ in four additional wells. Currently, the highest concentrations are in downgradient wells (Figure 5.22) but historically, the highest fluoride concentration was in upgradient well 299-W10-4 in late 1999 (5,250 $\mu \mathrm{g} / \mathrm{L})$. A fluoride plume appears to have passed well 299-W10-4 between mid-1997 and late 2000. Although a tank farm source for the fluoride contamination has not been ruled out, one or more of the nearby cribs are believed to be a more likely source for two reasons. The first reason is the high concentrations of fluoride in upgradient wells located near potential fluoride sources (see Table 5.7). Second, the fluoride/technetium-99 ratios vary from well to well at WMA T and with time in some wells (see Figure 5.23 for example). If the technetium-99 has a source within the waste management area, as suggested below, the fluoride/technetium-99 ratios suggest a different source for the fluoride. The most likely source or sources are past practice facilities located upgradient of the waste management area. 


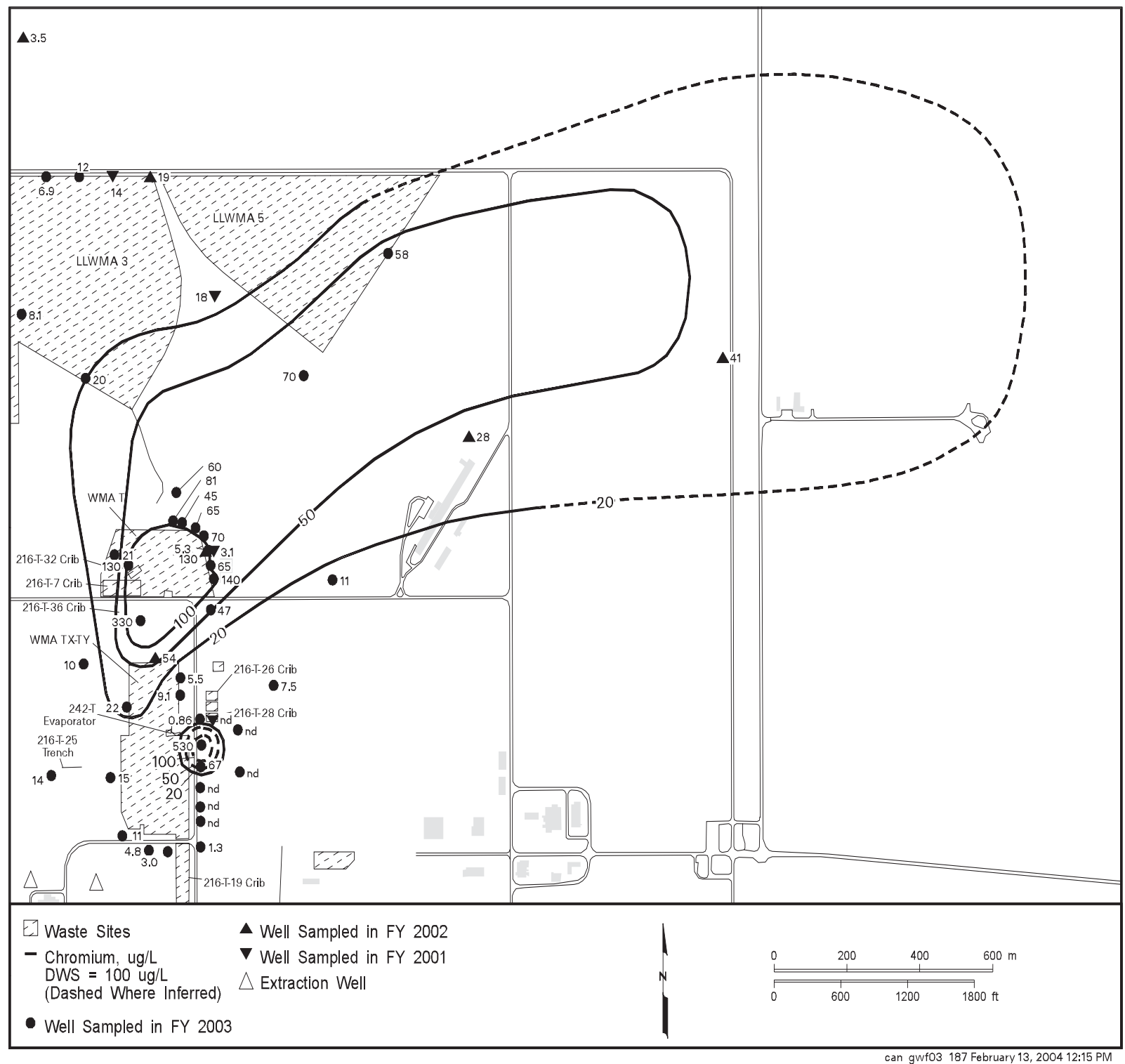

Figure 5.19. Average Concentrations of Chromium in the Area of Waste Management Area T, Top of the Unconfined Aquifer (from Hartman et al. 2003) 


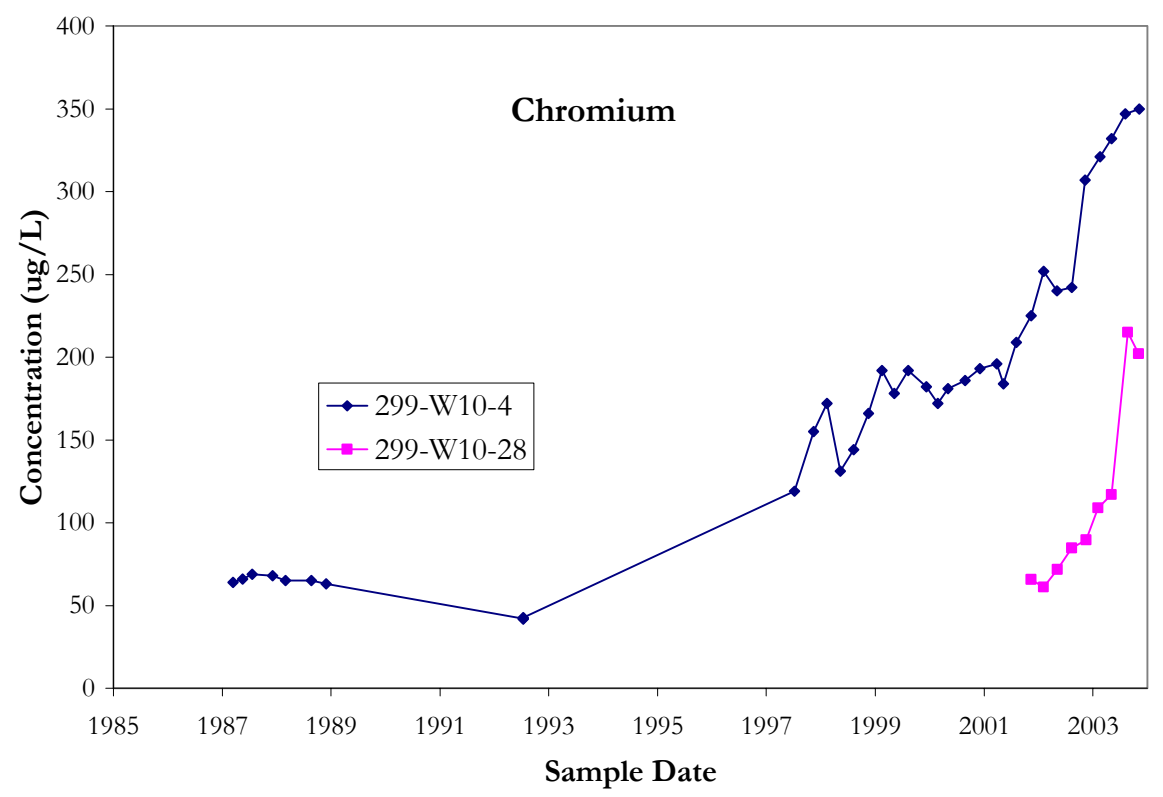

Figure 5.20. Chromium Concentration versus Time for Selected Upgradient Wells at Waste Management Area T

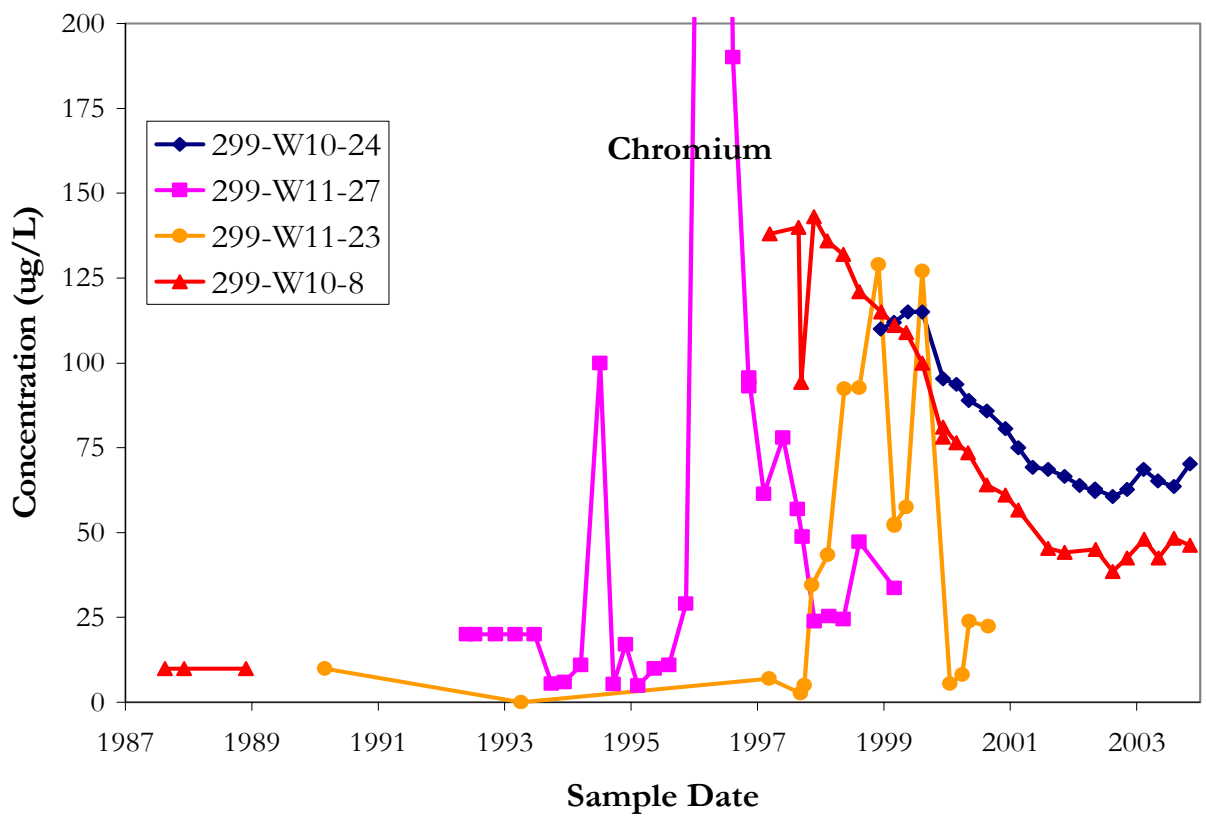

Figure 5.21. Chromium Concentration versus Time for Selected Wells North of Waste Management Area T 


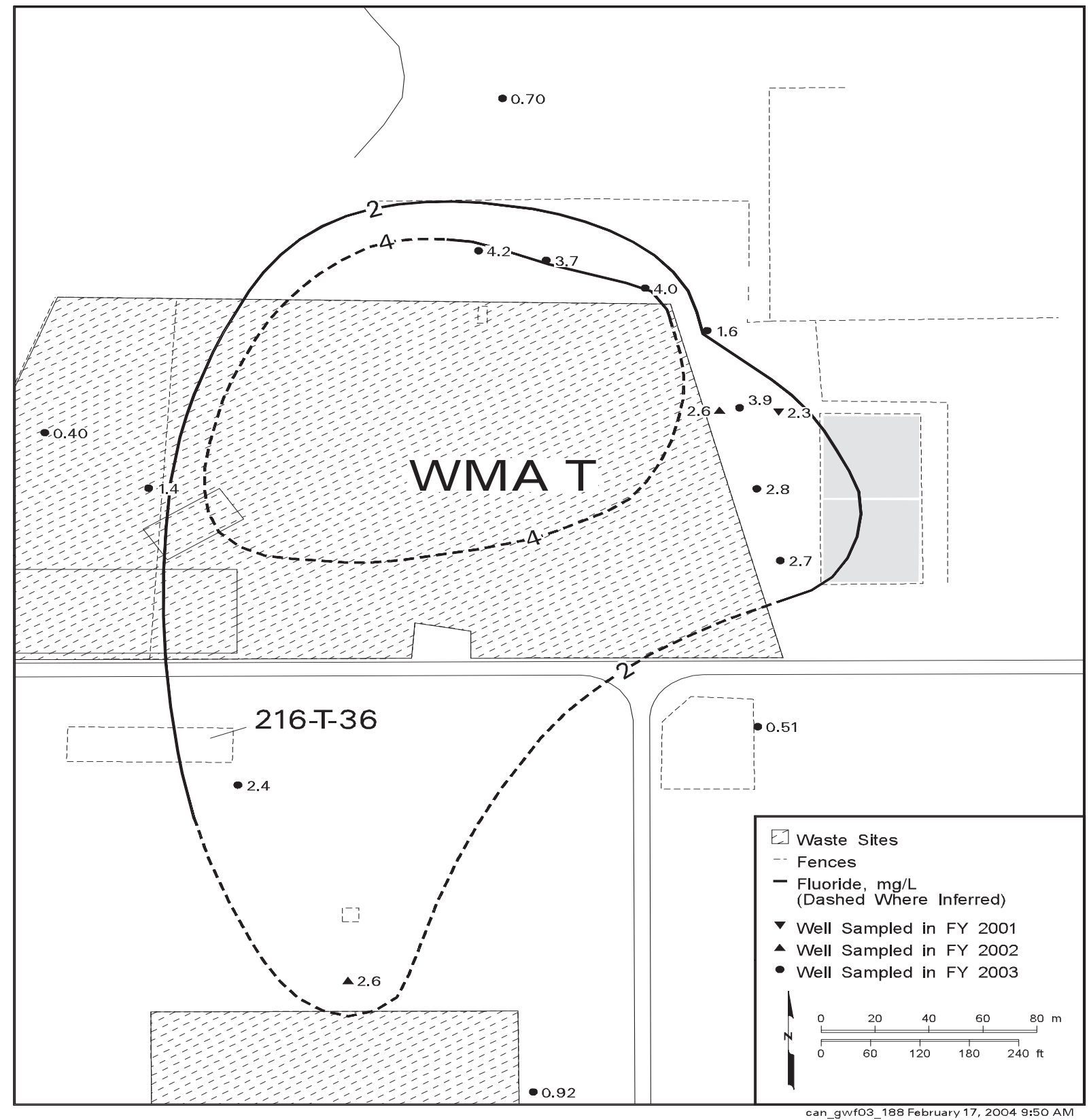

Figure 5.22. Average Concentrations of Fluoride in the Area of Waste Management Area T, Top of the Unconfined Aquifer (from Hartman et al. 2003) 


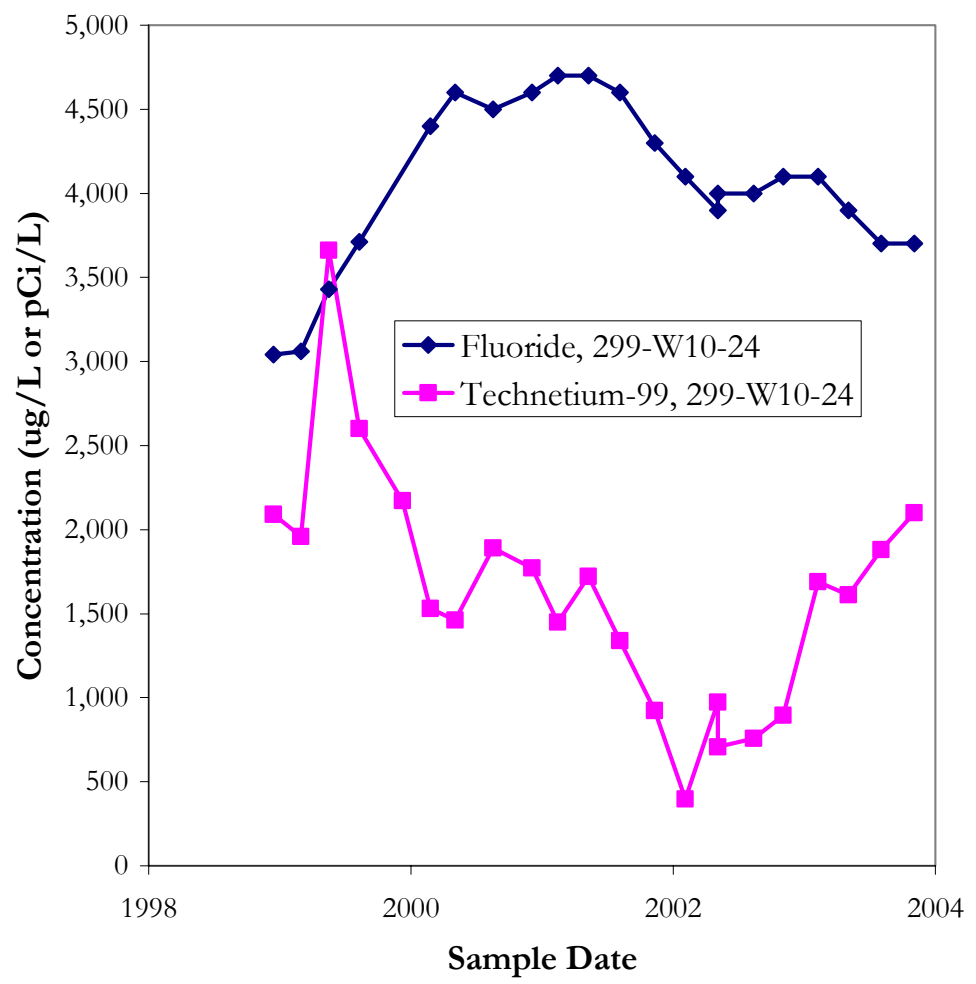

Figure 5.23. Technetium-99 and Fluoride Concentrations in Downgradient Well 299-W-10-24

A technetium-99 groundwater plume exists northeast and east of Waste Management Area T (Figure 5.24). The highest technetium-99 concentration in fiscal year 2003 was 9,200 pCi/L in downgradient well 299-W11-39. The most probable source for the technetium-99 is the waste management area.

Technetium-99 began to increase in well 299-W11-27, located at the northeast corner of 241-T tank farm, in late 1995, coincident with the cessation of surface water disposal in the 200 West Area. Concentrations reached a maximum of 21,700 pCi/L in February 1997 (see Figure 5.9). Technetium-99 concentrations in well 299-W11-27 subsequently decreased to 6,000 pCi/L in March 1999. Hodges (1998) suggested that technetium-99 had arrived at well 299-W11-27 by the early 1990s, but was masked by dilution with water from a leaking water line located immediately adjacent to the well. The water line carried cooling and ventilation steam condensate, process cooling water, and evaporator condensate from the 207-T retention basin to the 216-T-4-2 ditch (DOE/RL-91-61) until 1995. The subsequent decrease in technetium-99 in well 299-W11-27 since 1997 may have been a result of changing groundwater flow direction. 


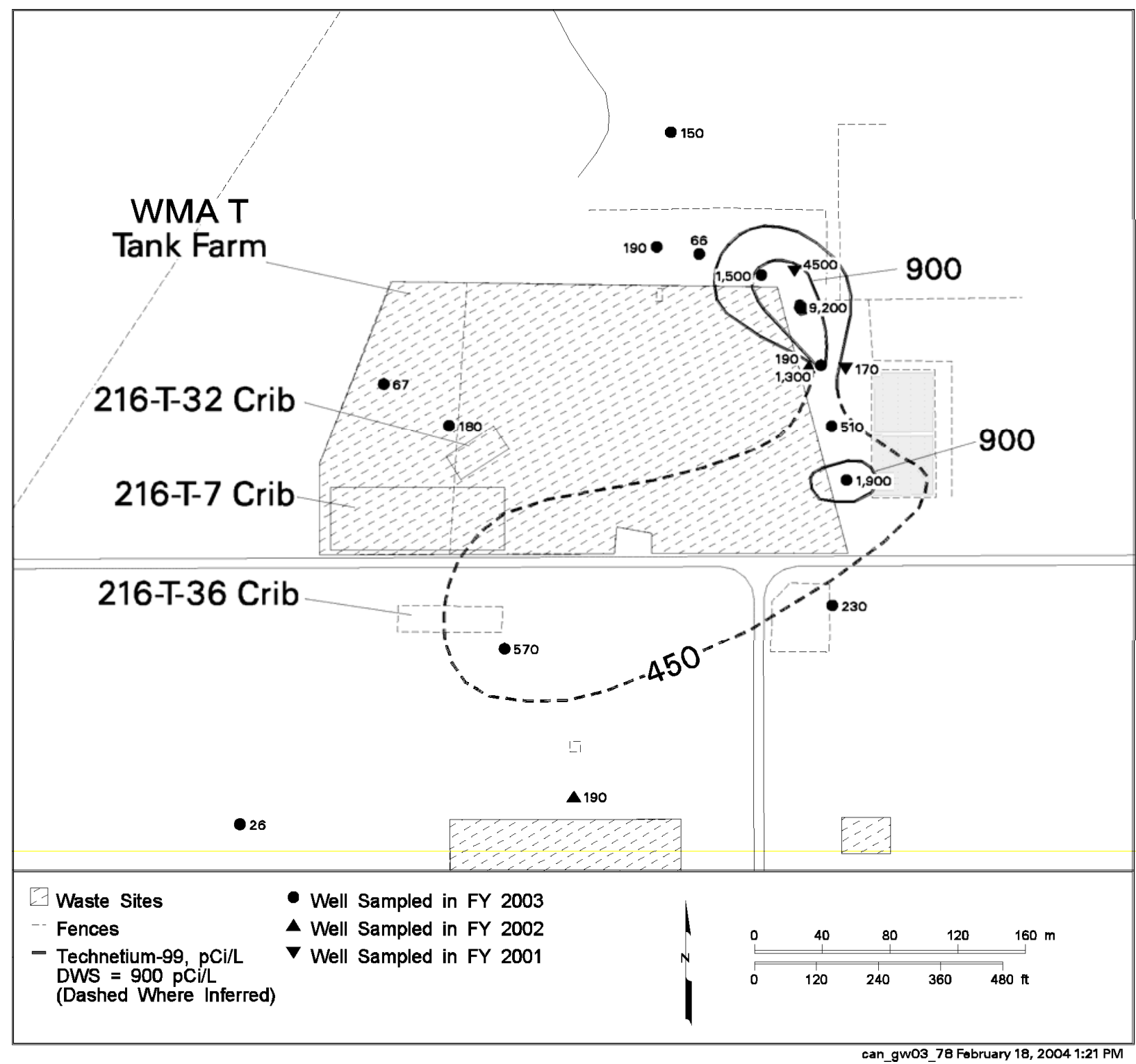

Figure 5.24. Average Concentrations of Technetium-99 in the Area of Waste Management Area T, Top of the Unconfined Aquifer (from Hartman et al. 2003)

Technetium-99 began to increase in well 299-W11-23, located east of well 299-W11-27, in November 1997 coincident with the change in groundwater flow to a more easterly direction. It increased to a high of $8,540 \mathrm{pCi} / \mathrm{L}$ in November 1998 (see Figure 5.9). Subsequently, technetium-99 values have fluctuated between 7,110 and $840 \mathrm{pCi} / \mathrm{L}$. The last sample from this well, taken in December 2000, indicated a technetium-99 concentration of 4,470 pCi/L. The most plausible explanation for the 1997 arrival of the contaminant plume at well 299-W11-23 is the change in groundwater flow direction. If this is the case, a narrow contaminant plume initially moved northeast across well 299-W11-27 but not across well 299-W11-23. Changing groundwater flow direction caused this plume to drift east across well 299-W11-23. Sampling of replacement well 299-W11-39 in 2001 detected technetium-99 concentrations 
between 4,160 and 5,010 pCi/L, indicating contamination of the upper portion of the aquifer at this well. Subsequently, the technetium-99 concentration rose to a high of $10,400 \mathrm{pCi} / \mathrm{L}$ in February 2003 and began a small decline in August 2003.

In early 2002, technetium-99 concentrations began to increase in well 299-W11-42, south of well 299-W11-39 and, in early 2003, technetium-99 began to increase in well 299-11-41, south of 299-W11-42. Apparently, the technetium-99 contamination that was detected in the northeast corner of 241-T tank farm is spreading southward along the east and downgradient side of the WMA. As shown in Section 5.2.1.3 ("Sampling During Drilling”), the highest recent technetium-99 concentrations are at or near the water table and concentrations decrease rapidly with increasing depth in the aquifer. This points to a nearby source for the technetium-99 because the contaminant has not traveled far enough to disperse vertically in the aquifer. The apparent nearness of the technetium-99 source suggests that WMA T is the most likely origin for the technetium-99.

Also, Hodges (1998) explains that even though most tank waste is a multi-molar sodium nitrate brine, calcium is the first cation to increase in concentration when tank waste enters groundwater. This is because 1) tank leaks and tank pipeline leaks are relatively small in volume (relative to the releases sent to cribs and tile fields) and 2) the sodium in the leaked fluids replaces the exchangeable calcium and magnesium in the vadose zone sediment. This results in a high calcium porewater that is pushed ahead of the sodium to the groundwater (see discussions in Serne et al. 2002b, 2002c, 2002d, 2002e and 2004).

Figures 4.18 and 4.46 in this report show this phenomenon in the vadose zone sediments and Figure 5.25 illustrates it in the groundwater at the $\mathrm{T}$ tank farm.

Figure 5.25 is a series of modified Stiff diagrams for groundwater samples from well 299-W11-27 in which technetium-99 was found in early 1996. (Nitrate has been added to the traditional Stiff diagram because nitrate is a major component in the groundwater beneath the 200 West Area.) The diagrams show that calcium, and not sodium, increases in the groundwater at the time technetium-99 is detected. Also, nitrate begins to increase at the same time as the increase in calcium. This argues for a relatively small, nearby source for the technetium-99 contamination in the area because a large volume source would have saturated the exchange sites in the vadose zone, and breakthrough of sodium to groundwater would have been detected. 

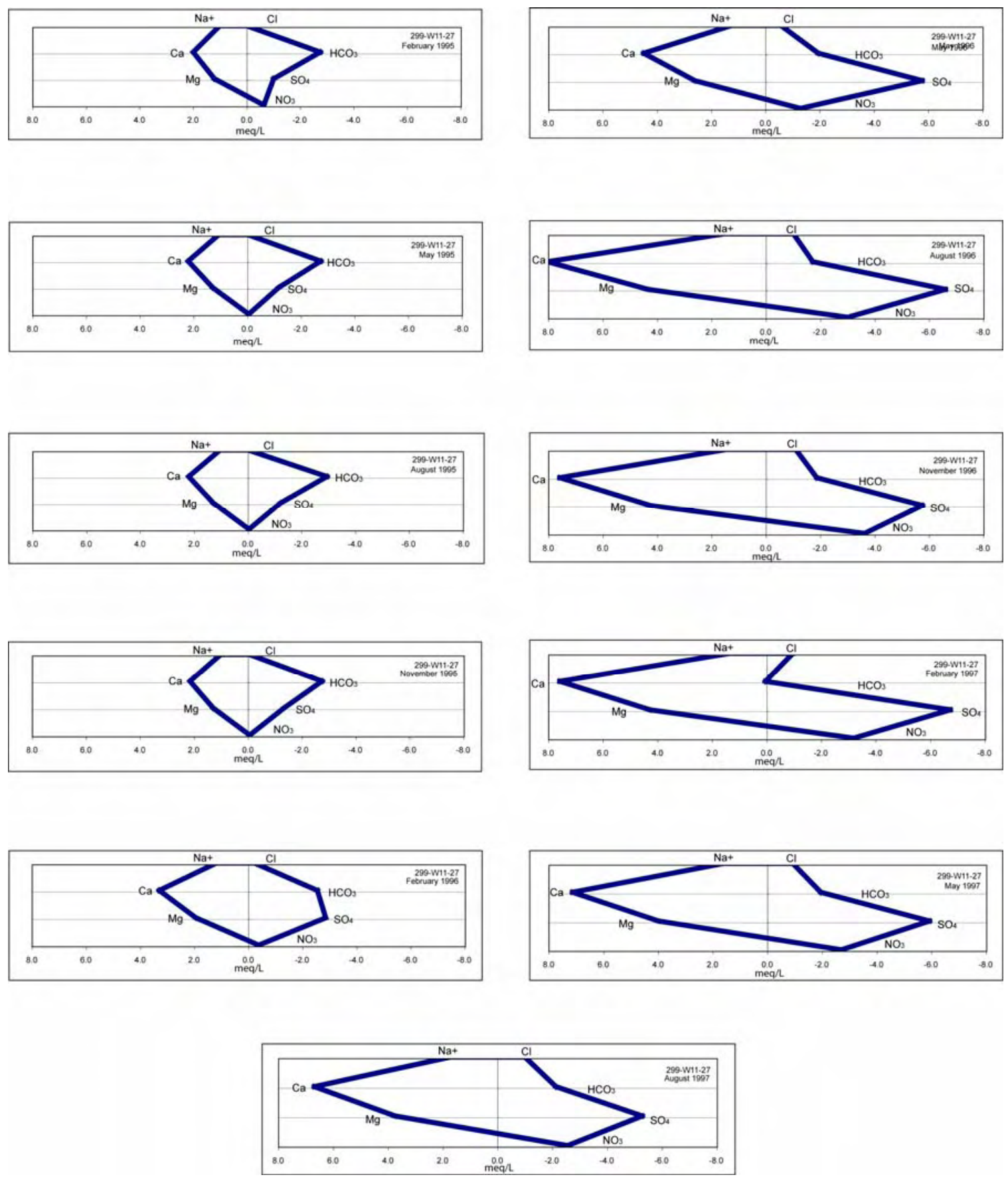

Figure 5.25. Time Series Stiff Diagrams Showing Breakthrough of Calcium and Nitrate to Groundwater at Well 299-W11-27 


\subsection{Comparison of Groundwater, Vadose Zone Porewater, and Tank Leak Compositions}

The previous section discussed the geographic distribution of contaminants and related the distribution to potential contaminant sources. This section compares the chemical composition of groundwater with the composition of the vadose zone porewater and with the composition of tank leaks and discharges to nearby cribs in an attempt to more accurately pinpoint specific sources for the contamination in the groundwater at WMA T.

The earliest evidence of groundwater contamination around WMA T as found in the HEIS ${ }^{(a)}$ database is high levels of gross beta in wells located at the cribs and trenches west of WMA T. By 1955 and 1956 levels of gross beta had reached values in excess of 1,000,000 pCi/L in well 299-W10-2, located about 20 meters south of the 216-T-7 tile field (Figure 5.26). The gross beta contamination was accompanied by nitrate levels in excess of 3,000,000 $\mu \mathrm{g} / \mathrm{L}$ in the general area and up to 6,900,000 $\mu \mathrm{g} / \mathrm{L}$ in well 299-W10-2. It is possible that gross beta and nitrate groundwater contamination pre-dates 1955, but there are no available analyses.

The oldest available analysis for cobalt-60 in groundwater in the area is from well 299-W10-4 in 1957; it showed that the cobalt-60 concentration was $2000 \mathrm{pCi} / \mathrm{L}$ at that time. Cobalt-60 was later found in well 299-W10-2 in 1969 at a concentration of 680 pCi/L. Finally, ruthenium-106 was first noted in groundwater in 1972 at wells 299-W10-2 and 299-W10-4 at concentrations of 140 pCi/L and 400 pCi/L, respectively.

Two things should be remembered about these early analyses. First, they are the oldest available analyses and do not represent the first arrival of contamination in groundwater in the area. Second, the concentrations should be considered approximate since detection limits and analytical accuracies have improved through the years.

This early groundwater contamination pre-dates any reported tank leak from the 241-T tank farm. The most likely source for this contamination is either the 216-T-7 crib and tile field, which operated between 1947 and 1955 and received 110,000,000 L of effluent, or the 216-T-32 crib, which operated between 1946 and 1952 and received 29,000,000 L of waste. Groundwater at that time was flowing toward the south from the disposal facilities toward the contaminated wells (Figure 5.4).

Groundwater contamination was first noted north of WMA T in well 299-W10-8 in October 1973, when ruthenium-106 was found at a concentration of $430 \mathrm{pCi} / \mathrm{L}$ and quickly increased to $1,100 \mathrm{pCi} / \mathrm{L}$ in March 1974. Cobalt-60 was first noted in the well in early 1974 at $20 \mathrm{pCi} / \mathrm{L}$. Groundwater had shifted flow direction from southerly to northeasterly in about 1957. This direction places well 299-W10-8 downgradient of the 216-T-7 tile field and 216-T-32 crib. Well 299-W10-8 is about 150 meters northeast of 216-T-32 crib and 180 meters northeast of the 216-T-7 tile field. Given a typical groundwater flow

(a) HEIS is the Hanford Environmental Information System. A URL is located at http://www.hanford.gov/docs/rl93-69/rl-93-69.pdf. This link is to DOE/RL-93-69, Revision 4, Tri-Party Agreement Databases, Access Mechanism and Procedures. It may be accessed by anyone. 

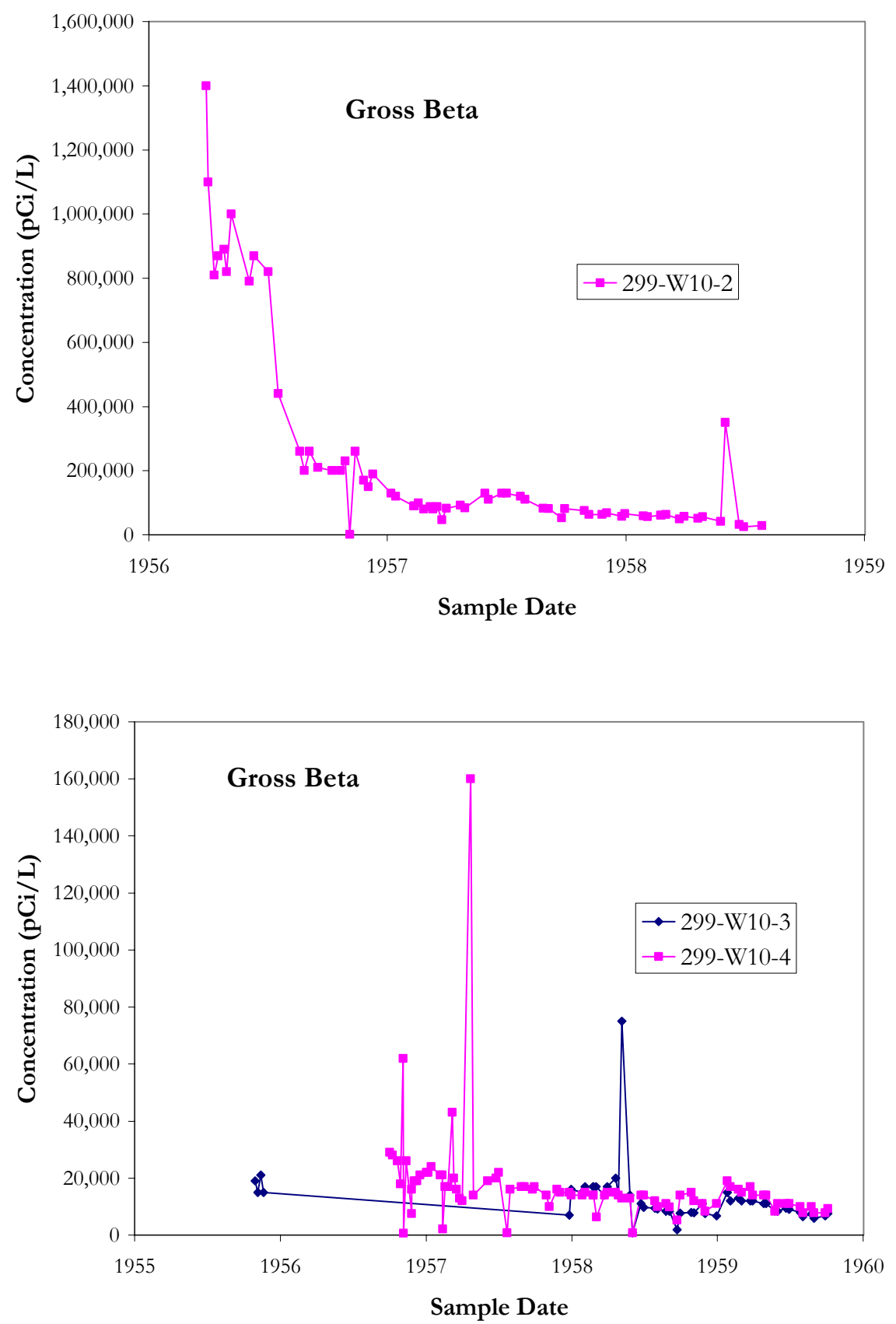

Figure 5.26. Gross Beta Contamination in Wells West and Southwest of WMA T

rate of 0.02 meter per day, contamination could have traveled about 130 meters from the disposal facilities between January 1956 and October 1973. It is possible that the groundwater flow rate was greater than $0.02 \mathrm{~m} / \mathrm{d}$ in the 1960 s driven by the groundwater mound under $\mathrm{U}$ pond. A groundwater velocity of $0.03 \mathrm{~m} / \mathrm{d}$ would allow for transport of contaminants from the 216-T-7 tile field well beyond well 299-W10-8 by late 1973 (assuming no contaminant retardation). Clearly, however, a groundwater flow rate of $0.03 \mathrm{~m} / \mathrm{d}$ is not sufficient to drive contaminants from the vicinity of tank T-106 to well 299- 
W10-8, a distance of about 105 meters, in the 4 month time period between the reported tank leak in June 1973 and the first detection of ruthenium-106 at the well.

To determine whether tank leak T-106 has impacted groundwater quality, one or more components of the leak need to be detected in groundwater. Estimates of the leak composition are available (Jones et al. 2000) but, unfortunately, the major, mobile components in the tank leak for which we have groundwater data, are also major, mobile components disposed in the nearby cribs and trenches.

Hodges (1998) used tritium/technetium-99 and nitrate/technetium-99 ratios from analyses of wells at WMA T to distinguish waste disposed of to cribs, trenches and tile fields in the area from evaporator condensate wastes and waste discharged from the Plutonium Finishing Plant. This section attempts to use the same ratios, and others, to distinguish tank leaks from wastes disposed to cribs and trenches west of WMA T.

Table 5.8 gives the estimated concentration of selected components found in two tank leaks at WMA $\mathrm{T}$ and in effluent disposed to three disposal facilities located west of WMA T. The constituents listed in Table 5.8 were dictated by the available analytes from groundwater analyses that also might be in tank and crib wastes. The data in Table 5.8 show that there are significant differences ( 2 or more orders of magnitude) in the concentrations of chromium, fluoride, tritium, cobalt-60, technetium-99, and ruthenium-106 between tank leaks and the waste streams of interest. Using these components plus nitrate, eight ratios (pairs of constituents) were examined: technetium-99/fluoride, technetium-99/nitrate, technetium-99/chromium, technetium-99/tritium, technetium-99/cobalt-60, cobalt-60/ruthenium-106, ruthenium-106/technetium-99, and chromium/cobalt-60.

Analyses for cobalt-60 and ruthenium-106 were common in the 1950s through 1970s but much less so in the 1980s and 1990s, mostly because these two radionuclides have short half-lives and decayed quickly. Analyses for metals (chromium), anions (fluoride), and technetium-99 are rare or non existent in the 1950s through 1970s but become more common in the 1980s and are abundant in the 1990s. Therefore, insufficient data were available for the analyte pairs of ruthenium-106 and cobalt-60 with technetium-99 or chromium. Some potentially useful information could be obtained from all other analyte pairs.

\subsubsection{Technetium-99 - Chromium}

The relative groundwater concentrations for technetium-99 and chromium behave quite differently at different wells within WMA T (Figure 5.27). The concentrations of both constituents track each (both increase with time since 1997) other through time in upgradient wells at the WMA (Figure 5.27 A). The same relationship holds for wells north of the WMA; however, the concentrations are dropping with time (Figure 5.27 B). The technetium-99 - chromium concentration relationship is different in wells located at the northeast corner (Figure 5.27 C) and east of the WMA (Figure 5.27 D) where the concentration of the two constituents do not track each other. 
Table 5.8. Estimated Compositions for Tank Leaks and Waste Streams Associated with WMA T

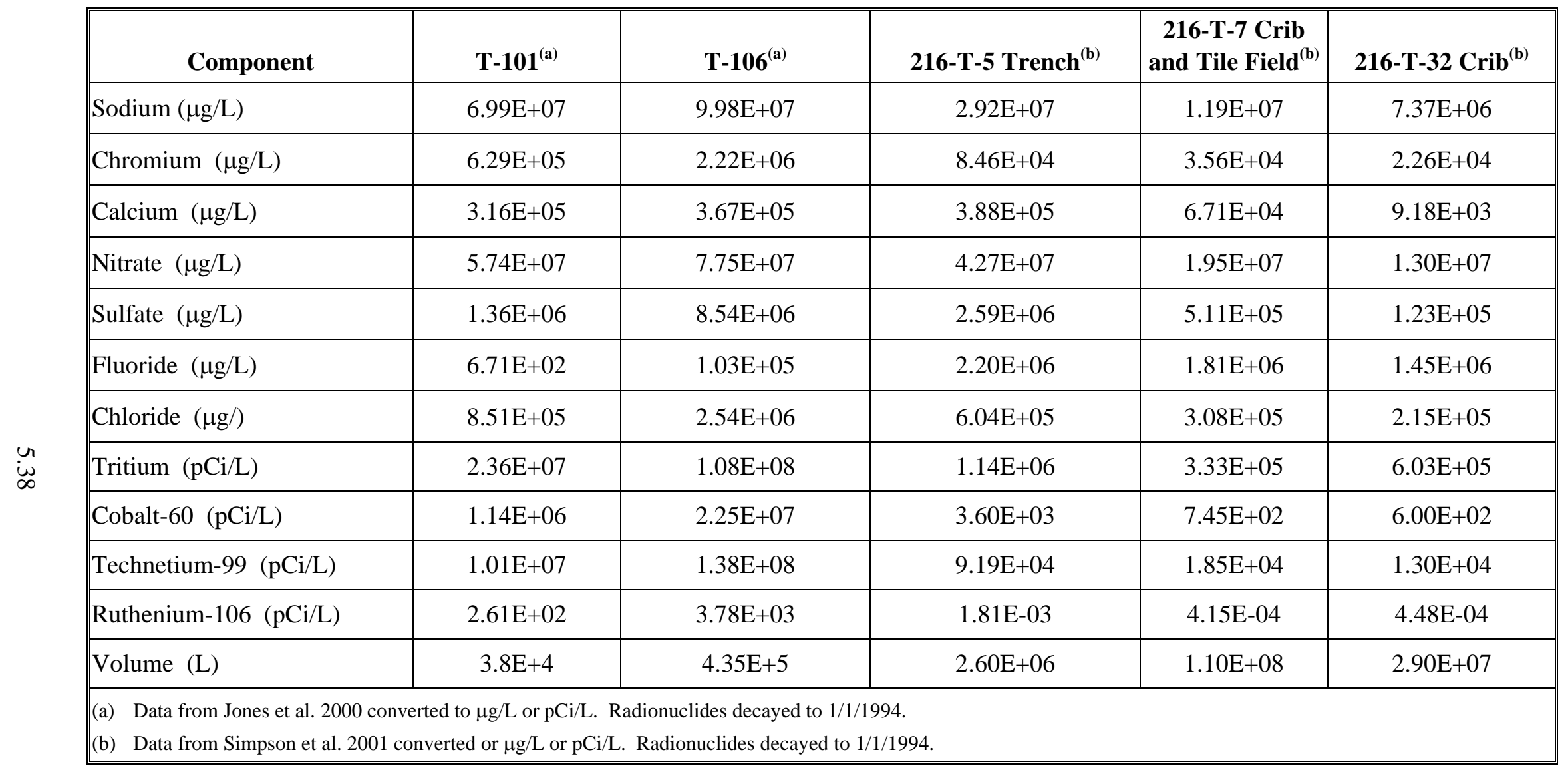


Figure 5.28 shows the technetium-99/chromium groundwater concentration ratios versus time for samples from selected wells at WMA T. The figure also shows the concentration ratios expected in the leaked tank waste from tanks T-101 and T-106 (Jones et al. 2000) and waste disposed to the cribs and trenches located west of WMA T (Simpson et al. 2000). The data plotted in Figure 5.28A show that the technetium-99/chromium ratio in samples from upgradient wells have a signature similar to the upgradient crib and trench disposal sites. Figure 5.28B shows that samples from wells north of WMA T have a similar composition as those from upgradient wells. This information, and the information in Figures 5.28A and B, suggest that the contamination detected in wells north of WMA T is very similar to that found upgradient of the WMA and is dominated by crib waste.

Figure 5.28C suggests a different source for the contamination at the northeast corner of WMA T. A technetium-99, chromium, nitrate, and tritium plume was first detected in this area in well 299-W11-27 in early 1996. Since that time, the technetium-99/chromium composition of the groundwater in that well has evolved toward tank waste compositions. Three other wells in the area support this hypothesis. The technetium-99/chromium compositions greater than the estimated tank waste compositions are in agreement with the data from vadose zone porewaters from boreholes C4104 and C4105 (Section 4 of this report) and probably reflect the slight retardation of chromium relative to technetium-99 as discussed in Section 6.6 (see Table 6.5 for in situ desorption $\mathrm{K}_{\mathrm{d}}$ values).

Since monitoring began in 1997, the technetium-99 to Cr ratio for groundwater from wells east of WMA T are intermediate between those from wells upgradient (west and north of the WMA) and those northeast of the WMA. Samples from these wells indicate that the tank waste initially identified at the northeast corner of the WMA is migrating south along the eastern edge of the WMA and is mixing with the crib waste that was initially sampled in the eastern wells. 


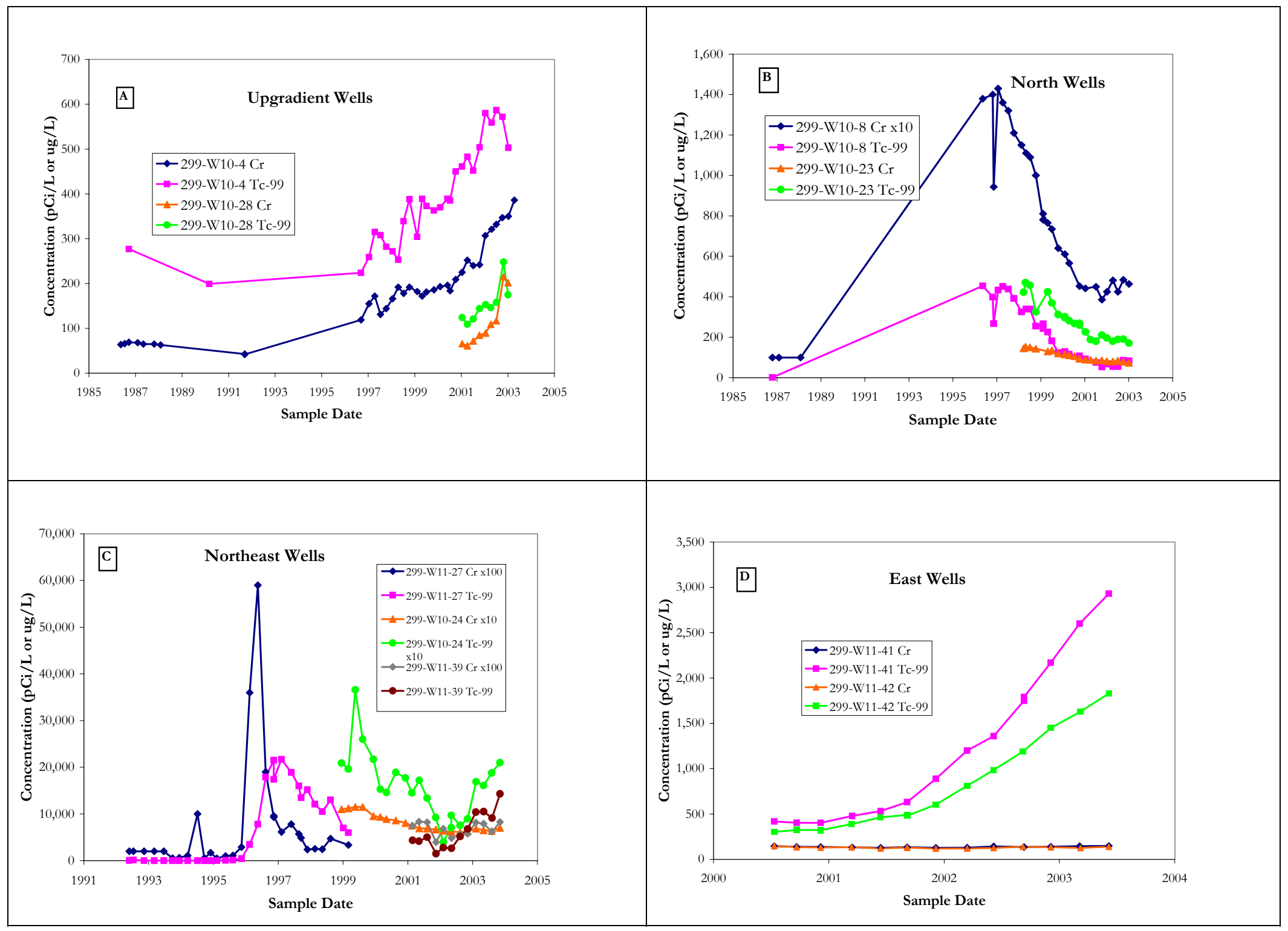

Figure 5.27. Technetium-99 and Chromium Concentrations in Selected Wells at WMA T 


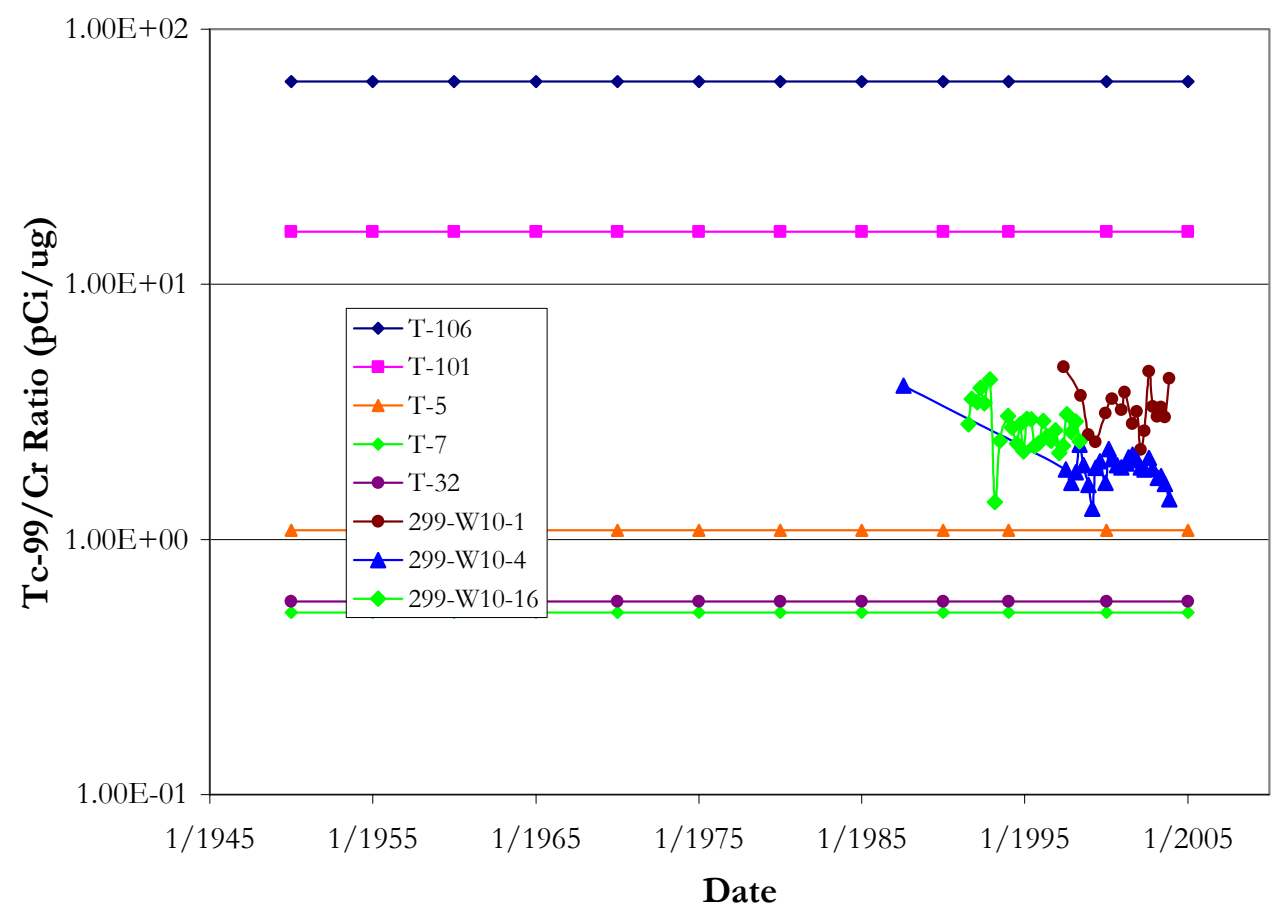

A

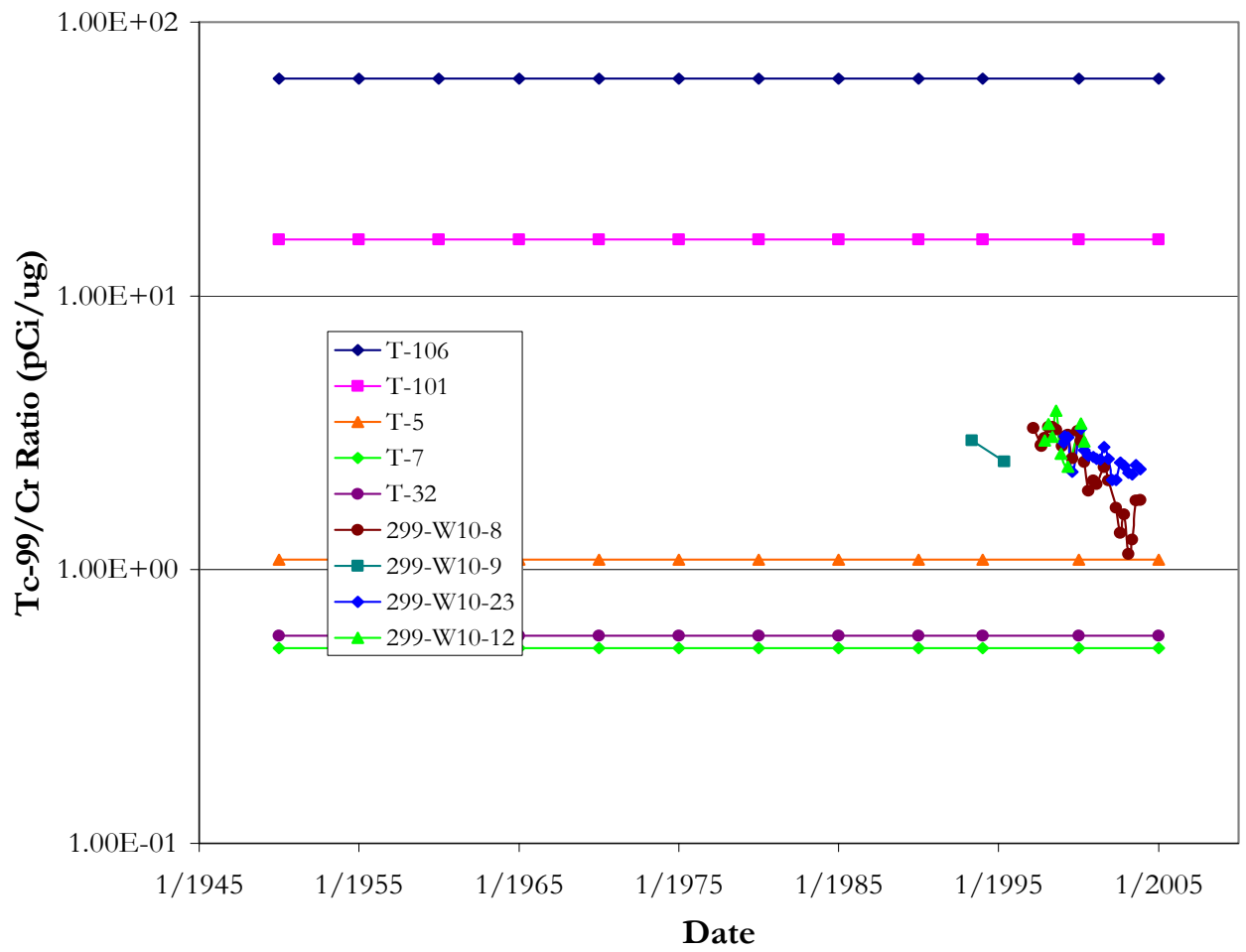

B

Figure 5.28. Technetium-99/Chromium Concentration Ratios in Samples from Selected Wells at WMA T. A=Upgradient (West) Wells; B=Northern Wells. 


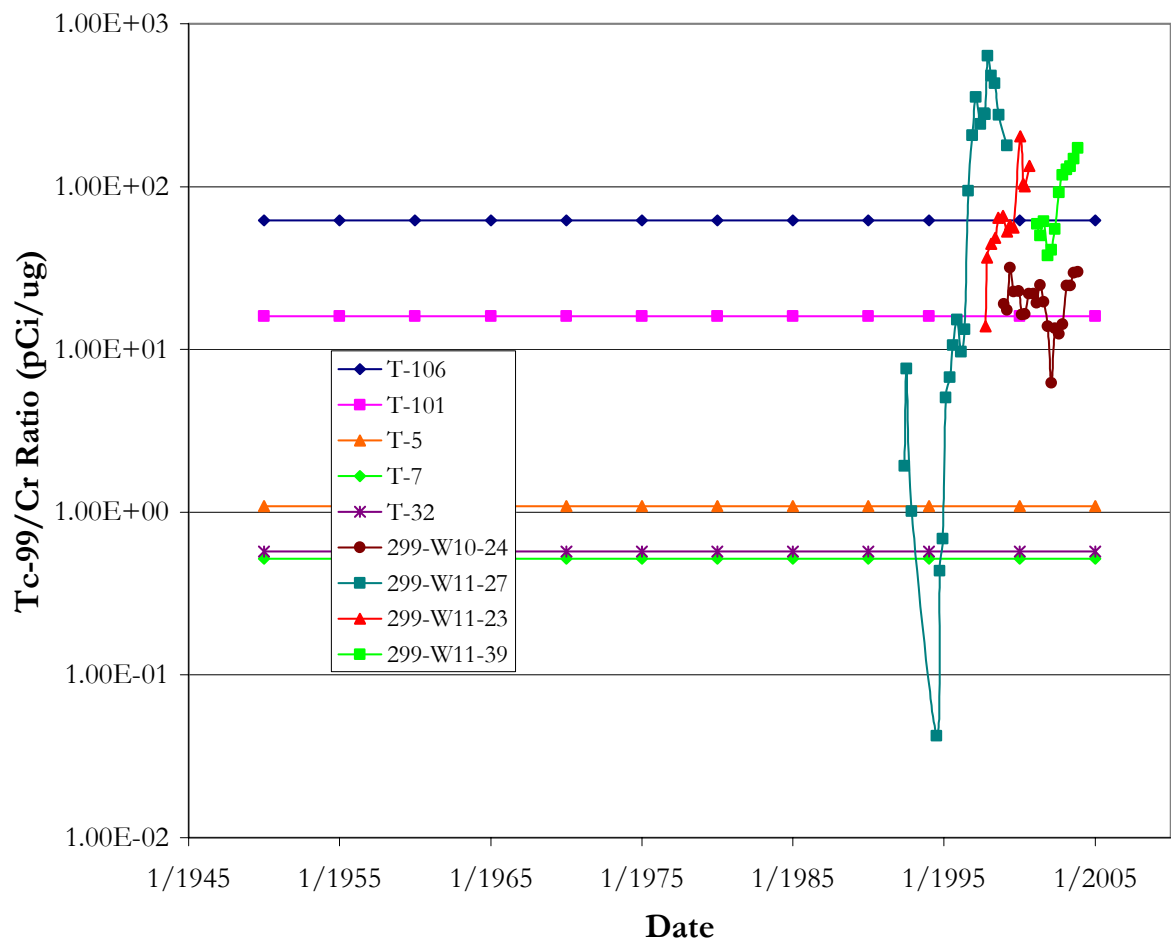

C

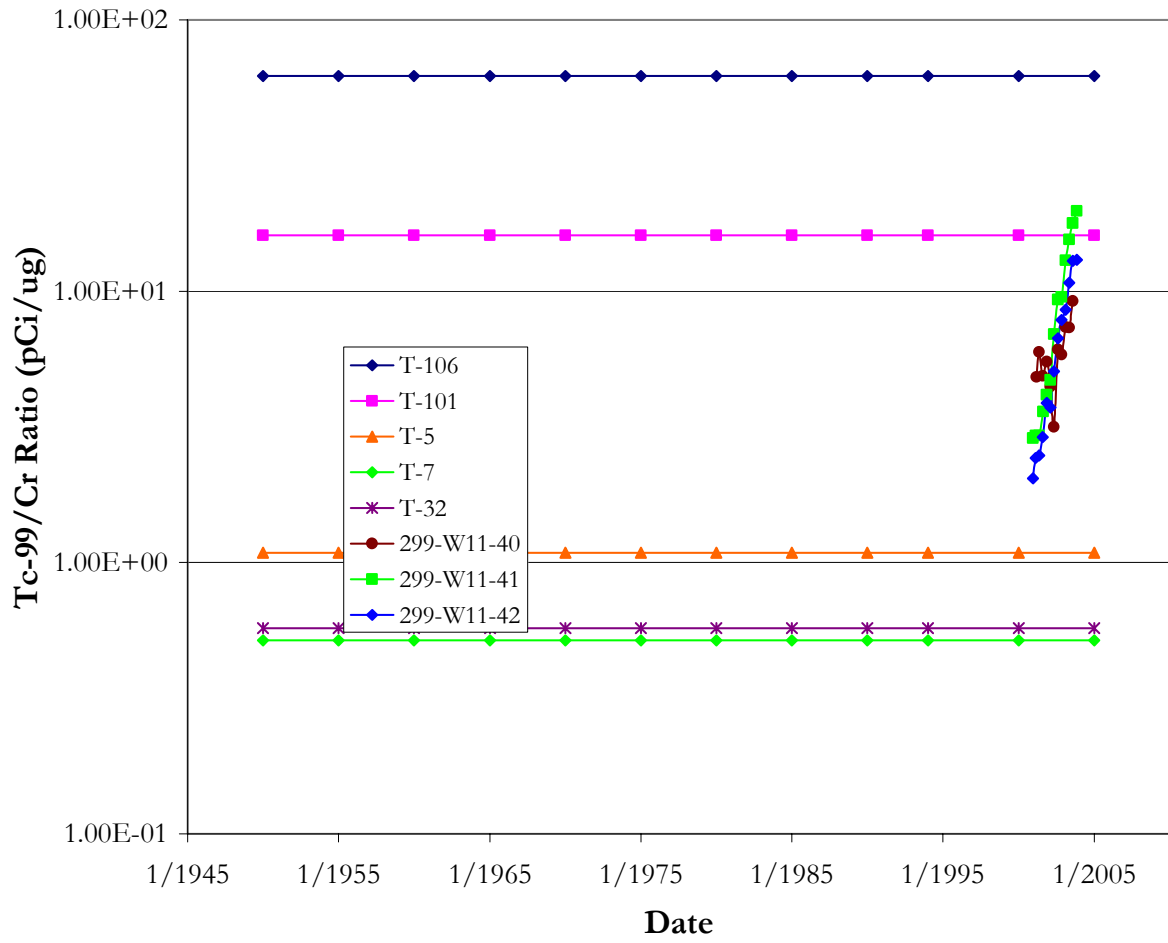

$\mathrm{D}$

Figure 5.28. Technetium-99/Chromium Concentration Ratios in Samples from Selected Wells at WMA T. $C=$ Northeastern wells, $\mathbf{D}=$ Eastern wells 


\subsubsection{Technetium-99 - Nitrate}

The compositional relationship between technetium-99 and nitrate at WMA T is complicated by the regional nitrate plume in the area. Unlike technetium-99 and chromium concentrations, the concentrations of technetium-99 and nitrate track each other through time in all monitoring wells at WMA T although there are about 3 orders of magnitude difference in the technetium-99/nitrate groundwater concentration ratios across the WMA (Figure 5.29). However, when plotted against time and compared to crib and tank waste compositions, the technetium-99/nitrate concentration ratios suggest the same conclusions reached with the technetium-99/chromium ratios (Figure 5.30).

Tc-99/NO3 vs NO3

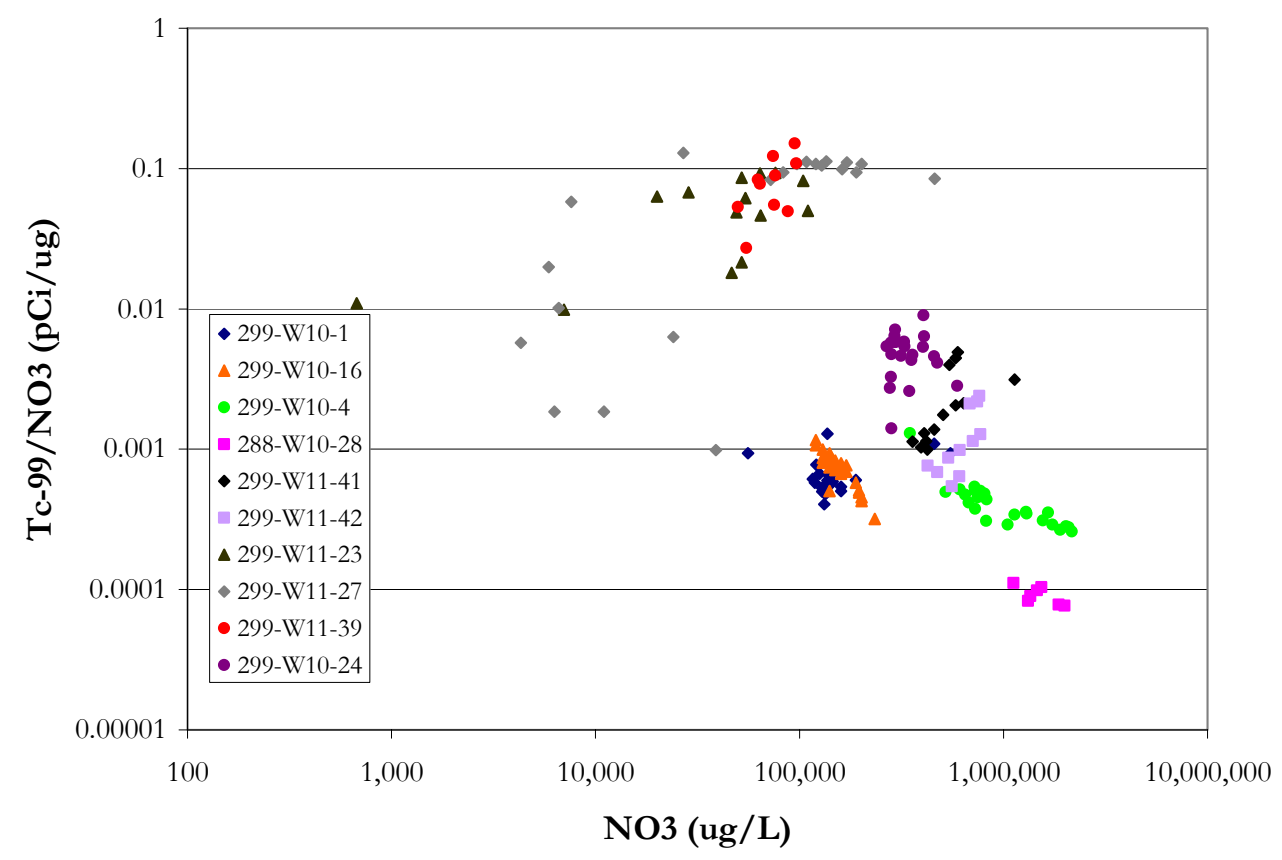

Figure 5.29. Technetium-99 and Nitrate Concentrations in Samples from Selected Wells at WMA T

Figure 5.30A shows the technetium-99/nitrate concentration ratios in samples from upgradient wells at WMA T and compares the ratios to those expected for tank and crib wastes. The figure shows that the groundwater from the upgradient wells has a strong crib waste component. Figure 5.30B shows the same relationship as in Figure 5.30A for the monitoring wells located on the north side of the WMA. Groundwater sampled from the northern wells is essentially indistinguishable, with respect to technetium-99/nitrate composition ratios, from groundwater in the upgradient wells. 


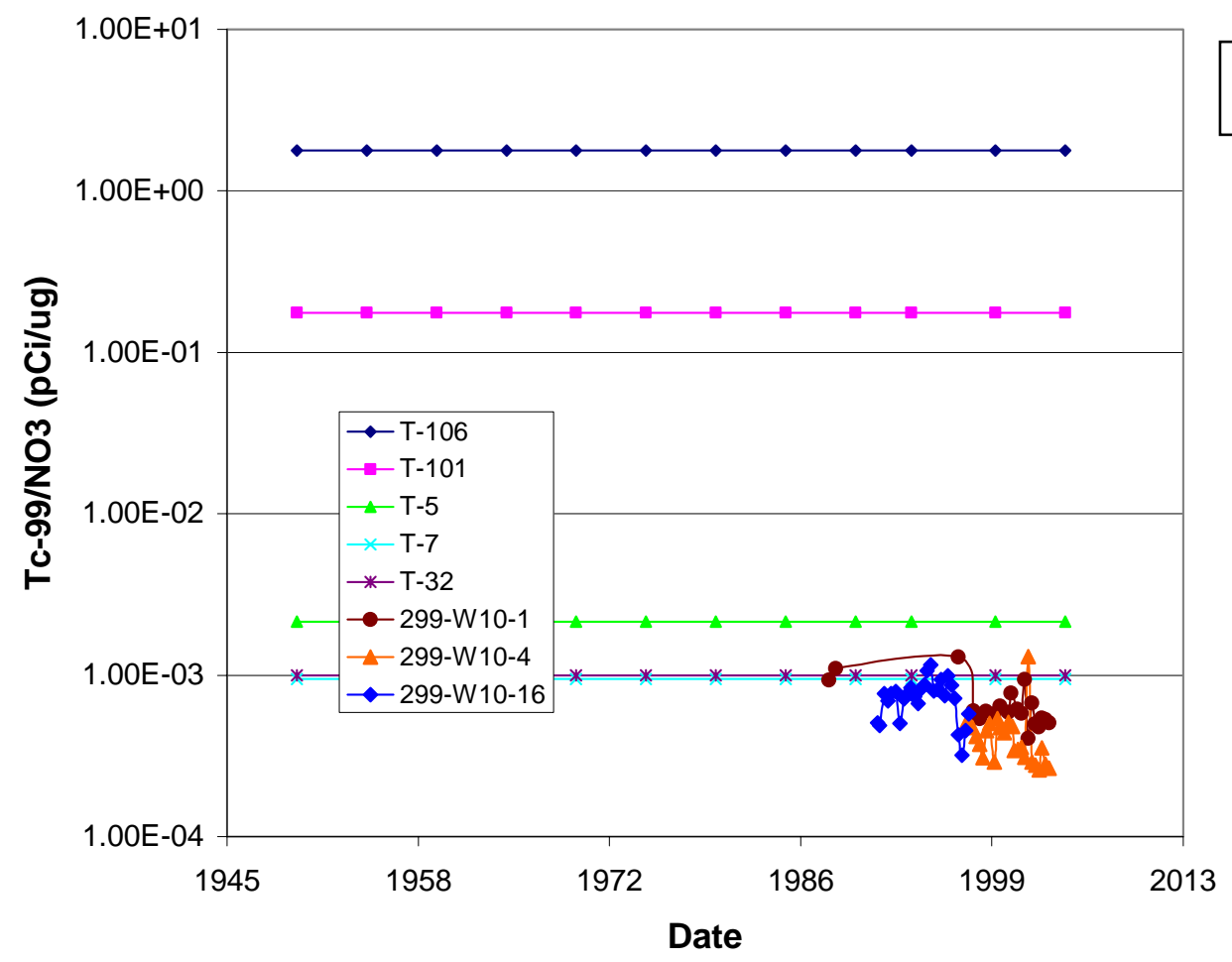

A

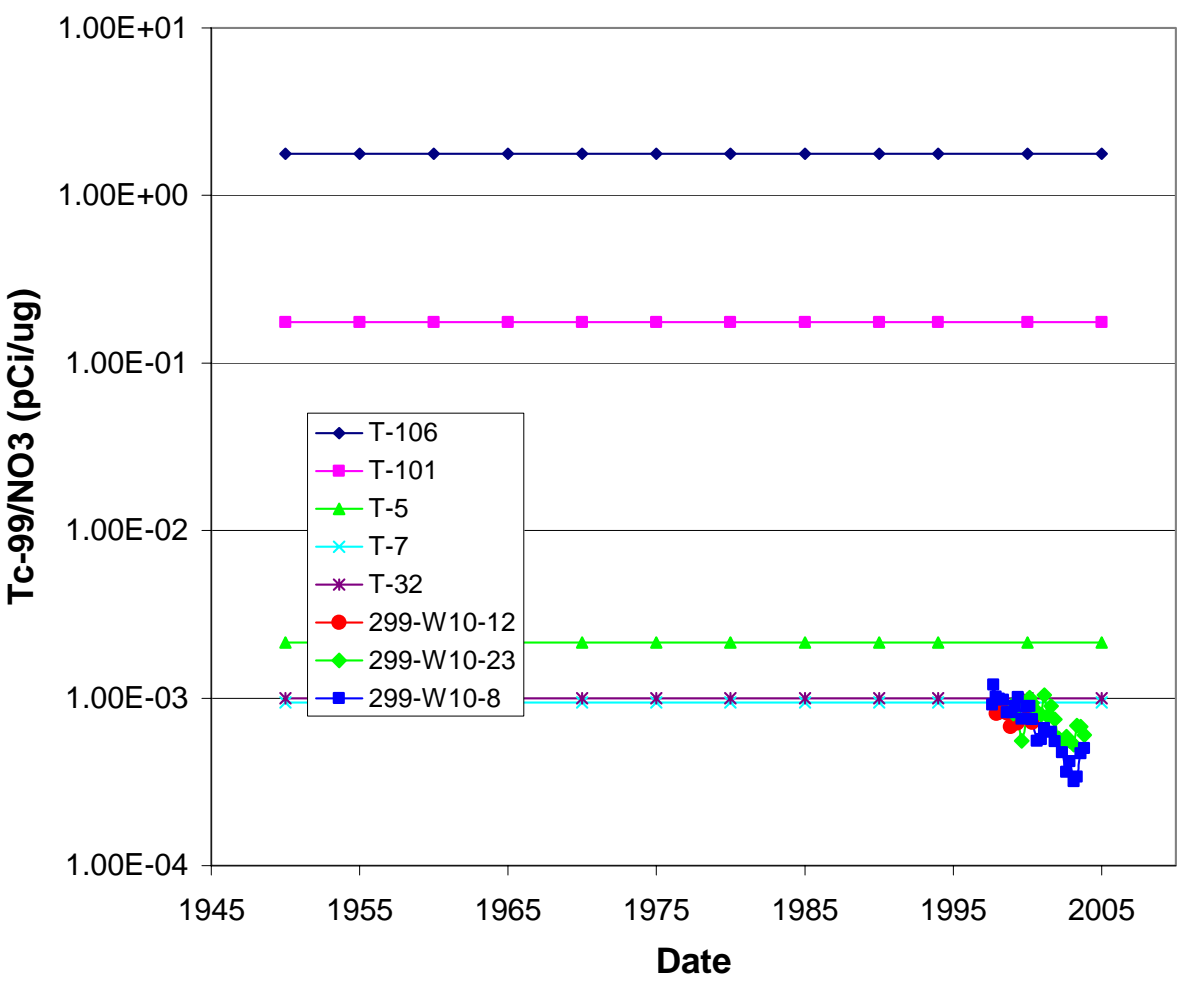

B

Figure 5.30. Technetium-99/Nitrate Concentration Ratios in Samples from Selected Wells at WMA T. A = Upgradient (west) wells, B $=$ Northern wells. 

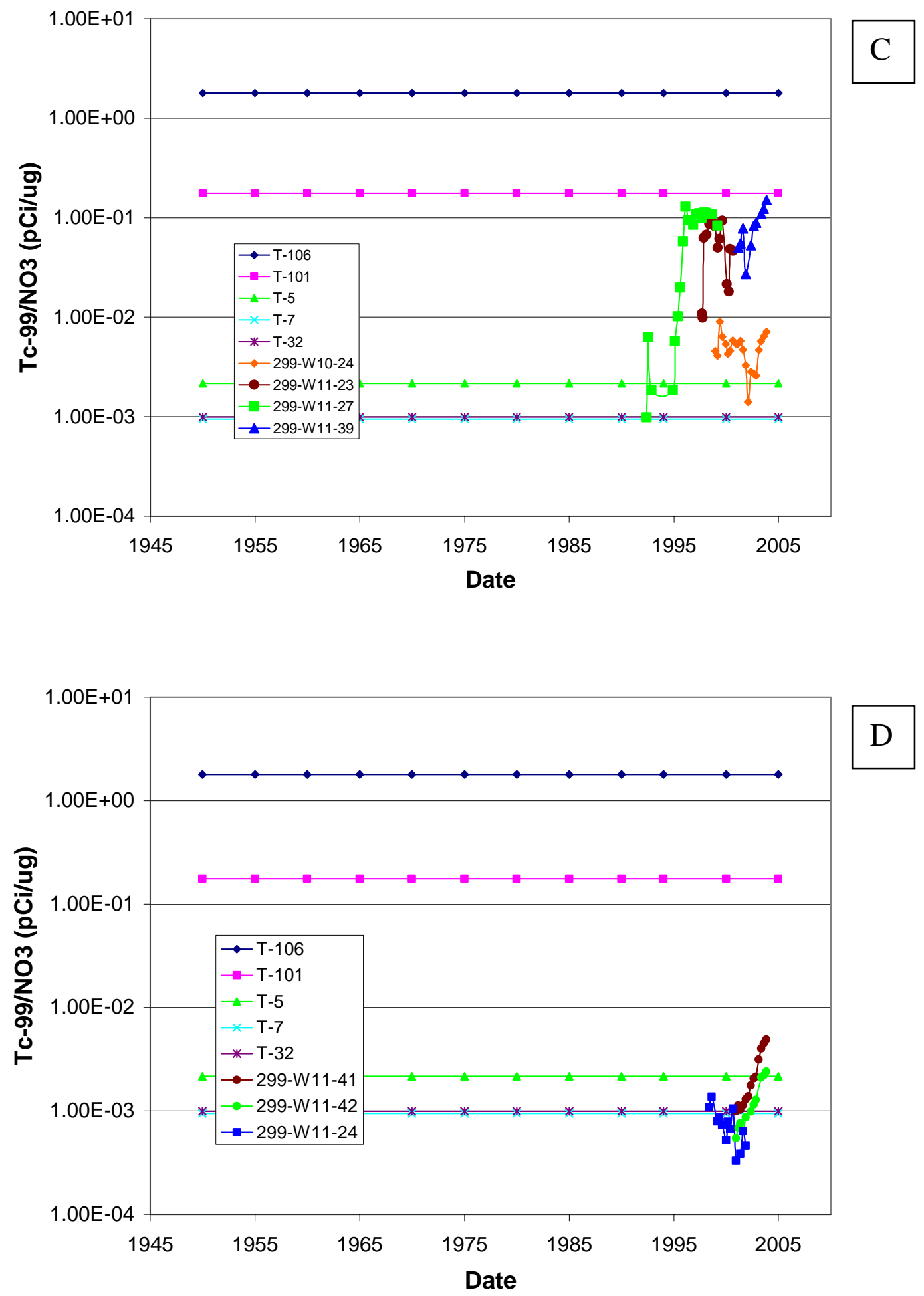

Figure 5.30. Technetium-99/Nitrate Concentration Ratios in Samples from Selected Wells at WMA T. $C=$ Northeastern wells, $D=$ Eastern wells 
Water sampled from wells located in the northeast corner of WMA T has a very different technetium99/nitrate signature than water from the upgradient and northern wells. Groundwater in the northeast corner of the WMA tends toward the technetium-99/nitrate ratios that are indicative of tank waste (Figure 5.30C). Well 299-W10-24 appears to be an exception. However, well 299-W10-24 has a technetium-99 concentration near $2000 \mathrm{pCi} / \mathrm{L}$, which is an order of magnitude greater than that in western (upgradient) or northern wells and samples a deeper part of the aquifer than did wells 299-W11-23 and 299-W11-27. (Both wells 299-W11-23 and 299-W11-27 are now dry and the last, high technetium-99 samples from those wells were collected from near the water table.) Horton et al. (2001) showed that nitrate concentration in the aquifer at well 299-W10-24 increases with depth to about 20 meters below the water table. Thus, the relatively low technetium-99/nitrate ratios from samples from well 299-W10-24 are a mixture of the relatively high technetium-99, low nitrate water near the water table surface with the low technetium-99, high nitrate water from deeper in the aquifer. Although less distinct, the same relationship can be seen for chromium (Figure 5.28C) and for tritium (Figure 5.31C). The nitrate, tritium, and chromium are more regional plumes dispersed deeper in the aquifer beneath WMA T.

Finally, Figure 5.30D shows the technetium-99/nitrate ratios from samples from wells located east of the WMA. As was the case for technetium-99/chromium concentrations, the technetium-99/nitrate concentrations from the eastern wells have a strong crib signature for the first samples collected from the wells in 1997 and then evolve toward tank waste compositions with subsequent samples, especially after 2001.

Figure 5.29 showed the technetium-99/nitrate concentration ratio versus nitrate concentration for several wells at WMA T. The figure shows that water sampled from upgradient wells is distinct with respect to technetium-99 and nitrate from water sampled from wells at the northeast corner of the T tank farm. Water sampled from the eastern wells (and well 299-W10-24) is a mixture of the two.

\subsubsection{Technetium-99 - Tritium}

Technetium-99 and tritium serve as a final example. Figure 5.31 shows the compositional relationship between technetium-99 and tritium at WMA T. As for nitrate, the tritium and technetium-99 relationship is complicated by a regional tritium plume in the area. However, the technetium-99/tritium ratios lead to the same conclusions as do the technetium-99/chromium and technetium-99/nitrate ratios. That is, groundwater from wells in the west (upgradient) and north sides of WMA T appear to be highly influenced by wastes disposed to the cribs and trenches on the west side of the WMA (Figures 5.31A and B). Groundwater from wells at the northeast corner and the east side of the WMA appears to be evolving towards tank waste from T-101 or T-106 characteristics (Figures 5.31C and D). 

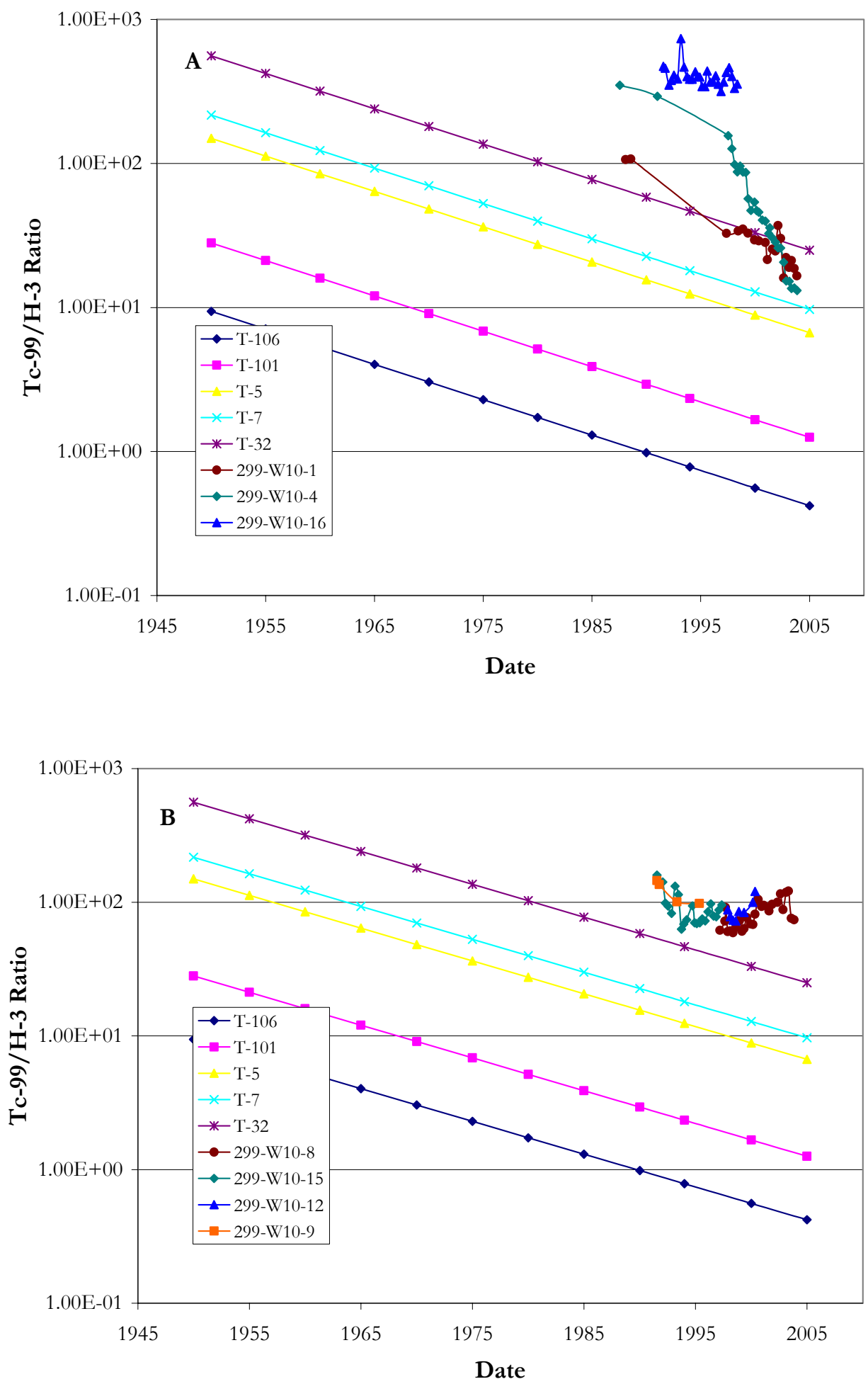

Figure 5.31. Technetium-99/Tritium Concentration Ratios in Samples from Selected Wells at WMA T. $A=$ Upgradient (west) wells, $B=$ Northern wells 

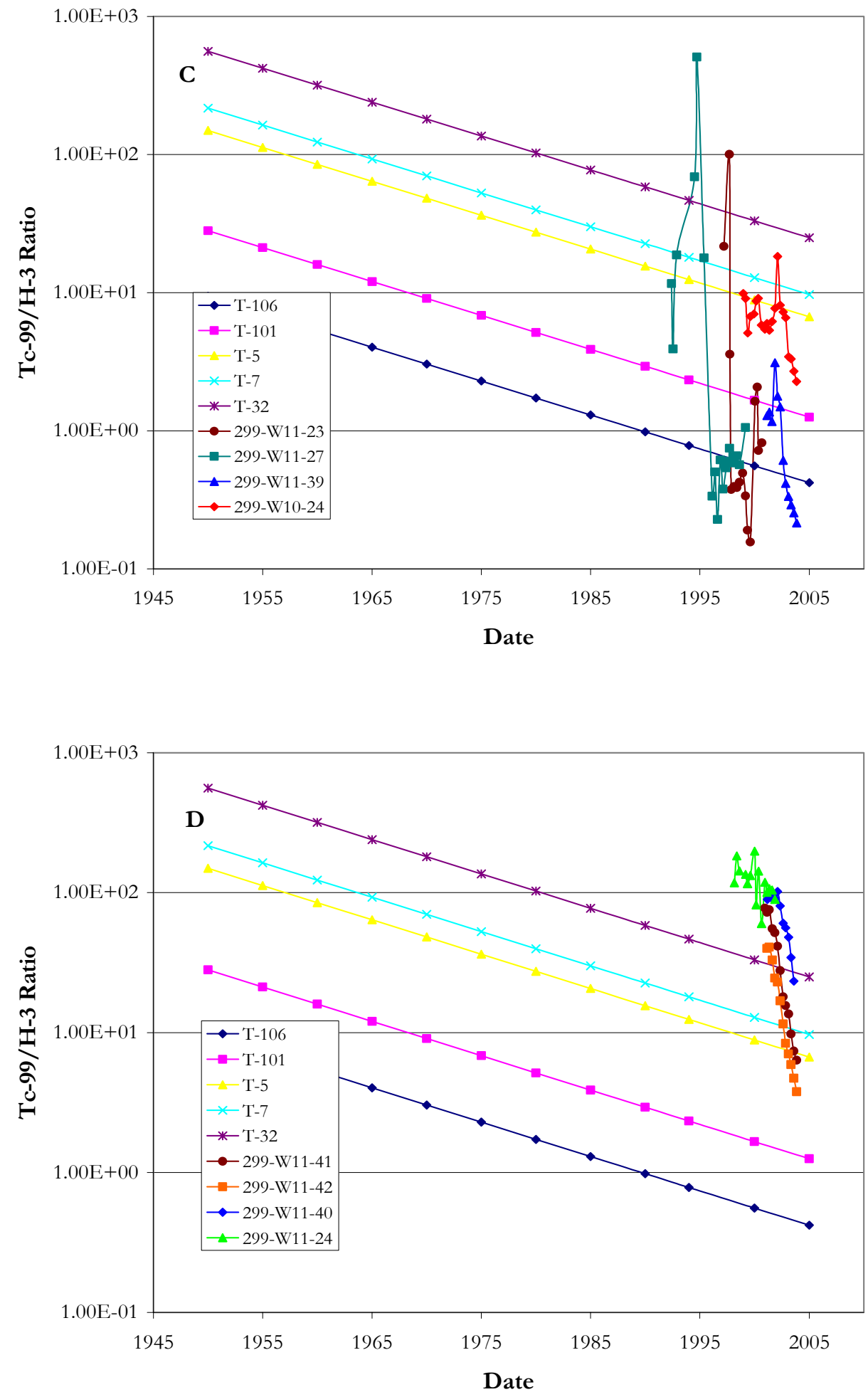

Figure 5.31. Technetium-99/Tritium Concentration Ratios in Samples from Selected Wells at WMA T. $C=$ Northeastern wells, $D=$ Eastern wells 


\subsection{Summary and Conclusions}

In this section, we present summary information on our interpretation of the T Tank Farm borehole sediment characterization data. Conclusions are included to aid in making decisions on what interim actions and future studies are needed to make sound waste-management decisions at the $\mathrm{T}$ tank farm.

\subsection{Drilling and Sampling Summary at the T Tank Farm}

Three boreholes were recently drilled and sampled within or near the T Tank Farm. Two of these holes (C4104 and C4105) were drilled via the closed-end probe method between tanks 241-T-106 and T-109 for the specific purpose of collecting core samples for physical, chemical, and radiological characterization. Locations for the boreholes were selected to evaluate changes in contaminant distributions in the vadose zone since the 1993 study (Freeman-Pollard et al. 1994) and to evaluate the migration of mobile contaminants from the 1973 leak at single-shell tank T-106 in the downgradient direction, respectively. Intermittent core samples, 1.25 -ft long by 2.5-in. diameter, were collected at predetermined intervals within the C4104 and C4105 holes.

In addition, almost continuous core samples were collected in well 299-W11-39 (C3117) from 20 to $94 \mathrm{ft}$ bgs. Well 299-W11-39 was installed as a RCRA groundwater monitoring well located along the northeast boundary of the T Tank Farm. Sediments from this well were characterized to determine the background or uncontaminated attributes of T Tank Farm vadose zone sediments, however as discussed in Section 4 the water extract data suggest that sediments from the Hanford formation appear to contain chemicals suggestive of process water. Thus, the sediments from the clean borehole at the TX Tank Farm (299-W10-27) were used as the baseline to compare data from the contaminated boreholes at the T Tank Farm.

Borehole 299-W11-39 (C3117) was drilled using cable-tool methods between November 10 and December 6, 2000. Total depth of the borehole is $282.31 \mathrm{ft}(86 \mathrm{~m})$ bgs; the hole terminated within fluvial gravels of the Ringold Formation member of Wooded Island (Unit E), about $40 \mathrm{ft}(12.2 \mathrm{~m})$ below the groundwater table. 29 splitspoon cores, 2.5 -ft long by 4 -in. diameter, were collected from this interval. Two 1.0-ft long plastic (i.e., lexan) core liners were collected for each 2.5-ft core run. The extra $0.5 \mathrm{ft}$ collected in the shoe of the splitspoon was used for geologic description in the field geologist's log. Accounting for the loss of the 0.5 -ft shoe samples and slough atop many of the cores, the total recovery for the 20 to $93.5 \mathrm{ft}$ interval is estimated at $66.6 \%$.

Borehole C4104 was drilled and sampled using a driven-probe technique between April 4 and May 22, 2003. The borehole lies between single-shell tanks 241-T-105, -106, -108, and -109 within the 241-T Tank Farm. It is closest to tank 241-T-106, where it lies $18.94 \mathrm{ft}(5.77 \mathrm{~m})$ to the southeast. Total depth of the borehole was $127.46 \mathrm{ft}$ (38.8 m) bgs; the hole was terminated when refusal was encountered approximately $5 \mathrm{ft}$ into cemented gravels of the Wooded Island member of the Ringold Formation. Decommissioning of probe hole C4104 was completed on June 9, 2003 by back-pulling the casing while filling the annulus with dry bentonite. During drilling, a total of 23, 1.25-ft long, splitspoon core samples were collected intermittently starting at a depth of $15 \mathrm{ft}$ bgs. A total of 44 characterization samples were collected from this hole. In all, about $30 \mathrm{ft}$ of core was obtained from C4104, or about $24 \%$ of the total length of the hole. No samples or drill cuttings were collected between core runs because the hole was 
advanced in a closed configuration using a solid, removable tip. Thus no near-continuous geologic field log is available for this hole, unlike the background hole (299-W11-39).

Borehole C4105 was drilled and sampled using the driven-probe technique between January 8 and March 12, 2003. The borehole is closest to single-shell tank 241-T-106, where it lies approximately $28.1 \mathrm{ft}(8.6 \mathrm{~m})$ southwest. The borehole is only slightly farther (36 ft [11 m]) from tank 241-T-109, located to the southeast. Borehole C4105 is $87.7 \mathrm{ft}$ west of borehole C4104 in the downgradient direction for most of the vadose zone beds that show dip. Total depth of the borehole was $130.9 \mathrm{ft}(39.9 \mathrm{~m}) \mathrm{bgs}$; the hole terminated within the vadose zone about $100 \mathrm{ft}(30 \mathrm{~m})$ above the groundwater table. During drilling, a total of 22, 1.25-ft-long splitspoon core samples were collected intermittently starting at a depth of about $14 \mathrm{ft}$ bgs. All samples were overdriven beyond the $1.25 \mathrm{ft}$ length of the splitspoon, which resulted in over-compaction of most samples. In all, $30 \mathrm{ft}$ of core was drilled in C4105, which accounts for about $23 \%$ of the total length of the hole. No samples or drill cuttings were collected between the 22 core runs because the hole was advanced in a closed configuration using a solid, removable tip. Probe hole C4105 was decommissioned between March 14-18, 2003, by back-pulling the casing while filling the annulus with dry bentonite. A total of 42 samples were collected for physical, chemical, and radiological characterization from C4105. The geology between core runs is inferred and interpreted based on available geophysical logs data, other nearby borehole geologic descriptions, core photographs, laboratory measured gravimetric moisture, and blow-count data.

Each of the 6-in.-long liners from all three boreholes were opened in the chemistry lab and geologically described during the sub-sampling process to obtain aliquots used in the various characterization activities. The geology between core samples was inferred and interpreted based on the geophysical log and blow-count data.

Borehole 299-W10-196 was drilled to $179.6 \mathrm{ft}$ in late 1992 to early 1993 to investigate the vadosezone contaminant distribution in the vicinity of Tank 241-T-106 (Freeman-Pollard et al. 1994). Borehole 299-W10-196 is included in this report because it is another boring that has produced representative splitspoon samples for physical, chemical, and radiological characterization from T Tank Farm. A total of 43 splitspoon sediment samples were collected and analyzed back in 1993. Spectral-gamma geophysical logging was also performed. During sampling, two overlapping zones of radioactive contamination were encountered; one at 34.5 to $70 \mathrm{ft}$ and the other to $115 \mathrm{ft}$ bgs. The location of 299-W10-196 lies 12.99 feet north and $1.94 \mathrm{ft}$ west of borehole C4104, described previously. Thus the two boreholes are $13.13 \mathrm{ft}$ apart. A main objective was to quantitate the differences in contaminant vertical distribution between these two boreholes to evaluate the extent of movement of species over the 10 year span between these two sampling campaigns.

\subsection{Conceptual Model for T Tank Farm Geology}

The geology of the vadose zone underlying the 241-T Tank Farm (T Tank Farm) forms the framework through which contaminants that leaked from single-shell tanks or their ancillary piping and junction boxes move, and is fundamental to the understanding of migration and distribution of the contamination in the vadose zone. Of particular interest are the interrelationships between the coarser and finer-grained facies, and the degree of contrast in their physical, chemical, and radiological properties.

Four primary stratigraphic units were encountered in each of the three boreholes: 1) backfill material, 2) the Hanford formation, 3) the Cold Creek unit, and 4) the Ringold Formation. Table 6.1 summarizes 
the contacts between the various stratigraphic units in the two new contaminated boreholes, the "clean" borehole (299-W11-39) and the 1993 contaminated borehole 299-W10-196. Below the backfill in the three contaminated boreholes lies the Hanford formation, which is divided into three informal units (H1, $\mathrm{H} 2$, and H3). However, the H1 unit was completely removed during excavation and then later used as backfill. Further, at the three boreholes there is no indication that H3 unit materials are present above the contact with Cold Creek units. Therefore, below the T tanks, the Hanford formation H2 unit predominates the stratigraphy. Individual geologic description summaries for each of the new boreholes follow.

The limited sampling at 299-W11-39 led to the following conclusions. Zones of elevated moisture occur within the Hanford formation $\mathrm{H} 2$ unit between 75-79 ft bgs, as well as sporadically within the CCU and $\mathrm{R}_{\mathrm{tf}}$ units. Moisture ranged from as low as $2.8 \mathrm{wt} \%$ in pebbly sands of the Hanford formation $\mathrm{H} 1$ unit up to $22.8 \mathrm{wt} \%$ in the upper CCU subunit. Because coring stopped above the lower CCU subunit, there were no $\mathrm{CCU}_{1}$ or Ringold Formation samples available for laboratory characterization in 299-W11-39. Based on the neutron-moisture log, moisture content is highly variable within the lower CCU subunit $\left[\mathrm{CCU}_{l}\right]$, a reflection of the high degree of internal heterogeneity within this unit.

The backfill in C4104 extends from the ground surface to a depth of $40 \mathrm{ft}(12.2 \mathrm{~m})$ where it lies in contact with the Hanford formation. Backfill material consists of poorly to moderately sorted, massive, gravelly sand to slightly gravelly sand with variable amounts of silt. Colors range from grayish-brown to olive and yellowish-brown. Backfill materials are unconsolidated and weakly to strongly calcareous. The overall moisture content for backfill materials is relatively low, averaging about $7.9+/-1.5 \mathrm{wt} \%$. This unit appears to be rather homogeneous and lacks lithologic variation, except at the base.

Pleistocene cataclysmic flood deposits of the Hanford formation underlie backfill materials to a depth of $24.6 \mathrm{~m}(80.7 \mathrm{ft})$ in probe hole C4104. Only the sand-dominated Hanford formation H2 unit is represented; all of the coarse-grained Hanford formation H1 unit was removed during tank-farm construction, to be used later as backfill around the tanks. The Hanford formation $\mathrm{H} 2$ unit is present between 40 to $80.7 \mathrm{ft}$ (12.2 to $24.6 \mathrm{~m}$ ) bgs. The $\mathrm{H} 2$ unit consists of predominantly fine-to-coarse-grained, gray to brownish-gray "salt and pepper" sand. The H2 unit is weakly to strongly calcareous and occasionally shows weak horizontal laminations. Dispersed within the Hanford formation H2 unit are at least two separate, relatively thin ( $\leq 0.5 \mathrm{ft}$ ), light olive-brown, compact, moderately to well-sorted, silty fine sand beds. These occur at depths starting at 58.6 and $63.5 \mathrm{ft}$ bgs. Other additional fine-grained beds may also be present between cored intervals. The base of the $\mathrm{H} 2 \mathrm{unit}$, consisting of medium sand, lies in sharp contact with the underlying silty fine sand of the upper CCU at $80.7 \mathrm{ft}$ bgs. Moisture within cores from the $\mathrm{H} 2$ unit ranged from dry to slightly moist. One higher moisture zone at about $74 \mathrm{ft}$ bgs, near the base of the $\mathrm{H} 2$ unit, is indicated by a spike in the neutron moisture log. This higher moisture interval is probably associated with a fine-grained lens within the $\mathrm{H} 2$ unit. Most of the samples from the $\mathrm{H} 2$ unit consisted of medium- to coarse-grained sand; two of the samples (S03072-07A and S03072-08B) contained some silty fine sand.

Below the Hanford formation lies the Cold Creek unit, which is 27.3-ft thick at the C4104 borehole. The top of the CCU lies at $80.7 \mathrm{ft}(24.6 \mathrm{~m})$ bgs and the bottom lies at about $108 \mathrm{ft}(32.9 \mathrm{~m})$. The unit is divided into two distinct subunits, $\mathrm{CCU}_{\mathrm{u}}$ and $\mathrm{CCU}_{\mathrm{l}}$, designating upper and lower, respectively. Both the upper and lower contacts of the $\mathrm{CCU}_{\mathrm{u}}$ were intersected during coring; the true thickness of the subunit is well established at 11.8-ft thick (80.7 to $92.5 \mathrm{ft} \mathrm{bgs).} \mathrm{Sediments} \mathrm{from} \mathrm{this} \mathrm{subunit} \mathrm{consist} \mathrm{of} \mathrm{compacted}$ and well-sorted silt to fine sand, which range from moderately to strongly calcareous. All the cores 
collected from the upper CCU in C4104 showed horizontal laminations, indicating the calcium carbonate is primarily of detrital origin and not the result of soil development, as is the case with calcic soils of the underlying lower CCU. The structure of upper CCU in this borehole indicates a probable fluvial overbank origin and not a paleosol, as suggested in Reynolds (2003a), because any primary sedimentary structures (e.g., laminae) would have been destroyed during soil development. Moisture in the $\mathrm{CCU}_{\mathrm{u}}$ core samples ranged from slightly moist to moist.

Table 6.1. $\quad$ Stratigraphic Units and Contacts (ft bgs)

\begin{tabular}{|c|c|c|c|c|c|}
\hline \multirow{3}{*}{\multicolumn{2}{|c|}{ Surface Elevation ft (amsl) }} & \multicolumn{4}{|c|}{ Well ID } \\
\hline & & 299-W11-39 & C4104 & C4105 & 299-W10-196 \\
\hline & & 688.6 & 675.3 & 675.0 & 675.4 \\
\hline \multirow{7}{*}{ 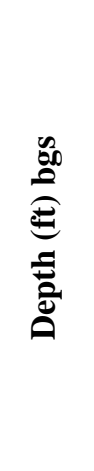 } & Backfill & 0 & 0 & 0 & 0 \\
\hline & $\mathrm{H} 1$ & 5 & NP & NP & NP \\
\hline & $\mathrm{H} 2$ & 33.5 & 40 & 40.6 & 38.9 \\
\hline & $\mathrm{CCU}_{\mathrm{u}}$ & 89.9 & 80.7 & 85.5 & 81 \\
\hline & $\mathrm{CCU}_{\mathrm{l}}$ & 98.0 & 92.5 & 92 & 91.8 \\
\hline & $\mathrm{R}_{\mathrm{tf}}$ & 120.0 & 108 & 111 & 105 \\
\hline & $\mathrm{R}_{\mathrm{wi}}$ & 130 & 120.9 & 122 & 121.3 \\
\hline \multirow{7}{*}{ 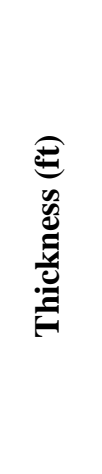 } & Backfill & 5 & 40 & 40.6 & 38.9 \\
\hline & $\mathrm{H} 1$ & 28.5 & NP & NP & NP \\
\hline & $\mathrm{H} 2$ & 55.4 & 40.7 & 44.9 & 42.1 \\
\hline & $\mathrm{CCU}_{\mathrm{u}}$ & 8.1 & 11.8 & 6.5 & 10.8 \\
\hline & $\mathrm{CCU}_{1}$ & 22 & 15.5 & 19 & 13.2 \\
\hline & $\mathrm{R}_{\mathrm{tf}}$ & 10 & 12.9 & 11 & 16.3 \\
\hline & $\mathrm{R}_{\mathrm{wi}}$ & ND & ND & ND & ND \\
\hline \multirow{7}{*}{ 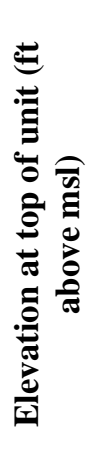 } & Backfill & 688.6 & 675.3 & 675.0 & 675.4 \\
\hline & H1 & 683.6 & NP & NP & NP \\
\hline & $\mathrm{H} 2$ & 655.1 & 635.3 & 634.4 & 636.5 \\
\hline & $\mathrm{CCU}_{\mathrm{u}}$ & 598.7 & 594.6 & 589.5 & 594.4 \\
\hline & $\mathrm{CCU}_{\mathrm{l}}$ & 590.6 & 582.8 & 583.0 & 583.6 \\
\hline & $\mathrm{R}_{\mathrm{tf}}$ & 568.6 & 567.3 & 564.0 & 570.4 \\
\hline & $\mathrm{R}_{\mathrm{wi}}$ & 558.6 & 554.4 & 553.0 & 554.1 \\
\hline \multicolumn{6}{|c|}{$\begin{array}{l}\text { Amsl = above mean sea level } \\
\mathrm{ND}=\text { not determined } \\
\mathrm{NP}=\text { not present }\end{array}$} \\
\hline
\end{tabular}


The contact between the laminated silty sediments of the upper CCU and the calcic paleosol sequence of the lower CCU lies at $92.5 \mathrm{ft}(28.2 \mathrm{~m})$ bgs. Sediments from the $\mathrm{CCU}_{\mathrm{l}}$ unit consist of mostly poorly sorted, massive mixtures of weathered, pale yellow sand, mud, and gravel, variably cemented with whitish pedogenic calcium carbonate. Some weak secondary pedogenic banding may also be apparent. The base of the lower CCU is defined by the depth of pedogenic weathering and calcic soil development and occurs at $108 \mathrm{ft}$ bgs. Moisture in the $\mathrm{CCU}_{1}$ core samples ranged from slightly moist to moist. Judging from the blow-count data, it appears that the middle portion of the $\mathrm{CCU}_{1}$ is the most strongly cemented.

Almost $20 \mathrm{ft}$ of Ringold Formation sediments were penetrated within C4104 before the probe hole met refusal and was terminated at $127.46 \mathrm{ft}$ bgs. The Ringold Formation member of Taylor Flat in probe hole C4104 extends from 108 to $120.9 \mathrm{ft}$ bgs and is $12.9 \mathrm{ft}$ thick. The $\mathrm{R}_{\mathrm{tf}}$ unit consists of mostly compacted, well-laminated, well-sorted, olive-brown to yellowish-brown sandy silt with lesser amounts of sand to slightly gravelly sand. The concentration of calcium carbonate appears to decrease with depth and distance from the overlying Cold Creek unit. Observed moisture in $\mathrm{R}_{\mathrm{tf}}$ core samples was slightly moist to moist and samples measured in the laboratory had the highest moisture of all the stratigraphic units measured with an average of $14.9+/-5.5 \mathrm{wt} \%$ water. The contact between fine-grained $\mathrm{R}_{\mathrm{tf}}$ unit with the underlying coarse-grained $\mathrm{R}_{\mathrm{wi}}$ unit lies at $120.9 \mathrm{ft}$ bgs. The borehole advanced only $6.6 \mathrm{ft}$ into the $\mathrm{R}_{\mathrm{wi}}$ unit before the borehole was abandoned. Based on core samples alone, all that can be said about the $\mathrm{R}_{\mathrm{wi}}$ unit is that it consists of a multi-lithologic sandy gravel. During drilling, much pulverization naturally occurred when trying to drive the splitspoon into clast-supported gravels that are larger than the diameter of the splitspoon. As a result, the drilling destroyed the original structure and fabric of the material while adding fines and producing abundant angular rock fragments to the mix.

Based on past studies using other, less-destructive drilling methods as well as outcrop investigations, undisturbed Ringold Formation member of Wooded Island (Unit E) is described as a fluvial, clastsupported, bimodal, pebble to cobble gravel, with well-rounded clasts of basalt, quartzite, porphyritic volcanics, and greenstone, in a well-sorted matrix of quartzo-feldspathic sand (Lindsey 1995). The colors of most facies of the Ringold Formation are shades of brown due to a pervasive iron-oxide film, a weathering product that coats most sand and gravel clasts within the Ringold Formation to varying degrees.

The backfill at C4105 extends from the ground surface to a depth of about $40.6 \mathrm{ft}(12.4 \mathrm{~m})$ where it lies in contact with the Hanford formation $\mathrm{H} 2$ unit. The exact depth of the base of the backfill is uncertain but tank construction is known to have occurred to a depth of about 37-40 ft. Core run \#4, composed of a silty gravelly sand, is identical to samples of backfill above; the contact apparently lies below, but not much below, the $40.53 \mathrm{ft}$ depth. The contact is thus estimated at $40.6 \mathrm{ft}$ bgs. The backfill material consist of predominantly gray to grayish-brown, poorly to very poorly sorted, silty gravelly sand to sandy gravel, which is unconsolidated and weakly to moderately calcareous. The gravimetric moisture content was relatively low, averaging $4.8+/-1.7$ wt\% water, in the backfill material from C4105.

About $45 \mathrm{ft}$ of Pleistocene cataclysmic flood deposits of the Hanford formation underlie backfill materials in C4105. Only the sand-dominated Hanford formation H2 is represented; all of the coarser-grained Hanford formation H1unit was removed during tank-farm construction and later used as backfill around the tanks. The Hanford formation H2 unit is present between 40.6 to $85.5 \mathrm{ft}$ bgs in C4105. The Hanford formation H2 sediments consist of mostly fine- to coarse-grained sand with occasional layers of gravelly sand or silty fine sand. The fine to coarse sand beds are loose, massive to 
laminated, brownish gray to olive-brown, moderately to well-sorted, and weakly to moderately calcareous. There appear to be at least two fine-grained layers within the Hanford formation H2 unit in C4105, which could cause lateral spreading of vadose zone moisture. One of these fine-grained layers was encountered at a depth of $\sim 56.5 \mathrm{ft}$ bgs. There is also a spike in the neutron-moisture log associated with this depth. Another fine-grained layer is suspected at a depth of $\sim 75 \mathrm{ft}$ bgs based on a second spike in the neutron-moisture log for the Hanford formation $\mathrm{H} 2$ unit.

The upper and lower contacts of the Cold Creek unit in C4105 are $85.5 \mathrm{ft}$ and $111 \mathrm{ft}$ bgs, respectively. The total thickness of the CCU in probe hole C4105 is $25.5 \mathrm{ft}$, slightly greater than that observed in companion hole C4104. While both subunits of the Cold Creek unit are clearly present and discernable, the relative thickness of the upper versus lower subunits is very different for the two probe holes. The upper:lower thickness ratio for C4104 is close to 1.0, while this ratio in C4105 is 0.3. This is a remarkable difference considering the holes are only $87.7 \mathrm{ft}$ apart, but serves to illustrate the highly heterogeneous nature of the Cold Creek unit. Sediments from the $\mathrm{CCU}_{\mathrm{u}}$ subunit are mostly compacted, laminated, well-sorted, olive-brown, fine sandy silt to silty fine sand. Thin lenses, as coarse as medium-grained sand, were also observed. The subunit is moderately to strongly calcareous, apparently due to a high concentration of detrital calcium-carbonate grains derived from the reworking of the underlying caliche-rich lower CCU. The $\mathrm{CCU}_{\mathrm{u}}$ in $\mathrm{C} 4105$ is relatively thin (only 6.5-ft thick) compared to adjacent boreholes. This may reflect more erosional scouring of the upper CCU during Ice-Age flooding. Gravimetric moisture content in $\mathrm{CCU}_{\mathrm{u}}$ samples shows relatively high water content, which averaged $15.0+/-3.9 \mathrm{wt} \%$.

The top of the calcic paleosol sequence of the lower CCU, $\mathrm{CCU}_{1}$, lies at a depth of about $92 \mathrm{ft}$, based on a slight increase in penetration resistance and neutron moisture, and sudden decrease in potassium-40 activity in the geophysical logs. The lower CCU in C4105 is relatively thick (19 ft) with an extremely high degree of internal heterogeneity, especially with respect to grain-size distribution and degree of weathering and pedogenesis. Grain sizes within the $\mathrm{CCU}_{1}$ subunit range from pebble gravel (mostly basalt) floating in a poorly sorted mixture of sand, silt, and/or clay to moderately to well-sorted sand and/or mud (i.e., silt and clay). As mentioned, the upper:lower subunit thickness ratio for C4104 is close to 1.0, while this ratio in C4105 is 0.3, illustrating the highly heterogeneous nature of the Cold Creek unit.

Multiple episodes of soil development occur internally within the $\mathrm{CCU}_{1}$ subunit, with tightly cemented, calcic, pedogenic horizons separated by relatively unweathered zones displaying only a few stringers or nodules of secondary calcium carbonate, some of which retain original sedimentary structures. This indicates long periods of land-surface stability and soil development separated by intermittent pulses of sediment accumulation during lower CCU time. Strongly calcic horizons are whitish to pale brown or grayish-brown in color; less pedogenically altered horizons are generally olive-brown. Interpretation of the KUT logs from the T Tank Farm dry wells (Sobczyk 2001) suggests at least two cemented caliche horizons are present, separated by less pedogenically altered sediments. The hardness of the lower CCU is quite variable, as indicated for the log of blow counts. One especially hard, thin cemented zone occurs about half way through the $\mathrm{CCU}_{1}$ at a depth of about $101 \mathrm{ft}$ bgs; this appears to be associated with the lower caliche horizon of Sobczyk (2001). The gravimetric moisture content of the $\mathrm{CCU}_{1}$ averaged $11.3+/-4.6 \mathrm{wt} \%$ water.

A total of $18 \mathrm{ft}$ of Ringold Formation sediments were penetrated within C4105 before the probe hole met refusal and was terminated at $130.9 \mathrm{ft}$ (39.9 m). The Ringold Formation member of Taylor Flat in probe hole C4105 extends from 111 to $122 \mathrm{ft}$ bgs and is about $11-\mathrm{ft}$ thick. The $\mathrm{R}_{\mathrm{tf}}$ unit is composed of 
interbedded layers of sand, silt, and clay. The strata are mostly fine-grained, compacted and cohesive, well-laminated, and well-sorted, in various shades of brown (gray, olive, and yellow). The concentration of calcium carbonate generally decreases with depth and distance from the overlying Cold Creek unit. Gravimetric moisture contents for the $\mathrm{R}_{\mathrm{tf}}$ sediments are highly variable - two are relatively high while the other two are low. The average gravimetric moisture was $14.7+/-10.7 \mathrm{wt} \%$ water. The contact between fine-grained $\mathrm{R}_{\mathrm{tf}}$ unit and the underlying coarse-grained $\mathrm{R}_{\mathrm{wi}}$ unit lies at $122 \mathrm{ft}$ bgs. The borehole advanced only $\sim 9 \mathrm{ft}$ into the $\mathbf{R}_{\mathrm{wi}}$ unit before the borehole was abandoned at $130.9 \mathrm{ft}$ bgs. The gravimetric moisture measured in the $\mathrm{R}_{\mathrm{wi}}$ samples averaged about $9.1+/-7.6 \mathrm{wt} \%$ water.

\subsection{Stratigraphy and Moisture Content}

In general, heterogeneities including fine-grained thin lenses in the Hanford formation and the relatively thick Cold Creek unit likely cause anisotropy in water flow. Increased moisture was found to correlate with each of the fine-grained thin lens intercepted by the coring; other fine-grained lens are inferred to be present in the Hanford formation $\mathrm{H} 2$ unit based on the field neutron logging profiles. Recall that only about $25 \%$ of the profiles in the boreholes were cored. Several findings and hypotheses on the relationship between moisture content and water and contaminant flow that are gleaned from the characterization efforts reported herein include:

- The highest concentrations of moisture in the vadose zone at T Tank Farm appear to lie within the Cold Creek unit and Ringold Formation member of Taylor Flat $\left(\mathrm{R}_{\mathrm{tf}}\right)$. Moisture is naturally high in these strata and not necessarily from tank leaks.

- Occasional, thin fine-grained lenses within the Hanford formation H2 unit also display higher moisture content.

- Relatively low moisture contents are found in gravelly facies, which include backfill materials, Hanford formation H1 unit, and the Ringold Formation member of Wooded Island.

- Sand-dominated facies of the Hanford formation (H2 unit) are also relatively low in moisture content.

- Average moisture content for the Hanford formation H2 unit and the upper CCU is about the same in the background hole as in the probe holes (C4104 and C4105) within the T Tank farm. This suggests movement of water under both artificial and natural recharge is transient in nature and may be difficult to distinguish with depth in the vadose zone.

\subsection{Vertical Extent of Contamination}

The following paragraphs describe measurements of various parameters that help us determine the extent of vertical migration of tank or ancillary equipment leaks. We used several parameters including moisture content, $\mathrm{pH}$, electrical conductivity, nitrate, technetium-99 (and other mobile fission products [i.e., ruthenium and molybdenum]), sodium, and uranium concentrations in water and acid extract for our main indicators to determine the leading edge of the plume. The concentrations of water-extractable (for mobile constituents) and acid-extractable or directly measured constituents in the sediment (for sorbing constituents) were used to delineate the total inventory of constituents within the plume. For technetium-99, the water-extractable data were judged to be a more accurate indication of past tank leaks 
than acid-extractable concentrations. In this section, we discuss all of the parameters measured except uranium and sodium. The uranium data suggest that only small quantities were present in the leaked fluid and the sodium data set shows obvious ion exchange interactions with the sediments that retard its migration in comparison to the most mobile constituents in the leaked fluids.

Based on evaluating all these measurements, we conclude that the borehole data do not establish the vertical extent of tank contamination, especially in boreholes C4104 and C4105, because contamination was found at the bottom of these boreholes, which met refusal before contamination could be shown to be absent.

The first parameter, moisture content, is a direct measure of the mass of water in the vadose zone sediment. One would logically assume that wetter than normal conditions would represent the existence of leaked tank liquor but, as found at most of the boreholes studied to date, the moisture content in the $\mathrm{T}$ boreholes is indicative mainly of grain size.

The second parameter measured was the $\mathrm{pH}$ of water extracts of the vadose zone sediment. Based on the assumption that tank fluids are generally caustic and, often, very caustic ( $>1 \mathrm{M}$ free hydroxide), elevated $\mathrm{pH}$ profiles should be indicative of the zones impacted by leaked fluids. The $\mathrm{pH}$ profiles for sediments from the two new boreholes (C4104 and C4105) show consistently elevated $\mathrm{pH}$ (pH values range from 8.6 to almost 10) in only borehole C4104 from 47 to $92.6 \mathrm{ft}$ bgs. But the $\mathrm{pH}$ data at all other depths in borehole C4104 and at all depths in borehole C4105 show no indication of significantly elevated $\mathrm{pH}$ values. Based on observations at other tank farms (SX and BX) where it is certain that caustic wastes are in the vadose zone, yet water extract $\mathrm{pH}$ values never exceed 10, we have concluded that $\mathrm{pH}$ is not a very sensitive parameter to use for evaluating the extent of plume migration in the vadose zone. A recent paper that provides a technically based conceptualization of the evolution of $\mathrm{pH}$ in sediments in contact with caustic fluids is Wan et al. (2004).

The third parameter that was assessed to estimate the vertical extent of the leaked plume was dilution-corrected water extract electrical conductivity (EC). The EC depth profiles for the two new T Tank Farm boreholes (C4104 and C4105) do show elevated EC in comparison to the background sediments from borehole 299-W10-27. We also found that the background borehole for the T Tank Farm, 299-W11-39, had suspiciously elevated EC values in the Hanford formation H2 unit above $78 \mathrm{ft}$ bgs so that we used the background borehole from the TX Tank Farm as a more appropriate background well. There is elevated EC in the $\mathrm{C} 4104$ borehole sediments from $47 \mathrm{ft}$ bgs to the bottom of the borehole near $127 \mathrm{ft}$ bgs. At $46 \mathrm{ft}$ bgs, EC of the C4104 water extracts and actual porewaters are 6 times higher than background values and differences reach values of $\sim 40$ times larger than background at $116 \mathrm{ft}$ bgs. The dilution-corrected (calculated) porewaters are also quite elevated between 59 and $76 \mathrm{ft}$ bgs. These data show that tank liquors from the T-106 leak are present in the sediments from C4104. The highest values of dilution-corrected porewater EC found at C4104 (33.4 mS/cm at $116 \mathrm{ft} \mathrm{bgs)}$ are equivalent to a pore solution of $0.21 \mathrm{M} \mathrm{KCl}$, the salt solution used to calibrate the conductivity probe.

There is also evidence of elevated EC starting at $86.7 .3 \mathrm{ft}$ bgs to the bottom of the C4105 borehole. The EC values for 1:1 water extracts from the Cold Creek units’ sediments at C4105 range from 1.2 to $3.1 \mathrm{mS} / \mathrm{cm}$, which is about 10 to 30 times higher than found in dilution-corrected porewaters from nearby background sediments. The six actual porewater EC values are quite similar to the dilution-corrected (derived) porewater conductivities. The highest values of dilution-corrected porewater EC in borehole C4105 occur in two zones, between 87 to $110 \mathrm{ft}$ bgs and at $123 \mathrm{ft}$ bgs. The dilution-corrected EC and 
actual porewater values for these two zones are equivalent to a pore solution of 0.10 to $0.175 \mathrm{M} \mathrm{KCl}$. Although dilution-corrected EC values peak slightly higher at C4104 both of the peak values for the two T boreholes are lower than the dilution-corrected EC maximum at borehole C3831 near Tank TX-107, which peaked between $60-61 \mathrm{ft}$ bgs with a value equivalent to a pore solution of $0.4 \mathrm{M} \mathrm{KCl}$.

Because the two new T Tank Farm boreholes could not be pushed through the Ringold Formation Wooded Island member beyond $\sim 130 \mathrm{ft}$ bgs, it is difficult to judge whether the vadose zone plumes of saline fluids stopped before reaching the water table. However, the earlier borehole (299-W10-196) that reached almost $180 \mathrm{ft}$ bgs suggests that contamination did stop percolating deeper into the vadose zone profile near the depth where refusal was met at C4104 and C4105. Unlike at SX Tank Farm where contamination appears to stop at the caliche layer (see Serne et al. 2002b and 2002c), contamination near T-106 has penetrated into the Ringold deeper than the upper fine-grained Taylor Flat member and into the upper portion of the coarse grained Wooded Island member.

Despite the evidence that elevated EC values may be present in both new boreholes to their depth of refusal, the concentrations are not large. For example, the maximum dilution-corrected EC at borehole C4104 is $33.41 \mathrm{mS} / \mathrm{cm}$ at $116 \mathrm{ft}$ bgs, and at borehole C4105 the maximum is $18.98 \mathrm{mS} / \mathrm{cm}$ at $123.9 \mathrm{ft}$ bgs. In both cases the peak EC is not at the very bottom of the borehole but there is no clear indication that the vertical distribution is tailing off dramatically towards background levels, which would indicate that the entire plume had been delineated.

The leaks near the SX108-109 and BX-102 tanks had peak vadose zone porewater concentrations that were equivalent to much more concentrated waste fluids, 524 to 1774 and $77 \mathrm{mS} / \mathrm{cm}$, respectively. At 299-E33-46 near tank B-110 the dilution-corrected EC was $15.1 \mathrm{mS} / \mathrm{cm}$, and at 299-W23-19 near tank SX-115, which contained dilute waste, the dilution-corrected EC was $33 \mathrm{mS} / \mathrm{cm}$. At the TX tank farm maximum dilution-corrected EC values were $6.27 \mathrm{mS} / \mathrm{cm}$ (C3830), $12.5 \mathrm{mS} / \mathrm{cm}$ (C3832) and $43.3 \mathrm{mS} / \mathrm{cm}$ (C3831).

The fourth parameter evaluated to define the vertical extent of contamination was nitrate. The nitrate water extract values for borehole C4104 are elevated from $64 \mathrm{ft}$ bgs to the bottom of the borehole. Starting at $64 \mathrm{ft}$ bgs the water-extractable nitrate is 10 times larger than background, at $87 \mathrm{ft}$ bgs the nitrate values exceed 100 times background, and at $111 \mathrm{ft}$ bgs the water-extractable nitrate is greater than 250 times values found in background sediments. At $116 \mathrm{ft}$ bgs, water-extractable nitrate peaks at 1000 times background sediment values. The water-extractable nitrate data for borehole C4105 sediments show slightly elevated values in comparison to background sediments in the deeper portion of the Hanford formation H2 unit and significantly higher concentrations (>1000 x) than background in both Cold Creek subunits. The nitrate concentrations in C4105 sediments within the Ringold Formation (both subunits) are also elevated versus background by factors of 500 and 100 in $R_{t f}$ and $R_{w i}$, respectively.

The comparison of the nitrate concentrations in the two contaminated boreholes suggests that in the Hanford formation tank leak fluid percolated into the sediments near C4104, intercept C4104 borehole starting at about $80 \mathrm{ft}$ bgs but did not flow horizontally in the Hanford formation all the way to C4105. However, in the Cold Creek upper subunit, the nitrate concentrations at C4105 exceed the concentrations at C4104 by a factor of 10, thus suggesting a large component of horizontal spreading in the Cold Creek Formation strata. In the $\mathrm{CCU}_{1}$ subunit there is somewhat larger concentrations of nitrate in $\mathrm{C} 4105$ sediments, suggesting perhaps some vertical penetration of high nitrate concentrations that originally spread horizontally in the overlying $\mathrm{CCU}_{\mathrm{u}}$ stratum. There is more nitrate (factor of 1 to $5 \mathrm{x}$ ) in the C4105 
sediments in the $\mathrm{R}_{\mathrm{tf}}$ stratum than at C4104, but in the deepest stratum penetrated, the top of Ringold Formation Wooded Island member, the nitrate concentrations in both contaminated boreholes are similar (several hundred $\mu \mathrm{g} / \mathrm{g}$ ). The nitrate distribution with depth at these two boreholes support a flow conceptual model that suggests vertical percolation through the Hanford formation H2 unit near tank $\mathrm{T}-106$ and then a strong horizontal spreading within the $\mathrm{CCU}_{\mathrm{u}}$ unit followed by more slow vertical percolation, perhaps via diffusion, into the deeper strata.

It is certain at the T-106 region that the plume of leaked fluid was not successfully stopped at the caliche layer $\left(\mathrm{CCU}_{\mathrm{l}}\right)$ as was inferred from boreholes at the SX tank farm. Around the T-106 tank, leaked tank fluids are found as deep as $130 \mathrm{ft}$ bgs in the Ringold Formation Wooden Island member. The nitrate profile at the 299-W10-196 borehole drilled in 1992 using a different technique reached $180 \mathrm{ft}$ bgs and both its and the C4104 vertical profiles of nitrate appear to show the leading edge of the bulk of the plume resides near $116 \mathrm{ft}$ bgs in the Ringold Formation Taylor Flat member. However, to the southwest at C4105 the high nitrate plume shows three maxima in the vertical profile: at 88, 107, and $124 \mathrm{ft}$ bgs with nitrate concentrations of $\sim 8630,5400$, and $7880 \mathrm{mg} / \mathrm{L}$, respectively. Again, this suggests significant horizontal migration of plume fluids.

The sampling frequency for the nitrate at 299-W10-196 is very sparse in the zone of interest. Further, neither C4104 or 299-W10-196 boreholes have frequent enough sampling to identify the exact depth of maximum concentration. Available data suggest that the maximum concentration in C4104 might be about $6 \mathrm{ft}$ deeper than at 299-W10-196, so perhaps there is some evidence of vertical migration in the ten years between drilling of the boreholes. The concentrations of nitrate found in the sediments vary some with peak concentrations of 4,400 and 2,600 $\mu \mathrm{g} / \mathrm{g}$, in 299-W10-196 and C4104, respectively.

The fifth indicator species often used to define the vertical extent of contamination is technetium-99 in water extract samples. Water-leachable technetium-99 is present in the C4104 sediment from $40 \mathrm{ft}$ bgs to the bottom of the borehole. The bulk of the technetium plume resides between the depths of 115 and $121 \mathrm{ft}$ bgs in the Ringold Taylor Flats unit. The maximum water-leachable technetium in this zone ranges from 500 to $1160 \mathrm{pCi} / \mathrm{g}$. This range is larger than values found at contaminated boreholes in the TX (20 to $130 \mathrm{pCi} / \mathrm{g}$ ), BX and $\mathrm{B}$ tank farms (5 to $20 \mathrm{pCi} / \mathrm{g}$ ), and higher than the values found at the 299-W23-19 borehole near SX-115 (100 to 500 pCi/g) but lower than the water leachable technetium-99 found in boreholes near the SX-108 and SX-109 tanks (1,000 to 10,000 pCi/g) as described in Serne et al. (2002b, 2000c, 2000d, 2000e, 2000f) and Serne et al. (2004). The maximum concentrations of technetium-99 at C4105 are found between 86.7 and $93.3 \mathrm{ft}$ bgs in the Cold Creek Formation upper subunit (the fine-grained sediment), although significant concentrations are found all the way down to the bottom of the $\mathrm{R}_{\mathrm{tf}}$ unit. The water-extractable technetium-99 concentrations in the sediments from C4105 are greater than the concentrations in sediments from C4104 in the two Cold Creek units by factors of four to thirty. Deeper in the two Ringold Formation units, the sediments at C4104 contain more water-soluble technetium-99 than the sediments from C4105 by factors of 1 to 10 .

We interpret the technetium-99 distributions between the two boreholes to reflect the rapid horizontal migration of the tank T-106 leak plume in the Cold Creek units and a rapid vertical migration of some of the tank fluids near the tank. Slow flushing by enhanced recharge appears to lead to more horizontal movement of the tank fluids downgradient towards C4105. The C4104 to 299-W10-196 comparison data show that technetium-99 present between the depths of 95 to $105 \mathrm{ft}$ bgs in the Cold Creek lower subunit in borehole 299-W10-196 in 1993 is not present in borehole C4104 at similar depths in 2004. 
Unfortunately, the sampling and technetium-99 measurement frequency in 1993 for borehole 299-W10-196 was too coarse to adequately complete a profile of the shape of the technetium-99 plume. Depending upon what the technetium-99 concentration was in the peak of the plume (between 105 and $115 \mathrm{ft}$ bgs; the zone where data are missing) in borehole 299-W10-196, the masses of technetium-99 in the two boreholes appears to be quite similar. The sediments below $120 \mathrm{ft}$ bgs in both boreholes are drier and coarser-grained Ringold Formation Wooded Island member. This stratum may be acting as a hydrologic barrier to the migration of unsaturated fluids that have accumulated in the finer-grained $\mathrm{R}_{\mathrm{tf}}$ strata. One plausible explanation of the differences in the shape (vertical distribution) of the technetium-99 plume between the observed profiles (299-W10-196 versus C4104) is that since 1993, the upper portion of the technetium-99 plume has vertically migrated from the Cold Creek Formation lower subunit into the moist and fine-grained Ringold Formation Taylor Flat member during the ten years that have elapsed since the 299-W10-196 borehole was drilled and measurements performed.

In summary, the moisture content, $\mathrm{pH}$, electrical conductivity, nitrate, and technetium-99 profiles versus depth in the three contaminated boreholes around T-106 do not clearly identify the leading edge of the plume. The profiles do collectively suggest that bulk of tank-related fluids (center of mass) still resides in Ringold Formation Taylor Flats member fine-grained sediments.

\subsection{Detailed Characterization to Elucidate Controlling Geochemical Processes}

The more detailed characterization activities of the cores from 299-W11-39 and the three contaminated boreholes added some insight on the processes that control the observed vertical distribution of contaminants and on the migration potential of key contaminants in the future.

The porewaters, either calculated by dilution correction of the 1:1 water extracts, or directly obtained by ultracentrifugation, had the following composition. Two regions of the C4104 vadose profile contain high total dissolved salts - 59 to 76 and $116 \mathrm{ft}$ bgs. The uncharged-balanced porewater at these two depth zones is approximated by the following compositions that are based on the actual porewaters, which were obtained by ultracentrifugation. The shallow (between 59 and $76 \mathrm{ft}$ bgs; Hanford formation $\mathrm{H} 2 \mathrm{unit}$ ) porewater is dominated by sodium and carbonate/bicarbonate alkalinity with the approximate composition of sodium (150 meq/L), calcium $(0.7 \mathrm{meq} / \mathrm{L})$, magnesium $(0.6 \mathrm{meq} / \mathrm{L})$, potassium (1.2 meq/L), alkalinity ( 220 meq/L), nitrate $(9.2 \mathrm{meq} / \mathrm{L})$, fluoride $(6.4 \mathrm{meq} / \mathrm{L})$, sulfate $(5.6 \mathrm{meq} / \mathrm{L})$, chloride $(3.0 \mathrm{meq} / \mathrm{L})$ and phosphate $(1.8 \mathrm{meq} / \mathrm{L})$, respectively.

The deeper saline porewater in the C4104 Ringold Formation member of Taylor Flat sediment is dominated by the divalent cations calcium and magnesium and the anions nitrate and nitrite, and represents tank liquor in the ion exchange front that is pushing the divalent cations off sediment exchange sites. The deep porewater has a chemical composition of calcium $(190 \mathrm{meq} / \mathrm{L})$, magnesium $(125 \mathrm{meq} / \mathrm{L})$, sodium (110 meq/L), and potassium (1.7 meq/L) and nitrate (212 meq/L), nitrite (40 meq/L), sulfate (37 meq/L), chloride (5 meq/L), and bicarbonate alkalinity of 6 meq/L.

These two C4104 porewaters are very dilute compared to the vadose zone porewaters found at the SX and BX tank farms where the total ionic strength of the porewaters were as high as 7,000 to 17,000 and $1,000 \mathrm{meq} / \mathrm{L}$, respectively. At the borehole emplaced near tank B-110, the most saline porewater was 150 
to $160 \mathrm{meq} / \mathrm{L}$. At the TX tank farm, the most saline porewater was found in borehole C3831, near tank TX-107, with a total ionic strength of $850 \mathrm{meq} / \mathrm{L}$, about $350 \mathrm{meq} / \mathrm{L}$ greater than the concentrations in C4104 sediments.

The porewater in the C4105 borehole Cold Creek upper subunit has a total concentration of $\sim 185 \mathrm{meq} / \mathrm{L}$ each of cations and anions consisting of 44 meq/L magnesium, 120 meq/L calcium, $18 \mathrm{meq} / \mathrm{L}$ sodium, $1.2 \mathrm{meq} / \mathrm{L}$ potassium, $5 \mathrm{meq} / \mathrm{L}$ chlorine, $30 \mathrm{meq} / \mathrm{L}$ bicarbonate, $130 \mathrm{meq} / \mathrm{L}$ nitrate, and 20 meq/L sulfate. The saline porewater in $\mathrm{C} 4105$ borehole's Cold Creek lower subunit contains $\sim 175 \mathrm{meq} / \mathrm{L}$ each of cations and anions consisting of 55 meq/L magnesium, 77 meq/L calcium, $40 \mathrm{meq} / \mathrm{L}$ sodium, $3 \mathrm{meq} / \mathrm{L}$ potassium, $0.3 \mathrm{meq} / \mathrm{L}$ fluoride, $3 \mathrm{meq} / \mathrm{L}$ chloride, $85 \mathrm{meq} / \mathrm{L}$ nitrate, $62 \mathrm{meq} / \mathrm{L}$ sulfate and $25 \mathrm{meq} / \mathrm{L}$ bicarbonate. The actual porewaters from caliche bearing sediments, obtained from ultracentrifugation, show that 1:1 sediment:water extracts inflate the calculated bicarbonate porewater concentration significantly from dissolution of the caliche. The porewaters from C4105 in the Cold Creek upper subunit are slightly more saline than comparable porewaters at C4104 (depths slightly more shallow and including the deep Hanford formation $\mathrm{H} 2$ unit) that contain $~ 150$ meq/L cations and anions that are predominately sodium bicarbonate. The chemical composition in the $\mathrm{CCU}_{\mathrm{u}}$ unit at $\mathrm{C} 4105$ shows more divalent cations from the ion exchange reactions and more nitrate and sulfate likely from the tank fluids than porewaters within the C4104 sediments from the same strata.

The C4105 porewater in the Cold Creek lower unit is more dilute ( 175 vs. $425 \mathrm{meq} / \mathrm{L}$ ) than the porewater from the same strata in borehole C4104. Both contain a mix of divalent cations (from ion exchange and naturally from caliche) and sodium (from the tank leak) and a mix of nitrate-nitrite and sulfate (from the tank leak) and bicarbonate (from the sediment and reactions with the caustic tank fluids). The porewater chemical compositions at C4104 and C4105 are consistent with a plume migration model that has the tank fluid quickly penetrating vertically right below T-106 through the Hanford formation $\mathrm{H} 2$ unit into the Cold Creek formations with additional fluid migrating horizontally in the two Cold Creek units downgradient towards C4105. With time, dilute recharge water has pushed the mobile nitrate out of the shallow C4104 sediments down to the Cold Creek strata where the mobile tank species are transported horizontally towards C4105.

The most concentrated porewaters found in boreholes C4104 and C4105 are shown in Table 6.2 in units of meq/L. Also included in the table for comparison are the maximum porewater concentrations found in other characterization work previously reported for the BX, B, SX, and TX Tank Farms.

As shown in Table 6.2, the calculated porewaters in the T boreholes are much less concentrated than porewaters found in the vadose zone sediments from both the BX and SX WMAs and slightly less than those from the most saline porewater found in the TX tank farm. 
Table 6.2. Maximum Pore Water Concentrations in Sediments from Contaminated Sediments in Various Tank Farms

\begin{tabular}{|c|c|c|c|c|c|c|c|c|c|c|}
\hline & & & & Closest & ST and Boreho & Number & & & & \\
\hline Tank & TX-107 & & & & \begin{tabular}{|l|l|}
106 \\
\end{tabular} & BX-102 & B-110 & SX-115 & SX-109 & SX-108 \\
\hline $\begin{array}{c}\text { Borehole/ } \\
\text { Strata }\end{array}$ & C3831-H2 & C4104-H2 & C4104-Rtf & $\begin{array}{l}\text { C4105- } \\
\text { CCUu }\end{array}$ & C4105-CCUI & E33-45 & E33-46 & W23-19 & 41-09-39 & Slant \\
\hline $\mathrm{Na}$ & 418.5 & 150 & 110 & 18 & 40 & 525 & 150 & 35.6 & 6066 & 16900 \\
\hline $\mathrm{Ca}$ & 1.2 & 0.7 & $190^{*}$ & 120 & 77 & 114 & 4 & 280.9 & 619 & 90 \\
\hline Mg & 0.2 & 0.6 & $125^{*}$ & 44 & 55 & 62 & 2.5 & 94.6 & 24 & 10 \\
\hline K & 4.7 & 1.2 & 1.7 & 1.2 & 3 & 13 & 0.5 & 3.6 & 42 & 92 \\
\hline $\mathrm{Sr}$ & 0 & 0 & 0 & 0 & 0 & 0 & 0 & 1.5 & 4.4 & 1 \\
\hline $\mathrm{UO}_{2}$ & 0 & 0 & 0 & 0 & 0 & 2 & 0 & 0 & 0 & 0 \\
\hline Total Cations & 424 & 152.5 & $426.7^{*}$ & 183.2 & 175 & 716 & 157 & 416.2 & 6755.4 & 17093 \\
\hline $\mathrm{NO}_{3}$ & 202.4 & 9.2 & 212 & 130 & 85 & 100 & 3 & 420 & 6710 & 15677 \\
\hline $\mathrm{NO}_{2}$ & 0 & 0 & 40 & 0 & 0 & 0 & 0 & 0 & 28 & 32 \\
\hline $\mathrm{SO}_{4}$ & 15.2 & 5.6 & 37 & 20 & 62 & 570 & 14 & 3.3 & 95 & 500 \\
\hline $\mathrm{CrO}_{4}$ & 0 & 0 & 0.0 & 0 & 0 & 0 & 0 & 100 & 0 & 0 \\
\hline $\mathrm{PO}_{4}$ & 8.4 & 1.8 & 0 & 0 & 0 & 0 & 0 & 0 & 0 & 0 \\
\hline $\mathrm{Cl}$ & 6.4 & 3.0 & 5 & 5 & 3 & 5 & 0 & 6 & 119 & 147 \\
\hline $\mathrm{F}$ & 0.8 & 6.4 & 0 & 0 & 0.3 & 1 & 10 & 0 & 0 & 0 \\
\hline $\mathrm{HCO}_{3}$ & 191.2 & $220^{*}$ & 6 & 30 & 25 & 40 & 130 & 7 & 0 & 666 \\
\hline Total Anions & 424 & $246^{*}$ & 300 & 185 & 175.3 & 716 & 157 & 536.3 & 6952 & 17022 \\
\hline \begin{tabular}{c|} 
Dilution- \\
corrected EC \\
$(\mathrm{mS} / \mathrm{cm})$
\end{tabular} & 43.26 & 24.3 & 33.4 & 15.6 & 18.1 & 76.8 & 15.1 & 33.1 & 524 & 1772 \\
\hline
\end{tabular}


The water-extractable major cations' distributions in borehole C4104 and C4105 sediments suggest that an ion-exchange process dominates the porewater/sediment interactions where tank fluid passed by or currently exists. The distribution of water-leachable divalent-alkaline-earth cations (magnesium, calcium, and strontium and to some extent barium) at C4104 shows low quantities between 40 and $93 \mathrm{ft}$ bgs. Conversely, the distribution of water-extractable sodium is higher than the mass that is water-leachable from uncontaminated sediments in the profile from 23 to $116 \mathrm{ft}$ bgs. These trends suggest that tank fluids that are high in sodium and nitrate did seep into the vadose zone near C4104 borehole. The sodium pushed the natural divalent cations off the sediment cation exchange sites in the C4104 sediments between 40 and $93 \mathrm{ft}$ bgs. At and right below the leading edge of the sodium plume, one finds elevated levels of the divalent cations that were displaced. We observe the high levels of divalent cations in the samples between $115 \mathrm{ft}$ bgs to the bottom of the borehole at $127 \mathrm{ft}$ bgs. The water-extractable sodium concentration approaches background levels below $116 \mathrm{ft}$ bgs. The maximum penetration of the cationexchange front is located between 116 and $120 \mathrm{ft}$. No samples were obtained between these two depths to locate the exact penetration depth of the cation exchange interactions.

The water-leachable cation distribution in C4105 sediments agrees with the hydrologic conceptual model wherein the T-106 tank leak with high soluble sodium percolates both vertically below tank T-106 into the sediments near borehole C4104 and also horizontally towards borehole C4105 in the Cold Creek upper subunit. As the T-106 tank fluids migrated, the sodium displaced the natural divalent cations and some of the natural potassium off the sediment cation exchange sites in the sediments between boreholes C4104 and C4105. The displaced divalent cations migrated horizontally into the area of borehole C4105 mainly in both Cold Creek units and the upper portion of $\mathrm{R}_{\mathrm{tf}}$. Similarly near C4104, some of the divalent cations were pushed vertically into the lower portion of the $\mathrm{R}_{\mathrm{tf}}$ and somewhat into the $\mathrm{R}_{\mathrm{wi}}$ unit. The water-leachable anions and cations data for the two boreholes near Tank T-106 show that horizontal plume migration can be as significant as vertical percolation. Borehole C4105 is about $88 \mathrm{ft}$ due west of C4104; thus, the ion exchange front has traveled horizontally as far as the ion exchange front penetrated vertically at C4104.

\subsection{Estimates of Contaminant Inventory and Sorption-Desorption Values}

In this section, we discuss our measurements and data synthesis used to quantify the inventory of key risk contaminants and our estimates of their adsorption-desorption tendencies. We did perform site-specific desorption studies for cobalt-60 on sediments from C4104 using deionized water as the leachant and the results are discussed below. Further, by combining the data from the dilution-corrected 1:1 water extracts, which represent the porewater, with the concentrations measured on the sediment, we can estimate the desorption $\mathrm{K}_{\mathrm{d}}$ values for the contaminants of interest. For a contaminant that has very little water-soluble mass such as cesium-137, the in situ desorption $\mathrm{K}_{\mathrm{d}}$ can be approximated as the mass in the total sample per gram of dry sediment divided by the mass in the porewater per milliliter. For a contaminant that is quite soluble in the water extract (this is approximately equivalent to stating that the contaminant resides mainly in the porewater within the sediment), one needs to subtract the amount that was present in the porewater from the total amount present in the moist sediment sample to obtain a value for the amount that would remain on the solid at equilibrium with the pore fluid.

We will first describe our inventory estimates and then address the mobility status of contaminants presently found in the $\mathrm{T}$ vadose zone sediments. Tables 6.3 and 6.4 provide our best estimate of the inventory of potentially mobile contaminants found in each of the two new boreholes near tank T-106. 
Potential contaminants of concern that have been selected for discussion include technetium-99, uranium, cobalt-60, chromium(VI), and nitrate. For the technetium-99 inventory, we suggest that the water extract data is most accurate and should be used to estimate technetium-99 inventory versus depth. However, we do present the technetium-99 acid extract data as the worst-case maximum inventory estimate. We assume that all technetium is water soluble in the sediments, as found during our characterization studies at SX and the BX WMAs (Serne et al. 2002b, 2002c, 2002d, and 2002e), and that the acid-extract data are biased high and are generally of lesser quality.

For uranium and chromium we have found that one must separate the natural background concentrations from the "Hanford added material" in discussing risk potential. The natural uranium and chromium are almost entirely resistant to water leaching and to becoming mobile, whereas the material added by Hanford activities is somewhat mobile. We thus recommend using the water-extractable uranium and chromium data as representative of the concentrations that could migrate to the water table for future risk calculations. However, we present the acid-extractable chromium and uranium inventories to allow very conservative risk calculations to be performed that assume all acid-extractable masses could ultimately become released to percolating recharge waters. For the cobalt-60, we present the total activity present in the sediments.

For nitrate, as for technetium-99, we assume that the water extract concentrations represent the total inventory. We have no other method to measure nitrate besides the water extract method. We use $8 \mathrm{M}$ nitric acid to measure the total amount of a constituent that is acid leachable. Thus, the nitric acid leachant overwhelms any nitrate present in the sediment. We have also designated in the tables, using yellow shading, samples that may contain Hanford-related wastes as opposed to samples that are likely uncontaminated natural sediments.

Semi-quantitative estimates of desorption $\mathrm{K}_{\mathrm{d}}$ values for the potential contaminants, identified in Table 6.5 for C4104 and C4105 vadose zone sediments, can be calculated using the inventory estimates (mass or activity per gram of sediment) divided by the estimated porewater concentration of the constituent. These values are found in Tables 4.30, 4.45, 4.60 (acid extract or direct measure; cobalt-60) and 4.27, 4.42, 4.57 (porewaters) and 4.34 (cobalt-60 in water extracts), respectively. In Table 6.5, the $\mathrm{K}_{\mathrm{d}}$ values for sediment samples where the bulk of the contamination is present are highlighted in yellow and in bold red type. The faint blue (lighter) shading in Table 6.5 designates data that are more dominated by natural constituents or impacted by low precision analytical values. From the table one can see two trends. First, where there are significant concentrations of contaminants in the sediments (between 46.33 and $125 \mathrm{ft}$ bgs for C4104 and 70 to $130 \mathrm{ft}$ bgs for C4105), the $\mathrm{K}_{\mathrm{d}}$ values for uranium and chromium are smaller than their values at shallower and deeper depths. This is caused both by there being more saline porewaters (competing ions) and higher contributions of Hanford waste species for chromium and uranium being present, which are generally more water leachable than naturally present species. 
Table 6.3. Inventory Estimates for Potential Contaminants of Concern in Borehole C4104 Sediments

\begin{tabular}{|c|c|c|c|c|c|c|c|c|}
\hline Depth (ft bgs) & Strat. Unit & Nitrate & Tc-99 & U-238 & $\mathrm{Cr}$ & Tc-99 & U-238 & $\mathrm{Cr}$ \\
\hline Extract & \multicolumn{5}{|c|}{ Water } & \multicolumn{3}{|c|}{ Acid } \\
\hline \multicolumn{2}{|c|}{ Units } & $\mu \mathrm{g} / \mathrm{g}$ & $\mathrm{pCi} / \mathrm{g}$ & $\mu g / g$ & $\mu g / g$ & $\mathrm{pCi} / \mathrm{g}$ & $\mu g / g$ & $\mu \mathrm{g} / \mathrm{g}$ \\
\hline 16.18 & Bckfl & 2.34 & $<1.70 \mathrm{E}-01$ & 2.05E-03 & (3.60E-04) & $(9.86 \mathrm{E}-01)^{(\mathrm{a})}$ & 4.35E-01 & $8.56 \mathrm{E}+00$ \\
\hline 22.69 & Bckfl & 2.72 & $<1.70 \mathrm{E}-01$ & $2.40 \mathrm{E}-03$ & (4.28E-04) & $(1.46 \mathrm{E}+00)$ & 3.84E-01 & $6.03 \mathrm{E}+00$ \\
\hline 30.74 & Bckfl & 1.77 & $<1.70 \mathrm{E}-01$ & $2.98 \mathrm{E}-03$ & (2.03E-03) & $(1.22 \mathrm{E}+00)$ & 4.09E-01 & $1.97 \mathrm{E}+01$ \\
\hline 36.88 & Bckfl & 0.79 & $(6.78 \mathrm{E}-02)^{(\mathrm{a})}$ & $1.60 \mathrm{E}-03$ & (1.41E-03) & $(1.34 \mathrm{E}+00)$ & 3.96E-01 & $8.77 \mathrm{E}+00$ \\
\hline 37.4 & Bckfl & 0.77 & $1.02 \mathrm{E}-01$ & $3.99 \mathrm{E}-03$ & (1.23E-04) & $(1.12 \mathrm{E}+01)$ & 4.17E-01 & $1.43 \mathrm{E}+01$ \\
\hline 40.01 & Bckfl & 2.05 & $2.12 \mathrm{E}-01$ & $8.49 \mathrm{E}-03$ & (6.47E-04) & $(1.61 \mathrm{E}+01)$ & 4.97E-01 & $2.17 \mathrm{E}+01$ \\
\hline 40.01 & Bckfl & 1.05 & $0.00 \mathrm{E}+00$ & $3.95 \mathrm{E}-03$ & (3.27E-03) & $(1.38 \mathrm{E}+00)$ & $4.68 \mathrm{E}-01$ & $1.09 \mathrm{E}+01$ \\
\hline 46.33 & $\mathrm{H} 2$ & $<0.43$ & $5.53 \mathrm{E}+00$ & 6.13E-02 & 4.14E-03 & $(4.03 E+01)$ & $1.07 \mathrm{E}+00$ & $1.36 \mathrm{E}+01$ \\
\hline 46.98 & $\mathrm{H} 2$ & 3.47 & $2.02 \mathrm{E}+00$ & 3.89E-02 & $5.28 \mathrm{E}-03$ & $(2.26 \mathrm{E}+01)$ & 7.56E-01 & $9.91 \mathrm{E}+00$ \\
\hline 58.39 & $\mathrm{H} 2$ & 4.08 & $1.52 \mathrm{E}+01$ & $8.34 \mathrm{E}-01$ & $1.61 \mathrm{E}-02$ & $(7.96 \mathrm{E}+01)$ & $2.51 \mathrm{E}+00$ & $5.40 \mathrm{E}+01$ \\
\hline 58.39 & $\mathrm{H} 2$ & 5.6 & $1.38 \mathrm{E}+01$ & $1.06 \mathrm{E}+00$ & $3.26 \mathrm{E}-02$ & $\mathrm{NS}^{(\mathrm{c})}$ & $\mathrm{NS}^{(\mathrm{c})}$ & $\mathrm{NS}^{(\mathrm{c})}$ \\
\hline 59.09 & $\mathrm{H} 2$ & 7.71 & $2.19 \mathrm{E}+00$ & 4.74E-01 & 3.03E-02 & $(1.41 \mathrm{E}+01)$ & $1.18 \mathrm{E}+00$ & $9.24 \mathrm{E}+00$ \\
\hline 63.38 & $\mathrm{H} 2$ & $<0.44$ & $1.32 \mathrm{E}+01$ & 7.18E-01 & $5.30 \mathrm{E}-02$ & $(4.12 E+01)$ & $1.20 \mathrm{E}+00$ & $1.71 \mathrm{E}+01$ \\
\hline 64.03 & $\mathrm{H} 2$ & 17.85 & $4.28 \mathrm{E}+00$ & $1.12 \mathrm{E}-01$ & $4.29 \mathrm{E}-01$ & $(1.97 \mathrm{E}+01)$ & $6.35 \mathrm{E}-01$ & $1.42 \mathrm{E}+01$ \\
\hline 64.03 & $\mathrm{H} 2$ & 20.6 & $4.51 \mathrm{E}+00$ & $1.15 \mathrm{E}-01$ & 3.04E-01 & $(1.97 \mathrm{E}+01)$ & 5.21E-01 & $1.48 \mathrm{E}+01$ \\
\hline 76.03 & $\mathrm{H} 2$ & 24.71 & $2.01 \mathrm{E}+00$ & $9.08 \mathrm{E}-01$ & 5.31E-01 & $(2.56 \mathrm{E}+01)$ & $2.46 \mathrm{E}+00$ & $1.24 \mathrm{E}+01$ \\
\hline 81.04 & $\mathrm{CCU}_{\mathrm{u}}$ & 78.22 & $5.73 \mathrm{E}+00$ & $9.46 \mathrm{E}-01$ & $1.47 \mathrm{E}+00$ & $(3.28 \mathrm{E}+01)$ & $2.30 \mathrm{E}+00$ & $2.57 \mathrm{E}+01$ \\
\hline 87.35 & $\mathrm{CCU}_{\mathrm{u}}$ & 168.18 & $4.43 \mathrm{E}+01$ & 2.07E-01 & $3.11 \mathrm{E}+00$ & $5.56 \mathrm{E}+01$ & $1.69 \mathrm{E}+00$ & $5.73 \mathrm{E}+01$ \\
\hline 87.35 & $\mathrm{CCU}_{\mathrm{u}}$ & 196.66 & $4.06 \mathrm{E}+01$ & 2.29E-01 & $2.74 \mathrm{E}+00$ & $5.19 \mathrm{E}+01$ & $1.63 \mathrm{E}+00$ & $5.74 \mathrm{E}+01$ \\
\hline 92.61 & $\mathrm{CCU}_{1}$ & 220.37 & $5.27 \mathrm{E}+01$ & 4.69E-01 & $1.83 \mathrm{E}+00$ & $2.55 \mathrm{E}+02$ & $2.42 \mathrm{E}+00$ & $1.92 \mathrm{E}+01$ \\
\hline 93.56 & $\mathrm{CCU}_{\mathrm{l}}$ & 510.87 & $2.95 \mathrm{E}+02$ & 7.64E-03 & $6.72 \mathrm{E}+00$ & $5.88 \mathrm{E}+02$ & $1.48 \mathrm{E}+00$ & $2.37 \mathrm{E}+01$ \\
\hline 94.67 & $\mathrm{CCU}_{\mathrm{l}}$ & 528.93 & $1.04 \mathrm{E}+02$ & 6.81E-03 & $2.17 \mathrm{E}+00$ & $2.60 \mathrm{E}+02$ & 7.39E-01 & $2.63 \mathrm{E}+01$ \\
\hline 99.7 & $\mathrm{CCU}_{\mathrm{l}}$ & 179.76 & $1.76 \mathrm{E}+02$ & 1.04E-02 & 5.70E-01 & $7.87 \mathrm{E}+02$ & 6.07E-01 & $1.87 \mathrm{E}+01$ \\
\hline
\end{tabular}


Table 6.3. (contd)

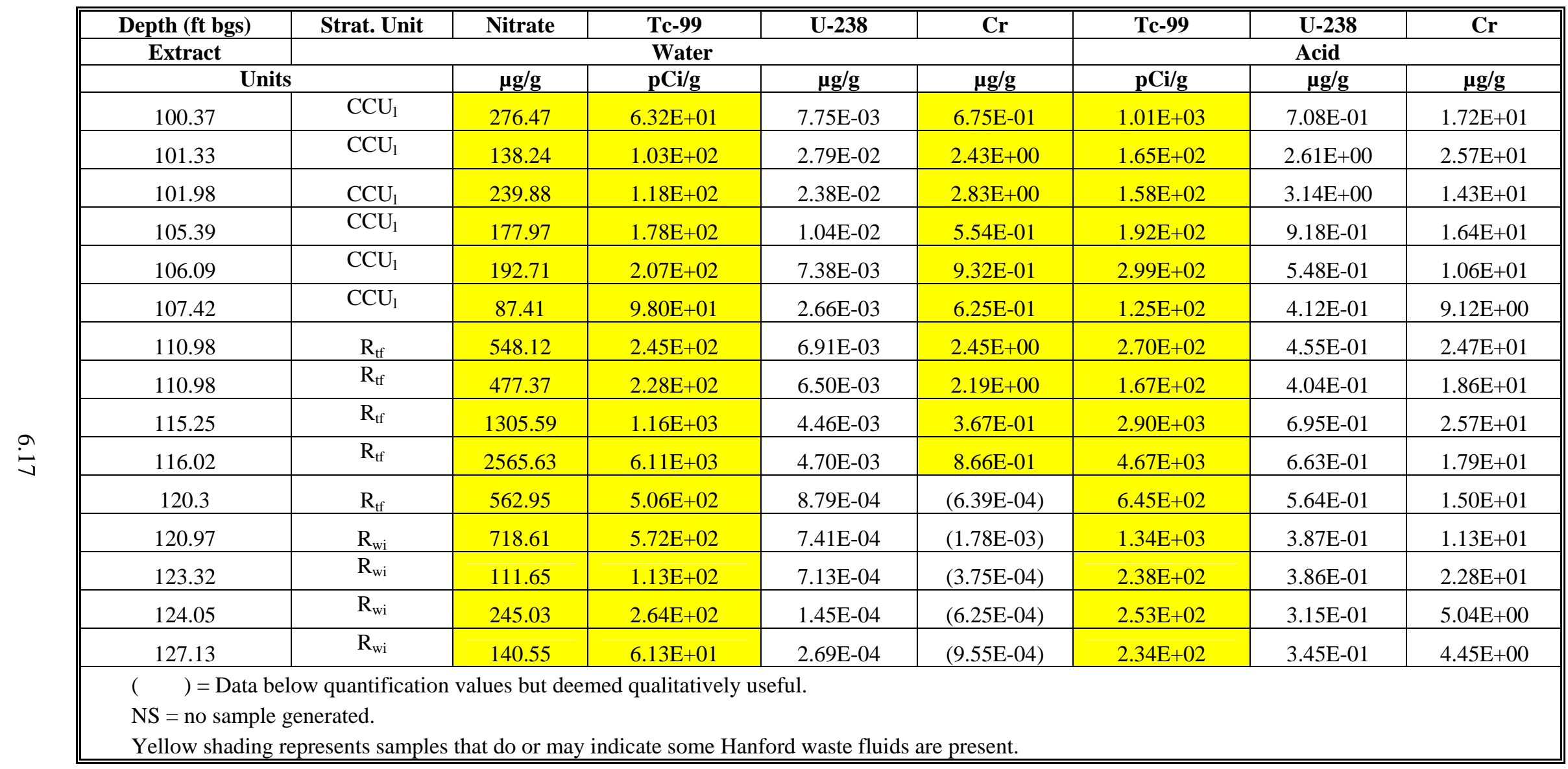


Table 6.4. Inventory Estimates for Potential Contaminants of Concern in Borehole C4105 Sediments

\begin{tabular}{|c|c|c|c|c|c|c|c|c|}
\hline Depth (ft bgs) & Strat. Unit & Nitrate & Tc-99 & U-238 & $\mathrm{Cr}$ & Tc-99 & $\mathrm{U}-238$ & $\mathrm{Cr}$ \\
\hline Extract & \multicolumn{5}{|c|}{ Water } & \multicolumn{3}{|c|}{ Acid } \\
\hline \multicolumn{2}{|c|}{ Units } & $\mu \mathrm{g} / \mathrm{g}$ & $\mathrm{pCi} / \mathrm{g}$ & $\mu \mathrm{g} / \mathrm{g}$ & $\mu \mathrm{g} / \mathrm{g}$ & pCi/g & $\mu \mathrm{g} / \mathrm{g}$ & $\mu g / g$ \\
\hline 15.3 & Bkfl & 1.59 & $(0.00)$ & 1.99E-03 & (1.52E-04) & $(0.00 \mathrm{E}+00)^{(\mathrm{a})}$ & 4.76E-01 & $1.18 \mathrm{E}+01$ \\
\hline 22.7 & Bkfl & 0.77 & $(0.00)$ & $1.32 \mathrm{E}-03$ & (1.63E-04) & $<4.68 \mathrm{E}+01$ & 4.16E-01 & $3.39 \mathrm{E}+01$ \\
\hline 36.8 & Bkfl & 0.5 & $(0.02)$ & 2.89E-03 & $1.24 \mathrm{E}-03$ & $0.00 \mathrm{E}+00$ & 4.21E-01 & $2.54 \mathrm{E}+01$ \\
\hline 40.2 & Bkfl & 1.4 & $(0.05)$ & 4.02E-03 & 1.03E-03 & $0.00 \mathrm{E}+00$ & 4.46E-01 & $2.67 \mathrm{E}+01$ \\
\hline 48.4 & $\mathrm{H} 2$ & 1.5 & $<0.170$ & 5.23E-04 & (1.07E-04) & $<4.28 \mathrm{E}+01$ & 4.38E-01 & $1.14 \mathrm{E}+01$ \\
\hline 56.1 & $\mathrm{H} 2$ & 2.17 & $(0.10)$ & 4.23E-04 & 9.15E-03 & (9.00E-01) & 4.04E-01 & $8.34 \mathrm{E}+00$ \\
\hline 70.1 & $\mathrm{H} 2$ & 15.44 & $9.04 \mathrm{E}+00$ & $1.38 \mathrm{E}-03$ & $1.09 \mathrm{E}-01$ & $(1.10 \mathrm{E}+01)$ & 3.68E-01 & $1.27 \mathrm{E}+01$ \\
\hline 81.2 & H2 & 9.37 & $6.04 \mathrm{E}+00$ & $1.31 \mathrm{E}-03$ & 7.19E-02 & $(8.56 \mathrm{E}+00)$ & 5.14E-01 & $1.26 \mathrm{E}+01$ \\
\hline 86.7 & $\mathrm{CCU}_{\mathrm{u}}$ & 1033.64 & $1.05 \mathrm{E}+03$ & $1.29 \mathrm{E}-03$ & $4.15 \mathrm{E}+00$ & $1.06 \mathrm{E}+03$ & 6.79E-01 & $2.45 \mathrm{E}+01$ \\
\hline 88.2 & $\mathrm{CCU}_{\mathrm{u}}$ & 1612.98 & $1.65 \mathrm{E}+03$ & $1.22 \mathrm{E}-03$ & $4.24 \mathrm{E}+00$ & $7.34 \mathrm{E}+02$ & 7.17E-01 & $2.34 \mathrm{E}+01$ \\
\hline 88.2 & $\mathrm{CCU}_{\mathrm{u}}$ & 1410.42 & $1.41 \mathrm{E}+03$ & $1.22 \mathrm{E}-03$ & $3.40 \mathrm{E}+00$ & $1.87 \mathrm{E}+03$ & $6.60 \mathrm{E}-01$ & $2.52 \mathrm{E}+01$ \\
\hline 93.3 & $\mathrm{CCU}_{\mathrm{l}}$ & 1066.31 & $8.12 \mathrm{E}+02$ & 3.27E-03 & $1.28 \mathrm{E}+00$ & $1.38 \mathrm{E}+03$ & 8.49E-01 & $1.50 \mathrm{E}+01$ \\
\hline 97.1 & $\mathrm{CCU}_{\mathrm{l}}$ & 768.82 & $4.97 \mathrm{E}+02$ & $1.67 \mathrm{E}-03$ & 3.76E-02 & $5.41 \mathrm{E}+02$ & 8.42E-01 & $1.56 \mathrm{E}+01$ \\
\hline 100.3 & $\mathrm{CCU}_{\mathrm{l}}$ & 458.07 & $4.07 \mathrm{E}+02$ & 2.02E-03 & 1.49E-02 & $6.13 \mathrm{E}+02$ & 7.04E-01 & $1.28 \mathrm{E}+01$ \\
\hline 102.0 & $\mathrm{CCU}_{\mathrm{l}}$ & 625.18 & $8.21 \mathrm{E}+02$ & 3.82E-03 & $2.15 E+00$ & $5.57 \mathrm{E}+02$ & $1.93 \mathrm{E}+00$ & $1.07 \mathrm{E}+01$ \\
\hline 103.2 & $\mathrm{CCU}_{\mathrm{l}}$ & 609.71 & $7.83 \mathrm{E}+02$ & 3.99E-03 & $2.52 \mathrm{E}+00$ & $7.64 \mathrm{E}+02$ & $1.69 \mathrm{E}+00$ & $1.40 \mathrm{E}+01$ \\
\hline 106.9 & $\mathrm{CCU}_{\mathrm{l}}$ & 949.66 & $3.94 \mathrm{E}+02$ & $3.40 \mathrm{E}-03$ & $4.25 \mathrm{E}+00$ & $8.17 \mathrm{E}+02$ & $1.02 \mathrm{E}+00$ & $3.20 \mathrm{E}+01$ \\
\hline 110.0 & $\mathrm{CCU}_{1}$ & 432.34 & $5.12 \mathrm{E}+02$ & 8.35E-04 & 3.59E-01 & $5.75 \mathrm{E}+02$ & 4.93E-01 & $1.55 \mathrm{E}+01$ \\
\hline 110.0 & $\mathrm{CCU}_{1}$ & 425.27 & $5.44 \mathrm{E}+02$ & 8.26E-04 & 9.33E-02 & $4.48 \mathrm{E}+02$ & 3.78E-01 & $1.63 \mathrm{E}+01$ \\
\hline 116.0 & $\mathrm{R}_{\mathrm{tf}}$ & 402.24 & $1.94 \mathrm{E}+02$ & $1.26 \mathrm{E}-03$ & (5.15E-04) & $9.59 \mathrm{E}+01$ & $8.16 \mathrm{E}-01$ & $1.65 \mathrm{E}+01$ \\
\hline 120.9 & $\mathrm{R}_{\mathrm{tf}}$ & 599.23 & $6.34 \mathrm{E}+02$ & 7.49E-04 & 8.46E-03 & $5.73 \mathrm{E}+02$ & 8.76E-01 & $1.89 \mathrm{E}+01$ \\
\hline 123.9 & $\mathrm{R}_{\mathrm{wi}}$ & 261.34 & $2.07 \mathrm{E}+02$ & $3.68 \mathrm{E}-04$ & $(6.78 \mathrm{E}-04)$ & $5.44 \mathrm{E}+02$ & 7.51E-01 & $2.14 \mathrm{E}+01$ \\
\hline 129.8 & $\mathrm{R}_{\mathrm{wi}}$ & 194.83 & $1.23 \mathrm{E}+02$ & 1.03E-04 & (7.97E-04) & $4.44 \mathrm{E}+02$ & 3.56E-01 & $1.09 \mathrm{E}+01$ \\
\hline $\begin{array}{l}(\quad)=\text { Data } \\
\text { Bright yellow s } \\
\text { Samples that m }\end{array}$ & $\begin{array}{l}\text { ow quantifi } \\
\text { ding represe } \\
\text { contain son }\end{array}$ & $\begin{array}{l}\text { ion value } \\
\text { s sample }\end{array}$ & $\begin{array}{l}\text { es but deem } \\
\text { s that do ind } \\
\text { waste fluids }\end{array}$ & $\begin{array}{l}\text { qualitativ } \\
\text { cate some I }\end{array}$ & $\begin{array}{l}\text { ford waste } \mathrm{f} \\
\text { ford. }\end{array}$ & are present & ht yellow s & ng represent \\
\hline
\end{tabular}


Table 6.5. Desorption $K_{d}$ Values $(\mathrm{mL} / \mathrm{g})$ for Potential Contaminants of Concern

\begin{tabular}{|c|c|c|c|c|c|c|c|c|c|c|}
\hline \multicolumn{2}{|c|}{ C4104 } & \multirow{2}{*}{$\begin{array}{l}\text { Tc-99 } \\
\mathrm{mL} / \mathrm{g}\end{array}$} & \multirow{2}{*}{$\begin{array}{c}\mathrm{U} \\
\mathrm{mL} / \mathrm{g}\end{array}$} & \multirow{2}{*}{$\begin{array}{c}\mathrm{Cr} \\
\mathrm{mL} / \mathrm{g}\end{array}$} & \multirow{3}{*}{$\begin{array}{c}\text { Co-60 } \\
\mathbf{m L} / \mathbf{g} \\
\mathrm{NA} \\
\end{array}$} & \multicolumn{2}{|c|}{ C4105 } & \multirow{2}{*}{$\begin{array}{l}\text { Tc-99 } \\
\mathrm{mL} / \mathrm{g}\end{array}$} & \multirow{2}{*}{$\begin{array}{c}\mathrm{U} \\
\mathrm{mL} / \mathrm{g}\end{array}$} & \multirow{2}{*}{$\begin{array}{c}\mathrm{Cr} \\
\mathrm{mL} / \mathrm{g}\end{array}$} \\
\hline $\begin{array}{c}\text { Depth } \\
\text { (ft bgs) }\end{array}$ & $\begin{array}{c}\text { Strat. } \\
\text { Unit }\end{array}$ & & & & & $\begin{array}{c}\text { Depth } \\
\text { (ft bgs) }\end{array}$ & $\begin{array}{c}\text { Strat. } \\
\text { Unit }\end{array}$ & & & \\
\hline 16.18 & Bkfl & 0.324 & $1.42 \mathrm{E}+01$ & $1.60 \mathrm{E}+03$ & & 15.3 & Bkfl & ND & $7.89 \mathrm{E}+00$ & $2.57 \mathrm{E}+03$ \\
\hline 22.69 & Bkfl & 0.498 & $1.04 \mathrm{E}+01$ & $9.23 E+02$ & NA & 22.7 & Bkfl & ND & $1.32 \mathrm{E}+01$ & $8.76 \mathrm{E}+03$ \\
\hline 30.74 & Bkfl & 0.587 & $1.29 \mathrm{E}+01$ & $9.20 \mathrm{E}+02$ & NA & 36.8 & Bkfl & $-5.36 \mathrm{E}-02^{(\mathrm{a})}$ & $7.76 \mathrm{E}+00$ & $1.09 \mathrm{E}+03$ \\
\hline 36.88 & Bkfl & 1.969 & $2.59 \mathrm{E}+01$ & $6.54 \mathrm{E}+02$ & NA & 40.2 & Bkfl & $-7.62 \mathrm{E}-02$ & $8.39 \mathrm{E}+00$ & $1.98 \mathrm{E}+03$ \\
\hline 37.4 & Bkfl & 18.285 & $1.75 \mathrm{E}+01$ & $1.97 \mathrm{E}+04$ & NA & 48.4 & $\mathrm{H} 2$ & ND & $3.12 \mathrm{E}+01$ & $3.97 \mathrm{E}+03$ \\
\hline 40.01 & Bkfl & 3.118 & $2.38 \mathrm{E}+00$ & $1.40 \mathrm{E}+03$ & -0.02 & 56.1 & $\mathrm{H} 2$ & 3.39E-01 & $4.13 \mathrm{E}+01$ & $3.95 \mathrm{E}+01$ \\
\hline 40.01 & Bkfl & ND & $7.55 \mathrm{E}+00$ & $2.14 \mathrm{E}+02$ & NA & 70.1 & $\mathrm{H} 2$ & $-9.87 E-03$ & $6.43 \mathrm{E}+01$ & $2.29 \mathrm{E}+01$ \\
\hline 46.33 & H2 & 0.210 & $5.58 \mathrm{E}-01$ & $1.12 \mathrm{E}+02$ & NA & 70.1 & $\mathrm{H} 2$ & $9.86 \mathrm{E}-03$ & $1.22 \mathrm{E}+01$ & $5.29 \mathrm{E}+00$ \\
\hline 46.98 & $\mathrm{H} 2$ & 0.336 & $6.08 \mathrm{E}-01$ & $6.19 \mathrm{E}+01$ & 0.31 & 81.2 & $\mathrm{H} 2$ & 2.01E-02 & $1.91 \mathrm{E}+01$ & $8.52 E+00$ \\
\hline 58.39 & $\mathrm{H} 2$ & 0.367 & 1.81E-01 & $2.80 \mathrm{E}+02$ & NA & 86.7 & $\mathrm{CCU}_{\mathrm{u}}$ & 8.05E-04 & $7.56 \mathrm{E}+01$ & 7.09E-01 \\
\hline 58.39 & $\mathrm{H} 2$ & 0.396 & $1.14 \mathrm{E}-01$ & $1.38 \mathrm{E}+02$ & NA & 88.2 & $\mathrm{CCU}_{\mathrm{u}}$ & $-1.14 E-01$ & $1.80 \mathrm{E}+02$ & $1.40 \mathrm{E}+00$ \\
\hline 59.09 & $\mathrm{H} 2$ & 0.245 & $6.74 \mathrm{E}-02$ & $1.37 \mathrm{E}+01$ & 0.33 & 88.2 & $\mathrm{CCU}_{\mathrm{u}}$ & $-1.10 \mathrm{E}-01$ & $1.16 \mathrm{E}+02$ & $9.00 \mathrm{E}-01$ \\
\hline 63.38 & $\mathrm{H} 2$ & 0.180 & $6.24 \mathrm{E}-02$ & $2.60 \mathrm{E}+01$ & NA & 88.2 & $\mathrm{CCU}_{\mathrm{u}}$ & $6.22 \mathrm{E}-02$ & $1.02 \mathrm{E}+02$ & $1.21 \mathrm{E}+00$ \\
\hline 64.03 & $\mathrm{H} 2$ & 0.157 & $1.77 \mathrm{E}-01$ & $3.88 \mathrm{E}+00$ & NA & 93.3 & $\mathrm{CCU}_{\mathrm{l}}$ & 1.83E-01 & $2.18 \mathrm{E}+02$ & $2.90 \mathrm{E}+00$ \\
\hline 64.03 & $\mathrm{H} 2$ & 0.179 & 2.34E-01 & $1.60 \mathrm{E}+00$ & 0.23 & 93.3 & $\mathrm{CCU}_{\mathrm{l}}$ & 9.31E-02 & $3.44 \mathrm{E}+01$ & $1.42 \mathrm{E}+00$ \\
\hline 64.03 & $\mathrm{H} 2$ & 0.186 & $1.95 \mathrm{E}-01$ & $2.64 E+00$ & 0.14 & 97.1 & $\mathrm{CCU}_{\mathrm{l}}$ & 1.09E-02 & $6.09 \mathrm{E}+01$ & $5.02 E+01$ \\
\hline 76.03 & $\mathrm{H} 2$ & 0.599 & 8.72E-02 & $1.14 \mathrm{E}+00$ & 0.22 & 100.3 & $\mathrm{CCU}_{\mathrm{l}}$ & 3.76E-02 & $2.58 \mathrm{E}+01$ & $6.39 \mathrm{E}+01$ \\
\hline 81.04 & $\mathrm{CCU}_{\mathrm{u}}$ & 0.615 & $1.86 \mathrm{E}-01$ & $2.14 \mathrm{E}+00$ & 0.21 & 102 & $\mathrm{CCU}_{\mathrm{l}}$ & $-3.07 E-02$ & $4.80 \mathrm{E}+01$ & $3.80 \mathrm{E}-01$ \\
\hline 87.35 & $\mathrm{CCU}_{\mathrm{u}}$ & -0.001 & $3.59 \mathrm{E}+00$ & $4.85 \mathrm{E}+00$ & 0.17 & 103.2 & $\mathrm{CCU}_{\mathrm{l}}$ & $-2.36 \mathrm{E}-03$ & $4.06 \mathrm{E}+01$ & 4.38E-01 \\
\hline 87.35 & $\mathrm{CCU}_{\mathrm{u}}$ & 0.045 & $1.29 \mathrm{E}+00$ & $3.13 E+00$ & 0.16 & 106.9 & $\mathrm{CCU}_{1}$ & -7.16E-02 & $9.25 \mathrm{E}+01$ & 4.79E- 01 \\
\hline 87.35 & $\mathrm{CCU}_{\mathrm{u}}$ & 0.055 & $1.20 \mathrm{E}+00$ & $3.91 \mathrm{E}+00$ & 0.12 & 106.9 & $\mathrm{CCU}_{\mathrm{l}}$ & 2.73E-01 & $7.59 \mathrm{E}+01$ & $1.65 E+00$ \\
\hline 92.61 & $\mathrm{CCU}_{1}$ & 0.457 & 4.95E- 01 & $1.13 E+00$ & 0.07 & 110 & $\mathrm{CCU}_{\mathrm{l}}$ & 8.27E-03 & $3.94 \mathrm{E}+01$ & $2.81 \mathrm{E}+00$ \\
\hline 93.56 & $\mathrm{CCU}_{1}$ & 0.383 & $1.06 \mathrm{E}+02$ & $1.41 \mathrm{E}+00$ & 0.14 & 110 & $\mathrm{CCU}_{\mathrm{l}}$ & $-1.39 E-02$ & $3.68 \mathrm{E}+01$ & $1.36 \mathrm{E}+01$ \\
\hline 93.56 & $\mathrm{CCU}_{1}$ & 0.172 & $3.32 E+01$ & 4.36E-01 & 0.07 & 116 & $\mathrm{R}_{\mathrm{tf}}$ & $-1.11 E-01$ & $1.42 \mathrm{E}+02$ & $7.05 E+03$ \\
\hline 94.67 & $\mathrm{CCU}_{\mathrm{l}}$ & 0.213 & $1.53 \mathrm{E}+01$ & $1.58 \mathrm{E}+00$ & 0.06 & 120.9 & $\mathrm{R}_{\mathrm{tf}}$ & 7.94E-03 & $4.25 \mathrm{E}+02$ & $1.29 \mathrm{E}+03$ \\
\hline 99.7 & $\mathrm{CCU}_{\mathrm{l}}$ & 0.306 & $5.06 \mathrm{E}+00$ & $2.80 \mathrm{E}+00$ & NA & 120.9 & $\mathrm{R}_{\mathrm{tf}}$ & $-2.48 E-02$ & $2.98 E+02$ & $5.69 \mathrm{E}+02$ \\
\hline 100.37 & $\mathrm{CCU}_{1}$ & 1.257 & $7.58 \mathrm{E}+00$ & $2.06 \mathrm{E}+00$ & NA & 123.9 & $\mathrm{R}_{\mathrm{wi}}$ & 5.57E-03 & $3.95 E+02$ & $5.40 \mathrm{E}+02$ \\
\hline
\end{tabular}


Table 6.5. (contd)

\begin{tabular}{|c|c|c|c|c|c|c|c|c|c|c|}
\hline \multicolumn{2}{|c|}{ C4104 } & \multirow{2}{*}{$\begin{array}{l}\text { Tc-99 } \\
\mathrm{mL} / \mathrm{g}\end{array}$} & \multirow{2}{*}{$\begin{array}{c}\mathbf{U} \\
\mathrm{mL} / \mathrm{g}\end{array}$} & \multirow{2}{*}{$\begin{array}{c}\mathrm{Cr} \\
\mathrm{mL} / \mathrm{g}\end{array}$} & \multirow{2}{*}{$\begin{array}{c}\text { Co-60 } \\
\mathrm{mL} / \mathrm{g}\end{array}$} & \multicolumn{2}{|c|}{ C4105 } & \multirow{2}{*}{$\begin{array}{l}\text { Tc-99 } \\
\mathrm{mL} / \mathrm{g}\end{array}$} & \multirow{2}{*}{$\begin{array}{c}\mathrm{U} \\
\mathrm{mL} / \mathrm{g}\end{array}$} & \multirow{2}{*}{$\begin{array}{c}\mathrm{Cr} \\
\mathrm{mL} / \mathrm{g}\end{array}$} \\
\hline $\begin{array}{l}\text { Depth } \\
\text { (ft bgs) }\end{array}$ & $\begin{array}{l}\text { Strat. } \\
\text { Unit }\end{array}$ & & & & & $\begin{array}{c}\text { Depth } \\
\text { (ft bgs) }\end{array}$ & $\begin{array}{l}\text { Strat. } \\
\text { Unit }\end{array}$ & & & \\
\hline 101.33 & $\mathrm{CCU}_{\mathrm{l}}$ & 0.052 & $9.70 \mathrm{E}+00$ & 9.92E-01 & NA & 123.9 & $\mathrm{R}_{\mathrm{wi}}$ & $-1.19 \mathrm{E}-01$ & $6.75 \mathrm{E}+01$ & $1.04 \mathrm{E}+03$ \\
\hline 101.98 & $\mathrm{CCU}_{\mathrm{l}}$ & NA & NA & NA & NA & 129.8 & $\mathrm{R}_{\mathrm{wi}}$ & 1.34E-01 & $1.78 \mathrm{E}+02$ & $7.03 E+02$ \\
\hline 101.98 & $\mathrm{CCU}_{\mathrm{l}}$ & 0.069 & $2.71 \mathrm{E}+01$ & 8.37E-01 & NA & & & & & \\
\hline 105.39 & $\mathrm{CCU}_{\mathrm{l}}$ & -0.012 & $7.13 \mathrm{E}+00$ & $2.32 \mathrm{E}+00$ & NA & & & & & \\
\hline 106.09 & $\mathrm{CCU}_{\mathrm{l}}$ & 0.042 & $6.98 \mathrm{E}+00$ & $9.90 \mathrm{E}-01$ & NA & & & & & \\
\hline 107.42 & $\mathrm{CCU}_{\mathrm{l}}$ & 0.014 & $7.67 \mathrm{E}+00$ & $6.80 \mathrm{E}-01$ & NA & & & & & \\
\hline 110.98 & $\mathrm{R}_{\mathrm{tf}}$ & 0.016 & $1.05 \mathrm{E}+01$ & $1.47 \mathrm{E}+00$ & NA & & & & & \\
\hline 110.98 & $\mathrm{R}_{\mathrm{tf}}$ & -0.029 & $6.57 \mathrm{E}+00$ & 8.04E-01 & NA & & & & & \\
\hline 115.25 & $\mathrm{R}_{\mathrm{tf}}$ & 0.309 & $3.14 \mathrm{E}+01$ & $1.40 \mathrm{E}+01$ & NA & & & & & \\
\hline 116.02 & $\mathrm{R}_{\mathrm{tf}}$ & -0.052 & $1.36 \mathrm{E}+02$ & $7.75 E+00$ & -0.25 & & & & & \\
\hline 116.02 & $\mathrm{R}_{\mathrm{tf}}$ & -0.058 & $3.43 E+01$ & $4.83 E+00$ & NA & & & & & \\
\hline 120.3 & $\mathrm{R}_{\mathrm{tf}}$ & -0.008 & $7.57 \mathrm{E}+01$ & $2.87 \mathrm{E}+03$ & NA & & & & & \\
\hline 120.97 & $\mathrm{R}_{\mathrm{wi}}$ & 0.269 & $2.42 \mathrm{E}+02$ & $5.65 \mathrm{E}+03$ & -0.17 & & & & & \\
\hline 120.97 & $\mathrm{R}_{\mathrm{wi}}$ & 0.225 & $8.74 \mathrm{E}+01$ & $1.07 \mathrm{E}+03$ & NA & & & & & \\
\hline 123.32 & $\mathrm{R}_{\mathrm{wi}}$ & 0.011 & $1.11 \mathrm{E}+01$ & $1.25 \mathrm{E}+03$ & NA & & & & & \\
\hline 124.05 & $\mathrm{R}_{\mathrm{wi}}$ & -0.002 & $1.01 \mathrm{E}+02$ & $3.73 \mathrm{E}+02$ & NA & & & & & \\
\hline 127.13 & $\mathrm{R}_{\mathrm{wi}}$ & 0.147 & $6.73 \mathrm{E}+01$ & $2.44 \mathrm{E}+02$ & NA & & & & & \\
\hline \multicolumn{11}{|c|}{$\begin{array}{l}\text { NA = No detectable Co-60/Tc-99 in the sediment or the water extracts; thus can not calculate a } \mathrm{K}_{\mathrm{d}} . \mathrm{ND}=\text { not determined } \\
\text { because not enough sample available. }\end{array}$} \\
\hline \multirow{2}{*}{\multicolumn{11}{|c|}{$\begin{array}{l}\text { Red (bold) type signifies depths where sediments show obvious signs of some tank related fluids. } \\
\text { Yellow (dark) shading signifies } \mathrm{K}_{\mathrm{d}} \text { values that are dominated by tank fluids as opposed to a mix of natural and Hanford } \\
\text { constituents. Faint blue (light) shading data are likely more dominated by natural constituents (uranium and chromium) or } \\
\text { imprecise analytical data (technetium-99 and cobalt-60). }\end{array}$}} \\
\hline & & & & & & & & & & \\
\hline \multicolumn{11}{|c|}{$\begin{array}{l}\text { (a) = negative } \mathrm{K}_{\mathrm{d}} \text { are caused by analytical uncertainties in the measurements of concentrations in the sediment and } \\
\text { porewater. For risk analysis assume that negative values are } 0 \mathrm{~mL} / \mathrm{g} \text {. }\end{array}$} \\
\hline
\end{tabular}


The changes in $K_{d}$ values for technetium-99 outside the zone of significant contamination are likely more a function of imprecision in the acid versus water extract analytical results. There does not seem to be any difference in the cobalt- $60 \mathrm{~K}_{\mathrm{d}}$ values in the depths where cobalt-60 is present at measurable concentrations and those zones shallower and deeper where cobalt-60 is not present at readily measurable concentrations. The other trend is that the desorption $K_{d}$ values for technetium-99 and cobalt-60 in the main portion of the vadose zone plumes are very close to $0 \mathrm{~mL} / \mathrm{g}$, while the desorption $\mathrm{K}_{\mathrm{d}}$ value for uranium in the main portion of the tank fluid plumes varies between 0.06 and $2 \mathrm{~mL} / \mathrm{g}$ in borehole C4104 and between 30 and $80 \mathrm{~mL} / \mathrm{g}$ in borehole C4105 sediments. The desorption $\mathrm{K}_{d}$ values for chromium in the zones where elevated chromium is present vary between 0.5 and $5 \mathrm{~mL} / \mathrm{g}$ in both borehole vadose zone sediments.

The in situ desorption $\mathrm{K}_{\mathrm{d}}$ results suggest that of the potential contaminants, technetium-99 and cobalt-60, are quite mobile, while uranium is considerably less mobile and chromium is the least mobile. For conservative modeling purposes, we recommend using $K_{d}$ values of $0 \mathrm{~mL} / \mathrm{g}$ for nitrate, cobalt-60, and technetium-99, a value of $0.1 \mathrm{~mL} / \mathrm{g}$ for uranium near borehole C4104 and $10 \mathrm{~mL} / \mathrm{g}$ for uranium at borehole C4105, and $1 \mathrm{~mL} / \mathrm{g}$ for chromium to represent the entire vadose zone profile from the bottoms of the tanks to the water table. The technetium in situ desorption $K_{d}$ value of zero is consistent with a wealth of literature that finds essentially no technetium adsorption onto Hanford Site sediment (Kaplan and Serne 1995; Kaplan and Serne 2000 and Cantrell et al. 2003). The cobalt-60 mobility suggests that some complex that perhaps has a net negative charge is altering cobalt's inherent cationic nature. Cobalt-60 has been found in the Hanford groundwater at several places, especially in the 1950s, and can still be measured in a few locations, most notably in the northern 200 East Area (Hartman et al. 2003 and 2004).

\subsection{Other Geochemical Characterization Observations}

The comparison of the percentage of a constituent that is water extractable versus acid extractable from the contaminated sediment and the total mass that is acid leachable can be used to infer contamination for Hanford tank constituents such as sodium, sulfate, uranium, chromium, and other trace metals that occur naturally in the environment.

For borehole C4104, the acid-extract data for most species suggest that variations in mass leached per gram of sediment versus depth are lithology-related more so than an indication of tank fluid contamination. However, for a few species such as sodium, sulfate, technetium-99, and uranium, chromium, molybdenum and ruthenium at selected depth regions, the acid extract concentrations are elevated and indicative of tank fluids being present. Acid-extractable sodium is elevated from 36 to $102 \mathrm{ft}$ bgs and acid-soluble sulfate is elevated throughout most of the profile indicating that the tank fluids also contained significant quantities of sulfate. The acid-extractable technetium-99 profile in the C4104 borehole sediments is elevated throughout most of the profile and correlates well with the water extract profile although the acid extract values are larger for every sample. The acid extract technetium-99 data are variable and are below our level of quantification. As found in sediments at borehole 299-E33-46 (see Serne et al. 2002f), measuring technetium-99 at low levels by acid extraction yields results that are not as reliable as water extraction data. We thus place more confidence in the water-extract technetium99 data. The acid-extractable uranium concentrations from the C4104 sediments clearly indicate elevated values between 58 and $94 \mathrm{ft}$ bgs; although natural sediment concentrations in the Cold Creek lower subunit (caliche) often approach the values found in the samples that are considered to be elevated. Thus, the acid-extractable uranium in the $\mathrm{CCU}_{1}$ strata (1 to $2.5 \mu \mathrm{g} / \mathrm{g}$; [ppm]) is an indication that the tank leak 
contained low concentrations of uranium. The acid-extractable chromium and molybdenum in the sample at $58.4 \mathrm{ft}$ bgs is the largest observed for these metals. The rest of the sediment profile does not show atypically high values of acid-extractable chromium but the acid-extractable molybdenum values between 58 and $115 \mathrm{ft}$ bgs do appear to be quite variable and larger than quantities that are acid extractable from background sediment. The acid-extractable ruthenium is also variable and higher than found in background sediments and is likely indicative of fission product-derived material.

The water versus acid extract data for C4104 sediments shows distinct regions where the water to acid extractable percentages are much larger than found for uncontaminated borehole (299-W10-27) sediments. At C4104, there are clear indications of tank fluids present in the vadose zone profile; the following qualitative measure of mobility is inferred: technetium-99 and ruthenium are slightly more mobile than molybdenum, sulfate, and chromium. Zinc and uranium are less mobile than these noted species.

Upon comparing the acid extract data for borehole C4105 with similar lithologies in the uncontaminated borehole 299-W10-27, most of the variation in mass leached per gram of sediment versus depth is found to be lithology related. That is, for most major constituents there are no signs of elevated values of acid-leachable constituents in borehole C4105 sediments, excepting acid-extractable sodium in the backfill, one elevated acid-extractable calcium value at $81.2 \mathrm{ft}$ bgs near the bottom of the Hanford $\mathrm{H} 2$ unit, sulfate throughout the profile, and the elevated technetium-99, ruthenium and molybdenum from the tank leak. The high acid-extractable sodium in the shallow background sediments suggests some waste was released on the sediment surface or from pipelines, the elevated calcium near the bottom of the Hanford H2 unit may indicate that the ion exchange front from the tank waste plume has reached C4105 borehole via horizontal flow. For the mobile fission products technetium-99, molybdenum and ruthenium, the C4105 acid extracts show elevated concentrations from 86.7 to the bottom of the borehole 130, 93.3 to 110, and 86.7 to $110 \mathrm{ft}$ bgs, respectively. The comparison of water to acid extracts for borehole C4105 sediments suggests that there are unnaturally high percentages (technetium-99: 50 to 100\%; molybdenum: 3 to 50\%; ruthenium: 30 to 85\%) of water-leachable technetium-99, molybdenum, and ruthenium between the stated depths.

The acid-extractable concentrations of major cations in the sediments at C4105 show significantly less sodium than the sediments at C4104 as would be expected if the tank leak fluids were interacting with the sediments and having sodium get incorporated into or onto the sediments in a form that readily dissolves in strong acid. Both ion exchangeable and sodium-rich secondary minerals would dissolve in the strong acid. There also appears to be less acid-soluble phosphate in the C4105 sediments than the C4104 sediments suggesting that phosphate present in the T-106 tank fluid that leaked deposited measurable amounts in the vicinity of C4104 but not in the vicinity of C4105.

These comparisons suggest that truly mobile constituents such as technetium-99 descended deep into the sediment profile from the tank T-106 bottom near C4104 as well as spreading out horizontally all the way to the C4105 sediments. Other water-extract data suggests that the Cold Creek Formation upper subunit was the stratum that promoted most of the horizontal migration. The water- to acid-extractable uranium percentages for the C4105 sediments do not show any high values (all are $<1 \%$ ) such that we do not believe there are measurable quantities of tank-derived uranium in the $\mathrm{C} 4105$ sediments. Uranium must be interacting quite significantly with the vadose sediments because it is not observed at elevated 
concentrations at C4105. Some interaction is also indicated for chromium and molybdenum because acid extractable concentrations at C4105 are lower than at C4104 in contrast to technetium-99, which is higher in sediments from borehole C4105.

As part of our characterization strategy for contaminated sediments, other parameters that can control contaminant migration were measured. For the T tank farm characterization, only calcium carbonate content and the particle size and bulk sediment and clay-sized fraction mineralogy of selected samples from C4105 borehole were measured. Photographs provided in Appendix A and the field moisture log, blow counts, and laboratory moisture contents identify that several fine-grained thin lenses are present within the Hanford formation H2 unit that can promote lateral spreading of leaked fluids. The upper, and to some extent, lower portions of the Cold Creek unit also contain a high percentage of fines that can lead to perched conditions and/or lateral spreading of percolating fluids. The Ringold Formation Taylor Flat member is also relatively fine-grained. XRD patterns for selected sediment samples from borehole C4105 are shown in Appendix C. Briefly, XRD analysis of C4105 borehole samples, excluding the Cold Creek lower subunit (caliche), shows the sediments are mineralogically quite similar. The sediments are dominated by quartz and feldspar (both plagioclase and alkali-feldspar), with lesser amounts of clay, calcite, and amphibole. For the non-caliche bearing samples characterized, quartz concentrations range from 27 to $54 \mathrm{wt} \%$,) with an average quartz concentration of $38 \pm 10 \mathrm{wt} \%$. Plagioclase feldspar is present at concentrations between 12 to $43 \mathrm{wt} \%$ and potassium feldspar concentrations are between 4 to $15 \mathrm{wt} \%$. Plagioclase feldspar was more abundant than potassium feldspar in all C4105 samples. The amphibole phase comprised $<5 \mathrm{wt} \%$. Calcite concentrations measured $55 \mathrm{wt} \%$ in caliche sample, with all other samples having $<4 \mathrm{wt} \%$. Clay minerals consist primarily of chlorite, smectite) and mica and they make up between 8 and 32 wt\% of the bulk sediment samples.

The clay-sized fraction of the caliche-free sediment is dominated by four clay minerals: smectite, chlorite, illite, and kaolinite with minor amounts of quartz and feldspar. Smectite concentrations range from 26 to $56 \mathrm{wt} \%$. Illite concentration varies from 33 to $50 \mathrm{wt} \%$ with an average concentration of $42 \mathrm{wt} \%$. Chlorite and kaolinite are the least abundant of the clay minerals identified in the samples with concentrations equal to or less than 20 and $7 \mathrm{wt} \%$, respectively.

Based on the distribution of tank T-106 constituents, potentially mobile tank constituents (nitrate, technetium-99, cobalt-60, uranium, and chromium(VI), and the ion exchange fronts for sodium replacing the native calcium and magnesium), it appears that there is a large horizontal component to the path that the leaked fluids took from the T-106 tank as it percolated into the vadose zone sediments at the three boreholes described in this report (C4104, 299-W10-196, and C4105). That is, the fine-grained sediments in the Cold Creek Formation and Ringold Taylor Flat Member have acted as a barrier to significant vertical percolation of contaminants below tank T-106 at least in the region probed by the three boreholes. As discussed in more detail in Chapter 3 of the T-TX-TY field investigation report, ${ }^{(a)}$ based on gross- and spectral- gamma field logging, it also appears that some of the horizontal migration of contaminants in the southwesterly direction (towards borehole C4105) from the two boreholes just south of T-106 tank occurred several years after the 1973 leak event. It is speculated that the large snow-melt event in February 1979 may have provided the driving force for this post-tank leak horizontal migration of T-106 tank constituents.

(a) Field Investigation Report for Waste Management Areas T and TX-TY, by FJ Anderson (CH2M HILL Hanford Group, Inc., Richland, Washington), under preparation. 
There are highly calcareous zones associated with the lower Cold Creek subunit in both boreholes ( $\mathrm{CCU}_{1}$ was not cored in the background borehole at T Tank Farm) at depths that range from 92.6 to 102, and 93.3 to $103 \mathrm{ft}$ bgs at C4104 and C4105, respectively. The caliche content in the samples characterized varies from 16 to $60 \%$ by weight in the two boreholes. The wide range in calcium-carbonate contents reflects the variability in weathering processes and time for paleosol horizon development. The caliche at borehole C4105 corresponds quite well to the high values (quantity) and depth of occurrence as the data from borehole C4104. This suggests that the caliche lenses are fairly continuous between these two boreholes. The sediment in the shallow Hanford formation $\mathrm{H} 2$ unit for the two contaminated and background borehole contains relatively low calcium carbonate ( $<2 \mathrm{wt} \%)$ and organic carbon. At depth, the $\mathrm{H} 2$ unit shows slightly more calcium carbonate ( $\sim \mathrm{wt} \%$ ). The fine-grained $\mathrm{CCU}_{\mathrm{u}}$ samples contain up to $3.3 \mathrm{wt} \%$ calcium carbonate. These data for the identified stratigraphic units are quite similar to the data for the same units at the TX Tank Farm background borehole (see Serne et al. 2004).

At 299-W11-39, continuous coring was not performed all the way to the water table; thus, the entire matric potential profile is not available. For the core samples available from 299-W11-39, the water potentials are generally much less than the gravity potential from the shallowest core at $50 \mathrm{ft}$ bgs, which means that the water potentials are consistent with a draining profile. For the core samples available from C4104, the measured water potentials are quite erratic and about two-thirds of the datum are generally greater than the gravity potential, especially in the deeper samples. Two of the samples, 8A and 16A, have very high matric potentials (signifies very dry conditions). About one-third of the matric potentials are very low in comparison of the gravity head suggesting a draining profile, but the general trend for the data from C4104 is that the water potentials are erratic and should not be used to infer whether the profile is draining or actively evapotranspiring water. It appears that inadvertent drying occurred in many of the samples during the core processing, sample photographing and aliquoting for geochemical characterization.

\subsection{Description of T Upper Unconfined Aquifer}

The suprabasalt aquifers below the Hanford Reservation have been impacted by past practice, liquid waste disposal operations and unplanned releases, and in some instances from single-shell tank leaks. In the area of WMA T, large volumes of waste water disposed to ground between the 1940s and 1997 created large artificial groundwater mounds particularly beneath the 216-T pond system, north of WMA T, and beneath the 216-U pond, southwest of WMA T. The disposed liquids contained many of the contaminants that now move through the upper unconfined aquifer.

The base of the uppermost, unconfined aquifer generally is regarded as the basalt surface and, where this is the case, the entire suprabasalt aquifer is unconfined. However, beneath WMA T (and beneath the entire 200 West Area), the silt and clay deposits of the Ringold Formation lower mud unit form a confining layer that separates the suprabasalt aquifer into the uppermost unconfined aquifer and the underlying Ringold confined aquifer (Williams et al. 2002). Thus, the uppermost, unconfined aquifer in the WMA T area extends from the water table down to the top of the lower mud unit. The unconfined aquifer is about 50 meters thick at well 299-W10-24, located at the northeast corner of WMA T, based on the August 2003 water level. The unconfined aquifer consists of sandy gravels and gravelly sands of the Ringold Formation member of Wooded Island. All wells in the WMA T monitoring networks are screened in hydrogeologic unit 5. Currently, the water table at WMA T is 136 to $137 \mathrm{~m}$ above sea level. 
Water levels in the uppermost unconfined aquifer raised as much as 13.5 meters (above the pre-Hanford natural water table) beneath WMA T because of artificial recharge from liquid waste disposal operations active since the mid 1940s. The largest volumes of discharge were to the 216-T pond system and the $216-\mathrm{U}-10$ pond. The $216-\mathrm{T}$ pond system is estimated to have received approximately 424 billion liters of effluent and the $216-\mathrm{U}$ pond to have received about 158 billion liters of effluent. The large-volume disposals to the ponds (and, lesser volumes to cribs and ditches) artificially recharged the uppermost unconfined aquifer creating these large water-table mounds. The increase in water-table elevation was most rapid from 1949 to 1956 and was somewhat stabilized between the late 1960s and the late 1980s. Water levels began to decline in the late 1980s beneath WMA T when wastewater discharges in the 200 West Area were reduced. Hydrographs show that water levels have declined by about 6.5 meters since 1991 beneath the $\mathrm{T}$ tank farm. This decline, resulting from decreasing effluent discharge in the 200 West Area, became much steeper in 1995 with the effective cessation of discharge to all nonpermitted facilities in this area. Between 1998 and 2004, the average rate of water table decline has been between about 0.3 and 0.4 meter per year in all monitoring wells at WMA T. The rapid decrease in water levels after 1995 has resulted in monitoring wells going dry more quickly than previously predicted and has necessitated the drilling of 7 new monitoring wells since 1999. Recently, Bergeron and Wurstner (2000) modeled the elevation of the water table beneath the Hanford Site. Their results predict a postHanford Site influenced water table elevation of about 130 to 132 meters above sea level in the T tank farm area.

Accompanying the changes in water level were changes in groundwater flow direction. Pre-Hanford Site groundwater flow direction was toward the east; groundwater flow changed toward the south in the area by the early 1950s. This shift resulted from the disposal of large volumes of liquid to the 216-T pond system. In 1956, groundwater flow direction changed again and started flowing towards the northeast due to the increasing influence of the groundwater mound under 216-U pond and a decreasing influence of the mound under 216-T pond. Discharges to 216-T pond ended in 1976 but continued at 216-U pond until 1984. As discharges to the $216-\mathrm{U}$ pond declined in the early 1980 s, groundwater flow shifted to a more northerly direction as the groundwater mound began to decrease and discharges to the 216-U-14 ditch continued. The slight westerly component to the groundwater flow direction between early 1980s and mid 1990s is probably a result of the discharges to the 216-U-14 ditch, located southwest of WMA T. All non-permitted discharges to the ground ceased and the influence of the 216-U pond mound on the groundwater beneath the $\mathrm{T}$ tank farm diminished in 1995. Consequently, the flow direction changed again in about 1996 and began to return toward an easterly direction.

These large shifts in groundwater flow direction have large implications for contaminant distribution in the uppermost aquifer beneath WMA T. In the late 1940s and early 1950s, contamination was spread south in the aquifer. Then, in the late 1950s and until the mid-1990s, that same contamination returned to the north along with any new contamination that entered the aquifer after the 1950s. Today, groundwater contamination beneath the WMA and surrounding area is generally migrating east.

Recent more detailed characterization of monitoring wells found vertical flow gradients detected in some wells, especially along the current downgradient edge of WMA T [eastern edge] that may have an impact on contaminant distribution patterns in the area. Other hydrologic test data suggest higher or lower hydraulic conductivity zones occur at certain depths within the screened interval of some wells relative to other depths. For example, tracer tests indicate that the upper 3 to 4 meters of the screened interval of well 299-W10-24 is less permeable than the lower part of the screened interval. However, a tracer test in nearby well, 299-W11-39, indicated that the lower 3 meters of the screened interval are 
relatively impermeable compared to the rest of the screened interval. Thus, apparent differences in permeability do not appear to correlate from well to well. However, there is nothing in the geologist's logs or the geophysical logs to suggest that the formation in the screened interval of these wells is significantly different than the formation at nearby wells.

Taken as a whole, the geologist's logs, geophysical logs, well-development pumping data, and the hydrologic testing data all indicate heterogeneity in aquifer properties within the screened intervals of several individual wells and among wells at WMA T.

\subsection{Historical Groundwater Contamination}

The earliest evidence of groundwater contamination around WMA T as found in the Hanford Environmental Information System (HEIS) ${ }^{(a)}$ database is high levels of gross beta and nitrate in wells located near the cribs and trenches west of WMA T. By 1955 and 1956, levels of gross beta and nitrate had reached values in excess of 1,000,000 pCi/L and 3,000 mg/L, respectively, in well 299-W10-2 located about 20 meters south of the 216-T-7 tile field. The oldest available analysis for cobalt-60 in groundwater in the area is from well 299-W10-4 in 1957 and showed that the cobalt-60 concentration was $2000 \mathrm{pCi} / \mathrm{L}$ at that time. Cobalt-60 was later found in well 299-W10-2 in 1969 at a concentration of $680 \mathrm{pCi} / \mathrm{L}$. Finally, ruthenium-106 was first noted in groundwater in 1972 at wells 299-W10-2 and 299-W10-4. These data are the oldest available analyses and may not represent the first arrival of contamination in groundwater in the area. The most likely source for this contamination is either the 216-T-7 crib/tile field, which operated between 1947 and 1955 and received 110,000,000 L of effluent, or the 216-T-32 crib, which operated between 1946 and 1952 and received 29,000,000 L of waste. Groundwater at that time was flowing toward the south from the disposal facilities toward the wells in which the contamination was observed in 1955 through 1972. The known and suspected T tank leaks occurred later and at locations that are too far away to have reached these wells at the cited dates. On the other hand given slightly increased groundwater velocities caused the mounding under the T WMA, both 216-T-7 and 216-T-32 contaminants could have readily reached the two wells by 1955.

\subsection{Existing Groundwater Contamination}

Groundwater at the T tank farm contains elevated concentrations of carbon tetrachloride, trichloroethene, chromium, nitrate, fluoride, technetium-99, and tritium. This contamination is a result of mixing of wastes from a number of past waste-disposal activities, including the disposal of process water and steam condensate at nearby ponds, cribs, and trenches; disposal of plutonium processing waste at cribs and trenches associated with the Plutonium Finishing Plant; and leaks from single-shell tanks and transfer lines within the $\mathrm{T}$ tank farm. Because concentrations change over time, a time-period must be chosen to examine spatial distribution patterns. For this purpose, the most recent data (average of fiscal year 2003 sampling events) were chosen.

Carbon tetrachloride is present in the unconfined aquifer beneath most of the 200 West Area. The highest carbon tetrachloride concentration near WMA T in fiscal year 2003 was 1,550 $\mu \mathrm{g} / \mathrm{L}$ in well 299-W10-4, south of the waste management area. High concentrations were also found north

(a) The Hanford Environmental Information System (HEIS) is a Hanford Site resource owned by the Department of Energy and operated by Fluor Hanford. 
(299-W10-23) and east (299-W11-7) of the waste management area. The carbon tetrachloride is believed to be from pre-1973 waste from the Plutonium Finishing Plant and not from the WMA T farm.

The major sources for trichloroethene are disposal sites associated with the Plutonium Finishing Plant. A second potential source is disposal near T Plant. The maximum trichloroethene concentration found near WMA T in 2003 was $10 \mu \mathrm{g} / \mathrm{L}$ both north (well 299-W10-23) and south (well 299-W10-4). The T tank farm waste management area is not considered a source for trichloroethene.

The highest chromium concentrations are in upgradient wells 299-W10-28 and 299-W10-4 where chromium reached 215 and $347 \mu \mathrm{g} / \mathrm{L}$, respectively, in 2003. Chromium was also elevated in well 299-W10-3, located inside the tank farm fence between the 216-T-7 crib and tile field and the 216-T-32 crib and upgradient of the current groundwater flow direction at $\mathrm{T}$ tank farm. This well was sampled only in 2000 during its decommissioning when the chromium concentration was $257 \mu \mathrm{g} / \mathrm{L}$. Prior to about 1997 when groundwater flow direction was toward the north, several wells on the north (then downgradient) side of the waste management area had relatively high chromium concentrations. Also, prior to 1997, well 299-W10-1, which was parallel to the tank farm with respect to groundwater flow direction but downgradient of the 216-T-5 trench, the 216-T-7 crib and tile field, and the 216-T32 crib, had chromium concentrations exceeding $200 \mu \mathrm{g} / \mathrm{L}$. After flow direction changed toward the east in about 1997, chromium concentrations dropped to $<40 \mu \mathrm{g} / \mathrm{L}$ in well 299-W10-1, decreased in all of the northern wells, and began increasing in well 299-W10-4.

The most likely source for the chromium west and north of Waste Management Area $\mathrm{T}$ is one or more of the disposal cribs and tile fields upgradient of the T tank farm WMA. Chromium from these facilities would have been moving north across well 299-W10-1 prior to 1997 and then east across the northern wells and the rest of the waste management area after 1997. Finally, since December 2000, chromium has exceeded the maximum contaminant level in two downgradient wells, 299-W11-41 (average for fiscal year 2003, $141 \mu \mathrm{g} / \mathrm{L}$ ) and 299-W11-42 (average for fiscal year 2003, $132 \mu \mathrm{g} / \mathrm{L}$ ). These wells are located downgradient of the disposal facilities east of WMA T but appear to be too far away for chromium to have migrated from west of the WMA to the wells since the 1996 change in groundwater flow direction, given a flow rate of 0.025 meter per day.

A regional nitrate plume underlies WMA T and much of the north part of the 200 West Area. However, unlike, carbon tetrachloride, trichloroethene, and tritium, there also appears to be a source of nitrate local, and upgradient, to Waste Management Area T. All monitoring wells in the WMA T monitoring network have nitrate concentrations in excess of the 45,000 $\mu \mathrm{g} / \mathrm{L}$ maximum contaminant level. The highest nitrate concentrations at the Hanford Site in fiscal year 2003 were from two upgradient wells at WMA T: 1,985,000 $\mu \mathrm{g} / \mathrm{L}$ in well 299-W10-4 and 1,835,000 $\mu \mathrm{g} / \mathrm{L}$ in well 299-W10-28. The nitrate concentration began to increase in well 299-W10-4 in about 1997 when the groundwater flow direction changed from northerly to easterly. Concentrations continued to rise until just recently. Since it was drilled in 2001, nitrate concentration in well 299-W10-28 has always been high and parallel to concentrations in well 299-W10-4. The most likely source for the nitrate in this area is one or more of the past-practice liquid disposal facilities upgradient of the $\mathrm{T}$ tank farm.

Fluoride concentrations exceeded the drinking water standard $(4,000 \mu \mathrm{g} / \mathrm{L})$ in three wells at Waste Management Area T in 2003. Currently, the highest concentrations are in downgradient wells but historically, the highest fluoride concentration was in upgradient well 299-W10-4 in late 1999 
(5,250 $\mu \mathrm{g} / \mathrm{L})$. A fluoride plume appears to have passed well 299-W10-4 between mid-1997 and late 2000. Although it is possible that there is a tank farm source for the fluoride contamination, one or more of the nearby cribs are believed to be a more likely source.

A technetium-99 groundwater plume exists northeast and east of Waste Management Area T. The highest technetium-99 concentration in fiscal year 2003 was 9,200 pCi/L in downgradient well 299-W11-39. The most probable source for the technetium-99 is the T tank farm waste management area. Technetium-99 began to increase in well 299-W11-27, located at the northeast corner of the 241-T tank farm in late 1995, coincident with the cessation of surface water disposal in the 200 West Area. Concentrations reached a maximum of 21,700 pCi/L in February 1997. Technetium-99 concentrations in well 299-W11-27 subsequently decreased to 6,000 pCi/L in March 1999. Hodges (1998) suggested that technetium-99 had arrived at well 299-W11-27 by the early 1990s, but was masked by dilution with water from a leaking water line located immediately adjacent to the well. The water line carried cooling and ventilation steam condensate, process cooling water, and evaporator condensate from the 207-T retention basin to the 216-T-4-2 ditch until 1995. The subsequent decrease in technetium-99 in well 299-W11-27 since 1997 may be a result of changing groundwater flow direction. In November 1997, technetium-99 began to increase in well 299-W11-23, located east of well 299-W11-27, coincident with the change in groundwater flow to a more easterly direction. It increased to a high of $8,540 \mathrm{pCi} / \mathrm{L}$ in November 1998 ; subsequently, technetium-99 values fluctuated between 7,110 and $840 \mathrm{pCi} / \mathrm{L}$ before the well went dry.

The most plausible explanation for the 1997 arrival of the contaminant plume at well 299-W11-23 is the change in groundwater flow direction. If this is the case, a narrow contaminant plume initially moved northeast across well 299-W11-27 but not across well 299-W11-23. Changing groundwater flow direction caused this plume to drift east across well 299-W11-23. Sampling of replacement well 299-W11-39 in 2001 detected technetium-99 concentrations between 4,160 and 5,010 pCi/L, indicating contamination of the upper portion of the aquifer at this well. Subsequently, technetium-99 concentration rose to a high of 10,400 pCi/L in February 2003 and began a small decline in August 2003.

In early 2002, technetium-99 concentrations began to increase in well 299-W11-42, south of well 299-W11-39 and, in early 2003, technetium-99 began to increase in well 299-11-41, south of 299-W11-42. Apparently, the technetium-99 contamination that was detected in the northeast corner of 241-T tank farm is spreading southward along the east and downgradient side of the WMA. The highest recent technetium-99 concentrations are at or near the water table and concentrations decrease rapidly with increasing depth in the aquifer. This points to a nearby source for the technetium-99 because the contaminant has not traveled far enough to descend vertically into the aquifer. The apparent nearness of the technetium-99 source suggests that the T tank farm is the most likely origin for the technetium-99.

A tritium plume lies beneath much of the north half of the 200 West Area. The plume geometry suggests that the major tritium source is near the 242-T evaporator, the TY tank farm, and nearby cribs. Other contributing sources are likely present in the vicinity of the $\mathrm{T}$ tank farm and include associated cribs and trenches and potentially leaks from $\mathrm{T}$ farm tanks. The highest tritium concentration near WMA T in 2003 was 52,100 pCi/L in well 299-W11-12, located at the southeast corner of the waste management area. Waste Management Area $\mathrm{T}$ is not thought to be a major contributor of tritium to groundwater in the area. 


\subsection{Complexities in Groundwater Data (Vertical and Temporal Variations)}

The groundwater data are complicated by signs that vertical stratification in contaminant and common solutes is present in many wells. Significant differences in specific conductance, technetium-99, chromium, nitrate, and tritium with depth were found in some monitoring wells. After purging some $\mathrm{T}$ wells, the pumped samples do not appear to be representative of ambient water because purging the well causes mixing of strata with different contaminant concentrations. Thus, interpreting the contaminant distribution in such wells is very difficult because groundwater at the well contains high concentrations of several contaminants that show different vertical concentration profiles and probably come from several sources in the area.

\subsection{Vadose Zone Porewater and Groundwater Chemical Ratio Comparisons}

To determine whether $\mathrm{T}$ tank leaks (T-106 or T-101) or the mentioned cribs and tile fields have impacted groundwater quality, one or more components of the leak need to be detected in groundwater. Estimates of the leak composition are available (Jones et al. 2000); unfortunately, the major, mobile components in the tank leak for which we have groundwater data are also major, mobile components disposed of to the nearby cribs and trenches.

The relative concentrations of technetium-99 and chromium behave quite differently at different parts of WMA T. The technetium-99/chromium concentration ratios versus time for samples from upgradient wells and wells to the north of the WMA T have a signature similar to the upgradient crib and trench disposal sites. This information suggests that the contamination detected in wells upgradient and north of WMA T is dominated by crib waste. The technetium-99 - chromium concentration relationship is different in wells located at the northeast corner and east of the WMA where the concentrations of the two constituents do not track each other and suggest a different source for the contamination. Since early 1996, the technetium-99/chromium composition of the groundwater in four wells in the northeast corner of WMA T have evolved toward tank waste compositions. Technetium-99/chromium ratios greater than the estimated tank waste compositions are in agreement with the data from vadose zone porewaters from boreholes C4104 and C4105 (see Section 4 of this report) and probably reflect the slight retardation of chromium relative to technetium-99 as discussed in Section 6.6 (see Table 6.5 for in situ desorption $\mathrm{K}_{\mathrm{d}}$ values). Since monitoring began in 1996, the technetium-99 to $\mathrm{Cr}$ ratio for groundwater from wells east of WMA T are intermediate between those from wells upgradient (west and north of the WMA) and northeast of the WMA. Samples from the wells to the east of the WMA indicate that the tank waste initially identified at the northeast corner of the WMA is migrating south along the eastern edge of the WMA and is mixing with the crib waste that was initially sampled in the eastern wells.

The compositional relationship between technetium-99 and nitrate at WMA T is complicated by the regional nitrate plume in the area. Unlike technetium-99 and chromium concentrations, the concentrations of technetium-99 and nitrate track each other through time in all monitoring wells at WMA T although there are about 3 orders of magnitude difference in the technetium-99/nitrate groundwater concentration ratios across the WMA. However, when plotted against time and compared to crib and tank waste compositions, the technetium-99/nitrate concentration ratios suggest the same conclusions reached with the technetium-99/chromium ratios. That is, the groundwater from the upgradient wells and wells to the north of WMA T have a strong crib waste component. Water sampled from wells located in the northeast corner of WMA T has a very different technetium-99/nitrate signature 
than does water from the upgradient and northern wells. Groundwater in the northeast corner of the WMA tends toward technetium-99/nitrate ratios indicative of tank waste.

The technetium-99/tritium ratios lead to the same conclusions as do the technetium-99/chromium and technetium-99/nitrate ratios. That is, groundwater from wells in the west (upgradient) and north of WMA T appear to be highly influenced by wastes disposed to the cribs and trenches on the west side of the WMA. Groundwater from wells at the northeast corner and the east side of the WMA appears to be evolving towards tank waste that has leaked from tank T-101 or T-106. 


\subsection{References}

Alexander, DJ, SD Evelo, VG Johnson, and MD Sweeney. 1995. Groundwater Impact Assessment Report for the 216-T-4-2 Ditch. WHC-EP-0815, Westinghouse Hanford Company, Richland, Washington.

ARHCO 1973. 241-T-106 Tank Leak Investigation, Atlantic Richfield Hanford Company, Richland, Washington.

American Society of Agronomy (ASA). 1986a. "Hydrometer Method.” Chapter 15-5 in Methods of Soil Analysis-Part 1, 2nd Edition of Physical and Mineralogical Methods, SSSA Book Series No. 5, ed. A Klute, pp. 404-408. Soil Science Society of America, Madison, Wisconsin.

American Society of Agronomy (ASA). 1986b. "Pynchnometer Method." Chapter 14-3 In Methods of Soil Analysis-Part 1, 2nd Edition of Physical and Mineralogical Methods, SSSA Book Series No. 5, ed. A Klute, pp. 378-379. Soil Science Society of America, Madison, Wisconsin.

American Society of Agronomy (ASA). 1996a. Methods of Soil Analysis-Part 3, Chemical Methods, SSSA Book Series 5, ed. DL Sparks, Soil Science Society of America, Madison, Wisconsin.

American Society of Agronomy (ASA). 1996b. "Elemental Analysis by XRF Spectroscopy." Chapter 7 in Methods of Soil Analysis-Part 3, Chemical Methods, SSSA Book Series 5, ed. DL Sparks, pp. 161-223. Soil Science Society of America, Madison, Wisconsin.

American Society for Testing and Materials (ASTM) D4129-88. 1988. "Standard Test Method for Total and Organic Carbon in Water by High Temperature Oxidation and by Coulometric Detection.” American Society for Testing and Materials, West Conshohocken, Pennsylvania.

American Society for Testing and Materials (ASTM) D2488-93. 1993. "Standard Practice for Description and Identification of Soils (Visual-Manual Procedure).” American Society for Testing and Materials, West Conshohocken, Pennsylvania.

American Society for Testing and Materials (ASTM) D2216-98. 1998. “Test Method for Laboratory Determination of Water (Moisture) Content of Soil and Rock.” American Society for Testing and Materials, West Conshohocken, Pennsylvania.

American Society for Testing and Materials (ASTM) D-5298-94. 2002. "Test Method for Measurement of Soil Potential (Suction) Using Filter Paper.” American Society for Testing and Materials, West Conshohocken, Pennsylvania.

Baker VR, BN Bjornstad, AJ Busacca, KR Fecht, EP Kiver, UL Moody, JG Rigby, DF Stradling, and AM Tallman. 1991. "Quanternary Geology of the Columbia Plateau.” In Quaternary Nonglacial Geology: Conterminous U.S. Geology of North America, ed. RB Morrison, K-2: 215-250. Geol. Soc. Am., Boulder, Colorado.

Baker, VR and RC Bunker. 1985, "Cataclysmic Late-Pleistocene Flooding from Glacial Lake Missoula: A Review.” Quaternary Science Reviews, v. 4, pp. 1-41. 
Bergeron, MP and SK Wurstner. 2000. Groundwater Flow and Transport Calculations Supporting the Immobilized Low-Activity Waste Disposal Facility Performance Assessment. PNNL-13400, Pacific Northwest National Laboratory, Richland, Washington.

Bjornstad, BN. 1984. Suprabasalt Stratigraphy Within and Adjacent to the Reference Repository Location. SD-BWI-DP-039, Rockwell Hanford Operations, Richland, Washington.

Bjornstad, BN. 1990. Geohydrology of the 218-W-5 Burial Ground. PNL-7336, Pacific Northwest Laboratory, Richland, Washington.

Bjornstad BN, KR Fecht, and CJ Pluhar. 2001. "Long History of Pre-Wisconsin, Ice-Age, Cataclysmic Floods: Evidence from Southeastern Washington State.” J. of Geology. Volume 109, p. 695-713.

Bjornstad, BN, GV Last, SP Reidel, DG Horton, KR Fecht, GA Smith, and KA Lindsey. 2002. "Characterization and Proposed Formalization (Hanford formation) for Ice Age Flood Deposits Within the Pacific Northwest," In Geological Society of America, Abstracts with Programs, p. A-24, Geological Society of America, Boulder, Colorado.

Bjornstad BN, GV Last, and DG Horton. 2003. Hydrogeology of the Hanford Site Vadose Zone. 4th Symposium on the Hydrogeology of Washington State, Abstracts with Programs, p. 61. Available online at URL: http://www.ecy.wa.gov/events/hg/abstracts2003.pdf, as accessed on June 10, 2004.

Black, RF. 1979. Clastic Dikes of the Pasco Basin, Southeastern Washington. RHO-BWI-C-64, Rockwell Hanford Operations, Richland, Washington.

Brindley, GW, and G Brown (eds.). 1980. “Crystal Structures of Clay Minerals and Their X-Ray Identification.” Monograph No. 5, Mineralogical Society, London, England.

Brown, DJ. 1959. Subsurface Geology of the Hanford Separation Areas. HW-61780, General Electric Company, Richland, Washington.

Brown, DJ. 1960. An Eolian Deposit Beneath the 200 West Area. HW-67549, General Electric Company, Richland, Washington.

Brown, DJ, RC Routson, WH Price, and KR Fecht. 1979. Status of Liquid Waste Leaked from the 241-T-106 Tank, Rockwell Hanford Operations, Richland, Washington.

Brown, RE. 1970. Interrelationships of Geologic Formations and Processes Affecting Ecology as Exposed at Rattlesnake Springs. BNWL-B-29, Battelle Northwest Laboratory, Richland, Washington.

Caggiano, JA and SM Goodwin. 1991. Interim Status Groundwater Monitoring Plan for the Single-Shell Tanks. WHC-SD-EN-AP-012, Westinghouse Hanford Company, Richland, Washington.

Cantrell, KJ, RJ Serne, and GV Last. 2003. Hanford Contaminant Distribution Coefficient Database and Users Guide. PNNL-13895, Rev. 1, Pacific Northwest National Laboratory, Richland, Washington.

Connelly, MP, BH Ford, and JV Borghese. 1992a. Hydrogeologic Model for the 200 West Groundwater Aggregate Area. WHC-SD-EN-TI-014, Westinghouse Hanford Company, Richland, Washington. 
Connelly, MP, JV Borghese, CD Delaney, BH Ford, JW Lindberg, and SJ Trent. 1992b. Hydrogeologic Model for the 200 East Groundwater Aggregate Area. WHC-SD-EN-TI-019, Westinghouse Hanford Company, Richland, Washington.

Crumpler, JD. 2002. Site Specific SST Phase 1 RFI/CMS Work Plan Addendum for WMAs T and TX-TY. RPP-7578, Rev. 2, CH2M HILL Hanford Group, Inc., Richland, Washington.

Deka RN, M Wairiu, PW Mtakwa, CE Mullins, EM Veenendaal, and J Towend. 1995. “Use and Accuracy of the Filter Paper Method for Measuring Soil Matric Potential.” European J. of Soil Sci. 46:233-238.

Delaney, CD, KA Lindsey, and SP Reidel. 1991. Geology and Hydrology of the Hanford Site: A Standardized Text for Use in Westinghouse Hanford Company Documents and Reports. WHC-SC-ERTI-003, Westinghouse Hanford Company, Richland, Washington.

Drever, JI. 1973. “The Preparation of Oriented Clay Mineral Specimens for X-Ray Diffraction Analysis by a Filter-Membrane Peel Technique.” Amer. Minerl. 58:553-554.

DOE/RL-91-61. 1992a. T Plant Source Aggregate Area Management Report. U.S. Department of Energy, Richland Operations Office, Richland, Washington.

DOE/RW-0164. 1988. Consultation Draft Site Characterization Plan, Reference Repository Location, Hanford Site, Washington. U.S. Department of Energy, Office of Civilian Radioactive Waste Management, Washington, D.C.

US Department of Energy (DOE). 1984. Draft Environmental Assessment, Reference Repository Location, Hanford Site, Washington, DOE/RW-0017, U.S. Department of Energy, Washington, D.C.

US Department of Energy (DOE). 1988. Consultation Draft Site Characterization Plan, Reference Repository Location, Hanford Site, Washington. DOE/RW-0164, U. S. Department of Energy, Office of Civilian Radioactive Waste Management, Washington, D.C.

US Department of Energy (DOE). 1992. T Plant Source Aggregate Area Management Report. DOE/RL-91-61, U.S. Department of Energy, Richland Operations Office, Richland, Washington.

US Department of Energy (DOE). 1999. Phase 1 RCRA Facility Investigation/Corrective Measures Study Work Plan for the SST Waste Management Areas. DOE/RL-99-36, Rev. 0, U.S. Department of Energy, Richland Operations Office, Richland, Washington.

US Department of Energy (DOE). 2002a. Standardized Stratigraphic Nomenclature for Post-RingoldFormation Sediments Within the Pasco Basin. DOE/RL-2002-39, U.S. Department of Energy, Richland Operations Office, Richland, Washington. 
DOE/GJO 1997. US Department of Energy, Grand Junction Office. (DOE/GJO). 1997. Hanford Tank Farms Vadose Zone, TX Tank Farm Report. GJO-HAN-11, prepared by U.S. Department of Energy Grand Junction Office for U.S. Department of Energy, Richland Operations Office, Richland, Washington.

DOE/GJO 1999a. US Department of Energy, Grand Junction Office. (DOE/GJO). 1999a. Hanford Tank Farms Vadose Zone, T Tank Farm Report. GHO-HAN-27, prepared by U.S. Department of Energy Grand Junction Office for U.S. Department of Energy, Richland Operations Office, Richland, Washington.

DOE/GJO 1999b. US Department of Energy, Grand Junction Office (DOE/GJO). 1999b. Tank Summary Data Report for Tank T-106, GJ-HAN-120, US Department of Energy, Grand Junction Office, Grand Junction, Colorado. Available on web http://www.gjo.doe.gov/programs/hanf

DOE/GJO 2000. US Department of Energy, Grand Junction Office (DOE/GJO). 2000. Hanford Tank Farms Vadose Zone, Addendum to the T Tank Farm Report. GHO-HAN-27, prepared by U.S. Department of Energy Grand Junction Office for U.S. Department of Energy, Richland Operations Office, Richland, Washington.

EPA (US Environmental Protection Agency)

EPA. 1986. Test Methods for Evaluating Solid Waste: Physical/Chemical Methods, SW-846, 3rd ed. U.S. Environmental Protection Agency, Office of Solid Waste and Emergency Response, Washington, D.C. [Online manual]. Available URL: http://www.epa.gov/epaoswer/hazwaste/test/sw846.htm

EPA Method 300.0A. 1984. Test Method for the Determination of Inorganic Anions in Water by Ion Chromatography. EPA-600/4-84-017, U.S. Environmental Protection Agency, Washington, D.C.

EPA Method 3050B. 2000a. “Acid Digestion of Sediments, Sludges, and Soils.” Test Methods for Evaluating Solid Waste, Physical/Chemical Methods. EPA Publication SW-846, available online http://www.epa.gov/epaoswer/hazwaste/test/sw846.htm

EPA Method 6010B. 2000b. “Inductively Coupled Plasma-Atomic Emission Spectrometry.” Test Methods for Evaluating Solid Waste, Physical/Chemical Methods. EPA Publication SW-846, available online http://www.epa.gov/epaoswer/hazwaste/test/sw846.htm

EPA Method 6020. 2000c. “Inductively Coupled Plasma-Mass Spectrometry.” Test Methods for Evaluating Solid Waste, Physical/Chemical Methods. EPA Publication SW-846, available online http://www.epa.gov/epaoswer/hazwaste/test/sw846.htm

EPA Method (see EPA US Environmental Protection Agency)

Fecht, KR and DC Weekes. 1996. Geologic Field Inspection of the Sedimentary Sequence at the Environmental Restoration Disposal Facility. BHI-00230, Bechtel Hanford, Inc., Richland, Washington.

Fecht, KR, BN Bjornstad, DG Horton, GV Last, SP Reidel, and KA Lindsey. 1999. Clastic Injection Dikes of the Pasco Basin and Vicinity: Geologic Atlas Series. BHI-01103, Rev. 0. Bechtel Hanford Company, Richland, Washington. 
Fecht, KR, GV Last, and KR Price, 1977. Evaluation of Scintillation Probe Profiles from 200 Are Crib Monitoring Wells, Volume III. ARH-ST-156, Atlantic Richfield Hanford Company, Richland, Washington.

Flint, RF. 1938. “Origin of the Cheney-Palouse Scabland Tract.” Geological Society of America Bulletin, v. 49, p. 461-524.

Folk, RL. 1968. Petrology of Sedimentary Rocks. Hemphill, Austin, Texas.

Freeman-Pollard, JR, JA Caggiano, and SJ Trent. 1994. Engineering Evaluation of the GAO-RCED-89-157, Tank 241-T-106 Vadose Zone Investigation. BHI-00061, Bechtel Hanford, Inc., Richland, Washington.

Gardner, MG, KD Reynolds, and DE Skoglie. 2002a. Completion Report for Probe Hole C3831 (TX-107) TX Tank Farm 200 West Area. RPP-12293, Rev. 0, Prepared for the Office of River Protection, CH2M HILL Hanford Group, Inc., Richland, Washington.

Gardner, MG, KD Reynolds, and DE Skoglie. 2002b. Completion Report for Probe Hole C3832 (TX-104) TX Tank Farm 200 West Area. RPP-12017, Rev. 0-A, Prepared for the Office of River Protection, CH2M HILL Hanford Group, Inc., Richland, Washington.

Gee, GW. 1987. Recharge at the Hanford Site. Status Report. PNL-6403, Pacific Northwest Laboratory, Richland, Washington.

Gee, GW, MJ Fayer, ML Rockhold, and MD Campbell. 1992. "Variations in Recharge at the Hanford Site,” NW Sci. 66:237-250.

Hartman, MJ, ed. 1999. Hanford Site Groundwater Monitoring for Fiscal Year 1998. PNNL-12086, Pacific Northwest National Laboratory, Richland, Washington.

Hartman, MJ, LF Morasch, and WD Webber (eds.). 2003. Hanford Site Groundwater Monitoring for Fiscal Year 2002. PNNL-14187, Pacific Northwest National Laboratory, Richland, Washington.

Hartman, MJ, LF Morasch, and WD Weber (eds.). 2004. Hanford Site Groundwater Monitoring for Fiscal Year 2003. PNNL-14548, Pacific Northwest National Laboratory, Richland, Washington.

Hodges, FN, 1998. Results of Phase 1 Groundwater Quality Assessment for Single-Shell Tank Waste Management Areas T and TX-TY at the Hanford Site. PNNL-11809, Pacific Northwest National Laboratory, Richland, Washington.

Hodges, FN and CJ Chou, 2001. RCRA Assessment Plan for Single-Shell Tank Waste Management Area TX-TY at the Hanford Site. PNNL-12072, Pacific Northwest National Laboratory, Richland, Washington.

Horton, DG. 2002. Borehole Data Package for Calendar Year 2001 RCRA Well Installation at Single-Shell Tank Waste Management Area T. PNNL-13830, Pacific Northwest National Laboratory, Richland, Washington. 
Horton, DG. 2003. Data Package for Calendar Year 2002 RCRA Groundwater Monitoring Wells at Single-Shell Tank Waste Management Area TX-TY. PNNL-14249, Pacific Northwest National Laboratory, Richland, Washington.

Horton, DG. and FN Hodges. 2001. Borehole Data Package for Calendar Year 2000 - 2001 RCRA Wells at Single-Shell Tank Waste Management Area T. PNNL-13590, Pacific Northwest National Laboratory, Richland, Washington.

Horton, DG, FN Hodges, VG Johnson, and CJ Chou, 2002. RCRA Groundwater Quality Assessment Report for Single-Shell Tank Waste Management Area T (January 1998 through December 2001). PNNL-13929, Pacific Northwest National Laboratory, Richland, Washington.

Jackson, ML. 1969. Soil Chemical Analysis - Advanced Course - 2nd Edition. Department of Soil Science, University of Wisconsin, Madison, Wisconsin.

Jones, TE, BC Simpson, MI Wood, and RA Corbin. 2000. Preliminary Inventory Estimates for Single-Shell Tank Leaks in T, TX, and TY Tank Farms. RPP-7218, Rev. 0, CH2M HILL Hanford Group, Inc., Richland, Washington.

Johnson, VG and CJ Chou, 2001. RCRA Groundwater Quality Assessment Report for Waste Management Area S-SX (November 1997 through April 2000). PNNL-13441, Pacific Northwest National Laboratory, Richland, Washington.

Johnson, VG, TE Jones, SP Reidel, and MI Wood. 1999. Subsurface Physical Conditions of the S-SX Waste Management Area. HNF-4936, Lockheed Martin Hanford Corporation, Richland, Washington.

Kaplan, DI, and RJ Serne. 1995. Distribution Coefficient Values Describing Iodine, Neptunium, Selenium, Technetium, and Uranium Sorption to Hanford Sediment. PNL-10379, Supplement 1, Pacific Northwest Laboratory, Richland, Washington.

Kaplan, DI, and RJ Serne. 2000. Geochemical Data Package for the Hanford Immobilized Low-Activity Tank Waste Performance Assessment (ILAW-PA). PNNL-13037, Rev.1, Pacific Northwest National Laboratory, Richland, Washington.

Kincaid, CT, MP Bergeron, CR Cole, MD Freshley, VG Johnson, DI Kaplan, RJ Serne, GP Streile, DL Strenge, PD Thorne, LW Vail, GA Whyatt, and SK Wurstner. 1998. Composite Analysis for LowLevel Waste Disposal in the 200 Area Plateau of the Hanford Site. PNNL-11800, Pacific Northwest National Laboratory, Richland, Washington.

Kipp, RL and RD Mudd, 1974. Selected Water Table Contour Maps and Well Hydrographs for the Hanford Reservation, 1944-1973. BNWL-B-360, Pacific Northwest Laboratories, Richland, Washington.

Last, GV, ed. 1994. 216-U-10 Pond and 216-Z19 Ditch Characterization Studies. WHC-EP-0707 (formerly RHO-ST-45), Westinghouse Hanford Company, Richland, Washington.

Last, GV, BN Bjornstad, MP Bergeron, DW Wallace, DR Newcomer, JA Schramke, MA Chamness, CS Cline, SP Airhart, and JS Wilbur. 1989. Hydrogeology of the 200 Areas Low-Level Burial Grounds An Interim Report. PNL-6820, 2 volumes, Pacific Northwest Laboratory, Richland, Washington. 
Lindenmeier, CW, RJ Serne, BN Bjornstad, GW Gee, HT Schaef , DC Lanigan, MJ Lindberg, RE Clayton, VL LeGore, IV Kutnyakov, SR Baum, KN Geiszler, KMM Valenta, TS Vickerman, and LJ Royack. 2002. Characterization of Vadose Zone Sediment: RCRA Borehole 299-E33-338 Located Near the B-BX-BY Waste Management Area, PNNL-14121, Pacific Northwest National Laboratory, Richland, Washington.

Lindsey, KA. 1995. Miocene-to Pliocene-Aged Suprabasalt Sediments of the Hanford Site, South Central Washington, BHI-00184, Bechtel Hanford Inc., Richland, Washington.

Lindsey, KA. 1996. Miocene-Pliocene Ringold Formation and Associated Deposits of the Ancestral Columbia River System, South-Central Washington and North-Central Oregon. Department of Natural Resources, Division of Geology and Earth Resources Open-File Report 96-8, Olympia, Washington, 45p.

Lindsey, KA, BN Bjornstad, JW Lindberg, and KM Hoffman. 1992a. Geologic Setting of the 200 East Area: An Update. WHC-SD-EN-TI-012, Westinghouse Hanford Company, Richland, Washington.

Lindsey, KA, MP Connelly, and BN Bjornstad. 1992b. Geologic Setting of the 200 West Area - An Update. WHC-SD-EN-TI-008, Westinghouse Hanford Company, Richland, Washington.

Lindsey, KA, SP Reidel, KR Fecht, JL Slate, AG Law, and AM Tallman. 1994a. “Geohydrologic Setting of the Hanford Site, South-Central Washington.” In Geologic Field Trips in the Pacific Northwest, eds. DA Swanson and RA Hagerud, pp. 1C-1 to 1C-16. Geological Society of America Meeting, Geological Society of America, Boulder, Colorado.

Lindsey, KA, JL Slate, GK Jaeger, KJ Swett, and RB Mercer. 1994b. Geologic Setting of the Low-Level Burial Grounds. WHC-SD-EN-TI-290, Rev. 0, Westinghouse Hanford Company, Richland, Washington.

Lindsey, KA, SE Kos, and KD Reynolds. 2000. Vadose Zone Geology of the Boreholes 299-W22-50 and 299-W23-19 S-SX Waste Management Area, Hanford Site, South-Central Washington. RPP-6149, Rev. 0, prepared for the Office of River Protection, CH2M HILL Hanford Group, Inc., Richland, Washington.

Lindsey, KA, SE Kos, and KD Reynolds. 2001. Vadose Zone Geology of Boreholes 299-W10-27 and 299-W11-39 T-TX-TY Waste Management Area, Hanford Site, South-Central Washington. RPP-8531, Rev. 0. prepared for the Office of River Protection, CH2M HILL Hanford Group, Inc., Richland, Washington.

March 8, 2004, Listing of borehole geophysical logs for Well 299W10-27; Available URL: http://boreholelogs.pnl.gov/200WEST/W10027

Maxfield, HL. 1979. Handbook 200 Areas Waste Sites, Volume II. RHO-CD-673, Rockwell Hanford Operations, Richland, Washington.

Moody, UL. 1987. Late Quaternary Stratigraphy of the Channeled Scabland and Adjacent Areas, Ph.D. Thesis, University of Idaho, Moscow, Idaho.

Myers, CW. and SM Price (eds.). 1979. Geologic Studies of the Columbia Plateau - A Status Report. RHO-BWI-ST-4, Rockwell Hanford Operations, Richland, Washington. 
O’Connor, JE. 1993. Hydrology, Hydraulics, and Geomorphology of the Bonneville Flood. Special Paper \#274, Geological Society of America, Boulder, Colorado, 83 p.

Or, D and JM Wraith. 2002. “Soil Water Content and Water Potential Relationships,” pp. 49-84. In: Soil Physics Companion, ed. AW Warrick, CRC Press, Boca Raton, Florida.

Pacific Northwest Laboratory (PNL). 1990a. Procedures for Groundwater Investigations.

PNL-MA-567-DO-1, Pacific Northwest Laboratory, Richland, Washington.

Pacific Northwest Laboratory (PNL). 1990b. Procedures for Groundwater Investigations.

PNL-MA-567-SFA-2, Pacific Northwest Laboratory, Richland, Washington.

Pacific Northwest National Laboratory (PNNL). 1995. Precipitation Plating of Actinides for

High-resolution Alpha Spectrometry. PNL-ALO-496, Pacific Northwest National Laboratory, Richland, Washington.

Pacific Northwest National Laboratory (PNNL). 1997. Gamma Energy Analysis Operation and Instrument Verification Using the Genie2000 ${ }^{T M}$ Support Software. PNNL-RRL-01, Pacific Northwest National Laboratory, Richland, Washington.

Pacific Northwest National Laboratory (PNNL). 1998. Inductively Coupled Plasma Mass Spectrometric (ICP-MS) Analysis. PNNL-AGG-415, Pacific Northwest National Laboratory, Richland, Washington.

Pacific Northwest National Laboratory (PNNL). 1999. Visual Description and Classification of Potentially Contaminated Borehole Samples. PNL Procedure D9T81-99-GVL-1, Pacific Northwest National Laboratory, Richland, Washington, 6 p.

Pacific Northwest National Laboratory (PNNL). 2000a. Liquid Scintillation Counting and Instrument Verification Using the 1400 DSM ${ }^{\mathrm{TM}}$ Support Software. PNNL-AGG-002, Pacific Northwest National Laboratory, Richland, Washington.

Pacific Northwest National Laboratory (PNNL). 2000b. Tc99 and Sr90 Analysis Using Eichrom TEVA-spec and Sr-spec Resin. AGG-RRL-003.2., Pacific Northwest National Laboratory, Richland, Washington.

Price, WH and KR Fecht. 1976. Geology of the 241-TX Tank Farm. ARH-LD-136, Atlantic Richfield Hanford Company, Richland, Washington.

Randall, R, R Price, and JA Caggiano. 2000. Analysis and Summary Report of Historical Dry Well Gamma Logs for the 241-T-Tank Farm - 200 West. RPP-6088, Rev. 0, CH2M HILL Hanford Group, Inc., Richland, Washington.

Reidel, SP, and KR Fecht. 1994. Geologic Map of the Priest Rapids 1:100,000 Quadrangle, Washington. Washington Division of Geology and Earth Resources Open-File Report 94-13, 22 p.

Reidel, SP, KA Lindsey, and KR Fecht. 1992. Field Trip Guide to the Hanford Site. WHC-MR-0391, Westinghouse Hanford Company, Richland, Washington. 
Reineck, HE, and IB Singh, 1975. Depositional Sedimentary Environments. Springer-Verlag, New York, 439p.

Reynolds, KD. 2003a. Completion Report for Probe Hole C4104 (T-106) T Tank Farm Drilling and Sampling. RPP-17275, Rev. 0, Prepared for the Office of River Protection, CH2M HILL Hanford Group, Inc., Richland, Washington.

Reynolds, KD. 2003b. Completion Report for Probe Hole C4105 (T-106) T Tank Farm Drilling and Sampling. RPP-16340, Rev. 0, Prepared for the Office of River Protection, CH2M HILL Hanford Group, Inc., Richland, Washington.

Rhoades, JD. 1996. “Salinity: Electrical Conductivity and Total Dissolved Solids.” In Methods of Soil Analysis Part 3, ed. JM Bigham, pp. 417-435. American Society of Agronomy, Madison, Wisconsin.

Routson, RC, G Jansen, and AV Robinson. 1976. "241-Am, 237-Np, and 99-Tc Sorption on Two United States Subsoils from Differing Weathering Intensity Areas.” Health Phys. 33:311-317.

Routson, RC, WH Price, DJ Brown, and KR Fecht. 1979. High-Level Waste Leakage from the 241-T-106 Tank at Hanford. RHO-ST-14, Rockwell Hanford Operations, Richland, Washington.

Salvador, A, ed. 1994. International Stratigraphic Guide. International Union of Geological Sciences and the Geological Society of America, Boulder, Colorado, second edition.

Serne, RJ, HT Schaef, BN Bjornstad, BA Williams, DC Lanigan, DG Horton, RE Clayton, VL LeGore, MJ O’Hara, CF Brown, KE Parker, IV Kutnyakov, JN Serne, AV Mitroshkov, GV Last, SC Smith, CW Lindenmeier, JM Zachara, and DS Burke. 2002a. Characterization of Vadose Zone Sediment: Uncontaminated RCRA Borehole Core Samples and Composite Samples. PNNL-13757-1, Pacific Northwest National Laboratory, Richland, Washington.

Serne, RJ, HT Schaef, BN Bjornstad, DC Lanigan, GW Gee, CW Lindenmeier, RE Clayton, VL LeGore, MJ O’Hara, CF Brown, RD Orr, GV Last, IV Kutnyakov, DS Burke, TC Wilson, and BA Williams. 2002b. Characterization of Vadose Zone Sediment: Borehole 299-W23-19 [SX-115] in the S-SX Waste Management Area. PNNL-13757-2. Pacific Northwest National Laboratory, Richland, Washington.

Serne, RJ, GV Last, GW Gee, HT Schaef, DC Lanigan, CW Lindenmeier, RE Clayton, VL LeGore, RD Orr, MJ O’Hara, CF Brown, DS Burke, AT Owen, IV Kutnyakov, and TC Wilson. 2002c.

Characterization of Vadose Zone Sediment: Borehole 41-09-39 in the S-SX Waste Management Area. PNNL-13757-3, Pacific Northwest National Laboratory, Richland, Washington.

Serne, RJ, GV Last, HT Schaef, DC Lanigan, CW Lindenmeier, CC Ainsworth, RE Clayton, VL LeGore, MJ O’Hara, CF Brown, RD Orr, IV Kutnyakov, TC Wilson, KB Wagnon, BA Williams, and DB Burke. 2002d. Characterization of Vadose Zone Sediment, Part 4: Slant Borehole SC-108 in the S-SX Waste Management Area. PNNL-13757-4, Pacific Northwest National Laboratory, Richland, Washington. 
Serne, RJ, GV Last, GW Gee, HT Schaef, DC Lanigan, CW Lindenmeier, MJ Lindberg, RE Clayton, VL LeGore, RD Orr, IV Kutnyakov, SR Baum, KN Geiszler, CF Brown, MM Valenta, and TS Vickerman, 2002e. Characterization of Vadose Zone Sediment: Borehole 299-E33-45 Near BX-102 in the B-BX-BY Waste Management Area, PNNL-14083, Pacific Northwest National Laboratory, Richland, Washington.

Serne, RJ, BN Bjornstad, GW Gee, HT Schaef, DC Lanigan, CW Lindenmeier, RD Orr, VL LeGore, RE Clayton, MJ Lindberg, IV Kutnyakov, SR Baum, KN Geiszler, MM Valenta, TS Vickerman, and LJ Royack. 2002f. Characterization of Vadose Zone Sediment: Borehole 299-E33-46 Near B-110 in the B-BX-BY Waste Management Area, PNNL-14119, Pacific Northwest National Laboratory, Richland, Washington.

Serne, RJ, BN Bjornstad, DG Horton, DC Lanigan, CW Lindenmeier, MJ Lindberg, RE Clayton, VL LeGore, RD Orr, IV Kutnyakov, SR Baum, KN Geiszler, MM Valenta, and TS Vickerman. 2004. Characterization of Vadose Zone Sediments Below the TX Tank Farm: Boreholes C3830, C3831, C3832 and RCRA Borehole 299-W10-27. PNNL-14594, Pacific Northwest National Laboratory, Richland, Washington.

Shaw, J, M Munro-Stasuik, B Sawyer, C Beaney, JE Lesemann, A Musacchio, B Rains, and RR Young. 1999. "The Channeled Scabland: Back to Bretz,” Geology, v. 27, p. 605-608.

Simpson, BC, RA Corbin, and SF Agnew, 2001. Hanford Soil Inventory Model. BHI-01496 Rev. 0, Bechtel Hanford, Inc., Richland, Washington.

Slate, JL. 1996. "Buried Carbonate Paleosols Developed in Pliocene-Pleistocene Deposits of the Pasco Basin, South-Central Washington.” USA: Quaternary International, Vol. 34-36, pp. 191-196.

Slate, JL. 2000. Nature and Variability of the Plio-Pleistocene Unit in the 200 West Area of the Hanford Site. BHI-01203, Rev. 0, Bechtel Hanford, Inc., Richland, Washington.

Smith, GA. 1993. "Missoula Flood Dynamics and Magnitudes Inferred from Sedimentology of Slack-Water Deposits on the Columbia Plateau.” Geological Society of America Bulletin, v. 195, p. $77-100$.

Sobczyk, SM. 2001. Subsurface Interpretation of the T Tank Farm, Hanford Site, Washington, Based on Gamma-Ray Logging, Nez Perce Tribe Environmental Restoration Waste Management Program, Lapwai, Idaho.

Spane, FA, Jr., PD Thorne, and DR Newcomer. 2001a. Results of Detailed Hydrologic Characterization Tests - Fiscal Year 1999. PNNL-13378, Pacific Northwest National Laboratory, Richland, Washington.

Spane, FA, Jr., PD Thorne, and DR Newcomer. 2001b. Results of Detailed Hydrologic Characterization Tests - Fiscal Year 2000. PNNL-13514, Pacific Northwest National Laboratory, Richland, Washington.

Spane, FA, Jr., PD Thorne, and DR Newcomer. 2002. Results of Detailed Hydrologic Characterization Tests - Fiscal Year 2001. PNNL-14113, Pacific Northwest National Laboratory, Richland, Washington. 
Spane, FA, Jr., PD Thorne, and DR Newcomer. 2003. Results of Detailed Hydrologic Characterization Tests - Fiscal Year 2002. PNNL-14186, Pacific Northwest National Laboratory, Richland, Washington.

Tallman, AM, KR Fecht, MC Marratt, and GV Last. 1979. Geology of the Separations Areas, Hanford Site, South-Central Washington. RHO-ST-23, Rockwell Hanford Operations, Richland, Washington.

Tallman, AM, JT Lillie, and KR Fecht. 1981. "Suprabasalt Sediment of the Cold Creek Syncline Area," In Subsurface Geology of the Cold Creek Syncline, eds. CW Myers and SM Price, RHO-BWI-ST-14, Rockwell Hanford Operations, Richland, Washington.

USGS (United States Geological Survey). 2001. “Alkalinity and Acid Neutralizing Capacity.” In: National Field Manual for the Collection of Water-Quality Data, $2^{\text {nd }}$ Edition, eds. SA Rounds and FD Wilde. [Online Report Revised 9/2001]. As of March 23, 2004 available URL: http://water.usgs.gov/owq/Field Manual/ Chapter6/section 6.6/html/section6.6htm.

Waldrop, WR and HS Pearson. 2000. Results of Field Tests with the Electromagnetic Borehole Flowmeter at the Pacific Northwest National Laboratory, Richland, WA. QEC-T-132, Quantum Engineering Corporation, London, Tennessee.

Wan, J, JT Larsen, TK Tokunaga, and Z Zheng. 2004. "pH Neutralization and Zonation in Alkaline-Saline Tank Waste Plumes.” Environ. Sci. Technol. Vol. 38, p. 1321-1329.

Ward, AL, GW Gee, and MD White. 1997. A Comprehensive Analysis of Contaminant Transport in the Vadose Zone Beneath Tank SX-109. PNNL-11463, Pacific Northwest National Laboratory, Richland, Washington.

Webster, GD, and JW Crosby, 1982, Stratigraphic Investigation of the Skagit/Hanford Nuclear Project, S/HNP-PSAR, Appendix 2R, Bellevue, Washington, Puget Sound Power and Light Company, p. 2R-i to 2R-35.

Wentworth, CK. 1922. “A grade scale and class terms for clastic sediments.” Journal of Geology, Vol. 30, p. 377-392.

WHC 1990. 1990. Liquid Effluent Study Final Project Report. WHC-EP-0367, Westinghouse Hanford Company, Richland, Washington.

Williams, JC. 2000. Historical Vadose Zone Contamination from T, TX, and TY Tank Farm Operations. RPP-5957, Rev. 0, CH2M HILL Hanford Group,, Inc., Richland, Washington.

Williams, BA, BN Bjornstad, R Schalla, and WD Webber. 2002. Revised Hydrogeology for the Suprabasalt Aquifer System, 200-West Area and Vicinity, Hanford Site, Washington. PNNL-13858, Pacific Northwest National Laboratory, Richland, Washington.

Wood, MI, R Schalla, BN Bjornstad, and FN Hodges. 2001. Subsurface Conditions Description of the T and TX-TY Waste Management Areas. RPP-7123, Rev. 0, CH2M HILL Hanford Group, Inc., Richland, Washington. 
Wood, MI, TE Jones, R Schalla, BN Bjornstad, and FN Hodges. 2001. Subsurface Conditions Description of the T and TX-TY Waste Management Areas. RPP-7123, Rev. 0. CH2M HILL Hanford Group, Inc., Richland, Washington.

Zachara, JM, SC Smith, C. Lui, JP McKinley, RJ Serne, and PL Gassman. 2002. "Sorption of Cs ${ }^{+}$to Micaceous Subsurface Sediments from the Hanford Site, USA.” Geochimica et Cosmochimica Acta. 66: 193-211. 


\section{Appendix A. Core Photographs}

A.1 C3117 (299-W11-39)

A.2. $\mathrm{C} 4104$ (T-106)

A.3. $\mathrm{C} 4105$ (T-106) 
Appendix A-1

C3117 (299-W11-39)

SPLITSPOON CORE

SAMPLE PHOTOGRAPHS 


\section{Contents}

Appendix A-1.

A-1.1

\section{Figures}

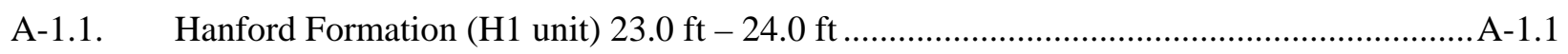

A-1.2. Hanford Formation (H1 unit) $31.5 \mathrm{ft}-32.5 \mathrm{ft}$.................................................................

A-1.3. Hanford Formation (H1 unit) $32.5 \mathrm{ft}-33.5 \mathrm{ft}$...................................................................

A-1.4. Hanford Formation (H2 unit) $34.0 \mathrm{ft}-35.0 \mathrm{ft}$.............................................................

A-1.5. Hanford Formation (H2 unit) $35.0 \mathrm{ft}-36.0 \mathrm{ft}$................................................................. A-1.5

A-1.6. Hanford Formation (H2 unit) $36.5 \mathrm{ft}-37.5 \mathrm{ft}$...............................................................

A-1.7. Hanford Formation (H2 unit) $37.5 \mathrm{ft}-38.5 \mathrm{ft}$............................................................... A-1.7

A-1.8. Hanford Formation (H2 unit) $39.0 \mathrm{ft}-40.0 \mathrm{ft}$................................................................. A-1.8

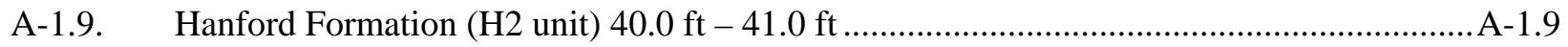

A-1.10. Hanford Formation (H2 unit) $41.5 \mathrm{ft}-42.5 \mathrm{ft}$............................................................... A-1.10

A-1.11. Hanford Formation (H2 unit) $42.5 \mathrm{ft}-43.5 \mathrm{ft}$.......................................................... A-1.11

A-1.12. Hanford Formation (H2 unit) $44.0 \mathrm{ft}-45.0 \mathrm{ft}$............................................................. A-1.12

A-1.13. Hanford Formation (H2 unit) $45.0 \mathrm{ft}-46.0 \mathrm{ft}$................................................................

A-1.14. Hanford Formation (H2 unit) $46.5 \mathrm{ft}-47.5 \mathrm{ft}$.................................................................. A-1.14

A-1.15. Hanford Formation (H2 unit) $47.5 \mathrm{ft}-48.5 \mathrm{ft}$........................................................ A-1.15

A-1.16. Hanford Formation (H2 unit) $49.0 \mathrm{ft}-50.0 \mathrm{ft}$........................................................... A-1.16

A-1.17. Hanford Formation (H2 unit) $50.0 \mathrm{ft}-51.0 \mathrm{ft}$............................................................ A-1.17

A-1.18. Hanford Formation (H2 unit) $51.5 \mathrm{ft}-52.5 \mathrm{ft}$............................................................. A-1.18

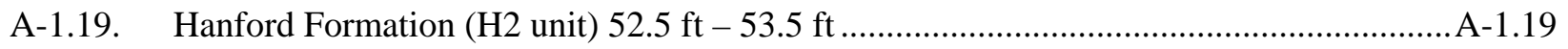

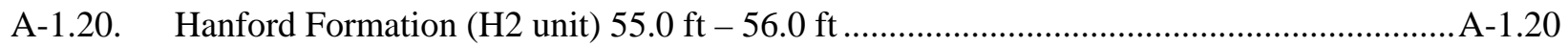

A-1.21. Hanford Formation (H2 unit) $57.5 \mathrm{ft}-58.5 \mathrm{ft}$............................................................... A-1.21

A-1.22. Hanford Formation (H2 unit) $59.0 \mathrm{ft}-60.0 \mathrm{ft}$......................................................... A-1.22

A-1.23. Hanford Formation (H2 unit) $60.0 \mathrm{ft}-61.0 \mathrm{ft}$........................................................... A-1.23

A-1.24. Hanford Formation (H2 unit) $61.5 \mathrm{ft}-62.5 \mathrm{ft}$..............................................................A-1.24

A-1.25. Hanford Formation (H2 unit) $62.5 \mathrm{ft}-63.5 \mathrm{ft}$....................................................................25

A-1.26. Hanford Formation (H2 unit) $64.0 \mathrm{ft}-65.0 \mathrm{ft}$........................................................... A-1.26

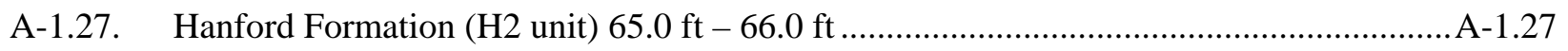


A-1.28. Hanford Formation (H2 unit) $67.5 \mathrm{ft}-68.5 \mathrm{ft}$........................................................... A-1.28

A-1.29. Hanford Formation (H2 unit) $69.0 \mathrm{ft}-70.0 \mathrm{ft}$............................................................. A-1.29

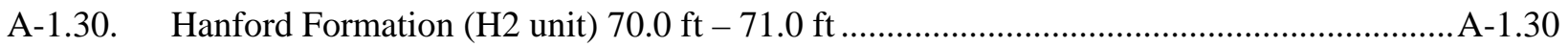

A-1.31. Hanford Formation (H2 unit) $71.5 \mathrm{ft}-72.5 \mathrm{ft}$............................................................... A-1.31

A-1.32. Hanford Formation (H2 unit) $72.5 \mathrm{ft}-73.5 \mathrm{ft}$............................................................... A-1.32

A-1.33. Hanford Formation (H2 unit) $74.0 \mathrm{ft}-75.0 \mathrm{ft}$........................................................... A-1.33

A-1.34. Hanford Formation (H2 unit) $75.0 \mathrm{ft}-76.0 \mathrm{ft}$............................................................... A-1.34

A-1.35. Hanford Formation (H2 unit) $76.5 \mathrm{ft}-77.5 \mathrm{ft}$.............................................................. A-1.35

A-1.36. Hanford Formation (H2 unit) $77.5 \mathrm{ft}-78.5 \mathrm{ft}$.............................................................. A-1.36

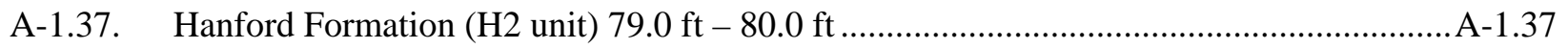

A-1.38. Hanford Formation (H2 unit) $80.0 \mathrm{ft}-81.0 \mathrm{ft}$.......................................................... A-1.38

A-1.39. Hanford Formation (H2 unit) $81.5 \mathrm{ft}-82.5 \mathrm{ft}$...................................................................

A-1.40. Hanford Formation (H2 unit) $82.5 \mathrm{ft}-83.5 \mathrm{ft}$............................................................. A-1.40

A-1.41. Hanford Formation (H2 unit) $85.0 \mathrm{ft}-86.0 \mathrm{ft}$...................................................................

A-1.42. Hanford Formation (H2 unit) $86.5 \mathrm{ft}-87.5 \mathrm{ft}$......................................................... A-1.42

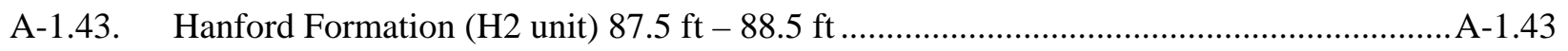

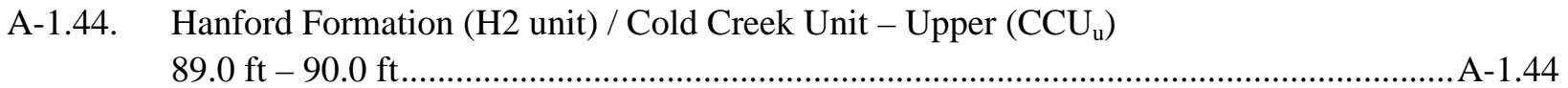

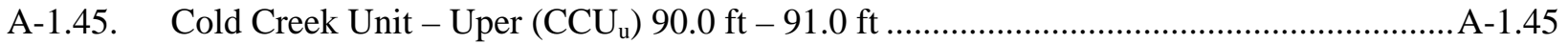

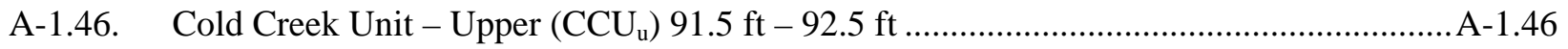




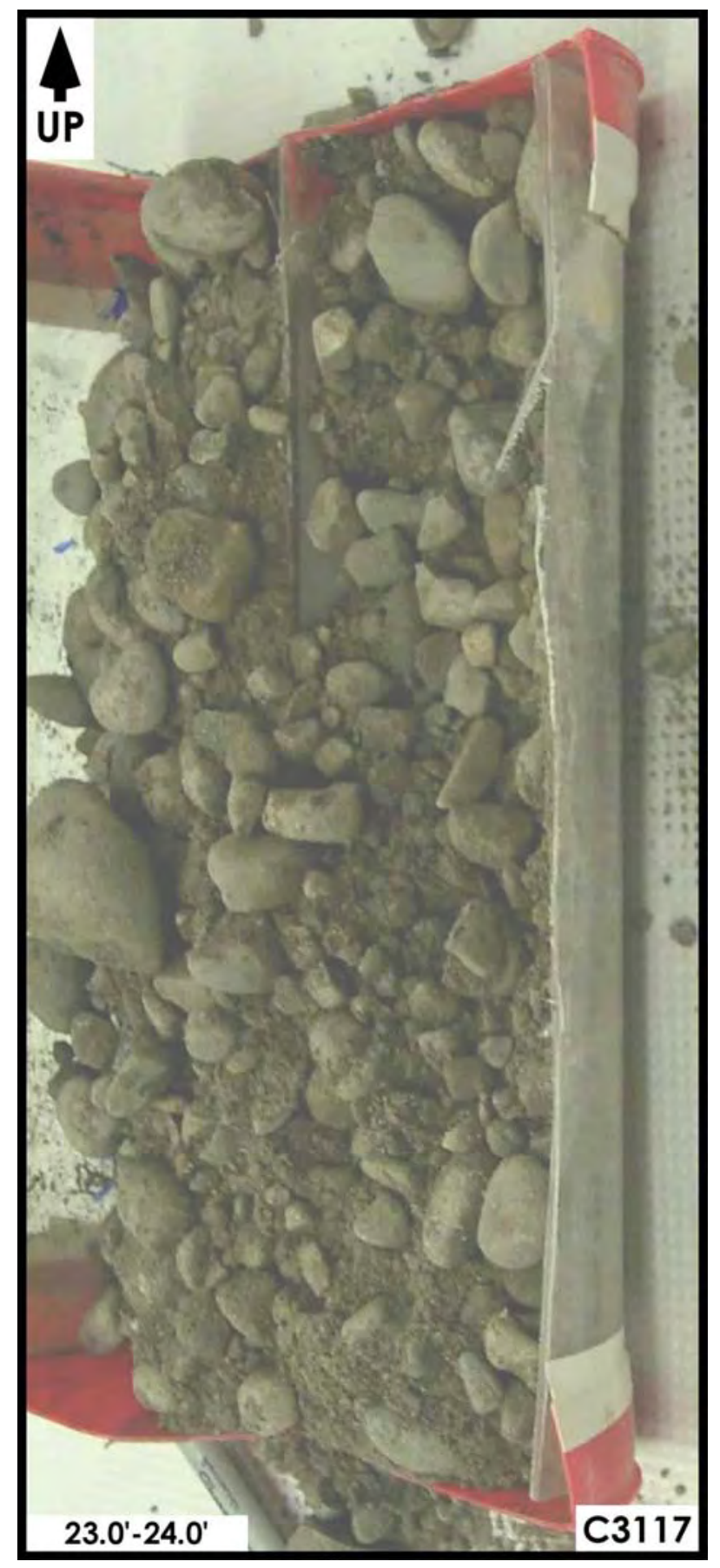

Figure A-1.1. Hanford Formation (H1 unit) $23.0 \mathrm{ft}-24.0 \mathrm{ft}$ 


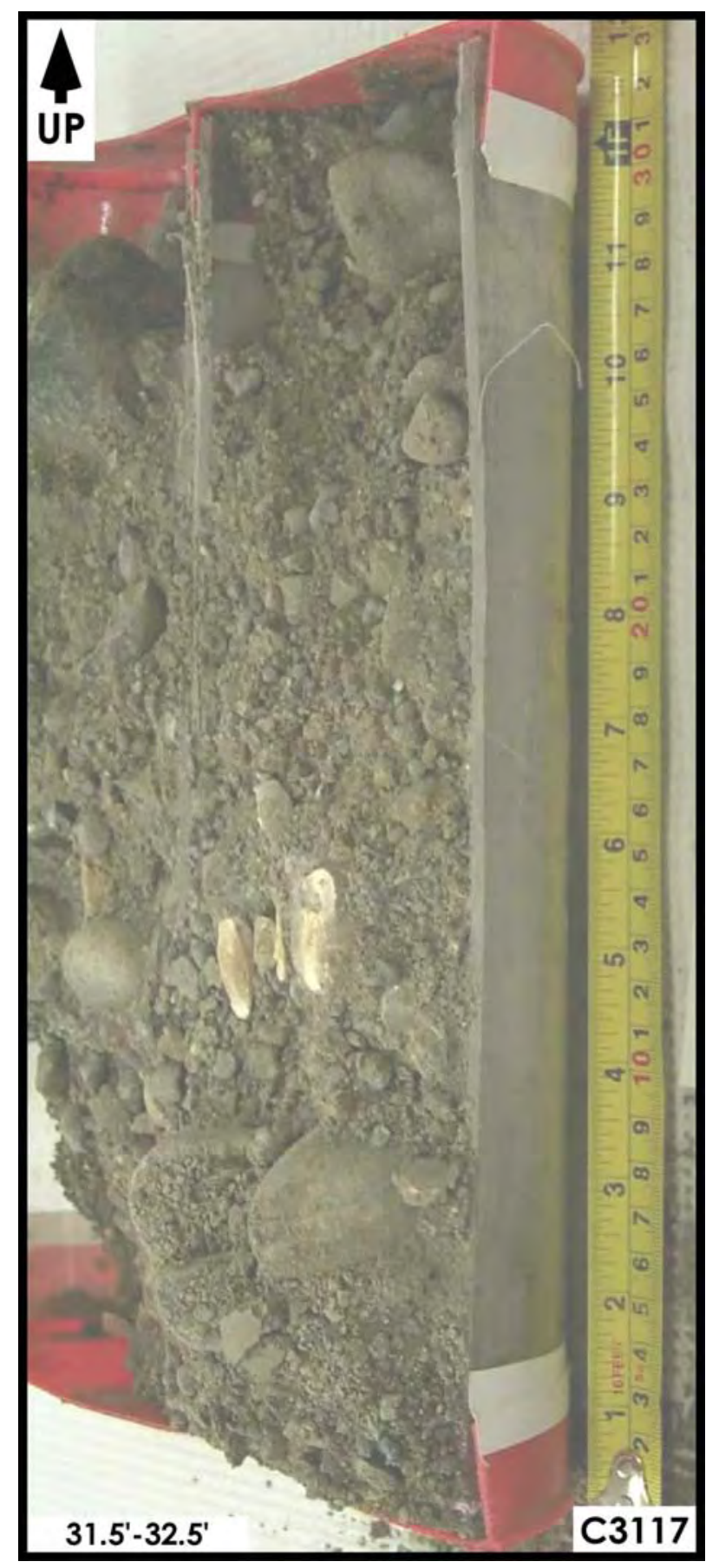

Figure A-1.2. Hanford Formation (H1 unit) 31.5 ft - 32.5 ft 


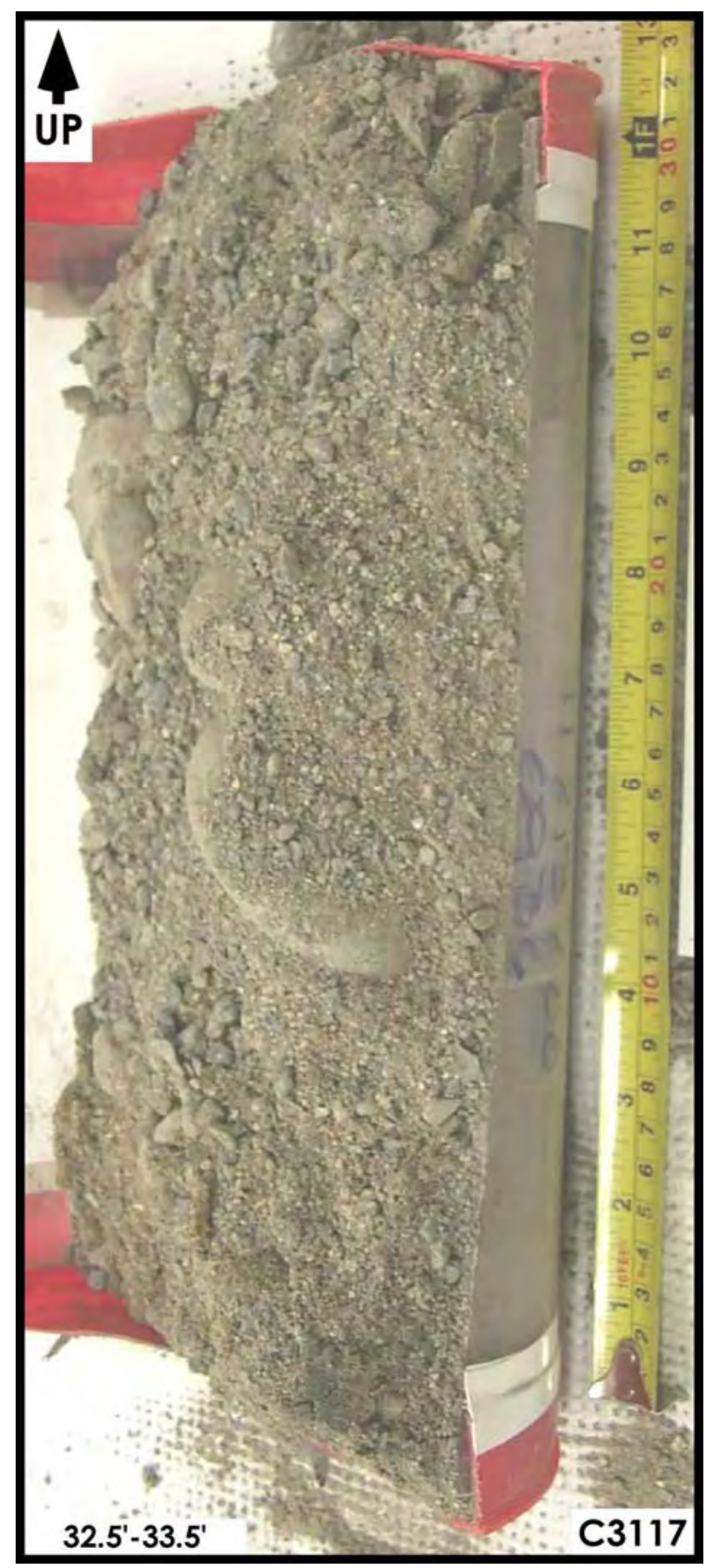

Figure A-1.3. Hanford Formation (H1 unit) $32.5 \mathrm{ft}-33.5 \mathrm{ft}$ 


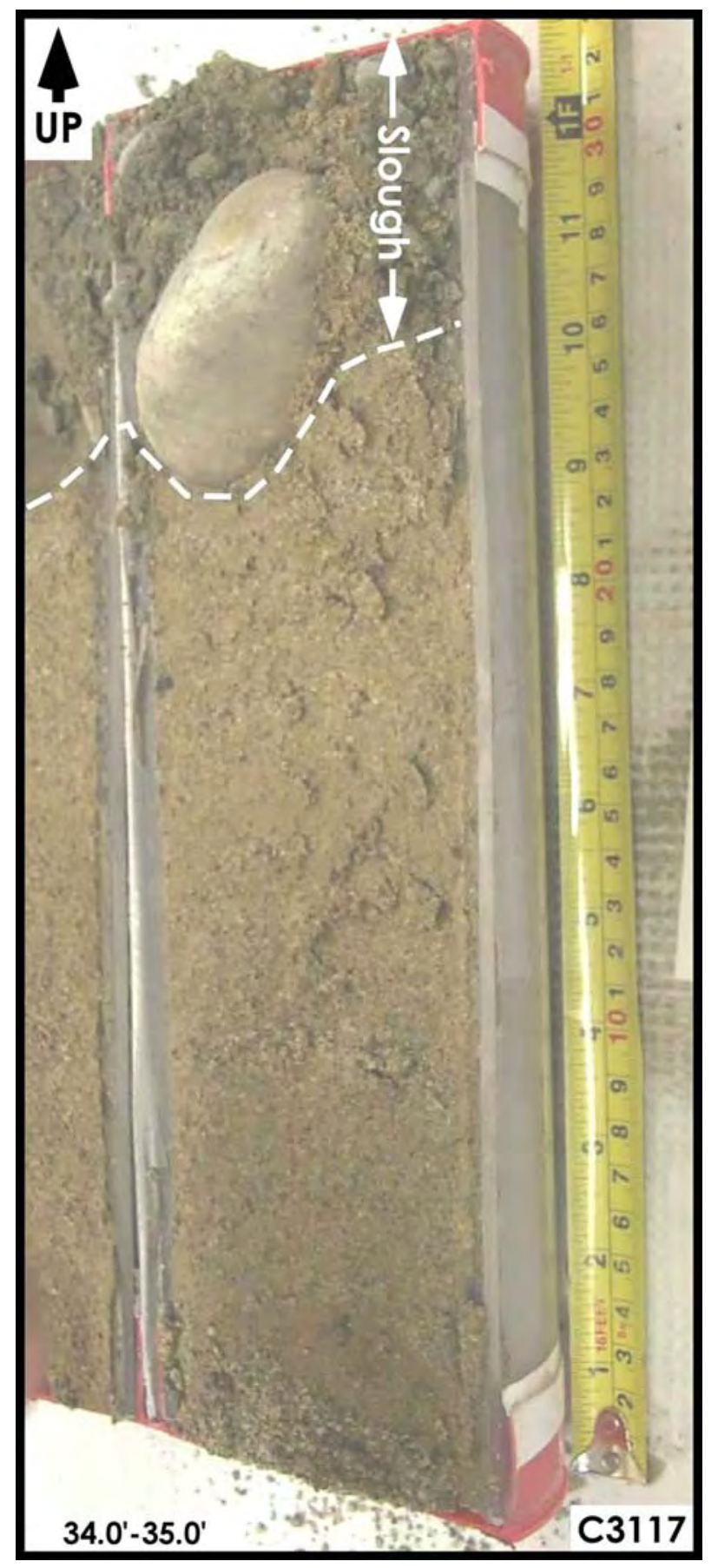

Figure A-1.4. Hanford Formation (H2 unit) $34.0 \mathrm{ft}-35.0 \mathrm{ft}$ 


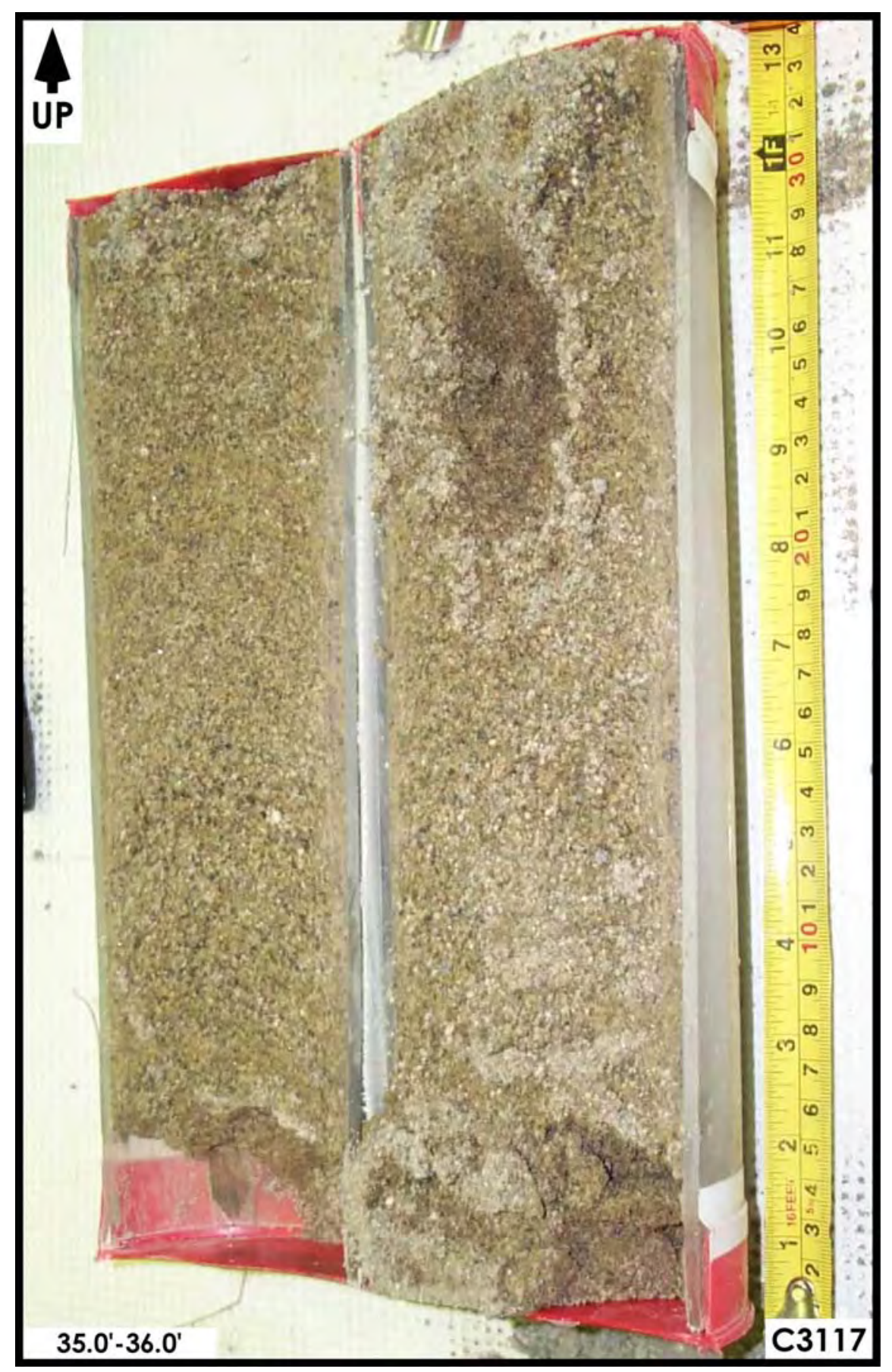

Figure A-1.5. Hanford Formation (H2 unit) $35.0 \mathrm{ft}-36.0 \mathrm{ft}$ 


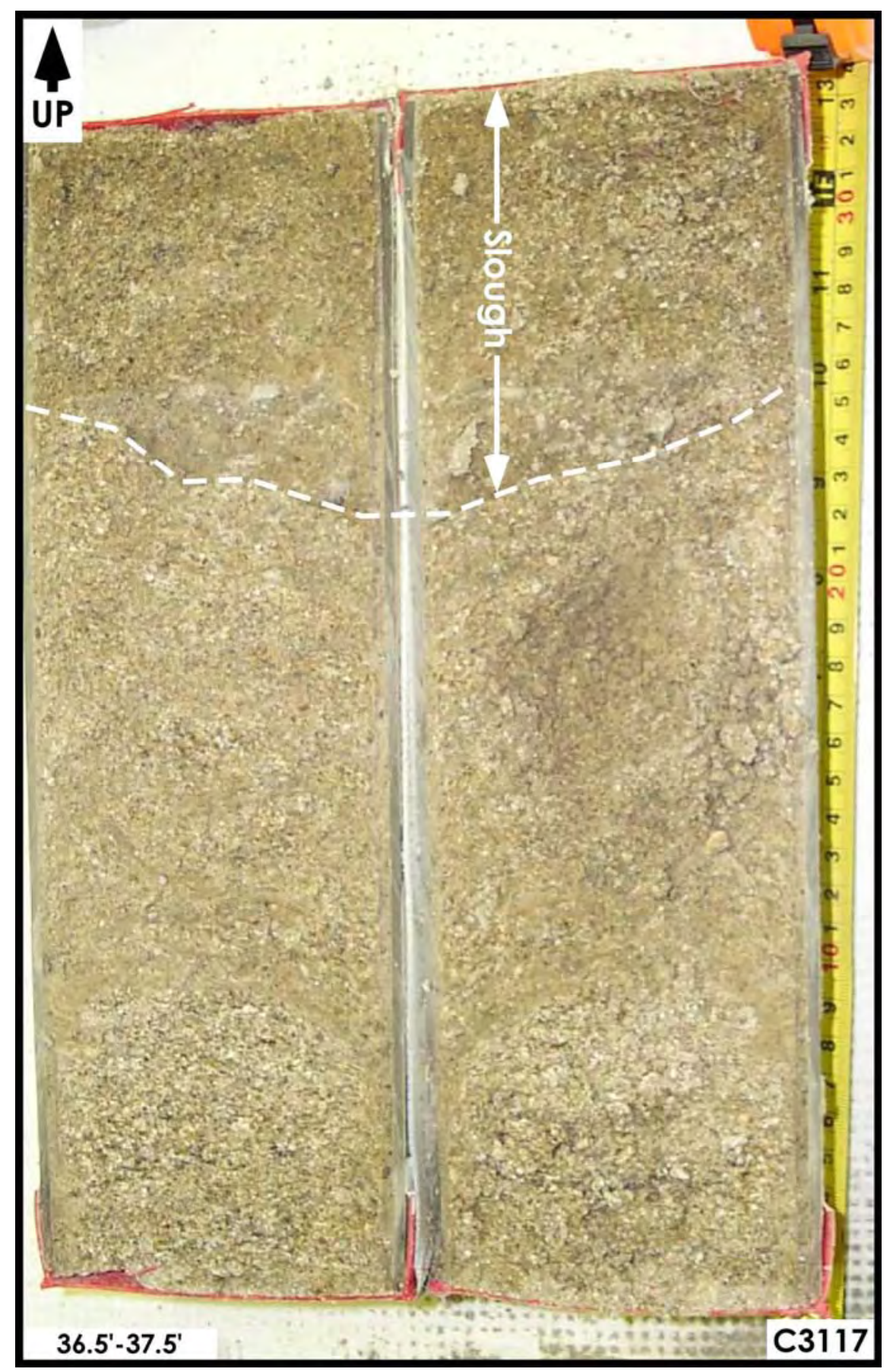

Figure A-1.6. Hanford Formation (H2 unit) 36.5 ft -37.5 ft 


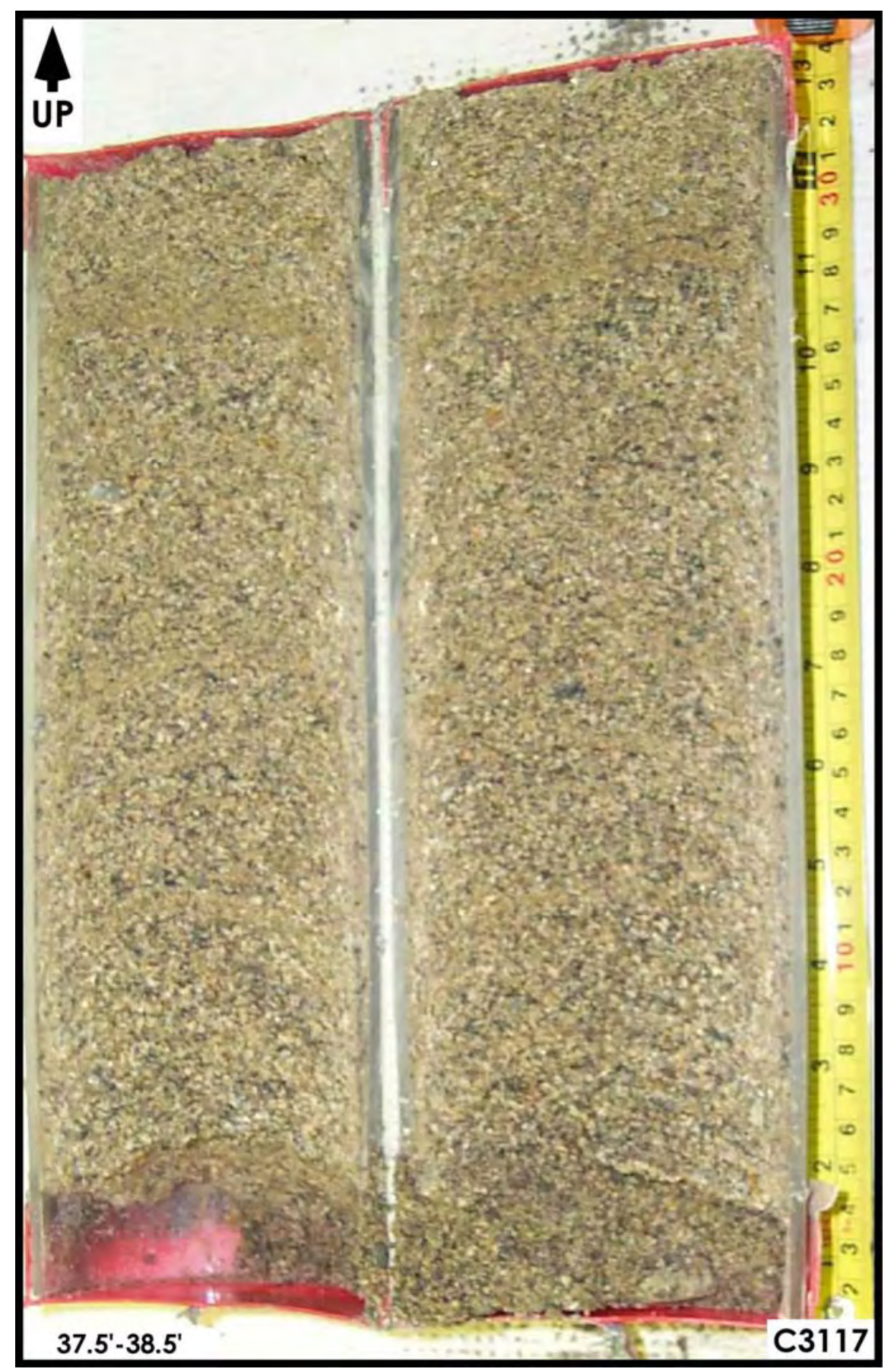

Figure A-1.7. Hanford Formation (H2 unit) $37.5 \mathrm{ft}-38.5 \mathrm{ft}$ 


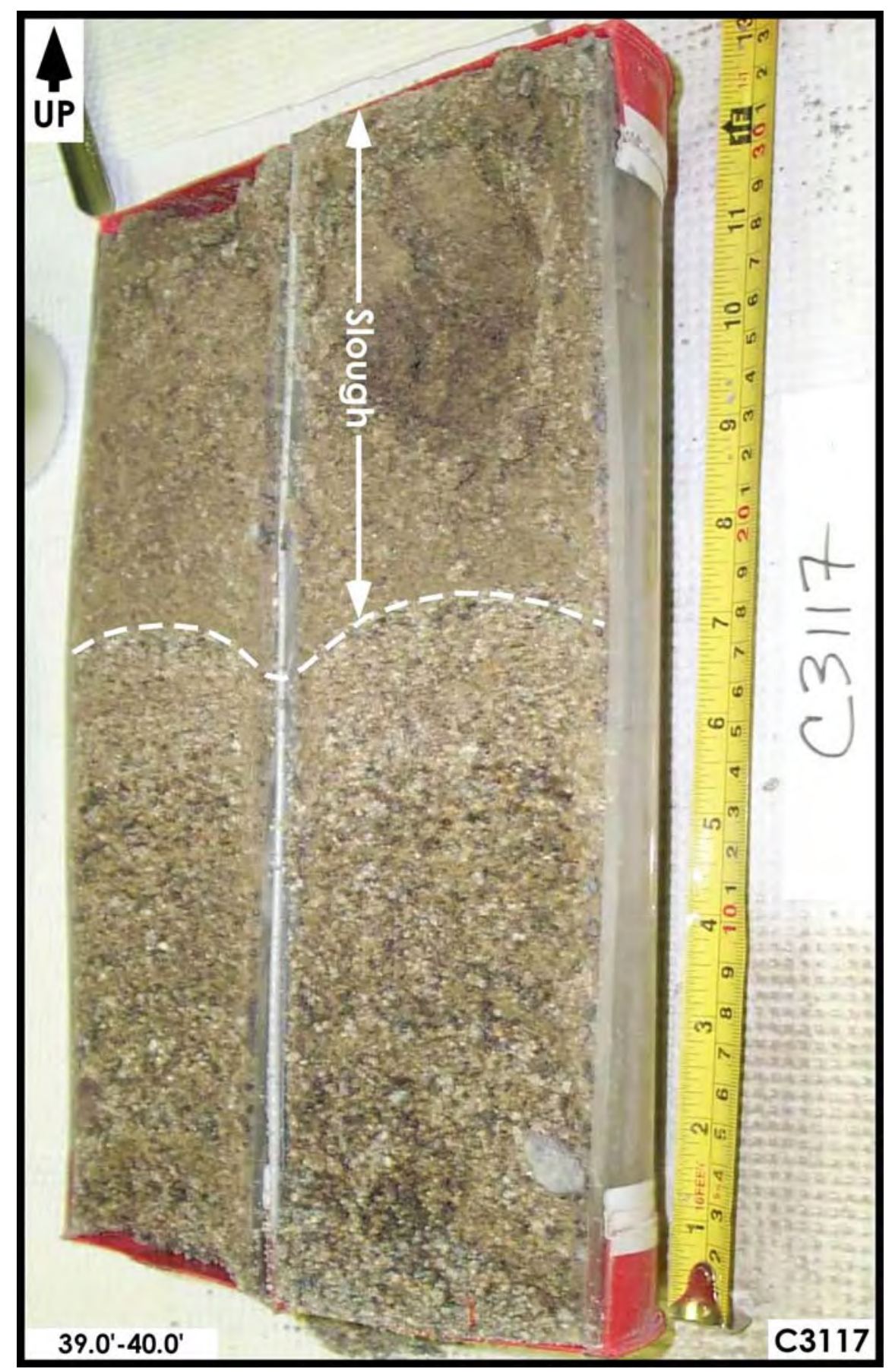

Figure A-1.8. Hanford Formation (H2 unit) $39.0 \mathrm{ft}-\mathbf{4 0 . 0} \mathrm{ft}$ 


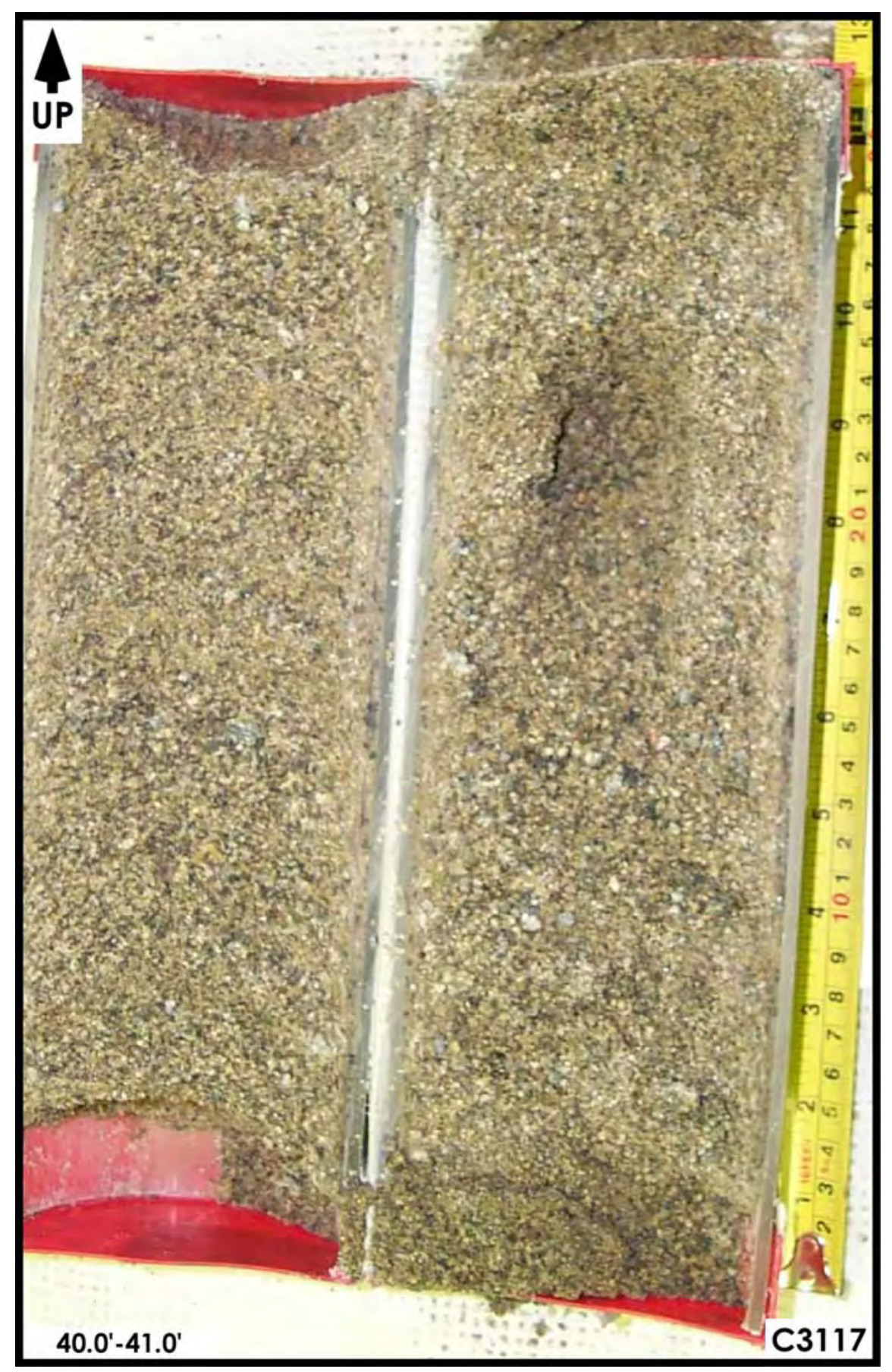

Figure A-1.9. Hanford Formation (H2 unit) $40.0 \mathrm{ft}-41.0 \mathrm{ft}$ 


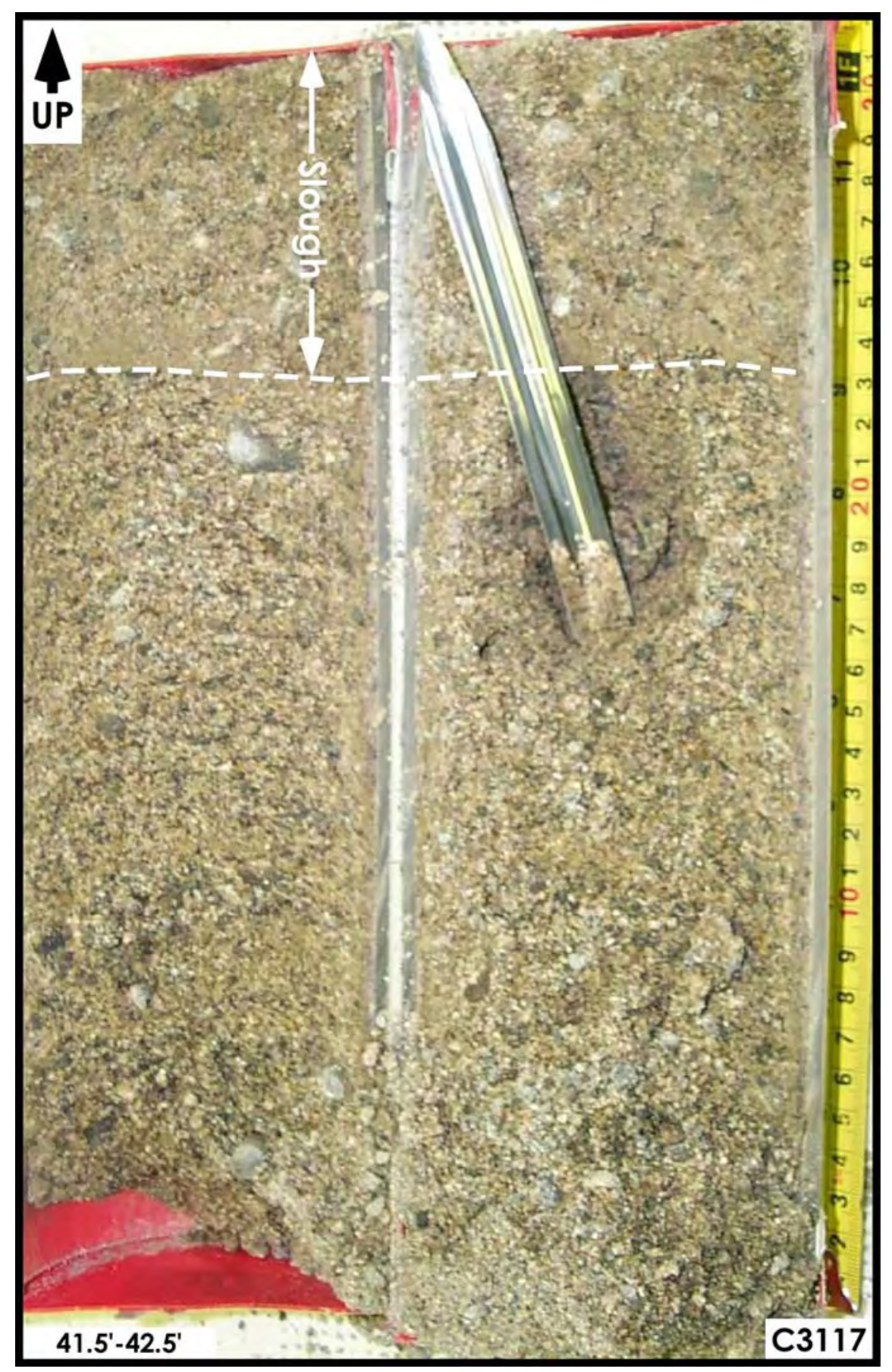

Figure A-1.10. Hanford Formation (H2 unit) $41.5 \mathrm{ft}-42.5 \mathrm{ft}$ 


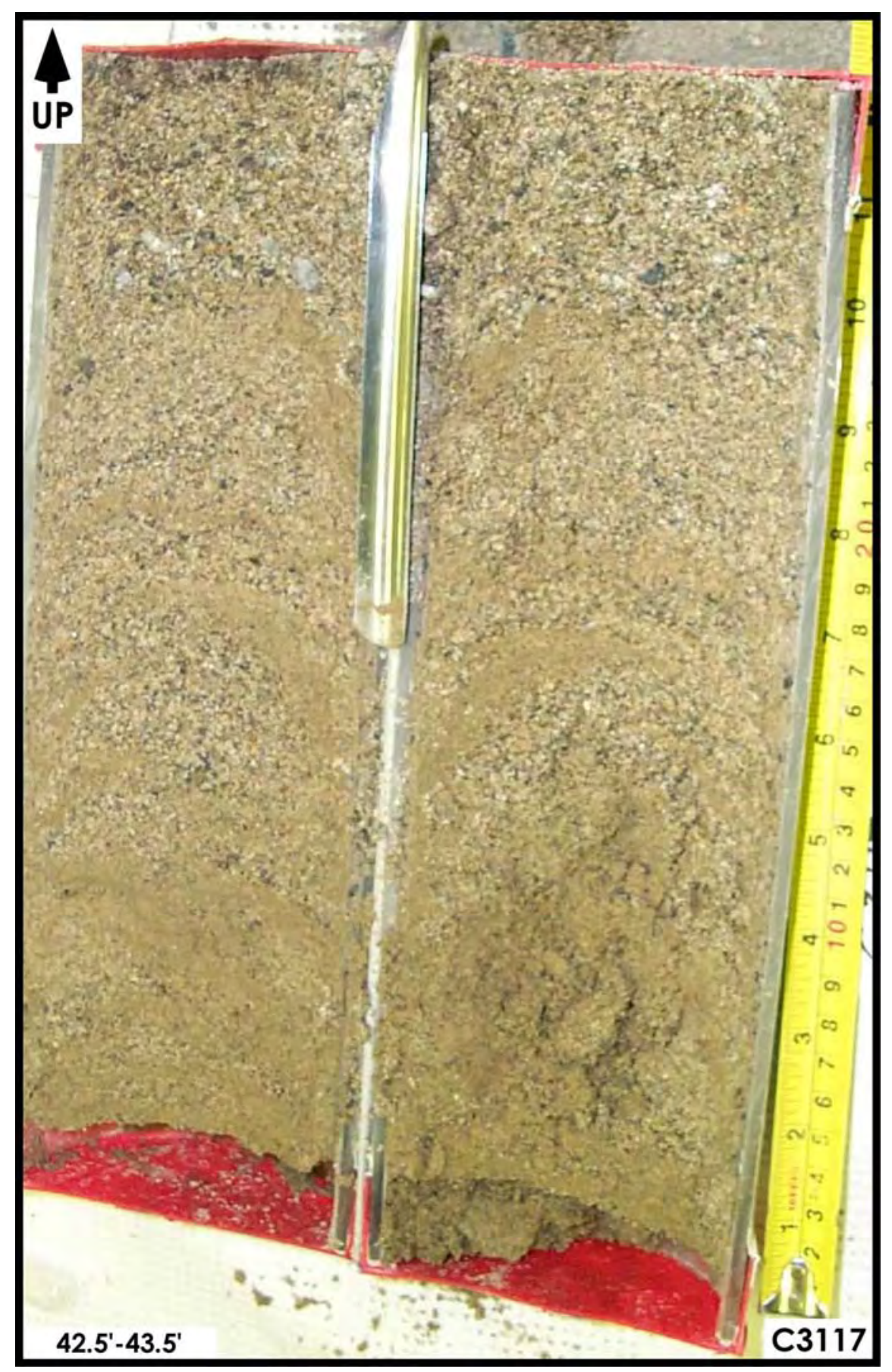

Figure A-1.11. Hanford Formation (H2 unit) $42.5 \mathrm{ft}-43.5 \mathrm{ft}$ 


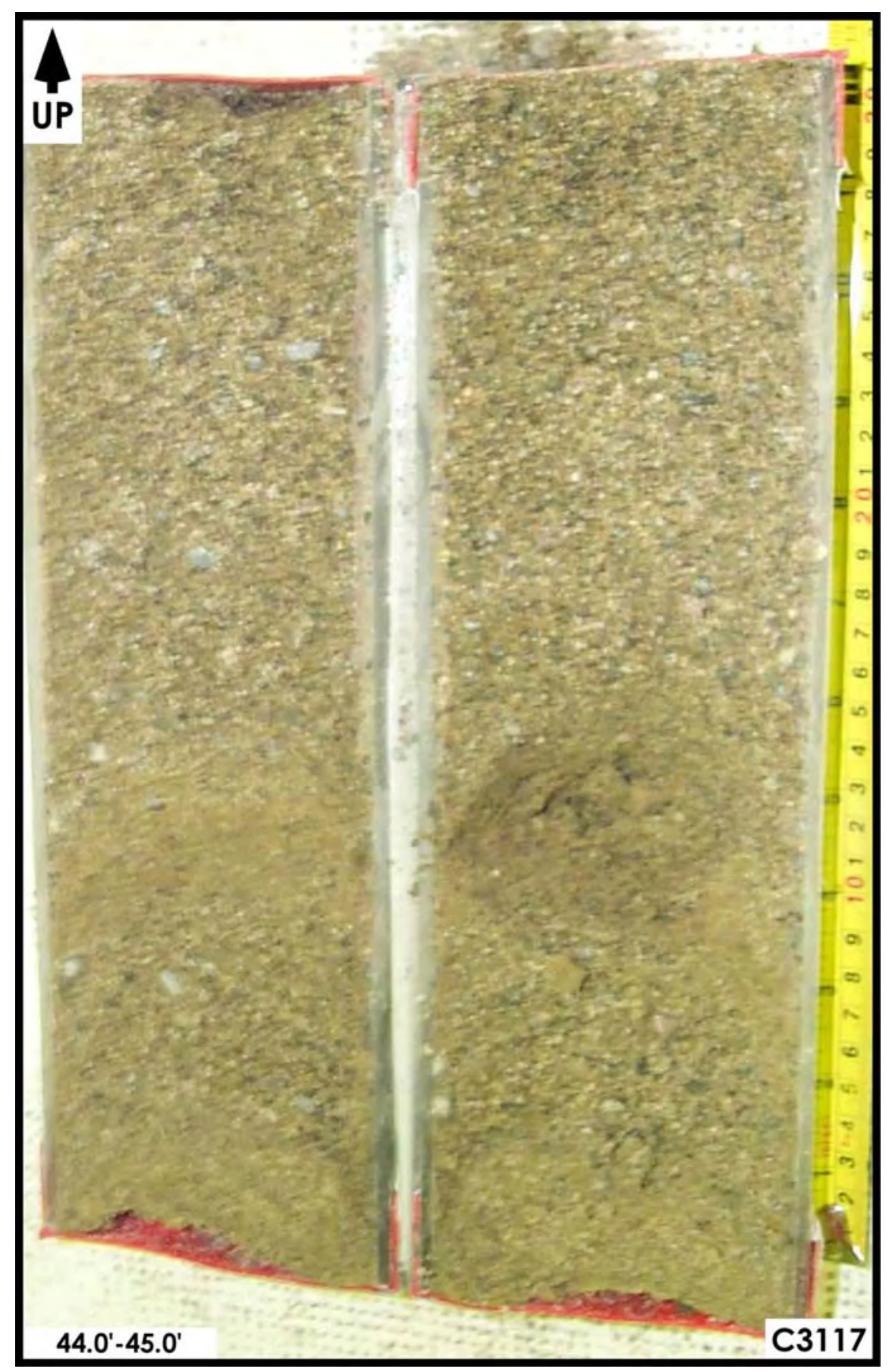

Figure A-1.12. Hanford Formation (H2 unit) $44.0 \mathrm{ft}-45.0 \mathrm{ft}$ 


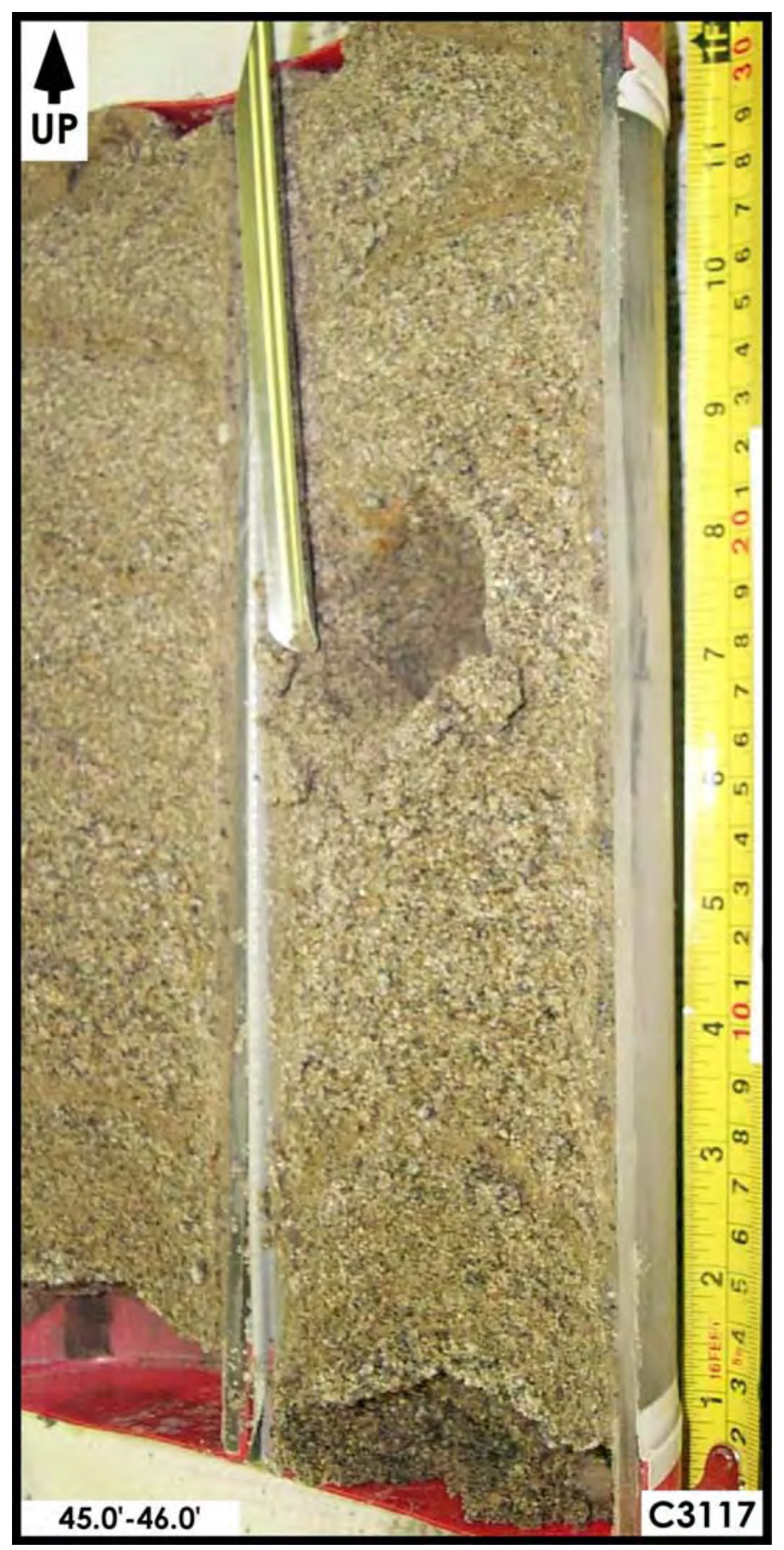

Figure A-1.13. Hanford Formation (H2 unit) $45.0 \mathrm{ft}-\mathbf{4 6 . 0} \mathrm{ft}$ 


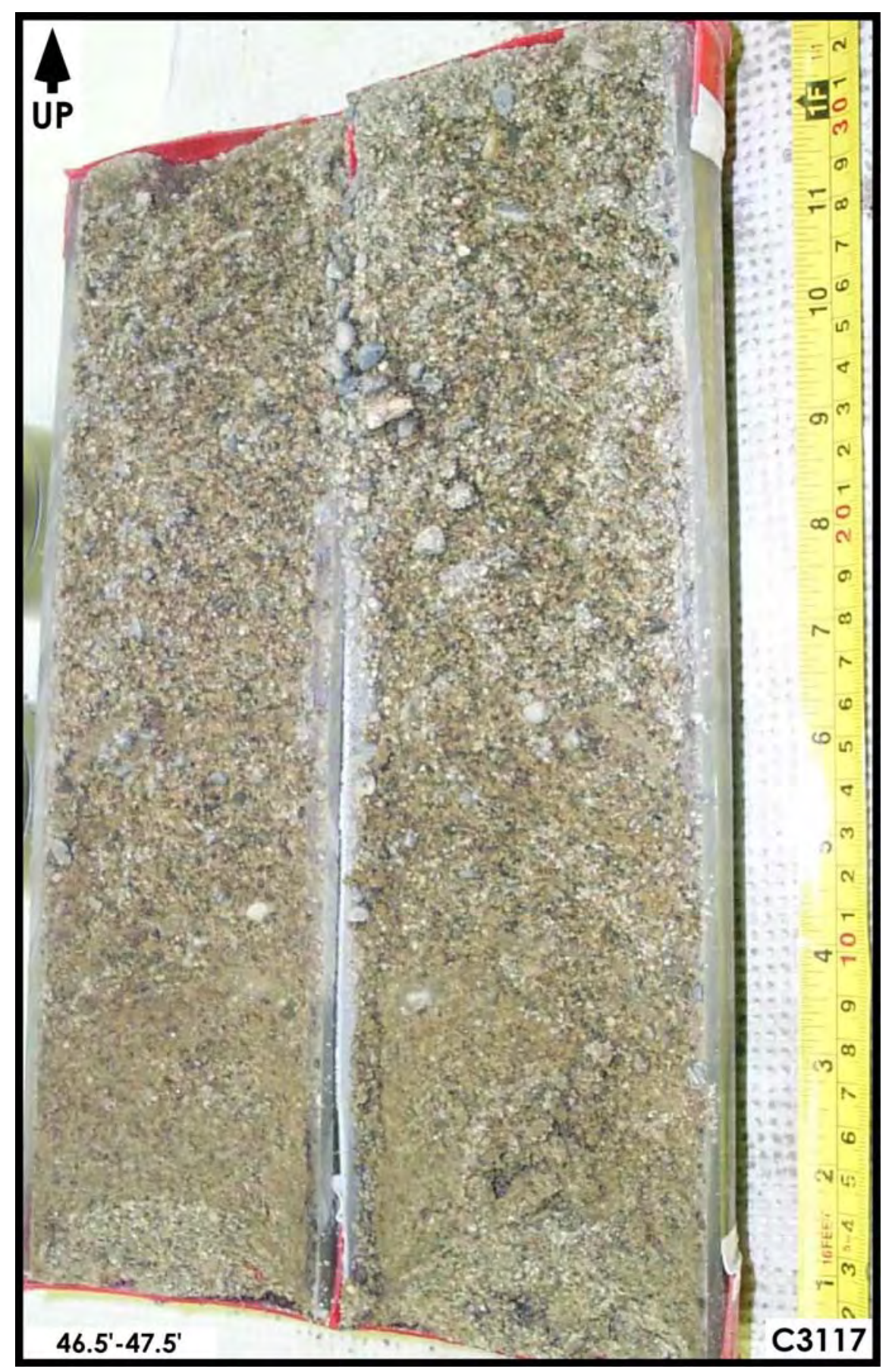

Figure A-1.14. Hanford Formation (H2 unit) $46.5 \mathrm{ft}-47.5 \mathrm{ft}$ 


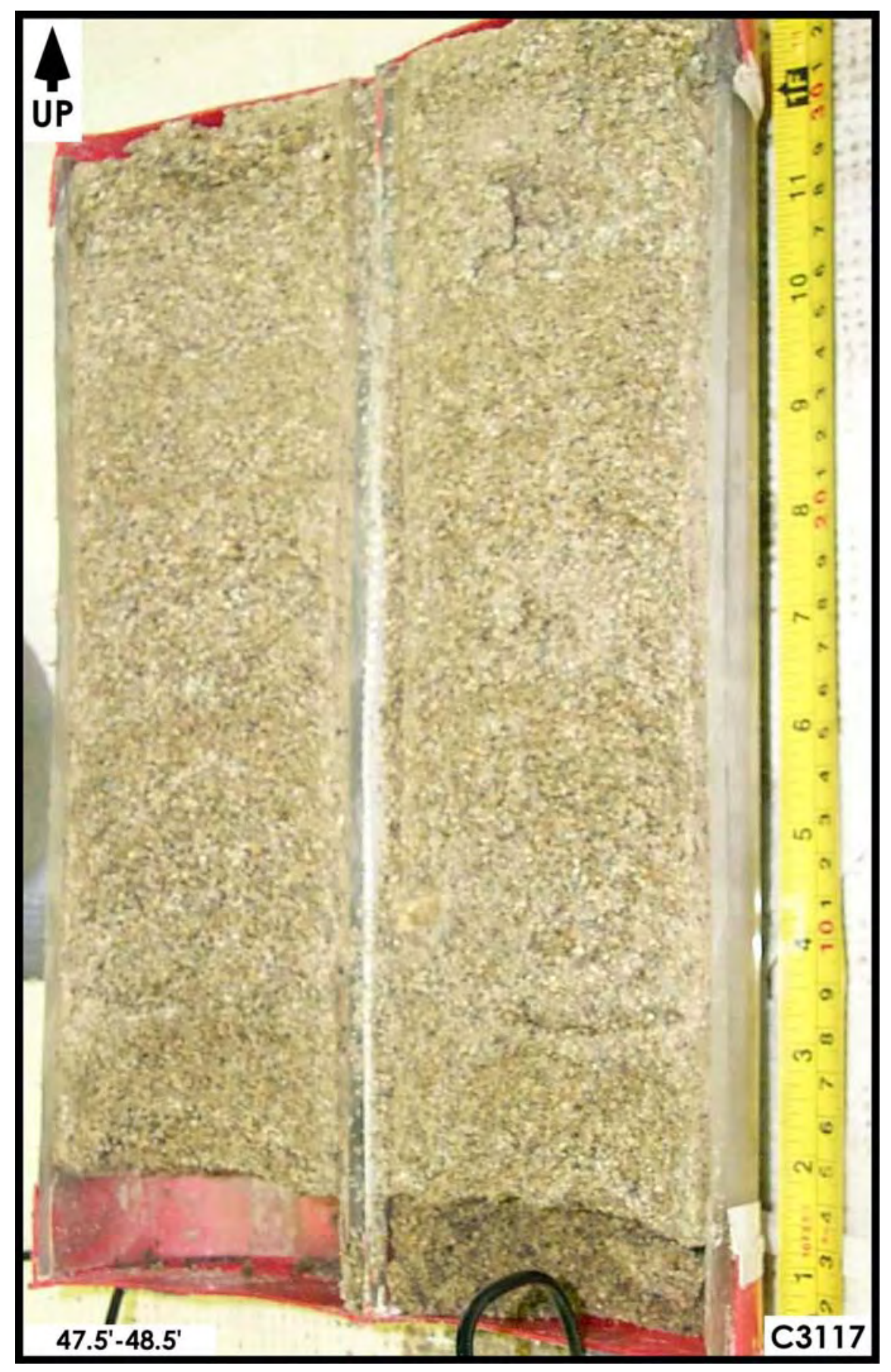

Figure A-1.15. Hanford Formation (H2 unit) $47.5 \mathrm{ft}-48.5 \mathrm{ft}$ 


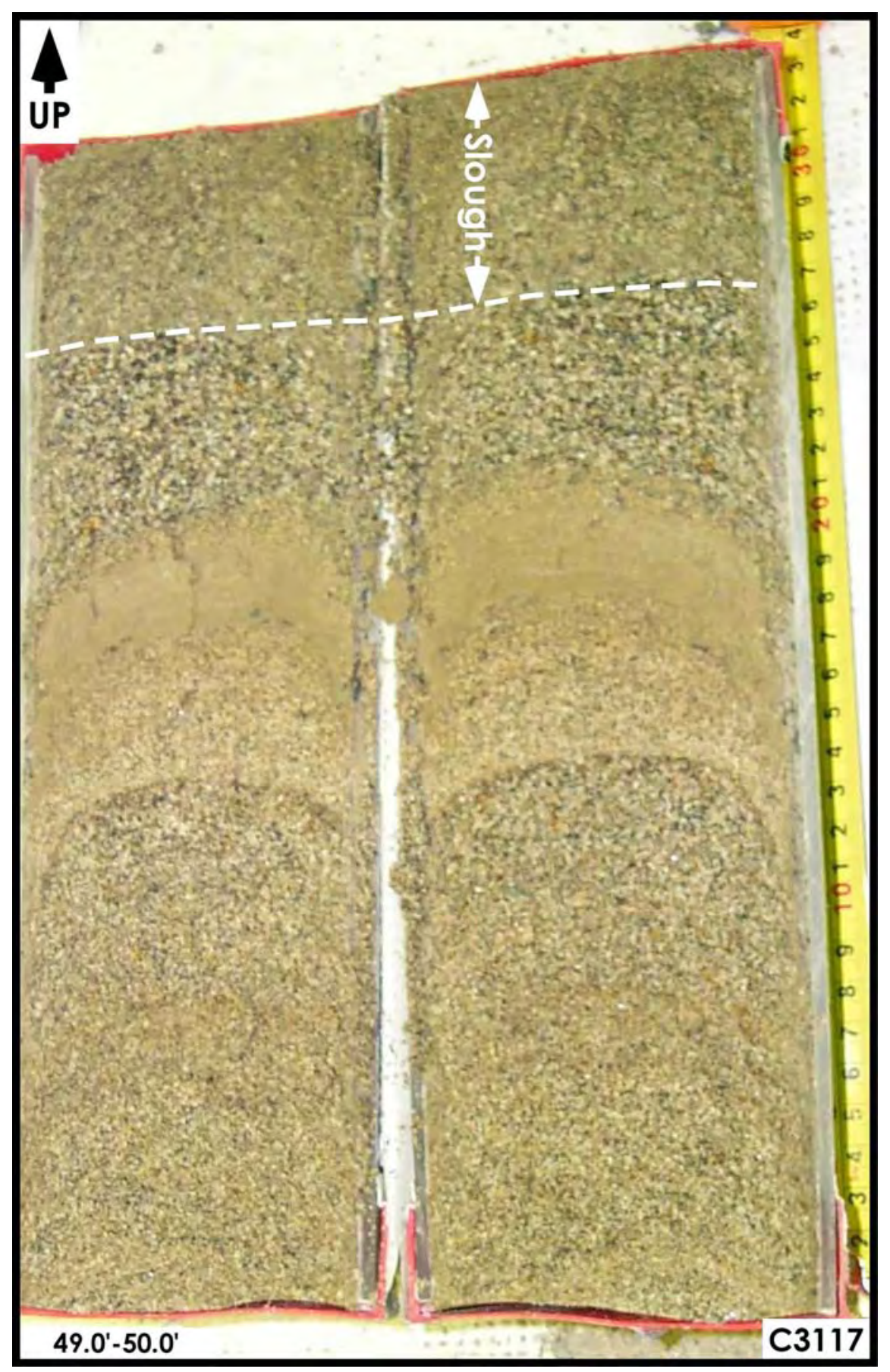

Figure A-1.16. Hanford Formation (H2 unit) $49.0 \mathrm{ft}-\mathbf{5 0 . 0} \mathrm{ft}$ 


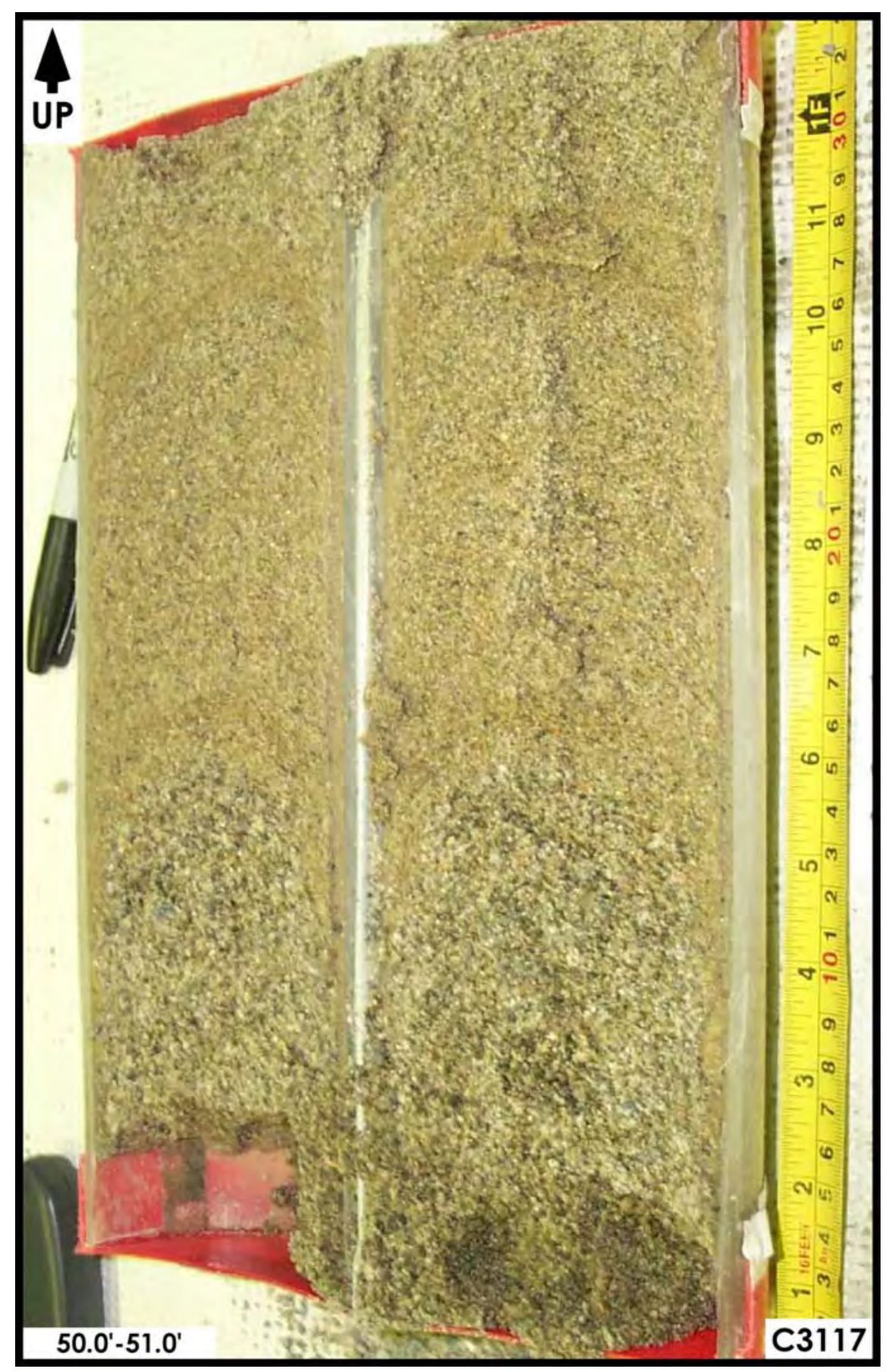

Figure A-1.17. Hanford Formation (H2 unit) $50.0 \mathrm{ft}-51.0 \mathrm{ft}$ 


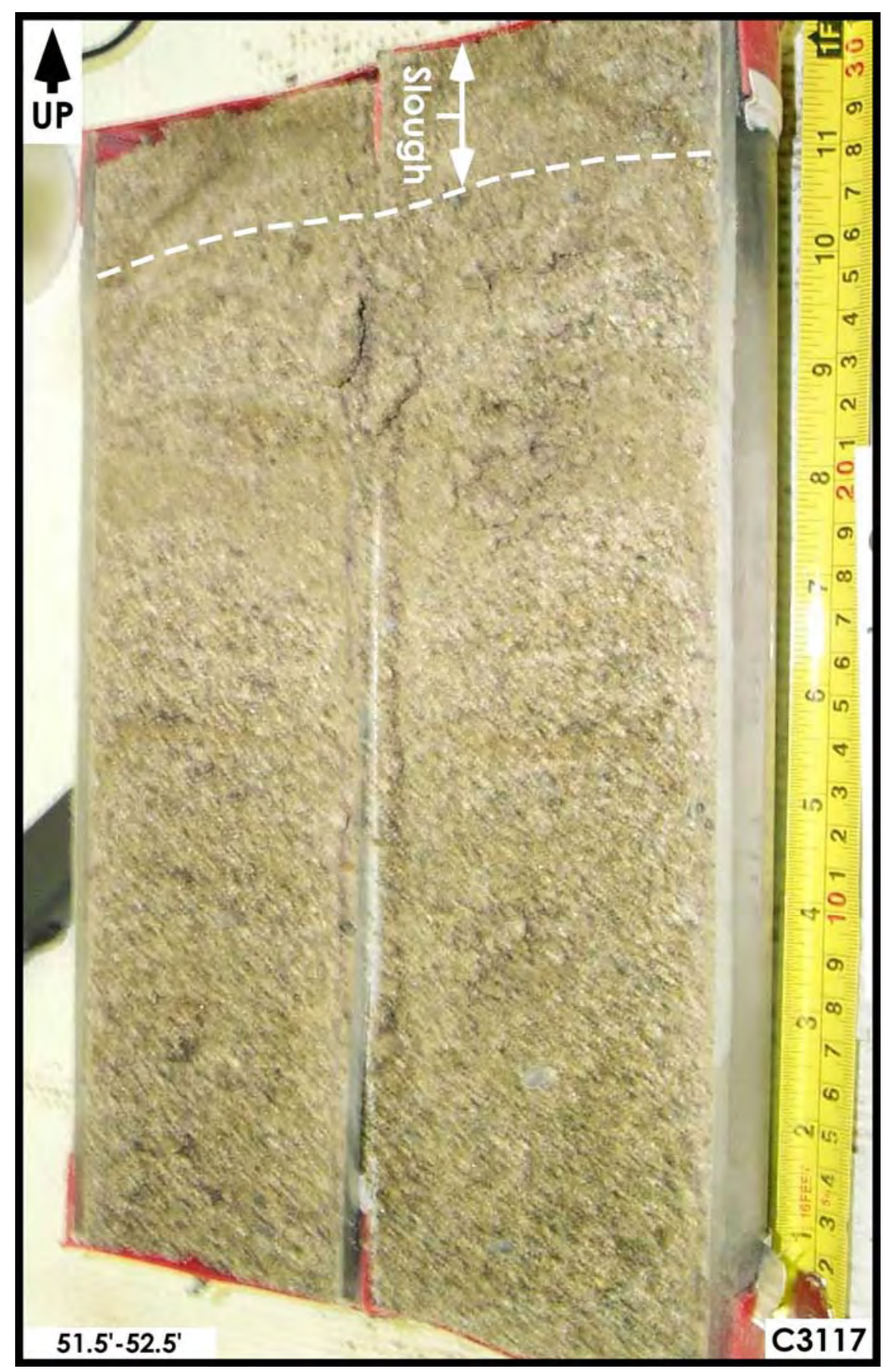

Figure A-1.18. Hanford Formation (H2 unit) $51.5 \mathrm{ft}-52.5 \mathrm{ft}$ 


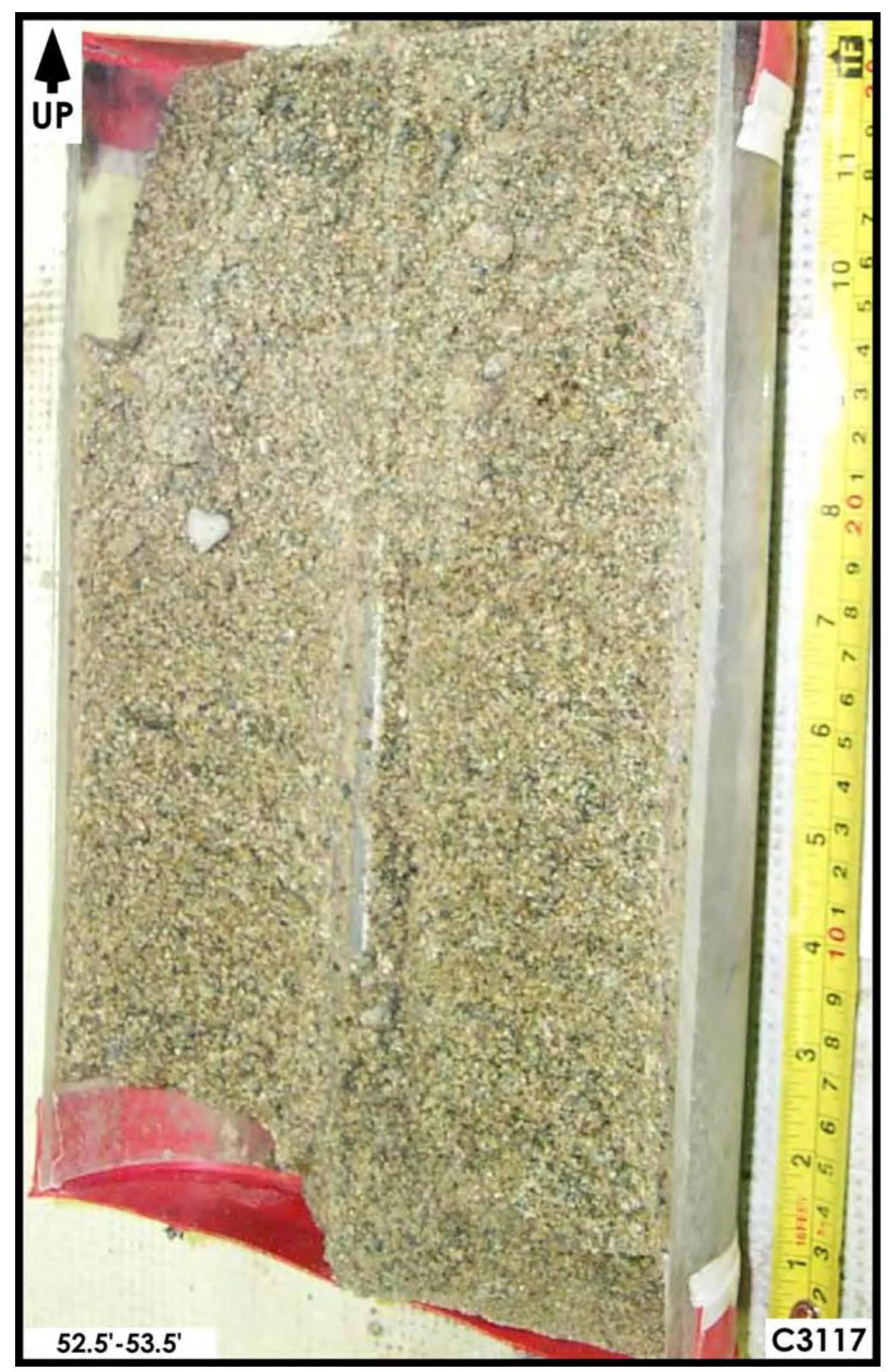

Figure A-1.19. Hanford Formation (H2 unit) $52.5 \mathrm{ft}-53.5 \mathrm{ft}$ 


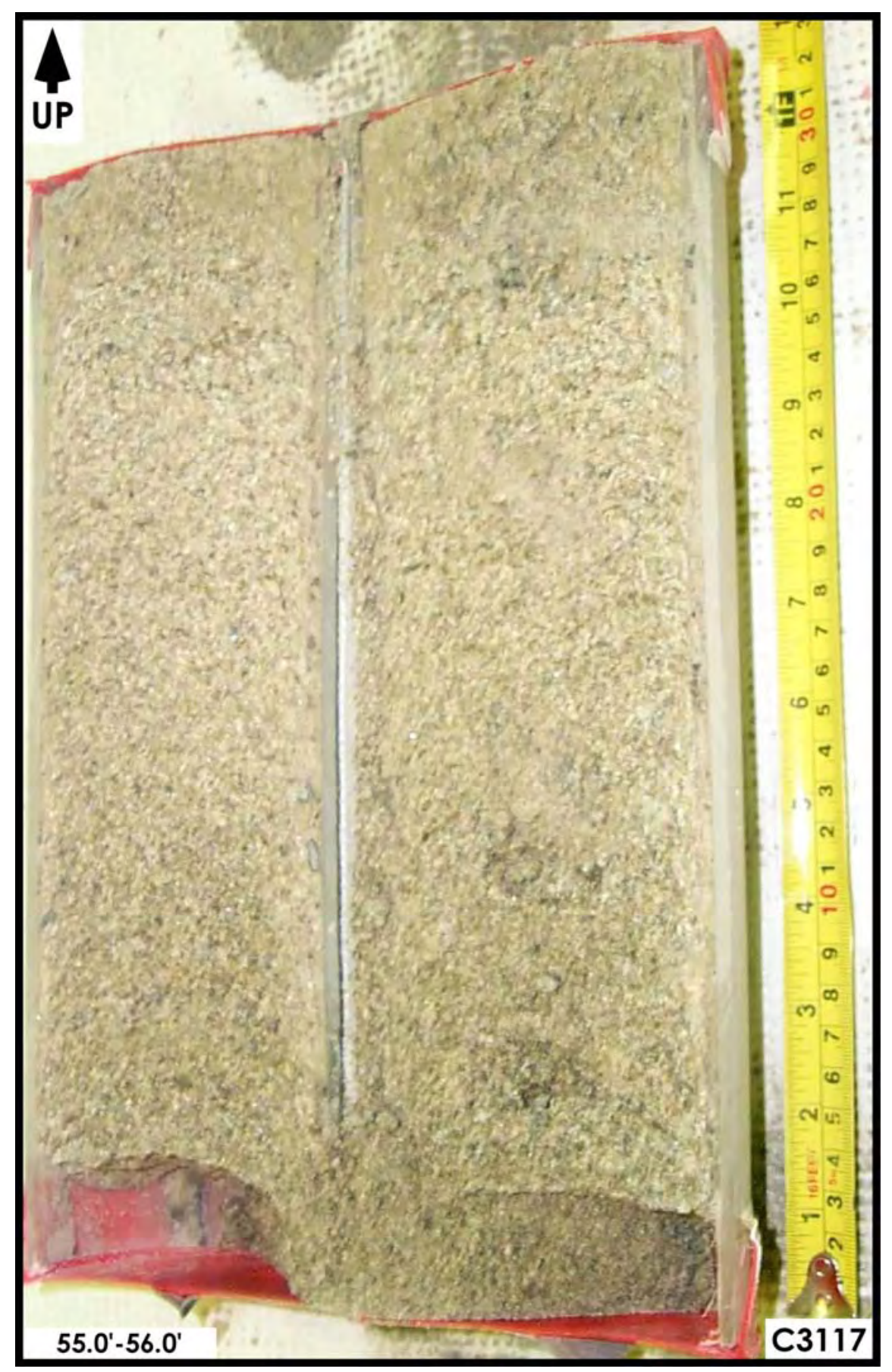

Figure A-1.20. Hanford Formation (H2 unit) $55.0 \mathrm{ft}-56.0 \mathrm{ft}$ 


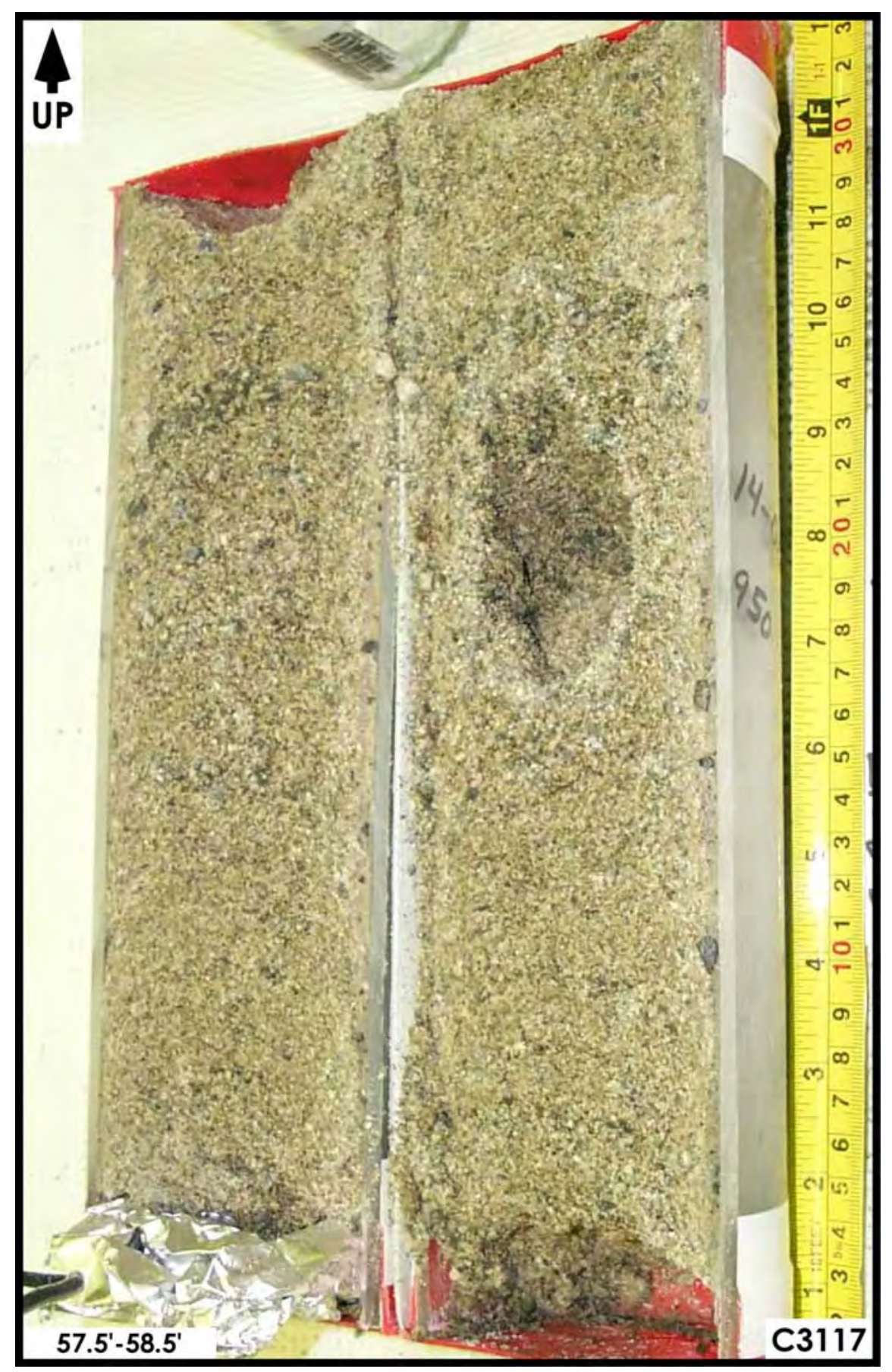

Figure A-1.21. Hanford Formation (H2 unit) $57.5 \mathrm{ft}-58.5 \mathrm{ft}$ 


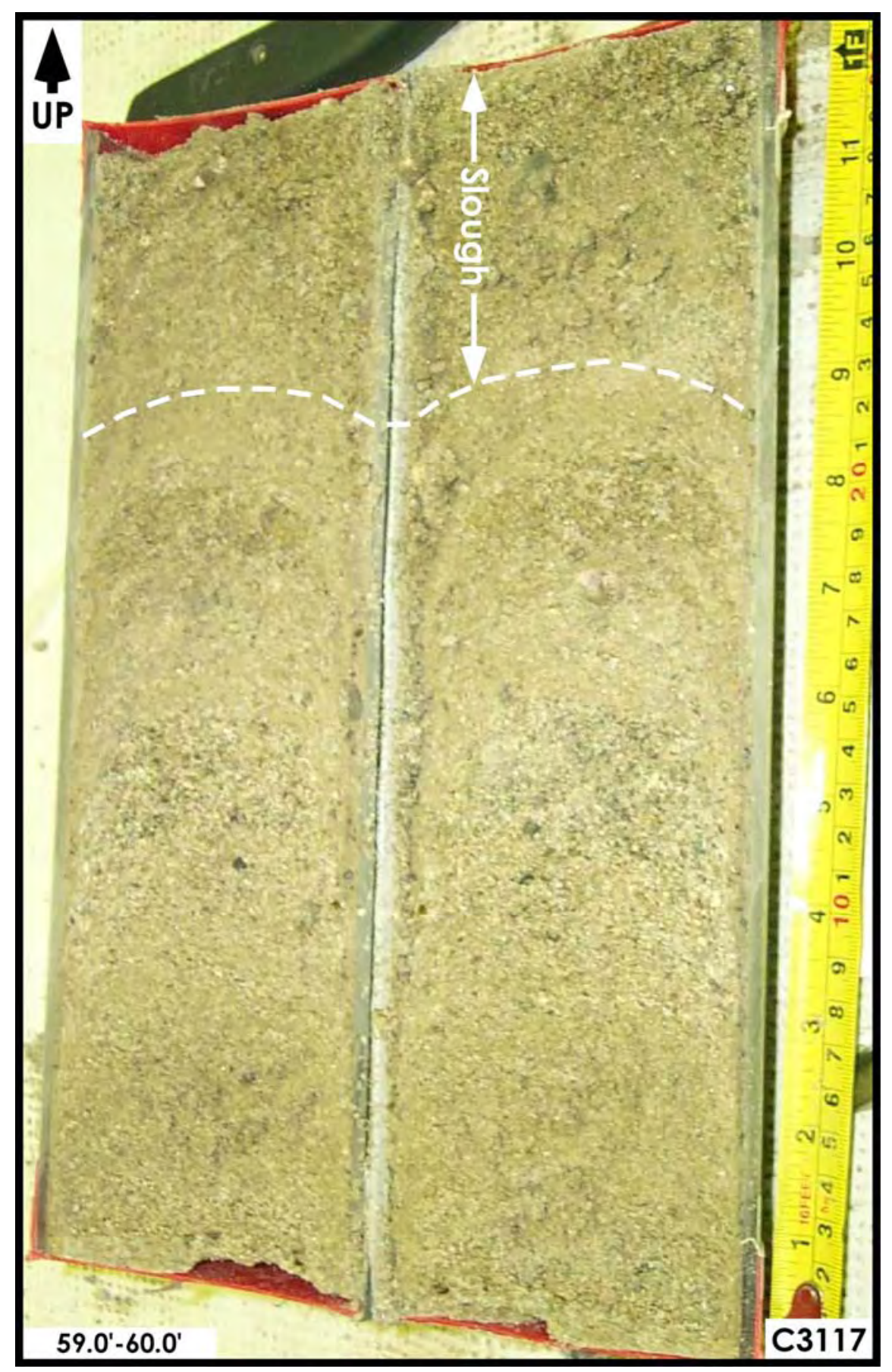

Figure A-1.22. Hanford Formation (H2 unit) $59.0 \mathrm{ft}-60.0 \mathrm{ft}$ 


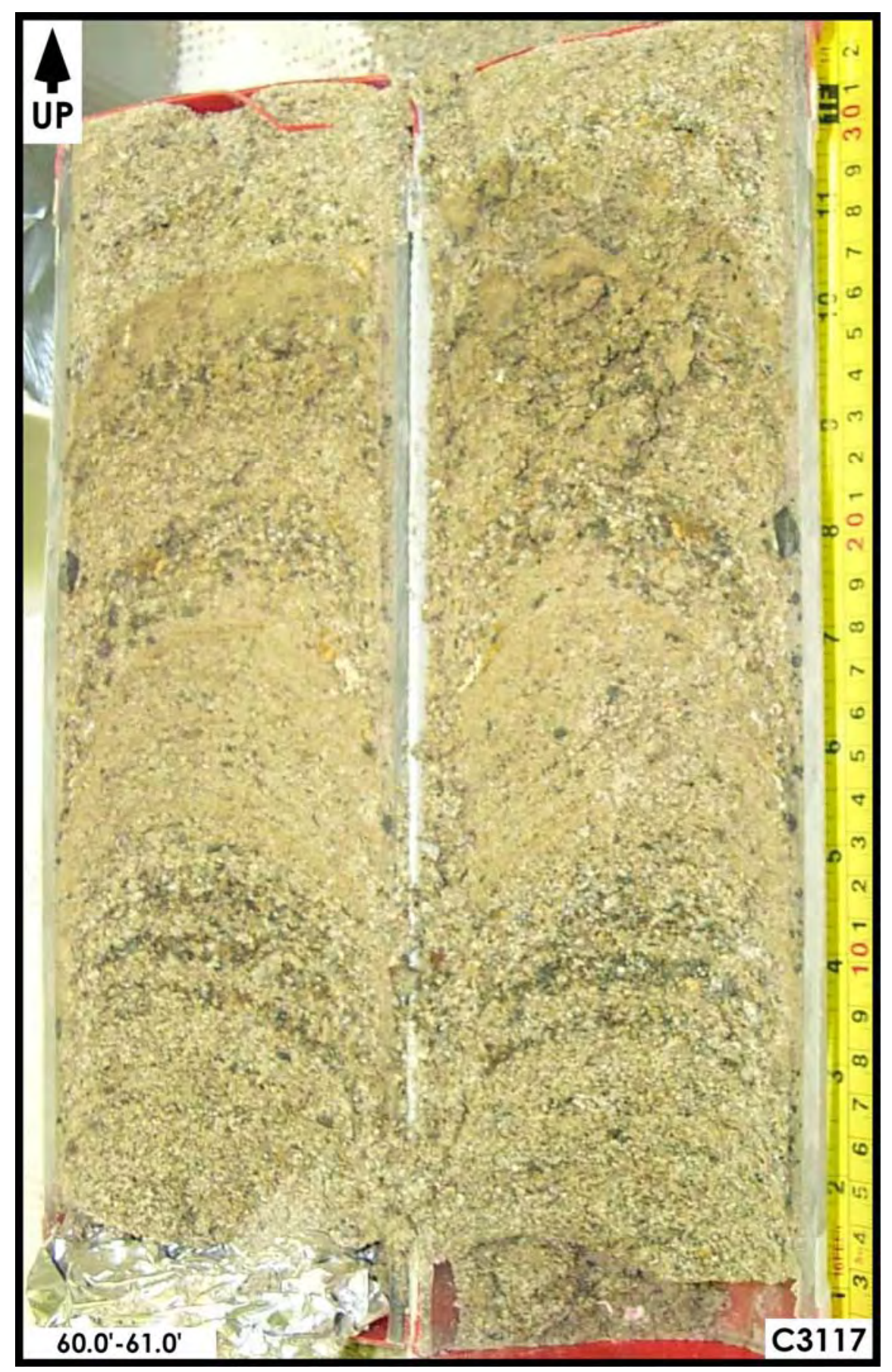

Figure A-1.23. Hanford Formation (H2 unit) $60.0 \mathrm{ft}-61.0 \mathrm{ft}$ 


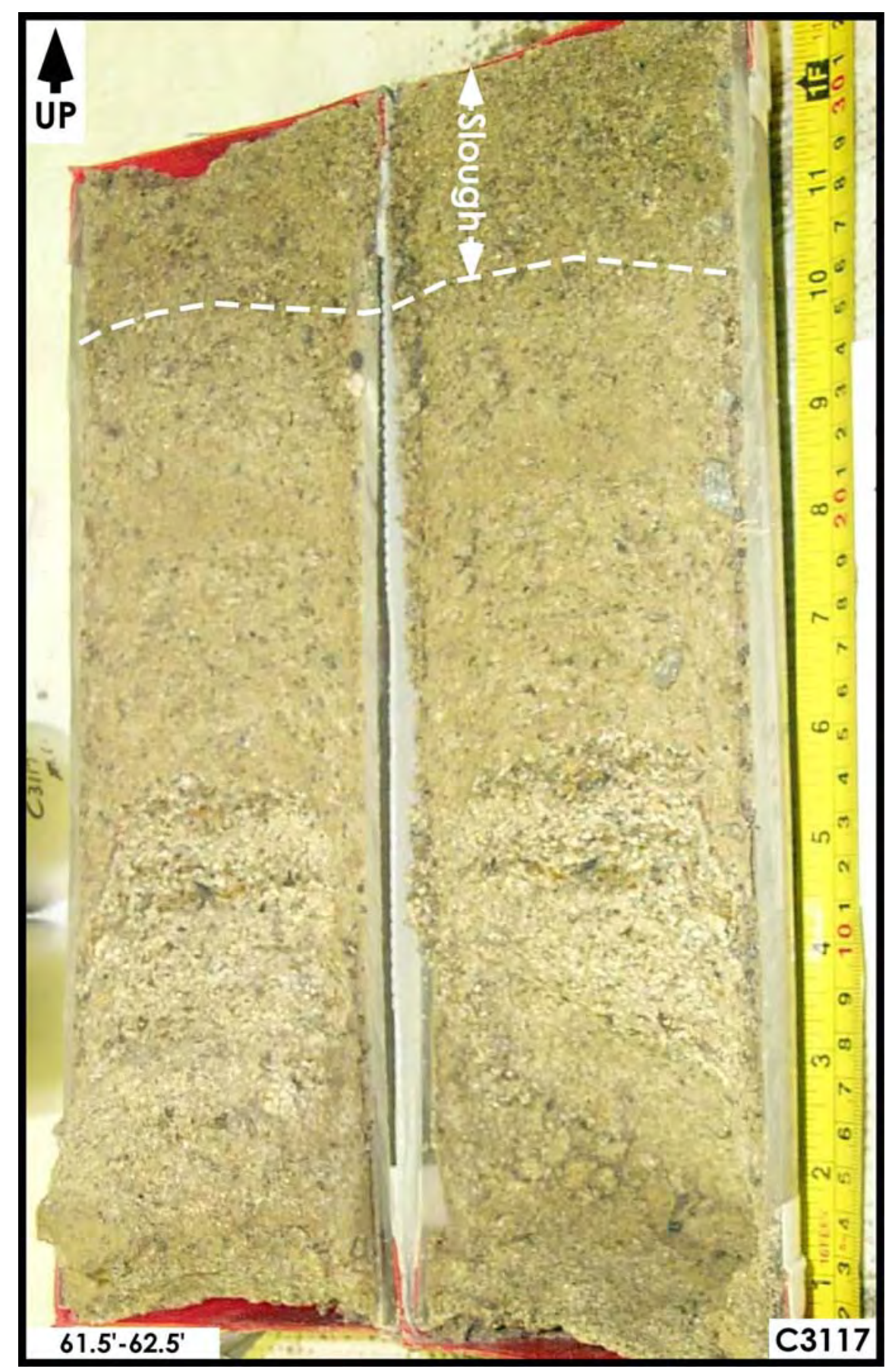

Figure A-1.24. Hanford Formation (H2 unit) $61.5 \mathrm{ft}-62.5 \mathrm{ft}$ 


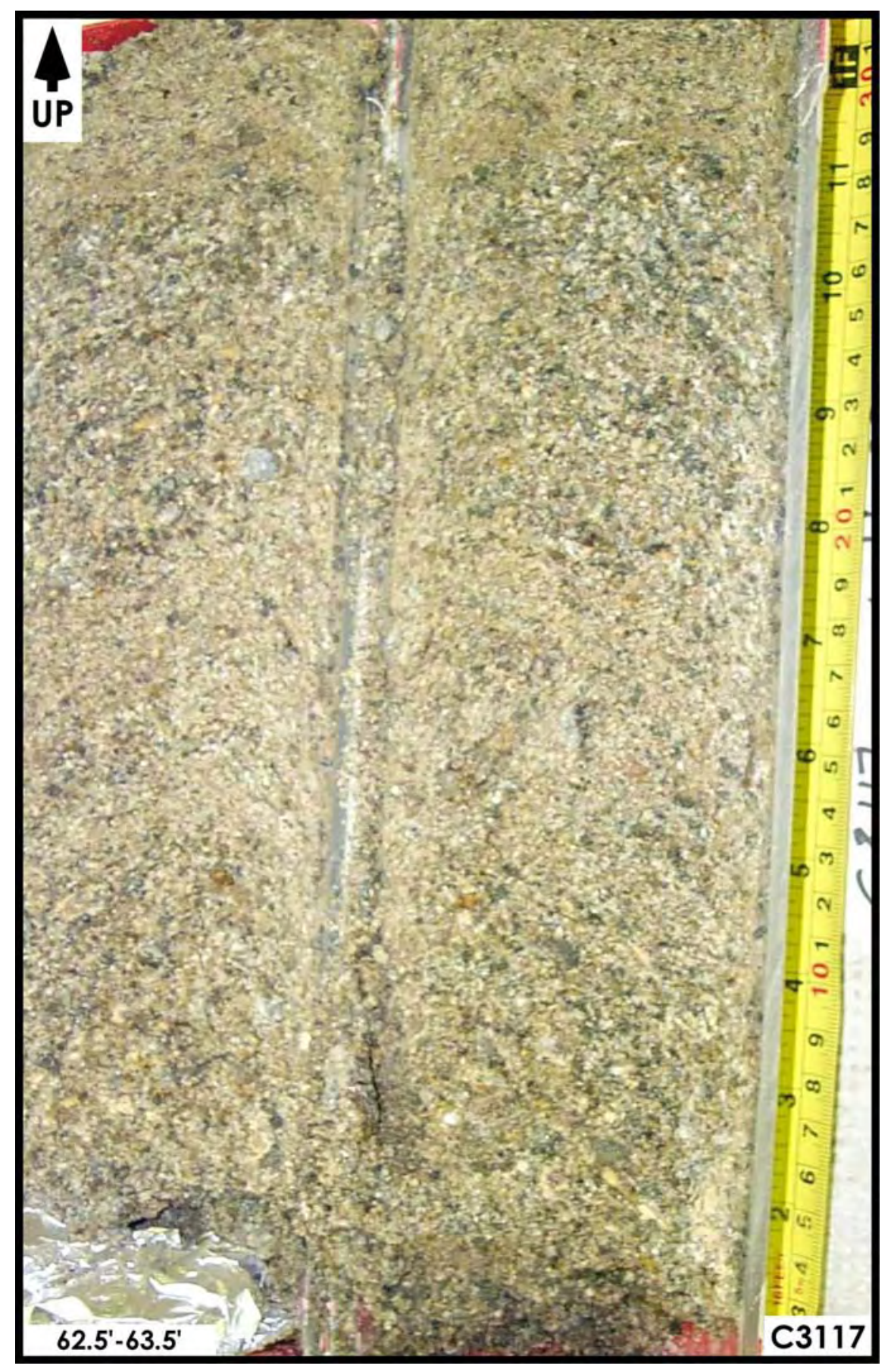

Figure A-1.25. Hanford Formation (H2 unit) $62.5 \mathrm{ft}-63.5 \mathrm{ft}$ 


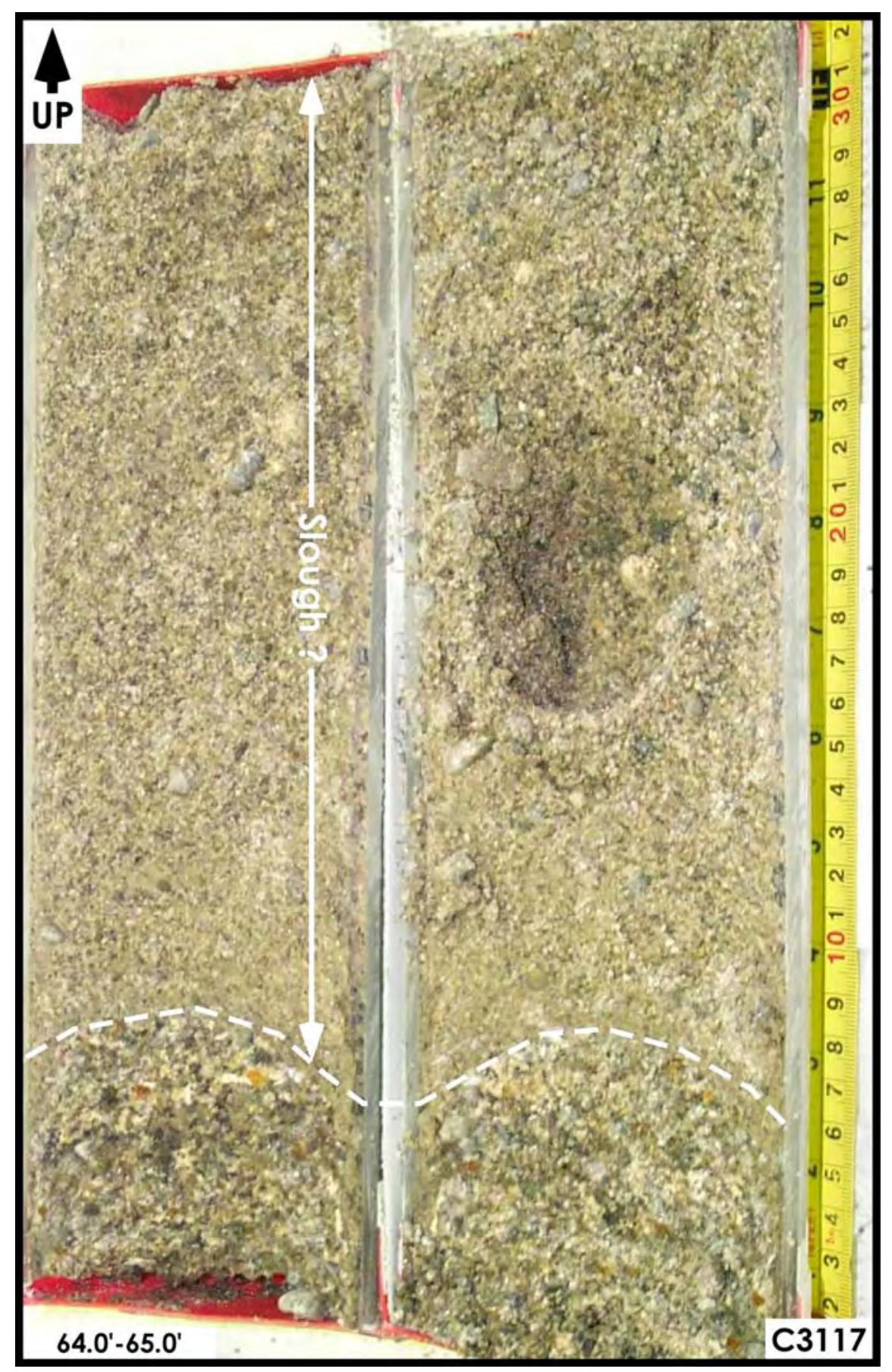

Figure A-1.26. Hanford Formation (H2 unit) $64.0 \mathrm{ft}-65.0 \mathrm{ft}$ 


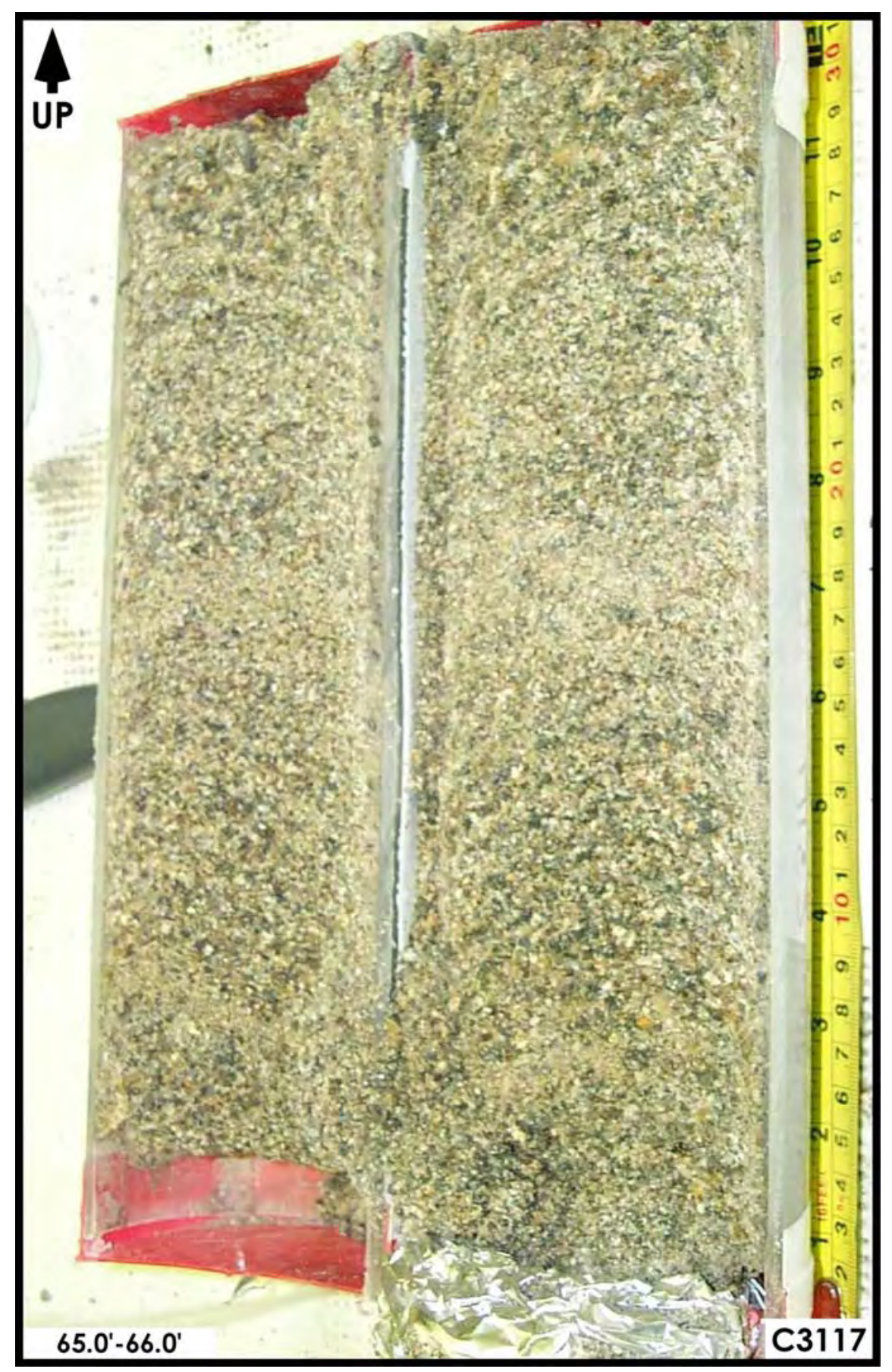

Figure A-1.27. Hanford Formation (H2 unit) $65.0 \mathrm{ft}-66.0 \mathrm{ft}$ 


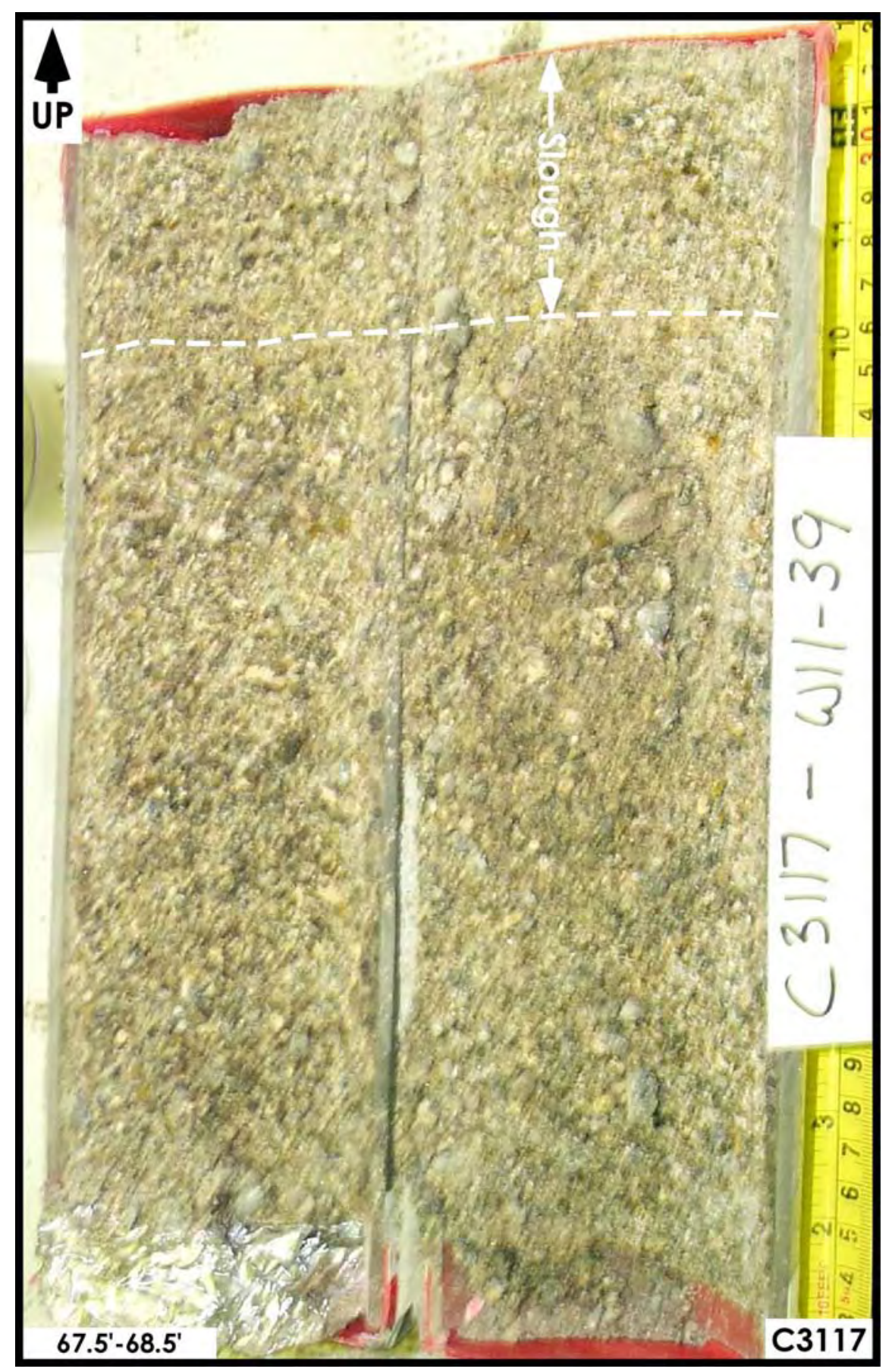

Figure A-1.28. Hanford Formation (H2 unit) $67.5 \mathrm{ft}-68.5 \mathrm{ft}$ 


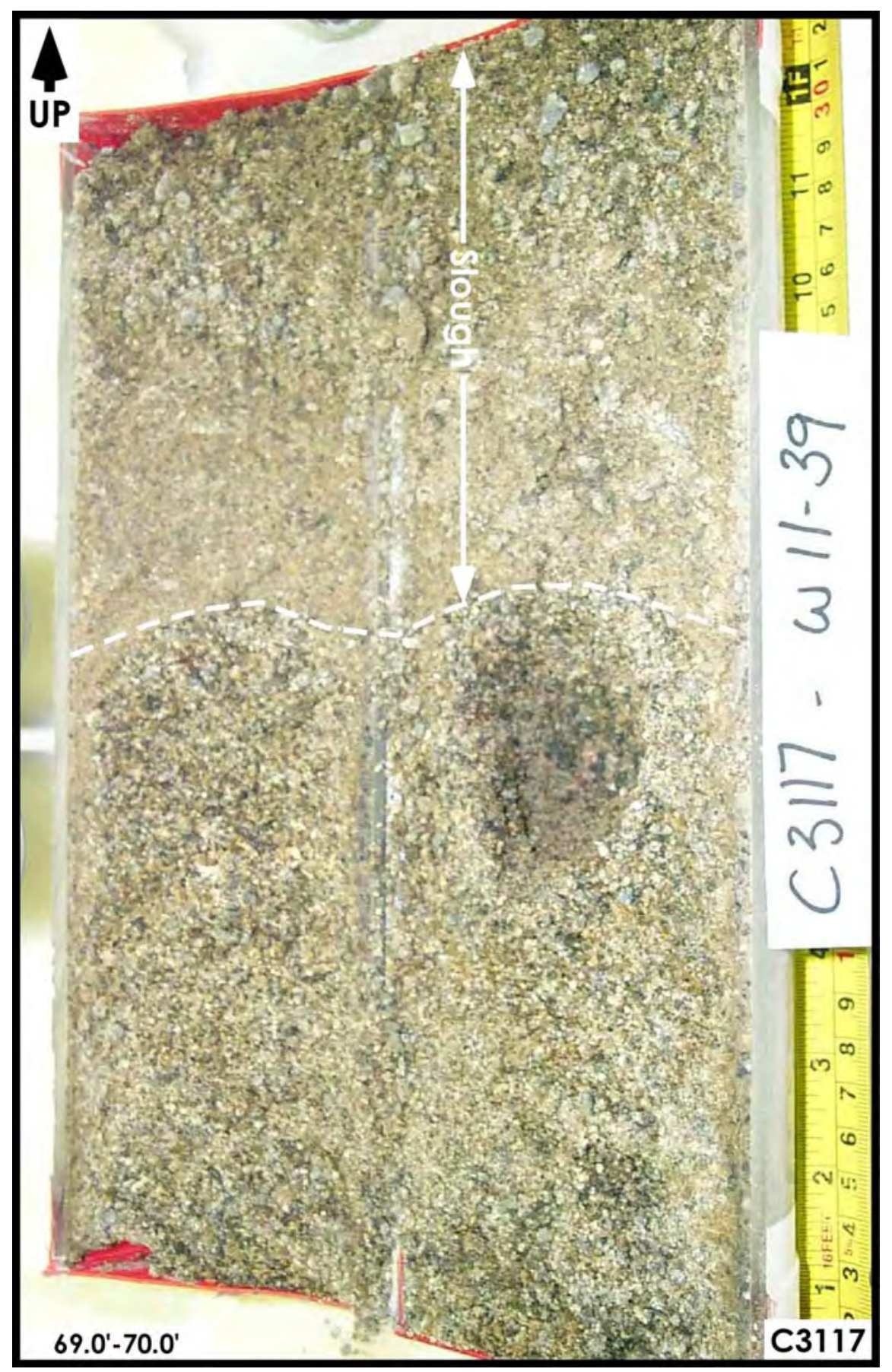

Figure A-1.29. Hanford Formation (H2 unit) $69.0 \mathrm{ft}-70.0 \mathrm{ft}$ 


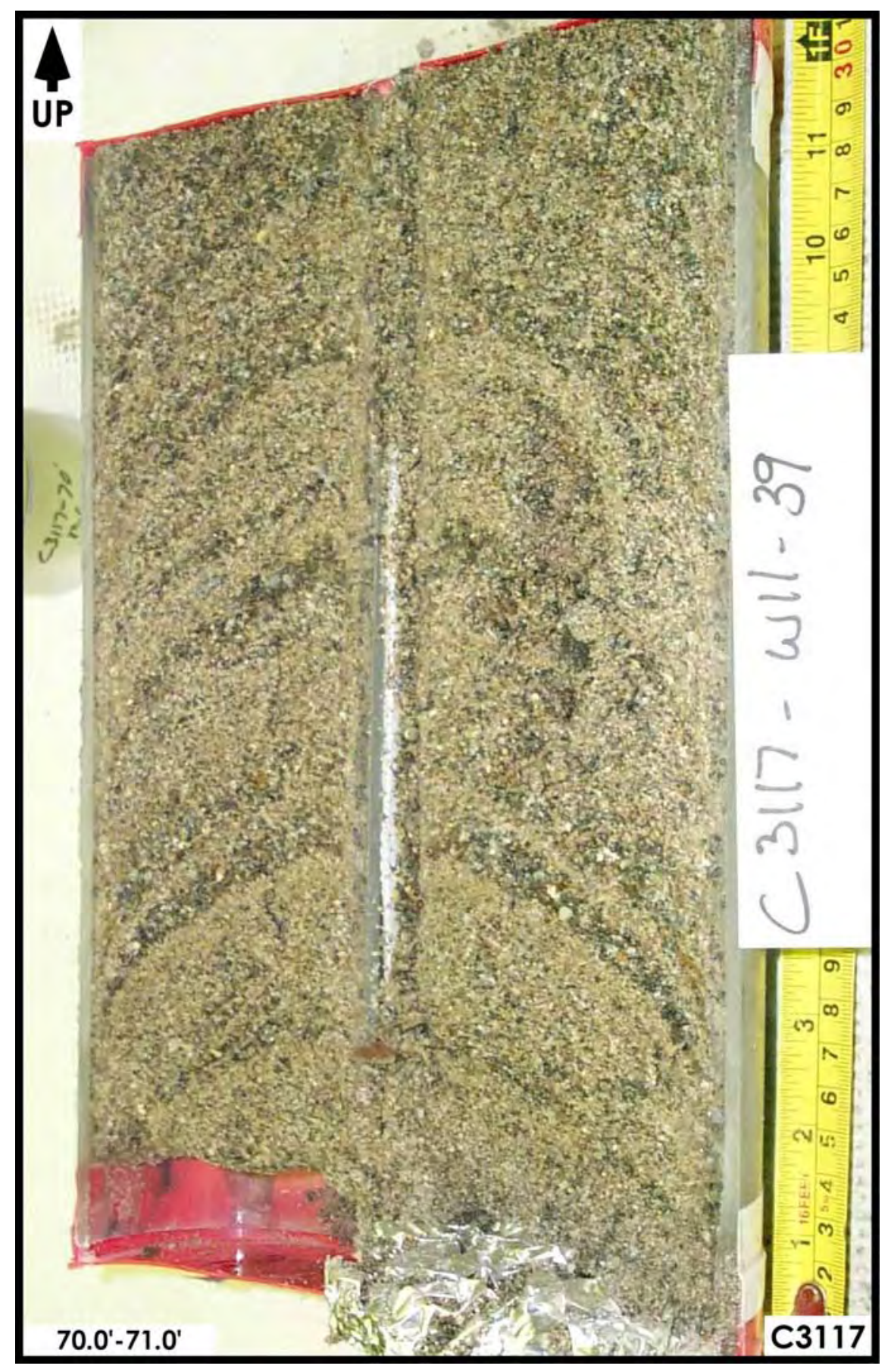

Figure A-1.30. Hanford Formation (H2 unit) $70.0 \mathrm{ft}-71.0 \mathrm{ft}$ 


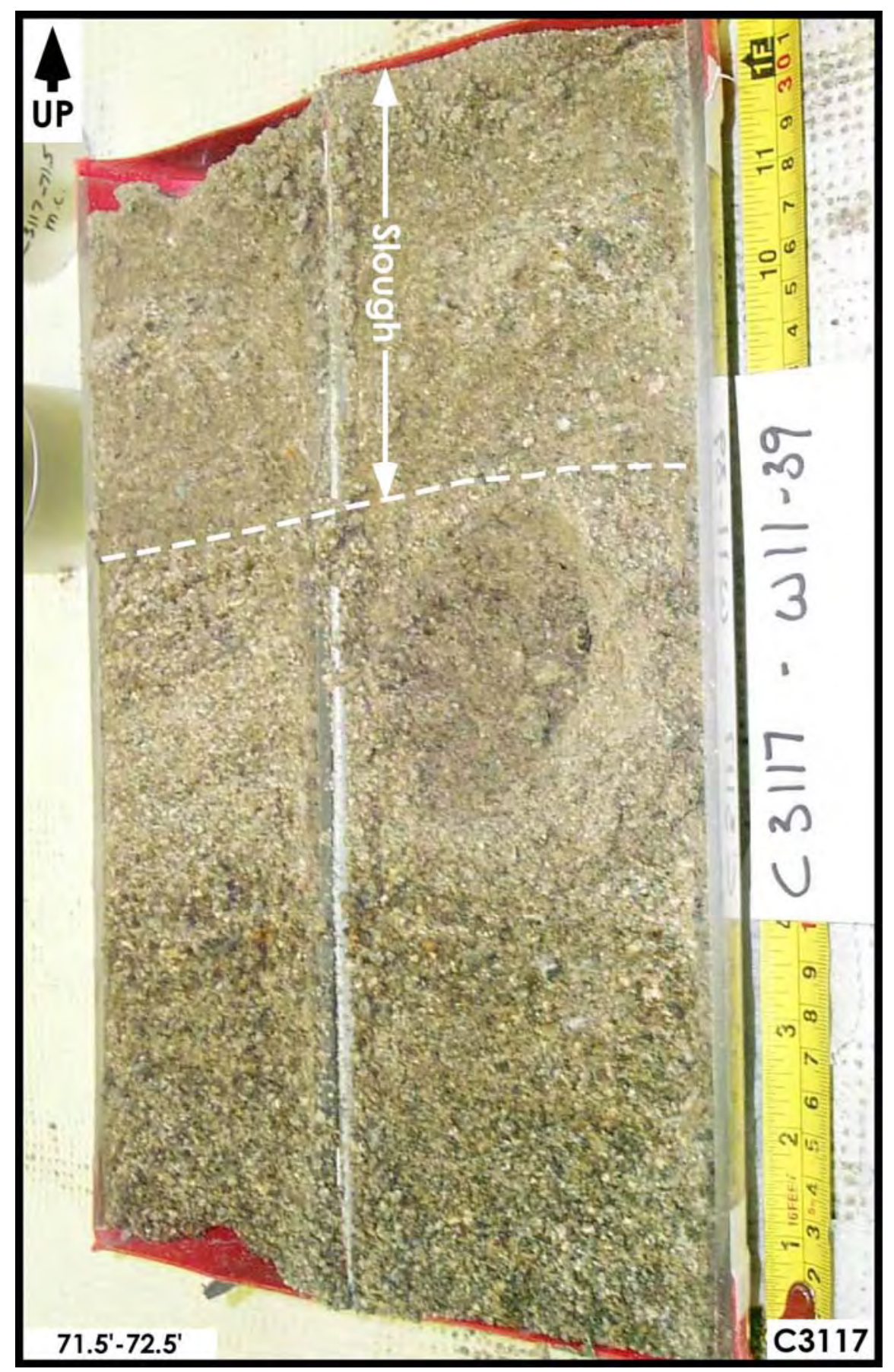

Figure A-1.31. Hanford Formation (H2 unit) $71.5 \mathrm{ft}-72.5 \mathrm{ft}$ 


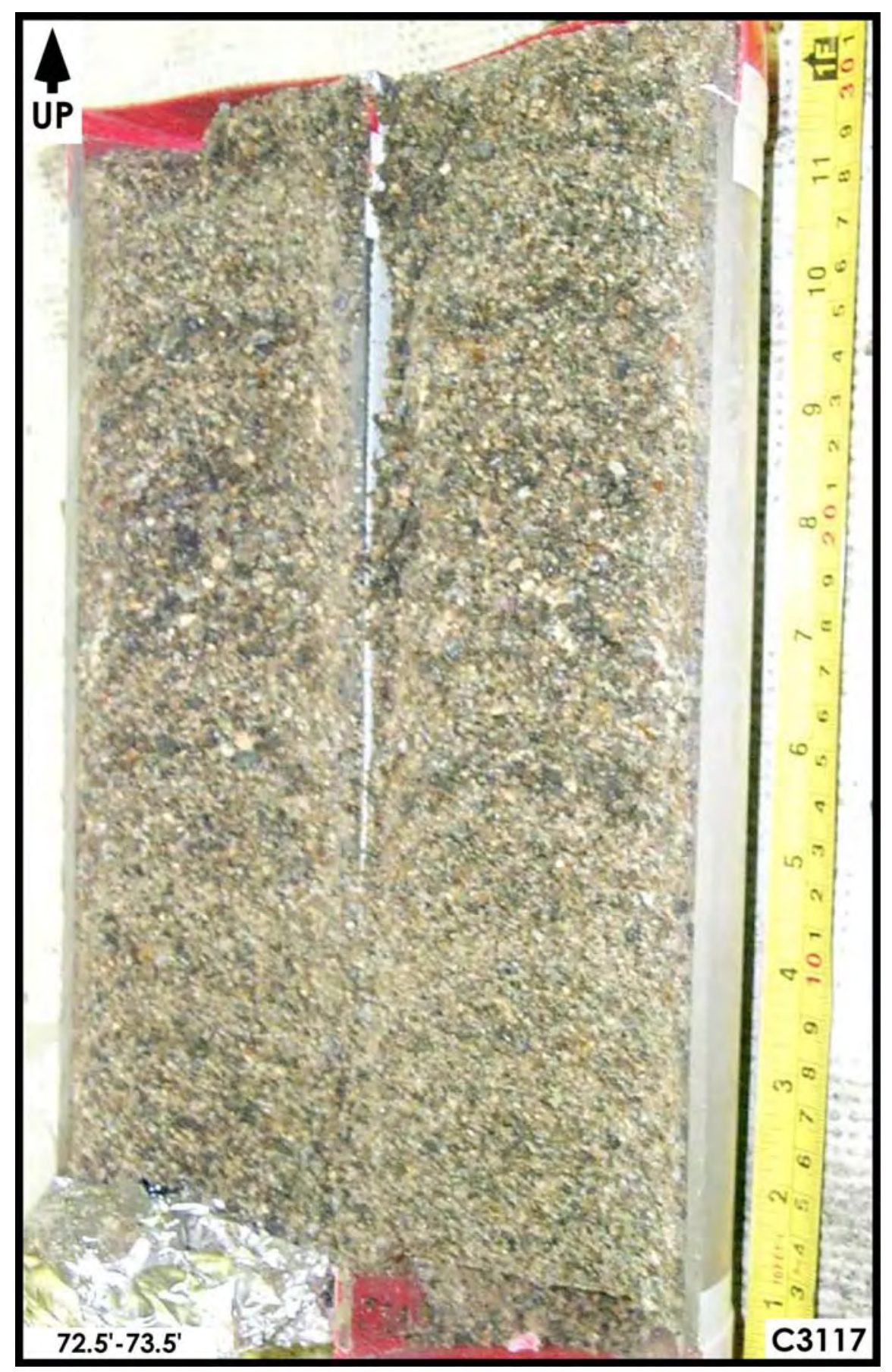

Figure A-1.32. Hanford Formation (H2 unit) 72.5 ft - 73.5 ft 


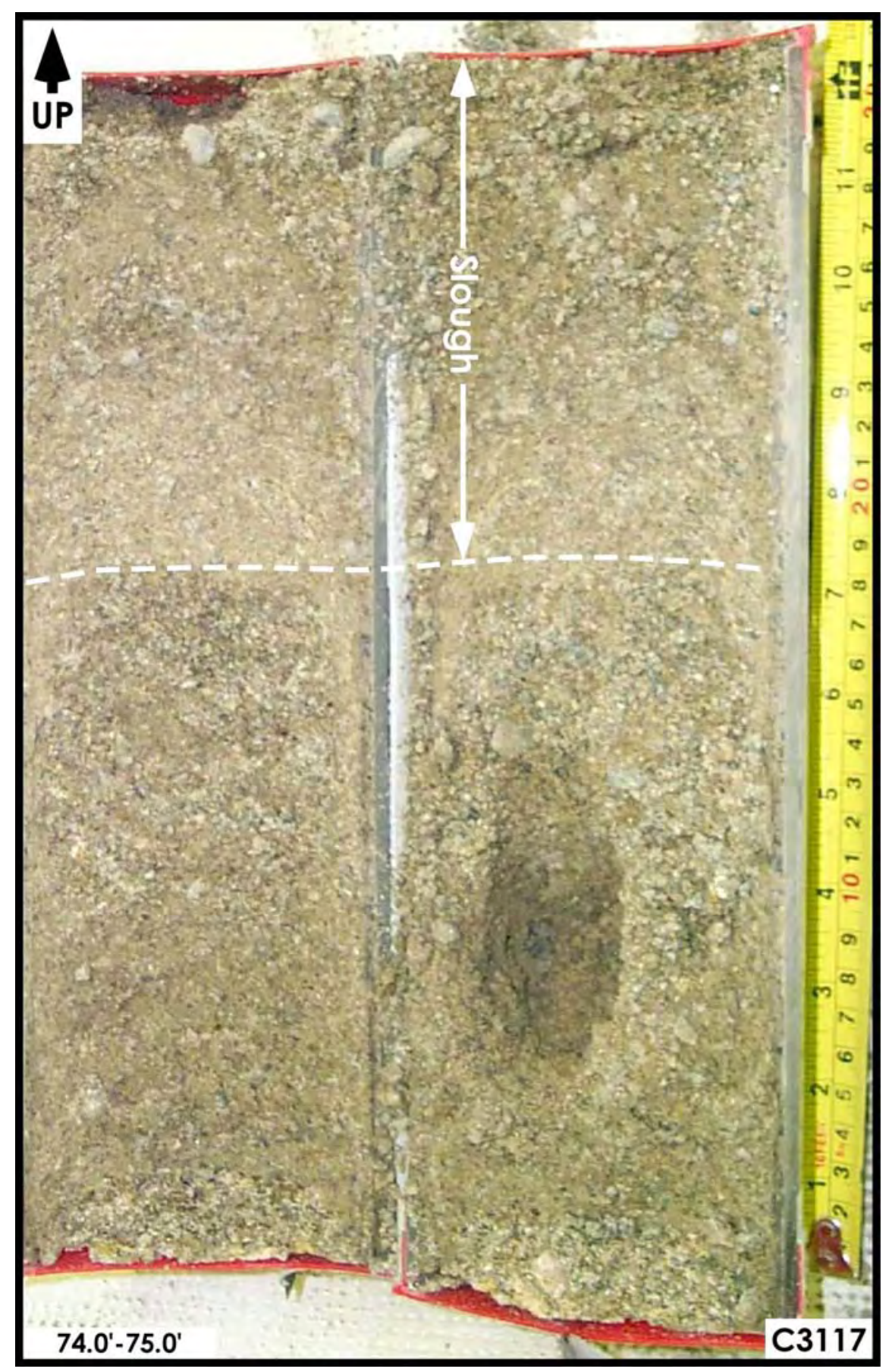

Figure A-1.33. Hanford Formation (H2 unit) $74.0 \mathrm{ft}-75.0 \mathrm{ft}$ 


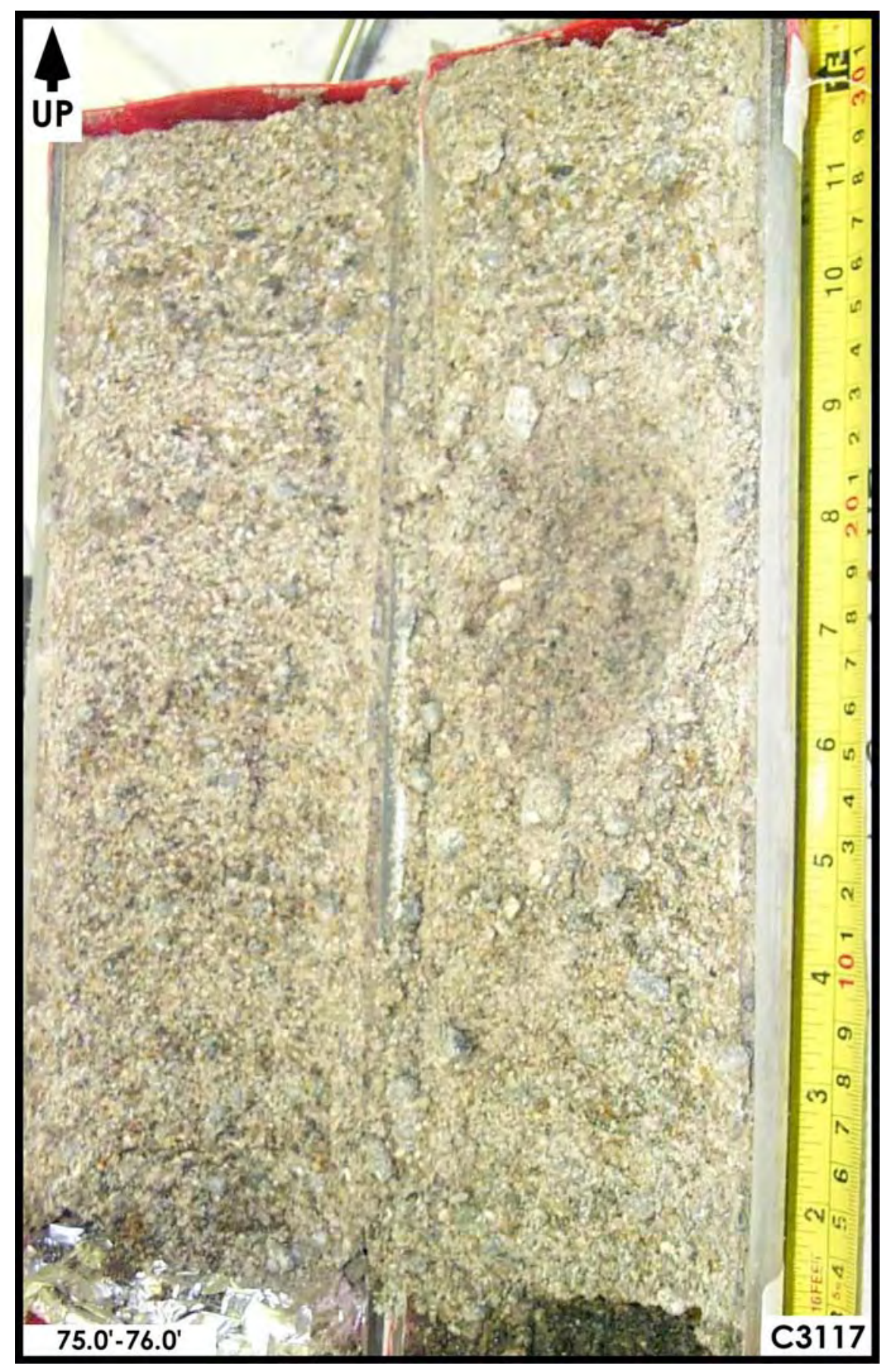

Figure A-1.34. Hanford Formation (H2 unit) $75.0 \mathrm{ft}-76.0 \mathrm{ft}$ 


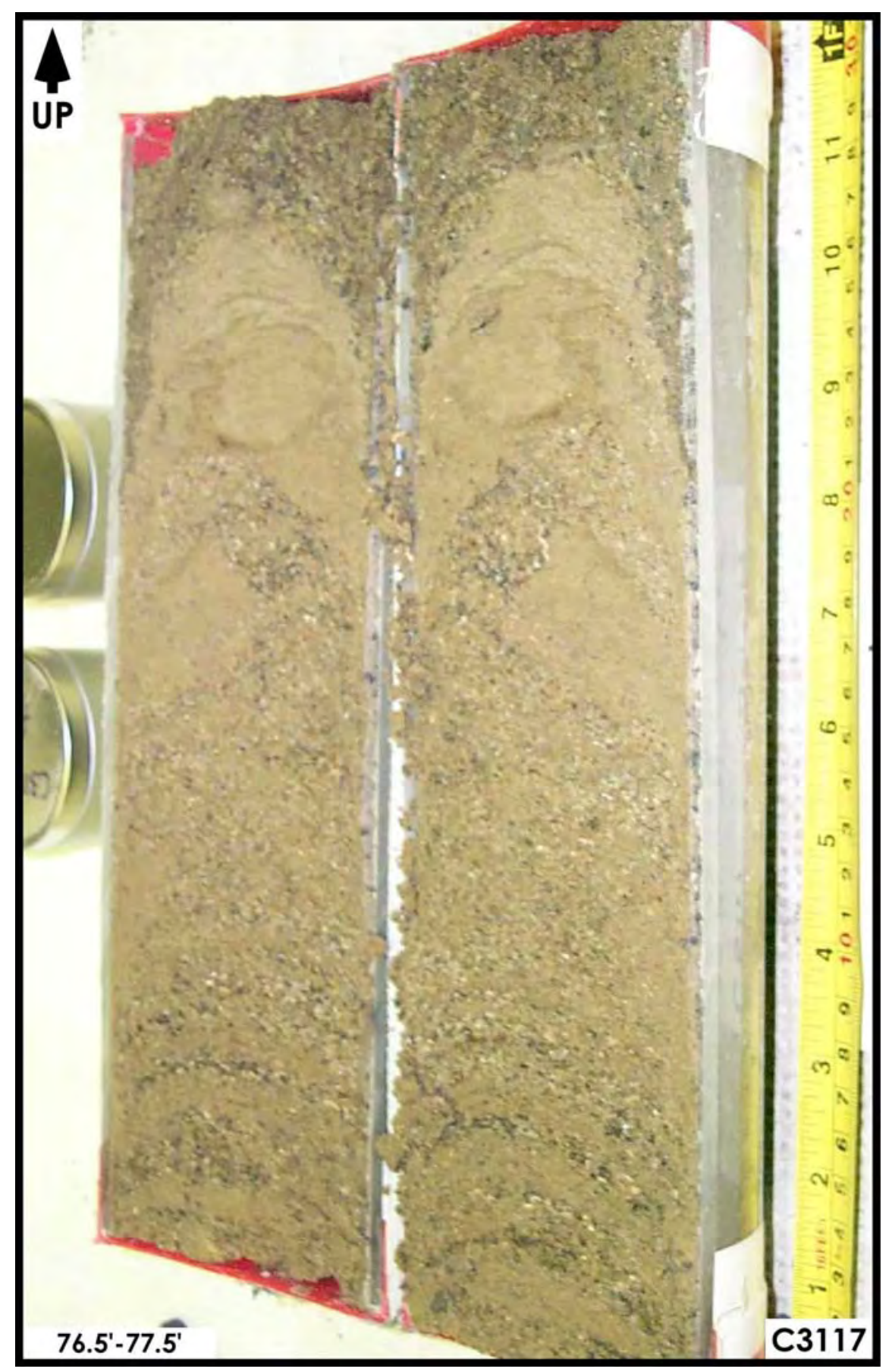

Figure A-1.35. Hanford Formation (H2 unit) $76.5 \mathrm{ft}-77.5 \mathrm{ft}$ 


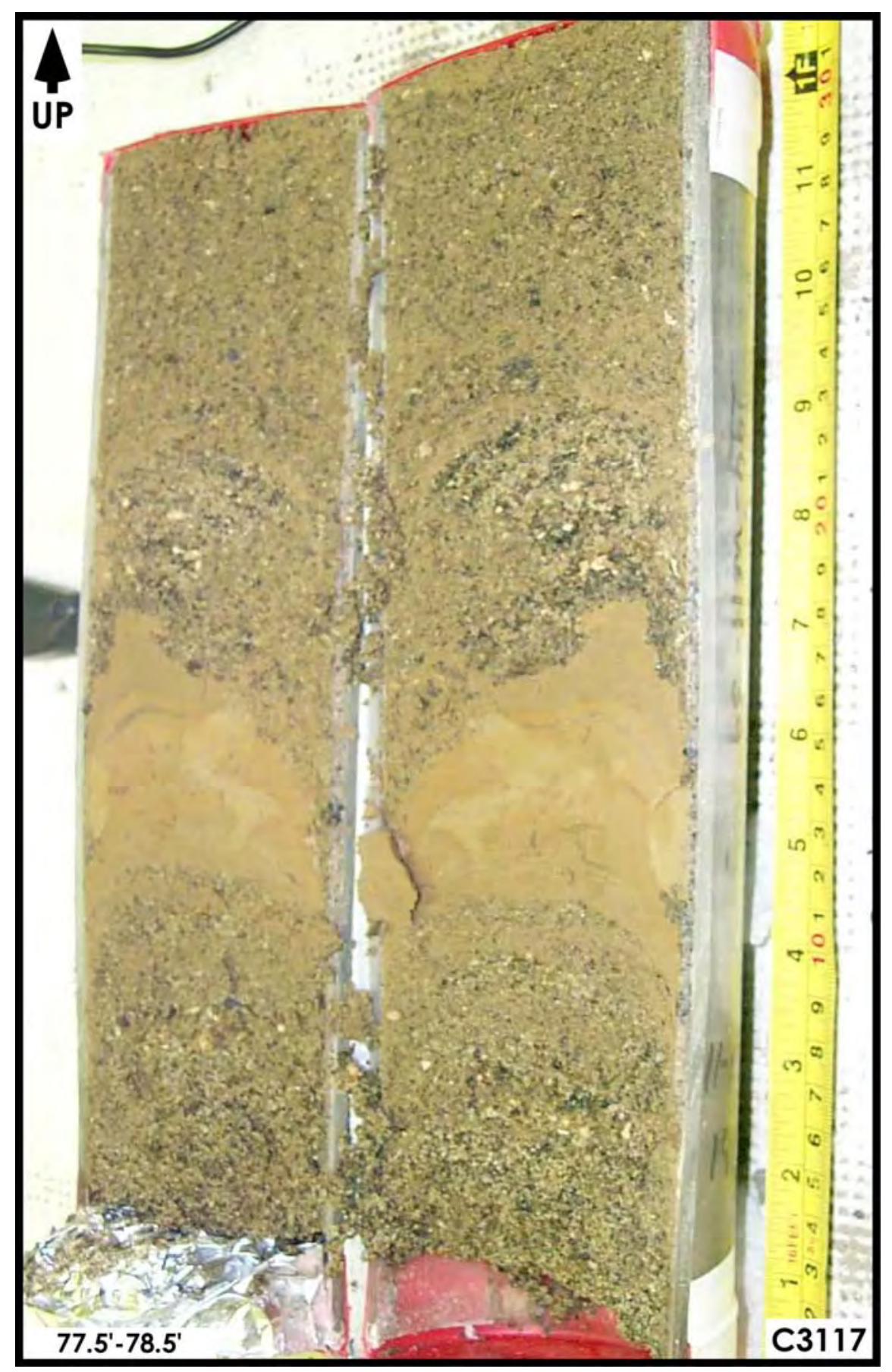

Figure A-1.36. Hanford Formation (H2 unit) 77.5 ft - 78.5 ft 


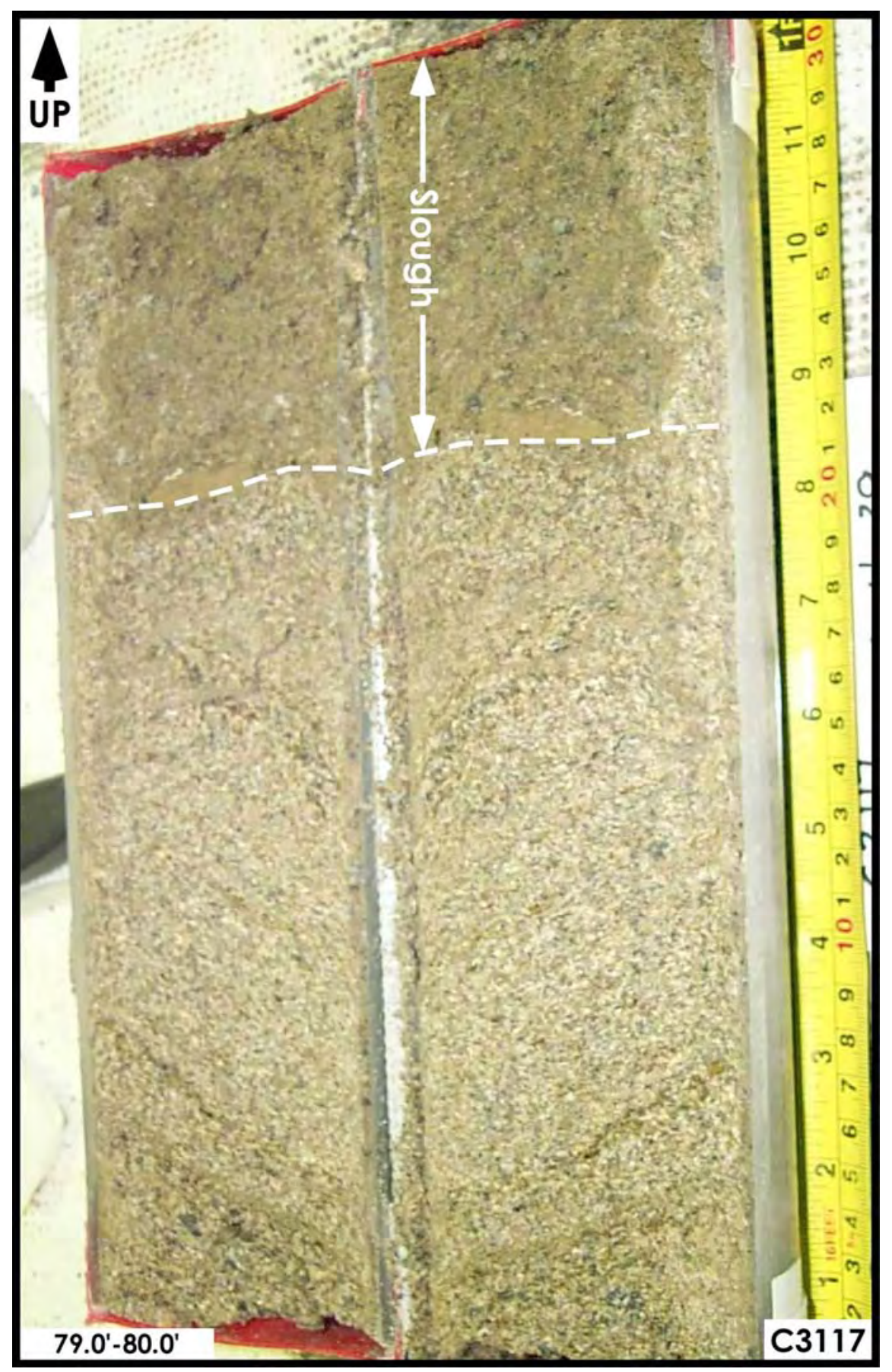

Figure A-1.37. Hanford Formation (H2 unit) $79.0 \mathrm{ft}-\mathbf{8 0 . 0} \mathrm{ft}$ 


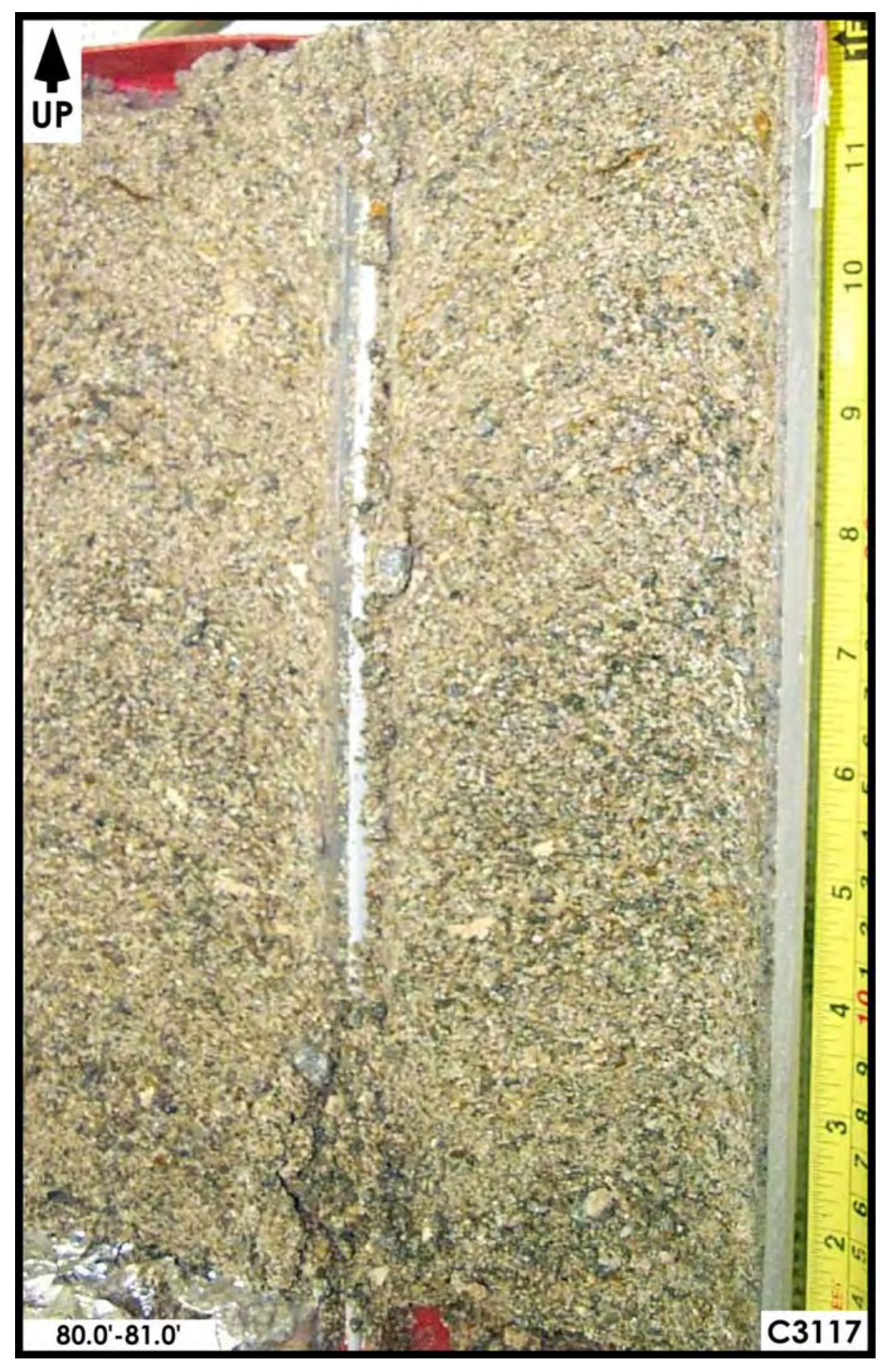

Figure A-1.38. Hanford Formation (H2 unit) $80.0 \mathrm{ft}-\mathbf{8 1 . 0} \mathrm{ft}$ 


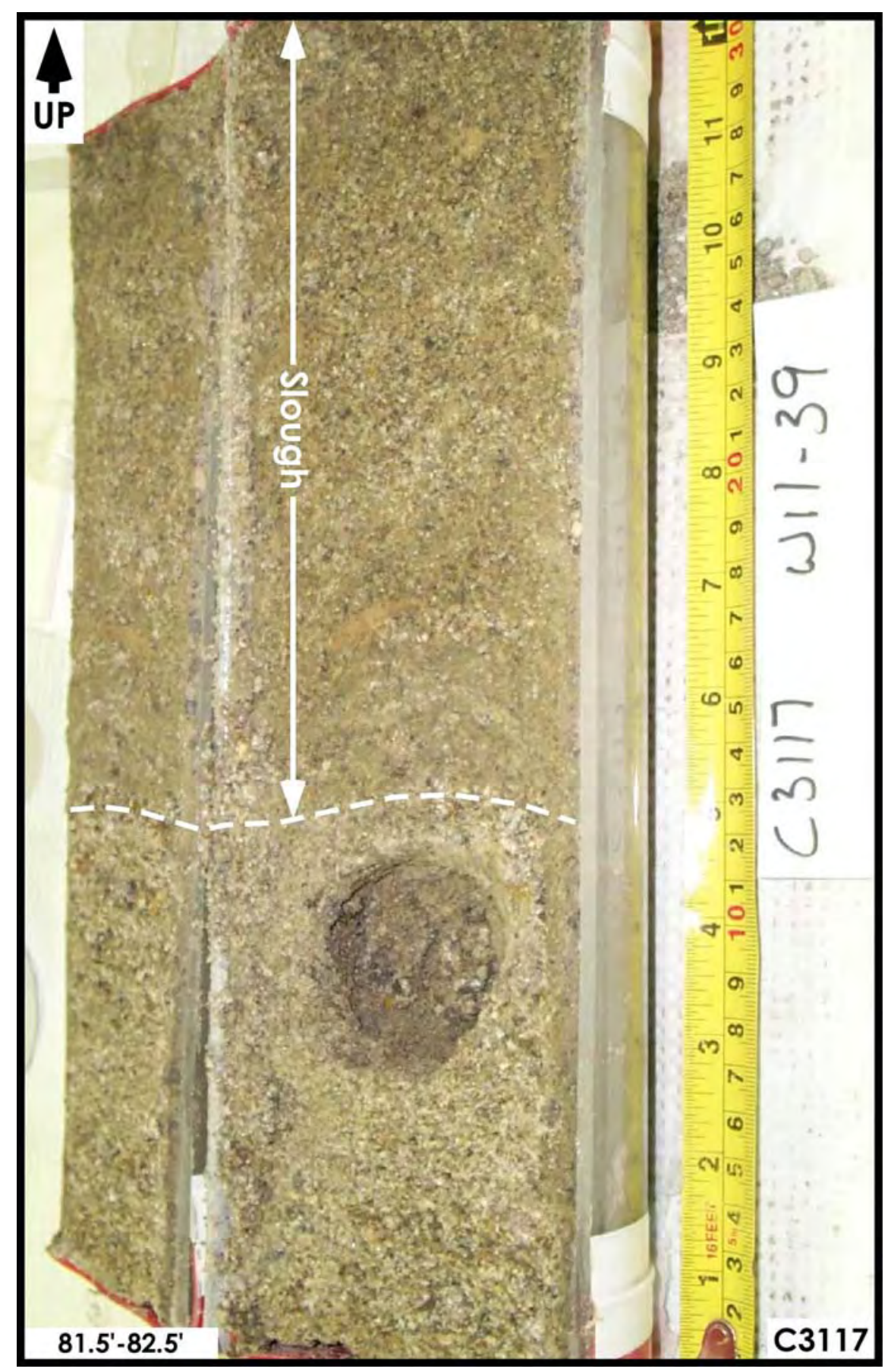

Figure A-1.39. Hanford Formation (H2 unit) $81.5 \mathrm{ft}-\mathbf{8 2 . 5} \mathrm{ft}$ 


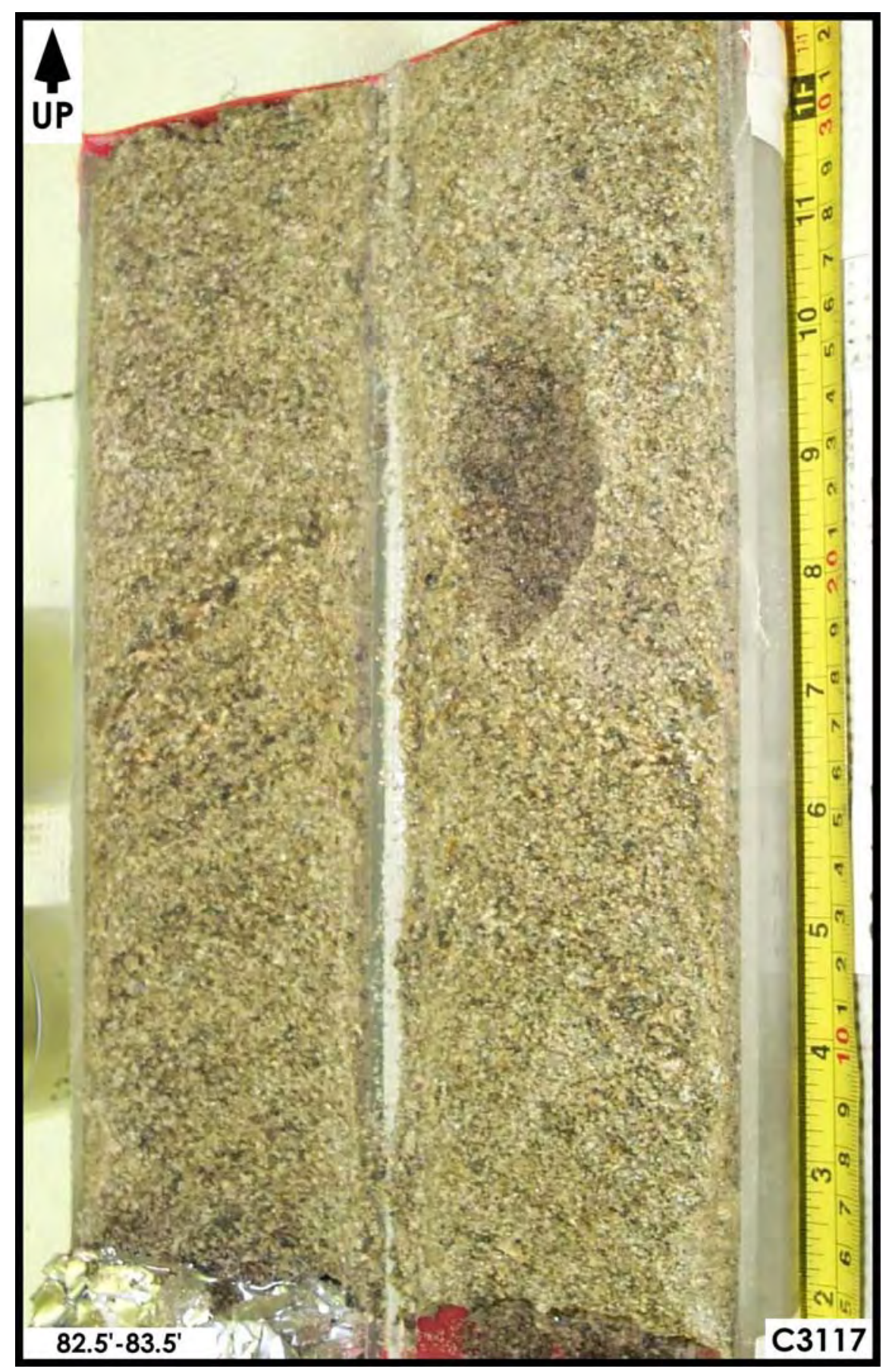

Figure A-1.40. Hanford Formation (H2 unit) $82.5 \mathrm{ft}-83.5 \mathrm{ft}$ 


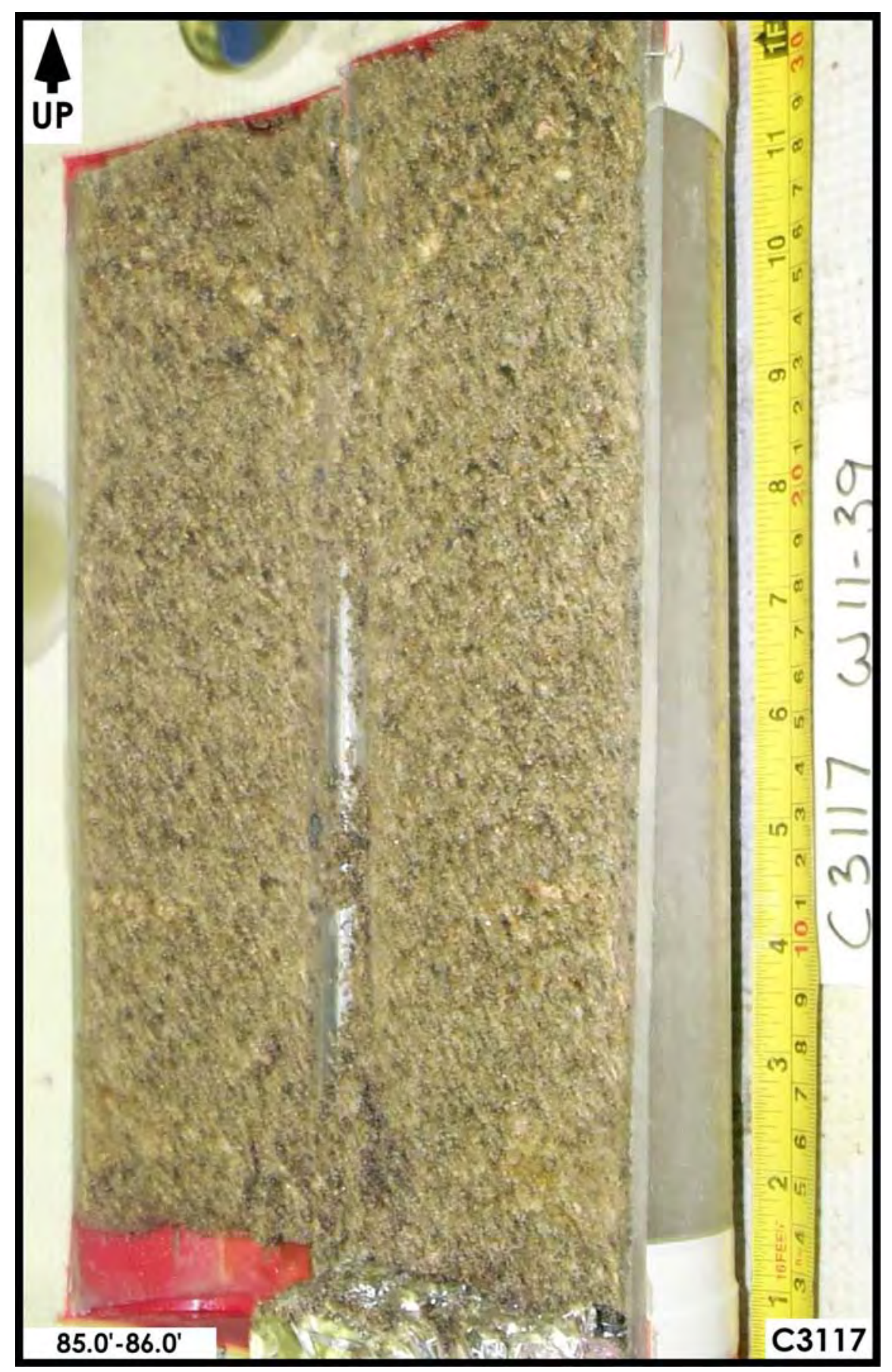

Figure A-1.41. Hanford Formation (H2 unit) $85.0 \mathrm{ft}-\mathbf{8 6 . 0} \mathrm{ft}$ 


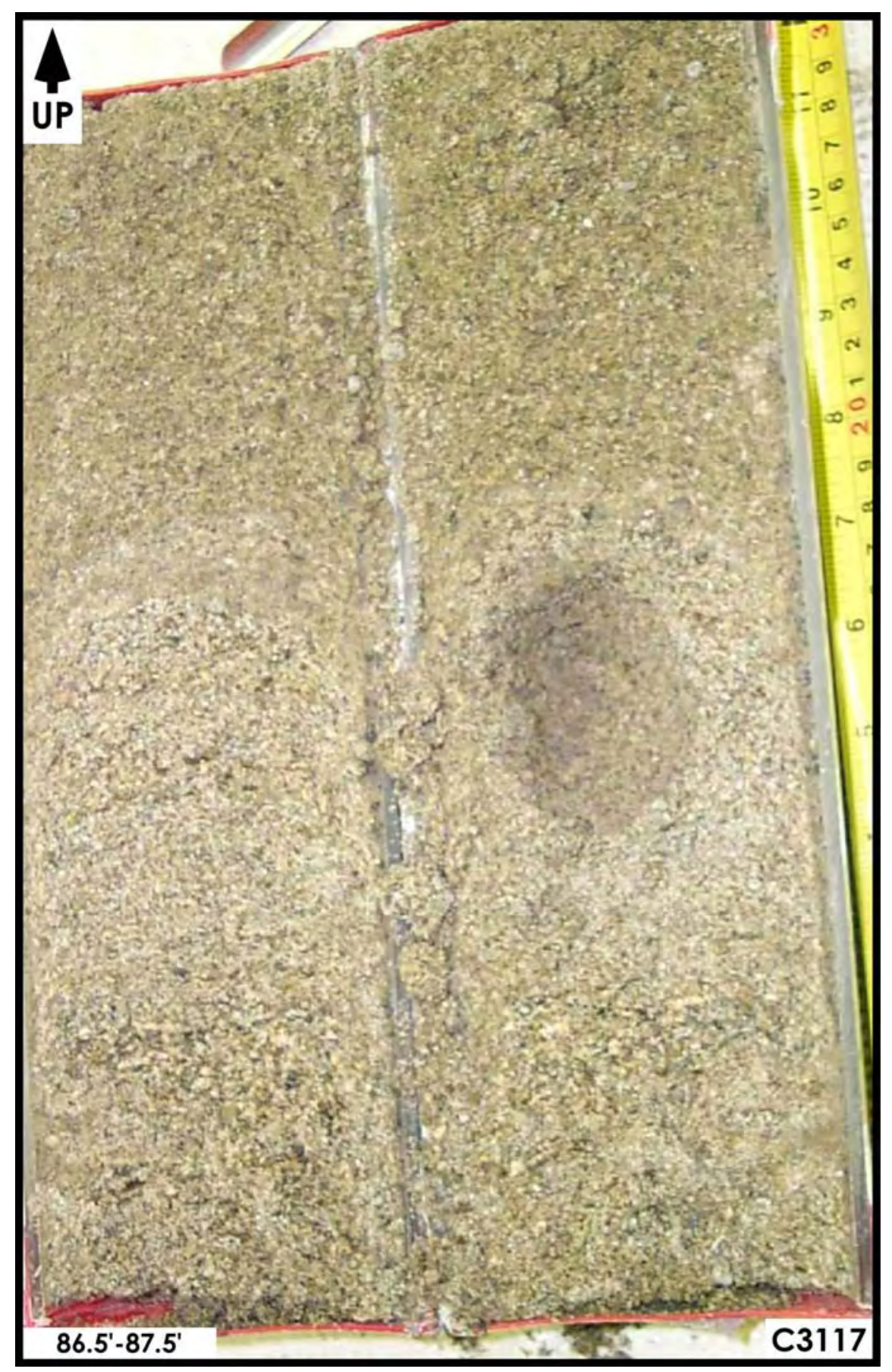

Figure A-1.42. Hanford Formation (H2 unit) $86.5 \mathrm{ft}-87.5 \mathrm{ft}$ 


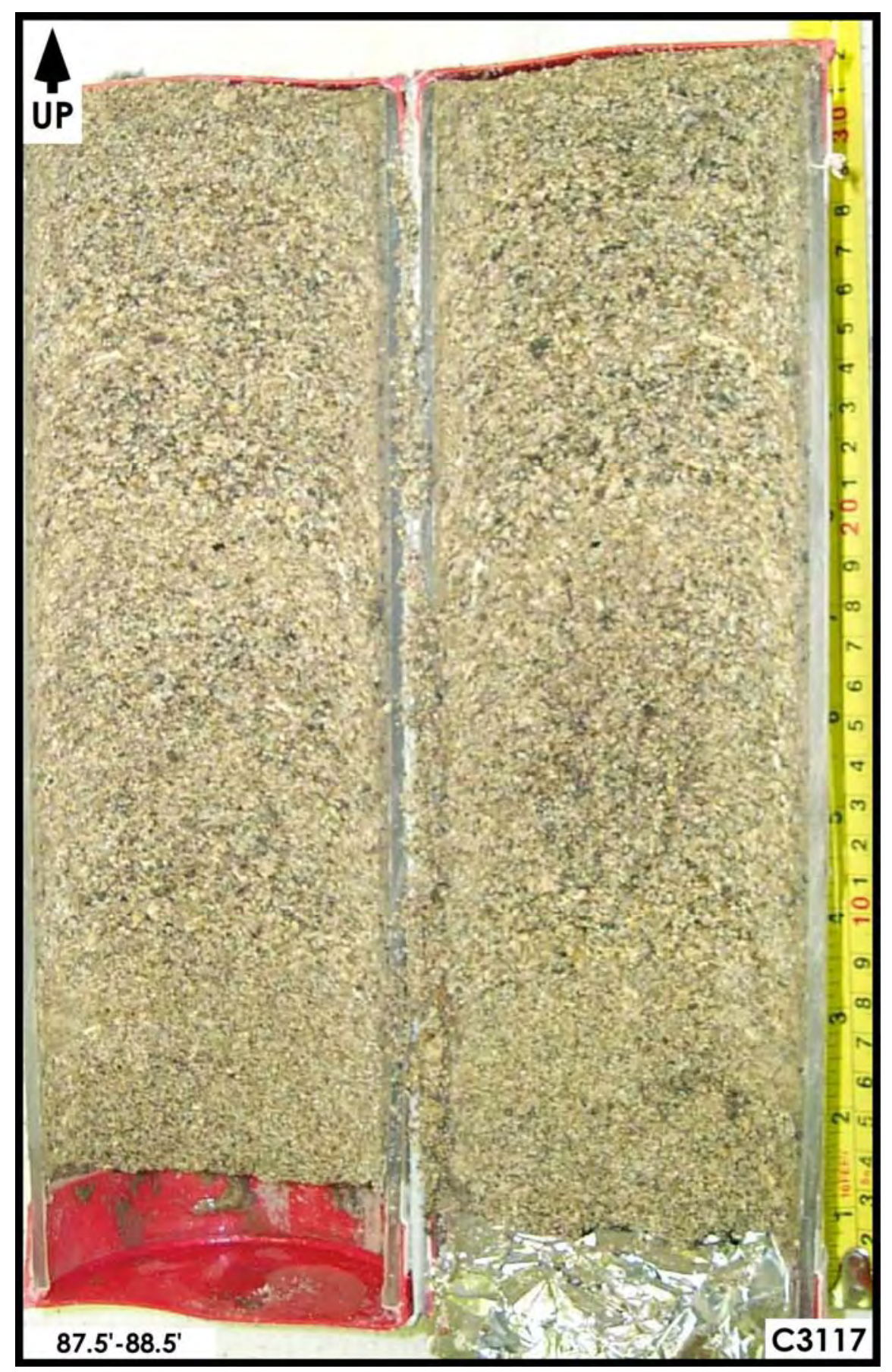

Figure A-1.43. Hanford Formation (H2 unit) $87.5 \mathrm{ft}-\mathbf{8 8 . 5} \mathrm{ft}$ 


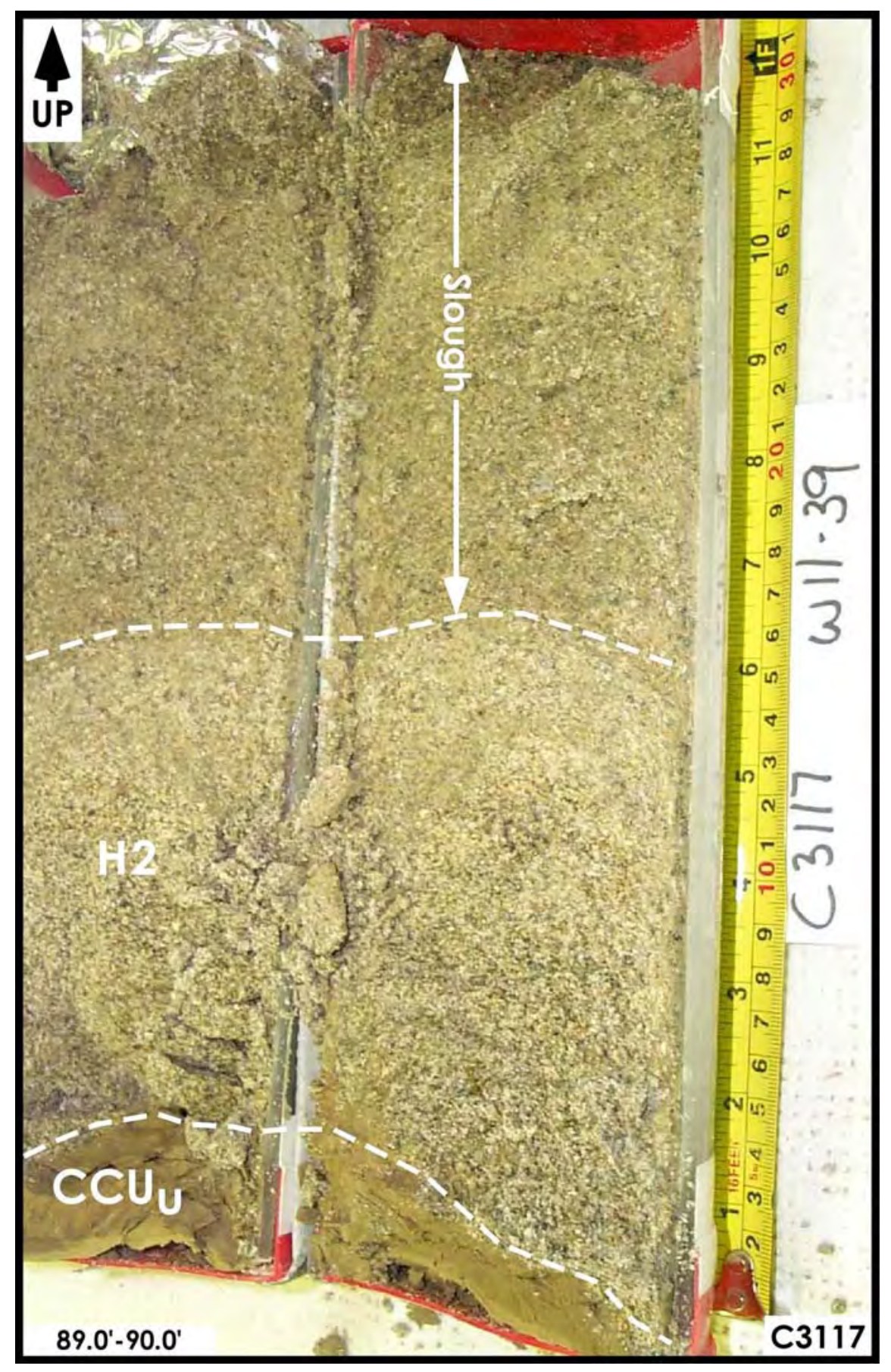

Figure A-1.44. Hanford Formation (H2 unit) / Cold Creek Unit - Upper (CCU $\left.\mathrm{U}_{\mathrm{u}}\right) \mathbf{8 9 . 0} \mathrm{ft}-\mathbf{9 0 . 0} \mathrm{ft}$ 


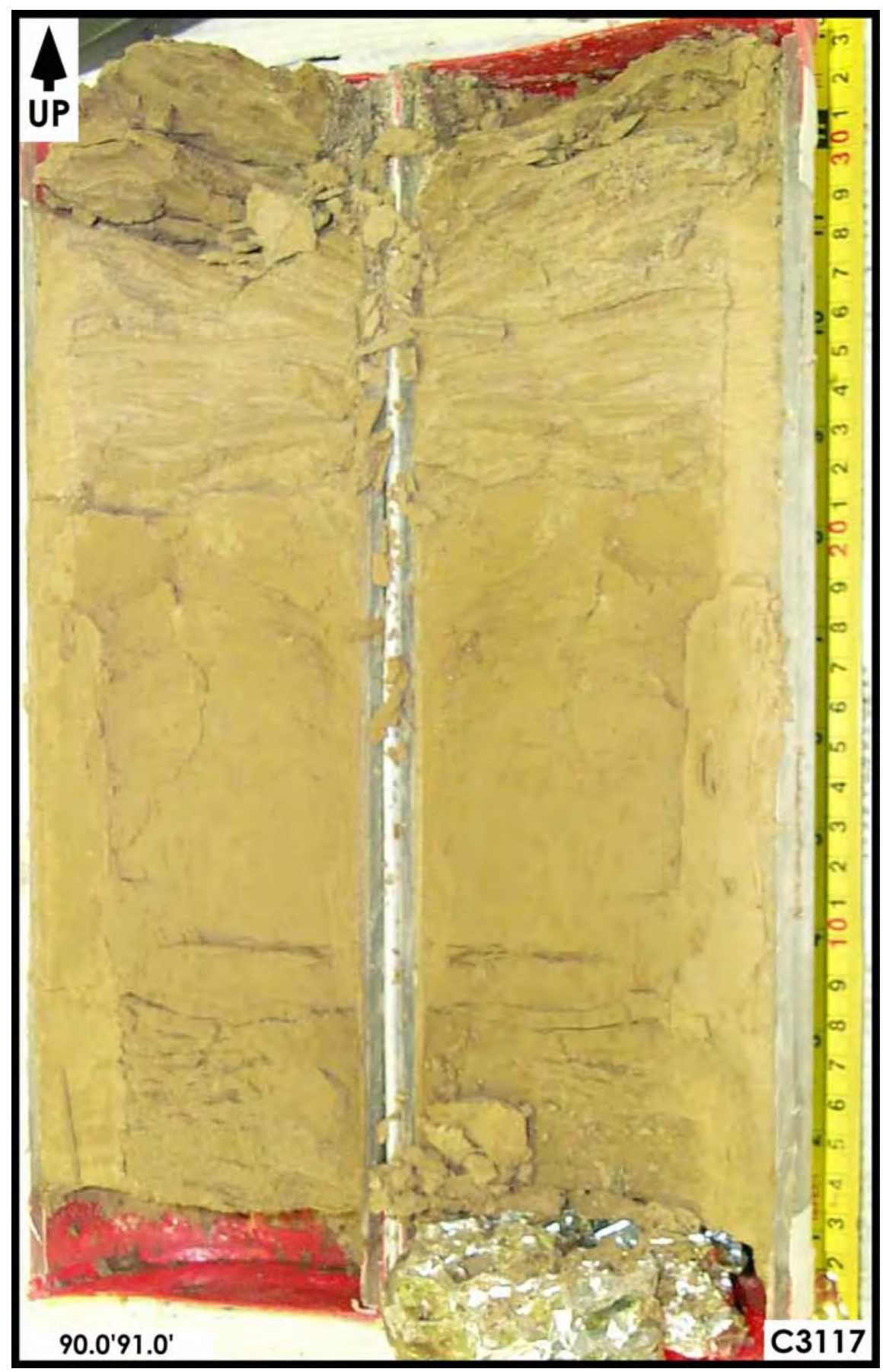

Figure A-1.45. Cold Creek Unit - Upper $\left(C_{C} U_{u}\right) 90.0 \mathrm{ft}-91.0 \mathrm{ft}$ 


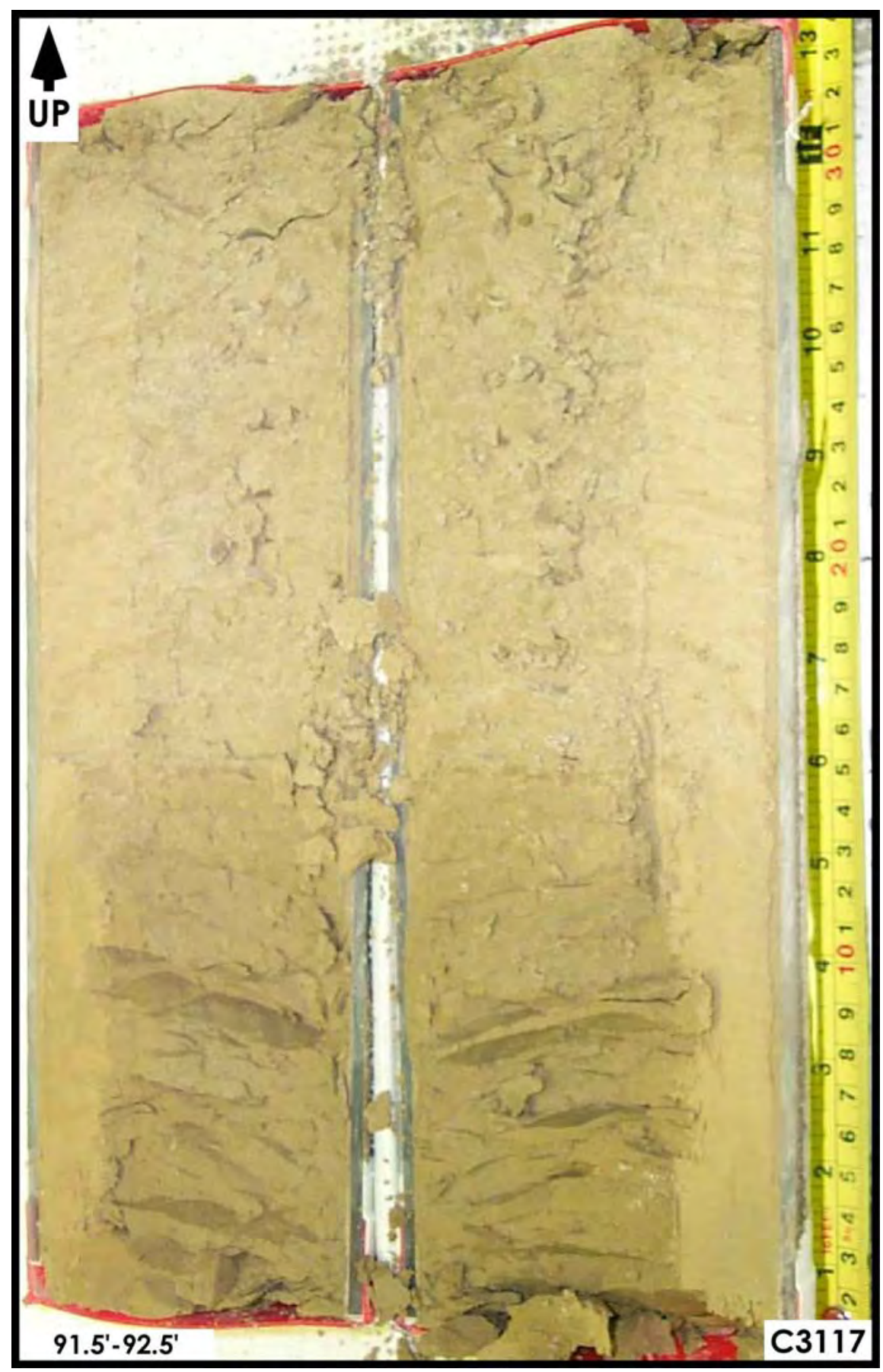

Figure A-1.46. Cold CreekUnit - Upper $\left(C_{C} U_{u}\right) 91.5 \mathrm{ft}-92.5 \mathrm{ft}$ 
Appendix A-2

C4104 (T-106)

SPLITSPOON CORE

SAMPLE PHOTOGRAPHS 


\section{Contents}

Appendix A-2.

A-2.1

\section{Figures}

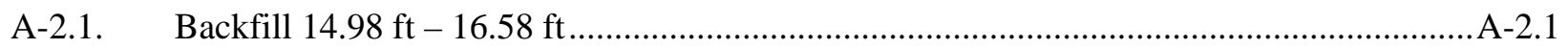

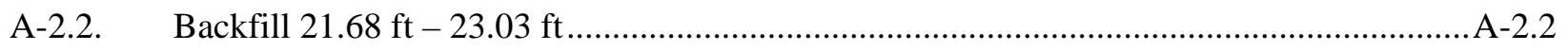

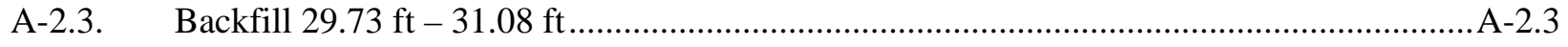

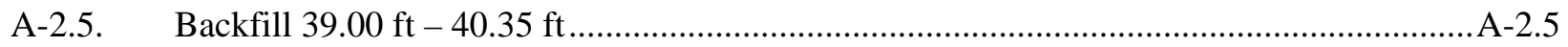

A-2.6. Hanford Formation (H2 unit) $46.00 \mathrm{ft}-47.30 \mathrm{ft}$............................................................. A-2.6

A-2.7. Hanford Formation (H2 unit) $58.04 \mathrm{ft}-59.44 \mathrm{ft}$........................................................ A-2.7

A-2.8. Hanford Formation (H2 unit) $63.05 \mathrm{ft}-64.35 \mathrm{ft}$......................................................... A-2.8

A-2.9. Hanford Formation (H2 unit) $75.05 \mathrm{ft}-76.35 \mathrm{ft}$............................................................ A-2.9

A-2.10. Hanford Formation (H2 unit) / Cold Creek Unit - Upper $\left(\mathrm{CCU}_{\mathrm{u}}\right) 80.05 \mathrm{ft}-81.37 \mathrm{ft} . . . . . . . \mathrm{A}-2.10$

A-2.11. Cold Creek Unit - Upper $\left(\mathrm{CCU}_{\mathrm{u}}\right) 86.30 \mathrm{ft}-87.70 \mathrm{ft}$................................................. A-2.11

A-2.13. Cold Creek Unit - Lower $\left(\mathrm{CCU}_{\mathrm{l}}\right) 92.58 \mathrm{ft}-93.88 \mathrm{ft}$................................................... A-2.13

A-2.14. Cold Creek Unit - Lower $\left(\mathrm{CCU}_{\mathrm{l}}\right) 93.73 \mathrm{ft}-95.17 \mathrm{ft}$................................................. A-2.14

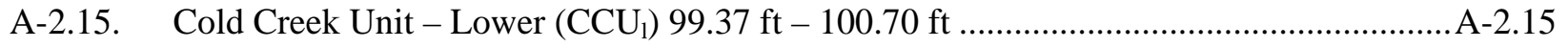

A-2.16. Cold Creek Unit - Lower $\left(\mathrm{CCU}_{\mathrm{l}}\right) 101.00 \mathrm{ft}-102.30 \mathrm{ft}$.................................................. A-2.16

A-2.17. Cold Creek Unit - Lower $\left(\mathrm{CCU}_{\mathrm{l}}\right) 105.04 \mathrm{ft}-106.44 \mathrm{ft}$.................................................2-2.17

A-2.18. Cold Creek Unit - Lower $\left(\mathrm{CCU}_{\mathrm{l}}\right) 106.44 \mathrm{ft}-107.74 \mathrm{ft}$............................................... A-2.18

A-2.19. Ringold Formation - Member of Taylor Flat $\left(\mathrm{R}_{\mathrm{tf}}\right) 110.00 \mathrm{ft}-111.30 \mathrm{ft}$......................... A-2.19

A-2.20. Ringold Formation - Member of Taylor Flat $\left(\mathrm{R}_{\mathrm{tf}}\right) 114.86 \mathrm{ft}-116.41 \mathrm{ft}$......................... A-2.20

A-2.21. Ringold Formation - Member of Taylor Flat $\left(\mathrm{R}_{\mathrm{tf}}\right) /$ Member of Wooded Island $\left(\mathrm{R}_{\mathrm{wi}}\right)$

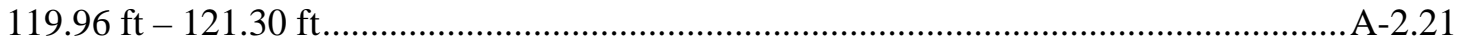

A-2.22. Ringold Formation - Member of Wooded Island $\left(\mathrm{R}_{\mathrm{wi}}\right) 122.96 \mathrm{ft}-124.41 \mathrm{ft}$.................A-2.22

A-2.23. Ringold Formation - Member of Wooded Island $\left(\mathrm{R}_{\mathrm{wi}}\right) 126.12 \mathrm{ft}-127.46 \mathrm{ft}$................. A-2.23 


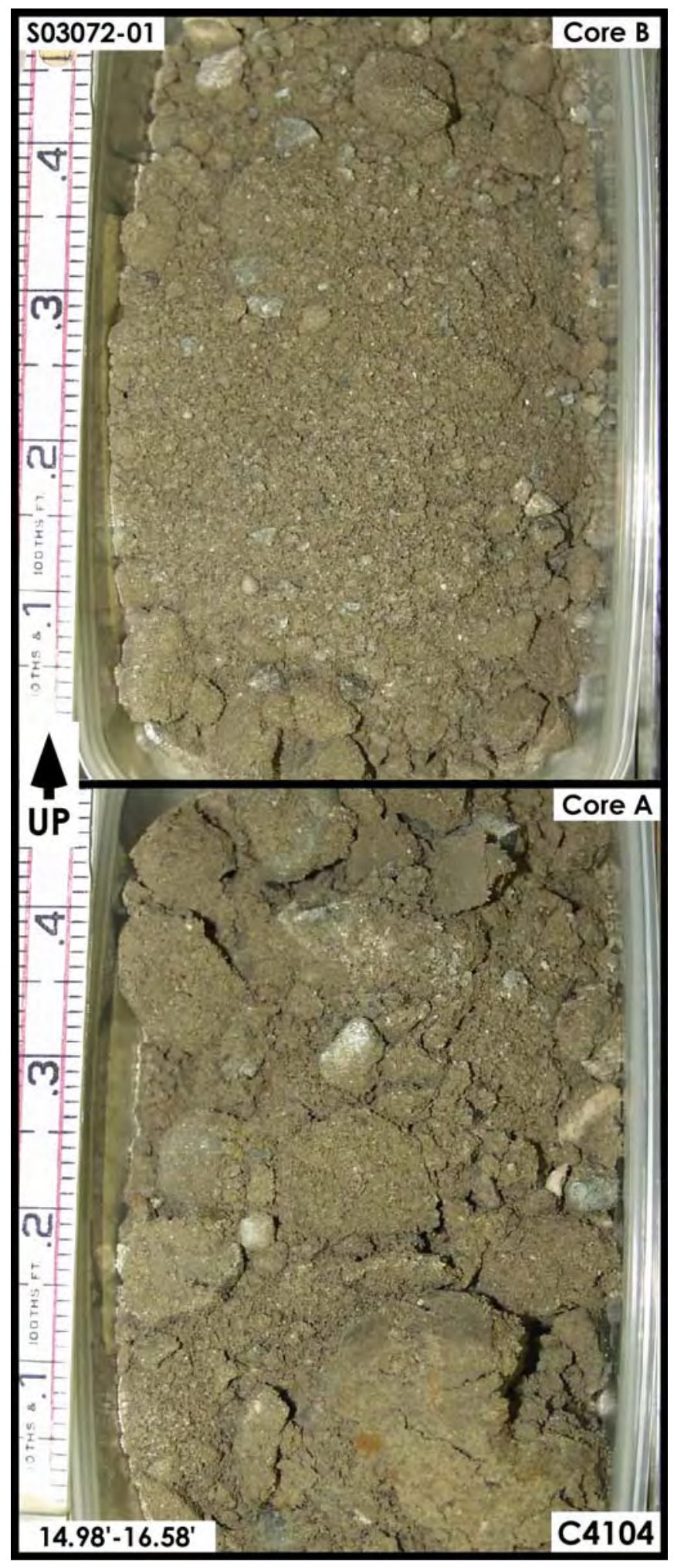

Figure A-2.1. Backfill $14.98 \mathrm{ft}-16.58 \mathrm{ft}$ 


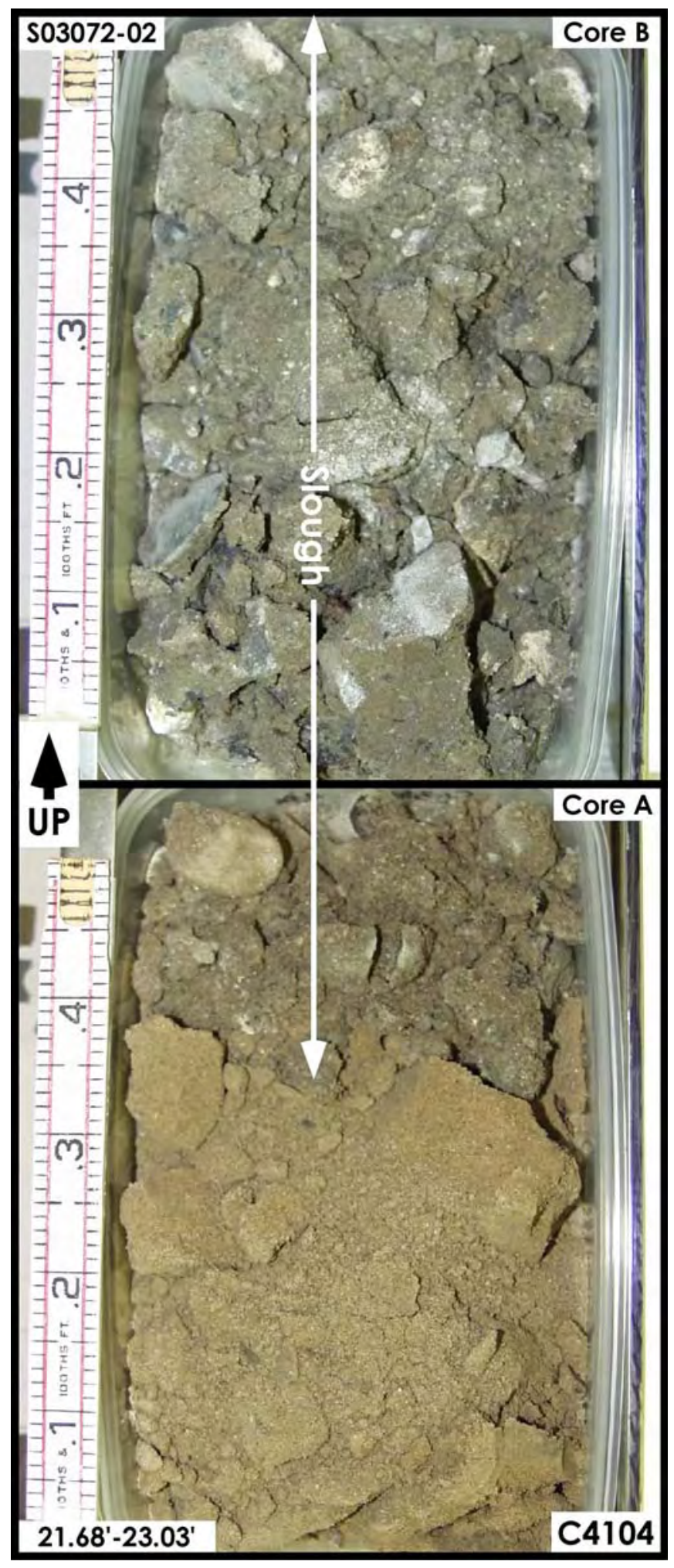

Figure A-2.2. Backfill $21.68 \mathrm{ft}-23.03 \mathrm{ft}$ 


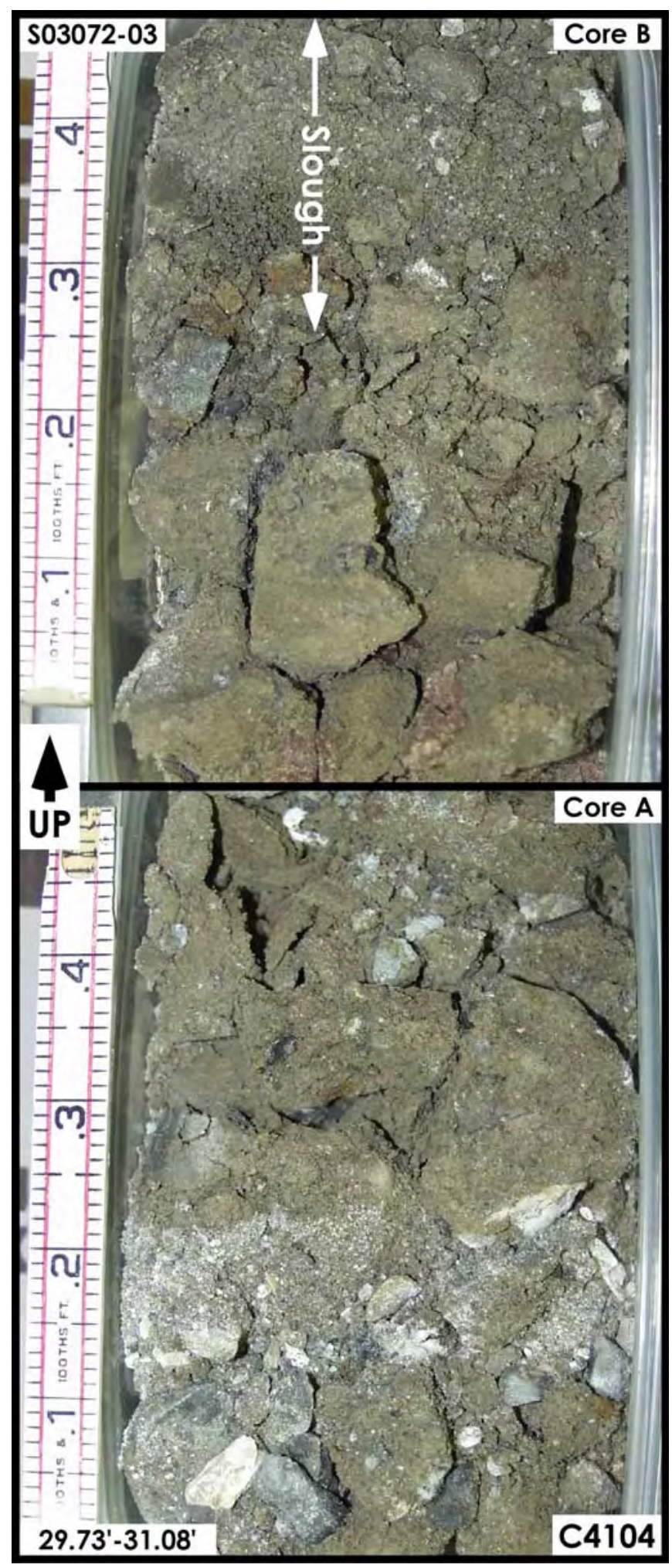

Figure A-2.3. Backfill $29.73 \mathrm{ft}-31.08 \mathrm{ft}$ 


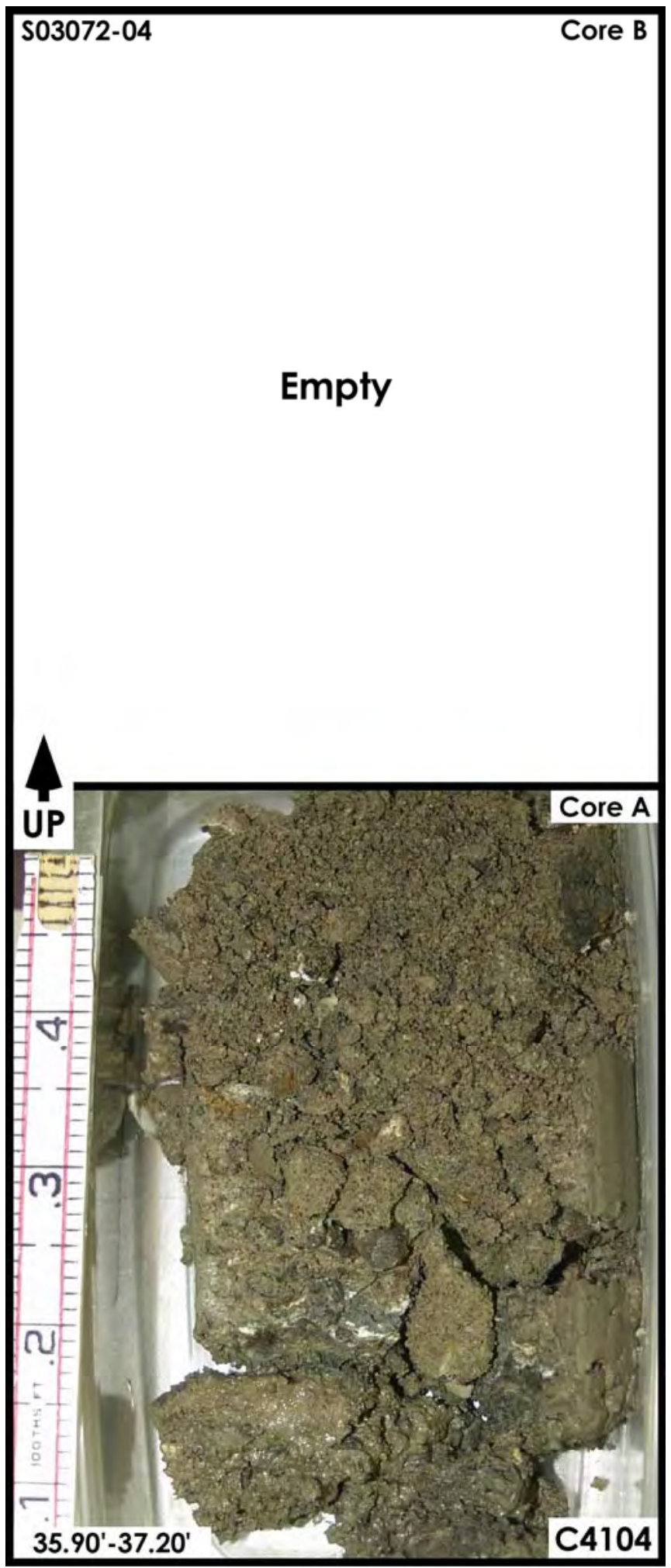

Figure A-2.4. Backfill $35.90 \mathrm{ft}-37.20 \mathrm{ft}$ 


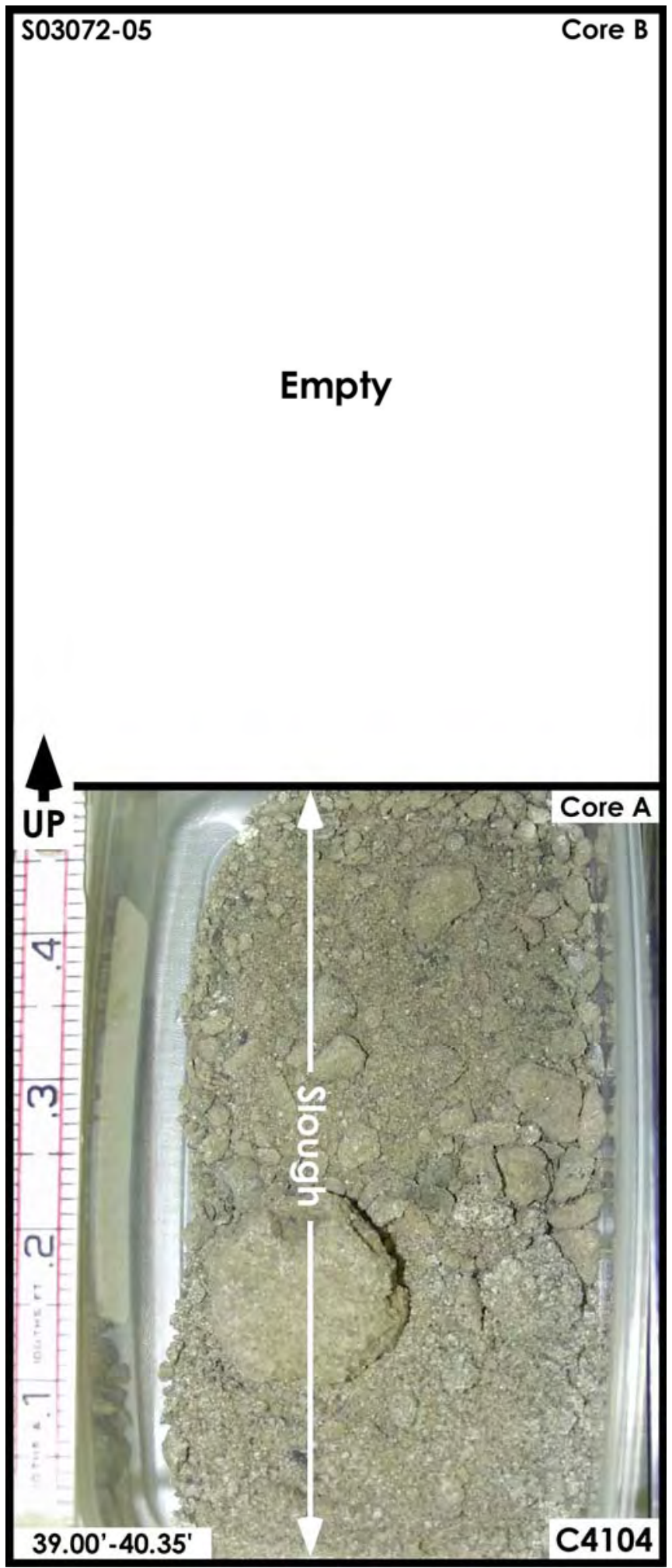

Figure A-2.5. Backfill $39.00 \mathrm{ft}-\mathbf{4 0 . 3 5} \mathrm{ft}$ 


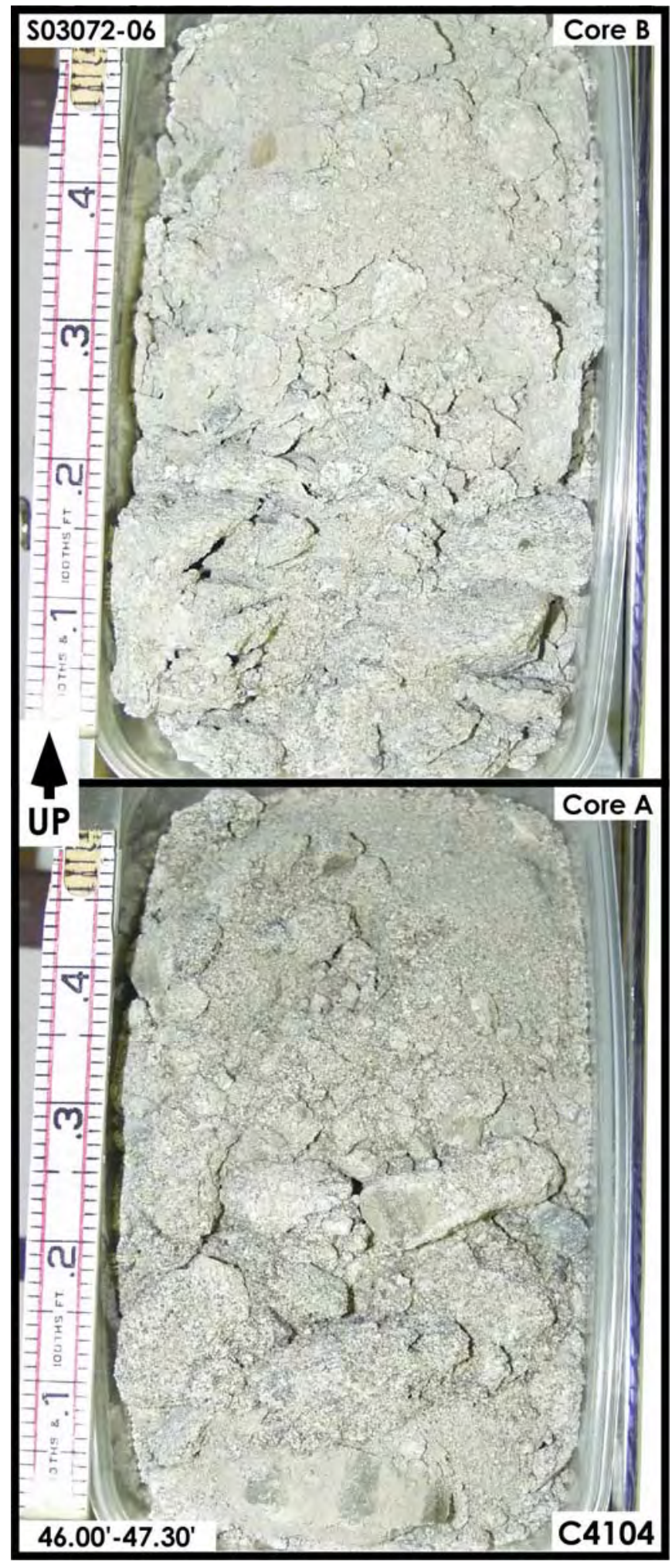

Figure A-2.6. Hanford Formation (H2 unit) $46.00 \mathrm{ft}-47.30 \mathrm{ft}$ 


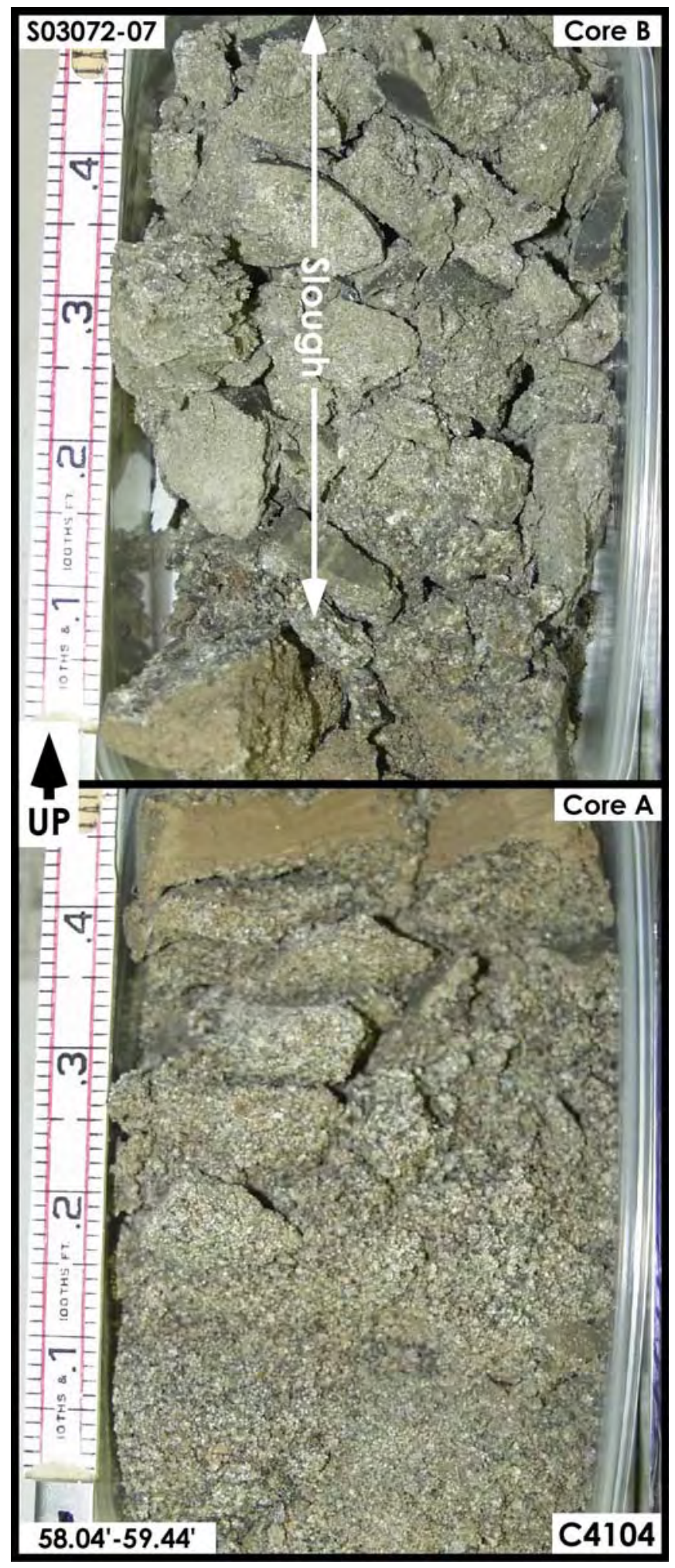

Figure A-2.7. Hanford Formation (H2 unit) $58.04 \mathrm{ft}-59.44 \mathrm{ft}$ 


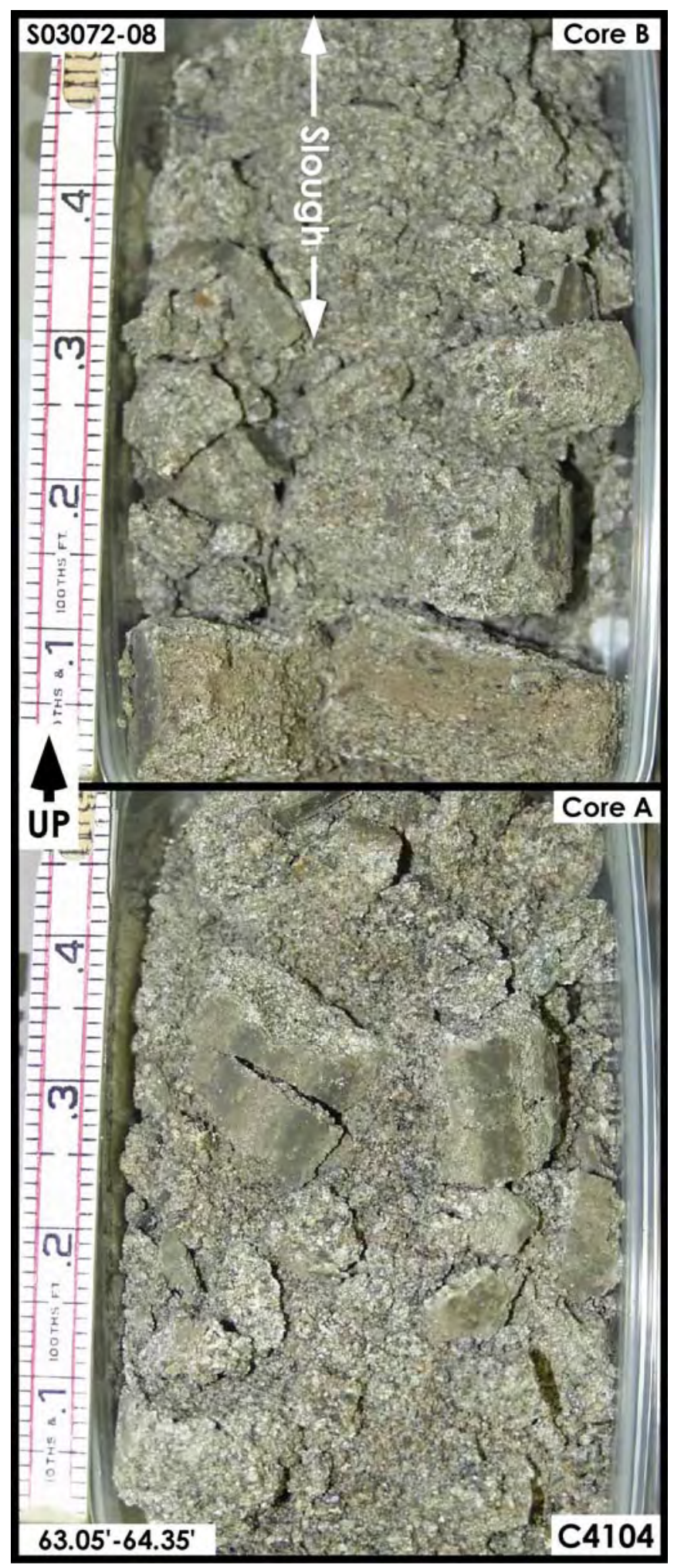

Figure A-2.8. Hanford Formation (H2 unit) $63.05 \mathrm{ft}-64.35 \mathrm{ft}$ 


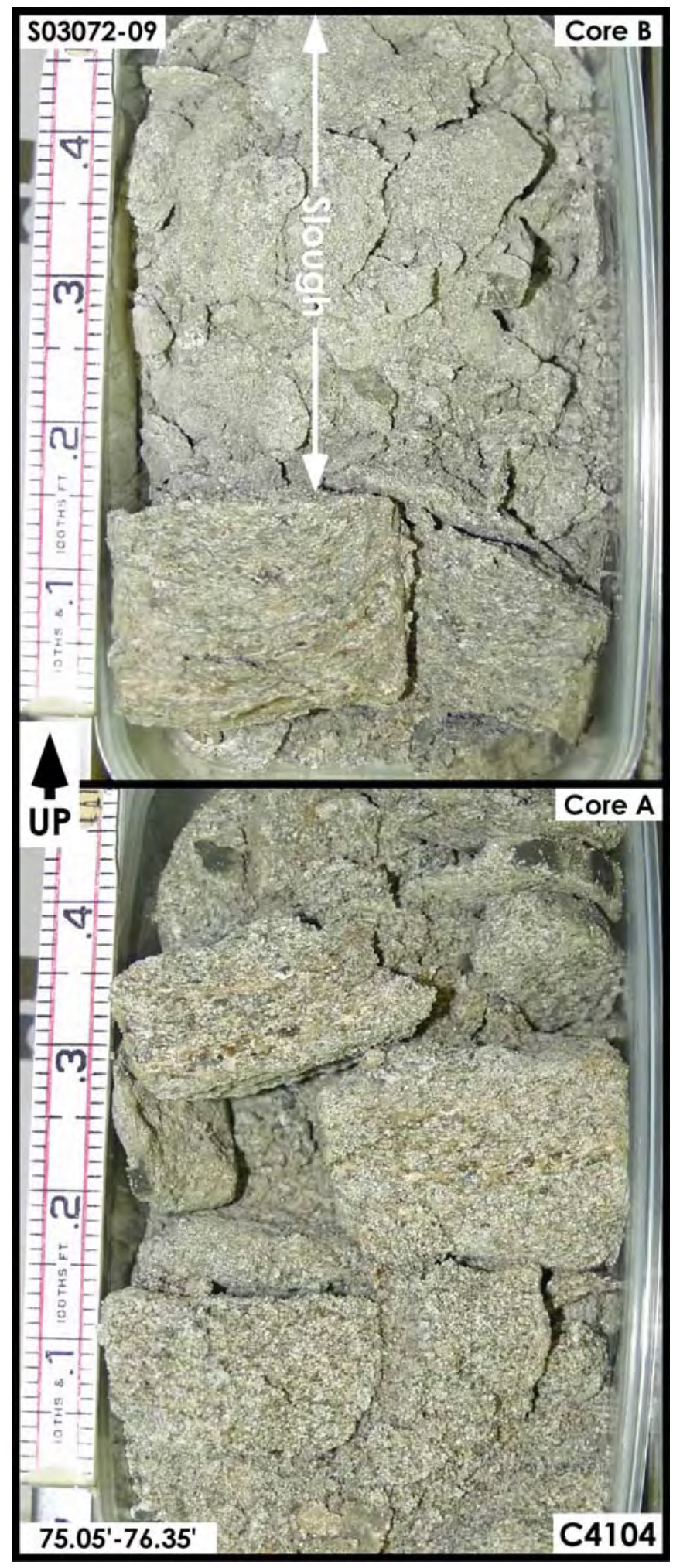

Figure A-2.9. Hanford Formation (H2 unit) $75.05 \mathrm{ft}-76.35 \mathrm{ft}$ 


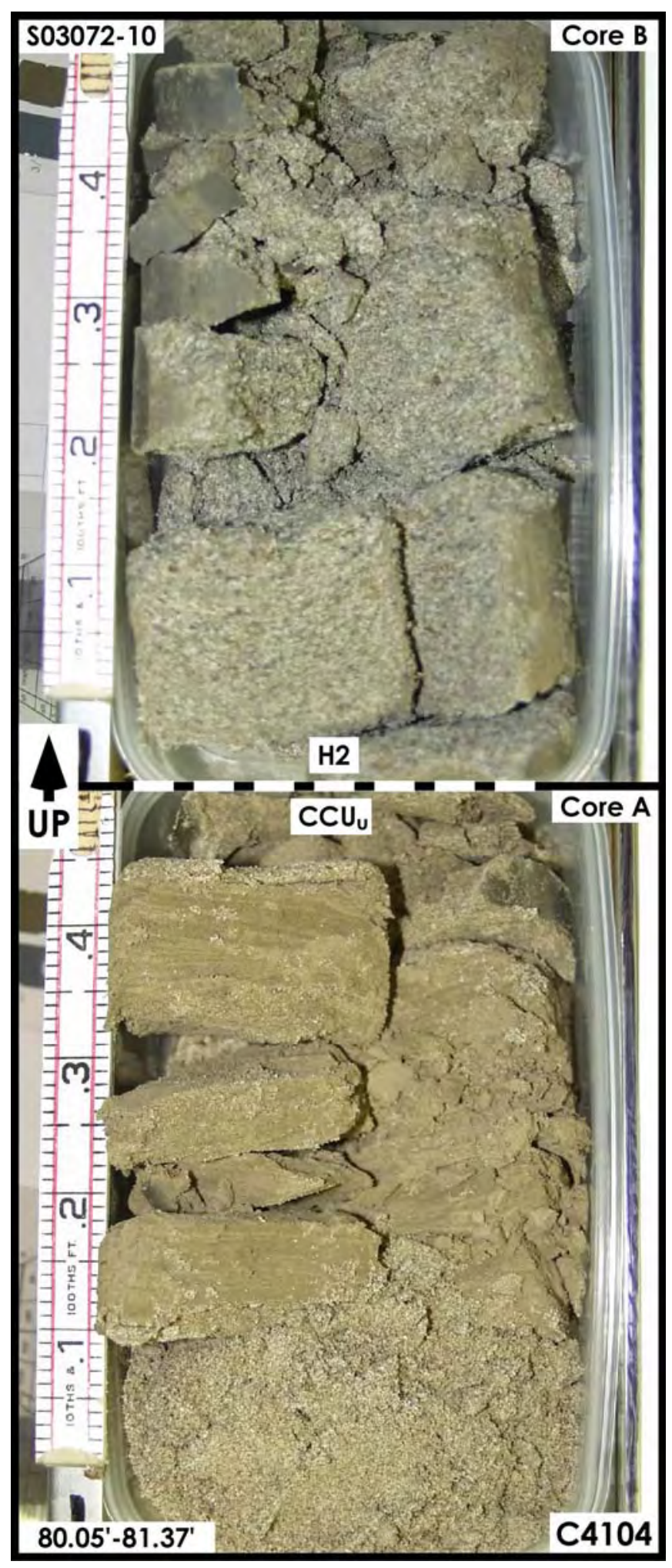

Figure A-2.10. Hanford Formation (H2 unit) / Cold Creek Unit - Upper $\left(C_{C} U_{u}\right) 80.05$ ft - 81.37 ft 


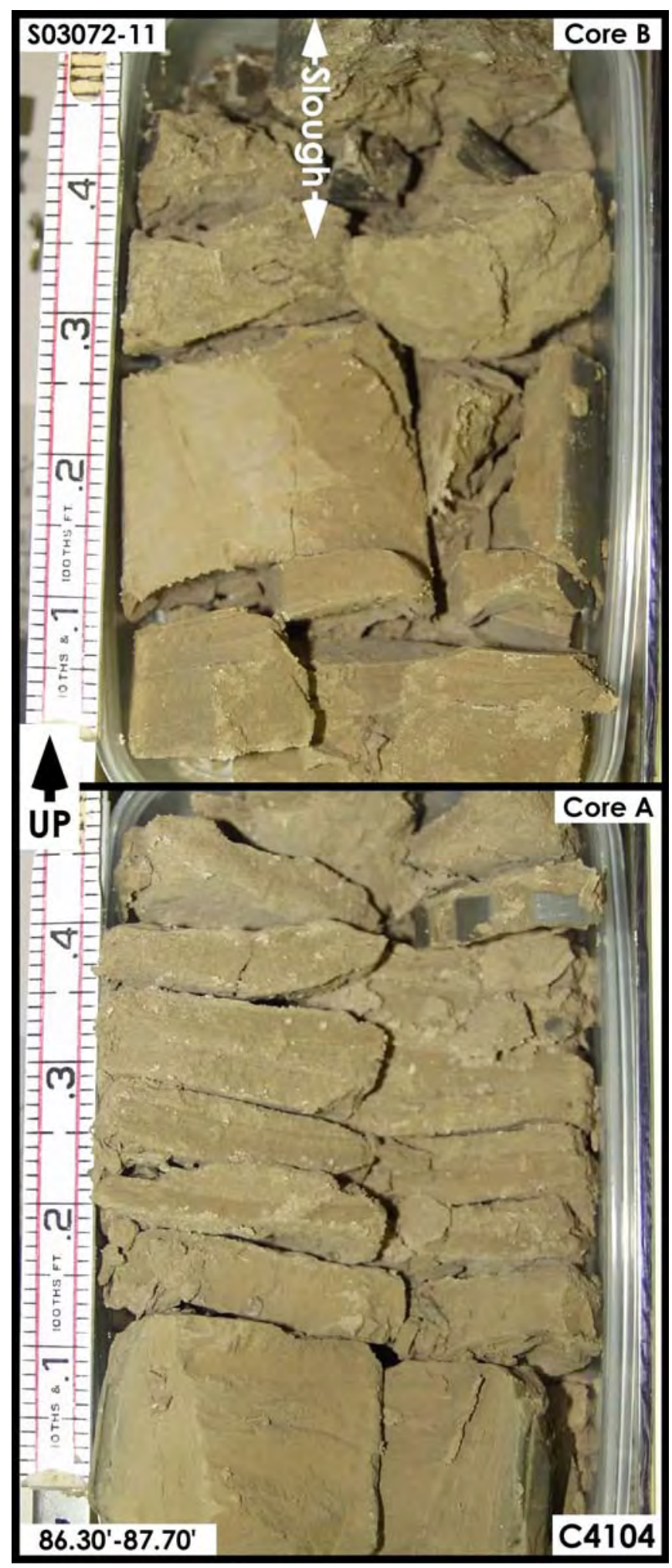

Figure A-2.11. Cold Creek Unit - Upper $\left(\mathrm{CCU}_{\mathrm{u}}\right) 86.30 \mathrm{ft}-87.70 \mathrm{ft}$ 


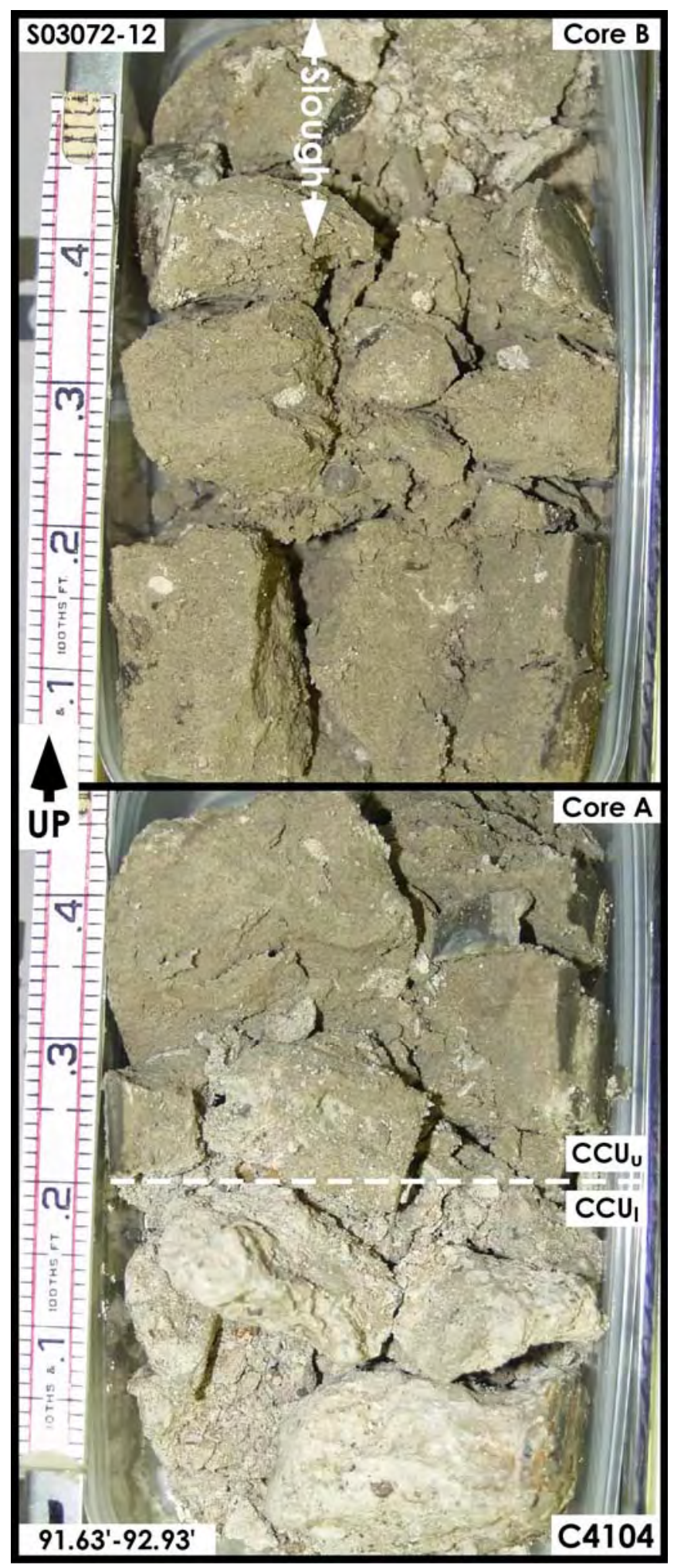

Figure A-2.12. Cold Creek Unit - Upper $\left(\mathrm{CCU}_{\mathrm{u}}\right)$ / Lower (CCUI) $91.63 \mathrm{ft}-92.93 \mathrm{ft}$ 


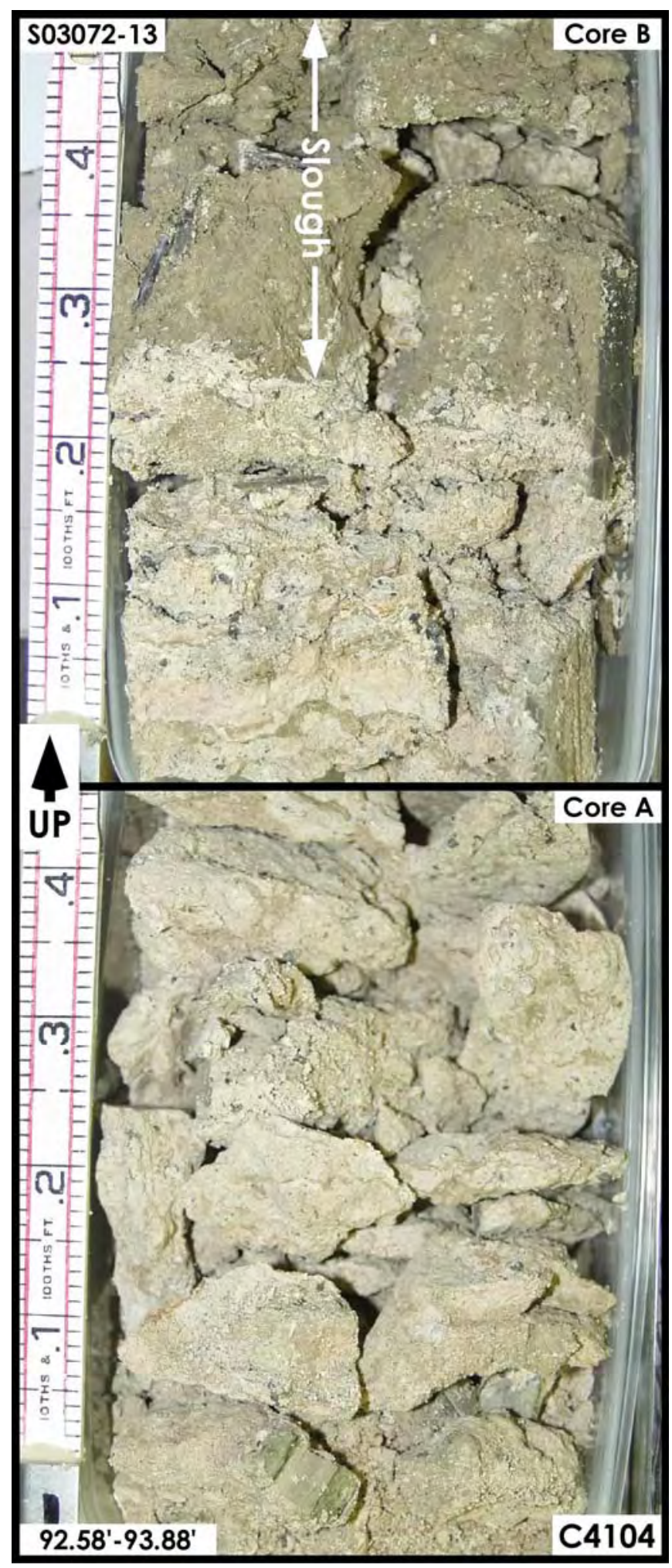

Figure A-2.13. Cold Creek Unit - Lower $\left(\mathrm{CCU}_{\mathrm{l}}\right) 92.58 \mathrm{ft}-93.88 \mathrm{ft}$ 


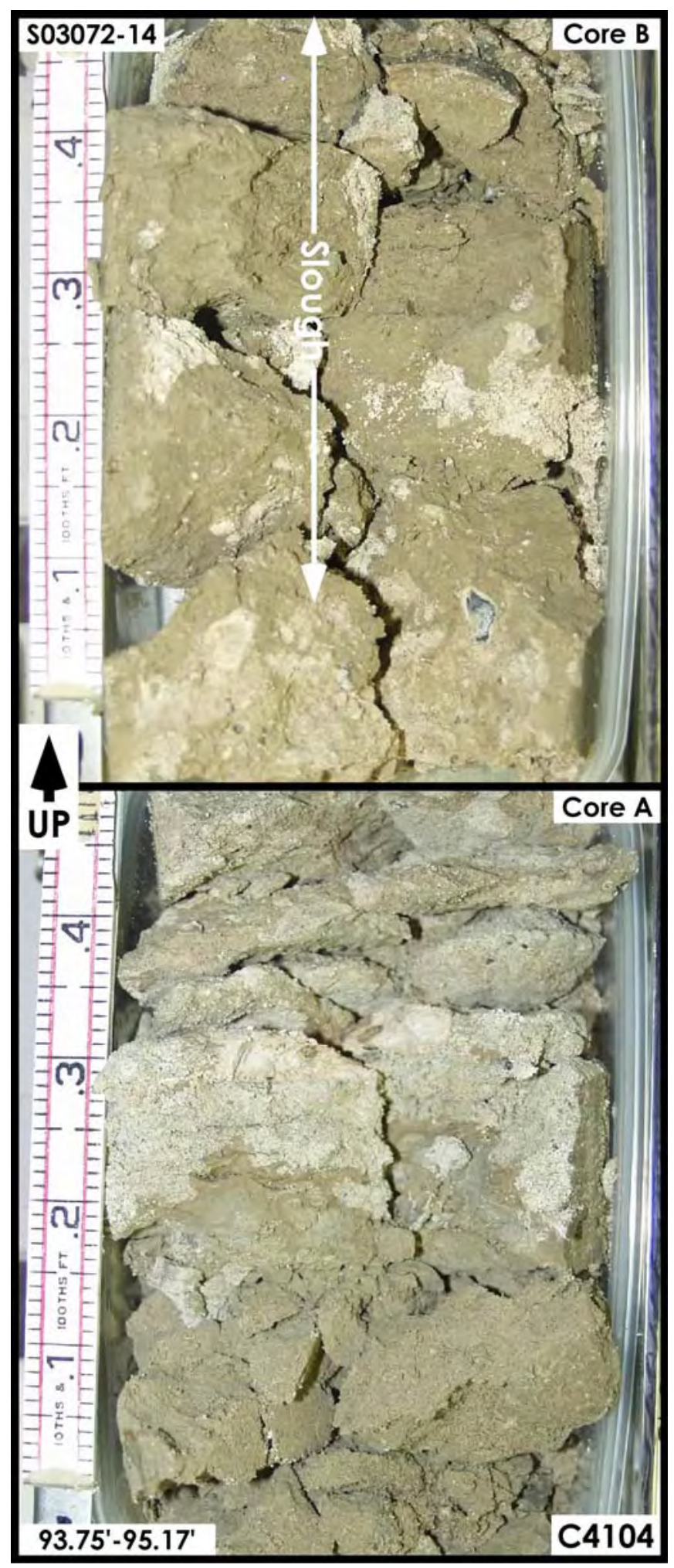

Figure A-2.14. Cold Creek Unit - Lower $\left(\mathrm{CCU}_{\mathrm{l}}\right) 93.73 \mathrm{ft}-95.17 \mathrm{ft}$ 


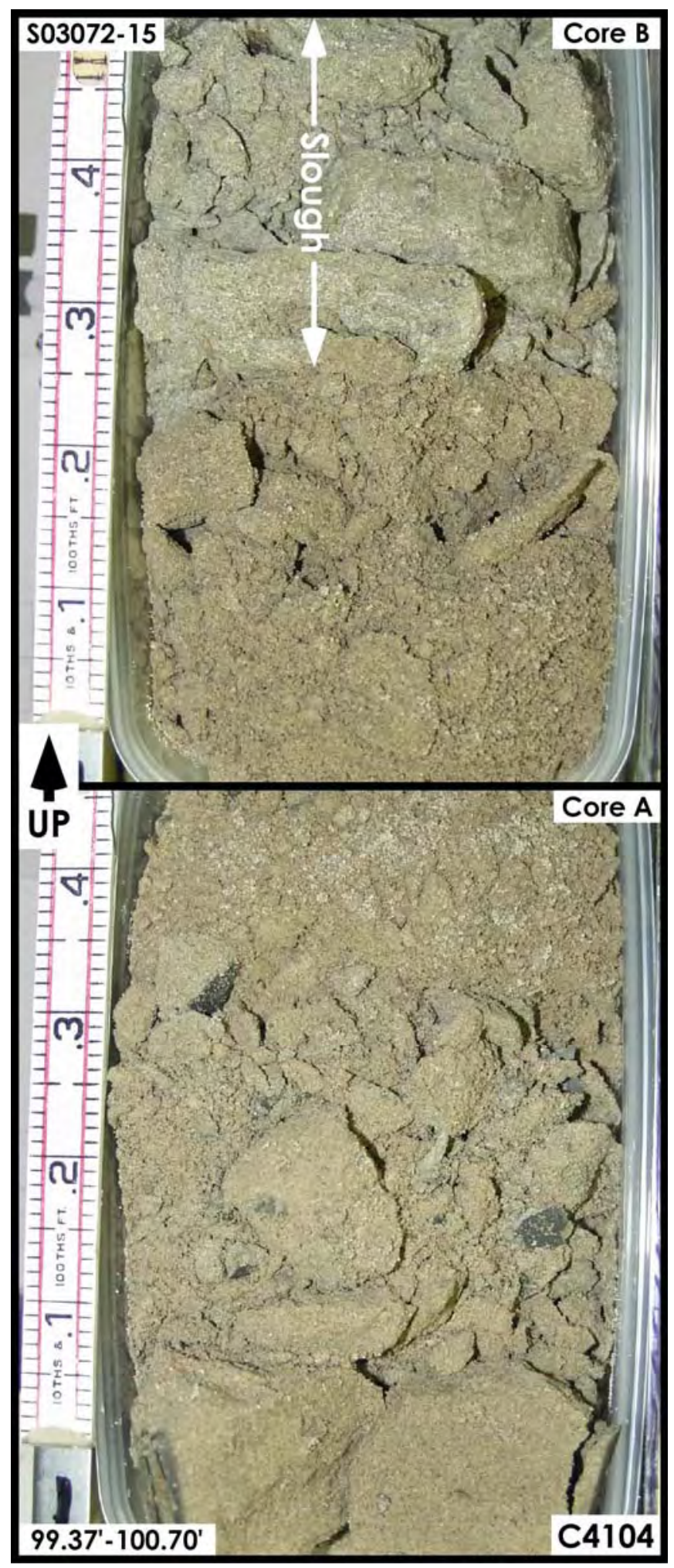

Figure A-2.15. Cold Creek Unit - Lower $\left(C C U_{I}\right) 99.37$ ft -100.70 ft 


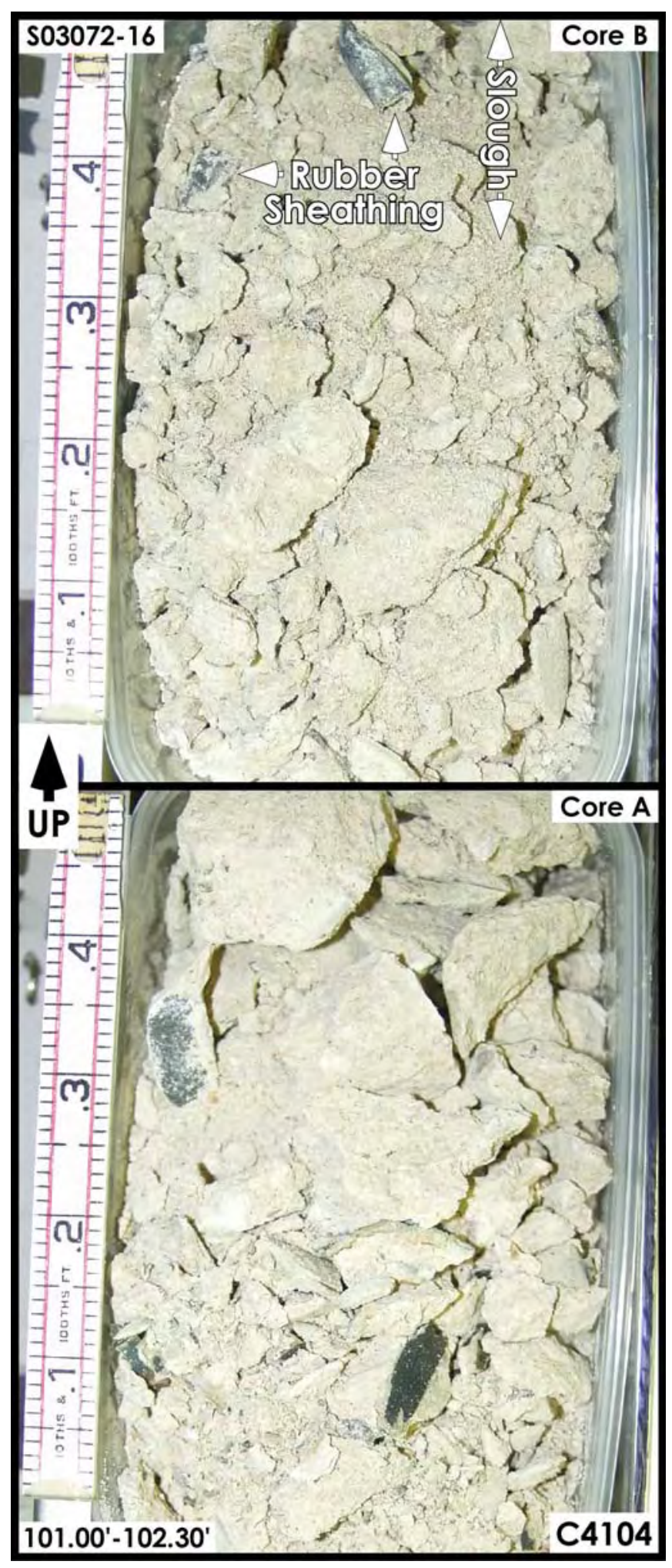

Figure A-2.16. Cold Creek Unit - Lower $\left(C C U_{l}\right) 101.00$ ft -102.30 ft 


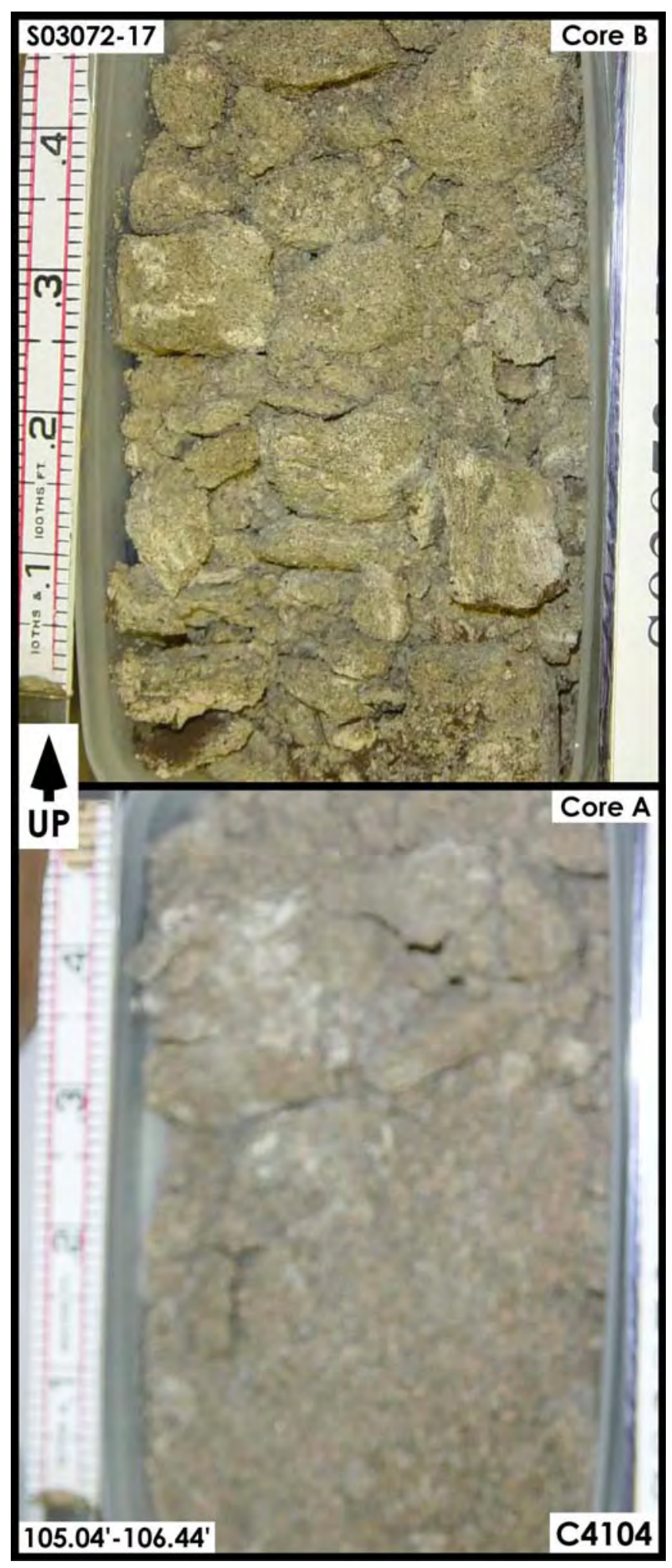

Figure A-2.17. Cold Creek Unit - Lower $\left(C C U_{l}\right) 105.04$ ft - 106.44 ft 


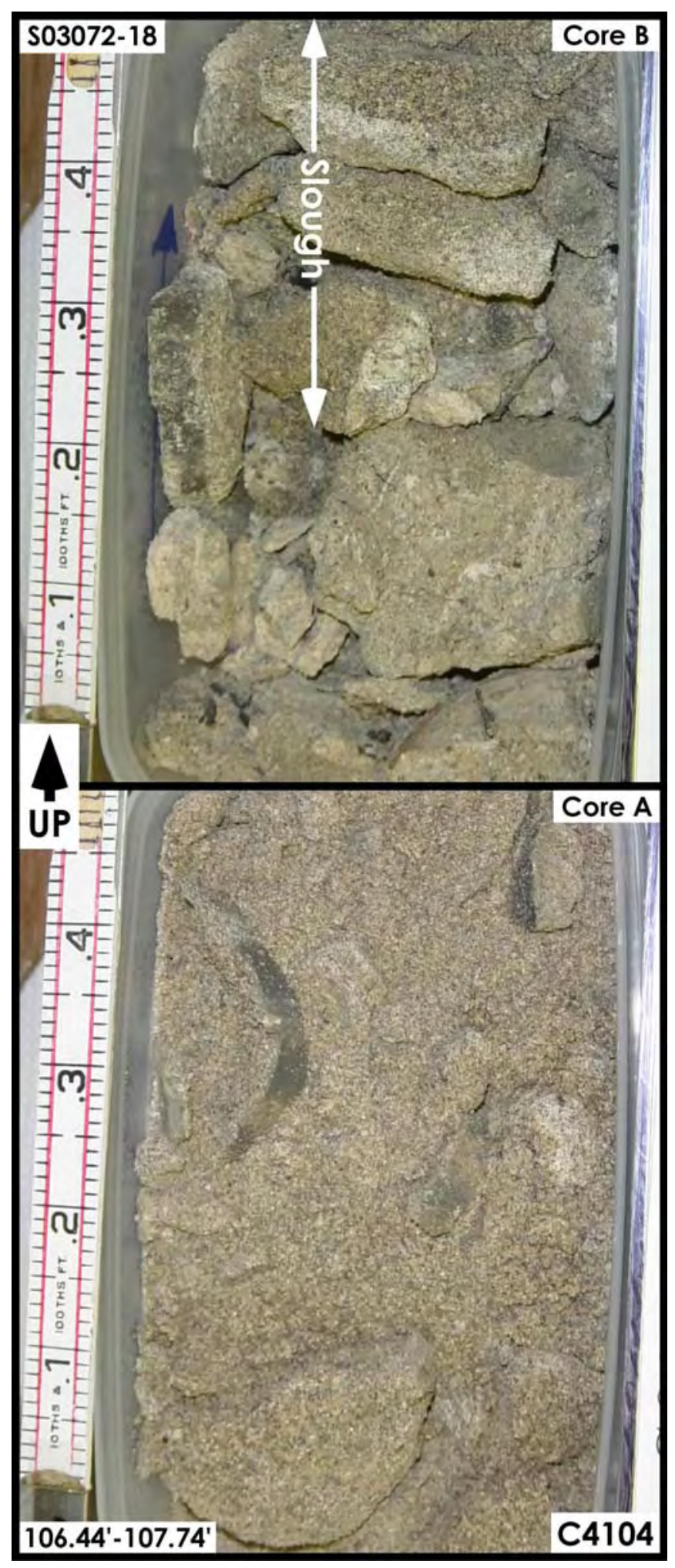

Figure A-2.18. Cold Creek Unit - Lower $\left(C C U_{l}\right) 106.44$ ft -107.74 ft 


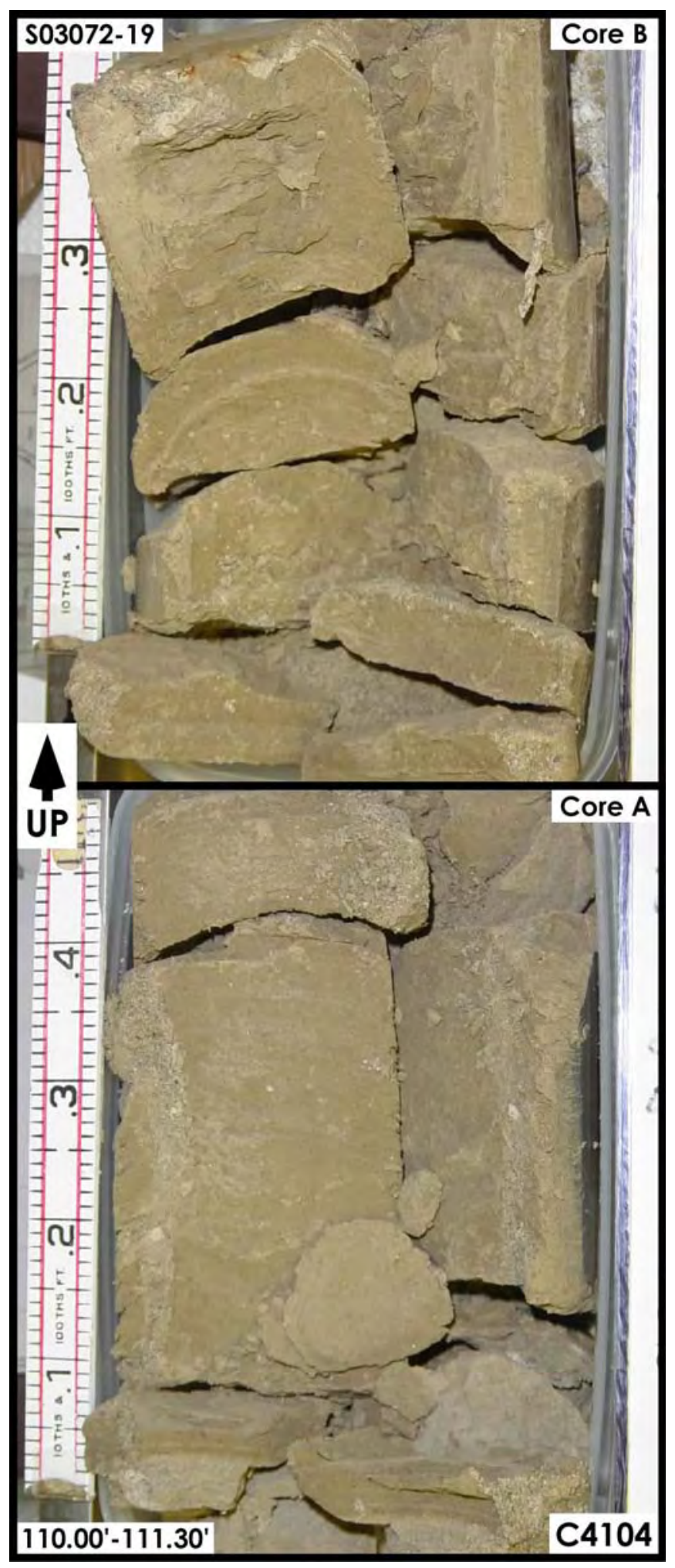

Figure A-2.19. Ringold Formation - Member of Taylor Flat $\left(R_{t f}\right) \mathbf{1 1 0 . 0 0} f t-111.30 \mathrm{ft}$ 


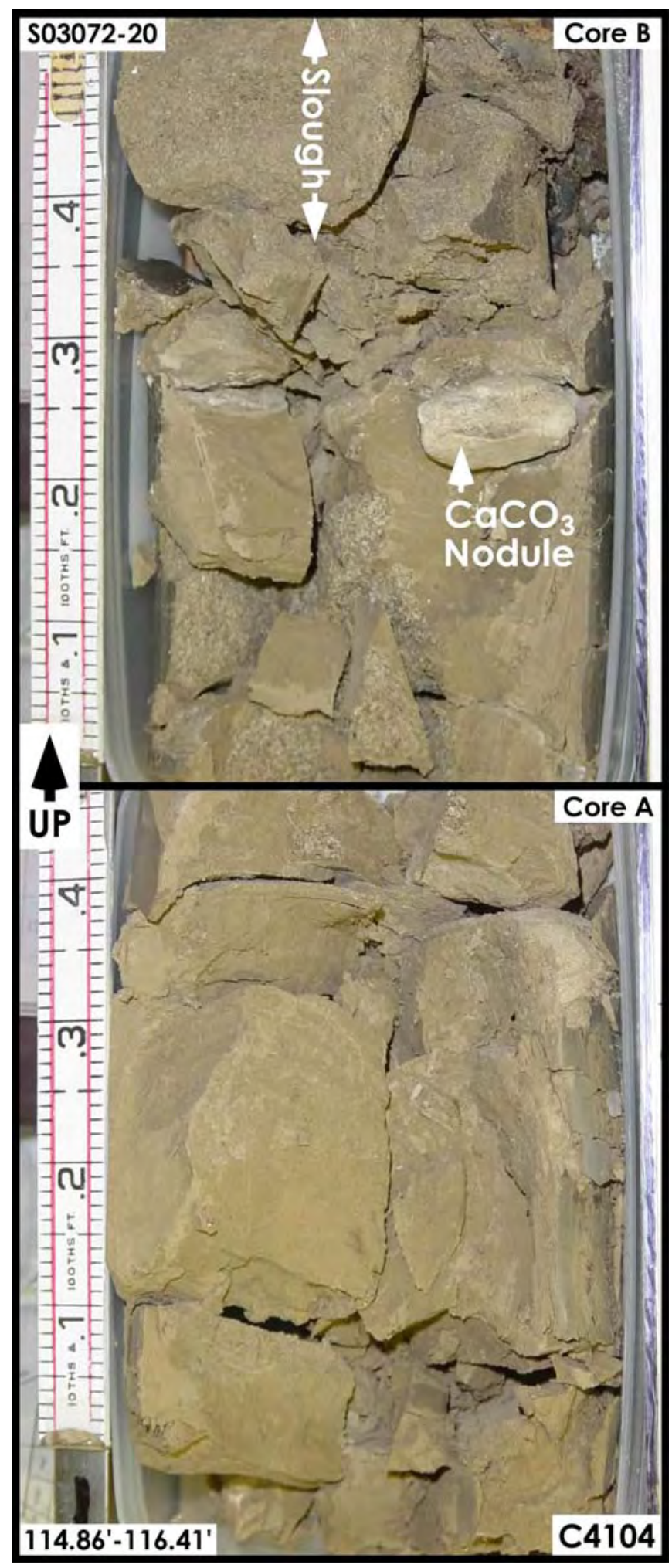

Figure A-2.20. Ringold Formation - Member of Taylor Flat $\left(R_{t f}\right) 114.86 \mathrm{ft}-116.41 \mathrm{ft}$ 


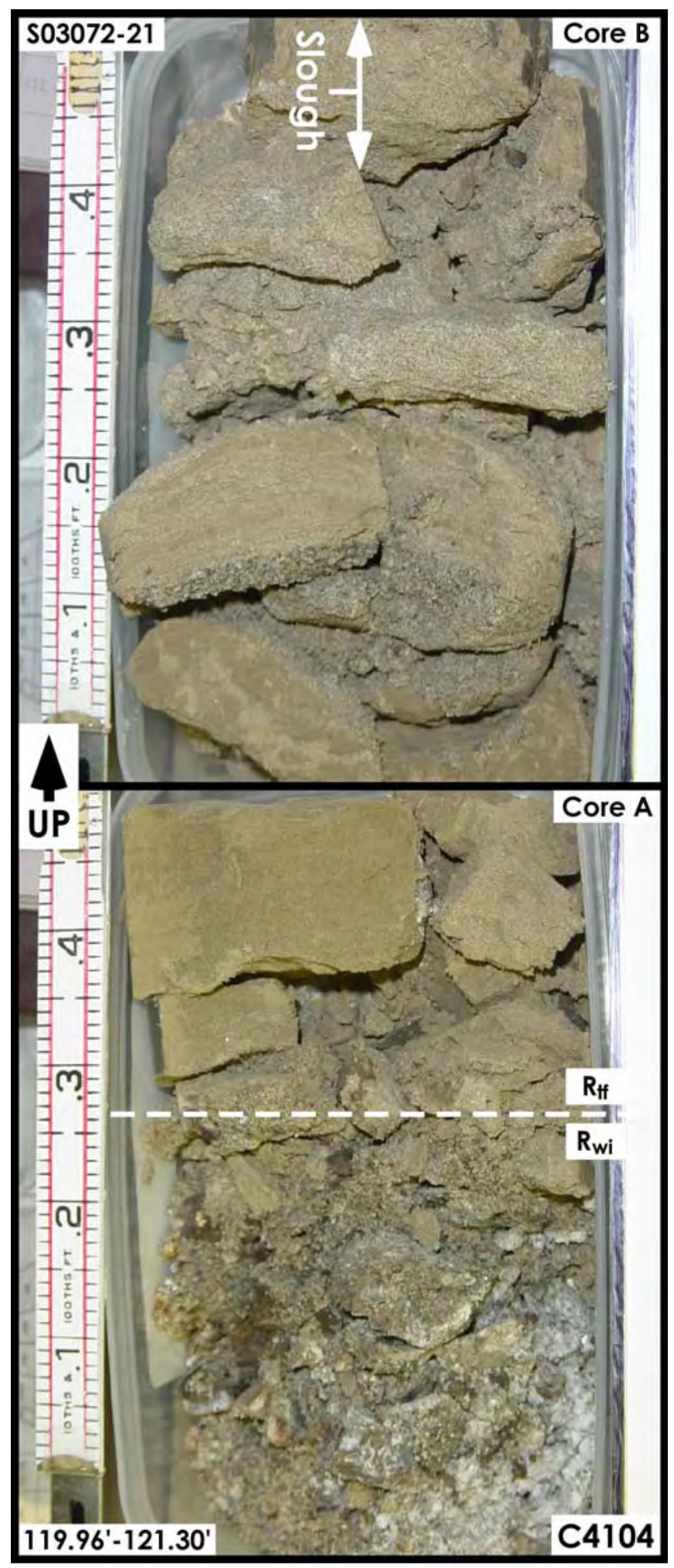

Figure A-2.21. Ringold Formation - Member of Taylor Flat $\left(\mathbf{R}_{\mathrm{tf}}\right)$ / Member of Wooded Island $\left(R_{w i}\right) \mathbf{1 1 9 . 9 6} f t-121.30 \mathrm{ft}$ 


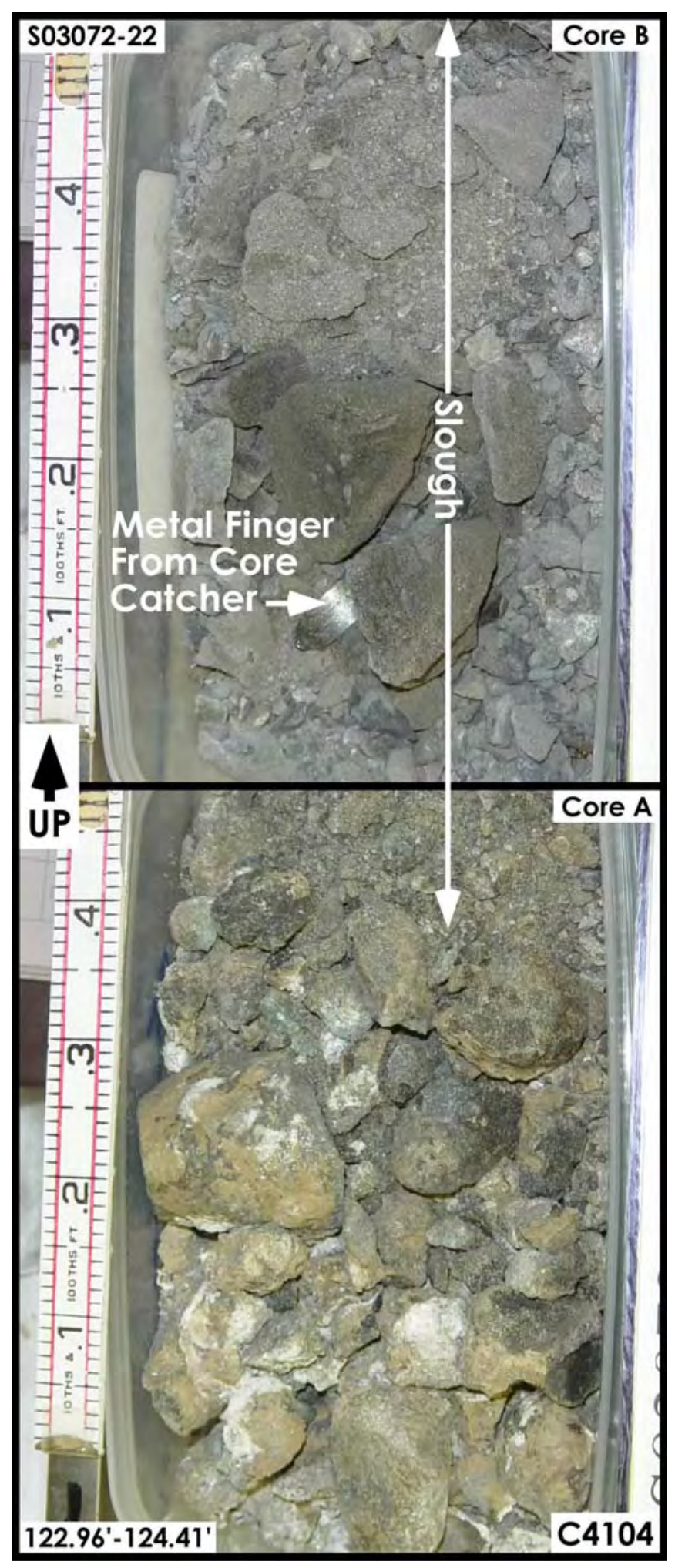

Figure A-2.22. Ringold Formation - Member of Wooded Island $\left(R_{w i}\right) 122.96 \mathrm{ft}-124.41 \mathrm{ft}$ 


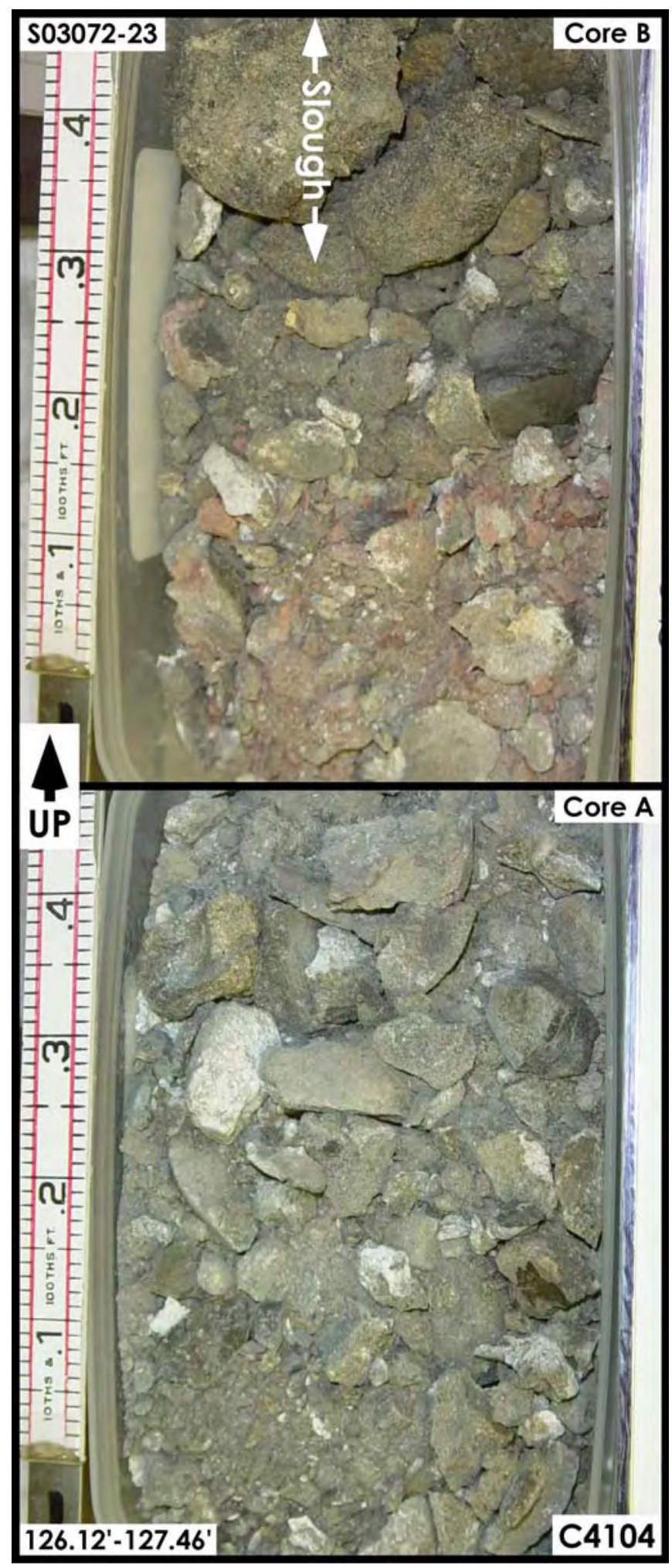

Figure A-2.23. Ringold Formation - Member of Wooded Island $\left(R_{w i}\right) 126.12 \mathrm{ft}-127.46 \mathrm{ft}$ 
Appendix A-3

C4105 (T-106)

SPLITSPOON CORE

SAMPLE PHOTOGRAPHS 


\section{Contents}

Appendix A-3.

A-3.1

\section{Figures}

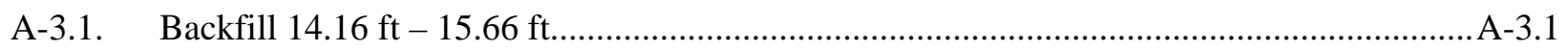

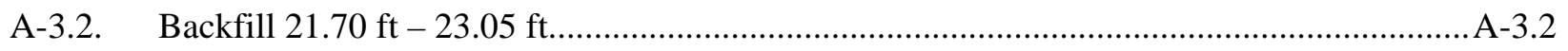

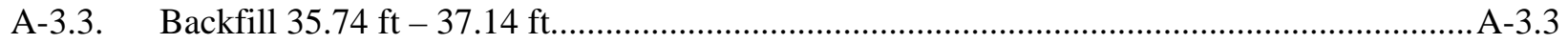

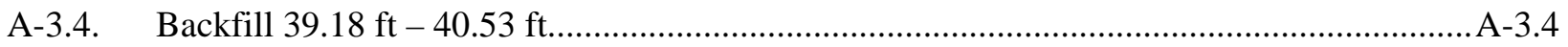

A-3.5. Hanford Formation (H2 unit) $47.30 \mathrm{ft}-48.03 \mathrm{ft}$...............................................................A-3.5

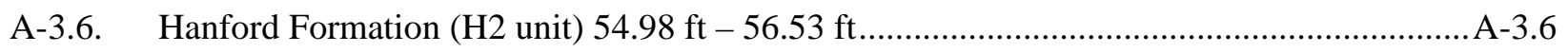

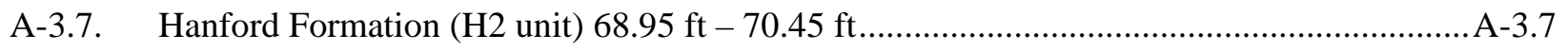

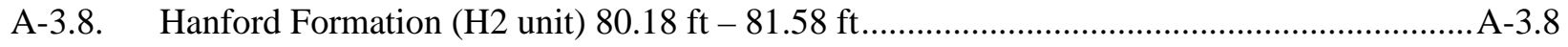

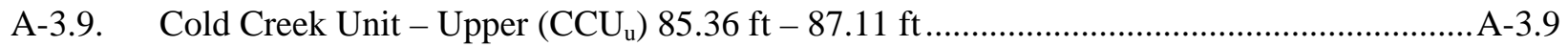

A-3.10. Cold Creek Unit - Upper $\left(\mathrm{CCU}_{\mathrm{u}}\right) 87.22 \mathrm{ft}-88.52 \mathrm{ft}$...................................................... A-3.10

A-3.11. Cold Creek Unit - Lower $\left(\mathrm{CCU}_{\mathrm{l}}\right) 92.24 \mathrm{ft}-93.59 \mathrm{ft}$..................................................... A-3.11

A-3.12. Cold Creek Unit -Lower $\left(\mathrm{CCU}_{\mathrm{l}}\right) 96.01 \mathrm{ft}-97.46 \mathrm{ft}$....................................................... A-3.12

A-3.13. Cold Creek Unit - Lower $\left(\mathrm{CCU}_{\mathrm{l}}\right) 99.33 \mathrm{ft}-100.68 \mathrm{ft}$..................................................... A-3.13

A-3.14. Cold Creek Unit - Lower $\left(\mathrm{CCU}_{\mathrm{l}}\right) 101.02 \mathrm{ft}-102.36 \mathrm{ft}$........................................................3.14

A-3.15. Cold Creek Unit - Lower $\left(\mathrm{CCU}_{\mathrm{l}}\right) 102.17 \mathrm{ft}-103.52 \mathrm{ft}$................................................. A-3.15

A-3.16. Cold Creek Unit - Lower $\left(\mathrm{CCU}_{\mathrm{l}}\right) 105.89 \mathrm{ft}-107.24 \mathrm{ft}$.................................................... A-3.16

A-3.17. Cold Creek Unit - Lower $\left(\mathrm{CCU}_{\mathrm{l}}\right) 109.07 \mathrm{ft} 110.37 \mathrm{ft}$..................................................... A-3.17

A-3.18. Ringold Formation - Member of Taylor Flat $\left(\mathrm{R}_{\mathrm{tf}}\right) 114.97 \mathrm{ft}-116.30 \mathrm{ft}$.......................... A-3.18

A-3.19. Ringold Formation - Member of Taylor Flat $\left(\mathrm{R}_{\mathrm{tf}}\right) 119.85 \mathrm{ft} 121.19 \mathrm{ft}$...............................3.19

A-3.20. Ringold Formation - Member of Wooded Island $\left(\mathrm{R}_{\mathrm{wi}}\right) 122.90 \mathrm{ft}-124.24 \mathrm{ft}$....................A-3.20

A-3.21. Ringold Formation - Member of Wooded Island $\left(\mathrm{R}_{\mathrm{wi}}\right) 128.91 \mathrm{ft}-130.12 \mathrm{ft}$....................A-3.21

A-3.22. Ringold Formation - Member of Wooded Island $\left(\mathrm{R}_{\mathrm{wi}}\right) 128.58 \mathrm{ft}-129.58 \mathrm{ft}$................... A-3.22 


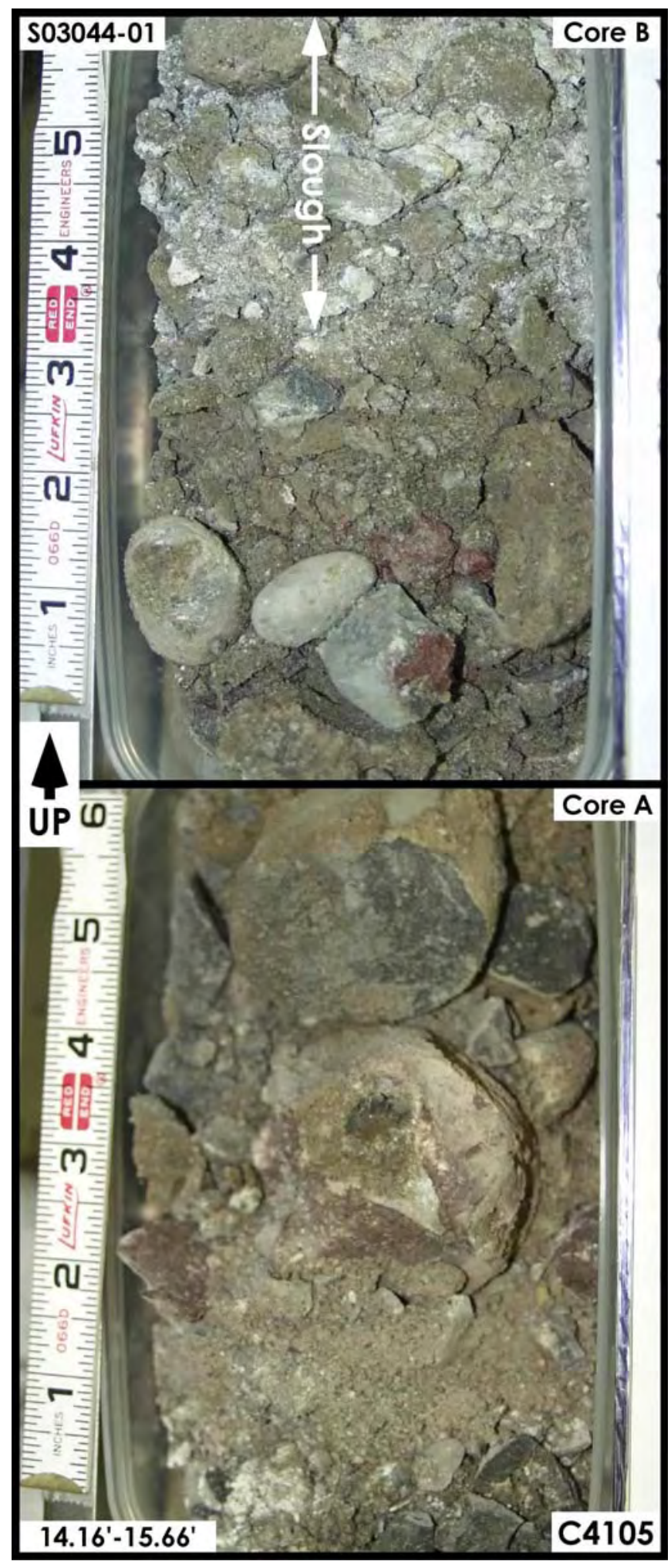

Figure A-3.1. Backfill $14.16 \mathrm{ft}-\mathbf{1 5 . 6 6} \mathrm{ft}$ 


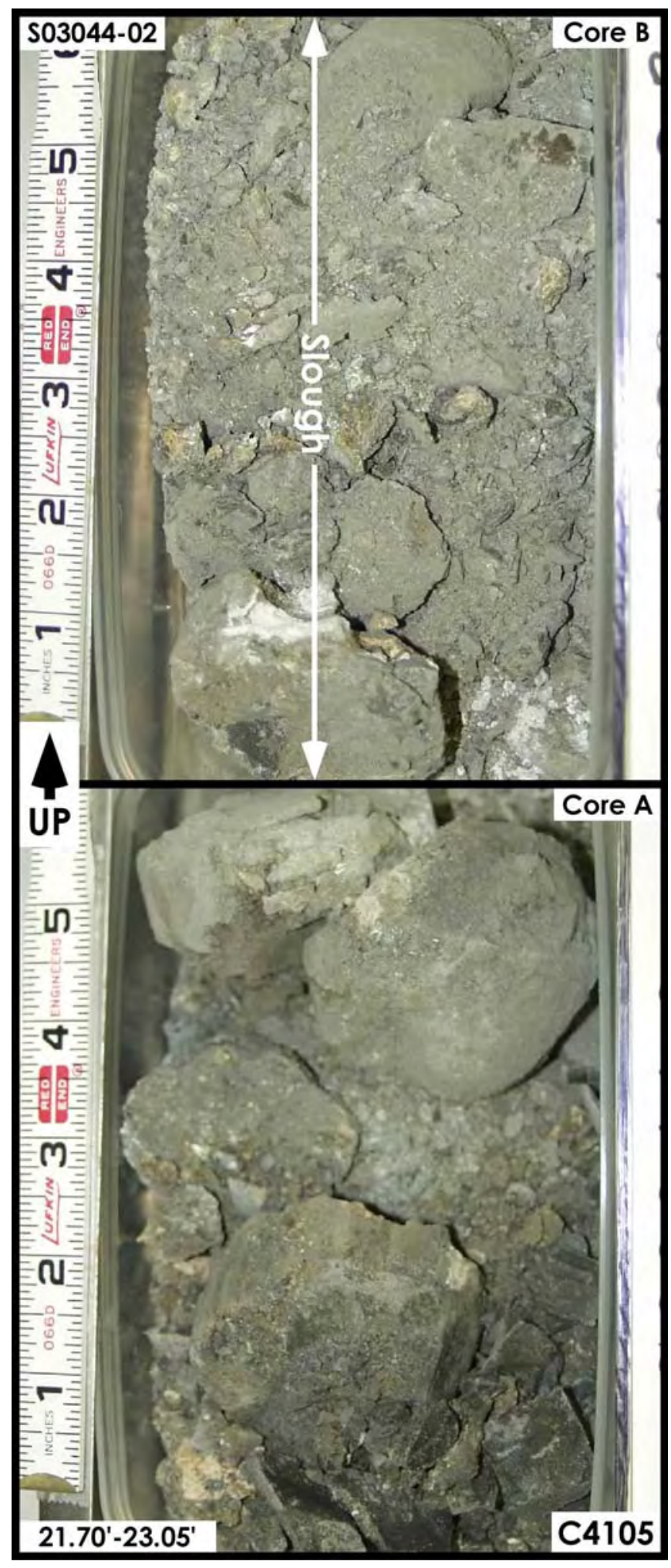

Figure A-3.2. Backfill $21.70 \mathrm{ft}-23.05 \mathrm{ft}$ 


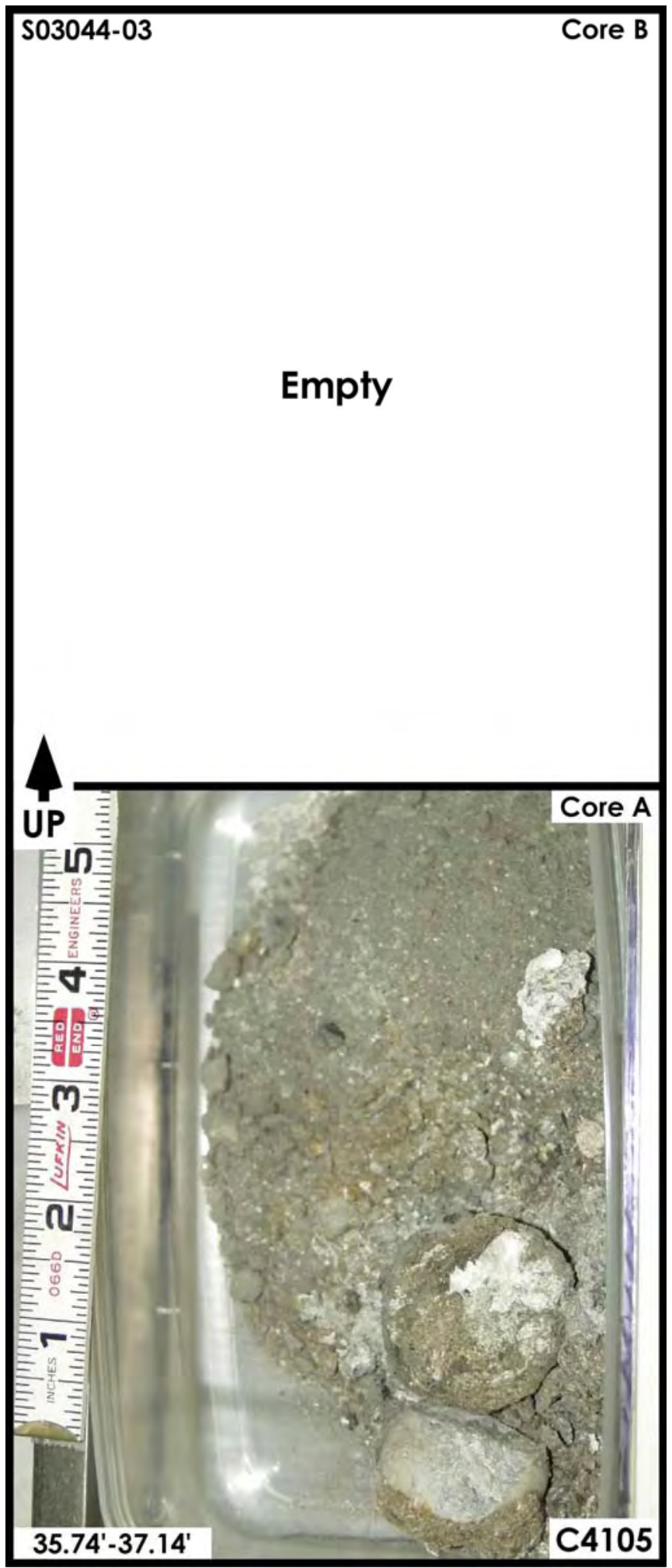

Figure A-3.3. Backfill $35.74 \mathrm{ft}-\mathbf{3 7 . 1 4} \mathrm{ft}$ 


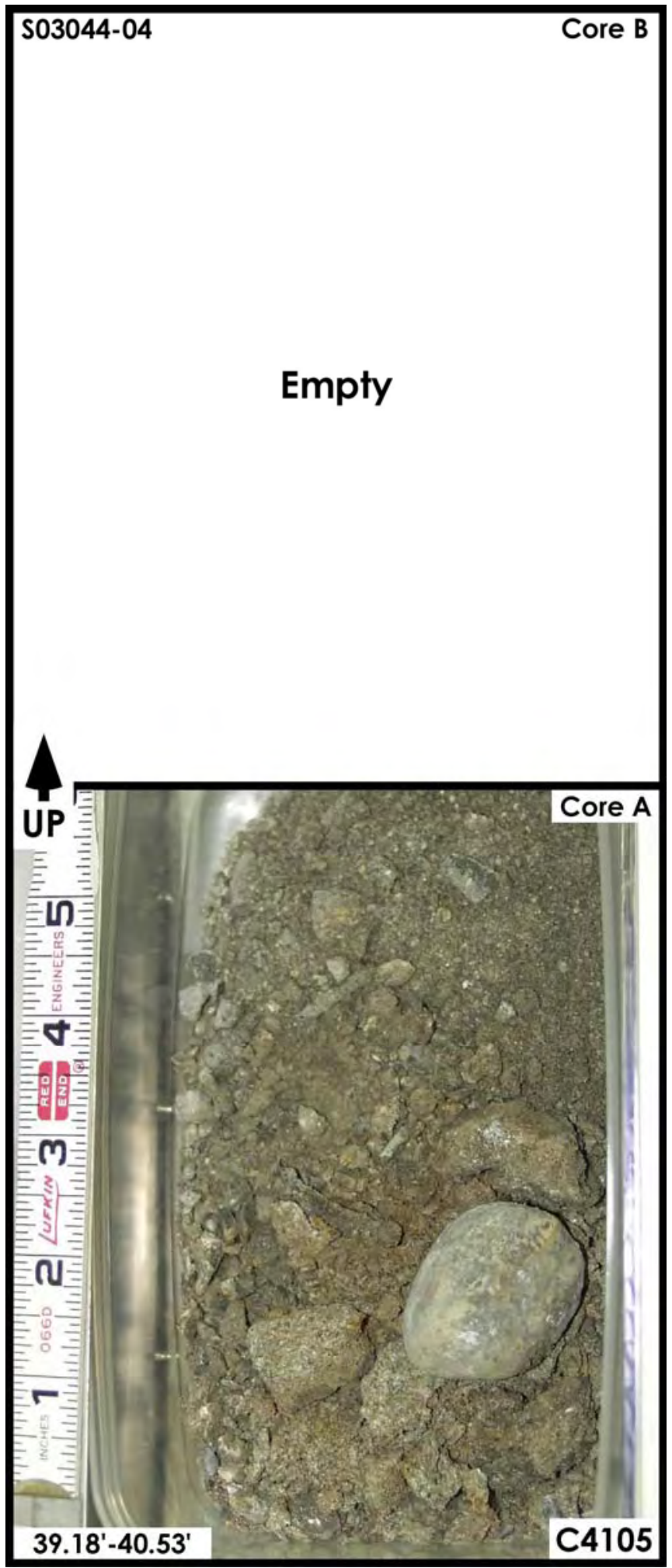

Figure A-3.4. Backfill $39.18 \mathrm{ft}-\mathbf{4 0 . 5 3} \mathrm{ft}$ 


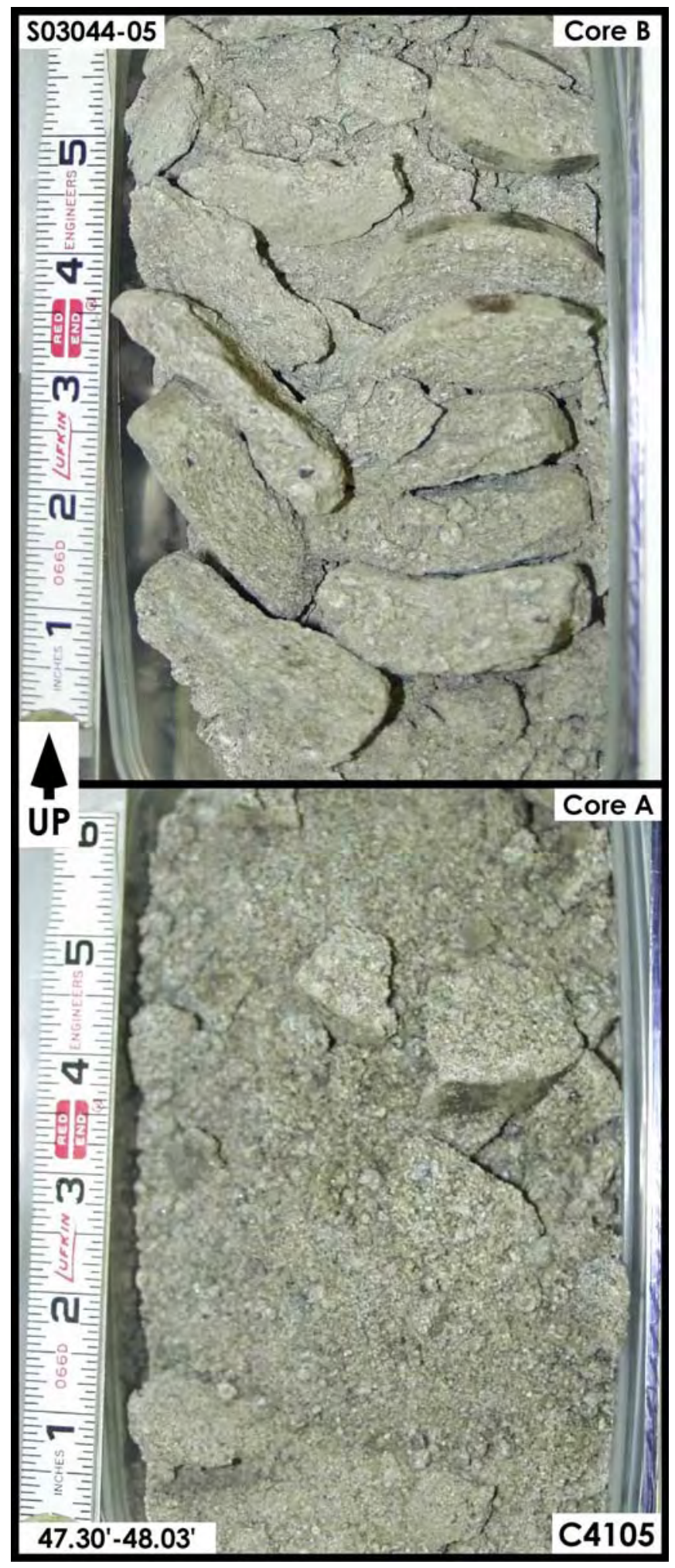

Figure A-3.5. Hanford Formation (H2 unit) $47.30 \mathrm{ft}-\mathbf{4 8 . 0 3} \mathrm{ft}$ 


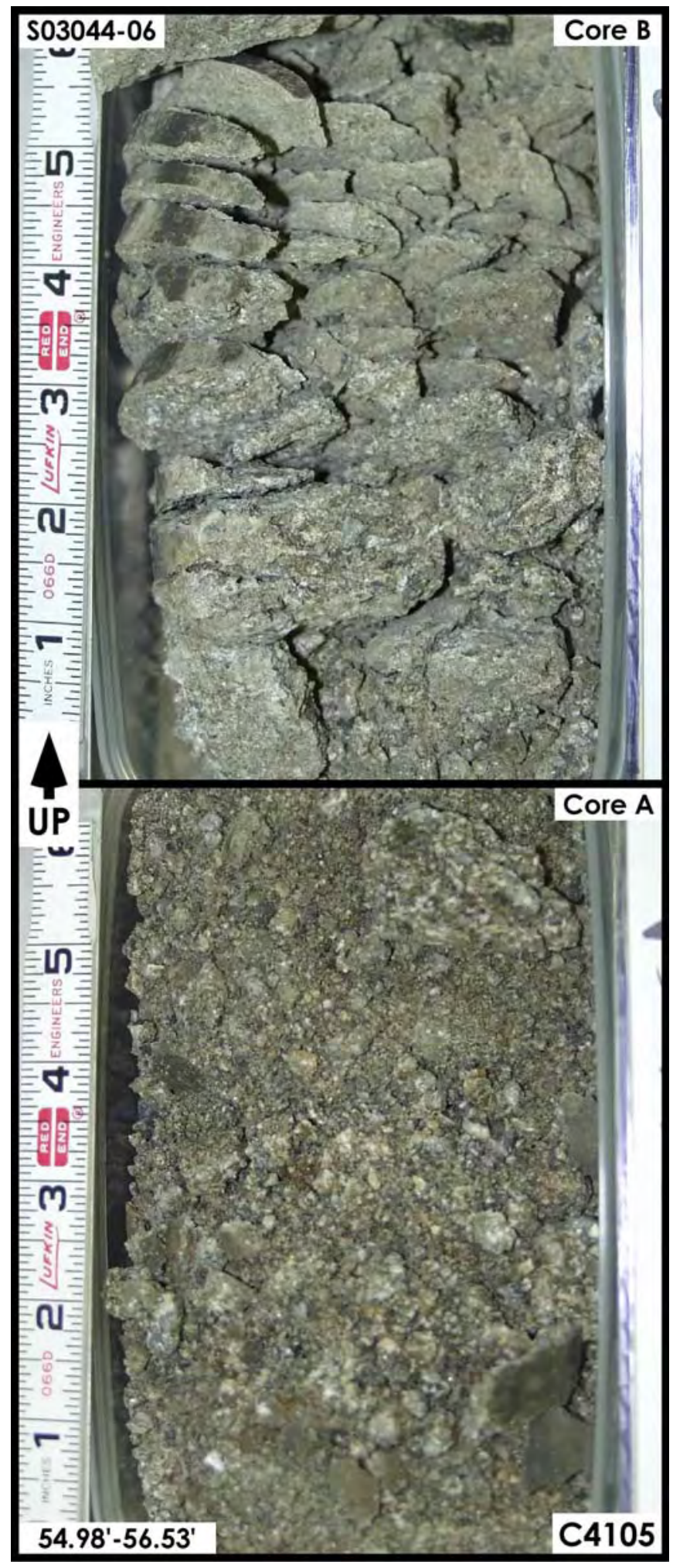

Figure A-3.6. Hanford Formation (H2 unit) $54.98 \mathrm{ft}-56.53 \mathrm{ft}$ 


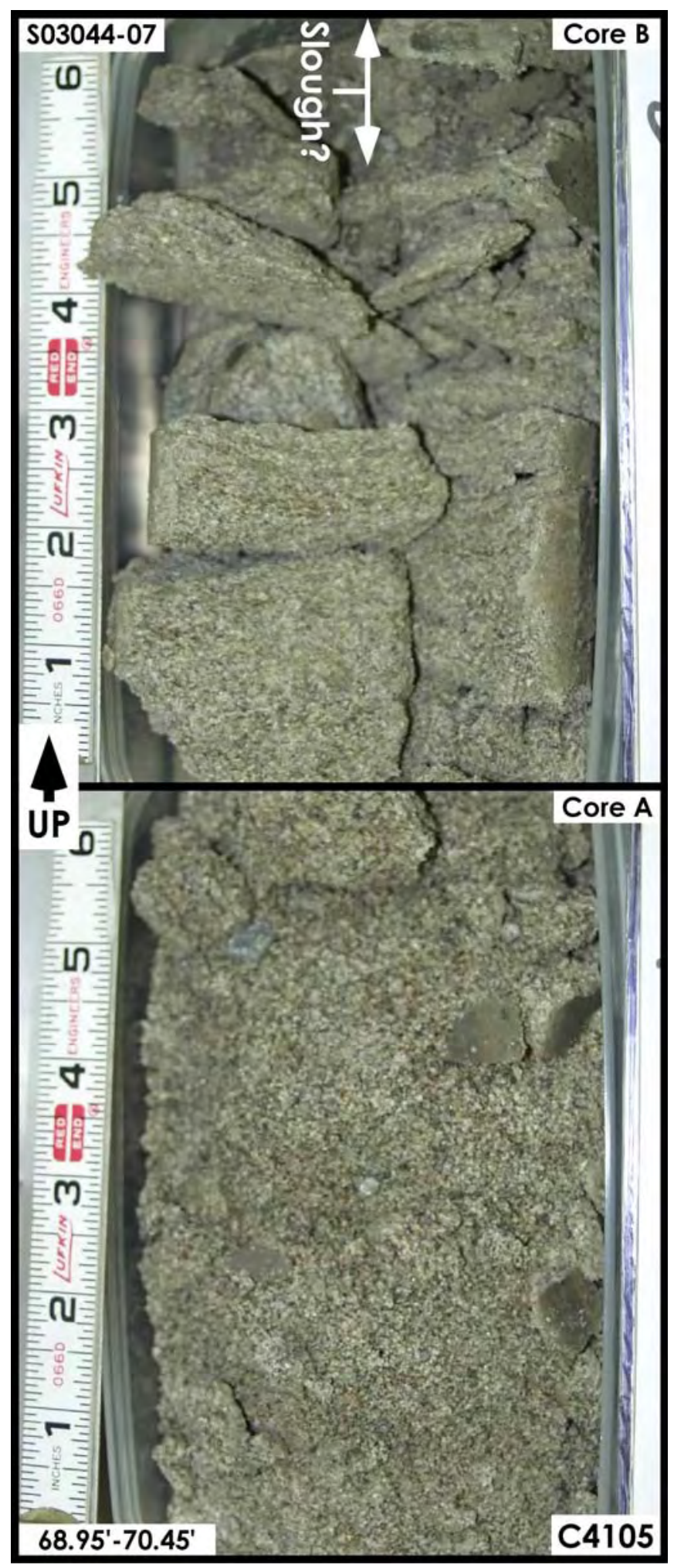

Figure A-3.7. Hanford Formation (H2 unit) $68.95 \mathrm{ft}-70.45 \mathrm{ft}$ 


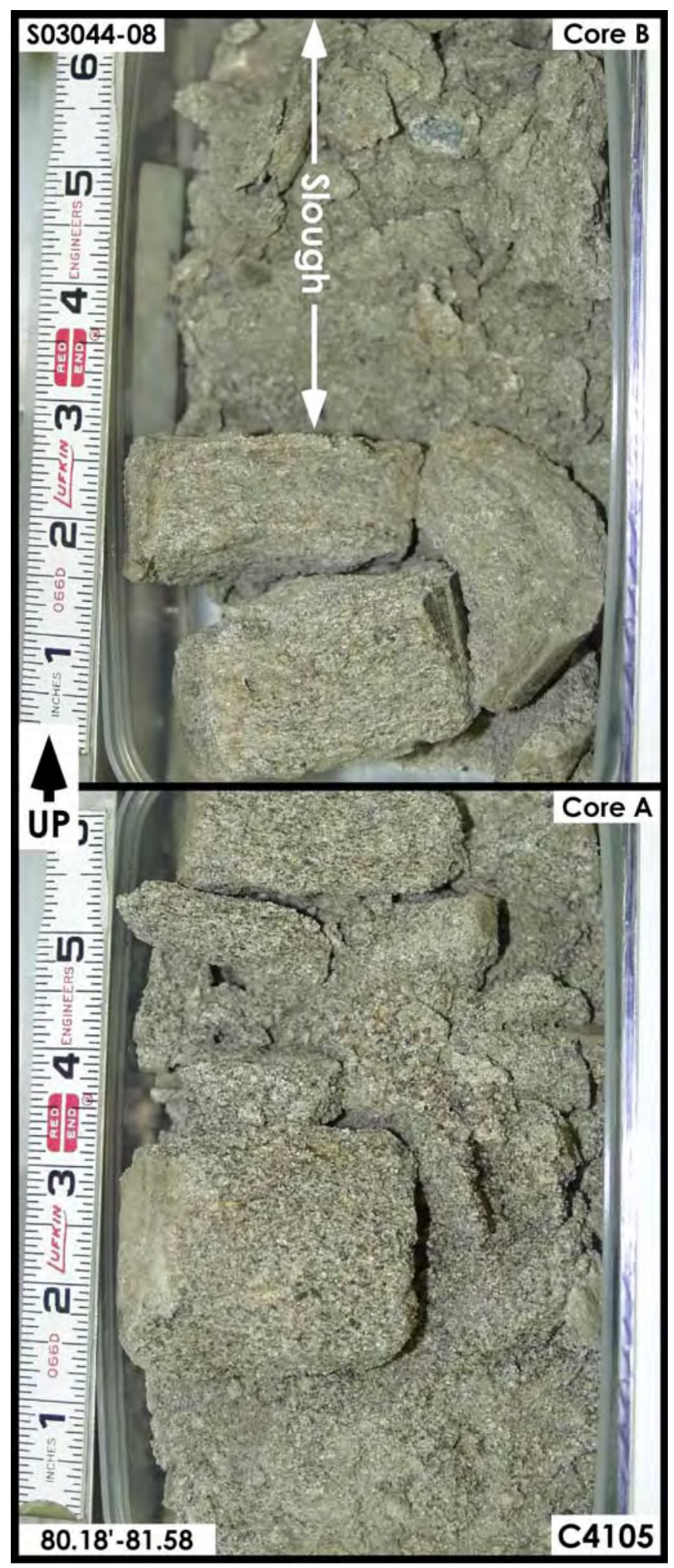

Figure A-3.8. Hanford Formation (H2 unit) $80.18 \mathrm{ft}-81.58 \mathrm{ft}$ 


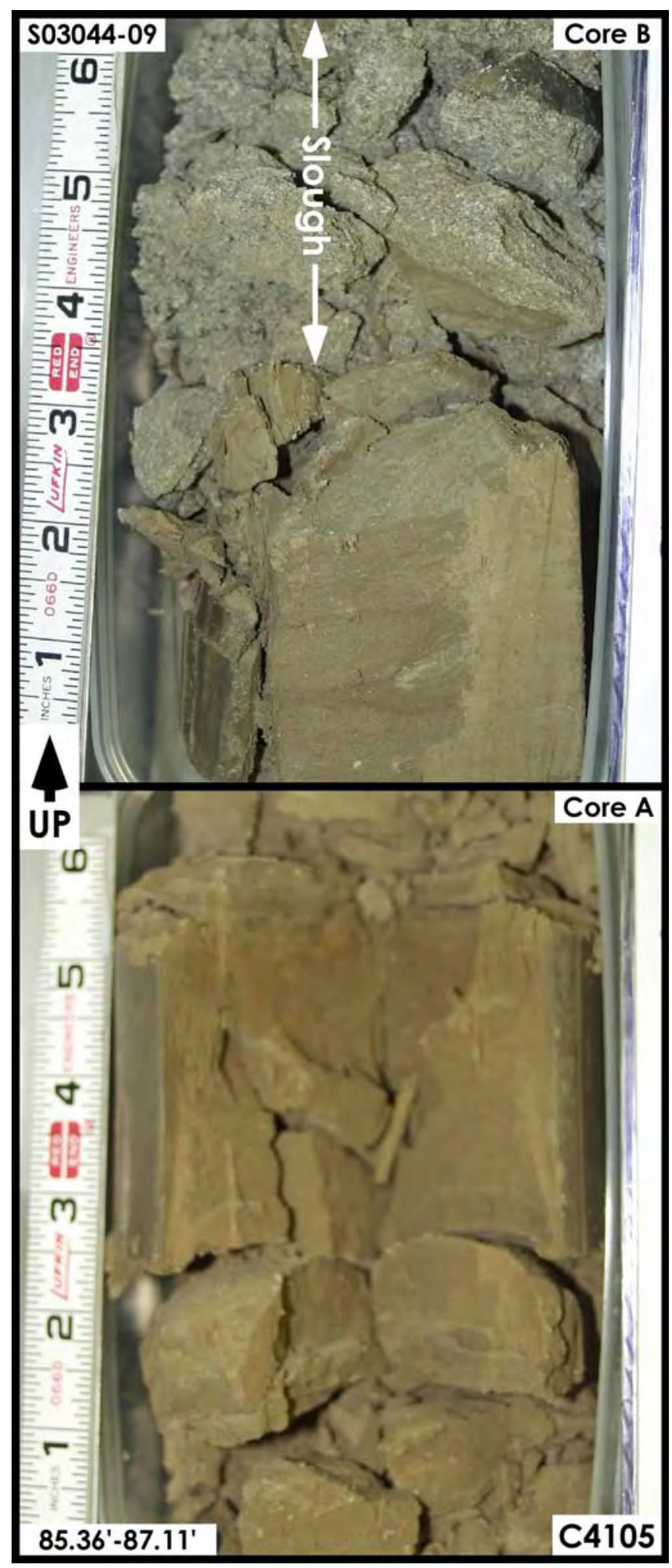

Figure A-3.9. Cold Creek Unit - Upper $\left(C^{C} U_{u}\right) 85.36$ ft - 87.11 ft 


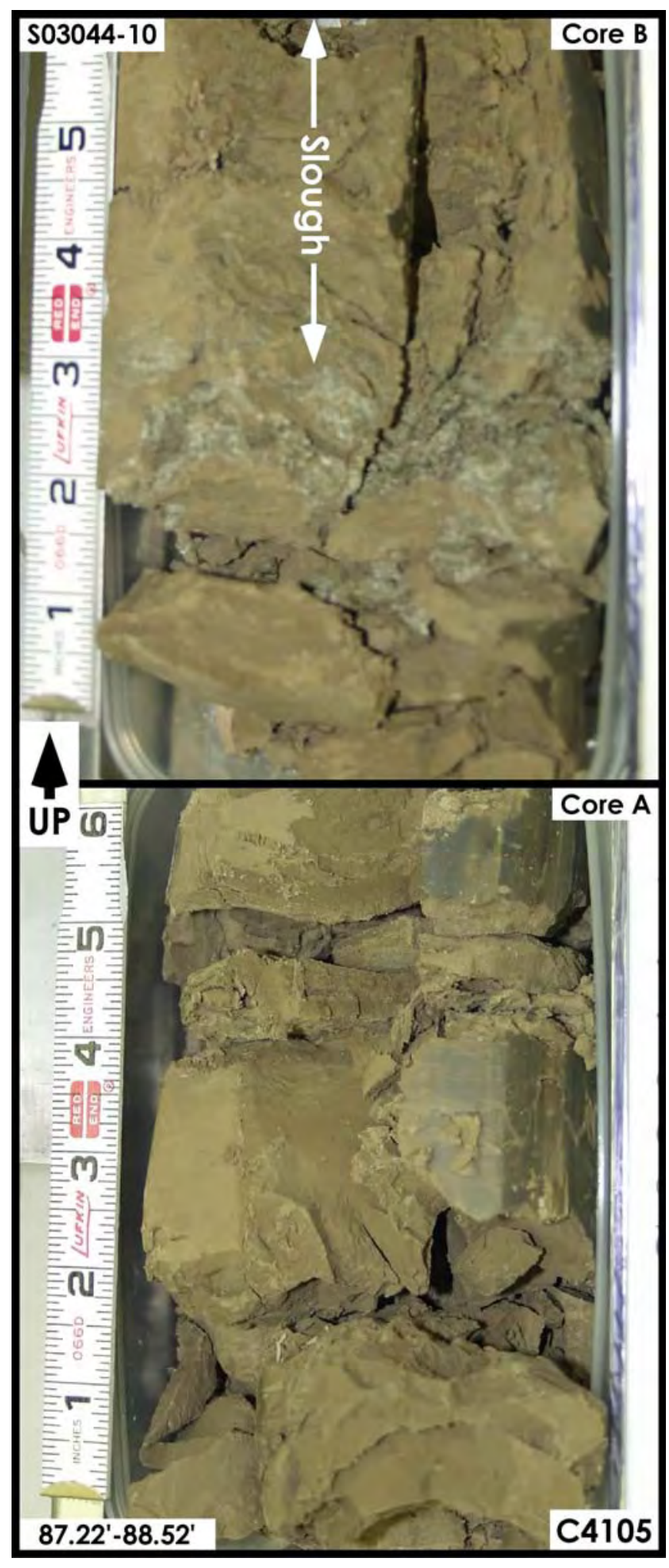

Figure A-3.10. Cold Creek Unit - Upper $\left(\mathrm{CCU}_{u}\right) 87.22 \mathrm{ft}-88.52 \mathrm{ft}$ 


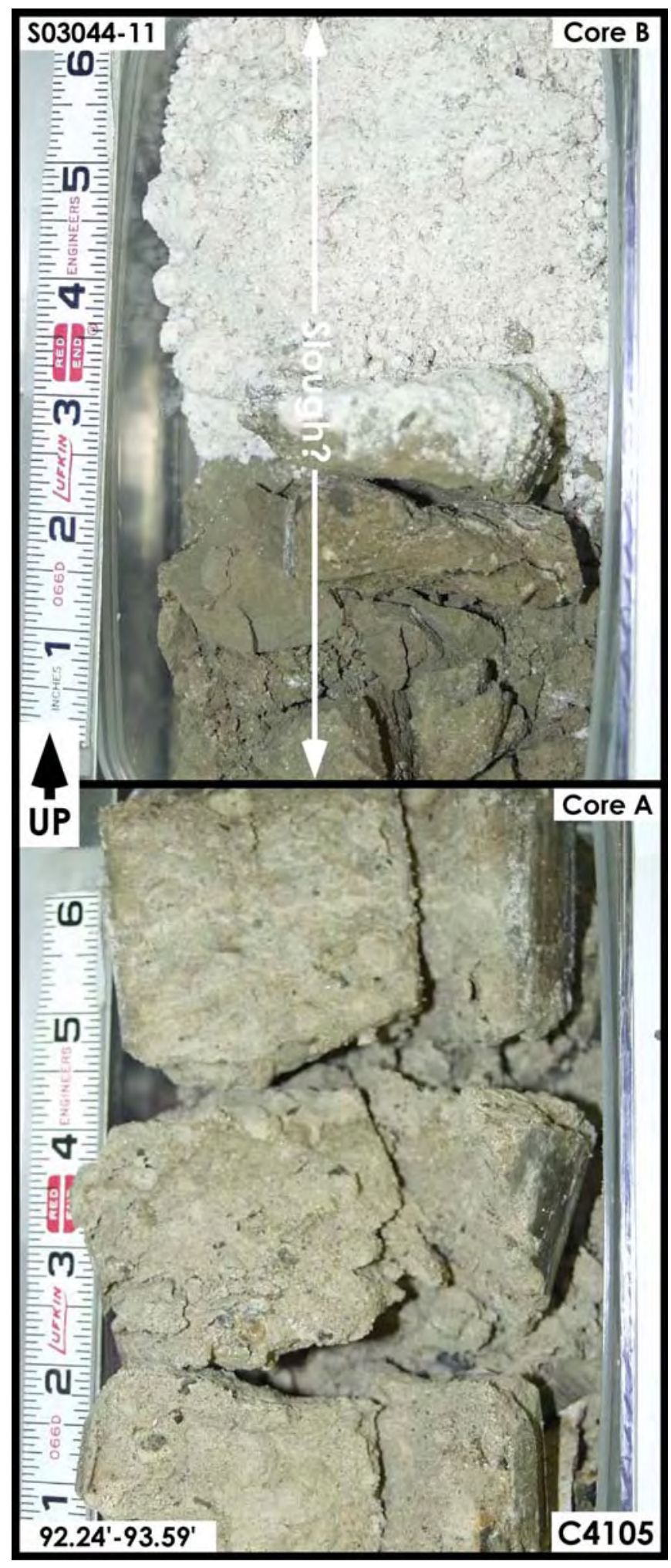

Figure A-3.11. Cold Creek Unit - Lower $\left(\mathrm{CCU}_{\mathrm{l}}\right) 92.24 \mathrm{ft}-93.59 \mathrm{ft}$ 


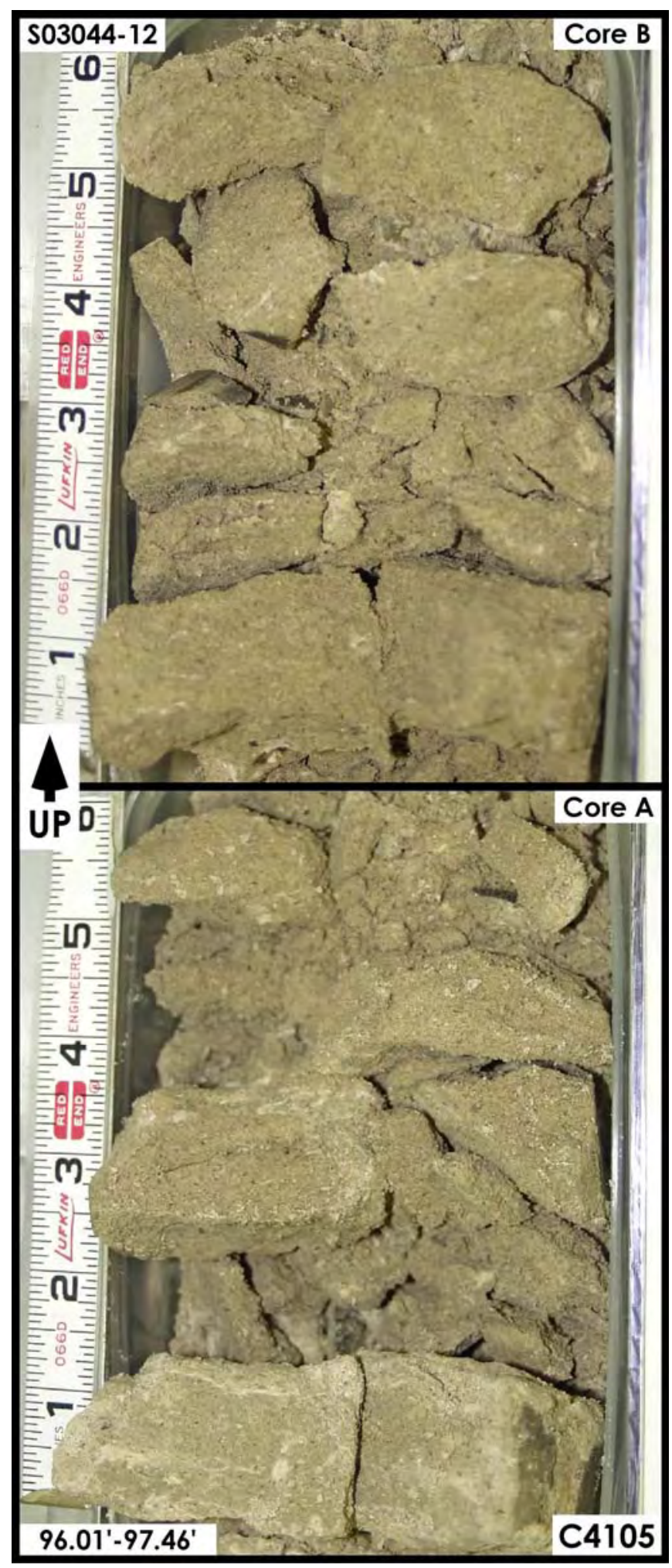

Figure A-3.12. Cold Creek Unit -Lower $\left(C C U_{l}\right) 96.01 \mathrm{ft}-97.46 \mathrm{ft}$ 


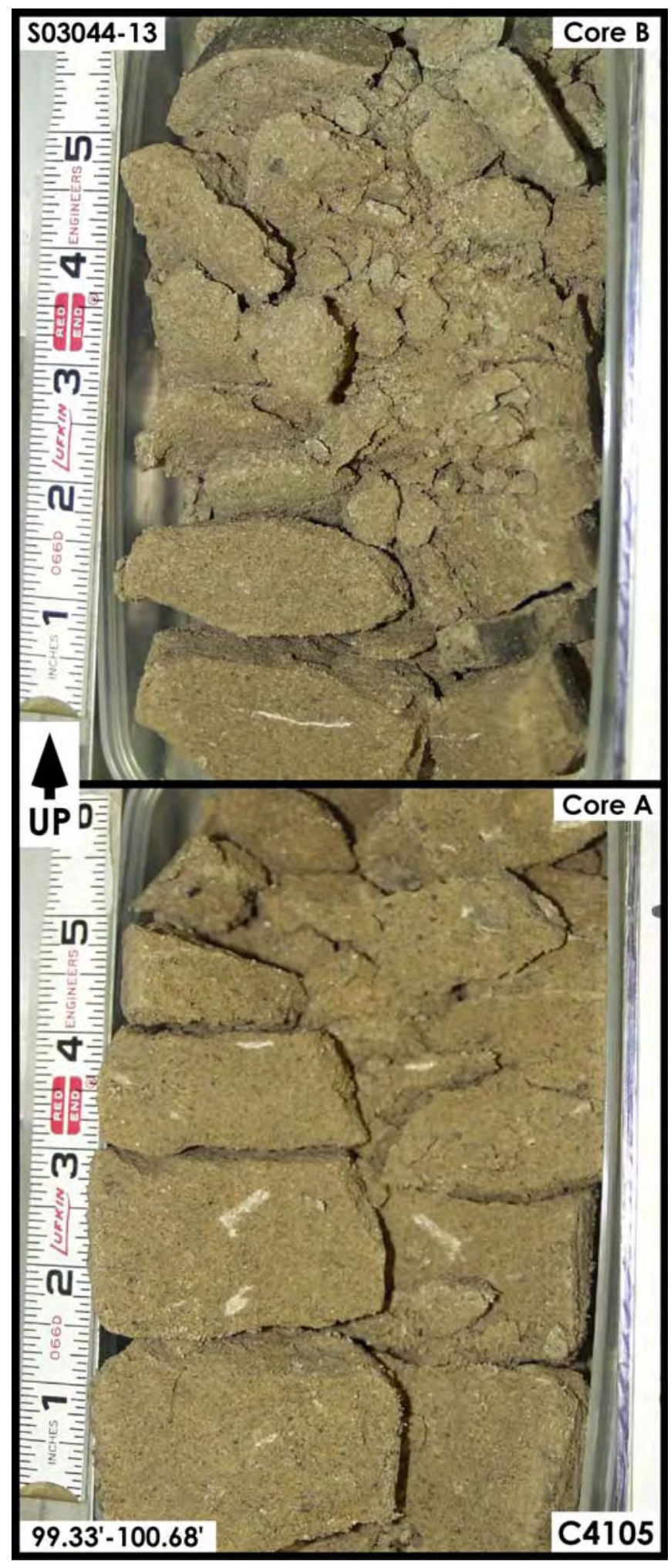

Figure A-3.13. Cold Creek Unit - Lower $\left(\mathrm{CCU}_{\mathrm{l}}\right) 99.33 \mathrm{ft}-100.68 \mathrm{ft}$ 


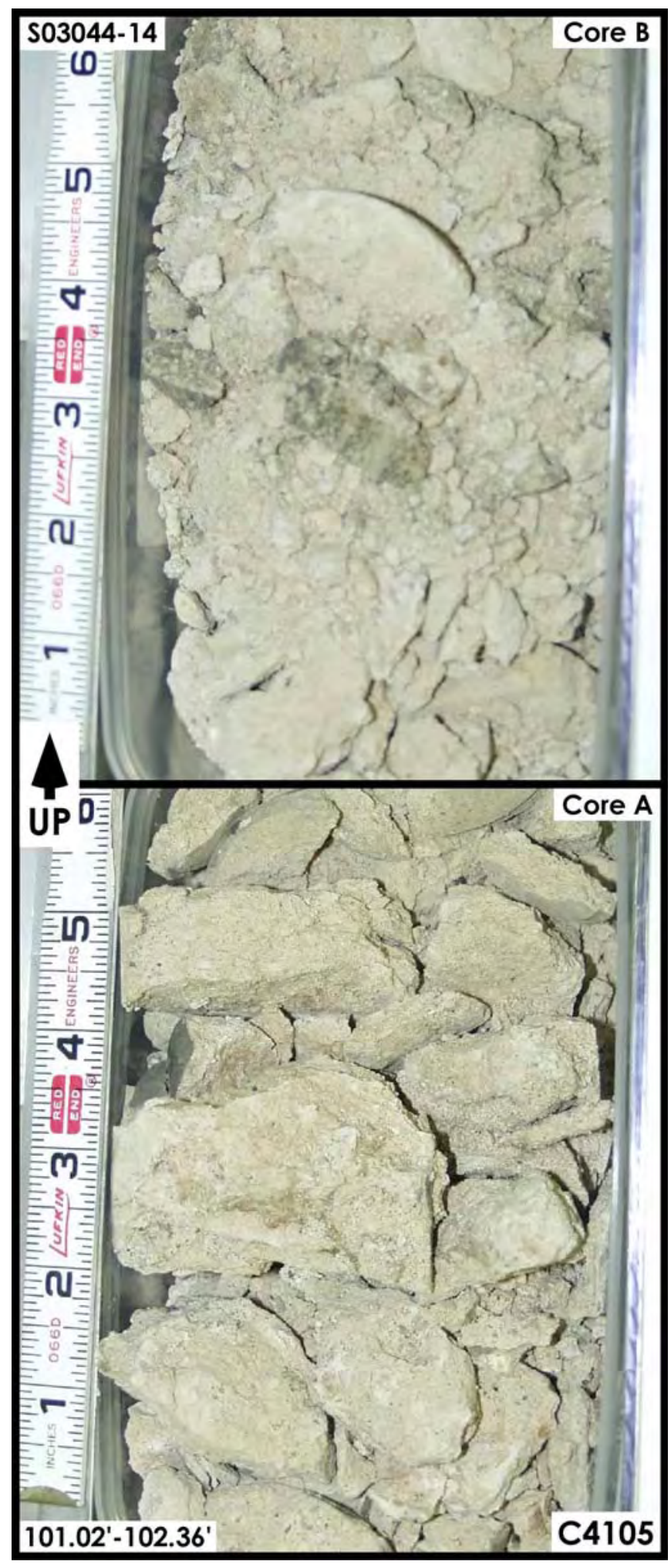

Figure A-3.14. Cold Creek Unit - Lower $\left(\mathrm{CCU}_{\mathrm{l}}\right) \mathbf{1 0 1 . 0 2} \mathrm{ft}-102.36 \mathrm{ft}$ 


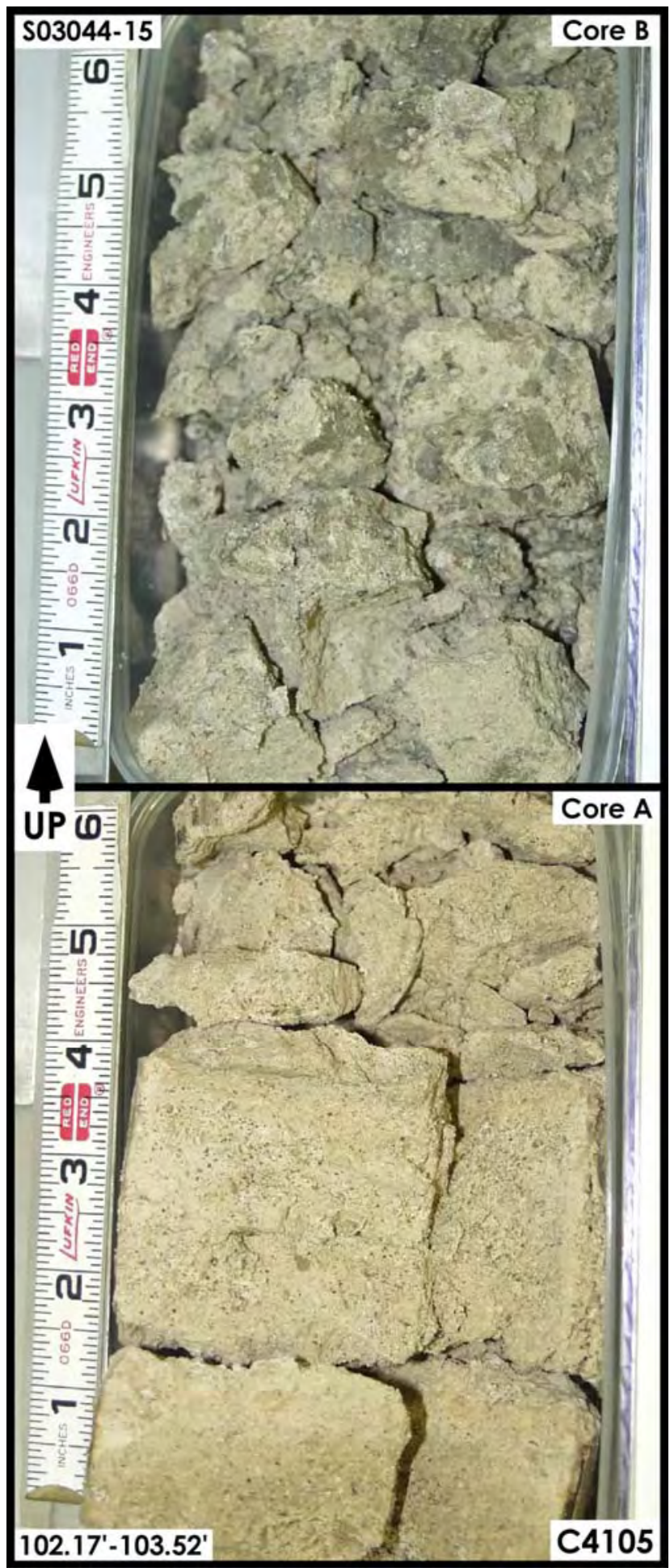

Figure A-3.15. Cold Creek Unit - Lower $\left(C_{C C U_{l}}\right) 102.17$ ft - 103.52 ft 


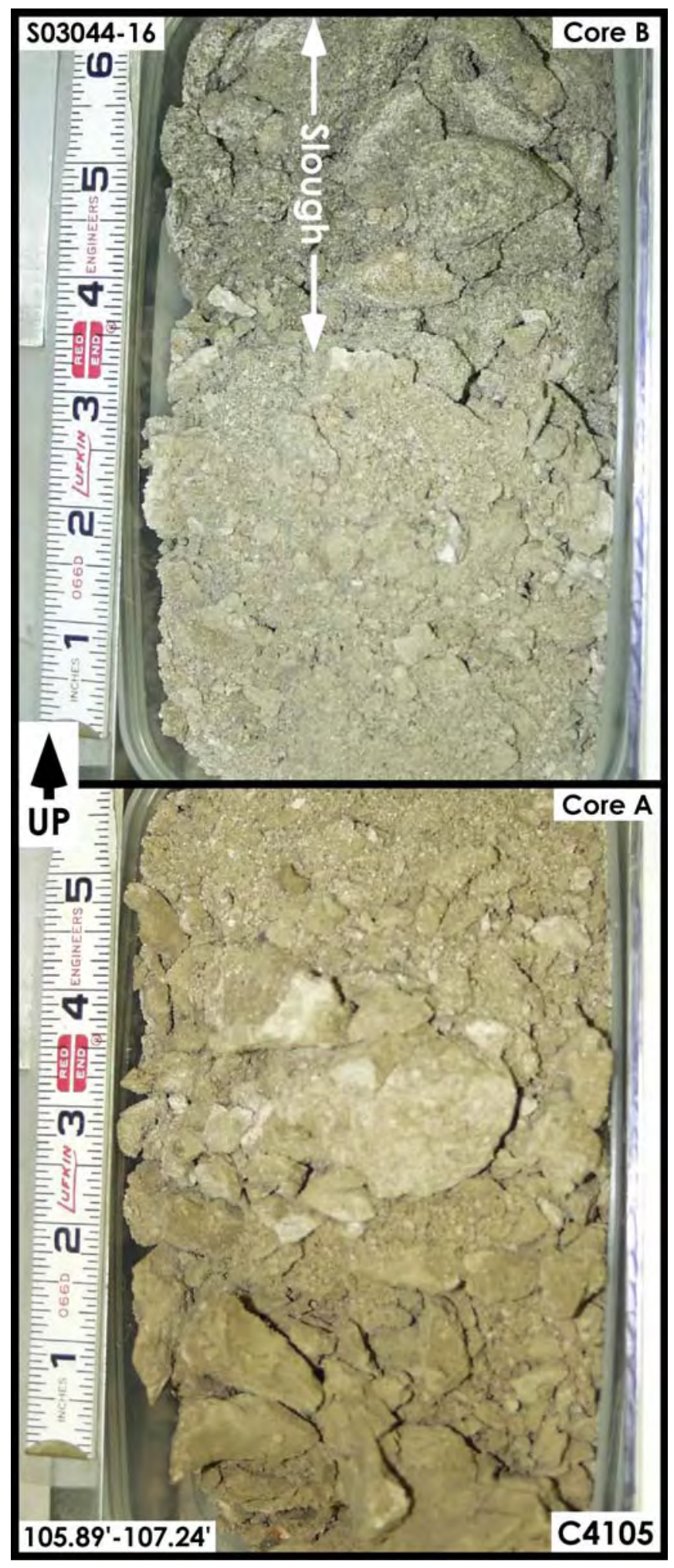

Figure A-3.16. Cold Creek Unit - Lower $\left(\mathrm{CCU}_{\mathrm{l}}\right) \mathbf{1 0 5 . 8 9} \mathrm{ft}-107.24 \mathrm{ft}$ 


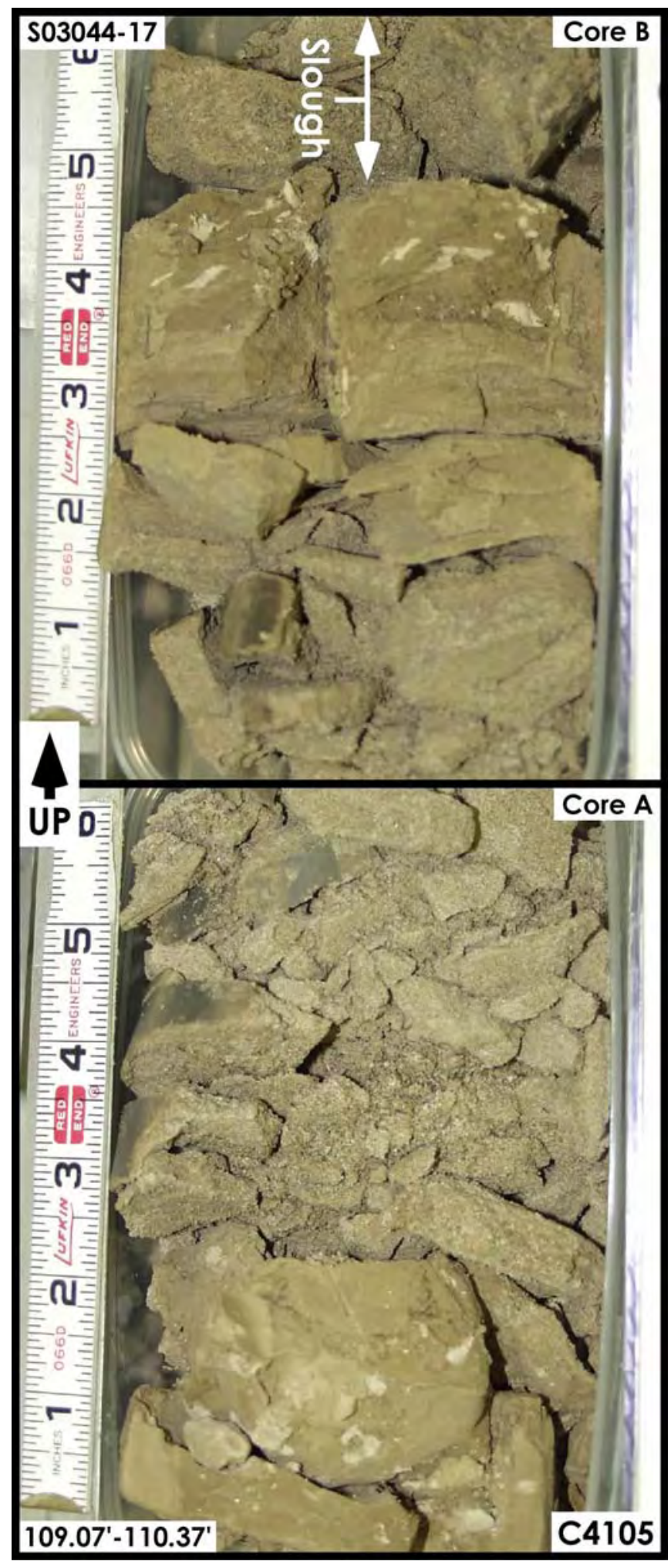

Figure A-3.17. Cold Creek Unit - Lower $\left(\mathrm{CCU}_{\mathrm{l}}\right) \mathbf{1 0 9 . 0 7} \mathrm{ft} 110.37 \mathrm{ft}$ 


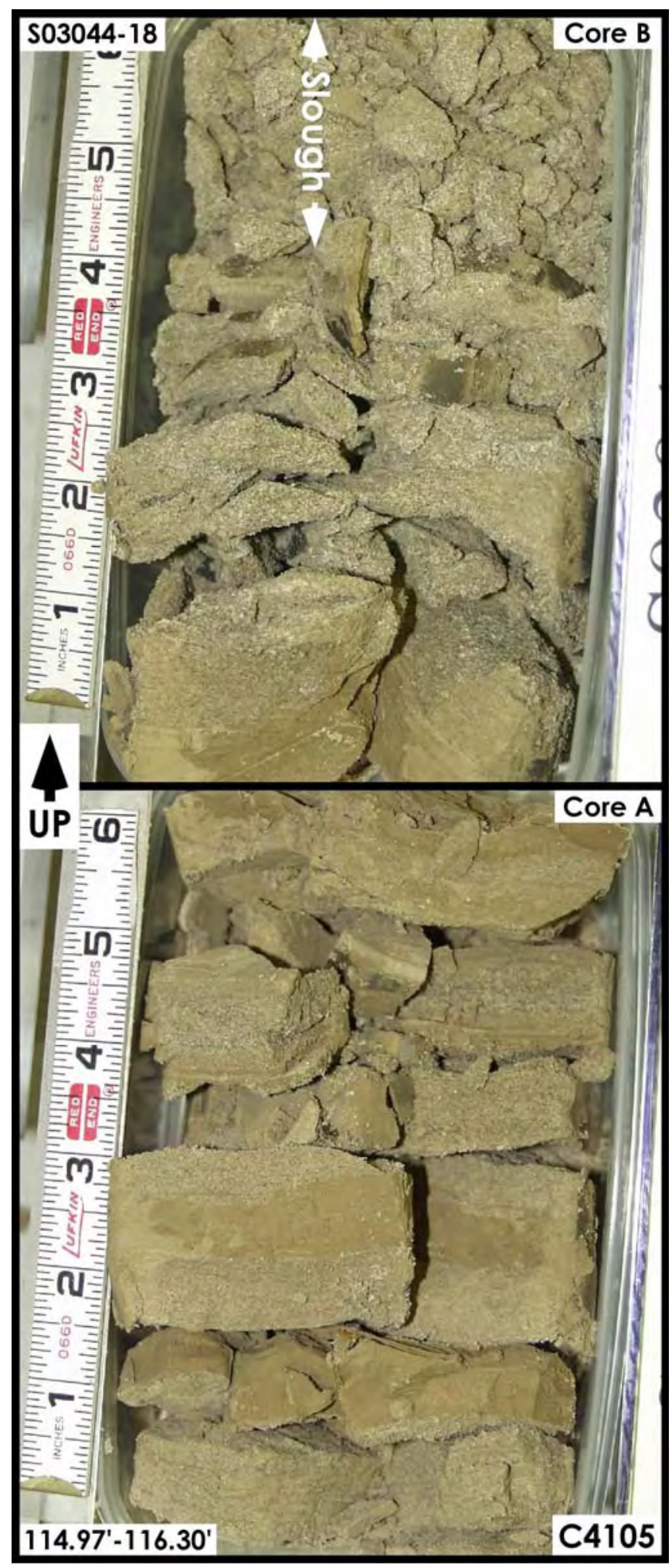

Figure A-3.18. Ringold Formation - Member of Taylor Flat $\left(R_{t f}\right) 114.97 \mathrm{ft}-116.30 \mathrm{ft}$ 


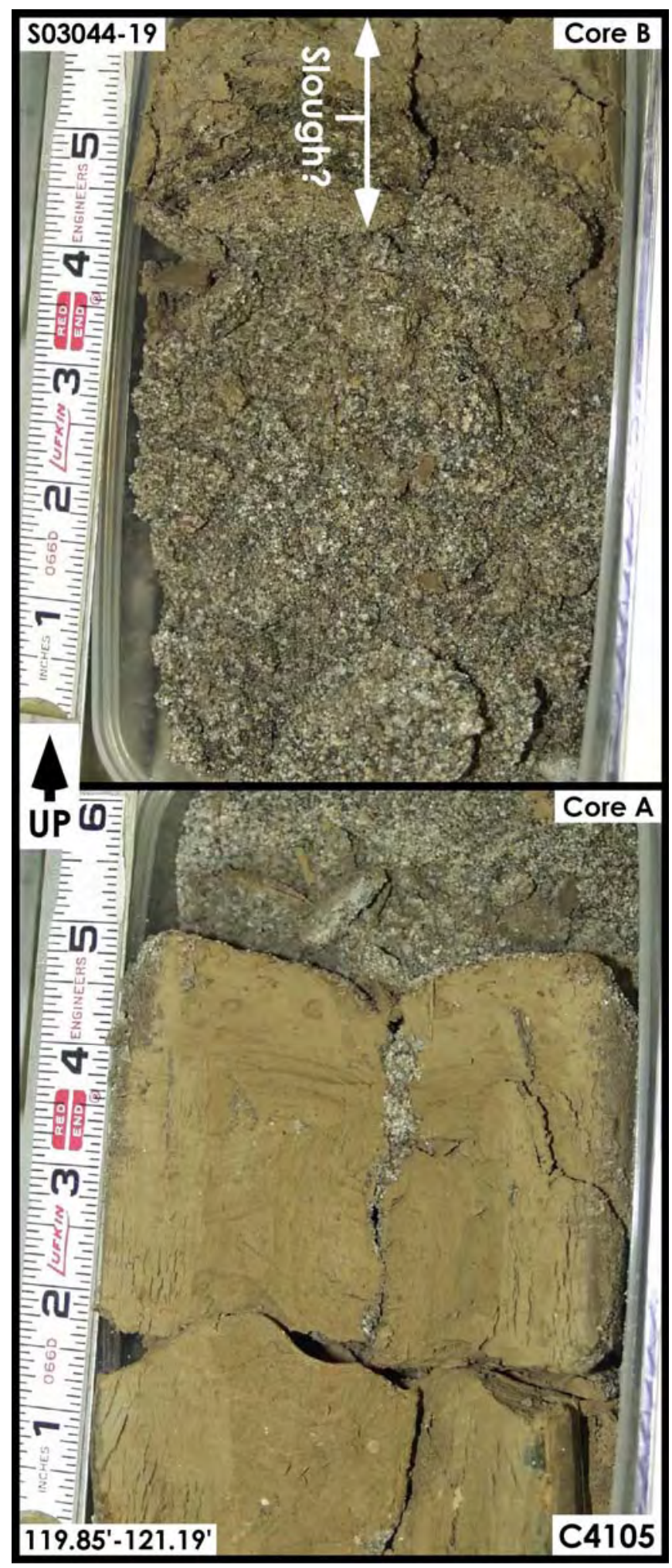

Figure A-3.19. Ringold Formation - Member of Taylor Flat $\left(R_{t f}\right) 119.85 \mathrm{ft} 121.19 \mathrm{ft}$ 


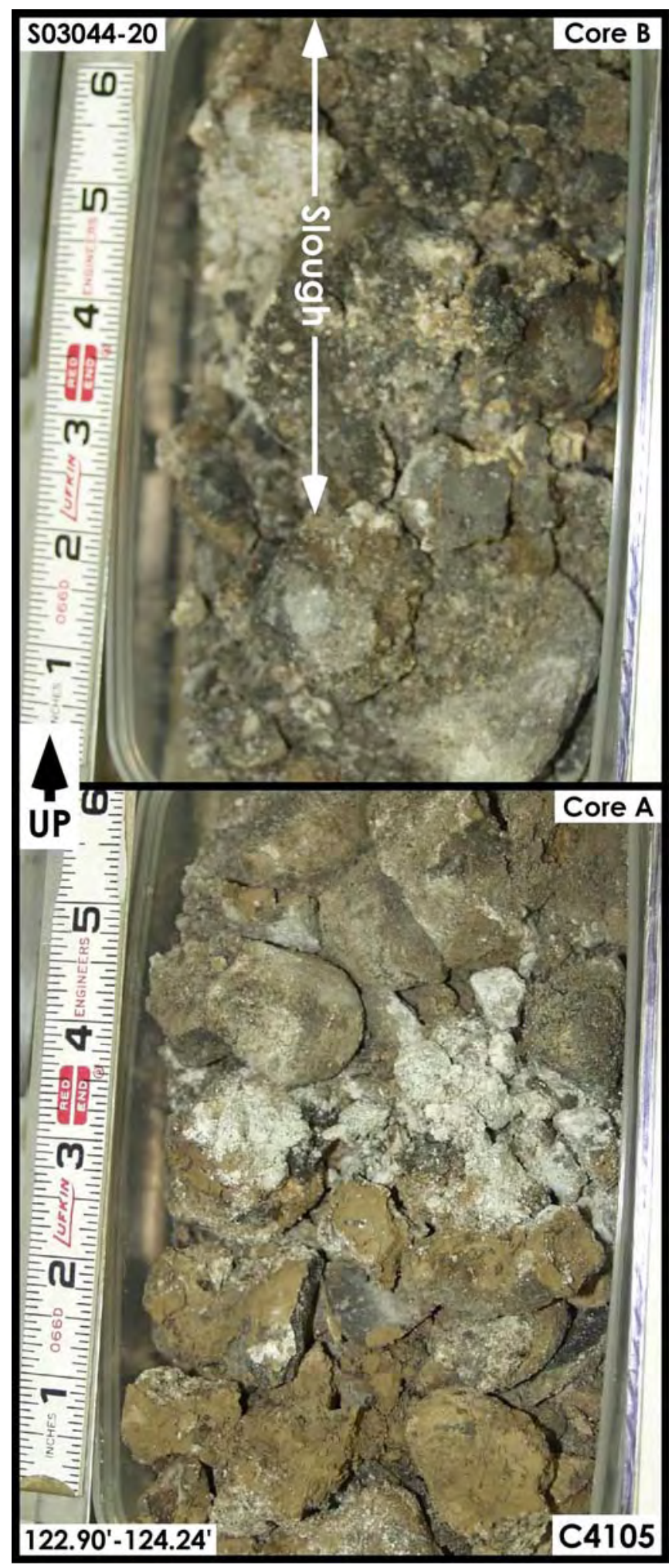

Figure A-3.20. Ringold Formation - Member of Wooded Island $\left(R_{w i}\right) 122.90 \mathrm{ft}-124.24 \mathrm{ft}$ 


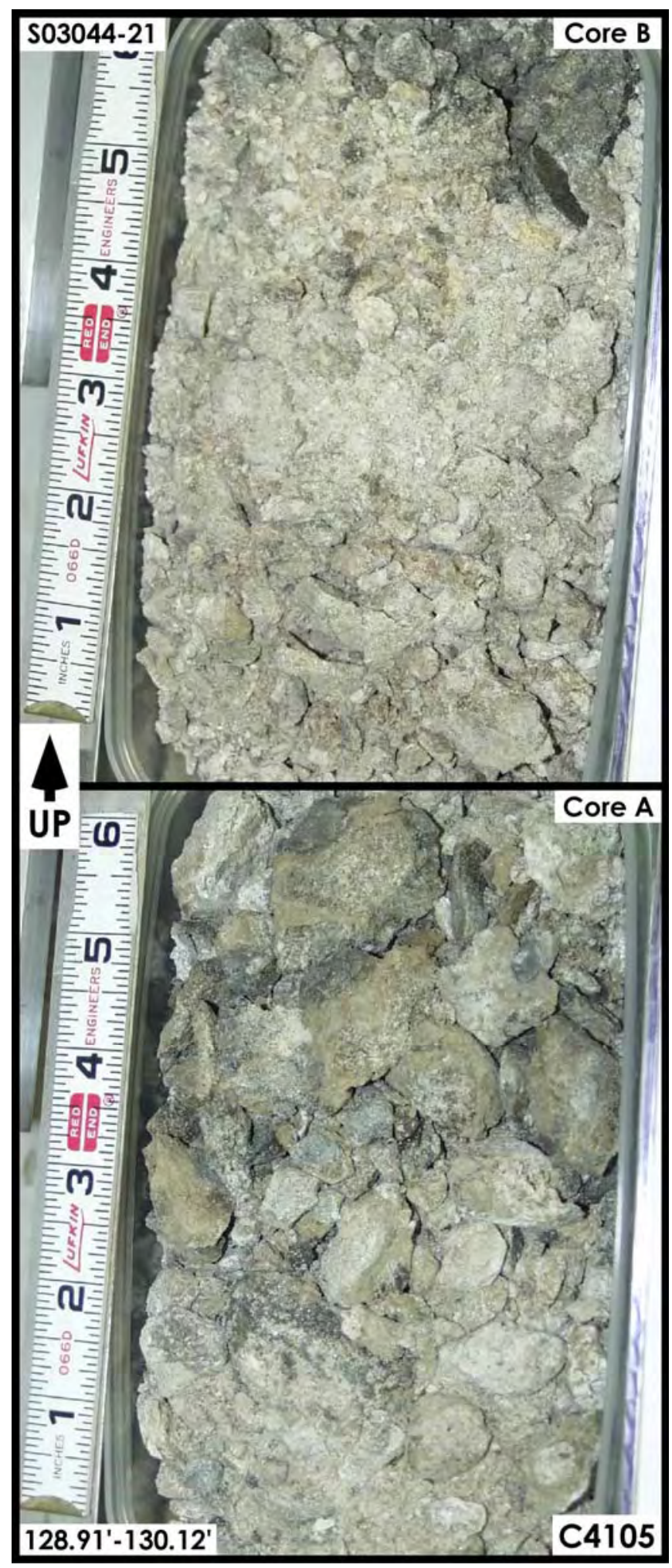

Figure A-3.21. Ringold Formation - Member of Wooded Island $\left(R_{w i}\right) 128.91 \mathrm{ft}-130.12 \mathrm{ft}$ 


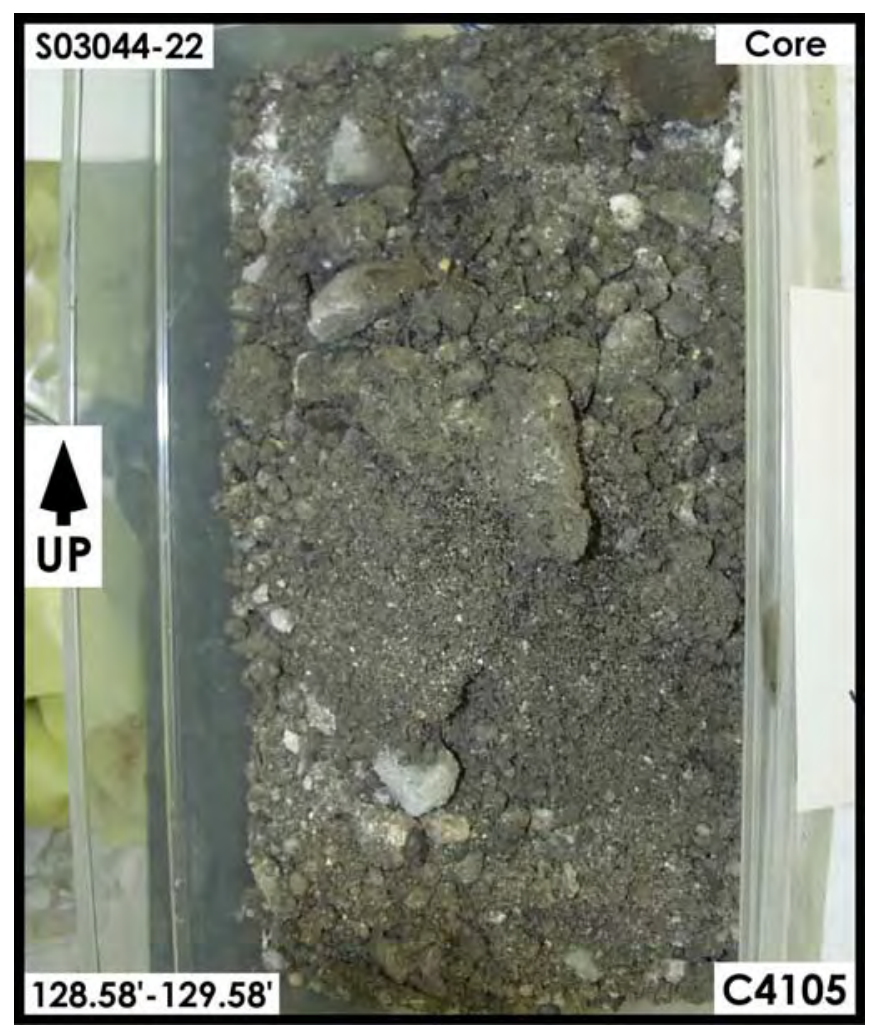

Figure A-3.22. Ringold Formation - Member of Wooded Island $\left(R_{w i}\right) 128.58 \mathrm{ft}-129.58 \mathrm{ft}$ 
Appendix B. Core Logs

B.1 C4104 (T-106)

B.2 C4105 (T-106) 
Appendix B-1

C4104 (T-106)

GEOLOGIC DESCRIPTION OF CORE

OBTAINED DURING OPENING IN LAB 


\section{Contents}

Appendix B.1 C4104 (T-106) GEOLOGIC DESCRIPTION OF CORE ............................................. B-1.1 


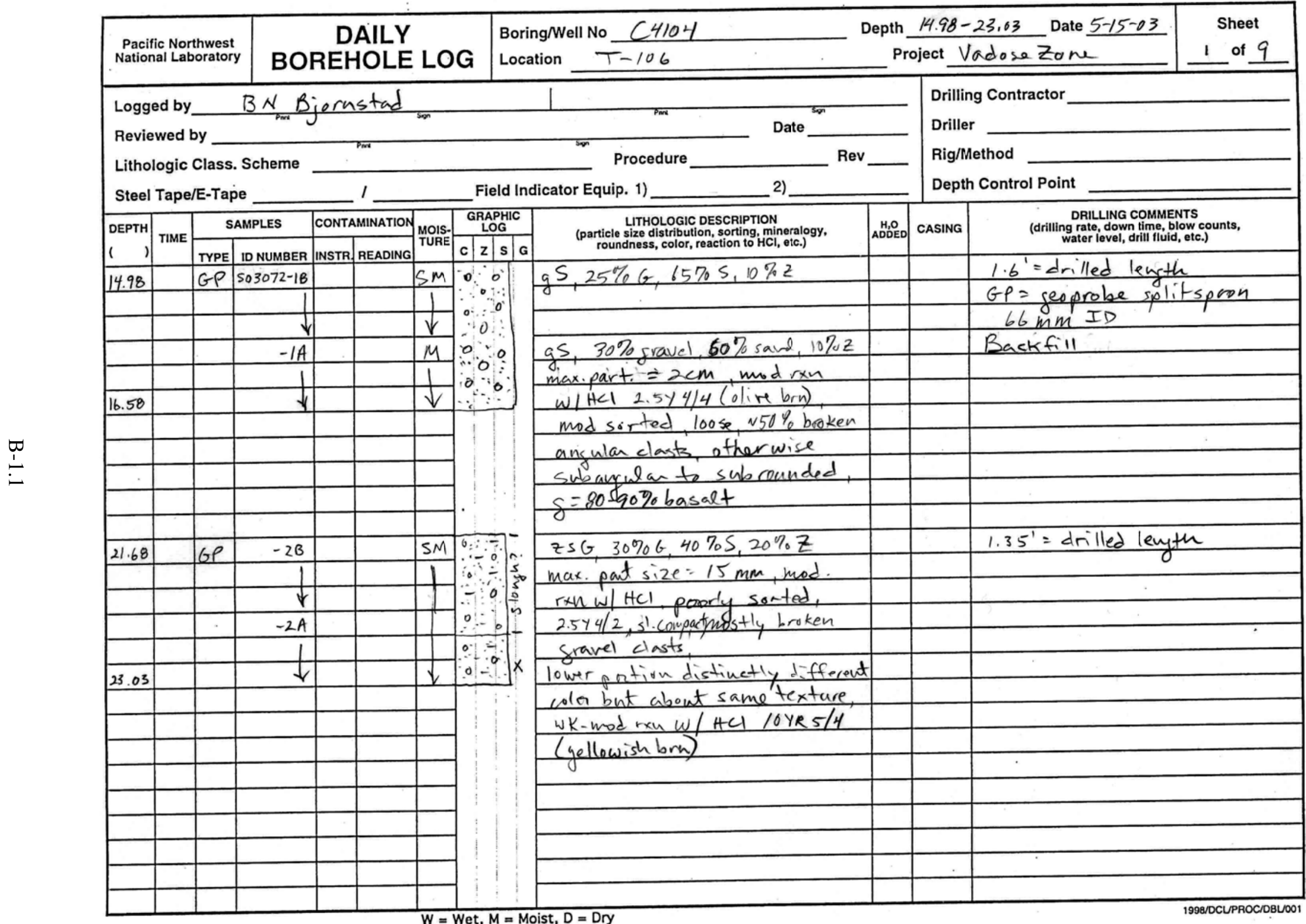




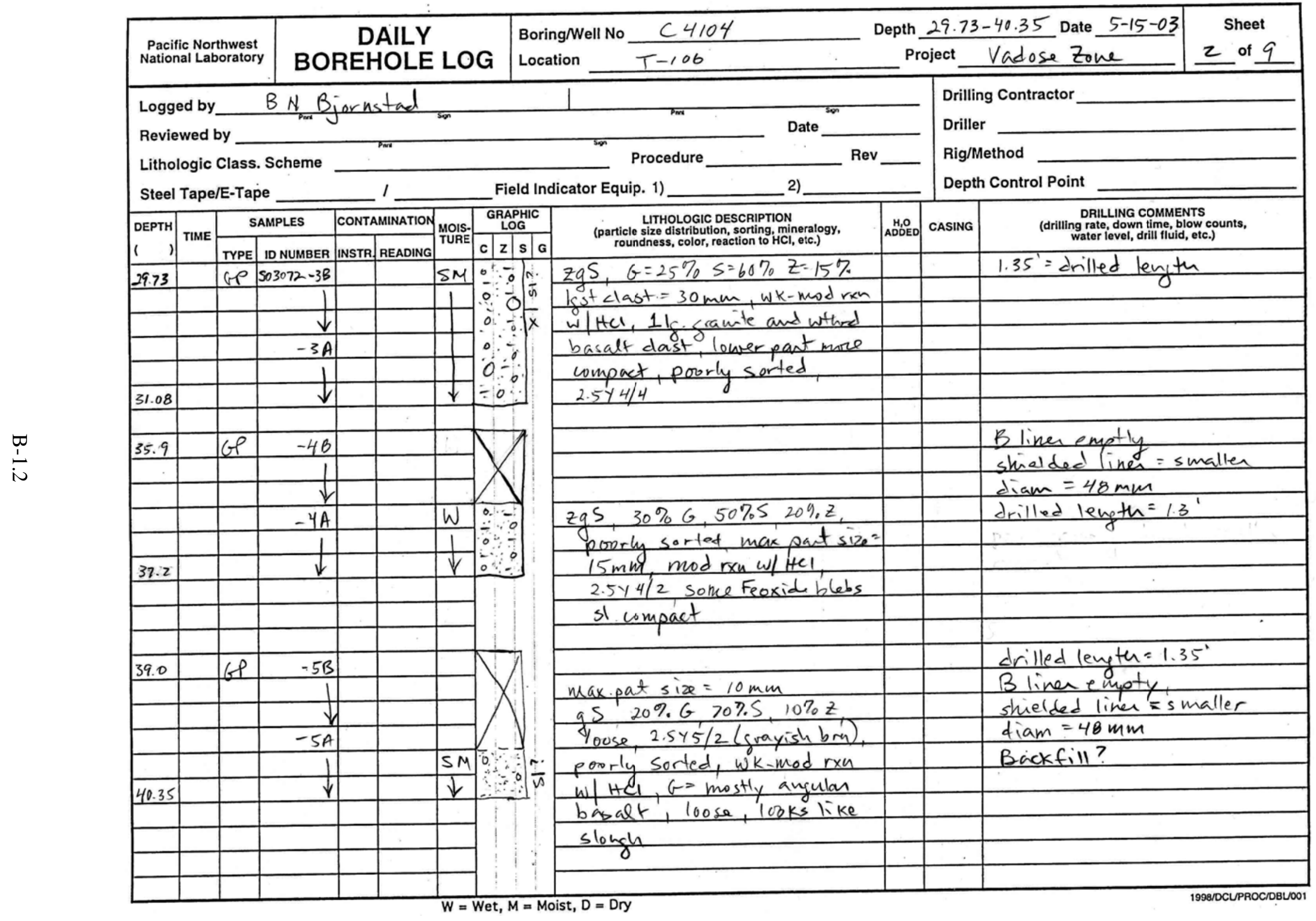




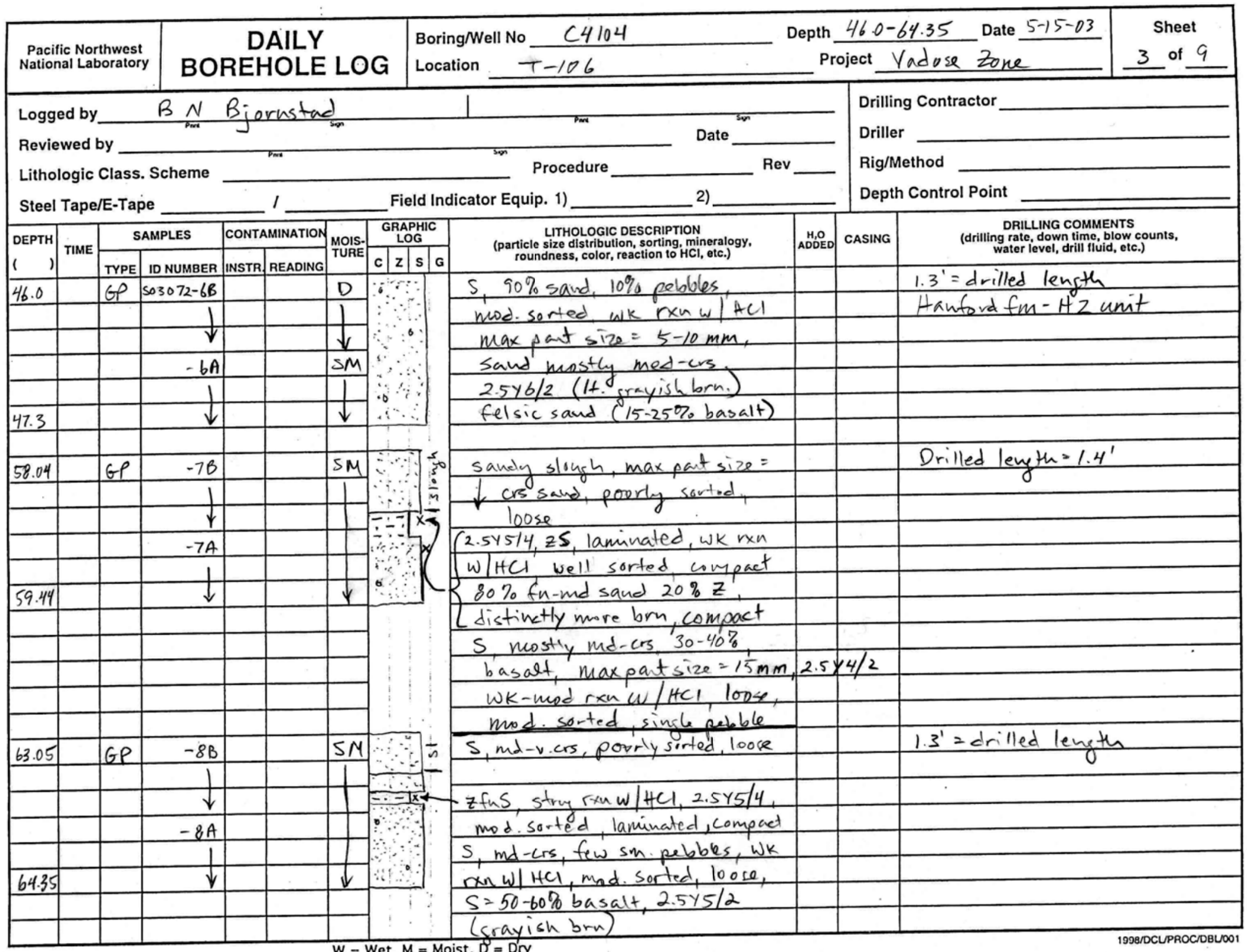




\begin{tabular}{|c|c|c|c|c|c|c|c|c|c|c|c|c|c|}
\hline \multicolumn{3}{|c|}{$\begin{array}{l}\text { Pacific Northwest } \\
\text { National Laboratory }\end{array}$} & \multicolumn{5}{|c|}{$\begin{array}{c}\text { DAILY } \\
\text { BOREHOLE LOG }\end{array}$} & \multicolumn{2}{|c|}{ Boring/Well No $\frac{C 4104}{T-106}$} & \multicolumn{3}{|c|}{$\begin{array}{l}\text { Depth } 75.05-87.7 \text { Date } 5-15-03 \\
\text { Project Vadose Zone }\end{array}$} & $\begin{array}{l}\text { Sheet } \\
4 \text { of } 9\end{array}$ \\
\hline & \\
\hline & & & & & & & & & Date_ & & \multirow{3}{*}{\multicolumn{3}{|c|}{$\begin{array}{l}\text { Driller } \\
\text { Rig/Method } \\
\text { Depth Control Point }\end{array}$}} \\
\hline \multirow{2}{*}{\multicolumn{4}{|c|}{$\begin{array}{l}\text { Reviewed by } \\
\text { Lithologic Class. Scheme } \\
\text { Steel Tape/E-Tape }\end{array}$}} & & & & & & Procedure & & & & \\
\hline & & & & & 1 & & & eld Ind & licator Equip. 1) __ & & & & \\
\hline \multicolumn{4}{|c|}{ 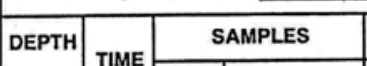 } & CONTA & MINATION & Mols- & \multicolumn{2}{|c|}{$\begin{array}{l}\text { GRAPHIC } \\
\text { LOG }\end{array}$} & $\begin{array}{l}\text { UTHHOLOGIC DESCRIPTION } \\
\end{array}$ & \multirow{2}{*}{ 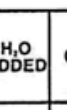 } & \multirow{2}{*}{ CASING } & \multirow{2}{*}{\multicolumn{2}{|c|}{ 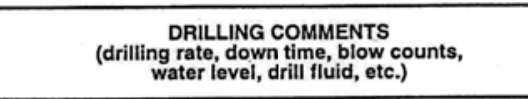 }} \\
\hline ( ) & & TYPE & ID NUMBER & INSTR & READING & TURE & $\begin{array}{ll}\text { c } & z \\
\end{array}$ & $\begin{array}{lll} & G \\
\end{array}$ & & & & & \\
\hline \multirow[t]{5}{*}{75.05} & & GP S & $503072-96$ & & & $S M$ & & 5 & $S$ mostly md-crs, laminated, & & & \multicolumn{2}{|c|}{$1.3^{\prime}=$ drilled length } \\
\hline & & & 1 & & & & \multirow{2}{*}{$e^{\frac{1}{x}}$} & \multirow{2}{*}{$\frac{\frac{0}{4}}{x}$} & $2.5 \% 5 / 2 . w k \operatorname{mond} r \times n \omega / \mathrm{HCl}$ & & & & \\
\hline & & & $\checkmark$ & & & & & & $s=20-30 \%$ basalt, max part & & & \multicolumn{2}{|c|}{$x=$ sample location } \\
\hline & & & $-9 A$ & & & & \multirow{3}{*}{$y^{x}$} & & size $=r \cdot c B \cdot$ sand & & & & \\
\hline & & & $\mathrm{H}$ & & & & & & lower half $=2.5 \times 5 / 4$ (1t. olive & & & & \\
\hline \multirow[t]{2}{*}{76.35} & & & $\downarrow$ & & & $\downarrow$ & & & $\mathrm{bm})$ & & & & \\
\hline & & & & & & & & & & & & & \\
\hline \multirow[t]{5}{*}{80.05} & & GP & $-10 B$ & & & $S M$ & & & $S$, fn-crs, mostly and & & & $1.32^{\prime}=$ Drilled leng & \\
\hline & & & 1 & & & 1 & & $x$ & $\omega k$-mod $r \times n \omega / H C l, \max p a n t s i z e^{-}$ & & & Hanford fm $-\mathrm{Hz}_{2} \mathrm{C}$ & nit \\
\hline & & & $\downarrow$ & & & $\downarrow$ & & & crs sand, finer at $v$. bottom? & & & $80.7^{\prime}=$ con & act \\
\hline & & & $-10 A$ & & & $M$ & & & B liner, 2.5 y $5 / 2$ (srayish bm) & & & upper Cold Creek c & int \\
\hline & & & $t$ & & & & & & laminated $20-30 \%$ basalt & & & & \\
\hline 81.37 & & & $\downarrow$ & & & SM & & & $Z$ fus mod-strm $r \times n w / H C l$, well & & & & \\
\hline & & & & & & & & & laminated compact, $2.5 \times 4 / 4,6$ & Well & sorted & & \\
\hline & & & & & & & & & $S$, $f_{n}$ well sorted, loose, mod $r \times n$ & $\omega / A$ & c) & & \\
\hline & & & & & & & & & & & & & \\
\hline 86.3 & & GP & -116 & & & $M$ & & & $z-z f_{n} S, z$ in middle is stiff, & & & $1.4^{\prime}=$ drilled length & \\
\hline & & & 1 & & & & $\therefore=($ & & well laminated, $2.594 / 4$, string & & & & \\
\hline & & & $\downarrow$ & & & & $=-2 x$ & & $r \times n w / \mathrm{HCl}$, compact, cohesive, & & & & \\
\hline & & & $-11 A$ & & & & $\therefore=$ & & V. well sorted $\max$ part size $=$ & & & & \\
\hline & & & 1 & & & & $=-1 \times$ & & fn sand & & & & \\
\hline 87.1 & & & $\downarrow$ & & & $t$ & 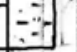 & & & & & & \\
\hline & & & & & & & & & & & & & \\
\hline & & & & & & & & & & & & & \\
\hline & & & & & & & & & & & & & \\
\hline & & & & & & & & & & & & & \\
\hline
\end{tabular}




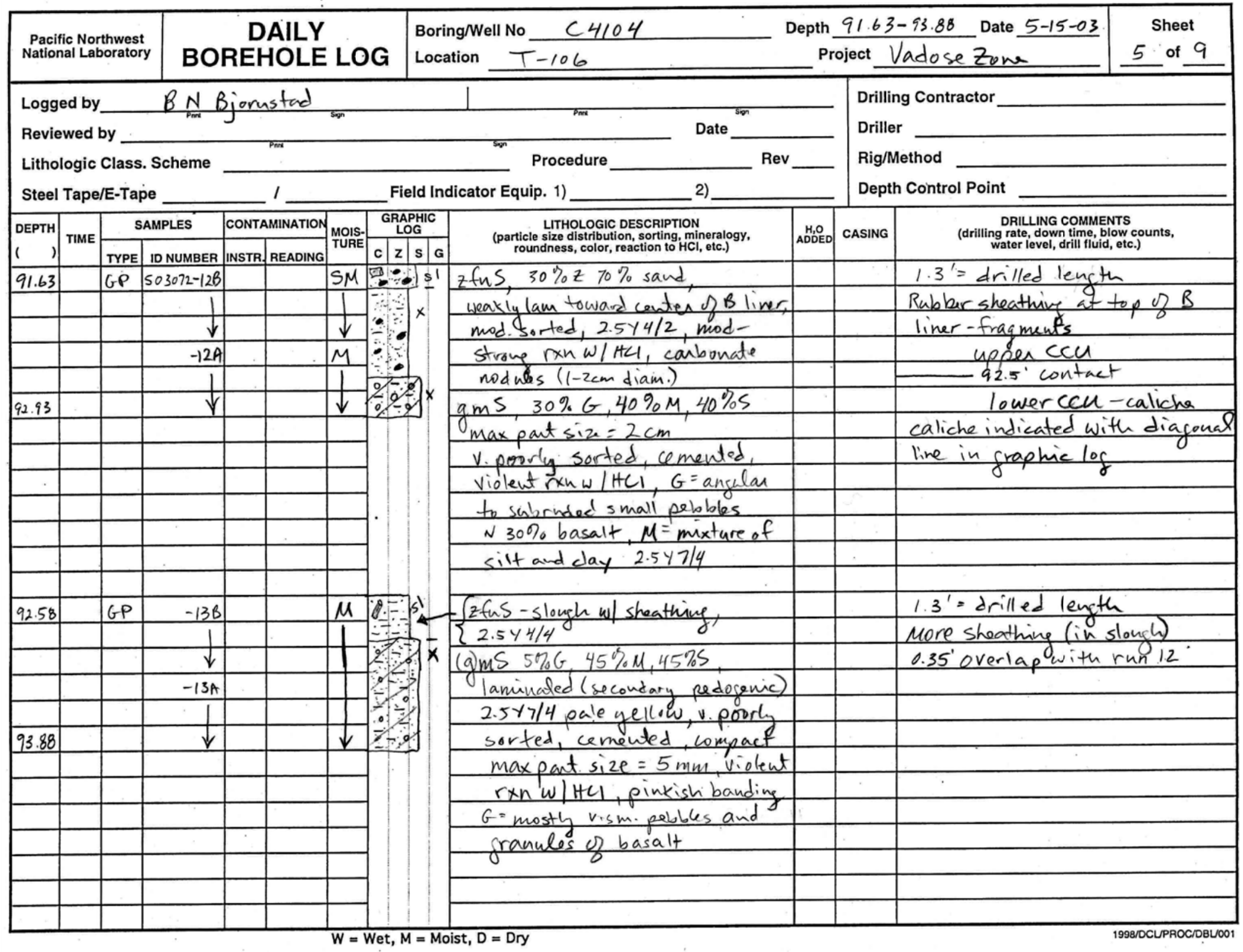




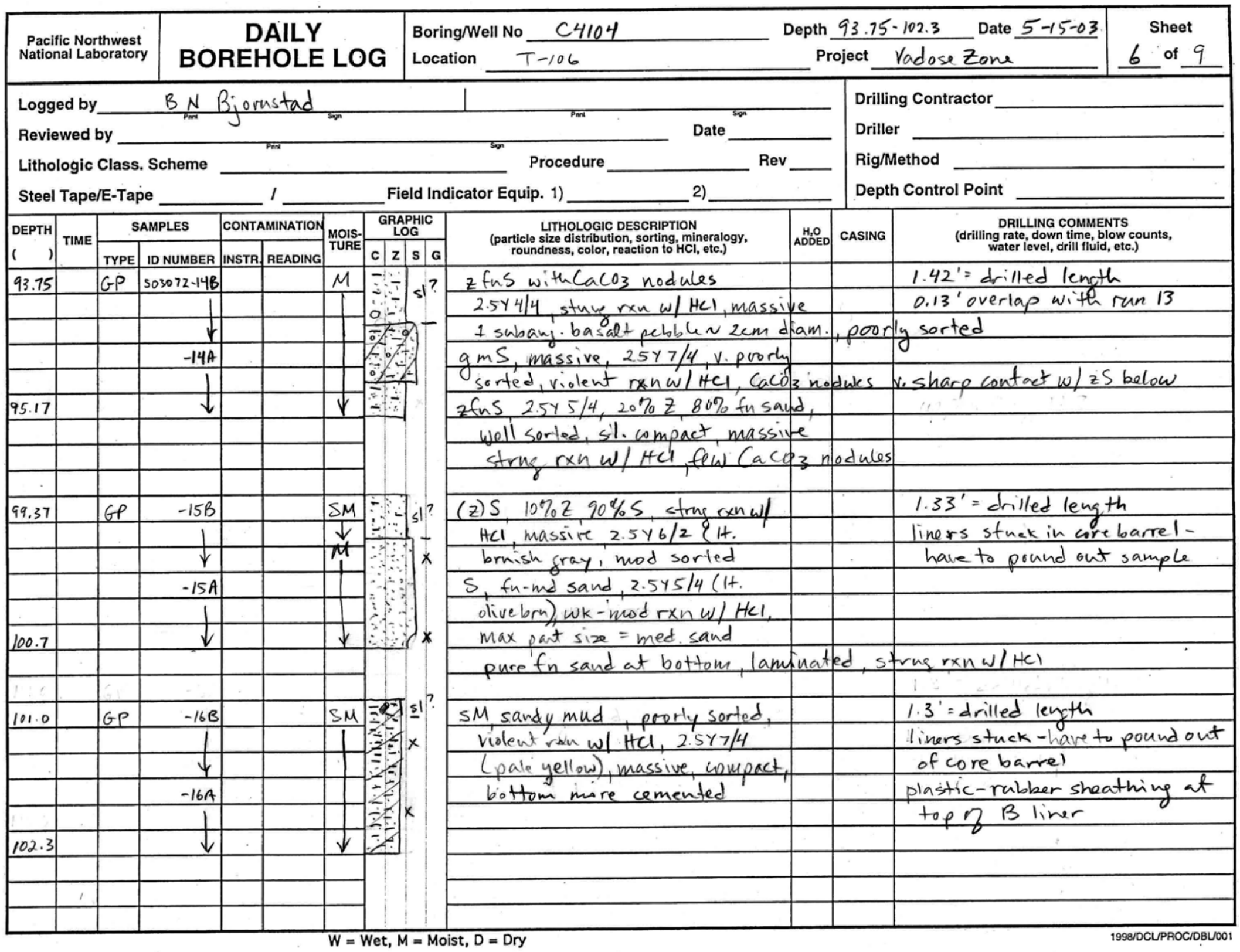




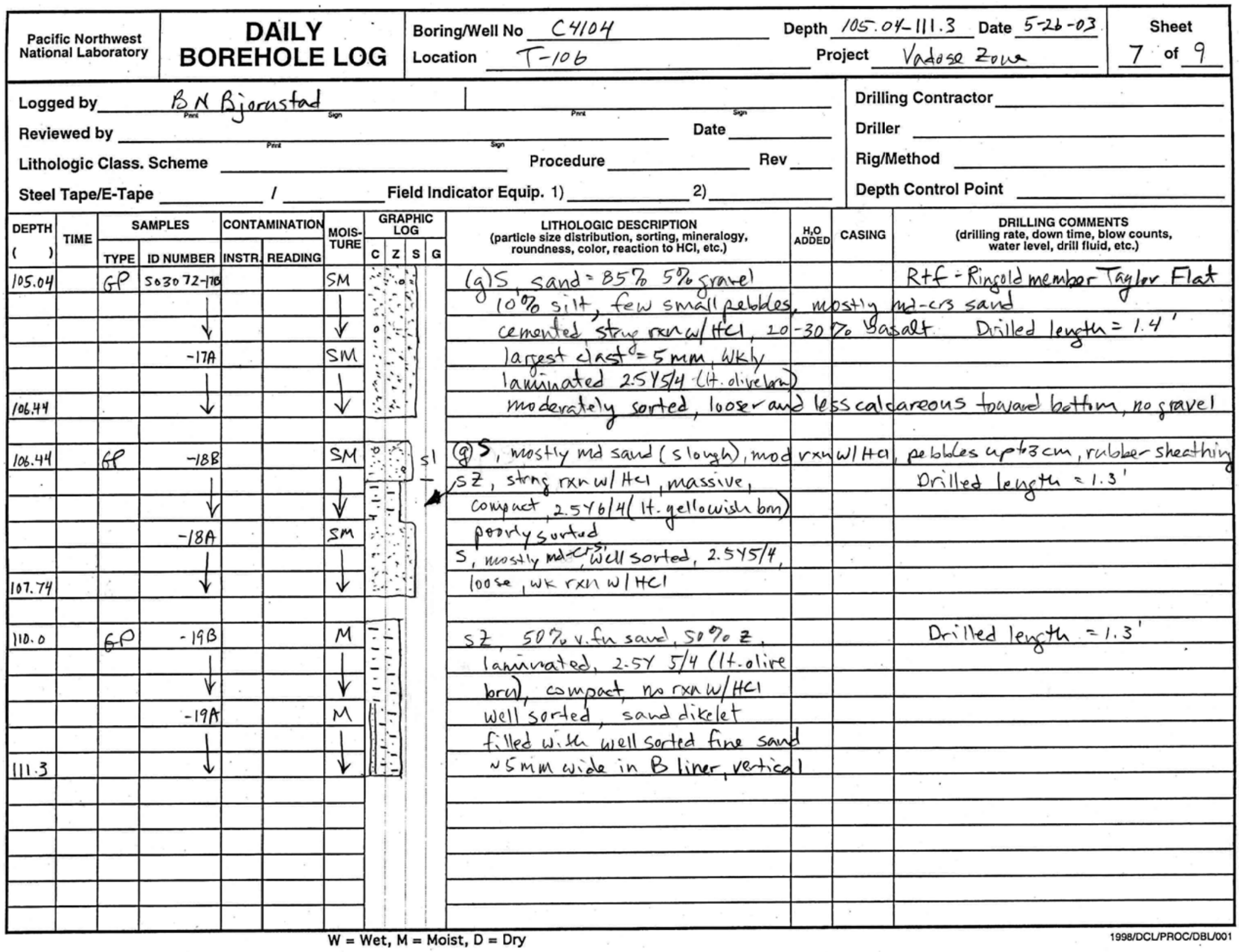




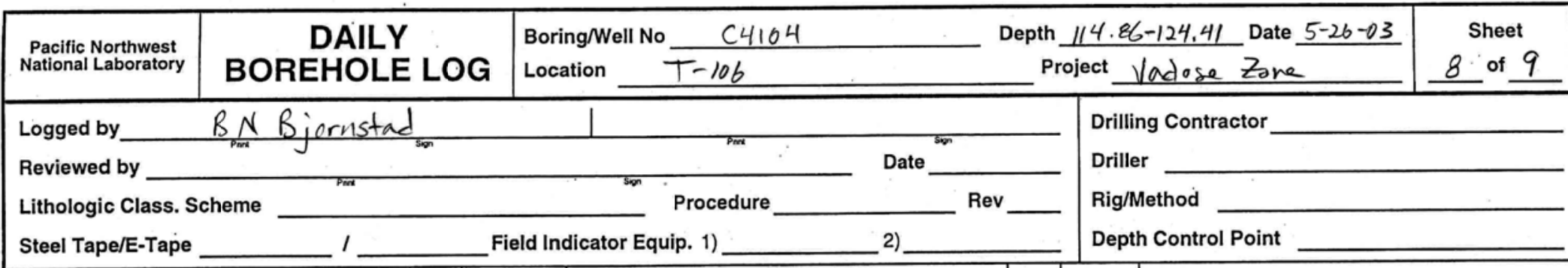

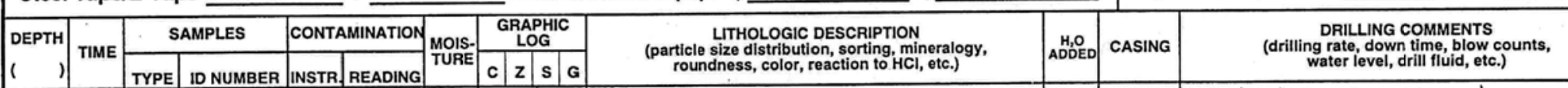

\begin{tabular}{|c|c|c|c|c|c|c|c|c|c|c|}
\hline \multirow{3}{*}{114.86} & TYPE & ID NUMBER & INSTR. & READING & & \multirow{2}{*}{ 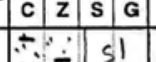 } & & & & \\
\hline & GP & So $3072-2013$ & & & $M$ & & $m S, m s v, 2.5 \times 5 / 4$ & & & Drilled length $=1.55^{\prime}$ \\
\hline & & $\mid$ & & & & $=0-$ & sz fusandy silt, $30 \%$ sand, & faled & dreous & concretion $\sim 3 \mathrm{~cm}$ dia toward top, \\
\hline & & $\downarrow$ & & & 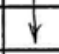 & $F=\left(\begin{array}{l}x \\
2\end{array}\right.$ & $70 \%$ silt, $25 \% 5 / 4$ laminated & well & sorted & compact, no $r \times n$ w/HCl \\
\hline & & $-20 \mathrm{~A}$ & & & $M$ & $\because \div$ & fn sand dikelet at bottom of A li & iher. & & except for concretion \\
\hline & & 1 & & & & $\therefore$ & sZ to ZS, gradin between fine sa & andy & silt & \\
\hline
\end{tabular}

to silt fr sand laminated $2.5 y 5 / 4$, well sorted, wh $r_{x}$ in $w / \mathrm{HCl}$

silty fu sand to medium sand

(ZS tos) interbedded and

laminated, sand is lonse-rest is compact, $2.596 / 4$ (1t. yellowish bra) mod-well sorted, WK-mod rxaw/ HCI.

SG $60 \% 0 \mathrm{G}, 30 \% \mathrm{~S}, 10 \% \mathrm{z}$, loose pall rerized (most clasts broken) R wi cont $2.5 \times 4 / 2$ (dk gragish bru), no rkn u/ $\mathrm{HCl}, 5430 \%$ basalt, poorly sorted

shoefilled with $S G$ also

$s G, d k$ gray $v$ poorly sorted mostly ancular basalt.

pulveried on top some cranitic clasts, no rxn wl HCl, $2.5 y 3 / 0$ ( $V$. dK gray), silt coating on sone gravel clast loose, v. porly sorted 


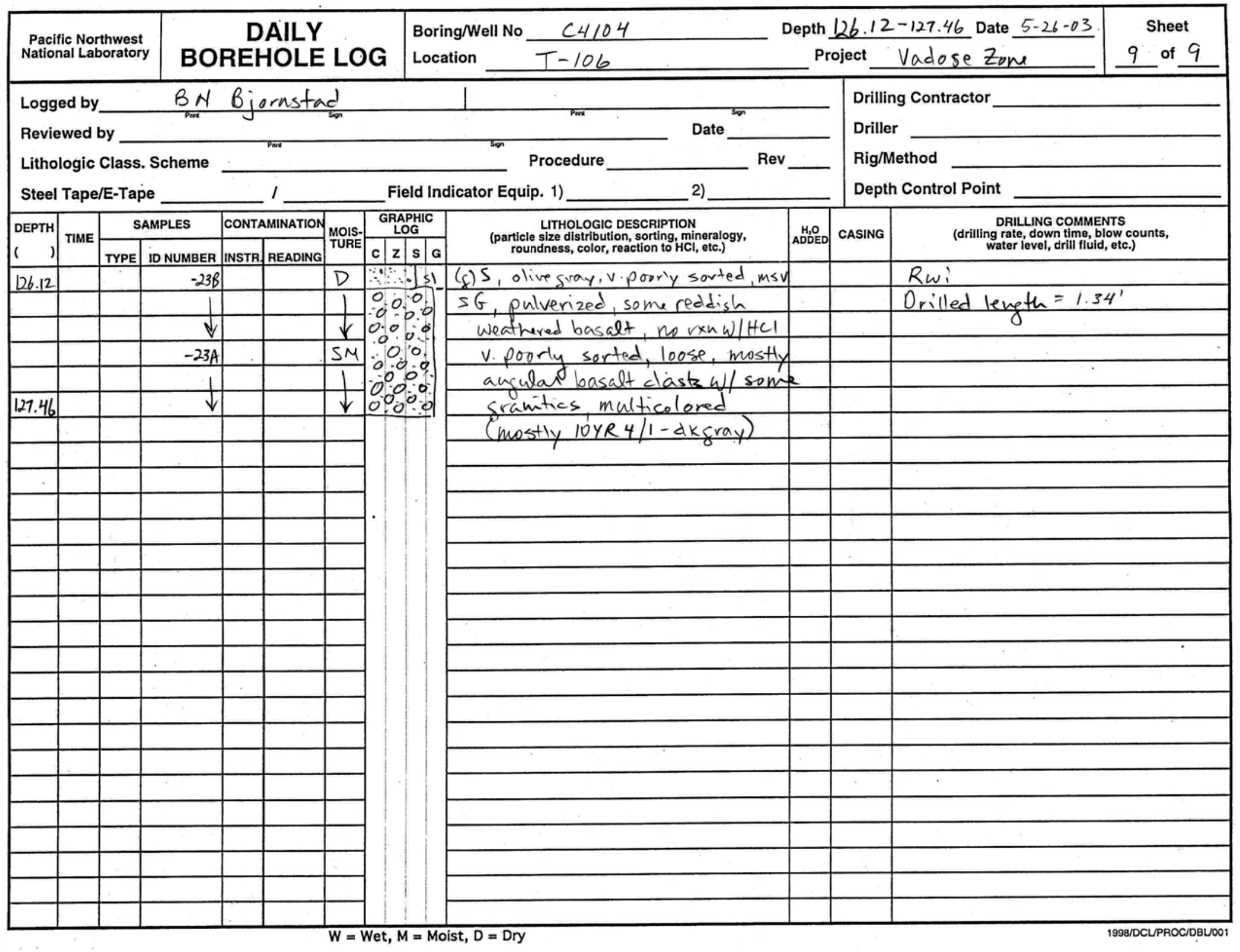


Appendix B-2

C4105 (T-106)

\section{GEOLOGIC DESCRIPTION OF CORE OBTAINED}

\section{DURING OPENING IN LABORATORY}




\section{Contents}

Appendix B-2 C4105 (T-106) Geologic Description of Core Obtained During Opening in

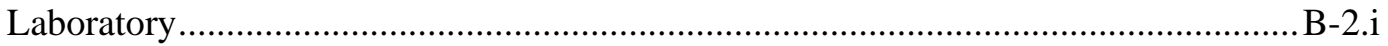

B-1.i 


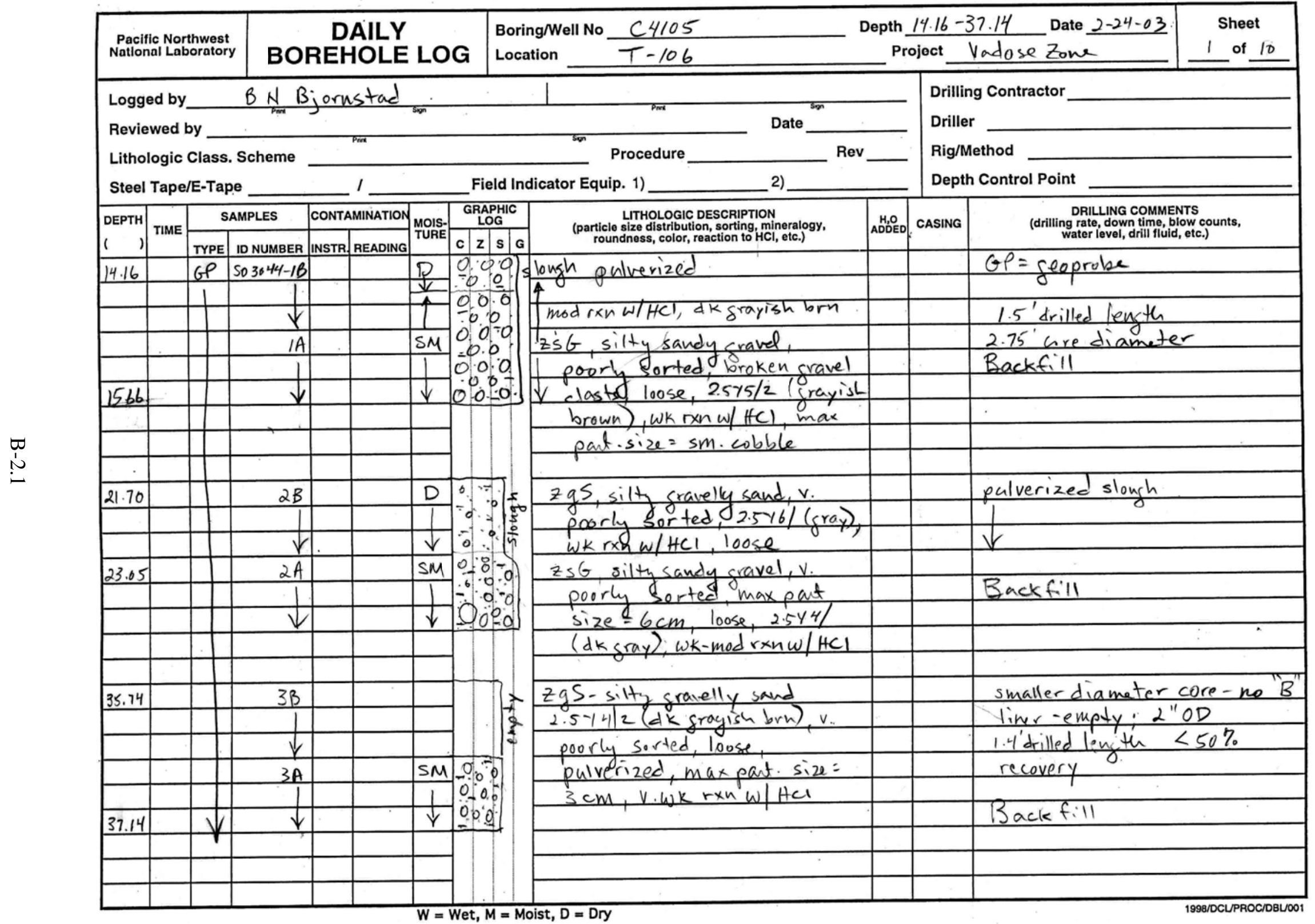




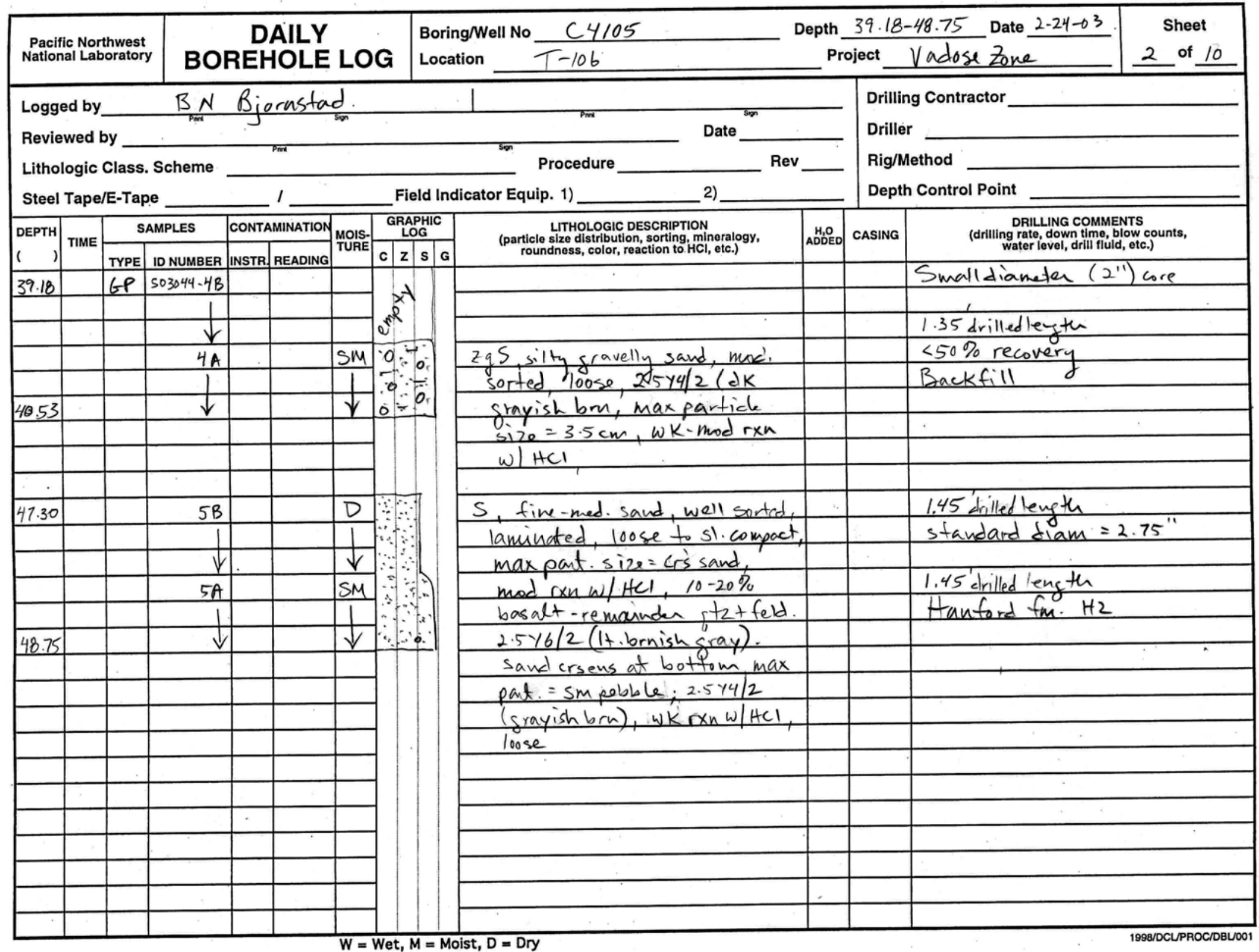




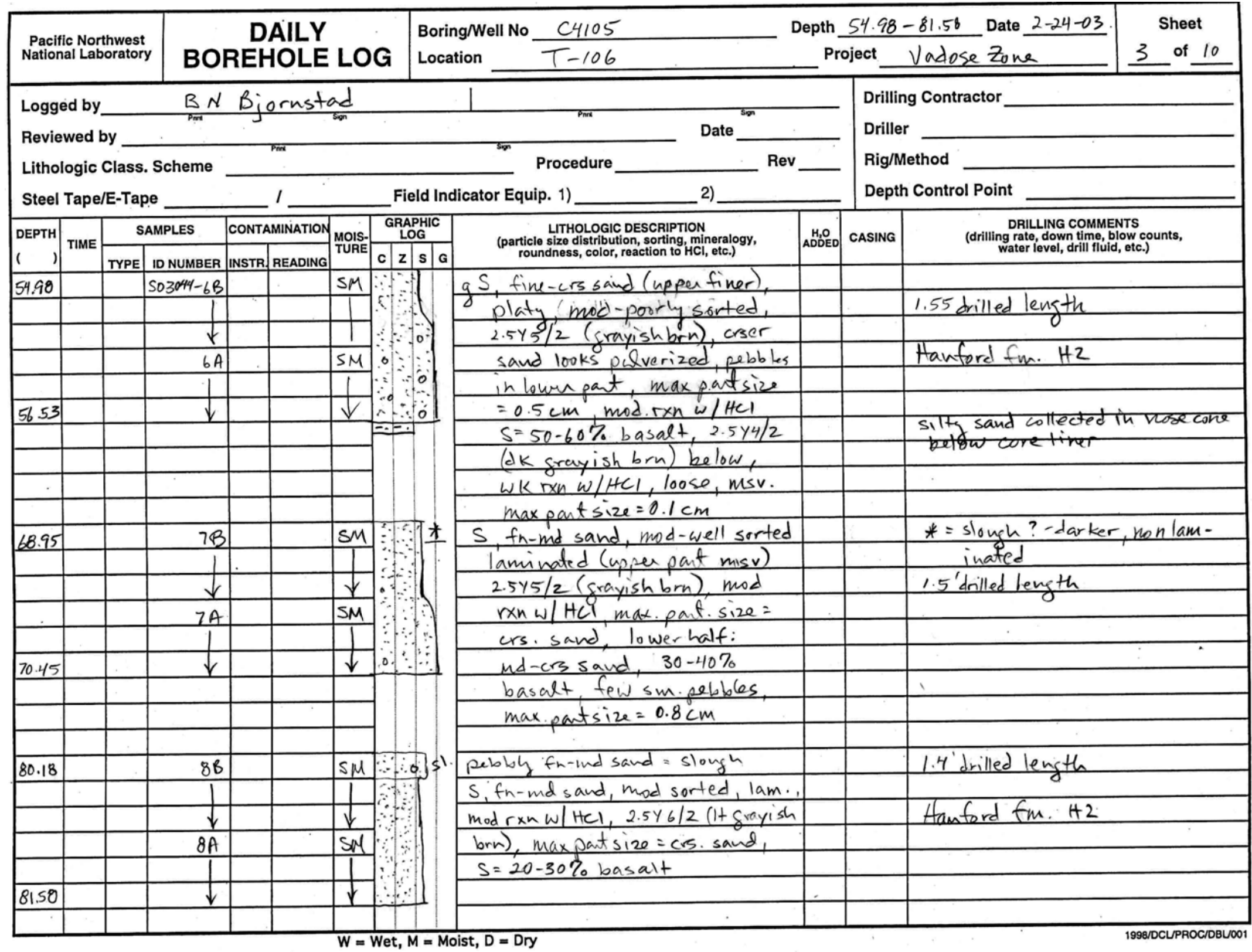




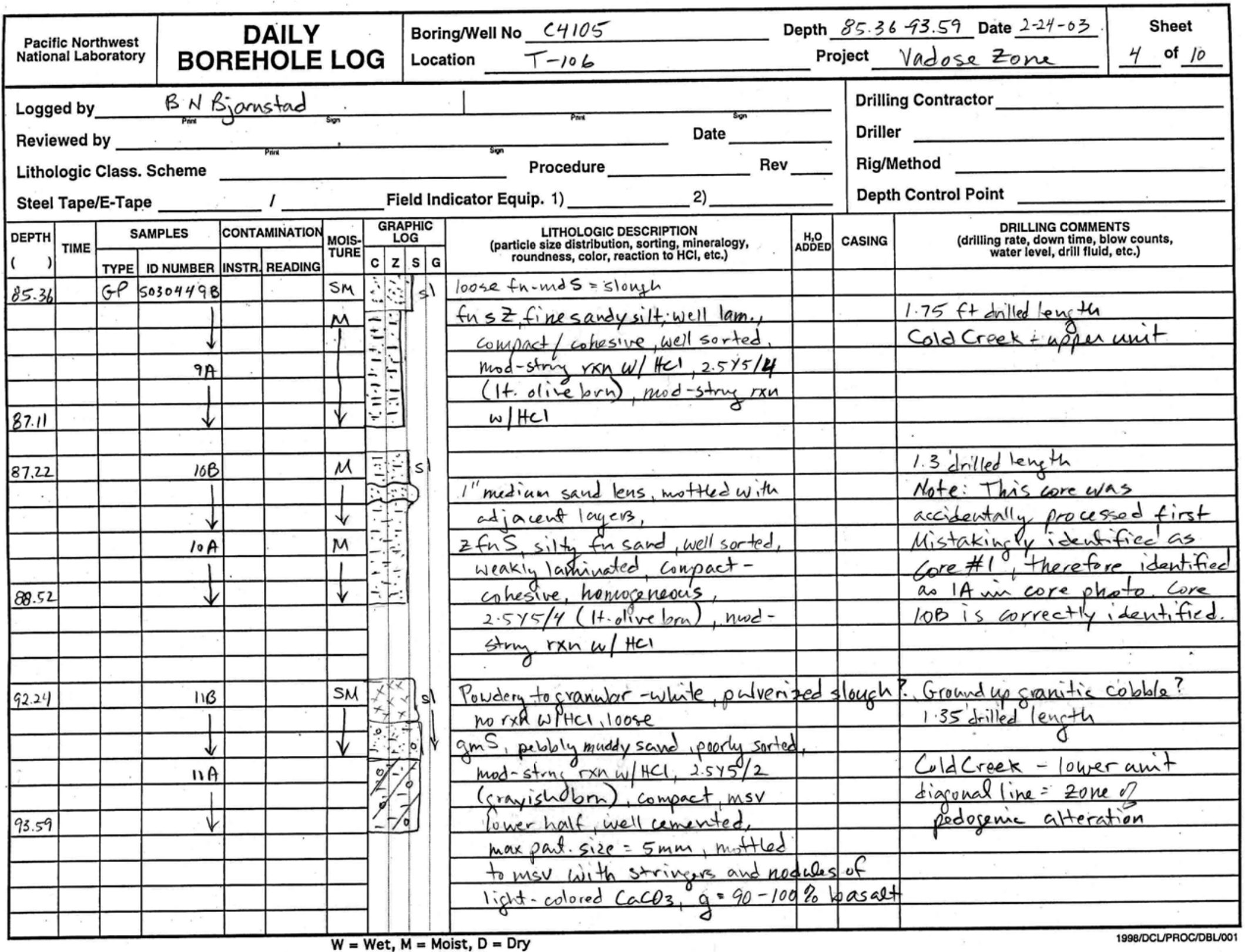




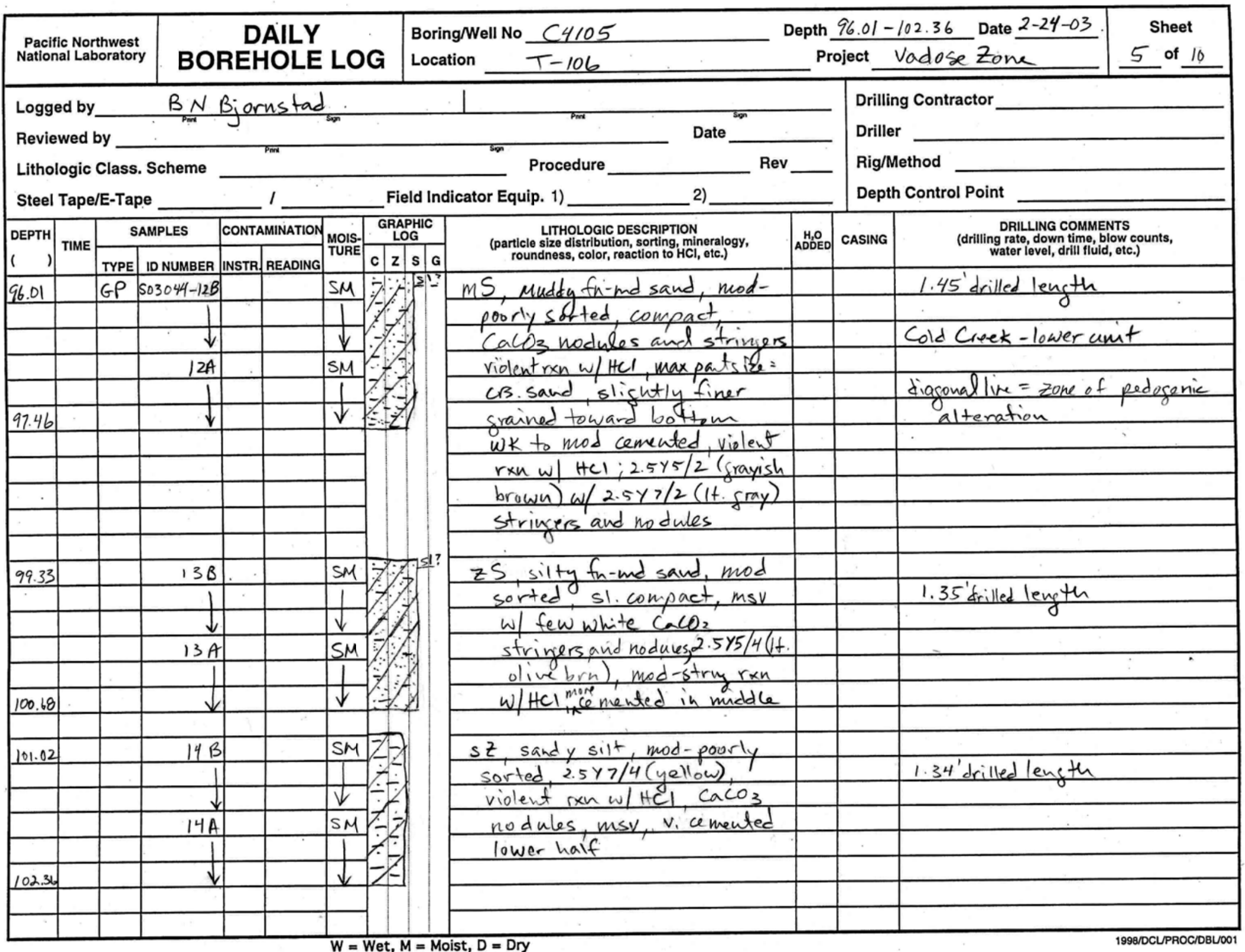




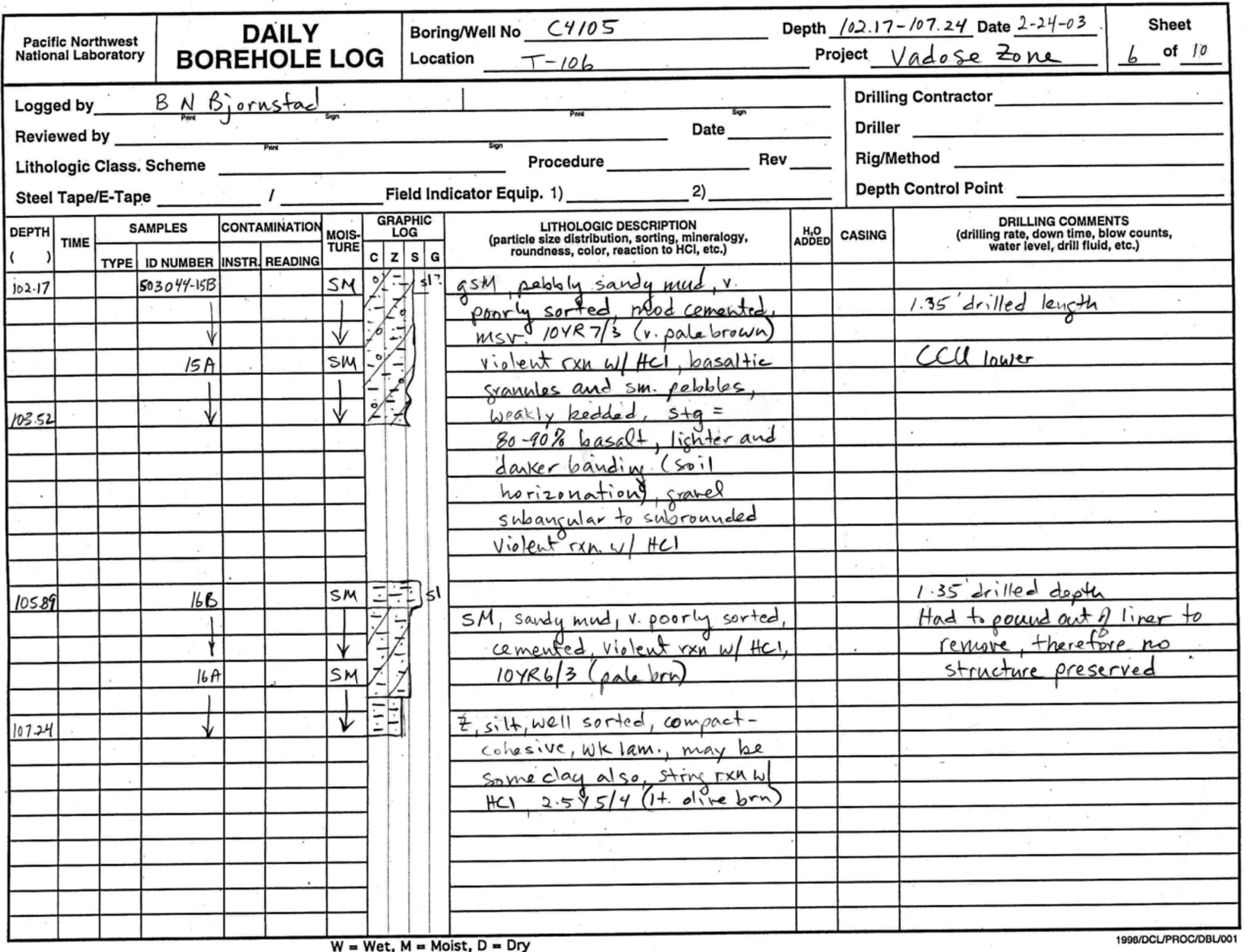




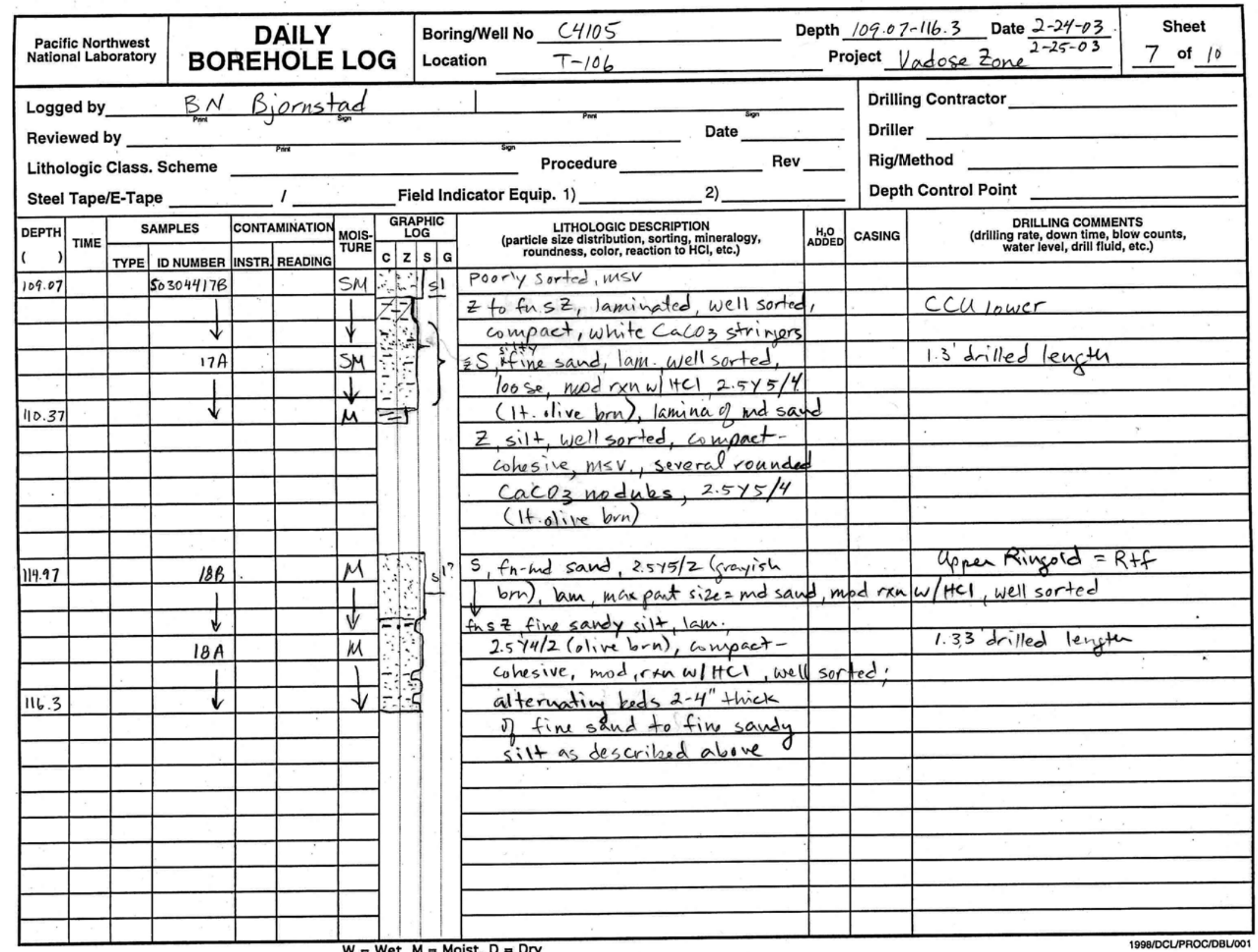




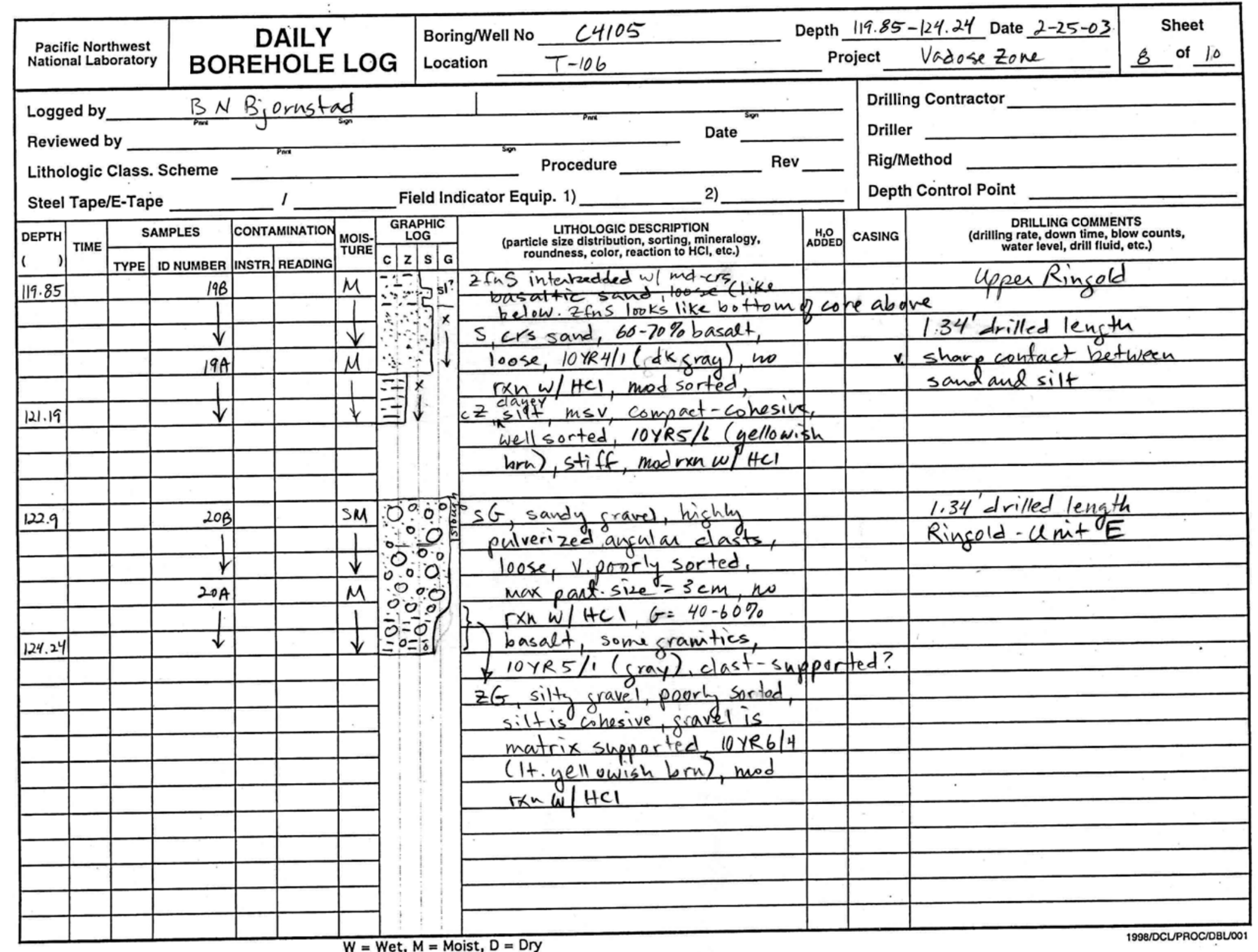




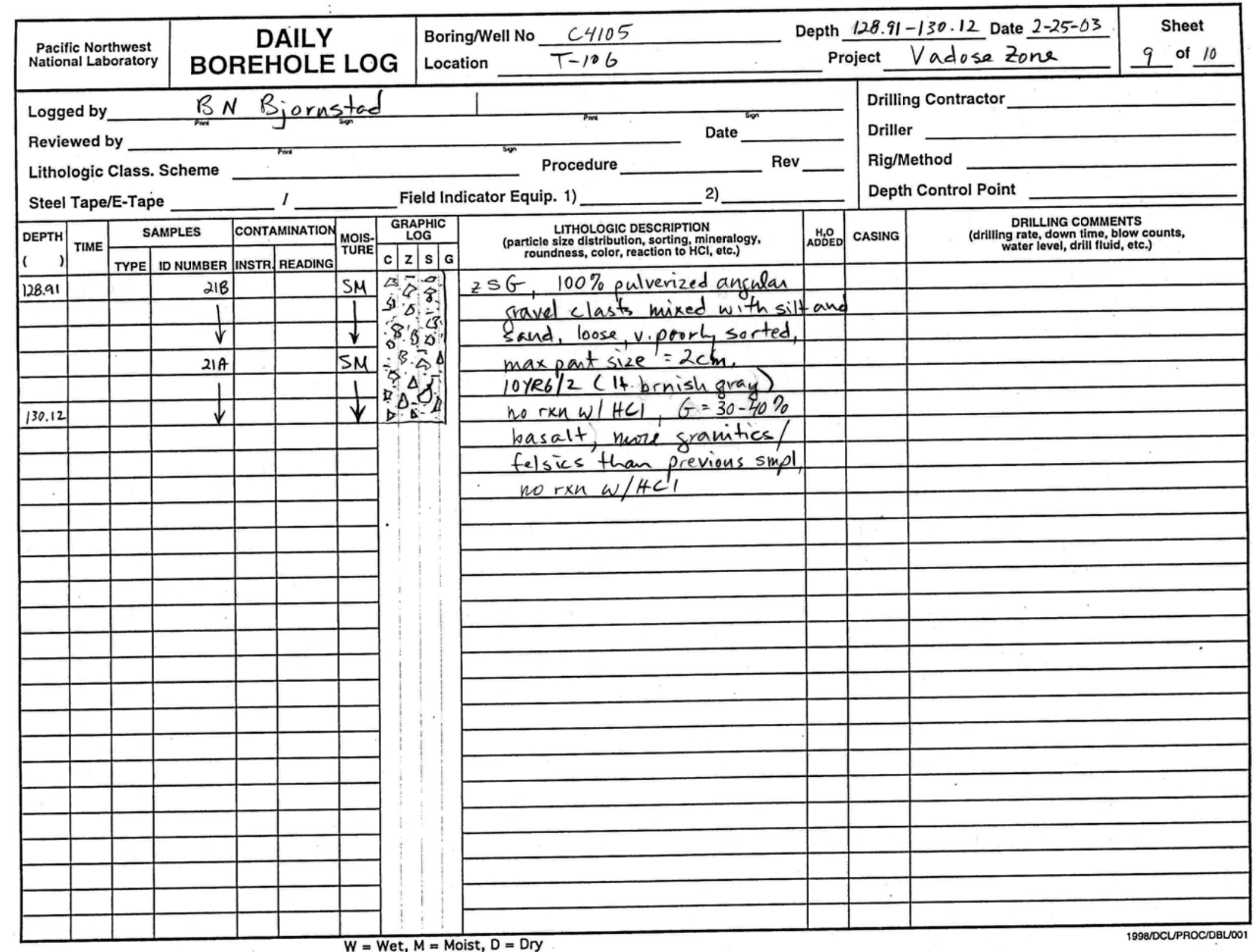




\begin{tabular}{|c|c|c|c|c|c|c|c|c|c|c|c|c|}
\hline \multicolumn{3}{|c|}{$\begin{array}{l}\text { Pacific Northwest } \\
\text { National Laboratory }\end{array}$} & \multicolumn{5}{|c|}{$\begin{array}{l}\text { DAILY } \\
\text { BOREHOLE LOG }\end{array}$} & Boring/Well No $\frac{C 4105}{T-106}$ & \multicolumn{3}{|c|}{$\begin{array}{l}\text { Depth } 128.58-130.9 \text { Date } 3-21-03 \\
\text { Project Vadose Zone }\end{array}$} & $\begin{array}{c}\text { Sheet } \\
10^{\text {of }} 10 \\
\end{array}$ \\
\hline \multirow{2}{*}{\multicolumn{10}{|c|}{$\begin{array}{l}\text { Logged by } B N \text { Bjornstad } \\
\text { Reviewed by }\end{array}$}} & \multirow{4}{*}{\multicolumn{3}{|c|}{$\begin{array}{l}\text { Drilling Contractor } \\
\text { Driller } \\
\text { Rig/Method } \\
\text { Depth Control Point } \\
\end{array}$}} \\
\hline & & & & & & & & Date & & & & \\
\hline \multirow{2}{*}{\multicolumn{4}{|c|}{$\begin{array}{l}\text { Lithologic Class. Scheme } \\
\text { Steel Tape/E-Tape }\end{array}$}} & & & & & Procedure & \multirow[t]{2}{*}{$\operatorname{Rev}$} & & & \\
\hline & & & & - & $1-$ & & Field In & ndicator Equip. 1) & & & & \\
\hline \multicolumn{2}{|c|}{\begin{tabular}{|c|c|} 
DEPTH & TIME \\
&
\end{tabular}} & \multicolumn{2}{|c|}{ SAMPLES } & \multicolumn{2}{|c|}{ CONTAMINATION } & MOIS- & $\begin{array}{l}\text { GRAPHIC } \\
\text { LOG }\end{array}$ & $\begin{array}{c}\text { LITHOLOGIC DESCRIITIION } \\
\text { (particle size eliststribution, sorting mineralogy, }\end{array}$ & \multirow{2}{*}{ ADDED } & CASING & \multicolumn{2}{|c|}{$\begin{array}{l}\text { DRILLING COMMENTS } \\
\text { (drilling rate, down toime, blow counts, } \\
\text { water level, drili flulide, etc.) }\end{array}$} \\
\hline \multirow[t]{3}{*}{128.58} & & \begin{tabular}{l|l} 
TYPE & II \\
$G P$ & $S$
\end{tabular} & $\frac{\text { ID NUMBER }}{\text { SO } 3044-22}$ & INSTR. & READING & SM & \multirow{4}{*}{$\begin{array}{r}0.00 \\
0.0 .0 \\
0.0 .0 \\
0.0 .0\end{array}$} & ms roundilty sand color, reaction to & & & Redrill $7 \# 21 ?$ & \\
\hline & & & & & & & & 2.54412 (dk cray ish bro) & & & & \\
\hline & & & & & & & & mod. $r \times n \omega / H c l$ most sravel & & & & \\
\hline \multirow[t]{5}{*}{129.58} & & & & & & & & clasts are ancular (ie. broken) & & & & \\
\hline & & & & & & & \multirow[t]{5}{*}{1} & loose, max panticle size = & & & & \\
\hline & & & & & & & & $2 \mathrm{~cm}, s=50 \%$ basalt & & & & \\
\hline & & & & & & & & & & & & $\therefore$ \\
\hline & & & & & & & & & & & & \\
\hline \multirow{4}{*}{130.55} & & & & & & & & & & & & \\
\hline & & Ambas & & & & $\omega$ & \multirow{4}{*}{$\begin{array}{r}0.00 \\
0.0 \\
0.0- \\
0.00 \\
0.0\end{array}$} & $\begin{array}{l}\text { MSG silty sandy fravel, } \\
2.5 \text { Y N2/ (black) no run w/ }\end{array}$ & & & & \\
\hline & & $\frac{\text { slass }}{\text { jar }}$ & & & & & & $\begin{array}{l}2.5 Y N 2 /(\text { black }) \text {, no rxnw/ } \\
\text { HCl max pant. size }=2 \mathrm{~cm}\end{array}$ & & & & \\
\hline & & $\frac{j a r}{500 \mathrm{~m}}$ & & & & & & HCl, max pant. size $=2 \mathrm{~cm}$ & & & & \\
\hline & & & & & & & & $\begin{array}{l}\text { vipoorly sorted, reduced } \\
\text { chemically? loose }\end{array}$ & & & & \\
\hline & & & & & & & & $\begin{array}{l}\text { chemically? loose, } \\
\text { pulverized cravel clasts }\end{array}$ & & & & \\
\hline & & & & & & & & $\begin{array}{l}\text { pulverized gravel clasts } \\
\text { subrnded to ancular }\end{array}$ & & & & \\
\hline & & & & & & & & & & & & \\
\hline & & & & & & & & & & & & \\
\hline & & & & & & & & & & & & \\
\hline & & & & & & & & & & & & \\
\hline & & & & & & & & & & & & \\
\hline & & & & & & & & & & & & \\
\hline & & & & & & & & & & & & \\
\hline & & & & & & & & & & & & \\
\hline & & & & & & & & & & & & \\
\hline & & & & & & & & & & & & \\
\hline & & & & & & & & & & & & \\
\hline
\end{tabular}




\section{Appendix C}

\section{X-Ray Diffraction Patterns for C4105 (T-106)}




\section{Contents}

Appendix C. X-Ray Diffraction Patterns for C4105 (T-106) ............................................................... C.1

C.1 X-Ray Diffraction Patterns for Bulk Sediment from C4105 (T-106) .......................................... C.1

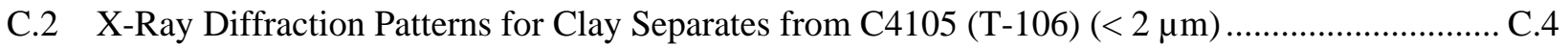

\section{Figures}

C.1 Bulk Sediment XRD Patterns for Samples 7A and 10A from $\mathrm{H} 2$ and $\mathrm{CCU}_{\mathrm{u}}$ Units,

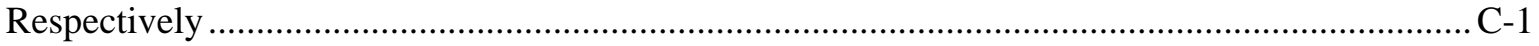

C.2. Bulk Sediment XRD Patterns for Samples 11A and 16A from $\mathrm{CCU}_{1}$ Unit ..................................2

C.3. Bulk Sediment XRD Patterns for Samples 19A and 20A from $R_{t f}$ and $R_{w i}$ Units,

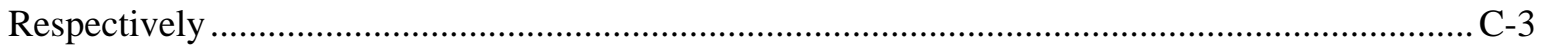

C.4. XRD Patterns for Clay Separates -Sample 7A (Standard and Ethylene Glycol Saturated) ............ C-4

C.5. XRD Patterns for Clay Separates -Sample 10A (Standard and Ethylene Glycol Saturated) .......... C-5

C.6. XRD Patterns for Clay Separates -Sample 16A (Standard and Ethylene Glycol Saturated) .......... C-6

C.7. XRD Patterns for Clay Separates -Sample 19A (Standard and Ethylene Glycol Saturated) ........... C-7

C.8. XRD Patterns for Clay Separates -Sample 20A (Standard and Ethylene Glycol Saturated) .......... C-8 


\section{Appendix C. X-Ray Diffraction Patterns for C4105 (T-106)}

\section{C.1 X-Ray Diffraction Patterns for Bulk Sediment from C4105 (T-106)}

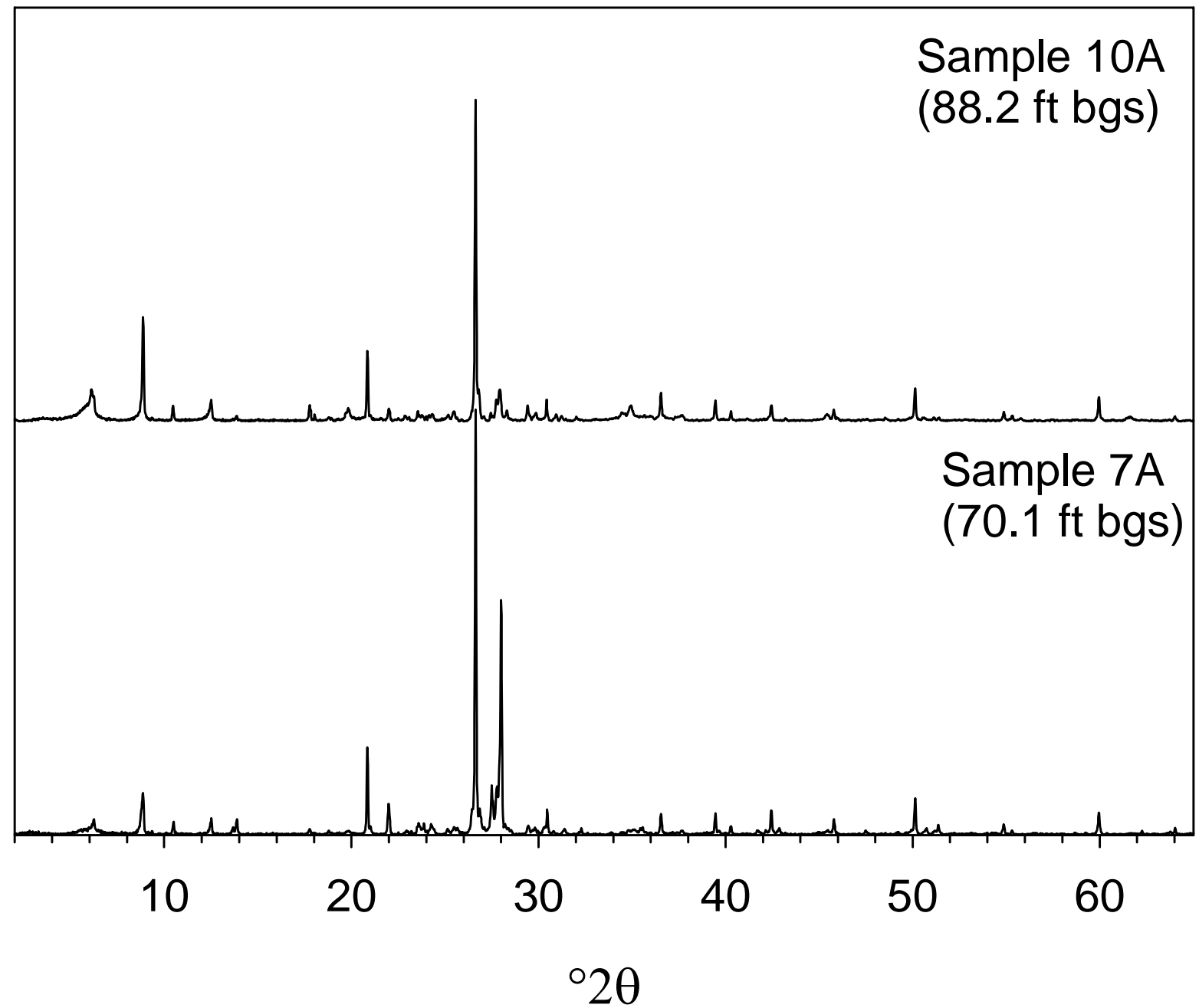

Figure C.1 Bulk Sediment XRD Patterns for Samples 7A and 10A from $\mathrm{H} 2$ and $C C U_{u} U_{n i t s,}$ Respectively 


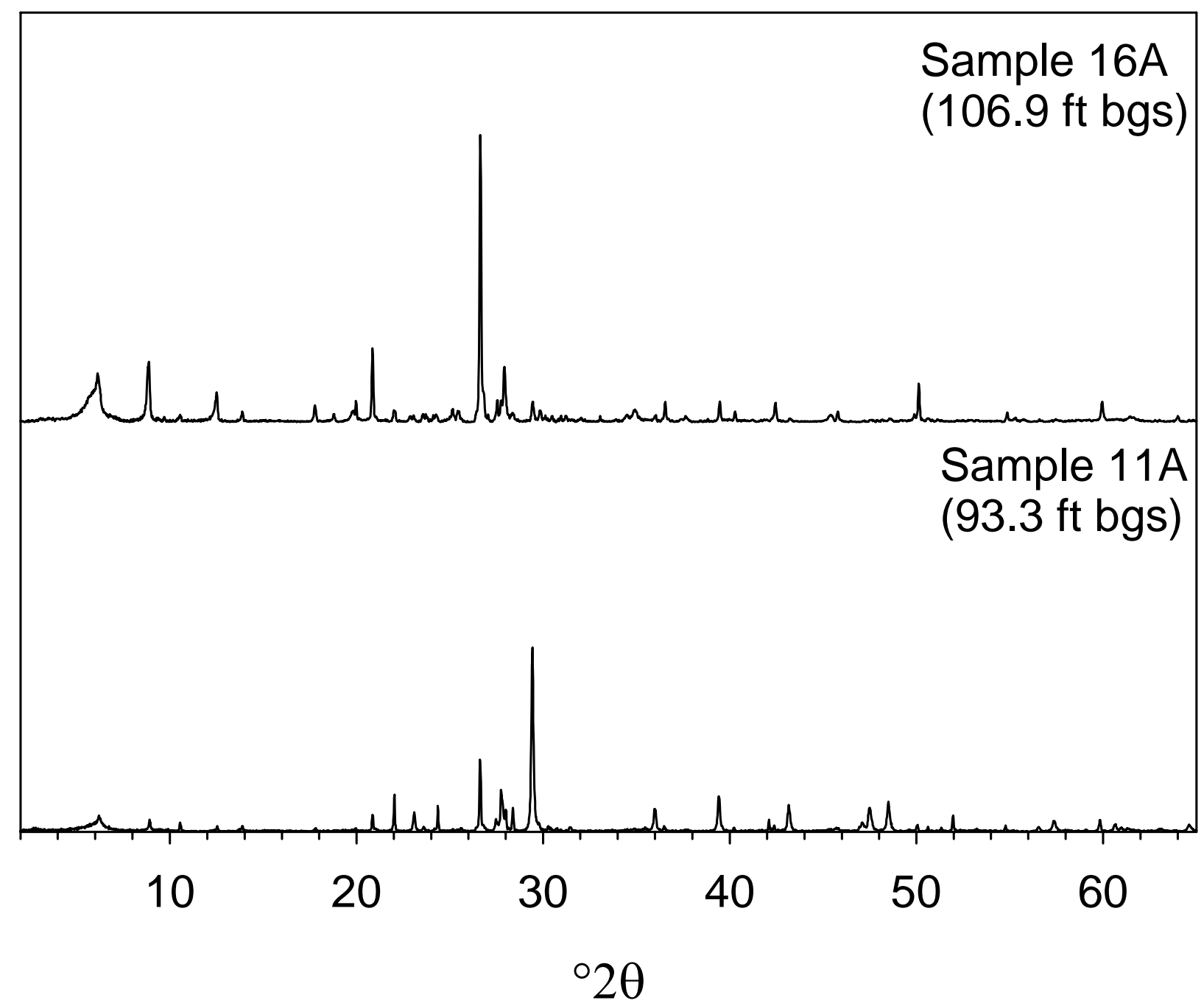

Figure C.2. Bulk Sediment XRD Patterns for Samples 11A and 16A from $C C U_{I}$ Unit 


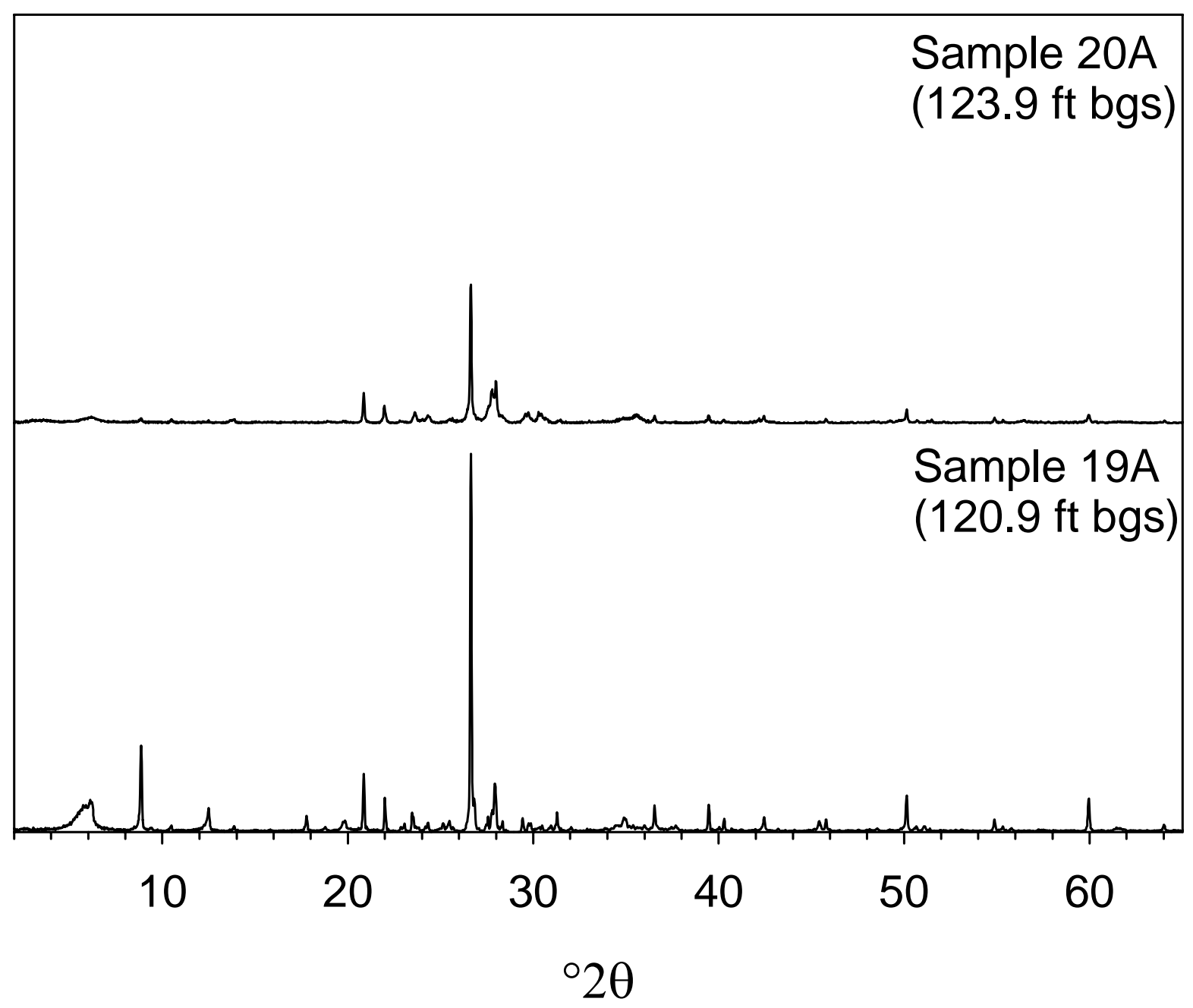

Figure C.3. Bulk Sediment XRD Patterns for Samples 19A and 20A from $R_{t f}$ and $R_{w i}$ Units, Respectively 


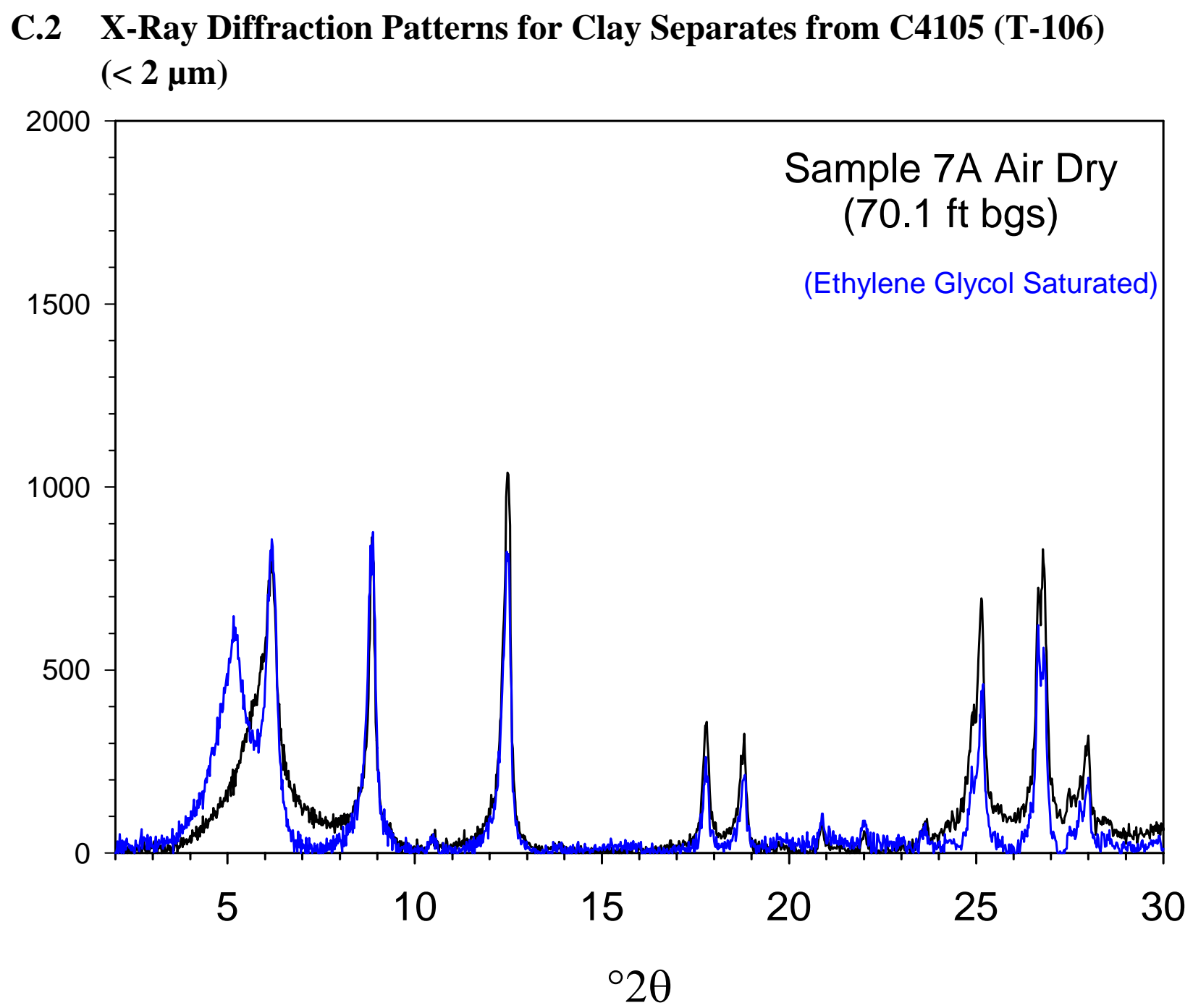

Figure C.4. XRD Patterns for Clay Separates -Sample 7A (Standard and Ethylene Glycol Saturated) 


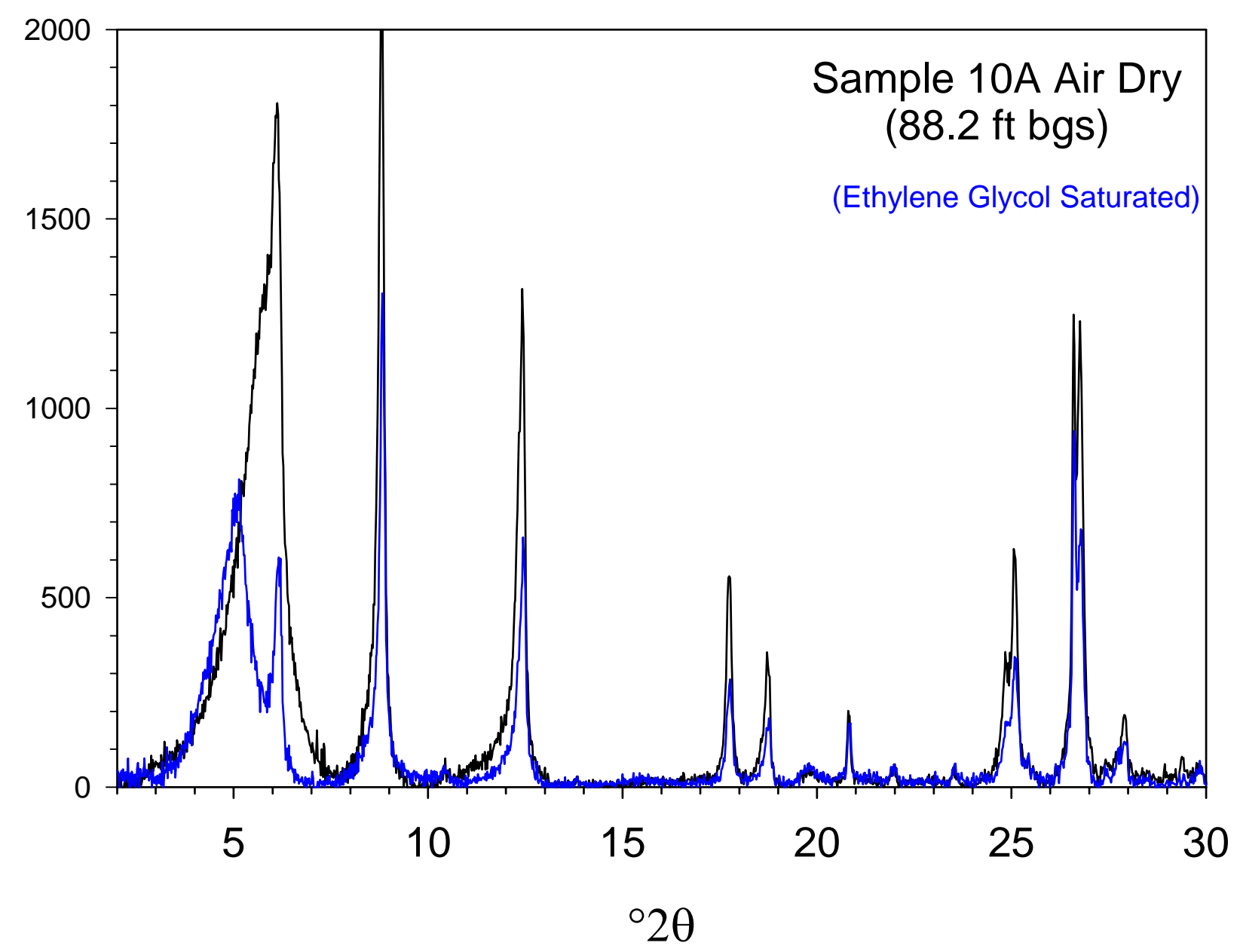

Figure C.5. XRD Patterns for Clay Separates -Sample 10A (Standard and Ethylene Glycol Saturated) 


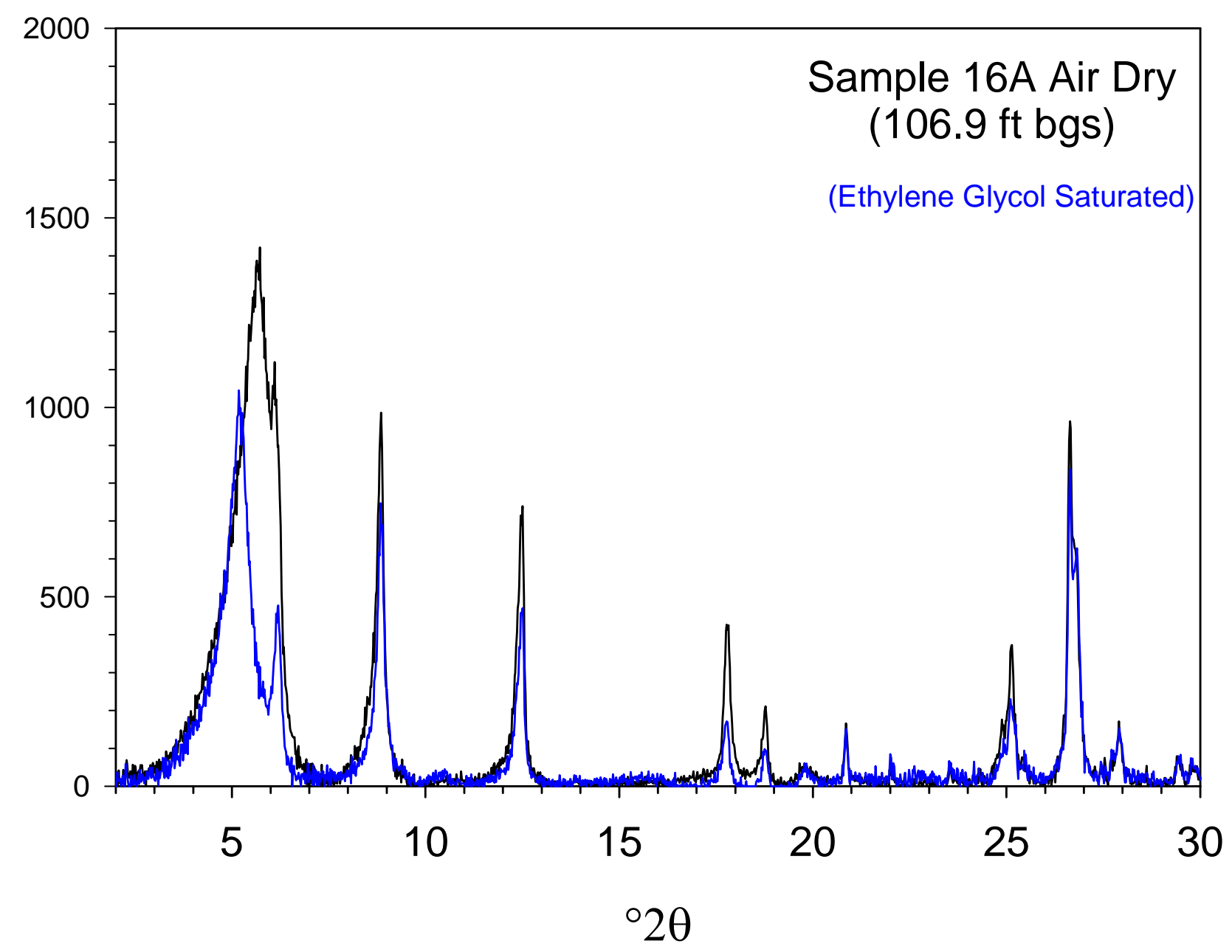

Figure C.6. XRD Patterns for Clay Separates -Sample 16A (Standard and Ethylene Glycol Saturated) 


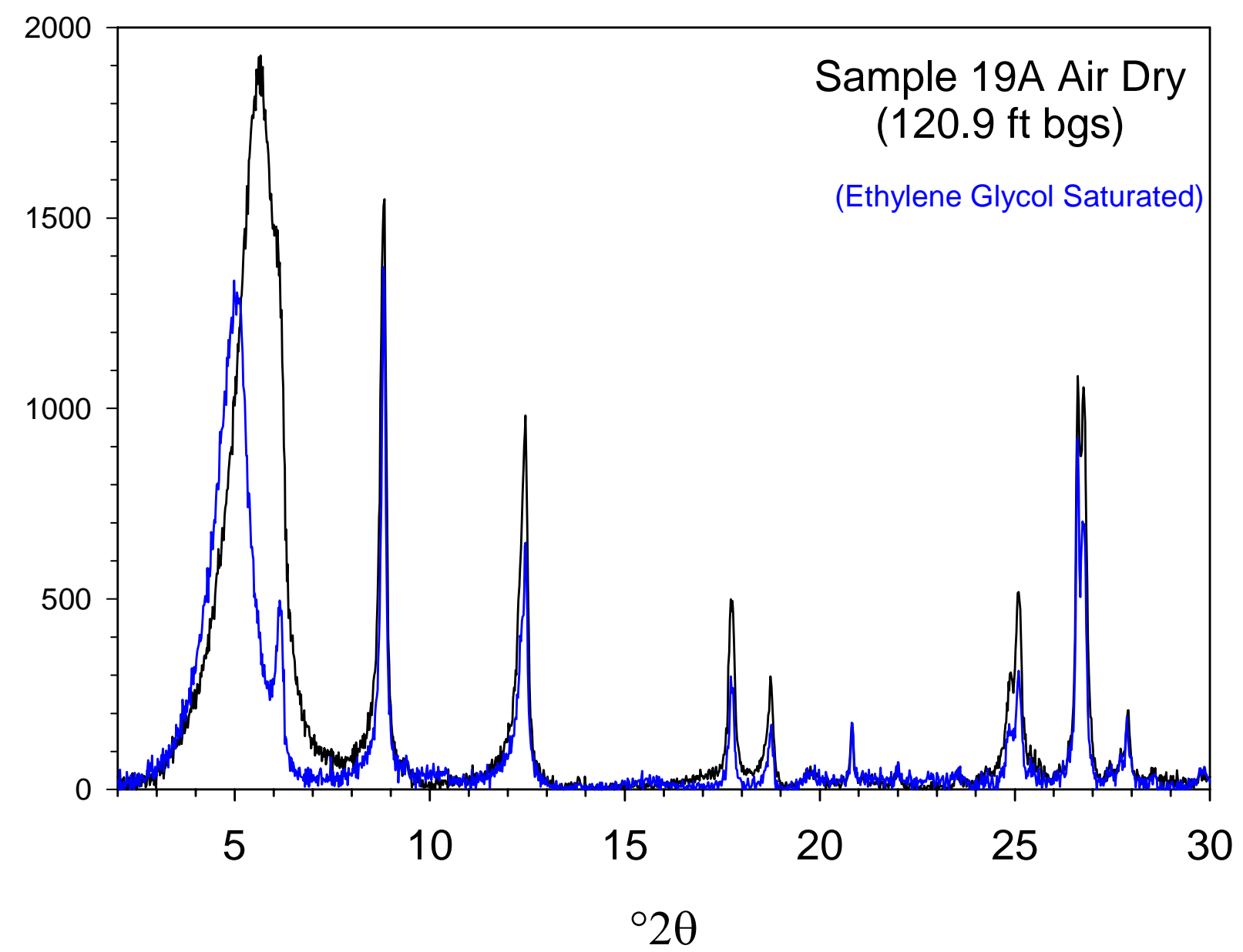

Figure C.7. XRD Patterns for Clay Separates -Sample 19A (Standard and Ethylene Glycol Saturated) 


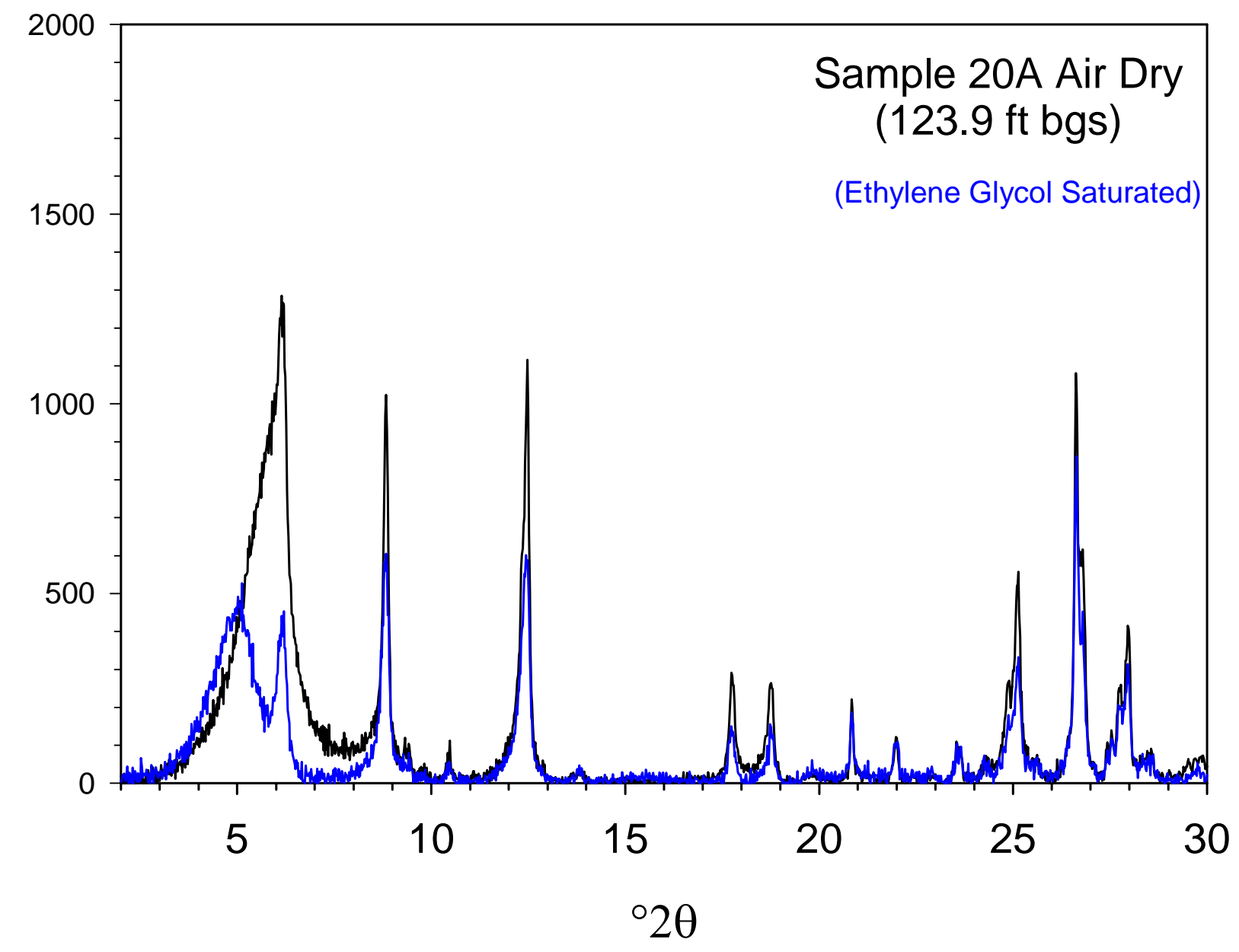

Figure C.8. XRD Patterns for Clay Separates -Sample 20A (Standard and Ethylene Glycol Saturated) 
PNNL-14849

\section{Distribution}

No. of

\section{Copies}

\section{OFFSITE}

Steve Airhart

Freestone Environmental Services

1933 Jadwin Ave.

Suite 135

Richland, WA 99352

Dr. Harry Babad

2540 Cordoba Court

Richland, WA 99352-1609

Pat Brady

Geochemistry Department, 6118

Sandia National Laboratories

P.O. Box 5800

Albuquerque, New Mexico 87185-0750

Charles R. Bryan

Sandia National Laboratories

4100 National Parks Highway

Carlsbad, N.M. 88220

Susan Carroll

Lawrence Livermore National Laboratory

Mail Stop L-219

Livermore, CA 94550

John N. Christensen

Center for Isotope Geochemistry

Lawrence Berkeley National Laboratory

1 Cyclotron Road Bldg, Mail Stop 70A4418

Berkeley, CA 94720-8179

Jon Chorover

Associate Professor - Environmental

Chemistry

Department of Soil, Water and

Environmental Science

Shantz 429, Building \#38

University of Arizona

Tucson, AZ 85721-0038
No. of

Copies

Dave G. Coles

Coles Environmental Consulting

750 South Rosemont Rd

West Linn, OR 97068

Mark Conrad

Department of Earth and Planetary Sciences

University of California Berkeley

Berkeley, CA 94720

Dr. James A. Davis

U.S. Geological Survey

MS-465

345 Middlefield Rd.

Menlo Park, CA 94025

Donald J. DePaolo

Geology \& Geophysics Dept., MC4767

University of California

Berkeley, CA 94720-4767

Dirk A. Dunning

Oregon Office of Energy

625 Mariona St. N. E.

Salem, OR 97301-3742

Mark Ewanic

MSE Technology Applications, Inc.

200 Technology Way

Butte, MT 59701

Markus Flury

Department of Crop and Soil Sciences

Washington State University

Pullman, WA 99164

Amy P. Gamerdinger

2122 E. Hawthorne

Tucson, AZ 85719

Distr.1 
PNNL-14849

No. of

\section{Copies}

Jim Harsh

Department of Crop \& Soil Sciences

Washington State University

Johnson Hall - Room 249

Pullman WA 99164-6420

Victoria Johnson

Kennedy/Jenks Consultants, Inc. 1020 N. Center Parkway, Suite F

Kennewick, WA 99336

Dr. Cliff Johnston

Soil Chemistry and Mineralogy

1150 Lily Hall

Purdue University

West Lafayette, IN 47907-1150

Dr. Daniel I. Kaplan

Westinghouse Savannah River Company

Bldg. 774-43A, Rm 215

Aiken, SC 29808

Dr. Peter C. Lichtner

Los Alamos Natl. Lab

P.O. Box 1663

Los Alamos, NM 87545

Kevin A. Lindsey

Kennedy / Jenks Consultants, Inc. 1020 N. Center Parkway, Suite F

Kennewick, WA 99336

Patrick Longmire

Los Alamos National Laboratory

Mail Stop J534

P.O. Box 1663

Los Alamos, NM 87545

Kate Maher

The Center for Isotope Geochemistry

301 McCone Hall

University of California, Berkeley

Berkeley, CA 94702-4746
No. of

$\underline{\text { Copies }}$

John M. Matuszek

82 McGuffey Lane

Delmar, NY 12054

Melanie A. Mayes

Environmental Sciences Division

Oak Ridge National Laboratory

P.O. Box 2008

[Bethel Valley Road for FedEX/UPS

delivery]

Oak Ridge, TN 37831-6038

Jean Moran

Isotopic Tracers and Transport Group

Analytical and Nuclear Chemistry Division

Lawrence Livermore National Laboratory

L-231, P.O. Box 808

Livermore, CA 94550

Dr. Kathryn L. Nagy

Department of Earth and Environmental

Sciences

University of Illinois at Chicago (MC-186)

845 West Taylor Street

Chicago, IL 60607-7059

Heino Nitsche

Director, Center for Advanced

Environmental and Nuclear Studies

Lawrence Berkeley National Laboratory

1 Cyclotron Road

MS 70A-1150

Berkeley, CA 94720

Phil Reed

U.S. Nuclear Regulatory Commission

Office of Nuclear Regulatory Research

Division of Systems Analysis and

Regulatory Effectiveness

Radiation Protection, Env. Risk and Waste

Management Branch

Mail Stop: T9-F31

Washington, DC 20555-0001 
PNNL-14849

No. of

Copies

Richard J. Reeder

Dept. of Geosciences

State University of New York at

Stony Brook

Stony Brook, NY 11794-2100

Al Robinson

68705, E 715 PRNE

Richland WA, 99352

Phil Rogers

13 Mountain Oak

Littleton, CO 80127

Sherry D. Samson

Research Assistant Professor

Department of Earth and

Environmental Sciences

University of Illinois at Chicago (MC186)

845 W. Taylor St.

Chicago, IL 60607-7059

Dawn A. Shaughnessy

Glenn T. Seaborg Center

Lawrence Berkeley National Laboratory

1 Cyclotron Road

MS 70A-1150

Berkeley, CA 94720

Doug Sherwood

Rivers Edge Environmental

1616 Riverside Drive

West Richland, WA 99353

David K. Shuh

Lawrence Berkeley National Lab

1 Cyclotron Road

Mail Stop 70A-1150

Berkeley, CA 94720

James "Buck” Sisson

Idaho National Engineering and

Environmental Laboratory

P.O. Box 1625, MS-2107

Idaho Falls, ID 83415-2107
No. of

Copies

Robert W. Smith, Ph.D.

Professor of Subsurface Science

Adjunct Professor of Geological Sciences

University of Idaho at Idaho Falls

1776 Science Center Drive

Idaho Falls, ID 83402

Stan Sobczyk

242 N. Laurel St.

Genesee, ID 83832-9760

Carl I. Steefel

Earth Sciences Division

Lawrence Berkeley National Laboratory

1 Cyclotron Road, Mail Stop 90R1116

Berkeley, CA 94720

Dr. Samuel J. Traina, Director

Sierra Nevada Research Institute

University of California, Merced

P.O. Box 2039

Merced, CA 95344

Dr. T. T. Chuck Vandergraaf

P.O. Box 857

Pinawa, Manitoba ROE 1LO

Canada

Dr. Jiamin Wan

Lawrence Berkeley National Laboratory

1 Cyclotron Rd. MS 70-0127A

Berkeley, CA 94720

Mr. Ronald G. Wilhelm

Office of Radiation and Indoor Air

401 M Street, S.W.,

Mail Code 6603J

Washington, D.C. 20460

W. Alexander Williams

U.S. Department of Energy

Office of Environmental Restoration

EM-33

19901 Germantown Road

Germantown, MD 20874-1290

Distr.3 
No. of

Copies

\section{ONSITE}

4 DOE Office of River Protection

P. E. LaMont

H6-60

R. W. Lober

S. A. Wiegman

R. B. Yasek

8 DOE Richland Operations Office

B. L. Foley

J. P. Hanson

R. D. Hildebrand

K. A. Kapsi

J. G. Morse

K. M. Thompson

DOE Public Reading Room (2)

Bechtel Hanford, Inc.

K. R. Fecht

H0-02

22 CH2M HILL Hanford Group, Inc.
A. Amonette
Technical Writer's Ink
F. J. Anderson
R. Calmus
M. P. Connelly
J.G. Field
T. E. Jones (2)
A. J. Knepp
S. L. Lambert
Lambert Engineering
J. E. Laurenz
F. M. Mann (5)
W. J. McMahon
C. W. Miller
D. A. Myers (3)
G. Parsons
T. L. Sams

H6-60

H6-60

A6-38

A5-13

A6-38

A5-13

A6-38

A6-38

H2-53
No. of

Copies

3 Duratek Federal Services, Inc., Northwest Operations
M. G. Gardner
H1-11
K. D. Reynolds
H1-11
D. E. Skoglie
H1-11

6 Fluor Hanford, Inc.

M. W. Benecke E6-35

T. W. Fogwell E6-35

B. H. Ford E6-35

J. G. Hogan H1-11

V. G. Johnson E6-35

M. I. Wood H8-44

72 Pacific Northwest National Laboratory

S. R. Baum

P7-22

B. N. Bjornstad (3) K6-81

T. M. Brouns K9-69

C. F. Brown P7-22

R. W. Bryce E6-35

K. J. Cantrell K6-81

R.. E. Clayton P7-22

W. J. Deutsch K6-81

P. E. Dresel K6-96

K. M. Geisler P7-22

M. J. Fayer K9-33

A. R. Felmy K8-96

V. L. Freedman K9-36

M. D. Freshley K9-33

J. S. Fruchter K6-96

G. W. Gee K9-33

D. G. Horton (3) K6-81 
No. of

Copies

J. P. Icenhour

C. T. Kincaid

K. M. Krupka

I. V. Kutnyakov

G. V. Last (2)

V. L. LeGore

M. J. Lindberg

C. W. Lindenmeier (2)

W. J. Martin

S. V. Mattigod

B. P. McGrail

P. D. Meyer

C. J. Murray

S. M. Narbutovskih

R. D. Orr

E. M. Pierce

Nik Qafoku

S. P. Reidel

R. J. Serne (20)

H. T. Schaef

W. Um
No. of

Copies

K6-81

E6-35

K6-81

P7-22

K6-81

P7-22

P7-22

P7-22

K6-81

K6-81

K6-81

BPO

K6-81

K6-96

K6-81

K6-81

K3-61

K6-81

P7-22

K6-81

P7-22
M. Valenta

P7-22

T. S. Vickerman

P7-22

A. L. Ward

K9-33

B. A. Williams

K6-81

S. B. Yabusaki

K9-36

J. M. Zachara

K8-96

F. Zhang

Information Release Office (2)

S.M. Stoller

R. G. McCain

B2-62

6 Washington State Department of Ecology

S. Dahl-Crumpler

HO-57

J. A. Caggiano

HO-57

F. Hodges

HO-57

A. D. Huckaby

HO-57

B. Rochette

HO-57

J. Yokel 